\title{
Schmeil,
}

\section{Lehrbuch der Botanik}

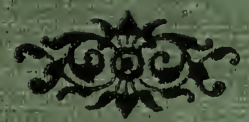

Stuttgart und Lolpzig

Vorlag von Erwin Nigolo. 


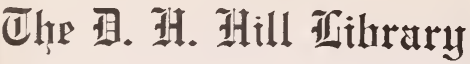

North Caralita \$tate Aluiuersity

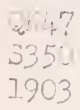


THIS BOOK IS DUE ON THE DATE INDICATED BELOW AND IS SUBJECT TO AN OVERDUE FINE AS POSTED AT THE CIRCULATION DESK.

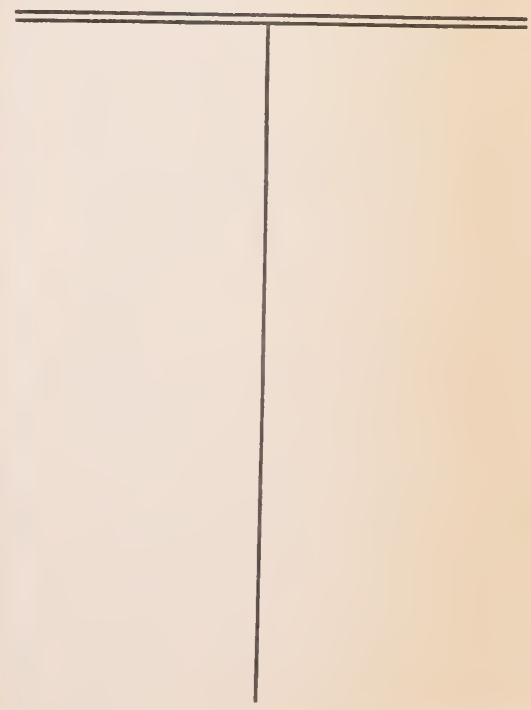





\section{Lehrbuch der Botanik}

für

höhere Lehranstalten und die Hand des Lehrers.

Von biologischen Gesichtspunkten aus bearbeitet

von

Dr. Otto Schmeil.

Mit 38 farbigen Tafeln und zahlreichen Textbildern von Kunstmaler W. Heubach-München.

3. unveränderte Auflage

(16-2000o).

Stuttgart und Leipzig.

Verlag von Erwin Nägele. 
Alle Rechte, insbesondere das der Übersetzung vorbehalten.

Druck von A. Bonz' Erben in Stuttgart. 


\section{Vorbemerkung zur zweiten Auflage.}

Dank der außerordentlich freundlichen Aufnahme waren die beiden ersten Hefte des Buches bereits vergriffen, bevor noch der Schlußteil herausgegeben werden konnte. Daß ich bei dieser Sachlage keine Veranlassung hatte, umfassende Ïnderungen vorzunehmen, liegt auf der Hand. Von Kleinigkeiten abgesehen, ist die zweite Anflage daher ein unveränderter Abdrnck der ersten. Der Schlußteil ist in beiden Auflagen sogar ein Abzug von denselben Platten.

Magdeburg, den 20. März 1903.

\section{Der Verfasser.}

\section{Vorwort zur ersten Auflage.}

Die Arbeit, die ich hiermit der Schnle und ihren Lehrern iibergebe, ist ein Seitenstïck zu meinem "Lehrbuch der Zoologie". Bei der Abfassung beider Bücher sind daher anch die gleichen Erwägungen maßgebend gewesen. Da ich nun meine Ansichten ïber die notwendige Um- und Ansgestaltung des naturgeschichtlichen Unterrichts in einer Broschüre* ansführlich entwickelt habe, kann ich hier von einer erneuten Darlegung absehen. Ich vermag dies unso eher, als die Schulen aller Gattungen sich immer mehr einem Unterrichte zuwenden, wie er durch den gegenwärtigen Stand der Natnrwissenschaften und der Pädagogik gefordert wird, einem Unterrichte, der dem Schüler ein seiner Fassungskraft entsprechendes Verständnis der Natur zu eröffnen vermag, der fernerden Natnrsinn der Jugendkräftig und nachhaltig zubeeinflusseuimstande ist, und der sichendlich an Bildangswert getrost mit jedem anderen Unterrichtszweige messen kann.

Da sich meine Arbeit nun in den Dienst eines solchen Unterrichts stellen möchte, mußte ich wie in dem "Lehrbnche der Zoologie“ (und seinen gekürzten Ausgaben) mit der veralteten Weise trockenen Beschreibens, die für Schüler wie Lehrer eine gleich große Qnal ist, brechen und den morphologischen Stoffendurch Hinzufïgung physiologischer II omente einen erhöhten Wert verleihen. Ich multe, um dies ganz kurz auszudrïcken,

* Über die Reformbestrebungen auf dem Gebiete des naturgeschichtlichen Unterrichts. 4. Autl. Stuttgart. Verl, von E. Nïgele. 
die Pflanzen wie die Tiereals lebende Wesen darzastellen versuchen.* Da die Lebenstätigkeiten der Pflanzen aber weit weniger angenfällig sind als die der Tiere - ein Umstand, der im botanischen Unterrichte außerordentlich zur Geltung kommt - so war dies auch z. T. ein sehr schwieriges Unternehmen.

Auch in dem allgemeinen Teile habe ich, $u m$ ein möglichst greifbares Bild "vom Bau und Leben der Pflanze" zu schaffen, I orphologie und Physiologie a ufsengste zu verschmelzenversucht. Allerdings setzt diese Art der Darstellung auch einen größeren Raum voraus, als diesem Stoffe in Schulbücheru gewöhnlich eingeräumt zu werden pflegt. Daß ich zu diesem "Bilde" auch den reichen morphologischen und biologischen Stoff zusammenfassend rerwendet habe, der in den Einzelbetrachtungen gewonnen worden ist, dürfte allgemeine Znstimmung finden.

Im allgemeinen, wie im speziellen Teile des Buches hoffe ich von neuem dargetan zu haben, daß die gebührende Betonung des Lebens a uch ohne Vernachlässigung der Morplologie möglich ist. Besonders die Einzelbetrachtungen enthalten so genaue "Beschreibungen" der Pflanzen, wie sie in Werken rein beschreibenden Inhalts nur selten zu finden sind. Die „biologische Betrachtungsweise" $\mathrm{z}$ w in g t Lehrer und Schüler geradezu, wie ich hier wiederholt betone, erst sorgfältig das Tatsächliche festzustellen, bevor an die Frage nach seiner Bedeutung herangetreten werden kann. Werden ïber der Erklärung der Tatsachen diese selbst vernachlässigt, dann artet der Unterricht wie in allen anderen Fächern (z. B. in Geographie oder Geschichte) allerding s in ein leeres Geschwätz a us. Dann werden die Bahnen sicheren Wissens verlassen, und eine hohle Phantasterei, eine Sucht, alles erklären zu wollen, macht sich breit. Gerade bei der Beurteilung biologischer Verhältnisse ist in der Schule die größte Vorsicht geboten. Ist eine Erklärung nicht über jeden Zweifel erhaben, so ist sie ausdrücklich als das zu bezeichnen, was sie ist: als eine Vermutung oder dgl. Mehrere neuere Forschungsergebnisse habe ich ans diesem Grunde gänzlich unberïcksichtigt gelassen, was man mir wohl kaum zum Vorwurfe machen dürfte.

Die Systematik, die früher einen der Hauptangelpunkte des botanischen Unterrichts bildete, hoffe ich auf das ihr gebührende Maß beschränkt zu haben. Daß sie keineswegs vernachlässigt ist, geht schon aus der systematischen Anordnung des Stoffes, sowie daraus hervor, daß ich bei jeder sich irgendwie nur bietenden Gelegenheit das Charakteristische der größeren Abteilungen herausgestellt und die natïrliche Einteilung der Pflanzen planmäßig aus ihrem Bau abgeleitet habe (s. besonders den allgemeinen Teil!). Allerdings auf „Vollständig-

* Meine im Jahr 1896 erschienene, aber längst vergriffene, kleine Arbeit: „P fla nzen der Heimat, biologisch betrachtet" dürfte der erste Versuch gewesen sein, unsere bekanntesten Pflanzen in dieser Weise ,der Schule und dem Hause" vorzuführen. 
keit" habe ich weder hier, noch in einem anderen Stoffgebiete irgend welchen Wert gelegt: denn der Schiiler soll durch den Unterricht ja nicht zu einem wandelnden Lexikon gemacht, sondern grïndlich und allseitig gebildet werden. Auch sonst hat sich das System im Interesse möglichster Terein fa ch ung mancherlei Eingriffe gefallen lassen mïssen, wie dies fü $r$ e in Schulbuch ja nicht anders sein kann. Im ïbrigen ist es dem Lehrer gänzlich unbenommen, wie viel er seinen Schülern von dem System bieten will.

Neben den trockenen, geistlosen Beschreibungen und einem Übermaße vou Systematik war es die Terminologie, die früher den Unterricht vielfach gänzlich beherrschte and dem Schüler die Natur oft geradezu verleidete. Durch zahlreiche neuere Schulbïcher, die sich auch in anderer Hinsicht wesentliche Verdienste um die Fortbildung der Methode erworben haben, ist es allerdings besser geworden; aber immer noch trifft man in vielen von ihnen „Beschreibungen", die sich in der Tat nur als eine - Anhäufung botanischer Kunstausdrücke darstellen. Durch die Beschränkung der Terminologie auf das Notwendigste hoffe ich auch hier gangbare Bahnen betreten zu haben. Im allgemeinen Teile ist der aus diesem Gebiete früher erarbeitete Stoff gleichfalls zusammengestellt worden. An mehreren Stellen hat auch eine Erweiterung des Stoffes, sowie eine schärfere Fassung der Begriffe stattgefunden; denn der Schüler, für den dieser Abschnitt des Buches bestimmt ist, muß unbedingt auch imstande sein, ein leichtes Bestimmungswerk* mit Vorteil zn gebrauchen. Betonen möchte ich bei dieser Gelegenheit, daß den Bestim m ung s üb un gen, die nicht selten als etwas sehr Überflïssiges betrachtet werden, nicht nur ein ziemlich hoher formalbildender Wert zukommt, sondern daß eine gewisse Artenkenntnis ohne Zweifel auch die Grundbedingung für eine erfolgreiche Bescliätigung mit der Pflanzenwelt ist.

Wie in dem "Lehrbuche der Zoologie* bin ich auch hier bezüglich der Abbildungen** eigene Wege gegangen. Bei näherem Zusehen wird man leicht finden, daß die Bilder weit mehr sind als ein Mittel, das Buch ansehnlicher zu machen, sondern daß sie einen integrierenden Bestandteil des Buches selbst bilden. Es gibt unter den vielen Bildern allerdings mehrere, durch die der Schüler den Naturgegenstand einfach kennen lernen soll - in dieser Hinsicht dürften besonders die Abbildungen der schwierig zu bestimmenden Gräser dem

* Da es anßerordentlich wïnschenswert ist, daß das dem Unterrichte zugrunde liegende „Lehrbuch" mit der vom Schüler gebrauchten „Flora * linsichtlich des Systems unil der Nomenklatur übereinstimmt, so bin ich in Gemeinschaft mit einem hervorragenden Kenner unserer Pflanzenwelt, meinem Freunde J. Fitschen-Altona, z. Z. damit beschäftigt, ein solches Büchlein herauszageben. Es soll das Bestimmen der Pflanzen in einfachster und leich test e $r$ W eise ermöglichen and in einigen Monaten erscheinen.

** Einige Abbildungen, die für das 1. und 2. Heft bestimmt waren, konnten leider erst nach der Herausgabe beider Hefte fertiggestellt werden, sie wurden daher delu allgemeinen Teile beigefügt, was ich freundlichst zu beachten bitte. 
Lehrer nicht unwilkommen sein! - , in der Mehrzahl der Fälle bringen sie aber bestimmte, im Texte berïhrte Erscheinnngen zur Darstellung. So habe ich z. B. durch die dem Buche beigegebenen Tafeln versucht, die in Worten ansgedrückte Schilderung der betreffenden Objekte gleichsam in eindringlicher "Bilderschrift" zu wiederholen; ich bin - um dies ganz kurz auszudrïcken anfs eifrigste bestrebt gewesen, die Abbildungen inhaltreich zu gestalten nnd sie mit dem Texte in engste Verbindung zu bringen. Daher darf ich wohl mit Zuversicht annehmen, iiber dem Verdachte erhaben zu sein, als wollte ich mich an dem kindlichen Wettstreite beteiligen, der mit großer Heftigkeit zwischen den Verlegern und Verfassern der verschiedenen naturgeschichtlichen Leitfäden entbrannt ist, und der darin besteht, ihren Büchern durch möglichst viele Bilder und in jüngster Zeit noch durch .,bunte" Tafeln einen erhöhten Wert zu verleihen. Diese schmückenden Beigaben können wohl das Auge des Unkundigen bestechen, irgendwelchen methodischen Wert kann man ihnen aber wegen der auffallenden Inhaltlosigkeit mit dem besten Willen nicht zuerkennen.

Bilder der Art, wie ich sie meinem Buche gegeben habe, sind - vou einigen wenigen, die aus anderen Werken erworben oder nach solchen gezeichnet worden sind - selbstverständlich nur $0 \mathrm{riginale}$, deren untrügliche Vorbilder nicht in den "Autoren", sondern in der Natur selbst gesucht wurden. Die Herstellung solcher Abbildungen ist allerdings nicht nur viel mühsamer und zeitranbender als die bekannte "erbliche" Übernahme von einem Buche in das andere - man braucht oft nur ein nenes Buch anfzuschlagen, um darin lanter alte Bekannte zu finden! - sondern stellt anch an die Opferwilligkeit des Terlegers ganz andere Anforderungen.

Endlich sind die Bilder - wie ich zn meiner großen Frende sagen kann von einem wirklichen Künstler entworfen. Sie dürften daher wohl auch imstande sein, das kü nst lerisch e Empfinden der Schüler anregen zu helfen.

Und somit entlasse ich denn das Buch mit den Segenswünschen, mit denen nur ein Vater sein eigen Kind in die Welt senden kann! MIöge es Gutes stiften in Schule und Familie! Möge es dem Lehrer die Arbeit leicht machen, der Jugend Sinn und Herz für das Verständnis und die Schönheit der Natur zu öffuen, und möge es alle, die Kleinen und die Großen, hinfïhren zn dem ewig frischen Quelle der Natur, aus dem es selbst geschöpft ist!

Magdeburg, den 20. März 1903. 


\section{Inhaltsverzeichnis,}

zugleich

\section{eine Übersicht über das dem Buche zugrunde liegende System.}

\section{Hauptabt. Blïten- oder Samenpfl. (Phamerogamae).}

Pfl., die dentlich sichtbare Bliiten besitzen und sich durch Samen fortpflanzen 1

I. Gruppe. Bedecktsam. Pfl. (Angiospermae).

1’hl, deren Samenknospen in einem Fruchtknoten eingeschlossen sind . . . . 1

1. Klasse. Zweikeimbl. Pfl. oder Blattleimer (Dicotyleae).

Keimling mit 2 Keimbl.; Laubbl, mit fiederig oder fingerig angeordneten Hauptnerven; Blütenteile meist in der 5- oder 4-Zahl vorhanden . . . 1

1. Tnterkl. Getrenntblumenbl. Pfl. (Choripetalae).

P’H. in der Regel mit doppelter Blütenhülle (Kelch und Blumenblätter).

Blumenblätter nicht miteinander verwachsen . . . . . . . . . . 1

1. Familie. Hahnenfufgew. (Ranunculaceae) . . . . . . . . . 1

2. Sauerdorngew. (Berberideae) . . . . . . . . . 11

3. $\quad$ Seerosen (Nymphaeaeeae) . . . . . . . . . . 12

4. . Kreuzbl. (Cruciferae) . . . . . . . . . . 16

5. Molngew. (Papaveraceae) . . . . . . . . 23

6.-8. - Erdranchgew. (Fumariaceae), Resedagew. (Resedaceae) unil

Hartheugew. (Hyperieaceae). I. A.: chines. Teestrauch 27

9. Veilchengew. (Violaceae) . . . . . . . . . . 29)

10., Sonnentaugew. (Droseraceae) und einige andere -insektenfressende ${ }^{\text {Pfl. . . . . . . . . . . . } 33}$

11. $r$ Nelkengew. (Caryophyllaceae) . . . . . . . . 36

12., Roßkastaniengew. (Sapindaceae) . . . . . . . . 41

13. . Ahorngew. (Aceraceae) . . . . . . . . . . 48

14. . Orangengew. (Rataceae) .......... . . 49

15., Lindengew. (Tiliaceae) u. nächste Verwandte . . . . . 50

16. $r$ Malvengew. (Malvaceae). I. A.: Kakaobaum . . . . . 52

17. . Storchschnabelgew. (Geraniaceae) ......... . 54

18., Sanerkleegew. (Oxalidaceae) ......... . . 57

19. $₫$ Leingew. (Linaeeae) ............. . . 58

20. Weinrebengew. (Vitaceae) ........... 60

21. $n$ Wolfsmilchgew. (Euphorbiaceae) . . . . . . . 66

22. $"$ Doldengew. (Umbelliferae) . . . . . . . . . 69

23. $\rightarrow$ Efengew. (Araliaceae) .......... . . 75

24. . Dickblattgew. (Crassulaceae) . . . . . . . . 78

25. $r$ Kaktusgew. (Cactaceae) ......... . . 80

26. r. Steinbrechgew. (Saxifragaceae) . . . . . . 81

27.-29. , Nachtkerzengew. (Onagraceae), Weiderichgew. (Lythraceae) u. Myrtengew. (Myrtaceae). I. A.: Mangrovebiume 83 
30. Familie Rosenartige Gew. (Rosaceae) . "

31. - Schmetterlingsblütl. (Papilionaceae) u. nächste Verwandte 99

2. Ǔnterkl. Verwachsenblumenbl. Pfl. (Sympetalae).

P'fl. mit doppelter Bliitenhülle, bei denen die Blumenbl. miteinander verwachsen sind . . . . . . . . . . . . 113

32. Familie. Heidekrantgew. (Ericaceae) . . . . . . . . 113

33. $"$ Schlüsselblumengew. (Primulaceae) . . . . . . . 120

34. " Grasnelkengew. (Plmmbaginaceae) ......... 124

35. n. 36. - Ölbaumgew. (Oleaceae), Enziangew. (Gentianaceae) und nächste Verwandte . . . . . . . . . 124

37. $₫$ Windengew. (Convolvulaceae) .......... 127

38. - Rauhblättr. Gew. (Asperifoliaceae). . . . . . 130

39. . Nachtschattengew. (Solanaceae) . . . . . . . 135

40. $\rightarrow$ Lippenbl. (Labiatae) u. näehste Verwandte . . . . . 146

41. Rachenbl. (Scropholariaceae) u. näehste Verwandte . . 153

42. - Wegeriehgew. (Plantaginaceae) . . . . . . 159

43., Glockenblumengew. (Campanulaceae) . . . . . . 160

44. $₫$ Kürbisgew. (Cncurbitaceae) . . . . . . . . . 162

45. $n$ Labkrautgew. (Rubiaceae) . . . . . . . . . 168

46. $n$ Geibblattgew. (Caprifoliaceae) . . . . . . . 171

47. n. 48. - Baldriangew. (Valerianaceae) и. Kardengew. (Dipsaceae) 173

49. Korbblütler (Compositae).......... 174

3. Unterkl. Blumenblattlose Pfl. (Apetalae)

Pfl. mit einfacher oder fehlender Blütenhülle . . . . . . . . . 190

5ั0. Familie. Becherfrüchtl. (Cupnliferae) . . . . . . . . 190

วl. n. 52. $\quad$ Birkengew. (Betulaceae) u. Walnubgew. (Jnglandaceae) . 198

53. $\pi$ Weidengew. (Salicaceae) . . . . . . . . 199

54. - Nesselgew. (Urticaceae) ......... 205

55. . Hanfgew. (Cannabinaceae) . . . . . . . . 207

56. и. 57 . $\rightarrow \quad$ Ianlbeergew. (Moraceae), Ulmengew. (Ulmaceae) n. nächste

Verwandte . . . . . . . . . . . 208

58. Mistelgew. (Loranthaceae) .......... 210

59. - Osterlnzeigew. (Aristolochiaceae) . . . . . . . 212

60. u. 61. ॠ Seidelbastgew. (Thymelaeaceae), Lorbeergew. (Lanraceae),

I. A. Mruskatnußbaum . . . . . . . . 213

62. $n$ Knöterichgew. (Polygonaceae). I. A.: Pfefferstranch . . 214

63. ๓ Gänsefußgew. (Chenopodiacea) . . . . . . . 216

2. Klasse. Einkeimbl. Ifl. oder Spitzkeimer (Monocotyleae).

Keimling mit nur einem Keimbl.; Lanbbl. in der Regel mit parallel ver-

laufenden Hauptnerven; Blütenteile meist in der 3-Zahl vorhanden • . 218

64. Familie, liliengew. (Liliaceae) . . . . . . . . . 218

65., Binsengew. (Juncaceae) . . . . . . . . 229

66. Narzissengew. (Amaryllidaceae) u, nächste Verwandte . 230

67. - Schwertliliengew. (Iridaceae) . . . . . . . 235

68. „ Palmen (Palmae). I. A.: Banane u. nächste Verwandte 238

69., Arongew. (Araceac) . . . . . . . . . 244 
70. u. 71. Familie. Rohrkolbengew. (Typhaceae), Laichkrautgew. (Najadaceae) 246

72., Gräser (Gramineae) ............ 248

73. Riedgräser (Cyperaceae) ........... 271

74. $₫$ Knabenkrantgew. (Orchidaceae) . . . . . . . 272

75. u. 76. , Frosehlöftelgewächse (Alismaceae) u. Froschlibgewächse

(Hydrocharidaceae) . . . . . . . . 278

II. Gruppe. Nacktsamige Pfl. (Gymmospermae).

Pfl., dẹren Samenknospen nicht in einem Fruchtknoten eingeschlossen sind, sondern sich auf dem offenen Fruchtblatte finden . . . . . . . . 280

77. Familie. Nadelhölzer (Coniferae). I. A.: Palmfarne . . . . 280

?. Hauptabt. Blütenlose- oder Sporenpfl. (Ḱryptogamae).

Pfl., die keine Bläten besitzen, u. deren Vermehrung (vorwieg.) dureh sporen erfolgt 294

I. Gruppe. Farnart. Pfl. oder Gefäß-Sporenpfl. (Pteridophyta).

Pfl., die in Stengel, Blätter u. Wurzeln gegliedert sind u. Gefäßbïndel entbalten 294

1. Klasse. Farne (Filicinae) . . . . . . . . . . . . . 294

2. Klasse, Schachtelhalme (Equisetinae) . . . . . . . . . . . . 304

3. Klasse. Bärlappgew. (Lycopodinae) . . . . . . . . . . . . 309

II. Gruppe. Moose (Bryophyta).

Pfl., die in Stengel und Blätter gegliedert sind oder ein laubartiges Gebilde darstellen, denen echte Wurzeln und Gefäßbïndel fehlen . . . . . . . 309

1. Klasse. Laubmoose (Husci) . . . . . . . . . . . . . . . . 309

2. Klasse. Lebermoose (Hepaticae) . . . . . . . . . . . . 320

1II. Gruppe. Lagerpfl. (Thallophyta).

Pfl., die nicht in Stengel und Blätter gegliedert sind, also ein sog. Lager darstellen

1. Kreis. Algen (Algae).

Lagerpfl, die meist im Wasser leben und Blattgrün enthalten . . . . 321

1. Klasse. Grïnalgen (Chlorophyceae) . . . . . . . . . . 321

2. и. 3. Klasse. Braunalgen (Phaeophyceae) u. Rotalyen (Rhodophyceae) . . 326

f. Klasse. Kieselalgen (Diatomacrae) . . . . . . . . . . . . 328

2. Kreis. Pilze (Fungi).

Lagerpfl. ohne Blattgrïn; Schmarotzer oder Fäulnisbewohner . . . . 330.

1. K7asse. Fadenpilze (Hyphomycetes) . . . . . . . . . . . 330

1. Unterkl. Ständerpilze (Basidiomycetes) . . . . . . . . . 330

2. Schlauchpilze (Ascomycetes) . . . . . . . . . . 338

3. u. 4. , Rostpilze (Uredinaceae) u. Brandpilze (Ustilaginaceae) . . 343

5. Algenpilze (Phycomycetes) . . . . . . . . . 345

2. Klasse. Spaltpilze (Thizomycetes) . . . . . . . . . . 346

3. Klasse. Schlrimpilze (Myxomycetes) . . . . . . . . . . 352

3. Kreis. Flechten (Lichenes).

Lagerpf., die aus Fadenpilzen n. Algen bestehen........... 353 


\section{Vom Ban und Leben der Pflanze (Morphologie und Physiologie).}

1. A bschnitt.

Seite

Vom Ban nud Leben der Zelle . . . . . . . . . . . . . . 357

A. Vom Wesen u. von der Bedentung der Zelle . . . . . . . . . 357

B. Das Protoplasma u. seine Teile................ 359

Ł. Die Zellhant .................... 363

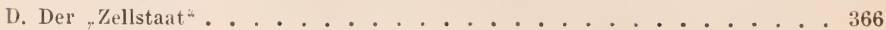

2. Absehnitt.

Vom Ban und Leben der einzelnen Pflanzenteile.

Die Grundformen der Pflanzen . . . . . . . . . . . . . . 367

I. Vom Bau u. Leben des Blattes............. . . 368

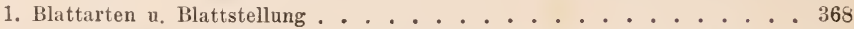

2. Das Blatt als Werkzeug der Aneignung orler Assimilation der Nährstofte 371

A. Die Aneignung oder Assimilation der Nährstofie . . . . . . . 371

B. Nur grüne Pflanzen u. Pflanzenteile assimilieren . . . . . . 376

C. Die Assimilation erfolgt nur im Lichte . . . . . . . . . . 377

D. Die Assimilation n. der feinere Bau des Laubblattes . . . . . . 379

E. Welche organischen Körper werden bei der Assimilation gebildet?. . 385

F. Die Wanderung, Verwenlung n. Aufspeicherung der gebildeten Stofte 387

3. Das Blatt als Werkzeng der Atmung $u$. d. Atmung der Pflanzen i. allgemeinen 390

4. Das Blatt als Werkzeug der Verdunstung des Wassers (od. der Transpiration) 393

II. Vom Bau u, Leben der Wurzel.

A. Die Aufgaben u. Hauptformen der Wurzel . . . . . . . . . 400

B. Die Aufgaben u. der feinere Ban der Wurzel . . . . . . . . . 401

III. Vom Bau n. Leben des Stammes.

A. Aufgabe, Wachstum u. Formen des Stammes . . . . . . . . 408

B. Die Richtnng der Stämme n. Zweige . . . . . . . . . . . . 411

C. Der Bau des Stammes in seinen Grundziigen ... . . . . . . 414

D. Die Gefäßbündel . . . . . . . . . . . . . 417

E. Leitungsbahnen im stamme . . . . . . . . . . . . . 422

F. Bekleidung der Stämme . . . . . . . . . . . . . . 425

G. Festigkeit der Stämme . . . . . . . . . . . 427

IV. Vom Bau u. Leben der Blüte.

A. Die Fortpflanzung u. die Blïte . . . . . . . . . . . . . 429

B. Die Teile der Blüte . . . . . . . . . . . . . 431

C. Die Bliitenstände . . . . . . . . . . . . . 436

D. Die Bestänbung der Blüte . . . . . . . . . . . . . . 438

E. Die Befruchtung der Blüte ... . . . . . . . . . . 444

V. Vom Bau u. Leben der Frueht u. des Samens ........445

\section{Anhang.}

1. Über Pflanzensysteme . . . . . . . . . . . . . . 454

2. Über die geographische Verbreitung ler Pft. . . . . . . . . . 457 


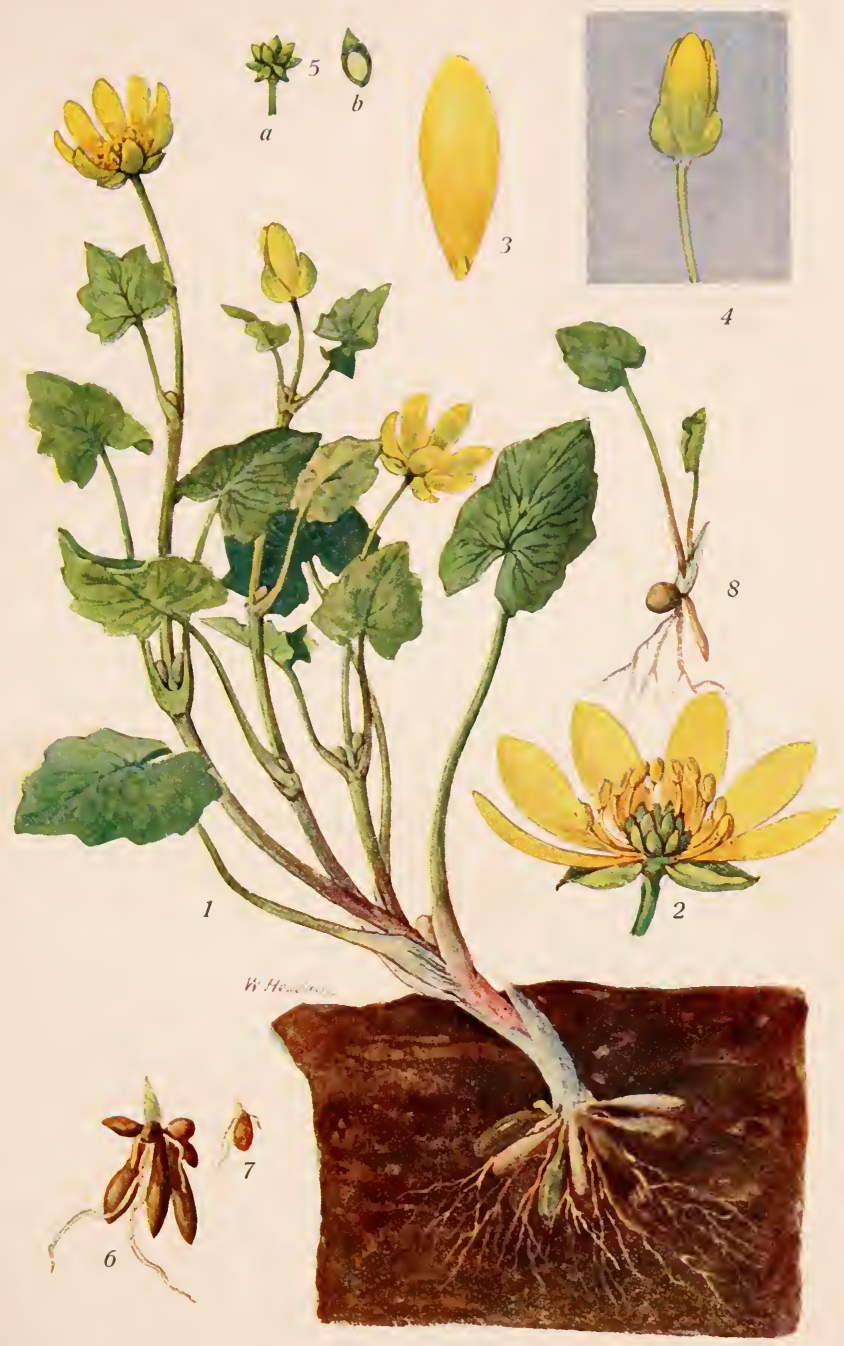

Scharbockskraut (Ficaria verna). 



\section{Hauptabteilung. Blüten- oder Samenpflanzen (Phanerógamae).}

Pflanzen, die deutlich sichtbare Blüten besitzen und sich durch Samen fortpflanzen.

\section{Gruppe. Bedecktsamige Pflanzen (Angiospérmae).} Pflanzen, deren Samenknospen in einen Fruchtknoten eingeschlossen sind.

\section{Klasse. Zweikeimblättrige Pflanzen oder Blattkeimer (Dicotýleae).}

Keimling mit zwei Keimblättern (s. Bohne). Laubblätter mit fiederig oder fingerig angeordneten Hauptnerven. Blütenteile meist in der 5- oder 4-Zahl vorhanden.

1. Unterklasse. Getrenntblumenblättrige Pflanzen (Choripétalae). Pflanzen in der Regel mit doppelter Blütenhülle (mit Kelch und Blumenblättern). Blumenblätter sind nicht miteinander verwachsen.

1. Familie. Hahnenfußgewächse (Ranunculáceae).

Blüten mit zahlreichen Staubblättern, mit einfacher oder doppelter Blütenhülle und meist zahlreichen Fruchtknoten, die von je einem Fruchtblatte gebildet werden (s. Abb. S. 10).

1. Das Scharborkskraut (Ficária verna). Taf. $1 . *$ )

A. Blitezeit und Standort. 1. Kaum hat die höhersteigende Sonne den Winterschnee geschmolzen, so sprießt auf nassen Wiesen, besonders aber unter dem Gebüsch, als erster Frïhlingsbote das Scharbockskraut hervor. Oft schon im März bildet es saftig grüne Teppiche. Im Mai aber ist für die Pflanze bereits - der Herbst gekommen: Die Blätter vergilben, vertrocknen und sind bald gänzlich verschwunden. Das Scharbockskraut ist also eine Pflanze des Vorfrïhlings, die unter Gebüsch und im Grase gedeiht.

2. Die jungen Pflanzen kommen (zu allermeist) aus kleinen Knollen (s. Absch. C.) hervor, die den Winter ïberdauert haben. Genau wie die junge Kartoffelpflanze (s. das.) baut sich auch das junge Scharbockskraut vor allen Dingen aus den Vorratsstoffen auf, die in der Knolle aufgespeichert sind. Es braucht

*) Die im Text eingeklammerten Ziffern beziehen sich hier und in allen folgenlen Betrachtungen auf die Figuren der beigefügten Tafel.

S ch meil, Lehrbuch der Botanik. 
sich also nicht erst Banstoffe zu erwerben, sondern findet solche fertig vor. Da zudem die Knnöllchen bereits im Herbst anfangen zu „treiben“, s o vermag das Scharbockskraut eben so früh im Jahre zu erscheinen. (Vgl. mit anderen Frühlingspflanzen und solchen Pflanzen, die erst im Frühlinge ans Samen hervorgehen!)

3. Im März und April steht das Gebüsch noch kahl da. Die Sonnenstrahlen, ohne die keine grüne Pflanze gedeihen kann, vermögen also bis zum Erdboden und zum Scharbockskrante zu gelangen. Im Mai dagegen bilden die Blätter der Büsche ein so dichtes Dach, daß kaum noch ein Lichtstrahl den Boden erreicht. Auf der Wiese ergeht es dem Pflänzchen ganz ähnlich: die benachbarten, vordem niederen Gräser und Kräuter sind emporgeschossen und rauben ihm das Licht. Darum muß das Scharbockskraut so zeitig im Jahre erscheinen und so zeitig auch seine Lebensarbeit beendigt haben. (Vgl. wit anderen zeitigen Frïhlingspflanzen! Beachte, wie an derselben Örtlichkeit dichtbeschattete Pflanzen des Scharbockskrautes frïher vergilben als freistehende!)

B. Stengel und Bliiten. 1. Der junge Sproß (6. n. 7.), der bereits im Herbst aus den Knollen hervorgeht, hat die Form eines Keils und ist somit wohl befähigt, den Boden zu durchbrechen. Da er einen Mantel aus häutigen farblosen (weil im Dunkeln wachsenden) Hüllblättern besitzt, so sind die zarten Teile im Innern gegen Verletzungen, die beim Durchbohren der Erde ja unvermeidlich wären, wohl geschïtzt. Hat der Sproß die Erdoberfläche erreicht, damn stellen die Hüllblättchen ihr Wachstum ein (1 u. 8). Je tiefer die Knollen liegen, desto länger sind daher anch die Hüllblätter. (Stelle entsprechende Versuche an!)

2. Neben dem Scharbockskrant wächst bis zu beendeter Blïtezeit keine andere Pflanze, die ihm das Licht streitig machen könnte. Der fleischige, hohle Stengel erhebt sich daher vielfach nur an der Spitze vom Boden. Trotzdem sind aber alle

3. Blätter dem Lichte ansgesetzt; denn sie besitzen sehr verschiedene Größe.

a) Die unteren, langen Blattstiele rücken ihre großen Blattflächen weit vom Stengel ab, so daß die kurzgestielten und kleinen oberen Blätter in der Nähe des Stengels genïgenden Platz finden. Der untere, scheidenartige Abschnitt der Blattstiele umgibt schïtzend die jungen, noch zusammengefalteten Blättchen (öffne auch einen jungen, keilförmigen Sproß!) und später die in deu Blattwinkeln sich bildenden Knollen (s. Absch. C. 2 b).

b) Die herzförmigen und meist gekerbten Blattflächen sind fleischig und gänzlich unbehaart. Schntzmittel gegen eine zu starke Verdunstung finden wir bei ihnen ebensowenig wie z. B. bei den Blättern des Windröschens (s. S. 7, c); denn der Boden, dem das Scharbockskraut entsprießt, ist im Frühjahre stets feucht. Zudem findet sich die Pflanze immer truppweis: sie beschattet den Boden und schützt ihn infolgedessen vor Austrocknung. 
c) Die saftigen Blätter müßten - so sollte man meinen - für Tiere eine vortreffliche Nahrung bilden. Dem ist jedoch nicht so. Selbst die gefräßigen Schnecken, die mit dem Scharbockskraute oft in großer Zahl dieselbe (̈)tlichkeit bewohnen, verschmähen sie. Die Blätter sowohl, wie alle iibrigen Teile der Pflanzen sind nämlich durch einen scharfen (schwach giftigen) St of f geschïtzt (kane ein Stiick der Pflanze!), wie folgender Versuch lehrt: Legt man hungernden Schnecken frische Blïtter vor und solche, die in Alkohol ansgelaugt, getrocknet und dann wieder in Wasser ausgewaschen und aufgeweicht wurden, so findet man, daß die Tiere letztere verzehren, erstere aber gänzlich unberïhrt lassen oder doch nur wenig benagen. -- Frïher wurden die Blätter als Heilmittel gegen den Skorbut oder Scharbock benntzt, d. i. eine Krankheit, dic besonders durch andiuterndon Genuß von Pökclfteisch bei langen Seereisen die Schiffer ergreift (Name!). „Feigwur" heißt die Pflanze, weil sie als Heilmittel gegen Feigwarzen diente, das sind eiternde Geschwüre bei gewissen, schlimmen Erkrankungen.

C. Blüte und Knollen. 1. Bl ïte (2.) Ein meist dreiblätteriger Kelch, sowie 8 oder mehr Blumenblätter ungeben die zahlreichen Staubbliitter und die gleichfalls zahlreichen Stempel. Jeder Stempel besteht (s. Frucht des Rittersporns S. 10!) ans einem einzigen Fruchtblatte (Hahnenfufblïte). Die einsamige Frucht (5 a u. b) öffnet sich bei der Reife nicht (Schließfrucht); erst durch den hervorbrechenden Keim wird ihre Hülle gesprengt.

a) Die goldgelben, außen zum größten Teil firnisglänzenden Blunenbliitter (3.) lassen die Blïte, die sich stets ein Stiick ïber das dunkelgrïne Blattwerk erhebt (warum?), wie einen leuchtenden Stern („Sternblümchen“) erscheinen, der die wiedererwachten Insekten zum

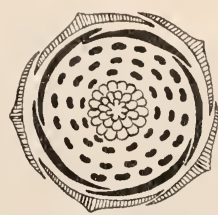

Grundriß (Diagramm) einer Hahnenfuß̧blite.*) Besuch einladet. Die Stempel bilden meist den Anflugsplatz, Blïtenstaub (zahlreiche Staubblïtter!) und Honig die Kost der Gäste. Der Honig findet sich am Grunde der Blumenblätter in je einer kleinen Girube, die von einer Schuppe bedeckt ist (Bedeutung der Schuppe?).

b) Mit Beginn der Dunkelheit schließt sich die Blïte (4): Kelch und Blumenblätter neigen sich zusammen und ïberdecken die inneren Blïtenteile wie ein Dach. Auf diese Weise wird die Blïte gegen zı großen Wärmeverlust und das Bliiteninnere gegen Befenchtung durch nächtlichen Tau geschïtzt. Wenn

*) Für das Verständnis der Blütengrundrisse sei folgendes bemerkt: Der Blütengrundriß besteht - wie z. B. in dem Diagramm der Rapsblüte (S. 18) deutlich zu sehen in der Regel aus 5 konzentrischen Kreisen. Anf dem 1. Kreise liegen die Kelchblätter (schraffiert), auf dem 2. die Blumenblätter (schwarz), auf dem 3. und 4. die Staubblätter (an der Form kenntlich) und auf dem 5. der Fruchtknoten mit den Samenanlagen. (In der Hahnenfußblüte sind die Staubblätter in einer Spirale angeordnet und melırere Fruchtknoten vorhanden.) 
wir bedenken, daß es ohne Wärme kein Pflanzenleben gibt (Beweis!), daß die Bliiten sehr zarte Gebilde sind, daß es nachts jetzt oft noch empfindlich kalt ist, und daß der Blïtenstaub durch Befeuchtung leicht verdirbt: so wird uns die Wichtigkeit dieser Einrichtung wohl verstindlich. Da die Kelchblïtter anf der Rückseite grünlich und die Blumenblätter daselbst ohne Glanz sind, erscheint die Bliite jetzt ganz unauffallig! Und das ist durchaus kein Nachteil für die P'flanze: denn die wärmeliebenden Insekten haben sich in sicherem Schlupfwinkel gleichfalls zur Ruhe begeben. Bei unfreundlichom Wetter bleiben die Bliten anch tagsïber geschlossen.

2. Knollen. Die Anzahl der blïtenbesuchenden Insekten ist in März und April weit geringer als in den wiirmeren Honaten. Daher unterbleibt beim Scharbockskraut auch vielfach die Bestäubung. Aber auch wenn die Blüten von zahlreichen Insekten besucht werden, setzen sie doch nur selten Früchte an: Die Pflanze rettet sich meist - wie wir bereits oben gesehen haben - mit Hilfe von Knollen in das nächste Jahr hinüber.

a) Die keulenförmigen Wurzelknollen sind verdickte Wurzelfasern, die zumeist in einem Büschelchen vereinigt bleiben. Wie aus der "alten" Kartoffel (s. das.) baut sich aus den Vorratsstoffen, die in den Wnrzelknollen aufgespeichert sind, die junge Pflanze auf. Infolgedessen schrumpfen die „alten“ Knollen immer mehr zusammen, bis sie endlich gänzlich verschwinden. Unterdes aber haben die Blätter neuen Baustoff bereitet. Er wandert nach abwärts und wird in neuen Wurzelknollen aufgesammelt, die sich am unteren Ende des Stengels bilden.

b) Die Vorratsstoffe lagert die Pflanze noch an einer anderen Stelle ab: In den Blattwinkeln entstehen schmutziggelbe Knospen, die gleichfalls die Form von Knnollen haben und Weizenkörnern entfernt ähnlich sind (1). Da aus ihnen im nächsten Jahre auch Pflänzchen hervorgehen, werden sie als Brutknospen oder Brutknollen bezeichnet. Nach dem Absterben der Pflanze findet man sie oft in großen Mengen am Boden liegen („Himmelsgerste“, Sage vom Getreideregen). Durch Regengiisse werden sie oft weithin verschwemmt, dienen daher auch der Verbreitung der Pflanze.

\section{Die nächsten Verwandten des Scharbockskrantes}

haben im wesentlichen den gleichen Blüten- und Fruchtban. Sie besitzen aber 5 Kelchund Blumenblätter. In sehr wechselvoller Gestalt und als Bewohnerin der verschiedensten Örtlichkeiten tritt uns die Gattung Hahnenfų̣ (Ranúnculus) entgegen. Mit Tausenden gelber, leuchtender Blüten überstreut der scharfe Hahnenfuļ (R. acer) im Frühjahre unsere Wiesen. Bei Eintritt der Dunkelheit sind die Blüten aber wie verschwunden: sie haben sich nicht nur wie die des Scharbockskrautes gesehlossen, sondern sind auch infolge der Krïmmung ihrer Stiele mehr oder weniger nickend geworden. (Beachte daraufhin auch die anderen Hahnenfubarten!) Durch einen scharfen, giftigen Stoff (Name!) ist die Pflanze gleich den meisten anderen Hahnenfußgewächsen gegen Tierfraß gesehützt. Im lleu dagegen wird sie von den Weidetieren verzehrt, weil der Giftstoff durch Trocknen verloren geht. Durch den runden (ungefurehten, Blütenstiel unterscheidet sich der scharfe Hahnenfub leicht von den beiden sehr ähnlichen und gleichfalls überall häufigen 
Arten, dem knolligen und dem kriechenden Halınenfuß (R. bulbisns und repens), die beide gefurchte Bliitenstiele besitzen. Wie schon die Namen andenten, ist erstere Form an der knolligen Ansehwellung des Stengelgrundes (Vorratsspeicher!) und letztere an den langen Ausläufern leicht zu erkennen. - An Gewässern und anf feuchten Wiesen findet sich die giftigste Art, der Gifthalımenfug (R. sceleratus), eine bis $1 \mathrm{~m}$ hohe, stark verzweigte und saftige Pflanze mit vielen kleinen Blüten. - Mehrere Hahnenfularten sind auch die Stammeltern der als Gartenzierpflanze bekannten , Goldknöpfehen".

Der Wasser-Iahmenfụ̧ (Batráchium aquátile) ist ein bekannter Bewohner unserer stehenden und langsam fließenden Gewässer. Durch zablreiche Wurzeln ist er im schlammigen Grunde verankert, und den Wasserspiegel iiberstreut er oft auf weite Strecken hin mit zarten, weißen Blütensternen. Seine Stengel, die gleich den Blättern aulerhalh

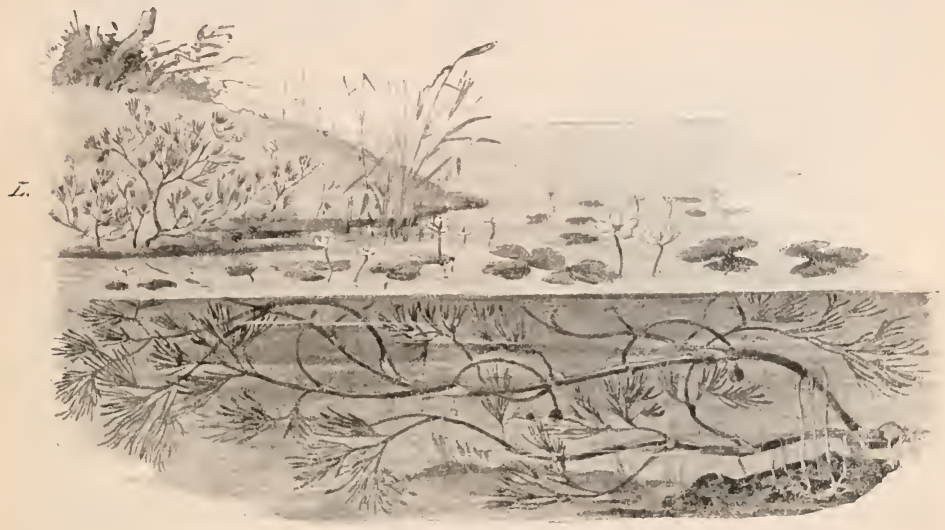

Wasser-Hahnenfuß L. dessen „Landform" (1/2 nat. Gr.).

des Wassers kraftlos zusammenfallen, sind wie die Blattstiele der Seerose (vgl, beide Pflanzen auch nach anderen Pnnkten!) von Luftkanälen durchzogen, so daß sie vom Wasser getragen werden (darum können sie auch so lange Seitenzweige treiben!), und auf der Wasseroberfläche breitet er meist zarte Schwimmblätter aus, die alle Eigenschaften der Seerosenblätter besitzen. Durch die haarförmig zerteilten, untergetauchten Blätter, die sich bei zahlreichen anderen Wasserpflanzen wiederfinden (Beweis!), unterscheidet sich der Hahnenfuß aber wesentlich von der Seerose. Welche Bedentung diese eigentïmliche Blattform hat, ist leicht einzusehen, wenn man folgendes beachtet: Schneidet man einen Zweig der Pflanze ab, so wächst er weiter, auch wenn er keine Wurzeln besitzt, ein Zeichen, daß die Nahrungsaufnahme nicht dureh die Wurzeln stattfindet. Sie erfolgt vielmehr durch die zarte Oberhaut der Stengel und Blätter und wird nm so erfolgreicher sein, je größer die Oberfläche dieser Teile ist. Ferner: im Wasser herrscht ein gedämpftes Licht, und in ihm ist nur eine geringe Jenge von atmosphärischer Luft gelöst, deren Sauerstoff von der Pflanze eingeatmet wird. Je größer aber die 
Oberfäche der Pflanze ist, desto erfulgreicher kann auf sie das Licht wirken, und desto lebhafter wird auch die Atmung sein. Da nun stark zerteilte Blätter eine größere Oberfläche besitzen als ungeteilte von gleielıer Blattmasse (selıneide cin scheibenförmiges Stück einer Kartoffelknolle in Streifen und beachte, wie sich die Oberfläche vergrößert!), so leuchtet die Bedeatung dieser Blattform für untergetanchte Blätter olıne weiteres ein. Endlich wird aneh ein solches Blatt durch die Bewegangen des Wassers bei weitem nicht so leicht zerrissen, wie ein ungeteiltes. Die schwimmenden Blätter dagegen, die mit jeder Welle auf und nielersteigen, bedürfen wic die Secrosenblätter eines solches Schutzmittels nicht. - In fließendem Wasser nimmt die Pflanze oft ein verändertes Ausselien an: sie bildet gewöhnlich keine Schwimmblätter; die Stengel sind lang und riemenförmig and die Blattzipfel stark verlängert und fast parallel laufend. (Erkläre diese ${ }_{n}$ Anpassungserscheinungen" ") - Versiegt das Gewässer, so stirbt der Wasser-HahnenfuB nicht: Die zarten Blätter gehen freilich zu Grunde; aus den Blattwinkeln aber wachsen kurze, kräftige Stengel hervor, an denen zwar anch zerteilte, jedoch weit dickere und steifere Blätter liervorsprossen. Eine gleiche Veränderung ist anch an solchen Teilen der Pflanze zu beobachten, die ïber das Wasser ragen oder auf das Trockene geraten. Diese „Landform" wird von der Winterkälte getötet, wälırend die „Wasserform" überwintert (s. Seerose).

\section{Das Busch-Windröschen (Ancmóne nemorósa). Taf. 2.}

1. Standort und Blitezeit. Die Pflanze bewolınt den laubbedeckten Boden in Busch (Name!) nnd Wald. Sie blüht daher wie das Scharbockskrant zeitig in Jahre (April und Mai - "Osterblnme“) und stirbt mit Eintritt des Sommers ab. Da sie aber das dichteste Gebïsch, also den tiefsten Waldesschatten meidet, so kann sie auch etwas später als jene Pflanze erscheinen und auch später wieder vom Schamplatze abtreten; denn an ihren Standorten dringen die Lichtstralılen anch später im Jalıre noch bis zum Boden hinab. Das frïhzeitige Erscheinen wird wie bei dem Scharbockskraut durclı das Vorhandensein eines Vorratsspeichers bedingt. Es ist dies

2. der nnterirdische Stamm, der Wnrzelstock, der von der Lanbdecke wohl geschützt den Winter überdanerte. Er ist federkieldick, von brauner Farbe und liegt wagerecht im Boden, in den er zahlreiche Wnrzeln sendet. Gräbt man ilın im Herbst aus, so findet man an einem seiner beiden Enden bereits den jnngen Trieb, an dem alle oberirdischen Teile schon zn erkennen sind (s. w. n.), eine Tatsache, die das frühzeitige Erscheinen der Pflanze noch mehr erklärlich macht. An der Stelle, an der sich der Trieb erhebt, findet sich anßerdem eine von weißen Blättchen umgebene Endknospe. Untersucht man den Wurzelstock zn oder - noch besser - nach der Blütezeit wieder, dann sieht man, wie diese Knospe durch fortgesetztes Wachstum den Wurzelstock iiber jenen Punkt himans verlängert hat (genau, wie dies an wachsenden oberirdischen Stämmen geschieht): der IVnrzelstock verjüngt sich beständig in dem Maße, in dem er am Hinterende abstirbt. Die Pflanze wandert also langsam weiter und gelangt somit fortgesetzt in einen Boden, dem sie die nährenden Bestandteile noch nicht entzogen hat. Die weißen Hüllblättchen schïtzen die im Boden allmählich vordringende Knospe vor Verletzungen. 


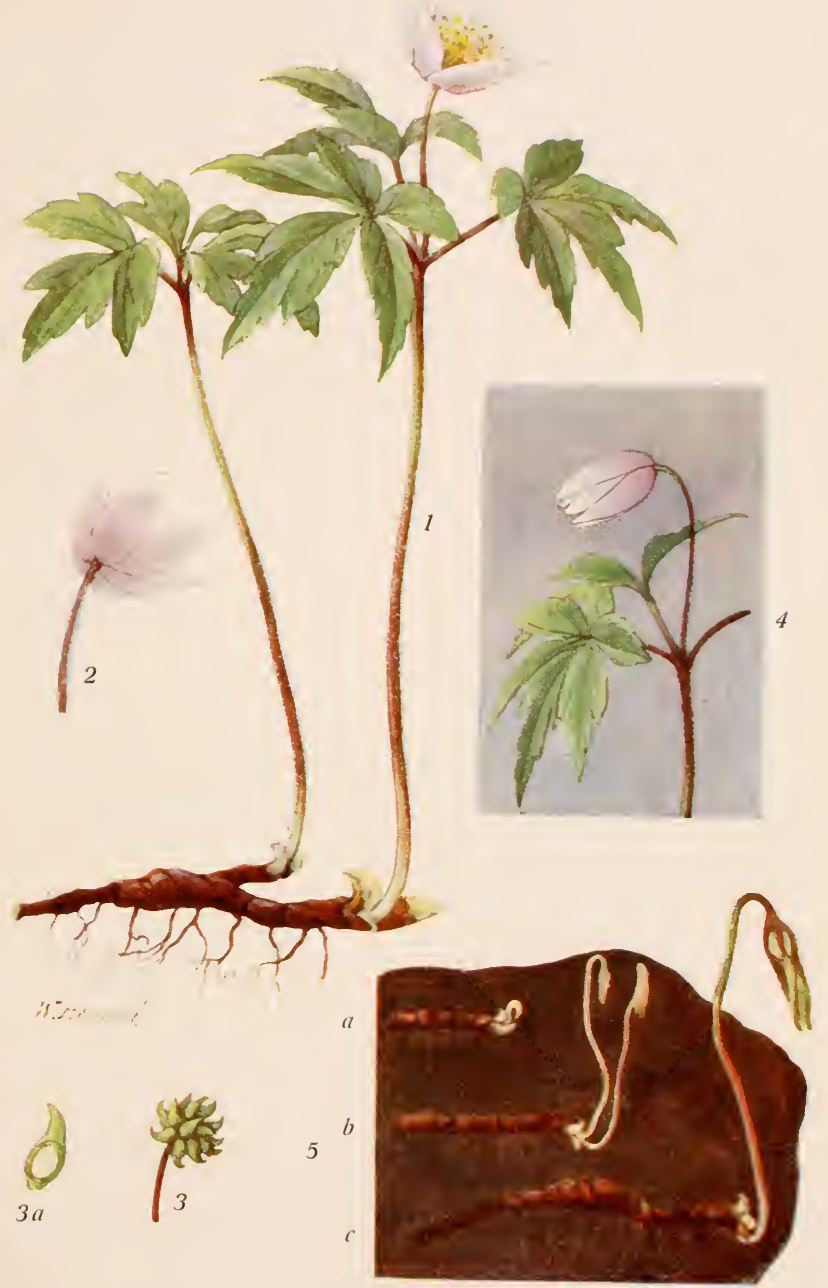

Busch-Windröschen (Anemone nemorosa). 

Haben sie ihre Anfgabe erfüllt, dann sterben sie ab, Narben am Wurzelstocke zuriicklassend. Durch seitliche Knospen entstehen am Wrurzelstocke Zweige (genau wie an den oberirdischen Stämmen). Stirbt der Wurzelstock an der Terzweigungsstelle ab, so wird der Zweig selbständig. Die Verzweigung ist hier also ein Mittel der Vermehrung, und zwar ein außerordentlich wichtiges, weil die Pflanze wie das Scharbockskrant nur selten Frichte hervorbringt.

3. Die zarte Blïte, die fast das Aussehen eines Röschens hat, und schon beim leisesten Winde hin und herschaukelt ("Windröschen“), steht am Ende eines langen Stieles. Wir finden an ihr, sowie an der Frucht (3.) die Verhältnisse des Scharbockskrautes wieder (Beweis!). Sie hat aber eine einfache Bliitenhïlle, die aus sechs weißen und außen oft rötlich angehauchten (1. und 2.) Blättern besteht. Da ihr der Honig fehlt, sind die besuchenden Insekten allein auf den Blïtenstaub angewiesen (zahlreiche Staubblätter! vgl. auch mit Klatschmohn!) Nachts und bei regnerischem Wetter schließt sich die Blüte wie die des Scharbockskrautes. Durch Krïmmung des Blütenstiels neigt sie sich aber seitwärts. - An dem Blïtenstiele finden sich stets drei mehrfach geteilte, grïne

4. Blätter. Untersucht man die Pflanze im Herbst, so sieht man, wie diese noch sehr kleinen und blassen Gebilde die winzige Blüte schützend umhïllen. Man bezeichnet sie daher als Ḧ̈llblätter. Das einzige, den Hüllblättern sehr ähnliche eigentliche $\mathrm{Blat}$ t entspringt mit einem langen Stiele neben dem Blïtenstiele oder an einer Verzweigung des Wurzelstockes oder fehlt auch gänzlich. Es ist im Herbste gleichfalls sehon in der Anlage vorhanden.

a) Sind denn aber - so muß man sich fragen - die zarten, zerteilten Blattflächen und die noeh zarteren Bliiten imstande, den Erdboden zu du rchbrechen, ohne sich dabei stark zu verletzen? Sie wären es sicher nicht, wenn ihnen hierbei nicht eine Eimrichtung zu Hilfe kime, die wir beim Bohnenkeimling wiederfinden: Die Stiele krïmmen sich stark nach oben, so daß sie gleichsam Erdbrecher darstellen. Bei fortgesetztem Wachstum heben sie infolgedessen die Erde empor, so daß dieselbe schließlich auseinanderbricht.

b) Zun Tindröschen können - zumal wenn die Bäume belaubt sind Lichtstrahlen nur in beschränktem Maße gelangen. Je größer aber die Blätter sind, desto mehr Lichtstrahlen vermögen sie aufzufangen, und je dünner sie sind, desto besser können sie durchlenchtet werden. Das Vindröschen besitzt darum verhältnismäßig großc und dünne Blätter.

c) Pflïckt man Windröschen zum Strauße, so welken sie viel schneller als Pflanzen, die auf dem Felde oder gar an öden Stellen wachsen. Wie erklït sich diese Erscheinung? Da der Boden des Laubwaldes stets reich an Fenchtigkeit ist, braucht das Windröschen mit dem Wasser nicht haushälterisch umzugehen. Es bedarf daher anch aller der Ausriistungen nicht, die zahlreiche andere Pflanzen besitzen, um die Verdunstung einzuschränken: es seien nur genannt die Behaarung, die starke Oberhaut und die Kleinheit der Blattliächen (s. z. B. Königskerze und Mauerpfeffer). Das Windröschen besitzt daher nicht. nur, wie erwälnt, verhältnismäßig $g r \circ \beta e$ Bläter, sondern diese 


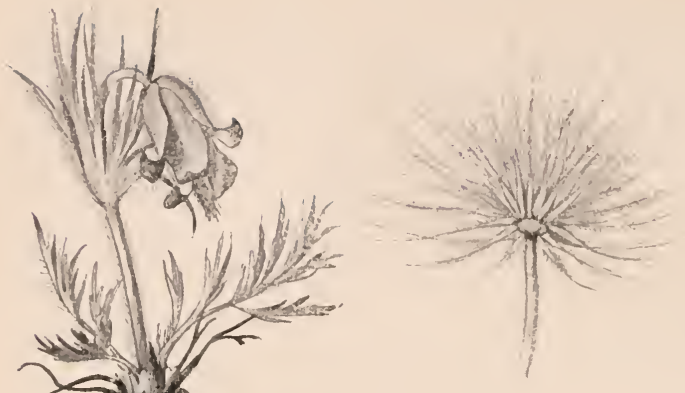

Kuhschelle (wenig verkl.). Die oberirdisehen Teile der abgebildeten Pflanze waren $7 \mathrm{~cm}$ hoch; die (hier des Raumes wegen abgeschnittene)Wurzel dagegen maß $48 \mathrm{~cm}$. Daneben: Fruchtstand. sind auch wie alle anderen Teile derPflanze nur sehr gering behart und anßerordent li c h zart. (Ganz ähnliche Blätter haben darum anch Lerchensporn, Einbeere, Frühlingsplatterbse und zahlreiche andere Waldpflanzen.)

\section{I)ie nächsten Verwandten des Windröschens.}

In der Gesellschaft des Busch-Windröschens findet sich vielfach das ganz ähnliche gelbbliihende Wintröschen (A. ranunculoídes). - Trockenere Laubwälder als beide bewohnt die freundliche Leberblnme (Hepática tríloba). Die Hüllblätter der prächtig blauen Blüten haben ganz die Stellung und das Aussehen eines wirklichen Kelches. (Beweis! Beachte, wie die Blumenblätter mit den Staubblättern wachsen und wie sich die Blüte abends schließt und nickend wird! Bedeutung dieser Erscheinungen?) Während des Blühens kommen auch die eingerollten und stark behaarten jungen Blätter zum Vorschein (Bedeutung dieser Eigenschaften?). Da die Blätter erst im nächsten Frähjahre absterben, sind sie lederartig wie bei dem Epheu (s, das). Fräher wurden sie, weil sie die Form einer Leber haben, als Heilmittel gegen Leberleiden benutzt (Name!). - Eine Bewohnerin sonniger Hügel und lichter Kiefernwälder ist die Kuhschelle (Pulsatilla praténsis), die ihres giftigen Saftes wegen (Schutzmittel gegen Weidetiere!) in der Medizin verwendet wird. Infolge der außerordentlich tiefgehenden Wurzel, der seidenartigen Behaarung und der Zerteilung der Blattfächen vermag sie der Wasserarmut ihrer Standorte zu trotzen. Die hängende, dunkelviolette Blüte gleicht einem Glöckchen (Name! - Aus Kühchenschelle ist Küchenschelle geworden!). 'Die Früchte besitzen je einen langen, federigen Anhang (der verlängerte Griffel) und können infolgedessen durch den Wind leicht verweht werden. - Dieselbe Flugausrüstung finden wir bei den Früchten der Waldrebe (Clématis vitálba). Die Pflanze ist eine der wenigen Lianen unserer heimatlichen Wälder (fehlt aber im Norden und Osten Deutschlands). Als Kletterwerkzeug dienen die Stiele der gefiederten Blätter. Sie werden 
wie Ranken um andere Gegenstände geschlungen, und verbolzen und verdicken an der betreffenden Stelle (vgl. mit Weinstock!). Des Klettervermögens wegen benutzt man die Pflanze, obgleich sie nur kleine, weiße Blüten besitzt, gern zur Bekleidung von Lauben und dergl. Die vielfach angepflanzten großblumigen Waldreben sind südeuropäische Arten.

\section{Die Sumpfdotterblume (Caltha palństris).}

A. Wie sie griint. Im Sumpfe (Name!), auf feuchten Wiesen, an den Rändern von Gräben und Bächen, kurz an wasserreichen Örtlichkeiten ist die allbekannte Dotterblume anzutreffen. Diese Stellen fliehen die meisten Pflanzen. Man wird daher bei der Dotterblume sicher zahlreiche Einrichtungen finden, die dem Leben im Sumpfe entsprechen.

1. Da ihr Wasser stets im Überfluß zur Verfïgung steht, braucht sie wie Pflanzen trockener Standorte (z. B. Kuhschelle) die Wurzeln nicht tief in die Erde zu senken. Die Wurzeln breiten sich daher nur in der obersten Bodenschicht aus. Um in dem oft sehr weichen Grunde aber Halt zu gewinnen, muß die Pflanze stark verankert sein. Daher strahlen von dem kurzen, unterirdischen Stamme (Wurzelstocke) auch zahlreiche, strangartige Wurzeln nach allen Seiten aus.

2. Im Gegensatz zu vielen „dïrren" Pflanzen trockener Standorte (s. aber Mauerpfeffer) sind bei der Dotterblume ferner alle grünen Teile saftstrotzend, fleischig. Und von den zahlreichen Mitteln, durch die sich diese Pflanzen gegen eine zu starke Ausdïnstung des eingesogenen Wassers schiitzen, finden wir hier (wie beim Windröschen; s. S. 7, c) nichts. So ist die Dotterblume z. B. an allen ihren Teilen völlig unbehaart und im Besitz

3. sehr großer Blätter. Die nierenförmigen und meist schwach gekerbten Blattflächen werden (wie beim Scharbockskraute) von sehr verschieden langen Stielen getragen; je weiter oben sie an dem hohlen Stengel stehen, desto kürzer sind sie gestielt. Die längsten Stiele besitzen die großen Blätter, die direkt aus dem Wurzelstocke entspringen. Infolge dieser Einrichtung beschatten die oberen Blätter die unteren nicht, so daß alle der belebenden Sonnenstrahlen teilhaftig werden. Die rinnigen Blattstiele sind nach dem Stengel zu stark verbreitert und umfassen ihn wie eine Scheide. Betrachtet man die Pflanze in ihrer Entwicklung, so sieht man, daß die scheidenförmigen Abschnitte der Blattstiele Schutzhïllen für die zarten, jungen Teile sind. (Vgl. nach den angegebenen Punkten die anderen dir bekannten Pflanzen feuchter Stellen und des Sumpfes!)

B. Wie sie blüht. 1. Zur Frühlingszeit entfalten sich an der Pflanze zahlreiche „H h h n en fußbl ü t en“, die gleich der des Windröschens eine einfache Bliitenhülle besitzen. Infolge der Größe und dottergelben Farbe der 5 Blätter (Name! Daher auch Butterblume!) leuchten die Bliiten weithin und locken zahlreiche Insekten zur Bestäubung herbei. Der Honig wird in je einer Vertiefung zu beiden Seiten der zahlreichen Fruchknoten abgeschieden.

2. Solange sich die Bliite im Knospenzustande befand, Stempel und Staubblätter also noch nicht völlig entwickelt waren, solange konnten auch die 
Insekten der Pflanze jenen wichtigen Dienst nicht erweisen. Darum war bis dahin in der Blïte kein Honig zu finden, und die Blïtenhïlle, welche die zarten, inneren Organe noch schïtzend umgab, war unscheinbar grün gefürbt. - Die geschlossenen Blïtenknospen werden in Essig eingelegt und als "deutsche Kapern" verspeist. (Die „echten“ Kapern sind die Blïtenknospen des Kapernstrauchs [Cápparis spinisa], der in Sïdemropa und Nordafrika gedeiht.)

3. Ist die Bestäubung vollzogen, so versiegt der Honigquell und die nutzlos gewordenen Blumenblätter fallen ab. Die nummehr sich ausbildenden Fr ï ch te besitzen gleich denen der nächsten Verwandten (s. w. n.) zahlreiche Samen. Würden die Samen sümtlich in der Fruchthülle zn keimen beginnen, wie dies bei den bisher betrachteten Hahnenfußarten geschieht, so würden die jungen Pflänzchen auf einem Trupp zusammenstehen und sich gegenseitig Licht, Nahrung und Platz streitig machen. Die Frïchte können daher nicht Schließfrïchte sein wie die jener Arten: sie mïssen sich öffnen, so daß die Samen verstreut werden können (Springfrïchte). Das Öffnen geschieht beim Austrocknen der Fruchthïlle durch einen Lüngsriß.

\section{Die nïchsten Verwandten der sumpfitotterblume.}

Der Feld-Rittersporn (Delphíninm consólida) zählt zn den bekanntesten Ackernnkräuterı, seine azurblane Blüte aber zu den sehönsten Feldblumen. Während zur Erntezeit die Sense alle größeren Aekerpflanzen tötet, bleibt der Rittersporn am Leben:

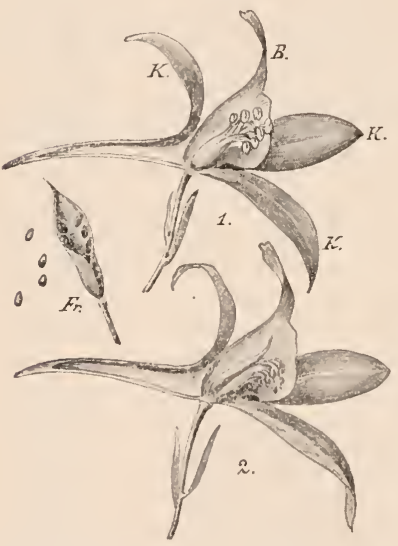

Feld-Ritterspor'n: 1. Blüte mit reifen Staubblättern. K. Kelehblätter. B. Die verwachsenen Blumenllätter. 2. Blüte mit reifer Narbe. Fr. Frncht; der Wind hat einige Samen ausgeschüttelt. (nat. Gr.). er treibt ans dem Stumpfe des Stengels von nenem Seitenzweige und blüht bis in den Ilerbst hinein. Vermöge der langen Pfahlwnrzel und der winzigen, zerteilten Blattfläehen vermag er diese troekenste Zeit des Jahres leieht 7.0 iiberstehen (vgl, mit anderen Trockenlandpflanzen). Die Blnmenblätter (B.) sind $\mathrm{zu}$ einem kleinen, helmartigen Gebilde verwachsen, das den Bliitenstanb gegen Tau und Regen schützt und am Hinterende einen Honigsporn (Name!) trägt. Die Anlockung der Insektell ist in erster Linie dem weit größeren Kelche (K.) ïbertragen, der daher gleichfalls gefärbt ist. Sein oberes Blatt ist in einen langen Sporn ausgezogen, der den Honigsporn wie eine Scheide schützend umgiebt. Da der Ionig tief geborgen ist, so vermögen nur langrüsselige Insekten bis z.u ihnı vorzudringen. In jüngeren Blüten, in denen die Staubblätter den einzig vorhandenen Stempel noch gänzlich umhüllen, stehen die Stanbbeutel vor der öffnung des Sporns. In älteren Blüten dagegen nimmt die nunmelır reife und freistehende Narbe diese Stelle ein. Es kann daher nieht ausbleiben, daf das 
saugende Insekt Blütenstaub jüngerer Bliiten zur Narbe älterer trägt, also Fremdbestäubung herbeiführt. Vor allen Dingen ist es die Gartenhummel, die der Pflanze diesen Dienst erweist. - Ganz ähnlich erfolgt die Bestäubung, und zwar gleichfalls ausschlieblich doreh Hummeln, bei zwei bekannten Gartenpflanzen, der Akelei (Aquilégia vulgáris) und dem Sturmhut (Aconitum napéllus). Die Akelei oder ,falsche Glockenblume" (warum?) komnt wild hier und da auch in Wäldern vor. Die Heimat des Sturmhuts, dessen sehr scharfes Gift in der Heilkunde Verwendung findet, sind die AIpen, sowie die Gebirge Süd- und Mitteldeutschlands. - Von dortber stammt auch die vielfach in Gärten angepflanzte schwarze Nieswurz (Helléborus niger), so genannt, weil ihre schwarze Wurzel im gepulverten Zustande Niesen erregt. Mitten im Winter entfaltet die Pflanze ilıre prächtigen, schneeweißen Bliiten ("Schnee- oder Christrose“), in denen sich ein Kranz zierlichster, tütenförmiger Honigbehälter (d. s. die umgewandelten Blumenblätter) findet. (Beschreibe die interessanten Blüten der letztgenannten Pflanzen näher und verfolge ilure Bestäubnng!) - Auch die in unsern Gärten meist mit gefiillten Bliiten gezogenen P'fingstrosen (Paeonia) sind HahnenfuBgewäelıse (Name!).

Als weitläufige Verwandte der betrachteten Pflanzen wären der Tulpenbaum (Liriodéndron tulipifera) und die prächtige Maønolie (Magnỏlia grandiflóra) zu nennen, die beide aus Amerika stammen und bei uns in Parks gepflegt werden.

\section{Familie. Sauerdorn- oder Berberitzen-Gewächse (Berberídeate).}

\section{Der Sauerlorn oder die Berberitze (Bérberis vulgáris).}

1. Der Sauerdorn findet sich wild in Hecken nnd Gebïschen und ist einer unserer beliebtesten Ziersträucher. In der Nähe von Getreidefeldern sollte man ihn aber nicht dulden. Auf der Unterseite der

\section{Blätter kommen näm-} lich häufig rostfarbene Flecke ror, die Sporenlager des Berberitzenuostes, dessen Gefährlichkeit wir bei der Betrachtung des Getreiderostes noch kennen lernen werden. Neben den gewöhnlichen, scharfgeziilınten Blättern fiuden sich an den jïngeren Zweigen noch Blätter, die in drei- bis siebenteilige, scharfe Stacheln ungewandelt sind. (Suche Ïbergänge zwischen beiden!) Sie fallen im Herbste nicht ab und stelien am Grunde der Winterknospen. Wenn sich nun im Frihjahre aus den Knospen Zweige entwickeln, so bilden

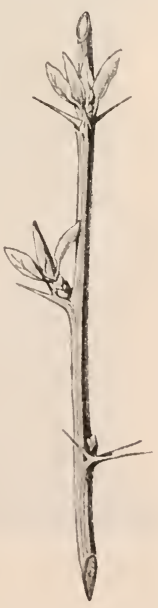

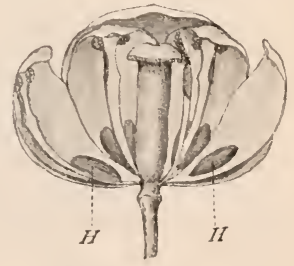

Sanerdorn.

Links: Zweigstüek mit Knospe and jungen Blätterm. (nat. Gr.)

Rechts: B I üte (nach Entfernung der vorderen Blütenteile). Das zum rechten (halben) Blumenblatte gehörige Staubblatt hat sich infolge eines Reizes der Narbe allgelegt. H. Honigdiriisen. (4 mal nat. (ir.) 
die Dornen für sie eine vortreffliche Schntzwehr gegen Weidetiere, sowie gegen Rampen nnd Schnecken. welch letztere, nach dem zarten Laube lüstern, am Stengel emporsteigen.

3. Die eigentïmlich duftenden $B l$ üten stehen in Trauben, werden also trotz ihrer Kileinheit auffällig, und dies umsomehr, als nicht nur die sechs Blïtenblätter, sondern anch die Kelchblätter an der Innenseite gelb gefärbt sind. Die anfïnglich aufrecht stehenden Tranben werden später hängend, so daß die Blüten wagereclıt oder schräg abwärts zn stelıen kommen. Da zudem dic Stanbbentel von den umgebogenen Zipfeln der Blïtenblätter ïberdeckt werden, so ist der Blütenstaub gegen Regen vollkommen geschïtzt. Die Weise, in der die Blüten bestäubt werden, ist höchst wunderbar. Berührt man mit einem spitzen Hölzchen den Grund eines Staubblattes, so sieht man, wie es plötzlich nach innen schnellt. Genau dasselbe erfolgt natïrlich, wenn das Staubblatt an jener Stelle von einem Insekt berührt wird. Diese Berührung erfolgt nun zufällig, oder - was die Regel ist - beim Saugen des Honigs; denn der süße Saft wird von zwei orangefarbenen Anschwellungen jedes Blïtenblattes abgeschieden, die unter dem reizbaren Grunde des Stanbblattes liegen. Dabei kann es natïrlich nicht ansbleiben, daß das Insekt mit Blïtenstanb beladen wird. Fliegt das Tier darauf zu anderen Blüten, dann werden sicher einige Staubkörnchen an der Narbe dieser oder jener Blüte abgestreift.

4. Der Fruchtknoten entwickelt sich zu einer eßbaren Beere, die mit leuchtendem Rot Vögel zum Verzehren des saftigen, sänerlichen Fruchtfleisches (Sanerdorn!) einladet (s. Weinstock).

Eine $n$ ahe Verwandte ist die Mahonie (Mahónia aquifólium), die wegen ihrer immergrünen Blätter und goldgelben Blütentrauben häufig in Parkanlagen zu finden ist. Sie stammt aus Nordamerika und ist gleichfalls ein Träger des Berberitzenrostes.

\section{Familie. Seerosen (Nymphaeáceae).}

Die weiße Seerose (Nymphéa alba). Taf. 3.

Der stille Weiber, der schilfumkränzte Teich, der blinkende See, alle erhalten erst durch die Seerose ihre schönste Zier. Die riesigen Blätter, die sich gleich schwimmenden Schilden auf dem Wasserspiegel ausbreiten, und die wunderbar zarten Blüten, die gefüllten Rosen ähneln (See-, Teich- und Wasserrose), erhöhen mächtig den geheimnisvollen Zauber, den das Wasser anf den Menschen ausübt (vgl. Goethes "Fischer"!). Darum ist auch die prächtige Pflanze schon seit uralten Zeiten durch Sage und Märchen verklärt: Auf den Blättern schankeln sich im Mondenscheine die Elfen and Nymphen (Nymphaea!), und nnter ihnen lauert die Nixe, um denjenigen zu sich in die Tiefe zu ziehen, der die herrliche Blüte brechen will ("Nixblume" - Die Nixe heißt auch "Wassermuhme", die Pflanze daher "Mummel").

Während die meisten Pflanzen (Beispiele!) bald zu Grunde gehen, wenn sie längere Zeit ïberflutet werden, spielt sich das Leben der Seerose (mit Ausnahme des Blïhens!) in Wasser ab: sie ist eine Wasserpflanze. 


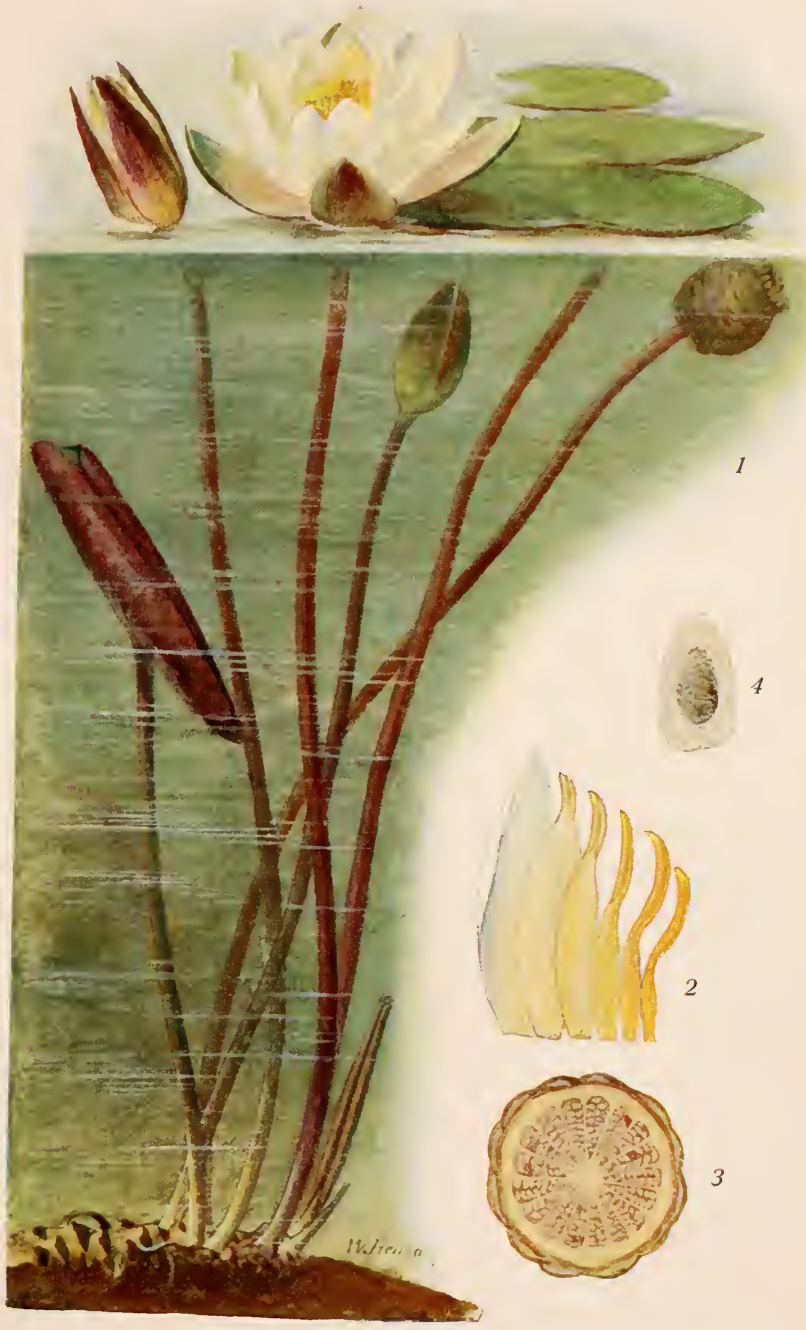

Weiße Seerose (Nymphaea alba). 

1. Ihr Stamm ist ein armdickes Gebilde, das mit vielen Blattnarben bedeckt und in schlammigen Grunde der Gewässer eingebettet ist. Da er durch zahlreiche Wurzeln, die sich tief in den Boden senken, verinkert wird, vermag die Pflanze nur Gewässer mit lockerem Untergrunde und im Gegensatz zu den nichtwurzelnden Wasserpflanzen (z. B. der Wasserprimel) auch langsain fließende (Fewässer zu bewohnen. Da die Wurzeln aber auch Werkzenge der Nahrungsaufnahme sind, kann die Seerose nur auf schlammigem Untergrunde gedeihen, nicht etwa auch auf nahrungsarmem Sand- oder Geröllboden. Am Ende des Stammes erheben sich die Stiele der Blitten und

2. Blätter. So lange sich die wachsenden Blätter unter Wasser befinden, sind ihre jetzt noch sehr zarten Blattflächen so von beiden Seiten nach innen gerollt, daß man die Unterseite sehen kann. Wären sie ausgebreitet, so würden sie sicher in noch weit höherem Grade der Gefahr ausgesetzt sein, durch Wellen und Strömung zerrissen zu werden, als sie es jetzt schon sind. Sobald die Blätter die Wasseruberfläche erreicht haben, stellt der Stiel das Wachstum ein, und die großen, am Grunde tief herzförmigen Blattflächen breiten sich auf dem Wasserspiegel aus, in vollem Genusse von Licht und Luft. Je nach der Tiefe des Wassers sind daher die Stiele von sehr verschiedener Länge. Ins Ungemessene können sie natürlich nicht wachsen; denn der Pflanze steht ja nur eine gewisse Menge von Baustoffen zur Verfïgung. Diese Tatsache macht es verständlich, daß die Seerose nur in verhältnismäßig flachen Gewässern oder in der Uferzone tiefer Gewässer lebt. Hat das Wasser seinen höchsten Stand inne, so stehen die Stiele fast senkrecht; sinkt es, so rücken die Blattflächen weiter auseinander, und die Stiele bewegen sich nach außen (etwa wie Stäbe eines Schirmes, den man mit der Spitze auf den Erdboden stellt und öffnet).

a) Reißt man einen Blattstiel vom Stamme los, so schwinmt er samt seiner Blattfläche auf dem Wasser. Dies ist eine Folge zahlreicher, grofer, luftgefiillter Zwischenzellräume, die auf zarten Querschnitten schon mit bloßem Ange deutlich zu sehen sind. (Ygl. mit einem Schwimmgïrtel!) Der schwimmenden Blätter wegen zählt die Seerose zu den "Schwimmpflanzen".

Auf den Querschnitten bemerkt man, falls man sie gegen das Licht hält, wie von den Zellwänden der Lufträume sternförmige Ha are ausstrahlen, die mit körnigen Rauheiten versehen sind. In diesen Gebilden glaubt man

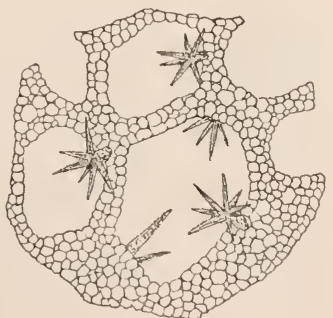

Querschnitt aus dem Blattstiele der weigen seerose mit großen Lufträumen und sternförmigen Haaren (etwa $50 \mathrm{mal}$ nat. Gr.) ein Schutzmittel der Pflanze besonders gegen Schnecken zu erkennen; denn wenn den gefräßigen Tieren beim Benagen der Stiele beständig jene scharfen Spitzen 
in den weichen Körper dringen - und das ist unausbleiblich! - so werden sie das Zerstörung'swerk wohl bald aufgeben müssen.

b) Da das Blatt in (Stiel) oder auf dem Wasser (Blattfliche) schwimmt, also von ihm getragen wird, so wird uns die auffallende Schlaffheit und Biegsamkeit des Stieles (der bei den Luftpflanzen bekanntlich die Blattlläche und sein eigenes Gewicht zu tragen hat) woll verständlich. Und solch ein seilartiger Sticl ist andererseits durchans notwendig; denn er ist allein imstande, den Bewegnngen der Blattfläche (Wellen, Wind!) leicht und schnell zu folgen. (Was wïrde im anderen Falle geschehen?)

Versiegt das Gewässer, dann sinken freilich die langgestielten Blätter in den Schlamm und gehen bald zu Grunde. Die Secrose stirbt aber nicht, falls nur der Boden fencht bleibt. Sie treibt kleinere Blaitter, deren (kurze) kräftige Stiele die (kleinere) Blattfläche wohl zu tragen vermögen; man sagt: sic wird zur Landform. (Häutiger als die Landform der weißen Seerose ist die der gelben Teichrose zu beobachten. Warum kann man diese Pflanzen als „amphibische" Gewächse bezeichnen?)

c) Schwimmende Blattflächen haben durch die auf- und absteigenden Wellen mehr oder minder heftige Erschiitterungen auszuhalten, und niederfallende Regentropfen treffen sie mit voller Kraft. (Durch welche Mittel geht bei den Luftpflanzen cin Teil der Kraft des Windes und der Regentropfen verloren? Vgl. z. B. Birnbamu.) Zarte Blätter würden daher bald von den Wellen zerrissen und von größeren Regentropfen durchlöchert sein: Die starke, lederartige Beschaffenheit der Blätter erscheint uns daher als ein wichtiges Schutzmittel gegen jene Kräfte.

d) Hält man ein abgeschnittenes Seerosenblatt unter Wasser und bläst durch den Stiel kräftig Luft ein, so sielit man, wie sie von der Oberseite der Blattfläche in Form glänzender Perlen wieder emporsteigt (vgl. Absch. 2 a). In Gegensatz zu den Blättern der Landpflanzen, bei denen die Spaltöffnungen zumeist an der Unterseite liegen, finden sich die Spaltöffnungen hier also an der Oberseite, die ja allein von Luft umspült wird. - Da der Seerose Wasser im Überfluß zur Verfïgung steht, so finden wir bei ihr anch keines der Mittel, die bei zahlreichen Landpflanzen eine allzu starke Ausscheidung von Wasserdampf verhindern (s. z. B. S. 7, 4 c). Im Gegenteil, je mehr Wasser durch die Blätter verdampft, desto besser ist es für die Pflanze; denn desto mehr Nahrungsstoffe werden ja mit dem Wasser durch die Wurzeln eingesangt. Daher besitzt das Seerosenblatt nicht nur eine sehr große Nenge von Spaltöffinungen (etwa zehn Millionen), sondern auch melrere Einrichtungen, die ein Verstopfen dieser Öffnungen durch Wasser verhindern:

c) Die Oberseite ist mit einem Wach sïberzuge versehen. Ein Versuch zeigt, daß Wasser von ihr abrollt wie von dem eingefetteten Gefieder der Ente oder Gans. Und dies geschieht um so leichter, als

f) die Blattfläche an der Verwachsungsstelle mit dem Stiele meist etwas erhöht ist, und als 
g) der Blattrand wellenartige Krïmmungen zeigt, also zahlreiche Rinnen für das abfließende Wasser bildet.

h) Im Gegensatz zu der grïnen Oberseite ist die Unterseite des Blattes meist violett gefürbt. Das Licht, welches die Blattmasse durchlenehtet, würde, wenn der violette Farbstoff fehlte, durch das Blatt hindureh nutzlos in das Wasser fallen. Durch ihn aber wird es wie von jedem dunklen Farbstoffe aufgefangen und - wie wir aus Erfahrung wissen - in Wärme umgesetzt (so sind z. B. dunkle Kleider im Sommer wärmer als helle). Eine Erhöhung der Temperatur hat aber stets auch eine Erhöhung der Verdunstung im Gefolge. Die violette Färbung, die sich zumeist auch an dem Blattstiele findet, gibt sich demnach als ein Förderungsmittel der Wasserdampfausscheidung zu erkennen.

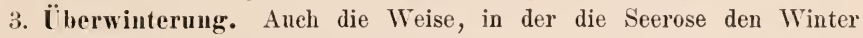
iibersteht, hängt mit ihrer Natur als Schwimmpflanze innig zusammen. Die auf dem Wasserspiegel schwimmenden Blätter wïrden durch die Winterkälte umso sicherer zerstört werden, als sich ja das Wasser mit einer Eisdecke iiberzieht. Die Blätter sterben daher im Herbste ab. Am Grunde der Gewässer dagegen sinkt selbst im kältesten Winter die Temperatur nicht bis auf den Nullpunkt, also so tief, đaß sie das dort herrsehende Pflanzenleben verniehtete. Dort können demnach Gewächse ïberwintern, und dort vermag auch der Stamm der Seerose seinen "Winterschlaf" zu halten. Die Seerose zählt daher wie alle Wasserpflanzen (mit Ansuahme einiger Uferbewohner) zu den a usdanernden Gewächsen.

4. Die Bliite steht am Ende eines langen Stiels, der alle Eigensehaften der Blattstiele besitzt (wieso? warum nötig?). So lange sich die Blüte unter Wasser befindet, bilden die 4 Kelchblätter für das Blïteninnere einen festschließenden Mantel; an der geöffineten Blüte dagegen stellen sie gleichsam kleine, auf dem Wasser schwimmende Boote dar (Bedentung?). Da sie innen weiß gefürbt sind, helfen sie die Augenfälligkeit der Blüte (Insekten!) erhöhen. Die zahlreichen, schneeweißen Blumenblätter werden nach innen zu beständig kleiner (Bedeutung?) und gehen allmählich in Sta ubblät ter über (2), ein Zeichen, daß auch diese Blïtenteile nichts weiter wie (umgewandelte) Blätter sind. Der Fruchtknoten, der oben die strahlig-schildförmige Narbe trägt, ist einer Mohnkapsel sehr ähnlich. Seiner Außenwand sind die Blumen- und Staubblätter in einer Spirale angeheftet (Fruchtwand daher mit zahlreichen Blattnarben).

Wenn die Morgensonne goldig am Himmel steht, öffnen sich die weithin leuchtenden, schwach duftenden Bliiten. Fliegen und Käfer, die sich aber mit Blütenstaub (zahlreiche Stanbblätter!) begnügen müssen, kommen bei ihnen zum Mahle. Gegen Abend schließen sich die Blumen wieder, so daß der leicht verderbende Blïtenstaub gegen den Tau der Nacht und die aus den Gewässern aufsteigenden Nebel wohl geschiitzt ist.

5. Die Frucht reift im Schutze des Wassers. Sie ist ein beerenartiges Gebilde, das im Innern mehrere Fächer mit zahlreichen Samen enthält. Jeder Same ist von einer weißen, schleimigen Hïlle, einem Samenmantel, umgeben (4). 
Platzt die Frucht bei der Reife, so werden die Samen frei. Da sich aber unter ihrem Mantel je eine große Luftblase bildet, so steigen sie zur Oberfläche empor, schwimmen dort umher und werden von der Strömung oder von Wind und Wellen oft weithin verschlagen. Entweicht die Luft, so sinken die Samen zu Boden und können an einer anderen Stelle des Wohngewässers eine neue Pflanze ins Dasein rufen. Da die Hülle klebrig ist, so kann es ferner anch nicht ansbleiben, daß die Samen am Schnabel oder Gefieder der Wasservögel haften und zn anderen Gewässern getragen werden: die Seerose gibt sich also anch durch die Verbreitung ihrer Samen als eine echte Wasserpflanze zu erkennen.

\section{Andere Seerosen.}

Gleich der weißen Seerose ist die gelbe Teichrose (Nuphar lútenm) eine bekanute Zierde unserer Gewässer. Sie stimmt mit ihrer weiß-blumigen Schwester in Ban und Lebensweise fast vollkommen überein; nur in der Bildung von Blüte und Frucht (beschreibe beide!) zeigen sich einige Abweichungen. - An Schönheit werden beide noch von den Seerosen der warmen Gegenden übertroffen. Unter diesen ist wieder der amerikanischen Seerose (Victória régia) der Preis zuzuerkennen. Sie bewohnt die großsn Ströme des warmen Südamerika. Ihre kreisrunden Blätter, die mit einem erhöhten Rande versehen sind, haben einen Durchmesser bis zu $2 \mathrm{~m}$, und die wohlriechenden, anfangs weißen, später rosafarbenen Blïten einen solchen bis zu $40 \mathrm{~cm}$. - Hohe Berïhmtheit hat die ägyptische Seerose oder die Lotosblume (Nymphǽa lotus) erlangt. Wenn der Nil das Land überschwemmt, so grünt und blüht die herrliche Pflanze bald in allen Gräben und Kanälen; wenn aber das Wasser wieder in seine Ufer zurückkehrt, so verschwindet anch sie wieder. Nur der im Boden eingebettete Stamm vermag die lange Zeit der Trocknis zu überdauern. Gleich dem heiligen Strome selbst galt die Lotosblume als ein Sinnbild der Fruchtbarkeit und war den hohen Göttern geweiht. Ihr mehlreicher Stamm und ihre Samen wurden besonders früher von den Bewohnern des Landes verzehrt. - Häufiger allerdings bautem an zn diesem Zwecke die indisehe Seerose (Nelúmbo nucifera) an, die heut noch einem großen Teile Südasiens eine wertvolle Nahrungspflanze ist. Die trichterförmigen Blätter und roten Blüten hebt die herrliche, von den Indern heilig gehaltene Pflanze über den Wasserspiegel empor.

\section{Familie. Kreuzblütler (Cruciferae).}

Blüten mit 4 Kelchblättern, 4 kreuzweis gestellten Blumenblättern, 2 kürzeren und 4 längeren Staubblättern und einem Fruchtknoten, der aus 2 durch eine häutige Scheidewand verbundenen Fruchtblättern besteht; Frucht eine Schote oder ein Schötchen.

\section{Der Raps (Brássica napus).}

A. Bedeutung. Zerdrückt man einige Samenkörner des Rapses, die als Futter für Stubenvögel allgemein bekannt sind, zwischen Papier, so entsteht ein bleibender Fettfleck. Das Öl, das diesen Fleck verursacht, bezeichnet man (im Gegensatz zu dem flüchtigen Öle; s. Rose) daher als fettes öl. Dieses sog. „Rüiböl“" war bis zur Entdeckung des Steinöls das wichtigste Mittel zur Beleuchtung der Wohn- und Arbeitsräume, der Straßen und dgl. Darum war 
auch der Raps (samt dem gleichfalls Ö) liefernden Rübsen; s. S. 20) für den Menschen bis dahin eine iiberaus wichtige Pflanze. Heutzutage wird das "Rüböl" vorwiegend nur noch zum Schmieren von Maschinen, zur Bereitung von Seife und zu anderen gewerblichen Zwecken verwendet. Es wird in Ölmühlen durch Zerstampfen oder Zerquetschen der Samen gewonnen. Die zurïickbleibenden festen Bestandteile preßt man zu „(̈lkuchen", die als Viehfutter geschätzt werden. - In einigen Gegenden verspeist man auch die jungen Rapsblätter als das erste Gemüse, das der Frühling liefert.

B. Anbau. Je nachdem der Landmann Winter-oder Sommerraps baut, sät er die Samen im Spätsommer oder Frühling aus. Da ohne Wärme ein Wachstum der Pflanzen nicht möglich ist (Beweis!), so sind die Pflanzen der ersteren Form zu einer Winterruhe genötigt. Ihre Stengelglieder bleiben so kurz, daß die Blätter fast in derselben Höhe stehen. Da nun an der hoch anfstrebenden Rapspflanze die Blätter am Stengel in einer Spirale angeordnet sind, so müssen sie auch an dem verkürzten Stengel nach allen Seiten ausstrahlen, also eine Rosette bilden. (Denke dir den Stengel von oben nach unten in sich zusammengedrückt!) Wenn man bedenkt, daß die ausgebildete Rapspflanze nur ein schwaches Gewächs ist, das im Winter durch die auf ihm lastende Schneemasse unbedingt zerknickt und vernichtet werden müßte, so wird man die Bedeutung dieser Erscheinung leicht einsehen. (Bestimme, welche Unkränter die zierlichen Rosetten bilden, die du im Herbst oder Winter auf dem Felde findest!) Sobald aber im Frühlinge die höhersteigende Sonne die Erde zu neuem Leben erweckt, setzt auch die Rapspflanze das nnterbrochene Wachstum fort: sie treibt gleich dem Sommerraps, der jetzt erst aus Samen hervorgeht, einen

C. Stengel, der eine Höhe von $1,50 \mathrm{~m}$ erreicht und im oberen Teile etwas verzweigt ist. Seine

D. 1. Blätter nehmen von unten nach oben beständig an Größe ab. Infolgedessen rauben sie sich gegenseitig nicht das zum Leben notwendige Sonnenlicht. Die oberen Blätter sind ganzrandig, die unteren dagegen stark eingebuchtet. (Da sich die Ausschnitte wie die Blättchen der Fiederblätter gegeniiberstehen, nennt man solche Blätter „fiederspaltig“")

2. Taucht man eine Rapspflanze in das Wasser, so bleibt sie auffallender Weise vollkommen trocken. Die Wassertropfen rollen von ihr ab wie von dem eingefetteten Federkleide der Ente oder Gans. Dasselbe ist bei einem Regen zu beobachten. Wischt man aber mit dem Finger anf einem Blatte oder Stengel einigemale hin und her und taucht die Pflanze von neuem ins Wasser, so findet man, daß die abgewischte stelle feucht geworden ist. Durch das Wischen ist nämlich der blaugrïne Anflug entfernt worden, der dem Raps eigen ist und von einer dünnen Wachsschicht herrührt. Der Wachsiberzug ist also ein Schutzmittel gegen Befeuchtung: er verwehrt dem Wasser, die Spaltöffnungen zu verstopfen, die sich auf beiden Seiten der Blätter und am Stengel finden, und mithin den Luftwechsel aufzuheben (s. das.), der durch diese Öffnungen vermittelt wird. - Wie genaue Untersuchungen ergeben haben, ist der Wachs- 
überzug zugleich ein Schutzmittel gegen zu starke Verdunstung des in den Blättern enthaltenen Wasser's.

3. Träufelt man Wasser auf die Blïtter, so sieht man, wie es zum Stengel abflicßt und schließlich zur Wurzel geleitet wird. Genau dasselbe geschieht mit den Regentropfen, die auf die Blätter fallen. Die Pflanze "begießt" sich also selbst. Diese Arbeit vermögen die Blätter vortrefflich zu leisten; denn sie

a) stehen ain Stengel schräg a ufwärts und

b) bilden (zumeist) flache) Rinnen;

c) die oberen unfassen den Stengel mit herzförmigem Grunde etwa zur Hälfte, und

d) bei den unteren Blättern zieht sich die Blattfläche in kleinen Lappen beiderseits bis zum Stengel herab (sie sind undentlich gestielt).

E. Wurzel. Die Rapspflanze leitet also das auf sie fallende Regenwasser nach innen (zentripetal), nach der Nitte zu ab. Dort müssen darum auch die

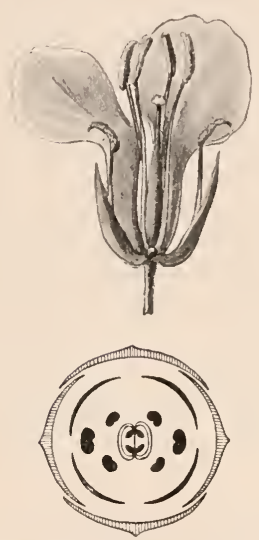

Blïte und Blïtengrundriß vom Raps. Von der Blïte sind ein Kelchblatt und zwei Blumenblätter entfernt (etwa 3 mal nat. Gr.). feinen Saugwurzeln liegen, durch welche die Pflanze das Wasser aufnimmt. Wir finden daher beim Raps kein weitverzweigtes Wurzelgeflecht wie z. B. bei einem Baume, sondern eine möhrenförmige Hauptwurzel, von der sich die Nebenwurzeln niemals weit entfernen. ( $\mathrm{Ygl}$. dag. Birnbaum!)

F. Blüte. 1. Blïtezeit. Das Rapsfeld gleicht in April und Mai (Winterraps) oder in Juli und August (Sommerraps) einem gelben Blütenmeere.

2. Blï ten bau. Mit den 4 schmalen, aufrechtstehenden Kelchblättern wechseln die 4 sich kreuzweis gegenüberstehenden Blumenblätter ab (Name der Familie!). Die unteren, schmalen Abschnitte der Blumenblätter bilden mit dem Kelche eine Röhre; die oberen, breiten Abschnitte sind rechtwinklig abgebogen. Von den 6 Staubblättern sind 2 (iußerer Kreis) kürzer als die 4 anderen (innerer Kreis). Der langgestreckte Fruchtknoten ist von 2 Fruchtblättern gebildet, deren verwachsene Ränder je eine Reihe Samen tragen (im ganzen also 4 Reihen) und durch eine häutige Scheidewand verbunden sind. Oben trägt der Fruchtknoten die knopfförmige Narbe.

3. Bestäubung. An warmen, sonnigen Tagen ist das blïhende Rapsfeld von vielen Tausenden von Insekten besucht. Ganz besonders zahlreich stellt sich die Honigbiene ein. Den hochwillkommenen Gästen macht sich die Blïte weithin bemerklich:

a) Die Blumenblätter sind von leuchtend goldgelber Farbe.

b) Solange der Kielch die anderen Blütenteile noch schützend umhïllte, 
war er nnscheinbar griü; jetzt aber ist er gelb oder wenigstens gelbgriun gefärbt. Er tritt also mit in den Dienst der Insektenanlockung.

c) Die einzelnen Blüten sind verhältnismäßig klein. Da sie aber am Ende des Stengels und seiner Zweige zahlreich beieinander stehen, sind sie doch weithin sichtbar. - Sie stehen auf gleichlangen Stielen, die am Hauptblütenstiele oder der Achse des Blütenstandes in verschiedener Höhe entspringen. Die unteren, weil älteren Blüten öffinen sich zuerst, die oberen zuletzt. Einen solchen Blütenstand bezeichnet man als Traube.

d) Die Blïten machen sich den (kurzsichtigen) Insekten um so bemerkbarer, als sie einen weithin vernehmbaren $\mathrm{Duft}$ aushauchen.

e) Außer Blütensta ub bieten sie den Gästen Honig zum Mahle, der von 4 grünen Drüsen am Grunde der Staubblätter abgeschieden wird. Senkt aber ein Insekt den Rüssel in die Blüitenröhre, um den süßen Saft zu trinken, so muß es auch eine Bestäubung der Pflanze herbeiführen; denn vor und in dem Eingange der Röhre haben ja Stanbbeutel und Narbe ihren Platz. - Da der Honig am Grunde einer Röhre geborgen ist, können kurzrüsselige Insekten (Käfer, die meisten Fliegen ı. a.), die eine Bestäubung nicht vermitteln würden, anch nicht $\mathrm{zu}$ ihm gelangen. (Des Honigreichtums wegen ist der Raps für den Bienenziichter eine der wichtigsten Pflanzen.)

G. Frucht. 1. Der Fruchtknoten entwickelt sich zn einer sogen. Schote, deren Ban wir bereits kennen gelernt haben (s. Absch. F. 2). Bei der Reife lösen sich die Fruchtblätter wie Klappen von unten nach oben ab, so daß die häutige Scheidewand mit den Samen anf dem Fruchtstiele stehen bleibt. Die Samen sitzen aber so locker auf ihren Stielchen, daß sie schon von einem leisen Winde abgeschüttelt werden. Darum schneidet der Landmann den Raps anch vor völliger Reife der Frïchte. Das fette Öl, das die Samen enthalten (s. Absch. A), dient dem Keimling als Banstoff.

\section{Die Gattung ,Kohl'6 (Brássica).}

1. Wie hentzutage mnßten sich auch in graner Vorzeit die umherschweifenden Völker mit dem begnïgen, was ihmen die Natur zur Nahrung gerade bot. Genau wie heute floß diese Quelle aber sehr verschieden stark, und es gab sicher auch Zeiten, in denen sie gänzlich versiegte. Der Mensch suchte sich daher von den zufälligen Gaben der Natur unabhängig zn machen: er wurde Viehzïchter und baute die P'flanzen an, die ihm Nahrung lieferten. A uf diese Weise sind a uch die Kohlarten in die Pflege des Menschen gekommen.

2. Nach und nach lernte der Mensch die Verhältnisse kennen, unter denen die Pflanzen am besten gedeihen: er pflanzte sie anf den geeignetsten Boden, den er zu bearbeiten, zu dïngen, von Unkrant reinzuhalten lernte und dgl. mehr. Infolgedessen erhielten seine Kohlpflanzen dickere und saftreichere Wurzeln und Stengel oder zartere und wohlschmeckendere Blätter oder ölreichere Samen, kurz: es fand eine allmähliche Veredlung ler Pflanzen statt. 3. Te nachdem der Mensch nun Wurzel, Stengel, Blätter oder Samen be- 
nutzte, je nachdem verfuhr er auch bei der Fortzucht seiner Pfleglinge: er suchte diejenigen Pfanzen zu vermehren, die ihm die dicksten und saftreichsten WVurzeln und Stengel, die zartesten und wohlschmeckendsten Blätter oder die ölreichsten Samen lieferten. Aus deren Nachkommen wählte er immer wieder die geeignetsten Pflanzen zur Nachzucht ans: und so sind die zahlreichen Spielarteu und Sorten des Kohls entstanden, die wir heute bauen. Immerfort noch arbeitet der Gärtner planmäßig an ihrer Veredlnng, und immer neue Sorten entstehen unter seiner kunstgeübten Hand. - Genau auf dieselbe Weise ist a uch die Veredlung aller anderen Kulturpflanzen erfolgt, und durch dieselbe planmäßige und beständige Auslese der geeignetsten Pflanzen zur Nachzucht sind die vielen Sorten und Spielarten entstanden, die wir heute besitzen.

4. Die zahlreichen Spielarten des Kohls (beschreibe sie näher!), die wir im Garten und auf dem Felde bauen, und die in den einzelnen Gegenden oft recht verschieden benannt werden, lassen sich auf 4 Stammformen zurückführen:

a) Der Rapskohl (B. napus) ist wie die beiden folgenden Arten wahrscheinlich aus Südeuropa zu uns gekommen und tritt in 2 Formen auf: Die eine Form,

den Raps, haben wir oben ausführlich besprochen; die andere Form ist

die Kohlrübe, die eine fleischige, eßbare Rübenwurzel besitzt. - Dem Rapskohl zum Verwechseln ähnlich ist

b) der Riibenkohl (B. rapa). (Bei ihm stehen die entfalteten Blüten mit den Blütenknospen in gleicher Höhe oder überragen dieselben noch; seine unteren Blätter sind grasgrün and steifhaarig. Beim Rapskohl dagegen werden die geöffneten Blüten von den Blütenknospen überragt; alle Blätter sind blaugrün, and nar die nnteren besitzen einzelne Haare.)

Er tritt ons in 3 Formen entgegen:

als $\mathrm{R} u ̈ b$ sen (Sommer- und Winterrübsen) der als Ölfrucht gebaut wird;

als weiße Rübe, die als Viehfutter dient, und

als Teltower-oder märkisches Rübchen, eine Gemüsepflanze, die ihren Namen nach der in der „Mark" Brandenburg gelegenen Stadt Teltow hat.

c) Den Gemüsekohl (B. olerácea) banen wir in besonders zahlreichen Spielarten; die wichtigsten sind:

Der Kopfkohl mit gewölbten, glatten, grünweißen oder roten Blättern (Grünund Rotkohl), die einen festen Kopf bilden;

der Welsch-oder Wirsingkohl mit blasigen Blättern, die sich zu einem lockeren Kopfe vereinigen;

der Rosenkohl, dessen Seitenknospen rosenartige Köpfchen bilden;

der Braunkohl mit kransen, fiederspaltigen Blättern;

der Kohlrabi, dessen Stengel äber dem Boden stark verdickt ist, nnd

der Blumenkohl, dessen Blütenstiele und obere Blätter za einer weißen, fleischigen Masse umgebildet and dessen Blüten verkümmert sind.

d) Der Senfkohl oder schwarze Senf (B. nigra) ist ein Glied der heimischen Flora. Wild kommt er hie und da an Flußufern vor; häufiger aber wird er seiner Samen wegen angebaut (s. weißer Senf). Von den anderen Kohlarten ist er leicht dadurch zu unterscheiden, daß seine Blätter sämtlich gestielt sind, während bei jenen dies nnr für die nnteren Blätter gilt. 


\section{Andere Krenzbliitler}

\section{A. Kreuzblütler mit Schoten (s. S. 19, G).}

Eine dem schwarzen Senf sehr ähnliche und gleichfalls vielfach angebaute Pflanze ist der weißge Senf (Sinápis alba). Beide enthalten in ihren Samen ein scharfes öl, dessen Geruch zu Tränen reizt (Schutzmittel gegen körnerfressende Vögel). Dieses öles wegen werden die Samen vielfach zu Heil- nnd Gewürzzwecken benutzt. Die sehr scharfen, schwarzen Samen der ersteren Art (Name!) dienen besonders zur Bereitung von Senfpflaster und Senfspiritus, die milderen, gelblichweißen der letzteren Art (Name!) vorwiegend als Küchengewürz und zur Herstellung von Tafelsenf oder Mostrich. - Der nächste Verwandte des weißen Senfs ist der Ackersenf (S. arvénsis), das allbekannte Unkraut, das oft ganze Felder gelb färbt. Fälschlicherweise wird die Pflanze zumeist ${ }_{n}$ Hederich" genannt. - Der Hederich oder Ackerrettich (Raphanístrum lámpsana) ist dem Ackersenf zwar sehr ähnlich und gleichfalls ein lästiges Ackerunkraut, unterscheidet sich von ihm aber leicht durch die hellere Blïtenfarbe, durch den der Blumenkronenröhre anliegenden Kelch und die Schote, die perlschnurartig eingeschnürt ist und bei der Reife in soviel Glieder zerfällt, als "Perlen" vorhanden sind (Ackersenf: Kelch abstehend, ohne ${ }_{n}$ Gliedersehote"). - Eine ähnliche Schote besitzt der Garten-Rettich (Ráphanus sativus), der aus China stammt und in mehreren Spielarten (Winter- und Sommerrettich, Radieschen) als beliebte Gemüsepflanze gebaut wird.

Gleichfalls Fremdlinge in unsern Gärten sind Goldlack (Cheiránthus cheiri), sowie Sommer- und Winterlerkoje (Matthiola ánnua und incána). Beide stammen aus Südeuropa.Ihre meist gefüllten und

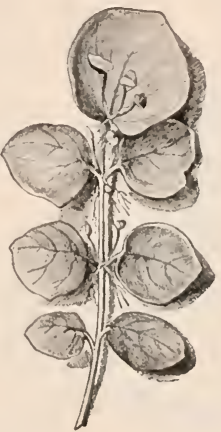

Blatt vom WiesenSchaumkraut, aus dem drei junge Pflanzen hervorsprossen.

(nat. Gr.)

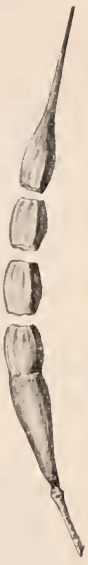

Frucht vom Hederich, in einzelne Glieder zerfallend.

(nat. Gr.) sehr mannigfach gefärbten Blüten hauchen einen angenehmen Veilchenduft aus. Darum nannte der Volksmund den Goldlack früher auch treffend "Gelbveigelein", und Levkoje heißt in Übersetzung: weißes Veilchen. Ganz ähnlich ist der Duft, der besonders am Abend (Name!) den lilafarbenen Blüten der Nachtviole (Hésperis matronális) entströmt. Die Heimat der bekannten Zierpflanze ist Südeuropa, Österreich und das südliche Deutschland.

Einen prächtigen Schmack nasser Wiesen bilden zur Früljahrszeit die Blütentrauben des Wiesen-Schaumkrauts (Cardámine praténsis). Bei Regenwetter und mit Anbruch des Abends aber verschwindet der Schmuck: die Blütenachsen krümmen sich, so daß die sich gleichzeitig schließenden, lilafarbenen Blüten nickend werden (Schutz gegen Nässe nnd Kälte). Ans einer Rosette gefiederter Blätter erhebt sich der Stengel, dessen Blätter und Fiederblättchen nach oben hin immer kleiner werden (Bedentung für die Belichtung?). Alle Blätter sind wie die der Sumpfdotterblume (s. das.), die gleich- 
falls nur auf feuchtem Boden gedeiht, saftstrotzend und völlig unbehaart. Mit dem Standorte hängt auch die eigentümliche Vermehrungsweise des zierlichen Pflänzchens innig zusammen, die man häufig beobaehten kann: kommen die grundständigen Blätter auf Wasser oder feuchtem Boden zu liegen, so bilden sich an den Ansatzstellen der Fiederblättchen bald Knospen, die sich zu neuen Pflanzen entwickeln (Versueh!). Die Schaumklümpehen, die man vielfich am Stengel findet, und in denen sich die Larve der Schaumzirpe versteekt hält (s. Lelirbuch d. Zoologie!), haben der Pflanze mit zu ihrem Namen

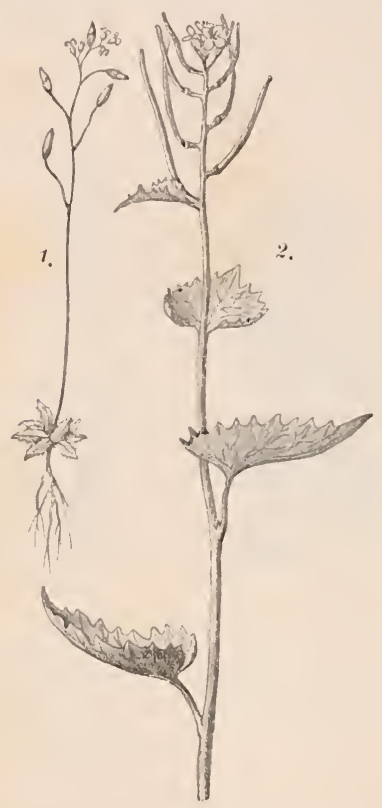

Humgerbliimcluen (1.) und Knoblauchsrauke (2.) (nat. Gr.). verholfen! - Die Bruunenkresse (Nastúrtium ofticinále) gedeiht in Quellen und Wassergräben. Sie ist daher in allen ihren Teilen noch saftstrotzender als das Wiesen-Schaumkraut und gleichfalls völlig kahl und glatt. Da ihre Blätter einen schmackhaften Salat liefern, wird die Pflanze hier und da (besonders bei der Blumenstadt Erfurt) in Großen angebaut. - Wie die Brunnenkresse als Wasserpflanze, so gibt sich die Kuoblauchssauke (Alliária offieinális) durch die großen, zarten Blätter sofort als Schattenpflanze zu erkennen (s. S. 7 c). Sie gedeiht überall häufig unter Gebüsch und unter dem Unterholze des Laubwalds und ist dureh einen scharfen Knoblauchsgeruch (Name!) gegen Weidetiere gesehützt. - Gerade das Gegenteil in der Belaubung zeigen die zahlreichen Kreuzblütler, die trockene Stellen (Schutthaufen, Wegränder, Manern und dergl.) bewohnen. Sie müssen, um nicht zu verdorren, mit der geringen Wassermenge, die ihnen der oft ausgedörrte Boden liefert, sehr sparsam umgehen. Darum finden wir bei ihnen zumeist ein gering entwickeltes Blattwerk und oft noch eine starke Behaarung. Als Beispiel für diese unschönen, sparrigen, aber ihrem Standorte vortrefflich angepaßten Pflanzen sei hier nur die Besen- oder Sehuttkresse (Sisýmbrium sóphia) genannt, die ein vielfach zerteiltes Laub besitzt. Weitere Beispiele finden wir unter den B. K reuzblütlern mit Schötehen (d. s. Schoten, die nicht oder wenig länger als breit sind).

Da ist zunäehst die Graukresse (Bertéroa incána). Sie ist an allen Teilen so dicht mit sternförmigen Haaren bedeckt, daß sie graufilzig erseheint. - Ein anderes Beispiel ist das niedliche Humgerbliimclieu (Eróphila verna), das selbst mit „hungrigstem“ Boden fürlieb nimmt. Kaum ist der Schnee geschmolzen, so entfaltet es seine winzigen Blïten, reift schnell Früchte und Samen, und wenn der Sommer komut, der es infolge seiner Troeknis vernichten würde, hat es seine Lebensarbeit bereits abgeschlossen. Seine Blätter sind mehr oder weniger dicht mit gegabelten Haaren bedeckt und zu einer zierlichen Rosette geordnet, - Ein solehes ${ }_{n}$ Hungergewäehs ${ }^{“}$ ist auch das Hirtentaischelkraut (Capsélla bursa pastóris - Name!), wenn es auf trockenem Boden wächst. Findet 


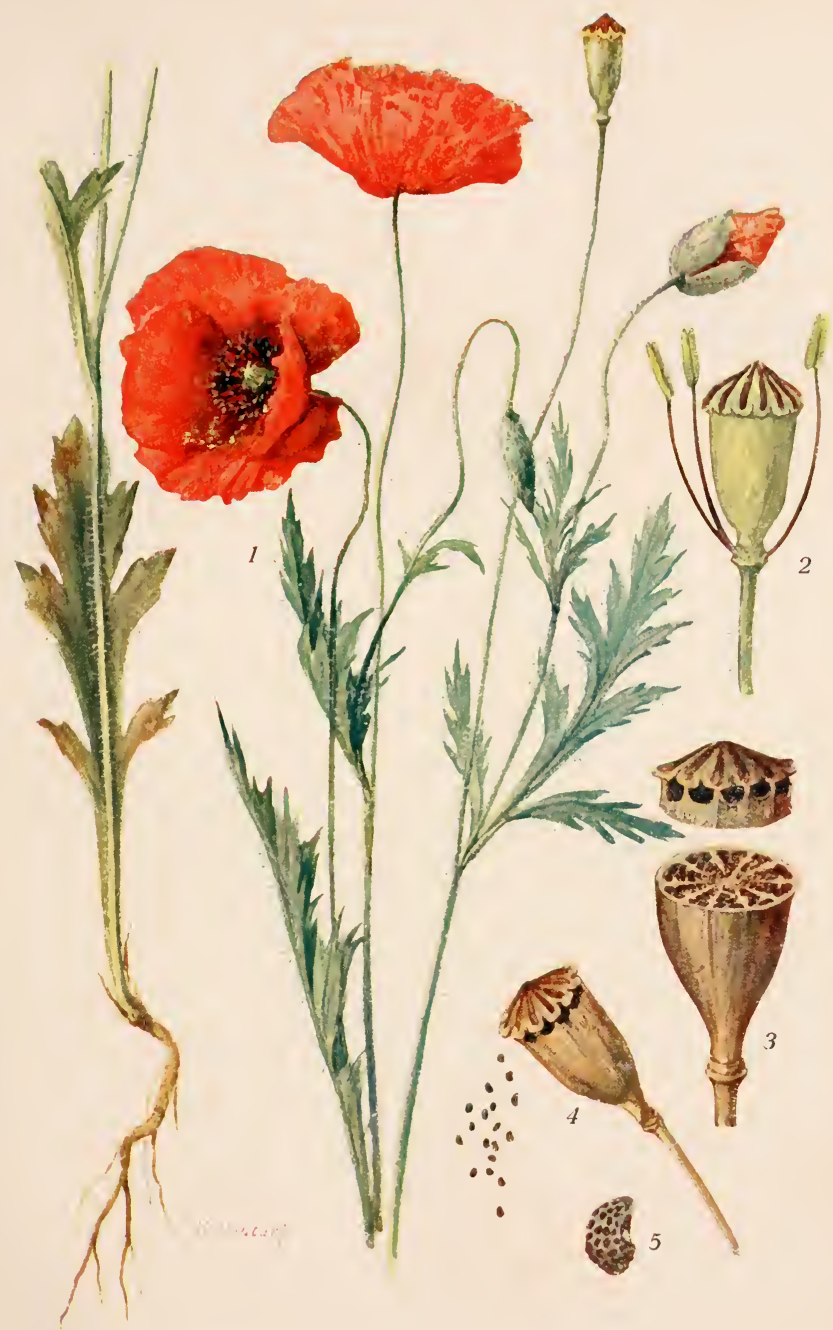

Klatschmohn (Papaver rhoeas). 

es sich aber auf feuchtem, fruchtbarem Ackerlande, so ist es kaum wiederzuerkennen, so ïppig ist es „in das Kraut geschossen". - Einen ähnlichen Unterschied im Wachstum zeigt auch das Heller-oder Pfennigkraut (Thláspi arvénse), das mit dem Hirtentäschelkraut zu unsern bekanntesten und lästigsten Unkräutern zählt. Seine Früchte (Name!) bilden infolge breiter Flügelränder flache Scheiben, die durch den Wind weithin verweht werden können (Verbreitung der Art).

Zu der Gruppe der „Schötchenfrüchtler" gehören auch mehrere Nutzpflanzen: Der Meerrettieh (Cochleária armorácia) liefert uns in seinem scharfsehmeckenden Wurzelstocke ein beliebtes Gemüse und Küchengewürz. Er stammt aus Südeuropa, findet sich bei uns aber an Flußufern und dgl. häufig verwildert. Richtiger sollte man ihn wohl II ähr-d.i. PferdeRettich nennen; denn der Volksmund verknüpfte gern den Namen einer Pflanze, die einer andern ähnlich, aber minder-

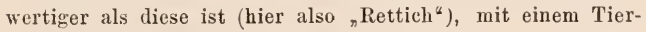
namen (Beispiel!). - Als Salatpflanze wird an vielen Orten die Gartenkresse (Lepidium sativum) angebaut, deren Samen sehr schnell keimen. - Der Leiulotter (Camelina sativa) liefert ein geschätztes Brenn- und Spciseöl. In Thüringen flechtet man aus den getrockneten Stengeln kleine Besen.

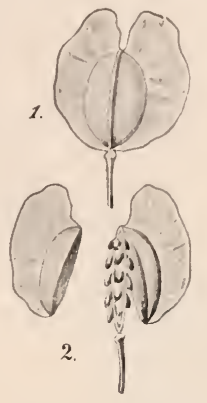

Schïtchen vom Hellerkraut. 1. geschlossen. 2. Klappen sich ablösend. (wenig vergr.)

\section{Familie. Mohngewächse (Papareráceae).}

Blüten mit 2-blättrigem, abfallendem Kelche, 4 kreuzweis gegenüberstehenden Blumenblättern, zahlreichen Staubblättern, einem Fruchtknoten, der ans 2 bis vielen Fruchtblättern gebildet ist nnd zu einer mit Löchern aufspringenden Kapsel oder zn einer Schote auswächst.

\section{Der Klatschmohn (Papáver rhóas). Taf. 4.}

1. Pflanze und Mensch. a) Herrlich leuchten die Bliiten des Klatschme 3 zwischen àen hohen Halmen des Roggens hervor, und das grüne Kleefeld abergießen sie oft wie mit feuerrotem Schein! Die Kinder pflücken die prächtigen Blumen gern zum Strauße, machen sich aus den Blïtenknospen Puppen zum Spiel und legen die zarten Blïtenblätter auf den durch Daumen und Zeigefinger gebildeten Ring, schlagen darauf und erfremen sich an dem klatschenden Schall (Klatschmohn, Klatschrose, Klatschblume). - Auch der Gärtner hat sich der schönen Feldblume angenommen. Seine Kunst schuf gefüllte Blumen von mannigfachster Färbung, die eine bekannte Zierde unserer Gärten bilden.

b) Für den Landmann dagegen ist die Pflanze nichts weiter als ein lästiges Unkraut; denn sie nimmt ja den angebanten Gewächsen Nahrung, Licht und Platz weg. Obgleich der Kampf zwischen ihr und dem Menschen sicher schon so lange währt, so lange ïberhaupt Getreidebau getrieben wird: so vermochte sie der Mensch doch noch nicht auszurotten; denn ihx Leben hailt mit dem des 
Getreides, zwischen dem sie wächst, gleichen Schritt. Mit dem Getreide sprießt der Mohn in Herbst oder Frühjahr ans dem Boden hervor, und mit dem Reifen des Getreides reifen auch seine Samen. Wenn nicht schon vorher, so werden sicher bei der Getreideernte Tausende von Mohnkörnern über den Acker verstreut, und andere Tausende nimmt der Mensch mit in die Scheuer. Die Mehrzahl der letzteren geht freilich beim Reinigen oder Verbrauch der Getreidesamen zu Grunde; es bleiben aber immer noch genug iibrig, die bei der Aussaat wieder auf den Acker zuriickgelangen. So muß der Mensch das Unkraut selbst erhalten und ausbreiten helfen! (Von welchen anderen Unkräntern gilt dasselbe?)

2. Wurzel, Stengel, Blatt. a) Die jungen Mohnpflanzen, die im Herbst aus Samen hervorgehen, bilden vor Eintritt des Winters je eine zierliche, dem Boden aufliegende Blattrosette, deren Bedeutung wir beim Raps (s. S. 17) bereits erkannt haben. Wenn aber im Frïhjahre die Saat zu sprießen beginnt, dann strecken sie sich auch zum Lichte empor (warum notwendig?): sie treiben je einen bis $1 \mathrm{~m}$ hohen Stengel, dessen fiederspaltige, gezähnte Blätter nach oben zu immer kleiner werden (s. S. 17, D 1). Die Mohnpflanzen dagegen, die erst im Frühlinge aus Samen entstehen, also keine Winterruhe durchzumachen haben, sprießen sofort empor.

b) Eine kräftige Pfahlwurzel gibt der Pflanze im Boden festen Halt. Je nachdem aber der Boden für Wasser durchlässig ist, je nachdem ist auch die Wurzel ausgebildet: Auf durchlässigem Sandboden senkt sich die Wurzel fast unverzweigt tief in den Grund; auf undurchlässigem Lehmboden dagegen breitet sie sich stark verzweigt in der obersten Erdschicht aus. (Versuch: Fülle Blumentöpfe mit beiden Bodenarten und beobachte, wie sich letztere gegen Wasser verhalten!)

c) Stengel, Blütenstiele und Blätter sind mehr oder weniger dicht mit stacheligen Haaren besetzt. An den jüngsten Blättern findet sich stets eine sehr dichte Behaarung, ein Mittel, durch das die zarten Gebilde wie die jungen Blätter der Roßkastanie (s. das.) gegen eine zu starke Wasserabgabe und somit gegen das Vertrocknen geschützt sind. (Beachte auch, wie die jungen Blätter zusammengefaltet sind und vergleiche deshalb gleichfalls die Roßkastanie!) Hier sowohl, wie bei den ausgebildeten Pflanzenteilen, sind die Haare zweitens aber noch ein Schutzmittel gegen Pflanzenfresser, die - wie die Erfahrung lehrt - rauhhaarige Gewächse gern meiden (s. Schwarzwurz). Ein anderes und zwar weit wirksameres Schutzmittel gegen diese Zerstörer besitzt die Pflanze in

d) dem weißen, giftigen Milchsafte (s. Schlafmohn), der bei Verletzungen aus der Wundstelle hervordringt. Er verleiht der Pflanze einen bitteren Geschmack und einen widerlichen Geruch, durch den sich sicher manches Tier zurïckschrecken läßt.

3. Die Bliiten stehen am Ende je eines langen Stieles, der die Fortsetzung des Stengels bildet oder aus den Blattwinkeln entspringt. So lange sich die Blïte im 
a) Knospenzustande befindet, ist sie von 2 kalınartigen $\mathrm{Kelchblät}$ tern schïtzend umhiillt und infolge der Krümmung des Stieles abwärts geneigt (1.). Öffnet sie sich, so streckt sich der Stiel, die nutzlos gewordenen Kelchblätter fallen ab, und die Blumenblätter, die in dem engen Raume nur dadurch Platz fanden, daß sie wie ein Stïck Papier zusammengeknittert waren, breiten sich ans.

b) Die entfaltete $\mathrm{Bl}$ ïte ist durch die 4 großen, feuerroten, kreuzweis gestellten Blumenblätter, die im Grunde oft nocl einen schwarzen Fleck mit weißem Rande besitzen (Erhöhung der Auffälligkeit!), weithin sichtbar. Sie bietet den besuchenden Insekten nur Blütenstaub zur Nahrung dar. Darum besitzt sie auch so zahlreiche Staubblätter, und diese erzengen eine so große Menge von Bliitenstaub, daß die Insekten ohne Schaden fïr die Pflanze davon speisen könnnen. Der bei dem Mahle verstreute Staub wird von den muschelförmigen Blumenblättern anfgefangen und bis zum Abholen durch andere Insekten aufbewahrt, ein Umstand, der die aufrechte Stellung, sowie die Schalenform der Bliite als sehr zweckmäßig erscheinen läßt. Vergleicht man die Mohnblïten mit Bliiten, die Honig enthalten (z. B. mit denen des Veilchens, der Erbse u. v. a.), so findet man sie höchst einfach gebaut; denn sie bedarf ja keiner der vielfachen Einrichtungen, die wir bei jenen Blüten zur

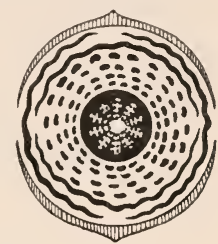

Bliitengrundriß̧ rom Klatschmohn. Aufbewahrung und zum Schutze des Honigs antreffen. (Nenne andere Pflanzen mit honiglosen Blïten ähnlicher Form!)

Die Blumenblätter sind von solcher Zartheit, daß sie schwere Insekten, die sich auf die Blïte niederlassen, nicht zu tragen vermögen. Als Anflugsplatz dient den Besnchern daher ein anderer Blütenteil: der Stempel, und zwar dessen schildförmige Narbe, die dem Fruchtknoten aufsitzt (2.). Lassen sich nun Insekten, die von anderen Mohnblïten kommen und oft gänzlich mit Blütenstaub eingepudert sind, auf dem Stempel nieder, so kann es nicht ausbleiben, daß einige Blïtenstaubkörnchen an den strahlenförmigen Haarleisten der Narbe haften bleiben und Fremdbestäubung verursachen. An einem Querschnitte der

4. a) Frucht (3.) ist leicht zu erkennen, daß der Fruchtknoten aus mehreren Bliittern besteht, die an ihren Rändern so mit einander verwachsen sind, daß sie kulissenartig in die Fruchtknotenhöhle ragen. Die Höhle wird dadurch in mehrere Kammern geteilt, die jedoch unvollkommen voneinander getrennt sind. An den kulissenartigen Wänden sitzen die Samen. Sie lösen sich zur Zeit der Reife von ihren Stielchen und harren der Ausstreumg. U'm diese zu ermöglichen, haben sich unter dem gelappten Narbenrande, der sich etwas in die Höhe gebogen hat, unterdes mehrere kleine Löcher gebildet, so daß der "Mohnkopf“ einer Streusandbïchse ähnlich geworden ist (3. u. 4.). Biegen wir jetzt einen Fruchtstiel nach der Seite und lassen ihn zuriickschnellen, so sehen wir, wie Samen aus den Öffnungen herausgeschleudert werden (4.). Genau dasselbe geschieht bei heftigen Windstößen. Jetzt verstehen wir auch, warum die Pflanze so auffallend lange 
Bliiten-(Frucht-)stiele besitzt, und warum diese bei der Reife der Samen so elastisch werden. Und da alle Samen iiber einen möglichst großen Raum verstreut werden mïssen, falls sich die jungen Pflanzen gegenseitig nicht Licht, Nahrung und Platz wegnehmen sollen, so wird uns anch klar, warum sich die Öffnungen gerade oben an der aufrechtstehenden Fruchtkapsel bilden. Andererseits sind aber auch die

b) Samen (5.) für diese Art der Ausstreunng geeignet; denn es sind kleine und leichte Gebilde, die daher weit fortgeschlendert werden können. Zu Boden gefallen, werden die Samen bald vom Regen verschwemmt. Da sie nun an der Oberfläche zahlreiche Vertiefungen besitzen, in denen sich Erdteilchen festsetzen, so verkitten sie gleichsam mit dem Boden und vermögen ungestört zu keimen. Und wenn auch Tausende von Samen verloren gingen: schon eine Pflanze erzeugt deren soviele, daß ihre Nachkommen bald ein ganzes Feld rot färben könnten!

\section{Andere Molngewäichse.}

Der Schlafmohn (P. somniferum), der in unsern Gärten mit gefüllten und sehr mannigfach gefärbten Blüten häufig als Zierpflanze gezogen wird, enstammt dem Orient.

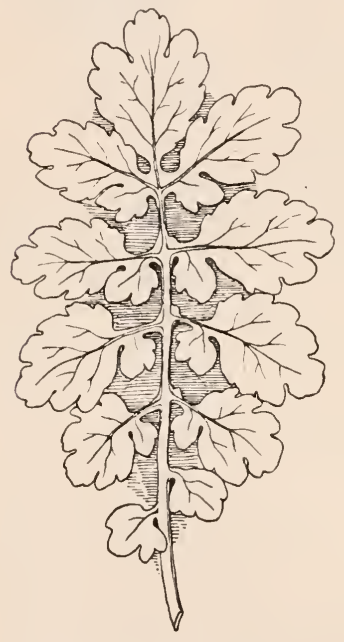

Blatt vom Schellkraut $(1 / 3$ nat. Gr.). Im großen baut man ihn bei uns nur seiner Samen wegen, die das wertvolle Mohnöl liefern und : $z u$ mancherlei Gebäck verwendet werden. In südlichen Ländern dagegen, besonders in Vorder-, Südund Ostasien, ist er eine der wichtigsten Kulturpflanzen, denn er liefert das wertvolle Opinm. Um diesen kostbaren Stoff zu gewinnen, ritzt man die halbreifen Mohnköpfe mit feinen Messern und schabt nach einiger Zeit den ausgeflossenen und eingetrockneten Milchsaft ab. Das Opium ist gleich dem Morphium, das aus ihm gewonnen wird, ein wichtiges Arzneimittel, das selbst die unerträglichsten Schmerzen stillt and dem Kranken den ersehnten Schlaf bringt. Dieser Wirkungen wegen dient es aber auch im Orient als ein Mittel, sich zu berauschen. Der Opiumesser oder -raucher sinkt bald in eine angenehme Betäubung: er glaubt sich den Sorgen und Leiden der Zeit entrückt, und süße Träume umgaukeln seinen Geist. Dem Erwachen folgt jedoch ein unerträgliches Übelbefinden, das meist dnreh erneuten Opinmgenuß beseitigt wird. Langsam aber sicher untergräbt der dem Laster Verfallene seine Gesundheit, bis er endlich, an Geist und Körper zerrüttet, vorzeitig in das Grab sinkt.

An Mauern, sowie unter Hecken und Zäunen, findet sich hänfig das Selrellkraut (Chelidónium majus), das seines gelben Milchsaftes wegen allgemein bekannt ist. Es blüht gelb and hat schotenförmige Frïchte. Die schwarzen Samen besitzen einen kammartigen, weißen, fleischigen Anhang. Dieses Gebilde wird von Ameisen gern verzehrt, 
welche die Samen daher oft weit verschleppen and somit die Pflanze verbreiten. (Vgl. mit Veilclıen.) Beachte, wie die mittleren Abschnitte der fiederteiligen Blätter nahe der Mittelrippe einen Lappen tragen, an der entgegengesetzten Seite dagegen einen Ausschnitt besitzen und erkläre diese Erscheinung!

\section{6., 7. und 8. Familie. Erdrauch-, Reseda- und Hartheugewächse} (Fumariáceae, Resedáceae und Hypericáceae).

1. Erdranchgewächse. Der Lerchensporn (Corydalis cava) ist wie das Windröschen (s. das.) eine Pflanze des Laubwaldes. Kein Wunder darum, daß sich zwischen beiden zahlreiche Übereinstimmungen finden: Der Lerchensporn blïht wie das Windröschen im zeitigen Frühjahr; er ïberwintert mit Hilfe eines Wurzelstocks, der freilich die Form einer Knolle besitzt und zur Blütezeit hohl ist („Hohlwurz"), und besitzt gleichfalls große, mehrfach geteilte, dünne und leicht welkende Blätter. Die purpurroten oder weißen, seitlich symmetrischen Bliiten dagegen sind viel kleiner als die des Windröschens. Da sie aber in einer großen Trambe beieinander stehen und einen zarten Duft aushauchen, werden sie den Insekten wohl bemerklich. Der Honig wird in einem Sporne geborgen (Name!), der von dem oberen der beiden äußeren Blumenblätter gebildet wird. Die beiden inneren Blätter bilden eine kapuzenförmige Schutzhülle für den Blütenstanb, der auf der noch unreifen Narbe abgelagert wird. Läßt sich aber auf der Blïte ein Insekt (Biene) nieder, dann klappt die

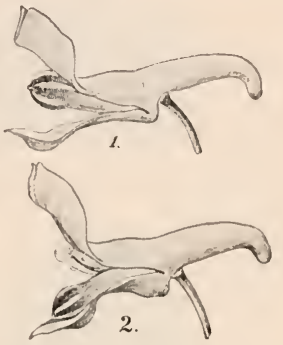

Blïte vom Lerchensporn 1. in der Ruhe. 2. "Kapuze" herabgedrückt. $\left(1^{1} /_{2} \mathrm{mal}\right.$ nat. Gr.) Kapnze nach unten, so daß das Tier mit dem Blïtenstanbe in Berührung kommen muß. Beim Saugen an einer älteren Blïte wird der Staub an der (später reifenden) Narbe abgestrichen - und die Bestäubung ist erfolgt.

Denselben Blütenbau und infolgedessen auch dieselbe Art der Bestäubung (Beweis!) finden wir bei einem allbekannten Unkraute unserer Gärten und Felder, dem Errlrauch (Fumária officinális), wieder. Da die zierliche, einjährige Pflanze aber auf stärker besonntem Boden gedeiht, so besitzt sie auch weit kleinere und derbere Blattflächen als der Lerchensporn. - Auch die aus China za uns gekommene Zierpflanze, die man ihrer schönen Blüten wegen ,flammendes Herz" (Dicẻntra spectábilis) nennt, zeigt im wesentlichen dieselbe Blüteneinrichtung (Beweis!).

2. Ein allbekanntes Glied der Reseda- oder Wa ugewächse ist die wohlriechencle Reseda (Reséda odoràta), die zu unseren geschätztesten Gartenpflanzen zählt. Das unsclıeinbare Gewäclıs stammt aus Nordafrika. Statt einer lenchtenden Blumenkrone ïbernimmt es weithin wahrnehmbarer Duft, die Insekten anzulocken. - Eine ganz ähnliche, nur größere und kräftigere Pflanze ist der gelbe Wau (R. lútea), der an Wegen und ähnlichen trockenen Orten gedeiht. 
3. Hartheugewächse. Das Tïpfel-Harthen (Hypericum perforátum) wächst an Wegen und anderen trockenen Stellen. Die hohe, sparrige Pflanze hat ihrem Standorte entsprechend (Beweis!) trockene Stengel und kleine Blätter (Gattungsname!). Zahlreiche helle Öldrüsen lassen die Blätter, gegen das Licht gehalten, wie durchlöchert erscheinen (Artname!). An den Blättern sowohl, wie an den 5 Kelch- und Blumenblättern, finden sich viele schwarze Punkte und Striche, die beim Zerreiben einen roten Farbstoff liefern. Das ist das ${ }_{n}$ Johannisblut", dem man früher wie der ganzen Pflanze, dem „Johanniskraute", besondere Zauberkräfte zuschrieb. Die gelben Blüten enthalten zahlreiche Staubblätter, deren Fäden am Grunde za 3 Bündeln verwachsen sind. Die dreifächerige Kapsel verhält sich gegen Trockenheit und Feuchtigkeit wie die Frucht der Stein-Nelke (Versuch!). - Zu den Hartheugewächsen steht in näherer Verwandtschaft

\section{Der chinesische Teestrauch (Thea sinénsis).}

Von dem Teestranche können wir uns durch die Betrachtung der Kamelie (Th. oder Caméllia japónica), die der prächtigen (gefüllten) Blïten wegen zu unsern beliebtesten Topfpflanzen zählt, leicht eine Vorstellung verschaffen: er ist wie sie eine Pflanze mit elliptischen, immergrïnen, lederartigen Blättern (vgl. mit Orange) und weißen, rosenähnlichen Blüten. In seiner Heimat, dem südlichen Asien, wächst er zu einem stattlichen Baume empor. In den Ländern dagegen, in denen er angebaut wird, in China, Japan, dem ganzen siidlichen Asien und auf den vorgelagerten Inseln, sowie am Sïdabhange des Kaukasus, wird er nur als kaum 1-2 m hoher Strauch gehalten.

Wenn man von dem Tee, wie er zu uns in den Handel kommt, etwas im Wasser aufweicht und vorsichtig auseinander breitet, so sieht man, daß er aus getrockneten und zusammengerollten Blättern besteht. Das Laub, das den Knospen entnommen ist oder sich soeben entfaltet, liefert die wertvollste Ware; denn es ist am reichsten an dem flüchtigen Öle (s. Rose), das dem Tee den bekannten Wohlgeruch verleiht, und an dem Stoffe (Theïn), der mit dem Öle die belebende Wirkung des Teeaufgusses bedingt.

Die Verarbeitung der Blätter ist in den einzelnen Ländern sehr verschieden. In China, dem wichtigsten Teelande der Welt, verfährt man in der Regel in folgender Weise: Man nimmt dem Strauche im Jahre gewöhnlich dreimal das junge Laub. Die eingesammelten Blätter werden an der Luft getrocknet und erhalten dadurch eine braune, fast schwarze Färbung (schwarzer Tee). Alsdann werden sie in Pfannen uiber einem Feuer geröstet, zwischen den flachen Händen gerollt, nochmals geröstet und schließlich langsam getrocknet. Setzt man die eingeernteten Blätter der Einwirkung lıeißer Wasserdämpfe aus, so bleibt die grüne Färbung mehr oder weniger erhalten, und man gewinnt so den „gr ün en 'T e e“. Von diesen beiden Teearten unterscheidet man wieder' eine große Menge Sorten, deren wertvollste nur im Hof halte des chinesischen Kaiserhauses verwendet und darum Kaisertee (Imperial) genannt wird. 

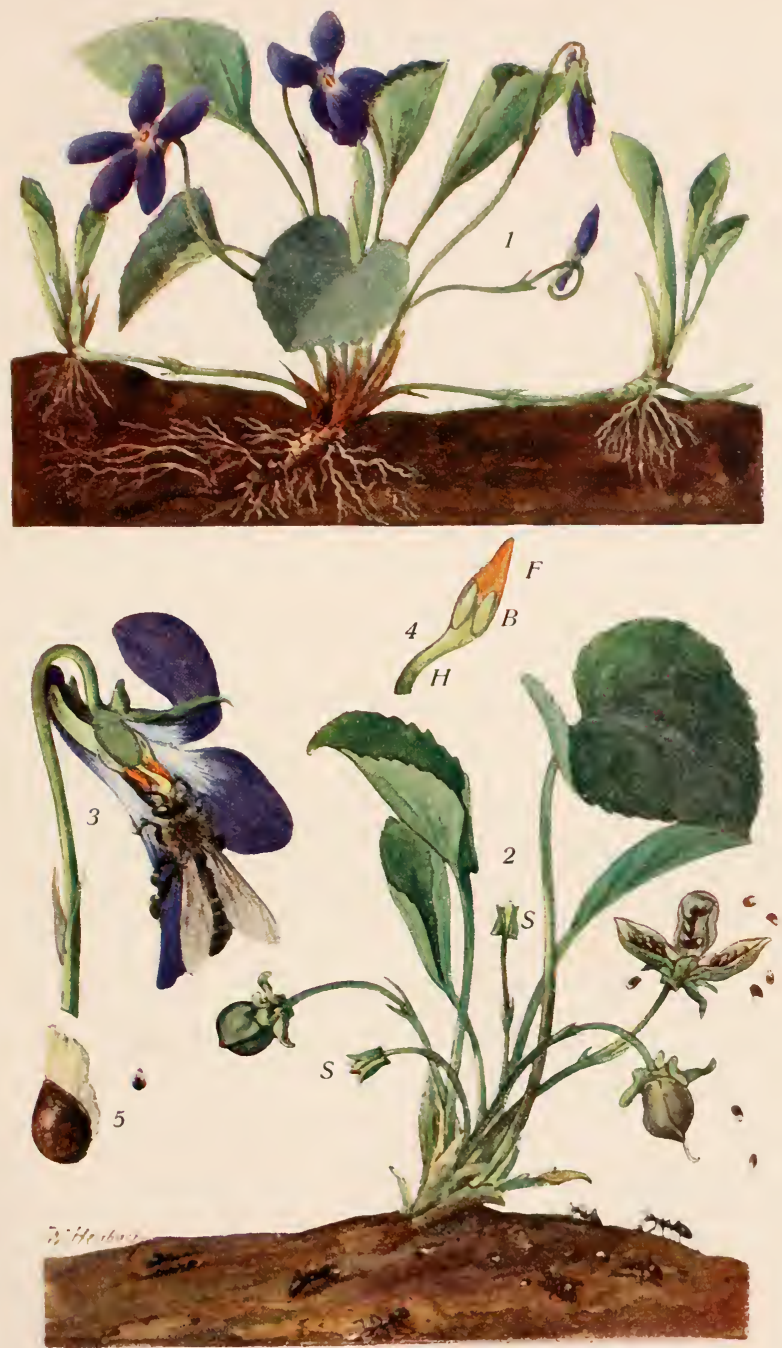

Wohlriechendes Veilchen (Viola odorata). 



\section{Familie. Veilchengewächse (Violáceae).}

Blüten seitlich symmetrisch, mit 5 Kelchblättern, 5 Blumenblättern, von denen das unterste gespornt ist, und 5 Staubblättern. Frucht eine einfächerige Kapsel; Samen in der Mitte der 3 Fruchtblätter.

Das wohlriechende Veilehen (Viola odoráta). Taf. 5.

A. Das Veilchen, eine Lieblingspflanze des Menschen. Keine Blume unserer Heimat begrüßen wir mit so großer Frende wie das erste Veilchen, das wir im jungen Grase des Gartens oder dranßen auf dem Wiesenplane, an der Hecke oder am Waldesrande finden: erblicken wir doch in ihm einen untrüglichen Boten des langersehnten Lenzes. Dichter haben das „kleine BlauVeilchen" darum besungen, und in zahlreichen Frühlingsliedern ist es verherrlicht (Beispiele!). Obgleich durch die zarte Farbe und den köstlichen Duft der Blüte mit hohen Gaben ausgestattet, blïht es doch still im Verborgenen. Darum gilt es uns auch als ein Sinnbild der Demut und Bescheidenheit. Jener Gaben gen ist es auch seit altersher eine der beliebtesten Gartenblumen, und fortzesetzt arbeitet man daran (s. S. 19), immer größere, schönere und duftendere Blïten zu erzielen, die sich je nach der Spielart zu jeder gewünschten Jahreszeit entfalten. Der köstliche Duft der Blüte wird auch zur Herstellung wohlriechender Wässer, Salben, Seifen u. dgl. benutzt.

B. Das Veilehen, eine Pflanze les Frühlings. 1. Ginge das Veilchen in jedem Frïhjahr aus Samen hervor, so könnte es unmöglich so zeitig im Jahre grïnen und blühen. Es ist aber eine ausdauernde Pflanze, die der Lenz bereits fertig vorfindet.

2. Die Baustoffe fïr Blätter und Blüten sind in dem Stengel anfgespeichert. Er ist zum größten Teil im Erdboden verborgen und treibt hier zahlreiche feine Wurzeln. Unrichtigerweise wird er meist selbst als Wurzel, und zwar als die stärkste, angesehen. Da er aber zahlreiche Blattnarben besitzt, früher also mit Blättern besetzt gewesen sein muß, kann er keine Wurzel sein; denn eine solche trägt niemals Blätter. Der kleinere Teil des Stengels ragt aus dem Boden hervor und trägt an seinem Ende einen Büschel von Blättern.

Die vorjährigen Blätter, die sich meist bis zum Frühjahre erhalten, sterben jetzt $a b$, und ïber ihuen bildet sich ein Büschel neuer. Der Stengel wächst also in jedem Frïhjahre ein Stück nach oben. Am entgegengesetzten Ende dagegen stirbt er beständig ab (genau wie wir dies am unterirdischen Stamme des Windröschens gesehen haben). Und wenn das Fortwachsen und Absterben noch so langsam erfolgte, so müßte sich der Stengel doch wohl schließlich aus dem Boden hervorschieben, so daß er a uf ihm zu liegen käme? Dies geschieht jedoch nicht! In demselben $\mathrm{Maße}$ nämlich, wie er unten abstirbt, wird er von den Wurzeln in den Boden gezogen.

3. Blätter. a) Die hervorsprießenden jungen Blätter sind von beiden Seiten her tütenförmig zusammengerollt (1.). Welche Bedeutung dies hat, 
wird uns folgender Versuch lehren. Wir nehmen 2 gleich große Blätter, die jene Zusammenrollung zeigen, legen beide, nachdem aber das eine ausgebreitet und vielleicht durch eine Stricknadel oder dgl. beschwert worden ist, an irgend eine Stelle, so daß sie von den Sonnenstrahlen getroffen werden. Nach einiger Zeit werden wir beobachten, daß das zusammengerollte Blatt noch ziemlich "frisch" aussieht, wïhrend das andere schon stark verwelkt ist. Wie durch einen anderen einfachen Versuch festzustellen ist (lege beblätterte Zweige irgend eines Strauches oder Baumes nnter eine Glasglocke und beobachte, wie die Glaswand beschlägt, während die Pflanzenteile verwelken!), beruht das Verwelken auf zu starker Abgabe des in den Blättern enthaltenen Wassers. Die Tiitenform des jungen Blattes ist also ein Schutzmittel gegen zu starke Wasserabgabe.

Der erste Versuch zeigt uns auch, warum gerade das junge Blatt eines solchen Schutzmittels bedarf: an dem kïnstlich ausgebreiteten Blatte welken und vertrocknen die Teile, die sonst eingerollt waren, zuerst. Sie sind sehr zart, geben darum am meisten Wasser in Dampfform ab, geben daher auch an ersten zu Grunde und - bedïrfen deshalb eines besonderen Schutzmittels.

b) Nach und nach breitet das junge Blatt seine herzförmige, gekerbte Fläche aus. Je nachdem das Veilchen in kurzem oder langem Grase wächst, je nachdem sind anch die Blattstiele von verschiedener Länge: stets aber sind sie so lang, um die Blattfläche in den vollen Genuß des Sonnenlichtes zu setzen (Bedeutung?). Am Grunde jedes Blattstieles sitzen 2 kleine, lanzettliche Nebenblätter.

C. Das Veilchen, eine Pflanze mit mehrfacher Vermehrung. 1. A usläufer. Aus den Winkeln der unteren Blätter wachsen Zweige hervor, die an den Stengelknoten Wurzeln schlagen. Die Zweige bleiben aber auf dem Erdboden liegen und treiben im Gegensatze zu dem kurzgliedrigen Stengel (kurzgliedrig; denn die Blätter, die ja stets an Stengelknoten entspringen, stehen dicht beieinander!) sehr lange Glieder (Kurz- und Langtriebe). Infolgedessen entfernt sich die Spitze des "Ausläufers" weit von der Mutterpflanze. Am Ende desselben bildet sich bald ein Blattbuischel, aus dem im nächsten Jahre Bliiten hervorbrechen: es ist eine neue Pflanze entstanden, die allerdings mit der Mutterpflanze noch lange im Zusammenhang bleiben kann (1.)

2. Frühlingsblüte. So prächtig die Blüte des Veilchens ist, so wunderbar ist auch ihr

a) Bau. Wie der Körper des Nenschen und zahlreicher Tiere (Beispiele!) kann die Bliite nur durch einen Schnitt (führe ihn!) in 2 spiegelbildlich gleiche Teile zerlegt werden: sie ist seitlich symmetrisch. Ein langer Stiel, der in der Mitte 2 schuppenartige Blättchen trägt, hebt sie aus dem (rrase empor. (Bedeutung? Beachte hier wie bei den Blattstielen die verschiedene Länge!) Die 5 Kelchblätter umschließen anfänglich die iuneren Blïtenteile gänzlich (Bedeutung?). Später werden sie von den violetten (selten weißen) $\mathrm{Bl}$ u me n blät tern auseinandergedrängt, von denen an der entfalteten 
Bliite je 2 nach oben und nach der Seite gerichtet sind und eins nach unten steht. Das untere Blumenblatt verlängert sich in einen Sporn (3.), in den die beiden unteren der 5 Staubblätter (4.) je einen langen, grïnen Fortsatz 4 H.) senden. Wie man sich durch den Geschmack leicht ïberzeugen kann, sondern diese Fortsätze Honig ab. Der süße Saft fließt in den Sporn, den man darum treffend auch als "Safthalter" bezeichnet. Die sehr kurzen Staubblätter umstehen den Fruchtknoten und besitzen am Vorderrande je einen orangefarbenen Fortsatz (4. F.). Die Fortsätze greifen etwas übereinander und bilden einen kegelförmigen Hohlraum, dessen Spitze von dem fadenförmigen Griffel durchbrochen wird. Das Ende des Griffels ist die hakenförmig nach unten gekrïmmte Narbe. Öffnen sich die Staubbeutel (4 B.), so fällt der trockene, mehlartige Blütenstanb in diesen Hohlraum. - Nicht weniger wunderbar als der Bau,

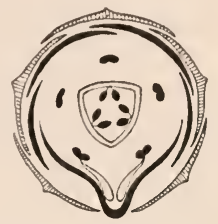

Bliitengrundriß vom Veilchen. ist auch die

b) Bestäubung der Blüte (3.). Durch die Färbung der Blumenblätter (violett, Blütenmitte weißlich, unteres Blatt mit dunkelblauem Streifen; selten ganz weiß) und den weithin wahrnehmbaren Duft werden die Bestäuber angelockt. Da der Honig im Sporn verborgen ist, können kurzrïsselige Insekten nicht bis zu ihm gelangen. Bienen und Hummeln sind die Hauptbestäuber. Sie lassen sich entweder auf dem unteren Blumenblatte $n$ ieder oder hängen sich an die beiden oberen Blätter, wobei sie sich an den Härchen der seitlichen Blätter festhalten.

Wie die Bestäubung erfolgt, läßt sich leicht durch folgenden Versuch feststellen: Man halte eine (junge) Bliite in ihrer natïrlichen Stellung so hoch, daß man bequein hineinschauen kann, und führe mit der andern Hand ein zugespitztes Hölzchen (Insektenrïssel!) in den Sporn. Sobald nun die Narbe, die den Eingang versperrt, vom Hölzchen getroffen wird, bewegt sich der Griffel ein wenig nach oben. Dadurch weichen die orangefarbenen Fortsätze der Staubblätter auseinander, d. h. der von ihnen gebildete kegelförmige Hohlraum öffnet sich, so daß etwas von dem mehlartigen Blütenstanbe herausfallen muß. Genan dasselbe erfolgt, wenn ein Insektenrïssel in die Blïte eindringt: ein Teil des Blütenstaubes fällt dem Tiere anf Rüssel und Kopf. Fliegt das Insekt nnn zu einer zweiten Blïte, so kann es nicht ausbleiben, daß einige Körnchen davon an der Narbe, die gerade im Wege zum Honig steht, abgestrichen werden, daß also Fremdbestänbung erfolgt. Jetzt wird uns auch verständlich, warum das Veilchen trockenen Blïtenstaub besitzt, während wir bei ,insektenblïtigen Pflanzen" der Regel nach klebrigen Staub (warum?) antreffen, weshalb die Bliite nicht aufrecht stehen oder senkrecht nach unten hängen darf (wohin wïrde der Bliitenstaub fallen?), sondern schräg nach unten geneigt sein muß, warum also - mit anderen Worten ausgedrückt - der Blïtenstiel an seinem oberen Ende die eigentiimliche Krïmmung macht. 
3. Sommerblüten. Außer den prächtigen Frühlingsblüten bringt das Veilchen später im Jahre noch andere, aber sehr unscheiubare Bliiten hervor (2 S.). Hhr Kelch bleibt geschlossen; die Blumenblätter färben sich nicht bunt; die Staubblätter und der Stempel aber sind wohl entwickelt, so daß regelmäßig Frïchte entstelien. Da die Bestäubung dieser "Sommerblüten“ ohne Hilfe der Insekten erfolgt (Selbstbestäubung), so fehlen ihnen selbstverständlich auch die Anlockungsmittel der Frühlingsblüten: die bunte Färbung, der Duft und der Honig.

4. Frucht. a) Der Fruchtknoten ist aus 3 Fruchtblättern gebildet, die an ihren Rändern zahlreiche Samen tragen. Die unreifen Fruchtkapseln hängen an gekrümmten Stielen nach unten oder liegen gar auf dem Boden. Sobald sie aber reif sind, richten sich die Stiele empor. Die 3 Klappen (d. s. die verwachsenen Hälften je zweier benachbarter Fruchtblätter), durch die sich die Frucht öffnet, schrumpfen vou der Seite her nach und nach zusammen. Infolgedessen geraten die Samen zwischen die Klappen und werden durch den Druck, der durch das fortgesetzte Eintrocknen erzengt wird, fortgeschnellt, ähnlich wie Kirschkerne, die wir mit den Fingern "fortschnippen“. Darum müssen sich auch die Fruchtstiele bei der Reife der Samen aufwärts bewegen. Und wenn man bedenkt, daß das Veilchen an geschützten Orten wächst, an denen ein Aussäen der Samen durch den Wind (wie z. B. bei der Steinnelke) kaum möglich ist, wird man leicht erkennen, daß diese Verbreitungsweise außerordentlich zweckentsprechend ist. Gleich wie sich aber nur glatte Körperchen „fortschnippen" lassen (Kirschkerne sind feucht!), sind auch

b) die Samen außerordentlich glatte Gebilde. Sie besitzen je einen weißen, fleischigen Anhang, der ohne Schaden für die Keimung entfernt werden kann. Man hat nun beobachtet, daß gewisse Ameisenarten den Anhang gern verzehren und deshalb die Samen in ihre Baue tragen oder verschleppen. Und das ist für die Pflanze ein Vorteil; denn viele Samen gelangen auf diese Weise an einen Ort, an dem sie keimen können: gewiß eine noch eigentümlichere Art der Verbreitung!

\section{Andere Veilchen.}

Im schattigen Walde, wie auf ödem Sandboden, auf nassen, wie trockenen Wiesen, in der Ebene, wie im Gebirge: überall treten uns Veilchen entgegen, die - weil gerachlos - der Volksmund gewöhnlich als "wilde Veilchen ${ }^{*}$ bezeichnet. Sie gehören sehr verschiedenen Arten an, die schwer voneinander zu unterscheiden sind. Am häufigsten ist das Hunds-Veilcheu (V. canina) mit seinem langgliedrigen Stengel und den hellblauen, weißgespornten Blüten, - Am bekanntesten jedoch ist das Stiefunitterchen (V. trícolor), das auf Feldern und Triften überall zu finden ist. (Wie ist es der Sage nach zu seinem Namen gekommen?) Unter den Stiefmütterchen macht sich aber ein bemerkenswerter Unterschied geltend: die einen besitzen große, prächtig blau oder blau und weiß (gelb) gefärbte Blüten; die anderen dagegen haben kleine, unscheinbare, meist gelblichweiße oder auch blaue und gelbe Blumenblätter. Mit dieser Verschiedenheit steht die Art der Bestäubung in innigstem Einklang! Die großen, auffallenden Blüten sind nur durch Fremdbestäubung za befruchten; die kleinen, unscheinbaren dagegen bestäuben sich selbst! Untersuche den Bau ihrer Griffel und führe dies näher aus! - Die 
großblumige Form des Feldstiefmütterchens und einige verwandte Arten sind die Stammeltern der Gartenstiofmütterchen (Pensées). Eine planmäßige Veredlung (s. S. 19) dieser herrlichen Gartenpflanze hat erst zu Anfang des 19. Jahrhunderts begonnen, und welehen Erfolg diese Arbeit gehabt hat, davon legen die erstaunliche Giölie und wechselvolle Farbenpracht der samtenen Blumen beredtes Zeugnis ab.

\section{Familie. Sonnentaugewächse (Droseráceae).}

\section{Der rundblättrige Sonneutau (I) rósera rotundifólia)} und einige andere, insektenfressende Pflanzen“.

1. Ein Bewohner des Moores. Die zierlichen B lattrosetten des eigentiimlichen Pflïnzchens finden sich dem fenchten Boden des Moores oder den weichen Polstern des Torfmooses (Sphagnum) aufgelagert, oder auch in dem niedrigen Grase, das den schwankenden Grund bedeckt. Zur Sommerzeit erheben sich aus der Mitte der Rosette einige kaum spannenlange Bliitenschafte. Die weißen, unscheinbaren Blïten entfalten sich aber nur im warmen Sonnenschein nnd zwar je nur auf einige Stunden. Die grïnen Blätter tragen auf langen Stielen kreisrunde, etwas ausgehöhlte Blattflachen, die an der Oberseite mit zahlreichen roten Haaren bedeckt sind. Die Haare nehmen vom Rande nach der Mitte zu beständig an Größe ab und sind von je einem roten Köpfchen gekrönt. (Vgl. die Blätter mit Löffelchen, die Haare mit Stecknadeln und die Blattflächen mit Nadelkissen!) Da die Köpfehen von einer farblosen Flüssigkeit umhüllt sind, glänzen und glitzern

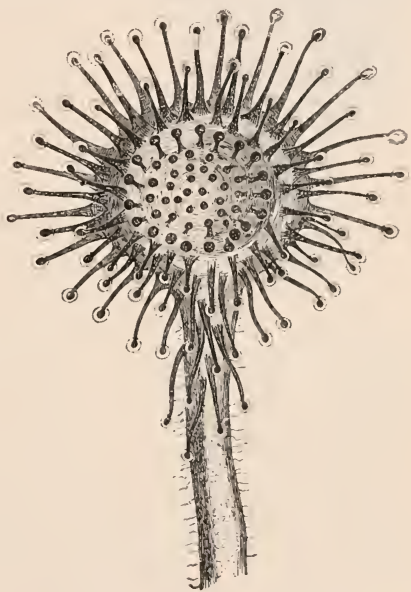

Ansgebreitetes Blatt vom Somnentau (etwa 5 mal nat. Gr.). sie im Sonnenscheine wie der Tau in der Morgenfriihe (Name!) oder wie der Honig in zahlreichen Bliiten (z. B. der Doldenpflanzen). Die Flüssigkeit verdunstet aber selbst an warmen Tagen nicht und schmeckt anch nicht siiß: sie kann also weder Tal, noch Honig sein. Berihren wie sie, so gibt sie sich als eine klebrige, fadenziehende Masse zı erkennen, die von den Köpfchen ansgeschieden wird. Die Köpfchen sind also Drïsen, die auf langen Stielen stehen. - Sehr häufig findet man auf den Blättern Panzer von Insekten oder Teile davon. Wie sind diese Körper dorthin gelangt? 
2. Eine „insektenfressende“ Pflanze. a) Wie die Beute gefangen wird. Durch die rote Färbung der Haare und die klebrige, wie Honigsaft glänzende Masse der Driisenköpfehen werden Insekten angelockt. Sobald sich aber ein Tierchen niederläßt, den vermeintlichen Nektar zu trinken, fühlt es sich gefangen und sucht zu enttliehen. Einem kleinen Insekt ist dies aber nicht mehr ınöglich: es wird von den Drïsen, die es berïhrt, wie von Leimruten festgehalten. Die Köpfchen nehmen jetzt eine dunkelrote Farbe an und scheiden eine größere Menge Flïssigkeit ans; ihre Stiele krümmen sich wie

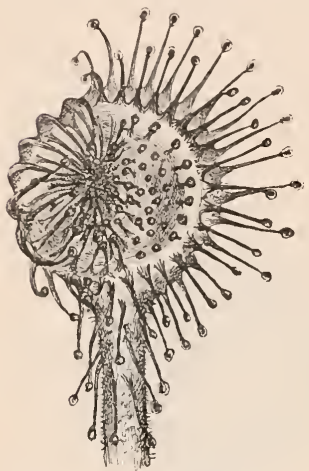

Blatt vom Somentan: Die gestielten Drüsen haben sich z. T. über einem Stückchen Fleisch nach innen gebogen. (etwa 5 mal nat. Gr.) Finger der Nitte der Blattfläche zu; die benachbarten Haare krümmen sich gleichfalls und drücken ihre Köpfchen anf die Bente; dasselbe tun die entfernteren Haare: und nicht lange währt es (bestimme die Zeit bei deinen Versuchen!), so ist das Insekt wie von hundert und mehr Sangnäpfen eines Polypen gepackt, zur Mitte des Blattes befördert und in der ansgeschiedenen Fliissigkeit ertränkt (erstickt).

b) Wie die Bente "verzehrt" wird. Nach ein paar Tagen finden wir auf dem Sonnentanblatte, dessen Drüsenhaare sich unterdes wieder anfgerichtet haben, nur noch den Hantpanzer des gefangenen Insekts. Wo sind aber die Weichteile des Tieres so schnell hingekommen? Die Flüssigkeit, die nach dem Fange des Insekts von den Drüsen ansgeschieden wurde, enthält einen Stoff, der wie unser Magensaft imstande ist, eiweißhaltige Kïrper (Fleisch und dgl.) aufzulösen. Durch seine Einwirkung wurden in der Höhlung der Blätter die Weichteile verflüssigt, und indem die ansgeschiedene Flüssigkeit von den Drïsen wieder zurïckgesogen wurde, wnrden anch die eiweißhaltigen Stoffe des Insektenleibes mit anfgenommen. Nit Recht nennt man daher den Sonnentan eine ,insektenfressende“ Pflanze. - Genau wie gegen lebende Tiere verhält sich die Pflanze auch gegen andere stickstoffhaltige Körper (Fleischstiickchen, gekochtes Hühnereiweiß, geronnenes Blut und dgl.). Bringt man dagegen stickstoffreie Körper (Sandkörnchen, Holz, Zucker und dgl.) auf die Blätter, so stellen sich jene Veränderungen zwar auch ein, aber in einem viel schwächeren Grade und ohne daß diese Körper irgendwie verändert oder gar aufgesogen würden. (Stelle entsprechende Versuche an! Wie verlaält sich das Blatt, wenn man ihm zwei Speisebrocken gibt? Inwiefern sind die ausgehöhlte Blattfläche und die Anordnung der Blätter zu einer Rosette für die Pflanze von Vorteil?)

Dienen dem Sonnentau die aufgesogenen Tierstoffe aber auch wirklich zur Ernährung? Daß dies der Fall ist, haben zahlreiche Versuche bewiesen: die 
mit tierischer Kost "gefiitterten" Pflanzen waren stets kräftiger und erzeugten größere Samen und Winterknospen als die Pflanzen, denen man eiweißhaltige Stoffe vorenthielt. (Stelle solche Versuche an!) Wir können hiernach auch verstehen, wie die Pflanze mit so dürftig entwickelten Wurzeln auskomint. Und wenn wir erfahren, daß der Ifoorboden sehr arm an Stickstoff ist, ohne den sich in den grïnen Blättern kein Eiweiß bilden kaun, so werden wir auch die Wichtigkeit des Insektenfanges für die Pflanze als für einen II $00 \mathrm{r}$ bew o h n er verstehen.

3. Andere, insektenfressende" Pflanzen. Anf sumpfigen Wiesen and in der Gesellschaft des Sonnentaus findet sich häufig das niedliche Fettkraut (Pinguicula vnlgáris). Wie die violette Bliite deutlich zeigt, ist das Pflänzchen gleich dem w. u. erwälnten Wasserschlanch den Lippenblütlern nahe verwandt. Da beide aber Tierfänger sind, sollen sie trotzdem hier kurz betrachtet werden. Die hellgrünen, fleischigen Blätter des Fettkrautes (Name!) bilden eine dem Boden aufliegende Rosette. Sie sind an den Seitenrändern etwas aufgebogen und an der Oberfläche mit zahlreichen Drüsen bedeckt, die einen klebrigen Saft ausscheiden. Kleine Insekten, die auf das Blatt geraten und in den Saft einsinken, suchen zu entfliehen. Sobald sie aber den Blattrand berühren, "bekommt das Blatt Leben": der Blattrand iiberdeckt das Tier und schiebt es nach der Mitte des Blattes, von den Drüsen wird ein Verdaunngssaft ausgeschieden, und bald ist die Beute getötet und verzehrt.

Aus dem Wasser der Teiche, Tümpel und Gräben ragen in den Sommermonaten nicht selten die prächtigen, gelben Lippenblüten des Wasserschlauchs (Utriculária vulgáris) hervor. Die Pflanze schwebt ohne Wurzeln frei im Wasser, bewohnt daher nur stehende Gewässer (warum?) und besitzt wie der Wasserhahnenfuß (s. das.) fein zerteilte Blätter. Einzelne Blattzipfel sind aber zn eigentümlichen Blasen oder kurzen Schläuchen (Name!) umgewandelt, die etwa die Größe von Pfefferkörnern besitzen nnd Tierfallen darstellen. In das Innere jeder Blase führt eine öffnung, die von mehreren kleinen und 2 verzweigten, größeren Borsten nmstellt and durch eine Klappe verschlossen ist. Schon durch den Anstob eines Wasserinsekts, eines Ruder-, Blattfuß- oder Muschelkrebschens öfnet sich die Klappe nach innen. Die Tierchen dringen auch zahlreich in die Blase ein, sind aber alsbald gefangen; denn die Klappe öffnet sich nicht nach außen. Nach einigen Tagen verenden sie; die Verwesungsstoffe aber werden von der Pflanze aufgesogen und zum Aufban ihres Körpers verwendet.

In wärmeren Ländern gibt es eine Reihe von Pflanzen, die den Tierfang mit Hilfe sehr verschieden gestalteter Fallgruben betreiben. Unter diesen sind wieder die bei uns häufig in Gewächshäusern gezogenen Kanneusträucher (Nepénthes) an seltsamsten. Sic gedeihen auf dem Sumpfboden der Urwälder oder klettern auch in dem niedrigen Buschwerk empor. Ihre Blattstiele sind im ersten Abschnitt blattartig verbreitert, in mittleren strangartig, im Endteile aher zu der kannenförmigen Fangvorrichtung umgewandelt, deren Deckel durch die kleine Blattfä̈he gebildet wird. Wie die Blumen, so bedient sich auch die Kanne besonderer Mittel, die Insekten anzulocken: der Deckel und besonders der gewulstete Rand sind oft mit Honig bedeckt, und die Buntfärbung des ganzen Gebildes zeigt den Tieren an, daß hier eine Nahrungsquelle flieBt. Der Kannenrand ist aber an der Innenseite abschüssig und durch einen Wachsüberzug geglättet. Es kann daher nicht ausbleiben, dab zahlreiche Näscher in die Kanne stürzen, die oft bis zur Hälfte mit Flüssigkeit gefiillt ist. Da die Innenwand der Kanne durch einen 
Wachsüberzug gleichsam poliert ist und vom Rande oft noch große Zähne nach innen starren, so giebt es für die Gefangenen kein Entkommen. Sie ertrinken; ihre Weichteile

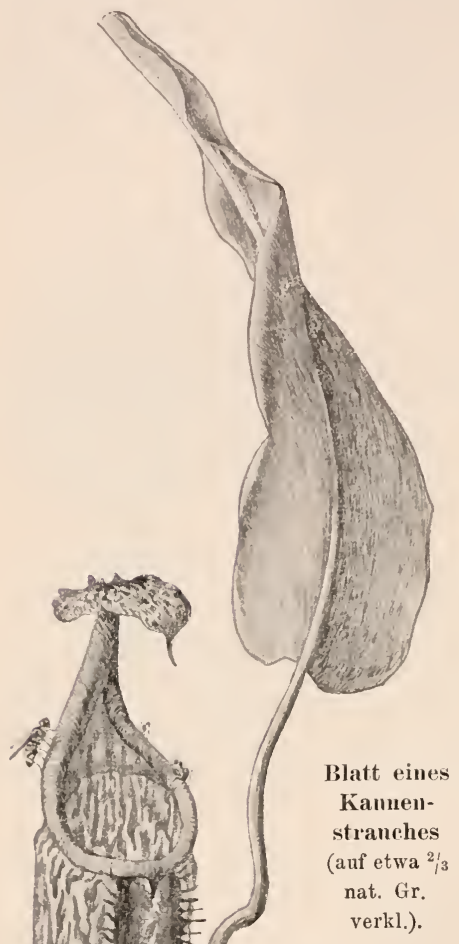
werden von dem ausgeschiedenenVerdauungssafte aufgelöst und von der Pflanze aufgesogen.

\section{Familie. Nelkengewächse} (Caryophyllíceae).

Bliiten: 4 oder 5 freie oder verwachsene Kelchblätter; 4 oder 5 Blumenblätter; Staubblätter in 2 Kreisen, meist 10; Früchte einfächerig; mit meist vielen Samen an einer mittelständigen Säule.

\section{Unterfamilie. Eigentliche Nelken} (Siléneae).

Kelchblätter zu einer Röhre verwachsen.

Die Stein-Nelke (Diánthus carthusianórum).

Die allbekannte*, anch Karthäuser**Nelke genannte Pflanze findet sich, wie schon der Name andeutet auf steinigem Untergrunde, grasigen Bergabhängen, in Straßengräben und an ähnlichen trockenen und dem Sounesibrande voll ansgesetzten Stellen. Sie ist also

A. eine Ödlandpflanze. 1) Untersucht man den Boden ihres Standorts im Sommer, wenn es längere Zeit nicht geregnet hat, so wundert man sich, daß auf einem (nach unserer Meinung) so „völlig“" ausgetrockneten Grunde noch nicht alles Pflanzenleben erloschen ist; die Nelke dringt aber mit ihrer starken Hauptwurzel, in die sich der verzweigte nuterirdische Stamm (s. Absch. 2) fortsetzt, bis zu den tieferen Erdschichten hinab, die selbst während der trockensten Jahreszeit etwas Feuchtigkeit besitzen. Anf Felsuntergrund freilich, der nur mit einer dïnnen Schicht Erde iiberzogen ist, können die Wurzeln

* An den wenigen Orten, an denen sie fehlt, kann die Heidenelke (s. w. u.) an ihre Stelle treten.

** Nach den beiden Naturforschern Karthauser, die im 18. Jahrhundert lebten. 
nicht tief hinabsteigen. Dort müssen sich die Pflanzen, die darum auch außerordentlich dürftig sind, dann mit dem nächtlichen Tau begnïgen, der von den oberflächlich liegenden Wurzeln aufgesogen wird. Und die geringe Menge von Fenchtigkeit genïgt der Pflanze, wie der Angenschein lehrt, das Leben zu erhalten.

2) Andererseits werden wir aber nicht fehl gehen, wenn wir annehmen, daß die Pflanze an allen Orten mit der geringen Wassermenge, die ihr zur Verfügung steht, sehr sparsam umgehen wird. Wir finden bei ihr keine großen Blattflächen, wie sie die Schatten- oder Wasserpflanzen (s. Windröschen und Sumpf-Dotterblume) besitzen, sondern schmale, grasartige Bläter. Und diese Blätter sind - wieder im Gegensatz zu jenen Pflanzen - sehr derb; selbst wenn wir einen Strauß Stein-Nelken stundenlang in der Hand tragen, so bringen wir ihn doch "frisch" mit nach Hause, ein Zeichen, wie gering die Wasserverdunstung durch die Blätter sein muß. - Die Blätter stehen sich paarweis gegenïber und sind am Grunde zu einer kurzen Röhre verwachsen, die den Stengel umschließt (vgl. mit Roggen). Neben solchen Zweigen, die sich in einem hohen, Bliiten tragenden Stengel fortsetzen, bildet der unterirdische Stamm (Wurzelstock) stets auch einige Äste mit sehr kurzen Gliedern, die erst im nächsen Jahre blïhen (d. s. bei der Gartennelke die sog. Absenker oder Ableger).

B. Eine Tagfalterblume. Bunte Tagfalter und träge Widderchen (Zygíena) besuchen häufig die Blïte der Steinnelke. (Bestimme die beobachteten Schmetterlingsarten!)

1. Wie sie die Falter anlockt. a) Die blütentragenden Stengel erheben sich - wie wir schon gesehen haben - hoch iiber die niederen Pflanzen der Umgebung. (Beachte an verschiedenen Örtlichkeiten, wie die Länge der Stengel stets zu der Höhe der umgebenden Pflanzen im Verhältnis steht!)

b) Die oberen, breiten und am Rande ausgezackten Abschnitte der 5 Bl um en blätter sind von lenchtend karminroter Färbung. (Wie sind die unteren schmalen Abschnitte gefürbt?)

c) Die Blïten stehen in Bïscheln beisammen, und zwar sind fast stets einige zugleich entfaltet, so daß die Auffälligkeit erhöltt wird.

2. Was sie den Faltern bietet. a) Die 10 Staubblätter sind an ihrem untersten Teile zu einem Ringe verwachsen, der in reichem Мaße Honig absondert.

b) Wie in der bekannten Curtmannschen Erzählung vou "Storch und Fuchs" der Fuchs allein von flachen Tellern, der Stor'h aber ans langhalsigen Flaschen speisen konnte, so vermögen die kurzrüsseligen Insekten (Fliegen, Käfer) den Honig nur aus flachen Schalen (Beispiele!) zu lecken, während die langrüsseligen ihn am liebsten ans tiefen Gefäßen entnehmen. 1)ie Schmetterlinge besitzen nun aber unter allen In-

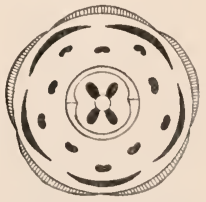

BIïtengrundrißg der Stein-Nelke 
sekten den längsten Rüssel. Sie saugen daher den Honig bequem aus langen Blumenröhren, wie wir eine solche auch bei der Nelke finden. Die Röhre wird hier aus den sehr schmalen unteren Abschnitten (den sog. Nägeln) der Blumenblätter gebildet. Diese Blütenteile sind aber (schlitze den Kelch auf!) von so großer Zartheit, daß sie sich ohne fremde Hilfe nicht aufrecht erhalten können. Sie wird ihnen von dem fünfzipfligen K elche gewährt, dessen Blätter zu einer steifen Röhre verwachsen sind. Die an sich schon enge Blïtenröhre wird durch die Staubblätter und Stempel noch mehr verengt. Darum kann nur ein Schmetterlingsrïssel in ihr vordringen. Unnützen Näschern aber ist durch diese Einrichtung der Weg zum Honig vou oben versperrt.

c) Und von unten vermögen die beißkräftigen Hummeln und Bienen, die bei zahlreichen Blumen (bei Taubnessel, Leinkraut u. v. a.) Einbruch verüben, nicht zum Honig vorzudringen; denn die Blïten sind am Grunde von festen, lederartigen (braunen) Schuppen umgeben.

3. Wie die Bestäubung erfolgt. a) Die 10, zu 2 Kreisen geordneten Staubblätter und die beiden Narben reifen (wie bei fast allen Gliedern der Unterfamilie) in einer bestimmten Reihenfolge: Zuerst strecken die 5 äußeren Staubblätter die Beutel aus der Blütenröhre hervor, bieten den grünblauen Blütenstaub ans und verschrumpfen bald. Ihnen folgen die Staubblätter des inneren Kreises, und erst nachdem sie verblüht sind, kommen die Narben hervor.

b) Da die Staubbeutel und Narben vor dem Zugange zum Honig stehen, müssen sie erstlich von den saugenden Schmetterlingen gestreift werden. Und da beide Blütenteile ungleichzeitig reifen, kann es zweitens nicht ausbleiben, daß die Tiere beim Flug von Blume zu Blume Blïtenstaub von jüngeren Blïten zu den Narben älterer Blüten tragen. Kurz: die Besucher müssen unfreiwillig Fremdbestäubung vermitteln. (Warum ist Selbstbestäubung völlig ausgeschlossen?)

C. Frucht und Same. 1. a) Der Anzahl der Narben entsprechend, ist der Fruchtknoten (die Frucht) aus 2 Fruchtblättern gebildet. In seine Höhlung ragt eine Verlängerung des Blïtenstiels, die zahlreiche Samenanlagen trägt.

b) Da sich die reife Kapsel an der Spitze mit 4 Zähnen öffnet, so können die Samen allein nicht ausfallen. Die Pflanze bedarf hierzu wie der Klatschmohn der Hilfe des Windes. Dieser Ausstreuungsweise entsprechend finden wir (s. a. B. 1. a.) bei der Nelke auch einen hohen und elastischen Stengel, der leicht vom Winde erschüttert werden kann.

c) Legt man Samen von Landpflanzen (Versuch!) längere Zeit ins Wasser, so gehen sie durch Fäulnis zu Grunde. Daher erscheint es für die Nelke doch sehr unvorteilhaft zu sein, daß ihre Fruchtkapseln nach oben geöffnet sind! Denn es kann doch wohl nicht ausbleiben, daß die Samen bei jedem Regen vollkommen durchnäßt werden? Das ist jedoch nicht der Fall. Betrachtet man nämlich Kapseln, die gestern bereits geöffnet waren, $\mathrm{n}$ ach Ein tritt eines Regenwetters, so findet man sie sämtlich wieder geschlossen: ihre Zähnchen haben sich (weil sehr hygroskopisch) wieder nach innen gekrümmt, so daß dem 
Wasser der Eintritt in das Fruchtinnere verwehrt wird. (Durch Eintauchen der Kapseln in Wasser und nachheriges Trocknen kann man den Vorgang im Zimmer beliebig oft wiederholen. - Beobachte daranfhin auch andere Nelken!)

2. Da die kleinen Samen rings von je einer trockenen Hant umgeben sind, so bilden sie flache Scheiben. Sie bieten dem Winde somit eine große Angriffsflliche dar und können infolgedessen weit verweht werden.

\section{Andere Nelken.}

Schon von alters her ist die vielgestaltige Gartemuelke (D. caryophýllus), die aus Südenropa stammt, ein Liebling des Menschen. Wegen des herrlichen Duftes ihrer Blüten, der lebhaft an den der Gewürz-Nelken oder Gewürz-Nägelein (so genannt nach der Ähnlichkeit mit einem Nagel) erinnert, erhielt die Pflanze (samt ihren nächsten Verwandten) den Namen ${ }_{n}$ Nägelein“, aus dem durch Verkïrzung das Wort ${ }_{n}$ Nelke ${ }^{4}$ entstanden ist. - An ähnlichen Örtlichkeiten wie die Steinnelke findet sich die zierliche Heidenelke (D. deltoídes). Thre einzeln stehenden Blüten sind aber in ein helleres Rot gekleidet, mit weißen Punkten überstreut und oft noch durch einen purpurnen Ring verziert. - Unter der Saat findet sich als schöne Feldblume, aber auch als lästiges Unkraut die Kornrade (Agrostémma githágo). Ihre schwarzen Samen sind schwach giftig. Finden sie sich daher in Menge unter dem Getreide, so machen sie das Mehl für den menschlichen Genuß unbrauchbar. - Ein prächtiger Schmuck feuchter Wiesen sind im Frühlinge die rosafarbenen Blüten der Kuckucksnelke (Coronária flos cúculi). Den Artnamen führt die Pflanze von dem "Kuckucksspeichel“, den man häufig an ihren Stengeln findet, der aber nicht vom Kuckuck, sondern von der Larve der Schaumzirpe herrührt (s. S. 22). Die zarten Blüten besitzen zerschlitzte Blumenblätter. Da die Blütenröhre verhältnismäßig kurz ist, vermögen auch langrüsselige Bienen und Fliegen bis zum Honig vorzadringen. - Noch mehr gilt dies von dem bekannten Taubenkropf (Siléne vulgáris), der auf trockenen Wiesen, an Wegrändern und dgl. häufig anzutreffen ist. Da sein netzadriger Kelch kropfartig (Name!) aufgeblasen ist, können nur ausnahmsweise sehr langrüsselige Hummeln durch Einbruch bis zum Honig vordringen. - Das Seifenkraut (Saponária officinális) dagegen, das an Flußufern, zwischen Gebüsch und dgl. wächst, hat eine so lange Blütenröhre, daß es nur von den langrüsseligsten Schmetterlingen, den Schwärmern, bestäubt werden kann. Die Wurzel der Pflanze, die beim Reiben im Wasser wie Seife schäumt (Name!), ist durch einen giftigen Bitterstoff gegen Mäuse und andere Nager geschützt.

Eine hänfige, aber sehr interessante Pflanze sonniger Hügel und trockener Wälder ist das nickende Leimkraut (Siléne nutans). Wenn der A b e n d anbricht, macht es sich zum Empfang seiner Bestäuber, der Nachtschmetterlinge, bereit: es entfaltet die weißen Blütensterne, streckt wie die Steinnelke 5 seiner Staubblätter oder die 3 Narben aus der Blütenröhre hervor und sendet einen köstlichen Duft aus. Da in der Nacht alle Blumen bis auf die hellsten den Blicken entschwinden (beobachte dies!), so wird uns die weiße Farbe der tiefgeteilten Blumenblätter wohl verständlich. Wer ferner jexuls Nachtschmetterlinge "geködert" hat (bestreiche in einer Sommernacht Baumstämme am Waldesrande mit etwas Apfeläther oder einer ähnlichen stark duftenden Flüssigkeit und beobachte den Anflug der Nachtinsekten!), der kennt auch die Bedeutung des weithin wahrnehmbaren Duftes. Und wer endlich weiß, daß zahlreiche Schmetterlinge (Schwärmer) beim Saugen des Honigs nur mit schnellem Flügelschlage vor der Blüte schweben, der versteht auch, warum sich die anfänglich aufrechtstehenden Blüten beim Entfalten 
nach der Seite richten (Artname!). - Sobald es $\mathrm{T}$ a g wird, gehen mit den Blüten in der Regel merkwürdige Veränderungen vor: sie hören auf zu duften; die Blumenblätter schrumpfen zusammen und rollen sich so ein, dab sie die grünliche Rückseite nach außen kehren; kurz, die Blüten erscheinen jetzt wie verwelkt und werden in diesem Zustande ron keinem Insekt besucht. Erst wenn die Nachtfalter wieder erwachen, „erwachen" auch die Blüten wieder. - Gleich den fliegenden Taginsekten verwehrt die Pflanze auch den am Stengel emporkriechenden Kerbtieren den Zutritt zur Honigquelle. Und zwar bedient sie sich hierzu eines Mittels, das auch der Ilensch anwendet, um seine Wald- und Obstbäume gegen ankriechende Schädlinge zu schützen, der Teer- oder Leim. ringe. Von der Stelle an, an welcher der erste Blütenzweig entspringt, ist nämlich der Stengel mit einer stark klebenden Masse überzogen (daher: Leimkraut!). An dieser "Leimrute" kleben die emporkriechenden Insekten fest, so daß sie bald zu Grunde gehen. Ist das Blühen vorbei, so verschwindet auch der nunmehr überflüssige Klebstoff.

Einen noch weit stärkeren Leimüberzug finden wir an den Stengeln der (darum so genannten) Pechuelke (Viscária vulgáris). Sie wächst an denselben Örtlichkeiten wie das nickende Leimkraut und ist wegen ihrer zahlreichen, purpurroten Blüten schon von alters her eine beliebte Gartenzierpflanze. - Eine Nachtfalterblume, die (wemn auch meist nicht mit gleicher Deutlichkeit) alle jene Veränderungen zeigt, die wir beim Leimkraut gesehen haben, ist die weibblïhende Nachtliclituelke (Melándryum album), die als oft meterhohe Pflanze an Wegrändern und dgl. wächst. - Ihre nächste Verwandte dagegen, die Taglichtuelke (II. rubrum), ist wie alle rotblühenden Nelken (warum?) eine Tagfalterblnme. Sie bewohnt feuchte Gebüsche und Wälder und zählt gleichfalls zu unsern gemeinsten Pflanzen.

\section{Unterfamilie. Mi e re n (Alsineae).}

Kelchblätter nicht verwachsen (frei).

\section{Die Vogelmiere (Stellária média)}

ist das gemeinste Unkrant unserer Gärten und Felder. Da sich die schwachen und darum zum Teil niederliegenden Stengel darmartig verschlingen, so daß meist große Rasen entstehen, führt sie auch die Namen „Hühner- oder Mäusedarm". "Vogel"-Miere heißt sie, weil ihre jungen Triebe gern von Stubenvögeln verzehrt werden. Im März entfaltet die einjährige Pflanze bereits ihre unscheinbaren Blüten, und im Spätherbst, ja selbst unter dem Schnee findet man sie oft immer noch blühend. Die Blüten und Frïchte sind im wesentlichen wie bei der Steinnelke gebaut (Beweis!); der getrenntblättrige Kelch aber erlaubt den kleinen, weißen, tiefgespaltenen Blumenblättern, sich auszubreiten. Infolgedessen ist der Honig selbst den kurzrïsseligsten Insekten zugänglich. Die rinnenförmigen Stiele der kleinen Blätter sind seitlich mit Haaren besetzt. Ähnliche, nur weit längere Haarleisten ziehen sich (in der Ein- oder Zweizahl) von einem Stengelknoten zum andern herab. Läßt man von oben Wasser auf einen Zweig der Pflanze tropfen, so sieht man, wie sich die Haarleisten voll Wasser saugen, und wie das Wasser, das nicht mehr festgehalten werden kann, an ihnen wie an Dochten herab und zur Wurzel fließt. Ein Teil des Wassers wird auch von den Haaren selbst aufgesogen; kurz, wir haben es hier mit einem jener mannigfachen Mittel zu thun, durch das die Pflanze den 


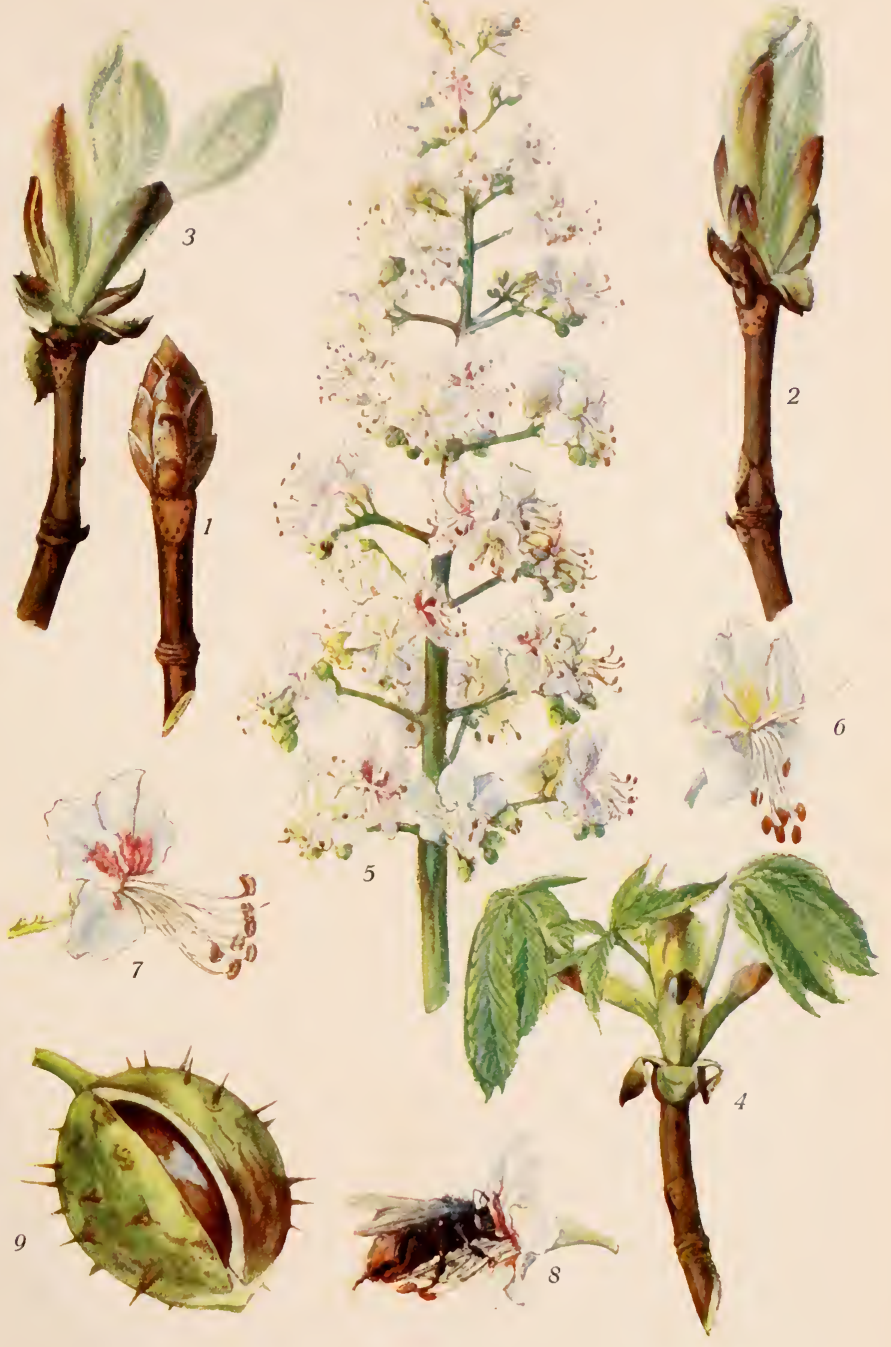

Roßkastanie (Aesculus hippocastanum). 

Regen und Tau, der sie benetzt, auf das sorgfältigste verwendet. Diese Einrichtung macht uns auch das Vorkommen der Pflanze an ganz trockenen Orten verständlich.

Ihre nächste Verwandte, die Stermmiere (St. holóstea), besitzt nicht allein weit größere Blüten, sondern als Bewohnerin lichter Wälder und Gebüsche auch viel größere Blätter (Bedentung?). - Hinsichtlich der Bläten ähnelt die schöne Frühlingspflanze im hohen Grade dem allbekannten Acker-IIornkraut (Cerástium arvénse), das aber 5 Griffel und seinem Standorte entsprechend (Wegränder und dgl.) weit kleinere Blätter besitzt. - Auf ödestem Sandboden (Blätter fast nadelförmig!) gedeiht der AckerSpark (Spérgula arvénsis), der hier und da anch als Futterpflanze angebant wird.

\section{Familie. Roßkastaniengewächse (Sapindáceae).}

Die Roßkastanie (Aescǔlus hippocástanum). Taf. 6.

A. Die Roßkastanie und der Mensch, Obgleich die Roßkastanie erst vor etwa 300 Jahren ihren Einzug in Europa gehalten hat, weiß man doch nicht genan, woher sie stammt. Die Gebirge Nord-Griechenlands, in denen man sie in großen Beständen antrifft, können kaum ihre Heimat sein; denn dann wäre sie dem kunstsinnigen Volke der alten Hellenen sicher nicht unbekannt geblieben. Hentzutage findet man den prächtigen Baum, der eine Höhe von mehr als $20 \mathrm{~m}$ erreichen kann, bei uns fast überall da, wo Menschen wohnen. Wegen des schnellen Wachstums, des dichten Schattens der mächtigen Krone und der herrlichen Bliitensträuße, die wie Weihnachtskerzen in die Frühlingspracht leuchten, pflanzt man ihn hier in Alleen, dort in Gärten und Anlagen, hier auf öffentlichen Plätzen und dort auf den stillen Friedhof.

Da sein Holz sehr weich ist (schneide einen Zweig ab!), kann es wie das Lindenholz fast nur zu Schnitzarbeiten verwendet werden, und die bitteren Samen (Kastanien) dienen zumeist nur als Winterfutter für die hungernden Hirsche, Rehe und Wildschweine.

B. Die Kuospen. 1. Wenn im Herbste die Blätter fallen, stehen bereits die Knospen da (1.). Sie mïssen sich also (beobachte dies!) schon während des Sommers und zwar in den Blattwinkeln gebildet haben. Öffnet man eine Knospe, so hat man zuerst eine Anzahl schuppenförmiger Blätter zu entfernen, von denen die äußeren pergamentartig hart und braun sind. Dasselbe gilt auch von den inneren Blättern, soweit sie sich nicht decken. Alle sind durch eine harzige Masse verklebt und halten umso fester zusammen, als sie zum großen Teil mit zottigen Härchen bedeckt sind. (Bestimme die Verteilung der Haare genauer!) Durchschneidet man eine Knospe, so sieht man mit Verwunderung, eine wie starke und feste Hiille diese "Knospenschuppen" um den jungen Trieb im Innern der Knospe bilden. Die einzelnen Teile des Triebes sind in dem engen Raume fest zusammengelegt. Bei einiger Vorsicht (und mit Hilfe einer Nadel!) gelingt es aber, sie voneinander zn trenuen. Wir sehen dann einen winzigen Zweig mit Blättern (Laubknospen) oder mit Blättern und Blïten (Blütenknospen) vor uns, dessen einzelne Teile von seidenartigen Haaren umhïllt siıd. Die Natur 
hat also den jungen Trieb so fest und sicher verpackt, wie wir es mit zerbrechlichen Gegenständen thun. (Führe den Tergleich näher aus!) Welche Bedeutung hat nun dieses sorgfältige "Verpacken"?

a) Der junge Trieb ist ein ungemein zartes Gebilde. Da er aber von einer festen Hülle umgeben ist, deren Schuppen zudem noch verklebt sind, so können ihn die Winterstüme nicht zerzausen, und es vermag kein Wasser (Regen, Tau, Reif, Schnee) bis zu ihm vorzudringen oder sich gar zwischen seinen Teilen anzusammeln. Gefrierendes Wasser würde den zarten Trieb aber unbedingt zerstören.

b) Um Rosen- und Weinstöcke oder andere Pflanzen gegen das Erfrieren zu schïtzen, biegen wir sie zum Erdboden herab und bedecken sie mit schlechten Wärmeleitern (Erde, Stroh, Laub u. dgl.), oder wir tuı nur das letztere. Da in einem strengen Winter der Erdboden selbst in unsern Breiten $1 / 2 \mathrm{~m}$ tief oder noch tiefer fest gefriert, so kühlen sich anch die „eingeschlagenen" Pflanzen oft weit unter $0^{0} \mathrm{ab}$. Trotzdem erfrieren sie aber - wie die Erfahrung lehrt - weit seltener als nicht umhüllte Pflanzen. Den weniger strengen und anhaltenden Frösten des zeitigen Frïhjahrs dagegen vermögen die Hüllen zu trotzen, und das ist umso wichtiger, als zu dieser Zeit der Saft bereits in die Bäume gestiegen (wie man an jedem Weidenzweige sehen kann) und infolgedessen die Gefahr des Erfrierens besonders groß ist. - Wenden wir dies auf die Kuospen der Roßkastanie an, so mïssen wir sagen, daß der in ihnen eingeschlossene junge Trieb bei strenger Kälte trotz Schuppenhïlle und Haarkleid sicher unter 00 abgekïhlt wird, daß diese Mittel aber wohl imstande sind, die schwachen Frühjahrsfröste abzuhalten. Und dieser Schutz ist von umso größerer Bedeutung, weil zu dieser Zeit das Erfrieren des saftreichen, aus dem "Winterschlafe erwachten" Triebes leicht möglich wäre.

c) Welche dritte Bedeutung endlich noch die Hülle hat, lehrt folgender einfache Versuch: Man schneide 2 noch festgeschlossene, gleich große Knospen an der Ansatzstelle ab, entferne von der einen sämtliche Knospenschuppen und lege beide in ein Zimmer. Ist das Zimmer geheizt, so wird man schon nach wenigen Tagen die Knospe ohne Schuppen vollkommen vertrocknet, die andere aber noch ganz "frisch" finden. Dies ist ein deutlicher Beweis dafür, ein wie wichtiges Schutzmittel gegen das Vertrocknen (Wasserabgabe) die Hülle ist. Da die Schuppen verklebt and die Außenschuppen zudem pergamentartig sind, so ist der Abschluß des jungen Triebes fast luftdicht. Und dies ist durchaus nötig; denn während der Wintermonate vermögen die Wurzeln des Baumes aus dem stark abgekïhlten oder sogar gefrorenen Boden kein Wasser aufzusangen (s. Kirschbaum).

2. Ende April oder Anfang Mai - im Süden früher, im Norden später (warum?) - beginnt die Knospe nach langer Winterruhe sich zu öffnen. Schon vorher ist sie stark angeschwollen und trieft von Harz. Die inneren, grünen Knospenschuppen haben sich mit dem wachsenden Triebe, um ihn weiter gegen die Unbilden der Witterung schützen zu können, stark in die Länge ge- 
streckt; endlich brechen sic auseinander, und wie der Schmetterling aus der Puppenhülle drängt sich der junge Trieb zum Lichte empor (2).

a) Der Umstand, daß jetzt die harzige Masse in großer Menge abgeschieden wird, deutet darauf hin, daß sie nicht nur - wie bisher angenommen ein Klebmittel ist. Sie überzieht das Ganze wie ein Firnis, schließt den jungen Trieb somit von der Außenwelt ab und schützt ihn infolgedessen gegen eine zu starke und zu schnelle Abgabe des Wassers oder kurz: gegen Vertrocknen.

b) Auch wenn sich die Knospe bereits zu öffnen beginnt, sind die stark vergrößerten Knospenschuppen noch nicht bedeutungslos. Sie halten von dem jungen Triebe den Anprall des Windes und die austrocknenden Sonnenstrahlen ab; sie sind also für das überaus zarte Gebilde Wind- und Sonnenschirm z ugleich.

Ist der junge Trieb den Schuppen aber "ïber den Kopf gewachsen", s0 haben sie keine Bedeutung mehr: sie fallen ab und lassen am Grunde des Jahrestriebes eine ringförmige $\mathrm{N}$ arbe zurïck.

C. Die Blätter. 1. Das junge Blatt weicht von dem völlig entwickelten seinem Aussehen nach erheblich ab: es ist - wie bereits erwähnt - mit weißen oder gelblichen Haaren bedeckt; seine Einzelblättehen (s. Absch. C 2, b) sind in der Mittelrippe zusammengefaltet und treten senkrecht aus der Knospe hervor (3.); dann breiten sie sich aus, hängen aber noch eine Zeitlang senkrecht nach unten (4.). Endlich nimmt das Blatt die Lage der ausgebildeten Blätter ein, und knrze Zeit darauf sind von dem Haarkleide nur noch in den Aderwinkeln an der Unterseite Spuren zu finden. Welche Bedeutung diese Erscheinungen haben, ist leicht einzusehen:

a) Fenchtet man 2 gleichgroße Schwämme gleichstark an, umwickelt sodann einen mit einem Tuche und legt beide endlich an dieselbe Stelle in das Freie oder das Zimmer, so findet man, daß der in das Tuch geschlagene weit länger feucht bleibt als der andere. Wie geht dies zu? Aus beiden Schwämmen entweicht Wasser in Dampfform, so daß beide bald von einer fenchten Luftschicht umgeben sind. Bei dem eingehiillten Schwamme wird die feuchte Luftschicht zwischeu den Fäden des Tuches und den einzelnen Teilen der Fäden gleichsam festgehalten, erneuert sich also nur sehr langsam. Bei dem anderen Schwamme dagegen entweicht der Wasserdampf ungehindert ins Freie; infolge= dessen muß die eingesogene Wassermasse auch viel schneller verdunsten als die des eingehïllten Schwammes. Genau dasselbe findet auch bei 2 (sonst gleichen) Blättern statt, von denen das eine kahl und das andere von einem Haarkleide umgeben ist. In der Behaarung der jungen Kastanienblätter haben wir also ein Schutzmittel gegen zu starke Wasserabgabe vor uns.

b) Wie die tütenförmig zusammengerollten Veilchenblätter (s. das.) bieten anch die gefalteten jungen Einzelblätter der Roßkastanie dem Winde eine viel kleinere Verdunstungsfläche dar, als wenn sie ausgebreitet wären.

c) Die Somnenstrahlen (S) treffen zur Mittagszeit - also wenn sie am kräftigsten wirken — das senkrecht aus der Knospe tretende (a b) oder später 
senkrecht nach unten hängende Blatt (a c) unter viel spitzerem Winkel als das vollkommen ansgebildete Blatt, das zu den einfallenden Sonnenstrahlen schräg gestellt ist (a d). Nun wissen wir aber, daß die Sonnenstrahlen einen

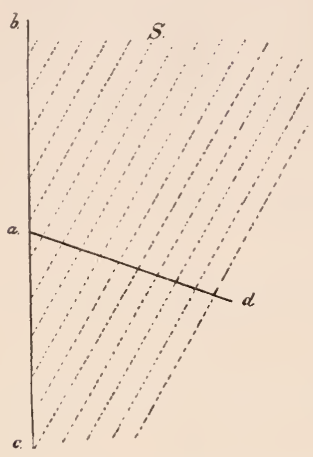

Körper umso stärker erwärmen, je "senkrechter" sie ihn treffen. (So schmilzt z. B. der Schnee auf dem schrägen Dache in der Mittagssonne, währ'end dieselben Sonnenstrahlen den Schnee auf dem wagerechten Erdboden nicht zu schmelzen vermögen.) Ein senkrecht gestelltes Blatt kanı zur Mittagszeit also nicht in dem Grade erwärmt werden wie ein wagerecht oder schräg gestelltes, folglich auch nichtsoviel Wasser verdunsten als jenes. (Pflanzenteile welken in einem kiihleren Zimmer oder im Schatten langsamer als in einem wärmeren Zimmer oder im Sonnenscheine. - Von wieviel Strahlen werden die beiden senkrecht gestellten Blätter [a b und a c] und das schräg gestellte Blatt [a d] getroffen?)

Also: alle drei Einrichtungen lanfen darauf hinaus, die Wasserdampfabgabe des jungen Blattes möglichst $\mathrm{zn}$ beschränken. Wenu wir bedenken, wie leicht junge Blätter welken, werden wir anch die Bedeutung dieser Schutzeinrichtungen verstehen; denn verwelken bedeutet für das Blatt - den Tod! Je melır die jungen Blätter erstarken, desto mehr sehen wir dann auch die nunmelır überflüssig werdenden Schutzmittel verschwinden.

2. Das a usgebildete Blatt. In unserer Heimat finden wir, abgesehen von dem Walnußbaum, neben der Roßkastanie keinen zweiten Baum mit so auffallend großen Blättern. Daher wirft die Krone anch einen so tiefen Schatten, daß nnter älteren Bäumen nicht einmal mehr das genügsame Gras gedeiht (vgl. dag. z. B. den grasbewachsenen Obstgarten!).

a) Ein Baum mit solchen Blättern kann keine hohe, pyramidenförmige Krone bilden etwa wie die "lichte“, locker belaubte, kleinblättrige Birke; denn die oberen Blätter wïrden ja dann den unteren das zum Leben durchaus notwendige Licht rauben (Beweis!). Die meist nnr am Ende beblätterten Zweige "drängen" sich im Gegenteil nach außen, so daß eine breite, weit ausgreifende Krone entsteht.

b) Jedes Blatt ist ans meist 7, am Rande gezähnten Einzelblättern zusammengesetzt, durch deren Lïcken selbst anf tiefer gestellte Blätter noch ab und zu Lichtstrahlen fallen. Die Einzelblätter stehen am Ende eines langen Stiels wie die Finger an der Hand (gefingertes Blatt); sie sind meist etwas schräg nach unten geneigt und stets so geordnet, daß keins das andere verdeckt. Darum sind sie auch nach dem Grunde zu keilfö rmig verschmälert. c) Auch die Blätter als Ganzes betrachtet, nehmen sich trotz ihrer Größe gegenseitig nich da Licht weg; je 2 stehen sich am Zweige gegenïber; 
jedes Blattpaar bildet mit dem vorhergehenden und nachfolgenden ein Krenz; die einzelnen Blattpaare sind meist weit auseinandergeriickt (lange Stengelglieder), und die Endblätter der Zweige sind stets viel kleiner und viel kïrzer gestielt als die weiter unten am Zweige stehenden, großen und langgestielten Blatter. Infolge dieser Anordnung werden an sen $\mathrm{krec} h$ ten $\mathrm{Z}$ we igen - wie man leicht beobachten kann - sïmtliche Blätter belichtet. An wagerechten Zweigen (s. Abb. S. 46)

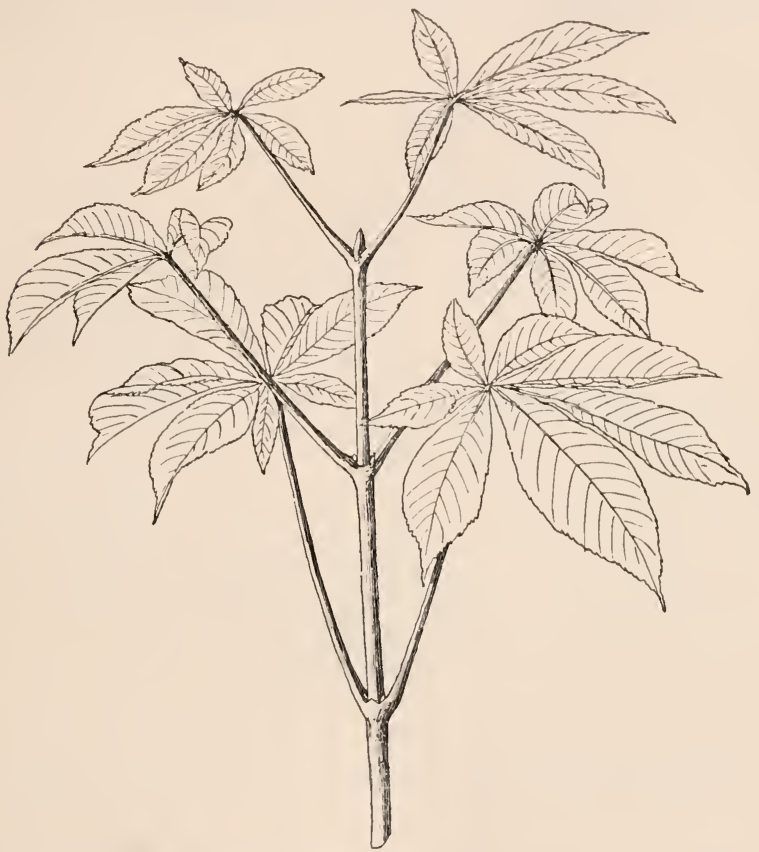

Senkrechter Zweig der Roßkastanie, von der Seite gesehen (verkl.).

ist die Blattstellung natiirlich genau dieselbe. Biegt man aber einen senkrechten Zweig soweit herab, daß er wagerecht zu liegen kommt, so stellen die nach oben gerichteten Blätter die unteren in den Schatten. Eine solch ungünstige Blatt= stellung bedarf hier darum gleichsam einer Korrektur, die in der Tat anch eintritt: Die Blaitter legen sich oft vollkommen in die Ebene, in die man sich den Zweig gelegt denken kann; die von der Zweigspitze entfernteren Blätter rücken ihre Blattflächen auf sehr langen Stielen aus dem Schattenbereiche in das Licht, und alle Blätter des Zweiges ordnen sich oft ïberaus regelmäßig so an, daß 
keins von dem anderen beschattet wird. Die Blätter schräggestellter Zweige nelımen zwischen denen an senkrechten und wagerechten Ästen die mannigfachsten Zwischenstellungen ein; kurz: iiberall sehen wir, wie sich die Blätter zum Lichte drängen und stets dorthin stellen, wo sie am meisten von den belebenden Sonnenstrahlen getroffen werden. (Sehr deutlich und leicht sind diese Erscheinungen an Zweigen zu beobachten, die aus einem Baumstumpfe hervorgehen, an sog. „Stockausschlag“. - Beobachte daraufhin anch Ahorn, Schneebeere und andere Pflanzen!)

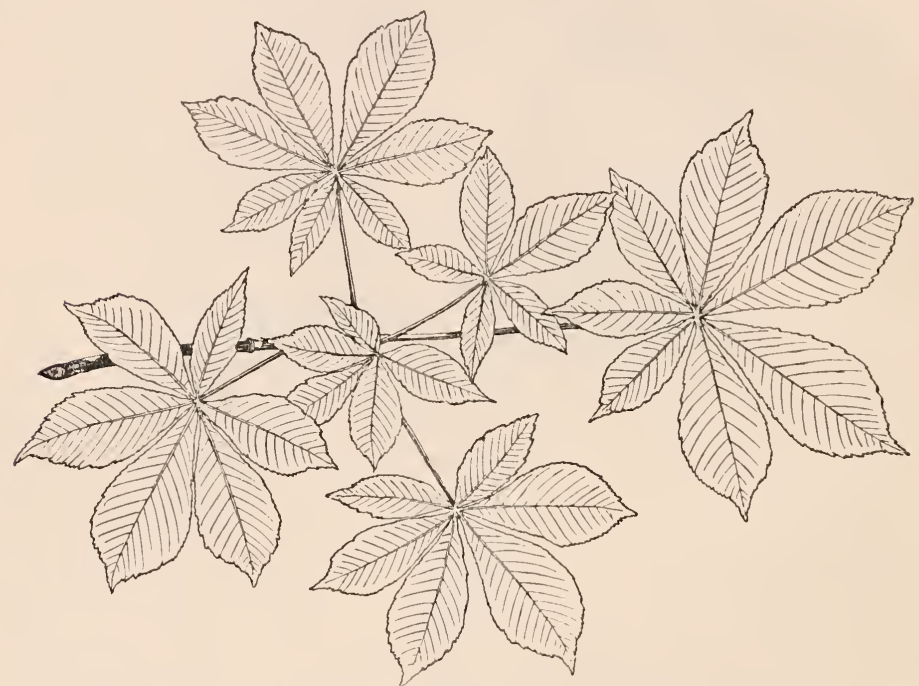

Wagerechter Zweig der Roßkastanie, von oben gesehen (verkl.).

3. Beim herbstlichen Laubfalle (s. Kirschbaum) lösen sich die Einzelblätter von den Stielen und diese von den Zweigen. Die Narben, welche die Blätter an den Zweigen zurïcklassen, haben die Form eines Pferdehufes. Ind die Narben der Gefäßbündel (s. das.), die sich in die Adern der Einzelblätter fortsetzen, kann man als die Nägel des kleinen Hufes deuten. (Daher vielleicht Roßkastanie! Vgl. auch Absch. E. 3.)

D. Die Bliite. 1. Blïtezeit. Da an dem jungen, in der Knospe liegenden Triebe die Blïten bereits ansgebildet sind, so wundert es uns gar nicht, daß die Roßkastanie kurz nach dem Entfalten ihrer Blätter bereits in voller Blïtenpracht dasteht. (Vgl. dag. Linde.)

2. Die jungen Blïten verlieren wie die Blätter bald das schützende 
Haarkleid. Nur an den Blütenstielen bleiben Überreste davon zurück. Anch der fïnfzipflige $\mathrm{Kelch}$, der anfänglich die Blïte ganz umschloß, bei ihrem Öffnen aber seine Aufgabe (welche?) erfüllt hat, füllt meist ab.

3. a) Die entfaltete Bliite (6. u. 7.) macht sich durch die 5 ungleich großen, weißen Blumenblätter, die mit einem anfänglich gelben, später roten Fleck geziert sind, weithin kenntlich (Anlockung der Insekten). Und dies geschieht umso mehr, als die Blüten große, pyramidenförmige Sträuße bilden (5.). die stets an der Außenseite der Krone stehen und sich prächtig von dem grïnen Hintergrunde abheben.

b) Zwitter- und Staubbliiten. Untersucht man die einzelnen Blüten eines Bliitenstranßes, so findet man, daß nur wenige von ihnen neben (meist) 7 Staubblättern einen wohl ausgebildeten Stempel besitzen (Zwitterblüten) Bei allen anderen Blïten ist der Stempel verkümmert (Staubblüten). Wenn man bedenkt, wie groß und schwer die Frïchte der Roßkastanie sind, wird man diese Erscheinung leicht verstehen: wïrde jede Blïte eine Frucht liefern, so müßten die Zweige unter der Last brechen. Darum finden sich die fruchtbaren Blüten auch nur im unteren Teile der Bliitenstände. Die unfruchtbaren Blüten sind aber nicht etwa ohne Bedeutung: sie helfen den Blïtenstand vergrößern (s. Absch. 3 a) und liefern, da sie sich stets zuerst entfalten, Blütenstaub für die

c) (Bestäubung) zuerst reifenden Narben der fruchtbaren Blïten. Die Narbe ist das zugespitzte Ende des langen Griffels, der weit ans der Blüte hervorragt. Die später reifenden Stanbbeutel sind jetzt (6.) noch nach unten geschlagen, heben sich aber später bis zur Höhe der Narbe empor (7). Da die Narbe und die geöffneten Staubbentel weit von der Blïtenöffinung abstehen, so können sie anch nur von größeren Insekten beim Saugen des Honigs berïhrt werden. Hummeln, welche Griffel und Staubblätter als. bequeme "Sitzstange" benutzen (vgl. mit dem Anflugbrett am Taubenschlag!), vermitteln daher besonders die Bestänbung (8). Da nun - wie erwähnt - Narbe und Stanbbentel nacheinander reifen, so müssen die Hummeln auch den Bliitenstanb (an der Unterseite des Hinterleibs) von einer Bliite zur andern tragen (Fremdbestänbung). - Alle kleinen Insekten sind unnütze Näscher. Der Honig wird im oberen Teile des Blütengrundes abgeschieden. $\mathrm{Er}$ ist durch die wagerechte Stellung der Blüte und durch Haarbesatz, der sich an Blumen- und Staubblïttern findet, gegen Regen geschïtzt.

E. Die Frucht. 1. Der Fruchtknoten zeigt im Querschnitt 3 Fächer mit je 2 Samenanlagen, von welchen sich aber nur $1-2$ zu Samen entwickeln.

2. Die Fruch thülle (9.) ist mit spitzen Stacheln bedeckt. Diese Gebilde stellen - nach ähnlichen Erscheinungen der heimatlichen Pflanzenwelt zu schließen (Beispiele!) - in der (unbekannten) Heimat des Baumes sicher Schutzmittel der unreifen Frucht gegen Tiere dar. Bei der Reife löst sich die Frucht vom Stiele, die Hülle zerspringt in 3 Stiicke, und

3. die großen, dunkelbrannen und glänzenden Samen werden frei. Der helle Fleck kennzeichnet die Stelle an, an welcher die Samen mit der Fruchthïlle 
verwachsen waren. Wegen der Ähnlichkeit der Samen mit denen der edlen Kastanie heißt unser Bamm "Kastanie"; "Roß kastanie“ nemut man ihn wahrscheinlich, weil seine Samen für uns ungenießbar sind (s. auch Meerrettich).

Eine nahe Verwandte ist die rote Kastanie (Pavia rubra), die gleichfalls häufig als Zierbaum angepflanzt wird. Sie stammt aus Nordamerika, hat schmutzig-rote Blüten und unbestachelte Früchte.

\section{Familie. Ahorngewächse (Aceráceae).}

Der Spitz-Ahorn (Acer platanoídes)

kommt vereinzelt in den Waldungen der Ebenen und Mittelgebirge vor und ist seines festen, zähen Holzes wegen, besonders aber als Alleebaum überall hoch geschätzt. Den Artnamen führt er von den schön geformten Blättern, deren

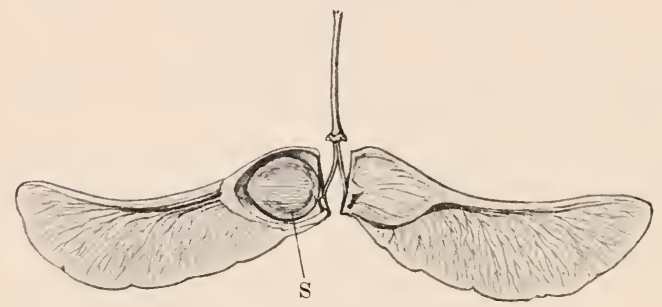

Frucht vom Spitz-Ahorn. Teilfrüchtchen von einander getrennt, aber noch an den Stielchen hängend. Fruchtfach des linken Früchtchens geöffnet, um den Samen $\mathrm{S}$ zu zeigen.
$5-7$ Lappen in feine Spitzen ausgezogen, und die denen der Platane sehr ähnlich sind. (Beobachte das Aufbrechen der großen, klebrigen Knospen, die Entfaltung der Blätter und ihre Stellung an senkrechten und wagerechten Zweigen! Vgl. mit Roßkastanie!) Die Blii-

ten (beschreibe sie!) sind trotz der unscheinbaren, gelbgrünen Färbung doch auffällig; denn sie öffnen sich vor der Entfaltung des Laubes nnd stehen in großen, aufrechten Sträußen beieinander. An dem Fruchtknoten bilden sich nach dem Verblühen 2 kleine Erhebungen, die allmählich zu großen Flägeln auswachsen. Bei der Reife zerfällt die Frucht (ähnlich wie die der Möhre; s. das.) in 2 Teile, die in dem inneren, angeschwollenen Abschnitte je einen Samen enthalten. Fallen die Teilfrüchte von dem Banme herab (laß einige ans größerer Höhe fallen!), so geraten sie gleich Windmühlenflïgeln in kreisende Bewegung und sinken infolgedessen viel langsamer (etwa 4 mal so langsam) zum Erdboden herab, als ein gleichgroßer und gleichschwerer ungeflïgelter Körper. Sie erhalten sich also infolge der Flugausrïstung lange in der Luft schwebend. Werden sie nun dabei von einem Winde ergriffen, so werlen sie weit verweht. Infolge dieser Einrichtung vermag der Ahorn also seine verhältnismäßig schweren Samen, die sonst sämtlich unter den Baum fallen würden, über einen großen Bezirk auszustrenen. (Warum ist das für die Pflanze von Vorteil? Warum besitzen nur Bäıme solche Früchte?) Bei näherer Betrachtung findet 
man anch, daß die Flügel ihrer Aufgabe entsprechend äßßerst „Zweckmäßig“ gebaut sind: sie sind sehr groß, bieten der Luft also eine große Angriffstlache dar, auffallend leicht, könmen folglich vom Winde getragen werden (vgl. mit Flugtieren!), und trotzdem selu fest, so daß sie dem Angriffe des Windes widerstehen können. Letzteres wird besonders durch eine verstärkte Randleiste erreicht, mit der die schraubenförmig sich drehende Frucht die Luft durchschneidet (vgl. mit Vogel-, Insekten- und Windmühlenflügel !).

Der Berg-Ahorn (A. pseudoplátanus) ist, wie schon sein Name sagt, ein Gebirgsbaum. Er bildet in den Alpen größere Bestände, ist aber in Parkanlagen überall häufig anzutreffen. Sein weißes, festes Holz wird besonders hoch geschätzt. Die 5 Lappen der Blätter sind grob gesägt und enden in stumpfe Spitzen. Die stark duftenden Blüten stehen in hängenden Trauben und öffnen sich erst nach der Laubentfaltung. - Der Feld-Ahorn (A. campéstre) kommt in Feldgehölzen (Name!), in Wald und Gebüsch als Strauch und Baum vor. Seine verhältnismäBig kleinen, 4-lappigen Blätter sind ganzrandig.

Eine entfernte Verwandte ist die zierliche, blau, rot oder weiß blühende Kreuzblıme (Polýgala vulgáris), die häufig an trockenen Stellen gedeilht. (Wie ist sie der Örtlichkeit „angepaßt"?) Da die kleine Blumenkrone als Schutzmittel des Stempels und der Staubblätter dient, haben zwei große, buntgefärbte Kelchblätter die Aufgabe übernommen, Insekten anzulocken.

\section{Familie. Orangengewächse (Rutáceae).}

Aus den Küstenländern und von den Inseln des Mittelmeers kommen in jedem Jahre riesige Mengen von Zitronen und Orangen zu nns: Die geschätzten Früchte entstammen niedrigen Bäumen oder Sträuchern, die sich von dem östlichen Asien aus über alle wärmeren Erdstriche verbreitet haben. Die Pflanzen besitzen immergrüne Blätter, die wie die des Epheus von lederartiger Beschaffenheit sind. Gleich wie der Epheu (s. das.), vermöge dieser eigenartigen Blätter der „Winterdürre“ unserer Breiten zu trotzen vermag, so vermögen diese Pflanzen die Trocknis auszuhalten, die im Mittelmeergebiete fast die ganze warme Jahreszeit hindurch ununterbrochen anhält. Die Zitrone (beschreibe sie!) ist die Frucht des meist strauchig gehaltenen Zitronenbaums (Citrus médica). Das flüchtige ÖI (s. Rose) der Schale dient besonders als Gewürz. Die gleiche Verwendung findet auch das saure Fruchtfleisch, dessen durststillender Saft namentlich zur Herstellung von Limonade gebraucht wird (die Zitrone heißt italienisch "Limone"). Die kopfgroßen Früchte einer Spielart geben, mit Zucker zubereitet, das Zitronat (Verwendung?). - Der Orangenbaum (C. aurántium) wird besonders in zwei Spielarten angebaut. Die eine liefert die Pomeranze oder bittere Orange, die andere die Apfelsine oder süße Orange. Die Pomeranze wird besonders zur Herstellung von Likören und eines wertvollen Öls benutzt, das in der Parfümerie verwendet wird. Die Apfelsine (d. i. Apfel aus China oder Sina, weil von dort der Baum nach Europa gekommen ist) wird als wohlschmeckendes Obst überall hoch geschätzt (beschreibe die Frucht!). Aus den weißen, stark duftenden Blüten beider Spielarten gewinnt man in großen Mengen ein wertvolles öl, das gleichfalls in der Parfümerie Verwendung findet. Orangen- und Zitronenbäume werden bei uns vielfach in Treibhäusern (Orangerien) gebalten.

Von den entfernteren Verwandten der Orangengewächse seien nur folgende genannt: Der Mahagonibaum (Swieténia), der das bekannte wertvolle Holz liefert und 
sich in den Urwäldern des heißen Amerika findet; der Cedrelıbamm (Cédrela) Brasiliens, aus dessen wohlriechendem Holze man die Cigarrenkisten herstellt; der Gïtterbaum (Ailảnthus glandulósa) aus China und Japan, der in unsere Parks eingewandert ist, sowie die Essigbaimme (Rhus), die in mehreren Arten gleichfalls bäufig in Anlagen zu finden sind.

\section{Familie. Lindengewächse (Tiliáceae).}

Die Sommer- und Winterliude (Tília platyphýllos und ulmifólia). Taf. 7.

A. Die Linde, unser Lieblingsbaum. Während die Linde in Osteuropa große Wälder bildet, treffen wir sie bei uns fast nur in der Nähe des Menschen. Sie ist der Lieblingsbaum des deutschen Volkes. Der schnelle Wuchs in der Jugend, das ehrwürdige Alter und die gewaltige Höhe, die sie erreichen kann (1000 Jahre; $30 \mathrm{~m}$ und mehr), die dichte Krone, das zarte Laub und die vielen Tausende von Blüten, die weithin die Luft mit sïßem Duft erfüllen, haben ihr diese Stellung in unsern Herzen erobert. Deshalb pflanzen wir sie als Schattenspenderin an Straßen, als Schmuckbaum auf freie Plätze und vor das Wohnhaus, sowie auf die Gräber unserer Toten. Deshalb knïpfen sich an sie auch so zahlreiche Sagen und Lieder (z. B. Siegfried - „Am Brunnen vor dem Tore“), und deshalb pflanzen wir sie (neben der Eiche) als Gedenkbaum an große Ereignisse (Beispiele!). Unsern Altvordern war die Linde ein heiliger Baum. Unter der ehrwürdigen Dorflinde berieten die Alten der Gemeinde, und noch heute versammelt sich unter ihr in vielen Gegenden die Jugend zu Lust und Freude.

Das weiche $\mathrm{Hol}$ z des Baumes wird vornehmlich zu Schnitzarbeiten verwendet; seine Kohle dient zum Zeichnen und frïher besonders zur Bereitung des Schießpulvers. Aus dem Bast (s. Lein) bereitet man, namentlich in Rußland, Decken und andere Flechtwerke. Die Blüten sind für die Bienen eine reiche Honigquelle; getrocknet liefern sie einen schweißtreibenden Tee.

B. Die beiden einheimisehen Lindenarten. Die Gattung "Linde" ist bei uns durch 2 Arten vertreten: Die Sommerlinde entfaltet ihr Laub bereits anfangs Mai (Frïhlinde) und hat unterseits kurzbehaarte, große Blätter (großblättrige Linde); die andere Art, die Winterlinde, schlägt erst Mitte Mai aus (Spätlinde), und ihre beiderseits kahlen Blätter sind viel kleiner als die der anderen Form (kleinblättrige Linde). Sonst aber stimmen beide in allen Stïcken fast völlig überein.

C. Vou den Blättern der Linde. 1. Wenn im Frühjahre der junge Trieb in der Knospe zu wachsen beginnt, drängt er die beiden braunen Knospenschuppen auseinander (1.). (Beachte ihre verschiedene Größe und dementsprechend ihre Stellung zu einander!) Statt des Triebes werden jetzt aber erst grüne oder rötlich angehauchte, schuppenförmige Blätter sichtbar, die sich stark in die Länge strecken und den umliüllten Trieb gegen die Unbilden der Witterung schïtzen (2.). Endlich tun auch sie sich auseinander, und die jungen Blätter treten zwischen ihnen hervor (3.). Nummehr erkennt man deutlich 


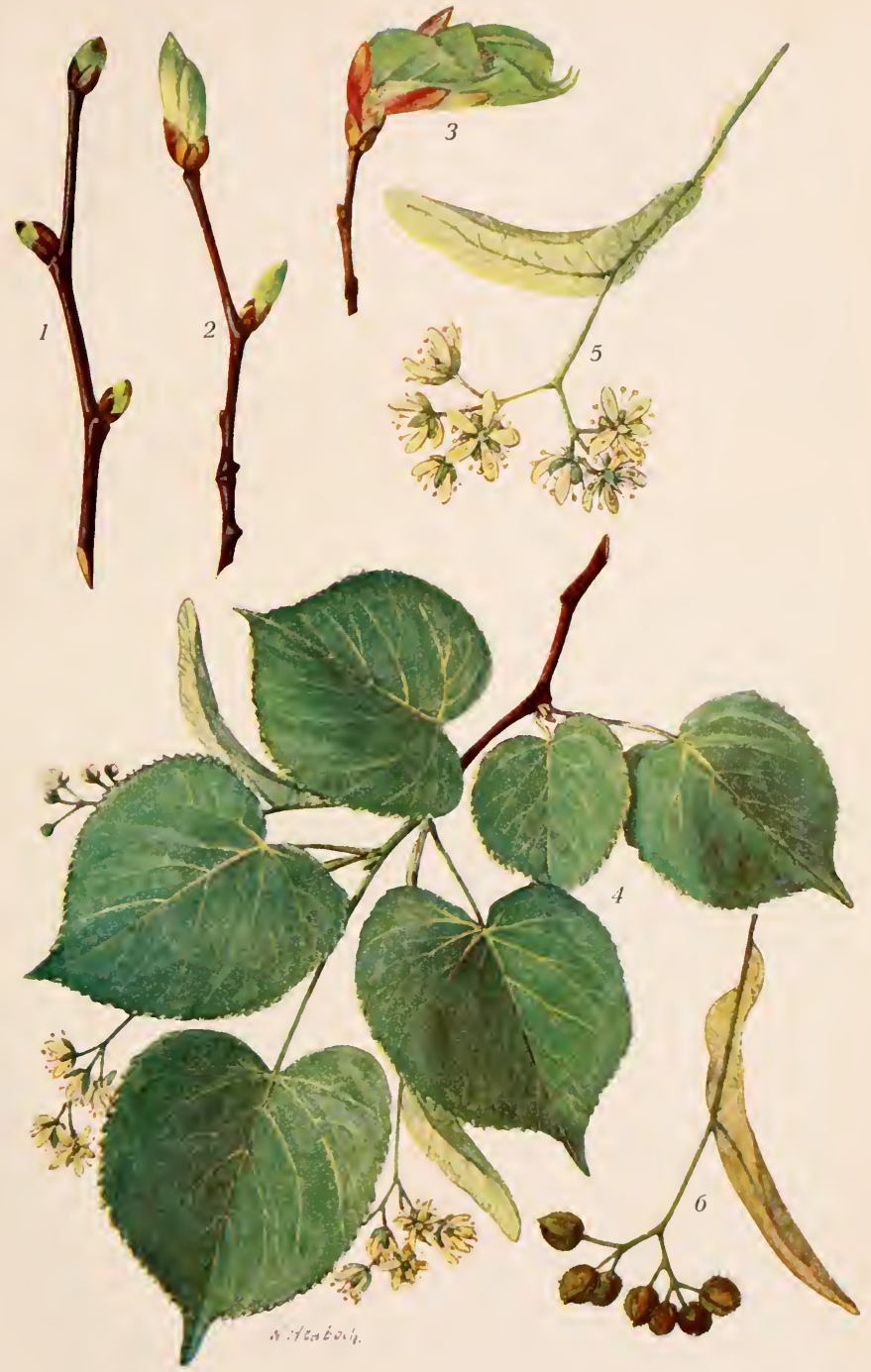

Winterlinde (Tilia ulmifolia). 

(noch deutlicher, wenn sich die jungen Stengelglieder bereits gestreckt haben), daß je 2 dieser "Schuppen" am Grunde der Blattstiele stehen. Wir haben es in ihnen also nicht mit Knospenschuppen zu tun, die den Trieb von außen umhïllen, sondern mit Nebenblättern, wie wir solche bei zahlreichen anderen Pflanzen (Beispiele!) finden. Ihrer Aufgabe entsprechend (Schutzmittel!) haben sie hier aber die Gestalt von Knospenschnppen. Ist der junge Tricb genïgend erstarkt, dann fallen die Knospenschuppen und Nebenblätter, weil nunmehr ïberfliissig geworden, ab. Die jungen Blätter sind mit langen, seidenartigen Haaren bedeckt, senkrecht gestellt und in der Mitte zusammengefaltet: wir treffen hier also fast alle die Schutzeinrichtungen wieder, die wir lei den Ḱnospen und jungen Blättern der Roßkastanie (s. das.) kennen und verstehen gelernt haben. (Öffne auch eine Knospe im Winter und beachte, wie zwischen den großen Nebenblättern die winzigen Lanbblätter, die fast wie kleine Haarbüschel aussehen, „verpackt" sind!)

2. Die Blätter stehen abwechselnd links und rechts, zu zwei "Zeilen“ geordnet, an den Zweigen, so daß die Blattflächen wie an den wagerechten Zweigen der Roßkastanie (s. S. 45) in eıne Ebene fallen (4.). Bei dieser Anordnung wäre es aber sehr leicht möglich, daß sich die Blätter gegenseitig teilweise bedeckten und somit des Sonnenlichts beraubten. Dies geschieht jedoch nicht: die herzförmigen Blattflïchen sind nicht nur wie bei jenem Baume ungleich groß und ungleich lang gestielt, sondern ihre „Hälften“ sind auch von nngleicher Größe. Die Blätter sind also unsymmetrisch. Wenn man sich das fehlende Stiick ergänzt denkt, dann erst wïrde jener Fall eintreten. Die Natur würde dann aber etwas Innniitzes oder Überflïssiges gebildet haben.

D. Yon den Bliiten der Linde. 1. Blïtezeit. In den Winterknospen der Linde werden wir trotz eifrigsten Suchens keine Bliitenanlage finden. Die Bliiten bilden sich nämlich erst an dem jungen Triebe, der aus der Knospe hervorgeht, und zwar sprießen sie aus den Blattwinkeln neben den Knospen hervor, die den nächstjührigen Trieb enthalten und sich jetzt bereits bilden. Diese Tatsache erklärt uns die verhältnismäßig späte lBliitezeit der Linde zur Genïge. (Wamn blühen Sommer- und Winterlinde in deiner lfeimat?)

2. Bliite. a) Von einem Hauptstiele strahlen bei der Sommerlinde gewöhnlich 2 oder 3 , bei der Winterlinde dagegen $5-7$ Nebenstiele aus, die je eine Bliite tragen (5.). Der Hauptstiel ist zum Teil mit einem bandförmigen, pergamentartigen, bleichen "Heckblatte" verwachsen, dessen Bedentung wir später (s. Absch. E) kennen lernen werden.

b) Da die Blïten zumeist nach nnten hängen und von den Laubblätern oft vïllig iiberdacht werden (4.), sind sie (Honig, Blïtenstanb!) vortrefflich gegen Regen geschïtzt. Iiesem Vorteil steht jedoch der Nachteil gegeniiber, daß die Blïten in ihrem "Verstecke" den Blicken der Insekten entzogen sind. Sie besitzen daher auch keine prïchtige Blïtenfarbe, die ja doch nicht zur Geltung. kommen könnte. Kelch und Blumenkrone, die aus je 5 kleinen, gelblichen [B]ittern bestehen, sind im Gegenteil ganz unscheinbar. Dil aber die IBlïten 
einen weithin walınehmbaren D u ft aushauchen, wird dieser Nachteil völlig wieder ausgeglichen.

c) Die zahlreichen, langen Staubblätter stehen in dichtem Kranze um den Stempel. Sie sind sämtlich nach außen gerichtet, ïberragen die kleine Bliitenhïlle und iiberdecken den Honig, der in großer Menge von den muldenförmigen Kelchblättern abgeschieden wird. Infolgedessen müssen sich die zahlreichen Insekten (Bienen und Fliegen), die auf der hängenden Blüte Fuß fassen wollen, an ihnen und dem Stempel festklammern. Da nun die Staubbeutel vor der Narbe reifen, kann es kaum ausbleiben, daß Blïtenstaub von den jüngeren Blïten auf die Narbe der älteren übertragen, also Fremdbestäubung herbeigefïhrt wird.

E. Von den Früchten der Linde (6.). Der Fruchtknoten (stelle einen Querschnitt her!) enthält 5 Fächer mit je 2 Samenanlagen. Von diesen 10 Anlagen entwickelt sich jedoch gewöhnlich nur eine; die ïbrigen verkümmern. Die nußartige Frucht (Lindennüßchen) brancht sich bei der Reife daher nicht zu öffnen (s. S. 10,3). Die lederartige Fruchthülle wird durch Verwesen zerstört.

Im Herbste löst sich der Fruchtstand mit dem fliigelartigen Hiillblatte vom Zweige und fällt wie die Ahornfrucht (s. das.) langsam herab. Wird er dabei vom Winde erfaßt, so gelangt er oft erst in großer Entfernung vom Baume zum Erdboden. Das Hüllblatt ist also gleich dem Flügel der Ahornfrucht ein Nittel zur Ausbreitung der Samen und damit zur Weiterverbreitung der ganzen Pflanze.

\section{Familie. Malvengewächse (Malváceae).}

Die Weg-Malve (Malva neglécta)

findet sich - wie schon der Name andeutet - als eine unserer gemeinsten Pflanzen an Wegen und in der Nähe der menschlichen Wohnungen. Vermöge einer sehr tiefgehenden Wurzel kann sie anf dem festen, diirren Boden wohl gedeihen. Macht ihr keine andere Pflanze das Licht streitig, so liegen die schwachen Stengel fast völlig dem Untergrunde auf; im anderen Falle aber sind sie genötigt, sich emporzurichten. Die rundlichen 5-7lappigen Blätter sind gleich den Stengeln melr oder weniger dicht mit sternförmigen Haaren bedeckt (Verdunstungsschutz!). In den Blattwinkeln stehen stets melrere langgestielte Bliiten, die unter dem fünfzipfligen Kelch noch je 3 Nebenblättchen besitzen. Die 5 rosafarbenen Blumenblätter sind am Grunde mit den zahlreichen Staubblättern verschmolzen, deren Fäden wieder zu einer die Griffel umschließenden Röhre (zu einem „Bündel“) verwachsen sind. (Beweise, daß die Bestäubung in derselben Weise wie beim Rittersporn erfolgt!) Die Frucht reift, vom Kelche bedeckt, zurückgebogen im Schutze der Blätter und ist einem kleinen Käse nicht unähnlich („Käsepappel“). Sie besteht aus einer mittelständigen Scheibe (einer Verlängerung des Fruchtstiels), die von zahlreichen 
Fruchtknotenfüchern umgeben ist. Die einzelnen Fächer nmschließen je einen Samen und lösen sich bei der Reife ab. Sie werden vom Regen verschlämmt und von Menschen oder Tieren mit dem aufgeweichten Boden leicht verschleppt. Diese Tatsache erklärt uns auch das Torkommen der Pflanze (s. oben).

Auf feuchten Wiesen, besonders auf Salzboden, findet sich der Eibisch (Althǽa officinális) als eine mehr denn meterhohe Pflanze, deren grüne Teile mit weißem Filz überzogen sind ( ${ }_{n}$ Sammetpappel $\left.{ }^{\mu}\right)$. Blätter, Blüten, besonders aber die Wurzeln sind von alters her wegen des Schleimes, den sie beim Kochen liefern, ein wichtiges Heilmittel. Deshalb baut man die stattliche Pflanze auch im großen an. - Gleiche Heilwirkung besitzen auch die Blüten der Stockrose (A. rósea), die aus dem Morgenlande zn uns gekommen und eine bekannte Zierpflanze ist. - Ein Malvengewächs ist auch

\section{Die Baumwolle (Gossýpium).}

1. Die artemreiche Gattung umfaßt eine Anzahl kraut-, strauch- und baumartiger Pflanzen, die in den heißen Gegenden der alten und nemen Welt heimisch sind. Die Formen, deren Samenhaare wir als wichtigsten Spimnstoff verwenden - kleidet sich doch die Mehrzahl der Menschen in baumwollene Gewebe! - haben sich weit über ihr ursprüngliches Gebiet verbreitet und selbst einen großen Teil der wärmeren gemäßigten Zonen erobert (z. B. Siideuropa und Nordamerika).

2. Die Pflanzen werden in Strauchform gezogen (warum nicht als Bäume?), haben große, 3-5lappige Blätter und (bis auf eine weißblühende Art) gelbe II a lvenblïten. Die Frucht ist eine Kapsel, ans der bei der Reife ein mächtiger Haarschopf hervorquillt. Die Haare haben eine Länge bis zu $5 \mathrm{~cm}$, sitzen an der Oberfläche der erbsengroßen Samen und dienen der Terbreitung der Pflanze durch den Wind (vgl. mit Löwenzahn, Weide u. a.).

3. Verwendung. Sobald sich die Kapseln zu öffnen beginnen, werden sie eingesammelt, und sofort trennt man mit Hilfe von Maschinen die Haare von den Samen. Der größte Teil der gewonnenen Haare wird gesponnen und entweder als Garn verwendet (Strick-, Häkelgarn und dgl.) oder zu Zengen verwebt (Kattun, Barchent, Musselin u. s. w.). Anch zur Herstellung von Watte, Schießbaumwolle und anderen gewerblichen Erzeugnissen finden die wertvollen Haare Verwendung. Aus den Samen, die man nicht zur Anssaat benutzt, wird Öl gepreßt (Baumwollsaatöl), und die Rückstände dienen noch als nahrhaftes Viehfutter.

Zn den Malvengewächsen zählt auch der Affenbrotbanm oder Baobab (Adansónia digitáta), der in den Steppen des heißen Afrika heimisch ist. Er bildet im Alter eine riesige Krone und dementsprechend einen sehr starken Stamm. In der trockenen Jahreszeit verliert er das Laub (vgl. mit Kirschbaum, Absch. $3 \mathrm{c}$ ), und dann hängen die bis $40 \mathrm{~cm}$ langen, spindelförmigen Früchte gespenstig von den gewaltigen Zweigen herab. Die Früchte sind nicht nar für die Affen (Name!), sondern anch für die Menschen ein wichtiges Nahrangsmittel. - Ein entfernterer Verwandter der Malven ist 


\section{Der Kakaobaum (Theobróma cacáo).}

Der Kakaobaum hat in den Urwäldern des tropischen Amerika seine Heimat, wird jetzt aber in fast allen heißen Ländern angebant. Seine gurkenähnlichen, bis 20 cm langen Friichte enthalten in einem sïnerlichen Fruchtfleische zahlreiche, sehr bittere Samen, die sog. Kakaobohnen. Die eingeernteten Frïchte legt man anf Haufen oder schïttet sie in Gruben und läßt

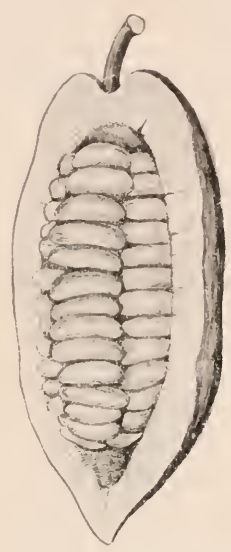

Frucht des Kakaobaumes, geöffuet, um die Samen, die "Kakaobolinen", zu zeigen $(1 / 3$ nat. Gr.). grannte $^{u}$ Teilfrüchte, die sich von der stehenbleibenden Verlängerung des Blätenstieles (Mittelsäule) lösen. Bohnen, die sodann von dem Fruchtfleische getrennt werden, einen angenehmeren, milderen Geschmack, so daß sie nummehr zur Herstellung von Schokolade tanglich sind. Zu diesem Zwecke werden sie geröstet, von den Schalen befreit, zerrieben und mit Hilfe hydraulischer Pressen entölt. I ler zur ïckbleibende „Pressknchen" wird gepulvert und liefert das Ka ka opulver; mit Zucker vermischt und gewïrzt (durch Vanille oder andere Stoffe) gibt er die Schokolade. Wie Kaffee und Tee enthält auch der Kakao einen Stoff (Theobromin), der auf den Menschen eine belebende Wirkung ausübt. Da man aber rom Kakao nicht mur einen Aufguß trinkt, sondern ihn als Ganzes genießt, so ist er zugleich ein Nahrungsmittel.

\section{Familie. Storchschnabelgewächse (Geraniáceae).}

Blüten: je 5 freie Kelch- and Blumenblätter; 10 am Grunde verwachsene Staubblätter; Fruchtknoten aus 5 verwachsenen Fruchtblättern zusammengesetzt; die geschnäbelte Frucht spaltet sich bei der Reife in 5 ,besie hier einige Tage liegen. Dadurch erhalten die

Der Reiherschnabel (Eródium cicutárium). Taf. 8.

1. Standort. Der Reiherschnabel ist auf Äckern, an Wegen und Rainen, besonders auf Sandboden, hänfig anzutreffen.

2. Wurzel. Obgleich die oberen Bodenschichten dieser Örtlichkeiten während der Sommermonate fast völlig austrocknen, geht die Pflanze doch nicht zu Grunde; denn sie sendet eine sehr lange Pfahlwurzel bis in die Bodenschichten hinab, die stets etwas feucht bleiben. Ein weiteres Schutzmittel gegen das Vertrocknen ist die sehr dichte, grane

3. Behaarung aller grïnen Teile bei denjenigen Pflanzen, die auf sehr sonnigem und dürrem Boden stehen (s. S. 43, Ca). Wachsen die Pflanzen unter günstigeren Bedingungen, so sind sie stets viel geringer, oft nur ganz wenig 


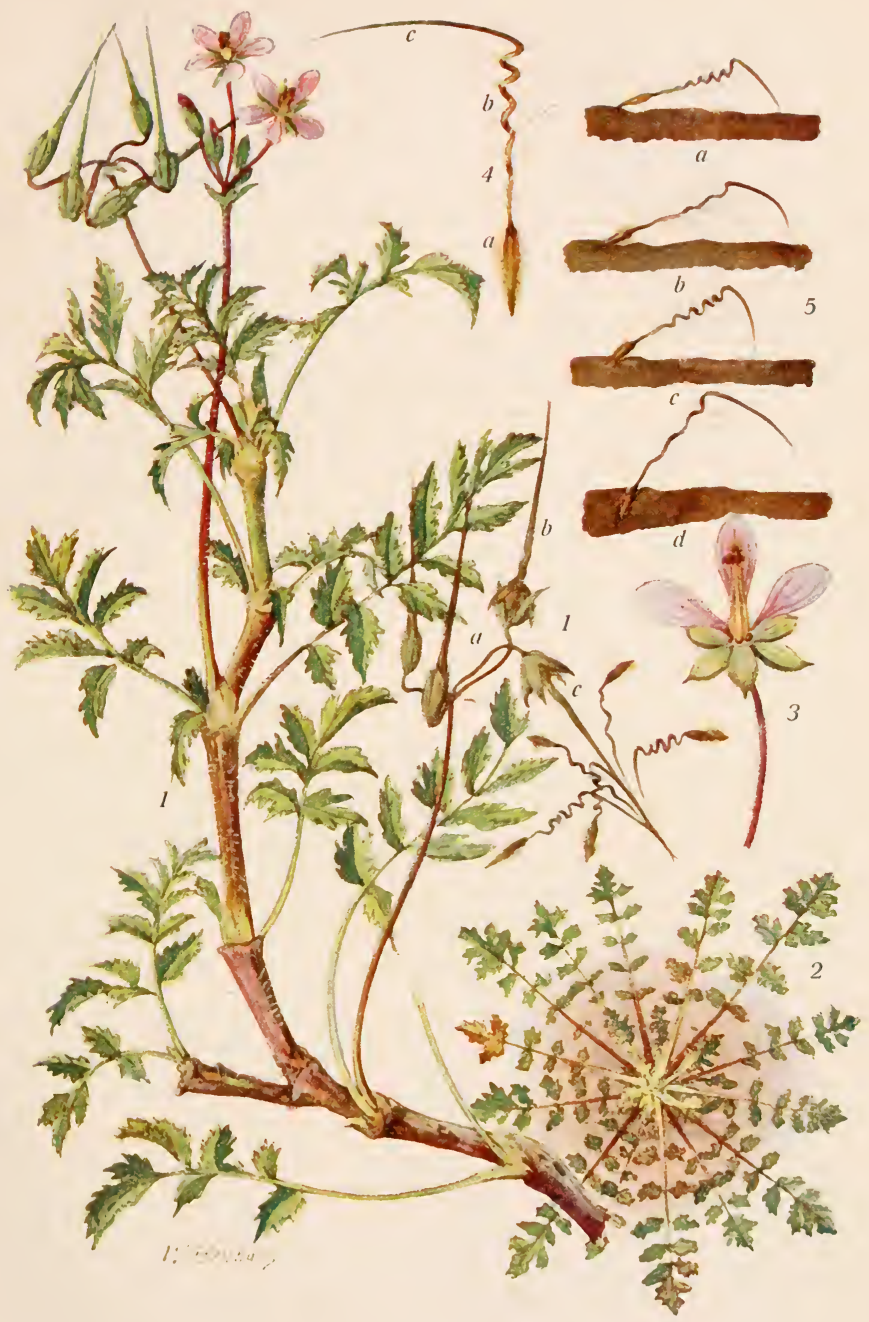

Reiherschnabel (Erodium cicutarium). 

behaart. Einen ähnlichen Interschied finden wir meist auch beziiglich der zierlich gefiederten

4. Blätter, deren Fiedern wieder mehr oder weniger tief eingeschnitten sind. In den kleinen IBlattflichen, die natiirlich weniger Wasser verdunsten als sonst gleiche, aber größere, besitzt der Reiherschnabel - an welchen Orten er auch wachsen mag - ein drittes Schutzmittel. Ind dieses Mittel muß umso wirksamer sein, je kleiner die Blattflichen sind. Die kleinsten Flächen finden wir nun abermals bei den Pflanzen der sonnigsten Stellen: die Fiederblätter sind bis auf den Grund geteilt, so daß jedes abermals gefiedert ist. (Vgl. beziiglich dieser Punkte andere Pflanzen trockener Standorte!)

Im Herbste und Winter bilden die Blätter des veränderlichen Pflänzchens oft außerordentlich regelmäßige, dem Boden aufliegende Rosetten (2). Infolge dieser Lage kann kein Blatt dem andern auch nur einen Lichtstrahl rauben, und so allein vermag die winterliche Schneelast dem schwachen Gewächse keinen Schaden zuzufügen (Beweis! s. S. 17, B; s. auch Löwenzahn!). Im Frülijahr setzt die Pflanze das Leben fort, das durch die Kälte zum Stillstand gebracht wurde: sie treibt langgliedrige, meist rot angelaufene, beblätterte

5. St engel (1.) Wächst der Reiherschnabel zwischen anderen Pflanzen, die ihm das Licht streitig machen, dann richten sich die Stengel hoch empor; im anderen Falle dagegen bleiben sie meist dem Boden angedriickt. Über Stengel und Blätter ragen, dem Insektenvolke sichtbar (Bedeutung?), die

6. Blït en empor. Neben Pflanzen mit kleinen Blïten findet man solche, die weit größere Bliiten tragen. Während erstere von Insekten wenig beachtet werden und darum in der Regel auf Selbstbestäubung angewiesen sind, erfreuen sich die anderen eines regen Insektenbesuchs. (Untersuche die Bliiten auf Fremdund Selbstbestänbung genaner! Tgl. auch mit Stiefmiitterchen!) Hehrere der kurz gestielten Bliiten (3) stehen auf einem langen, gemeinsamen Stiele. Schon wenige Stunden nach dem Aufbliihen verlieren sie die 5 rosafarbenen, oft dunkler gestreiften oder gefleckten und verschieden großen Blumenblätter, die am Grunde je einen Büschel seitlich gerichteter Härchen tragen. Diese Haare überdecken die 5 Honigdriisen an Grunde der Staubblätter und verwehren somit den Insekten, von unten her zum Honig vorzudringen (Bedentung?). Die 10 am Grunde miteinander verwachsenen Staubblätter sind nur zur Hältte

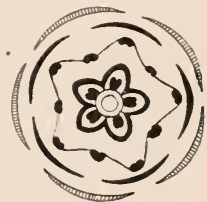

Bliitengrundrig rom Reiherschuabel. mit Staubbenteln ausgeriistet. Sie umschließen den Stempel, dessen merkwürdigen Bau uns die reifende Frucht $(1$ a - c) dentlich erkennen lïßt. Wir sehen, wie der Fruchtknoten nach und nach in 5 Teilfriichte zerfällt, die um eine Verlängerung des Fruchtstiels, eine Mittelsänle, geordnet sind. Lösen wir die noch unreifen, einsamigen Teilfrïichte (eine 2. Simenanlage grelangt nicht zur Entwicklnng!) ab, so sehen wir weiter, wie ihre Huillen (die 5 Fruchtblätter) in je einen langen Fortsatz, eine "(iranne“, ausgezogen sind. 
Jede Teilfrucht besteht also ans 2 deutlich geschiedenen Abschnitten: aus dem Fruchtfache mit dem Samen (4a) und der Granne (4b und c). Die 5 Grannen bilden mit dem oberen Teile der Mittelsäule den Griffel, und ihre obersten Abschnitte stellen die 5 Narben dar. Nach dem Verblïhen wächst der Griffel weiter, so daß er samt der Frucht schließlich einem langgeschnäbelten Vogelkopfe ähnelt (Reiherschnabel - Storchschnabel). Anch der 5-blättrige Kelch vergrößert sich noch nach dem Verblühen und umhïllt schützend die sich ansbildende

7. Frucht. a) Bringt man einen reifen Fruchtstand (vgl. die Stellung. ron Blïte und Frucht!) in das geheizte Zimmer, auf den warmen Ofen, oder sorgt man sonstwie dafür, daß er schnell austrocknet, so beobachtet man, wie sich die Teilfrüichte von der Mittelsäule ablösen $(1 \mathrm{~b})$, wie sich der untere Teil der Granne korkzieherartig aufrollt (1 c und 4), und wie das ganze Gebilde ein Stïck fortgeschlendert wird. Dasselbe erfolgt natiirlich auch im Freien, bei warmem, trockenem Wetter. In dem eigentümlichen Ban der Frucht erkennen wir erstens also ein Nittel zur Verbreitung der Samen.

b) Befenchtet man eine Teilfrucht, so streckt sich die Granne: die Windungen werden immer weiter und verschwinden schließlich vollständig. Läßt man die Granne wieder anstrocknen, so rollt sie sich wieder auf. (Die gegen Fenchtigkeit sehr empfindlichen [hygroskopischen] Teilfrïchte werden darum anch zur Herstellung von Fenchtigkeitsmessern oder Hygrometern benutzt.) Wiederholt man denselben Versuch in der Weise, daß man den rechtwinklig abgebogenen, geraden Endteil der Granne festhält, so wird das Fruchtfach in drehende Bewegung versetzt. Stellt man nun endlich eine angefenchtete Teilfrucht mit der Spitze des Fruchtfaches in Sand oder lockere Erde und dicht daneben ein Stäbchen, das den Endteil der Granne hindert, sich beim Strecken des korkzieherartigen Abschnittes zu drehen, so muß dasselbe erfolgen, d. h. das Fruchtfach in den Sand oder die Erde gebohrt werden. Dasselbe erfolgt natïrlich anch im Freien, wenn der Endteil der Granne durch Pflanzen oder Unebenheiten des Erdbodens festgehalten wird (stelle einen entsprechenden Versuch an!), und wenn Tan- oder Regentropfen die Granne strecken, und der Sonnenschein sie wieder trocknet $(5 \mathrm{a}-\mathrm{d})$. Man findet daher in der Umgebung der Pflanze zur Zeit der Fruchtreife meist anch einige eingebohrte Frïchte. Der eigentümliche Ban der Frucht und ihre große Empfindlichkeit gegen Befeuchtung sind also zweitens ein Mittel, die Samen in den Erdboden, also an den Ort zu bringen, an dem sie zu keimen vermögen.

Diese Erkenntnis macht uns weitere Einzelheiten im Ban der Teilfrucht verständlich: 1) der gerade Endteil der Granne bewirkt, daß die Spitze des Fruchtfaches stets schräg gegen den Erdboden gerichtet ist (5 a). 2) Die als Erdbohrer dienende Spitze des Fruchtfaches ist scharf (4 a). 3) Das Fruchtfach ist mit kurzen, steifen Haren besetzt, die wie Widerhaken wirken. Rollt sich nämlich die anstrocknende Granne anf, so verhindern sie, daß das Fruchfach wieder aus dem Boden gedreht werde. Durch abwechselnde Befenchtung 
und Austrocknung muß das Fruchtfach (Same) also immer tiefer in die Erde eindringen $(5 \mathrm{~b}-\mathrm{d})$. 4) Die kurzen und langen Haare an dem korkzieherartigen Grannenteile (4 und 5) verhindern ein Abspringen der Regentropfen. 5) Das Fruchtfach ist vollkommen geschlossen, so daß ein Herausfallen des Samens verhindert wird (vgl. dag. Wiesen-Storchschnabel). Kurz: wir haben es hier mit einem wahren Wunderwerke der Natur zu tun!

Die nächsten Verwandten des interessanten Pflänzchens sind die Storchschnabelarten (Geránium), die Wald und Feld, trockene und feuchte Örtlichkeiten bewohnen. Wie bei ihnen die Samenverbreitung erfolgt, mag uns der Wiesen-Storchschnabel (G. praténse) lehren, der mit seinen großen, blauen Blumen Wiesen und lichte Gebüsche schmuickt. (Durch welche Einrichtung wird Selbstbestäubung verhindert? Beachte den klebrigen Stengel! Vgl. mit Leimkraut!) Die sich ablösenden Teilfrüchte schnellen an der sich bogenförmig krümmenden Granne mit ziemlicher Gewalt nach oben, bleiben aber an dem oberen Grannenteile mit der Mittelsäule verbunden. Dadurch werden sie in ihrer Bewegung aufgehalten, so daß ein heftiger Ruck entsteht. Da nun die Fruchtfücher auf der Immenseite einen großen Spalt besitzen, so werden die Samen in weitem Bogen fortgeschleudert, etwa wie ein Stein, den man aus der hohlen Hand mit einen kurzen Ruck des Armes fortwirft. Dieselbe Verbreitung finden wir bei allen grofblumigen Storchschnabelarten. Bei den kleinblumigen Arten dagegen lösen sich die Grannen vollständig $a b$, so dab die Teilfrüchte fortschnellen. Um das Herausfallen der Samen zu verhindern, sind bei ihnen die Fruchtfächer wie beim Reiherschnabel völlig geschlossen. Als bekanntestes Beispiel dieser Formen sei das Ruprechtskraut (G. robertiánum) genannt, das an feuchten, schattigen Orten überall vorkommt. Durch den widerlichen Geruch (Schutz gegen Tiere!) und die tiefgeteilten, fiederspaltigen Blätter unterscheidet es sich leicht von dem sonst sehr ähnlichen Reiherschnabel. - Zahlreiche ausländische, meist aus dem Kaplande stammende „Geranien“ (Pelargónium) zählen za unsern beliebtesten Topfpflanzen.

\section{Familie. Sauerkleegewächse (Oxalidáceae).}

\section{Den Sauerkleo (Óxalis acetosélla)}

kennzeichnet die große Zartheit aller Teile schon als einen B ew ohner. schattiger, feuchter Wälder und Gebüsche (s. S. 7, e). Ton den kleeartigen Blättern und dem Reichtum an sauerschmeckendem, giftigem Kleesalz (Schutzmittel gegen Tiere!) hat er seinen Namen. An sonnigen Tagen kann man leicht beobachten, wie dicht beieinanderstehende Pflanzen ein sehr verschiedenes Aussehen haben: die beschatteten breiten ihre Blätter so aus, daß die drei herzförmigen Einzel-Blättchen in einer Ebene liegen; die von den warmen Sonnenstrahlen getroffenen dagegen haben die Blättchen senkrecht nach unten geschlagen und falten sie dabei (des Platzes wegen!) in der Mittellinie etwas ein. Die Blätter dieser Pflanzen werden infolgedessen weniger besonnt und mithin auch weniger erwärmt, daher werden sie anch weniger Wasser verdunsten, als weun sie ausgebreitet wären (s. S. 43, C c.). (Vgl. auch die jungen Blätter nach Stellung und Faltung mit denen des Roßkastanie!) Nachts nehmen die Blätter die gleiche „Schlafstellung“ ein (s. Gemïsebohne). Auch lie weißen, 
rot geaderten Blïten (beschreibe sie!) schließen sich und werden nickend, sobald es Abend wird. Bei Eintritt eines Regenwetters tun sie dasselbe, und bei kaltem, unfreundlichem Wetter öffnen sie sich gar nicht (s. S. 3, b). Drïckt man eine ziemlich reife Frucht ein wenig, so werden die Samen mit großer Heftigkeit ausgeschlendert. Dasselbe geschieht bei völliger Reife von selbst: die äußere Schicht der Samenschale reißt an der Anßenseite auf und rollt blitzschnell zurück; dadurch erhalten die glatten Samen einen so heftigen Stoß, daß sie durch die Spalten der Kapsel ins Freie geschleudert werden. Diese Ausstreuungsweise der Samen macht uns auch verständlich, warum sich der gekriimmte Fruchtstiel zar Zeit der Fruchtreife emporrichtet.

Eine $\mathrm{nahverwandte} \mathrm{Pflanze}$ ist das Springkrant oder das Kräutchen „Riihr mich nicht an" (Impátiens noli tángere), das an Waldbächen und anderen feuchten Waldstellen gedeiht. Es ist, seinem Standorte entsprechend (s. S. 7, c), ein ïberaus saftreiches, zartes Gewächs, dessen hellgrüne Teile von einer bläulichen Wachsschicht überzogen sind (s. S. 17, 2). Die gelben, trompetenälnlichen Blïten stehen unter den Blättern wie unter einem schützenden Regendache. Berührt man die schotenähnlichen Früchte, so lösen sich die 5 Klappen von der Mittelsänle ab, rollen sich spiralig zusammen und schleudern die Samen nach allen Seiten. Dasselbe geschieht, wenn der Wind die Pflanzen schüttelt, oder wemn ein vorbeistreifendes Tier die Kapseln berührt (Namen!). - Eine gleiche Samenverbreitung findet man bei der (iarten-Balsamine (J. balsamína), die aus Ostasien stammt, - Gespornte Blüten besitzen auch die Kapllzinerkressen (Tropx́olum), die zu unseren beliebtesten Zierpflanzen zählen. Ihre Heimat ist Peru. Sie besitzen meist schildförmige Blätter. Die Blütenknospen und jungen Früchte werden wie Kapern verwendet (s. S. 10).

\section{Familie. Leingewächse (Lináceae).}

Der Lein oder Flachs (Linum usitatissimum). Taf. 9.

\section{A. Die Pflanze selbst.}

"Auf, kommt in die Felder und blühenden Au'n, Das liebliche Pflänzchen der Mädehen zu schan'n!"

Einen so prächtigen Anblick das blühende Flachsfeld gewährt, einen so bescheidenen Eindruck macht die einzelne Pflanze (1.). Der schwache, aber sehr elastische

1. Stengel, der im oberen Teile mehrfach verzweigt ist, wird bis zu $1 \mathrm{~m}$ hoch.

2. Die Blätter sind klein und schmal. Infolgedessen beschatten sie sich gegenseitig bei weitem nicht so stark wie große Blätter und sind daher in verhältnismäßig großer Anzahl vorhanden. (Vgl, mit anderen klein- und großblättrigen Pflanzen!)

3. Die Blïten stehen an den Zweigenden oder auf langen Stielen und sind aus 5 Kelchblättern, ebensovielen himmelblauen Blumen- und Staubblättern und einem Stempel zusammengesetzt. Da auch die am Grunde verwachsenen Staubblätter und die 5 Griffel (2.) mit den Narben prächtig blan gefurbt sind - 


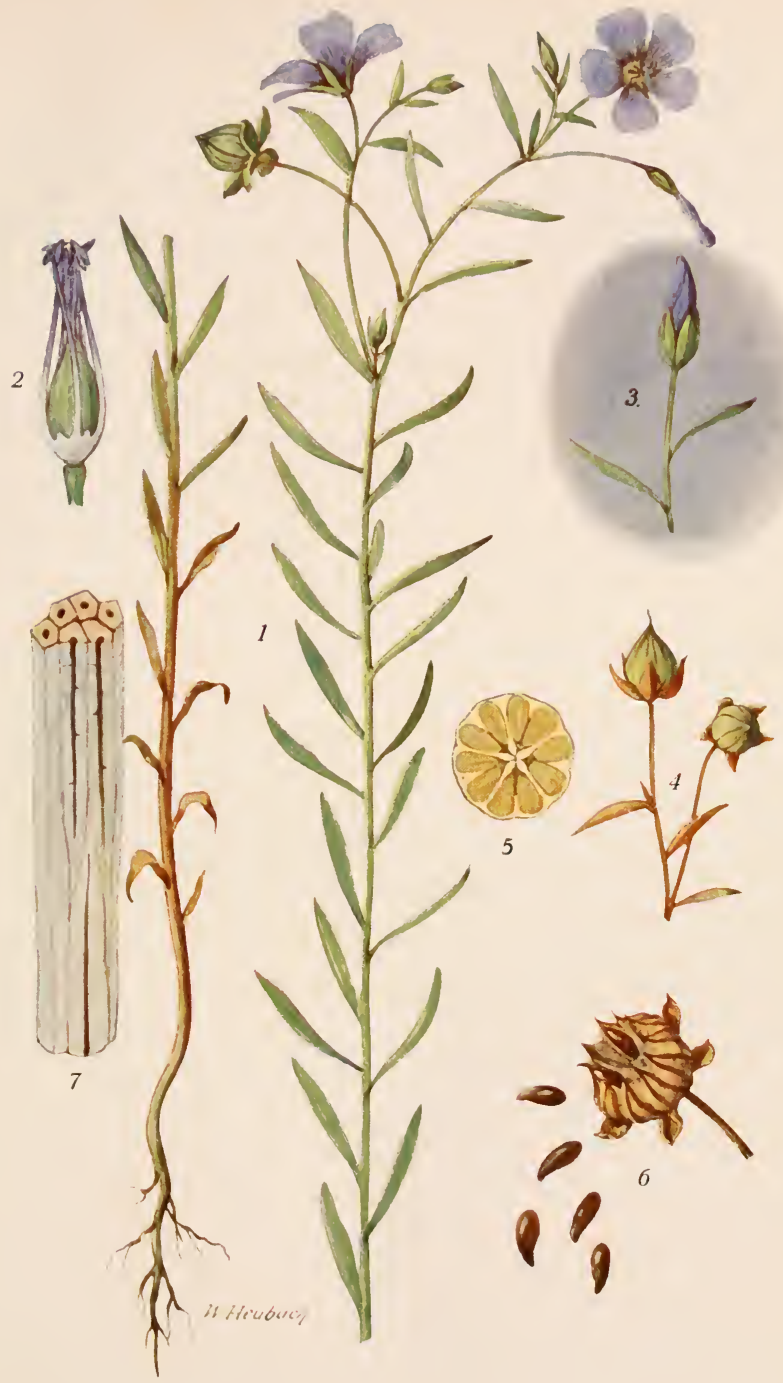

Lein oder Flachs (Linum usitatissimum). 

aber nur soweit, als sie von außen gesehen werden können - so treten sie mit in den Dienst der Insektenanlockung. Selbst wenn sich kein Insekt einstellt, bleibt die Pflanze doch nicht unfruchtbar: die Bliiten, die sich bei den ersten Strahlen der Morgensonne öffnen, schließen sich bereits am Nachmittage wieder, indem die Blumenblätter die zusanmengedrehte Haltung wie in der Knospe einnelmmen (3.); dadurch kommen aber Narben und Staubbeutel in innige Berührung, so daß Selbstbestüubung eintritt. An naßkalten Tagen und bei Regenwetter öffinen sich die Blïten gar nicht (s. S. 3, b).

4. a) Die Frucht (4.) ist bis zur Reife schiitzend vom Kelche umhüllt. Sie ist eine kugelige Kapsel („Flachsknoten“), die in jedem der 5 Fruchtfächer 2 Samen enthält (5.). Die Fächer sind aber durch eine unvollständige Scheidewand nochmals geteilt, so daß scheinbar 10 einsamige Fächer vorhanden sind. Bei der Reife öffnen (6.) sich die Kapseln entweder mit einem knackenden Geräusch oder sie bleiben gesehlossen, so daß die Samen durch Aussehlagen gewonnen werlen miissen. Ersteres ist bei dem kleineren „Klang- oder Springlein “, letzteres beim größeren "Schließ- oder Dreschlein" der Fall. Da wildwachsende Pflanzen ihre Samen verstrenen müssen (warum?), ist die zweite Spielart ohne Zweifel eine vom IIenschen noch mehr veränderte Form als die erste.

b) Befeuchtet man die glatten, bräunlichen Samen (6.), so wird die Oberfliche bald im hohen Grade klebrig. Bei der Aussaat verkittet infolgedessen der Same mit dem Boden, so daß das Keimen sicher von statten gehen kann (vgl. mit Kü̈rbis). Des Schleimes wegen benutzt man die Samen auch in der Heilkunde (zu Tee und Umschlägen). Besondere Bedentung erhalten sie aber durch den großen Reichtum an dem fetten Leinöl, das ausgepreßt zur Herstellung von Ölfarben, Druckerschwärze, Seife und dgl. mehr verwendet wird.

B. Der Lein als Gespinstpflanze. 1. Die Flachsfasern. Zerreißt man einen Flachsstengel, so schanen aus den Rißstellen (ähnlich wie beim Durchreißen der Blattstiele des Wegerichs) dünne Fäden hervor. Betrachtet man einen solchen Faden unter dem Mikroskope, so giebt er sich als aus zahlreichen Zellen bestehend zu erkennen (7.). Die Zellen sind sehr lang (bis $4 \mathrm{~cm}$ ), mit den zugespitzten Enden gleichsam ineinander gekeilt und so dickwandig, daß ihr Innenraum nur noch als eine dnnkle Linie erseheint. Sie bilden daher nicht nur sehr lange, sondern auch sehr feste Stränge, die man als Flachsfasern oder - da sie in dem (zwischen Rinde und Holz befindlichen) Bast eingelagert sind - Bastfasern bezeichnet. Infolge der Länge nnd Festigkeit eignen sich die Fasern vortrefflich zur Herstellung von Geweben und machen den Lein zu einer der wichtigsten Gespinstpflanzen. Soll die Pflanze diesem Zwecke dienen, so mïssen die Flachsfasern von den umgebenden Geweben selbstverstïndlich befreit werden.

2. Die Gewinnung der Flachsfasern geschieht nun von alters her in folgender Weise: Sobald die Stengel anfangen gelb zu werden, ranft man die Pflanzen aus dem Boden und beseitigt („riffelt") die Samenkapseln mit Hilfe eiserner Kämme. Bündelweis legt man die P'flanzen sodann in stehendes oder 
langsam fließendes Wasser, oder man breitet sie auf Feldern und Wiesen aus und überläßt sie einige Wochen dem Regen und Tau. In den durchfenchteten Pflanzenteilen tritt (unter Einwirkung von Spaltpilzen; s. das.) bald eine Gärung ein: die Rinde und die weichen Bastteile werden zerstört, so daß sich die Flachsfasern leicht abziehen lassen. Nachdem dieser Vorgang, der als das "Rösten" des Flachses bezeichnet wird („Wasser- und Tauröste“), beendigt ist, kommt es noch darauf an, den Holzkörper zu beseitigen. $\mathrm{Zu}$ diesem $\mathrm{Zwecke}$ werden die Stengel zunächst getrocknet ("gedörrt") und sodann gebrecht, d. h. das mïrbe gewordene Holz wird durch besondere Vorrichtungen (Flachsbreche) in kleine Stiicke zerbrochen. Die somit freigewordenen Flachsfasern, die aber noch miteinander netzförmig verbunden sind, werden nunmehr durch Schlagen mit einem schwertförmigen Holze („Schwingen“) von den anhängenden Holzund Rindeteilchen befreit und endlich durch die Zähne einer Hechel gezogen. Hierdurch wird das Netzwerk in einzelne Stränge zerrissen; die langen Fasern erhalten eine gleichmäßige Lage und werden von den kurzen Fasern, dem Werg oder der Hede, getrennt.

3. Die Verwendung von Flachsfasern. Schon seit undenkliclien Zeiten hat der Mensch verstanden, die Bastfasern des wahrscheinlich aus dem Mittelmeergebiete stammenden Leins (und seiner näclısten Verwandten) zu Garn zu spinnen und Leinwand daraus zu verfertigen. Jahrtausende hindurch bediente man sich zum Spinnen der Handspindel. Sie mußte dem um das Jahr 1530 erfundenen Spinnrade weichen, das in der Gegenwart wieder von sinnreich konstruierten Spinnmaschinen fast völlig verdrängt worden ist. Wie diese Maschinen ein billigeres Garn liefern, als dies mit Hilfe des Spinnrads möglich ist, so vermag auch der alte Handwebstuhl nicht mehr gegen die mechanischen Webstühle der Fabriken den Wettbewerb aufzunehmen. Da die Leinwand immer mehr von der billigeren Baumwolle verdrängt wird, so ist auch der Flachsball stark zurïckgegangen, und jetzt schon giebt es weite Bezirke, in denen das schnurrende Spinnrad und das blaue Flachsfeld nur noch von Hörensagen bekannt sind. - Von den zahlreichen Leinwandsorten, die man herstellt, seien nur genannt: der Zwillich und der Drillich oder Drell, das sind - wie schon der Name sagt - Zeuge, die mit 2 bezw. 3 schräg verlanfenden Fäden gewebt sind; sehr feines Leinen nennt man Batist; das stärkste ist das Segeltuch.

Das minderwertige Werg verwendet man zur Füllung von Polstern, sowie zur Herstellung von Stricken und Packleinwand. Aus nnbranchbar gewordenen Leinengeweben (Lumpen) bereitet man bekanntlich das Papier.

\section{Familie. Weinrebengewächse (Vitáceae).}

Der Weinstock (Vitis vinifera).

1. Heimat und Verbreitung. Die Heimat des Weinstockes glaubt man in den Ländern um das Mittelmeer gefunden zu haben. Vollkommen wild soll er heutzutage noch in den Wäldern von Westasien vorkommen, in denen er als 
iippig wuchernde Schlingpflanze bis zu den Kronen der höchsten Bäume emporsteigt. Auch die Weinstöcke, die man in den Uferwäldern der Donau und des Rheins antrifft, sollen wirklich wilde Pflanzen sein. Verwildert kommt die Rebe in allen Ländern vor, in denen Weinban getrieben wird.

Der köstlichen Früchte wegen hat der Mensch den Weinstock schon seit uralten Zeiten (Noah) in Pflege genommen und über einen großen Teil der Erde verbreitet. Als eine Pflanze wärmerer Gegenden meidet er sowohl den kalten Norden, als auch die heiße Zone. Etwa der 52. Breitengrad bildet in Deutschland die Grenze seines Gedeihens, und zwar vermag er bis zum 51. Grad herab meist nur an der Wand der Häuser, die von den Sonnenstrahlen stark erwärmt wird, seine Trauben zu reifen. Südlich von dieser Linie dagegen, am rebenumkränzten Rhein, an der Mosel und Alrr, am Main und Neckar, in Franken und Baden und an vielen anderen Orten, bewohnt er das freie Feld oder den sonnigen Bergeshang. Dort, wo die Sonne kräftiger wirkt, wie in Südtirol, zieht man ihn in Laubengängen; in der lombardischen Tiefebene umschlingt er den Maulbeerbaum, und noch weiter südlich klettert er an Ulme und Pappel empor. Und wie in Deutschland und dem alten Weinlande Italien, reift er seine köstlichen Früchte auch (gib die Gegenden näher an!) in Frankreich, in Spanien und Portngal, in der Schweiz, in Österreich und Ungarn, in Griechenland und auf den Inseln des Mittelmeeres, in Rumänien und dem südlichen Rußland, in ganz Vorderasien, auf Madeira und im Kaplande, in Nordamerika und an vielen anderen Orten der Erde.

Ein so weit verbreitetes Gewächs lebt natürlich unter den verschiedensten Verhältnissen (Boden, Wärme, Feuchtigkeit, Pflege und dgl.). Er tritt daher auch in einer großen Zahl von Spielarten oder Sorten auf, die sich besonders durch die Form, Größe und Behaarung der Blätter, sowie durch die Form und Färbung der Beeren und die Größe der Trauben voneinander unterscheiden.

2. Wurzel. In den wärmeren Ländern fällt während eines großen Teiles des Jahres und zwar in der Zeit, in der der Weinstock Blüten trägt und Frïchte reift, meist kein Regen. Auch in unsern Weinbergen sind in den Spätsommerund ersten Herbstmonaten die oberflächlichen Erdschichten oft im hohen Grade ausgetrocknet. Da aber die Wurzeln des Weinstockes tief in den Boden dringen, so vermögen sie selbst während dieser Zeit genïgend Wasser zu beschaffen.

3. Stamm und Ïste (Reben) sind von einer graubraunen Borke bedecht, deren abgestorbene Lagen in bandartigen Streifen abgestoßen werden. Wohl kann der Stamm bei hohem Alter banmartige Stärke erreichen, die Reben aber bleiben stets verhältnismäßig schwach. Besonders gilt dies für die jüngsten Reben ("Lotten“), die im Frühjahre aus braunbeschuppten Knospen hervorbrechen (vgl. mit Roßkastanie!). Da es nun für den wildwachsenden oder verwilderten Weinstock ein Vorteil ist, möglichst bald den besonnten Gipfel des Baumes zu erreichen, an dem er emporklettert, so witchst der Jahrestrieb den ganzen Sommer hindurch fort (vgl. dag. mit Roßkastanie, Linde und andern 
Bäumen!). Der angebante Weinstock hat diese Eigenschaft beibehalten und bildet nicht selten Jahrestriebe von 4 und mehr Meter Länge. Diese Triebe sind aber so schwach, daß sie weder die eigene Last, noch die der Friichte zn tragen vermögen. Wir geben daher den baumartigen Stöcken, die wir an Wänden ziehen, ein Spalier, und den strauchartigen der Weinberge Stäbe, an denen sie Halt und Stïtze finden. Anßerdem ist der Weingärtner das ganze Jahr hindurch aufs eifrigste bemïht, jeden Weinstock in den Vollgennß von Licht und Luft zu setzen, die zu gutem Gedeihen nötig sind: er schneidet zu dem Zwecke die überflüssigen Reben $a b$, bindet die fruchttragenden fest und dgl. mehr. Dem wildwachsenden oder verwilderten Weinstocke dagegen läßt niemand eine solche Pflege angedeihen. Er mïßte am Boden liegen bleiben und wïrde bald von den benachbarten Pflanzen überwuchert und erstickt sein, wenn er nicht in den

4. Ranken ein Hilfsmittel besäße, sich an anderen, stärkeren Pflanzen (Bäumen) anzuklammern und zum Lichte emporzudringen. Die Ranken sind fadenförmige Gebilde, die den Blättern gegenüberstehen. In der Mitte besitzen sie ein Blättchen, aus dessen Achsel ein kleiner Ast hervorsproßt, so daß sie wie gegabelt erscheinen. Da die Trauben gleichfalls den Blättern gegenïberstehen und dieselbe Gliederung wie die Ranken zeigen, so ist dies ein Zeichen, daß wir es in den Ranken mit umgewandelten Bliitenstielen zu tun haben ("Stengelranken").

a) Betrachtet man ein Weinspalier, so findet man, daß alle Ranken sich nach der Wand, also dorthin wenden, wo eine Stiitze zu finden ist. Dasselbe beobachtet man auch an jedem Stocke im Weinberge. Ihrer Aufgabe entsprechend ist also die Ranke im Gegensatz zu den lichtliebenden Blättern ein lichtscheues Gebilde.

b) Die Rankenäste bewegen sich wie der Uhrzeiger langsam, aber stetig im Kreise. Je mehr sie in die Länge wachsen, desto größer werden die Kreise, und desto größer wird auch die Möglichkeit, eine Stätze zu finden. Die Zeit, in der ein solcher Umlanf vollendet wird, ist je nach der Temperatur verschieden. (Wie lange brauchte der von dir beobachtete Rankenast dazu?)

c) Bringen wir der kreisenden Ranke ein Holzstäbchen in den Weg, so beobachten wir folgendes: Einige Stunden, nachdem die hakenartige Spitze oder eine andere Stelle des Astes den Stab berührt hat, hat ihn die Ranke in einer Schlinge umwunden. Einige Stunden, oder auch einen Tag später (stelle die Zeit bei deinem Versuche genauer fest!) hat sich der Endteil des Astes in weiteren, sehr engen Windungen um die Stiitze gelegt. Dasselbe erfolgt, wenn die Ranke einen anderen Gegenstand, einen Zweig, einen Blattstiel oder dgl. erfaßt.

d) Nach Verlauf einiger Tage hat sich der zwischen Stütze und Pflanze ausgespannte Rankenteil korkzieherartig zusammengezogen. Infolgedessen wird die Pflanze enger und fester an die Stiitzen gefesselt, und 
da die korkzieherartigen Ranken federn, so vermag der Wind den Weinstock bei weitem nicht so leicht von seiuen Stïtzen loszureißen als in anderen Falle. Dies ist umso weniger möglich, als die

e) anfangs sehr zarten Ranken uicht nur stärker werden, sondern auch verholzen. Dadurch erhalten sie fast die Festigkeit von Eisendraht. Die Rauken aber, die keine Stütze ergreifen konnten, vertrocknen und fallen ab. Dies ist für die Pflanze kein sonderlicher Verlust; denn

f) an jeder Rebe werden eine größere Anzalıl von Ranken gebildet. Dem unteren Rebenteile aber fehlen die Ranken; denn er vermag sich ja olme Hilfe dieser "Hände" dem Lichte entgegen zu strecken.

5. a) Das Blatt ist von präichtiger Form, so daß es in der Kunst vielfache Verwendung findet (Beispiele!). Durch 2 tiefere und 2 flachere Einschnitte ist es in 5 Lappen geteilt, in die je eine Hauptrippe vom Blattgrunde aus eintritt. Der Blattrand ist gesägt. (Welche Eigenschaften des jungen Blattes der Roßkastanie finden wir am Weinblatt wieder?)

b) Obgleich die Blätter verhältnismäßig groß sind, rauben sie sich doch nicht gegenseitig das Licht: Sie stehen abwechselnd an der Rebe und sind in 2 Zeilen angeordnet. Außerdem nehmen sie

c) eine ganz bestimmte Stellung zu den Sonnenstrahlèn ein. Dies ist deutlich zu sehen, wenn die Reben angebunden werden. Durch diesen Eingriff wird das gesamte Blattwerk in "Unordnung“ gebracht, so daß der Stock struppig und unschön aussieht. Nach einigen Tagen aber schon ist die alte "Ordnung" wieder hergestellt: Die Blätter haben sich so gedreht, daß die Stiele wieder schräg aufwärts gerichtet und die Blattflächen schräg abwärts geneigt sind. Infolgedessen werden sie von den Sonnenstrahlen senkrecht getroffen, also unter einem Winkel, unter dem die Strahlen ihre größte Wirkung austiben (Beweis!). - In den Blattwinkeln bildet sich je eine Knospe, aus der noch in demselben Sommer ein Trieb, die sogenannte

6. Geize, hervorgeht. Da dieser Trieb im Herbst zum Teil abstirbt und bei uns fast niemals "reifes" Holz entwickelt, das der Winterkälte widerstelın könnte, so entfernt ihn der Gärtner („geizen"), um für die anderen Reben („Lotten“) Platz zl schaffen. Am Grunde der Geize entsteht die Winterknospe, aus der im nächsten Jahre eine neue Rebe hervorgeht.

7. Die Blïten sind sehr klein und zu aufrecht stelienden Rispen (im gewöhnlichen Leben "Trauben", in den Weingegenden "Gescheine" genannt) vereinigt. So lange sie sich im Knospenzustande befinden, erhebt sich über dem napfförmigen, fünfzipfligen $\mathrm{Kelche}$ je eine kleine Kappe oder Hanbe. Sie wird von den verwachsenen $B I n m e n b l a ̈ t e r n$ gebildet und iberdeckt schïtzend die 5 noch eingebogenen Staubblätter und den flaschenförmigen Stempel, an dessen Grunde sich 5 gelbe $\mathrm{H}$ onigdrüsen vorfinden. Wahrend sich bei den allermeisten Pflanzen die Blumenblätter beim Aufblühen anseinander tun, um den Zugang zum Bliitengrunde freizugeben, bleiben sie hier an dem oberen 'Teile fest miteinander verbunden. Dadnrch wiirde aber die 
Bestänbung erschwert, wenn nicht gar unmöglich gemacht werden! Als Gebilde, die ihre Anfgabe erfiillt haben, lösen sich die Blumenblätter daher beim Aufbliihen an der Ursprungsstelle los und werden als flache Hauben von den sich

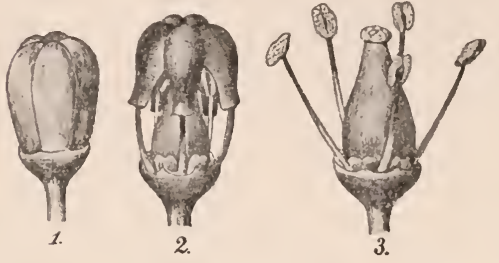

Blite des Weinstocks (vergr.) 1. geschlossen, 2 Die Blumenblätter werden abgeworfen, 3. entfaltet. streckenden Staubblättern emporgehoben und schließlich abgeworfen. Da die Blumenblätter grïn gefärbt sind und mithin die Aufmerksamkeit der Insekten nicht erregen können, so ist es anch aus diesem Grunde kein Verhust für die Pflanze, daß sie abfallen. Wie bei der gleichfalls unscheinbaren Lindenblüte besorgt ein köstlicher Duft die Anlockung der Bestäuber(Käfer, Fliegen und Bienen). Vielfach fällt auch der Blütenstaub auf die Narbe derselben Blüte, und es ist selbst beobachtet worden, daß sich die Staubblätter strecken und krümmen und infolgedessen mit Narben benachbarter Bläten in Berïhrung kommen.

8. Die Frucht des Weinstocks ist eine Beere von gelber, grüner, roter oder blaner Färbnng. Sie ist mit einem abwischbaren Wachsüberzuge wie mit einem Reif versehen (Schutz gegen Befeuchtung und damit verbundener Fäulnis, sowie gegen Verdunstung der Fruchtsäfte; (Beweis!) und enthält 1-4 Sa men. Durch das Gewicht der Beeren wird der anfänglich aufrechte Traubenstiel abwärts gezogen.

a) Verbreitnng. Die Pflanzen - und somit auch der Weinstock erzeugen Samen, damit daraus neue Pflanzen (derselben Art) entstehen. Werden die Weintrauben vom Menschen verspeist oder sonstwie verwendet, so gehen die Samen zu Grunde, ohne ihre Aufgabe erfüllt zu haben. Anders aber, wenn die Beeren von Staren, Sperlingen, Drosseln oder anderen Vögeln verzehrt werden: während das saftige Fruchtfleisch verdant wird, können die Samen infolge der steinharten Hülle von den scharfen Verdaungssäften nicht zerstört werden; sie gehen unverletzt durch den Körper des Vogels und werden mit dem Kote wieder ausgeschieden. Geschieht dies nun an einem Orte, an dem die Samen keimen und sich zu neuen Weinstöcken entwickeln können, so ist nicht nur cine Vermehrung, sondern auch eine Weiterverbreitung der Pflanze eingetreten. Durch Hilfe der Vögel werden die Samen der wildwachsenden Weinstöcke allein verbreitet, nnd die verwilderten sind nur durch Vögel ansgesät. (Warum sind aber die Wespen, die gleichfalls den Beeren eifrig nachstellen, unnïtze Näscher? - Die angebauten Reben vermehrt man ansschlieBlich durch Stecklinge.)

Einer Pflanze aber, die nichts zu bieten vermag, werden die Vögel einen solchen Dienst nicht erweisen. Wie die Insekten die Blumen nur besuchen, weil sie hier Nahrung finden, so besuchen anch die Vögel den Weinstock allein, um die süßen, saftigen und wohlschmeckenden Beeren zu verzehren. 
Und wie die Blumen ihre Bestäuber durch (Duft und) leuchtende Farben anlocken, so lo ck t der Weinstock seine Terbreiter dadurch zum süßen Mahle, daß seine Fr ï ch te eine Färl) ung besitzen, die von der des Laubes mehr oder weniger absticht.

Würden die Vögel die Beeren bereits verzehren, ehe die Samen reif, d. h. keimfähig wären, so wïrde das für den (wildwachsenden) Weinstock ein großer Nachteil sein (warum?). Wir sehen daher, daß die Frïchte erst zur Reifezeit wohlschmeckend werden und "Lockfarben" annehmen. Vordem sind sie zusammenziehend saner, ungenießhar und heben sich der grünen Färbung wegen von dem Blattwerke nicht ab. (Vgl. in diesen Punkten andere I'tlanzen mit fleischigen Früchten, sowie die P'flanzen, die sich zur Samenverbreitung nicht der Hilfe der Vögel bedienen!)

b) Verwendung der Trauben. Die Trauben preisen wir mit Recht als das vornehmste Erzeugnis der Pflanzenwelt. Frisch genießen wir sie als schmackhaftes Obst, getrocknet als Rosinen und Korinthen. In dieser Form kommen sie besonders aus dem weinreichen Griechenland und Kleinasien. Die Korinthen haben ihren Namen nach der Stadt Korinth, in deren Nähe die kernlose Spielart zuerst gebaut wurde. - Thre Hauptbedentung erhalten die Trauben jedoch erst dadurch, daß aus ihnen das edelste Getränk, der Wein, gewonnen wird, der - in kleinen Mengen genossen - den Gesunden erfreut und den Kranken labt, der den ,niedergesunkenen Mut emporhebt und den Betrïbten erquickt". Unmäßiges Weintrinken ist aber wie der übermäßige Genuß aller anderen alkoholischen Getränke der Gesundheit des Menschen in hohem Grade nachteilig und eine Quelle vielen Elendes (führe dies näher aus!). Fï r Kinder ist sogar der beste Wein schädlich, selbst wenn er in kleinsten Mengen genossen wird.

Zum Zwecke der Weinbereitung werden die Trauben ansgepreßt. Der hierdurch erhaltene süße Saft (Most) beginnt schon nach einigen Stunden sich zu trüben. Unzällige mikroskopische Weinhefepilze (s. Bierhefe) beginnen nämlich ihre Arbeit. Die Keime dieser Pflänzchen ruhen im Boden des WVeinberges, werden durch den Wind verweht, fallen и. a. anch anf die Schalen und Stiele der Beeren, werden durch Insekten von Frucht zu Frucht verschleppt und gelangen somit beim Auspressen in den Most. Dort vermehren sie sich außerordentlich schnell und bringen eine wichtige Änderung hervor, die man bekanntlich als Gärung bezeichnet. Sie zerspalten nämlich den Traubenzucker in Alkohol (Weingeist!) und Kohlensäure, die unter Brausen und Schäumen entweicht. Durch diesen Vorgang verwandelt sich der sïße Saft allmählich in klaren, alkoholreichen Wein. Will man Rotwein bereiten, so läßt man die Schalen blauer und roter Beeren eine zeitlang mitgären. (Warum ist die ïbliche Bezeichnung "Weißwein" ungenau?)

9. Die Feinde, die dem edlen Weinstocke Schaden zufügen oder ihn gar vernichten, sind außerordentlich zahlreich. Ein Pilz, der Rebenmehlta u (Oidium túckeri), ïberzieht wie ein weißer Schimmel Blätter und Früchte, denen er durch eingesenkte Fortsïtze Nahrung entzieht. Die Blätter verdorren schließ- 
lich, die Beeren zerplatzen und verfaulen, und oft schon hat der winzige Schmarotzer die Weinernte weiter Bezirke gänzlich vernichtet. Man tötet ihn durch Bestrenen mit Schwefelpulver. Ein ähnlicher Verwïster ist der sog. falsche Rebenmehltan (Peronóspora vitícola), der im Innern der Blätter lebt. Gegen ihn ist nur aufzukommen, wenn man seine Sporen vernichtet, die durch den Wind auf die Blätter getragen werden. Das wirksamste Mittel hat man in dem Besprengen der Reben mit einer Lösung von Kupfervitriol gefunden. - Von den tierischen Feinden seien nur genannt der Trauben wi ckler (Heu- und Sauerwurm) und das schlimmste Übel von allen: die Reblaus (s. "Lehrbuch der Zoologie").

Ein $n$ aher Verwandter der edlen Rebe ist der sog. wilde Wein (Ampelópsis quinquefólia). Er stammt aus Nordamerika und wird zur Bekleidung von Hauern, Lauben und dgl. allgemein verwendet. Da er selbst an glatten Wänden emporklettern kann, müssen seine Ranken wesentlich anders als die des Weinstocks gebaut sein. Sie sind mehrfach verästelt und an den Enden hakig gekrümmt. Kommen sie mit der Wand in Berührung, so spreizen die Rankenäste weit voneinander, und ihre Enden schwellen zu kleinen "Haftballen" an, die einen klebrigen Stoff ausscheiden (vgl. mit dem Laubfrosch!). Die schwarzen, für uns ungenießbaren Beeren fallen bei der Reife umso mehr auf, als sich die "gefingerten" Blätter im Herbst in ein leuchtendes Rot kleiden.

Entferntere Verwandte. Ein weit verbreiteter Stranch der Gebüsche und Hecken ist das Pfaffenliitlein (Evónymus europæus). Der Name rübrt von den rosafarbenen Fruchtkapseln her, die geöffnet einige Ähnlichkeit mit den viereckigen Hüten der katholischen Geistlichen haben. Die Auffälligkeit der an sich schon auffälligen Früchte (Färbang!) wird noch dadurch erhöht, daß die orangefarbenen Samen, an kleinen Fäden hängend, aus den Kapseln hervortreten. Die breiige Hülle des Samens, der Samenmantel, ist für das Rotkehlchen eine beliebte Speise ("Rotkehlchenbrot"). Ja, es steht sogar fest, daß die Verbreitung der Pflanze mit der des Vogels genau äbereinstimmt. - In Gebüschen feuchter Stellen findet sich häufig der Faulbaum (Frángula alnus), an den erst grünen, dann roten und endlich schwarzen Beeren leicht kenntlich. Der Genuß der Beeren bewirkt beim Menschen Durchfall (daher als Abführmittel verwendet); Drosseln und andere Vögel verspeisen sie aber ohne Schaden, - Die Stechpalme (Ilex aquifólia) ist ein beliebter Zierstrauch der Anlagen, der in den Wäldern an der Ost- und Nordseeküste und im Rheingebiete wild wächst. Die immergrünen, lederartigen Blätter (s. Efeu) sind in stachelige Spitzen ausgezogen. Da sie in den Alpenländern am Palmsonntage statt wirklicher Palmen benutzt werden, ist der Name ${ }_{n}$ Stechpalme ${ }^{\text {" voll- }}$ kommen gerechtfertigt. Die leuchtend roten Beeren heben sich im Herbst von dem dunklen Laube prächtig ab (vgl. mit ,wilden Wein"). Eine andere Art der Gattung liefert den Pa ra g a a - T e e oder M a té, der in einem großen Teile von Südamerika Volksgetränk ist.

\section{Familie. Wolfsmilchgewächse (Euphorbiáceae.)}

Meist Milchsaft enthaltende Pflanzen. Blüten in der Regel einhänsig. Meist mehrere Stanbblüten (die nur aus je einem gestielten Staubblatte bestehen) und eine Stempelblüte (die von einem gestielten Stempel dargestellt wird) zu einem blütenähnlichen Blütenstande vereinigt und von einer gemeinsamen Hülle umgeben. Fruchtknoten 3-fächerig; bei der Reife lösen sich die Kapselwände von einer stehen bleibenden Mittelsäule ab.

Die Sonnen-Wolfsmileh (Euphórbia helioscópia). Taf. 10.

1. Vorkommen. Die einjährige Pflanze ist eines der gemeinsten und lästigsten Unkräuter in Garten und Feld. Verletzt man sie an irgend einem 


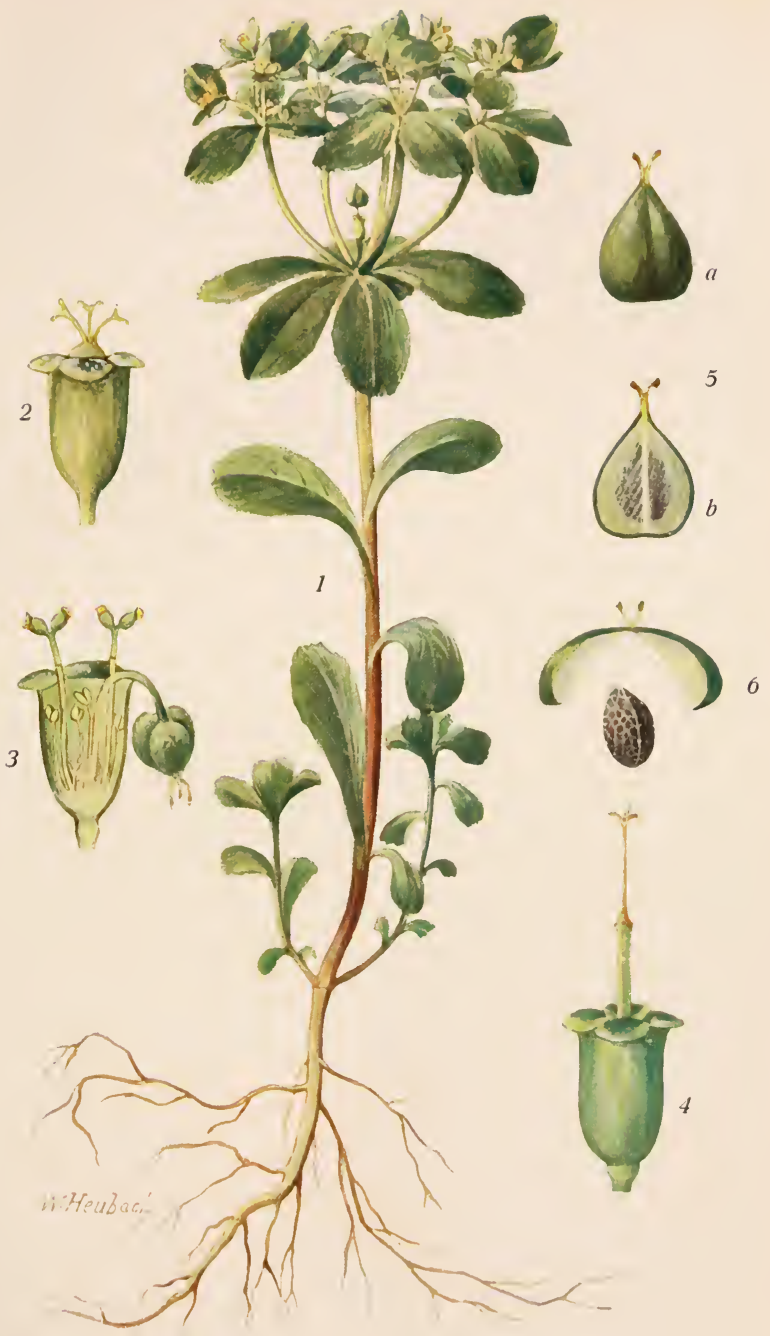

Sonnen-Wolfsmilch (Euphorbia helioscopia). 

Teile, so dringt aus der Wunde sofort ein weißer Saft hervor, der wegen der Ähnlichkeit mit Tiermilch als

2. Milchsaft bezeichnet wird. Er ist aber ätzend und giftig. Daher wird die Pflanze "Wolfsmilch" genannt und gleich ihren Verwandten von den Weidetieren sorgsam gemieden. Da der Nilehsaft etwas Federharz oder Kautschuk (s. w. u.) enthält, so ist er sehr klebrig und gerinnt schnell. Infolgedessen verschließt er die Wunde, ans der er hervorquillt, und verwehrt den Fäulnis erregenden Spaltpilzen (s. das.), in das Innere der Ptlanze zu dringen. (V'gl. mit dem Blute, das aus der Wumde tließt und gerinnt.) .

3. A ussehen. Der etwa spamnenhohe Stengel besitzt nur in unteren Teile 1 oder 2 Ästchen, die zumeist blütenlos bleiben (1). Beide, Stengel und İste, tragen einige Blitter, die sich nach dem Grunde zu keilartig verschmälern und am abgerundeten oberen Teile fein gezähnt sind. An der Spitze les Stengels erheben sich in gleicher Höhe 5 Blütenzweige, zwischen denen sich eine einzelne "Blïte" befindet. Jeder Zweig teilt sich in der Weise des Stengels abermals, und diese Teilung kann sich — je nachdem die PHlanze kräftig ist - noch ein oder mehrere Male wiederholen. Am Ende der feinsten Verzweigungen stcht wie zwischen den Zweigen je eine "Blüte". Der Blütenstand ist also einer zusammengesetzten Dolde (s. Möhre) sehr ähnlich (wodurch unterscheidet er sich aber von ihr?), und wie dort finden wir anch hier unter jeder Teilnng eine Hiille, die ans melıreren Blättern (gib die Anzahl genau an!) gebildet wird. - Da die Pflanze gleich vielen anderen Gewächsen den Blïtenstand der Sonne zuwendet, führt' sie den Namen Sonnen-Wolfsmilch.

4. a) "Blïte". Betrachten wir jetzt das Gebilde, das wir bisher als "Blüte" bezeichnet haben, genauer! Auf dem Boden einer bechcrförmigen Hülle (3) erhebt sich um einen langgestielten Stempel eine Anzahl von Staubblättern, die auffallenderweise gleichfalls gestielt sind. Da nun obendrein am Grunde der (meisten) Stanbblätter noch je ein zerschlitztes Blättchen zu finden ist, so faßt man jedes Staubblatt als Staubblïte und den Stempel als Stempelblüte auf. D ie "Blï te" der Wolfsmilch ist demnach ein Blütenstand, der ans zahlreichen Staubblïten und einer Stempelblüte zusammengesetzt nnd von einer krugförmigen Hïlle umgeben ist. (Zu dieser Auffassung drängt auch der Vergleich mit verwandten Gattungen, bei denen die sonst gleich gebauten Einzelblïten je eine einfache Blütenhülle besitzen. Untersuche z. B. die Blïten des Bingelkrauts !)

b) Aus der Hülle wird zuerst der Stempel hervorgestreckt (2.). Er besteht aus einem dreiteiligen Fruchtknoten und 3 Griffeln mit je 2 Narben. Nach kurzer Zeit vertrocknen die Narben; der Sticl des Stempels streckt sich stark in die Länge, und der Fruchtknoten neigt sich nach unten. Daldurch wird für die jetzt reifenden Staublätter Platz geschaffen (3.). Eins nach dem anderen erhebt sich iiber die Öffnung der Hülle, und die getrennten Staubbentelfächer bieten den Blütenstaub aus. Selbstbestäubung ist demnach ansgeschlossen (fülıre dies näher aus!).

Die unscheinbar gelbgrüne Färbung der Hülle läßt schon vermuten, daß Insekten, die bunte Farben lieben (Schmetterlinge und Bienen), die Blïten- 
stände meiden. Fliegen sind daher besonders die Vermittler der Bestäubung. Den kurzrïsseligen Gästen erreichbar liegt der Honig offen zu Tage. Er wird von 4 rundlichen Honigdrüsen ansgeschieden, die den Rand der Hülle krönen. Infolge der Lage dieser Drïsen kan es nun wieder nicht ansbleiben, daß die Besucher in jüngeren Blïten die Narben oder in älteren Blitten die Staubbentel herühren, also beim Besnch mehrerer Blïten Fremdbestäubung herbeiführen müssen.

5. Frucht. Bei beginnender Fruchtreife streckt sich der Stiel der Stempelbliite wieder senkrecht (s. die älteste Bïite in Abb. 1). Bringt man zu dieser Zeit einige Pflanzen (in einem Glase mit Wasser) in das Zimmer, so kann man den Vorgang der Samenausstreuung leicht beobachten: Von der stehenbleibenden Mittelsäule (4.) lösen sich die 3 Fücher des Fruchtknotens mit solcher Kraft los, daß sie oft mehr als $1 / 2 \mathrm{~m}$ weit fortgeschlendert werden $(5 ;$ a von außen, b von innen dargestellt). Dabei reißt die Kapselwand in 2 Stiicke, so daß der eingeschlossene Same frei wird (6.). Soll das Ausstreuen der Samen aber unbehindert von statten gehen, so muß die Frucht völlig frei stehen, der Stiel also die oben erwähnte Bewegung ausführen.

Der S ame ist ein kleines, schwarzes Köruchen, dessen Oberfläche zahlreiche Vertiefungen zeigt (s. S. 26, b).

\section{Andere Wolfsmilchgewächse.}

An denselben Stellen, an denen die Sonnen-Wolfsmilch gedeiht, findet sich als gleich lästiges Unkraut die sehr ähnliche Garten-W. (En. peplus). Durch die halbmondförmigen Drüsen der Hülle und die 3 Doldenstrahlen ist sie aber leicht von jener zụ unterscheiden. - Auf Sandboden, an Wegrändern und dgl. wächst oft in großen Beständen die Cypressen-W. (Eu. cyparissias), auf der die bunten Raupen des schmucken WolfsmilchSchwärmers leben. Wie zahlreiche andere Pflanzen der Ödung (vgl. mit Steinnelke, Heidekraut, Kiefer u. a.) besitzt sie viele, fast nadelförmige Blätter (Name!). Im Frühjahre findet man nicht selten Pflanzen, die ein völlig verändertes Aussehen haben: sie sind blütenlos, unverzweigt und besitzen dicke, rundliche Blätter mit brännlichen Flecken auf der Unterseite. Diese Veränderungen hat ein Pilz, der Erbsenrost (s. das.), hervorgebracht, der seine Entwicklnng zum Teil auf der Cypressen-W. durchmacht. In Norddeutschland wird die Pflanze durch die größere Esels-W. (Eu. ésula) vertreten, die etwas breitere Blätter besitzt. - Auf Schutthaufen und als Unkrant in Gärten findet sich hänfig das einjährige Schutt-Bingelkrant (Mercuriális ánnua), das keinen Yilchsaft enthält. Bei ihm sind Staub- und Stempelblüten auf verschiedene Pflanzen verteilt und besitzen - wie bereits erwähnt - je eine einfache Blütenhülle.

Im Gegensatz zu den meist niedrigen Arten unserer Breiten beherbergen die heißen Länder zahlreiche strauch- und baumartige Formen von außerordentlicher Vielgestaltigkeit. Diejenigen unter ihnen, die in den Steppen und Wüsten besonders von Afrika leben und mit der größten Trocknis zu kämpfen haben, besitzen völlig das Aussehen der ausgeprägtesten Trockenlandpflanzen, der Kaktusgewächse (s. das.). - Afrika gilt auch als das Vaterland des weit verbreiteten Wunderbaumes (Rícinus commúnis), der seiner prächtigen Blätter wegen vielfach als einjährige Zierpflanze gezogen wird. Bei uns bleibt er strauchartig, während er in den Tropen schnell zu einem stattlichen Baume emporwächst ("Wunderbaum" wegen seines schnellen Wuchses!). Aus den Samen preBt man das Ricinusöl, das als wichtigstes Abführmittel allgemein bekannt ist. - Ein anderes 
Glied der großen Familie, der Maniok-oder Cassavestrauch (Mánihot utilissima), wird seiner stärkemehlreichen Knollen wegen in allen heißen Ländern als wichtige Nahrungspflanze angebaut. - In den Wäldern des tropischen Südamerika finden sich mehrere Wolfsmilch-Bänme, die unter dem Sammelnamen Federharz- oder Kautschukbiume zusammengefaßt werden, und von welchen der wichtigste (Hévea brasiliénsis) nur im Überschwemmungsgebiete des Amazonenstromes vorkommt. Der Milchsaft dieser Bäume enthält in großer Mfenge das bereits erwähnte Federharz oder den Kautschuk, ein Harz, das wegen seiner großen Elastizität außerordentliche Bedeutung erlangt hat. Der wertvolle Stoff, der den Eingebornen bereits vor ihrer Berührung mit Europäern bekannt war, wird in sehr verschiedener Weise gewonnen. Die älteste, aber immer noch vielfach angewendete Art ist folgende: Man macht Einschnitte in den Baumstamm, fängt den austretenden Milchsaft in Gefäben auf und bestreicht damit Bretter oder Formen aus ungebranntem Ton. Werden diese Gegenstände sodann über ein rauchendes Fener gehalten, so trocknet die Flüssigkeit nicht nur sehr schnell, sondern der Kautschuk gerinnt auch und bleibt als dünne Schicht zurück. Durch fortgesetztes Eintauchen und Trocknen wird die Lage immer dicker. Schließlich werden die wertlosen Tongefäße zertrümmert und entfernt. Letzteres geschieht auch mit den Brettern, die man aus der aufgeschnittenen Kautschukschicht leicht hervorziehen kann. Lange Zeit diente der Kautschuk nur als Radiergummi, zar Anfertigung von Gummibällen u. dgl. Seitdem man aber durch Zusatz von Schwefel (Vulkanisieren) verstanden hat, ihn auch unter $0^{0}$ elastisch zu erhalten und gegen hohe Temperaturen widerstandsfähig zu machen, ist seine Verwendung ungemein manuigfaltig geworden; man benutzt ihn zur Herstellung von Schläuchen, Gummischuhen, wasserdichten Überzügen und hundert anderen Sachen. Vermengt man ihn bis zur Hälfte seines Gewichts innig mit Schwefel, so erhält er fast die Härte von Horn und Fischbein. Man verwendet diesen Hartgummi oder „Ebonit" daher zur Anfertigung von Kämmen, Knöpfen und vielen anderen Gegenständen. - (Außer, wie angegeben, von mehreren Wolfsmilcharten wird der Kautschuk auch noch von zahlreichen anderen Pflanzen gewonnen. Von diesen seien hier nur die meist kletternden Landolphia-Sträucher Afrikas und der Gummibaum Ostindiens [Ficus elastica; s. das.] genannt. - Ein ähnlicher Stoff wie der Kautschuk ist die Guttapercha, die aus dem Milchsafte mehrerer ostindischer Bäume gewonnen wird. Sie läßt sich gleichfalls härten und wird daher ganz ähnlich wie Kautschuk verwendet. Vor allen Dingen dient sie als ein schlechter Leiter der Elektrizität zur Umhüllung von Kabeln u. dgl.)

Ein entfernter Verwandter der Wolfsmilchgewächse ist der in allen Teilen giftige Buchsbaum (Buxus sempérvirens), der aus dem Orient stammt. Eine Zwergform dient zur Einfassung von Gartenbeeten a. dgl. Sein außerordentlich hartes, gelbes Holz wird besonders zur Herstellung von Holzschnitten verwendet.

\section{Familie. Doldengewächse (Umbelliferae).}

Pflanzen mit meist mehrfach zerteilten Blättern. Blüten in der Regel in zusammengesetzten Dolden. Je 5 Kelch-, Blumen- und Staubblätter. Fruchtknoten unterständig, a of der Oberfläche mit einer fleischigen Scheibe und aus 2 Fruchtblättern gebildet, die je einen kurzen Griffel tragen. Bei der Reife trennen sich die beiden Fruchtblätter: es entstehen 2 einsamige Teilfrüchtchen.

Die Möhre oder Mohrribe (Dancus caróta). Taf. 11.

1. Standort. Wildwachsend findet sich die Möhre auf Wiesen, an Wegrändern und ähnlichen Stellen. Vermöge der sehr tiefgehenden 
2. a) Wurzel vermag sie die heißen Sommermonate zu ïberdauern, in denen die oberen Bodenschichten dieser Örtlichkeiten meist gänzlich anstrocknen. Die Wurzel (Fig. 6 ist ein Querschnitt der Wurzel) ist holzig, gelb und rübenförmig (daher "gelbe Rübe, gelbe Wurzel" oder anch nur "Wurzel" genannt). Sät man Samen (Teilfrïchte) wildwachsender Pflanzen in gutbearbeiteten Garten- oder Ackerboden, so verliert sich die holzige Beschaffenheit der Wurzel etwas. Streut man den von diesen Pflanzen gewonnenen Samen wieder aus, und fahrt man mit dieser planmäßigen Veredlung (s. S. 19) fort, so hat man schon nach wenigen Jahren eine fleischige, wohlschmeckende Wurzel geschaffen, die für den menschlichen Genuß tanglich ist: Auf diese Weise ist ans der wildwachsenden Möhre die wichtige Gemiise- und Futterpflanze entstanden, die sie jetzt ist. (In einigen Gegenden wird der Möhrensaft zu Syrup eingedickt. - Die Spielart mit kurzen, dicken und sehr zarten Wurzeln nemit man Karotte.)

b. Pflanzt man im Frühjahre eine angebante Wurzel, die man an einem frostfreien Orte ïberwintert hat, so treibt sie einen hohen, beblïtterten und bliitentragenden Stengel. Untersucht man sie nach einigen Wochen wieder, so ist sie wie ausgesogen: sie ist diinner, holzig und zäh geworden. Die ihr entnommenen Stoffe sind nämlich zum Aufban der oberirdischen Teile verwendet worden. Dieselbe Erscheinung ist auch bei den wildwachsenden Pflanzen zu beobachten. Die Wurzel ist demnach ein Nahrungsspeicher, und die Möhre eine zweijährige Pflanze: Im 1. Jahre ihres Lebens treibt sie nur einen kurzen Stengel mit einer Blattrosette und speichert die in den Blättern bereiteten Vorratsstoffe in der Wurzel auf, die sich darum verdickt; im 2. Jahre setzt sie das Leben fort, das durch die Winterkälte unterbrochen wurde und in der Erzeugung von Samen (Nachkommen!) seinen Abschluß findet: die Ptlanze stirbt samt der ausgesogenen Wurzel ab.

3. Der Stengel wird oft mehr als $1 / 2 \mathrm{~m}$ hoch; er ist gefurcht, mit steifen Haaren besetzt und hohl (s. Roggen).

4. Die Bliitter sind auffallend groß. Trotzdem werden die unteren von den oberen nicht in den Schatten gestellt; demn

a) Die Blattflächen sind in viele, kleine Abschnitte geteilt, zwischen denen das Sonnenlicht einen Weg findet: Die Blätter sind doppelt-gefiedert und die Blättchen meist nochmals tief gespalten. (Durch welche Mittel wird bei ungeteilten Blättern eine Besonnung aller Blätter herbeigeführt? Vgl. Scharbockskraut, Linde, Weinstock und andere Pflanzen!)

b) Die Blattstiele sind im unteren Teile zu Scheiden verbreitert. Wie sich leicht beobachten läßt, umhüllen diese Gebilde den weiterwachsenden Stengel mit seinen Blättern und Blütenständen. Sie schützen somit die zarten Teile gegen Verletzung, Wärmeverlust und zu große Wasserabgabe (vgl. mit Roßkastanie).

5. Die Bliiten sind sehr klein. Ständen sie wie die großen Blüten zahlreicher anderer Pflanzen (Klatschmohn u. v. a.) einzeln, so würden sie die Aufmerksamkeit der Insekten wohl kaum erregen können. Da sie aber in großen a) Blïtengemeinschaften beieinander stehen, wird dieser Übelstand 


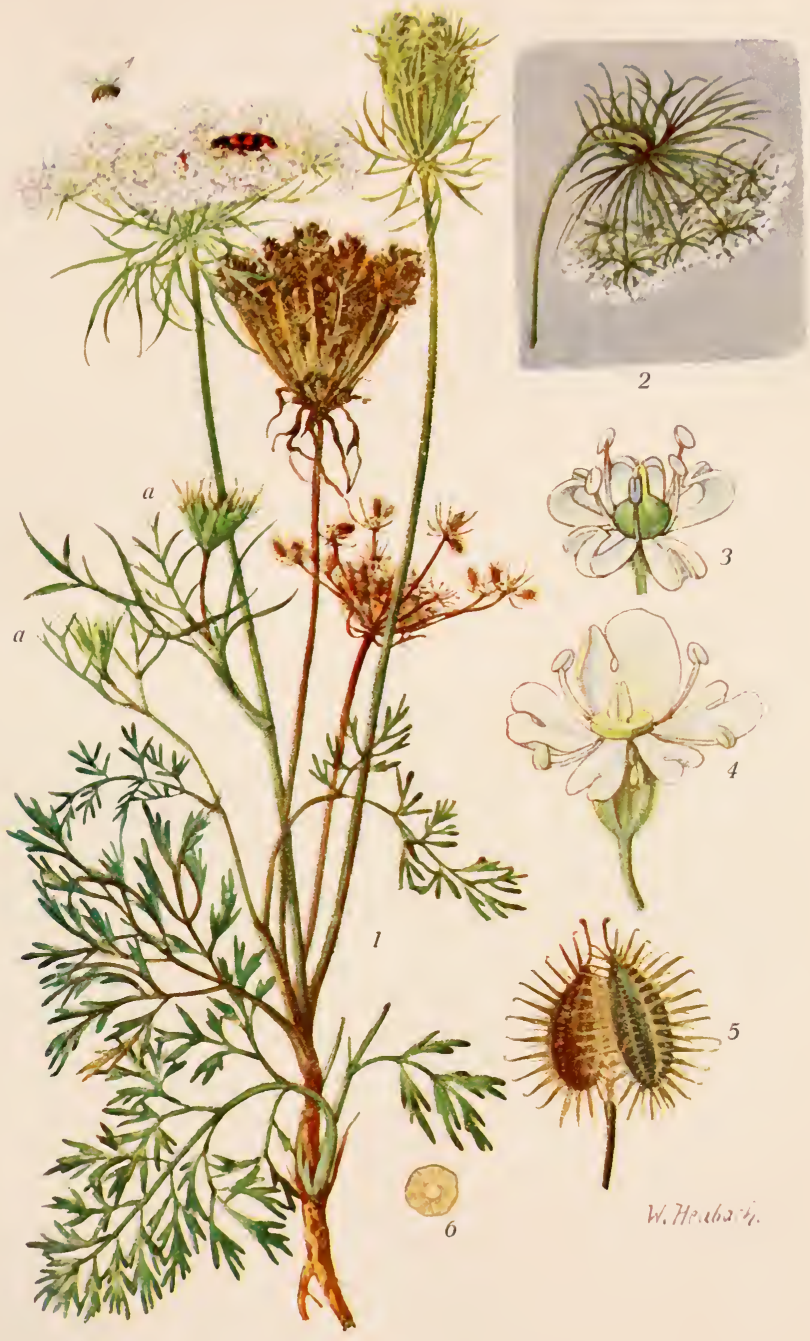

Möhre oder Mohrrübe (Daucus carota). 

vollkommen ausgeglichen. Der Stengel und seine Zweige enden je in einer Verdickung, von der eine Anzahl Blütenstiele ausstrahlen. Einen solchen Bliitenstand nennt man eine Dolde („Doldengewächse" - vgl. mit einem Schirm; daher auch „Schirmblütler"). Jeder Doldenstrahl trägt nochmals eine Dolde, die man zum Unterschiede von dem Hauptblütenstande als "Döldchen" bezeichnet. Die Möhre hat daher (wie die meisten anderen Doldenpflanzen) eine zusammengesetzte Dolde.

Die Auffälligkeit des Blïtenstandes wird noch dadurch erhöht, daß die Bliiten am Rande der Dolde (4.) und besonders deren äußere Blumenblätter stark vergrößert sind. (Solehen Blïtenstand nennt man "strahlend“.)

Unter der Dolde findet sich eine Anzahl geteilter Blätter, die man als Hülle bezeichnet. Unter jedem Döldchen steht ein ähnliches "Hüllchen". Wenn man die noch unentwickelten Bliitenstände betrachtet, wie sie von diesen Blïttern schïtzend umhïllt werden (1 a), so erkennt man, daß diese Bezeichnungen wohl berechtigt sind.

Junge Blïtendolden werden durch Krïmmung der Bliitenstiele mit Beginn der Dunkelheit nickend (2.). Dadurch werden die Bliiten gegen Regen geschützt und vor zu großem Wärmeverlust bewahrt (warum ist beides von Wichtigkeit?). Nach erfolgter Bestäubung nehmen die Dolden diese Schutzstellung nicht mehr ein (warum ist dies auch nicht mehr nötig?).

b) Die einzelne Blïte (3. und 4.): Der Kelch ist nur durch 5 Zähnchen angedeutet und gleich den 5 weißen, etwas eingefalteten oder geteilten Blumenblättern dem oberen Rande des Fruchtknotens eingefügt. (Den Fruchtknoten bezeichnet man daher als „unterständig“, d. h. unter den anderen Blütenteilen stehend. - Wann nennt man ihn wohl oberständig? Beispiele!) Mit den Blumenblättern wechseln die $5 \mathrm{Staubblätter} \mathrm{ab.} \mathrm{Der} \mathrm{Frucht-}$ knoten trägt oben eine fleischige Scheibe, die eine glänzende Lage von Honig absondert. Über die Scheibe erheben sich die beiden Griffel mit den Narben. Der offenen Lage des Honigs entsprechend (s.S. 37, B 2 b) werden die Blïten besonders von kurzrïsseligen Insekten besuch $\mathrm{t}_{\mathrm{t}}$ (Fliegen, Käfern und manchen Bienen). Da alle Blüten in einer Ebene liegen (Dolde!), vermögen die Tiere leicht von Blïte zu Blïte zu schreiten. Hierbei müssen sie unbedingt Staubbeutel und Narben streifen und somit unfreiwillig Bestänbung vermitteln.

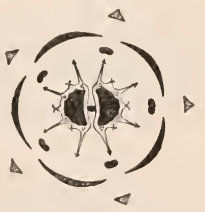

Blitengrundriß der Mïhre.

Die mittelste Blüte der Dolde ist oft stark vergrößert und von purpurroter Farbe (1.). Welche Bedeutung diese nicht äberall auftretende Erscheinung für die Pflanze hat, vermochten die Naturforscher bisher nicht zu ergrïnden.

6. Frucht. a) Fruchtstand. Sind die Blïten mit Erfolg ausgeboten (Bestiubung!), daun neigen sich die Doldenstrahlen wie zu einem Togelneste zusammen. Auf diese Weise werden die noch nicht keimfähigen Samen geschiitzt, von der Mutterpflanze getreunt zu werden. Die reifen Samen da- 
gegen müssen verbreitet werden (warum?). Zur Zeit der Fruchtreife breiten sich die Strahlen darmm wieder ans, wenn auch nicht so weit wie während des Blïhens. Dies geschieht jedoch nur bei trockenem Wetter; bei fenchtem schließt sich das "Vogelnest" wieder. (Durch Befeuchten des Fruchtstandes und nachheriges Trocknen kann man diesen Vorgang beliebig oft wiederholen.)

b) Die beiden Fruchtblätter verwachsen nach und nach fest mit dem Samen, den sie umschließen, und tremnen sich bei der Reife voneinander (Spaltfrucht). Die Tremung erstreckt sich anch auf die Verlängerung des Fruchtstiels, den fadenförmigen Fruchtträger, an dem die beiden "Teilfrüchtchen" gleichsam aufgehängt sind (5.). Die Oberfläche der Teilfrïchtchen ist mit 5 Reihen kurzer nnd 4 Reihen langer Stacheln besetzt, die oft in einfache oder doppelte oder

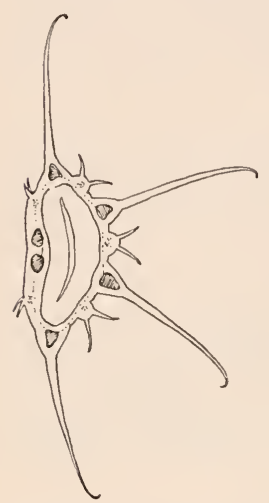

Teilfrïchtehen der Möhre (etwa 10 mal nat. Gr.) Vgl. auch den Blütengrundrib. gar dreifache Widerhäkchen enden. Infolge dieser Ausrüstung haften die Früchtchen wie Kletten leicht in dem Haarkleide der Tiere (Hasen, Kaninchen 1 . a.) und könneu so weithin verbreitet werden(Bedentung?). Die keimenden Samen werden durch die Stacheln am Boden gleichsam verankert (Bedeutung?).

Betrachtet man feine Querschnitte der Teilfriichtchen bei geringer Vergrößerung, so bemerkt man in der Fruchthïlle dunkle Stellen, d. s. Kanälchen, die mit einem flüchtigeu öle (s. Rose) gefüllt sind. Dieses öl findet sich auch in allen anderen Teilen der Pflanze, die darum beim Zerreiben einen eigentïmlichen, wïrzigen Geruch hat.

\section{Audere Doldengewächse.}

Gleich der Möhre liefert die angebaute Pastinake (Pastináca sativa) in ihren weißen Wurzeln ein geschätztes Gemüse. Wild findet sich die meterhohe Pflanze, die nur einfach-gefiederte Blätter besitzt, häufig auf Wiesen und an Wegen. Die Teilfrüchte bilden flache, große Scheiben, die von einem häutigen Saum umgeben sind und daher leicht

vom Winde verbreitet werden können. Sie entbehren daher auch der Stacheln. Aus der fleischigen Wurzel des Sellerie (Ápium gravéolens) bereitet man einen schmackhaften Salat. Wild wächst die Pflanze auf salzhaltigem, feuchtem Boden und am Meeresstrande. Sie hat daher (vgl. mit Sumpfdotterblume!) saftige Blätter (Verwendung?), und die angebaute Pflanze bedarf deshalb zum Gedeihen auch hinreichender Bodenfeuchtigkeit. Der Sellerie besitzt wie die Möhre einen eigentümlichen Geruch, der gleichfalls von einem flüchtigen öle herrührt. Diese Erscheinung ist auch an fast allen anderen Doldenge wächsen zu beobachten. Wie die Erfahrung lehrt, ist das öl bei einigen dieser Pflanzen ein wirksames Schutzmittel gegen Tierfraß (welche der angeführten Formen werden z. B. von Weidetieren nicht angerührt?). Andererseits aber werden durch den Ölreichtum zahlreiche Arten für uns zu wichtigen Gewürzpflanzen. Als solche seien zuerst Dill (Anéthum gravéolens) und Fenchel (Foenículum capilláceum) genannt. Beide entstammen dem Mittelmeergebiete und zeichnen sich durch haarförmig feine Blattzipfel 
und gelbliche Blüten aus. Das Kraut sowohl, wie die Blütendolden und reifen Früchto finden besonders beim Einmachen vou Gurken Verwendung. Der Fenchel wird auch zu Heilzwecken benutzt. - Dieselbe Ileimat haben auch Anis (Pimpinélla anisum) und Coriander (Coriándram satívum), deren Samen besonders in der Bäckerei Verwendung finden. - Anisduft hat auch der Gartenkerbel (Anthrisens cerefólium), der gleichfalls ans dem Süden stammt und als Gewürzpflanze bei uns angebaut wird. - Der Kiimmel (Carum carvi) dagegen scheint in Mitteleuropa heimisch zu sein. Er wird zwar seiner gewürzhaften Samen wegen (Verwendung?) im Großen angebaut, kommt aber auch hänfig wild oder verwildert auf Wiesen vor. Leicht zu erkennen ist er daran, daß die fiederteiligen Blättchen an der Hauptrippe des Blattes ein Kreuz bilden. - Die P'etersilice (Petroselinum sativum) ist wieder aus Südeuropa eingeführt. - Diese wichtige Gewürzpflanze (Verwendung?) wird leicht mit dem sehr giftigen Gartensehierling oder der Hundspetersilie (Aethúsa cynápium) verwechselt, die gern zwischen jener (und dem Kerbel) wächst, und deren Genuß sogar den Tod herbeiführen kann (s. Abb. S. 74). Darum sollte man nur die kransblättrige Spielart der Petersilie anbauen, die mit dem Giftkraut nicht verwechselt werden kann! Sicher zı unterscheiden ist die Hundspetersilie von der Petersilie durch den unangenehmen, knoblauchartigen Geruch, der beim Zerreiben der Blätter entsteht, durch die glänzenden (daher auch „Gleiße“) und viel schmaleren Blättchen, durch die 2 oder 3 langen und einseitig herabhängenden Blätter der Hüllchen, sowie durch die weit dünneren Wurzeln (einjährige Pflanze, die in den Wurzeln keine Vorräte fïr das nächste Jahr aufspeichert!). - An Zäunen und Gräben, sowie auf Schutthaufen und Gemïseland befindet sich der gefleckte Schierliug (Cónium maculátum). Alle Teile sind für den Menschen ein fürchterliches Gift (Schutzmittel gegen Pflanzenfresser!), das aber in der Hand des Arztes zn einer wirksamen Medizin wird. Der Giftbecher, den Sokrates trinken muBte, war mit dem Safte des Schierlings gefüllt. Zu erkennen ist die Pflanze an den hohlen Blattstielen, dem braun gefleckten Stengel (Name!), dem mäuseartigen Geruch nnd den welligen Rippen der Früchte. - Die giftigste aller Doldenpflanzen ist der Wassersehierling (Cicúta virósa), der an Wassergräben und ähnlichen feuchten Stellen gedeiht. Der giftigste Teil, der quer-gefächerte, sellerieähnliche Wurzelstock, ist zugleich das sicherste Erkennungsmerkmal der mehr als meterbohen Pflanze. - Durch geringere Giftigkeit ist der betäubende Kailloerkropf oder Tanmelkerbel (Chaerophýllum ténulum) gegen Tierfraß geschützt. Die kerbelartige Pflanze (Name!) wächst in Gebüschen, Hecken, an Mauern u. dgl. und hat sehr langgestreckte Früchte.

Von den zahlreichen Gliedern der großen Familie, die für den Menschen geringe Bedeutung haben, seien nur folgende genannt: Der Giersclı (Aegopódium podagrária), eine stattliche Pflanze (Höhe bis $1 \mathrm{~m}$ ) an Hecken und auf Wiesen, die an den dreizähligen Blättern leicht zu erkennen ist. Da sie unterirdische Ausläufer treibt (Vermehrung!), ist sie von bebautem Boden nur schwer zu entfernen. - Die Bärenklau (Heraclénm sphondýlium) ist eine unserer gröLten Doldenpflanzen (bis $1 \frac{1}{2} \mathrm{~m}$ hoch). Sie wächst auf Wiesen und an lichten Waldstellen und hat einfach gefiederte Blätter mit großen, mehrlappigen Blättchen. - An dürren, sandigen Orten und Wegrändern findet sich häufig die Feld-Mämuertreu (Erýngium campéstre), die einer Distel viel ähnlicher ist als einer Doldenpflanze. In den dornigen Blättern besitzt sie eine so vortreffliche Schntzwehr gegen Pflauzenfresser, daB sie auf Viehweiden oft die Oberhand über die nützlichen Grïser gewinnt. Da die Blüten ungestielt und von breiten Hüllblättern ungeben sind, haben die Dolden ganz das Aussehen kleiner Blätenköpfchen. 
22. Fam. Doldengewảchse. 23. Fam. Efeugewächse.

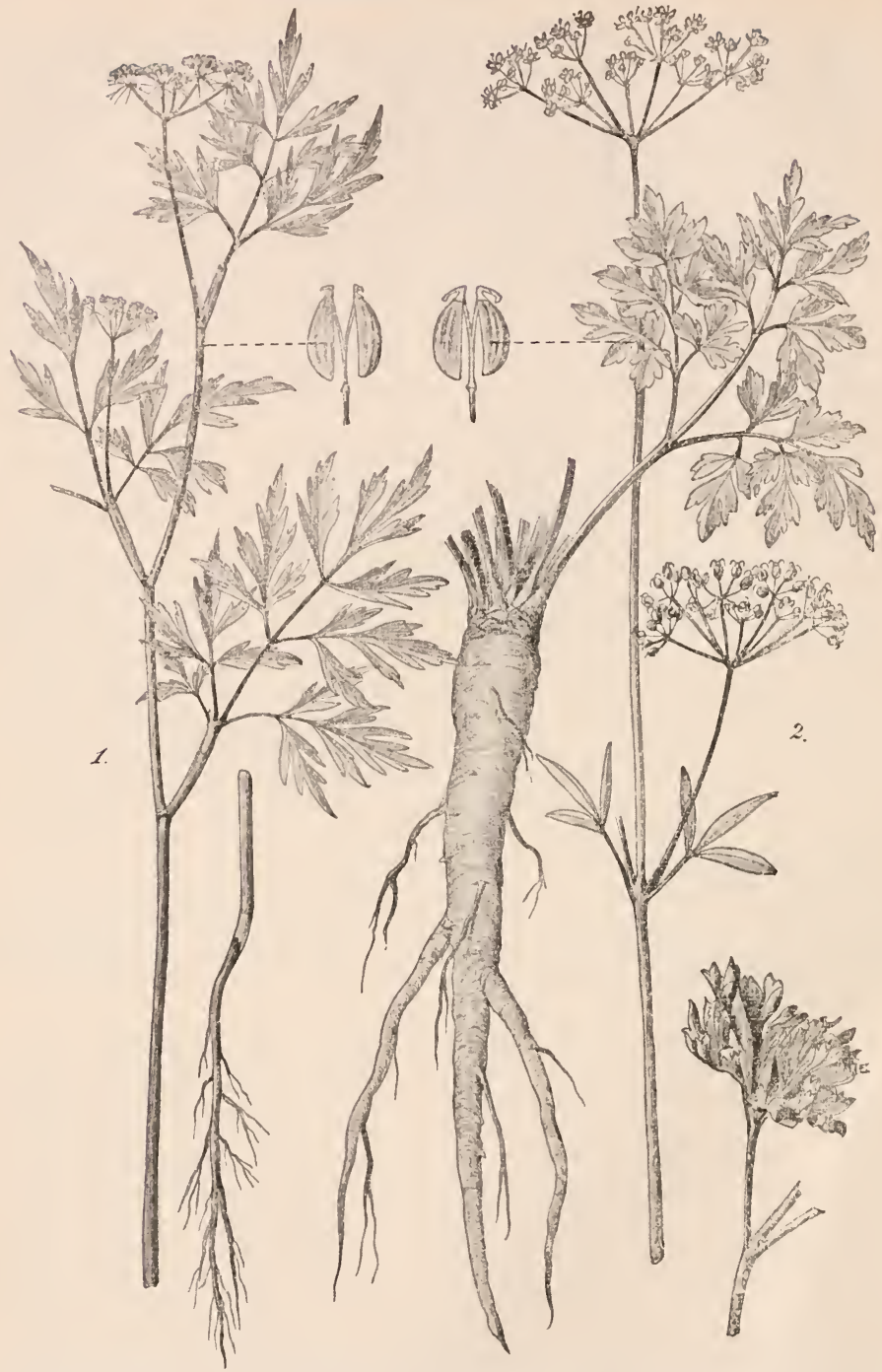

Hundspetersilie (1.) und Petersilie (2.). Rechts unten neben letzterer ein Blättchen der krausblättrigen Spielart. 


\section{Familie. Efeugewächse (Araliáceae). \\ Der Efeu (Hédera helix).}

A. Die Pflanze im Schatten. 1. Stamm. Abgesehen von sehr alten Pflanzen, wie man sie nicht selten an Bnrgruinen und ähnlichen Bauwerken findet, ist der vielfach verzweigte Stamm des Efeus so schwach, daß er sich selbst nicht zu tragen vermag. Er liegt darum auf dem Waldboden, auf dem man die Pflanze nicht selten wildwachsend antrifft. Sobald er jedoch einen Baumstamm, eine Felswand oder dgl. erreicht, klettert er daran empor, dem Lichte entgegen. Hierzu wird er durch zahlreiche, kleine

2. Wurzeln befahigt, die wie die Zweigenden das Licht fliehen und sich daher stets dem Stamme oder Felseu zuwenden. Sie schmiegen sich allen Unebenheiten dèr Unterlage gleich einer wachsartigen Masse an, so daß die Pflanze wie mit tausenden von Fingern festgeheftet wird. (Daher die Verwendnng des Efens zur Bekleidung von Nauern und dgl.) Da diese Klammer-oder $\mathrm{L} n \mathrm{ftw}$ uzeln nicht in die Unterlage eindringen, der zumeist anch keine Nahrung entzogen werden könute, (wieso?), so ist der Efeu kein Schmarotzer wie z. B. die Flachsseide (s. das.). Er entnimmt vielmehr wie die meisten Pflanzen seine Nahrung dem Boden durch weit längere Saugwnrzeln. Schneidet man eine kletternde Efeuptlanze dicht ïber der Erde ab, so geht sie daher zu Grunde; sie müßte denn auf ihrem Wege zum Lichte nährendes Erdreich getroffen und in dasselbe Sangwurzeln gesandt haben.

3. Blätter. a) Im Gegensatz zu den meisten unserer Pflanzen hat der Efeu immerğrüne, "winterharte" Blätter. Wenn man bedenkt, daß er im Schatten des Waldes gedeiht, so wird man leicht einsehen, daß dies für ihn von größtem Vorteile ist: so lange die Bänme belaubt sind, dringt nur wenig Licht zu ihm hinab; dafür kann er aber auch während der kälteren und kalten Jahreszeit jeden Lichtstrahl ausnützen, der ihn trifft, und dies ist jetzt in besonders reichem \aße möglich, weil die Waldbänme ja entlanbt sind. Daher kann er seine Früchte sogar während des Winters reifen, und daher meidet er auch den immergrïnen Nadelwald.

b) Wie wir bei der Betrachtnng des Kirschbaums sehen werden, stellen die Sangwurzeln der Pflanzen bei Eintritt der Kälte ihre Arbeit ein. Die Efenwurzeln vermögen daher im Winter dem Boden nur sehr wenig oder - wenn er gefroren ist - gar kein Wasser zu entnehmen. Soll der Efeu in dieser Zeit nicht vertrocknen, so müssen seine Blätter die Abgabe von Wasserdampf möglichst

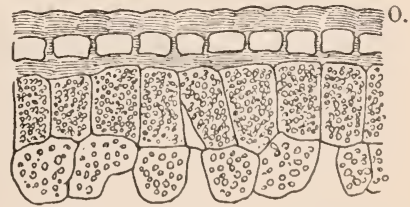

Teil vom Querschnitt durch ein Efenblatt, die verdickte Oberhaut 0 . zeigend (240 mal vergr.). einschränken. Dies geschieht nun infolge der sehr starken Oberhant, die für Wasserdampf fast nndurchlässig ist und den Blättern eine lederartige Beschaffenheit verleiht. 
c) Die Blattfläche ist fünflappig, und die Lappen stoßen meist unter scharfen Winkeln zusammen. (Wegen der edlen Form findet das Efenblatt in der Kunst mannigfache Terwendung! Beispiele!) Betrachtet man die am Waldboden hinkriechenden Pflanzen, so sieht man, wie die Lappen des einen Blattes in die Buchten der benachbarten Blätter gestellt sind. Diese Anordnung ist oft so genau wie bei den Tausenden von Steinchen, die zu einem kunstvollen Mosaikbilde zusammengefïgt sind. Darum redet man hier treffend von einer „Blattmosaik“. Infolge dieser Anordnung ranbt einerseits kein Blatt dem anderen das belebende Sonnenlicht, und andererseits wird die gesamte, spärlich be-

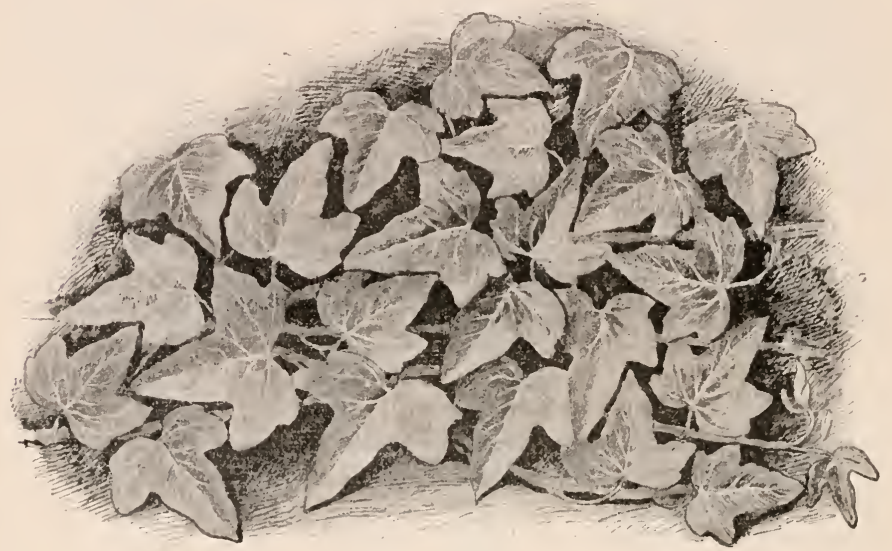

Efen: Schattentriebe, dem Waldboden aufliegend; Blätter bilden eine Mosaik.

leuchtete Fläche aufs vollkommenste ausgenïtzt. (Die Blattmosaik ist oft auch sehr gut auf Friedhöfen zu beobachten; denn mit immergrïnem Efell, dem Sinnbilde der Hoffnung, überkleiden wir gern die Grabhïgel unserer Toten. Beachte auch die Stellung der Blätter an mehr einzeln stehenden Zweigen, die an Mauern oder dgl. emporklimmen!)

d) Eine solche Stellung ist aber nur bei langgestielten Blättern möglich (wieso?). Betrachtet man die Stiele genaner, so sieht man, welche vielfachen Drehungen, Wendungen und Streckungen nötig waren, um aus den iu 2 Zeilen angeordueten Blättern ein solch kleines Kunstwerk zu schaffen.

B. Die Pflanze im Lichte. 1. Sobald die Pflanze die Höhe der Mauer oder des Felsens erklommen hat oder sich vom Baumstamme abwendet und nun allseitig vom Lichte umflutet wird, nimmt sie ein ganz fremdartiges Aussehen an: Die Zweige sind so kräftig, daß sie sich ohne Stiitze zu halten 
vermögen. Sie erzengen darum auch keine Luftwurzeln. Die Blätter sind allseitig um den Stengel geordnet, hahen kurze Stiele und ganzrandige, eiförmige Blattflächen. I)iese „Lichttriebe" sind es anch, die allein

2. Blïten tragen. Die unscheinbaren Blïten stehen in Dolden, sind denen der Doldengewächse sehr ähnlich gebant(Beweis!) nud entfalten sich erst in den Monaten August bis November. Dil vou ihnen ein weithin wahrnehm-
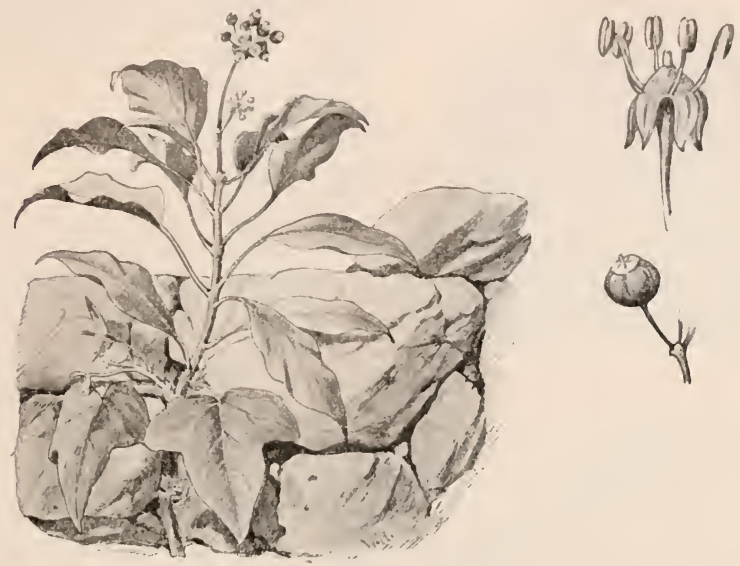

Efen, der die Höhe einer Wand erklommen und einen ${ }_{\text {Lichttrieb }}{ }$ gebildet hat. Am unteren Teile des Stengels noch zwei gelappte Blätter und Klammerwurzeln. Daneben in nat. Gr. eine Bläte und eine Frueht.

barer, fast fauliger Geruch ansgeht, stellen sich besonders Fliegen ein, die sieh gern auf Strohdinger und ähnlichen faulenden Stoffen anfhalten. Da wir nun wissen, daß diese Blumengäste die Bestänber der Pflanzen sind, erkemen wir anch, daß es für den Efeu höchst vorteilhaft ist, nur an den Enden der Lichttriebe Blïten zu tragen; dem von dort aus allein vermag sich der Duft nach allen Seiten anszubreiten, und dort können die Blïten von den Insekten, die der Duft anlockt, weit besser gesehen werden, als wenn sie an den "Schattentrieben" ständen. Letzteres gilt auch für die

3. Fr ̈̈ chte, kleine, schwarze Beeren, deren Samen durch Vögel rerbreitet werden (vgl. mit Weinstock!). Sie reifen, wie bereits erwähnt, während des Winters und sind fiir den Menschen giftig.

Nahe verwandt sind die Hartriegelgewäehse oder Hornsträucher (Cornáceae), so nach ihrem außerordentlich harten Holze genannt. Die eine Art, die Kornelkirsehe (Cornus mas), ist ein bekannter Straueh unserer Anlagen, kommt jedoch auch wild in Bergwäldern vor. Die gelben Blüten sind zu kleinen Dolden gehäuft, die 
sehr dicht an den Zweigen stehen. Da sie sich aber vor den Blättern entfalten, kommen sie trotzdem genügend zur Geltung (Insekten!). Die eßbaren, kirschenartigen Früchte sind scharlachrot and leuchten infolgedessen vortrefflich ans dem Grün des Laubes (Vögel!). - Die andere Form, der rote Hartriegel (C. sanguínea), ist gleichfalls häufig in Anlagen, aber auch in Laubwäldern und Gebüschen zu finden. Sie blüht nach dem Ausbruche des Laubes. Die kleinen, weißen Blitten sind dementsprechend zu weit größeren, doldenartigen Blütenständen vereinigt, und diese finden sich an den Enden der Zweige. Im Herbste färbt sich das Laub rot und gelb, so daß sích die schwarzen Früchte deutlich von ihm abheben. Während des Winters sind die Zweige gleichfalls von lebhaft roter Färbung (Name!).

\section{Familie. Dickblattgewächse (Crassuláceae).}

Der scharfe Mauerpfeffer (Sedum acre). Taf. 12.

1. Standort. Das Pflänzchen wächst auf Mauern (Name!) und ähnlichen dürren, unfrnchtbaren Stellen: in engen Felsspalten, an trockenen Abhängen und auf ödem Sandboden. Es hat in den meisten Fällen also einen sehr ungünstigen Standort; denn von den Mauern und Felsen läuft das Regenwasser schnell ab, und in den Sandboden sickert es fast ebenso schnell ein. Schon wenn eine kurze Zeit kein Regen fallt und die Sonne heiß auf die dïrstende Erde herabscheint, briitet iiber der Pflanze eine heiße, trockene Luft, welche die Verdunstung stark befördert (Beweis!). Dem Mauerpfeffer steht Wasser aber kaum noch zur Verfügung; denn die geringe Erdmenge, welche die Haner- und Felsenritzen ausfïllt, oder die oberste Schicht des Sandbodens ist gänżlich ausgetrocknet. Auf trockenem Untergrunde könnte sich der Mauerpfeffer wie andere Ödlandpflanzen (Beispiele!) wenigstens noch durch lange

2. Wurzeln helfen, welche die belebende Fenchtigkeit aus tiefen Bodenschichten heraufbeförderten. Jedoch solche Wurzeln suchen wir vergeblich. Sie sind im Gegenteil verhältnismäßig kurz und fadenförmig. Trotzdem übersteht das zarte Gewächs wochenlange Trocknis mit Leichtigkeit. Selbst aus dem Boden gerissen vermag es weiter zu grïnen, ja sogar Blüten zu treiben. (Beobachte dies an Pflanzen, die du in das Zimmer legst! Suche die Pflanze zu pressen und beobachte ihre Widerstandsfähigkeit!) Diese anßerordentliche Lebenszähigkeit verdankt die Pflanze in erster Linie den eigentümlich gebauten

3. a) Blättern. Da sie sehr kleine Gebilde sind, geben sie auch weniger Wasser in Dampfform ab, als dies vonseiten großer Blätter geschehen wïrde.

b) Sie liegen dem Stengel meist dicht an und decken sich sogar zum Teil gegenseitig. Infolgedessen können sie von der Luft nicht in dem Maße bestrichen werden, als wenn sie weit und frei vom Stengel abständen. Je mehr aber ein Körper, der Wasser durch Verdunstung abgibt (z. B. trocknende Wäsche), von der Luft bestrichen wird, desto öfter wird die durch die Verdunstung feucht gewordene Luftschicht, die den Förper umgilbt, erneuert, desto mehr also die Verdunstung befördert. 

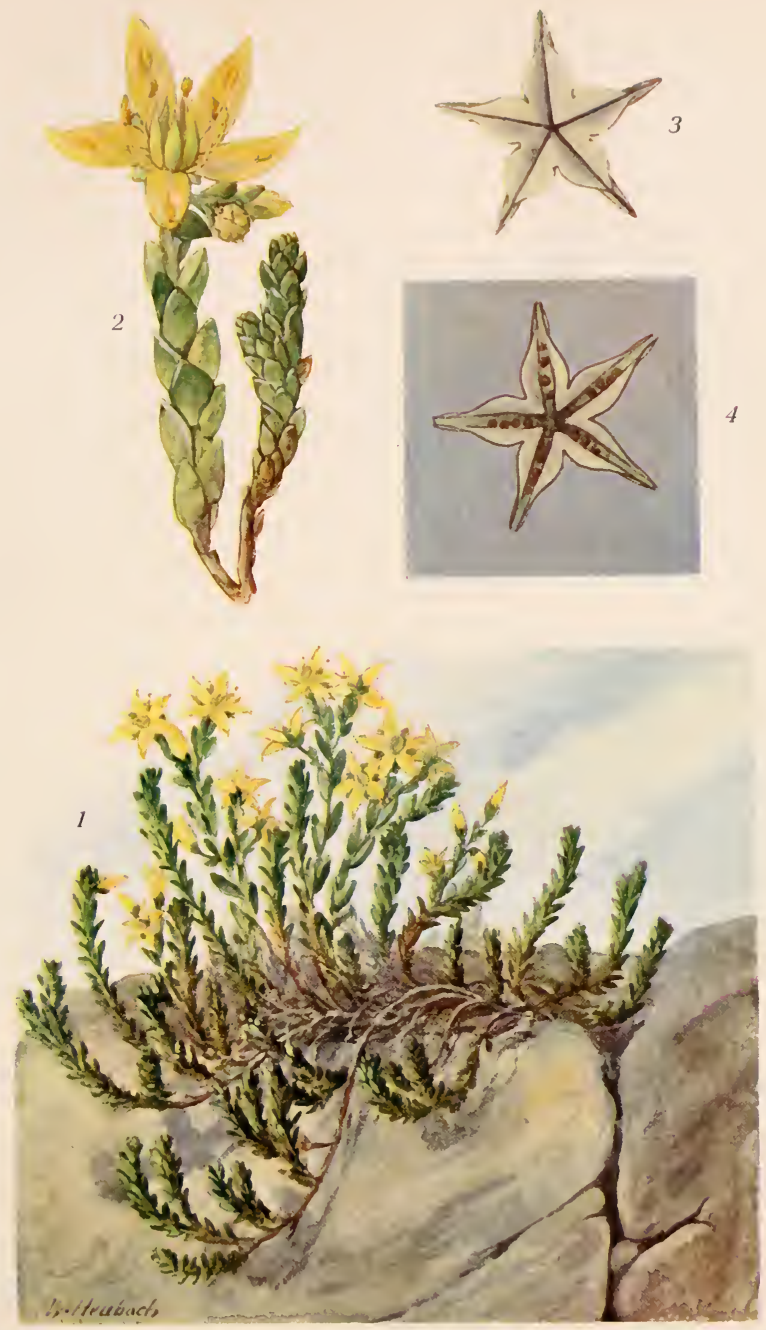

Scharfer Mauerpfeffer (Sedum acre). 

c) Die Blätter sind dicke, fleischige Körper, die als Wasserspeicher dienen: sobald Regen fällt, nehmen sie (durch Vermittlung der Wurzeln) soviel als möglich Wasser auf, das während der Trockenzeit allmählich verbraucht wird. Die Blätter eignen sich aber nicht nur vortrefflich zur Aufnahme großer Wassermengen, sondern in der eigentümlichen Blattform besitzt die Pflanze auch ein wichtiges Schutzmittel gegen zu schnelle Wasserabgabe. Ein einfacher Versuch wird uns dies leicht verständlich machen: Formt man aus einer knetbaren Masse (Teig, Ton oder dgl.) eine kleine, dünne Plitte, die man sodann zu einem festen Stabe von gleicher Länge umformt, so sieht man dentlich, daß dieser Körper eine weit geringere Oberfläche hat als vordem die Platte. So hat auch ein dünnes, "flächenförmiges" Blatt (Beispiele!) eine verhältnismäßig größere Oberfläche als ein dickes, mehr "körperliches". (Denke dir anch ein dickes Blatt durch Längsschnitte in eine Anzahl dünner Blätter zerlegt!) Da nun bei sonst gleichem Bau das Blatt umso mehr Wasser verdunstet, je größer seine Oberfläche ist, so werden wir die Richtigkeit obiger Behauptung wohl bestätigt finden. - Pflanzen mit solchen Blättern bezeichnet man als Fettpflanzen, Saftpflanzen oder Succulenten. - Trotz des Saftreichtums wird der Manerpfeffer von Tieren nicht berïhrt; denn die grïnen Teile besitzen einen pfefferartig scharfen Geschmack (Name!).

d) Zerschneidet man ein Blatt vorsichtig; so sieht man nicht selten, wie sich der Zellsaft in Fäden anszieht. Dies rührt von dem Reichtum an Schleim her. Pflanzenschleime geben das Wasser aber nur sehr langsam ab. Hiervon kann man sich leicht überzengen, wenn man einen „blattartigen" Kaktus oder das Blatt einer anderen größeren Fettpflanze, z. B. einer Aloë oder Agave, zerbricht. - Als weiteres Mittel, die Verdunstung einzuschränken, kommen in Betracht:

e) die verhältnismäßig dicke Oberhaut (vgl. mit Efen),

f) die auffallend geringe Zahl der Spaltöffnungen, durch die mit der austretenden Luft Wasser in Dampfform entweicht, sowie der Umstand, daß die

4. Stengel sehr niedrig bleiben und die Pflanze einen dichten Rasen bildet; denn eine Pflanze, die sich dem Boden anschmiegt, wird (s. Absch. 2 b) bei weitem nicht so stark vom Winde umspült als eine höhere Pflanze, und die Luftschicht, die sich zwischen den Stengeln und Blättern des Rasens findet und durch die Waszerabgabe der Pflanze fencht geworden ist, wird infolgedessen nicht so oft erneuert, als dies bei einer höheren Pflanze der Fall sein würde. Die einzelnen (wurzelschlagenden) Triebe der Pflanze haben ein zweijähriges Leben; im ersten Jahre bleiben sie kurz, sind dicht beblättert und tragen keine Blüten; in zweiten dagegen strecken sie sich, so daß die Blätter weiter anseinanderrücken, blühen und sterben ab, sobald die Samen gereift sind. Durch die sich streckenden Triebe werden die

5. Bliiten iiber den Rasen emporgehoben und mithin den Insekten sichtbar gemacht. Da sich nun viele Bliiten (Rasen!) zugleich entfalten, so werden sie, obgleich verhältnismäßig klein, doch weithin sichtbar. Sie bestehen (2) 
aus einem 5-teiligen Kelche, 5 goldgelben Blumenblättern, 10 Stanbblättern, die zı 2 Kreisen geordnet sind, und 5 Stempeln. Die großen Fruchtknoten werden aus je einem Fruchtblatte gebildet (vgl. mit Hahnenfußgewächsen) und endigen in je eine kleine Narbe. Zwischen den Blumenblättern und den Stanbblättern des inneren Kreises finden sich die kleinen Honigdrüsen.

6. Frucht. Nach dem Verblühen spreizen die sich vergrößernden Fruchtknoten auseinander und bilden einen 5-strahligen Stern (3.). Bei trockenem Wetter bleiben die Fruchtfächer geschlossen. Bei Regenwetter dagegen (tanche einige reife Früchte ins Wasser!) öffnen sie sich so weit (4), daß die kleinen, braunen Samen von den Regentropfen leicht ausgespült werden können. Auf diese Weise werden die Samen in Spalten des Bodens, Manerritzen und dgl. geschwemmt, also an Orte, an denen sie sich zu neuen Pflanzen entwickeln können. (Daher auch das Auftreten des Mauerpfeffers an senkrechten Wänden!) Hat der Regenguß noch nicht alle Samen ausgewaschen, dann schließen sich die Fruchtfächer wieder, um sich bei einem zweiten oder dritten Regen abermals zu öffnen. (Versuch! Warum wäre die Verbreitung der Samen durch den Wind für die Pflanze viel unvorteilhafter? Könnte wohl der Wind bei dem niedrigen Pflänzchen mit den kurzgestielten Friichten diese Arbeit überhampt verrichten?)

Verwandte. Auf sonnigen Hügeln und Felsen, sowie in trockenen Wäldern wächst häufig die weit größere Fetthenne (S. máximum). Sie besitzt breite und flache, aber gleichfalls sehr fleischige Blätter (Name!), und ihre kleinen, grüngelben Blüten sind zu großen Blütenständen gehänft. - A uf Dächern und Nanern findet man vielfach die Hauswurz (Sempervívum tectórum) angepflanzt; denn das zarte Pflänzchen galt in alten Zeiten für ein sicheres Mittel, allerlei Unglück, besonders aber den Blitzstrahl von dem Hause abzuhalten („Donnerkraut"). Wild kommt es auf Alpenfelsen, sowie am Rhein und an der Mosel vor. Die ungestielten Blätter sind an den "Kurztrieben" so dicht and regelmäßig gestellt, daß sie zierliche Rosetten bilden. Aus den ältesten Rosetten erhebt sich je ein "Langtrieb", der zahlreiche, rosafarbene Blüten trägt und nach der Fruchtreife abstirbt. Die Pflanze vermehrt sich auch durch Ansläufer, die aus den unteren Blattwinkeln der Rosetten hervorkommen, nnd an denen sich wieder Rosetten bilden.

\section{Familie. Die Fackeldisteln oder Kaktusgewächse (Cactáceae)}

sind bis auf wenige Ausnahmen im warmen A merika heimisch. Und zwar bewohnen sie daselbst die weiten Wïsten ond Steppen, in denen nur während weniger Monate des Jahres Regen fällt. Sie gedeihen also an ganz ähnlichen Orten wie der Manerpfeffer und seine Verwandten, und es ist darum vollkommen erklärlich, daß sie gleichfalls „Fettpflanzen" (Succulenten) sind, Da sie aber mit einer noch weit größeren Dürre zu kämpfen haben als diese, so müssen sie auch in erhöhtem Grade gegen zu starke Verdunstnng des aufgenommenen Wassers geschützt sein. Betrachten wir daraufhin z. B. die Kaktusformen, die wir in Blumentöpfen ziehen, so finden wir wie beim Mauerpfeffer einen schleimigen Saft und verhältnismäBig wenig Spaltöffnungen, eine stark verdickte, fast wasserdichte Oberhaut und nicht selten ein dichtes Haarkleid, das die ganze Pflanze umliüllt (vgl. mit Turban und Burnus der Bedninen!). Das wichtigste Schutzmittel liegt bei allen aber in dem Verluste der Teile, die das 
meiste Wasser verdunsten, nämlich der Blätter, die zu dürren Dornen umgewandelt sind. (Vgl. mit den Bäumen, die mit Eintritt der trockenen Jabreszeit ihr Laub abwerfen! s. Kirschbaam.) Als Wasserspeicher dient daher der Stamm, der zumeist Kugel-, Säulen- oder Cylinderform besitzt (geringe Oberfäche!), oder in scheibenförmige, blattartige Teile (s. u.) gegliedert ist und den Pflanzen das eigentümliche Aussehen verleiht. Und dieser Speicher vermag so viel Wasser zu fassen, daß die Pflanze lustig weiter grünt, wenn um sie her alles Leben bereits in Staub zerfallen ist. Die Kaktusgewächse sind daher auch die "Quellen der Wüste", an denen die lechzenden Tiere den brennenden Durst za stillen suchen. Doch die "Quelle" ist durch die ${ }_{n} \mathrm{Stachelblätter} \mathrm{"} \mathrm{wohl}$ geschützt; denn aus Verletzungen, die sich ein Tier an diesen nadelspitzen und oft noch mit Widerhaken versehenen Gebilden zuzieht, entstehen oft gefährliche Wunden. Da der Stamm die Arbeit der ,verkümmerten“ Blätter übernehmen muB, ist er mit Blattgrün ausgerüstet. Während der Regenzeit entfalten die Pflanzen ihre herrlichen, trichterförmigen $\mathbf{B} l u ̈$ te $\mathbf{n}$, die oft einen köstlichen Duft aushauehen.

Der seltsamen, wechselvollen Gestalt und der herrlichen Blüten wegen gehören die Kaktasgewächse za unsern beliebtesten Gewächshaus- und Topfpflanzen. Von Wichtigkeit für den Menschen sind aber nur wenige Formen. Dies gilt besonders für einige Arten der Gattung der Fackeldisteln (Opúntia), die cinen aus ovalen, flachgedrückten Gliedern zusammengesetzten Stamm haben. Auf ihnen leben die Cochenille-Schildläuse, die getrocknet das wertvolle Karmin liefern. Den Namen tragen die Pflanzen von dem Reichtum an Stacheln und von der Verwendung, den die getrockneten, mit Öl getränkten Stämme in früheren Zeiten in Amerika gefunden haben sollen. Die feigenartigen Früchte $\left({ }_{n}\right.$ Feigendistel ${ }^{\star}$ ) werden gegessen. In Südeuropa und Nordafrika, wohin die Pflanzen eingeführt wurden, dienen sie wie in ihrer Heimat zur Cochenille-Zucht und zur Herstellung von Hecken und ITmzäunungen. - Der Riesen-Kaktus (Céreus gigánteus) hat einen nur wenig verzweigten Stamm, der eine Höhe von $20 \mathrm{~m}$ erreichen kann. Durch wunderbare Blüten, die nur während der Nacht geöffinet sind, zeichnet sich die Königin der Nacht (C. grandiflórus) aus, und an Schlangen und Melonen erinnern die Stämme anderer Arten (Schlangen- und Melonen-K.), die bei uns gleichfalls häufig gezogen werden.

\section{Familie. Steinbrechgewächse (Saxifragáceae).}

1. Der Stachelbeerstrauch (Ribes grossulária) wird seiner wohlschmeckenden Früchte wegen (Verwendung?) überall angebaut, kommt aber auch verwildert (oder wild?) in Wäldern und Gebïschen vor. Im Schutze scharfer Stacheln (Name!) entfaltet er bereits im Vorfrühlinge die gelappten und eingekerbten $\mathrm{Blätter} \mathrm{(beobachte,} \mathrm{wie} \mathrm{dies} \mathrm{erfolgt!).} \mathrm{Gleichzeitig} \mathrm{kommen} \mathrm{auch} \mathrm{die}$ unscheinbaren Blïten zum Vorschein. Sie gleichen hängenden Glöckchen (Schutz des Blütenstaubes!). Fruchtknoten und Kelch sind mit gestielten, klebrigen Drüsen dicht besetzt, die ankriechenden Insekten (Honignäschern!) den Zutritt zum Blïteninnern erschweren. Die 5 kleinen, weißen Blumenblätter stehen am Rande des glockenförmigen Kelches, dessen zurückgeschlagene 5 Zipfel innen meist rötlich angehaucht sind und daher mit in den Dienst der Insektenanlockung treten. Da im zeitigen Frühjahre erst wenige Blumen Honig ausbieten, stellen sich zahlreiche Gäste ein (welche Insektenordnung ist am zahl- 
reichsten vertreten?). Wollen aber die Besucher den süßen Saft im Kelchgrunde lecken, so müssen sie die Narbe oder eines der 5 Staubblätter streifen (Bestäubung!). Die grüne oder rote Frucht ist eine saftige Beere, die gern von Vögeln verzehrt wird (s. Weinstock!). Daher findet man den Stachelbeerstrauch auch häufig verwildert auf altem Gemäuer, in der Gabelung hohler Bäume und an ăhnlichen Orten.

Mit der Stachelbeere wird stets auch die Johannisbeere (R. rubrum) ihrer saftigen, roten oder weißen Früchte wegen angebaut (warum Johannisbeere?). Seltener trifft man in Gärten die schwarze Johaunisbeere (R. nigrum), deren Blätter und Beeren einen wanzenartigen Geruch haben. - Ein beliebter Zierstrauch ist die gelbe Johannisbeere (R. aureum), deren Heimat Nordamerika ist.

2. Auf sonnigen Hügeln, Wiesen u. dgl. wächst häufig der Körner-Steinbrech Saxifraga granuláta). „Steinbrech" heißt die zierliche Pflanze, weil viele ihrer nächsten Verwand ten Gebirgsbewohner sind, und diesen sagt man irrtümlicherweise nach, sie hätten sich die Felsenspalten, in denen sie wurzeln, selbst gebrochen. Den Artnamen hat sie von den rötlichen Brutzwiebeln, die sich in den Winkeln der untersten (zar Blütezeit meist schon abgestorbenen) Blätter entwickeln und der Erhaltung und Verbreitung der Art dienen (vgl. mit Scharbockskrant). Im unteren Teile ist die Pflanze zottig behaart und im oberen wie die Blüte der Stachelbeere (s. das.) mit gestielten, roten Drüsen dicht besetzt. Die Blätter sind etwas fleischig (vgl. mit Mauerpfeffer) und nehmen von unten nach oben an Größe ab (vgl. mit Raps). Aus den zarten, weißen Blüten (beschreibe sie!) entwickelt sich eine Kapselfrucht, die mit einem Loche zwischen den bleibenden, hörnera:tigen Griffeln aufspringt (Verbreitung der Samen durch den Wind!).

3. Im Spätsommer und Herbst (vgl. mit Herbstzeitlose) erhalten die nassen Wiesen durch das Herzblatt (Parnássia palústris) nicht selten einen letzten Schmuck. Auf schwanken Stengeln, die in der Mitte je ein herzförmiges, saftstrotzendes Blatt tragen (Name! - vgl. mit Sumpfdotterblume), erheben sich wunderbar zarte Blütensterne. Innerhalb der weißen Blumenblätter stehen 5 grüngelbe Blättchen, die in mehrere langgestielte Drüsen ausgezogen sind (vgl. mit dem Fuße des Laubfrosches!). Die Drüsenköpfchen locken durch ihren Glanz Insekten herbei, für die sich an der Innenseite der Blättchen etwas Honig vorfindet. Kleine Insekten sind meist unnütze Näscher, größere aber durchaus notwendige Vermittler der Bestäubung. Betrachtet man eine Blüte genauer, so findet man in der soeben entfalteten, daß die Beutel der 5 Staubblätter auf den noch unentwickelten Narben liegen. Am nächsten Tage öffnet sich ein Beutel und bietet den Staub aus. Am folgenden Tage biegt sich das Staubblatt zurück, und ein zweiter Beutel öffnet sich, und so kommen nach und nach alle Beutel an die Reihe. Dann erst reifen die Narben. Da diese nun genau an der Stelle stehen, an der vordem die Beutel standen, so muß ein größeres Insekt, das die Blütenmitte als Sitzplatz benutzt, Fremdbestäubung herbeiführen.

4. Der Pfeifenstrauch (Philadélphus coronárius), so genannt, weil man die schlanken Schosse zu Pfeifenrohren verwendet, findet sich häufig in unsern Anlagen. Er stammt aus Südeuropa. Der stark duftenden weißen Blüten wegen nennt man ihn auch fälschlich „wilden Jasmin“. (Der echte Jasmin [Jasmínum grandifórum] ist eine südasiatische Pflanze, die bei uns nicht im Freien wächst.) 


\section{7.-29. Familie. Nachtkerzen-, Weiderich- und Myrtengewächse (Onagríceae, Lythráceae und Myrtáceae).}

1. Nachtkerzen-Gewächse. Das Wald-Weidenröschen (Epilóbium angustifólium) findet sich - wie schon der Artname sagt - auf Waldblößen und an Waldrändern als eine mehr denn meterhohe prächtige Pflanze. Von den weidenartig-schmalen und daher zahlreichen Blättern (s. S. 58,2) und den herrlichen, purpurroten Blüten ist der Gattungsname abgeleitet. Da stets mehrere Blüten der langen Traube zugleich entfaltet sind, und da auch der Kelch, der unterständige Fruchtkuoten, der Blütenstiel und der Stengel wenigstens soweit, als er mit Blüten besetzt ist, meist lebhaft rot gefärbt sind, so wird die Pflanze auf große Entfernung sichtbar. (Bedeutung? Beschreibe die Bliite und beobachte, wie an die Stelle der zuerst reifenden Staubblätter die sternförmige Narbe tritt! Vgl. mit Rittersporn!) Die Frïchte sind schotenförmige Kapseln. Sobald sich ihre 4 Klappen von der Mittelsäule ablösen, werden die zahlreichen Samen frei. Sie breiten ilhre Federkrönchen schnell aus und werden bald ein Spiel der Lüfte. Daher braucht nur irgendwo ein Stück Wald niedergeschlagen zu, sein, so stellt sich auch das Weidenröschen sofort ein. Wenn aber die jungen Bäume emporschießen und die Pflanze beschatten, und wenn infolgedessen die lichtliebenden Hummeln und Bienen sich immer seltener einstellen, dann verkümmern die Blüten. Dafür treibt das-WVeidenröschen jetzt aber weit längere unterirdische Ausläufer als vordem: ein Mittel, durch das es sich aus dem Schatten an eine besonnte Stelle "zu retten sucht".

Die Nachtkerze (Oenothéra biénnis) ist eine unserer bekanntesten Zierpflanzen. Sie stammt aus Nordamerika, hat sich bei uns aber so vollkommen eingebürgert, daß man sie nicht selten, besonders auf Sandboden, verwildert antrifft. Im ersten Jahre treibt sie eine Blattrosette (s. S. 17), im zweiten dagegen einen hohen Stengel mit zahlreichen, großen Blüten, um nach erfolgter Fruchtreife abzusterben. Gleich dem nickenden Leimkrant (s. das.) ist sie eine Nachtfalterblume (Name!). Dementsprechend sind die Bläten auch nur während der Nacht geöffnet (wie oft öffnet und schließt sich die einzelne Bläte?), seitlich gerichtet und stark duftend; die Blumenblätter sind helk (blaßgelb) gefärbt, und der Honig ist im Grunde ciner sehr langen Röhre geborgen. - Zu den Nachtkerzengewächsen gehört auch die Wassermug (Trapa natans), die in Seen und klaren Teichen wächst. Gleich dem Wasserhahnenfuß (s. das.) hat sie stark zerteilte untergetauchte und große, ungeteilte schwimmende Blätter. Letztere haben einen langen, aufgeblasenen Stiel, der als Schwimmwerkzeug dient. Die Früchte der immer mehr verschwindenden, weißblühenden Pflanze sind mit 4 "Hörnern" (umgewandelte Kelchzipfel) ausgerüstet, durch die sie im Schlamme verankert werden (Bedeutung?). Die nußartigen Samen sind eBbar. - Auch die Fuchsien (Fúchsia), die aus Südamerika stammen und wegen ihrer prächtigen Blüten zu unsern beliebtesten Topfpflanzen zählen, sind Nachtkerzengewächse.

2) Weiderich-Gewächse. Zwischen Weidengebüsch (Name!) und an anderen feuchten Stellen ist häufig der Weiderich (Lýthrum salicária) zu finden. An den ungestielten Blättern und den zahlreichen roten Blüten, die beide quirlartig um den Stengel gestellt sind, ist die mehr als meterhohe Pflanze leicht zu erkennen. Betrachtet 
man die Blüten genau, so findet man, daß wie bei der Schlüsselblume ein erheblicher Unterschied in der Länge der Stempel und Staubblätter obwaltet. Hier sind jedoch diese Organe in 3 Höhen angeordnet. Und wie bei der Schlüsselblume ist die Bestäubung auch hier nur von günstigem Erfolg, wenn Blütenstaub auf eine Narbe gelangt, die mit den betreffenden Staubbeuteln in gleicher Höhe steht.

3. Die Myrten-Gewächse sind Bewohner der warmen und wärmeren Länder. Ein Glied der großen Gruppe ist in der „bräutlichen“ Myrte (Myrtus commúnis), mit der geschmäckt die Jungfrau vor den Traualtar tritt, allgemein bekannt. Die Pflanze ist ein immergräner Strauch oder Baum der Mittelmeerländer (vgl. mit Orange). Hier ist auch die Heimat des Granatbaums (Púnica granátum), der wegen des dunkelgrünen Laubes und der prächtigen, scharlachroten Blüten bei uns gleichfalls in Töpfen gezogen wird. Die Früchte (Granatäpfel) waren schon im alten Israel ein beliebtes Obst.

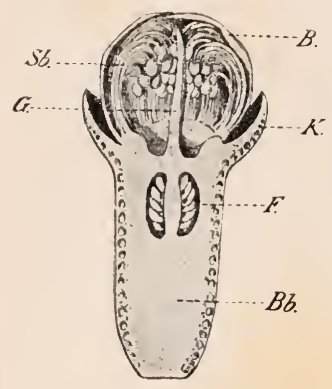

Blittenknospe vom Gewürznelkenbaum. Bb. Blütenboden. F. Fruchtknoten mit Samenanlagen. G. Griffel. Sb. Staubblätter. B. Blumenblätter. K. Kelch. (etwa 5 mal nat. Gr.).
- Der Gewïrznelkenbanm (Caryophýllus aromáticus) liefert uns in den getrockneten Blütenknospen die bekannten Gewürz-Nelken oder -Nägelein (s. Gartennelke), die wegen des Reichtums an Nelkenöl als vielverwendetes Gewürz dienen. (Beim Durchschneiden einer aufgeweichten "Nelke" kann man die einzelnen Blütenteile erkennen.) Die Heimat des Baumes sind die Molukken; jetzt ist er über alle Tropenländer verbreitet. - Die erbsengroßen, nelkenartig riechenden Früchte des Nelkenpfefferbaums Westindiens (Piménta officinális) sind als Nelkenpfeffer; Piment oder Neugewürz (weil erst nach der Entdeckung Amerikas bekannt geworden!) im Gebrauch. - Zu den Myrtengewächsen gehören auch die riesigen (bis $150 \mathrm{~m}$ hoch) Eukalyptusbäume (Eucalýptus) Australiens und der benacbbarten Inseln. $\mathrm{Da}$ sie einem außerordentlich trockenen Klima ausgesetzt und zudem immergrün sind, treffen wir bei ihnen zahlreiche Einrichtungen, die wir bei heimischen Pflanzen als Schutzmittel gegen zu starke Wasserabgabe finden: sie besitzen lederartig steife, sehr schmale, stielrunde oder senkrecht gestellte Blätter (vgl, mit Efen, Kiefer und Stachel-Lattich), die oft noch mit einer bläulichen Wachsschicht überzogen sind (daher auch „neuholländische Gammibäume“). Infolge der Form und Stellung der Blätter geben die Bäume nur sehr wenig Schatten, so daß man mit gewissem Recht von den „schattenlosen" Wäldern des trockenen Australiens redet. Da die Bäume in der trockenen Zeit blühen, so fehlen ihnen auch die mannigfachen Einrichtungen (Beispiele!), durch die bei unsern Pflanzen der Blütenstaub gegen Befeuchtung und damit vor Verderben geschützt ist. Bei ihnen ragen vielmehr die Staubblätter weit über die winzigen Blumenblätter hinaus. Auf sumpfigem Boden wachsen die seltsamen Bäume außerordentlich schnell. Darum wird auch eine Art, der blaue Gummibaum (Eu. glóbulus), in den Sumpf- und Fiebergegenden Südeuropas häufig angepflanzt.

4. Einer anderen verwandten Familie gehören die Mangrovebäume (Rhizóphora) an, die mit anderen sehr ähnlich gebauten Bäumen (woher diese Übereinstimmang?) die darch ihre Fieberluft berïchtigten Mangrovewälder bilden. Diese Wälder erheben sich über dem salzigen oder brackigen Wasser an tropischen Küsten, die sie oft auf viele 

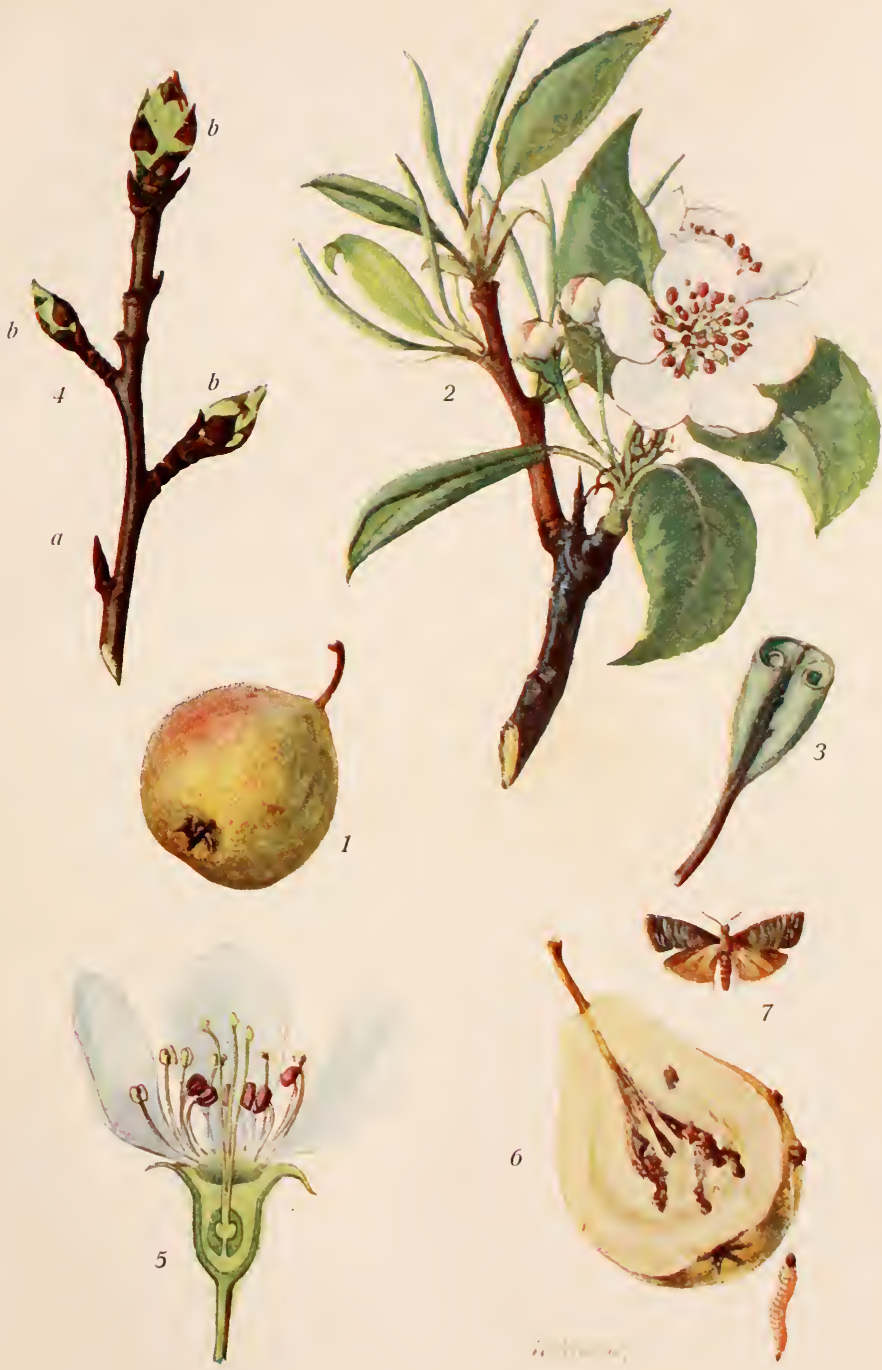

Birnbaum (Pirus communis). 


$$
\text { - }
$$


Meilen hin wie eine grüne Mauer umzäunen. Vorbedingung für ihr Auftreten sind ein verhältnismäßig ruhiges Wasser and ein lockerer, schlammiger Boden (warum?). Daher trifft man sie auch besonders in Buchten und an Flußmündungen an. Auf dem weichen Untergrunde finden die Bäume aber nur dadurch Halt, daß sie aus dem Stamme oder auch noch aus den Ästen zahlreiche Wurzeln in den Boden senken. Bei der Ebbe erhebt sich darum der Wald, wie auf unzähligen Stelzen stehend, über das Wasser oder den schwankenden Sumpfboden. Bei der Flut dagegen sind die Stätzwurzeln zumeist vom Wasser bedeckt. Als eine weitere Anpassung an das Leben auf diesem sonderbaren Boden sind die eigentümlichen Früchte zu erwähnen. Während sie noch am Baume hängen, keimt bereits der Same, den sie einschließen. Er entwickelt sich zu einem dolchartigen Gebilde, das sich schlieBlich ablöst und infolge seiner Schwere wie ein Pfahl in den Boden dringt.

\section{Familie. Rosenartige Gewächse (Rosáceae).}

Pflanzen mit Nebenblättern. Blütenboden scheibenförmig, stielförmig verlängert, becheroder krugförmig; auf seinem Rande stehen (meist) 5 Kelch-, 5 Blumen- und zahlreiche Staubblätter.

\section{Unterfamilie. Kernobstgewächse (Pómeae).}

Der mehrfächerige Fruchtknoten ist ans 2-5 Fruchtblättern gebildet und mit dem Blütenboden verwachsen. Fruchtknoten und Blütenboden bilden bei der Reife zusammen eine Scheinfrucht.

Der Birnbaum (Pirus commúnis). Taf. 13.

1. Vorkommen und Bedeutung. Der Birnbaum ist eine einheimische Pflanze, die wild in Laubwäldern und Feldgehölzen vorkommt. Die kleinen und herben Früchte (1. zeigt eine Frucht in nat. Gr.), die reich an steinigen Einschlïssen sind und daher "Holzbirnen" genannt werden, dienten in alten Zeiten dem Menschen zur Nahrung. (Die Einschlüsse bestehen - wie man sich mit Hilfe des Mikroskops leicht überzengen kann — aus sehr dickwandigen Zellen.) Daher ist der Baum auch schon außerordentlich früh in menschliche Pflege übergegangen, und durch jahrtausendelange Zucht (s. S. 19) ist schließlich unser "edler" Birnbaum mit seinen großen, saftig-süßen und zartfleischigen Friichten entstanden, die zu unserm wichtigsten Obste zäblen. (Gib an, wie die Birnen verwendet werden!) Wahrscheinlich haben bei dieser

2. Veredlung die Reiser anderer, ans Asien stammender Arten mit eine Rolle gespielt. Darauf

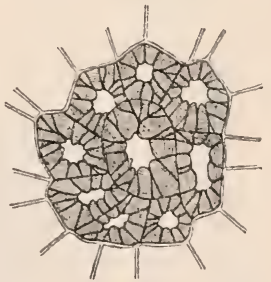

Ein ,Stein" aus dem Fruchtfleische der Birne, aus sehr dickwandigen Zellen bestehend (270 mal vergr.). deutet u. a. die Tatsache hin, daß aus dem Samen selbst der edelsten Sorte stets Bäume hervorgehen, deren Früchte mehr oder weniger die Gestalt und den Geschmack der "Holzbirnen" haben. Alle unsere zahlreichen Sorten (nenne solche und beschreibe ihre Früchte!) lassen sich nur 


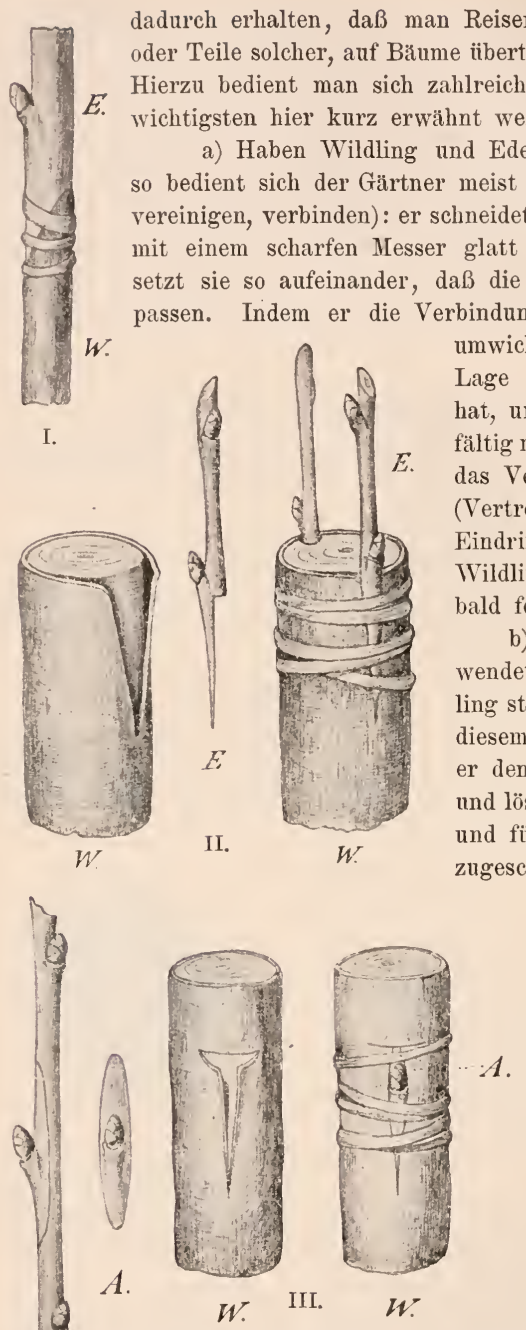

I. Kopulieren. II. Pfropfen (unter die E. Rinde). III. Okulieren. Die Bezeichdadurch erhalten, daß man Reiser von ihnen, d. s. kleine Zweige
oder Teile solcher, auf Bäume überträgt, die aus Samen gezogen sind.
Hierzu bedient man sich zahlreicher Verfahren, von denen nur die erden sollen.

a) Haben Wildling und Edelreis nahezu gleiche Stärke (I.), so bedient sich der Gartner meist des Kopulierens (kopulieren = (Wildling (W.) und Edelreis (E.), glatt und schräg (warum?) durch und penau aufeinander bindungsstelle fest mit Bast oder dgl. wickelt, sucht er das Edelreis in der age $\mathrm{zu}$ erhalten, die er ihm gegeben at, und indem er die Wundstelle sorgfältig mit Baumwachs überstreicht, will er das Verdunsten des aufsteigenden Saftes (Vertrocknen des Edelreises!) und das Eindringen von Pilzsporen verhindern. Wildling und Edelreis verwachsen daun ald fest miteinander.

b) Das Pfropfen (unter die Rinde) vendet der Gärtner an, wenn der Wildng stärker als das Edelreis ist (II.). Zu iesem Zwecke stutzt (schneidet oder sägt) r den Wildling (W.) wagerecht, spaltet and löst die Rinde auf eine kurze Strecke nd fügt das Reis (E.), das er zuvor so geschnitten hat, wie es die Abbildung zeigt, in den Spalt ein. Sodann legt er wie beim Kopnlieren einen Verband um die Pfropfstelle und bestreicht endlich die Schnittfläche des Wildlings mit Baumwachs.

c) Beim Okulieren (III.) schneidet man eine Knospe oder ein "Ange" (daher: Okulieren) mit einem schildförmigen Stiick Rinde (A.) aus dem Edelreise (E.), macht am Wildling (W.) einen T-förmigen Schnitt, hebt die Rinde etwas empor, schiebt das "Ange" darunter und verbindet die Wundstelle sorg- 
fältig. Ist das "Auge" angewachsen, dann schneidet man den Wildling darüber ab.

3. Dornen. So lange der wilde Birnbaum jung ist nnd einen kleinen Strauch bildet, enden die holzigen Zweige in scharfe, stechende Dornen, die eine vortreffliche Schutzwehr gegen Weidetiere bilden. Auch wenn sich der Stranch höher über den Boden erhebt, sind die Zweige etwa so weit, als die größten Weidetiere, die Rinder, reichen können, stark bedornt. Darüber hinaus aber werden die Dornen immer seltener, bis sie endlich ganz versclıwinden. Ebenso fehlen sie an dem Baume, in den der Stranch allmählich übergeht: der Stamm ist durch die harte, rissige Rinde wohl geschützt, und bis zur Krone vermögen die Weidetiere nicht emporzureichen. Auch der angebaute Birnbaum, der ja im Schutze des Menschen steht, ist meist völlig dornenlos. Der Birnbaum verhält sich eben wie der Mensch, der „in der Wildnis die Waffen nicht aus der Hand gibt, im sicheren Schiriii der Städte dagegen sie ablegt".

4. Kuospen. Im Frühjahre lassen sich an dem Birnbaume deutlich zweierlei Knospen erkennen (4.): kurze, spitze, aus denen lange, beblätterte Zweige (Blattknospen, 4 a.) und größere, dickere, ans denen kurze, blätter- und blütentragende Zweige hervorgehen (Bliiten- oder Tragknospen, 4 b.). Wie bei der Roßkastanie (s. das.) sind die Knospen von schuppenartigen Blättern umhïllt, die entweder ganz oder teilweise pergamentartig sind und später abfallen. Blïtenknospen treten jedoch erst auf, wenn der Baum ein gewisses Alter erreicht hat.

5. Die Äste sind steil aufwärts gerichtet. Infolgedessen hat die Krone, die bei alten Bäumen einen mächtigen Umfang erreicht, meist die Form einer Pyramide.

6. Blätter. Das junge Blatt (2. und 3.) tritt senkrecht zwischen den Knospenschuppen hervor. Es ist nach dem Hauptnerv zu zusammengerollt, an der Unterseite mit seidenartigen Härchen bedeckt und am Grunde des Stieles mit 2 fadenförmigen Nebenblättern versehen, alles Erscheinungen, die wir bereits früher (s. Veilchen, Roßkastanie und Linde) kennen und verstehen gelernt haben. Am ausgebildeten Blatte sind Nebenblättchen und Härchen verschwunden: es hat sich aufgerollt und

a) schräg gestellt, so wie es von den Sonnenstrahlen am besten durchleuchtet werden kann (s. S. 63, c). Diese gïnstige Stellnng einzunehmen wird ihm besonders durch den langen Blattstiel ermöglicht; denn er erlanbt del (eiförmigen, am Rande gesägten) Blattfläche, sich zu heben oder zu senken, zu wenden oder zu drehen, ganz wie die Belichtungsverhältnisse es erfordern.

b) Wenn ein heftiger Wind weht, zeigt sich, daß der Blattstiel noch eine zweite, wichtige Bedentung hat. Obgleich der Wind Ziegel von den Dächern reißt und anderes Unheil anrichtet, spotten die zarten Blïtter des Birnbaums (wie die aller anderen größeren Pflanzen) zumeist seinem Toben: Sobald sie voll einem Windstoße getroffen werden, stellen sie sich vermöge der biegsamen Stiele wie cine Wetterfahne in die Richtung des Windes, so daß der Anprall ohue Wirkung bleibt. Ist der Windstoß vorüber, so kehren sie, da der Stiel zugleich 
elastisch ist, in die ursprüngliche Lage zurïck. (Beurteile hiernach die Elastizität der Stämme und Äste.) Ein ebenso wichtiges Schutzmittel sind die elastischen Stiele gegen den Anprall schwerer Regentropfen. (Führe dies näher aus! Beachte, wie leicht der Sturm Birnen und Äpfel, die auf kurzen und unelastischen Stielen sitzen, vom Baume wirft! Vgl. dag. die langgestielten Kirschen und Pflanmen! Warum können niedrige Pflanzen oder solche mit kleinen Blättern der Blattstiele entbehren? Beispiele!)

Das Blatt weicht also den beiden feindlichen Kräften, dęm Winde und den aufschlagenden Regentropfen, aus. Trotzdem bedarf es aber einer gewissen Festigkeit, um von ihnen nicht zerrissen oder durchschlagen zu werden. Diese erlangt es (wie die Blätter aller anderen Landpflanzen) durch das Gerüst der Adern oder Nerven, von dem die Blattfläche durchzogen wird. (Beschreibe den Verlauf der Adern im Blatte des Birnbaums und anderer bekannten Pflanzen! Vgl. die Adern mit den Stäben eines aufgespannten Schirms! Gegen welche Gewalten erweisen sich die erwähnten Schutzmittel als unzureichend! Beobachte, wie die zarten, jungen Blätter vom Winde zerzanst werden!)

c) Die oben (Absch. a) erwähnte Schrägstellung der Blätter ist für den Baum auch noch aus einem anderen Grunde vorteilhaft. Werden schräg nach außen gerichtete Blätter vom Regen getroffen, so fließt das Wasser nach $a u ß e n a b$, so daß es auf tiefer stehende Blätter fallen muß. Diese leiten es weiter nach außen, und so geht es fort, bis am Umfange der Krone alles Wasser, das den Baum trifft, wie von einem Dache oder aufgespannten Schirme zur Erde tropft. Erst ein heftiger oder anhaltender Regen vermag durch die Krone zu dringen und die Erde unter ihr zu nässen. (Darum flüchten wir, wenn wir im Freien vom Regen iiberrascht werden, unter einen Baum.) Gräbt man nun an der Stelle vorsichtig nach, an der die Traufe niedergeht, so findet man dort stets die feinen Saugwurzeln, die allein imstande sind, Feuchtigkeit aus dem Boden aufzunehmen, während die stärkeren Wurzeln durch die dicke Rinde daran gehindert werden. Diese Art der Wasserableitung bezeichnet man im Gegensatz zn der nach innen gerichteten, der "centripetalen“, wie wir sie beim Raps kennen gelernt liaben, als "centrifugale“. Wir finden sie bei allen Bäumen wieder, und sie erscheint uns um so zweckentsprechender, wenn wir bedenken, daß nur ein weit ausgebreitetes Wnrzelwerk imstande ist, den Angriffen der Winde auf die schwere Krone zu widerstehen. (Bei was für Pflanzen ist die Ableitung centripetal? Wo finden sich bei ihnen die Saugwurzeln? Warum bedürfen Wasser- und Sumpfpflanzen dieser Einrichtung nicht? Warum gibt der Gärtner der Laub- und Wurzelkrone von Bäumen, die er pflanzen will, gleichen Umfang?)

7. a) Die Blüten (2.) stehen in kleinen Sträußen an kurzen Zweigen. (Das „Beschneiden" der Bäume bezweckt, sie zu zwingen, solche „Kurztriebe" oder - wie der Obstziichter sagt — „kurzes oder Frucht-Holz" zu bilden.) Von den Blättern, die gleichzeitig aus den Knospen hervorbrechen, sich aber viel langsamer entwickeln, werden sie nicht verdeckt. Infolgedessen erscheint 
der blühende Birnbaum wie ein wahres Blütenmeer (vgl. mit anderen Obstbäumen!). Da die Blüten zudem duften und honigreich sind (wo findet sich der Honig?), ist der blühende Banm oft von Hunderten naschender Insekten umschwärmt. (Vgl. W. Müllers „Frühlingsmahl“: Wer hat die weißen Tücher gebreitet über das Land etc.!) Wie notwendig den Blüten der Besuch dieser Gäste ist, beweist folgende Tatsache: In Australien wollten die Obstbänme trotz aller Miihe der Ansiedler keine Frïchte tragen (weil die zur Bestäubung nötigen Insekten fehlten). Da wurden von einem deutschen Imker Bienen eingeführt - und in demselben Jahre zeigten die Obstbäume jener Gegend reichen Fruchtansatz.

b) Durchschneiden wir eine einzelne Blüte der Länge nach (5.), so sehen wir, wie der oberste Teil des Blïtenstiels, der Bliitenboden, an den Seiten emporgewachsen ist, so daß er einen kleinen Becher bildet. Der Becherrand trägt 5 kleine Kelchblätter, etwas weiter nach innen 5 große, weiße Blumenblätter und hinter diesen wieder etwa 20 Staubblätter mit roten Staubbeuteln. (Man sagt daher auch ungenaner Weise, die [Blumen- und] Staubblätter ständen auf dem Kelchrande.) Aus der Öffnung des Bechers ragen 5 Griffel hervor, die zu dem Fruchtknoten in Grunde des Bechers führen. An einem Querschnitte (s. Diagramm) ist deutlich zu erkennen, daß der 5-fächerige Fruchtknoten aus 5 Fruchtblättern gebildet wird, und daß er mit dem becherförmigen

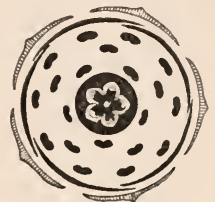

Bliitengrundrif des Birnbaums. Blütenboden verschmolzen ist. Aus beiden Teilen, aus Fruchtknoten und Blütenboden, geht die

8. a) Frucht hervor: Der Fruchtknoten wird zu dem "Kernhause“, dessen 5 Fächer je 2 braune Samen enthalten, und der Blütenboden zu dem Fruchtfleische. Am oberen Ende der Frncht finden wir daher selbst noch zur Reifezeit den vertrockneten Kelch. Da an der Bildung der Frucht also noch ein anderer Blütenteil als der Fruchtknoten beteiligt ist, bezeichnet man sie als "Scheinfrucht". (Warum schneidet der Obstzüchter einen Teil der Früchte ab, wenn der Fruchtansatz zu reich ist?)

b) Verbreitung der Samen. Sollen sich die Samen (Obstkerne - Kernobst!) zu einer neuen Pflanze entwickeln, so muß das Fruchtfleisch samt der pergamentartigen Hülle der Fruchtfächer verfaulen, oder ein Vogel muß das Fleisch verzehren, das Kernhans öffnen oder die mitverzehrten Kerne wieder von sich geben. Und dabei leiden die Kerne durchans keinen Schaden; denn sie sind gegen die Verdauungssäfte durch eine pergamentartige Hülle geschützt. Gleich dem Weinstocke (s. das.) erzeugt der Birnbaum das saftige Fruchtfleisch allein seiner Verbreiter wegen, die er durch lenchtende Färbung (gelb, an der Außenseite oft noch mit roten "Backen") und angenehmen Duft der Frïchte anzulocken sucht. So lange die Samen noch unreif sind, schützen wieder wie beim Weinstocke! - saure, zusammenziehende Sifte die unscheinbar grünen Früchte, vorzeitig verspeist zu werden. 
9. Feinde. Der Birnbaum ist gleich seinem nächsten Verwandten, dem Apfelbaume, von einem Heer von Feinden bedroht. Der Maikäfer, sowie die Raupen von Frostspanner, Baumweißling, Goldafter, Ringelspinner zehren von den Blättern; der Apfelblütenstecher vernichtet die Blüten; der Weideubohrer durchwühlt den Stamm und der Apfelwickler die saftigen Früchte (6. u. 7.). Von den schädlichen Pflanzenläusen sei nur die schädlichste, die Blutlaus, genannt, die in einigen Gegenden an Apfelbäumen große Verheerungen angerichtet hat. (S. „Lehrbuch der Zoologie“.) Pilze (s. das.) bilden auf Blättern und Früchten "Rostflecke" und Schorfe und erzengen in Wundstellen krebsartige Bildungen.

Andere Kernobstgewächse.

Eine noch weit größere Bedeutung als der Birnbaum hat für uns der Apfelbaum (P. malus). Beweis! Er ist gleichfalls ein einheimisches Gewächs (Holzäpfel!) und wird in vielen Sorten angebaut (beschreibe die Früchte der dir bekannten Sorten!). Im Gegensatz zum Birnbaume hat er eine breite, niedrige Krone, und die prächtigen Blüten zeigen außen einen roten Anflug. - Quitte (Cydónia vulgáris) und Mispel (Méspilus germánica), von denen letztere $a b$ und $z u$ auch verwildert in Wäldern vorkommt, entstammen den Mittelmeerländern. Sie haben groBe Bliiten, die (s. Rose) darum auch einzelnstehend die Aufmerksamkeit der Insekten erregen. Die gelben, duftenden Quitten sind nur eingemacht

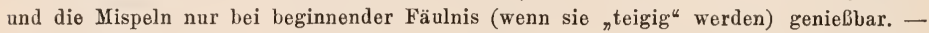
Bei Weigdorn (Cratágus oxyacántha) und Eberesche (Sorbus aucupária) sind die Blüten verhältnismäßig am kleinsten. Wir finden sie daher gleich den leuchtend roten Früchten auch zu großen, doldenartigen Ständen gehäuft. Der Weiß- oder Hagedorn (erkläre die Namen! vgl. mit "Schwarzdorn“!) wird gern zur Anlage von Hecken benutzt. Seine rotblühende Abart, der Rotdorn, ist in Baum- oder Strauchform eine bekannte Zierpflanze. Die Eberesche (d. i. After-Esche, wegen der eschenartigen Blätter) oder der Vogelbeerbaum (warum wohl?) steigt in den Gebirgen bis zur Baumgrenze empor.

\section{Unterfamilie. Steinobstgewächse (Prúneae).}

Der einfächerige Fruchtknoten ist aus einem Fruchtblatte gebildet und nicht mit dem Blütenboden verwachsen. Frucht eine Steinfrucht.

\section{Der Süßkirschbaum (Prunus ávium).}

1. Heimat und Bedeutung. Gleich Birn- und Apfelbaum hat der Süßkirschbaum in mittleren Europa seine Heimat. Er findet sich hier und da in Waldungen und ist der Stammvater der zahlreichen Spielarten, die wir in Gärten, an Straßen und.Bergabhängen der veredelten (d. h. größeren, fleischigeren und wohlschmeckenderen) Früchte wegen anbauen. (Welche Spielarten sind dir bekannt? Wie verwendet man die Früchte?) Sowohl die wilde, als auch die angebaute Pflanze wächst zu einem stattlichen Baume heran. (Stelle Stammumfang und -durchmesser einiger größerer Bäume fest!) Die kugelige Krone wird von einem entsprechend starken

2. Stamme getragen, der mit einer glatten, graubraunen Rinde bedeckt ist. Bei Verletzungen lösen sich die oberen Rindenschichten in ringförmigen, lederartig-biegsamen Streifen ab. Häufig fließt aus dem Stamme ein klebriger Stoff, das Kirschgumi, das in Wasser leicht löslich ist und darum 
wie das arabische Gummi (s. das.) als Klebmittel verwendet werden kann. (Der Ausfluß von Gummi ist bei allen Steinobstgewächsen zu beobachten und zumeist wohl als Krankheitserscheinung zu deuten.)

3. Blatt. a) Die jungen Blätter treten (gleich den Blitten, die sich in blattlosen Knospen entwickeln - vgl. dag. Sauerkirsche!) aus Knospen hervor, die von Schuppen umhïllt sind (Schutzmittel; vgl. mit Roßkastanie). Zwischen den Schuppen und den Laubblättern, die am Grunde mit 2 später abfallenden, kleinen Nebenblättern versehen sind, findet ein vollständiger Übergang statt: ein Zeichen, daß wir es in ersteren gleichfalls nur mit Blättern zu tun haben. Die Flächen der jungen Blätter sind in der Mittelader gefaltet, senkrecht gestellt und mit einem firnisartigen Überzuge versehen: Einrichtungen, in denen wir bereits früher (s. Roßkastanie) Schutzmittel der zarten Gebilde erkannt haben.

b) Die entwickelten Blätter sind eiförmig und am Rande gesägt. Am oberen Ende des langen Blattstiels finden sich 2 meist rote Drïsen, die eine zuckerhaltige Flïssigkeit ausscheiden. (Welche Bedeutung diesen Gebilden zukommt, ist bisher nicht sicher erwiesen; s. dag. Wicke. Wo finden sich die Drüsen am Blatte des Sauerkirschbaums?)

b) Laubfall. Sobald der Herbst in das Land zieht, verändern sich die Blätter des Kirschbaumes wesentlich: alle wertvollen Stoffe, die sie enthalten, werden in den Stamm und die Äste geleitet, um im nächsten Frühjahre zum Aufbau der jungen Zweige, Blätter und Bläten wieder verwendet zu werden. Infolge dieses Verlustes erscheinen die Blätter wie ausgetrocknet; sie färben sich gelb und rot und lösen sich schließlich vom Baume. Die Trennung erfolgt in einer Korkschicht, von welcher der Blattstiel am Grunde quer durchsetzt wird. Da diese Schicht sehr leicht reißt, wird das Blatt schon durch einen leisen Windstoß oder die eigene Schwere zu Fall gebracht. (Dieselben Erscheinungen sind an allen unsern Laubbäumen und den meisten Sträıchern - s. aber Efeu und andere immergrüne Gewächse - zu beobachten. Die Stauden Beispiele! - sterben bis auf die unterirdischen Teile ab.)

Durch das Abfallen der Blätter verliert der Baum eine Menge von Stoffen, die er sich aus dem Boden oder der Luft (Kohlenstoff) erworben hat. Es scheint daher, als ob der herbstliche Laubfall für ihn von großem Nachteil wäre. Daß dies jedoch nicht der Fall ist, werden wir einsehen, wenn wir die Ursachen des Laubfalls kennen gelernt haben. Leicht anzustellende Beobachtungen sollen uns dabei leiten.

Die Blätter von Goldlackpflanzen, die wir während des Winters im Garten belassen, werden, sobald Kälte eintritt, welk, runzelig und hängen schlaff herab. Dasselbe beobachten wir an Goldlackpflanzen, die wir im Zimmer halten, sobald wir ihnen nicht genügend Wasser zuführen. Tritt wieder milde Witterung ein, oder begießen wir die dürstenden Zimmerpflanzen, so werden die Blätter auch wieder straff und richten sich empor. Bohnen- und Tabakpflanzen vertrocknen sogar, sobald sich die Luft auf einige Grad über Null abkühlt. (Man sagt ungenauer Weise - warum? - sie seien "erfroren“.) Nun wissen wir, 
daß die Blätter dann welk werden, wenn sie mehr Wasser verdunsten, als die Wurzeln aufnehmen können (Zimmerpflanzen!). Wasser stand aber den Goldlackpflanzen im Freien, sowie den Bohnen und dem Tabak genügend zur Verfügung. Daß sie dennoch welkten, ist ein Zeichen dafür daß ihre Wurzeln doch nicht soviel Wasser aufnahmen, wie nötig war, um den Verlust zu ersetzen. Wie unsere Lebenstätigkeiten stocken und schließlich ganz aufhören, sobald die Blutwärme unter $37^{\circ}$ C. sinkt; wie Eidechsen und Lurche bei eintretender Kälte in Erstarrung verfallen: so stellen nämlich auch die Wurzeln ihre Arbeit ein, sobald sich der Erdboden stark abkühlt. Das kann bei der einen Pflanze (Bohne, Tabak) früher, bei der anderen (Goldlack) später geschehen, genau wie dies bei den verschiedenen Tieren der Fall ist. Entzieht man nun einer Pflanze längere Zeit das Wasser (Versuch!), so vertrocknet sie schließlich, d. h. sie geht an Wassermangel zu Grunde. So würde es dem Kirschbaum und anderen Bäumen auch ergehen, wenn sie nicht im Herbste ihr Lanb verlören: die Blätter würden immerfort Wasser verdunsten; da die Wurzel aber ans dem Boden, der sich schon im August und September (kurze Tage, lange Nächte!) stark abzukühlen beginnt, keinen Ersatz schaffen kann, so würden die Pflanzen schließlich vertrocknen, absterben. Infolge des herbstlichen Laubfalls verlieren die Pflanzen zwar, wie oben erwähnt, eine Menge von Stoffen;

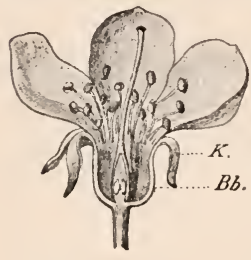
aber dieser Verlust ist bei weitem nicht so schlimm, als wenn sie ihr - Leben verlieren wïrden! (Vgl. aber unsere Nadelhölzer; s. Kiefer. - Wie bei uns die kalte Jahreszeit, ist in sehr trockenen Tropengegenden die heiße Jahreszeit die ungünstige für die Pflanzen. Dort werfen daher die Bäume das Laub mit dem beginnenden Sommer ab.)

Selbst wenn die Wurzeln ihre Tätigkeit in der kalten Jahreszeit nicht einstellen würden, könnten

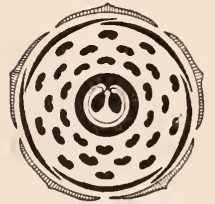

Blïte und Blïtengrundrif rom Kirsehbaum.

Die Blüte ist halb durchschnitten. Bb. Blütenboden. K. Kelch (etwa 2mal nat.Gr.). die Bäume unserer Gegenden mit dem Laube den Winter nicht ïberdauern. Schon bei geringem Schneefall würden die Kronen so stark belastet werden, daß Zweige und Stamm brechen mïßten. (Vgl. dag. die Kiefer! S. auch S. 17, B.)

4. Blüte. Die rein weißen, langgestielten Blïten besitzen einen angenehmen Duft und sind wie die des Birnbaums gebaut (Beweis!). Nur bezüglich des flaschenförmigen Fruchtknotens macht sich ein Unterschied geltend: er ist aus nur einem Fruchtblatte gebildet und steht vollkommen frei im Grunde des kelchförmigen Blïtenbodens. Nach erfolgter Bestäubung (welche Insekten vermitteln sie?) löst sich der Blütenboden samt den Blütenteilen, die er trägt, am Grunde ab, so daß der Frnchtknoten allein auf dem Blïtenstiele zurückbleibt. 
5. Frucht. Die Verbreitung der Pflanze erfolgt wie die des Weinstockes und Birnbaumes (s. das.) durch Vögel, besonders durch Drosseln ("Vogelkirsche"). $\mathrm{Zu}$ diesem Zwecke erfahrt die von dem Fruchtblatte gebildete Wand des reifenden Fruchtknotens eine eigentümliche Ausbildung. Sie spaltet sich in 3 deutlich voneinander getrennte Schichten: eine äußere, abziehbare Haut von auffallender Färbung (gelblich mit roten Backen, heller oder dunkler rot bis fast schwarz), eine saftige, süße, fleischige Mittelschicht und eine steinharte Hülle, die den Samen umschließt. (Steinfrucht; Steinobst. - Welche Aufgaben haben die einzelnen Teile zu erfüllen? Vgl. auch die unreife Frucht mit Weinbeere und Birne!) In der Regel entwickelt sich von den beiden Samenanlagen nur eine. (Beachte daraufhin Aprikose und Mandel!)

Die Vögel, die nur das süße Fruchtfleisch naschen (Sperlinge, Stare n. a.) oder wie der Kirschkernbeißer gar die Kerne zertrümmern und der Samen berauben, sind Feinde des Baumes. Die Made der Kirschfliege, die in dem Fruchtfleische lebt, macht die wohlschmeckenden Frïchte für den Menschen oft ungenießbar.

\section{Andere Steinobstgewächse.}

Die meisten und wichtigsten Steinobstgewächse sind aus Asien zu uns gekommen. Aus Vorderasien stammen die Sauerkirsche (P. cérasus), die der Sage nach Lukullus aus Kerasunt (daher „Kirsche") zuerst nach Europa gebracht haben soll, und die echte Pflaume oder Zwetsche (P. doméstica). Die Aprikose (P. armeníaca) und P'firsiche (Amýgdalus pérsica) haben in Ostasien oder auch - worauf die Namen hinweisen - in Armenien, bezw. Persien ihre Heimat. Alle diese Bänme zählen zu unseren wichtigsten Obstarten und werden in zahlreichen Sorten gebaut. (Beschreibe die Bäume, besonders deren Früchte! Verwendung?) — In Süd- und Mitteleuropa ist wahrscheinlich die Kriechenpflaume ( $P$. insititia) heimisch, die bei uns besonders in 2 Spielarten gezogen wird : mit gelben, kleinen (Mirabelle) oder grünen, großen Früchten (Reine-claude). - Der Mandelbaum (Amýgdalus commúnis) wird bei uns zumeist nur der prächtigen Blüten wegen als Ziergehölz angepflanzt. Für die Länder um das Mittelmeer dagegen bilden seine großen, eßbaren Samen, die Mandeln, eins der wichtigsten Erzengnisse (Verwendung?). Der bei anderen Steinobstgewächsen fleischige Teil der Frucht ist bei ihm lederartig and ungeniebbar. Die Mandeln sind entweder von säßem oder bitterem Geschmack. Die bitteren Mandeln sind infolge ihres Gehaltes an blausäurereichem Bittermandelöl giftig. Diese Eigenschaft, die auch den Samen der anderen Steinobstgewächse in geringem Grade zukommt, geht aber durch Kochen, Rösten und Backen verloren. Bei den ${ }_{\pi}$ Krach- oder Knackmandeln" ist die Steinschale dünn und zerbrechlich.

An Waldrändern und trockenen Orten bildet die Schlehe (P. spinósa) oft undurchdringliche Hecken. Wegen der schwarzen Rinde (im Gegensatz zum „Weißdorn ${ }^{*}$ ) und der dornigen Äste (s. Birnbaum) führt die sehr zeitig im Frühjahr blühende Pflanze auch den Namen "Schwarzdorn". Ihr zähes Holz benutzt man zur Anfertigung von Spazierstöcken. Die schwarzen, herben Früchte werden erst nach einem Froste geniebbar. In Anlagen findet man häufig die duftende Weichselkirsche (P. máhaleb), aus deren SchöBlingen man besonders Pfeifenrohre anfertigt, und die Traubeukirsche (P. padus), deren Blüten in großen Trauben stehen. Letztere Pflanze wird hier and da unrechtmäßig auch ${ }_{n}$ Faulbaum" (s. das.) genannt. Die schwarzen Frächte beider sind für den Menschen nicht genießbar, werden aber von Vögeln gern verzehrt. 


\section{Unterfamilie. Rosengewächse (Róseae).}

Mehrere einfächerige Fruchtknoten, die aus je eimem Fruchtblatte gebildet sind und frei auf dem Blütenboden stehen.

\section{Die Rose (Rosa).}

A. Die Hundsrose (R. canina).

1. Rosenhecke. An Waldrändern, in Gebüschen, an Wegen mnd ähnlichen Orten findet sich die wilde oder Hunds-Rose (Gegensatz zur "edlen" Rose), oft große, undurchdringliche Hecken bildend. Wie kommt eine solche Hecke zustande? Die jungen, weichen Sprosse kommen senkrecht aus dem Boden hervor. Bald aber verholzen sie und neigen sich in großem Bogen mit der Spitze zur Erde herab. Von der oberen Seite der Bogen erheben sich im nächsten Jahre kurze, blütentragende Zweige und sehr lange, aufrechte Triebe, die sich wieder bogenförmig herabkrümmen und meist an den Enden vertrocknen. Die jungen Bogen legen sich anf die alten und treiben wieder senkrechte Zweige, die sich abermals herabbiegen. So baut sich die Hecke immer löher auf, und so geben sich die sehr langen, aber verhältnismäßig schwachen Stämme gegenseitig Halt und Stïtze. Auch an Umfang und Dichte nimmt die Hecke stetig zu; denn aus dem Boden kommen alljährlich neue Sprosse hervor, die, weil unverzweigt, sich leicht durch das Gewirr der Stämme und Äste hindurcharbeiten können. (Märchen von „Dornröschen“.) Die Undurchdringlichkeit der Hecke wird wesentlich durch die

2. Stacheln erhöht, die sich in besonders großer Anzahl an den jungen Trieben, aber auch an der Mittelrippe der Blätter und an den Blütenstielen finden. Im Gegensatz zu den Dornen, die kurze, stechende Zweige darstellen (s. Birnbaum), sind die Stacheln Auswïchse der Rinde und daher leicht abzubrechen. (Beurteile hiernach das bekannte Sprichwort: „Keine Rose ohne Dorn“!) Sie sind scharf stechend, hakenförmig herabgebogen und stellen somit vortreffliche Schutzwaffen dar: sie verwehren den Weidetieren und anderen Pflanzenfressern von den grünen Teilen zu naschen, sowie den gefräßigen Schnecken zu den saftigen Blättern und den Mäusen zu den wohlschmeckenden Hagebutten emporzukriechen. (Goethes „Heideröschen"!) Älteren Stämmen fehlt die Schutzwehr; sie sind durch die harte, trockene Rinde genügend geschützt (vgl. mit Birnbaum).

3. Das Blatt ist unparig gefiedert, $d$. h. es besteht aus einer langen Nittelrippe und 5-7 einzelnen Blättchen, von denen sich je 2 und 2 gegenüber stehen, während das einzelne oder unpaare Blättchen das Ende der Nittelrippe einnimmt (vgl. mit einer Feder!). Die Fiederblättchen sind eirund und am Rande scharf gezähnt. Am Grunde des Blattes finden sich 2 Nebenblätter, die mit der Mittelrippe der ganzen Länge nach verwachsen sind. Welche Bedentung diese Gebilde haben, ist an wachsenden Zweigen (besonders wenn sie aus der Knospe hervortreten) deutlich zu sehen: die Nebenblätter des äußersten, ältesten Blattes umfassen wie eine Scheide das nächst jüngere Blatt; zwischen dessen Nebenblättern ist wieder das nächst jüngere Blatt geborgen u. s. f. Auf diese Weise sind alle Blätter des jungen Zweiges gleichsam ineinander geschachtelt 
und die innersten, sehr zarten Blätter durch die ¿ıßeren, schon mehr erstarkten geschïtzt. Die jungen Fiederblätter sind, wie wir dies bereits bei der Roßkastanie (s. das.) kennen und verstehen gelernt haben, in der Mittelrippe gefaltet und wie die Blätter eines Buches eng zusammengelegt. - An den Zweigspitzen finden sich häufig die wie mit Moos umkleideten Rosen-oder Schlafäpfel. Sie sind durch den Stich der Rosengallwespe entstanden und beherbergen in mehreren Höhlen die Larven des Insekts (s. "Lehrbuch der Zoologie").

4. a) Bliite. An den Blüten erkennen wir den Bau der Birnblüte mit geringen Abweichungen deutlich wieder (Vergleich!). Wir finden einen krugförmigen Blïtenboden, der mit einem gelben, fleischigen Ringe abschließt und 5 Kelchblätter, 5 rosafarbene Blumenblätter und sehr zahlreiche Staubblätter trägt. (Beobachte an der Knospe, wie die zum 'Teil fiederspaltigen Kelchblätter, sowie die Blumenblätter an den Rändern übereinandergreifen und somit das Blüteninnere gegen Nässe und andere Schädigungen schützen!) In der Höhlung des Blïtenbodens finden sich zahlreiche, freie Fruchtknoten, deren Griffel durch die Öffnung des "Kruges" ins Freie treten und dort zu hellgelben Narben anschwellen. Jeder Fruchtknoten besteht aus einem Fruchtblatte und enthält eine Samenanlage.

b) Wie beim Birn- und Kirschbaume stelien anch hier meist mehrere Blïten beieinander. Sie entfalten sich aber stets nachcinander; denn da sie von beträchtlicher Größe sind, vermögen sie auch einzeln die Aufmerksamkeit der Insekten zu
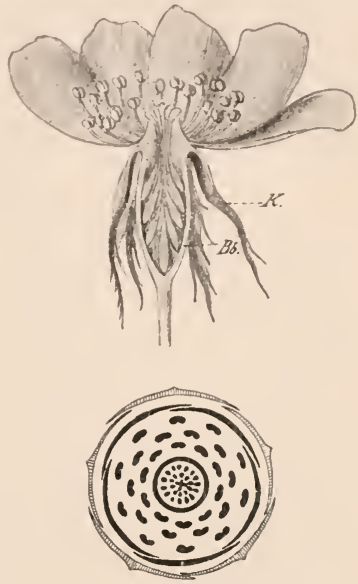

Bliite und Blïtengrumdriß̧ der Hundsrose. Die Bläte ist halb durchschnitten. Bb. Blätenboden. K. Kelch.

$(1 / 2$ nat. Gr.). erregen. (Vgl. mit anderen großblumigen Pflanzen!) Mit der prächtigen Blütenfarbe wirkt der köstliche Duft als Anlockungsmittel (s. S. 97, 3).

Die zarten Blumenblätter können wie die der Klatschmohnblüte (s. S. 25, b) großen Insekten nicht als Anflugsplatz dienen. Ein solcher wird vielmehr von den zahlreichen Narben und dem fleischigen Ringe gebildet. (Inwiefern wird durch diese Einrichtung die Möglichkeit der Fremdbestäubung erhöht?)

Den Bestäubern gewährt die Rose nur Blïtenstaub als Gegengabe (welche Insekten hast du in ihr beobachtet?). Wir finden daher bei ihr auch viel mehr Staubblätter als in den honigreichen Blüten des Birn- und Kirschbaums nnd wie bei der Mohnblüte große, muschelförmige Blumenblätter, die den verstreuten Staub anffangen. 
Wenn irgend möglich, folgt die geöffnete Blïte dem Laufe der Sonne. Gegen Abend schließt sie sich. Die Blumenblätter neigen sich zusammen und bilden ein schützendes Dach für den Blütenstaub, den der nächtliche Tau leicht verderben könnte.

5. Frucht. Wie die Frucht vom Birn- und Kirschbaume wird auch die der Rose durch Vögel verbreitet. Dementsprechend färbt sich der schwellende Blütenboden scharlachrot (Anlockung der Vögel) und wird fleischig und wohlschmeckend (Nahrung der Verbreiter). Im Innern des fleischigen "Kruges" finden sich die zahlreichen, behaarten Früchte, die je ein kleines, hartschaliges Nüßchen darstellen (Schutz gegen Verdauungssäfte). Die "Hagebutte“ ist also eine Scheinfrucht wie die Birne und zugleich eine "Sammelfrucht". (Gib weitere Unterschiede zwischen Birne und Hagebutte an!) - Nach Entfernung der steifhaarigen Frïchte wird die Hagebutte auch vom Menschen genossen.

\section{B. Die edle Rose.}

1. Die edle Rose gilt schon seit dem grauen Altertume als die Königin unter den Blumen. Der zarte Bau, die Farbenpracht und der köstliche Duft der Blüten haben ihr diesen Rang erobert. Sie gilt daher als das Sinnbild der Jugend ("Rosenzeit des Lebens"), der Unschuld und Schönheit, und in zahllosen Liedern ist sie gefeiert. Mit Rosen schmücken wir uns und unser Heim bei fröhlichem Feste, und Rosen legen wir unsern Lieben auf den stillen Grabhügel.

2. In fast unendlicher Mannigfaltigkeit findet sich die Rose in den Gärten. Von den zahlreichen Sorten - man zäblt deren mehr als $6000-$ seien nur die beiden bekanntesten genannt, die rote Gartenrose oder Centifolie (d. h. die Hundertblättrige) und die allbekannte "weiße Rose". Von den meisten Sorten kennen wir weder Heimat, noch Herkunft. Nur soviel ist sicher, daß die edle Rose viel mehr ein Erzengnis menschlicher Kunst als eine „Schöpfung der Natur" ist. Das beweist schon die Tatsache, daß es keine wilde Rosenart gibt, die wie unsere edle Rose gefüllte Blüten besitzt. Solche Blüten sind entweder dadurch zustande gekommen, daß Staubblätter in Blumenblätter umgewandelt sind, oder daß eine Vermehrung der Blumenblätter über die Fünfzahl der wilden Formen hinaus erfolgt ist. Für ersteres sprechen die Übergänge, die sich vielfach zwischen Blumen- und Staubblättern finden, für das zweite, daß es zahlreiche Sorten gibt, die wohl eine erhölte Zahl von Blumenblättern besitzen, zugleich aber die Staubblätter wohl ausgebildet und vollzählig erhalten haben.

Die Züchtung der zabllosen Sorten ist einesteils in derselben Weise wie die aller anderen Kulturpflanzen erfolgt (s. S. 19): man pflanzte wilde Rosenarten (unsere heimatliche Pflanzenwelt weist deren schon eine ganze Anzahl auf, die sich aber sehr stark ähneln) in besseren Boden, ließ ihnen eine sorgsame Pfiege angedeihen und wählte stets nur die Pflanzen zur Fortzucht aus, bei denen eine Vermehrung der Blumenblätter eingetreten war. Anderenteils suchte man die Arten unter einander zu "kreuzen": man brachte Blütenstaub einer Art anf die Narben einer anderen, und aus den dadurch entstehenden Samen 
gingen Pflanzen hervor, welche die Eigenschaften beider „Eltern" zeigten. Mit diesen Mischlingen, Hybriden oder Bastarden verfuhr man nun weiter in der zuerst angedeuteten Weise, und noch heutzutage werden bei der Zucht neuer Sorten genau dieselben Wege eingeschlagen. Die Vermehrung der edlen Sorten erfolgt stets durch "Augen", die man wilden Rosenstämmen mit Hilfe des Okulierens (s. S. 86) einpflanzt.

3. Der Duft sowohl der wilden, als auch der edlen Rosen rührt von einem Öle her, das sich leicht verflïchtigt und auf Papier keinen bleibenden Fettfleck zurückläßt (flüchtiges Öl im Gegensatz zu den fetten Ölen; s. S. 16, A.). Dieses „Rosenöl" wird (durch Destillation mit Wasser) als ein ïberans teurer und wertvoller Stoff besonders in der Türkei und Persien, aber auch in zahlreichen anderen Ländern ans den Bliiten bestimmter Sorten gewonnen und zur Herstellung wohlriechender Wässer, zum Parfümieren von Seifen, Salben und dgl. benutzt.

Andere Rosengewäichse.

In sonnigen Wälderu und Gebüschen, an Bergabhängen und ähnlichen Orten findet sich die Wald-Erdbeere (Fragária vesca) als eine unserer gemeinsten Pflanzen. Aus den Achseln der dreizähligen Blätter (beobachte, wie sie sich entfalten!) entspringen lange Ansläufer, die wie beim Veilchen zahlreiche junge Pflanzen ins Dasein rufen. Die weißen Blüten sind nachts und bei Regenwetter nickend (Bedeutung!). Nach erfolgter Bestäubnng richten sie sich nicht wieder empor (warum ist dies auch nicht nötig?), so daß die reifende ${ }_{n}$ Frucht" von dem Kelche, zu dem noch ein 5-blättriger ${ }_{n}$ A ufenkelch" tritt, wie von einem Dache überdeckt ist. Der stielförmig verlängerte Blütenboden vergrößert sich jetzt immer mehr, indem er zugleich fleischig und saftig wird. In ihm sind die zahlreichen Früchte, die je ein winziges Nüßchen darstellen, zur Hälfte eingesenkt. Das so entstehende Gebilde nennen wir bekanntlich „Erdbeere“. In ihr haben wir also wie in der Hagebutte eine Schein- und Sammelfrucht vor uns. Die scharlachroten, duftenden Beeren erscheinen für uns vielfach zwischen dem Lanbe versteckt; nicht so aber für die Vögel (Drosseln n. a.), die sich gern am Waldboden aufhalten und die Verbreitung der Pflanze besorgen. (Wie ist die Erdbeere im einzelnen dieser Verbreitung nangepaßt" ?) - Die Erdbeeren, die wir im Garten banen (Verwendung?), entstammen zumeist ausländischen Arten. Sie zeichnen sich durch besondere Größe aus, stehen aber an Duft und Wohlgeschmack ("Aroma") weit hinter den Walderdbeeren zurück, - An feuchten Waldstellen und besonders gern auf Waldblößen bildet die Himbeere (Rubus idéus) oft ausgedehnte liestände (Ansläufer!). Die Stämme sind dicht mit Stacheln besetzt (vgl. mit Rose), tragen erst im 2. Jahre Blüten und sterben nach der Fruchtreife ab. (Warum kommen die Blüten später als bei der Stachel- und Johannisbeere zum Vorschein?) Die Blätter sind wie bei der Salweide (s. das.) auf der Unterseite

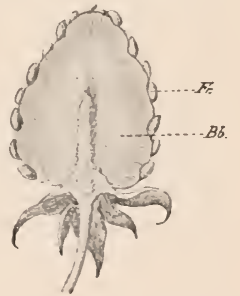

Schein- und Sammelfrucht der Erilbeere. Bb der fleischig gewordene Blütenboden. Fr.

Eine Einzelfrucht. weißfilzig. Aus jedem der zahlreichen Fruchtknoten, die auf dem stielförmig verlängerten Blütenboden stehen, bildet sich bei der Reife eine kleine Steinfrucht (s. Kirsche), Die Gesamtheit der Frïchtchen bildet die „Himbeere", die also eine Sammelfrucht ist (warum nicht auch eine Scheinfrucht?). Der wollschmeckenden Früchte wegen (Verbreitung 
durch Vögel!) zählt die Pflanze zu unseren wichtigsten Beerenobstarten. Sie gehört mit der Brombeere ( $R$. fraticósus), die von den Botanikern in zahlreiche, schwer zu unterscheidende Arten gespalten ist, zu derselben Gattung (weise dies aus dem Bau der Frucht nach!).

Im Gegensatz zu den besprochenen Pflanzen haben die folgenden Arten saft- und schmacklose Früchte. Daher werden sie auch nicht durch Vögel verbreitet. Dies sehen wir z. B. dentlich an den Fingerkriutern (Potentilla), deren Sammelfrüchte genau wie die der Erdbeere gebaut sind, aber vollkommen trocken bleiben. Von den zahlreichen Arten seien nur genannt: das gelbblühende Frïllings-F. (P. verna), das an trockenen Stellen wächst und zu unsern ersten Frühlingsblumen zählt, und das Gänse-F. (P. anserína), das sich häufig in der Nähe der Menschen findet (auf Gänseweiden - Name!) und zierlich gefiederte, unterseits silberweiße Blätter, sowie gleichfalls gelbe Blüten hat. - Eine unserer bekanntesten Pflanzen, die gemeine Nelkenwurz (Géum urbánum), wird wie die Möhre durch vorbeistreifende Tiere verbreitet. Dies geschieht vermittelst des Griffels, der nach dem Ver-

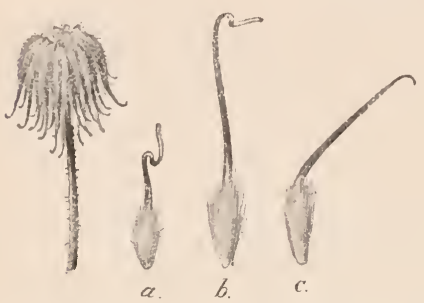

Fruchtstand und Einzelfrïchte der gemeinen Nelkenwurz.

Bezeichnungen sind im Texte erklärt. blühen weiter wächst und schließlich verholzt. Indem sich sein oberer Teil ablöst $(\mathrm{a}, \mathrm{b})$, gestaltet sich der untere zu einem kräftigen Haken um (c). Die Pflanze findet sich unter Gebüsch (große, zarte Blätter! beachte die Form der Fiederblättchen besonders an den herbstlichen Rosetten!). Die nelkenartig riechende Wurzel (Name!) wird vom Volke gegen allerlei Krankheiten angewendet $\left({ }_{n} \mathrm{Heil}\right.$ aller Welt $\left.{ }^{\mu}\right)$. - Ihre nächste Verwandte, die Bach-Nelkenwurz ( $G$. rivále), hat nickende Blüten (Bedeutung?). Da sie einen großen, abwärts geschlagenen Kelch besitzt, der die gelben Blumenblätter zum großen Teil verdeckt, so ist auch dieser farbig (rotbraun) entwickelt. Der obere Abschnitt des Griffels fällt bei der Fruchtreife nicht ab. Er dient vielmehr, da er mit langen Haaren dicht besetzt ist, der Verbreitung durch den Wind. - Der gelbblühende Odermeunig (Agrimónia eupatória), der sich häufig an Hecken und Wegrändern findet, häkelt seine Früchte gleichfalls Tieren an. Hier ist es der Blütenboden, der zahlreiche, widerhakige Stacheln trägt. - Mehrere Rosengewächse haben sehr kleine Blüten. Da letztere aber zu großen Blütenständen gehäuft sind, werden sie den Insekten doch auffällig. Das sehen wir z. B an den prächtigen Blütenstränßen der allbekannten SumpfSpierstaude oder des Mädesüiß (Ulmária pentapétala). Gleich zahlreichen anderen Gewächsen feuchter Standorte (Beispiele!) hat die stattliche Pflanze Blätter mit weiffilziger Unterseite (s. Salweide). - Unterseits helleres Laub hat auch der Wiesenlinopf (Sanguisórba officinális), der gleichfalls auf nassen Wiesen häufig vorkommt, und dessen sehr kleine, rotbraune Blüten za Köpfchen vereinigt sind (Name!). - Beim Frauenmantel (Alchemílla vulgáris) werden die unscheinbaren Blüten trotz der Häufung (für uns!) wenig aufällig. Am Morgen findet man im Grunde der Blätter, die einem ausgebreitetem Mantel nicht unähnlich sind (Name!), je eine große, glänzende Wasserperle, die aus den zusammengeflossenen Tautröpfchen entstanden ist ( Taubecher"). 


\section{Familie. Schmetterlingsblütler (Papilionáce:te).}

Pflanzen, die „Sehmetterlingsblüten“ besitzen (s. S. 105) und deren Frucht eine "Hülse“ ist $(\mathrm{s}, \mathrm{S}, 108)$.

\section{Die Gemiisebohne (Phaséolus vulgáris).}

1. Ieimat und Bedeutung. Die Gemïsebohne hat gleich der Feuerbohne (Ph. multiflórus), die meist als Sclılingpflanze an Lauben und dgl. gezogen wird, ihre Heimat im tropischen Amerika. Wie schon ihr Art-Name andeutet, ist sie eine wertvolle Gemüsepflanze: sowohl die griinen Frïchte, als auch die reifen Samen ("Bohnen") dienen uns als nahrhafte Speise. Wie von allen anderen wichtigen Nutzpflanzen hat man auch von ihr eine große Menge von Sorten gezogen (s. S. 19). Einige derselben, die Zwerg- oder Buschbolnen (Gegensatz: Kletter- oder Stangenbohnen), haben unter der zwingenden Hand des Menschen sogar eine wichtige Eigensehaft der Art, das Emporklettern an Stiitzen, abgelegt.

2. Same. Legen wir einige "Bohnen" (oder "Feuerbohnen") etwa 12 Stunden in das Wasser, so läßt sich die verschieden gefärbte, lederartige Hant, die Samenlıaut, von der die Bohnen rings umgeben sind, leicht abziehen. An der Stelle, an der die Bohnen zumeist etwas eingebuchtet sind, besitzt die Samenhaut einen matten Fleck, den sog. Nabel, d. i. die Stelle, an der die Bolinen durch je ein Stielchen an der Fruchtwand festsaßen. Nach Entfernung der Samenhaut erblicken wir 2 große, halbnierenförmige Körper, die Keimblätter (Kotyledonen - Zweikeimblättrige Pflanzen, Blattkeimer oder Dikotylen; s. dag. Roggen!). Beseitigen wir eins derselben, so sehen wir deutlich das zukünftige Pflänzchen: wir erblicken einen winzigen Stiel, aus dessen unterem Ende, dem WVürzelchen, die Wurzel der Pflanze hervorgeht, der in der Mitte die beiden großen Keimblätter und am oberen Ende eine Knospe trägt, an der die ersten Laubblitter bereits deutlich zu erkennen sind. Der Same der Bohne ist also die von der Samenhaut umschlossene Anlage oder der Kein der jungen Pflanze. Wenn wir bedenken, wie zart die einzelnen Keimteile sind, so wird uns die Bedentung der lederartigen Samenhaut als einer Schutzhülle wohl verständlich. Der zarteste Keimteil, die Knospe, ist wieder zwischen den derberen Keimblättern geborgen. - Um die weitere Entwicklung des Keims zum jungen Pflänzchen oder

3. die Keimung zu verfolgen, legen wir abermals einige Bohnen in das Wasser. Schon nach einiger Zeit liaben sie sich so voll Wasser gesogen, daß sie an Umfang und Gewicht (Beweis durch Wiegen!) stark zugenommen laben. Schließlich sprengt der sich immer mehr ausdehnende Keim die Samenhaut, und das Würzelchen kommt zum Vorschein.

Legen wir die Bohnen jetzt in lockere Gartenerde (oder gut durclifeuchtete Sägespäne), so sehen wir, wie die Wurzel abwärts in den Boden dringt und bald nach allen Seiten Nebenwurzeln ausschickt. Der Stengelteil unter den Keimblättern beginnt sodann stark in die Länge zu wachsen. Er krümmt sich 
hakenförmig, durchbricht den Boden und zieht - sich immer mehr streckend schließlich die nach unten gerichteten Keimblätter samt der Knospe, die sich unterdes stark vergrößert hat, aus der Erde hervor. Die Keimblätter tun sich jetzt auseinander; das Stengelstïck ïber ihnen wächst in die Länge und streckt sich gerade; das erste Blattpaar entfaltet sich; alle oberirdischen Teile ergrïnen: und die junge Pflanze steht fertig da. Während der Stengel kräftig weiter wächst und Blatt um Blatt treibt, verschrumpfen die Keimblätter nach und nach und fallen schließlich vom Stengel ab. (Bei der Feuerbohne, der Erbse und zahlreichen anderen zweikeimblättrigen Pflanzen bleiben die Keimblätter unter der Erde).

Diese Vorgänge geben uns mancherlei zu denken:

a) Legen wir Bohnen (oder irgend welche andere Samen) an einen trockenen Ort, so keimen sie niemals. Erst nachdem sie befeuchtet (in feuchte Erde gelegt) werden, geschieht dies. Warum versorgt aber die Mutterpflanze den Keimling nicht gleich mit dem zum Keimen notwendigen Wasser? Die Antwort auf diese Frage gibt uns leicht folgender Versuch: wir legen an einem kalten Wintertage einige trockene und einige aufgequollene Bohnen mehrere Stunden ins Freie. Bringen wir die Bohnen darauf in Blumentöpfe, die wir in das erwärmte Zimmer stellen, so werden die trockenen Samen bald, die aufgequollenen aber niemals keimen. Letztere sind durch die Kälte zerstört, sie sind erfroren. Dasselbe Schicksal hätten selbstverständlich auch die Samen, wenn sie das Wasser von der Mutterpflanze erhalten hätten. - Beide Versuche zeigen uns ferner, daß Wasser und Wärme es sind, welche die im Samen schlafende Pflanzenanlage erwecken.

b) Das Würzelchen kommt zuerst aus der Samenhaut hervor; denn die junge Pflanze muß bereits im Boden befestigt sein, wenn sie die Erde durchbricht. Da nun die Verlängerung des Würzelchens, die "Hauptwurzel", nach allen Seiten fast rechtwinklig abgehende Nebenwurzeln aussendet, so ist die Verankerung um so sicherer: der Wind kanu wehen, aus welcher Richtung er will, er wirft das Pfänzchen nicht um. (Denke, die Nebenwurzeln strahlten nur nach einer oder nach 2 oder 3 Seiten aus oder stiegen senkrecht in den Boden hinab! Vgl. mit einem Fahnenmaste, der durch Taue befestigt ist!)

Die Wurzel hat aber noch die zweite Aufgabe, dem Boden im Wasser gelöste Nährstoffe zu entnehmen, die in den grünen Blättern weiter verarbeitet werden (s. den letzten Absch. des Buches!). Da sich die Wurzel nun zuerst entwickelt, kann sie den Blättern auch sofort Nährstoffe zuführen, sobald sich die Blätter über den Boden erhoben haben und ergrünt sind. Und da von der Hauptwurzel nach allen Seiten Nebenwurzeln ausstrahlen, so vermag die Pflanze auch einer weit größeren Bodenmenge Wasser und Nährstoffe zu entziehen, als wenn die Nebenwurzeln mit der Hauptwurzel nach unten wüchsen.

c) Die Knospe ist ein ungemein zartes Gebilde. Wenn sie - ihrer Stel- 
lung entsprechend und wie später oberirdisch - beim Durchbrechen der Erde vorangehen würde, müßte sie unbedingt verletzt werden. Diese Arbeit ist daher dem weit festeren Stengel übertragen, der darum hakenartig gebogen ist. Hat er aber die Erde gespalten und die Keimblätter samt der zwischen ihnen geborgenen Knospe aus dem Boden hervorgezogen, so streckt er sich auch sofort gerade. (Welcher Stengelteil krümmt sich beim Keimen der Fenerbohne und Erbse?)

d) Alle Teile des Keimes sind, solange sie von der Samenhant umhüllt oder von Erde umgeben werden, vollkommen farblos. Die Teile der jungen Pflanze dagegen, die sich ïber den Boden erheben, ergrünen. Lassen wir aber Bolınen im Finstern keimen (in Blumentöpfen, die wir in einen Schrank stellen), so bleiben die oberirdischen Teile blaß. Stellen wir diese Pflanzen darauf ins Licht, so ergrünen sie alsbald. Das Licht bewirkt also das Ergrïnen der Pflanzen. (Andere Beispiele!)

e) Die wachsende Pflanze baut sich aus den Stoffen immer weiter auf, die in den grünen Blättern bereitet werden (s. den letzten Absch. des Buches!). Woher nimmt aber der Keim die zum Wachstnm nötigen Stoffe, da er ja noch keine solchen Blätter besitzt? Die Antwort auf diese Frage erhalten wir, wenn wir die Keimblätter genauer beobachten. Die anfangs festen, prallen Gebilde werden immer weicher und schlaffer, bis sie schließlich gänzlich verschrumpft vom Stengel abfallen: die wachsenden Teile haben sich auf Kosten der in den Keimblättern a ufgespeicherten Stoffe gebildet. Die Mutterpflanze gibt nämlich den Samen, auf daß sie die „ersten Ausgaben“ bestreiten können, Vorratsstoffe mit, die bei der Bohne (wie bei allen Schmetterlingsblütlern, den Kreuzblütlern ı. a.) in den Keimblättern eingelagert sind. (Bei zahlreichen anderen Pflanzen sind die Vorratsstoffe vom Keimlinge gesondert, also nicht in das Keimblatt oder die Keimblätter eingelagert; s. z. B. Roggen. Man nennt diese Masse „Eiweiß", weil sie der jungen Pflanze zum Aufban dient, wie das Eiweiß im Vogelei dem sich bildenden Tiere.) Läßt man Bohnen in Sägespänen oder besser (warum?) in ansgeglühtem Sande keimen, und begießt man die jungen Pflanzen nur mit destilliertem Wasser, so können sie dem Boden keine Nährstoffe entnehmen. Trotzdem wachsen sie aber zu beträchtlicher Höhe empor, ehe sie „an Hunger“ zu Grunde gehen: ein Zeichen, daß in den Keimblättern große Mengen von Vorratsstoffen enthalten sind. Lassen wir Samen der Erbse, Linse oder eines anderen Schmetterlingsblütlers ebenso keimen, so sehen wir dasselbe: eine Tatsache, die uns den großen Nährwert der "Hülsenfrüchte" hinreichend erklärt.

4. Stengel. a) Bei den Zwerg- oder Buschbohnen(s. Absch. 1) ist der Stengel so niedrig und kräftig, daß er sich selbst, sowie die ihm ansitzenden Blätter, Blïten und Früchte zu tragen vermag. Die Kiletter- und Stangenbohnen dagegen besitzen einen so langen und schwachen Stengel, daß sie wie der Weinstock (s. S. 61, 3) genötigt sind, andere Gegenstände als Stïtzen zu benutzen. Dieses Emporsteigen geschieht bei der Bohne aber in ganz anderer Weise als bei dieser 
Pflanze. Um es genau verfolgen zu können, lassen wir Samen in Blumentöpfen keimen nnd stecken neben jede junge Pflanze einen dünnen Stab in den Boden. Anfangs wächst der Stengel gerade empor; dann aber neigt sich die Stengelspitze zur Seite und beginnt langsam kreisende Bewegungen auszuführen. In etwa $1^{1}-2$ Stunden ist ein Umzug beendet. (Bestimme die Zeit an den Versuchspflanzen bei verschiedener Temperatur!) Der Stengel "sucht" wie die Ranke der Weinrebe eine Stiitze. Hat er sie gefunden, so wird er an der Berührungsstelle festgehalten. Da die Stengelspitze aber weiter kreist, so ist die Stiitze bald ein- oder mehrfach locker umwnden. Der Richtung der kreisenden Stengelspitze entsprechend verlaufen die Windungen fast wage recht und zwar in der entgegengesetzten Richtung, in der sich der Uhrzeiger bewegt. Man sagt daher: die Bohne ist linkswindend (vgl. dag. Hopfen).

Betupft man den Stengel in den wagerechten Windungen an beliebiger Stelle mit Tusche oder Tinte and merkt die Stelle an der Stïtze gleichfalls durch ein Zeichen an, so wird man bald finden, daß das Zeichen am Stengel über das am Stabe geriickt ist: ein Beweis, daß sich der Stengel in den wagerechten Windungen etwas emporgerichtet hat. Er hat nämlich wie jeder wachsende Stengel das Bestreben, sich gerade nach oben zu strecken. Was die Folge dieses Streckens ist, wird uns ein anderer Versuch lehren: wir winden einen Faden locker um einen Stab, halten das untere Fadenende fest und ziehen das andere krïftig nach oben; dann werden die Windungen des Fadens steiler, und der Faden legt sich fester um den Stab. So werden auch die Windnngen des sich streckenden Bohnenstengels immer steiler, und die Pflanze schlingt sich immer fester um die Stütze.

b) Als Hilfsmittel beim Festhalten dienen die kurzen, steifen Haare, mit denen der Stengel dicht besetzt ist (vgl. mit anderen windenden Pflanzen).

c) Erleichtert wird den Pflanzen das Winden um die Stïtze dadurch, daß die Blätter an dem kreisenden Stengelabschnitte auffallend klein sind ihn also nur unwesentlich beschweren (vgl. mit anderen windenden und mit nicht windenden Pflanzen, z. B. mit der Erbse!).

5. Blätter. a) Die beiden ersten Blätter, die am Stengel der jungen Bohnenpflanze entspringen, sind sehr groß und „einfach"; alle folgenden dagegen sind aus 3 Blättchen zusammengesetzt (dreizählige Blätter). Im Gegensatz za dem Endblättchen sind die beiden seitlichen ähnlich wie das Lindenblatt (s. S. 51) unsyminetrisch, und zwar findet sich die größere "Hälfte" auf der dem Endblättchen abgekehrten Seite. Wären die „Hälften“ gleich, so würden sich die Blättchen (ihre jetzige Größe und Stellung vorausgesetzt) zum Teil gegenseitig bedecken das wäre aber für die Pflanze durchaus ungünstig, wie wir bereits bei der Betrachtung des Lindenblattes gesehen haben.

Am Grunde des langen, gemeinsamen Blattstiels und der kurzen Stiele der Einzelblättchen finden sich winzige Nebenblättchen. Wenn man sieht, wie in der Gipfelknospe des Stengels die Nebenblätter des ganzen Blattes die zarten, noch zusammengefalteten Blättchen umhüllen, so wird man selbst diesen 
scheinbar wertlosen Gebilden jegliche Bedeutung fïr die Pflanze nicht absprechen könneu. (Vgl. mit der Knospe der Roßkastanie. - Bei anderen Schmetterlingsblütlern, z. B. bei Erbse und Wiesenklee, sind die Nebenblätter viel größer.)

b) Ani Tage sind die dreizähligen Blätter, wenn sie nicht direkt von den Sonnenstrahlen getroffen werden (im "zerstrenten" Lichte stehen), meist wagerecht ausgebreitet. Bei anbrechender Dunkelheit aber richtet sich der gemeinsame Blattstiel empor, so daß der Winkel, den er mit dem Stengel bildet, kleiner wird (stelle dies mit Hilfe des Transporteur's fest!), und die 3 Blättchen senken sich, so daß sie fast senkrecht herabhängen. Indem man diese Erscheinung mit dem Schlafe der Menschen und Tiere vergleicht, sagt man: die Blätter schlafen, Diese Stellung der Blätter bezeichnet man daher als Na ch t- oder Schlafs tellung. Am Iforgen senkt sich der Blattstiel, und die Blätchen richten sich wieder empor: das Blatt nimmt die Tagstellung ein. Diese regelmäßig sich wiederholenden Bewegungen erfolgen in dem angeschwollenen Grunde des gemeinsamen Blattsticls und in den gleichfalls verdickten Stielchen der Einzelblätter, in den sogen. Gelenken des Blattes.

Welche Bedentung hat diese seltsame Erscheinung? Wir wissen, daß die PHanze dem Boden Nährstoffe entnimmt, die, in Wasser gelöst, zu den 13lättern emporgehoben werden. Je mehr Wasser also von den Blättern verdunstet wird, desto mehr Nährstoffe miissen auch in die Blätter gelangen nnd hier verarbeitet werden. Jede Hemmung des Stroms ist für die Pflanze demnach ein Nachteil. Eine solche Hemmung tritt aber ein, wemn die Blätter stark betaut sind. Nun betanen aber - wie die Erfahrung lehrt - senkrecht gestellte Blätter viel weniger als wagerecht gestellte. Bei ersteren ist demnach am Morgen die Verdunstung nicht in dem Grade gehemon wie bei letzteren.

c) Werden die Pflanzen aber an warmen Tagen direkt von den Sonnenstrahlen getroffen, so kömnten sie leicht mehr Wasser verdunsten, als die Wurzeln aufzusaugen vermöchten. (Was wäre die Folge?) Dann drehen sich die Blättchen - besonders die beiden seitlichen - meist so, daß ihre Flächen senkrecht zu stehen kommen. Infolgedessen werden sie - wie wir S. 44 geselien haben - von den Sonnenstrahlen unter spitzerem Winkel getroffen, nicht so stark erwärmt und demnach auch weniger Wasser durch Verdunstung verliexen, als wenn sie die eigentliche Tagstellung innebehalten hätten.

6. Die Bliite ist bei den einzelnen Sorten von sehr verschiedener Färbung. Sie ist eine Schmetterlingsblite, die bis auf geringe Abweichungen (stelle sie fest!) ganz wie die der Erbse gebaut ist (s. das.). Ein Gleiches gilt auch von der Frucht.

2. Die Erbse (Pisum sativum).

1. Die Erbse, eine Nutzpfianze. Die Erbse entstammt den Mittelmeerländern and dient dem Menschen schon seit undenklichen Zeiten als wichtige Gemisepflanze. Wir verspeisen ihre reifen und halbreifen samen; von einigen 
der zahlreichen Sorten werden hier und da auch die noch weichschaligen Früchte ganz verzehrt.

2. Die Erbse, eine rankende Pflanze. a) Der hohe, vielfach verzweigte, hohle, schwache und saftige Stengel kann sich bei fortschreitendem Wachstum nicht aufrecht erhalten. Um

b) die Blätter dem Lichte und der Luft, sowie die Bliiten den Blicken der Insekten darzubieten, bedient sich die Pflanze wie der Weinstock (s. das.) der Hilfe von Ranken. Diese Gebilde finden sich an den Enden der gefiederten Blätter und umschlingen benachbarte Pflanzen oder Reiser, die wir dem schwachen Gewächs als Stïtze darbieten. Da sie an der Mittelrippe des Blattes genau wie die Fiederblättchen angeordnet sind (mitunter stehen sich sogar ein Fiederblättchen und eine Ranke gegenüber!), und da sich an Stelle des Endblättchens gleichfalls eine Ranke findet, so faßt man sie als Fiederblättchen auf, deren Blattfläche bis auf die Mittelrippe geschwunden ist. In Gegensatz zu den "Stengelranken" des Weinstocks sind die Ranken der Erbse (wie aller anderen Schmetterlingsblütler) also "Blattranken“.

Als Ersatz für die in Ranken umgewandelten Fiederblätter treten sehr große Nebenblätter anf, die den Stengel meist umfassen. Anfangs sind sie senkrecht gestellt und umgeben schützend die jungen Blätter, Zweige und Blüten; dann tun sie sich anseinander, bieten ihre ganze Fläche dem Sonnenlichte dar und verrichten die Arbeiten der eigentlichen Blätter. (Beachte die Faltung der jungen Blätter und den Wachsüberzug aller grünen Teile; vgl. mit Roßkastanie und Raps!)

3. Die Erbse, ein Stickstoffsammler. Zieht man eine kräftige Erbsenoder andere schmetterlingsblütige Pflanze (Bohne, Lupine und dgl.) ans dem Boden, so erblickt man an den Wurzeln zahlreiche Knöllchen sehr verschiedener Größe (bei der Lupine werden sie bis haselnußgroß), deren Wesen und Bedentung man erst in jüngerer Zeit erkannt hat: In jedem Krümchen Ackererde sind Tausende von Spaltpilzen (s. das.) vorhanden. Gewisse Formen dieser winzigen Lebewesen, die sog. Wurzelbakterien, haben die Gewohnheit, in die feinsten Wurzeln der Schmetterlingsblütler einzudringen, der "Wirtspflanze“ nährende Stoffe zu entziehen und sich stark zu vermehren. Ähnlich wie an dem Eichblatte, in das die Eichgallwespe ein Ei gelegt hat (s. "Lehrbuch der Zoologie"), infolge des Reizes eine Wucherung, eine Galle, entsteht, so entstelien hier durch den von den Spaltpilzen verursachten Reiz jene Knöllchen. Die Wurzelspaltpilze entnehmen der "Wirtspflanze" aber nicht sämtliche Stoffe, die zum Aufban ihres Körpers dienen. Sie besitzen nämlich die wunderbare Kraft, Stickstoff aus der atmosphärischen Luft aufzunehmen und in Stickstoffverbindungen (Eiweiß) überzuführen, eine Fähigkeit, die allen anderen Pflanzen abgeht. Nach einiger Zeit sterben die Spaltpilze $a b$, die Knöllchen verwesen, und die stickstoffhaltigen Verwesungsprodukte werden von der Pflanze aufgesogen. Unterdes haben sich wieder neue Knöllchen gebildet, die abermals zu Grunde gehen: so wird den schmetterlingsblütigen Pflanzen durch Vermitt- 
lung der Spaltpilze fortgesetzt Stickstoff der Luft zugeführt. Die Ptlanze hat also durch den Spaltpilz, den sie in den Knöllchen beherbergt und zum Teil ernährt, einen großen Vorteil. Beide, Pflanze und Spaltpilz, sind nehmend und gebend zu gleicher Zeit. Sie haben sich zu gegenseitigem Nutzen vergesellschaftet; sie bilden eine "Pfla nzengenossenschaft" und führen ein "Genossenschaftsleben" (Symbiose), ähnlich wie wir es zwischen gewissen Tieren, sowie zwischen einigen Tier- und Pflanzenformen fiuden (s. "Lehrbuch der Zoologie").

Die 'Tatsache der Stickstoffautnahme aus der atmosphärischen Luft hat ıun für die Landwirtschaft eine ganz außerordentliche Bedeutung. Mit jeder Ernte entnimmt der Landmann dem Felde eine große Menge stickstoff haltiger Verbindungen (beson ders in der Form ron Eiweiß.) Soll das Feld im nächsten Jahre wieder eine gute Ernte bringen, so muß er dem Acker neue Stickstoffverbindungen zufïhren. Dies geschieht bekanntlich durch Düngung mit tierischen Auswurfstoffen und verwesenden Pflanzenteilen. Bant der Landmann aber schmetterlingsblïtige Pflanzen, die er nicht aberntet, sondern unterpflïgt, so besorgen diese dureh Vermitt lung der Wurzelbakterien die Düngung des Bodens. Als der beste "Stickstoffsammler" hat sich die Lupine bewährt. Da sie eine sehr ,geniigsame" Pflanze ist, vermag der Land-

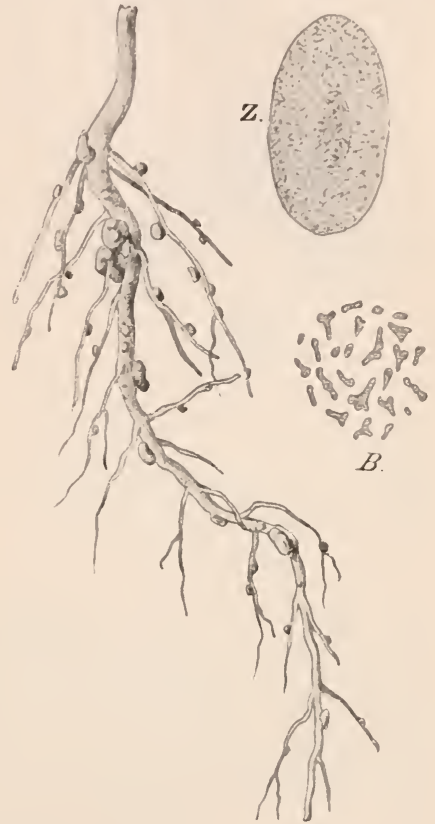

Wurzel der Erbse mit Wurzelknöllchen (nat. Gr.). Daneben: Z. Zelle aus einem Wurzelknöllchen, dicht mit Spaltpilzen erfüllt. (120 mal vergr.). B. Spaltpilze bei starker (etwa 800 maliger) Vergrößerung. mann mit ilser Hilfe selbst dem sandigsten Acker noch einen Ertrag abzuringen: er baut sie als Viehfutter oder pflügt sie als Dünger für ,anspruchsvollere" Gewächse (Getreide, Rüben u. s. w.) in den Boden. Finden sich in dem Ackerlande keine Wurzelbakterien, so vermögen die Hülsenfrïchte hier anch nicht ihre segensreiche Tätigkeit zu entfalten.

t. Die Erbse, ein Schmetterlingsbliitler. Die seitlich symmetrische Blüte (s. 30, a) hat einige Ähnlichkeit mit einem Schmetterlinge (Familienname!). 
Der becherförmige Kelch (der Kopf des Schmetterlings!) ist in 5 Zipfel ansgezogen, ein Zeichen, daß er durch Verwachsung ebenso vieler Blättchen entstanden ist. Die Blumenblätter sind meist sämtlich weiß gefärbt und unter sich an Größe und Gestalt sehr verschieden. Das obere, aufgerichtete Blatt wird als Fahne bezeichnet; die beiden seitlichen Blätter heißen Flügel,

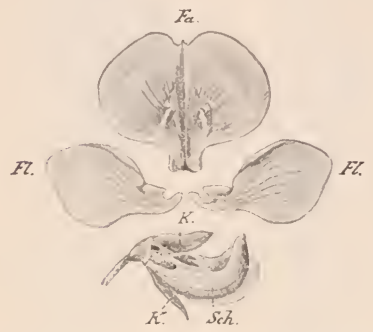

Blïte der Erbse, in die einzelnen Teile zerlegt (11/2 mal nat. Gr.). Fa. Fahne. Fl. Flügel. Sch. Schiffchen. K. Kelch, von dem der vordere Teil entfernt ist.

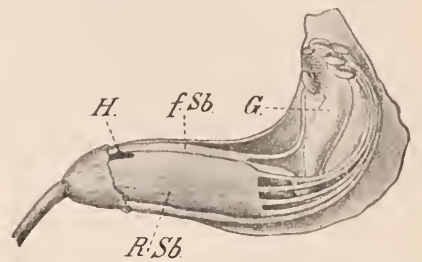

Schiffchen der Erbsenlliite, 3 mal nat. Gr. und durch Beseitigung der rechten Hälfte geöffnet. G. Griffel mit Narbe und Griffelbürste. RSb. die aus den 9 verwachsenen Staubblättern gebildete Röhre. (Von den Staubblättern sind nur $4 \mathrm{zu}$ sehen.) f.Sb. freies Staubblatt. H. Zugang zum Honig.

und die unteren sind zu einem kahnförmigen Gebilde, dem Schiffchen, verwachsen. Das Schiffchen umschließt schïtzend (Regen, Tau, Näscher!) den Stempel und die Stanbblätter. Der langgestreckte Fruchtknoten, über dessen Bau uns am besten die Frucht belehrt (s. das.), setzt sich in einen langen Griffel fort. Unter der Narbe am Griffelende findet sich ein einseitiger Haarbesatz, den man treffend als Griffelbiirste bezeichnet. Staubblätter sind 10 vorhanden. Die Fäden von 9 derselben sind miteinander zu

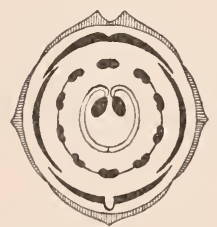

Blïtengrundriß der Erbse. einer oben offenen Röhre verwachsen, die den Fruchtknoten wie eine Scheide umschließt. Der Spalt zwischen den Rändern der Röhre wird von dem Faden des 10. (freien) Staubblattes bedeckt. Der Honig wird von der Innenseite der Staubblätter am Grunde der Röhre abg̨esondert.

Der verwickelte Blïtenban der Erbse, von dem wir in folgendem noch weitere Einzelheiten kennen lernen werden, ist (wie der Bliitenbau der Schmetterlingsblütler iiberhaupt) nur zu verstehen, wenn wir die Bestäubung genan verfolgen:

a) Wie bei allen "Insektenblïtlern" werden auch hier die Bestanber durch die bunten Blumenblätter angelockt. Und zwar ist es besonders die Fahne, welche die Bliite anffällig macht: sie ist groß, breit und senkrecht empor- 
gerichtet, ein wirkliches "Aushängeschild".

An liliten, die sich noch nicht geöffnet haben, umhïllt die Fahne die übrigen Teile wie eine schützende Decke; sie setzt also die Arbeit fort, die zuerst der Kelch verrichtete.

b) Die Flïgel, die das Schiffchen vollkommen überdecken, dienen dem saugenden Insekt als "Sitzbrett". Sie besitzen - von anderen Tnebenheiten abgesehen - da, wo sie sich zu verbreitern beginnen, eine tiefe, nach innen gerichtete Einbuchtung, die genau in eine entsprechende Vertiefung

c) des Schiffchens eingreift. Hierdurch werden Fahne und Schiffchen fest miteinander verbunden, gleichsam verankert. Iriickt man daher mit einem Stäbchen die Flügel etwas herab, so wird auch das Schiffchen nach unten bewegt. Dasselbe geschieht aber auch, wenn sich ein kräftiges Insekt auf den Flügeln niederlïßt, den Kopf in den Blïtengrund drängt und zu saugen beginnt. Sobald aber das Schiffchen herabgedriickt wird, tritt aus der Öffnung an seiner Spitze

d) der Griffel hervor. Zuerst berührt die Narbe die Unterseite des Insekts. Bringt das Tier vom Besuch einer anderen Erbsenbliite an jener Körperstelle bereits Blïtenstaub mit, so ist die Bestäubung vollzogen. Dann kommt auch die Griffelbürste mit dem Insekt in Berührung. Da nun die Bürste mit Blïtenstaub bedeckt ist, so kann es nicht ausbleiben, daß ein Teil desselben im Haarkleide des Tieres hängen bleibt. Vor Entfaltung der Blïte haben sich nämlich

e) die Beutel der Staubblätter bereits geöffnet und ihren Staub in den kegelförmigen Hohlraum der Schiffchenspitze entleert, so daß Narbe und Griffelbiirste damit bedeckt sind. (Daher ist auch Selbstbestäubung möglich; s. Absch. g. - Öffnet man Blïten, die sich noch im Knospenzustande befinden, so findet man die Beutel noch prall mit Staub gefüllt; in völlig entfalteten Bliiten dagegen sind sie leer und verschrumpft.) Fliegt das Insekt wieder von dannen, so bewegen sich Flügel und Schiffchen auch wieder aufwärts (warum?), und der Griffel kehrt in seine Schutzhïlle, das Schiffehen, zurück. Bei jedem folgenden Insektenbesuche fegt er stets von nenem Blïtenstaub aus dem Schiffchen hervor, bis der Vorrat schließlich erschöptt ist.

Da die Staubfäden miteinander ver wa ch sen sind, werden die Staubblätter in ganz bestimmter Lage gehalten, so daß sämtliche Bentel ihren Inhalt in den vorderen Abschnitt des Schiffehens entleeren mïssen. (Welche Bedeutung hat das Verwachsensein der Staubblätter bei den 3 anderen Arten der Bestäubung, die wir S. 109 bis 111 noch kennen lernen werden?)

f) Da sich der Ho nig im hintersten Teile der Stanbfadenrölure findet, dart die Röhre nicht völlig geschlossen sein. Das Insekt würde ja sonst nicht zu dem süßen Safte gelangen können! Dieser notwendige Zugang zum Honig ist nun dadurch geschaffen, daß ein Staubblatt — wie oben bemerkt - nicht mit in den Verband der anderen eintritt. Am Grunde dieses "freien" Stanbblattes finden sich rechts und links je eine Öffuung, die zu dem Honig tührt. (Eine gleiche Einrichtung treffen wir auch bei allen anderen honighaltigen 
Schmetterlingsblüten. Bei denjenigen Bliiten aber, die des Honigs entbehren - z. B. beim Besenginster, bei den Ginsterarten, bei Lupine und Hauhechel sind stets alle Staubblätter verwachsen; die Staubfadenröhre ist also geschlossen.)

g) Der "hinterste Winkel“ der Blüte ist auch der rechte Ort für den Honig. Diejenigen Insekten, die sich auf der Blüte nicht niederlassen, (Schwärmer), oder die zu schwach sind (Fliegen, Tagfalter, kleine Käfer u. a.), das Schiffchen niederzudrücken, wären unnïtze Näscher. Ihnen ist darum der Weg zum Honig versperrt. Nur die Bienen vermögen den Verschluß der Schmetterlingsblïte zu öffnen und eine Bestäubung zu vermitteln. Für diese mit mittellangem Rüssel ausgerüsteten Insekten liegt der Honig an jener Stelle aber gerade recht. Kurz, man kanu die Schmetterlingsblüte betrachten, wie man will: sie ist in allen Stïcken so recht eine „Bienenblume“. - Da bei der Erbse Flügel und Schiffchen sehr fest zusammenhalten, so kann hier der Verschluß nur durch kräftige Bienen geöffnet werden. Solche Bienenarten gibt es wohl in der Heimat der Pflanze; bei uns aber selten. Daher ist die Erbse in nördlicheren Gegenden zumeist auf Selbstbestäubung angewiesen. (Leicht nachzuweisen, indem man einige Bliiten mit Gaze umhüllt und somit den Insekten den Zutritt verwehrt.) - Manche Bienen suchen den Honig auch auf unrechtmäßige Weise durch Anbeißen der Blüte zu erlangen.

h) Soll eine Bestäubung wirklich herbeigeführt werden, so ist nötig, daß die einzelnen Blïtenteile ihre Lage zueinander genau innehalten. (Denke z. B. die "Terankerung“ zwischen Flïgel und Schiffchen wäre gelöst!) Es ist daher von Wichtigkeit, daß die 5 Blättchen, aus denen der Kelch besteltt, miteinander verwachsen sind. (Spalte den Kelch vorsichtig an mehreren Stellen und untersuche, ob der Verband der Blumenblätter nicht gelockert ist!)

i) Das Insekt vermag den notwendigen Druck auf das Schiffchen umso eher auszuïben, als die Blüte wagerecht gestellt ist. (Denke, sie wäre senkrecht auf- oder abwärts gerichtet! Beobachte daraufhin andere Schmetterlingsblütler! Wie stehen die Erbsenblüten vor dem Blühen? wie die Fruchtstiele?)

5. Die Erbse, ein Hiilsenfriichtler. Wie man an der reifenden Frucht (Fruchtknoten!) deutlich sehen kann, bestelit sie aus einem langen Blatte, das in der Nittelrippe derartig "geknifft" ist, daß die Ränder zusammenstoßen. An den Rändern sitzen in je einer Reihe die Samen, die sogen. Erbsen. Eine so gebildete Frucht nennt man "Hülse" (in einigen Gegenden ungenau "Schote"; s. Raps). - Bei der Reife spaltet sich das Fruchtblatt sowohl an der Verwachsungsstelle, wie an der Mittelrippe, so daß die Hülse mit 2 Klappen aufspringt. - Die „Haden“, die häufig die Samen zerstören, sind meist die Raupen des Erbsenwicklers (s. "Lehrbuch der Zoologie").

\section{Andere schmetterlingshliitler.}

Um vielfache Wiederholungen zu vermeiden, seien die Schmetterlingsblütler, denen wir noch kurz unsere Aufmerksamkeit schenken wollen, nach der besonderen Weise, in der bei ihnen die Bestäubung erfolgt, zusammengestellt. 
1. Blüten mit Bürsteneinrichtung (Griffelbürste wie bei Erbse nnd Belne). Als wichtige Futterkräuter banen wir die Saatwicke und die Pferle-oder saubohne (Vícia sativa und faba) an. Die großen, grünen Hülsen der letzteren werden hier und da wie die der Gemüsebohne verspeist. Die İlüten beider sind infolge greller Farbenzusammenstellungen besonders auffällig (Bedeutung?). - Von den zahlreiehen wildwachsenden Wickenarten seien nur die beiden häutigsten, die Vogel und Zauwicke (V. crícca und sépium), genannt. Erstere tritt auf Äckern oft als lästiges Unkrant (Ranken!) auf. Ihre präehtig blauen Blüten sind zu großen Trauben angeordnet, and ihre Samen werden besonders gern von der Feldtaube verzehrt (Name!). Letztere wäehst auf Wiesen, in Gebüsch und an Hecken (Name!). Thre Bliitenstände bestehen nur ans wenigen rötlich-violetten Blüten. Betrachtet man die Pflanze genauer, so findet man vielfach kaum ein Exemplar, das nicht von Ameisen bevölkert wäre. Die Tiere stellen, wie man sich leicht ïberzengen kann, dem sïßen Safte nach, der von braunen Honigdrïsen auf der Rückseite der Nebenblätter oft in großen, glänzenden Tropfen abgeschieden wird. Bisher fanden wir den Honig stets in der Blüte und erkannten in ihm eine Gegengabe der Pflanze an ihre Bestäuber. Warum scheidet aber die Zaunwicke gleich der Saatwicke, der Pferdebohne und mehreren anderen Wicken außerhalb der Blïte Honig ab? Ist das nicht eine zweeklose Verschwendung? Die Naturforscher, die sich diese Fragen lange vergeblich vorlegten, glauben jetzt eine Antwort darauf gefunden zu haben: die Ameisen sind den Forstleuten als eifrige Vertilger blattfressender Insekten and deren Larven (Raupen u. a.) längst bekannt. Die Pflanzen, die fleißig von Ameisen besucht werden, sind daher vor anderen, die nicht besucht werden, im Vorteil: sobald sich auf ihnen ein Verwïster ansiedelt, wird er meist alsbald eine Bente der bissigen Tiere. Die Ameisen sind daher für die Wicken gleichsam eine "Schutzgarde*, und der Honig das Anlockungsmittel derselben. - In der heißen Zone giebt es sehr viele soleher "Ameisenpflanzen*. Einige derselben liefern ihren Beschützern nicht nur Honig, sondern erzeugen sogar besondere Futterkörperehen und Wohnräume für sie.

Eine gleiehfalls sehr hänfige Pflanze unserer Wiesen ist die gelbblühende WiesenPlatterbse (Láthyrus praténsis). - Ihre nächste Verwandte, die rankenlose FriihlingsPlatterbse (L. vérnns), giebt sich durch die breiten, zarten Fiederblätter ohne weiteres als Waldpflanze zu erkennen (vgl. mit Windröschen). - Aus den Mittelmeerländern ist die Liuse (Lens esculénta) zu uns gekommen (Verwendung?). - Aus Nordamerika stammt die Robinie (Robinia psend-acácia), die fälschlich allgemein "Akazie genannt wird und wegen der zarten Fiederblätter ( ${ }$ Kngelakazien ${ }^{*}$ ) und der weißen, duftenden Blüten ein allbekannter Zierbaum geworden ist. Am Grunde der Blattstiele - ein Zeichen, daß wir es hier mit umgewandelten Nebenblättern zu thuı haben! - finden sich je 2 scharfe Stacheln, die wie eine Schntzwehr die Knospe und das junge Blatt umsehließen. Erreicht die Pflanze eine gewisse Höhe, so bilden sich keine Stacheln mehr (vgl. mit den Dornen des Birnbaums). Die Fiederblätter senken sich nachts herab; in den heißen Mitt agsstunden dagegen richten sie sich senkrecht empor, wäbrend sie in südlichen Ländern meist vom Morgen bis zum Abend in dieser Stellung verharren (Bedeutung? s. Bohne!). - Der Blaseustrauch (Colitea arboréscens), gleichfalls eine bekannte Parkpflanze, stammt ans Südeuropa. Die blasig aufgetriebene Hülse (Name!) dient als "Flugausrüstung" zur Verbreitung der kleinen Samen.

2. Blïten mit einfacher Klappvorriehtng.

Diese einfachste Weise der Bestänbung wollen wir am Wiesenklee (Trifólium paténse) kennen lernen (Taf. 1.1): Drücken wir das Schiffchen nieder (4.), so treten 
Stempel und Staubblätter lervor; hört der Druck auf, so kehren beide wieder in ihre Schutzhïlle zuriick (3.). Die roten, duftenden Blïten dieser unserer wichtigsten Futterpflanze sind wie bei allen anderen Kleearten verhältnismäßig klein. Da sie aber zu "Köpfchen" zusammengestellt sind, werden sie doch weithin sichtbar (Bedentung?). Die hinteren Teile der Blumenblätter sind sowohl unter sich, als auch mit den 9 unteren Staubfäden zu einer etwa $9 \mathrm{~mm}$ langen Röhre verschmolzen (3. und 4.). Daher sind die langrüsseligen Hummeln die ausschließlichen Bestäuber der Pflanze. Vielfach findet man die Blunenröhre von der kurzrïsseligen Erdhummel und der Honigbiene angebissen (3.), die beide also „Einbruch verüben". Da die Hülse von der vertrockneten Blumenkrone umhüllt bleibt, bietet sie dem Winde eine große Angriffstläche dar und kann somit leicht verweht werden (5. und 6.). Die dreizähligen Blätter („Kleeblatt") nehmen wie die Bohnenblitter abends Schlafstellung ein (2.), richten sich dabei aber (wie bei allen anderen Kleearten, sowie beim Stein-, Schnecken- und Hornklee, beim Goldregen, Ginster und zahlreichen anderen Schmetterlingsblütlern) senkrecht empor. Wie man in dieser Einrichtung ein Förderungsmittel der Verdunstung erkannt hat, so auch in den weißen Bändern, die sich ïber die Blattflächen hinwegziehen (1.). Da sich dunkle Gegenstände schneller abkühlen als helle (Versuch!), so werden weißgefleckte Blätter die Wärme auch eine längere Zeit zurückhalten als gleichmäßig grüne Blätter. Erstere werden daher bei Eintritt der nächtlichen Kühle noch längere Zeit stark verdunsten. Hiermit steht auch im Zusammenhange, daß man bei Kleepflanzen, die auf beschattetem oder feuchtem Grunde wachsen, breitere Bandzeichnungen findet als bei solchen auf sonnigem, trockenem Boden. Die Nebenblätter (2. und 7.) sind miteinander verwachsen und können daher die Aufgabe, als Schutzhülle der jungen Blätter zu dienen, vortrefflich erfïllen.

Von den zahlreichen anderen Kleearten sei nur noch der Weißklee (T. repens) erwähnt. Da er eine weit kürzere Blütenröhre besitzt als der Wiesenklee, so kann sein Honigreichtum anch von der Honigbiene ausgebentet werden. Die kriechende, sehr veränderliche Pflanze (vgl, mit Reilerschnabel u. a.!) hat daher für die Bienenzucht besondere Bedeutung. - Dasselbe gilt für die rotblühende Esparsette (Onóbrychis sativa), die gleichfalls eine wichtige Futterpflanze ist. - An Wegen und auf Wiesen findet sich häufig der Steinklee (Melilótus), dessen weiße oder gelbe, duftende Blüten in langen Trauben beieinander stehen. - Der Goldregen (Cýtisus labúrnum) ist wegen seiner prächtigen, goldgelben Blütentranben (Name!) ein allgemein beliebter, aber in allen Teilen giftiger Zierstranch. Die anfangs aufrechten Tranben werden später hängend, so daß bei der Entfaltung der Blüten die Fahne nach unten gerichtet sein würde. Der Blütenstiel macht daher eine Drehung und bringt die Bläte wieder in die "richtige" Lage (s. S. 108, i). Die Blüten sind scheinbar honiglos (s. S. 107, f), und freien Honig besitzen sie auch in der Tat nicht. Trotzdem sieht man an ihnen aber Insekten saugen. Die Tiere bohren nämlich das zarte Gewebe am Grunde der Fahne an und sangen den erbohrten Saft.

3. Blüten mit Schnell-Vorrichtung.

Drückt man in den Blüten des weit verbreiteten Besenginsters (Sarothámuus scopárius) die Fliigel nnd das Schiffchen nieder, so schnellen Staubblätter nnd Stempel, die in ihrer Hülle zum Teil wie gespannte Uhrfedern liegen, hervor und streuen den 


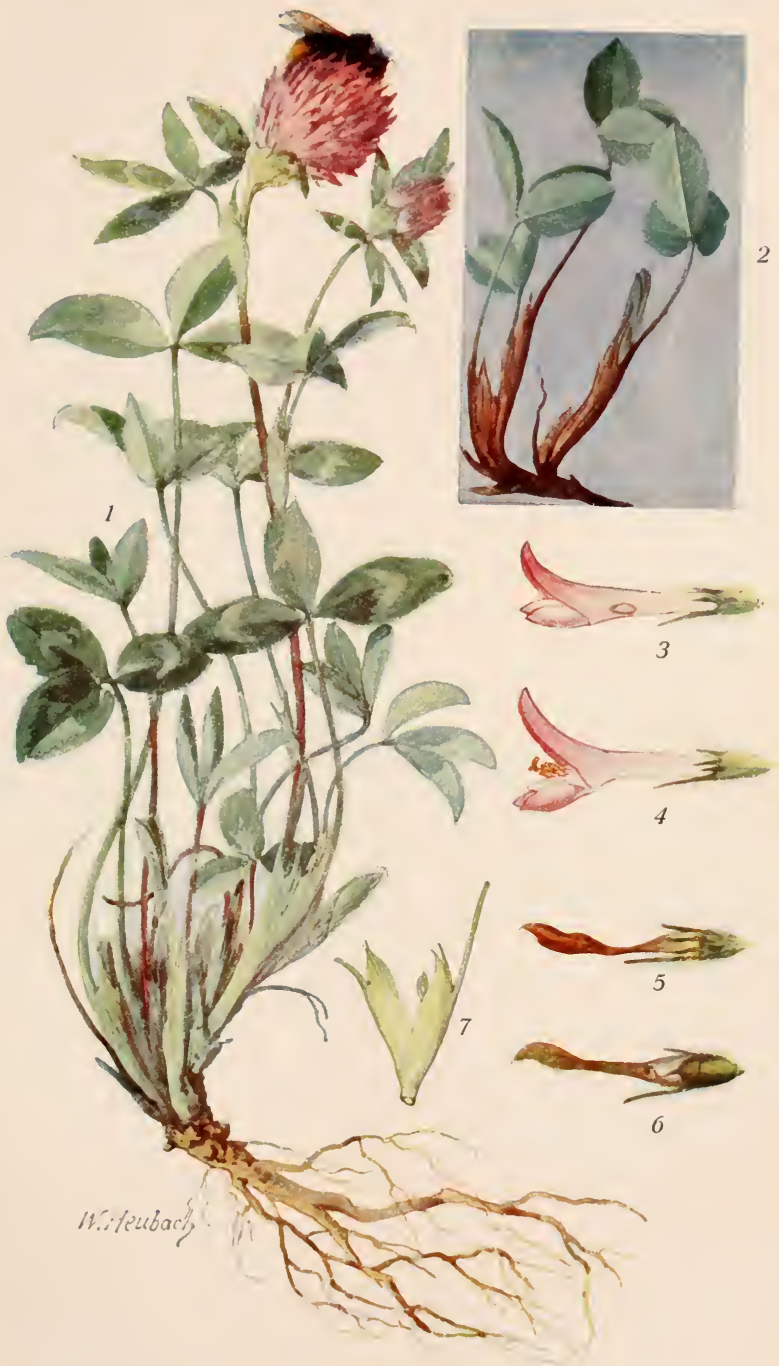

Wiesenklee (Trifolium pratense). 

Blütenstaub aus. Dasselbe geschieht natürlich auch, wenn eine Hummel oder Biene den „Verschluß" der Blüte öffnet. Hierbei wird das Tier mit Blütenstaub förmlich überschiittet. Flügel und Sehiffchen kehren darauf aber nicht wieder in ihre ursprüngliche Stellung zurück. Die prächtigen, gelben Blüten der Pflanze sind honiglos, dafür aber besitzen sie - der Art der Bestäubung entspreeliend - sehr viel und zwar mehlartig trockenen Blütenstaub. Da der mannshohe Strauch in sandigen WäIdern und an ähnlichen Orten gedeiht, besitzt er wie zahlreiche andere Ödlandpflanzen (Beispiele!) nur kleine Blätter. Als Ersatz dafür treften wir aber in der Rinde der kantigen, rutenförmigen Stengel, die zur Herstellung von Besen (Name!) benutzt werden, Blattgrün an. Die Ï̈̈lsen drehen sieh im Angenblicke des Öffnens schraubig zusammen, so daß die Samen fortgeschlendert werden. (Bedentung? Beobachte anch diese Erscheinung bei Platterbse, Hornklee und Lupine!) - Wie schon die Bezeichnung ,Ginster" andentet, ist die Pflanze mit den Ginsterarten (Genista) nahe verwandt. Die zum Teil dornigen Sträucher gedeihen an denselben Örtlichkeiten und besitzen daher gleichtalls sehr kleine Blätter und grüne Stengel. - Gleiche Blüteneinrichtung zeigen anch die zahlreichen kleeartigen Gewächse, die nach den schneckenartig (oder sichelartig) gewundenen Hülsen Schmeckenklee (Medicágo) genannt werden. Eine Art, die aus Südeuropa stammende, blaublühende Luzerne (M. sativa), wird als Futterpflanze im großen angebaut.

4. Blüten mit Pum pen-Einrichtung.

Diese Art der Bestäubung zeigt sehr deutlich der Horuklee (Lotus cornieulátus), der allenthalben auf Wiesen und Grasplätzen seine gelben, meist rötlich angehauchten Bläten entfaltet. Die Staubbentel entleeren wie bei der Erbse bereits in der Knospe ilhren Inhalt in den vorderen Abschnitt des Schiffchens, worauf sie verschrnmpfen. Fünf Stanbfäden dagegen wachsen mit der Blüte weiter und schwellen keulenförmig an. Wird nun das Schiffchen niedergedrückt, so pressen sie wie der Kolben einer Pumpe einen Teil des Staubes als bandartige Masse ans der Schifichenspitze hervor. Ist die Biene an der Bauchseite mit dem klebrigen Staube beladen, so kelıren die Blütenteile wieder in ihre ursprüngliche Lage zarück. - Ganz ähnlich erfolgt die Bestäubung bei der Lupine (Lupinus duteus), die aus Südeuropa stanımt, und deren Bedeutung für die Landwirtschaft bereits früher kurz gekennzeichnet worden ist; desgleichen bei den Hanlechelarten (Onónis), jenen allbekannten, zum Teil stark dornigen Pflanzen, die an Wegrändern and älnlichen Orten wachsen.

Von den zahlreichen a usländischen
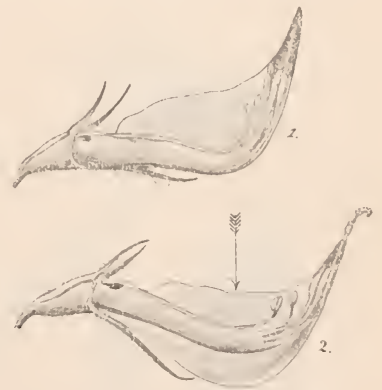

Schiffehen ans der Bliite des Hornklees. 1. In der Ruhe; 2 herabgedrückt. Der von oben wirkende Druck ist durch einen Pfeil angedeutet. Die einzelnen Blütenteile wie bei der Erbsenblüte.

Schmetterlingsblütlern scien kurz fol-

gende erwähnt: Das Sïßhol\% (Glycyrrhiza glabra) ist ein Straueh der Mittelmeerländer, der aber auch in einigen Gegenden von Mitteleuropa angebaut wird. Der eingedickte Saft der süßschmeckenden Wurzeln (Name?) ist als Lakritze allgemein bekannt. - Die Indigopflanzen (Indigófera) sind Sträncher und Kräuter der Tropen, aus 
deren Blättern man den Indigo gewinnt. Man bringt die abgeschnittenen Pflanzen zu diesem Zwecke in Bassins, die mit Wasser gefüllt sind. Nachdem das Wasser eine gränliche Färbung angenommen hat, leitet man es in ein zweites Bassin und bringt es durch Räder and Schaufeln mit dem Sauerstoff der Luft in innige Berührung. Infolgedessen geht die grünliche Färbung bald in eine blaue über: es ist der Indigo entstanden, der sich, weil im Wasser unlöslich, bald als tiefblauer Schlamm absetzt. Dieser für die Zeugfärberei überaus wichtige Farbstoff wird jetzt auch künstlich hergestellt.

Verwandte der Schmetterlingsblütler: In den Ländern um das Mittelmeer wächst der Johannisbrotbaum (Ceratónia síliqua), dessen große Hülsen bei uns fast nur als Leckerei für Kinder, in der Heimat der Pflanze dagegen als Nahrung für Menschen und Vieh dienen. - - In Gewächshäusern trifft man oft merkwürdige Pflanzen, die von ihrer Empfindlichkeit gegen Berührung den bezeichnenden Namen Simupflanzen (Mimósa) erhalten haben. - Die Steppengegenden der heißen Zone sind die Heimat der Akazien (Acácia), von denen besonders afrikanische Arten das wertvolle Gummi arabicum liefern (Verwendung?). Es sind Bäume und Sträucher, die mit unserer Robinie (s. das.) große Ähnlichkeit haben. Gleich dieser Pflanze besitzen sie die Fähigkeit, die Fiederblättchen senkrecht zu stellen, eine Tatsache, deren Wichtigkeit wir ermessen können, wenn wir an die große Trockenheit ihres Wohngebiets denken. Wir finden bei ihnen auch wie bei den Eukalyptusarten (s. das.) winzige Blütenhüllen, aber zahlreiche, freistehende and buntgefärbte Staubblätter. 


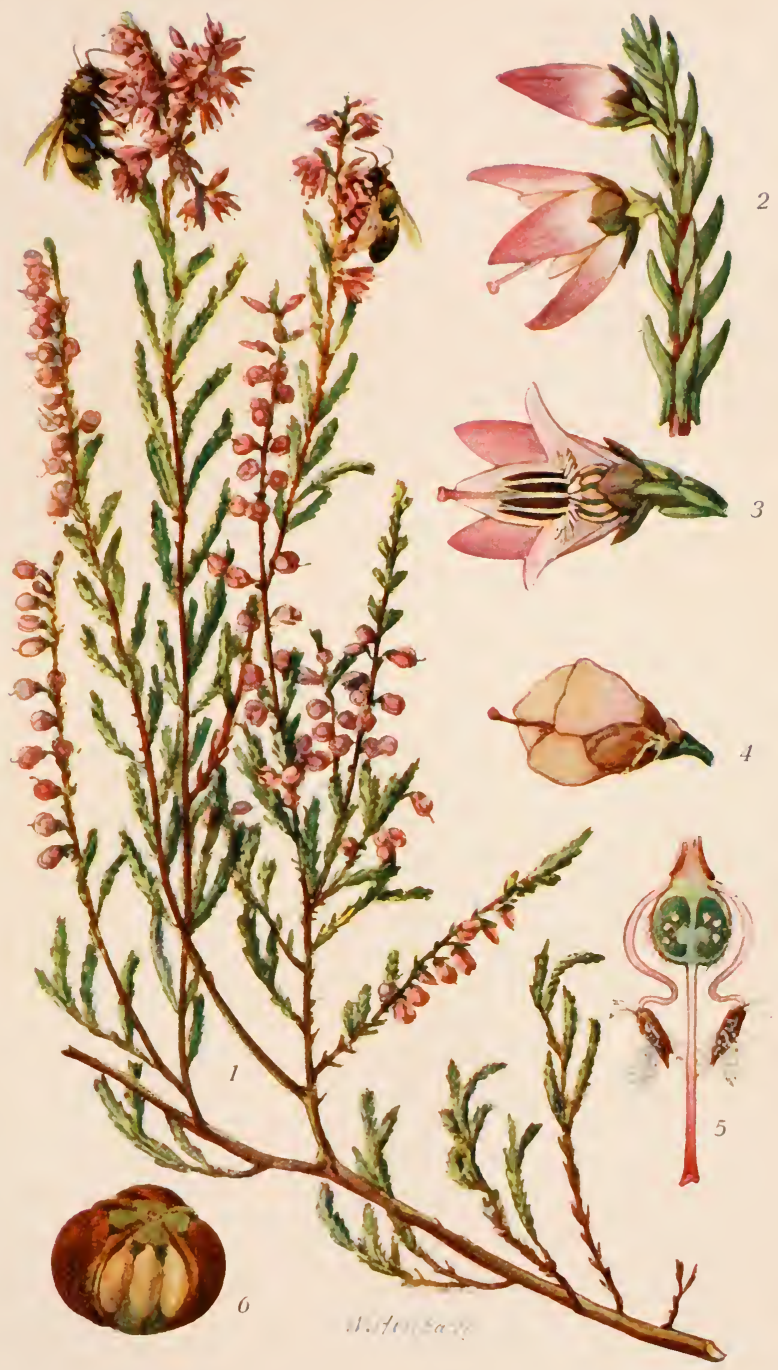

Heidekraut (Calluna vulgaris). 



\section{Unterklasse. Verwachsenblumenblät1rige l'flanzen (Sympétalae).}

Pflanzen mit doppelter Blïtenhülle (mit Kelch and Blumenkrone), bei denen die Blumenblätter (wenigstens am Grunde) miteinander verwachsen sind.

\section{Familie. Heidekraut-Gewächse (Ericáceae).}

1. Unterfamilie, Eigentliche Heidekräuter (Ericeae).

Das Heidekraut (Callúna vulgáris). Taf. 15.

A. Verbreitung. Auf trockenem Sandboden, wie auf schwankendem Torfmoor, auf sonniger Ebene, wie im Schntze des Kiefernwaldes, auf niedrigem Hügel, wie auf sturmumbranster Höhe findet sich das anspruchslose Heidekrant. Es ist iiber ganz Europa und dariber hinaus verbreitet und bildet stets kleinere oder größere Bestände. In Norddentschland besonders bedeckt es zahlreiche, oft viele Quadratmeilen große Gebiete, „Heiden" genannt, von denen auch die Pflanze ihren Namen erhalten hat. (Gib die Verbreitung der Heiden genaner an!) Soweit das Ange reicht, erblickt man dort fast nichts weiter als Heidekraut. Nur hier und da wird das Einerlei unterbrochen von einer verkrïppelten Kiefer, von Wacholder- und Ginsterbïschen, von Weidengestrïpp, das sich nur wenig iiber den Boden erhebt, von stechenden Gräsern, von Flechten- und Moospolstern, vom gelbblühenden Mauerpfeffer und duftenden Thymian, von Preißelbeere und Johanniskrant oder von anderen „Heidepflanzen". Das "gesellige" Heidekraut aber ist stets das "herrschende" Gewächs. Hieraus ergibt sich auch die

B. Bedleutung, welche die Pflanze für den Menschen hat. Kurz gesagt, sie macht jene öden, unfruchtbaren Gegenden erst bewohnbar. Wenn die sengenden Strahlen der Sommersonne die Heide fast ansgedörrt haben, brennt der Heidebauer den Pflanzenwuchs auf einem Teile seines Besitztums nieder („Höhenranch!“.) In den Boden, der durch die untergepflïgte Asche einige Fruchtbarkeit gewonnen hat, sät er im nächsten Frühjahre dann das "Heidekorn", den Buchweizen, dessen mehlreiche Samen das Hanptnahrungsmittel der Heidebewohner bilden. Die jungen Triebe des Heidekrantes liefern ferner ein dürftiges Futter für Rinder und Schafe (Heidschnneken der Lüneburger Heide!), und wenn sich im Spätsommer die Heide mit Millionen honigreicher Blïten wie mit einem "rosenroten Schimmer" ïberzieht, dann finden endlich die Bienen der Banern einen reichgedeckten Tisch. (Daher in Heidegegenden zuneist starke Bienenzucht.) Heidekraut strent der Heidebewohner anch dem Vieh in die ställe und dann als nährenden Dünger auf den sandigen Acker; mit Heidekrant deckt er das Dach seiner Hütte, und mit Heidetorf erwärmt er im Winter die ärmliche Wohnung.

Dieser Torf verdankt gleichfalls der unscheinbaren Pflanze seine Entstehung: Zwischen den dïnnen, stark verzweigten Wurzehn, die nahe der Erd- 
oberfläche liegen, sowie zwischen den Stämmen und Zweigen, die sich dem Boden vielfach eng anschmiegen, sammeln sich allerlei Pflanzenreste, so daß bald ein dichter Filz entsteht. Sterben die Wurzeln und unteren Stengelteile ab, und wächst die Pflanze auf diesen Resten dann weiter, so wird der „Filz" immer mehr von der Luft abgeschlossen. Was die Folge dieses Luftabschlnsses ist, lehrt ein einfacher Versuch: Erhitzt man Sägespäne in einer Retorte, so verkohlen sie wie das Holz in dem Kohlenmeiler. Durch den Luftabschluß geht nämlich die Zersetzung der Holzteile (d. i. Verbrennung im chemischen Sinne) nur unvollständig vor sich. Es wird infolgedessen Kohlenstoff angehänft, oder kurz, es entsteht "Holzkohle". So geht auch die Zersetzung der Pflanzenreste unter der lebenden Heidekrantdecke nur unvollkommen vor sich: es erfolgt gleichfalls eine Anhäufung von Kohlenstoff und zwar in der Form von (Heide-) Torf, der eben wegen seines Reichtnms an Kohlenstoff ein wertvolles Brennmaterial liefert. (Vgl. mit Moostorf; s. Moose.)

C. Trockenlandpflanze. So verschieden anch der Boden ist, auf dem das Heidekrant wächst, eins zeichnet ihn stets aus: die anffallend große Trockenheit. Wie aber oben erwähnt, gedeiht die Pflanze anch auf Torfboden, der sich oft wie ein Schwamm voll Wasser saugt. Einen solchen Boden kann man aber doch unmöglich als trocken bezeichnen wollen, und doch ist er es - für die Pflanze! Dieser Widerspruch klärt sich leicht auf, wenn man sich folgendes klar macht: Setzt man z. B. einen feuchten Körperteil etwa die schweißbedeckte Stirn - der Luft aus, so kühlt er sich bald stark ab; denn überall da, wo Wasser verdunstet, wird Wärme verbrancht (andere Beispiele!). Nasse Erde gibt nun sehr viel Wasser in Dampfform an die Luft $a b$; dies zeigen z. B. die Nebel, die von fenchten Wiesen, aus Mooren u. dgl. emporsteigen. Durch die Verdunstung dieses Wassers wird also dem Boden viel Wärme entzogen: nasser Boden ist darum kalter Boden. Da wir nun aus der Betrachtung des Kirschbaums (s. S. 91) wissen, daß kalter Boden ebenso auf die Pflanzen einwirkt wie trockener Boden, so ist jener Widerspruch vollkommen gelöst: Wir können daher das Heidekraut mit Recht für eine Trockenlandpflanze erklären.

Trockenheit des Bodens ist für eine Pflanze aber stets sehr ungünstig (warum?). Das Heidekrant besitzt daher besondere Einrichtnngen, die ihm eine Existenz unter diesen nngünstigen Umständen erlauben:

1. Alle seine Teile sind auffallend dürr und trocken, geben daher an die umgebende Luft auch nur wenig Wasser in Dampfform ab. (Die Sumpfdotterblume und zahlreiche Pflanzen trockener Standorte haben aber dicke, fleischige Stengel nnd Blätter, ein Zeichen, daß die Natur mit verschiedenen Mitteln dasselbe erreicht.)

2. Das Heidekraut ist ein Straucl, der - wie bereits oben bemerkt in dichten Beständen auftritt und sich

3. meist nur wenig über den Boden erhebt. Infolgedessen wird er wie wir dies schon beim Manerpfeffer gesehen haben - auch weit weniger unter 
den austrocknenden Winden zu leiden haben, als wenn jede Pflanze einzeln stände und sich hoch über die Erde erhöbe. Es kann uns daher auch nicht wunder nehmen, wenn das Heidekrant auf stürmischem Bergesrücken oft nur handhoch wird, im Schutze von Kiefernschonungen dagegen eine Höhe von $1 / 2 \mathrm{~m}$ und mehr erreicht.

4. Das wichtigste Mittel gegen zu starke Verdunstung ist aber wie beim Mauerpfeffer in dem eigentümlichen Bau der Blätter (2.) zu erblicken. Es sind dies

a) sehr kleine Gebilde (s. S. 78, 3 a), die in 4 Längsreihen an den Zweigen stehen und hinten in 2 Spitzen ausgezogen sind (besonders deutlich an den Blättern zu sehen, aus deren Achseln junge Zweige hervorgehen).

b) Da sie ungestielt und an der den Zweigen zugekehrten (Ober-) Seite so gebogen sind, daß sie wie a usgehöhlt erscheinen, vermögen sie sich den Zweigen eng anzuschmiegen und $\mathrm{z}$. T. gegenseitig zu decken (s. S. 78, 3 b). - An Ptlanzen dagegen, die im Schatten des windstillen Kiefernwaldes wachsen, findet man meist weit größere und rechtwinkelig von den Zweigen abstehende Blätter. Da diese Pflanzen wegen der geringen Besonnung zudem keine Blüten tragen, sehen sie dem Heidekraut nur noch wenig ähnlich.

c) Stellt man durch ein Blatt dünne Querschnitte her, so sieht man die Ränder nach der Unterseite zu so umgebogen, daß sie zusammenstoßen. Ein solches

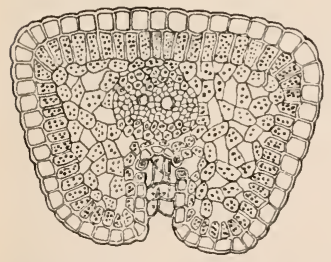

Querschnitt aus dem Blatte des Heidekrautes $(250 \mathrm{mal}$ vergr.). In dem, windstillen

Raume" 2 Spaltöffnungen "Rollblatt" bietet der Luft nur die Fläche der Oberseite dar, wird darum auch weit weniger Wasser verdunsten, als wenn esansgebreitetwäre.

Bei Anwendung mikroskopischer Vergrößerung sieht man weiter, daß das Blatt nur auf der Unterseite Spaltöffnungen besitzt, und daß der $\mathrm{Zu}$ gang zu ihnen durch haar-

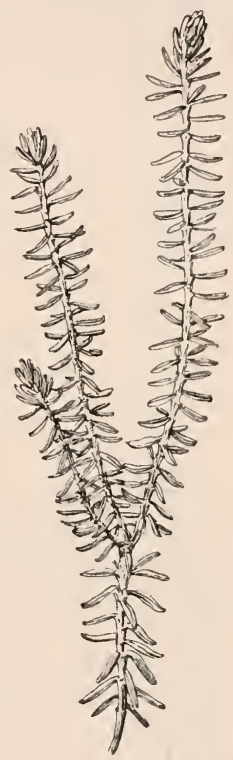

,Scliattenform" des

Heidekrantes ans einem Kiefernhochwalde (nat. Gr.).

artige Bildungen versperrt ist. Die Spaltöffnungen, durch die besonders der Wasserdampf aus der Pflanze entweicht, münden hier also nicht direkt ins Freie, sondern in einen fast geschlossenen, "windstillen Raum": eine Einrichtung, durch welche die Verdunstung gleichfalls stark herabgesetzt wird.

Wie schon mehrfach erwähnt, steigen die von der Wurzel aufgesngenen Nährstoffe in einem Wasserstrome zu den Blättern empor, woselbst eine Ver- 
dunstung des Wassers erfolgt. Jede Unterbrechung dieses Stromes ist für die Pflanze daher von Nachteil. Eine solche würde aber eintreten, wenn Tauoder Regentropfen die Spaltöffnungen verschlössen. Da nun bei den Blättern des Heidekrantes die Feuchtigkeit nicht bis zu den Spaltöffunngen vordringen kann, so gibt sich das Rollblatt auch als ein Mittel zn erkennen, die Bahn für den Wasserdampf frei zu halten. Wenn wir weiter bedenken, daß die Moore regenreiche Örtlichkeiten sind, daß es auf ihnen fast allnächtlich stark taut, und daß ihnen selbst an klaren Sommerabenden dichte Nebel entsteigen, so werden wir die Bedeutung dieser Einrichtung für die hier wachsenden Heidekrantsträucher wohl ermessen. Für diese Pflanzen ist es auch von großer Wichtigkeit, daß sie

d) immergrïne Blätter besitzen: Auf dem kalten Moorboden zieht der Frïhling später ein als in den umliegenden Feldern und Wäldern. Wollte das Heidekraut jetzt erst Blätter treiben, so könnte es in den wenigen Monaten, die zwischen diesem Zeitpunkte und dem Herbste liegen, unmöglich Blïten bilden und Früchte zur Reife bringen. Vermöge der immergrünen Blätter dagegen ist es beim Eintritt des Frïhlings s of ort imstande, die Arbeit aufzunehmen, und selbst während der kälteren und kalten Jahreszeit vermag es jeden Sonnenblick auszuniitzen.

Für das Heidekrant, das auf trockenen Stellen wächst, sind solche Blätter gleichfalls von Torteil. Dort erwärnt sich der Boden im Hochsommer anßerordentlich stark und wird so trocken, daß er zu Staub zerfällt. Da heißt es fïr das Heidekraut, mit der geringen Wassermenge, die es der Erde entuehmen kann, sparsam umzugehen. Je weniger aber - wie oben bemerkt - die Pflanzen Wasser aufsaugen, desto weniger Nährstoff nehmen sie auch auf. Dafïil dehnen sich aber beim Heidekraut, weil es eben immergrüne Bliitter besitzt, dic Arbeiten der Nährstoffaufnahme und -verarbeitung iiber einen viel größeren Teil des Jahres ans als z. B. bei den Bäımen und Sträuchern, die im Herbst das Lanb abwerfen.

D. Blïte. 1. Im August verschwindet das Grün der Blätter fast vor dem zarten Rosenrot der Blïten (2. und 3.). Die 4 kleinen Blumenblätter, die in der unteren Hälfte miteinander verwachsen sind, werden von den 4 größeren Kelchblättern fast verdeckt. Das ist für die Pflanze aber ein großer Nachteil (warum?), der darum wieder ausgeglichen werden muß. Dies geschieht dadurch, daß der Kelch gleichfalls bunt gefärbt ist. Die Stelle des Kelches wird wieder durch 2 Blattpaare ausgefüllt, die sich von den gewöhnlichen Laubblättern durch beträchtlichere Größe und meist anch durch einen Anflug von Buntfärbung unterscheiden.

Aus der Blïtenmitte ragt der Griffel mit der Narbe hervor (3). Er ist von den Beuteln der $\times$ Staubblätter umgeben, die zusammen einen kleinen, braunroten Kegel bilden und sich an der Spitze mit je 2 Löchern öffnen. Jeder Staubbeutel besitzt am Grunde 2 Anhüngsel, die den Weg zum Honig im Blïtengrunde versperren und daher von dem sangenden Insekt be- 
rïhrt werden mïssen. Sobald dies aber geschieht, werden auch die Staubbeutel erschïttert, so daß aus ihnen der Blütenstaub wie aus einer Streusandbiichse auf das Insekt herabrieselt (5.). Stößt dis mit Blütenstaub beladene Tier beim Besuche einer zweiten Blïte an die im Bliiteneingange stehende Narbe, so hat es die von der Pflanze "gewïnschte" Fremdbestäubung vollzogen. Mit dieser Art der Bestäubung hängt es innig zusammen, daß das Heidekraut im Gegensatz zu den meisten anderen "Insektenblïtlern" trockenen Blïtenstaub besitzt, und daß die Staubfaden eine schwancnhalsartige Krïmmung zeigen. Infolge dieser Einrichtung werden die Staubfäden nämlich zu federnden Gebilden, so daß die von ihnen getragenen Staubbentel bereits bei der geringsten Erschïterung ins Schwanken geraten.

2. Obgleich die Blüten verhältnismäßig klein sind, ist das blühende Heidekraut doch weithin sichtbar, so daß es sich eines außerordentlich regen Besuchs zu erfreuen hat:

a) Jeder Zweig der Pflanze trägt zahlreiche Blit ten, die sämtlich nach einer Seite gerichtet sind.

b) Das Heidekraut wächst - wie oben erwähnt in mehr oder weniger großen Beständen, so daß die blïhende Pflanze schon auf eine größere Entfernung hin sichtbar wird.

c) Die Blïten werden - im Gegensatz zu denen der meisten anderen Pflanzen - nach dem Verblühen nicht unscheinbar (1. und 4.). Ein Besuch dieser Blïten wäre fïr das Heidekrant aber nicht allein vollständig wertlos, sonder'n sogar von Nachteil; denn die Insekten wïrden - so za sagen - damit die kostbare Zeit nur vertrödeln. Durch Einwärtskrümmen der (etwas verblaßten) Kelchblätter wird daher der Eingang zum Blïteninnern verschlossen, so daß die Insekten genötigt sind, nur den geöffneten Blïten zu dienen. - Im Schutze des Kelches reift auch die

E. Frucht. Sie ist eine kleine Kapsel, die zur Zeit der Reife mit 4 Klappen (Fruchtblätter!) aufspringt, so daß der Wind die winzigen Samen leicht verstremen kann (6.).

\section{Andere Heidekrant-Gewiichse.}

Von den $n$ ä ehsten Verwandten des Heidekrauts sei nur die Glocken-Heide (Erica tétralix) erwähnt, die auf Torfund Moorboden gedeiht (daher auch Sumpf-H.). Thre immergrünen Blätter sind nur an den Rändern zurückgerollt, dafür aber sind sie wie alle jungen (diesjährigen) Teile mit Ausnahme der Blumenkrone dicht von kurzen einfachen, sowie von langen Drüsenhaaren (s. S. 33) bedeckt. Am Ende der Stengel stehen wie zierliehe Glöekchen (Name!) die fleischfarbigen Blüten in einem

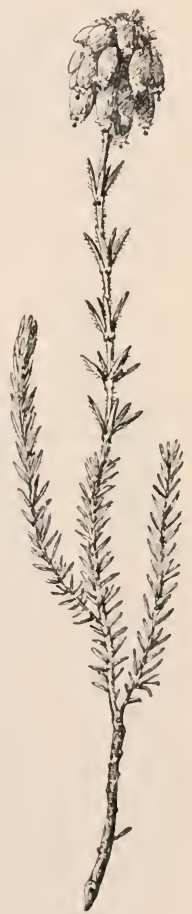

Glocken-Heisle (nat. Gr.) 
Büschel. - Die zahlreichen Heidearten, die bei uns als Topfpflanzen gezogen werden, entstammen zumeist dem trockenen Kaplande.

2. Unterfamilie. Heidelbeergewä chse (Vaccinieae). In lichten Wäldern, aber auch auf Heiden (Name!) und Mooren bedeckt die Heidelbeere (Vaccininm myrtillus) den Boden oft auf weite Strecken. Gegen die Trockenheit des Standorts ist sie durch die starke Oberhant der Blätter, die infolgedessen lederartig hart erscheinen, im Winter aber abfallen, wohl geschützt (s. S. 75). Zudem leitet die Pflanze - wie folgender einfache Versuch zeigt - fast jeden Regentropfen, der sie trifft, zur Hauptwurzel herab. Taucht man einen abgeschnittenen Heidelbeerstrauch in das Wasser und hält ihn sodann senkrecht frei hin, so wird man bemerken, dab - von wenigen Tropfen abgesehen - das Wasser in einem starken Strome am Stamme abläuft: Die schräg stehenden, rinnigen Blätter leiten es über den kurzen, gleichfalls rinnenförmigen Blattstiel zu dem Zweige, dem sie ansitzen; in einer tiefen Furche, die sich von Blatt zu Blatt zieht, flieBt es an diesem

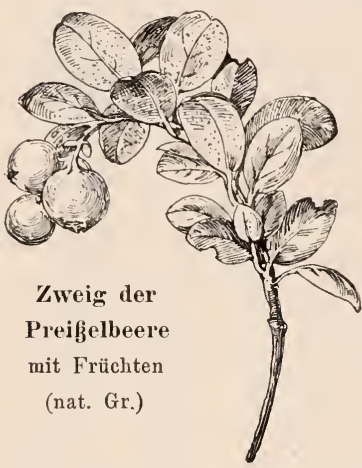
hinab und sammelt sich von sämtlichen Zweigen am Hauptstamme, der es schlieBlich der Wurzel zuführt. Die rot angehauchten Blüten, die denen des Heidekrauts sehr ähnlich gebaut sind (Beweis!), gleichen hängenden Glöckchen (Schutz des Blütenstaubes gegen Befeuchtung!). Die blanschwarzen Früchte („Blaubeeren“) dienen dem Menschen als willkommene Speise, so daß das Sammeln der wohlschmeckenden Beeren für viele Gegenden eine wichtige Erwerbsquelle bildet. Bestimmt jedoch sind die Früchte, die sich von dem herbstlich roten Laube scharf abheben, für die Verbreiter der Pflanze, für Drosseln und andere Waldvögel (s. S. 64, 8). Die Preifelbeere (V. vitis idéa) teilt mit der Heidelbeere Bedeutung (Beweis!) und Standort. Vielfach überdeckt sie jedoch auch Bergrücken. Ferner besitzt sie im Gegensatz zu jener Pflanze immergrünes Laub, aus dem die roten Beeren prächtig hervorleuchten (Bedeutung?). - Letzteres gilt auch für die zierliche Moosbeere (V. oxycóccus), deren schwache Stämme besonders zwischen Torfmoos dahinkriechen.

3. Unterfamilie. Wintergrüngewächse (Piróleae). Im Moder des Waldbodens wurzeln die zahlreichen Arten des Wintergrïns (Pirola). Die zierlichen Pflanzen besitzen zarte, nickende Blüten (verfolge die interessante Bestäubung!) und immergrüne Blätter (Name), die dementsprechend von lederartiger Beschaffenheit sind. In der Gesellschaft der Wintergrünarten findet sich zumeist auch der nahe verwandte, seltsame Fichtenspargel (Monótropa hypópitys). Da er kein Blattgrün besitzt, erscheint er in allen Teilen blaB, wachsgelb, so daB die jungen Triebe hervorbrechenden Spargelsprossen nicht unähnlich sind (Name!). Infolgedessen vermag er einerseits selbst im dunkelsten Waldesdickicht zu gedeihen, das von allen grünen Pflanzen gemieden wird, ist aber andererseits auch genötigt, wie z. B. die Hopfenseide (s. das.) seine Nahrung in nfertiger Form" aufzunehmen. Gräbt man jedoch nach, so findet man, daß der korallenförmige, brüchige Wurzelstock der Wurzel anderer Pflanzen nicht aufsitzt. Dagegen zeigt das Mikroskop, daß er mit Pilzfäden, die den Waldboden durchwuchern, in innigster Verbindung steht: ihnen entzieht der Fichtenspargel alle zum Aufbau seines Körpers 
notwendigen Stoffe. Wir haben es hier also mit einer Blütenpflanze zu thun, die auf Pilzen schmarotzt, ein Fall, der in der heimischen Natur einzig dasteht. Der saftige Stengel des seltsamen Gewächses, der schuppenförmige, aufrechtstehendo Blätter trägt, ist zur Blütezeit am oberen Ende abwärts geneigt, so daß die Blüten nach unten gerichtet sind (Bedeutung?) Da sich die blasse Pflanze von dem dunklen Waldboden genügend ablıebt, so wird uns ancli ler Mangel einer leuchtenden Blütenfarbe verständlich. Nach erfolgter Bestäubung richtet sich der stengel empor und streckt sich (besonders in dem blütentragenden Abschnitte) stark in die Länge. Dadurch werden die Fruchtkapseln nicht allein senkrecht gestellt (warum nötig?), sondern auch höher über den Boden gehoben, so $d a b$ dem Winde leichter Gelegenheit gegeben ist, die staubförmigen Samen aus den sich öffnenden Kapseln zu blasen. Diese Ausstreuungsweise setzt aber einen widerstandsfähigen Stengel voraus; daher wird der anfangs saftige und brüchige Stengel nach der Bestäubung hart, steif und elastisch.

4. Unterfamilie. Alpenrosengewächse (Rhodóreae). Eine herrliche Zier der Alpenberge bilden die vielbesangenen Alpenrosen (Rhododéndron), die mit ihren prächtigen Blüten oft weite Flächen mit leuchtendem Rot äberkleiden. Vermöge der außerordentlich biegsamen Zweige, die sich dem Boden dicht anschmiegen, können die Sträucher den Druck der mächtigen Schneemassen, die alljährlich monatelang auf ihnen lasten, wohl ertragen. Und da sie (wie Heidekraut, Preißelbeere u. a.) immergrüne Blätter besitzen, deren Spaltöffnungen infolge besonderer Einrichtungen gegen Verschluß durch Feuchtigkeit geschützt sind, können sie selbst unter den außerordentlich ungünstigen Verhältnissen leben, die auf den Alpenbergen herrschen (kurzer Sommer, in dem die Früchte nicht einmal reifen; regenreiche Orte; selbst im Sommer oft in Wolken gehüllt und allnächtlich mit Tan oder Reif beschlagen). - Zahlreiche ausländische Alpenrosen zählen gleich den farbenprächtigen Azaleen (Azálea) zu unseren beliebtesten Topfpflanzen.
Fichtenspargel.

1. blähende Pflanze mit Wurzelstock und jüngeren Trieben.

2. oberirdischer Teil des stengels z. Z. der Fruchtreife. Der Wind bläst die samen aus den Kajseln.

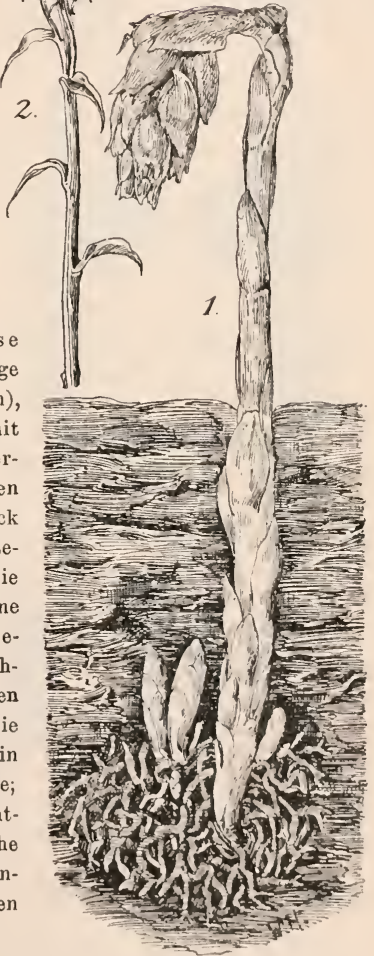




\section{Familie. Schlüsselblumen-Gewächse (Primuláceae).}

Alle Bliitenteile 5-zählig. Fruchtknoten 1-fächerig mit mittelständigem Samenträger und einfachem Griffel. Frucht eine Kapsel.

Die duftende Sclıliisselblume (Prímula officinális).*). Taf. 16.

A. Eine Friihlingspflanze. Wenn die Schlüsselblume draußen auf der Wiese oder im Walde wieder blüht, so ist der Frühling endlich da. Die freundliche Blume ist gleichsam der Schlïssel, der den Himmel des Frühlings mit all' seiner Herrlichkeit öffnet. Daher wird sie anch treffend Schlïsselblume oder Himmelschlïsselchen genannt. "Primel" heißt sie, weil sie ein Erstling unter den Blumen ist (primula ist die Verkleinerung von prima, die erste).

Gleich zahlreichen anderen Pflanzen (Beispiele!) vermag die Schlïsselblume so früh im Jahre zu erscheinen; denn sie ist

1. eine a usdauerude Pflanze, die während des Vorjahres in dem

2. unterirdischen Stamme oder Wurzelstocke (1.) reichlich Baustoffe aufgespeichert hat. Es ist dies ein kurzes, dickes, mit zahlreichen Wurzeln und Blattresten besetztes Gebilde, das sich in jedem Jahre am oberen Ende um ein Stïck verlängert und am entgegengesetzten Ende allmählich abstirbt (s. S. 29, 2). Aus den Vorratsstoffen bestreitet die Pflanze die ersten Ausgaben zur Bildung der Blïten und

3. Blätter. Die jungen Blätter (2. und 3.) stehen senkrecht, und ihre Flïchen, die an den Blattstielen als Sänme herablaufen, sind nach der Unterseite zu beiderseits eingerollt: Eigentümlichkeiten, in denen wir bereits Schutzmittel gegen das Vertrocknen kennen gelernt haben (s. Roßkastanie und Veilchen).

Eine gleiche Bedeutung hat auch die Runzelung der Blattfläche. Wollen wir Wäsche trocknen, so legen wir sie nicht etwa zusammengeknittert an irgend einen Ort, sondern hängen sie auf, d. h. wir setzen sie vollkommen ausgebreitet den Somenstrahlen und der bewegten Luft ans; denn ein feuchter Körper verliert umso mehr Wasser durch Verdunstung, je mehr er von der Sonne beschienen (erwärmt) und von bewegter Luft umspült wird. Da ein germueltes Blatt den Sommenstrahleu und dem Winde nun eine geringere Fläche darbietet als ein gleich großes, aber vollkommen ausgebreitetes, so wird es unter denselben Verhältnissen anch weniger Wasser verdunsten als dieses.

Größer geworden breiten sich die eiförmigen Blattflächen immer mehr aus, die Runzelung verschwindet und die Blätter ordnen sich - je nach der Höhe der umgebenden Pflanzen - zu einer mehr oder weniger deutlichen Rosette (vgl. mit Reiherschnabel, Wegerich und Löwenzahn!).

B. Von der Blüte. 1. Blïtenstand. Aus der Mitte der Blattrosette erhebt sich ein blattloser Stengel (ein sog. Schaft), der am Ende eine Dolde

*) An feuchteren Stellen wächst die ganz ähnliche hohe Schlüsselblume (8. w. u.), die an Stelle der betrachteten Art treten kanı. 


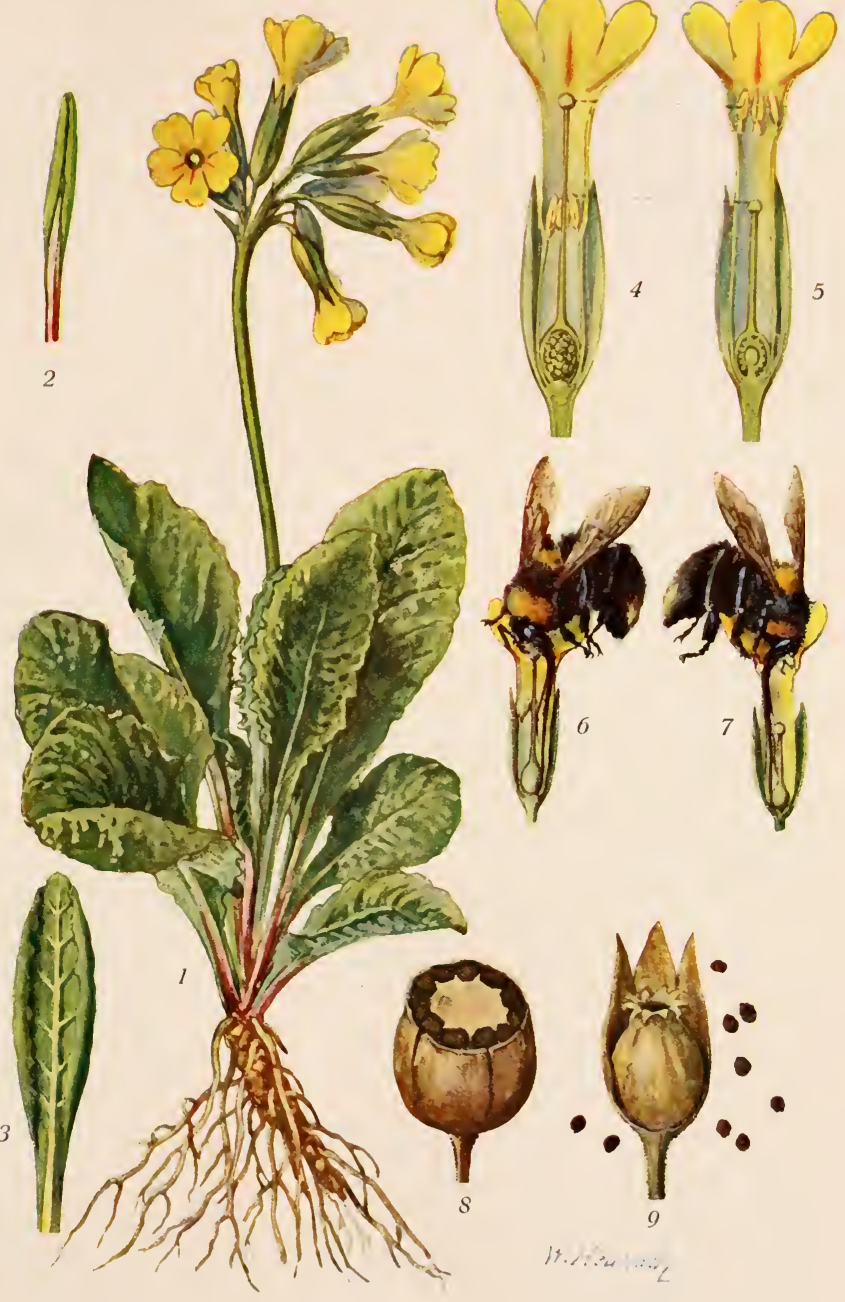

Duftende Schlüsselblume (Primula officinalis). 

(s. S. 71) gestielter Blïten trägt. Die Blïten entspringen aus den Achseln winziger Blättehen und sind meist seitwäts orler schräg alwärts geneigt, so daß Blïtenstaub und Honig gegen Regen geschützt sind.

2. Einzelblüte (4.-7.). Der röhrenförmige Kelch endet in 5 Zipfel. In der jungen Bliitenanlage waren diese 5 Zipfel zuerst vorhanden; später wurden sie von einem röhrenfürmigen Walle emporgehoben, der sich am oberen Ende des Bliitenstiels, auf dem sog. Bliitenboden, bildete, so daß ler Keleh in seiner jetzigen Form entstand. In derselben Weise bildete sich auch die dottergelbe Blumenkrone. (Solche Gebilde bezeichnet man kurz, aber ungenau als "verwaehsenblattrig". "Verwaehsenblumenblättrige Pflanzen"!) sie lat die Form einer langen Rölıre, die sieh oben glockenförmig erweitert und in 5 Zipfel gespalten ist. Dureh eine kleine, bald in der Mitte, bald im oberen Teile der Röhre liegende Erweiterung ist den $5 \mathrm{Stanbblittern,} \mathrm{die} \mathrm{der} \mathrm{Innen-}$ wand der Röhre zu entspringen scheinen, Platz gesehaffen. Da wir nun wissen (s. Seerose und edle Rose), daß die Staubblitter Blattgebilde sind, die stets aus einem Stengel hervorgehen, so können sie an der Blütenröhre anch nieht ihre Entstehung haben. Sie bildeten sich - wie dies von allen Staubblattern gilt - auch in der 'Tat auf dem Blïtenboden, wurden aber von dem rölnren-

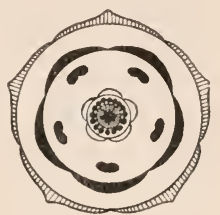

Bliitenerumbrig drer sihliisselblume. förmigen Absehnitte der Blumenkrone mit emporgetragen, so daß sie dieser eingefügt erscheinen. Der Stempel besteht aus einem kugeligen Fruchtknoten (s. Absch. C), an dessen Grunde der Honig abgesondert wird. einem mehr oder minder langen Griffel und einer knopfförmigen Narbe.

3. Bestäubung. a) Die Bestäuber werden durch den Duft und die leuchtende Färbung der Blïten angelockt. Auf der Innenseite des gloekenförmigen Abschnittes der Blumenkrone finden sich 5 orangefarbene Streifen, die sich nach dem Eingange zur Blïtenröhre hinziehen. Ähnliche Zeichnumgen finden sich bei zahlreichen anderen Bliiten (Beispiele!). Ob sie aber wirklich den Insekten den Weg zum Honig zeigen, wie vielfach angenommen wird, un ol) sie daher mit Recht als "Honig-oder Saftmale" bezeichnet werden, ist eine kaum zu entscheidende Frage (warum?).

b) Tha der Honig am Grunde einer langen, engen Blütenröhre abgeschieden wird, sind auch nur die langriisseligen Hummeln und Falter imstande, bis zu ihm vorzudringen (vgl. mit Stein-Nelke).

c) In den Weg, der zum Honig führt, sind die Staubblätter und die Narbe gestellt. Sie mïssen daher beim Saugen gestreift werden. Die Insekten. denen der Honig zugängig ist, sind infolgedessen anch die Bestäuber der Ptlanze. Damit sie sich mit Blütenstaub beladen, öffnen sieh die Staubbeutel nach innen.

d) Wie bereits oben erwälnt, sind in den einzelnen Bliiten die Griffel von verschiedener Länge und die Staubblätter in verschiedener Höhe der Bliitenröhre eingefügt. In diesen Verhältnissen herscht nun nicht etwa der Zufall, 
sondern eine bestimmte Gesetzmäßigkeit: Neben solchen Pflanzen, deren sämtlicbe Blïten lange Griffel besitzen, und bei denen die Staubblätter in der Mitte der Blumenröhre eingefügt sind (4. und 6.), trifft man andere, bei denen die Griffel kurz sind, die Staubblätter dagegen am oberen Ende der Blütenröhre stehen (5. und 7.). Man unterscheidet daher eine langgriffelige und eine kurzgriffelige Form der Schlüsselblume.

Um die Folgen dieser "Verschiedengrifflichkeit" (Heterostylie) zu erkennen, brauchen wir nur ein Insekt, z. B. eine Hummel, auf dem Fluge von Blüte zu Blüte etwas genaner zu verfolgen. Sangt die Hnmmel zuerst an einer langgriffeligen Blïte (6.), so mnß sie mit dem Kopfe die gerade im Eingang zur Blütenröhre stehende Narbe, mit der Mitte des Rüssels dagegen die Staubbentel berühren und sich daselbst mit Blütenstaub behaften. Hält die Hummel darauf bei einer kurzgriffeligen Blüte Einkehr (7.), so berührt sie hier umgekehrt mit dem Kopfe die Staubblätter, mit der Rüsselmitte dagegen die Narbe. Da sie nun von der ersten Pflanze an derselben Rüsselstelle Bliitenstaub mitgebracht hat, so muß sie eine Bestäubung der 2. Blïte herbeiführen. Fliegt darauf die Hummel, am Kopfe mit Blütenstaub beladen, wieder zu einer langgriffeligen Bliite (6.), so muß sie diese gleichfalls bestäuben: kurz, sie wird bei fortgesetztem Besuche der Schlüsselblume den Stanb von der langgriffeligen Form zur kurzgriffeligen und umgekehrt tragen und damit eine Fremd- (Wechsel-) Bestäubung beider Formen herbeiführen (in der Abb. 4. und 5. durch punktierte Linien angedeutet).

Welche Bedeutung hat nun diese seltsame Einrichtung? Naturforscher haben durch sorgfältige Versuche die Antwort auf diese Frage gefunden: brachten sie Blïtenstanb anf die Narbe derselben Blütenform (führe dies näher aus!), so entwickelten sich nur wenige Samen, aus denen (ausgesät) schwächliche Pflanzen hervorgingen; ahmten sie aber die Tätigkeit der Insekten nach, d. h. brachten sie Staub der langgriffeligen Form auf die Narbe der kurzgriffeligen und umgekehrt, so bildeten sich zahlreiche Samen, aus denen sich kräftige Pflanzen entwickelten. Die Verschiedengrifflichkeit ist also eines jener mannigfaltigen Mittel (gib andere an!), deren sich die Natur bedient, die für die Samenbildung günstige Fremd- (Wechsel-) Bestäubung herbeizuführen. (Warum ist bei den Bliiten der Schlüsselblume Selbstbestäubung nicht völlig ausgeschlossen? Wann kann sie leicht bei der langgriffeligen Form, wann bei der kurzgriffeligen eintreten?)

Daß Fremd- (Wechsel-) Bestäubung der von der Natur "gewollte“ Vorgang ist, geht auch noch aus einer anderen interessanten Tatsache hervor: Wie das Mikroskop zeigt, ist der Blïtensta ub der langgriffeligen Form kleiner als der der kurzgriffeligen; umgekehrt aber hat die Narbe der ersteren Form größere Rauhigkeiten (Narbenhaare) als die der letzteren. Wenn man einerseits bedenkt, daß die kleinen Staubkörner nur einen verhältnismäßig kurzen, die großen dagegen einen langen Keimschlauch bis zu den Samenanlagen im Fruchtknoten zu treiben haben (s. den letzten Absch. des Buches), so wird 
man es wohl verstehen, daß ilhnen die Natur anch eine verschiedene Menge von Baustoff für diese Schläuche gegeben hat. Und wenn man andererseits erwägt, daß die Narbenranhigkeiten der langgriffeligen For'm große Staubkörner, die der kurzgriffeligen dagegen kleine Körner festzuhalten haben, so wird man auch die Bedeutung dieser Verschiedenheit leicht einsehen.

C. Von der Frucht. 1. I)ie Frucht (Fruchtknoten) ist eine Kapsel (8.), deren Wand aus 5 Frnchtblättern gebildet ist. Durchschneidet man sie senkrecht (5.), so sieht man, daß der verlängerte Fruchtstiel in den Hohlraum ragt, daselbst kngelig angeschwollen ist und zahlreiche Samen trägt.

2. Im Schutze des Kelches, der hart und derb wird, reift die Frucht heran. Schließlich öffnet sie sich an der Spitze mit 10 Zähnen und überläßt es dem Winde, die Samen auszustrenen (9.).
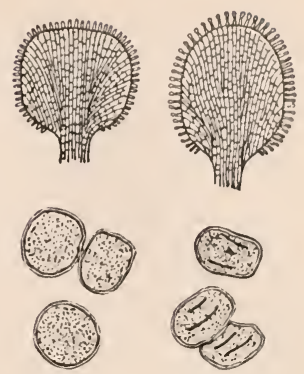

kgF

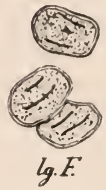

Narben und Bliitenstaub der Schliisselblume: kg. F. von der kurzgriffeligen, lg. F, von der langgriffeligen Form. (Narben etwa 20 mal, Blütenstaub 300 mal vergr.) Damit letzteres mit Erfolg geschehen kann, haben sich die Blüten- (Frucht-) Stiele bereits nach dem Verblïhen senkrecht emporgerichtet (was würde geschehen, wenn sie ihre ursprüngliche Stellung beibehielten?), und sie sowohl, als auch der Schaft sind zu festen, elastischen Gebilden herangereift: der Fruchtstand ist also eine Schleuder einfachster Ait geworden (vgl. mit Klatschmohn). Die nach oben geöffneten Fruchtkapseln schließen sich bei Eintritt feuchter Witterung, indem sich die Zähne einwärts krümmen (vgl. mit Stein-Nelke). Die kleinen Samen haben gleich denen des Klatschmohns (s. das.) eine rauhe Oberfläche.

\section{Andere Schlïsselblumen-(iewiichse.}

Mit der duftenden Schlüsselblume stimmt die hohe Sch. (P. elátior) in allen Stücken überein. Sie wächst jedoch auf fenchterem Grunde, ist etwas größer als jene und besitzt geruchlose, schwefelgelbe Blüten, deren Blumenkronen im vorderen Abschnitte flach ausgebreitet sind. Von ihr stammt die buntblütige Garten-Primel ab. Die dickblättrige Garten-Aurikel, die in einer noch viel größeren Anzahl von Farbenspielarten gezogen wird, ist der Abkömmling eines Bastards (s. S. 97), der durch Krenzung zweier Alpen-Primeln entstanden ist. - Eine allgemein bekannte Topfpflanze ist die chinesische Primel (P. sinénsis). - Über den Spiegel stehender Gewässer hebt die Wasserfeder (Hottónia palústris) ihre weißen, oft rosenrot angehauchten Bläten empor, die za weithin sichtbaren Trauben gehänft und wie die erwähnten Schlüsselblumen-Arten „verschieden-grifflig“ sind. Da die prächtige Pflanze unter denselben $\mathrm{Be}$ dingungen wie der Wasser-Hahnenfuß (s. S. 5) wächst, so finden wir bei ihr auch einen schwachen Stengel mit großen Lufträumen und tiefzerteilte Blätter (Name!). Sobald die kalte Jahreszeit eintritt, sinkt das zarte Gewächs in die frostfreie Tiefe; versiegt 
das Wohngewässer, so bildet es eine Landform mit kurzen Stengelgliedern und steiferen Blättern. - Unter der Saat und auf Brachäckern wächst, der Vogelmiere sehr ähnlich ( „rote Miere"), der Ackergauchheil (Anagállis arvénsis). Seine kleinen, meist ziegelroten Blüten schließen sich nachts und werden zugleich nickend (Bedeutung?). Die Frucht ist eine zierliche, kugelförmige Kapsel, deren obere Hälfte sich bei der Reife wie ein Deckel ablöst. - Auf feuchten Wiesen, in Straßengräben und an ähnlichen Orten entfaltet das Pfennigkraut (Lysimcichia nummulária) seine grolen, gelben Blüten. Die Blätter stehen sich zu je 2 gegenüber, und je 2 aufeinander folgende Paare bilden ein Kreuz. Da nun der schwache Stengel dem Boden (zumeist) dicht aufliegt, so müßte stets eines von je 4 Blättern abwärts gerichtet sein. Das ist jedoch nicht der Fall. Das betreffende Stengelglied macht nämlich eine halbe Drehung um seine Längsachse, so daß anch dieses Blatt emporgehoben wird. Übrigens stellen sich anch alle Blattstiele senkrecht zum liegenden Stengel, und die rundlichen Blattflächen (Name!) sind wagerecht gelagert: alles Einrichtungen, die eine möglichst vollkommene Ausnützung des belebenden Sonnenlichts ermöglichen. - Der nächste Verwandte des Pfänzchens ist der oft mehr als meterhohe Gilbweiderich (L. vulgáris), der an Flußufern, in Weidenbeständen (Name!) und an anderen nassen Stellen gedeiht. - Einen prächtigen Schmuck feachter Wälder und schattiger Matten der Voralpen bildet das Alpenveilchen (Cyclamen europáum), das mit anderen Arten seines Geschlechts eine unserer beliebtesten Topfpflanzen geworden ist. Aus dem scheibenförmigen Knollenstamme ( heben sich schöngeformte, weißgefleckte und unterseits rote Blätter (vgl. mit Wiesenklee und Seerose), sowie zahlreiche nickende, rote Blüten von zierlichem Bau und lieblichem Duft.

Ein Glied der nahe verwandten

\section{Familie der Grasnelken (Plumbagináceae)}

ist die gemeine Grasnelke (Arméria vulgáris), eine allbekannte Pflanze trockener Grasplätze und anderer derartiger Orte. Daher finden wir bei ihr wie bei der iiberaus ähnlichen Steinnelke (Name!) eine sehr tiefgehende Wurzel (beobachte daraufhin besonders Pflanzen, die in trockenstem Sande wachsen!) und schmale, grasartige Blätter. Die kleinen, rosafarbenen Blüten (beschreibe sie!) sind zu ansehnlichen Köpfen gehäuft, die von je einem hohen Blütenschafte ïber die Umgebung emporgehoben werden (Bedeutung?). Unterhalb des Köpfchens stehen einige Hüllblättchen, deren obere Abschnitte die Blüten vor dem Entfalten wie ein Kelch schützend umgeben und deren untere Abschnitte zu einer häntigen Scheide verwachsen sind. Untersucht man einen jungen Blütensehaft, so findet man, daß3 er allein unter der Scheide noch weich und zart ist, hier also fortgesetzt. wachsen, und somit den Blütenkopf emporheben kann: die Scheide giebt sich demnach als ein Schutzgebilde ohne weiteres zn erkennen. Der trichterformige Kelch bleibt an der Frucht sitzen und bildet einen kleinen Fallschirm, der die Verbreitung der Pflanze durch den Wind (hoher, elastischer Schaft!) befördert.

\section{5. und 36. Familie. Ölbaum- und Enziangewächse. (Oleáceae und Gentianáceae.)}

1. Ölbaumgewäclıse. Der Flieder (Syringa vulgáris), hier und da fïlschlich auch Holunder genannt (s. das.), hat sich als überall beliebter Schmukbaum vom südöstlichen Enropa ans über alle wärmeren und 
gemäßigten Länder unseres Erlteils verbreitet. In warmen Süden stellen die Saugwurzeln mit Beginn der kälteren Tahreszeit ihre Tätigkeit nicht ein, so daß der Baum dort das ganze Jahı hindurch seine großen, herzförmigen Blatter behält (vgl. S. 91). Die lilafarbenen, rötlichen oder weißen Blïten (beschreibe sie!) sind an sich zwar klein; di sie aber zu großen Sträußen gehäuft sind, einen angenehmen Duft aushanchen und im unteren Teile der engen Bliitenröhre oft mehrere Millimeter hoch mit Honig angefïllt sind, werden sie fleißig von Insekten besucht. An dem durch das Sangen klebrig werdenden Rüssel tragen die Besucher den Bliitenstanb von Blïte zu Bliite (Staubbentel und Narbe stelien im Zngange zum Honig). Bleibt Insektenbesuch aus, dann fällt der Staub anf die unter den Benteln stehende Narbe, so daß Selbstbestäubung eintrit. Die Frucht ist eine Kapsel. Sie öffnet sich bei der Reife mit 2 Klilppen, su dilb der Wind die Samen ansstrenen und verwehen kann. Letzteres geschieht umso eher, als die Simen sehr leichte, flachgedrïckte Gebilde darstellen, die zudem noch von einem Flïgelrande umgeben sind (vgl. mit Spitzahorn). Häufiger jedoch als durch Samen pflanzt sich der Banm durch Schößlinge fort, die sich meist in großer Zahl aus dem Wurzelstocke erheben und ein dichtes Gebiisch bilden.

Noch stärker tritt diese Art der Vermehrung beim Liguster oder der Rainweide (Ligústrum vulgáre) in die Erscheinung, so daß sich die Pflanze vortrefflich zur Anlage "lebender Heeken“ eignet. Die weidenartigen Blätter (Name!) sind etwas lederartig. Infolgedessen überdauert an jedem Strauche stets eine Anzahl von ihnen selbst den kältesten Winter (vgl. mit Efeu). Aus den weißen Blüten, die nach Ban und Häufung denen des Flieders gleichen, entwickeln sich schwarze Beeren, die für zahlreiche Vögel in der kalten Jahreszeit eine willkommene Speise bilden (vgl. mit Weinbeere).

Die Esche (Fráxinus excélsior) findet sich in Wäldern und Anlagen oft als ein mehr denn $30 \mathrm{~m}$ hoher Baum mit mächtiger Krone. Sie besitzt unpaarig gefiederte Blätter, deren Hauptstiel auf der Oberseite eine deutliche Rinne bildet. Nur da, wo die Fiederblätter entspringen, ist die Rinne geöffnet. Hier tritt das von den Fiederblättern aufgefangene Regenwasser in die Rinne, woselbst es vou haar- und sehildförmigen Zellgruppen aufgesogen wird. Die Bestäubung der Pflanze wird wie bei den meisten Waldbäumen durch den Wind vermittelt (s. Haselnub). Daher blïht die Esche auch vor der Entfaltung des Laubes und besitzt sehr einfach gebante Blïten (beschreibe sie!), die entweder nur einen Stempel oder 2 Staubblätter oder beide Blïtenteile zugleich enthalten. Der Wind besorgt auch die Verbreitung der flachen, geflügelten Früchte. Eine Spielart der Esche ist die bekannte Traueresche, die wir als ein Sinnbild der Trauer (hängende Zweige!) gern anf die Ruhestätten der Toten pflanzen.

Eines der wichtigsten Gewächse der Mittelmeerländer ist der Öl- oder Olivenbanm (Ólea europía), der besonders in den Küstengegenden oft weite Strecken bedeckt. Er erreicht ein außergewöhnlich hohes Alter und ähnelt mit seinem oft hohlen Stamme, den sparrigen Ästen und sehmalen Blättern einem Weidenlaume im hohen Grade. Da er aber alljährlich eine lange Sommerdïrre zu überstehen hat, ist sein immergrünes Laub lederartig (s. Orange) und - ein zweites wichtiges Schutzmittel gegen zu starke Wasserdampfabgabe - besonders unterseits dicht mit schuppenförmigen Haaren bedeckt. Gleich tler $\ddot{l} \mathrm{l}$ weide (Eleágnus), die bei uns vielfach als Ziergelı̈lz angepłlanzt wird, 
erscheint der Ölbaum daher grau belaubt, so daB den Olivenhainen das belebende Grün unserer Wälder fehlt. Die Blüten gleichen nach Färbung, Bau und Häufung ganz denen

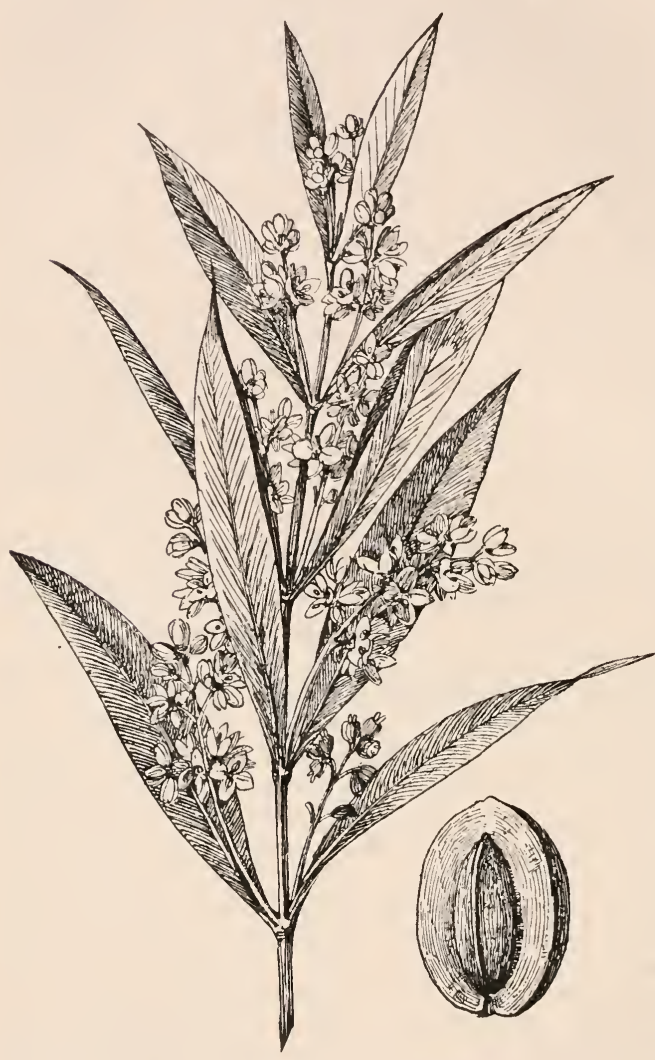

Blihhender Zweig voun Ölbaume. Daneben eine geöffnete Frucht (nat. Gr.) des Ligusters. Die pflanmenähnlichenSteinfrüchte sind in allen Teilen anßerordentlich ölreich. Sie liefern das wertvolle Oliven- oder Baumöl. Die besseren Ölsorten, unter denen wieder das Provenceröl hervorragt (so genannt, weil besonders in der Provence gewonnen), erhält man durch gelindes Pressen der entsteinten Früchte. Sie dienen besonders als Speiseöle. Die geringeren Sorten, die man durch Auspressen der ganzen Frïchte gewinnt, werden zur Herstellung von Seifen oder als Brennund Schmieröle verwendet. Auch das feste, schön geaderte und politurfähige Olivenholz wird hoch geschätzt (Spazierstöcke und andere Drechslerarbeiten). Es ist daher nicht $\mathrm{zu}$ verwundern, daß ein so wichtiger Baum in den Mittelmeerländern bereits seit dem grauen Altertume (Jnden, Griechen) in hohem Ansehen steht. Ein aus seinen Zweigen geflochtener Kranz war der Lohn des Siegers in den Olympischen Spielen, und noch hente gilt der ölzweig als ein Sinnbild des Friedens (Taube Noahs).

2. Enziangewächse. Die zahlreichen Enzianarten (Gentiána), die zumeist prächtig blane Röhrenblüten besitzen, sind vorwiegend Gebirgspflanzen. Besonders für die Alpenmatten bilden sie eine herrliche Zier. Die Wurzeln der Arten, die einen wirksamen Bitterstoff enthalten, werden in der Heilkunde und zur Bereitung des Enzian- 
Branntweins verwendet. - Auf sonnigen, sandigen Triften und an ähnlichen Orten entfaltet das Tausendgiildenkraut (Erythræa centaurum) seine zierlichen, rosafarbenen Blüten, die sich abends zum ${ }_{\text {Schlafe }}$ " schließen (Bedentung?). Da alle Teile der Pflanze stark bitter schmecken (Schutzmittel gegen Weidetiere), finden sie eine ähnliche Verwendung wie die Enzianwurzeln.

3. Glieder nahe verwandter Familien. Am Boden lichter Wälder kriecht das Immergriiı (Vinca minor) dahin. Das blaublïhende Pflänzchen, das auch häufig an schattigen Stellen der Gärten angepflanzt wird, hat wie der Efeu (s. das.) immergrünes (Name!), lederartiges Laub. - Gleiche Blätter (s. Orange) hat auch der Oleauder (Nérium oleánder). Dieser aus Südeuropa stammende, rotblühende Zierstrauch enthält in allen Teilen ein scharfes Gift. - Weit stärker allerdings ist das Gift, das aus den Samen des ostindischen Brechunģbaums (Strýchnos nux vómica) gewonnen wird. In größeren Gaben dient das „Strychnin“ zor Vertilgang von Raubtieren, Mäusen und anderen Schädlingen, in kleinen Gaben dagegen ist es ein wichtiges Heilmittel.

\section{Familie. Windengewächse (Convolvuláceae).}

\section{Die Ackerwinde (Convólvulus arvénsis).}

1. Ein windendes Unkraut. a) Die Ackerwinde findet sich als lästiges Unkraut überall auf Äckern (Name!) und in Gärten, wächst ebenso gern aber auch an Wegen, auf Schutthalden und an ähulichen Stellen.

b) Ihr dünner, weitverzweigter unterirdischer Stamm (Wurzelstock) durchzieht den Boden sehr tief und sendet in noch tiefere Erdschichten lange Wurzeln hinab. Infolgedessen vermag die zarte Pflanze selbst auf dürrem Grunde zu leben und ist außerordentlich schwer auszurotten.

c) Aus dem Wurzelstocke erheben sich zahlreiche Stengel. Da sie sehr lang und schwach sind, vermögen sie weder die eigene Last, geschweige demn die der Blätter, Blïten und Früchte zn tragen. So lange die Winde von Nachbargewächsen nicht beschattet wird (an Wegen und ähnlichen Orten), bleibt der Stengel daher ohne Nachteil für die Pflanze am Boden liegen. Sobald dies aber geschieht, sucht sie genau wie die Bohne (s. S. 101) durch Umwinden (Name!) fremder Gegenstände zum Lichte emporzudringen. Dann entfaltet sie anf angebautem Boden ihre ganze Schädlichkeit: sie umstrickt die Nutzpflanzen, zieht das Getreide zum Boden herab nnd verhindert die Halme, die sich infolge eines heftigen Regengusses "gelagert" haben, sich wieder aufzurichten. (Inwiefern bedingt dies eine Schädigung der angebanten Pflanzen?,

d) Bei gleichmäßiger Belichtung sind die pfeilförmigen Blätter auch gleichmäßig um den windenden Stengel geordnet; bei ungleichmäßiger dagegen ist die Blattstellung mannigfach gestört. Dasselbe gilt auch für die Blätter an solchen Stengeln, die wagerecht am Boden liegen. Da sie nur von oben belichtet werden, haben sich die langen Blattstiele alle senkrecht gestellt, so daß die Blattllächen in einer Ebene liegen (vgl. S. 44, c). (Bringe den Stengel aus der eingenommenen Lage und beobachte, wie anch die Blïter ihre Stellung indern!)

2. Von der Bliite und der Frucht. a) Die langen Blütenstiele, die aus 
den Blattwinkeln entspringen, machen oft merkwürdige Krümmungen, um die Blüten aus dem Blattgewirr herauszuheben (Bedeutung?). Sie tragen deren 1-3 und ebensoviele Paare winziger Nebenblät chen, die weit unter dem kurzen,

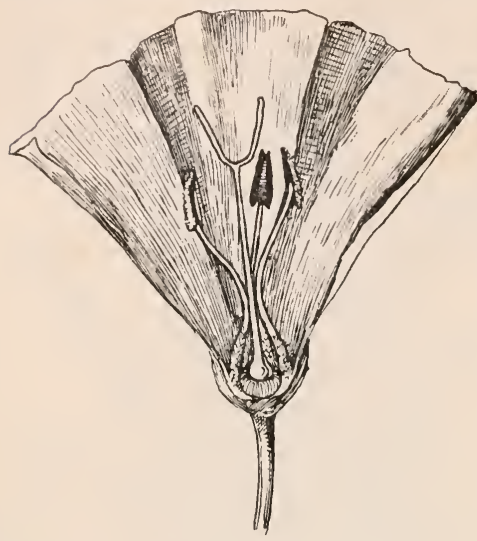

Blïte der Ackerwinde (21/2 mal vergr.) fïnfzipteligen $\mathrm{Kel} \mathrm{che}$ stelien ( $\mathrm{vgl}$. dag. Zaunwinde). Die große, trichterförmige Blnmenkrone, die im Knospenzustande in Falten gelegt und zusammengedreht ist,lockt durch bunte Färbung (gib sie näher an!) und zarten Duft zahlreiche Insekten herhei. Den Besuchern ist jedoch der Honig, der von einem orangefarbenen Polster unter dem Fruchtknoten abgeschieden wird, nicht ohne weiteres zngängig. Die Fäden der 5 Staubblätter sind nämlich am unteren Teile, da wo sie mit der Blnmenkrone verwachsen sind, so stark verbreitert und legen sich weiter oben so dicht an den Griffel, daß nur 5 enge Zngänge zum Honig vorhanden sind. An den zusammenstoßenden Seitenwänden sind sie aber mit kleinen Stacheln besetzt, vor denen die Insekten ihren emptindlichen Riissel wohl in acht nehmen. Wollen die Tiere Honig saugen, so miissen sie mithin den Rüssel durch eine jener Öffnungen stecken. Dabei muß sich aber wenigstens jedes größere Insekt mit Blätenstanb beladen; denn die violetten Staubbentel öffnen sich nach außen. Streift das Tier den anhaftenden Staub beim Verlassen der Bliite an einem der beiden großen and weit gespreizten Narbenäste ab, so muß Selbstbestäubung erfolgen. Geschieht dies erst beim Besuch einer zweiten Blïte, so tritt Fremdbestänbung ein.

b) Gegen Abend (bestimme die Zeit für deinen Wohnort näher!) begibt sich die Blïte wie ihre Bestäuber „zur Ruhe": sie schließt sich, indem sie wieder die Knospenlage einnimmt, und, da sie jetzt keinen Besuch mehr „wünscht", hört sie auch auf zu duften. Bei Regenwetter öffnet sich die Blüte gar nicht (Bedeutung?).

c) Die Frucht ist eine Kapsel, die sich bei der Reife mit 2 Klappen öffnet. Der Wind schuittelt die Samen ans.

Verwandte. Die Zaunwinde (C. sépiam) umspinnt besonders an feuchten Orten Büsche und Zäune in dichtem Gewirr. Sie ähnelt der Ackerwinde in allen Stäcken, ist von ihr n. a. aber leicht dureh die großen Nebenblätter zu unterscheiden, die unmittelbar unter dem Kelche stehen. Ihr Hauptbestänber ist der schmucke Windenschwärmer. Daher ist wie bei allen Falterblumen (s. Steinnelke) anch bei ihr der Honig in einer tiefen Blütenröhre geborgen, die Blüte also weit größer als bei jener Art. 


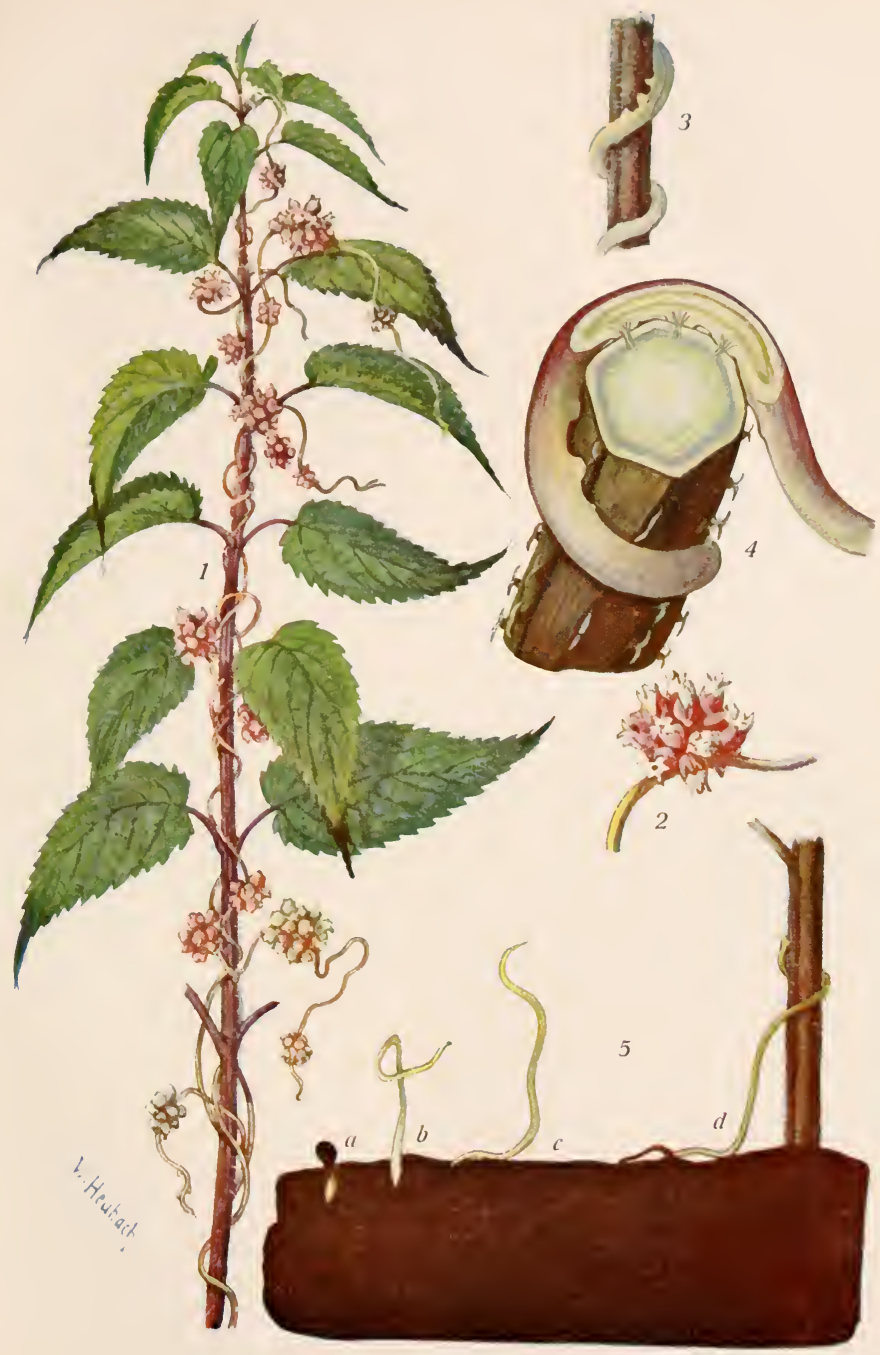

Hopfenseide (Cuscuta europaea). 

Da der Windenschwärmer erst mit Eintritt der Dämmerung zu fliegen beginnt, besitzt die Bhïte wie alle Naehtfalterblumen (vgl. mit Leimkraut) eine Färbung (schneeweiß), die selbst im Dunkeln auffällig ist, und sie schlieBt sich anch - von ganz finsteren Nächten abgesehen - im Gegensatz zu der der Aekerwinde nicht. - Die Winde, die wir gern znr Bekleidung von Lauben u. dgl. verwenden, und die uns durch prächtige, wechselvolle Blïtenfarbe erfrent, ist die Purpurwinde (C. oder Ipomóa purpúrea). Sie stammt aus Nordamerika. - Ein Windengewächs ist auch die Batate oder siį̧- Kartoffel (Ipomóa batátas), deren stärkemehlhaltige Wurzelknollen in allen Tropenländern ein wichtiges Nahrungsmittel bilden.

\section{Die Hopfenseide (Cúscuta europǽa). Tafel 17.}

Das I)ickicht, das vom Hopfen, von Weiden und Brennesseln (1.) gebildet wird, findet man nicht selten wie mit zahlreichen, unentwirrbaren, blaßroten Fäden („Seide“) umsponnen. Bei näherem Zusehen erkennt man, daß diese Fäden Pflanzenstengel sind, die zahlreiche Knänel kleiner Blïten (2.) tragen (vgl. die Blïten mit denen der Winde!), aber der Blätter und selbst des Blattgrïns (bis auf geringe Spuren) entbehren. Das ist die seltsame Hopfenseide, die im Volksmunde treffend anch "Teufelszwirn" genannt wird. Nun ist aber" das Blattgrïn derjenige Körper (s. den letzten Absch. des Buches), in dem unter Einwirkung des Sonnenlichts aus Wasser, den aus dem Boden entnommenen Salzen und der Kohlensäure der Luft alle die Stoffe (Stärke, Zucker, Zellstoff ı. s. w.) bereitet werden, ans denen sich die Pflanze anfbant. Da die Hopfenseide - wie erwähnt - des Blattgrïns entbehrt, so ist sie anch nicht imstande, die zum Aufbau und Leben nötigen Stoffe selbst herzustellen. Sie ist daher genötigt, sie anderswo herzmnehmen. Zu dem Zwecke bilden sich an dem fadenförmigen Stengel zahlreiche kleine Anschwellungen, die sich dem Stengel der Wirtspflanze eng anschmiegen. (In Fig. 3 einem Brennessel-, in 4 einem Hopfenstengel; 4 etwa $10 \mathrm{mal}$ vergr.) Aus der Mitte dieser Gebilde erhebt sich je ein kleiner Zapfen, der die Rinde der Wirtspflanze durchbricht und bis zum Holzkörper derselben vordringt. Mit Hilfe dieser „Saugwärzchen " entzieht die Hopfenseide wie mit ebensovielen Schröpfköpfchen den befallenen Pflanzen alle zum Leben und Wachstum nötigen Stoffe: sie nährt sich also ant Kosten anderer Wesen; sie ist ein Schmarotzer (Parasit). Dieser Lebensweise entsprechend entbehrt sie auch der Wr urzeln, wie sie andere Pflanzen besitzen, und fïgt den befallenen Gewächsen großen Schaden zu. Ja, es ist nichts Seltenes, daß sie die Ernte von Hopfen- und Hanfteldern ganz oder teilweise vernichtet. Hat der Schmarotzer bis zum Herbst anf Kosten seines Wirtes gelebt, dann stirbt er ab.

Wie aber kommt er im nächsten Jabre wieder auf andere I'flanzen? Die Antwort auf diese Frage erhalten wir leicht, wemn wir im Friblijalıre einige in Herbst gesammelte Samen anf feuchtgehaltener Erde aussäen. Schon nach einigen Tagen sehen wir, wie aus der zersprengten, braunen Samenhïlle der fadenförmige Keimling hervortritt und ein kleines Stïck in den Boden wïchst (5 a.). (Der Hoptenseide fehlen also dio bei allen Pflanzen der Klasse vorhandenen 
beiden Keimblätter. Dasselbe gilt anch für die anderen Arten der Gattnng.) Nach wieder ein paar Tagen (b. und c.) hat der Keimling bereits die Samenhïlle abgeworfen und sich zı einem fadenförmigen Körper entwickelt, dessen oberes Ende sich wie die Ranke des Weinstocks (s. das.) langsam im Kreise bewegt: der Keimling "stucht" eine Wirtspflanze. Hat er sie gefunden (d.), so ist sie anch alsbald umschlungen. Indem sein unterer Teil nunmehr abstirbt, entwickelt sich der obere zum Schmarotzer, wie wir ihn kemnen gelernt haben. Gelingt es dem Keimling nicht, eine Wirtspflanze zn ergreifen, dann geht er — da er nicht selbst Blätter treibt und Banstoffe bereitet - nach einiger Zeit zu Grunde. Da dieser Fall sicher nun sehr oft eintritt, so wird uns anch die anßerordentlich große Anzahl der Blïten und die noch weit größere Menge der Samen verständlich, welche die Hopfenseide hervorbringt; denn je größer die Anzahl der Samen ist, desto größer ist für die Pflanze anch die Möglichkeit, ihre Art zu erhalten (vgl. mit tierischen Schmarotzern, z. B. dem Bandwurm!).

Die nächsten Verwandten der Hopfenseide sind ihr iiberaus ähnliche schmarotzer. In Klee- und Luzernefeldern richtet die Ḱleeseide (C. epithymum) oft großen Schaden an, und Flachsfelder werden von der Flachsseide (C. epilinum) nicht selten gänzlich verwüstet. Durch Abbrennen oder Abuähen der befallenen Pflanzen, bevor der Sehmarotzer noch Samen angesetzt hat, läbt sich dem Übel allein Einhalt tun.

\section{Familie. Rauhblättrige Gewächse (Asperifoliáceae).}

Meist rauhhaarige Pflanzen. Kelch, Blumenkrone und Staubblätter 5 -zählig. Frucht eine in 4 Teilfrïchtchen zerfallende Spaltfrucht.

Die Sclıwarzwurz (Sýmphytum officinále). Tafel 18.

A. Staudort und Wurzel. Die Schwarzwurz ist anf nassen Wiesen, sowie an den Ufern der Gräben und Bäche ïberall häufig anzutreffen. Da die Pflanze also auf lockerem Boden wächst nnd zudem nicht selten die Höhe von $1 \mathrm{~m}$ erreicht, so muß sie im Untergrunde sicher "verankert" sein. Darum setzt sich anch der kurze, unterirdische Stamm oder Wurzelstock (d. i. der mit Blättern und Blattresten besetzte obere Teil des im gewöhnlichen Leben ungenau als "Wurzel" bezeichneten Gebildes) in eine tiefgehende, spindelförmige Wurzel fort. Bei älteren, großen Pflanzen strahlen an der Stelle, an der der Stamm in die Wurzel iibergeht, meist noch starke Seitenwurzeln ans, die gleichfalls ziemlich senkrecht in den Boden hinabsteigen (vgl. mit einem Fahnenmaste, der im Boden steckt und noch durch Tane gehalten wird!). Die unterirdischen Teile sind anßen schwarz gefärbt (Schwarzwurz!) nnd wurden früher für ein Heilmittel bei Knochenbrïchen gehalten. Dieser Verwendung verdankt die Pflanze auch den Namen "Beinwurz".

B. Stengel und Blätter. Aus dem unterirdischen Stamme erheben sich ein Büschel (grundständiger) Blätter und ein oder mehrere verzweigte Stengel, die gleichfalls Blätter tragen (1.). 

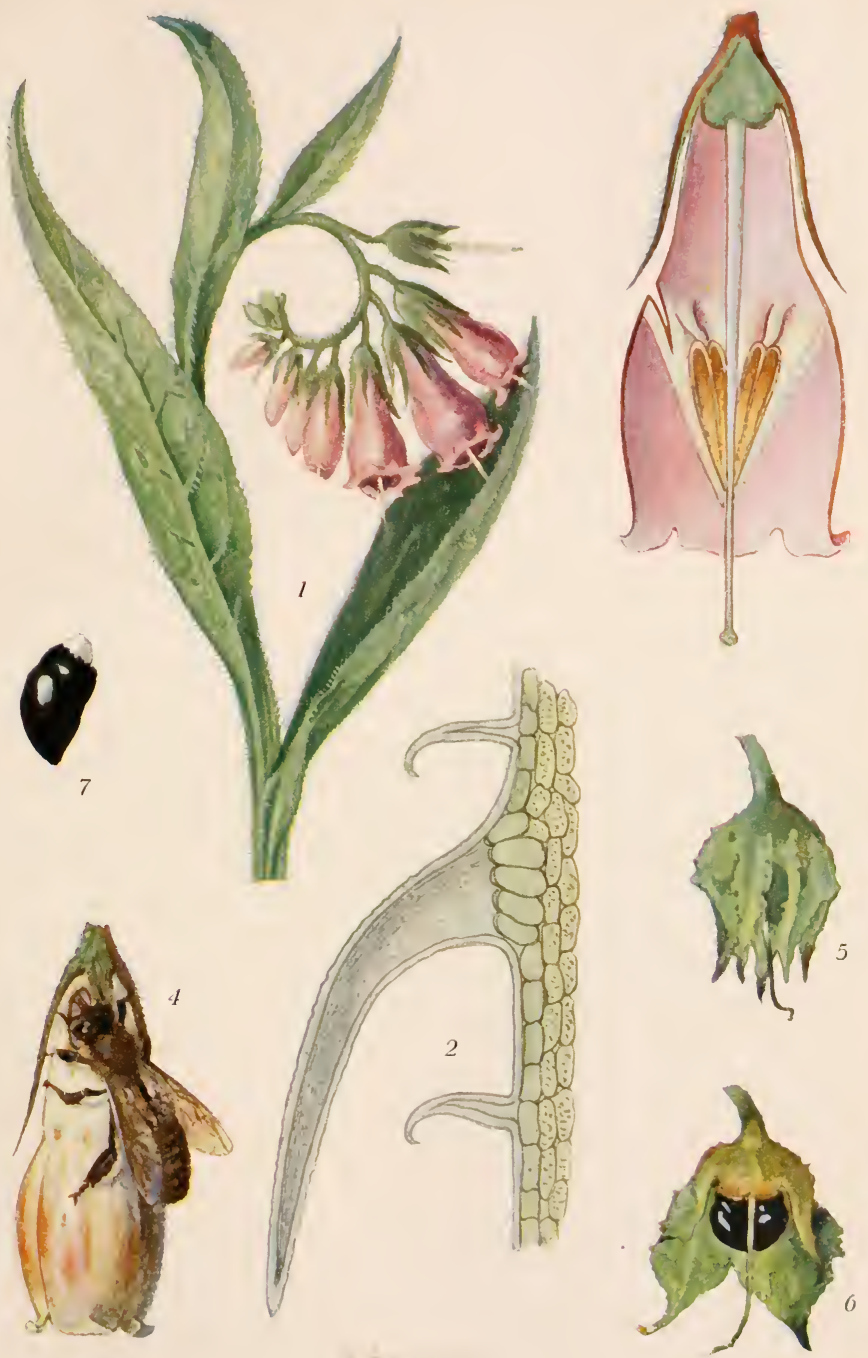

Schwarzwurz (Symphytum officinale). 

1. Belichtung. Obgleich die Stengelglieder nach oben hin immer kürzer werden, die Bliitter also näher beieinander stehen als am unteren Sitengelabschnitte, werden doch sämtliche Blätter des zum Leben notwendigen Somnenlichts teilhaftig; demn

a) sie nehmen von unten nach oben an Größe (Länge, Breite! gib die blattform näher an!) allmählich ab.

b) l)ie grundständigen- und unteren Stengelblitter sind gestielt. Hie oberen Stengelblätter dagegen entbehren der Stiele: sie sind "sitzend".

c) Bindet man um den Stiel eines der unteren Stengelblätter einen Faden, den man zum zweiten, dritten Blatt u. s. w. tïhı't, su sieht man, daß die Blätter in einer Schraubenlinie am Stengel stehen.

2. Wasserableitung. Träufelt man auf die Bläter eines abgeschnitteneu Stengels Wasser, so fließt es - von wenigen Tropfen abgesehen - am unteren Stengelende in einem starken Strome ab. Die Wasserableitung ist also wie beim Raps eine nach innen gerichtete, eine „centripetale“, und entspricht der Richtung der mit Saugwurzeln besetzten Wurzel (s. S. s8, c). Bedingt wird diese Art des Wasserabflusses durch folgende Einrichtungen:

a) Pie Blätter stehen am Stengel sehräg a nfwärts.

b) Sie besitzen gleich den Blattstielen (soweit solche vorhanden sind) die Form von Rinnen. - Bei den grundständigen und anteren Stengelblättern ist die äußere Hälfte der Blattfläche meist abwärts gebogen. Die anf diesen Abschnitt der Blätter fallenden Regentropfen werden daher nicht der Wurzel zugeführt.

c) Die Blattflächen setzen sich in die Blattstiele fort und lanfen wie bei den sitzenden Blättern in Form zweier Säume an dem Stengel herab, so daß dieser „geflïgelt“ erscheint. Die Sänme verhindern ein Abspringen der Wassertropfen und leiten sie am Stengel herab.

3. Behaarung. Alle grïnen Teile sind dicht mit stacheligen Borstenhaaren bedeckt, so daß sich die Pflanze sehr ranh anfïhlt („Rauhblättrige Gewächse“). Wie sich leicht feststellen läßt, sind die Borsten mehr oder weniger rïckwärts (dem Boden zu) gerichtet und - wie schwache mikroskopische Vergrößerung zeigt - von doppelter Form: neben sehr großen, mehr geraden finden sich kleinere von der Gestalt eines Gemshorns (Fig. 2: Stïck ans der Oberhant des Stengels bei etwa 70 facher Vergr.). Da die Wände aller Borsten roichlich Kieselerde enthalten, sind sie selır hart und ihre Spitzen scharf und stechend.

Hieraus läßt sich schon erkennen, welche Bedeutung die Borsten fïr die l'tlanze haben: wenn die größeren von ihnen selbst in die Haut unserer Händle einzudringen vermögen, wie viel mehr müssen sie die zarte und empfindliche Mundschleimhant der Tiere verletzen, die das rauhe Gewächs verzehren wollen! ¿usere größten Pflanzenfresser, Rind und Pferd, lassen sich durch den Borstenbesatz freilich nicht zurïckschrecken; anders jedoch die gefräßigen Schnecken. Setzt man eine Garten- oder Weinbergschnecke anf den Stengel der Pflanze, so 
dringen die langen, scharfen Borsten, die infolge ihrer Richtung dem Tiere wie Lanzenspitzen entgegenstarren, in die weiche "Kriechsohle“, und die gemshornartigen mögen nicht unempfindliche Wunden reißen! Das Tier bewegt sich daher sehr unbeholfen fort, zieht bei jeder Berïhrung mit einer Borste die Fühler ein und verläßt den gefahrvollen Boden, sobald sich ihm die Möglichkeit dazu bietet. Ganz ähnlich verhalten sich die Schnecken, wenn man ihnen die Pflanze als Futter vorsetzt: sie vermögen dem stacheligen Gewächs nicht recht beizukommen. Schneidet man aber von einem sonst unverletzten Blatte ein Stück ab, so wird es sofort verzehrt, weil man den Tieren einen Angriffspunkt geschaffen hat. Dasselbe ist an Blatt- oder Stengelteilen zu beobachten, die vorher in einem Mörser zerrieben wurden: ein deutlicher Beweis, daß nur die Borstenhaare es sind, welche die Schnecke abhalten, an der Pflanze emporzukriechen und sie zu verzehren. In den Borstenhaaren haben wir also wichtige $\mathrm{Schutzw}$ affen der Pflanze vor uns. (Stelle mit anderen rauhblättrigen Gewächsen dieselben Versuche an!)

C. Blïte und Frucht. 1. Blüt enstand (1.). Die zahlreichen kurzgestielten Blïten stehen in einer Tranbe, die anfänglich etwas spiralig eingerollt ist ("Wickeltranbe“). Daher müssen die Bliiten anch alle nach einer Seite des Hauptbliitenstiels (nach welcher?) gerichtet sein. In dem Maße, in dem sich die Blïten entfalten, rollt sich auch die Traube auf. Da immer nur einige Blüten geöffnet sind, währt das Blühen eine lange Zeit. Infolgedessen werden selbst bei ungünstigster Witterung sicher einige Blüten von Insekten besucht und bestäubt, so daß die oberirdischen Teile der Pflanze im Herbste nicht absterben, ohne eine Anzahl von Samen (Nachkommen!) gebildet zu haben.

2. Einzelblüte (3.). a) Die geöffnete Blüte ist nach unten geneigt, so daß der leicht verderbende Blütenstaub gegen Befeuchtung wohl geschützt ist. Ein kurzer, fünfzipfeliger und rauhhaariger $\mathrm{Kelch}$ umschließt die glockenförmige Blnmenkrone, die sich im vorderen Abschnitte etwas erweitert, in 5 zuriickgebogene, kleine Zipfel endigt und bald gelblich-weiß (4.), bald rosa bis fast violett gefärbt ist. Und zwar findet sich die purpurne Farbung nur an der sichtbaren

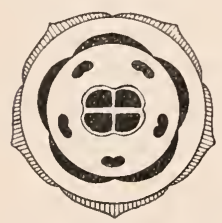

Blïtengrundrig der Schwarzwurz.

Außenseite, soweit sie nicht vom Kelche verdeckt ist (Bedeutung? vgl. mit Blüten, bei denen die Innenseite der Blumenkrone sichtbar ist!).

b) Von der Unterlage des Fruchtknotens (s. Absch.3) wird der Honig abgeschieden. Da der Griffel sehr lang ist, ragt die Narbe weit aus dem Eingange der Blïtenglocke hervor. Sie wird daher von einem anfliegenden Insekt zuerst berührt (Fremdbestäubung). Die 5 St a u bblïtter sind mit der Blumenkrone verwachsen (s. S. 121,2). Ihre Beutel sind nach innen geneigt und bilden einen Kegel, dessen Spitze von dem Griffel durchbrochen wird. Sie öffnen sich bereits in der Knospe, und zwar nach innen, so daß ein Teil des Blütenstaubes in die Spitze des Kegels fällt. 
c) Würde ein Insekt den Rüssel zwischen den Staubfäden hindurch zum Honig senken, so könnte es sich nicht mit Staub beladen; der Honig würde also nutzlos verloren gehen. Um dies zu verhindern, ist eine sehr interessante Einrichtung getroffen: An der Stelle, an der sich die Blumenglocke erweitert, springt ihre Wand in Form von 5 Hohlschuppen nach innen vor, die sich wie eine Kuppel als ein zweiter Kegel über die Staubbeutel legen. (V'gl. die Schuppen mit Handschuhfingern! Die Öffunngen der „Handschnhfinger" sind anßen an der Blïtenröhre als Eindrïcke sichtbar.) Da nun die Schuppenwände mit harten, stacheligen Spitzen besetzt sind (streiche an ihnen mit einer Nadel entlang!), hüten sich die Insekten wohl, diese gefahrlichen Gebilde zu berühren, also zwischen den Staubfäden hindurch zum Honig vorzudringen. Sie füihren den Rüssel vielmehr an der Spitze der Kuppel ein. Dabei müssen sie aber die Staubbeutel auseinanderdrängen, so daß ihnen etwas von dem Blütenstaube auf den Kopf fällt. (Ahme die Tätigkeit der Insekten mit Hilfe eines spitzen Hölzchens nach!) Infolge der Anwesenheit der Schuppen wird also nur langrüsseligen Insekten (gewissen Hummeln und Bienen), die den Pflanzen eimen Gegendienst (welchen?) leisten können, der Honig zugänglich. Mit der Art der Bestäubung hängt es auch innig zusammen (Beweis!), daß die Pflanze trockenen, mehlartigen Blütenstaub und hängende Blüten besitzt.

d) Sehr häufig tindet man die Blumenkrone von der kurzrüsseligen Erdhummel angebissen, die den süßen Saft auf ,ungesetzlichem“ Wege zu erreichen sucht. Diese Löcher benutzt auch die Honigbiene, um zu saugen (4.).

3. Frucht. a) Nach einiger Zeit fällt die Blumenkrone ab. Da sich nun - wie oben bemerkt - der Hauptblütenstiel weiter aufrollt, so wird der übrig bleibende $\mathrm{Kel} \mathrm{ch}$ mit emporgehoben. Ist die Blïte aber vorher bestäubt worden, so wird der Kelch durch Krümmung seines Stielchens wièder nickend. Gleichzeitig wächst er kräftig weiter und seine Zipfel legen sich zusammen, so daß er zu einem Schutzdache fä̈r die sich entwickelnde Frucht wird (5.). Ist die Frucht gereift, so daß sie sich von der Intterpflanze trennen muß, so biegen sich auch die Kelchzipfel wieder auseinander (6. im Durchschnitt gez.).

b) Der Fruchtknoten ist bereits während des Blühens durch tiefe Spalten in 4 Teile geschieden, aus deren Mitte sich der Griffel erhebt. Indem die Teilung. immer vollkommener wird, entwickelt sich die Frucht, die also eine Spaltfrucht darstellt, zu 4 Teilfriichtchen. Diese enthalten je einen Samen, sind also Schließfrüchte oder Nüßchen (s. S. 10, 3). Die glänzend schwarzen Gebilde sind am Grunde ausgehöhlt und besitzen daselbst einen weißen, fleischigen Anhang (7.). Ob der Anhang wie der am Samen des Veilchens (s. das.) von Ameisen verzehrt wird, also der Verbreitung der Pflanze dient, ist mit Sicherheit nicht erwiesen.

\section{Andere rauhblittrige Gewächse.}

Im schattigen Laubwalde erschließt das Lungenkraut (Pulmonária officinális) als eine der ersten Frühlingspflanzen seine anfänglich roten, später blauen Blüten, die gleich denen der Schlüsselblume (s, das.) verschieden lange Griffel besitzen. Wie zahl- 
reiche andere Waldpflanzen (s. S. 7, b. und c.) ist das Lungenkrant ein zartes Gewächs mit großen Blättern und im Gegensatz zu den Trockenlandpflanzen der Familie (s. w. u.) nur gering behaart. Die Blätter, die früher für ein Heilmittel gegen Lungenkrankheiten galten (Name!), sind meist weibfleckig, eine Erscheinung, in der wir bereits beim Wiesenklee (s, das.) ein Förderungsmittel der Verdunstung kennen gelernt haben. Deshalb finden sich solche Blätter auch besonders an Pflanzen, die an sehr schattigen und daher feuchten Orten wachsen. - Von ähnlicher Zartheit ist das Sumpf-Vergigmeinnicht (Myosótis palústris), das Uferränder und andere nasse Stellen bewohnt. Durch die prächtig blauen, mit gelbem Stern geschmückten Blüten hat es sich schon von alters her die Zuneigung der Menschen erworben, die in ihm ein Sinnbild der Treue und Liebe erblicken (Name!). Der ${ }_{n}$ Stern “, der die Auffälligkeit der "tellerförmigen" Blumenkrone erhöht (Bedeutung?), wird durch Hohlschuppen gebildet. Da diese Gebilde den Eingang der kurzen Blïtenröhre stark verengen, so verwehren sie (Blüte nach oben geöffnet!) den Regentropfen, zu Blütenstaub und Honig vorzudringen und diese wichtigen Stoffe zn verderben. Zugleich nötigen sie auch die saugenden Insekten, Narbe und Staubbeutel zu berühren. - Die zahlreichen Vergißmeinnicht-Arten, die an trockenen oder gar sandigen Orten wachsen, haben weit kleinere Blätter (s. S. 22) und sind viel stärker behaart, als die Schatten und Fenchtigkeit liebenden Formen, ein Zeichen, daß bei ihnen die Behaarung nicht nur ein Schutzmittel gegen TierfraB, sondern auch gegen zu starke Wasserdampfabgabe ist (s. S. 43, C 1 a). - Dasselbe gilt auch von anderen Trockenlandbewohnern der Familie. Von ihnen seien nur Ochsenzunge, Natterkopf und Hundszunge genannt, die an Wegen und ähnlichen trockenen Orten häufig anzutreffen sind. Es sind ausdauernde oder 2-jährige, hohe Pflanzen, die darum auch sehr tiefgehende Wurzeln besitzen. Die Ochsenzunge (Anchúsa officinális) weiß sich den Verhältnissen ihres Standortes insofern innig anzuschmiegen, als sie auf trockenem Sandboden schmälere und stärker behaarte Blätter treibt als z. B. im feuchten Thalgrunde. Die prächtig blaven Blüten haben in der Mitte einen aus Hohlschuppen gebildeten, weißen Stern

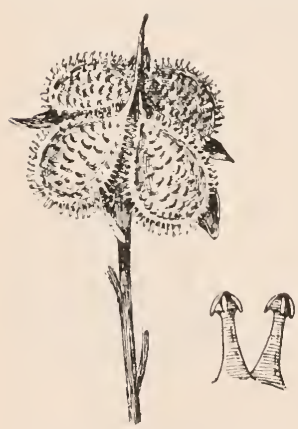

Frucht der Hundszunge, in 4 Teilfrüchtchen zerfallen (etwa $3 \mathrm{mal}$ vergr.). Daneben 2 ankerartige Stacheln (stärker vergr.). (Bedeutung?). - Der allbekannte, stachelhaarige Natteykopf (Échium vulgáre) hat gleichfalls blaue Blüten. Sie entbehren aber der Schuppen und haben mit dem Kopfe einer Schlange entfernte Ähnlichkeit (Name!). Die weit aus der Blütenröhre hervorragenden Staubgefäße dienen gleich dem Griffel den sangenden Insekten als "Sitzstangen" (Bestäubung?). - Die braunroten Blüten der Hundszunge (Cynoglóssum officinále) sind wieder mit Hohlschuppen ausgerüstet. Im Gegensatz zu den honigduftenden Blüten riechen die grünen Teile ekelhaft nach Mäusen (Schutzmittel gegen TierfraB). Da die großen Teilfrüchtchen, deren Oberseite mit ankerartigen Stachelı dicht besetzt ist, vorbeistreifenden Tieren angeheftet werden, drängt die wachsende Frucht den Kelch auseinander. Infolgedessen stehen die Teilfrüchtchen schließlich vollkommen frei da (wie dag. bei den anderen erwähnten Arten der Familie?). Und wie fest die Früchtchen haften, kann man leicht an den eigenen Kleidern beobachten. Als bekannte Feldunkräuter sind noch zu erwähnen der Ackersteinsame (Lithospérmum arvénse) mit kleinen, 


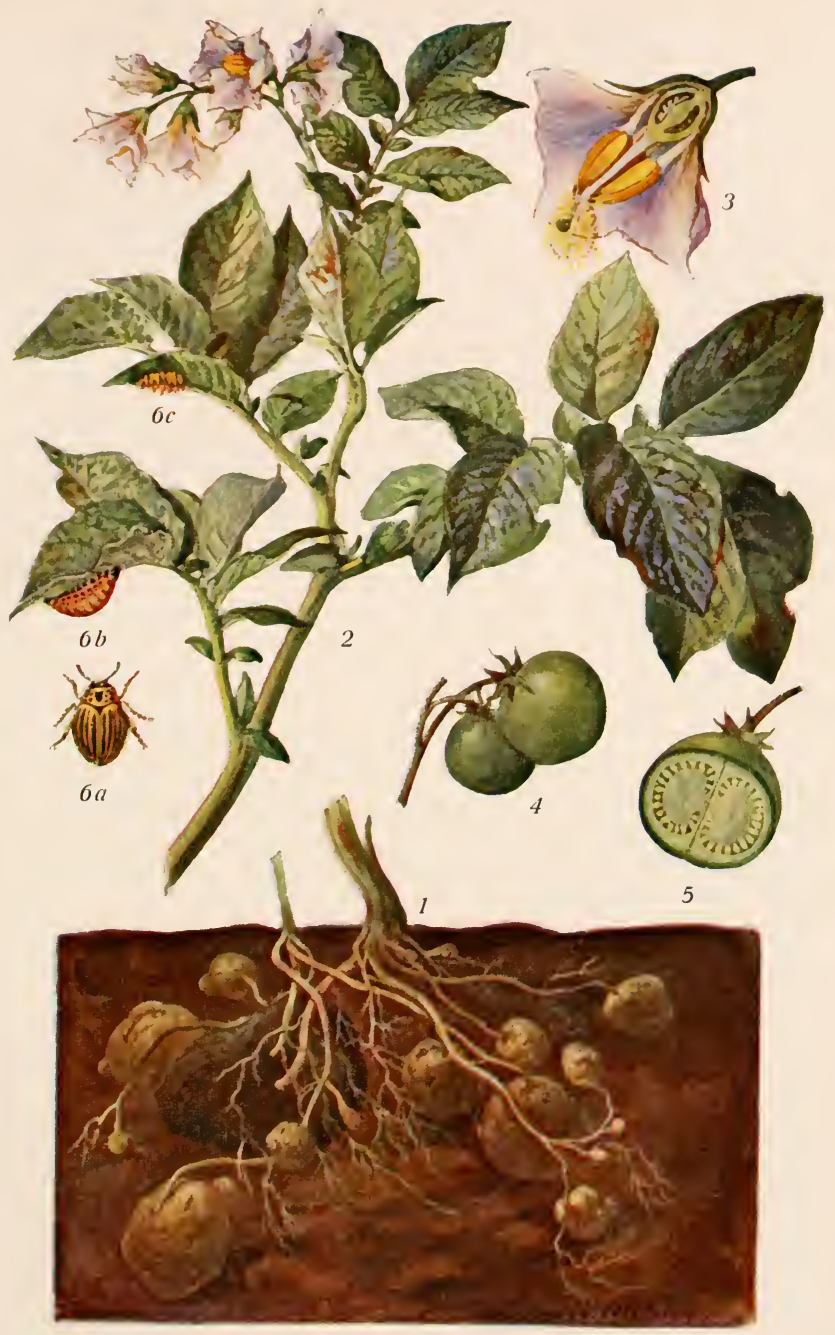

Kartoffel (Solanum tuberosum). 

weißen Blüten und steinähnlichen Samen, sowie der Arkerkrummhals (Anchisa arvénsis), dessen blane Blüten wie die der Ochsenznnge gebant sind, aber eine gebogene Blütenröhre besitzen (Namen!). - I)er Boretsch (Borágo officinális) wird wegen der gurkenartig schmeckenden Blätter (Verwendung?) und der prächtigen blanen Blütensterne vielfach in Gürten angebaut, Kr stammt aus dem Mittelmeergebiete.

\section{Familie. Nachtschattengewächse (Solanáceae).}

Kelch 4- oder 5-spaltig. Blumenkrone röhren- oder trichterförmig, 4- oder 5-zipfelig 5 Staubblätter. Fruehtknoten aus 2 Fruchtblättern gebildet, mit dickem Samenträger und zahlreichen Samenknospen. Frucht eine Beere oder Kapsel.

Die Kartoffel (Solánum tuberósum). Taf. 19.

A. Von den Knollen und der Bedeutung der Kartoffel. Die Knollen der Kartoffeln zählt man mit den Rüben, Möhren, Zwiebeln u. s. w. zu den „Feldfrïchten"; oft werden sie sogar als die „Frïchte" der Kartoffel selbst bezeichnet. Daß wir es hier aber nicht mit „Früchten“ im botanischen Sinue zu tun haben, zeigt schon ihre Entstehung: sie gehen - im Gegensatz zu wirklichen Früchten -- nicht aus dem Fruchtknoten der Pflanze hervor. Fragen wir uns daher:

1. Was ist die Knolle? Eine Antwort anf diese Frage erhalten wir, wenn wir verfolgen, wie sich die Knollen bilden (1.).

a) In Frühjahre fangen die Knollen, die wir in Keller aufbewahren, an zu „keimen“, d. h. aus den "Angen" gehen beblätterte Stengel hervor. (Warum ist der Ansdruck „keimen" ungenan?). Die Stengel suchen das spärliche Licht auf, das durch das Kellerfenster einfällt, und sind, weil im Dunkeln wachsend, blasse und zarte Gebilde. Genan so gehen - wie wir uns leicht ïberzengen köunen - anch aus den "Augen" der Knollen, die wir (etwa einen Spatenstich tief) in die Erde legen, Stengel hervor. Nehmen wir eine solche junge Pflanze, nachdem sie einige Blätter entwickelt hat, ans dem Boden, so sehen wir, wie an dem nnterirdischen Stengelteile (Abb. S. 136, St) schuppenartige Blättchen (B) sitzen, und wie aus deren Achseln fadenförmige Seitenzweige (A) hervorgehen, die sich niemals über den Boden erheben. (Warum sind alle diese unterirdischen Teile farblos?). Diese "A uslä ufer" tragen hier nnd da gleichfalls wieder schuppenförmige Blättchen und am Ende eine Knospe (E), genau wie die oberirdischen Stengel und Zweige solche Endknospen besitzen. Beides sind Zeichen dafür, daß wir es hier wirklich mit Stengelteilen und nicht mit Wurzeln zu tun haben; denn diese sind stets unbeblättert. In den Achseln der schuppenförmigen Blätter finden sich ferner ebenso wie an oberirdischen Stengeln Seitenknospen, die zumeist wieder zu Zweigen auswachsen. Und an der Stelle endlich, an der die Blätter dem Stengelteile ansitzen (Stengelknoten), brechen Wurzeln hervor, wie dies gleichfalls vielfach an oberirdischen Stengehn zu beobachten ist (besonders an solchen, die man ebenfalls als Ausläfer bezeichnet; Beispiele!). Die schuppenförmigen Blätter gehen, weil für die Pflanze wertlos, meist bald zu Grunde. 
b) An den Auslänfern und ihren Seitenzweigen bemerkt man nun am freien Ende je eine kleine Anschwellung (vor E). Nimmt man einige Zeit darauf $\begin{gathered}\text { Bildung der } \\ \text { Kartoffel- } \\ \text { knollen. } \\ \text { (Bezeichnungen } \\ \text { sind im Texte } \\ \text { erklärt.) }\end{gathered}$
wo sieht man, wie die Anschwellungen größer ge-
ausgebildet haben. (Die Anschwellung kann sich
anch etwas entfernt vom Ende des Ausläufers
bilden. Ebenso kann der kurze
Stengelteil der Seitenknospen, ohne der Landmann wohl tut, die jungen Kartoffelpflanzen zu „behäufeln“, d. h. Erde um die unteren Teile der oberirdischen Stengel anzuhäufen; denn die Zweige, die sich in den mit Erde bedeckten Blattachseln bilden, entwickeln sich gleichfalls zu (unterirdisch bleibenden) Ausläufern, so daß eine erhöhte Knollenbildung eintreten muß. (Warum werden die Kartoffeln „gehackt", d. h. warum wird der Boden mit Hilfe der Hacke gelockert und von Unkraut gereinigt?)

c) Die unterirdischen Stengel tragen, wie wir soeben gesehen haben, Seitenknospen in den Achseln der schuppenförmigen Blätter. Da nun die Knollen nichts anderes als Stengelteile sind, so müssen wir an ihnen diese Gebilde wiederfinden: es sind die "A ug en" der Knolle, die - wollgeschützt gegen Verletzung - in einer Vertiefung der Knolle liegen. Somit wird es uns vollkommen verständlich, wie aus einer Knolle und sogar aus einem Teile einer solchen (was mnß ein solcher Teil aber besitzen?) eine neue Pflanze hervorgehen kann. Die schuppenförmigen Blättchen sind an ganz jungen Knollen noch deutlich sichtbar, an älteren verschrumpfen sie wie an den sich nicht verdickenden Stengelteilen gleichfalls bald.

d) Im Herbst gehen die A usläufer zu Grunde, so daß bei Pflanzen, deren oberirdische Teile gänzlich abgestorben sind, die Knollen getrennt im Boden liegen.

2. Welche Bedeutung hat die Knolle für die Pflanze? a) Schon wenn in einer Frühjahrsnacht das Thermometer auf einige Grad unter Null sinkt, sind am nächsten Morgen die grünen Teile der Kartoffeln gänzlich er- 
froren. Die viel niedrigeren Temperatnren unseres Winters könnte die Pflanze demnach noch viel weniger ertragen. Sie stirbt daher im Herbste ab, hinterlaßt aber (von den Samen abgesehen; s. Absch. B, 3) zahlreiche Knollen. Werden diese vou dem Menschen vor Kälte bewahrt - denn durch Käle werden sie oft selbst im Keller vernichtet - und im nächsten Frïhjahre wieder gepflanzt, so geht aus ihnen je eine neue Pflanze hervor. Etwas ganz Ähnliches findet natiirlich anch bei der wild wachsenden Kartoffel statt (fiihre dies näher aus!). Die Knollenbildung ist also eine Veranstaltung der Pflanze, durch die sie die ungünstige. Jahreszeit ïbersteht, und zugleich ein Mittel der Vermehrung.

b) Bei der wildwachsenden Kartoffel gehen ans den Knollen im nächsten Jahre also zahlreiche junge Pflanzen hervor. Wenn diese auf einem Trupp ständen, so würden sie sich gegenseitig Nahrung, Licht und Luft streitig machen. Es ist daher von größter Wichtigkeit für die Pflanze, daß sich die Knollen (meist) am Ende langer Auslänfer bilden.

c) Wenn man die Bedentung der Knolle im Auge behält, wird man auch leicht ihren $\mathrm{Bau}$ verstehen. Nimmt man 2 gleich große Knollen (derselben Sorte) und legt sie, nachdem man eine davon geschält hat, an einen warmen Ort, so findet man die geschälte nach einiger Zeit gänzlich verschrumpft, während die andere fast unverändert geblieben ist. Die erstere hat - wie die Wage zeigt - sehr viel, die andere dagegen nur wenig von der Fliissigkeit verloren, von der die Knollen durchtränkt sind. Pflanzt man eine solche geschälte, vertrocknete Knnolle, die aber alle ibre Augen behalten hat, so geht darans keine nene Pflanze hervor; denn die Angen sind mit vertrocknet. (Vgl. mit den Knospen eines abgeschnittenen oberirdischen Zweiges, der längere Zeit trocken gelegen hat!) Die "Schale" der Knolle ist also ein Schutzmittel gegen das Vertrocknen. Und wenn man bedenkt, daß die Knolle bei uns etwa 7 Monate im Jahr außerhalb der Erde zubringt, so wird man die Wichtigkeit eines solchen Hittels leicht ermessen. (Warum bedarf die Pflanze in wilden Zustande gleichfalls dieses Schutzmittels?)
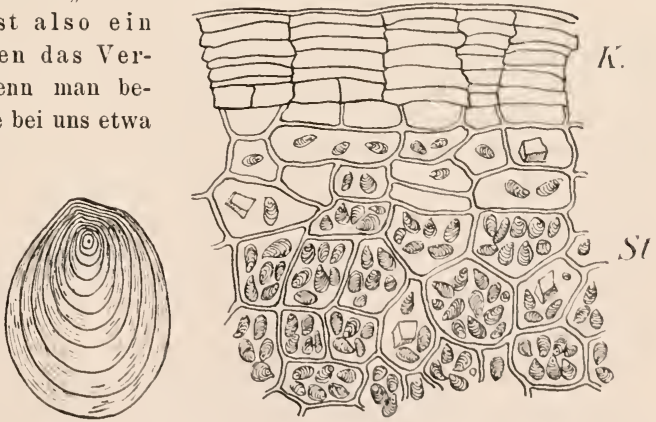

Mikroskopischer Schnitt aus einer Kartoffelknolle.

Wie uns das Jikroskop an einem

K. Korkzellen. St. Stärkehaltige Zellen (140 mal vergr.) Die würfelförmigen Gebilde sind Eiweißkristalle. Links daneben ein Stärkekorn in 500 facher Vergr. 
feinen Schnitte zeigt, ist die Schale aus mehreren Schichten von Zellen zusammengesetzt, deren Wände aus Kork bestehen. Nun kennen wir diesen Stoff (Flaschenkorke!) aber als ein vortreffliches Mittel, Flüssigkeiten, die wir in Flaschen und Büchsen aufbewahren, gegen Verdunstung zu schïtzen. Die Natur hat der Kinolle also eine Hülle aus einem sehr geeigneten Stoffe gegeben. (Da aber die Knollen während des Winters, auch wenn sie noch keine Stengel getrieben haben, etwas einschrumpfen, so ist dies ein Zeichen, daß sie trotz der Korkhülle einiges Wasser durch Verdunstung verlieren.) Auch gegen Verletzungen, sowie gegen das Eindringen von Pilzsporen und Spaltpilzen ist der blaue, rote oder weiße "Korkmantel" der Knolle ein wichtiges Schutzmittel (vgl. mit der Schale saftiger Früchte; Beispiele!).

d) Die Stengel, die aus der im Keller keimenden Knolle hervorgehen, können die Stoffe, aus denen sie sich aufbauen, nirgends anders hernehmen als aus der Knolle. Dasselbe gilt auch für die Stengel, die aus einer in die Erde gelegten Knolle hervorbrechen; denn erst nachdem sie grüne Blätter gebildet und Wurzeln geschlagen haben, sind sie imstande, sich selbst zu ernähren. Bis dahin sind sie auf die Knolle angewiesen. Mit dieser beständigen Abgabe von Baustoffen steht im Einklange, daß die "alte“ Knolle schließlich wie ausgesogen erscheint. Hat sie endlich nichts mehr abzugeben, so ist sie für die junge Pflanze, die sich jetzt selbst ernähren kann, wertlos geworden, und ihre Reste gehen durch Fäulnis zu Grunde (vgl. mit Samen und Keimling! s. S. 101, e). Welcher Art sind nun die Bau- und Vorratsstoffe, die in der Knolle aufgespeichert liegen?

Schneidet man eine Knolle durch und betupft die Schnittfläche mit Jodlösung, so tritt sofort starke Blaufärbung ein, ein Zeichen, daß die Knolle sehr reich an Stärke ist (vgl. den letzten Absch. des Buches). Wenn wir ferner einen sehr dünnen Schnitt ans der Knolle durch das Mikroskop betrachten, können wir uns leicht davon überzeugen, daß in der Tat fast alle Zellen mit Stärkekörnchen gleichsam vollgestopft sind (s. Abb. S. 137). Und wenn wir endlich einige rohe Knollen zerreiben und den Brei wiederholt im Wasser auswaschen, so bleibt die Stärke als ein weißes Pulver zurück. Der Stärkegehalt der Knollen beträgt durchschnittlich etwa $20 \%$. Nur $2 \%$ sind Eiweiß (in den Zellen unter der Korkhaut); alles ïbrige ist - von den Stoffen abgesehen, die in noch geringerer Menge vorhanden sind - Wasser (etwa $75 \%$ ). (Wiege eine geschälte Knolle, lege sie auf den warmen Ofen, bis sie gäuzlich eingetrocknet ist, und bestimme den Gewichtsverlust!) - Aus diesen Tatsachen geht nun ohne weiteres hervor,

3. welche Bedeutung die Kartoffel für den IIenschen hat. a) Wie bekannt, ist die Stärke ein wichtiger Nährstoff, der uns außer von der Kartoffel besonders vom Getreide und von den Hülsenfrüchten geliefert wird. Da nun die Knollen sehr reich an Stärke sind, so ist die Kartoffel eine unserer wichtigsten Nährpflanzen. Damit ist aber ihre Bedeutung bei weitem noch nicht erschöpft! Da wir nämlich mit ihrer Hilfe von einer Ackerfläche erheblich 
mehr Nährstoffe gewinnen, als von einer gleich großen, selbst mit Getreide bestellten Fläche; da sie selbst noch auf magerstem Sandboden und in Höhen (Gebirge!) gedeiht, auf denen kein Getreide mehr wächst; da sie fast alljährlich eine reiche Ernte liefert; da die eingeernteten Knollen verhältnismäßig leicht und lange haltbar sind und selbst bei täglichem Genuß gleich dem Brote eine Speise bilden, die uns nie zum Ekel wird: so ist die Kartoffel nächst den Getreide unsere wichtigste Volksuahrungspflanze. So lange sie auf unseren Feldern gedeiht, hat eine Hungersnot wie vordem unser Land nicht wieder verwïsten können.

Wenn wir uns nun noch vergegenwärtigen, welches wichtige Futtermittel die Knnollen für die Haustiere siud, wie sie zur Herstellung vou Stärke (Kartoffelstärke oder Kartoffelmehl) dienen, und wie die Stärke zu Stärkezucker und in den Bremnereien weiter zu Spiritus (Alkohol) verarbeitet wird: dann haben wir etwa ein Bild von der außerordentlichen Bedeutung der unscheinbaren Pflanze. Darum arbeitet man auch unablässig an ihrer Veredlung weiter (s. S. 19), und fort und fort zïchtet man Sorten, deren Knollen einen immer höheren Stärkegehalt aufweisen.

Da aber die Knollen sehr arm an Eiweiß sind und gar kein Fett enthalten, so können sie uns als einzige Nahrungsquelle nicht dienen; denn diese beiden Stoffe sind neben der Stärke (oder einem anderen Kohlenhydrat, z. B. dem Zucker) für die Erhaltung unseres Körpers unbedingt notwendig (Näheres hierüber s. "Der Mensch“, Absch. über die Verdaunng). Dasselbe gilt auch für die Tiere. Da die Stärke besonders fettbildend wirkt, so wird uns auch die Verwendung der Kartoffel beim Mästen der Hanstiere verständlich.

B. Vou den iibrigen Teilen der Kartofiel (2.). 1. Stengel und Blätter. a) Die kantigen Stengel tragen zahlreiche, große, rauhhaarige Blätter, deren Flächen so tief geteilt sind, daß sie sich an der Mittelrippe nur noch als schmale Säume entlang ziehen. Wir haben es hier also nicht mit gefiederten, sondern wie beim Raps mit fiederspaltigen Blättern zu tun. Zwischen den größeren fiederartigen Abschnitten sind, soweit Platz vorhanden ist (das heißt?), kleinere eingefügt, so daß der Raum, welcher der Pflanze für die Besonnung zur Verfïgnng steht, nach Möglichkeit ausgenützt ist. Andererseits werden die Lïcken zwischen den großen Abschnitten doch nicht so ausgefüllt, daß nicht noch genug Licht zu den tiefer stehenden Blättern gelangen könnte. Nach dem Blattgrunde zu werden die größeren Abschnitte allmählich kleiner; denn in der Nähe der Stengel werden ja Licht und Raum von mehreren Blättern beansprucht. Sollen sich die (tief geteilten) Blattflächen daselbst nun nicht gegenseitig decken (Nachteil?), so muß eben eine Verschmälerung eintreten.

b) Stengel und Blätter enthalten ein Gift (Solanin), so daß sie - von einigen wenigen Insekten abgesehen (s. Absch. D.) - kaum von einem Pflanzenfresser berührt werden. Walıscheinlich merken die Tiere, daß sie es hier mit etwas Ungenießbarem zn tun haben, schon an dem eigentïmlichen Geruch, der den grünen 'Teilen entströmt. In noch größerer Menge findet sich das Gift 
in deu Frïchten, in den "Keimen" und in denjenigen Knollen, die vom Sonnenlicht getroffen wurden und (wie andere Stengelteile) ergrünt sind. (Wie hat man sich daher gegen gekeimte und ergrïnte Ḱnollen zu verhalten?)

2. Blïte (3.). Die Blüte besteht ans einem 5-zipfeligen Kelch, einer radförmigen Blumenkrone, deren Rand in 5 Ecken ausgezogen ist, 5 Staub-

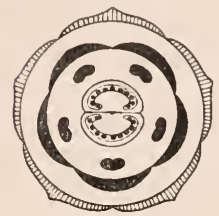

Bliitengrundrif der Kartoffel. blättern, deren große Beutel einen Kegel bilden, und einem Stempel, dessen Griffel den Staubbeutelkegel an der Spitze durchbricht. Obgleich die Bliite durch das Weiß oder Blaßviolett der Blumenkrone, sowie durch das leuchtende Gelb der Staubbeutel ziemlich auffällig ist, wird sie doch nur selten von Insekten (Fliegen) besucht; denn sie besitzt keinen Honig und nur wenig Blütenstaub. Bei mehreren Spielarten der Pflanze tritt regelmäßig Selbstbestäubung ein: der Staub rieselt aus 2 Löchern an der Spitze der Beutel hervor und fällt, da die Blïten meist schräg oder gar senkrecht nach unten gerichtet sind, auf die darunter befindliche Narbe. Bei anderen Kartoffelsorten findet ïberhaupt keine Bestäubung statt, und bei wieder anderen fallen die Blïten sogar ab, bevor sie sich noch geöffnet haben: die Pflanzen sind unter der Hand des Menschen, für den die Blüten und Früchte völlig wertlos sind, entartet. (Vgl. mit ähnlichen Erscheinungen an Haustieren!)

3. Frucht (4. und 5.). Stellt man durch die Frucht einen Querschnitt her, so sieht man, daß ihre Wand aus 2 Fruchtblättern gebildet ist, die an den Rändern miteinander verwachsen sind und sich als eine Scheidewand quer durch das Fruchtinnere erstrecken. Die Scheidewand ist an beiden Seiten zu halbkugeligen Samenträgern angeschwollen, die dicht mit Samenknospen besetzt sind. Zur Zeit der Reife werden Fruchtblätter und Samenträger fleischig, so daß die Frucht eine vielsamige, 2 fächerige Beere darstellt. Sie ist von grüner Färbung und, weil giftig (s. Absch. 1 b), ungenießbar. Auch die Samen haben für uns keine Bedeutung. Die aus ihnen hervorgehenden Pflänzchen bringen zwar gleichfalls Knollen hervor; doch sie sind so klein, daß diese Art der Vermehrung durchaus unwirtschaftlich wäre.

C. Von der Heimat und Verbreitung der Kartoffel. Schon die oben erwähnten Tatsachen, daß die grünen Teile der Kartoffel bereits durch einen gelinden Frost getötet werden, und daß die Knollen selbst im Keller oft erfrieren, weisen darauf hin, daß die überaus wichtige Pflanze kein Glied der heimatlichen Natur, sondern ein Kind wärmerer Gegenden ist. Erst etwa in der Mitte des 16. Jahrhunderts wurde sie aus ihrer südamerikanischen Heimat durch Spanier nach Europa gebracht und anfänglich nur als Zierpflanze angebaut. Von Spanien kam sie bald nach Italien und erhielt hier wegen der Ähnlichkeit der Knollen mit den Trïffeln den Namen "Tartuffoli", woraus unsere Bezeichnung "Kartoffel" entstanden ist. Langsam verbreitete sie sich weiter; ihre Knollen galten aber geraume Zeit hindurch nur für einen Lecker- 
bissen. Erst als im 18. Jahrhundert große Teile von Dentschland durch Miliernten heimgesucht wurden, denen Hungersnot und Teuerung folgten, erkannte man allmählich den Wert der Pflanze. Ihr Anbau wurde jetzt allgemeiner. Vorher aber galt es, in einem langen, hartnäckigen Kampfe den Widerstand zu brechen, der von seiten der Landbevölkerung der Einführung des neuen Gewächses entgegengesetzt wurde. Es war ein Kampf, der vielfach nur durch Anwendung von Gewaltmitteln entschieden werden konnte, und in dem sich besonders die beiden Prenßenkönige Friedrich Wilhelm I. und Friedrich der Große unsterbliche Verdienste erworben habeu. Hentzntage ist die Kartoffel iiber den größten Teil der Erde in zahllosen Spielarten verbreitet (nenne die dir bekannten und beschreibe ihre Knollen!). Nur in den wärmsten Ländern vermag sie nicht $\mathrm{zu}$ gedeihen.

D. Yon den Krankheiten und Feinden der Kartoffel. Wie anf allen anderen Pflanzen schmarotzen auch auf der Kartoffel zahlreiche niedere Pilze, die verschiedenartige Krankheiten hervorrufen. Die gefürchtetste unter ihnen ist der Pilz der eigentlichen Kartoffelkrankheit (s. das.). Er tritt besonders in nassen Jahren auf, bewirkt ein Schwarzwerden des Lanbes und durchwuchert die Knollen, so daß sie sich schließlich in eine janchige oder bröcklige Masse verwandeln (nasse und trockene Fïule).

Von den tierischen Feinden seien nur der Engerling und die Erdraupen, die an den Knollen nagen, sowie der Kolorado-Kartoffelkäfer genannt (s. Lehrb. d. Zoologie). Der schmucke Käfer (6a.) ist in Nordamerika heimisch und nährt sich gleich seiner Larve $(6 \mathrm{~b}$.) von den Blättern, an die er anch seine Eier legt (6c.). Das Auftreten des ïberaus gefährlichen Schädlings in Europa war glïcklicherweise stets nur von kurzer Daner.

\section{Andere Nachtschattengewiichse.}

A. Nachtschattengewächse mit Beerenfrüchten.

Wie die Kartoffel enthalten zahlreiche andere Glieder der Familie in allen oder vielen ihrer Teile ein scharfes Gift (Schutzmittel gegen Pflanzenfresser), das auf den Menschen je nach seiner Art und je nach der Menge, in der es genossen wird, sehr verschieden einwirkt. Solche Giftgewächse sind die beiden nächsten Verwandten der nützlichen Kartoffel, der schwarze und der bittersïge Nachtschatten (Solánum nigrum und dnleamára). Ersterer kommt auf Schutt, sowie als lästiges Unkraut in Gärten und Feldern häufig vor, ist einjährig (schwache Wurzel!), hat weiße Blüten und schwarze, giftige Beeren; letzterer wächst in Gebïschen, besonders an Flußufern, ist eine ausdauernde Kletterpflanze (tiefgehende, holzige Wurzel!), hat meist sehr verschiedengestaltete Bläter, violette Blïten and rote, aher nicht giftige Beeren, die anfangs bitter und nachher süßlich schmecken ("Bittersü $\left.B^{4}\right)$. - - Als das gefährlichste Gewächs, das die heimatliche Pflanzenwelt iiberhanpt besitzt, ist die Tollkirsche (Átropa belladónna) zn nennen. Die meterhohe Pflanze wächst in schattigen Bergwäldern und besitzt denentsprechend (s. S. 7, b. u. c.) große und verhältnismäBig zarte Blätter. Die Blüten bilden bräunliche, hängende Glocken (Bedeutung?). Die Frucht ist eine glänzend schwarze Beere, die aber in dem bleibenden Kelche sitzt. Da sie einer Herzkirsche (Name!) 
ähnelt, wird sie besonders von Kindern leicht lafür gehalten. Sie ist aber mit der Wnrzel der giftigste Teil der ganzen Pflanze. Ihr Genuß bewirkt Sehwindel, Betänbung und oft den Tod (Gegenmittel: Brechmittel und

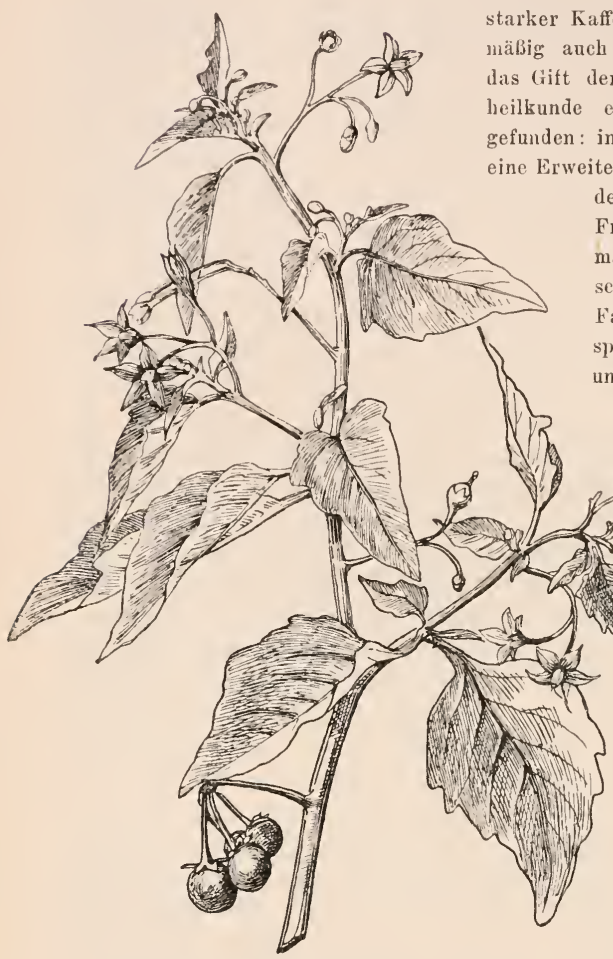

Sehwarzer Nachtschatten. (Nat. Gr.) las dare geträufelt. Früchte vou solcher Giftigkeit - sollte mall meinen - müßten auch den Tieren sehädlich sein. Das ist auch meist der Fall. Drosseln und Amseln jedoch verspeisen sie mit sichtlichemWohlbehagen und besorgen dadurch nnfreiwillig die Aussaat der Samen (s. S. 64,8 ). Darum besitzen auch diese Früchte, so giftig sie fïr $\mathrm{uns}$ sind, auffiillige Färbung, sowie süßes, saftiges Fruchtfleisch. Früher benutzte man in Italien die Beeren zum Schminken: daher "bella donna", d. h. schöne Frau.

Neben diesen Naehtschattenarten gibt es aber auch mehrere andere, die kaum giftig sind und deren Beeren z. T. sogar vom Mensehen genossen werden. Als die wichtigste wäre zuerst der Liebesapfel oder die Tomate (Solánum lycupérsicum) zu nennen. Die Pflanze ist der Kartoffel überaus ähnlich, stammt aus Südamerika und wird

der prächtig roten Früchte wegen (Name! Verwendnng?) bei uns immer mehr angebant. Eßbar sind anch die Früchte der bei uns heimischen Judeıkirsche (Phýsalis alkekéngi), die zumeist aber nur als Zierpflanze bekannt ist. Zur Zeit der Reife sind die roten, kirschengroßen Beeren von dem aufgeblasenen, gleichfalls roten Kelche umhiillt, welcher der Kopf bedecknng ähnelt, wie sie im Mittelalter die Judenfrauen trugen (Name!). - Die roten, schotenähalichen Früchte der Paprikaptlanze oder des spanischen Pfeffers, (Cápsicum) sind von sehr scharfem Geschmack und werden wie die Früchte des Pfefferstrauchs als Gewürz verwendet. Die Pflanze entstammt dem tropischen Amerika und wird n. a. in großer Menge bei Cayenne ( $w 0$ der Pfeffer wächst*), aber anch in Südeuropa und 
besonders in Ungarn angebaut. - Der Tenfelszwirn (Lýcium barbarum), der vielfach zur Bildung von Hecken (Name!) angepflanzt ist, aber auch oft verwildert vorkommt, hat im Mittelmeergebiete seine Heimat.

B. Nachtsebattengewächse mit Kapselfrüchten.

Nïchst der Kartoftel hat kein Nachtschattengewächs eine so große Bcdentung fïr den Menschen erlangt wie der Tabalk (Nicotiána). Von seinen zahlreichen Arten werden bei uns hesonders zwei angepflanzt: am häutigsten der 1-2 $\mathrm{m}$ hohe virginisrle T. (N. tábacum), seltener der kleinere (Höhe nur bis $1 \mathrm{~m}$ ), aber breithlättrigere Bauern-T. (N. rística). Beide sind einjälrige Pflanzen, die in Amerika ihre Heimat haben. Alle griinen Teile sind dieht mit klebrigen Drïsenhaaren besetzt

(Schutz gegen

Ptlanzenfresser). Die sehr großen Blitter nehmen nach oben hin allmählich an Größe ab, eine Einrichtung, die wir als vorteilhaft für die Belichtıng bereits kennen gelernt haben. Da sie sich - von den obersten abgesehen - mit der Spitze zum Erdboden herabneigen, so leiten sie das Regenwasser, von dem sie getroflen werden, nach außen (centrifugal). Dementsprechend verlanfen auch die Seitenwurzeln, die meist am oberen Teile der tiefgehenden Pfahlwurzel entspringen, wagerecht im Boden und gehen samt ihren Verzweigungen nicht über den Umkreis der Pflanze hinaus (s.

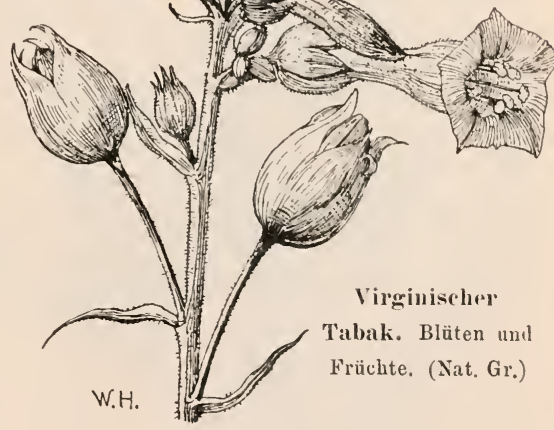
S. 88, c). Der Stengel und seine Zweige tragen am Ende große Sträuße von Röhrenblüten, die beim virginischen T. lang und von roter, beim Bauern-T. wesentlich kürzer und von gelb-grüner Färbung sind. Die Frucht ist eine Kapsel, die sich im Schutze des Kelches entwickelt, in 2 Klappen aufspringt und zahlreiche, sehr kleine Samen enthält.

Haben die Pflanzen ihre volle Größe erreicht, so werden die Blätter abgebrochen, auf Schnïre gereiht und unter einem Dache zum Trocknen aufgehăngt. In der Fabrik werden sie wieder angefenchtet und zu großen Haufen anfgeschichtet, in denen sich, durch Spaltpilze veranlaßt, unter Entwicklung hoher 
Wärme (vgl, mit feuchtem Heu!) bald eine Gärung einstellt. Sind die Haufen einigemal umgeschichtet, dann sind die Blätter zum Gebranch fertig, so daß sie nunmehr als Rauch-, Kau- und Sclnupftabak verwendet werden können.

Als die Spanier zuerst mit den Eingeborenen von Amerika in Beriihrung kamen, war unter diesen die Sitte des Tabakrauchens bereits ïblich. Es wälırte nicht lange, so fand sie auch in Europa Eingang. Obgleich der Genuß des Tabaks in mehreren Ländern selbst mit den schwersten Strafen bedrolit wurde, breitete er sich doch unaufhaltsam immer weiter ans, und jetzt gibt es wohl

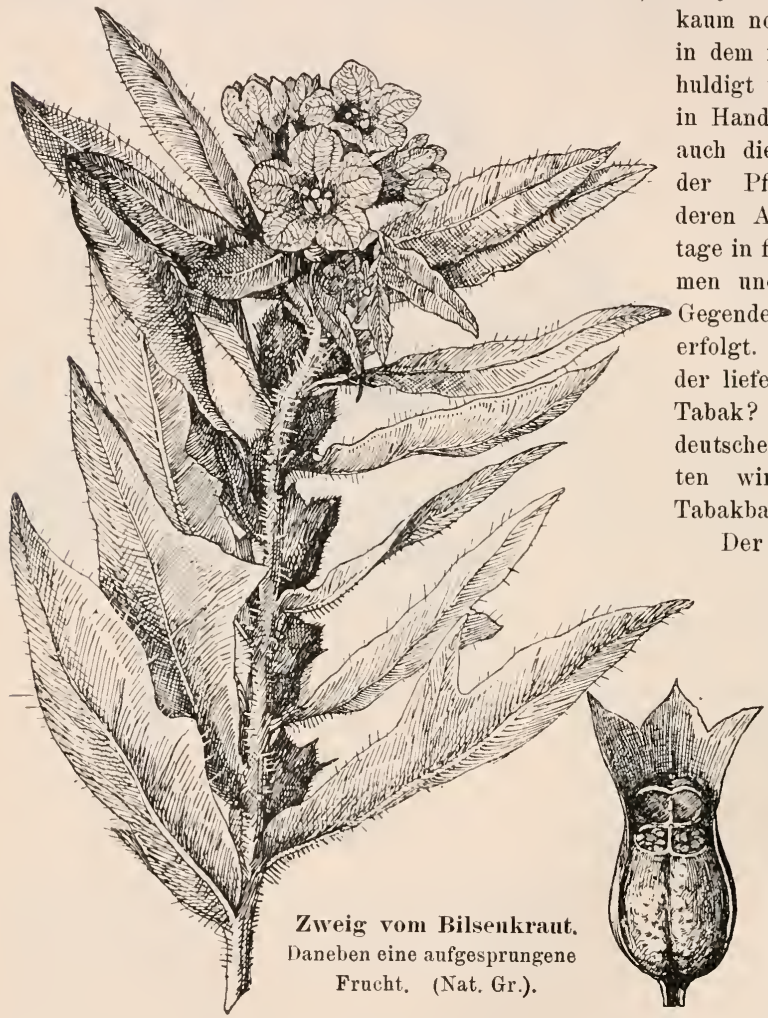
kaum noch ein Land, n dem ihm nicht gehuldigt wïrde. Hand in Hand hiermit ging auch die Verbreitung der Pflanze selbst, deren Anbau heutzutage in fast allen warmen und gemäßigten erfolgt. (Welche Länder liefern den besten Tabak? In welchen deutschen Landschaften wird besonders Tabakbau getrieben?)

Der Tabak enthält ein Gift, das Nikotin, von dem schon ein einziger Tropfen genügt, einen Hund zu töten. Fortgesetzter starker Genuß von Tabak ganz gleich in welcher Form - ruft daher nicht selten Darm- und Herzerkrankungen hervor, ja er kann sogar eine gänzliche Zerrüttung des Körpers herbeiführen. Für Kinder ist der Tabak selbst in kleinen Mengen ein gefährliches Gift. 
Auf Schutthaufen und an Wegen findet sich das Bilsenkrant (Hyoscýamus niger), eine allbekannte, sehr giftige Pflanze mit klebrigen Blättern und von ekelhaftem Geruch. Die schmutzig-gelben, violett geaderten Blüten sind alle nach einer Seite gerichtet. Die vom stachelspitzigen Kelch umhüllte Kapsel springt mit einem Deckel auf. - An denselben Örtlichkeiten wächst auch der gleichfalls

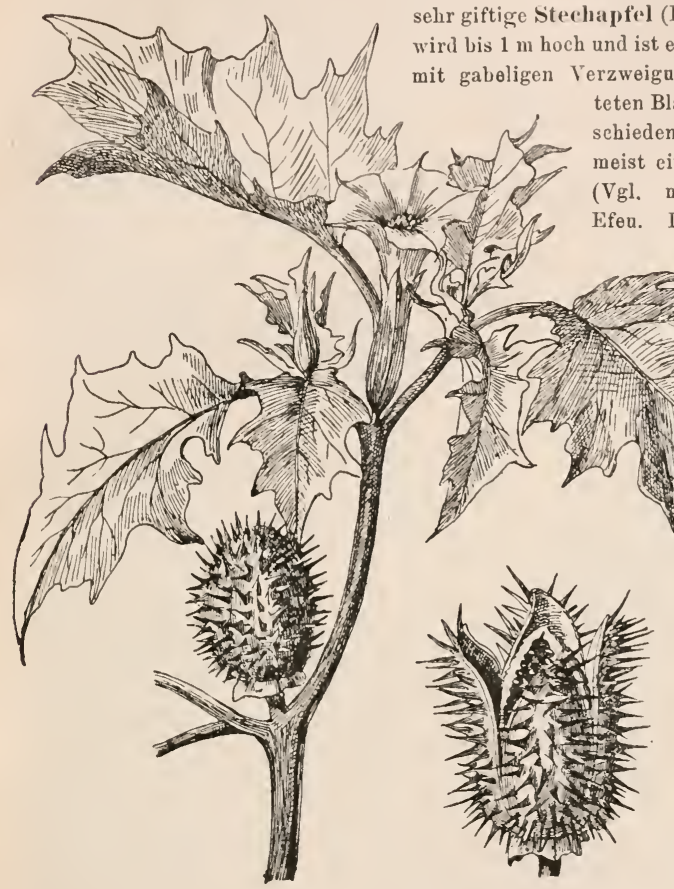

'/weig vom Stechapfel. (Daneben eine aufgesprungene Frucht.) (Nat. Gr.)

Abbildung nicht zo sehen, weil - um alle Teile sichtbar zo machen - die Pflanze von der Seite gezeichnet ist.) Die Blüte wird von Nachtfaltern bestäubt. Sie besitzt daher, wie die des Leimkrautes (s. das.) eine lange Blütenröhre und weiße Färbung, öftnet sich mit beginnen-

der Dunkelheit und haucht besonders während der Nacht einen starken Duft aus. Die Fruchtkapseln, die mit 4 Klappen aufspringen, sind anßen mit vielen spitzen Stacheln besetzt (Name!), ein Schutzmittel der zahlreichen Samen, die, so giftig sie für uns sind, von mehreren körnerfressenden Vögeln ohne Schaden verzehrt werden. - Als letztes Glied der Familie sei endlich die Petunie (Petúnia) erwälnt, die in zahlreichen spielarten unsere Gärten schmückt. Ihre Heimıt ist Südamerika. 


\section{Familie. Lippenblütler (Labiátae).}

Pflanzen mit 4-kantigem Stengel, gegenständigen Blättern und Lippenblüten. Die Blüten besitzen (in der Regel) 2 lange und 2 kurze Staubblätter, sowie einen Fruchtknoten, der bei der Reife in 4 Teilfrüchtchen zerfällt.

Die weiße Taubnessel (Lamium álbum). Tafel 20.

Die Taubnessel, die sich an Zäunen und Hecken, an Wegen, Gräben und ähnlichen Orten findet, zählt zu unseren bekanntesten Pflanzen. Gibt es doch wohl kaum ein Kind, das aus ihren weißen Blüten mit den Hummeln und Bienen nicht schon den süßen Honig genascht hätte („weißer Bienensaug“)! Und jedermann ist auch genötigt, sich die Pflanze genauer anzusehen; denn sie gleicht täuschend der Brennessel, vor deren Brennhaaren (s. das.) sich jeder wohl in acht nimmt. Ihr fehlen aber diese giftigen Waffen ("Ta ubnessel") und darum wird sie auch von den meisten Weidetieren gern verzehrt. Der unangenehme Geruch, der ihr entströmt, und die kurze, rauhe Beha a rung aller grünen Teile sind ihr wenigstens gegen diese Zerstörer kein genügendes Schutzmittel (vgl. mit Schwarzwurz). - Die Ähnlichkeit mit der Brennessel beruht vor allen Dingen in der Form und Stellung der

A. Blätter: sie sind gestielt, eiförmig, am Rande sägezähnig eingeschnitten, stehen sich paarweise gegenüber, und jedes Paar bildet mit dem vorhergehenden oder nachfolgenden Paare ein Krenz (1.). Infolge dieser Anordnung der Blätter ist einerseits der Stengel gleichmäßig belastet (Vorteil?), und andererseits können die Blätter trotz der verhältnismäßig großen Breite doch alle von den Sonnenstrahlen getroffen werden. Aus den Achseln besonders der unteren Blätter gehen vielfach Seitenzweige hervor. - Wie wir w. n. sehen werden, sind die Wurzeln weit im Boden verstreut; wir finden daher an den Blättern auch keine besonderen Einrichtungen, die eine Ableitung des Regenwassers zu den Wurzeln bewirken köunten (vgl. dag. z. B. mit Raps, Birnbaum und Schwarzwurz!).

Vergleicht man Taubnesseln, die an schattigen und feuchten Standorten wachsen, mit solchen trockener und sonniger Stellen, so findet man, daß jene stets größere und viel zartere Blätter besitzen als diese. Diese Verschiedenheit in der Belaubung wird uns sofort erklärlich, wenn wir bedenken, daß ersteren wie den Pflanzen des fenchten Waldbodens (s. S. 7, b. u. c.) genügende Feuchtigkeit, aber schwaches Licht, letzteren dagegen wie allen "Sonnenpflanzen" wenig Feuchtigkeit, aber ungeschwächtes Licht zur Verfügung stehen. Daß wirklich die derberen und meist etwas gerunzelten Blätter der letzteren weit weniger Feuchtigkeit an die umgebende Luft abgeben als die Blätter der ersteren, läßt sich leicht nachweisen. Man brancht nur je eine dieser Pflanzen abzuschneiden, dann wird man finden, daß die Schattenpflanze viel früher welk wird als die "Sonnenpflanze".

B. Stengel. 1 a) Der oberirdische Stengel hat nicht nur die eigene Last und die der Blätter zu tragen, sondern muß auch gegen den Wind, der die Blätter zur Seite weht und ihn daher selbst biegt, widerstandsfähig sein: 


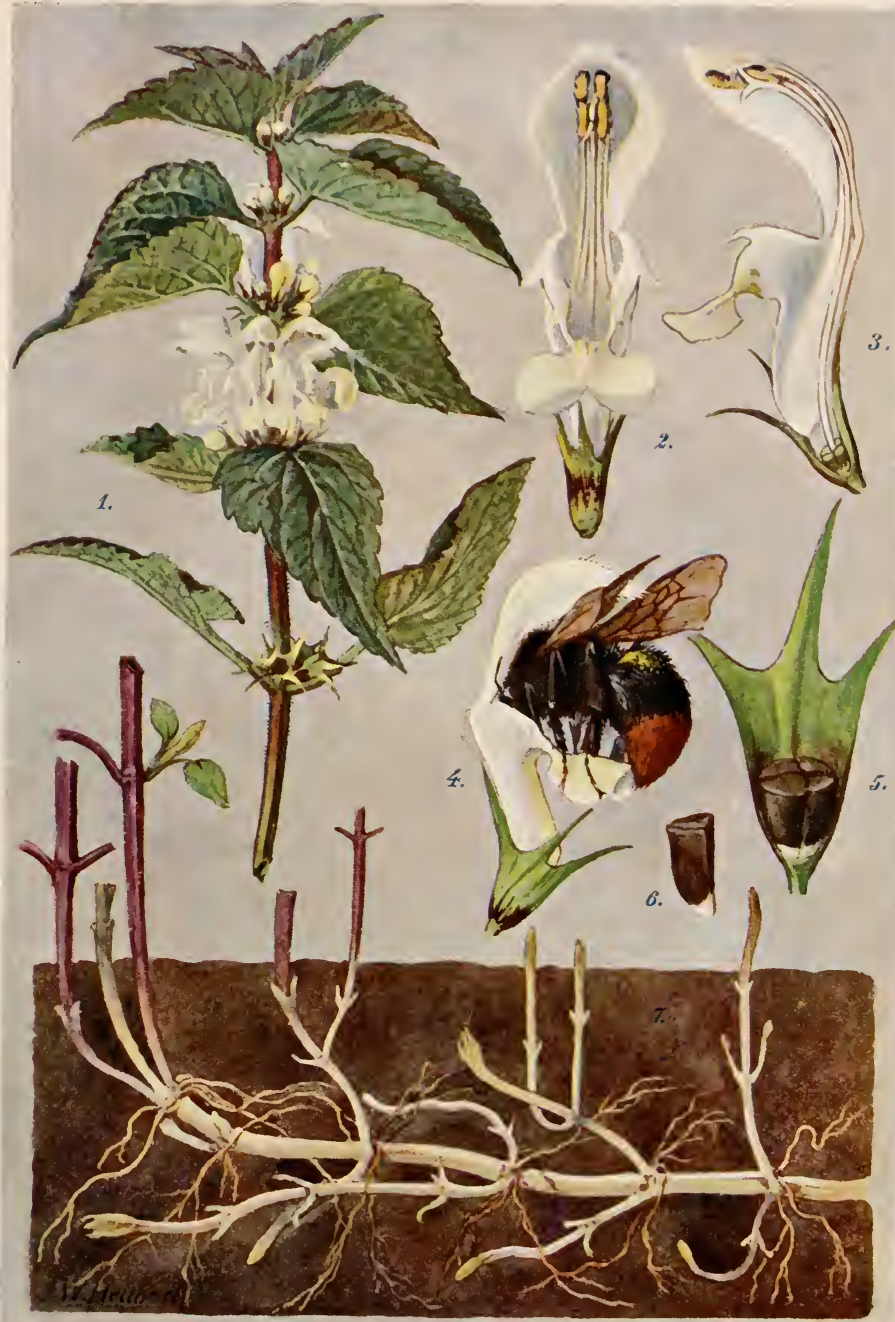

Weiße Taubnessel (Lamium album). 

er muß Trag- und Biegnngsfestigkeit besitzen. Bei einer Biegung werden die Zellen an der konkaven Seite stark zusammengedrückt, die an der konvexen dagegen ansgedehnt. Die zwischen den beiden Seiten liegenden Zellen haben unter der Biegung umso weniger zu leiden, je mehr sie der Mitte des Stengels genähert sind. Daher müssen die festesten Teile in der änßersten Stengelschicht liegen. Stellt man nün durch den Stengel einen sehr dünnen Querschnitt her, so sieht man bei schwacher mikroskopischer Vergrößerung, daß dies auch der Fall ist: man erblickt am Umfange des Stengels 4 Stränge, die aus Zellen mit (besonders in den Ecken) stark verdickten Wänden bestehen. Da diese Zellstränge iiber den Umfang des Stengels etwas hervortreten, so erscheint der letztere vierkantig und zwischen den Kanten rinnig vertieft.

b) Wie jeder Baumeister mit möglichst wenig Material die größte Festigkeit seines Bauwerks zu erreichen sucht - man brancht nur an den Bau von eisernen Brücken zu denken! -, so auch die Natur. Sie vermeidet sorgfältig alles Entbehrliche oder gar Überflüssige. Nun haben wir gesehen, daß bei der Biegung des Stengels die im Innern liegenden Teile umso weniger auszuhalten haben, je weiter sie von den Seiten entfernt sind. Die in der Mitte liegenden haben ïberhaupt nichts mehr auszuhalten; sie tragen demnach auch nichts zur Festigung des Ganzen bei und können daher fehlen. Der Stengel ist also unbeschadet seiner Festigkeit hohl.

c) Wie ein einfacher Versuch zeigt, ist eine lange (Glas-) Röhre weit leichter zu zerbrechen als eine kurze. Dasselbe gilt natürlich auch für röhrentörmige Stengel. Wir sehen daher den Stengel der Taubnessel durch Querwände in mehrere kleine Röhren geteilt. Diese Querwände liegen in den Knoten der Stengel, an denen die Blätter entspringen.

d) Vielfach - besonders bei hohen Pflanzen - liegt der untere Stengelteil dem Boden auf. Dann brechen aus den Knoten dieses Abschnittes zumeist Wurzeln hervor, die das schwankende Gewächs am Boden gleichsam verankern.

2. Gräbt man eine Taubnessel aus der Erde, so sieht man, daß die oberirdischen Stengel ans einem Wurzelstocke hervorgehen. Da dieses Gebilde nichts anderes als ein unterirdischer Stengel ist, so finden wir an ihm auch dieselbe Blattstellung und Verzweigung wie am oberirdischen Stengel ( 7 .).

a) Die Zweige des unterirdischen Stengels erheben sich entweder über den Boden (oberirdische St.) oder kriechen wie der Stengel selbst, von dem sie entspringen, wagerecht in der Erde dahin, bilden also unterirdische Ausläuf'er. Stirbt der Mutterstock ab, so werden die Ausläufer selbständig. Die Bildung: von Ausläufern ist also mit einer Vermehrung der Pflanze gleichbedentend. Da sich nun die Ausläufer wieder verzweigen, so wird uns das truppweise Auftreten der Taubnessel wohl verständlich.

b) Die Blätter der unterirdischen Stengel sind, weil im Dunkeln wachsend, schuppenförmig und wie alle unterirdischen Teile der Pflanze farblus. Sie schïtzen die im Boden vordringenden Enden der Ausläufer und die in ihren Achseln sich bildenden Knospen der Zweige gegen Verletzung. Haben sie diese 
Aufgabe erfüllt, dann sind sie für die Pflanze ohne Bedentung und verschrumpfen. Darum findet man sie anch nur an den jüngsten Auslänfern.

c) Ton den Knoten, aber auch von anderen Stellen der unterirdischen Stengel entspringen zahlreiche fadenförmige Wurzeln (Bedentnng?).

C. Blüten. 1. Blütenstand (1.). In den Achseln der oberen Blätter stehen je 3-7 Blüten, an deren Grunde sich meist noch einige borstenförmige Blättchen finden. Da die Blïten atch die Stengelseiten, an denen keine Blätter entspringen, meist gänzlich verdecken, so sieht es aus, als ob sie in einem "Quirle" rings um den Stengel ständen.

2. Lippenblïte (2.-4.). Ein glockenförmiger, fünfzipfeliger Kelch

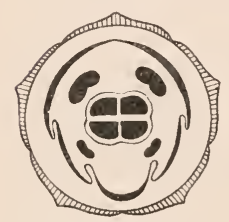

Blïtengrundriß der Taubnessel. umschließt die weiße, seitlich symmetrische Blumenkrone (s. S. 30, a). Ihr unterer Teil ist eine knieförmig gebogene Röhre, deren Seitenwände oben zwei in je ein Zähnchen ansgezogene Lappen bilden. Die Hinterwand der Röhre, deren Öffnung man mit dem Naule eines Tieres vergleichen kann, setzt sich in die helmartige "Oberlippe“, die Vorderwand in die herzförmig ausgeschnittene "Unterlippe" fort ("Lippenblüte"; Familienname!). Unter der Oberlippe finden sich die Beutel der 4 Staubblätter, deren Fäden mit der Röhre z. T. verwachsen sind. Zwischen den Staubbeuteln hat die zweigespaltene Narbe ihren Platz. Der Fruchtknoten (s. Absch. D) findet sich im Blïtengrunde und ist z. T. von der gelappten, helleren $\mathrm{H}$ onigdrïse nmgeben.

3. Hummelblume. Da sich der Honig am Grunde einer langen Röhre findet, ist er nur langrïsseligen Insekten erreichbar. Die Schmetterlinge jedoch sind, obgleich sie den läng'sten Rüssel besitzen, wieder ausgeschlossen: schon die großen und steifen Flïgel hindern sie, soweit in die Blïte einzndringen, als zum Sangen notwendig wäre. Es bleiben daher nur die großen Hummelarten übrig, die auch leicht als die ausschließlichen Besucher der Tanbnesselblïte festzustellen sind. Und wenn man das Verhältnis, das hier zwischen Tier und Pflanze besteht, näher verfolgt, dann wird man anch zahlreiche Einzelheiten im Bau der Blïte verstehen und die Blïte selbst als eine vollendete „H um melblume" erkennen lernen.

a) Die blaßgelbe Unterlippe bildet die "Anflugstange“ und das "Sitzbrett" der Hummel. Daher ist dieser Blütenteil anch wagerecht gestellt. Grïnliche Punkte und Striche, die sich auf ihm und im Eingange zur Blïtenröhre finden, werden als "Honigmale" gedentet (s. S. 121, 3).

b) Die beiden Seitenlappen der Blütenröhre sind genan so weit voneinander entfernt, daß Kopf und Brust der saugenden Hummel zwischen ihnen Platz haben.

c) Hat die Hummel die ztum Saugen notwendige Stellnng eingenommen, so füllt sie mit der Rückenseite gerade die Höhlung der Oberlippe ans, oder 
anders ausgedrückt: die Entfernung zwischen Unter- und Oberlippe entspricht erstlich genau der Größe der Bestäuber, und zweitens, die Oberlippe ist gleichsam nach dem Hummelrïcken "modelliert". - Da die saugende Hummel den Rücken an die Unterseite der Oberlippe drïcken muß, so ist diese Stelle auch der geeignetste Ort für die Narbe und die Stanbbentel; denn diese Blütenteile mïssen von dem Insekt berïhrt werden, falls dessen Besuch für die Pflanze nicht wertlos sein soll.*) - Zugleich ist auch die Oberlippe ein vortreffliches Regendach für den leicht verderbenden Blïtenstanb. Am Rande ist sie mit wimperartigen Haaren besetzt, eine Einrichtung, durch welche die anffallenden Regentropfen verhindert werden, auf die Unterseite ïberzutreten (Versuch!).

d) Soll die Hummel die zur Bestäubung durchans notwendige Stellung einnehmen, so muß der Blüteneingang seitwärts gerichtet sein.

e) Um die von den Pflanzen, gewïnschte" Fremdbestäubung herbeizuführen, muß das mit fremdem Blütenstaub behaftete Insekt zuerst die Narbe berühren (tühre dies näher aus!). Daher ist hier einer der beiden Narbenäste senkrecht nach unten gerichtet, so daß er früher als die Staubbeatel vom Hummelrüicken berührt werden muß.

f) Damit sich die saugende Hummel wirklich mit Blütenstaub belade, iffinen sich erstlich die Staubbeutel nach unten. Alle Beutel "wollen" aber vom Rüicken des Insekts beriihrt sein: sie liegen daher zweitens in einer Ebene. Der geeignetste Ort tïir eine solche Berührung ist nun aber ohne Zweifel die Mitte der Oberlippe. Um dort jedoch Platz zu finden, können die Beutel nicht neben-, sondern müssen hintereinander liegen: 2 Staubblätter besitzen längere, 2 kürzere Fäden (eine Eigentïmlichkeit der ganzen Familie!).

g) Wie oben erwähnt, ist der Honig wegen der Länge der Blütenröhre nur langrïsseligen Hummeln zugängig; kurzrüsselige (darunter auch die Honigbiene) suchen ihn wie z. B. aus der Blüte der Schwarzwurz durch Einbruch zu erlangen.

h) Nicht weit von ihrem Unterende ist die Blïtenröhre plötzlich verengt und innen (öffne sie!) mit einem schräg verlaufenden Ringe feiner Haare ausgerïstet. Schneidet man sie dicht über dieser Stelle quer durch, so sieht man, daß der Haarring gleichsam eine Reuse darstellt, die den untersten, honig-, gefüllten Teil der Röhre abschließt. Kleine Insekten, die in der Röhre hinabgekrochen sind, können den Haarzaun nicht durchdringen: für den Rüssel der krïftigen Hummel dagegen bildet diese "Saftdecke" kein Hindernis.

Knrz: man kann die Taubnesselblüte betrachten wie man will, sie ist in allen Stücken ihren Bestäubern auf's innigste ,angepaßt“.

D. Frucht. Der Fruchtknoten ist genau wie bei der Schwarzwurz (s. das.)

*) Die in Fig. 4 dargestellte Hummel hat sich soeben auf der Unterlippe niedergelassen und ist im Begriff, zum Honig vorzudringen. Erst wenn sie den Kopf noch tiefer in die Blütenröhre senkt, füllt sie die Höhlung der Oberlippe aus. Sie hat von einer andern Blüte Blütenstaub mitgebracht (beachte die Rückenseite des Hinterleibs!), kann hier also Fremdbestäubung vermitteln. 
gebaut und zerfällt bei der Reife gleichfalls in 4 Teilfrüchtchen (5.). Da sie vom bleibenden Kelche fest umschlossen werden, platten sie sich gegenseitig ab und steigen, wenn sie sich bei der Reife vom Blütenboden lockern, in der Kelchröhre gleichsam empor. Dann genügt schon ein leiser Wind, sie ans ihrem Behältnis zu schütteln. Es sind olivenfarbene Gebilde (6.) mit einem weißen, fleischigen Anhange, über dessen Bedeutang aber wie bei den Nüßchen der Schwarzwurz keine sicheren Beobachtungen vorliegen. (Man bekommt die Früchte am leichtesten zu Gesicht, wenn man verblühte Pflanzen in ein Glas mit Wasser steckt.)

\section{Andere Lippenblïtler.}

Die Gattung Tanbnessel (Lámium) wird bei uns noch durch 3 rotblühende Arten vertreten. Eine überaus stattliche Pflanze ist die gefleckte T. (L. maculátum), die der weißblühenden Form sehr ähnlich ist. Sie wächst in Laubwäldern und feuchten Gebüschen und hat dementsprechend große und zarte Blätter, die zudem häufig noch weiß gefleckt sind (Name! vgl. mit Wiesenklee und Lungenkrant). Die beiden anderen rotblühenden Arten sind weit kleiner und kommen auf bebautem Lande als Unkräuter, sowie an Wegen und Hecken überall häufig vor. Sie lassen sich leicht dadurch voneinander unterscheiden, daß die eine Form, die stengelumfassende T. (L. amplexicānle), am oberen Teile stengelumfassende Blätter besitzt, während bei der anderen Art, der roten T. (L. purpúreum), sämtliche Blätter gestielt sind. An der stengelumfassenden Taubnessel finden sich häufig unscheinbare Blüten, dje sich ähnlich wie die Sommerblüten des Veilchens nie öffnen. - Eine prächtige Frühlingspflanze ist die gelbblühende (Name!) Goldnessel (Galeóbdolon lúteum). Da sie dieselben Örtlichkeiten wie die gefleckte Tanbnessel bewohnt, so ist sie gleichfalls ein überaus zartes Gewächs. Auch ihre Blätter sind oft weiß gefleckt.

Bereits im April entfaltet der überall häufige Gundermann (Glechóma hederácea) seine zarten, blanen Lippenblüten. Nur die blütentragenden Triebe sind kräftig genug, sich senkrecht vom Boden zu erheben; sonst liegt das Pflänzchen, aus allen Knoten Wurzeln schlagend, der Erde auf. Diese Lage ist aber für ein Gewächs, dessen Blätter wie bei allen Lippenblütlern kreuzweis gestellt sind, sehr ungünstig. Hier mnB ein Ausgleich geschaffen werden, und das ist auch der Fall : die langen Blattstiele stellen sich senkrecht nach oben; die Blattflächen nehmen die wagerechte Lage ein, und die Blätter, die der Blattstellung entsprechend nach unten wachsen würden, sind durch eine Drehung der Stengelglieder zur Seite gerückt, so daB sie gleichfalls das Licht aufsuchen können. Wie sehr sich die Pflanze den Verhältnissen, unter denen sie gedeiht, anzuschmiegen "versteht", ist auch aus folgender Tatsache ersichtlich: an schattigen Orten sind die Blätter (oft auffallend) groB und zart, an sonnigen dagegen viel kleiner und derber (s. S. 146, 2). - Eine andere bekannte Frühlingspflanze unserer Wiesen und Laubwälder ist der kriechende Gïnsel (Ajúga reptans). Seine leuchtend blauen Blüten besitzen eine so kurze Oberlippe, daß Stanbblätter und Narbe weit aus der Röhre hervorragen. Dafür stehen sie aber so dicht zusammen, daß sie durch die darüber befindlichen Blätter vor Regen geschützt sind. Am unteren Teile des aufrechten Stengels brechen lange Ausläufer hervor (Artname!), an denen dieselbe „Korrektur“ der Blätter wie beim Gundermann zu beobachten ist. Am Ende der Ausläufer, die im Herbste absterben, bilden sich Blattrosetten, aus denen iø nächsten Frühjahre neue Pflanzen hervorgehen (Vermehrung!). - Später im Jahre entfaltet an denselben Örtlichkeiten die Brunelle 
(Brunélla vulgáris) ihre violetten Blüten. Sie stehen dicht übereinander, werden aber von den Blättern, aus deren Achseln sie entspringen, nicht verdeckt; denn diese bleiben nicht nur klein, sondern sind gleich den Kelchen meist sogar bunt (rotbraun) gefärbt (Bedeutung ?).

An Wegen, auf Schutt und an ähnlichen Orten macht sich häufig die Schwarznessel (Ballóta nigra) breit. Die der weißen Taubnessel sehr ähnliche Pflanze hat aber schmutzig rote Blüten. - An denselben Stellen, wie auch als Unkraut unter der Saat findet sich der (gemeine) Hohlzahn (Galéopsis tétrahit). Die Unterlippe der roten Blüten besitzt 2 zahnartige Ausstülpungen (Name!), durch welche die Hummeln genötigt werden, den Kopf so in die Blütenöffnung einzuführen, daß die Staubbeutel unbedingt berührt werden müssen. - Über Wald und Heide, über Feld und Sumpf, über Berg und Tal sind die zahlreichen Ziestarten (Stachys) verbreitet. - Die formenreiche Gattung der Minzen (Mentha) liebt das Wasser (Ufer der Bäche und Flüsse, Sümpfe, feuchte Äcker n. dgl.). Alle Arten baben einen eigentümlichen Geruch, der wie bei der Rose von einem flüchtigen öle herrührt. Das Öl (Verwendung?) wird besonders von der Pfefferminze gewonnen (II. piperita), die wahrscheinlich aus dem Mittelmeergebiete stammt und hier und da, vorwiegend aber in England und Nordamerika im Großen angebaut wird. - Sebr reich an flüchtigen ölen und daher wertvolle Gewürz- oder Arzneipflanzen sind ferner das Bohnenkraut (Saturéja horténsis), der Majoran (Oríganum majorána), der Garten-Thymian (Thymus vulgáris) und der Garten-Salbei (Sálvia officinalis). Die Heimat dieser allgemein bekannten Pflanzen sind die Länder um das Mittelmeer. Das vielfach als Topfgewächs gezogene Basilienkraut (Ócimum basilicum) dagegen stammt aus Ostindien.

Indem wir uns fragen, welche Bedeutung der große Ölreichtum für die Ptlanzen selbst hat, wollen wir uns wieder der Heimat und damit den beiden letzten Gliedern der großen nnd wichtigen Familie zuwenden : dem Feld-Thymian oder Feld-Quendel (Thymus serpýllnuı) und dem Wiesen-Salbei (Sálvia praténsis). Beide sind stark duftende, ausdauernde Pflanzen, die an kahlen Berglehnen, auf sandigen Triften, kurz an trockenen Stellen im heißesten Sonnenbrande wachsen. Der rotbliihende Thymian ist daher auch nur ein niedriges, rasenbildendes Pflänzchen mit winzigen Blättchen (vgl. mit Heidekrant!), und der stattliche Salbei besitzt tiefgehende Wurzeln und stark gerunzelte Blätter (s. S. 120,3). Gleiche wasserarme Örtlichkeiten bewohnen nun in ihrer Heimat die oben erwähnten Gewïrz- und Arzneipflanzen (mit Ausnalıme der Minzen), eine Tatsache, die für die Beantwortung der aufgeworfenen Frage nicht unwichtig zu sein scheint. Es ist nämlich sicher nachgewiesen, daß Luft, die reich an flüchtigen Ölen in Dampfform ist, weit weniger Wärmestrahlen durchgehen läßt, als reine Lnft. Da nun die Pflanzen von einer solchen Dufthülle beständig umgeben werden, so ist es nicht unwahrscheinlich, daß wir es in dem sich stetig verflüchtenden Öle mit einem Schntzmittel der Gewächse gegen zu hohe Erwärmung und damit gegen zu starke Wasserdampfabgabe zn tun haben.

Der Wiesen-Salbei verdient noch wegen seiner interessanten Bestänbungsweise nnsere Beachtung. Von den 4 Staubblattern, wie wir sie bei den Lippenblütlern regelmäßig finden, sind bei ihm (wie bei allen Salbeiarten und einigen anderen Familiengliedern) nur die beiden vorderen vorhanden, die zudem eine 
sehr merkwürdige Ausbildung erfaluren haben: bei den meisten Pflanzen ist der Teil des Staubblattes, der die beiden Staubbentelfächer verbindet, sehr kurz.

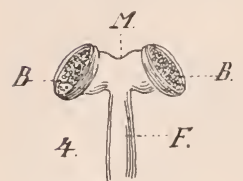

Bei anderen, wie bei dem soeben erwälnten Feld-Thymian, ist dieses sog. Mittelband schon breiter, und beim Salbei endlich iibertrifft die eine Hälfte desselben den Staubfaden sogar an Länge. Die andere Hälfte des Mittelbandes dagegen, der zudem das Staubbeutelfach fehlt,
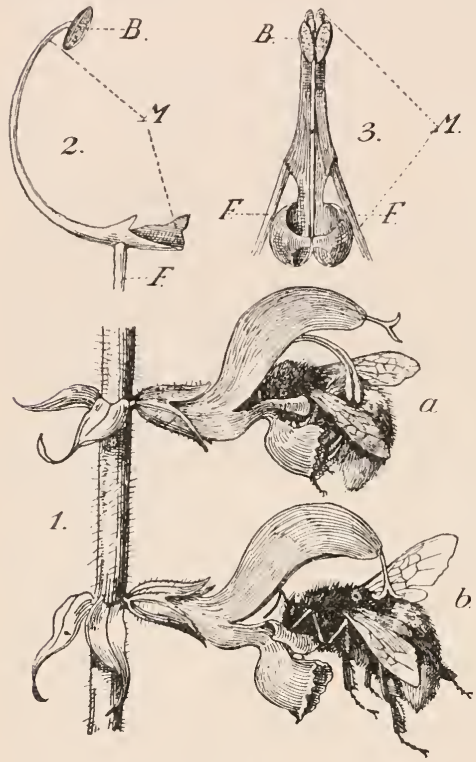

Bestäubung des Wiesen-Salbei.

1. Zwei Blüten, die von je einer Hummel besucht werden: a. jüngere Blüte; die Staubbeutelfächer berühren den Rücken des Tieres. b. ältere Blüte; die anfliegende Hummel streift mit der blütenstaubbehafteten Stelle des Rückens die Narbe. 2. Ein Sta ubblatt, von der Seite, 3. beide Staubblätter, von vorn gesehen. 4. Staubblatt des Feld-Thymians zum Vergleich. F. Staubfaden. II. Mittelband, B. Staubbentelfächer. bleibt verhältnismäßig kurz und ist am Ende zu einer löffelartigen Platte verbreitert, die mit der Platte des anderen Staubblattes den Eingang zur Bliitenröhre versperrt. Der lange Abschnitt des Mittelbandes mit seinem Staubbeutelfache dagegen ist in der Oberlippe der azurblauen Blüte geborgen. Schickt sich nun eine Hummel an, die sich auf der Unterlippe einer jungen Blïte niedergelassen hat, Honig zu saugen, so stößt sie mit dem Kopfe oder Rüssel gegen die beiden erwähnten Platten. Da aber die Mittelbänder mit den Staubfäden gelenkig verbunden sind, so werden die Platten durch das Tier zugleich nach hinten gedrïckt: infolgedessen senkt sich aber der lange Arm des ungleicharmigen Hebels herab, und die geöffneten Staubbeutelfächer schlagen auf dem Rücken der Hummel auf. (Ahme die Tätigkeit des Insekts mit Hilfe eines zugespitzten Bleistifts nach!) Fliegt das Tier, mit Bliitenstaub beladen, nun zu einer älteren Blüte, in der die Staubblätter zwar schon verstäubt haben, die zweigespaltene Narbe sich aber gerade in den Eingang zur Blüte gestellt hat, so muß es die Narbe gleichfalls mit dem Rücken berïhren, also Fremdbestäubung herbeiführen. Diese eigentümliche Art der Bestäubung macht uns auch die verhältnismäßig große Entfernung zwischen Unter- und Oberlippe (melnr 


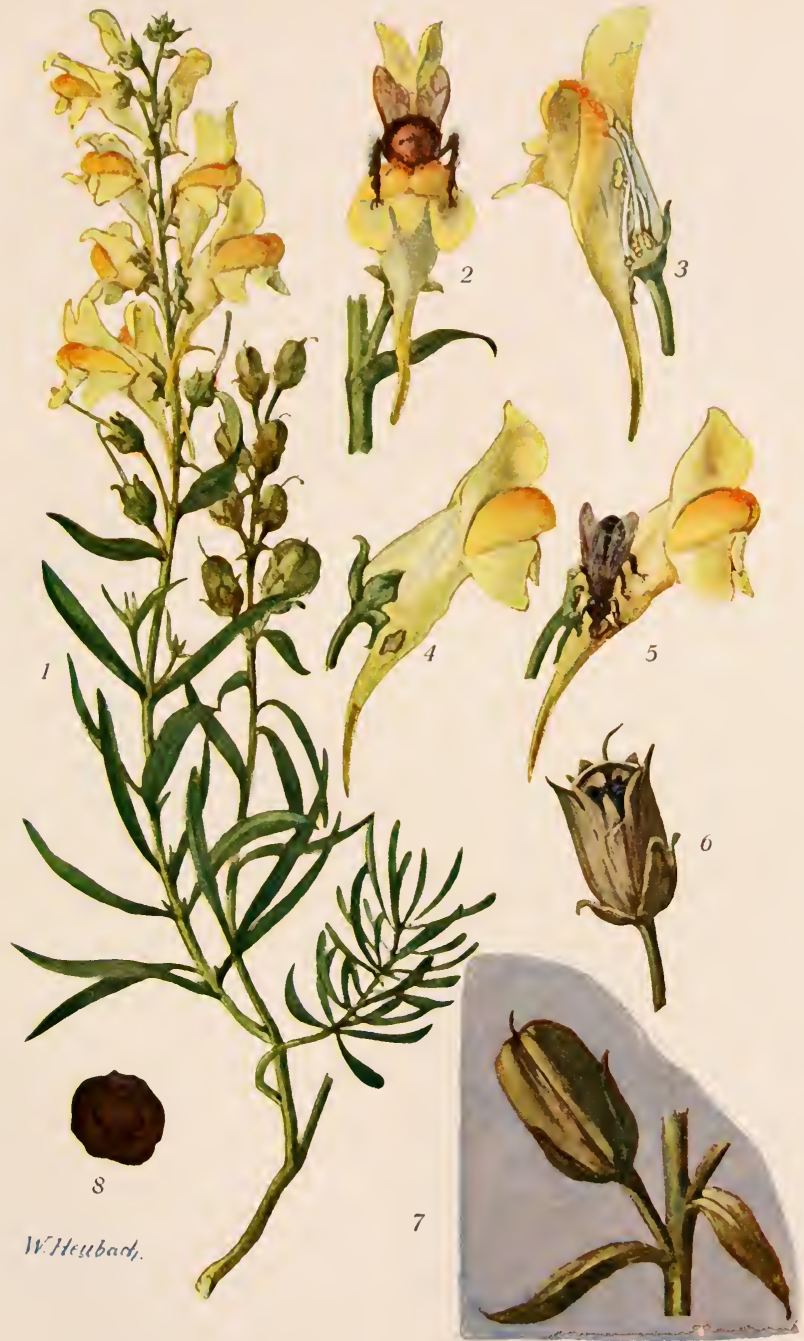

Leinkraut oder Frauenflachs (Linaria vulgaris). 

als Hummelgröße!), sowie die auffallende Schmalheit der Oberlippe verständlich (vgl. mit Taubnessel).

Ein Glied einer nahe verwandten Familie ist das Eisenkraut (Verbéna officinális), das an Wegrändern nnd ähnlichen Orten gedeiht. Es trägt kleine, blaue Blüten und ist, seinem Standorte entsprechend (Beweis!), ein sparriges, rutenförmiges Gewächs mit schmalen, eingeschnittenen Blättern und tiefgehender Wurzel. Im Altertum schrieb man der unscheinbaren Pflanze Wunderkraft zu; so sollte z. B. Eisen darch nichts so gnt gehärtet werden können als durch sie (Name!). - Die prächtigen Ver benen unserer Gärten sind Abkömmlinge einer südamerikanischen Art. - Eine andere, mit den Lippenbliitlern nahe verwandte Pflanze ist die erhte Biirenklaue (Acánthus), die in Südeuropa heimisch ist, bei uns aber öfter als Zierpflanze angebant wird. Die tief eingebuchteten, malerischen Blätter finden seit den Zeiten der alten Griechen besonders in der Bildhauerkunst reiche Verwendung.

\section{Familie. Rachenblütler (Scrophulariáceae).}

Blüten wie bei den Lippenblütlern (s. das.); Frucht aber eine zweifächerige Kapsel.

\section{Das Leinkraut oder der Frauenflachs (Linária vulgáris). Tafel 21.}

Auf Sandboden und an anderen unfruchtbaren Örtlichkeiten ist die zierliche Ptlanze (1.) fast überall häufig anzutreffen. Je nachdem sie unter größerem oder geringerem WVassermangel zu leiden hat, senkt sie den vielverzweigten unterirdischen Stengel (Wurzelstock) samt den Wurzeln, die von ihm ausgehen, mehr oder weniger tief in den Boden. Auch in den schmalen, mit einer Wachsschicht ïberzogenen Blättern (tanche einen Stengel ins Wasser!) besitzt sie ein wichtiges Schutzmittel gegen zu starken Wasserverlust (vgl. S. 22, bezw. 17, 2). Da sich schmale Blätter gegenseitig nur wenig beschatten, sind die aufrechten Stengel anch sehr dicht mit solchen besetzt. Durch diese zahlreichen, schmalen und langen Blätter erhält die (noch nicht blühende) Pflanze eine große Ähnlichkeit mit dem Lein oder Flachs, eine Tatsache, welche die oben angegebenen $\mathrm{Namen}$ hinreichend erklärt.

Aus den Achseln der oberen, kleinen (Bedeutung?) Blätter entspringen die kurz gestielten, zierlichen, gelben $\mathrm{Bl}$ ï te $\mathrm{n}$ (2.-5.), die zusammen eine weithin sichtbare Traube bilden (Bedeutung?). Sie sind denen der Taubnessel außerordentlich ähnlich und gleichfalls vollendete Hummelblumen (beweise beides!). Der mittlere Abschnitt der dreigespaltenen Unterlippe, dessen Orangefarbe als „Saftmal" gedentet wird, ist aber kissenförmig angeschwollen und legt sich dicht und fest an die zweispaltige Oberlippe. Während kleinere Insekten diesen Verschluß nicht zu öffnen vermögen (Bedeutung?), ist dies den großen, kräftigen Hummelarten ein leichtes: sie lassen sich auf der Unterlippe nieder (beachte die Richtung der Zipfel!) unıl kriechen soweit als möglich in den sich öffnenden „Blïtenrachen" (2.). ("Rachenblütler". - Die Pffanze heißt sehr bezeichnend auch „Feld-Löwenmaul".) Da die Hummeln

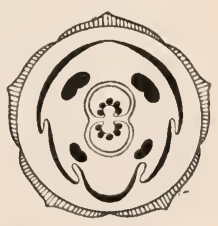

Bliitengrundriß vou Leinkraut. 
infolge ihrer Größe hierbei die Blütenröhre vollkommen ausfüllen, so sind sie auch die gewiesenen Bestäubungsvermittler (Beweis!). Ihnen ist daher auch allein der Honig zugänglich. Er wird von der Unterlage des Fruchtknotens abgeschieden, fließt aber in einen langen Sporn hinab (3.), zu dem der untere Teil der Blütenröhre ausgezogen, und der oft bis zur Hälfte mit dem süßen Safte gefïllt ist (halte die Blïten gegen das Licht!). Die vom Honiggenuß ausgeschlossenen kurzrïsseligen Hautflügler veriiben allerdings sehr häufig Einbruch (4. u. 5.).

Hinsichtlich der Frucht dagegen unterscheidet sich das Leinkraut wesentlich von der Taubnessel: sie ist eine Kapsel, die sich bei der Reife im oberen Teile mit 6 unregelmäßigen Zähnen öffnet (6). Der Wind schüttelt dann die zahlreichen Samen aus (8.). Da sie rings von einem Hautrande umgeben sind, können sie weit verweht werdeu (Bedeutung?). Bei Eintritt feuchter Witterung schließt sich, wie wir dies bereits bei zahlreichen anderen Pflanzen kennen gelernt haben (Beispiele! Bedeutung?), die Kapsel wieder (7.).

\section{Andere Rachenbliitler.}

1. An Felsen and altem Mauerwerk siedelt sich gern das efeublätrige Leinkraut (L. cymbalária) an, das aus Südeuropa eingewandert ist. Das überaus zierliche Pflänzchen hat schwache, kriechende Stengel, fünflappige BIätter wie der Efeu (Name!) und violette Blüten, die von langen Stielen in das Licht gerückt werden (Bedeutung?). Nach dem Verblühen aber krümmen sich die Blütenstiele zarück, so daB die reifenden Kapseln der Unterlage zugewendet werden. Infolgedessen gelangen die ausfallenden Samen in Felsenspalten and Mauerritzen, also an Orte, an denen der Keimling and die junge Pflanze die zam Leben notwendige Erdmenge finden. - Gleichfalls aus Südeuropa ist das Löwenmaul (Antirrhinum majus) zu uns gekommen, das in fast zahllosen Farbenspielarten eine unserer bekanntesten Zierpflanzen ist. - Kurze Röhrenblüten mit kleinen Lippen besitzt die knotige Braunwurz (Scrophalária nodósa), die ihren Namen nach dem knotigen, dunkelgefärbten Wurzelstocke trägt. Die allbekannte Pflanze findet sich in feuchten Wäldern und Gebüschen und hat den Standorten entsprechend (s. S. 7, b und c) groBe und zarte Blätter. Die braunen Blüten werden vorwiegend von Wespen besucht und bestäubt.

Der rote Fingerhnt (Digitális purpúrea) bewohnt Gebirgsgegenden. Dort schmückt er besonders Waldblößen mit seinen prächtigen, einseits-wendigen Blätentrauben. Die großen, purpurroten Bläten stellen hängende Glocken dar (Name, Schutz gegen Regen!). Nachdem die Blütenkrone abgefallen ist, richten sich die Blütenstiele wieder empor, so daB die am oberen Teile sich öffnenden Früchte aufrecht gestellt sind. Infolgedessen fallen die zahlreichen kleinen Samen nicht - wie es sonst der Fall sein würde - sämtlich in nächster Nähe der Pflanze zu Boden, sondern können durch WindstöBe leicht über einen großen Umkreis verstreut werden (Bedeutung?). Alle Teile des stolzen Gewächses enthalten ein sehr heftiges Gift (Digitalin), das Weidetiere vom Verzehren der grünen Teile abhält, uns aber als wirksames Heilmittel, vorzüglich bei Herzkrankheiten, dient.

2. Zahlreiche andere Glieder der formenreichen Familie besitzen Blüten, die einige Ähnlichkeit mit einem Rade haben: die kurze Blütenröhre (Nabe des 

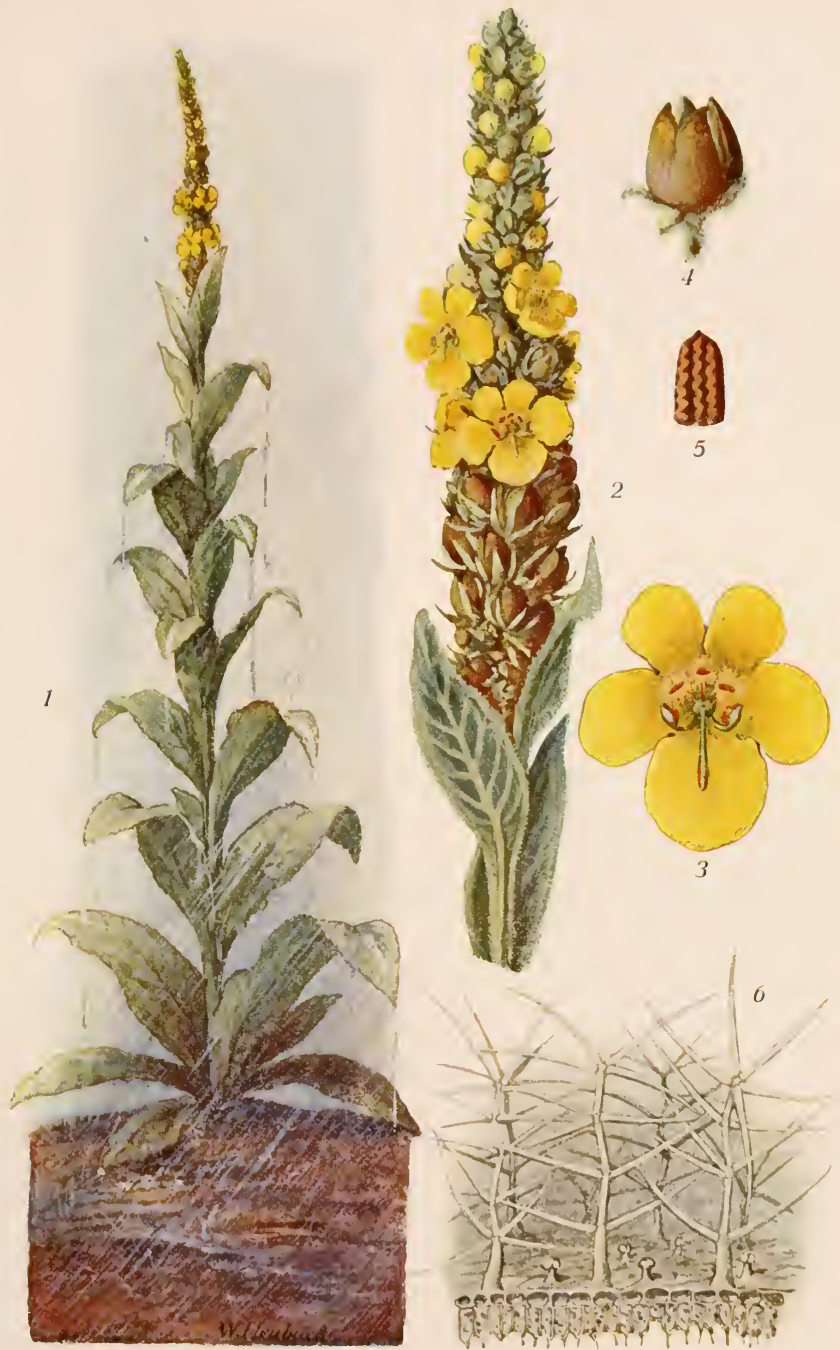

Echte Königskerze (Verbascum thapsus). 

Rades!) breitet sich in einen Saum ans, der in 4 oder 5 Abschnitte (Speichen des Rades!) gespalten ist. Bliiten dieser Art finden wir z. B. bei den Königskerzen (Verbáscum), die in zahlreichen Arten zumeist steinige, sonnige Orte bewohnen. Eine der am häufigsten vorkommenden Formen ist die echte K. (V. thapsus), die nicht selten die Höhe von $1 \frac{1}{2} \mathrm{~m}$ erreicht und zumeist die Gestalt einer regelmäßigen Pyramide aufweist (Belichtung! Auf Tafel 22, 1 ist die Pflanze bei einem heftigen Regen dargestellt). Die Spitze der Pyramide wird von dem kerzenartigen Blütenstande gebildet (Name!), der aus zahlreichen, leuchtend gelben Blüten (2. u. 3.) zusammengesetzt ist. Da sich die braunen Fruchtkapseln bei der Reife im oberen Teile öffnen (4.), so vermag der Wind, der den hohen, elastischen Stengel erschïttert (Schlender!), die zahlreichen, kleinen und gefurchten Samen (5.) leicht über einen weiten Bezirk zu verstrenen. Die grünen Teile der stattlichen Pflanze sind so dicht mit Haaren bedeckt, daß sie sich wie Filz anfïhlen (darum auch "Wollkraut" genannt). Auf der Schleimhaut des Mundes verursachen die Haare ein lästiges Jucken und Kratzen. Darum hïten sich Weidetiere anch, die Pflanze zu beriihren. Bei mikroskopischer Betrachtung geben sich die Haare als Gehilde zu erkennen, die wie Tannenbäumchen verzweigt sind ( 6 . Haarfilz bei 50 facher Vergr.). Sie verhindern daher auch in vortrefflicher Weise eine zu schnelle Ernenerung der Luftschicht, von der die Pflanze umgeben wird, und damit eine zu starke Verdunstung des Wassers durch die Blätter (s. S. 43. ( a). Dieser Schutz ist um so wichtiger, als ja die Pflanze auf sehr trockenem Boden wächst. Darum finden wir auch erstlich den Haarüberzug an jungen Teilen besonders entwickelt; daher erscheint ferner die Blattrosette, welche die Königskerze im ersten Jahre bildet, und die den trockenen Winter zu überstehen hat (s. S. 92), wie aus Filz geschnitten, und darum kann endlich die Pflanze im Gegensatz zu zahlreichen kleinblättrigen Gewächsen derselben Standorte (Beispiele!) auch so große, weil wohlgeschützte Blätter tragen. Die Blätter sind infolge ihrer Größe andererseits auch wieder imstande, eine verhältnismäßig große Menge von Regenwasser aufzufangen und der Wurzel zuzuleiten, die sich fast unverzweigt tief (Bedeutung!) in den Boden senkt. Der Ableitung des Wassers nach der Mitte der Pflanze scheint aber die Haltung der Blätter nur teilweise zu entsprechen. Zwei Drittel jeder Blattfläche sind allerdings zum Stengel schräg aufwärts gestellt. Das andere Drittel dagegen ist schräg nach unten gerichtet, so daß das Wasser yon ihm auch nach außen abfließen muß. Trotzdem geht es für die Pflanze nicht verloren: wie leicht $\mathrm{zu}$ beobachten ist (1.), tropft es nämlich auf ein darunter stehendes Blatt und zwar stets an eine Stelle desselben, von der ans es dem Stengel und damit der Wurzel zugefuihrt werden muß.

Gleichfalls radförmige Bläten, aber nor mit 2 Staubblättern, besitzen die zahlreichen Arten der Gattung Ehrenpreis (Verónica), von denen hier nur die verbreitetsten erwähnt werden können. Anf Wiesen und an ähnlichen Orten wächst der Gamander.E. (V. chamédrys), der an den zweireihig behaarten Stengeln leicht kenntlich ist. Die 
prächtig blauen Blüten sind zu Trauben gehäuft, werden daher trotz der Kleinheit weithin sichtbar. Besonders zahlreich stellen sich zierliche Schwebfliegen ein, die zameist den unteren Zipfel des Blumenkronensaumes als Anflugsplatz benutzen. Dabei
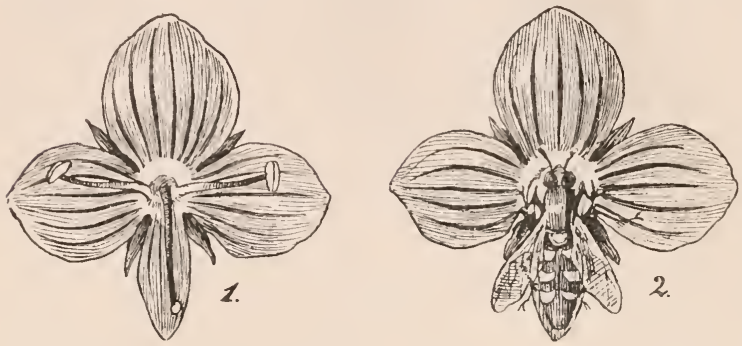

Blïten vom Gamander-Elurenpreis. Bei 2 hat sich eine Schwebfliege an dem unteren Zipfel des Blumenkronsaums festgeklammert, so daß die Blüte bestäubt wird. (Etwa 4 mal nat. Gr.)

drücken sie denGriffel herab und ergreifen die drehbaren Staubfäden, so daB auch deren Beutel mit der Unterseite des Körpers in Berührung kommen (Bedeutung?). Da die Blumenkrowen sehr leicht abfallen, hat das Volk dem zier-

lichen Pflänzlein den Spottnamen „Männertreu“ beigelegt. - Im Frühjahre findet sich besonders unter der Saat der Efell-E. (V. hederifólia) mit einzelnstehenden blaßblauen Blüten und efeuähnlichen Blättern - Ein Bewohner von Bächen und Gräben dagegen ist der Bachbungen-E. (V. beccabunga), der seinem Standorte entsprechend dicke, saftstrotzende Blätter wie die Sumpf-Dotterblume besitzt (s. das.).

3. Die folgenden Rachenblütler haben wieder deutlich zweilippige Blüten wie das Leinkraut und seine nächsten Verwandten, unterscheiden sich von diesen u. a. aber wesentlich dadurch, daß sie sämtlich "Wurzelschmarotzer" sind. Nimmt man z. B. den großen Klappertopf (Alectorólophus májor) vorsichtig aus dem Boden, so staunt man, wie eine Pflanze, die bis $\mathrm{zu}^{1 / 2} \mathrm{~m}$ hoch wird, mit so gering entwickeltem Wurzelwerk ,auskommen" kann. Bei näherem Znsehen findet man aber an den Wurzeln zahlreiche, 2-3 $\mathrm{mm}$ große Wärzchen, die sich an den Wurzeln der Nachbarpflanzen anlegen und diesen Nahrungsstoffe entziehen (vgl. mit Hopfenseide!). Daher sieht man auch häufig auf Wiesen, auf denen der Klappertopf in großen Trupps auftritt, wie die Gräser um ihu absterben. Da er aber grüne Blätter besitzt, vermag er einen großen Teil der zum Leben und Wachstum nötigen Stoffe selbst zu bereiten: er ist nur ein „Halbschmarotzer". Die gelbe Blüte, deren Oberlippe zwei blane Zähnchen besitzt, ist von einem blasigen Kelche umgeben (verfolge die interessante Bestäubung!). Er umhüllt auch die Frucht und dient in erster Linie als ein Windfang: indem er nämlich leicht vom Winde geschüttelt wird, werden anch die Kapseln hin und her bewegt. Dadurch werden aber die Samen, die in den Kapseln bei Erschütterungen klappern (Name!), herausgeschleudert und, weil von einer Flughaut umgeben, leicht weithin verweht (Bedeutung?).

Mit dem Klappertopf tritt auf den Wiesen und Matten zumeist anch der Augen- 


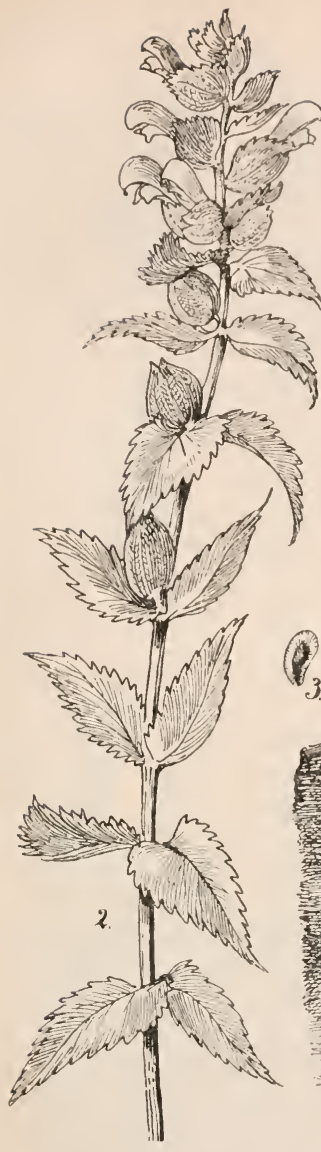

trost (Euphrásia) in großen Mengen auf. Er fügt aber dem Landmann, der ihn hier and da als „Milehdieb" bezeichnet, gleich den anderen Halbsehmarotzern sicher nur geringen Schaden zu. Von der zierlichen, weißblühenden Art, dem „remeinen Au. (Eu. officinális), der früher als Heilmittel gegen Augenleiden galt, führt die Gattang den Namen. Der größere rote Au. (Eu. odontites) kommt als Unkraut häufig auch auf feuchten Äckern vor. - Auf torfigen Wiesen wächst in mehreren Arten das Läusekraut (Pediculáris) mit zierlich zerteilten Blättern und meist roten Rachenblüten. Die niedliche Pflanze ist zu dem unschönen Namen gekommen, weil man eine Abkochung von ihr früher gegen das Ungeziefer der Haustiere anwendete. - Im Schatten der Wälder findet sich der HainWachtelweizen (Melampýrum nemorósum). Da die Blätter, in deren Achseln die gelben Blüten stehen, wie Blumenblätter bunt nnd zwar prächtig

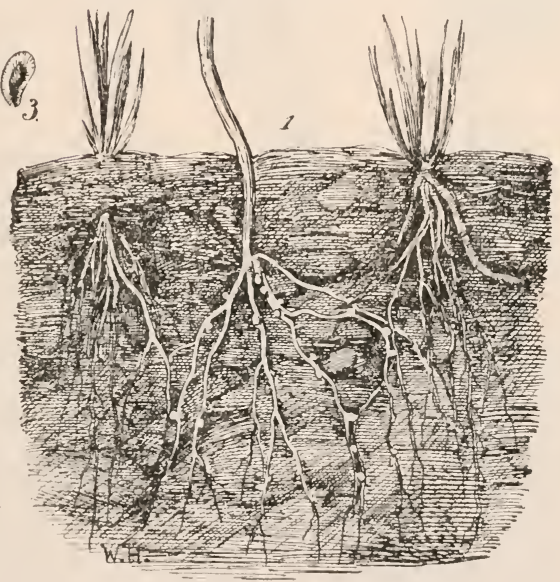

Grogger Klappertopf. 1. Wurzeln mit Saggwärzchen. 2. Blühender nnd Früchte tragender Stengel. 3. Same. (Nat. Gr.).

blau gefärbt sind, wird die zarte Schattenpflanze sehr auffällig (Bedeutung?). - Beim Wiesen-W. (M. praténse), der ein läufiger Schmuck der Waldwiesen ist, findet sich diese Doppelfärbung nicht. Die Samen beider Pflanzen werden gern von Ameisen verschleppt; die weizenkornähnlichen Gebilde (Name!) besitzen nämlich einen sackartigen Anhang, der diesen Tieren als willkommene Speise dient. 


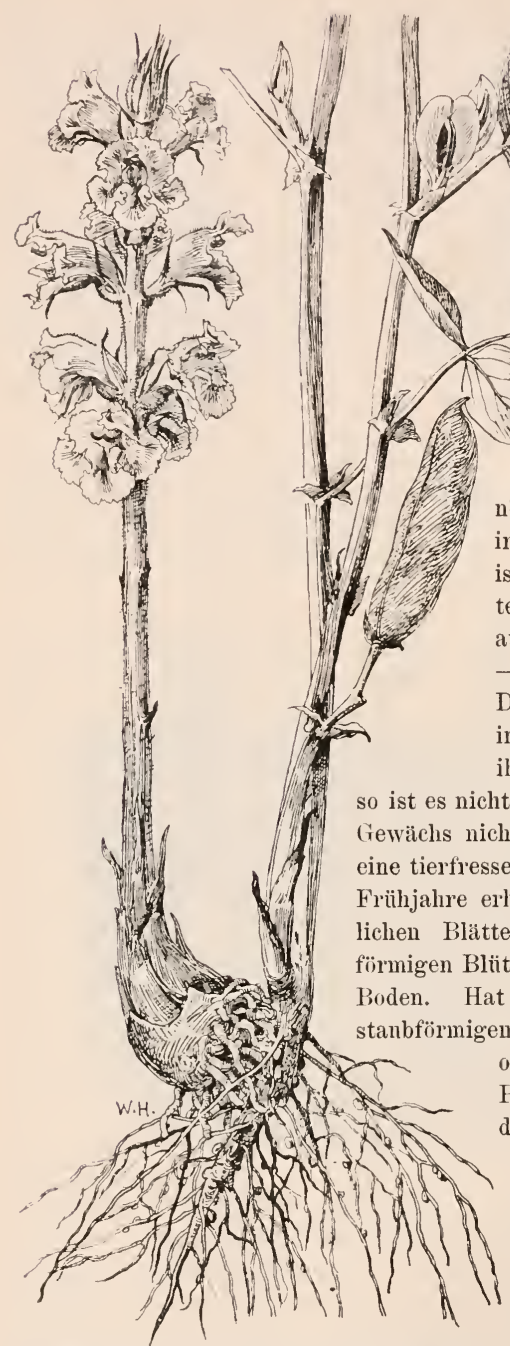

Eine Sommerwurz auf der Wurzel der Pferdeoder Saubohne schmarotzend. (Wenig verkl.)
4. Im Gegensatz zu diesen „Halbschmarotzern" besitzt dieSchuppenwurz (Lathrǽa squamária) kein Blattgrün. Daher ist sie wie die Hopfenseide (s. das.) genötigt, sich vollkommen von anderen Pflanzen ernähren zu lassen. Sie lebt unterirdisch auf den Wurzeln der Laubbäume, denen sie durch Saugwarzen die zum Leben und Aufbau nötigen Stoffe entzieht. Der unterirdische, farblose und fleischige Stamm ist dicht mit schuppenförmigen Blättern (Name!) besetzt, die - wie man auf einem Durchschnitt sehen kann - innen je einen Hohlraum besitzen. Da dieser Raum mit der Außenwelt in Verbindung steht, und da man in ihm Reste sehr kleiner Tiere findet, so ist es nicht unwahrscheinlich, daß das seltsame Gewächs nicht nur ein Schmarotzer, sondern anch eine tierfressende Pflanze ist (s. Sonnentau!). Im Frühjahre erhebt die Schuppenwurz die mit rötlichen Blättern und einseitswendigen, rachenförmigen Blüten dicht besetzten Stengel über den Boden. Hat der Wind die sehr zahlreichen, aberirdische Stengel $a b$, und die Pflanze zieht sich wieder gänzlich in den Boden zurück. Wenn wir bedenken, wie geringe Aussicht die keimenden Samen haben, eine geeignete Wurzel zu treffen, so wird uns ihre große Anzahl wohl verständlich. Und wenn wir weiter bedenken, daß die Samen über ein umso größeres Gebiet verstreut werden können, je kleiner 


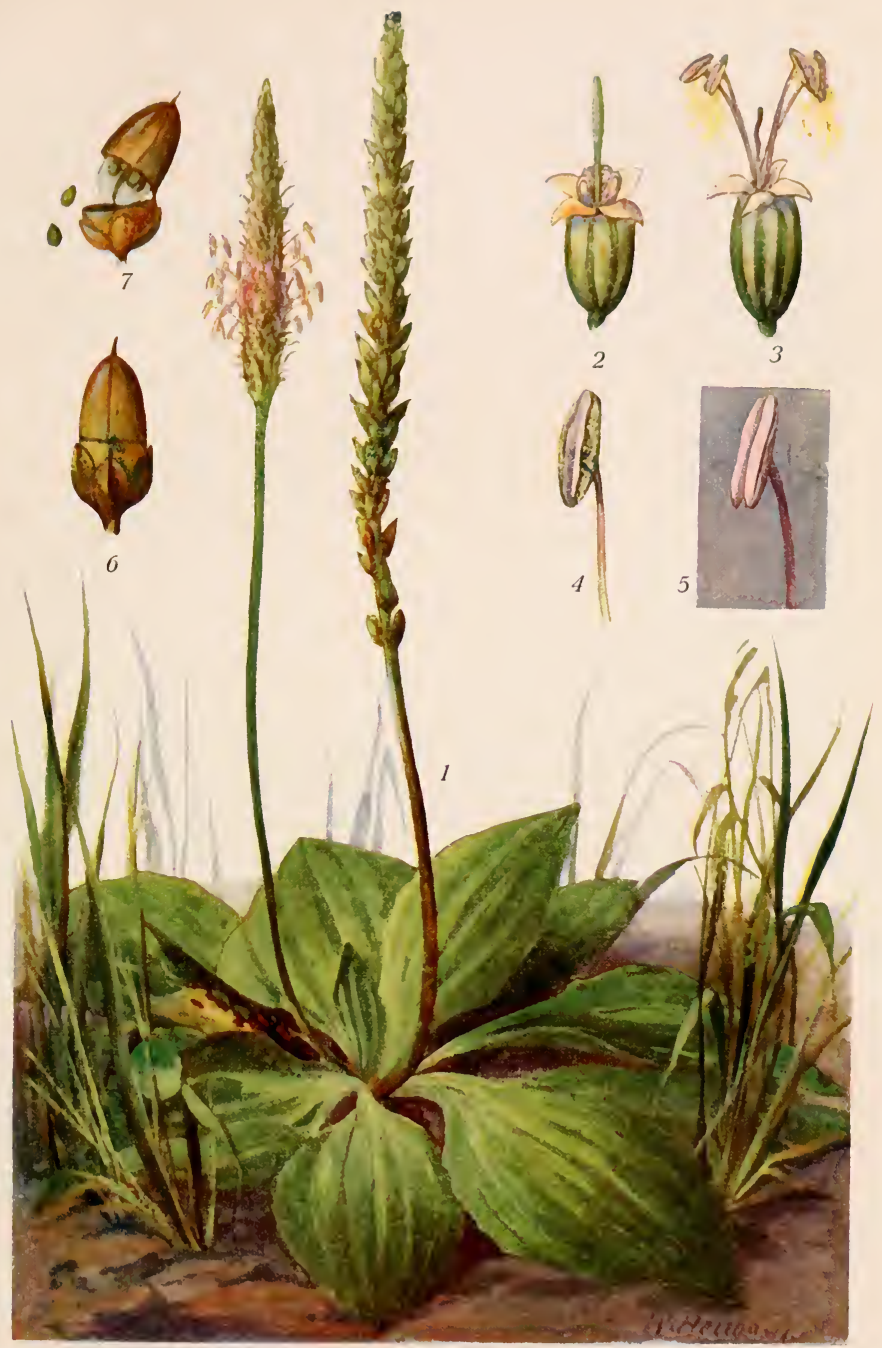

Mit.ierer Wegerich (Plantago media). 


$$
\text { - }
$$


sie sind, so werden wir anch ihre stanbförmige Feinheit als wichtige oder gar notwendige Eigenschaft erkennen.

Eine in allen Stücken ganz ähnliche Lebensweise führt ein Glied einer $\mathrm{n}$ ahe verwandten Familie, die Sommerwurz (Orobánche), die in zahlreichen, schwer zu unterscheidenden Arten auf den Warzeln der verschiedensten Pflanzen schmarotzt (z. B. auf Klee, Hanf, Gerste u. v. a.). Von dem unteren, knollenförmigen Teile des unterirdischen Stammes, der mit schuppenförmigen Blättern besetzt ist, gehen zahlreiclıe Wurzeln aus, die mit denen der Nährpflanze in Verbindung stehen. Mit Beginn oder während des Sommers (Name!) wächst die Gipfelknospe des Stammes zu einem Stengel ans, der sich über den Boden erhebt und zahlreiche, meist bunt gefärbte Rachenblüten trägt. - Gleichfalls nahe Verwandte der Rachenblütler sind das Fettkraut (Pinguicula) und der Wasserschlauch (Utriculária), die bei den „insektenfressenden Pflanzen “ bereits erwähnt worden sind.

\section{Familie. Wegerich-Gewächse (Plantagináceae).}

Der Wegerich (Plantágo). Tafel 23.

1. Die verbreitetsten Arten. Schon bei einiger Anfmerksamkeit merkt man, daß der Wegerich in mehreren, wohl unterschiedenen Arten anftritt, von denen die 3 folgenden überall häufig anzutreffen sind: der Spitzwegerich (P. lanceoláta) ist leicht an den lanzettlichen Blättern zu erkennen: der große und der mittlere W. (P. májor und média) dagegen besitzen viel breitere Blätter, die jedoch wieder voneinander verschieden sind. Während sie bei ersterem deutlich gestielt sind, verschmälern sich bei letzterem die Blattllächen nur in je einen kurzen, breiten, undentlichen Blattstiel. (Erkläre die Artnamen!)

2. Standort. Diese drei Wegericharten bewohnen Wiesen, Triften und ähnliche Orte. Vor allen Dingen sind sie regelmäßige Begleiter der Wege (Gattungsname!); ja sie siedeln sich sogar zwischen dem Pflaster wenig betretener Straßen an. An allen diesen Orten findet sich auch der allbekannte Löwenzahn, und es ist daher durchans nicht zu verwundern, daß zwischen diesen Pflanzen hinsichtlich der

3. Wurzeln und Blätter eine so große Ïbereinstimmung herrscht. Wie der Löwenzahn (s. das.) haben die Wegericharten sehr tiefgehende Wurzeln (dem "großen Wegerich" fehlt aber die Pfallwurzel der beiden anderen Arten!), sowie Blätter, die oberseits mit Rinnen versehen und an trockenen Standorten zu regelmäßigen Rosetten geordnet sind (1.). An Stellen dagegen, an denen die Pflanzen mit anderen um das Licht ringen (Wiese), sind auch die ganzrandigen Blätter mehr oder weniger aufwärts gerichtet.

4. Blïte. a) Auf einem langen Stiele, der aus der Achsel eines Blattes entspringt, stehen dicht gehäuft zahlreiche Blüten (Ähre). Sie bestehen (2. n. 3.) ans einem vierteiligen $\mathrm{Kelche}$, einer kleinen $\mathrm{Blumenkrone}$ mit vierteiligem Saume, vier Staubblätern und einem Stempel.

b) In der Regel ragt der Griffel mit der behaarten, einem Cylinderputzer ähnlichen Narbe bereits aus der Blüte hervor (2.), wenn die Staubblätter noch zu- 
rïckgebogen sind (s. S. 161). Später strecken sich anch diese hervor (3.). Obgleich die Staubbeutel dann vollkommen frei stehen, ist der Bliitenstaub doch nicht ohne jeden Schutz: die bereits geöffneten Beutel (4.) schließen sich nämlich in taureichen Nächten und beim Eintritt feuchter Witterung wieder (5.; Versuch!) Erschüttert man den Blütenstand bei trockenem Wetter, so entweichen aus den Beuteln Wölkchen trockenen Stanbes. Dasselbe geschieht natiirlich anch beim Wehen des Windes (langer, beweglicher Stiel!), und es kann daher nicht ansbleiben, daß auf diesem Wege Staub zu den freistehenden Narben gelangt, der Wind also die Bestäubung vermittelt. Andererseits sieht man aber auch, wie die Blüten von Insekten besucht werden, die Blütenstaub verzehren oder "einernten“. Besonders häufig hat sich der "mittlere Wegerich" eines solchen Besuchs zu erfreuen. Seinen Blïten entströmt aber anch ein sehr zarter Duft, und die violetten Staubblätter machen die unscheinbaren Blüten doch weithin bemerkbar. Die beiden anderen Arten dagegen haben duftlose Blüten und nur gelbliche oder weilse Staubblätter. Der Wegerich stellt also einen Übergang von den insektenblütigen zu den windblütigen Pflanzen dar, von welch letzeren wir in der Haselnuß (s. das.) einen ansgeprägten Vertreter kennen lernen werden. (Stelle auch fest, in welchen anderen Punkten die Wegerichblïte Eigentïmlichkeiten dieser beiden Pflanzengruppen zeigt, nnd wie sich dies bei den einzelnen Arten entweder zu Gunsten der Windoder der Insektenblütigkeit verschiebt!)

5. Die Frucht (6.) ist eine Kapsel, deren oberer Teil sich bei der Reife ablöst (7.). Jndem der Wind den Fruchtstand hin- und herbewegt, werden die kleinen Samen heransgeschleudert. Befeuchtet man die Samen, so wird die Oberhaut schleimig und klebrig, eine Eigentïmlichkeit, deren Bedentung wir beim Kürbis noch kennen lernen werden.

\section{Familie. Glockenblumen-Gewächse (Campanuláceae).}

\section{Die rundblättrige Glockenblume (Campánula rotundifólia). Tafel 24.}

A. Wie sie griint. Die zierliche, sehr veränderliche Pflanze (1.) liebt sonnige Standorte: trockene Wiesen, Wegränder, Bergabhänge, lichte Waldstellen u. dgl. Sie senkt daher gleich anderen Trockenlandpflanzen (Beispiele!) den langen unterirdischen Stamm (Wurzelstock) und die von ihm ausgehenden Wurzeln bis in die tieferen, feuchten Bodenschichten hinab und besitzt ferner sehr kleine Blätter, die auch nur geringe Iengen von Wasser verdampfen (vgl. dag. Windröschen und andere Schattenpflanzen). An den "Kurztrieben", d. i. an den kurzen Zweigen des unterirdischen Stammes, die erst im nächsten Jahre Blüten tragen, sind die Blätter gestielt, rundlich (Artname!) und am Rande meist gekerbt. Ebenso sind sie am unteren Teile der blütentragenden Zweige gestaltet, die - weil sie die Blüten den Bestäubern ja sichtbar machen müssen - stark in die Länge gestreckt sind. Nach oben hin verschmälern sich 


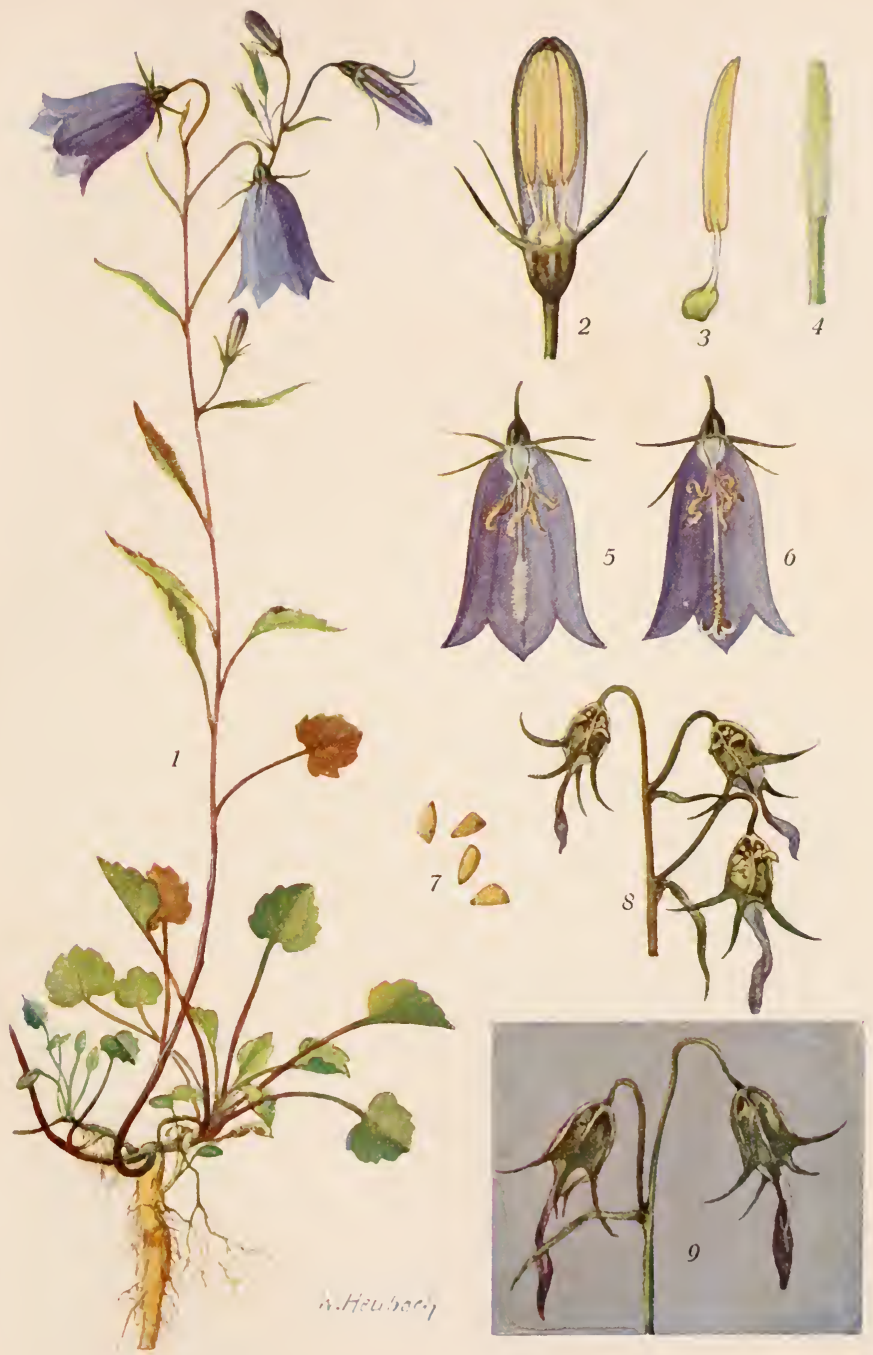

Rundblättrige Glockenblume (Campanula rotundifolia). 

die Blätter dieser "Langtriebe" aber immer mehr, bis sie endlich fast linienförmig und ganzrandig werden.

B. Wie sie blïht. 1. Wenn sich die anfangs aufrecht stehenden Blïten öfinen, neigen sie sich durch Krümmung ihrer Stiele herab, so daß Blütenstaub und Honig vortrefflich gegen Regen geschützt sind (1. 5. u. 6.). Die meist himmelblane Blumenkrone stellt ein zierliches Glöckchen dar (Gattungsname!), das sich in 5 zurïckgebogene Zipfel spaltet. Da es seine Außenseite den Blicken der Insekten darbietet, ist es auch hier viel lebhafter als an der Innenseite gefärbt. (Vgl. dag. die Blïten, bei denen die Innenfläche der Blumenkrone besonders sichtbar ist!) Der $\mathrm{Kelch}$ ist im unteren Teile mit dem Fruchtknoten innig verwachsen, im oberen dagegen in 5 fadenförmige Zipfel gespalten (warum wären breite Zipfel hier durchaus unvorteilhaft?). Der Oberfläche des Fruchtknotens ist die scheibenförmige, gelbe Honigdrüse aufgelagert. Sie umgibt den Griffel und ist von den stark verbreiterten unteren Abschnitten der 5 Staubblätter (3. 5 mal vergr.) wie von einem Gewölbe überdacht, so daß nur 5 spaltenförmige Zugänge zum Honig vorhanden sind. Da die Spalten zudem durch Härchen, die von den Rändern der Staubblätter ausstrahlen, versperrt sind, so ist kleinen und daher (Beweis!) unnützen Blütengästen der $\mathrm{Zu}$ tritt zum süßen Safte verwehrt. Größere Insekten dagegen können die Haarreusen mit Hilfe des Rüssels leicht durchdringen und bis zum Honig herabreichen. Um zu erkennen, wie die von diesen Gästen vermittelte

2. Bestäubung erfolgt, muß man die Entwicklung der Blüte genaner verfolgen.

a) Öffnet man eine noch aufrechtstehende Blütenknospe, deren Blumenkrone sich blau zu färben beginnt (2.3 mal vergr.), so sieht man, wie der obere Teil des Griffels (4. 5 mal vergr.) rings mit Haaren besetzt ist, so daß er einem Cylinderputzer ähnelt. Die Staubbentel sind noch mit Blütenstaub gefïllt und liegen dem Griffel dicht an.

b) Bei einer etwas älteren, aber gleichfalls noch geschlossenen Bliite bemerkt man, wie sich die Staubbeutel nach innen öffnen und den grïnblauen Blütenstaub auf der "Griffelbürste" ablagern. Weil nunmehr für die Blüte ohne Bedentung, verschrumpfen sie bis auf die stark verbreiterten unteren Abschnitte („Saftdecke"!); der Griffel dagegen streckt sich in die Länge. Jetzt öffnet sich die nickend gewordene Blüte (5. 2 mal vergr.), und der Blütenstaub wird von größeren Insekten, die zum Honig vordringen, leicht abgestreift.

c) Nach einiger Zeit (6. 2 mal vergr.) vertrocknen die Haare der "Griffelbürste"; die 3 Narbenäste dagegen, die bisher eng aneinander lagen, spreizen auseinander, so daß jetzt erst eine Befruchtung erfolgen kann. Da nun die Narbenäste in der Blïte dieselbe Stelle einnehmen wie der (abgelagerte) Blütenstaub, so müssen beide, Blütenstaub und Narben, von den Besuchern auch mit demselben Körperteile gestreift werden (führe dies näher ans!). Und zwar miissen die Insekten Blïtenstaub jüngerer Blïten auf die Narben alterer tragen, 
also Fremdbestäubung vermitteln, die - wie wir schon mehrfach gesehen haben - stets von erhöhter Fruchtbarkeit begleitet ist.

C. Wie sie Friichte trägt. Der Fruchtknoten, von dem sich die vertrocknete Blumenkrone nicht ablöst, entwickelt sich zu einer dreifächerigen Kapsel (stelle einen Querschnitt her und beschreibe den Bau!). Da die Frucht wie die Blïte nach unten hängt (8. u. 9. 5 mal vergr.), so kann sie sich wie z. B. die Kapseln der Schlüsselblume oder des Leinkrautes unmöglich am oberen Teile öffinen. Die Samen würden ja sonst alle in unmittelbarer Nähe der Mutterpflanze auf den Boden fallen, so daß die jungen Pflänzchen gegenseitig um Licht, Nahrung und Raum kämpfen müßten. Die Kapsel öffnet sich darum nahe dem Grunde: aus der Fruchtwand lösen sich drei scharf umgrenzte Stücke, die wie Klappfenster nach unten schlagen (8.). Ans den so entstandenen Öffnungen vermag nun der Wind die sehr kleinen Samen herauszuschïtteln und über einen großen Umkreis zu verstreuen. Sobald aber feuchte Witterung eintritt, die den Samen verderblich werden könnte (s. S. 38, C, c), schließen sich die „Fensterchen" wieder (9.).

\section{Andere Glockenblumen-Gewächse.}

Von den zahlreichen anderen Glockenblumen, deren blaue Blüten unsere Fluren schmücken, sei nur die häufigste, die Wiesen-G. (C. pátula) erwähnt. Ihre rotblauen Blüten stehen im Gegensatz zu denen der eingehend betrachteten Art aufrecht, werden aber beim Beginn der Dämmerung und beim Eintritt feuchter Witterang nickend: so finden Blütenstaub und Honig, wenn sie am meisten gefährdet sind, doch den Schutz, den sie in hängenden Blüten stets genießen. Auch die Früchte stehen aufrecht. Im Gegensatz zu den Arten mit hängenden Früchten bilden sich dementsprechend auch hier die ${ }_{n}$ Fensterchen" am oberen Teile der Fruchtkapseln, eine Erscheinung, die auch bei allen anderen Formen mit aufrecht stehenden Früchten zu beobachten ist. - Die großblumige, blan oder weiß blühende Garten-Glockenblume oder Marienglocke (C. médinm), die häufig als Zierpflanze gezogen wird, stammt ans Südeuropa.

Neben den Glockenblumen gehören zu der Familie auch einige Pflanzen, die man leicht für Korbblütler halten könnte: sie besitzen so kleine Blüten, daß diese erst in großer AnzahI auffällig werden und daher zu ansehnlichen Köpfehen gehäuft sind. Von diesen Gewächsen seien genannt die zierliche, blau blühende Schaf-Skabiose (Iasióne montána), die anf sonnigen und sandigen Stellen wächst, sowie die weiß oder violett blühende Tenfelskralle (Phyteuma spicátum), die im Schatten des Waldes gedeiht. (Beweise, daß beide Pflanzen ihrem Standorte vortrefflich "angepaßt" sind, und erkläre ihre Namen!)

\section{Famile. Kürbis-Gewächse (Cucurbitáceae).}

Der Kürbis (Cucúrbita pepo).

A. Frucht und Verwendung. Den Kürbis baut nan in zahlreichen Spielarten vorwiegend seiner Frïchte wegen an, die von sehr verschiedener, oft riesiger Größe und grün, weiß oder bunt gefärbt sind. Sie werden vom Ifenschen verspeist („Speisekürbisse“) oder den Haustieren als Futter vorge- 
legt. Andere Spielarten dagegen pflanzt man nur zur Zierde ("Zierkürbisse“): man erfrent sich an den oft seltsamen Formen der Früchte (beschreibe und zeichne solche!) oder benutzt die kletternde, großblittrige Pflanze zur Bekleidung von Lauben $\mathrm{n}$. dgl.

Stellt man durch die unreife Frucht einen Querschnitt her, so sieht man, wie von der ringförmigen Wand meist 3, seltener 4 oder 5 „Zapfen" in das Innere vorspringen, und wie in diese Zapfen am Grunde mehrere Reihen von Samen eingebettet sind. An der reifen Frucht ist die Wand bis auf die harte Außenschicht („Rinde"; Bedentung?) von fleischiger Beschaffenheit, während sich die Zapfen in eine faserige, klebrige Masse verwandelt haben. Welche Bedentung diese eigentümliche „Zweiteilung“ der Fruchtwände für die Pflanze hat, wird uns klar, wemn wir

B. Samen und Keimung näher betrachten. 1. a) Legen wir einige Samen ("Kürbiskerne"), die noch mit Teilchen des klebrigen Fruchtfleisches oder mit dem Safte desselben behaftet sind, auf feuchten Boden (Blumentopf), so verkleben sie bald mit der Erde. Sorgen wir weiter für die nötige Fenchtigkeit, so fangen sie an zu keimen: Ans einem kleinen Lọche am zugespitzten Ende (1.)

tritt zuerst die Hauptwurzel hervor. Sie senkt sich sofort in den Boden

und verzweigt sich daselbst sehr bald (2.): alles Erscheinungen, wie wir sie bereits bei der keimenden Bohne kennen nnd verstehen gelernt haben. Nunınehr beginnt sich der StengelKeimung des Kürbis. Ziffern im Texte erklärt.

3.

2.

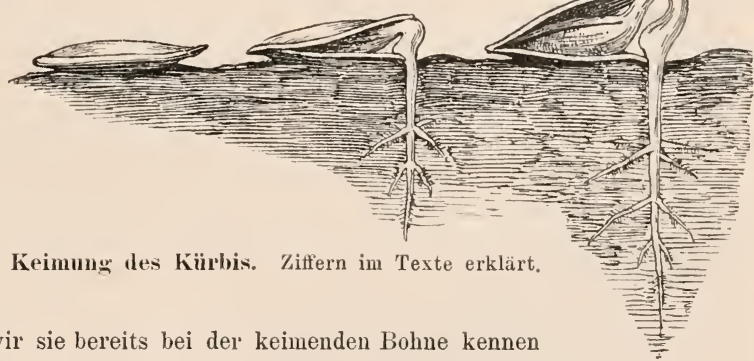
teil, der mit der Wurzel ins Freie getreten ist und sich gleichfalls nach unten gewendet hat, stark in die Länge zu strecken. Da aber die Wurzel im Boden befestigt und die Samenschale mit der Erde verklebt ist, so bildet sich an dem wachsenden Stengel ein kleiner, nach oben gerichteter Bogen (3.). Infolge fortgesetzten Wachstums wird dieser Bogen immer straffer gespannt, bis endlich die Keimblätter aus der Samenschale herausgezogen werden. Bei dieser Arbeit kommt dem Stengel noch ein kleiner Wulst zu statten, der sich an ihm bildet. Er drïckt die untere Hälfte der Schale nach unten und verschwindet wieder, sobald die Keimblätter aus ihrer Hülle befreit sind.

Legen wir neben diese Samen einige andere aus, von denen wir jede Spur des Fruchtfleisches und seines Saftes sorgfältig entfernt haben, so keimen diese gleichfalls bald. Da sie aber mit der Erde nicht verkleben, so wird dabei die Samen- 
schale wie eine Mütze mit emporgehoben. Die Keimblätter vermögen sich daraus nicht oder nur schwer zu befreien, so daß die junge Pflanze verkümmert oder wohl gar zu Grunde geht. Diese Tatsache zeigt, wie wichtig es für den Kürbis ist, daß die Samenschalen mit dem Erdboden verkleben, oder anders ausgedrückt, daß sich Teile der Fruchtwand, die "Zapfen", bei der Reife in eine klebrige Masse verwandeln.

Legen wir nun drittens auch einige Samen in den Boden, so hält die obere Erdschicht die Fruchtschale fest und die Keimung kann ungestört erfolgen, ganz gleichgiiltig, ob noch Fruchtfleisch an den Samen haftet oder nicht. Dieser Fall wird beim wildwachsenden Kürbis aber wohl kaum eintreten. Die Samen werden wohl stets a uf dem Erdboden zu liegen kommen, und dort bedürfen sie, wie wir gesehen haben, einer besonderen Befestigung an das "Keimbett".

b) Hierbei kommt den Samen die Form wesentlich zu statten: Da sie flache, breitgedrückte Gebilde sind, mïssen sie den Boden stets mit einer Breitseite berühren, oder mit anderen Worten, ihm stets eine große Befestigungsoder Klebfläche darbieten.

c) Die Frucht des Kürbis springt, um die Samen zu entlassen und zu verstreuen, von selbst nicht auf. Bei den angebauten Pflanzen ist hierzu die Hilfe des Menschen, bei wildwachsenden die von Tieren (Wildschweinen, Hirschen u. a.) nötig. Gleich zahlreichen anderen Gewächsen, deren Samen durch Tiere verbreitet werden (s. S. 64, 8), besitzt daher anch der Kürbis ein Anlockungsmittel für seine Verbreiter: die Wandschicht der Frucht bildet zur Zeit der Reife eine wohlschmeckende, fleischige II asse.

Wenn etwa ein Wildschwein eine Frucht verzehrt, so wird es sicher auch zahlreiche Samen mit verspeisen. Bei der großen Menge der Samen ist dies für die Pflanze aber kein besonderer Verlust. Andererseits werden aber auch zahlreiche Samen dem Tiere an Maul und Füßen kleben bleiben, so daß auf diese Weise die Pflanze iiber ein weites Gebiet verbreitet werden kann.

2. Hat der Stengel die Keimblätter aus der Samenschale befreit, so streckt er sich gerade, und die ergrünenden Keimblätter biegen sich auseinander, so daß sie von den Sonnenstrahlen durchleuchtet und durchwärmt werden können (Bedeutung?). Mit Eintritt der Dunkelheit dagegen klappen sie wieder zusammen: sie nehmen Nacht- oder Schlafstellung ein, eine Erscheinung, deren Bedeutung wir bereits früher (S. 103) kennen gelernt haben. Durch die zusammengeneigten Keimblätter wird zugleich die zarte Knospe zugedeckt und somit gegen zu starken Wärmeverlust geschützt. Da es nun ohne Wärme kein Wachstum gibt (Beispiel!), so ist also anch in dieser Hinsicht die Schlafstellung der Keimblätter für die Pflanze von Vorteil. Und ein solcher Schutz ist für die Knospe um so wichtiger, als

3. der Kürbis gegen Wärmeverlust außerordentlich empfindlich ist. Schon der geringste Frost tötet ihn, und seine Samen keimen erst bei einer Wärme von wenigstens $11-16^{\circ} \mathrm{C}$. Diese Tatsachen zeigen dentlich an, daß die Heimat der Pflanze nicht in unseren Gegenden zu suchen ist. 
Wahrscheinlich ist sie das tropische Amerika. Die Empfindlichkeit des Kürbis gegen Kälte veranlaßt uns anch, seine Samen (sowie die der Gurke) erst dann ins freie Land z legen, wenn wir keine Nachtfröste mehr zu befürchten haben, also etwa Mitte Mai.

C. 1. Stengel, Ranken und Blätter sind mit größeren oder kleineren Stacheln bedeckt, die z. B. gleich den Haaren der Schwarzwurz Schutzmittel der (wildwachsenden) Pflanze gegen Tiere darstellen. An den Blattstielen sind sie besonders stechend.

2. Der fünfeckige, hohle Stengel ist saftreich und nicht imstande, sich empor zu richten oder gar die Last der Blätter und Früchte zu tragen. Er liegt darum entweder dem Boden auf oder klettert mit Hilfe von

3. Ranken, die neben den Blättern entspringen, an fremden Gegenständen empor. Jede Ranke besteht ans einem gemeinsamen Stiele, der am Ende meist 3-5 Äste trïgt. Vergleicht man die Ranke mit den Blättern, so ergibt sich, daß wir es in ihr wie bei der Erbse (s. das.) mit einem umgewandelten Blatte, mit einer "Blattranke" zn tun haben: der gemeinsame Stiel entspricht dem Blattstiele, und die Äste stellen die von einem Punkte ausstrahlenden Hauptrippen der Blattfläche dar. Ja, die Übereinstimmung geht noch weiter: wie nämlich an der Blattfläche die Mittelrippe die anderen Hauptrippen an Länge und Stärke übertrifft, so ist auch hier der Ast, der die Verlängerung des Stieles bildet, stets weit länger und stärker als die anderen Äste. (Beobachte, wie die Rankenäste gleich den Ranken des Weinstocks kreisen, die Stütze umschlingen und sich korkzieherartig zusammenziehen! An abgeschnittenen Zweigstïcken, die man in ein Gefäß mit Wasser stellt, läßt sich der Vorgang sehr bequem verfolgen.)

4. a) Die Blätter sind um den Stengel in einer Spirale angeordnet (s. S. 131, 1 c). Da eine am Boden liegende oder kletternde Pflanze aber nur von einer Seite belichtet wird, so müssen sämtliche Blätter auch dorthin gerichtet sein. $\mathrm{Zu}$ diesem Zwecke machen die langen, hohlen Blattstiele die mannigfachsten Krümmungen: sie heben die Blattflächen erstlich von der Unterlage (Erdboden, Stütze) ab und stellen sie zweitens abwechselnd rechts und links vom Stengel, so daß alle von den Sonnenstrahlen getroffen werden können. Und da die Blattflächen zudem noch eine solche Richtung zu den Sonnenstrahlen einnehmen, in der sie am besten durchleuchtet werden können (wie bei liegenden und wie bei kletternden Pflanzen?), so ist die ungünstige Spiralstellung in allen Stïcken aufs vollkommenste "korrigiert".

b) Die Blattflächen sind sehr groß, herzförmig und besitzen je nach der Spielart 5- oder $7 \mathrm{mehr}$ oder weniger tief eingeschnittene Lappen. Wenn wir bedenken, wie saftreich alle Teile des Kürbis sind, wie groß demnach sein Bedürfnis nach Wasser ist, werden wir in der Größe der Blätter leicht einen Vorteil für die Pflanze erkennen: große Blätter beschatten den Boden mehr, schïtzen ihn also auch in höherem Мaße gegen Austrocknung als gleich viele, aber kleinere Blätter. (Beachte hierauf vor allen Dingen auch die Gurke!)

c) Große Blatter sind andererseits aber der Gefahr, vom Winde zerrissen 
zu werden, viel stärker ausgesetzt als kleine Blätter. Bei h e r z fö rmigen, großen Blättern ist nun wieder der Blattgrund am meisten gefährdet. Darum hat diese Stelle anch eine besondere Festigung erfahren: Die beiden änßersten großen Seitennerven sind bis zu ihrer ersten Verzweigung nicht nur sehr stark, sondern bilden auf dieser Strecke auch den Rand der Blattfläche. (Vgl. mit dem Saum der Tüicher und Kleider! Wie sichern wir Knopflöcher gegen das Einreißen?)

D. Blïte und Bestäubung. 1. Die sehr großen Blïten erheben sich auf kurzen Stielen einzeln aus den Blattwinkeln (vgl. mit S. 95, b). Der Kelch ist bis auf 5 Zähne vollkommen mit dem unteren Teile der gelben, trichterförmigen und gleichfalls 5zipfeligen Blumenkrone verwachsen, deren Innenseite dicht mit feinen Härchen bedeckt ist. Der Grund der Blüte ist mit einer gelben, fleischigen Masse ausgekleidet, in der wir - wie schon der Geschmack lehrt - die Honigdrïse vor uns haben. - Soweit stimmen sämtliche Blïten miteinander ïberein. Hinsichtlich der Befruchtungswerkzenge macht sich aber ein sehr bemerkenswerter Unterschied geltend:

2. In der Mehrzahl der Blüten finden wir nur Staubblätter. Diese "Staubblïten" bringen selbstverständlich anch keine Frïchte hervor und werden darum im Volksmunde als „taub" bezeichnet. Die Staubbentel sind miteinander zu einer kurzen Säule verwachsen, die auf 3 ,Trägern“ ruht, so daß sich das ganze Gebilde wie ein Dreifuß ïber der napfförmigen Honigdrüse erhebt. Wie der Augenschein lehrt, haben wir in den "Trägern", zwischen denen nur je eine Lïcke zum Honig offen bleibt (Bedentung?), die Staubfäden vor uns. Da zwei "Träger" den dritten an Stärke aber weit ïbertreffen, so ist dies ein Zeichen, daß wir es in ihnen nicht mit einfachen Staubfäden zu tun haben, sondern daß sie durch Verschmelzung je zweier entstanden sind. In der Blïte sind also, den ïbrigen „fünfzähligen" Blïtenteilen entsprechend, auch 5 Staubblätter vorhanden. (So sind auch die meist 3 Fruchtfächer $-\mathrm{s}$. Absch. A - durch Verschmelzung ans 5 hervorgegangen.)

3. Im Gegensatz zu den Staubblüten, besitzen die anderen Bliiten nur einen wohl ausgebildeten Stempel; man bezeichnet sie daher als Stempeloder Fruchtblïten. Der unterständige Fruchtknoten (s. S. 71, b), dessen Bau wir in Absch. A bereits kennen gelernt haben, ist in einen säulenförmigen Griffel verlängert, der eine große, 5-lappige Narbe trägt.

4. a) Beim Kürbis sind also Staubblätter und Stempel anf verschiedene Blïten verteilt, die sich aber an ein und derselben Pflanze finden oder, bildlich ausgedrückt, die ein Haus bewohnen (..einhäusige" Pflanzen im Gegensatz zu „zweihäusigen", s. z. B. Weide). Un die Bedeutung dieser Eimrichtung zu verstehen, branchen wir uns bloß daran zu erinnern (s. z. B. 122), daß Selbstbestäubung stets geringere Fruchtbarkeit im Gefolge hat als die von den Pflanzen "herbeigewünschte" Fremdbestäubung: bei einläusigen Pflanzen is aber die minderwertigere Selbstbestäubung völlig ausgeschlossen.

b) Die Überträger des Blïtenstaubes sind beim Kürbis stets In sek ten. 
(Woraus ist dies sehon zu schließen? Welehe Insekten hast du in den Blïten beobachtet? Vgl. dag. die gleichfalls „einhäusige“ Haselnuß!) Sollen die Tiere beim Besuch der Blïten aber wirklich Bestäubung vermittelı, so müssen sie Stanbbentel und Narbe streifen. Und hierzu werden sie von der Pflanze gleichsam genötigt; die Innenseite der Blumenkrone, auf der ja die Insekten zum Honig hinab kriechen könnten, ist - wie wir bereits gesehen haben dicht mit feinen Haaren besetzt. In dem Haardickicht verstricken sich aber die Insekten leicht mit den Fußklauen, so daß sie auf diesem Wege nur mit

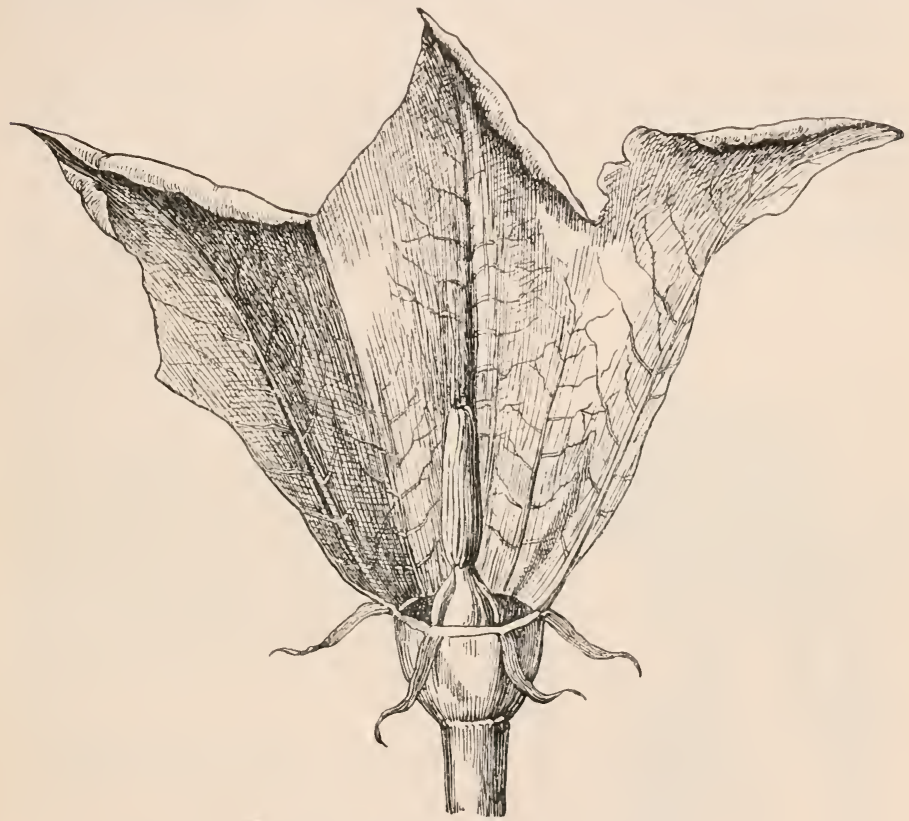

Staubbliite vom Kiirbis (etwas verkl.).

großer Mrïhe zum Honig vorzudringen vermöehten. Ganz anders aber, wenn sie die natïrlichen "Anflugsstangen" der Blïten benutzen, die Staubbeutelsäule oder die große Narbe, von denen glatte Wege (Stanbfäden und Griffel sind unbehaart!) in den Bliitengrund zum süßen Mahle führen.

Andere Kïrbismewächse.

Eine weit höhere Bedentung als der Kürbis hat die ihm in allen Stücken ähnliche (iurke (Cúcumis sativus), die aus Ostindien zu uns gekommen ist. Sie besitzt aber einfache Ranken und langgestreckte Früchte (Verwendung?). - Ostindien ist anch die 
Heimat der Zuckermelone (C. melo), auch kurz „Melon e“ genannt. Das gelbliche, würzhafte Fleisch der kürbisähnlichen Frächte wird als wohlschmeckendes und erfrischendes Obst überall hoch geschätzt. Deshalb hat sich die Pflanze auch über fast alle warmen und wärmeren Länder verbreitet. Bei uns gedeiht sie nur in Treibhäusern. - Eine ähnliche Bedeutung und Verbreitung hat die Wassermelone (C. citrúllus). Sie stammt aus dem heißen Afrika. Ihre hochgeschätzten Früchte besitzen ein rötliches und sehr saftiges (Name!) Fleisch und schwarze Samen, - Das tropische Asien und Afrika ist auch die Heimat der Luffapflanze (Luffa cylíndrica), die in neuerer Zeit eine groBe Bedeutung erhalten hat. Das feste GefäBbündelnetz der gurkenartigen Früchte wird zu den bekannten Luffaschwämmen, sowie zu leichten Hüten, Schuhen a. dgl. verarbeitet.

An Zäunen und Gebüschen klettert mit Hilfe einfacher, empfindlicher Ranken (berühre sie und beobachte, wie schnell sie sich an dieser Stelle krümmen!) die Zaunrïbe (Bryónia) empor. Sie besitzt eine sehr giftige, rübenförmige Wurzel (Name!) und wird durch Vögel verbreitet, denen die saftigen, schwarzen oder roten Früchte zur Nahrung dienen (vgl. S. 64, 8). An der Färbung der Früchte lassen sich auch leicht die beiden Arten, die schwarzbeerige und die rotbeerige $Z$. (B. alba und dióica), erkennen. - Eine Pflanze mit sehr merkwürdiger Samenverbreitung ist die Spritzgurke

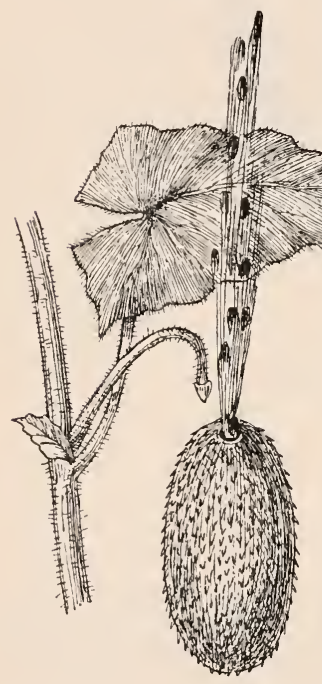

Spritzgurke. Ein Zweig mit Blatt und Fracht. Die Frucht hat sich vom Stiele abgelöst, so daß die Samen daraus her-

vorspritzen. (Nat. Gr.)

(Ecbállimm elatérium), die in den Mittelmeerländern heimisch ist und bei uns der eigentümlichen Früchte wegen $\mathrm{ab}$ und $\mathrm{zu}$ in Gärten gezogen wird. Die etwa $4 \mathrm{~cm}$ langen gurkenähnlichen Gebilde lösen sich bei der Reife von den Stielen, und in demselben Augenblicke spritzt aus der entstandenen Öffnung der schleimige Inhalt samt den Samen in kräftigem Strahle hervor. Infolgedessen werden die Samen weit über das Gebiet der Mutterpflanze hinaus verbreitet. Werden nun gar Tiere, die durch Anstreifen die Frucht von den Stielen lösen, von dem "Geschosse " getroffen, so kann die Pflanze infolge dieser Einrichtung sogar über größere Bezirke ausgesät werden.

\section{Familie. Labkraut-Gewächse (Rubiáceae).}

\section{Das Klebkraut (Gálium aparíne)}

ist eine unserer gemeinsten Pflanzen. Es bewohnt vorwiegend Hecken und Gebüsche und ist wie alle Sehatten pflanzen (s. S. 7, b und c) ein überaus zartes Gewächs. Die bis $2 \mathrm{~m}$ hohen Stengel sind so schwach, dass sie sich allein nicht aufzurichten vermögen. Die Pflanze häkelt sich darum meist an den Stämmen und Zweigen der Sträucher an, unter denen sie dem Boden entsprießt, und 
klettert so zum Lichte empor. Befähigt wird sie hierzu durch rückwärts gerichtete Stacheln, die infolge ihrer Kleinheit und großen Zahl das ganze Gewächs klebrig ersclieinen lassen. (Name! Beobachte, wie leicht Zweige z. B. an deinen Kleidern haften!) Dio Stacheln finden sich an den 4 Kanten des Stengels, sowie an den Rändern und der Mittelrippe der quirlförmig gestellten Blätter. Fehlen dem Klebkraut fremde Gegenstände zum Anhäkeln, so halten sich die einzelnen Stengel der in großen Trupps wachsenden Pflanze gegenseitig: vereinigt werden eben selbst die Schwachen mächtig. (Entferne von einem solchen Trupp einen Stengel nach dem andern und beobachte, wie die letzten kraftlos umsinken!) Aus den kleinen weißen Bliiten (beschreibe sie!) entwickeln sich je 2 Teilfrïchtchen, die dicht mit widerhakigen Stacheln bedeckt sind. Infolgedessen haften sie leicht an den Haaren vorbeistreifender Tiere und werden auf diese Weise oft über große Bezirke verbreitet (Bedeutung?).

Von den zahlreichen anderen Labkrautarten (Gálium) seien hier nur das gelbblühende erhte und das weißblühende gemeine L. (G. verum und mollúgo) genannt. Sie bewohnen trockene, rasige Orte und zeigen dementsprechend auch alle Eigenschaften der Trockenlandpflanzen (Beweis!). "Labkräuter" heißen sie, weil der Saft mehrerer Arten die Milch wie das Lab des Kälbermagens schnell zum Gerinnen bringt. Dies gilt besonders von der ersteren Form (darum „echt" !), die bei den alten Germanen der Freya geweiht war und von der eine später entstandene Sage erzählt, daß sie das Lager des Christuskindes gebildet habe. Darum heiBt sie anch noch hente in gewissen Gegenden „Unserer lieben Franen Bettstroh" oder ähnlich. - Besonders in Buchenwäldern befindet sich der zierliche Waldmeister (Aspérula odoráta), der wie sein „Nachbar ${ }^{4}$, das Windröschen, eine in allen Stäcken ausgeprägte Schattenpflanze darstellt (Beweis!). Er enthält in allen Teilen einen scharfriechenden Stoff (Cumarin), dnrch den Weidetiere abgeschreckt werden, der aber auch die Verwendung der duftenden Pflanze als würzende Zutat zum Wein bedingt ( Maitrank“). Die Früchte sind "Kletten“ wie die des Klebkrautes. - Reibt man die unterirdischen Stengel (Wurzelstöcke) der Labkraut- und Waldmeisterarten zwischen den Fingern, so sieht man, daB die meisten gelb oder rot färben. In weit höherem $\mathrm{MaBe}$ gilt dies von dem Wurzelstocke der Färberröte oder des Krapp (Rúbia tinctórum). Die Pflanze stammt aus dem Mittelmeergebiete und ähnelt vollkommen einem Labkrante. Seitdem man versteht, den wertvollen, roten Farbstoff, den sie früher allein lieferte, billiger künstlich herzustellen, ist ihr Anbau aber stark zurückgegangen. - Zn den Labkrautgewächsen gehört auch eine unserer wichtigsten ausländischen Kulturpflanzen:

\section{Der Kaffee (Cóffea arábica).}

1. Die Kaffeepflanze ist ein kleiner Baum oder Strauch, dessen gegenständige, immergrüne Blätter etwa die Form und Größe der Lorbeerblätter besitzen. In den Blattwinkeln stehen Knäuel weißer, kurzgestielter Röhrenbliiten, aus denen die anfangs grïnen, dann roten und zuletzt violetten Frïchte hervorgehen. Sie haben die Form und Größe kleiner Kirschen und sind auch wie diese gebaut. Das saftige, siiße Fruchtfleisch umschließt aber 2 hornartige Samen, die als "Kaffeebohnen" allgemein bekannt sind, und die nach der Ernte vom Fruchtfleisch getrennt werden. (Beweise aus der Färbung und 
dem Bau der Frucht, daß die ursprünglich wilde Pflanze auf die Verbreitung durch Vögel angewiesen war! Vgl. S. 64, 8 a und b.)

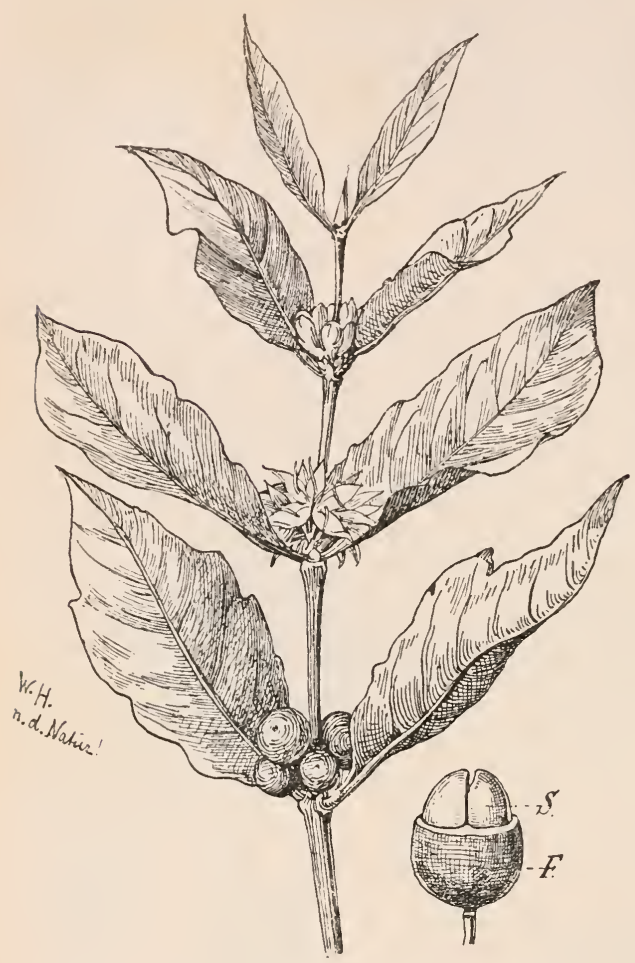

Zweig vom Kaffeebaum mit Blüten und jungen Früchten. Daneben eine reife Frucht, von der der obere 'Teil des Fruchtfleisches abgelöst ist. F. Fruchtfleisch. S. Samen. (Nat. Gr.)
2. Das aus den gerösteten und gemahlenen Kaffeebohnen bereitete duftende Getränk, der Kaffee, ïbt auf uns bekanntlich eine belebende Wirkung aus: Gehirn und Nerven werden erregt, das Gefühl der Nüchternheit und des Hungers wird beseitigt und der Schlaf verscheucht. Diese Wirkung ist in erster Linie einem Stoffe, dem Coffeïn, zuzuschreiben, der in deu Bohnen enthalten ist und in den Kaffeeaufguß übergeht (darum werden die Bohnen gemahlen!). Schon in etwas größerer Henge genossen, ist dieser Stoff aber ein heftiges Gift. Daher erzeugt sehr starker Kaffee Herzklopfen, Blutandrang nach dem Kopfe, Angstgefühl, Iruskelzittern und bei fortgesetztem Genuß sogar schwere Nervenleiden. Irgend welche nährenden Bestandteile enthält der Kaffee nicht: er ist nur ein Reiz-oder Genußmittel wie der Alkohol.

Den Kaffee-Ersatzmitteln (Surrogaten), unter denen Cichorie und Gerste am gebräuchlichsten sind, fehlt das Coffeïn und daher anch die Wirkung, die der Genuß dieses Stoffes im Gefolge hat.

3. Die Heimat des Kaffeebaums ist wahrscheinlich der gebirgige, östliche Teil des heißen Afrika. Sicher ist nur, daß er zuerst in Sïd-Arabien angebaut wurde ("Mocca"-Kaffee nach der gleichnamigen Hafenstadt) nnd am Ende des 


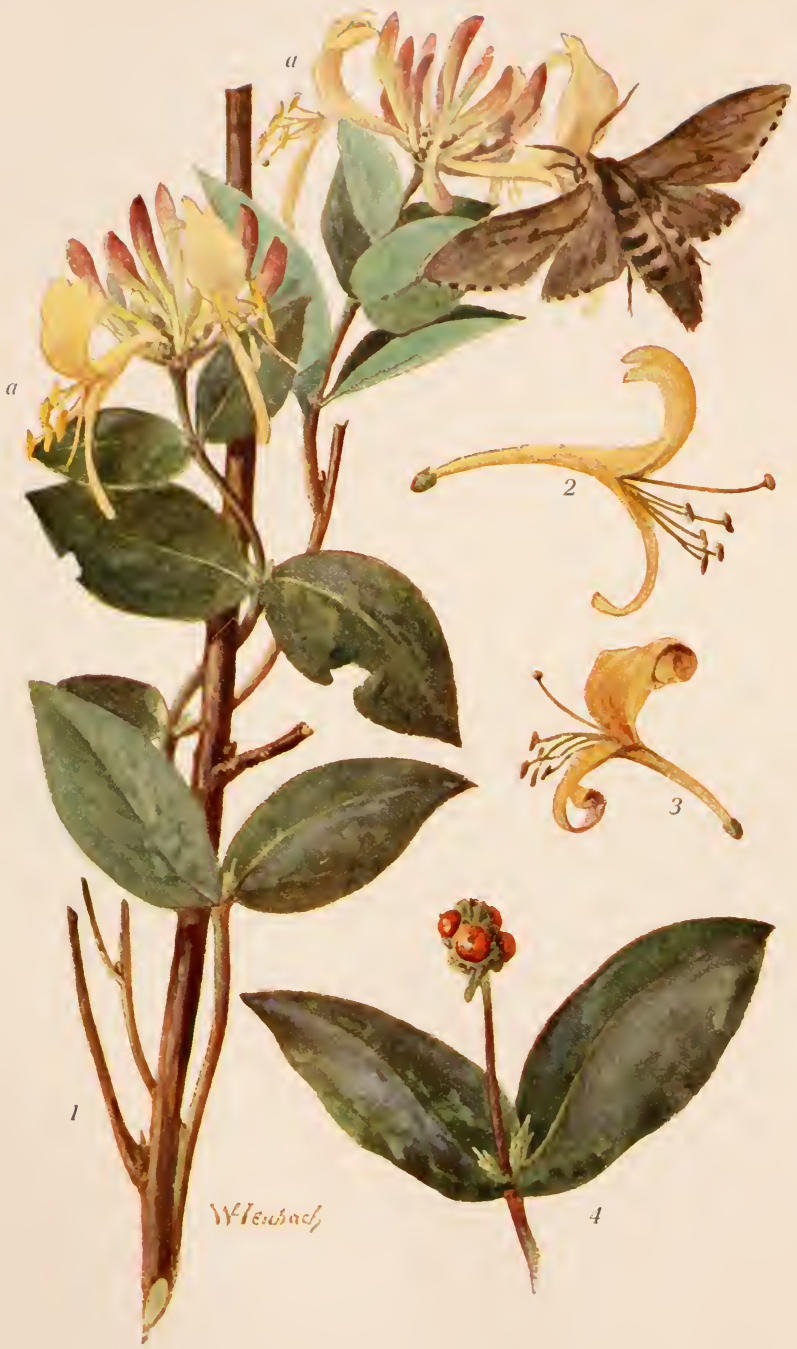

Wald-Geißblatt (Lonicera periclymenum). 

17. Jahrhunderts in Java eine nene Heimat fand. In der Folgezeit verbreitete sich der Aubau der wichtigen Pflanze ïber fast ganz Ostindien, ging auf Amerika (besonders Brasilien) ïber und hat jïngst anch im deutschen Schutzgebiete von Ostafrika Eingang gefunden. Der Kaffeegenuß ist in Europa erst seit etwa der Mitte des 17. Jahrhunderts bekannt.

Nahe Verwand te der Kaffeepflanze sind die China- oder Fieberrindenb:inme (Cinchona) der südamerikanisehen Anden. A as den Rinden dieser immergränen Gewächse bereitet man das wichtigste Fiebermittel, das Chinin.

\section{Familie. Geißblatt-Gewächse (Caprifoliáceae).}

\section{Das Wald-Geißblatt (Lonícera periclýmenum). Tafel 25.}

1. Eine Nachtfalterblume. Laubwald und Gebiisch sind im Hochsommer oft von dem köstlichen Dufte erfüllt, der den Blïten des WaldGeißblattes entströmt. Besonders abends und nachts ist der Duft sehr stark; am Tage dagegen verschwindet er oft fast gänzlich (stelle einen Strauß in das Zimmer!). Wenn wir nun noch die lange Röhre der 2 lippigen Blïte (beschreile sie näher!) betrachten, bis zu deren Grunde nur die längsten Insektenrïssel hinabreichen, so steht es für uns anßer Zweifel, daß wir es hier wie bei dem nickenden Leimkraut (s. das.) mit einer Nachtfalterblume zu tun haben. I)arum öffnen sich auch wie bei jener Pflanze die Blïten mit Anbruch des Abends, darum haben sie eine helle Farbe (gelblichweiß; außen [warum hier nicht schädlich?] wie die Knospen oft mit rötlichem Anflug), und darum stellen sie sich wagerecht, sobald sie zum Empfang der Besucher bereit sind (1. - S. dag. die Stellung der Knospen!). Am ersten Abend ( 1 a) stehen die 5 Staubblätter vor dem Blïteneingange, während der Griffel mit der Narbe abwärts gebogen ist. Die vor der Blïte schwebenden Schwärmer (in der Abb. ist es ein Kiefernschwärıner) mïssen mit der Unterseite also die Staubbentel berïhren. Am nächsten Abend (2) ist an der Bliite eine merkliche Veränderung eingetreten: Die Staubblätter sind herabgebogen und ihre Beutel verschrumpft, während der Griffel mit der Narbe nunmehr ihre Stellung einnimmt. Infolgedessen muß jetzt anch die Narbe von dem sangenden Schmetterling gestreift werden. Das Tier muß also beim Besuch jïngerer und älterer Blïten unbedingt Fremdbestäubung vermitteln. Die Blüte zeigt am zweiten Abend (2) anch noch andere Veränderungen: sie ist gedunkelt, hellgelb geworden, und die beiden Lippen haben sich etwas nach hinten anfgerollt. An den folgenden Tagen (3) verfärbt und rollt sich die Blnmenkrone immer mehr auf, bis sie schließlich abfällt. Wenn wir bedenken, daß durch diese Veränderungen die Bliite immer unauffalliger wird (Beweis!), so werden wir die Bedeutung dieser Erscheinung leicht einsehen: die anfliegenden Schwärmer werden die hellen, auffälligen jungen Blïten zuerst bemerken, sie also auch zuerst besuchen; darnach erst werden sie sich den weniger anffitligen älteren Blïten zuwenden. Die Tiere werden beim Besuch der Blïten also (in 
der Regel) wohl die Reihenfolge innehalten, in der - wie wir oben gesehen haben - eine Bestäubung der Pflanze nur möglich ist.

2. Eine Schlingpflanze. Das Wald-Geißblatt findet man nicht nur seiner duftenden Blüten wegen, sondern weil es sich auch vortrefflich zur Bekleidung von Lauben eignet, vielfach in Gärten angepflanzt. Es ist nämlich eine Schlingpflanze, eine Liane, die in ihrer Waldheimat mit Hilfe des schwachen, windenden S t a m m es (vgl. mit Bohne) das Unterholz umschlingt und an niedrigen Bäumen bis in die Kronen emporsteigt. Im Vollgenusse des Lichts breitet sie dort die mit einer bläulichen Wachsschicht (s. S. 17, 2) überzogenen, elliptischen Blätter aus. - Wie im Sommer die Schwärmer, so lockt das Geißblatt im Herbste die Waldvögel herbei: sie sollen die roten, saftigen Beeren (4.) verspeisen und deren Samen aussäen (s. S. 64, a). Nach den Früchten führt die Pflanze wie ihre nächsten

Verwandten, von denen zahlreiche, meist ausländische Arten in Parkanlagen angepflanzt werden, auch den Namen ${ }_{n}$ Heckenkirsche Form ist der bekannte Jelängerjelieber (L. caprifólium), der in Sädeuropa heimisch, bei uns aber vielfach verwildert ist. Wir lieben ihn besonders an der "Geißblattlaube", die er mit Grün bekleidet nnd mit dem herrlichen Duft seiner Blüten erfüllt. Er ähnelt dem Wald-Geißblatt, das darum auch "Wald- oder dentscher Jelängerjelieber" genannt wird, in allen Stäcken. Als bemerkenswerter Unterschied sei nur hervorgehoben, daB bei ihm die oberen Blätter am Grunde verwachsen sind, so daB der Stengel durch sie hindurch zu wachsen scheint. - Die in Laubwäldern und Gebüschen häufigste einheimische Art ist die gemeine Heckenkirsche (L. xylósteum). Sie ist im Gegensatz zu den beiden vorigen Formen keine Schlingpflanze (Stengel verhältnismäBig kräftig!). Da sie weit kürzere Blüten besitzt, wird sie vorwiegend von Hummeln bestäubt nnd ist eine "Tagblume". Die leuchtend roten Beeren stehen stets zu zweien dicht beieinander und sind am Grunde verwachsen. - Der Holunder (Sambúcus nigra) war bei den alten Germanen der hohen Göttin Freya oder Holla geweiht, deren Name in dem Worte Holunder (ans Holla und tar, der "Baum") wahrscheinlich bis heute erhalten ist. Darum findet sich der Holunder auch noch jetzt fast ansschlieBlich in der Nähe menschlicher Wohnungen, und tausend Sagen, Märchen und Volksbränche, die bis in die heidnische Vorzeit zurückreichen, knüpfen sich an ihn. Die Zweige, die jung ein sehr dickes Mark haben (Verwendung?), tragen unpaarig gefiederte Blätter und enden in großen Blütenständen, die sog. Trugdolden darstellen (erkläre den Namen!). Infolge der beträchtlichen Häufung werden die weißen und stark duftenden Bläten (Verwendung?) trotz ihrer Kleinheit weithin anffällig (Bedeutung?). Dasselbe gilt von den schwarzen Beeren (Verwendung?), die sich von den roten Fruchtstielen und den grünen Blättern dentlich abheben and von zahlreichen Vögeln mit Vorliebe verzehrt werden. Diesen Verbreitern verdanken die Holundersträuche, die man nicht selten auf Manern und an anderen unzugänglichen Orten findet, ihre Entstehung. - Als Unterholz in Lanbwäldern findet sich nicht selten der Schneeball (Vibúrnnm ópulus), der an den 3-5lappigen Blättern, an den leuchtend roten Früchten und den eigentlichen Blätenständen leicht zıl erkennen ist. Während die inneren Blüten der "Trugdolde" nämlich klein und unscheinbar sind, haben die ä口ßeren stark vergrößerte Blumenkronen, besitzen aber weder Stempel noch Staubblätter und bringen demnach auch keine Früchte hervor. Sie sind aber für die Pflanze durchans nicht bedentangslos: machen sie doch die von ihnen ein- 
geschlossenen, unscheinbaren, fruchttragenden Blüten für die Besucher anffällig. Die kugeligen Blütenstände (Name!) des Schneeballs, den wir als Zierstrauch pflegen, bestehen nur aus solchen "tauben" Blüten. (Wie kann diese Spielart demnach auch nur vermehrt werden?) - Sehr hänfig ist in Parkanlagen auch die Sehmeebecre (Symphoricárpus racemósus) angepflanzt, die aus Nordamerika stammt. Ihre Früchte bleiben noch lange nach dem Laubfall an den Zweigen hängen, und wie deutlich sie sich infolge der weißen Färbung (Name!) von dem dunkleu Hintergrunde abheben, ist leicht zu beobachten (Bedentung?). (Beachte auch die bei der Roßkastanie erörterte, verschiedene Blattstellnng an senkrechten, wagerechten und hängenden Zweigen!)

\section{7. und 48. Familie. Baldrian- und Karden-Gewächse (Valerianáceae} und Dipsáceae).

1. Der echte Baldrian (Valeriána officinális) liefert uns in seinem Wurzelstocke, dessen Geruch die Katzen lieben („Katzenkrant"), ein wichtiges Heilmittel. Die Pflanze, die fast Manneshöhe erreichen kann, wächst in feuchten Wäldern, auf Wiesen nnd an Flußufern, hat gefiederte Blätter und kleine, rötliche Blüten, die aber zu ansehnlichen, doldenartigen Blütenständen gehäuft sind. Die einsamigen SchlieBfrüchtchen besitzen je eine "Federkrone" (s. Löwenzahn), die der Verbreitung der Pflanze dient. (Stelle aber die Unterschiede fest, die im Blütenbau zwischen Baldrian und Korbblütlern obwalten!). - Ein handhohes Gewächs ist das Rapünzchen (Valerianélla olitória), das gern als Salatpflanze ( ${ }_{n}$ Feldsalat") angebant wird. Es entstammt dem mittelländischen Pflanzengebiete, ist aber bei uns vollständig heimisch geworden.

2. Die Familie der Kardengewächse nähert sich den Korbblütern in noch höherem Iaße. Wie uns z. B. die Tauben-Skabiose (Scabiósa columbária) zeigt, die auf trockenen Wiesen und an ähnlichen Orten vielfach vorkommt, sind die kleinen, lilafarbenen oder weißen Blïten zu ansehnlichen, ${ }_{n}$ strahlenden " Köpfchen gehäuft; sie stehen in den Achseln von ${ }_{n}$ Sprenblättern "; ihre Gesamtheit ist von einem "Hüllkelche" umgeben, und der Kelch, der die Schließfrüchtchen wie ein häutiger Saum krönt, tritt wie bei zahlreichen Korbblütlern als Fallschirm in den Dienst der Windverbreitung. (In welchen Punkten unterscheiden sich beide Familien aber wesentlich voneinander?) - Ganz ähnlich gebaut sind die meist roten Köpfchen der AckerSkabiose (Knautia arvénsis), die auf Feldern, Rainen und trockenen Wiesen sehr häufig anzutreffen ist. - Die Kardendiestel (Dípsacus silvéstris) dagegen, die sich an Waldrändern und unbebauten Orten findet, hat langgestreckte Blütenköpfe, an denen die stachelspitzigen Sprenblätter die rötlichen Blüten und später die Früchte überragen. Da zudem auch die Blätter des Hüllkelchs dicht mit Stacheln besetzt sind, so stellt das Köpfchen zur Zeit der Fruchtreife ein überaus stacheliges Gebilde dar. Auch die Mittelrippen der Blätter, sowie besonders die Stengel and $\mathrm{Z}$ weige sind

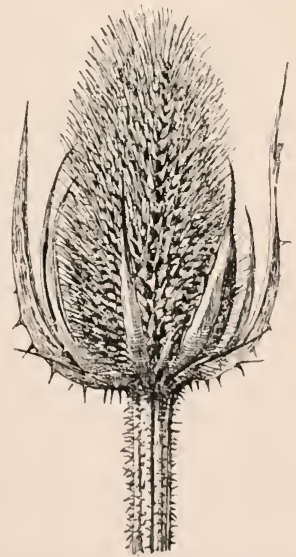

Fruchtstand der Kardendistel ( $1 / 2$ nat. Gr.). 
dicht mit Stacheln bewehrt. (Eine andere, aber noch stärker bestachelte Art wurde früher zum Aufkratzen oder „Karden" des Tuches benutzt. Name!) Zu diesem Schutzmittel (gegen Tierfraß) tritt noch ein anderes and zwar sehr eigentümliches. Indem die unteren Abschnitte der gegenständigen Blätter miteinander verwachsen, entstehen Becken, die durch das von den Blättern ablaufende Regenwasser gefüllt werden. Kriechen nun Insekten, die dem Honig in den Blüten einen Besuch abstatten wollen, an dem Stengel empor, so fallen sie in diese Becken und müssen ertrinken. Und welche Jengen von Insekten hierdurch oft ums Leben kommen, ist erstaunlich. Das Wasser erhält infolgedessen eine jaucheartige Beschaffenheit. Ob aber die Pflanze einen Teil dieser „düngenden" Flüssigkeit anfsaugt, ist noch nicht sicher festgestellt.

\section{Familie. Korbblütler (Compósitae).}

Zahlreiche kleine Blüten sind zu einem köpfchenartigen Blütenstande gehänft und werden von einer gemeinsamen Hülle umgeben, so daß das Ganze das Aussehen einer einfachen Blume erhält (Blütenkorb). Einzelblüte: Kelch wenig ausgebildet oder in eine Haarkrone (Pappus) umgewandelt; Blumenkrone entweder röhren- oder zungenförmig; Bentel der 5 Staubblätter zu einer Röhre verwachsen, die den Griffel umschliebt; der unterständige Fruchtknoten entwickelt sich zu einer einsamigen Schliebfrucht.

\section{Die Sonnenrose oder Sonnenblume (Heliánthus ánnuus).}

A. Bedleutung. Die Sonnenrose oder Somnenblume ist eine riesenhafte Sommerpflanze (verfolge sie vom Keimen bis zum Tode!), die aus dem heißen Amerika zu uns gekommen ist. Sie ist bei uns wegen der mächtigen, lenchtenden "Blumen", die sich mit strahlenden Sonnen vergleichen lassen (Name! s. anch Absch. E, 1), eine allgemein beliebte Zierde der Gärten. In einigen Gegenden, namentlich in Süd-Rußland und den Balkanstaaten, wird sie aber auch der Samen wegen angebaut. Man schlägt daraus ein wertvolles fettes Öl (s. S. 16, A), das als Speise- und Brennöl, sowie zur Bereitung feiner Seifen und in der Ölmalerei verwendet wird.

B. Stengel. Die Samen, die man im Frühjahre in die Erde legt, entwickeln sich sclnnell zu kräftigen Pflanzen, die nicht selten eine Höhe von $3 \mathrm{~m}$ und darüber erreichen. Ihr oft armdicker Stengel ist nur im oberen Teile verzweigt, fühlt sich wie alle grünen Teile ranh an und bildet eine weite Röhre (s. Roggen), die mit lockerem Mark (Verwendnng?) angefuillt ist.

C. Blätter. Eine Pflanze von solcher Höhe ist aber den Einwirkungen des Windes im hohen Grade ansgesetzt, zumal sie sehr große Blätter besitzt.

1. Da die herzförmigen Blattflächen aber von langen, beweglichen Stielen getragen werden, können sie, wie wir bereits bei der Betrachtung des Birnbaums gesehen haben, dem Anprall des Windes leicht answeichen. Bei einem solchen im Winde flatternden Blatte ist der Blattgrund der Gefahr des Einreißens besonders ausgesetzt, zumal wenn die Blattfläche wie bei der Sonnenrose sehr groß und am Grunde tief herzförmig ausgeschnitten ist. Dort ist das Blatt darum auch besonders gefestigt: wie beim Kürbisblatt bilden 
die sehr starken Seitennerven bis zu ihrer ersten Verzweigung feste "Säume", die selbst heftigen Stiirmen widerstehen.

2. Betrachtet man eine (noch niedrige) Pflanze von oben, so macht es den Eindrnck, als bildeten die Blätter eine Rosette: so gleichmäßig sind sie um den Stengel geordnet. Und zwar ist dies - von den ersten, sich gegeniiberstehenden Blättern abgesehen - in einer Schrauben linie erfolgt (wiederhole den S. 131 angegebenen Versuch mit dem Faden!). Infolge dieser regelmäßigen Verteilung werden sie wie die Blätter einer wirklichen Rosette trotz ihrer Größe von all den Sonnenstrahlen getroffen. Da nun die Sonnenstrahlen dann am wirksamsten sind, wenn sie das Blatt möglichst senkrecht treffen (s. S. 43, c), so verstehen wir auch

3. warum sich das Blatt mit seiner Spitze nach unten neigt. Infolge dieser Haltung muß aber auch das Regenwasser, das anf die Blätter fällt, nach außen geleitet werden (Versuch!). Hiermit stehen wieder die Verhältnisse der

D. Wurzel im innigsten Einklange. 1. Die Somnenrose ist - wie wir gesehen haben - eine hohe Pflanze mit großen Blïttern, die infolgedessen dem Winde stark ansgesetzt ist. Man erwartet daher bei ihr eine tiefgehende Haupturzel und weit ausgreifende Seitenwureln, die das schwere Gewächs sicher im Boden verankern. Gräbt man die Sonnenrose aber aus, so findet man zwar eine Hauptwurzel, die senkrecht in den Boden hinabsteigt; die von ihr nach allen Seiten ausstrahlenden Seitenwurzeln dagegen sind auffallend kurz. Dafür sind sie aber in sehr großer Zahl vorhanden und verzweigen sich so stark, daß ein dichtes Wurzelgeflecht, ein "Ballen" entsteht, aus dem die Erde nur schwer (durch Klopfen!) zu entfernen ist. Was den Seitenwurzeln an Länge abgeht, wird eben durch ihre Zahl und reiche Verzweigung ersetzt.

2. Faßt man die Länge der Seitenwurzeln genan ins Ange, so merkt man, daß sich die entferntesten Wurzelspitzen ïber den Umfang der Blattkrone (wenn man bei der Sonnenrose iiberhaupt von einer solchen sprechen kann!) nicht hinaus erstrecken, eine Erscheinung, die wir beim Birnbaum bereits kennen und verstehen gelernt haben (s. S. 88 , e) und bei den meisten Pflanzen mit „centrifugaler" Wasserableitung wiederfinden. Da die Sonnenrose aber nicht eine so dicht geschlossene "Krone“ wie z. B. der Birnbaum hat, so tropft das Regenwasser auch nicht nur am Umfange derselben zum Erdboden herab. Es wird im Gegenteil der ganze Bezirk, der unter den Blättern liegt, durchnäßt. Die Saugwurzeln finden sich daher auch nicht in einer ringförmigen Zone (wie dies z. B. beim Birnbaum der Fall ist), sondern sind iiber den ganzen Wurzelballen verteilt, oder anders ausgedrïckt: die oben erwähnte Auflösung der Seitenwurzeln in sehr zahlreiche, immer feiner werdende Zweige, deren Endteile das Wasser a ufsangen, ist also anch noch ans diesem zweiten Grunde notwendig.

Wenn die Sangwnrzeln wie beim Birnbanme nur in einer ringförmigen Zone lägen, würden sie ïbrigens anch gar nicht imstande sein, das notwendige Wasser aufzunehmen. Man braucht nur zu bedenken, erstens, daß die Sonnen- 
rose eine große Pflanze ist und daher auch viel Wasser gebraucht, zweitens, daß die Aufnahme der Wassermenge zahlreiche Sangwurzeln voraussetzt, und drittens, daß diese Wurzeln in einer ringförmigen Zone, die der "Krone" entsprechend nur sehr klein sein würde, unmöglich Platz finden könnten.

E. Bliitenstand. 1. Stengel und Zweige tragen am Ende je eine große "Blume“, die sich bei freistehenden Pflanzen gern der Sonne zukehrt (daher vielleicht "Sonnenblume“). Sie hat oft einen Durchmesser von $25 \mathrm{~cm}$ und mehr (Stamm und Zweige kräftig!) und ist infolge der Schwere bald mehr oder

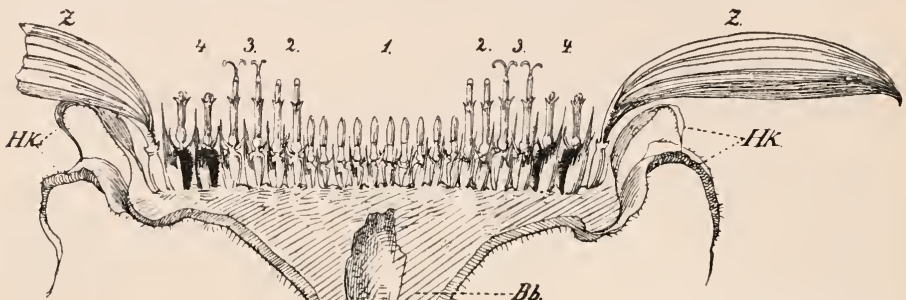

Querschnitt durch den Bliitenstand der Sonneurose.

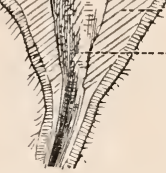

1.-4. Röhrenblüten (1. noch nicht geöffnet; 2. der Blütenstaub ist aus der Blütenröhre hervorgeschoben; 3 . die Narben spreizen auseinander; 4. verblüht (vgl. die Abb. auf S. 178). Z. Zungenblüten. H.K. Hüllkelch. Bb. Blütenboden. H. Der mit der Höhlung des Stengels in Verbindung stehende Hohlraum im Blütenboden.

weniger nickend. Trotz dieser Haltung wird sie aber den Blicken der Insekten nicht entzogen; denn die Sonnenrose ist eine hohe Pflanze, und die honigsuchenden Insekten fliegen meist nur in geringer Höhe ïber dem Erdboden dahin. (Welche Mittel wenden niedrige Pflanzen an, um ihre nickenden Blüten sichtbar zu machen?)

2. Durchsclneiden wir eine solche Blume der Länge nach, so sehen wir, daß auf dem scheibenförmig erweiterten Ende des Stengels, dem Blütenboden, sehr viele kleine, ungestielte Blüten sitzen. Wir haben es hier also nicht mit einer einzelnen Blüte, sondern mit einer Blütengenossenschaft oder einem Blütenstande zu tun, den man seiner Form nach (wie z. B. beim Wiesenklee und der Grasnelke) als $\mathrm{K} \ddot{\mathrm{p}} \mathrm{f} \mathrm{chen}$ bezeichnet.

Sämtliche Blüten werden von mehreren großen, grünen Blättern umgeben. So lange sich das Köpfchen im Knospenzustande befindet, sind die Blüten von diesen Blättern vollkommen überdeckt, und auch noch späterhin lassen die derben Gebilde den zarten Blïten einen wirksamen Schutz, besonders gegen ankriechende Tiere (Ameisen, Schnecken u. dgl.) angedeihen (vgl. anch diejenigen Familienglieder, deren Blütenköpfchen sich nachts schließen, z. B. Löwenzahn, Wiesen- 
bocksbart!). Darch diesen sog. Hïllkelch erhält der Blütenstand das Aussehen eines mit vielen Blüten gefüillten Körbchens. Darum bezeichnet man ein so gebildetes Köpfchen treffend auch als Blütenkörbclien („Korbblütler“").

3. Die Einzelbliiten entspringen in den Achseln kleiner, dreizackiger Blätter, die sich besonders bei der Fruchtreife spreuartig trocken anfühlen und daher Spreublätter genannt werden. Entfernt man die reifen Friichte, so erhält der Blïtenboden, den man jetzt als Fruchtboden bezeichnet, durch die Spreublätter fast das Aussehen einer Bienenwabe. (Zahlreichen andern Korbbliitlern, wie z. B. dem Löwenzahn, fehlen diese Blätter.)

4. Wenn man bedenkt, daß die Einzelblüten nur sehr kleine Gebilde sind, so wird man auch die $B$ ede $u t u n g$ ihrer $H a ̈ u f u n g$ verstelıen: ein einzelnes Blïtchen wäre so unscheinbar, daß es unmöglich die Blicke der Insekten auf sich lenken könnte, ganz anders aber, wenn es sich mit vielen seinesgleichen vereinigt (vgl. hierzu auch Absch. F., 2).

F. Einzelbliite. Zwischen den Einzelblüten macht sich nun wieder ein großer Unterschied bemerklich: die in der Mitte der Blumenscheibe stehenden haben eine kleine, gelbbraune, röhrenförmige Blumenkrone, während die am Rande des Körbchens befindlichen eine gelbe Blumenkrone besitzen, die zu einem langen Bande oder einer Zunge ausgezogen ist. Nach der Stellung kann man die Blüten also als Scheiben- und Randblüten, nach der Form als Röhren- und Zungenblïten unterscheiden.

1. Röhrenblïte (s. Abb. S. 178). Der unterständige (s. S. 71, b) Fruchtknoten trägt oben (meist) 2 Blättchen, in denen wir den Kelch vor uns haben. Wenn wir uns daran erinnern, daß der Hüllkelch für die Gesamtheit der Blüten die Bedeutung eines Kelches besitzt, so wird uns die geringe Ausbildung des wirklichen Kelches leicht verständlich. (Bei anderen Korbblütlern, z. B. bei der Wucherblume, sind vom Kelche noch viel geringere Spuren zu finden, während er bei wieder anderen Arten zu einer "Haarkrone" umgebildet ist; s. S. 182.) Die Blumenkrone ist eine enge Röhre, die etwas über dem Grunde eine kugelförmige Erweiterung zeigt und in 5 Zipfel endet. Am Grunde der Erweiterung sind die Fäden der 5 Staubblätter eingefügt, deren Beutel zu einer den Griffel umgebenden Röhre verwachsen sind. Der Griffel endet in $2 \mathrm{Narben}$, die aber erst im letzten Blütenzustande (Fig. 4 der Abb. auf S. 178) auseinanderspreizen. Der $\mathrm{Honig}$ wird von einem kleinen Wulst am Grunde des Griffels abgeschieden, nnd zwar in so großer Menge, daß der untere Teil der Blütenröhre oft damit gefüllt ist. -

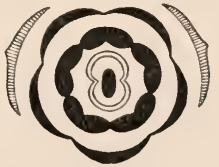

Bliitengrundrig einer Röhrenblite der sonnenrose. Un die Art der Bestäubung kennen zu lernen, müssen wir

a) bereits eine Blüte öffnen, wenn sie sich noch im Knospenzustande befindet (1). Wir selıen, wie die Staubbeutel noch geschlossen sind, wie der Griffel noch nicht bis zu der Staubbeutelröhre empor reicht, und wie die beiden Narben noch eng aneinander liegen. Außen sind die Narbenäste, 
sowie ein Stiick des Griffels selbst mit zahlreichen feinen Haaren besetzt, so daß der Griffel das Aussehen eines winzigen Cylinderputzers erhält.

b) Bei einer etwas älteren Blïte finden wir die Bentel nach innen geöffnet, so daß die Röhre mit Blütenstaub ausgefüllt wird. Bei einer wieder älteren, aber immer noch geschlossenen Blüte (2) ist der wachsende Griffel wie ein Kolben in der Staubbentelröhre vorgedrungen. Infolgedessen schiebt er den Blïtenstanb vor sich her und nimmt die etwa zurïickbleibenden Körnchen in seinem Haarbesatze mit empor.

c) Nunmehr öftnet sich die Blumenkrone (3). Der sich immer mehr

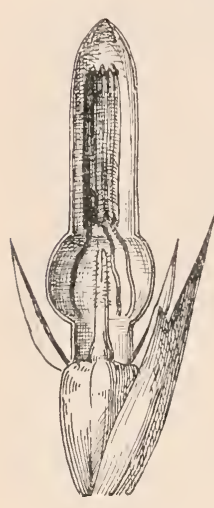

1.

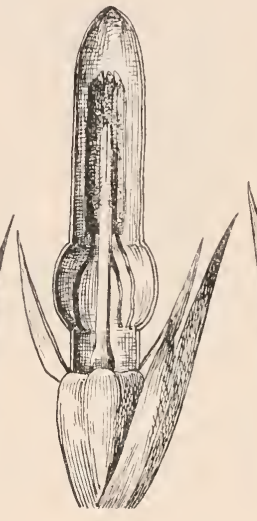

2

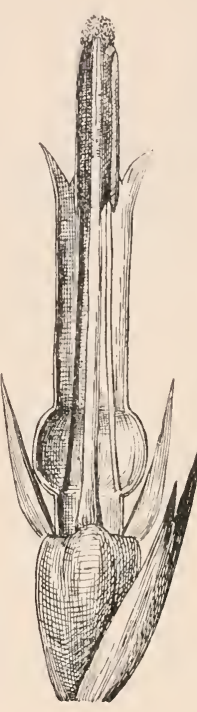

3.

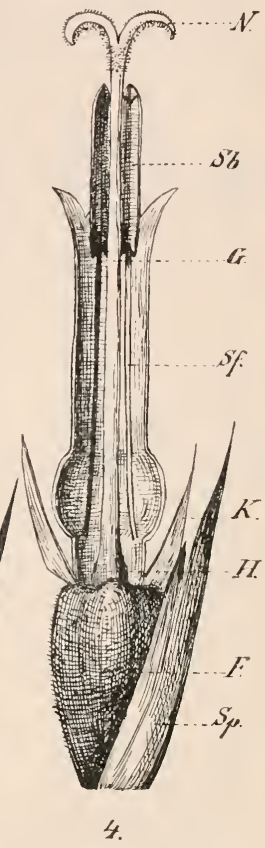

Röhrenblite der Somenrose in ihrer Entwicklung. Die einzelnen Entwicklungszustände sind im Texte erklärt. Die Blütenröhre ist der Länge nach halbiert; von den Staubblättern sind in Fig. 1 u. 2 nur je 3, in Fig. 3 u. 4 nur je 2 zur Darstellung gelangt. - Sp. Spreublatt. F. Fruchtknoten. H. Honigabsondernde Stelle des Griffels. K. Kelchblätter. Sf. Staubfäden. G. Griffel. Sb. Staubbeutelröhre (geöffnet). N. Narbe. (Etwa 5 mal vergr.)

streckende Griffel hebt die schwarzbranne Staubbentelröhre - die Stanbfäden haben sich gleichzeitig stark verlängert - aus der Blïte herans nnd drängt zugleich den Bliitenstaub in Formeines gelben Hänfehens ans der Staubbentelröhre hervor. Jetzt befindet sich der Staub an der Stelle, an der er von Insekten leicht abgestreift werden kann. Und in welch' 
reichlichem Maße dies geschieht, zeigt die oft ganz gelbe Körperunterseite der saugenden Besucher.

d) Ist der Blütenstaub abgeholt, dann spreizen erst die Narben auseinander, so daß ihre allein ,belegnngsfähige" Innenseite offen daliegt (4.) Gewöhnlich dautert es anch nicht lange, so bringen die Insekten, die von IBlite zu Blüte schreiten, von jüngeren Blïten Staub herbei. Das ungleichzeitige Reifen der Staubbentel und Narben in derselben Bliite lıat also wie bei der Glockenblume (s. das.) meist Fremdbestäubung im Gefolge.

e) Auch wem die Insekten von anderen Pflanzen oder von anderen Bliitenkörben derselben Pflanze keinen Bhitenstaub herbeitragen wiirden, erfolgt in der Regel doch die "erwïnschte" Fremdbestäubung; denn die Bliiten eines Köpfchens öffnen sich ja nicht alle zu gleicher Zeit. Abgesehen von den ersten und letzten Tagen des Blïhens findet man - wie die Abb. auf S. 176 zeigt in jedem Körbchen Blïten in allen Entwicklungszuständen, und zwar erfolgt das Aufblïhen reihenweis von außen nach innen (ebenso natïrlich auch das Verbliihen!).

f) Tritt aber infolge ausbleibenden Insektenbesuchs Fremdbestäubung nicht ein, so „bequemt" sich die Pflanze schließlich zur Selbstbestänbung: die Narbenïste rollen sich so weit zurïck, daß ihre Oberseiten die verschrumptiten "Fegehaare" berühren, in denen stets noch einige Blïtenstaubkörnchen hängen geblieben sind. (Derselbe Vorgang ist anch an der Glockenblume zn beobachten. Ähnlich erfolgt auch bei zahlreichen anderen Pflanzen Selbstbestäubung, wenn Fremdbestäubung nicht eintritt.)

2. Zungenblïten. a) Die am Rande des Köpfchens stehenden Zungenblüten (s. Abb. S. 176) zeigen im wesentlichen denselben Ban. Ihre sehr kurze Blütenröhre ist jedoch - wie bereits erwähnt - zu einem langen Bande ausgezogen, und Stanbblätter sowohl, als einen Griffel sucht man bei ihnen vergeblicl. Sie sind demnach nnfruchtbar (der Fruchtknoten verschrumpft), aber durchaus nicht ohne Bedeutung für die Pflanze. Indem die bandförmigen Abschnitte der Blumenkrone nach anßen strahlen, erhöhen sie die Auffälligkeit des Blütenkorbes und helfen dadurch die Bestäuber der Röbrenblüten herbeilocken. Die Randbliiten bezeichnet man daher auch als Strahlenblïten und Bliitenköpfe dieser Art als "strahlend" (vgl. mit Möhre und Schmeeball!). In den Blïtenständen der Sonnenrose (und aller jener anderen Korbblütler mit ähnlichen Bliitenkörben) ist also eine "Arbeitsteilnng" eingetreten: die Blüten haben sich in Frucht- und "Lockblïten" geschieden.

b) Da Rand- und Scheibenblitten außerdem noch von verschiedener Färbung sind, so werden die Bliitenstände umso auffälliger; denn Farbengegensiatze (Farbenkontraste) erhöhen bekanntlich die Auffälligkeit eines Gegenstandes; wir brauchen nur an Plakate, Firmenschilder u. dgl. zu denken. (Es gibt aber auch eine gärtnerische Spielart der Sonnenrose, bei der Rand- und Scheibenblïten gelb gefürbt sind. - Ton zahlreichen anderen Korbblïtlern, z. 13. Von Asterı, Georginen und Gäuseblïmchen, hat der Mensch Spielarten 
geziichtet, bei denen die Blumenkronen der ursprïnglich röhrenförmigen Scheibenblüten zungenförmig geworden sind. Solche Blütenstände bezeichnet man bekanntlich als "gefïllte" Blumen.)

c) Wie wir oben gesehen haben, blühen die Scheibenblïten nicht alle zugleich, sondern nacheinander, und zwar jede nur eine verhältnismäßig kurze Zeit. Da die Randbliiten aber allen Scheibenblïten „dienen" mïssen, so blühen sie auch während einer viel längeren Zeit, oder bestimmter ansgedrückt: die Blïtezeit der Randblüten ist gleich der Gesamtblütezeit der Scheibenblïten.

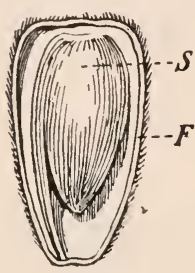

Fruchtknoten der Somnenrose, geöffnet. F. Frachthälle. S.Die gestielteSamenanlage ( 8 mal vergr.).

G. Frucht. Die Fruchthïlle - sie ist, wie die 2 Narben andeuten, aus 2 Fruchtblättern gebildet schließt nur einen Samen ein, der sich vom Grunde erhebt. Die schwarzgraue Frucht öffnet sich daher bei der Reife nicht: sie ist eine Schließfrucht (s. S. 10, 3). Indem der Wind die hohe Pflanze schïttelt, strent er die glatten Frïchte über ein größeres Gebiet aus. (Bei welchen anderen Korbblïtlern erfolgt die Verbreitung auf dieselbe Weise? Welche Vögel stellen den Früchten gern nach?)

\section{Der Löwenzahn (Taráxacum officinále).}

1. Bedeutung. Der Löwenzahn ist so recht die Pflanze der Kinder: jubelnd pflücken die Kleinen die leuchtend gelben Blïtenköpfe zum Strauß („Butterblume“), "schmieden" die hohlen Blïtenstiele zu vergänglichen Kettlein („Kettenblume“, „Ringelblume") und fragen die zierlichen Fruchtstände ("Lichter", „Lampen"), wie lange sie wohl noch leben („Pustblume“).

Die Blätter, die gleich allen anderen Teilen einen weißen, klebrigen II ilchsaft enthalten, werden von den Weidetieren gern verzehrt („Kuhblume"). Den Verlust der Blätter verwindet die Pflanze jedoch gewöhnlich sehr bald; denn der kurze, dicke (oft verzweigte) Stamm (Wurzelstock) ist im Erdboden geborgen. Er kann daher von den Blatträubern nicht mit verletzt werden und beginnt meist bald darauf von nenem zu treiben. Genan so verhält sich der Löwenzahn der Sichel gegenüber: anf Rasenplätzen ist er - wie der Gärtner sagt - nicht „tot zu bekommen" und dort daher ein lästiges Unkraut. Die jüngsten Blätter werden in einigen Gegenden auch als Salat verzehrt.

2. Standort. Der Löwenzahn ist auf Wiesen und Grasplätzen, sowie an Wegen und ähnlichen Stellen überall häufig anzutreffen. Während er hier auf sehr trockenem Boden im stärksten Sonnenbrande wächst, bewohnt er dort fenchte, schattige Orte; während er hier nur mit niederen Gräsern das Gebiet teilt, steht er dort mitten zwischen den hohen Wiesenpflanzen, die ihn fast zu „erdrücken" scheinen. Er gedeiht also unter sehr verschiedenen Verhältnissen; allen aber ist er - wie wir sofort sehen werden - vortrefflich "angepaßt". 
3. Wurzel. Da sich der kurze Stamm in eine lange Pfahlwurzel fortsetzt, die bis zn den stets feuchten Bodenschichten hinab steigt, vermag der Löwenzahn selbst der Wasserarmut festgetretener Wege zu trotzen. An diesen Stellen findet man seine

4. a) Blätter stets zu einer Rosette (s. S. 17, 3) geordnet, die dem Boden dicht aufliegt, ihn beschattet und mithin vor zu starker Austrocknung schützt.

b) Die so geordneten Blätter sind zudem auf der Oberseite mit einer oder mehreren deutlichen $\mathrm{R}$ innen versehen. Infolgedessen leiten sie jeden Regentropfen, von dem sie getroffen werden, der dürstenden Wurzel zu. (Der Richtung der Wurzel entsprechend, ist die Wasserableitung also centripetal; s. S. 88.)

c) Infolge der Rosettenstellung der Blätter verdrängt der Löwenzahn (wie der Wegerich; s. Taf. 23, anf der diese Erscheinung angedentet ist) endlich auch die kleineren, benachbarten Pflanzen, die ihm ja Bodenfeuchtigkeit wegnehmen würden: er bedeckt sie mit seinen Blättern, raubt ilınen also das Licht, und - Lichtmangel ist stets der Tod der grünen Gewächse. Darum ist er auch wie sein trenster Genosse, der Wegerich, an Orten mit niedrigem Pflanzenwuchs vielfach die "herrschende" Pflanze. - Dieses Verhalten des Löwenzahns gegen andere, schwächere Gewächse ist ein deutliches Beispiel von dem erbitterten und ununterbrochenen Kampfe, der in der scheinbar so friedlichen Welt der Pflanzen herrscht, von einem Kampfe, der sich um Nahrung, Licht, Luft und Raum dreht! (Verfolge diesen Kampf auch bei anderen Pflanzen nnd beobachte, wie stets die stärkere als Siegerin daraus hervorgeht!)

d) Steht der Löwenzahn aber zwischen üppig wachsenden Pflanzen, etwa auf einer wohlgepflegten Wiese, so kommt er häufig in die Gefahr, überwuchert zu werden. Dann verlassen die Blätter mehr oder weniger die zierliche Rosettenstellung: sie richten sich schräg oder gar senkrecht anfwärts, dem belebenden Lichte entgegen.

e) Da sich der Löwenzahn hier, sowie an wirklich schattigen Stellen (gib solche an!) nicht im Vollgenusse des Lichts befindet, sind seine Blätter sehr groß und zart wie die der eigentlichen Schattenpflanzen (s. S. 7, a u. b). (Stelle die verschiedene Größe der Blätter von "Sonnen- und Schattenpflanzen" durch Messungen fest, und beobachte, wie verschieden sich diese Blätter gegen das Vertrocknen verhalten!)

f) Anßerden erhalten hier die Blatter oft ein ganz verändertes Anssehen: während sie bei Pflanzen trockener oder mäßig feuchter Standorte mehr oder weniger tief wie eine Schrotsäge eingeschnitten sind (Löwenzahn"; Abschnitte meist rückwärts gerichtet, oft nochmals mit kleinen Zähnen), ist hier der Blattrand oft nur noch schwach gezähnelt, eine Erscheinung, die gleichfalls auf eine Vergrößerung der Blattfläche hinaus läuft.

5. Blüte. a) Die Blütenköpfe stehen einzeln am Ende je eines blattlosen, hohlen Stieles (eines sog. Schaftes), der je nach der Höhe der umgebenden Pflanzen sehr kurz, aber auch außerordentlich lang sein kann 
(Beweis! Bedeutung?). Im Blïtenköpfchen finden sich nur Zungenblüten. Sie entspringen nicht in den Achseln von Spreublättern und unterscheiden sich von denen der Sonnenrose besonders dadurch, daß sie wie die Röhrenblüten dieser Pflanze wohl ausgebildete Staubblätter und einen ebensolchen Griffel besitzen. Auch die Bestäubung erfolgt genan wie bei der Sonnenrose. Hinsichtlich der Bildung des Kielches dagegen zeigt sich ein wesentlicher Unterschied: der Fruchtknoten setzt sich oben in ein kurzes Stielchen fort, das auf seiner Spitze (anßer der Blumenkrone) einen Haarkranz trägt, in dem wir den Kelch vor uns haben. Dieser "Haarkelch" (Pappus) krönt später die reife Frucht und wird daher auch .Ha ar- oder Federkrone" genannt.

b) Schon lange bevor sich das Köpfchen öffnet, sind die äußeren Blätter des Hüllkelchs herabgeschlagen; die inneren dagegen stehen aufrecht und umhïllen schützend die zarten Blïten. Dabei schließen sie so eng aneinander, daß es den Eindruck macht, als seien sie in der unteren Hälfte miteinander verwachsen. An einem sonnigen Morgen ist endlich für das Köpfchen die Zeit des Öffnens gekommen. Die Blötchen spreizen weit anseinander, so daß sie eine große, leuchtend gelbe Fläche bilden (Bedeutung?) und die Blätter des Hiillkelchs nach außen drängen. Bereits lange vor Anbruch des Abends schließen sich die Köpfchen wieder: die Blüten kehren in die Knospenlage zurïck, werden wieder vom Hüllkelch umgeben, nnd von der früheren Herrlichkeit ist nichts mehr zu sehen (s. S. 3, b). Dieser Vorgang wiederholt sich täglich, bis das Blühen ein Ende erreicht hat. Bei regnerischem und kaltem Wetter öffnen sich die Köpfchen gar nicht! (Verfolge, zu welchen Tagesstunden das Öffnen und Schließen in deiner Heimat während der einzelnen Monate erfolgt!)

6. Frucht. a) Im Schutze des Hüllkelchs reifen auch die Früchte. Die Blumenkrone ist nach dem Verblïhen abgefallen; die stielchenartige Verlängerung des Fruchtknotens dagegen hat sich gleich den Haaren der Haarkrone stark in die Länge gestreckt. Sind die Früchte reif und somit verbreitungsfähig geworden, und scheint die Sonne warm herab, dann spreizen die Haare auseinander, während sich die Blätter des Hüllkelchs gleichzeitig nach unten schlagen: es haben sich jene bekannten, kugeligen Fruchtstände gebildet, die an Zierlichkeit ihresgleichen suchen.

b) Jetzt "Warten" die Frïchte auf einen Windstoß, der sie uiber ein weites Gebiet aussäen soll (Bedentung? s. S. 10, 3). Diesen wichtigen Dienst vermag der Wind der Pflanze wohl zu leisten; denn die Haarkrone liefert ihm einerseits eine große Angriffsfläche, so daß er die Frucht leicht vom Fruchtboden ablösen kann, und sie stellt andererseits einen winzigen Fallschirm dar. Wie ein solcher Schirm der Luft einen großen Widerstand entgegensetzt, so daß der an ihm hängende Luftschiffer nur langsam zur Erde herabschwebt, so wird auch durch die Haarkrone ein schnelIes Fallen der Früchte verhindert. Sollen die Früchte aber wirklich über ein weites Gebiet verbreitet werden, dann müssen die Fallschirme anch die zum Schweben notwendige Stellung beibehalten 
(was würde im anderen Falle geschehen?). Auch dafür ist gesorgt: da sich das "Sticlchen" sehr lang gestreckt hat, ist der Schwerpunkt des ganzen, federleichten Gebildes verhältnismäßig tief zu liegen gekommen, so daß es wie ein "Stehauf" stets senkrecht stehen muß. Sind die Frïchte vom Winde nicht abgeholt, dann legen sich die (hygroskopischen) Fallschirme in der fenchten Abendluft wieder zusammen, und die Kelchblïter umgeben sie abermals; denn der Tau der Nacht würde die Haarkrone so durchfenchten und beschweren, daß an eine Verbreitung durch den Wind nicht mehr zu denken wäre. Am nächsten Tage im warmen Sonnenscheine beginnt das Spiel von nenem. Bei feuchter Luft dagegen öfnen sich die Fruchtstände üherhaupt nicht.

c) Ist das "Luftschiff" gestrandet, dann löst sich die Haarkıone mit dem Stielehen von der Frucht ab, die durch zahlreiche Zähnchen der Fruchtschale bald sicher im Boden verankert ist (Bedentung?).

\section{Andere Korbbliitler.}

Die Korbblütler stellen mit ibren etwa 12000 Arten die gröBte aller Pflanzenfamilien dar. Sie sind über alle Zonen verbreitet und finden sich bei uns an den versehiedensten Standorten. Nach der Bildung der Blütenköpfchen lassen sie sich leicht in folgende drei Gruppen ordnen:

1. Gruppe. Strahlenbliitige: Die röhrenförmigen Seheibenblüten werden (wie bei der Sonnenrose) in der Regel von einem Kranze zungenförmiger Rand-oder Strahlenblüten umgeben.

Mit der Sommenrose haben zahlreiche andere Korbblütler Einzug in unsere Gärten gehalten. Von diesen seien nur die beiden wichtigsten, die Garten-Aster (Aster ehinénsis) aus China und die Georgine (Dáhlia variábilis) aus Mexieo, genannt. Gärtnerische Kunst hat aus ihnen eine unabsehbare Anzahl von Spielarten gezüehtet (s. S. 19), die hinsichtlieh der gesamten Gestalt (z. B. „Zwergastern“), sowie der Größe, Farbe und Form der Blütenköpfe $u$, dgl. oft beträchtlieh voneinander abweichen. Wie man an den wildwaehsenden Asterarten unserer Heimat, sowie an "einfaehen " Georginen sehen kann, haben die Köpfchen dieser Pflanzen wie die der Sonnenrose ursprünglich aueh nur einen Kranz von Zungenblüten. Gelegentlich zeigen sich aber auch einige oder mehrere Röhrenblüten der Scheibe zungenförmig umgestaltet. Da dem Menschen solehe Blütenköpfe besonders gefielen, suchte er zur Fortzucht stets nur die Pflanzen aus, bei denen solehe regelwidrigen (abnormen) Blütenbildungen besonders ausgeprägt waren: auf diese Weise sind im Laufe der Zeit die Formen mit gefüllten Blüten" entstanden, die heute fast allgemein angepflanzt werden.

Wie sehnell eine solche "Veredlung " erfolgen kamn, zeigt deutlieh eine allbekannte Wiesenpflanze, das freundliehe (đïssebliimchen oder Maßgliebchen (Bellis perénnis). Man braueht es nur in gute Gartenerde zu pflanzen, so tritt aueh alsbald eine Vermehrang der Strahlenblüten ein, und es entsteht das bekannte, weiß- oder rotblühende Tausendsehönehen. Die wildwachsende Pflanze blüht fast das ganze Jahr hindurch. Die Köpfchen, die sich a uf mehr oder weniger langen Stielen über die zierlichen Blattrosetten erheben, schließen sich abends nicht nur wie die des Löwenzahns, sondern werden meist anch niekend. - In der Gesellschaft des Gänseblümchens (Standort!) findet sich vielfach die weige Wurherbhume (Chrysánthemum leueánthemum) mit ganz ähnliehen, nur weit größeren Blütenküpfeben (erkläre den Namen!). Eine in Ostasien heimisehe nahe Verwandte 
der Wucherblume ist die Stammutter der zahlreichen Winterastern (ChrysánthemumFormen), die in immer größerer Blütenpracht von den Gärtnern gezogen werden. Aus den Blütenköpfen anderer nahe verwandter Arten bereitet man in Persien, den Kaukasusländern und Dalmation das bekannte Insektenpulver. - Einen prächtigen Schmuck der Gebirgswiesen bilden die großen, gelben Blütenstände des Wohlverleih oder der Arnica (Árnica montána). Die stark gewürzhaft riechenden Wurzeln nnd Blüten (Schutz gegen Weidetiere!) standen früher in der Heilkunde in hohem Ansehen. - Sehr kleine, weiße Blütenköpfe besitzt die Schafgarbe (Achilléa millefólium). Da sie aber zu ansehnlichen Trugdolden gehäuft sind, werden sie doch weithin sichtbar. Die Pflanze wächst aufer auf trockenen Wiesen, besonders an Wegen und ähnlichen Stellen. Dementsprechend besitzt sie auch wie zahlreiche andere Gewächse dieser Örtlichkeiten (Beweis!) sehr tiefgehende unterirdische Teile (Wurzelstock und Wurzeln), überaus zähe Stengel und vielfach zerteilte Blattflächen. - Ähnliche Verhältnisse finden wir beim Raiufarn (Tanacétum vulgáre) wieder, der den Namen von seinem Lieblingsstandorte, dem Ackerraine, und den farnwedelartigen Blättern hat. Die gelben Blütenköpfe besitzen keine Strahlenblüten.

An feuchten Stellen, in Gräben, an Teichrändern u, dgl., wächst überall häufig der Sumpf-Zweizahn (Bidens tripartitus). Bei ihm verwandeln sich die 2-4 Kelchblätter zu starren Fortsätzen der Frucht (Name!). Da diese Gebilde mit zahlreichen Widerhäkchen besetzt sind, bleiben die Früchte ("Bettlerlänse“) im Fell oder Gefieder

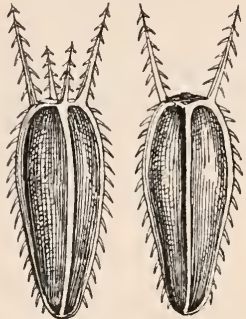

Friichte vom Sumpf-

Zweizahn (etwa $12 \mathrm{mal}$ vergr.) vorbeistreifender Tiere oder in den Kleidern des Menschen hängen und werden auf diese Weise oft weit verschleppt (Bedeutung?). - An Grabenrändern, auf feuchten Äckern und an ähnlichen Orten entfaltet als eine der ersten Frühlingspflanzen der Huflattich (Tussilágo fárfara) seine gelben Blütenkörbe, die sich mit Beginn des Abends schlieben und nickend werden (Bedeutung?). Nach beendeter Blütezeit streckt sich der von schuppigen Blättern besetzte Blütenschaft stark in die Länge. Infolgedessen wird der Fruchtstand äber die Pflanzen der Umgebung, die mit emporgeschossen sind, gehoben, so daß der Wind die mit Haarkronen ausgerüsteten Früchte zu verbreiten vermag. Erst nachdem dies geschehen ist, wachsen die unterseits weibfilzigen Blätter heran (s. Salweide). Da sie von außerordentlicher Größe sind, würden sie die Blütenköpfe verdecken, die sich daram eben vor ihnen entwickeln. Dell Baustoff liefern die mächtigen Wurzelstöcke, die sich weit im Boden ausbreiten. Der willkommene Lenzbote wird dadurch freilich für den Landmann ein lästiges Unkraut.

Von den bekanntesten Ackerunkräutern dieser Gruppe, die aber a u ch an trockenen Stellen (an Wegen, auf Rainen, auf Schutthaufen u. dgl.) wachsen, wären weiter folgende Arten zu nennen: die echte Kamille (Matricária chamomilla), deren Blüten in der Heilkunde mannigfache Verwendung finden. Durch den starken Duft, die herabgeschlagenen Randbläten und den kegelförmigen, hohlen Blütenboden ist die Pflanze leicht von der falschen Kamille (M. inodóra) zu unterscheiden, die geruchlos ist und einen halbkugeligen, nicht hohlen Blütenboden hat. - Zwei andere sehr hänfige Unkräuter sind das gemeine und das Frühlings-Kreuzkraut (Senécio vulgáris und vernális). 
Die erstere Art ist eine beliebte Nahrung der Stubenvögel and hat kleine Blätenköpfe, denen die Strahlenblüten fehlen. Die andere Form dagegen besitzt große, gelbe, strahlende Köpfo; sie ist aus Osteuropa zu uns gekommen und verbreitet sich außerordentlich schnell (zahlreiche Früchte mit wohlausgebildeter Haarkrone!) immer weiter nach Westen. - Etwas Ähnliches gilt von dem kanadischen Berufskraute (Erigeron canadénsis), das - wie der Artname angibt - aus Kanada stammt. und sich bei nns besonders an unbebauten Stellen oft in großen Beständen findet.

Viele andere Formen sind ansgeprägte $0 ̈ \mathrm{~d}$ landpflanzen. Als solche wären zuerst die zahlreichen Beifußarten (Artemísia) zu nennen, von denen der gemeine B. (A. vulgáris) an unbebauten Stellen am häufigsten anzutreffen ist. Dem Standorte entsprechend (vgl. mit Steinnelke und Königskerze) hat die meterhohe, sparrige Pflanze kleine, tiefgeteilte nnd anf der Unterseite weißfilzige Blätter. Die zahlreichen winzigen Blütenköpfchen sind ganz unscheinbar. Da die Blütchen zudem honiglos sind, so werden sie kaum einmal von einem Insekt besncht. Sie sind daher auf die Bestäubung durch den Wind angewiesen, der den trockenen Blütenstaub verweht: daher die große Übereinstimmung mit anderen windblütigen Pflanzen (s. z B. Haselnuß) auch in Punkten, die hier unerwähnt geblieben sind (Beweis!). Die blühenden Zweige werden vielfach als Kächengewürz benutzt. - Ein feineres Gewürz liefert der ganz ähnliche Estragon (A. dracúnculus), der ans Südrußland stammt. Der Wermut (A. absinthium) dagegen, der an unbebauten Orten wächst, bei uns aber wohl nur verwildert ist, enthält einen sehr scharfen Bitterstoff (der sprichwörtlich gewordene, Wermuttropfen“!). Die Pflanze findet daher in der Heilkunde, aber auch als Zusatz zu Wein und Branntwein vielfache Verwendung. - Ein dichtes, weißes Haarkleid, das Blätter und Stengel äberzieht, erlaubt der niedlichen Saud-Strohblune (Helichrýsum arenárium) selbst auf ödestem Sandboden zu wachsen und in der Hitze des Hochsommers za blühen. Obgleich die Einzelblüten ganz unscheinbar sind, werden sie im Gegensatz za denen des BeifuB nicht vom Winde bestäubt. Die Aufgabe, die Insekten anzulocken, übernimmt hier der Hüllkelch, dessen zahlreiche Blättchen meist zitronengelb gefärbt sind. Und die A uffälligkeit

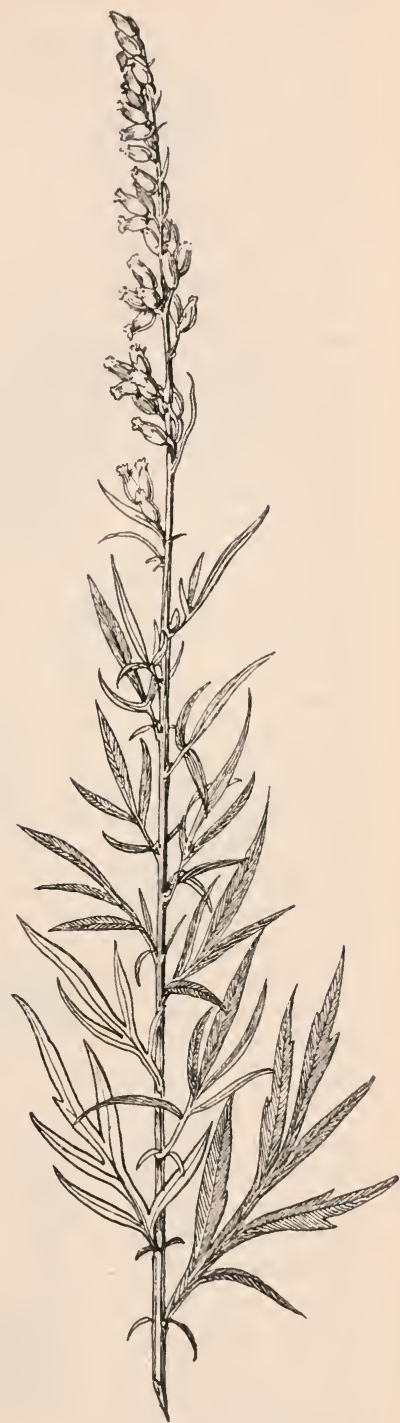

Zweim des grem. Beifuß. (Nat. Gr.) 
ist umso größer, als die kleinen Köpfchen dicht gehäuft sind. Da der Hällkelch strohartig trocken ist (Name!), behalten die abgeschnittenen Köpfchen auch nach der Blütezeit ihr Aussehen ( Immerschön"; "Immortelle, d. h. die Unsterbliche). Deshalb verwendet man die zierliche Pflanze auch gern zu Kränzen. Dasselbe gilt von mehreren ausländischen Strohblumen-Arten unserer Gärten. - Abgesehen von zahlreichen anderen filzig-behaarten Korbblütlern unserer Flnren, sei hier nur noch des herrlichen Elelweiß (Gnaphálinm leontopódium) gedacht, das jeder rüstige Alpenwanderer zu pflücken bestrebt ist. Es findet sich auf Triften und schmalen, oft nur handbreiten Felsvorsprüngen meist dicht unter der Grenze des ewigen Schnees, also an Stellen, die häufig von Winden umbraust und von den Strahlen der Sommersonne außerordentlich stark erwärmt werden. Obgleich das Pflänzchen oft nur in einer ${ }_{n}$ Hand voll" Erde wurzelt, die durch Verdunstung bald alles Wasser verliert, vermag es hier doch zu gedeihen: das dichte, dicke Haarkleid - die Blüten sind wie aus Filz geschnitten! - ist ihm ein wirksames Schutzmittel. In das Tal oder die Ebene verpflanzt, verliert das Edelweiß die weiche, zarte Behaarung (Name!) fast gänzlich (Bedeutung?). Obgleich die kleinen Köpfchen doldenartig gehäuft sind (s. Schafgarbe), erlangen sie die notwendige Auffälligkeit (Insekten!) doch erst dadurch, daß sie von einem Kranze weißwolliger Blätter umgeben werden: das Ganze bildet die sog. ${ }_{n}$ Blüte $^{\prime}$ des EdelweiB.

\section{Gruppe. Röhrenbliitige.} Köpfchen bestehen nur aus $\mathrm{Röh}$ renblüten.

Obgleich die Kornblume (Centauréa cýanus - Taf. 26.) nur ein gemeines Ackerunkraut ist, hat sie doch die größte Zuneigung des Menschen gefunden; denn gar zu herrlich lenchten ihre prächtig blauen Blïtenköpfe zwischen den reifenden Halmen des wogenden Kornfeldes hervor. Sie darf in keinem „Feldblumenstrauße" fehlen, und wenn die Schnitter die goldenen Ähren zum

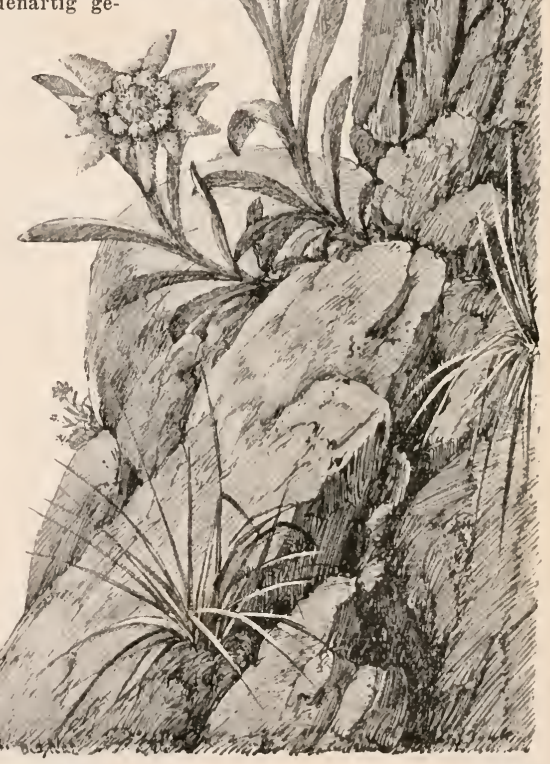

Ellelweiß (etwas verkl.). 


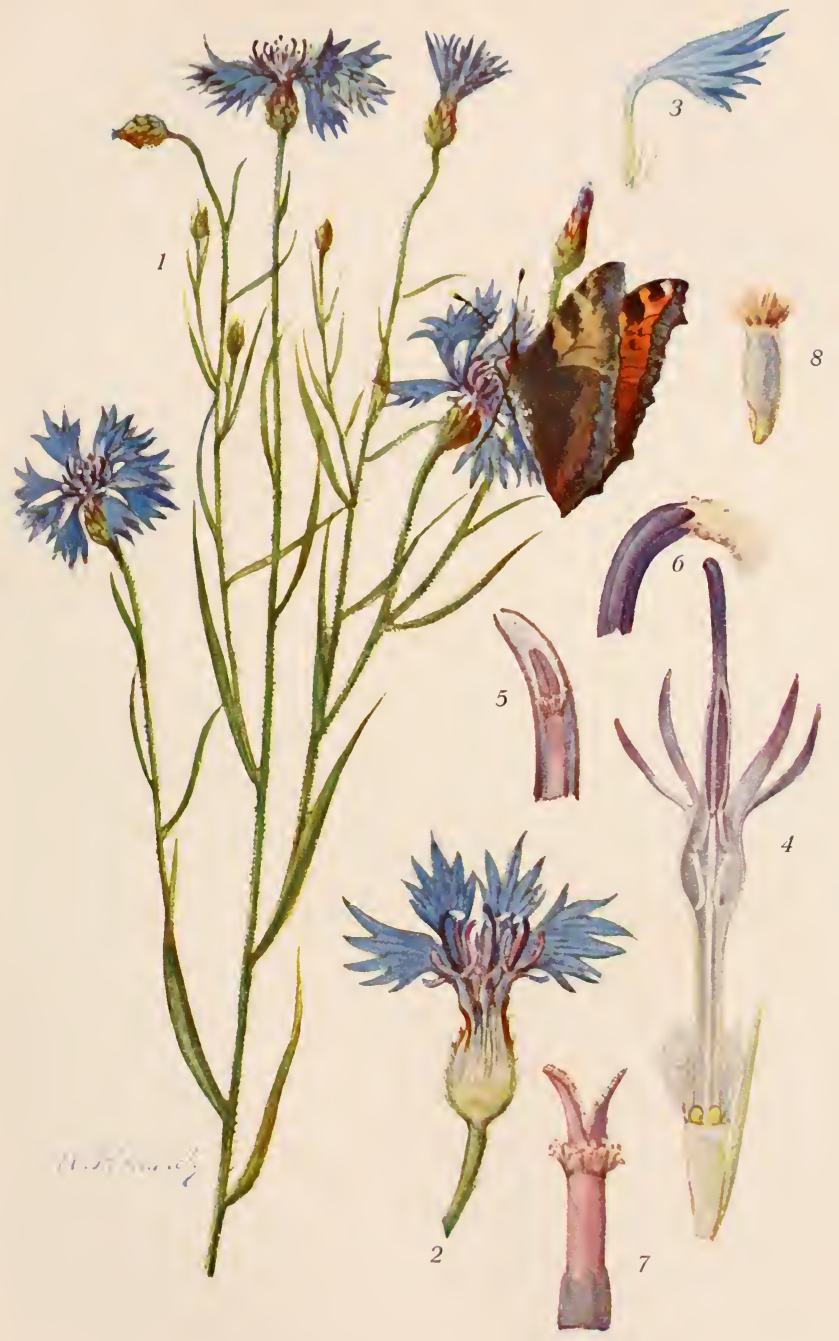

Kormblume (Centaurea cyanus). 

Erntekranze winden, flechten sie auch "blane Cyanen" mit ein (cyaneus = dunkeblau). Da die freundliche Pflanze vorwiegend trockene Felder bewohnt, besitzt sie anch nur kleine Blattflichen (1.), die mehr oder weniger dicht behaart sind: zwei Eigenschaften, in denen wir schon mehrfach Schutzmittel gegen zu starke Verdunstung des aufgenommenen Wassers keunen gelernt haben (Beweis!). An den jungen Teilen, die vor allen Dingen eines solchen Schutzes bedïrfen, tritt die Behaarung daher auch stets besonder's stark auf. Obgleich die Blütenköpfe nur ans Röhrenblïten zusammengesetzt sind (2.), macht sich zwischen letzteren doch derselbe Untersehied geltend wie zwischen den Bliten der Sonnenrose. Die Randbläten sind nämlich wie bei dieser Pflanze unfruchtbar und gleichfalls in den Dieust der Insektenanlocknng getreten. Und diese Aufgabe können sie umso vollkommener erfüllen, als ihre Blütenröhre im Endteile stark erweitert und nach anßen gebogen ist (3). Nit der hierdurch eingetretenen Vergrößerung der Blütenfläche hängt es auch znsammen, daß die Röhren der Scheibenblïten umso mehr gebogen sind, je näher sie dem Rande stehen. Die Bestäubung, die dem ïbereinstimmenden Blütenbau entsprechend genan wie bei den anderen Korbblïtlern erfolgt, zeigt eine interessante Besonderheit: Führen wir in eine junge Scheibenblüte (4.) ein zugespitztes Hölzchen oder dgl. ein, und berühren wir dabei einen der im Wege stehenden Stanbfäden, so quillt ans der Stanbbeutelröhre alsbald weißer Blïtenstaub hervor. Infolge der Berührung verkürzen sich nämlich die reizbaren Staubfäden sofort, so daß die Staubbeutelröbre herabgezogen und der in ihr lagernde Blïtenstaub durch den Griffel hervorgedrängt wird (6.). Dasselbe erfolgt natïrlich anch, wenn die Stanbfäden von einem Insektenrüssel berührt werden. Bis zu diesem Augenblicke lag der Blïtenstanb wohl geschützt in der Staubbentelröhre (5.); sobald er aber hervortritt, wird er auch schon von dem sangenden Insekt mit der Interseite abgestreift (vgl. den sangenden Falter!). Erst später spreizen die Narben auseinander, unter denen ein Kranz von „Fegehaaren" sichtbar ist (7.). Die Früchte tragen eine ans kurzen Haaren bestehende Krone (8.), die für die Verbreitung der Pflanze nur wenig in Betracht kommt. - In ähnlicher Weise erfolgt die Bestäubung anch bei der nächsten

Verwandten der Kornblume, der rotblühenden Wiesen-Flockenblume (C. jácea). Je nachdem sich die Pflanze auf fenchteren Wiesen oder an dürren Berglehnen und ähnlichen Orten findet, hat sie grobe, breite und ziemlich wagerecht gestellte, oder schmale, mehr aufgerichtete Blätter (vgl. mit Stachel-Lattich) von fast grauer Farbe (Bedentung?). - Die Blätenköpfe der Distelı (Cárdnus) und Kratzdisteln (Cirsium) enthalten gleichfalls nur Röhrenblüten, die aber nicht in Frucht- und luockblüten getrennt sind. Beide nahe verwandte Gattungen lassen sich leicht durch die Haarkrone voneinander unterscheiden: bei den Disteln sind die Haare borstenförmig, bei den Kratzdisteln dagegen gefiedert. Bei allen sind sowohl die Spitzen der Blattzipfel, als auch die an den Stengeln herablaufenden Blattteile und die Blätter des Hüllkelchs in lange, starre Stacheln ausgezogen, welche die Pflanzen gegen die Angriffe der Tiere schützen. Yon den Disteln sei nur die nickeule D. (C. nutans) genannt, die auf Triften, an Wegen und ähnlichen Orten im Herbst und Winter ihre regelmäBigen Blattrosetten ausbreitet. Im Frühjahre streckt sich der Stengel bis zn Meter- 
höhe empor und trägt zahlreiche große, duftende und nickende Blätenköpfe. Als die gemeinste Art der Kratzdisteln ist die Acker-K. (C. arvénse) zu nennen, die auf Feldern ein sehr lästiges Unkraut bildet. - Distelartige Blütenköpfe, aber unbestachelte Blätter besitzen die Kletten (Lappa), die an Wegen und auf wästen Plätzen wachsen. Da die Blätter des Hällkelchs in je eine hakenförmig gebogene Spitze endigen, bleiben die Blütenstände leicht in dem Haarkleide vorbeistreifender Tiere hängen (Verbreitung der Früchte!).

3. Gruppe. Zungeublïtige. Köpf $\mathrm{ch}$ en bestehen (wie beim Löwenzahn nur a us Zungenblüten.

Die Glieder dieser Gruppe lassen sich zumeist nur schwer voneinander unterscheiden. Sie haben in der Regel gelbe Blüten und in allen Teilen einen weißen Milchsaft (s. Wolfsmilch). Hinsichtlich des erstgenannten Merkmals macht von allen hier erwähnten Arten allein die Zichorie (Cichórinm íntybus) eine Ansnahme. Ihrem Standorte, den wasserarmen Wegrändern entsprechend ("Wegwarte"), besitzt sie wie der Löwenzahn eine tiefgehende Pfahlwurzel, and ihre Blätter sind wie bei jener Pflanze je nach dem Boden, auf dem sie wächst, mehr oder weniger tief eingeschnitten. Im zweiten Jahre baut sich aus den Vorratsstoffen der fleischigen Wurzel (vgl. mit Möhre) ein hoher, sparriger Stengel auf, dessen Blätter nach oben immer kleiner werden. Die großen, blauen Blütenköpfe schließen sich je nach Blütezeit (Sommer oder Herbst) und Witterung früher oder später am Tage (wann durchschnittlich in deiner Heimat?). Da die fleischigen Wurzeln (schneide eine solche in kleine Stücke; röste nnd zerstoße sie sodann!) einen vielbenutzten Kaffee- ${ }_{n}$ Ersatz " liefern, wird die veredelte Pflanze in manchen Gegenden im Großen angebant. - Die nächste Verwandte der Zichorie, die aus den Mittelmeerländern stammende Endivie (C. endivia), wird bei nns als Salatpflanze angebaut. - Sie wird an Bedeutung aber weit von dem (karten-Salat (Lactrica satíva) übertroffen. Er hat gleichfalls im Mittelmeergebiete seine Heimat und wird wie mehrere Kohlarten zumeist in ${ }_{n}$ Kopfform" gezogen (Bedentung?). - Eine unscheinbare, aber überaus merkwürdige Pflanze ist der Stachel-Latticlı (L. scariola), der an unbebauten Orten zumeist häufig anzutreffen ist. Ist sein Standort schattig und feucht, so streckt er die stacheligen, schrotsägeförmigen Blätter wie andere Pflanzen nach allen Seiten. Steht er aber an sehr sonnigen und trockenen Stellen, so hat er ein ganz verändertes Aussehen: die Blätter sind nicht nur alle senkrecht gerichtet, sondern haben sich auch so gedreht, daß sie die Breitseiten nach Osten und Westen, die Kanten dagegen nach Süden und Norden richten. An dem Lattich kann man daher - die Himmels. gegenden ablesen, so daB man ihn mit Recht als eine ${ }_{n} \mathrm{KompaBpflanz} \mathrm{e}^{\mu}$ bezeichnet. ( ${ }_{n}$ Anklänge" an diese Blattstellung sind nicht selten anch beim Garten-Salat zu beobachten.) Welche Bedeutung hat nun diese sonderbare Erscheinung? Die senkrechte Stellung der Blätter haben wir bereits (s. S. 44) als ein Schutzmittel gegen starke Erwärmung und hohe Wasserdampfabgabe kennen gelernt. Und die Richtung der Blätter nach den Himmelsgegenden läuft auf dasselbe hinaus: morgens und abends werden die Blattflächen von den Sonnenstrahlen senkrecht getroffen; da es zu diesen Zeiten aber verhältnismäßig kühl ist, so werden sie weder stark erwärmt, noch übermäßig zur Verdunstung angeregt. Am heißen Mittag dagegen wirken die Sonnenstrahlen viel kräftiger: dann aber bietet ihnen die Pflanze nur die Schmalseite dar, so daß Erwärmung und Verdunstung gleichfalls nur gering sein können. Die eigentümliche Blattstellung ist also ein Schutzmittel gegen das Vertrocknen und tritt darum anch nur dann auf, wenn die Pflanze dieser Gefahr ausgesetzt ist, nämlich wenn sie - wie oben erwähnt - auf trockenem, schattenlosem Boden im heißen Sonnenbrande wächst. (Beachte hiernach auch die senkrecht an den Stengeln herablaufenden Blattteile der Disteln!) 
Von den zahlreichen, schwer unterscheidbaren Arten der Gattung Habichtskraut (Hierácinm) sei nur das gremeine H. (H. pilosélla) kurz berücksichtigt. Das zierliche Pflänzehen, d.ıs nach allen Seiten lange Ausläufer aussendet (Vermehrung!), ist auf Sandboden und trockenen Grasplätzen überall häufig anzutreffen. Aus einer grundständigen Blattrosette erhebt sich auf langem Stiele das gelbe Blütenköpfchen, das sich mit Anbruch des Abends, sowie bei schlechtem Wetter schließt. Wenn es längere Zeit nicht geregnet hat, zeigt die Pflanze eine merkwürdige Veränderung: Die Blätter haben die mit einem Filzüberzuge versehene Unterseite dem Lichte zugewendet, so daß sie jetzt gleichsam wie von einem Sonnenschirme bedeckt und somit gegen zu starke $\mathrm{Be}$ sonnung, zu hohe Erwärmung nnd tödlichen Wasserdampfverlust. geschützt sind. (Warum hat bei großer Trockenheit z. B. die Sand-Strohblume eine Wendung der Blattflächen nicht nötig?). - Eine prächtige Pflanze unserer Wiesen ist der Wiesen-Boeksbart (Tragópogon praténsis), der scine großen, leuchtenden Blütenköpfe bereits in den letzten Vormittagsstunden wieder schließt. Die Strahlen der radförmigen Federkrone sind durch Fiederhärchen untereinander verbunden. A tof diese Weise finden die verhältnismäßig großen Früchte auch einen größeren Luftwiderstand als z. B. die des Löwenzahns (Bedentung?). - Eine dem Bocksbart in allen Stücken ähnliche Pflanze ist die Schwarzwuzel (Scorzonéra hispánica). Sie ist aus dem Mittelmeergebiete zu nns gekommen nnd wird ihrer schmackhaften Wurzeln wegen vielfach als Gemüse gebant.-Mit der Erwähnung eines allbekannten Ackerunkrautes, der Acker-Gïnsedistel (Sonchus arvénsis), sollen endlich die Korbblütler, von denen hier nur wenige kurz betrachtet werden konnten, abgeschlossen sein.
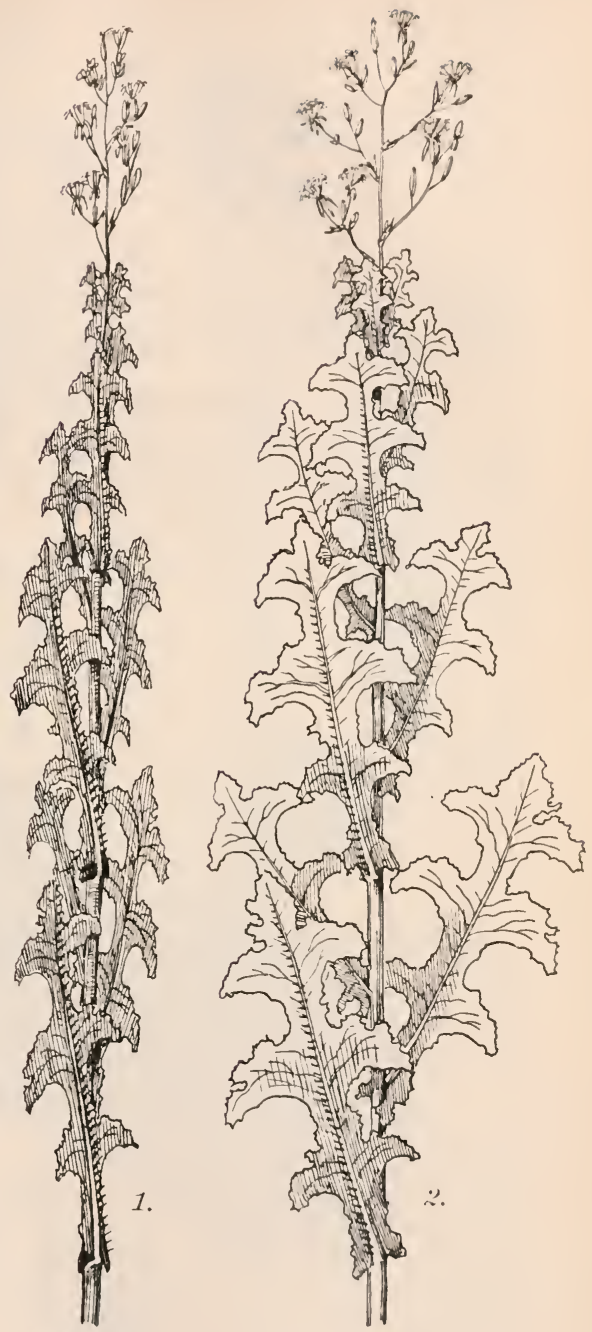

Stachel-Lattieh, der auf trockenem, stark besonntem Boden gewachsen ist. 1. von Süden oder Norden geschen; 2. dieselbe Pflanze, von Osten oder Westen gesehen. (Kleines Expl.in etwa ${ }^{1} / 2$ nat.Gr.). 


\section{Unterklasse. Blumenblattlose Pflanzen (Apétalae).}

Pflanzen mit einfacher oder fehlender Blütenhülle.

\section{Familie. Becherfrüchtler (Cupuliferae).}

Staubblüten in Kätzchen, ohne oder mit Blïtenhülle. Stempelblüten einzeln oder in geringer Anzahl beisammen (nicht in Kätzchen). Frucht eine NuB in einer Becherhülle. (Diese Familie bildet mit den 3 folgenden Familien die Gruppe Kätzchenblütler.)

Der Haselnußstrauch (Córylus avellána). Taf. 27.

A. Der Haselnußstrauch und der Menscl.. Der Haselnußstrauch war bei den alten Germanen dem Donar geweiht, und noch lange Zeit, nachdem das Christentum in den dentschen Gauen siegreichen Einzug gehalten hatte, schrieb man ihm Zauber- und Wunderkräfte zn. Vor allen Dingen schnitt man aus seinen Zweigen das „unentbehrliche“ Werkzeng der Schatzgräber, die Wünschelrute. Mit ihrer Hilfe meinte man unterirdische Schätze heben, Quellen anffinden, Hexen und Diebe „bannen" zu können ı. dgl. mehr.

Obgleich hentzutage dieser Aberglaube zumeist wohl verschwunden ist, so verknüpfen uns doch noch mancherlei Beziehungen mit dem unscheinbaren Stranche draußen im Walde: Wenn im Februar und März die "Hasel wieder stäubt", so erfüllt Frïhlingshoffen unsere Brust:

Mit Eis bedeckt ist noch der See,

Noch herrscht im Walde Winters Schweigen,

Sieh, da fällt Goldstaub auf den Schnee

Von der blühenden Hasel Zweigen.

Im Herbste schallt der Wald wieder von den Stimmen Haselnïsse suchender Kinder und im Winter von dem Axtschlag des Holzhauers; denn wie die sïßen Nüsse als schmackhaftes Obst gelten, so werden die biegsamen und zähen Zweige des Strauches vom Korbmacher und Böttcher wohl geschätzt. Verfolgen wir die Pflanze ein Jahr ihres Lebens hindurch!

B. Der Ilaselnufstrauch im Vorfriihlinge. 1. Staubblüten. An den braunen Zweigen des Strauches (1.) finden wir bereits seit dem Herbste des Vorjahres Knospen, wie sie auch andere Holzgewächse besitzen, und langgestreckte Gebilde, die man bekanntlich "Kätzchen" nennt (warum wohl? „Kätzchenblütler"). Sobald die höhersteigende Sonne die Erde etwas mehr erwärmut, und an einigen Tagen wieder lindere Lïfte wehen, erwachen die Kätzchen, die bis jetzt starr und steif nach allen Seiten von den Zweigen abstanden, aus dem Winterschlafe: das dïnne, stengelartige Gebilde, von dem sie der Länge nach durchzogen werden, die "Achse", beginnt sich zu strecken; infolgedessen nehmen sie stark an Länge zu, werden weich und biegsam, so daß sie bald wie schwankende Troddeln herabhängen (2.). Reißt man ein Kätzchen quer durch, 


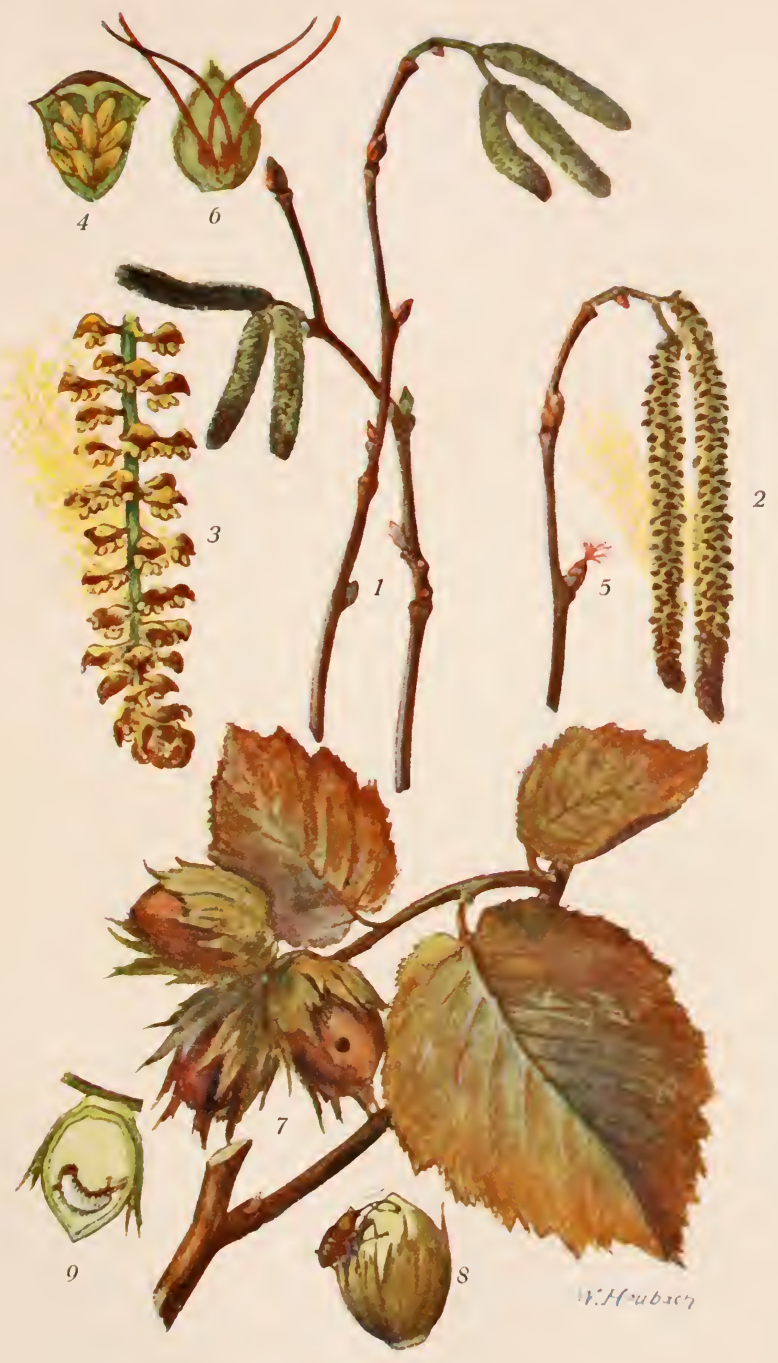

Haselnußstrauch (Corylus avellana). 

so sieht man, wie von der Achse nach allen Seiten Blättehen ausstrahlen (3.). Anf der Unterseite jeder dieser „Kätzchenschuppen“ (4.) finden sich noch 2 mit ihnen verwachsene, sehr zarte Blätchen und unter diesen 8 Staubblatter. (Richtiger gesagt sind nur 4 Staubblitter vorhanden, die aber bis zum Grunde geteilt und deren Hälften auseinander geriickt sind. Dies erkennt man daraus, daß erstlich jeder Staubbentel nu ein Fach besitzt, während sonst deren stets 2 vorkommen, und daß zweitens bei nahe verwandten Arten die Teilung noch deutlich zu sehen ist. Vgl. daraufhin z. B. Weißbuche und Birke!). Da sich Staubbliitter stets nur in Blïten finden, so haben wir es hier also gleichfalls mit solchen zn tun. Es fehlen ihnen freilich Keleh und Blumenblätter. Auch von einem Stempel ist keine Spur zu finden. In den Hasel$n u ß k a t z c h e n$ haben wir also Blütenstände vor uns, die aus zahlreichen, "nackten" Staubblïten zusammengesetzt sind.

2. Stempelblïten. Hier und da sieht man Knospen, die etwas mehr angeschwollen sind als die anderen, und aus deren Spitzen mehrere purpurrote Fädehen hervorragen (5.). Beseitigt man die Knospensehuppen, so findet man neben gewöhnlichen jungen Blättern (s. Absch. C, 1) in der Mitte einige schuppenartige Blätter und an deren Grunde je 2 Gebilde, in denen wir leicht ebensoviele Stempel erkennen(6.). Jeder von ihnen besteht ans einem kugeligen Fruchtknoten, der von einer kleinen, aus 3 grünen Blättchen gebildeten, zerschlissenen Hülle nmgeben ist und 2 jener purpurroten Fädchen trägt, in denen wir also die Narben vor uns haben. Am oberen Teile des Fruchtknotens findet sich ein winziger, gezïhnelter Rand, d.i. der "Überrest" der Blïtenhïlle. Jeder Stempel stellt also eine Blïte mit stark verkümmerter Blïtenhïlle dar.

3. Bestäubung. Beim Haselnußstrauch sind also Staubblätter und Stempel in versehiedene Blüten verteilt, die sich wie beim Kürbis (s. das.) auf derselben Pflanze finden. Wir haben es hier also wie in diesem mit einer sug. einhäusigen Pflanze zu tun. Da bei einer solchen Selbstbestäubung niemals stattfinden kann, so mïssen wir uns fragen: wer besorgt beim Haselnußstranche die Übertragung des Blïtenstaubes zur Narbe? Insekten wie beim Kürbis können es nicht sein; denn wenn an einem somnigen Tage auch wirklich einmal eine Blïtenstaub naschende Biene auf einem Kätzchen anzutreffen ist: das Heer der Insekten liegt zu dieser Zeit noch in tiefem Winterschlafe!

Den wirklichen Überträger des Blütenstaubes erkennen wir leicht, wenn wir den blühenden Haselnußstranch an einem sonnigen, aber etwas windigen Tage besuchen. Daın sehen wir, wie der Wind die Äste und „reifen“ Kätzchen schiittelt, wie aus den Kätzchen kleine Wolken gelben Blïtenstaubes hervorgehen (2. u. 3.), wie der Staub verweht wird und sich nach einiger Zeit anf den Erdboden, anf Äste, Zweige und andere Gegenstände herabsenkt. Dabei kann es uun nicht ausbleiben, daß auch die Narben von einigen Staubkörnehen getroffen werden. Der Vermittler der Bestaubug ist also - der Wind, und der Haselnußstrauch demnach eiue „windblütige“ Pfllanze 
oder kurz: ein Windblütler. - Wenn wir dies im Auge behalten, werden uns leicht zahlreiche Einzelheiten im Blütenban, sowie andere Verhältnisse klar werden.

a) Da weder die Staub-, noch die Stempelblüten von Insekten besucht werden, so fehlen der Pflanze auch alle die verschiedenen Mittel, deren sich die Insektenblütler bedienen, die Bestäuber anzulocken. Von diesen Mitteln wären besonders zu nennen die leuchtende Blïtenfarbe, der Duft und der Honig, der den Bestänbern als Gegengabe gereicht wird. Die Bliiten des Haselnußstrauchs sind ganz unscheinbar, duft- und honiglos.

b) Kurz vor Beginn des Stäubens streckt sich - wie wir oben gesehen haben - die Kätzchenachse stark in die Länge, so dał die Schuppen auseinander rïcken und das anfänglich starre Kätzchen außerordentlich biegsam wird. Dadurch wird einerseits dem Winde Zutrittzu den Staubbeuteln geschaffen, und andererseits ist jetzt schon ein leichter Windhanch imstande, das wie eine Troddel herabhängende Kätzchen in Schwankungen zu versetzen und den Blütenstaub herauszuschïtteln.

c) Die Kätzchen sind umso leichter zu erschïttern, als sie sich stets an den Enden kurzer Ästchen finden, die wieder nur von dünnen Zweigen abgehen.

d) Außerdem stäubt der Haselnußstrauch zu einer Zeit, in der häufig Winde wehen. Heftige Winde oder gar Stürme sind für die Bestänbung allerdings ungünstig; denn sie entführen den Bliitenstaub nur nach einer Richtung, verhindern also eine Verbreitung desselben über einen großen Raum und sind zudem vielfach mit Regen verbunden. Die Regentropfen würden aber den Blätenstanb, der durch Befeuchtung sehr leicht verdirbt, vernichten oder doch aus den Kätzchen spülen und zur Erde führen. Daher öffnen sich die Staubbeutel bei kaltem, regnerischem Wetter nicht. Selbst die Kätzchen, die zum Stäuben "fertig“ sind, "warten" damit, bis wieder mildere Witterung eintritt.

e) Rieselt der Blütenstanb bei vollkommener Windstille aus den Beuteln, so fällt er nicht etwa zum Erdboden herab. Er würde dann ja nur selten eine Narbe treffen, in den meisten Fällen also verloren gehen. Da die Kätzchen hängende Stellung einnehmen, wird er vielmehr auf der Rückseite der wagerecht stehenden Kätzchenschuppen abgelagert (3.). Hier bleibt er liegen, bis ihn ein Windhauch ,abholt" und ausstreut. (Der Vorgang läßt sich leicht an Kätzchen beobachten, die man im Zimmer „zum Anfblühen " bringt.)

f) Der Haselnußstrauch blültt in einer Zeit, in der er noch unbelaubt ist. Im anderen Falle würde das Blätterdach dem Winde den Zutritt zu den Kätzchen verwehren und die Narben verdecken, also den niederfallenden Blütenstaub von ihnen abhalten.

g) Bei einzeln stehenden Pflanzen ist die Möglichkeit, durch den Blütenstaub anderer Pflanzen bestäubt zu werden, sehr gering. Der Haselnußstrauch kommt im Walde aber gewöhnlich in großen Beständen vor. 
h) Wie oben erwähnt, gelangt der größte Teil des Blïtenstaubes nicht an den Ort seiner Bestimmung. Je mehr Staub vorhanden ist, desto größer ist aber die Möglichkeit, daß er beim Niederfallen eine Narbe trifft. Daher erzengt der Hasehußstrauch auch eine viel größere Menge von Bliitenstaub als jede insektenbliitige Pflanze.

i) Während bei dieser der Blïtenstanb (zumeist) klebrig ist (warum?), ist er hier staubartig trocken, kann somit leicht verweht werden.

k) Sollen die Narben ein paar Staubkörnchen anffangen, so miissen sie gleichfalls dem Winde frei ausgesetzt sein. Sie durchbrechen daher zur Blütezeit die Knospenspitze. Der Fruchtknoten dagegen kann ruhig im Schutze der Knospe verbleiben. Und dies ist umso wichtiger, als die Pflanze ja in dem unbeständigen Vorfrühlinge mit seinen oft noch recht kalten und regnerischen Tagen stänbt, oder umgekehrt: die geschïtzte Lage des Fruchtknotens erlaubt der Pflanze eine so frïhe Blätezeit.

l) Vorteilhaft für die Bestäubung ist es (Beweis!), daß die Narben verhältnismäßig sehr groß und dicht mit winzigen Härchen besetzt sind, so daß sie rechte "Stanbfänger" darstellen. (Untersuche, wie weit sich alle die angeführten Tatsachen anch bei anderen Windblütlern nachweisen lassen und suche allgemeine Regeln dafür aufzustellen!)

C. Der Hasehußstrauch im Frïhlinge und Sommer. Erst einige Wochen nach dem Bestänben der Kätzchen öffnen sich die schwellenden Knospen. Der zum Vorschein kommende

1. junge Trieb ist anfangs abwärts gerichtet; seine Blättchen sind in der Mittelrippe gefaltet, dicht mit seidenartigen Haaren bedeckt nnd stehen wie die der Linde im Schutze großer, schuppenartiger Nebenblätter. Je mehr sich die Blätter ausbreiten, desto mehr verschwindet die Haardecke. Kurze Zeit, nachdem der Trieb die bleibende Stellung eingenommen hat, fallen endlich wie bei der Linde auch die nutzlos gewordenen Nebenblätter ab: alles Erscheinungen, deren Bedentung wir bereits bei der Betrachtung der Roßkastanie verstehen gelernt haben. Die ansgebildeten

2. Blätter (7.) haben fast Herzform, sind mit zerstrenten Haaren bedeckt und am Rande mit großen Sägezähnen versehen, die wiederum fein gezähnelt sind („doppelt gesägte Blätter").

a) Da der Haselnußstranch mit den wenigen Lichtstrahlen fïrlieb nimmt, die durch die Kronen der Waldbänme ihren Weg finden, so sind seine Blätter :ihnlich wie die der eigentlichen Schattenpflanzen (s. S. 7, b und c) verhältnismäßig zart und groß.

b) Durch die Größe der Blätter wird andererseits anch deren Stellung a m Zweige bedingt: sie stehen abwechselnd und sind so in 3 Reihen geordnet, daß sie sich gegenseitig nicht beschatten. Eine solche "dreizeilige" Stellung ist jedoch nur an senkrechten Zweigen zu beobachten. An wagerechten oder schräg gerichteten $Z$ weigen werden die Blätter zumeist viel weniger belichtet. 
Darum drehen sich hier die Stengelglieder so, daß die Blätter wie in 2 "Zeilen" angeordnet erscheinen. (Warum sind die Knospen und Zweige ebenso angeordnet?)

D. Der Haselnußstrauch im Herbst und Winter. 1. Frucht. Nach erfolgter Bestäubung beginnt der Fruchtknoten zu schwellen: die Fruchtknotenwand wird zu der harten, holzigen "Schale" und die Samenanlage zum "Kerne" der Haselnuß (9.). Gleichzeitig vergrößert sich auch die "zer'schlissene Hülle“, die den Fruchtknoten umgibt (7. u. 8.): sie wird zu dem „Becher", der die reifende Nuß einhiillt („Becherfriichtler“). Welche Bedeutung haben nun die einzelnen Teile der Frucht für den Haselnußstrauch?

a) Da der Kern aus der Samenanlage hervorgeht, so stellt er den Samen der Pflanze dar. In der Regel enthält die Frucht nur einen Samen. Sie ist daher eine "Schließfrucht" (s. S. 10, 3), deren feste Wand erst durch den keimenden Samen gesprengt wird.

b) Der wohlschmeckende Kern ist reich an Stärkemehl und fettem öle. Daher bildet er auch ein vielbegehrtes Nahrungsmittel für zahlreiche Waldtiere. Da er aber von einer festen, holzigen Schale umgeben ist, vermögen ihn nur größere Tiere zu erlangen, von denen hier nur Eichhörnchen, Haselmäuse und Häher, sowie das Wildschwein genannt sein mögen. Diese Tiere leisten aber der Pflanze einen wichtigen Gegendienst. Wieso? Die harte Schale verhindert die Eichhörnchen, Haselmäuse und Häher, die Kerne beim Auffinden der Frïchte sofort zu verzehren; denn zum Öffnen der Nüsse gehört eine gewisse Zeit. Während dieser Zeit verweilen die Tiere aber nicht gern auf dem Erdboden oder in dem Gezweig des Strauches, weil sie dort allen Gefahren schutzlos ausgesetzt sind. Sie suchen im Gegenteil mit ihrer Beute einen gesicherten Ort zu erreichen, um dort in Ruhe das Mahl zu halten. Bei diesem Verschleppen entfallen den Tieren aber zahlreiche Nüsse, die auf diese Weise über einen weiten Bezirk verbreitet werden können. Ferner ist es bekannt, daß Eichhörnchen und Haselmäuse Wintervorräte aufspeichern, und daß der Häher die Gewohnheit hat, Niisse (sowie Bucheckern und Eicheln) in den Erdboden zu verstecken. Ebenso bekannt aber ist es auch, daß diese Tiere sehr häufig die Vorräte vergessen oder nicht wieder aufzufinden vermögen. In de n genannten Tieren haben wir also die Verbreiter des Strauches vor uns.

Der Haselnußstrauch muß seinen Verbreitern allerdings große Opfer bringen. Aber tun das die Pflanzen mit saftigen, wohlschmeckenden Früchten nicht auch (s. S. 64, a)? Freilich wird bei diesen Früchten der Same nicht mit vernichtet. Wenn wir aber bedenken, daß die Haselnuß (gleich der Buche und Eiche) eine sehr langlebige Pflanze ist, die alljährlich eine große Anzahl von Früchten erzeugt, so wird uns dieser Verlust nicht gar zu beträchtlich vorkommen! Selbst wenn sich nur die zehn- oder hunderttausendste $\mathrm{Nuß}$ wieder zu einem Strauche entwickeln würde, hätte diese seltsame Art der Verbreitung noch - eine Vermehrung der Pflanze im Gefolge. 
Neben den genannten Tieren ist es — wie erwähnt - besonders das Wildschwein, das die Haselnüsse gern verzehrt. Es verschleppt sie aber nicht, kann also auch nicht als Verbreiter der Pflanze in Betracht kommen. Da es aber den Waldboden mit Rüssel und Hauern gleichsam durchpflïgt und somit sicher auch manche Nuß (Buchecker, Eichel) an den zum Keimen günstigen Ort bringt, so werden wir in ihm nicht einen ausschließlichen Feind des Strauches (der Buche und Eiche) erkennen.

c) Würden Eichlörnchen, Haselmänse und Häher die Nüsse bereits vor der Reife verzehren, so könnten sie eine Verbreitung der Pflanze nicht bewirken. Wie die unreifen fleischigen Früchte (s. S. 65) sind auch die unreifen Haselniisse durch schlechten Geschmack geschützt, nur mit dem Unterschiede, daß dieser Geschmack nicht den Nïssen selbst, sondern dem zerschlitzten Becher eigen ist, von dem sie umbüllt werden. Erst bei der Reife löst sich die Nuß aus dem Becher und fällt zu Boden. Der matte Fleck an der Schale ist die Verwachsungsstelle zwischen der Nuß und dem Becher.

d) Findet man in der Schale der Haselnuß ein kreisiundes Loch (7.), so ist auch stets der Kern zerstört. Beides ist das Werk der Larve des Haselnußbohrers (8. u. 9.; s. "Lehrbuch d. Zoologie").

2. La u b f 11. Zur Zeit der Fruchtreife beginnt das Laub, sich herbstlich gelb und rot zu färben (7.), und ehe meist noch der Oktober zu Ende gegangen ist, steht der Haselnußstrauch kahl da (vgl. S. 91, c).

- 3. Knospen. Das nächste Frühjahr trifft die Pflanze aber nicht unvorbereitet an. Bereits im Juli begannen in den Blattwinkeln sich die nächstjährigen Triebe, sowie die beiderlei Blïten zu bilden. Wenn das Laub abgefallen ist, sind anch die Vorbereitungen abgeschlossen, d. h. die Knospen ausgebildet. Während die kurzen jungen Triebe und die winzigen Stempelblüten durch Knospensch upen gegen die Unbilden des Winters geschützt sind, iiberwintern die zu Kätzchen gehänften Staubblüten „frei"; denn infolge der Größe der Kätzchen ist eine solche winterliche Hülle ausgeschlossen (vgl. hierzu auch Birke und Erle, sowie Weide und Pappel!). Die Staubblüten entbehren aber des notwendigen Schntzes gegen eindringendes Wasser und gegen zu starke Wasserdampfabgabe (s. S. 42, a, b und c) durchaus nicht: die Kätzchenschuppen liegen nicht allein eng übereinander, sondern ihr äußerer verdickter Abschnitt ist nach der Spitze des Kätzchens zu so gebogen, daß sie sich z. T. gegenseitig decken. Außerdem sind die Kätzchenschuppen, besonders an ihren nach außen gerichteten Abschnitten, filzig behaart, eine Einrichtung, in der wir schon melıfach (Beispiele!) ein wichtiges Schutzmittel gegen das Austrocknen erkaunt haben. - Die Kätzchen können also einer besonderen winterlichen Hülle vollkommen entbehren. In Knospenschmppen eingeschlossen wären sie gar nicht imstande, den Winter in fast ausgebildetem Zustande zu überdauern, oder was dasselbe sagen will: so zeitig im Jahre zu stäuben, wie wir es am Anfange der Besprechung gesehen haben. (Vgl. hiermit die Blütezeit der Erle, sowie die der anderen Becherfrüchtler und der Weidengewächse!) 


\section{Andere Becherfrichtler.}

1. Die Eiche (Quercus), die in unsern Wäldern in 2 Arten anftritt, steht bei uns unter allen Landbäumen am höchsten im Ansehen. Die hänfigere Stiel- oder Sommereiche (Qn. pednnculáta), die besonders in den Auenwäldern der Ebene vorkommt, ist an den langgestielten Frïchten („Stieleiche“) und den kurzgestielten Blättern leicht zu erkennen. Während sie sich (im Mai) mit jungem Grün bekleidet, steht die 2. Art, die Stein- oder Wintereiche (Qu. sessiliflóra) noch winterlich kahl da (daher die Unterscheidnng "Sommer- und Wintereiche“). Letztere findet sich mehr im Gebirge („Steineiche“), ergrïnt erst etwa 14 Tage später und hat kurze Frucht-, aber lange Blattstiele. Beide Pfianzen wachsen zu riesigen Bänmeu (Höhe bis $35 \mathrm{~m}$ ) beran, die durch ein gewaltiges Wurzelwerk im Boden verankert sind. Der kurze, von rissiger Borke bedeckte Stamm, der nicht selten einen Durchmesser von melreren Metern besitzt, löst sich in zahllreiche, knorrige Äste anf, die jeder für sich einen kräftigen Baum abgeben würden. Da die Eiche eine lichtliebende Pflanze ist, tragen nur die äußersten Zweige der Krone die schöngeformten, tiefeingebuchteten $\mathrm{Blätter}$. Daher dringt auch genïgend Licht bis zum Boden herab, so daß sich dort eine vielgestaltige Gesellschaft niedriger Pflanzen anzusiedeln vermag (nenne die daselbst gefundenen!). Anf den Blättern, die sich im Herbste besonders an jungen Bäumen nicht alle von den Zweigen lösen, finden sich hänfig Galläpfel sehr verschiedener Form (s. „Lehrbuch der Zoologie"). Da die Blïten während des Winters in Knospen eingeschlossen sind, stäubt die Eiche anch erst, wenn sich das Lanb entfaltet (vgl. dag. Haselnußstranch und Erle). Dies ist für die Pflanze aber von umso geringerem Nachteile, als die Bln̈ten sämtlich an der Außenseite der Krone stehen. Die Staubblüten, die je eine einfache, unscheinbare Blütenhülle besitzen, stehen in langen, beweglichen Kätzchen. Die Stempelblïten finden sich entweder einzeln oder zu mehreren gehäuft an den Enden mehr oder minder langer Stiele (s. oben). Der Fruchtknoten ist von einem Becher umgeben, der ans zahlreichen Blättchen gebildet ist und sich zum Näpfchen der Frucht, der Eichel, entwickelt. (Beschreibe die Blïten näher, nnd zeige besonder's, wie sie zur Windbestäubung eingerichtet sind! Vergleiche die Bildung und Verbreitung: der Frucht mit der der Haselnuß!).

Das $\mathrm{Holz}_{\mathrm{z}}$ der Eiche ïbertrifft an Festigkeit, Härte und Danerhaftigkeit jedes andere Holz unserer Wälder. Daher wird es besonders zn Wasserbauten (Brïcken u. dgl.) verwendet. Anch als Möbelholz ist es hochgeschätzt. Die an Gerbstoff reiche Rinde liefert die Gerberlohe. Die Frïchte dienen in waldreichen Gegenden Schweinen als gutes Mastfutter; geröstet und gemahlen geben sie den sog. Eichelkaffee und mit einem Zusatz von Kakao den Eichelkakao.

Uns ist aber die Eiche noch weit mehr als ein bloßer Nutzbanm. Wegen des hohen Alters (bis 2000 Jahre), das sie erreicht, wegen der gewaltigen Größe, zu der sie heranwächst, wegen des fast unvergänglichen Holzes ist sie für uns das Sinnbild der Kraft und Stärke. Bei den Griechen und 
Römern war sie dem Jupiter, bei den alten Germanen dem Donar geweiht (die heilige, durch Bonifacius gefällte Eiche bei Geismar!), und ein Kranz von Eichenblättern ist schon seit jenen Zeiten das Zeichen des Siegers.

${ }_{n} J a$, dich nennt man mit Recht des Waldes Königin, Eiche,

Unter den Bäumen ist herrlicher keine als da!“

2. So wenig ein anderer Banm nnserer Walder der Eiche an Macht und Stärke gleichkommt, so sicher wird sie von der Buche oder Rotburhe (Fagns silvática) an Schönheit iibertroffen. Ja, wir halten die Buche fïr den schönsten Baum des Laubwaldes und bringen daher dem Buchenwalde die größte Zuneigung entgegen. Die hohen, glatten, silbergrauen Stämme alter Bämme gleichen schlanken Sïulen, die anf mächtigen Spitzbogen das grïne Laubdarh tragen. Wemn wir in eine solche "Säulenhalle" eintreten. dann durchrieseln uns heilige Schauer wie in jenen himmelanstrebenden, gotischen Domen, deren l'rbild im Buchenwalde zu suchen ist. (Vgl. Eichendorfts: Wer hat dich, du schöner Wald etc. und andere Waldlieder!) Besonders erhaben ist diese Stimmung, wenn das frische "Buchengrün" hervorsprießt, und wem die in das Waldesdunkel eindringenden Sonnenstrahlen helle Kringel aut Stamm und Boden zeichnen.

Wie die Blätter der Roßkastanie (s. das.) kommen anch die Buchenblätter mit einem Haarkleide bedeckt und zusammengefaltet ans der Knospe hervor. Die Behaarung findet sich allerdings nur am Rande und auf der Unterseite des Blattes und zwar dort wieder nur an den Seitenrippen. Da aber die grünen Teile zwischen diesen Rippen so gefaltet sind, daß das junge Blatt einen kleinen Fächer darstellt, so ist die Unterseite von den langen, parallel gerichteten Seidenhaaren vollkommen ïberdeckt. Je mehr die zweizeilig angeordneten Blätter (s. S. 51, 2) erstarken, desto mehr verschwinden anch die Falten und die Behatarung; nur an Rande bleibt die glatte, eiförmige Blattfläche weiter bewimpert. (In gleicher Weise entfaltet die Weißbuche ihre Blätter. Beobachte es!) Da die Buche anch im Innern der Krone sehr reich belaubt ist (vgl. dag. z. B. die Eiche!) und trockene Standorte liebt, auf denen die abgefallenen Blätter nur schwer verwesen, so bildet sich im Buchenwalde bald eine sehr dicke Lanbdecke, die nur wenige Pflanzen zu durchbrechen vermögen. (Welche Pflanzen hast du beobachtet nnd an welchen Stellen?) Auch Unterholz findet sich nur selten; denn infolge der dichten Belaubung herrscht zumeist ein so stark gedämpftes Licht, wie es den Stränchern nicht zusagt. Das Bliilnen erfolgt wie bei der Eiche zur Zeit der Laubentfaltung. Die Stanbkätzchen bilden langgestielte, hängende, fast kugelige Bliitenbiischel, während die Stempelbliiten aufrecht stehen. Je 2 Stempelbliiten sind von einer Hiille ungeben, aus der sich der Frnchtbecher entwickelt. Er ist mit Stacheln bedeckt (Bedeutung?) und öffnet sich bei der Reife in 4 Klappen, so daß die beiden dreikantigen Friichte ins Freie gelangen kömmen. (Beschreibe die Blïten nnd Früichte genatuer!) Die als Bucheckern oder Büchelen bezeichneten Früchte liefern ein wertvolles Speiseäl. Viel wichtiger ist uns aber das harte, feste, rötliche Holz („Rotbuche“) der Buche, das als Brenn- und Nutzholz gleich hoch geschät\%t wird. 
198 Taf. 28. 51. u. 52. Fam. Birken- u. Walnußgewächse. 53, Fam. Weidengewächse.

3. Die Weif- oder Hainbuche (Carpinus bétnlus) ist wie die Rotbuche ein hoher, glattrindiger Waldbaum. Sie ist von dieser jedoch leicht zu unterscheiden durch den mehr oder weniger seilartig gedrehten Stamm and die ebenso gebildeten Äste, durch die elliptischen, zugespitzten und doppelt gesägten Blätter, sowie durch die Fruchtbecher, die blattartige, dreilappige Flügel darstellen (vgl. mit Ahorn!) and am Grunde die kleinen Nüßchen umschließen. Das weiße Holz ( ${ }_{n}$ Weißbuche") ist sehr fest ("Hornbaum") and wird deshalb besonders von Drechslern and Stellmachern verwendet.

4. Die Korkeiche (Quercus suber) ist ein immergrüner Baum der Mittelmeerländer, dessen Stamm und stärkere Zweige sich mit einer dicken Korkschicht äberziehen. Diese Schicht wird etwa alle 6-10 Jahre abgeschält, wobei man sich sorglich in acht nehmen muß, die darunter liegende eigentliche Rinde zu verletzen (warum?). Die losgelösten Platten liefern den Kork des Handels (Verwendung?). - Die edle Kastanie (Castánea vesca) ist in Südenropa heimisch, kommt scheinbar wild aber auch in der Rheingegend vor und wird hier und da in Parkanlagen gepflegt. Der Baum erreicht ein sehr hohes Alter und dementsprechend oft eine erstaunliche Größe. Er besitzt lange lanzettliche Blätter, die am Rande` zu Stachelzähnen ausgezogen sind, und stachelige Fruchtbecher mit je 1-3 Früchten. Diese „ebbaren Kastanien" oder Maronen sind den Samen der Roßkastanie sehr ähnlich und gelten hesonders in der Heimat der Pflanze als ein wertvolles Nahrungsmittel.

\section{1. und 52. Familie. Birken- und Walnußgewächse (Betuláceae und Juglandáceae).}

1. Birken-Gewächse (Staub- und Stempelblüten in Kätzchen; Frucht ein Nüßchen ohne Becherhülle). Die Weißbirke (Bétula alba), gewöhnlich nur Birke genannt, findet sich zumeist im Walde zwischen anderen Baumarten eingestreut; hier und da bildet sie aber selbst größere Wälder. Die weiße Borke, die den Stamm mittelgroßer Bäume bedeckt (vgl. dag. junge Zweige und alte Stämme!) und sich in papierdünnen Fetzen ablöst, sowie die lockere, "duftige" Krone machen sie zu einem beliebten Schmnckbaume des Parkes. Bei jungen Bäumen stehen die Zweige schräg aufwärts; mit zunehmendem Alter aber bilden sich längere, rutenförmige Äste, die infolge ihrer Schwere meist hängend werden. Die jungen Blätter sind durch einen Harzüberzug gegen zu starke Wasserdampfabgabe geschützt (s. S. 91, a). Dieses Harz gibt der Birke zur Frühlingszeit einen angenehmen Duft. Darum bringen wir sie

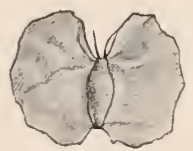

Frucht der Birke. (Etwa 10 mal vergr.) auch am lieblichen Pfingstfeste als duftende "Maie" in unser Haus. Während die Staubkätzchen wie beim Haselnußstranche frei überwintern, kommen die weit kleineren Stempelkätzchen erst mit den meist rautenförmigen Blättern aus den Knospen hervor (beschreibe die Blïten näher!). Die Früchte, die mit den dreilappigen Kätzchenschuppen abfallen, sind federleichte Gebilde, die jederseits zu einem großen Flïgel verbreitert sind und daher vom Winde leicht weit verweht werden können (Bedeutung?).

Die Birke liefert uns wertvolles Brenn- und Werkholz. Aus dem Reisig 
stellt man Besen her, und den Birkensaft, den man im Frühjahre durch das Anbohreu des Stammes gewiunt, läßt man hier und da zu Birkenwein vergären.

Die Schwarzerle (Alnus glutinósa) liebt fenchten Untergrund, findet sich daher besonders an den Ufern der Gewässer und bildet im "Erlenbruche oft ausgedehnte Bestände. Sie tritt als Strauch and Baum auf. Ist sie belaubt, dann bilden die rundlichen, abgestutzten Blätter ein leichtes Erkennungszeichen, ist sie kahl, die Knospen, die wie bei keinem anderen heimischen Baume gestielt sind. Da sowohl die Staub-, als auch die kleineren Stempelkätzchen frei äberwintern, so stänbt die Erle mit dem Haselnußstrauche bereits im Vorfrühlinge. Die Stempelkätzchen bilden sich durch Verholzung der bleibenden Schuppen zu rundlichen, zapfenartigen Fruchtständen aus. Im Winter oder Vorfrühlinge spreizen die Schuppen anseinander, so daß die Früchte herausfallen können. Obgleich nur wenig geflügelt, werden sie doch leicht ein Spiel des Windes; denn es sind winzig kleine, plattgedrückte Gebilde.Die Granerle (A. incána) ist ein Gebirgsbaum, der sich u. a. durch die schräg aufrecht stehenden Zweige und den silbergrauen Stamm von der Schwarzerle leicht unterscheidet.

2. Die Wa lnuB-Gewächse unterscheiden sich von den übrigen Kätzchenblütlern besonders durch den Bau der Frucht, die vom Walnuģbaume (Juglans régia) her jedermann bekannt ist: Der äußere Teil der Fruchtwand bildet die grüne, unangenehm schmeckende Hülle (Schutzmittel!), während der innere Teil die holzharte, 2 klappige "Nußschale" darstellt. Der Walnußbaum, der ein hohes Alter und einen gewaltigen Umfang erreicht, hat im Mittel-

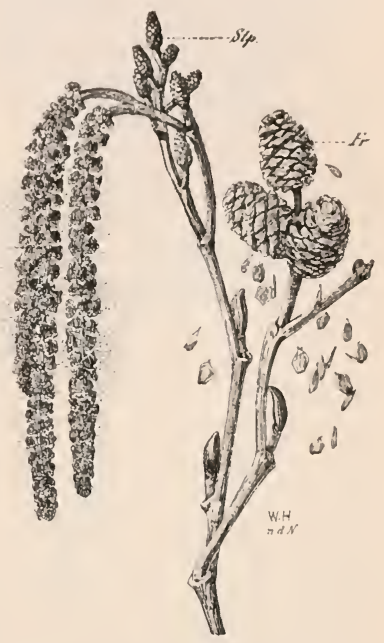

Zweig der Schwarzerle mit Knospen, Stempelblüten (Stp.), stäubenden Staubblüten (Stb.) und Fruchtständen (Fr.), aus denen soeben die Früchte ausfallen. (Nat. Gr.). meergebiete (in "Welschland" - Name!) seine Heimat. Das harte, schön gemaserte Holz wird gleich dem einiger amerikanischer Arten zur Herstellnng von Möbeln hoch geschätzt.

\section{Familie. Weidengewächse (Salicáceae).}

Zweihäusige Pflanzen, deren Staub- und Stempelblüten keine Blütenhïlle besitzen und Kätzchen bilden. Frucht eine zweiklappige Kapsel. Samen mit Haarschopf.

Die Sal- oder Palmweide (Salix cáprea). Taf. 28. (Zugleich ein Blick auf die übrigen Weidenarten.)

A. Standort. Gleich zahlreichen anderen Weidenarten ist die Salweide eine trene Begleiterin der Bäche und Flïsse, umsäumt Teiche und Seen, findet 
sich aber anch in fenchten Gebiischen und Waldungen, ja kommt selbst noch auf ziemlich trockenem Boden vor.

B. Stamm und Zweige. Die Salweide ist ein Strauch oder Banm und wird gleich anderen Arten vorwiegend durch

1. Stecklinge vermehrt. Schneiden wir im Winter oder Frühlinge, bevor sich die Knospen $z$ entfalten beginnen, einige Zweiglein ab und stecken sie in ein Glas Wasser oder pflanzen sie in einen mit feuchter Erde gefüllten Blumentopf, so sehen wir, wie aus den im Wasser oder in der Erde befindlichen Teilen lange, vielfach verzweigte Wurzeln hervorgehen, die nach einigen Wochen oft das ganze Glas erfüllen oder die Erde nach allen Richtungen durchziehen. Will man Weiden aupflanzen, so verfährt man ganz ähnlich: man schneidet Zweige ab und pflanzt sie in fenchte Erde. Verwendet man hierzu größere Zweige, so gehen daraus oft stattliche Bäume mit mächtigen Kronen hervor.

Da sich die langen Wurzeln nach allen Richtungen im Boden ansbreiten, und vielfach verzweigen, so eignen sich die Weiden vortrefflich, Ufer und Dämme zu befestigen. Die größte Bedentung erhalten sie aber durch

2. die Zweige, die sich infolge sehr großer Biegsamkeit und Zähigkeit besonders zur Herstellung von Korb- und Stuhlwaren, sowie zu Faßreifen eignen. Hierzu kann man aber nur glatte, astlose Ruten benutzen. Deshalb zieht man die Weiden zumeist als Sträncher, die man alljährlich oder in längeren Zwischenräumen bis zum Boden abschneidet. Die baumartig wachsenden Weiden mit den krummen, ästigen Zweigen und dem weichen, wenig danerhaften Holze dagegen haben für den Menschen nur eine geringe Bedeutung. Sie werden von dem "Beherrscher der Natur" (beweise, daß seine Herrschaft aber nur eine sehr beschränkte ist!) zumeist arg verstümmelt und treten uns dann als die sog.

3. Kopfweiden entgegen. Diese eigentümliche Baumform kommt dadurch zustande, daß man den jungen Baum stutzt oder "köpft" und ihm alle Seitenzweige nimmt. Am abgestutzten Ende bildet sich dann eine besenförmige Krone langer Zweige, wie sie der Mensch zu erhalten wünscht. Indem die Zweige nach Verlauf einiger Jahre immer wieder von neuem entfernt werden (Verwendung?), schwillt das obere Ende, der sog. Kopf, unverhältnismäßig an, so daß der Baum oft eine seltsame Gestalt erhält (vgl. Goethes „Erlkönig“!). In die zahlreichen Wunden, die man der Weide auf diese Weise fortgesetzt schlägt, dringen nun aber Wasser und Pilzsporen ein: es entsteht eine Fäulnis, durch die sich das Holz in eine braune, lockere Hasse, die Weiden- oder Baumerde (Verwendung?), verwandelt. So wird nach und nach fast der ganze Holzkörper zerstört und der Baum schließlich hohl. (Bei welchen Bäumen hast dn gleichfalls hohle Stämme angetroffen? Beobachte, wie die hohlen Kopfweiden und die hohlwerdenden Stämme großkroniger Bäume dem Sturme nur geringen Widerstand leisten können! Für welche Tiere bilden die hohlen Stämme einen willkommenen Schlupfwinkel? Beobachte die Gänge des Weidenbohrers und die Löcher, die der Specht gehackt hat!)

C. Knospen $(1-4)$. In den Achseln der Blätter bilden sich bereits im Spätsommer die Knospen, die von je einer kapuzenförmigen, lederartigen, braunen 


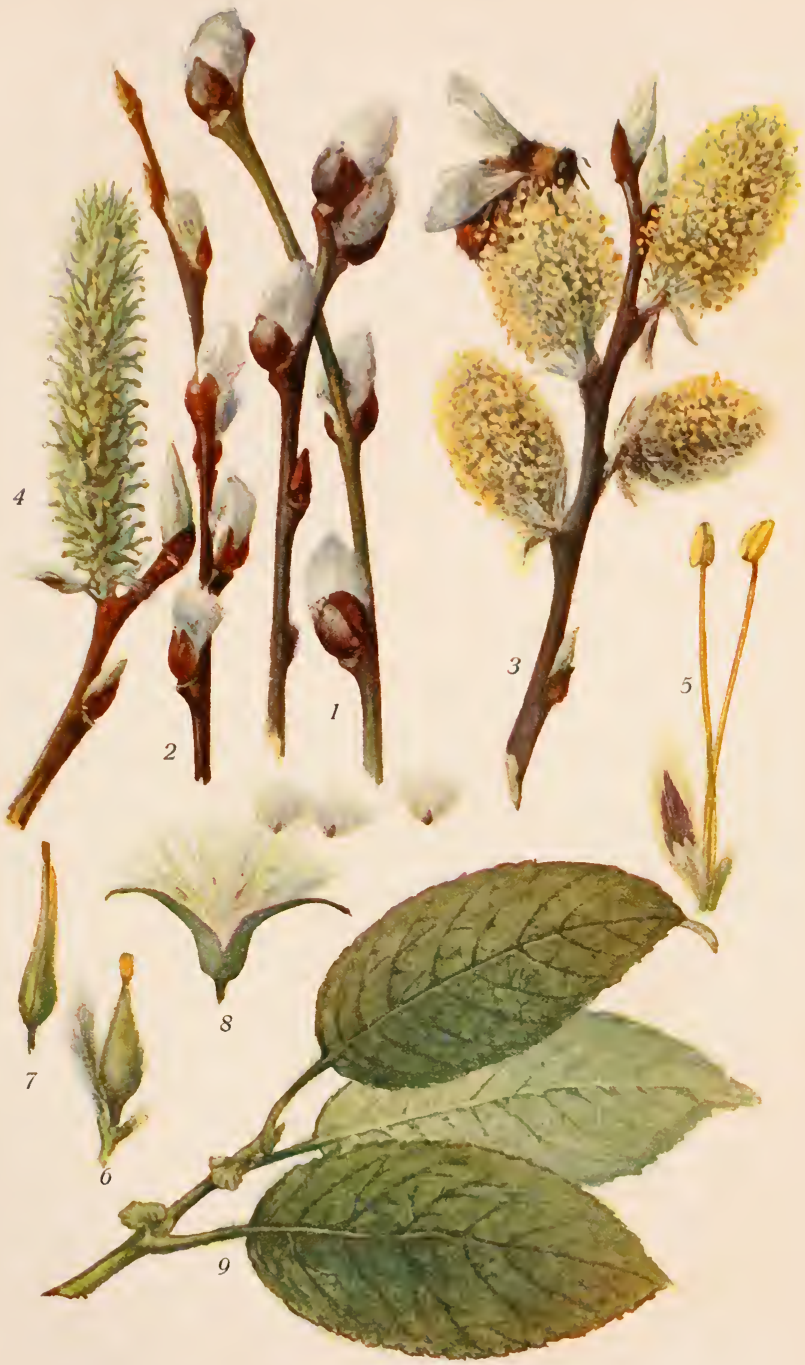

Sal- oder Palmweide (Salix caprea). 

Schuppe eingehüllt sind (Bedentung s. S. 4l, B). Junge Salweiden tragen nu kleine, spitze Knospen. Sie enthalten, wie eine I'ntersuchung ergibt oder wie man im Frïhlinge leicht beobachten kann, nur je einen jungen, beblätterten Zweig (Laubknospen). Ist die Weide aber tulter geworden, so treten neben diesen Knospen dickere und rundere auf, aus den'n die Blïten hervorgehen (Blïtenknospen). Im März beginnen die Knospen zu schwellen; der junge Trieb oder die eingeschlossenen Bliiten sprengen die Schuppen, die schließlich, weil nunmehr ohne Bedeutung, abfallen. Zucrst erscheinen die

D. Blïten. I. Die jungen Blütenkätzchen sind in ein silberweißes Haarkleid eingehiillt (daher "Kätzchen"; Bedentung s. S. 43, C a; Fig. 1 Zweigstïcke mit jungen Staub-, Fig. 2 Zweigstïck mit Stempelkitzchen).

Dieser zierlichen Gebilde wegen steht die Salweide in vielen Gegenden in hohem Ansehen: die mit Kätzchen besetzten Zweige gelten als eine Erimnerung an die Palmenzweige, die man (hristus beim Einzuge in Jerusalem aut den Weg gestreut hat. Iarum nennt man die Pflanze anch "Palmweide". (Das liestimmungswort "Sal" in "Salweide" ist aus dem lat. salix = Weide hervorgegangen.)

2. Die anfangs kleinen Kätzchen (sie waren ja in Knospen eingeschlossen!) streck'n sich rasch in die Länge, und im März oder April blüht die Salweide bereits, bevor die Blätter sich noch entwickelt haben. Da die Kätzchen alsı) viel weniger ausgebildet überwintern als die des Haselnubstrauches, so wird uns auch die spätere Blütezeit der Pflanze vollkommen verständlich.

3. An den blühenden Kätzchen macht sich leicht ein bemerkenswerter Unterschied geltend: neben solchen, die allein aus Staubblïten zusammengesetzt sind (3.), finden sich andere, die nur aus Stempelblïten bestehen (4.) Beide Blïten- oder Kätzchenarten trifft man aber nie anf demselben Strauche oder Baume an. Wenn wir den Haselnußstrauch eine einhäusige Pflanze nannten, müssen wir die Salweide daher als ein ,zweihäusiges Gewächs" bezeichnen. (I)asselbe gilt für alle Weidengewächse.)

4. Die Staubkätzchen (3) sind kurze, eiförmige Gebilde, die bei völliger Entfaltung prächtig gelb aussehcn. Unter jeder Kätzchenschuppe findet sich eine Blïte (5), die nur aus 2 Staubblättern mit schr langen Staubfäden und einer kurzen, stäbchenförmigen Honigdrüse besteht (prïfe mit der Zunge!). Die schuppe ist in ihrem äußeren Teile schwarzbram, sonst griun und dicht mit jenem Seidenhaar besetzt, das dem jungen Kätzchen das zierliche Aussehen verleiht.

5. Die Stempelkätzchen (4) sind ganz ähnlich gebaut. Unter jeder śchupe (6) findet sich außer der Honigdriise ein Stempel, der aus einem Haschentörmigen, grïnen Fruchtknoten und eincr gelben Narbe zusammengesetzt ist. Da auch die Schuppe von grïner Färbung ist, sind die langgestreckten Stempelkätzchen viel unscheinbarer als die Staubkätzchen.

6. Dịe Bestäubung kamn im Gegensatz zu den Blïten des Haselnn(3stranches hier nnmöglich der Wind vermitteln; deun wir sehen niemals, daß er wie bei jener Ptlanze Blütenstaubwolken entführt. Die Salweide ist 
gleich allen anderen Weidenarten im Gegenteil ein Insektenblütler. Dafür sprechen schon die zahlreichen Blütengäste - besonder's sind es Bienen und Hummeln -, die sich auf den Kätzchen einstellen. Aus dieser verschiedenen Bestänbungsweise erklären sich anch die zahlreichen Unterschiede, die sich zwischen den Blüten und Blütenständen beider Pflanzen finden:

a) Während die Kätzchen des Haselnußstrauches ganz unscheinbar sind, haben die der Salweide eine auffallende Färbung. An die Stelle der fehlenden Bliitenhïlle, die in der Regel die Anlockung der Bestäuber übernimmt, treten die prächtig gelben Staubblätter und die grïnen mit einer gelben Narbe gekrönten Stempel. Ein mit Staubkätzchen bedeckter Baum oder Strauch erregt in dem woch kahlen Walde oder Ufergebüsch schon von weitem die Aufmerksamkeit, ein Stempelkätzchen tragender allerdings weniger. Das vorwiegende Grün der Stempelkätzchen ist aber in dieser Jahreszeit eine immerhin auffällige Färbung.

b) Während bei den meisten Insektenblütlern diese Blütenteile von der Blütenhülle meist mehr oder weniger umschlossen und verdeckt werden (Beispiele!; gib aber auch Beispiele an, bei denen dies nicht der Fall ist!), und während sie bei dem windbliitigen Haselnußstrauche zum größten Teile verborgen sind, stehen sie hier ihrer Aufgabe gemäß frei da.

c) Die sehr kleinen Einzelblïten können aber nur dann die Aufmerksamkeit der Insekten erregen, wenn sie in großer Anzahl zusammen stehen. Daher sind hier im Gegensatz zur Haselnuß auch die Stempelblüten stark gehäuft. Sie bilden, wie wir schon oben gesehen haben, gleich den Staubblüten große Kätzchen.

d) Da die Salweide blüht, bevor sich die Blätter entfalten, werden die Kätzchen umso auffälliger.

e) Zudem hat die Salweide, da sie so verhältnismäßig frï im Jahre blïht, auch nur wenige „Konkurrenten", die ihr die Bestäuber abspenstig machen könnten.

f) Im Gegensatz zu den geruch- und honiglosen Blüten der Haselnuß besitzen die der Salweide einen weithin wahrnehmbaren Duft und - wie wir schon gesehen haben -

g) siißen Honig in ziemlich großer Menge.

h) An schwankenden Kätzchen, wie solcher die Haselnuß bedarf (wieso?), würden die saugenden Insekten einen schlechten Halt finden. Die Kätzchen der Salweide dagegen sind von wenig biegsamen Achsen durchzogen. Sie stellen keine pendelnden Quasten oder Troddeln, sondern steife und schräg a ufwärts gerichtete Gebilde dar, auf denen die Bestäuber leicht festen Fuß fassen können (vgl. auch S. 192, e!).

i) Der Blïtenstaub ist nicht wie bei der Haselnuß staubförmig trocken, sondern klebrig, zum Haften an dem behaarten Insektenkörper wohl geeignet.

k) Da die Insekten weit sicherere Bestäubungsvermittler sind als der ungewisse Wind, so wird der Blïtenstaub auch in viel geringerer Menge erzeugt als bei den Windblütlern. 
l) Für die zweihänsigen Weiden ist es von besonderer Wichtigkeit, daß Pflanzen mit Staub- und Stempelblüten möglichst eng beieinander stehen, oder anders ausgedriickt, daß sie größere Bestände bilden.

m) Da in demselben Bezirke meist mehrere Arten vorkommen, so kann es auch nicht ausbleiben, daß die Insekten Bliitenstaub anf die Narben anderer Arten tragen. Infolge dieser "Kreuzung" entstehen zahlreiche "Mischlinge oder Bastarde" (s. S. 96, 2).

E. Blätter. 1. Die jungen Blätter (3 und 4) kommen gleich den Kätzchen ganz mit weißem Flaum umhïllt ans den Knospen hervor (Bedeutung?).

2. Beim ausgebildeten Blatte dagegen (9), das am Grunde des Blattstieles 2 nicht abfallende Nebenblättchen trägt, bleibt die Behaarung nur auf der Unterseite erhalten. Die eiförmige Blattfläche erscheint daher oben dunkelgriin und unten hellgrau gefärbt. Die Haardecke hat fïr die Pflanze nun eine doppelte Bedeutung:

a) Tanchen wir ein Blatt der Salweide in das Wasser, so erscheint die Unterseite wie von einem silberglïnzenden Überznge bedeckt; denn das Wasser rermag die Luft zwischen den Härchen nicht zı verdrängen. (Stelle denselben Versuch anch mit einer Haarbürste, sowie mit einem Stïck Filz oder Samt an!) Dasselbe geschieht natïrlich auch im Freien, wenn die Blätter vom nächtlichen Tau benetzt werden: das Wasser vermag nicht bis zu der Blattoberfläche vorzudringen und die Spaltöffungen zu verschließen, durch die ein beständiger Luftwechsel stattfindet (s. später!). Durch den Verschluß dieser Öffnungen würde - um nur eine Seite dieses Gasaustansches zu erwähnen das Atmen gänzlich anfgehoben, die Pflanze also schwer geschädigt werden. Da sich nun die Spaltöffnungen nur auf der Unterseite des Blattes finden, so ist anch sie allein filzig behaart, und da die Salweide an feuchten Orten wächst, an denen die Pflanzen fast allnächtlich vom Tan triefen, so bedarf sie eines solchen Schutzmittels ganz besonders. (Beobachte, wie der Tau sich nicht nur anf der Oberfläche der Blätter „niederschlägt"! — „Doppelfarbige“ Blätter finden sich auch bei zahlreichen anderen Pflanzen, die mit der Salweide den Standort teilen, wie beim Huflattich, bei der Himbeere, der Sumpf-Spierstaude u. a. Bei vielen anderen Weidenarten ist als Schutzmittel der Spaltöffnungen ein Wachsüberzug vorhanden; s. S. 17, 2).

b) Als ein häufiges Schutzmittel gegen zu starke Abgabe von Wasser in Dampfform (s. S. 43, C a) haben wir vielfach die mehr oder weniger dichte Behaarung der Pflanzenteile kennen gelernt (Beispiele! Gib anch andere Schutzmittel gegen das Vertrocknen an!). Mit einem solchen haben wir es anch hier zn tun. Bei Windstille sind die Blätter der Salweide so gerichtet, daß sie die grïne Oberseite den Sonnenstrahlen zukehren. Wenn man sich nicht gerade unter den Baum stellt, dann ist von dem Grauweiß der Interseite nichts zu sehen. Sobald aber schon ein leichter Wind einsetzt, ändert sich dies vollstïndig: er krümmt die langen Blattstiele und die sehr biegsamen Zweige so, daß die behaarte Unterseite nach oben und anßen gekehrt wird. 
Dann streicht der austrocknende Wind ïber sie hinweg und ist nicht imstande, den Blättern soviel Feuchtigkeit zu entziehen, daß sie unter seiner Einwirkung vertrocknen mïßten.

F. Frucht. Der Fruchtknoten bildet sich zu einer Kapsel aus (7), die sich mit 2 Kilappen bereits im Mai ïffnet (8). Sie umschließt zahlreiche Samen, die rings ron Haaren eingehiillt sind. Bei der Reife spreizen die Haare, die am Grunde der Samen entspringen, auseinander. Dadurch werden die Samen emporgehoben (beobachte dies im Zimmer!) und in den Bereich des Windes gebracht, der sie bald weithin verweht (s. Löwenzahn!). Die Härchen dienen den Samen aber nicht nur als Verbreitungsmittel, sondern auch zur Befestigung beim Kieimen. Gelangen die Samen nämlich auf feuchten Boden, dann verkleben die Härchen alsbald mit ihm, so daß die Keimung sicher vonstatten gehen kann (vgl. mit Lein, Kürbis u. a.). Die Samen aber, die nicht auf diese Weise am .. Keimbett" befestigt sind, gehen zu Grunde.

\section{Andere Weidengewiichse.}

Unter den zahlreichen Weidenarten der heimatlichen Pflanzenwelt ist wohl die Korbweide (S. viminális) die wichtigste. Sie ist eine unserer bekanntesten Uferweiden, die sowohl zur Befestigung von Wasserbauten dient, als auch ihrer wertvollen Zweige wegen überall angepflanzt wird. Die linealen Blätter sind unterseits glänzend weißhaarig. - Die Trauerweide (S, babylónica), die aus dem Morgenlande stammt, pflanzen wir als Sinnbild der Traner (hängende Zweige!) auf die Gräber unserer Toten.

Im Gegensatz zu den Weiden sind die Pappelı (Pópulus) windblütige Pflanzen mit allen den Eigenschaften, die wir beim Haselnußstrauche kennen gelernt haben (Beweis!). Die Schwarz.-P. (P. nigra) hat fast rechtwinklig vom Stamm abstehende Äste und daher eine mächtige Krone. Der allbekannte Waldbaum, der gern an Wegen, auf Dorfstraßen u. dgl. angepflanzt wird, ist sehr schnellwüchsig und erreicht einen mächtigen Umfang. - Bei der italienischen oder Pyıumiden-P. (P. pyramidális) dagegen bilden Stamm und Zweige sehr spitze Winkel. Der hohe, schlanke Baum stammt aus dem Oriente. $\mathrm{Zu}$ uns ist er über Italien gekommen und wird besonders an Landstraßen angepflanzt. - Die Silber-P. (P. alba) ist in feuchten Waldungen Mitteldentschlands heimisch, hat sich aber als beliebter Parkbaum (warum eignet er sich dazu lesonders?) weit über ihr ursprüngliches Gebiet hinaus verbreitet. Die schön geformten Blätter sind anfangs beiderseitig filzig behaart; später findet sich die silberweife Haardecke aber nur an der Unterseite. (Erkläre die Namen der angeführten Pflanzen!). - Ein häufiger Baum feuchter Laubwälder ist die Zitterpappel oder Espe (P. trémula), die meist rundliche Blätter mit kürzeren und mit längeren Stielen besitzt. Da die langen Sticle zugleich seitlich zusammengedrïckt sind, so geraten ihre Blattflächen schon beim geringsten Luftzuge ins Schwanken. Dieser Erscheinung (was erzählt die Sage von ihrer Entstehung?) verdankt der Baum den Namen, und „das Zittern wie Espenlaub“ ist sprichwörtlich geworden. Die Blätter mit kürzeren, runden Stielen dagegen erzittern im Winde nicht. Am Grunde ihrer Blattfläche finden sich aber 2 napfförmige Drüsen, die einen süßlich schmeckenden Stoff ausscheiden. Welche Bedeutung diese Drüsen und das Zittern der langgestielten Blätter für den Baum haben, darüber sind die Naturforscher noch geteilter Ansicht. 


\section{Familie. Nesselgewächse (Urticáceae). \\ Die grobe Bremnessel (Úrtica dióica).}

1. Die Brennessel ist anf wïsten Plätzen und Schutthaufen, an Wegen und Hecken überall liänfig anzutreffen. Wie bei der frïher besprochenen Taubnessel (s. das.) durchziehen zahlreiche unterirdische Stengel den Boden, nnd wie bei dieser Pflanze sind anch die oberirdischen Stengel, sowie die Blätter (Form und Stellung!) gebildet.

2. Im Gegensatz zu der schutzlosen Tanbnessel ist die Brennessel aber stark bewehrt. Alle grünen Teile sind nicht nur wie z. B. bei der Schwarzwurz und anderen rauhblättrigen Pflanzen mit kurzen, stechenden Borsten besetzt, sondern noch mit ganz besonderen Waffen, den sog. Brennharen, ansgerïstet. Ein solches Haar stellt eine lange Röhre dar, deren Wand im oberen Teile durch eingelagerte Kieselsäure hart und spröde wie Glas ist. Während es unten stark

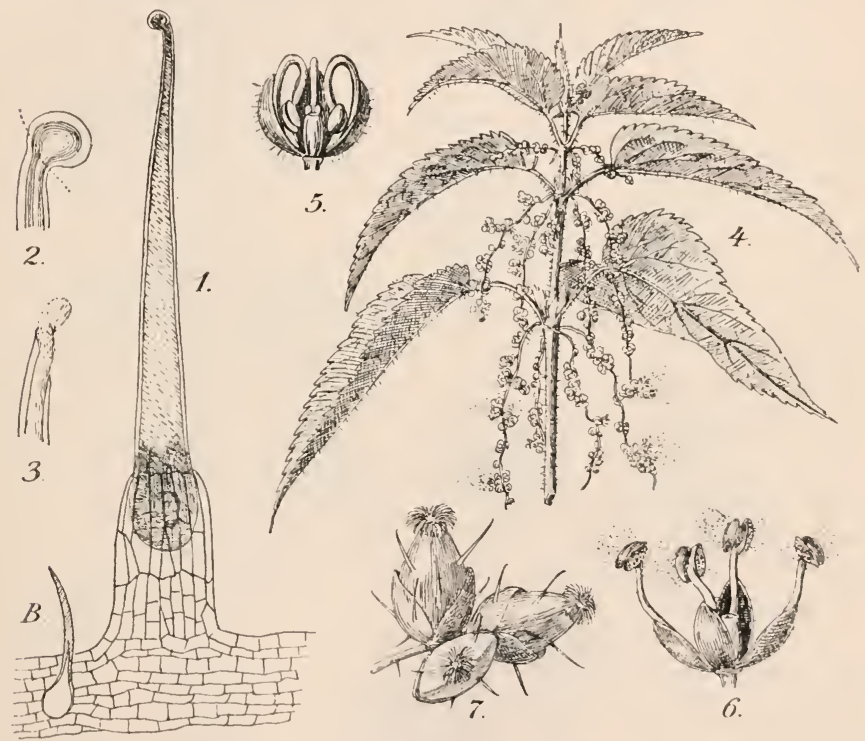

Grofge Brennessel. 1. Brennhar; an seinem Fuße eine Borste B. 2. Oberes Ende des Brennhaars; 3 . dasselbe, aber mit abgebrochenem Köpfehen. 4. (Oherer Abschnitt der Pflanze mit Staubblïten (stïubend). 5. Staubblïte; das vordere Blatt der Bliitenhülle ist entfernt; die Staubblitter sind noch nach innen gebogen. 6. Staubblïte im Augenblicke des Stäubens. 7. Drei Stempelblïten. (Fig. 1.-3. 100- bezw. $150 \mathrm{mal}$ vergr. Fig. 4, etwas verkl. Fig. 5.-7, etwa 10 mal vergr.) 
angeschwollen und in einen Zellbecher eingesenkt ist, besitzt es am oberen Ende ein seitwärts gerichtetes Köpfchen, unter dem die Wand der Röhre sehr dünn ist. Infolgedessen bricht das Köpfchen schon bei der leisesten Berührung ab. Da nun die dïnne Stelle schräg verläuft, so entsteht gleichzeitig eine scharfe Spitze, aus welcher der giftige Inhalt des Haares hervorquillt. (Vgl. mit dem Giftzahn der Schlangen und mit der „Einstichkanüle“, mit deren Hilfe der Arzt dem Kranken Medizin unter die Haut spritzt!). Wird das Köpfchen nun von einem Menschen oder Tiere abgebrochen, so dringt die Spitze leicht in die Haut ein, der giftige Inhalt gelangt in die Wunde, so daß ein brennendes Gefühl (Name!) und eine kleine Entzündung der Haut entsteht. Weidetiere hüten sich daher wohl, die empfindliche Nasen- und Mundschleimhant mit diesen giftigen Waffen in Berührung zu bringen (Bedeutung für die Pflanze?). (Welche Schmetterlingsraupen leben aber auf der Brennessel? - Warum „nesselt" die Pflanze nicht, wenn man sie fest angreift, oder wenn man von unten nach oben über sie hinwegstreift?)

3. Die Brennessel ist eine zweibäusige Pflanze wie die Salweide. Da sie aber ein Windblütler wie der Haselnußstrauch ist (s. d.), besitzt sie ganz unscheinbare Blüten (beschreibe sie näher), eine große Menge trockenen Blütenstaubes, sowie freistehende, pinselförmige Narben. Die zu hängenden Rispen gehäuften Staub- und Stempelblüten sind ferner dem Winde frei ausgesetzt, und die Pflanze wächst endlich in großen Beständen. Das Ausstrenen des Blütenstaubes erfolgt aber in anderer Weise als bei der Haselnuß. Betrachtet man eine Staubblüte, bevor sie sich öffnet, so sieht man, wie die Fäden der 4 Staubblätter nach innen gebogen sind und von den 4 weiß-rötlichen Blättern der einfachen Blïtenhülle in dieser Lage gehalten werden. Biegt man mit einer Nadel eines dieser Blätter nach außen, so schnellt der wie eine Feder gespannte Faden zurïck, sein Staubbeutel platzt, und eine kleine Wolke von Blütenstaub steigt in die Luft. Derselbe Vorgang spielt sich ohne unser Zutun am frühen Morgen ab, wenn die Brennessel von den ersten Sonnenstrahlen getroffen wird: bald hier, bald da erfolgt mit hörbarem Knall eine kleine „Explosion", und es steigt ein Wölkchen Blïtenstaub empor, den der geschäftige Morgenwind nunmehr leicht zu den Narben verwehen kann. (Sehr bequem läßt sich der Vorgang im Zimmer beobachten, wenn man die in Wasser stehende Pflanze in die Morgensonne stellt.) Die Frucht ist ein kleines einsamiges Nüßchen.

Die kleine Bremnessel (U. urens) wächst an denselben Orten wie die größere Art, tritt aber vielfach auch als lästiges Unkraut auf bebautem Boden auf. Sie ist eine einjährige und einhänsige Pflanze mit eiranden, tief gesägten Blättern. - Beide Nesselarten haben gleich dem Lein sehr lange nnd feste Bastfasern, die zu dauerhaftem Garne versponnen und zu einem leinwandartigen Zenge, dem Nesseltuche, verwebt werden können. Die größere Art hat man in der Tat früher auch verwendet. Jetzt kommen jedoch nur ausländische Nesselgewächse dafür in Betracht. Besonders gilt dies von der Ramiepflanze (Boehméria nivea), die namentlich in Ostasien nnd auf den Sundainseln angebaut wird und sich $\mathrm{n}$. a. durch das Fehlen der Brennhaare von den eigentlichen Nesseln unterscheidet. Der Wurzelstock treibt zahlreiche, 1-2 m hohe Stengel, die im Jahre 2 oder 3 mal geschnitten werden und die wertvolle Ramiefaser liefern. 


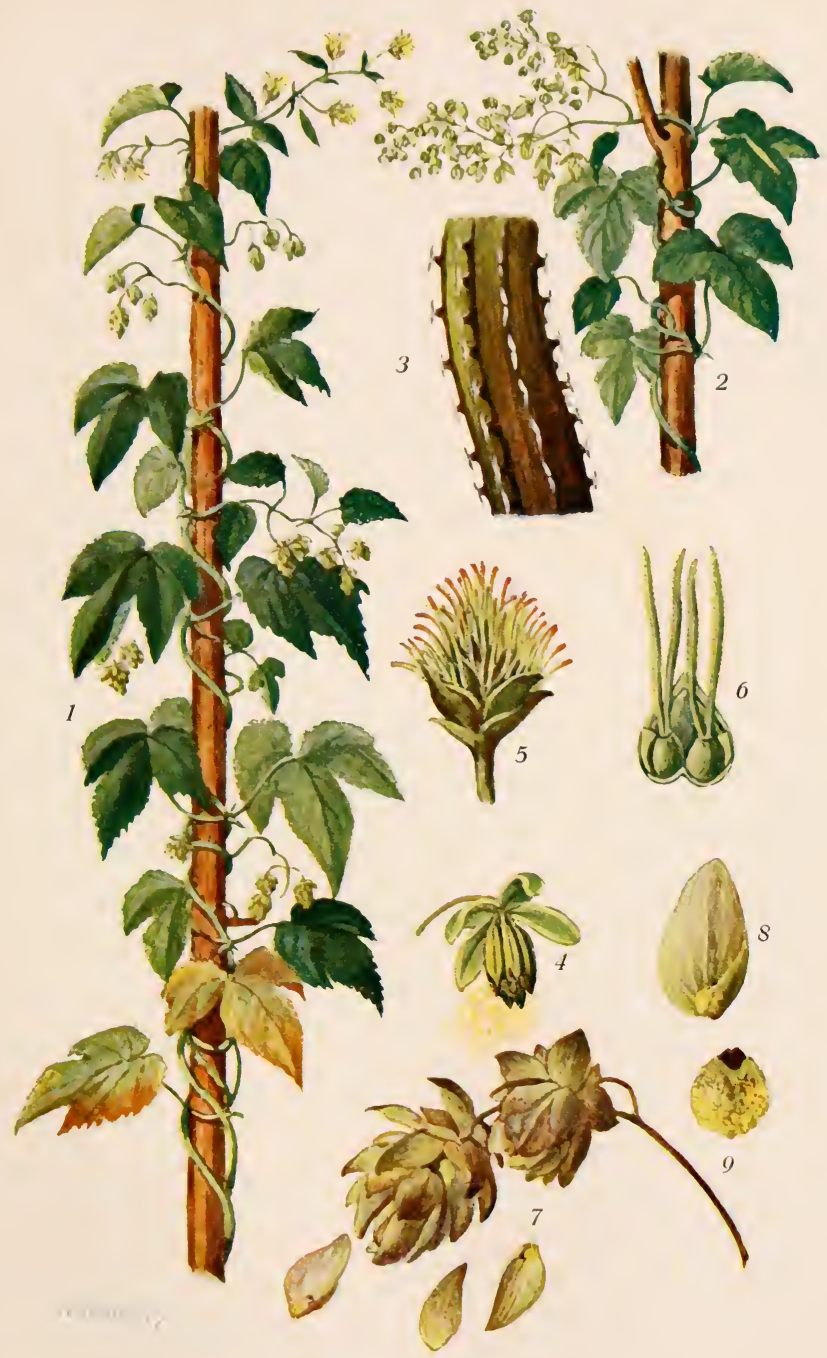

Hopfen (Humulus lupulus). 



\section{Familie. Hanfgewächse (Cannabináceae).}

1. Der Hanf (Cúnnabis sativa) ist seit uralten Zeiten eine wiehtige Gespinnstpflanze, deren lange, feste Bastfasern besonders zu Bindfaden und Seilen, sowie zu Segeltuch und anderen Geweben verarbeitet werden. Die einjährige und zweihäusige P'flanze (beschreibe die Blüten!) stammt aus Mittelasien. Sie erreicht eine Höhe von 1,5 m unı hat wie die Roßkastanie gefingerte Blätter, die aber aus weit schmäleren Einzelblättern zusammengesetzt sind. Den grünen Teilen entströmt ein widerlicher Geruch (Schutz gegen Tiere 1), der selbst Betäubung hervorrufen kann. Hierauf beruht auch die Verwendung, welche die Blätter in Indien finden: sie werden als "Haschisch" wie Opium gegessen oder geraucht, wirken außerordentlich berausehend und untergraben bald die Gesundheit desjenigen, der dieser Leidenschaft verfallen ist. Die Hanfsamen dienen bei uns besonders als Futter für. Stubenvögel, geben aber auch ein wertvolles fettes Öl, das ähnlich wie Rüböl verwendet wird.

2. Der Hopfen (Húmulus lúpulus - Taf. 29) umspinnt Zäune und Hecken und verwandelt das Ufergebüsch, sowie das Unterholz des Waldes nicht selten in ein undurchdringliches Dickicht. Im Frühjahre treiben ans dem Wurzelstocke zahlreiche Stengel hervor, die außerordentlich lang und dünn und daher genötigt sind, an Holzpflanzen eine Stïtze zu suchen. Rechtswindend (s. S. 101, 4) umschlingt der Hopfen Stämme und Äste des Strauchwerkes (1. n. 2.), zwischen dem er wächst, und gelangt so bald bis zu sonniger Höhe empor. Hierbei wird er wesentlich unterstiitzt durch amboß-oder ankerartige "Klimmhaken", die sich mit den scharfen Spitzen in die Rinde der Bäume und Sträucher einhaken und in 6 Reihen am Stengel entlang ziehen (3.). Am Grunde der herzförmigen oder 3-5 lappigen, schöngeformten Blätter, finden sich je 2 Nebenblätter, die zumeist gänzlich miteinander verwachsen sind. An den jungen Trieben sieht man, daß die Nebenblätter Schutzwerkzeuge sind: sie verdecken die noch zarten Blätter, schïtzen sie also gegen das Vertrocknen, sowie gegen Verletzungen beim Vordringen der Zweigspitze.

Der Hopfen ist wie die Weide eine zweihäusige Pflanze, zeigt aber alle Merkmale eines echten Windbliitlers (Beweis!). Die unscheinbaren Staubblïten bestehen aus einer einfachen, 5 blattrigen Blïtenhülle und 5 Staubblättern (4.). Da sie zu großen, leicht beweglichen Rispen (2.) geordnet und beim Blïhen dem Erdboden zugekehrt sind, und dil die großen Staubbeutel an dünnen Fäden herabhängen, so vermag schon ein leiser Windstoß den Bliitenstaub in ansehnlichen Wolken heraus zn schïtteln. Die Stempelblïten sind ganz unscheinbare Gebilde, die, zu zapfenartigen Blïtenständen vereinigt (5.), wie die Rispen an der Anßenseite des Hopfendickichts stehen (1. - Bedeutung?). Sie finden sich von je einem Deckblatte halb umhïllt, zu zweien am Grunde eines schuppenartigen Blattes (6.). Eine nnscheinbare, krngförmige Blütenhülle umschließt den Frnchtknoten. Die beiden Narben ähneln kleinen Cylinderpatzern und ragen iiber die Schnppen hinans ins Freie (Bedeutung?). Nach erfolgter Bestäubung vergrößern sich die Fruchtknoten and die umhüllenden Blattgebilde, so daß sich der Blïtenstand zu einem gelblichen 
Fruchtzapfen umgestaltet (7.). Am Grunde der Schuppen und Deckblätter (8.), sowie auf del (gleichfalls bleibenden) Blïtenliülle (9.) bemerkt man jetzt zahl= reiche gelbe Drïsen. Sie enthalten einen scharf riechenden und sehr bitter schmeckenden Stoff, durch den die körnerfressenden Vögel vom Verzehren der Frïchte abgehalten werden. In diesem „Hopfenbitter" liegt aber anch die Bedentung der Pflanze für den Menschen: er gibt dem Biere die eigentïmliche Wïrze, sowie die große Haltbarkeit. Dieser Verwendung wegen wird der Hopfen in vielen Gegenden auch im Großen angebaut. Bei völliger Reife lösen sich die einsamigen Frïchte los (7.), bleiben aber mit dem Deckblatte im Zusammenhange und werden infolgedessen vom Winde leicht weitlin verweht (Bedeutung?).

\section{6. u. 57. Familie. Maulbeer- und Ulmengewächse (Moráceae und Ulmáceae).}

1. Maulbeergewächse. Der schwarze Maulbeerbaum (Morus nigra), der aus dem Mittelmeergebiete stammt, findet sich hier und da der schwarzroten Früchte wegen angepflanzt. Diese "Maulbeeren" sind wie die ähnlich gestalteten Himbeeren Sammelfrüchte. Sie entstehen dadurch, daß die unscheinbaren Bliitenhüllen zur Frnchtzeit fleischig und saftig werden. Die ungeteilten oder gelappten Blätter eignen sich weniger gut zum Futter für die Seidenraupe als die des weißgen Maulbeerbaums (M. alba), der weiße Beeren trägt und in Ostasien seine Heimat hat

Die wohlschmeckenden, süßen Feigen, die zu uns meist getrocknet, zusammengepreßt und auf Bastfäden gereiht in den Handel kommen, entstammen dem Feigenbaum (Ficus cárica). Er ist schon seit den ältesten Zeiten (Bibel, Homer !) einer der wichtigsten Obstbäume der Mittelmeerländer, liefert aber auch in den nach Sïden gelegenen Alpentälern eßbare "Frïchte" und wird selbst noch in den milderen Teilen Süddeutschlands (z. B. im Rhein- und Neckartale) angepflanzt. Der sparrige Baum hat meist 5 lappige, schöngeschnittene Blätter, enthält in allen Teilen einen weißen Milchsaft (s. Wolfsmilch) und trägt das ganze Jahr hindurch umreife oder reife "Feigen". Durchschneidet man eine solche, so lange sie noch grïn ist, so sieht man deutlich, daß man es hier mit einem Blütenstande zu tun hat: Auf einem fleisehigen Blütenboden stelıen ähnlich wie bei der Sonnenrose zahlreiche, kleine Blïten. Der Bliitenboden ist jedoch nicht flach ausgebreitet wie bei dieser Pflanze, sondern so gebogen, daß ein krng- oder urnenförmiges Gebilde entsteht. Stempel und Staubblätter sind anf verschiedene Blïten verteilt, und zwar finden sich in den Bliitenständen des wilden Feigenbaumes, der keine eßbaren Feigen trägt, Stempel- und Staubblïten, während der angepflanzte Baum nur Stempelblüten entwickelt. Soll eine Bestäubung dieser Stempelblüten erfolgen, so muß also ein Vermittler vorhanden sein. Als solcher gibt sich ein kleiner Hautflïgler, die Feigengallwespe, zı erkennen. (Die Unansehnlichkeit der Blüten deutet auf Windbestäubung hin. Warum ist eine solche aber ausgeschlossen? Warum wären schön gefärbte Blïten olne Vorteil füir die Pflanze?) Die 
Bestäubung selbst ist ein außerordentlich verwickelter Vorgang. Es sei hier nur bemerkt, daß die Gallwespe in den Feigen des wilden Stockes ihre Verwandlung durchläuft und mit Blütenstaub beladen in die Feigen des angebauten Baumes eindringt. Ist die Bestäubung vollzogen, so werden Blïtenboden und Blütenhüille weich und saftig, und aus den Fruchtknoten gehen die senfkornähnlichen Früchte hervor, die als "Kerne" in dem süßen Fruchtfleische eingelagert erscheinen. Durch die jahrtausendlange Pflege ist $\mathrm{der}$ Baum aber anch imstande, ohne Vermittlung der Wespen wohlausgebildete Feigen hervorzubringen. (Beweise, daß die Feige eine Schein- und Sammelfucht wie die Erdbeere ist! Inwiefern ist die Pflanze der Verbreitung durch Vögel angepaßt?)

Zahlreiche Verwandte des wichtigen Baumes, die zumeist auf die heiße Zone beschränkt sind, haben für den Menschen gleichfalls eine große Bedeutung. So liefert der Gummibaum Ostindiens ( $F$. elástica), den wir seiner großen, lederartigen Blätter wegen gern als Zimmerpflanze pflegen, neben mebreren anderen Arten Federharz oder Kautschuk (s. S. 69). - Durch den Stich der Gummilack-

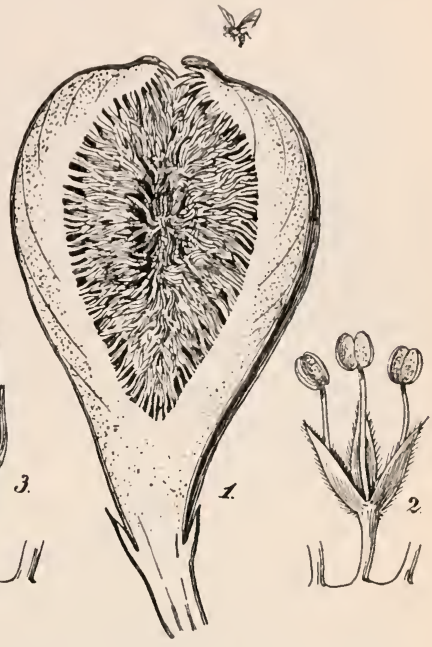

Bliiten des Feigenbaums. 1. Blütenstand (Feige) im Längsschnitt. Der Mündung fliegt eine Feigengallwespe zu. 2, Teil des Blütenbodens mit einer Staubblüte (aus der Feige des wilden Baumes) und 3. einer Stempelbliite. Die Stiele der benachbarten Blüten sind angedeutet. (Fig. 1 wenig, Fig. 2 u. 3 etwa $8 \mathrm{mal}$ vergr.) Schildlaus (s. "Lehrb. d. Zool.“) entstehen an den Zweigen wieder anderer Feigenbäume, die gleichfalls Indien bewohnen, Saftausflüsse, aus denen der Schell ack gewonnen wird.

Nahe Verwandte der Feigenbäume sind die Brotfruchtbainme (Artocárpus), deren mehlreiche, kopfgroße Scheinfrüchte in allen Tropengegenden ein überaus wichtiges Nahrungsmittel darstellen. Zwei oder drei dieser riesigen Bäume rermögen einen Menschen das ganze Jahr hindurch zu ernähren.

2. Ulmengewä chse. Die Feldnlme oder Rïster (Ulmus campéstris) ist ein stattlicher Baum, der sich in Wäldern und Anlagen häufig findet nnd in der äußeren Erscheinung der Linde in hohem Maße ähnelt. Eine bekannte Abart von ihm zeichnet sich durch leistenartige Korkbildungen der \%weige aus. Die Blätter sind gleich denen der Linde unsymmetrisch (s. S. 51), und da sie zudem noch von verschiedener Größe sind, bilden sie an wagerechten Zweigen oft die zierlichste Mosaik (Bedeutnng?). Die unscheinbaren, kurzgestielten Zwitterblüten (beschreibe sie!) entfalten sich lange vor den Blättern und werden durch den Wind bestäubt. Die Frucht ist ein Nüßchen, das 
durch einen breiten Flügelsaum flugfähig wird (Bedeutung?). - Die in allen Strïcken ähnliche Flatterriister (U, effúsa) besitzt langgestielte Blüten und Früchte.

Eine verwandte Pflanze ist unser beliebtester Schattenbaum, die Platane (Plátanus), die sich leicht durch die ahornartigen Blätter, die kugeligen Blüten- und Fruchtstände, sowie besonders durch die abblätternde Borke zu erkennen gibt. Bei der amerikanischen Pl. (Pl. occidentális), die in Nordamerika ihre Heimat hat, löst sich die Borke in Schuppen, bei der aus dem Orient stammenden morgenländischen Pl. (Pl. orientális) dagegen in großen Platten ab.

Anhangsweise seien hier kurz einige weit verbreitete Wassergewä chse erwähnt. Da sie unter denselben Verhältnissen leben wie der Wasserhahnenfuß (s. das.), so besitzen sie gleichfalls schwache Stengel und fein zerteilte Blätter. Das einhäusige Hornblatt (Ceratophýllum) schwebt, ohne Wurzeln zu schlagen, frei im Wasser, über dessen Spiegel es sich niemals erhebt. Der Blütenstaub muß daher durch das Wasser zu den Narben getragen werden. Daher fehlen den Blüten auch alle die Mittel, die bei Luftpflanzen zum Schutze des Bliitenstaubes u. dgl. vorhanden sind: sie sind höclist einfach gebaute, unscheinbare Körperchen in den Blattwinkelu. - Das überans zarte im Schlamme wurzelnde Tausendblatt (Myriophýllum) dagegen hebt seine Blütenähre über das Wasser nnd nimmt zur Bestänbung die Hilfe des Windes in Anspruch.

\section{Familie. Mistelgewächse (Lorantháceae). \\ Die Mistel (Viscum album).}

1. Wenn Schwarzpappel und Apfelbaum ihres grïnen Blätterschmnckes beraubt sind, dann findet man hier häufig, dort selten in dem Gezweig die merkwürdigen, grünen Zweige des Mistelstrauches. Die sonderbare Pflanze siedelt sich gleichfalls gern auf der Edeltanne an, nimmt aber anch mit anderen Laub- und Nadelbäumen fürlieb. Die gelbgrünen Stengel entspringen direkt aus den Ästen und teilen sich, da die Endknospen der Zweige zu Blütenknospen werden, wiederholt gabelig. Obgleich sehr brïchig, überstehen sie sogar in belaubtem Zustande die Winterstiirme, die durch das kahle Gezweig der Bäume fegen. Die lanzettlichen Blätter sind nämlich am Grunde etwas gedreht (s. Abb. S. 212), so daß sie vom Winde nie mit voller Kraft getroffen werden können; denn da die einzelnen Teile des Blattes verschiedene Richtung einnehmen, wird der Luftstrom gleichsam in eine Menge einzelner Ströme zerlegt, von denen nur die senkrecht anftreffendeu eine merkliche Wirkung ausïben. Der Wassermangel ist der zweite Feind, mit dem die Mistel während des Winters zu kämpfen hat; denn sie vermag das Wasser, das sie verbraucht, nur dem Baume zu entnehmen, auf dem sie lebt; dieser kann aber - wie wir früher gesehen haben (s. S. 91, c) - aus dem kalten oder gar gefrorenen Erdboden nur wenig Wasser aufsangen. Da die Blätter jedoch von lederartiger Beschaffenheit sind, so vermag die Mistel wie der Efeu (s. das.) selbst eine monatelange Trocknis leicht auszuhalten. (Beobachte, wie lange ein abgeschnittener Zweig selbst im warmen Zimmer „frisch" bleibt!) Die Blïten der zweihäusigen Pflanze sind sehr unscheinbar. Da sie aber angenehm duften und Honig enthalten, werden sie trotzdem vou Insekten besucht, und zwar umso eher, als sie sich bereits Mitte März entfalten, 
wenn die Bäume noch unbelaubt sind, und wenn in der Natur erst wenige Honigquellen fließen.

2. Wie aber gelangt die seltsame Pflanze auf den Baum? Gleich dem Stachelbeerstrauche, der Eberesche oder anderen Pflanzen mit fleischigen Früchten, die wir nicht selten auf Mauern, Burgruinen oder an ähnlichen schwer zugänglichen Orten antreffen, ist auch der Mistelstrauch allein durch Vermittelung eines Vogels hierher gekommen. Wieso? Die Frïchte der Mistel sind erbsengroße Beeren, die sich infolge der weißen Färbung leicht von dem Grïn der Zweige und Blätter abheben (Bedeutung?), und die besonder's von der Misteldrossel, aber auch von anderen Drosselarten gern verzehrt werden. Da nun das Fruchtfleisch außerordentlich

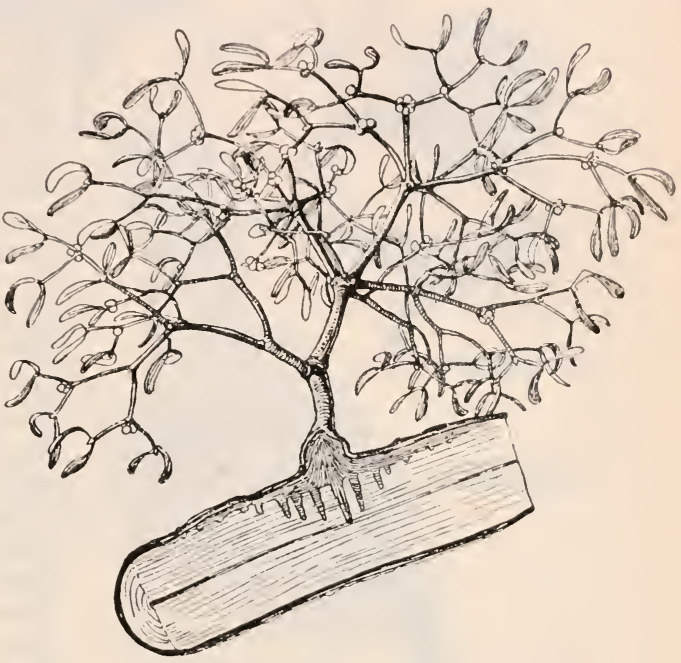

Mistel. Ein Strauch (verkl.) mit einem Teile des gespaltenen Zweiges, auf dem er schmarotzt. Rindenwurzeln und Senker sind zu sehen.

klebrig ist, so bleiben

die Samen leicht am Schnabel der Vögel haften. Werden sie verzehrt, so verwandeln sie den Kot der Tiere in eine klebrige Masse, die sich zu langen Fäden auszieht. (Zerdriicke eine Beere zwischen den Fingern! Aus den Beeren bereitet man Vogelleim.) Streichen die Vögel daranf den Schnabel an einem Aste ab, oder bleibt ihr Kot auf oder an einem. Zweige haften, so sind die harten, unverdaulichen Samen dadurch nicht allein an die Stelle gelangt, an der sie keimen und sich zu einer jungen Pflanze entwickeln können, sondern sie sind daselbst auch gleichsam angeleimt (Bedeutung?). Die Keimwurzel, die stets den Ast zu finden "weiß", durchbohrt dessen Rinde, dringt bis zum Holze vor und entsendet nach allen Seiten Wurzeln, die unter der Rinde verlaufen. Aus diesen „Rindenw urzeln" gehen nunmehr andere Wurzeln, die sog. Senker hervor, die nach und nach immer tiefer in den sich verdickenden Holzkörper des Astes eindringen.

3. Wie schon bemerkt, ist die Mistel genötigt, dem Baume, in dessen Zweigen sie wurzelt, das Wasser zu entnehmen. Mit dem Wasser entzieht sie ihm aber auch alle die Nahrungsstoffe, die andere Ptlanzen aus dem Erdboden 
aufsaugen. Sie ist also ein Schmarotzer. Im Gegensatz zu der Hopfenseide (s. das.) besitzt sie jedoch Blattgrïn. Sie ist daher auch instande, mit dem

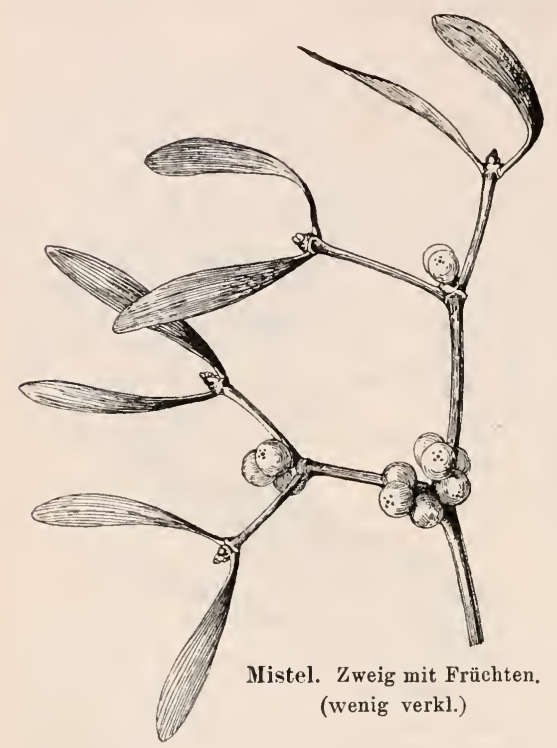
aufgenommenen Wasser, den in ihm gelösten Salzen und der Kohlensäure der Luft selbst alle die Stoffe $\mathrm{zu}$ bereiten, deren sie zum Aufbau ihres Körpers bedarf. (S. den letzten Absch. des Buches. - Ob sie dem Baume auch fertige Nahrung entzieht oder nicht, ist unbekannt. Vgl. mit Klappertopf!)

4. Die Fähigkeit der Mistel, hoch oben in den Kronen der Bäume zu leben und selbst wälrrend des Winters grün zu bleiben, sowie die gabelige Verzweigung der Stengel und die eigentümliche Form der Blätter haben der seltsamen Pflanze schon seit undenklichen Zeiten ein hohes Ansehen bei dem Menschen verliehen. In der Götterlehre der alten Völker spielte sie daher eine hervorragende Rolle, und die Germanen hielten sie geradezu für ein heiliges Gewächs. Noch heutzutage gilt sie in England am Weihnachtstage, dem alten Feste der Wintersonnenwende, für das Sinnbild des wieder erwachenden Lebens; sie vertritt dort also unsern immergrïnen Tannenbaum.

\section{Familie. Osterluzei-Gewächse (Aristolochiáceae).}

Die Osterluzei (Aristolóchia clematítis). Taf. 30.

Die Osterluzei ist eine fast meterhohe Pfanze, die mit Hilfe eines weitverzweigten unterirdischen Stammes überwintert. Da sie im Schatten der Bäume und Sträncher wächst, besitzt sie gleich zahlreichen anderen Schattenpflanzen (s. S. 7) große, zarte und demnach auch leicht verwelkende Blätter. (Beobachte die Stellung der herzförmigen Blattflächen und die Ableitung des Regenwassers! Wie sind die jüngsten Blätter geschïtzt?) Allen grünen Teilen entströmt ein widerlicher Geruch, in dem wir es wie in zahlreichen anderen Fällen (Beispiele!) mit einem Schutzmittel gegeu Pflanzenfresser zu tun haben. 


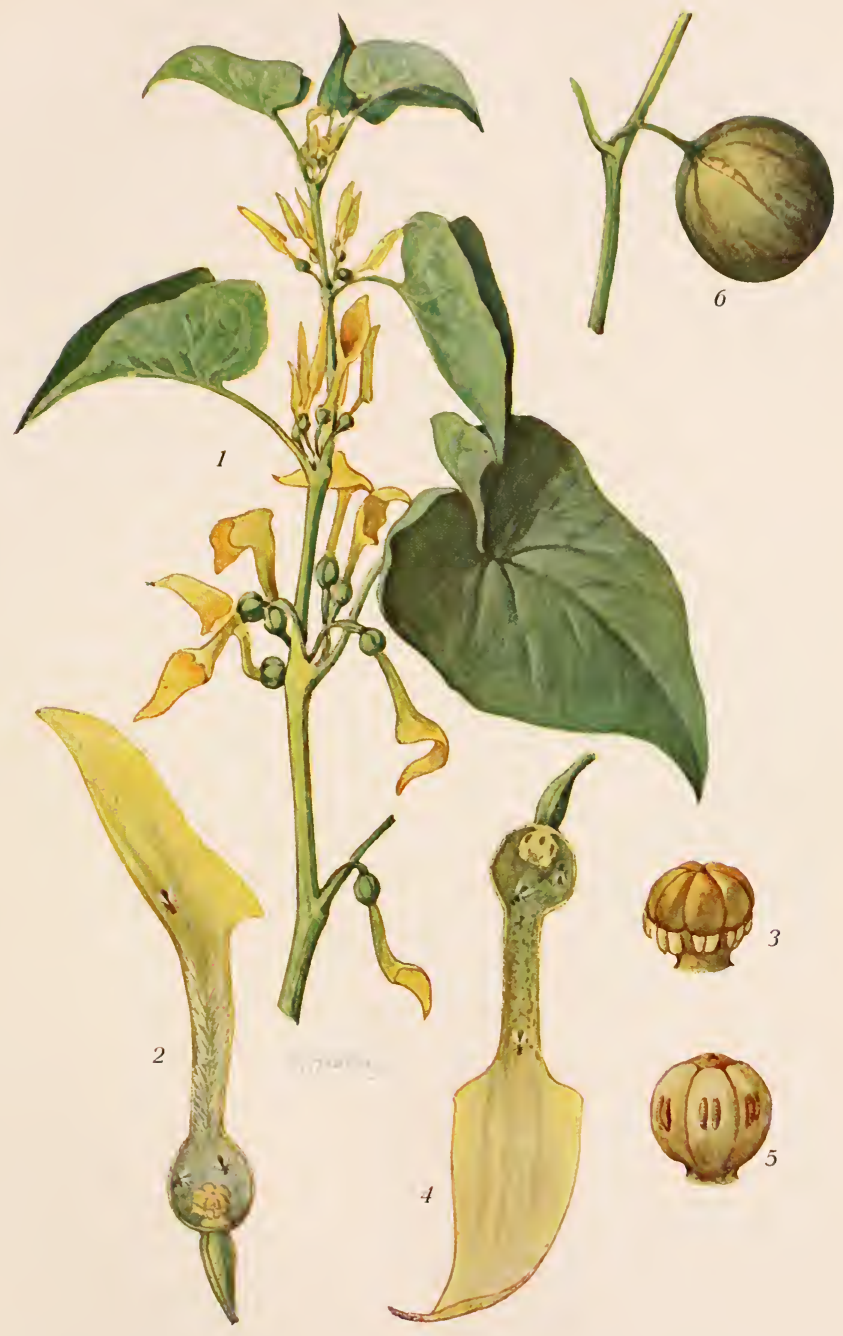

Osterluzei (Aristolochia clematitis). 

Die Blïten, die in den Blattachseln entspringen (1.), zeigen einen höchst sonderbaren Bau (2.; etwa $3 \mathrm{mal}$ vergr.). Die gelbe Blütenhïlle stellt eine Röhre dar, die am Grunde zu dem sog. Kessel erweitert und im oberen Abschnitte zungenförmig verlängert ist. In den Kessel ragt das obere Ende des Fruchtknotens, der wie ein Teil des Bliitenstiels aussieht, mit mehreren Narben gekrönt und mit den Stanbblittern innig verwachsen ist. Im Innern des röhrenförmigen Abschnittes tinden sich zahlreiche lange Haare, die gleichsam eine kleine Reuse bilden (stelle durch diesen Teil einen Querschnitt her!).

Diese eigentümlich gebaute Blïte ist anch nur auf besondere Art zu bestäuben. Schlitzt man die Hülle einer jüngeren Blïte (2.) auf, so findet man im Kessel hănfig zahlreiche, kaum $2 \mathrm{~mm}$ große Fliegen und Mricken, die sich auf dem zungenförmigen Abschnitte der Blïtenröhre (Anflugstelle!) niedergelassen hatten und durch die Rölıre eingedrungen sind. Hier sind sie nun für einige Tage gefangen; denn die nach innen gerichteten Reusenhaare erlauben ihnen wohl einzudringen, aber nicht herauszukriechen. Kommen die Tiere mit Blïtenstaub beladen bereits aus einer anderen (älteren) Blïte, so werden sie ihn leicht an den Narben abstreifen, die jetzt gerade reifen $(3$; die Narben und geschlossenen Staubbeutel etwa 10 mal vergr.). Die saftigen Wände des Kessels geben den Gefangenen während dieser Zeit Nahrung zur Geniige. Nach etwa 2 Tagen (4. u. 5.) verschrumpfen die Narben, die Staubbeutel lassen den mehligen Staub fallen, so daß die Tierchen oft wie eingepudert erscheinen. Gleichzeitig schrumpfen die Reusenhaare zusammen, so daß der Ansgang frei wird. Die Insekten kommen nunmehr aus der Blüte hervor, um gewöhnlich bald darauf in einer zweiten Einkehr zu halten. Vor den Eingang der anfangs aufrechten, jetzt aber herabgebogenen Blüten legt sich nun der zungenförmige Teil der Blütenhïlle, so daß die Bestäuber genötigt sind, stets nur diejenigen Blïten zu besuchen, in denen sie der Pflanze allein einen Dienst leisten können.

Obgleich man sicher in den meisten Blüten Insekten findet, setzt die Pflanze doch nur selten Früchte an. (Beachte die Erhaltung und Vermehrung der Art durch den unterirdischen Stamm!) Es sind dies Kapseln von der Form kleiner Birnen, die sehr zahlreiche Samen enthalten (6.).

Eine nahe verwandte Pflanze ist der Pfeifenstrauch (A, sipho), den wir seiner machtigen Blätter wegen gern zar Bekleidung von Lauben verwenden. Der kletternde Strauch, dessen Blüten kleinen Tabakspfeifen ähneln (Name!), stammt aus Nordamerika. - Anch die Haselwurz (Asaram europáum) steht der Osterlazei sehr nahe. Sie findet sich am Boden des Laubwaldes (unter Haselnußsträuchern!), hat derbe, nierenförmige Blätter und bräunliche Blüten, die sich im zeitigen Frühjahre entfalten.

60. u. 61. Familie. Seidelbast- und Lorbeergewächse (Thymelaecáceae und Lauráceae).

1. Der Seidelbast oder Kellerhals (Daphne mezéreum) ist ein kleiner Strauch der Gebirgswälder, der bereits im zeitigen Frühjahre blüht. Und zwar entfaltet er seine ungestielten, rosenroten Blüten vor den lanzettlichen Blättern, die sonst die kleinen 
Gebilde den Blicken der Insekten zam gröBten Teile entziehen würden. Sowohl die roten Frächte, als auch alle anderen Teile des Strauches, der gern als Gartenzierpflanze verwendet wird, enthalten ein starkes Gift (Schutzmittel gegen Tiere!).

2. Der Lorbeerbaum (Laurus nóbilis) ist ein Baum des Mittelmeergebietes, dessen beiderseits zugespitzte, etwas gewellte Blätter lederartig derb sind (s. S. 49). Der Lorbeerkranz gilt schon seit dem Altertnme als ein Zeichen erworbenen Ruhmes, und gern legen wir ihn auf die Ruhestätte unserer Verstorbenen. Da sowohl die Blätter, als auch die beerenartigen Früchte ein flüchtiges öl von angenehmem Duft enthalten, dienen sie als Gewürz an Speisen. - Ein weit wertvolleres Gewürz, den Zimt, liefern uns andere Lorbeergewächse in der Rinde ihrer Stämme und Zweige. Unter diesen Pflanzen nimmt wieder der Ceylon-Zimtbaum (Cinnámomum ceylánicum) die erste Stelle ein. Er kommt wild jetzt noch anf den Gebirgen Ceylons vor, wird aber zam Zwecke der Zimtgewinnung als Strauch in Pflanzungen gezogen. Haben die Stänme eine Stärke von etwa $4 \mathrm{~cm}$ erreicht, dann schneidet man sie dicht über dem Boden ab, entblättert sie und löst von Stamm und Ästen die Rinde los. Nachdem die äuBeren, bitter

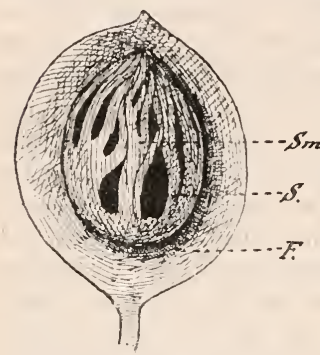

Frucht d. Muskatmuß̧baums. F. Fruchtfleisch. S. Same. Sm. Samenmantel. (Nat. Gr.) schmeckenden Teile sorgfältig entfernt sind, werden die Rindenstücke getrocknet. Hierbei rollen sie sich zusammen, nehmen eine rotbranne Farbe an und kommen als Zimt in den Handel.

Einer nahe verwandten Familie gehört der Muskatnugbaum (Myristica fragrans) an, der auf den Molukken heimisch ist, aber auch anf den Antillen angebaut wird. Die walnußgroße Frucht ist eine Beere, deren steinharter Samenkern die besonders früher als Gewürz hoch geschätzte Muskatnuß liefert. Umgeben ist der Same von einem karminroten, zerschlitzten Gebilde, dem sog. Samenmantel, der als Macis oder Muskatblüte (warnm ist diese Bezeichnung unrichtig?) in den Handel kommt und gleichfalls ein wertvolles Gewürz bildet. Die harte Fruchthülle dagegen dient nur den Eingeborenen als Speise.

\section{Familie. Knöterichgewächse (Polygonáceae).}

Eine Pflanze, mit deren Hilfe der Mensch selbst sandigen Äckern (Heidekorn!) noch einen Ertrag abzaringen versteht, ist der Buchweizen oder das Heidekorn (Polýgonum fagopýrum). Die zierliche, einjährige Pflanze stammt wahrscheinlich aus Mittelasien, wird etwa $1 / 2 \mathrm{~m}$ hoch, hat herzförmige Blätter und kleine Blüten mit einer einfachen, 5 blättrigen Blütenhülle (beschreibe die Pflanze näher!). Da die weißen oder rötlichen Blüten aber dicht gehänft stehen, sehr honigreich sind und einen angenehmen Duft aushauchen, so erfreuen sie sich doch eines reichen Insektenbesnchs. Die kleinen, schwarzbraunen Früchte sind dreikantig wie die der Buche and werden wie die Körner der Getreidearten verwendet (Name!). - Der Vogel-Knöterich (P. aviculáre) ist eines unserer gemeinsten Unkräuter, das selbst auf hartgetretenen Wegen und zwischen dem Straßenpflaster noch zu gedeihen vermag. - Im Gegensatz za diesem, dem Boden anfliegenden Pflänzchen klettert der Winden-Kü̈terich ( $P$. convólvulns) gleich der Winde an den Stengeln anderer Pflanzen empor. - Über den Wasserspiegel 
hebt oft der Wasser-Küutericlı (P. amphíbium) seine großen, rosafarbenen Blütenähren empor. Er wurzelt im schlammigen Grunde und läßt seine langgestielten, kahlen Blätter auf dem Wasser schwimmen (vgl. mit Seerose!). Versiegt das Gewässer, so bildet er gleich dem Wasserhahnenfub (s. das.) eine Landform mit kurzgestielten, behaarten und viel schmaleren Blättern.

Im Gegensatz zum Knöterich sind die zahlreichen Ampferarten (Rumex), die an den verschiedensten Örtlichkeiten oft in großen Mengen auftreten, windblütige Pflanzen (inwiefern stimmt hiermit der Bliitenbau überein?). Es sei hier nur der Sauerauıperer (R. acetósa) genannt, der auf Wiesen und Grasplätzen überaus häufig anzutreffen ist und durch hohen Gehalt an Kleesalz gegen Pflanzenfresser (besonders Schnecken; Versuch!) vortrefflich geschützt ist. Die Blütenhülle wird zur Zeit der Fruchtreife zu Flügeln für die eingeschlossenen, kleinen, dreieckigen Früchte (Bedeutung?). - Der als Blattpflanze für Rasenbeete und als Küehengewächs (Verwendung?) gebante Rhaloarber (Rheum) ist aus Mittelasien zu uns gekommen. Aus den fleischigen Wurzeln einer anderen Art, die in Tibet und China heimisch ist, wird ein als Rhabarber bekanntes, wichtiges Abführmittel hergestellt.

Einer nahe verwandten Familie gehört der Pfeffer-

\section{strauch (Piper} nigrum) an, der uns in dem Pfeffer ein schon seit den ältesten Zeiten gebräuchliches, wertvolles Gewürz liefert. Die wichtige Pflanze wird z. Z. in vielen Tropenländer'n angebaut, ganz besonders in Ostindien und auf den Sundainseln, woselbst anch ihre Heimat zu 
suchen ist. Sie klettert gleich dem Efen mit Hilfe von Wurzeln an Stämmen und Stïtzen empor, und wird daher meist wie bei uns der Hopfen an Stangen gezogen. Den eiförmigen Blättern gegenüber entspringen die ährenartigen Blütenstände. Aus den unscheinbaren Blïten entwickeln sich rote Beeren, deren Fruchtfleisch je einen hartschaligen Samen umschließt. (Vgl. mit der Kirsche! Weiche ein "Pfefferkorn" in Wasser auf und schneide es durch!) Werden die Frïchte unreif abgepflückt und getrocknet, dann schrumpft das Fruchtfleisch zusammen, und man erhält den „schwarzen Pfeffer". Läßt man sie dagegen vollkommen reif werden und beseitigt das Fruchtfleisch, dann liefern sie den "weißen Pfeffer".

\section{Familie. Gänsefußgewächse (Chenopodiáceae). Die Runkelrübe (Beta vulgáris)}

bildet ähnlich wie die Möhre (s. das.) im ersten Jahre eine dicke, fleischige Wurzel und einen Schopf großer Blätter. Aus den in der Wurzel aufgespeicherten Stoffen baut sich im zweiten Jahre ein oft mehr als meterhoher Stengel auf, der nach der Spitze zu mit immer kleiner werdenden Blättern besetzt ist (vgl. mit Raps) und zahlreiche unansehnliche Blüten trägt (beschreibe sie!).

Die Stammform der Runkelrübe ist ein unscheinbares Gewächs, das an den Küsten des Mittelmeeres noch heutzutage wild angetroffen wird und eine zwar verdickte, aber holzige Wurzel besitzt. Gelangt die Pflanze in menschliche Pflege, dann wird die Wurzel jedoch bald fleischig. Da man nun viele Jahrhunderte hindurch stets nur die vortrefflichsten Pflanzen zur Nachzucht auswählte (s. S. 19), sind die zahlreichen Spielarten entstanden, die wir auf nnseren Feldern bauen.

Die meisten von ihnen sind wichtige Futterpflanzen. Eine rotfleischige Form dient auch dem Menschen als Speise (Salat). Alle aber werden an Bedeutung weit von der Zuckerrübe übertroffen, die wegen des Reichtums an Rohrzucker in allen fruchtbaren Gegenden der nördlichen gemäßigten Zone im Großen angebaut wird. Der Gehalt an Zucker ist der Runkelrübe wie zahlreichen anderen Pflanzen von Natur eigen. Durch beständige Auswahl der zuckerreichsten Rüben zur Fortzucht hat es der Mensch aber verstanden, den Zuckergehalt, der ursprünglich $7-8 \%$ betrug, so erheblich zu steigern, daß er hente ungefähr doppelt so groß ist (bis $18 \%$ ), und zwar begann diese "Veredlung" der Pflanze erst um das Jahr 1850.

Aus dem mittelländischen Pflanzenreiche entstammt auch der Spinat (Spinácia oléracea), der bei uns als Gemüsepflanze hoch geschätzt wird. - Von den vielen bei uns wildwachsenden Verwandten der Runkelrübe seien nur die zahlreichen Gänsefug-(Chenopódium) und Melden-Arten (Átriplex) genannt, die besonders auf Schutt und in der Nähe des Menschen wachsen und vielfach lästige Unkräuter darstellen. Andere Arten finden sich wieder nur am Meeresstrande und an solchen Stellen des Binnenlandes, deren Boden außerordentlich reich an Salz ist (an Salzquellen, in Salzsteppen und an ähnlichen Orten). Obgleich auch zahlreiche Glieder anderer Pflanzen- 
familien zu diesen "Salzpflanzen" zälılen, sind doch die allermeisten von ihnen „Fettpflanzen" wie der Mauerpfeffer. Viele dieser unscheinbaren Gewächse haben nun ohne Zweifel mit großer Trockenheit der Luft und des Bodens zu kämpfen, so daB der sonderbare Bau sofort verständlich wird. Die Meerstrandpflanzen dagegen wachsen in feuchter Luft und werden nicht selten sogar zeitweise äberflutet. Trotzdem müssen sie aber gleich dem Mauerpfeffer gegen zu starke Verdunstung sorgsam geschützt sein; denn die Pflanzen vermögen aus Salzlösungen nur schwer Wasser zu entnehmen. Das bekannteste dieser seltsamen Gewächse, das Salzkraut (Salicórnia herbácea), das an den Küsten der Nord- und Ostsee, sowie im Binnenlande oft weite Strecken überzieht, hat es sogar wie die Kaktusgewächse (s. das.) bis zam gänzlichen Verlust der Blätter gebracht. 


\section{Klasse. Einkeimblättrige Pflanzen oder Spitzkeimer (Monocotýleae).}

Keimling mit nur einem Keimblatt (s. Roggen). Laubblätter in der Regel mit parallel verlaufenden, unver'zweigten Hauptnerven. Blütenteile meist in der 3-Zahl vorhanden.

\section{Familie. Liliengewächse (Liliáceae).}

Blütenhülle blumenblattartig und wie die Staubblätter aus 2 dreiblättrigen Kreisen bestehend. Fruchtknoten oberständig, dreifächerig. - Stauden, deren unterirdische

Stengel vielfach Zwiebeln oder Knollen darstellen.

\section{Unterfamilie. Eigentliche Lilien (Liliéae).}

Die Tulpe (Túlipa gesneriána).

A. Die Tulpe, eine Zierpflanze. Es gibt wohl kaum einen Blumengarten, in dem nicht auch einige Tulpen zu finden wären! Denn wenn der Mensch den Pflanzen auch oft gleichgültig gegenübersteht: ein Beet mit Tulpen und Hyazinthen, mit Schneeglöckchen und Crocus oder anderen Frühlingsgewächsen betrachtet jeder mit Wohlgefallen.

Die Tulpe ist in den Steppenländern Westasiens heimisch. Zuerst nahmen sie die Türken in ihre Gärten auf. Von dort aus gelangte sie etwa um die Mitte des 16. Jahrhunderts nach Deutschland, und schon nach einigen Jahrzehnten hatte sich die willkommene Frühlingsgabe über alle europäischen Länder verbreitet. Ganz besonders nahmen sich die blumenliebenden Holländer ihrer Pflege an, und bald entstanden zahlreiche Spielarten (s. S. 19), die während der ersten Hälfte des 17 . Jahrhunderts z. T. zu ganz nnverhältnismäßig hohen Preisen verkauft wurden. So zahlte man z. B. für eine einzige Zwiebel einer besonders seltenen Sorte nicht weniger als 13000 Gulden!

B. Die Tulpe, ein Zwiebelgewäclis. 1. a) Das Wesen der Zwiebel wird uns leicht klar werden, wenn wir uns an die Knospe der Roßkastanie erinnern! In diesem Gebilde erkannten wir einen winzigen Zweig, der Blätter und auch oft Blüten trägt, und der von besonders gestalteten Blättern, den Knospenschuppen, umhüllt ist. Durchschneiden wir eine Tulpenzwiebel, bevor sie „ausgetrieben“ ist, der Länge nach, so finden wir fast dieselben Verhältnisse vor. Wir sehen erstlich, daß ihr unterster Abschnitt von einem scheibenförmigen Körper gebildet ist. Diese "Zwiebelscheibe“ stellt einen kurzen, plattgedrïckten Stamm dar, der unten mit einem Kranze faseriger Wurzeln besetzt ist. Ferner erkennen wir, wie sich dieser Stamm in einen Stengel verlängert, der einige Laubblätter und eine Blüte trägt. (Junge Zwiebeln treiben nur einen kurzen, beblätterten Stengel.) Und endlich finden wir, daß sich auf der Zwiebelscheibe rings um den Stengel noch mehrere Blätter, die sog. 
Zwiebelschalen, erheben. Sie machen die Hauptmasse der Zwiebel aus nnd sind (Querschnitt!) kreisförmig geschlossen, so daß sie etwa die Form von Hohlkegeln haben. Die ämßeren Schalen sind trocken, brïchig und von brauner Färbung, die inneren dagegen saftig, fleischig und (wie die meisten iu Finstern wachsenden Pflanzenteile; Beispiel!) farblos. Da die Zwiebel also vorwiegend aus Blättern besteht, kann sie keine Wurzel darstellen, wofür sie im gewöhnlichen Leben meist gehalten wird; denn eine Wurzel trägt niemals Blätter. Sie ist vielmehr eine unterirdische Knospe oder ein kurzer, unterirdischer Stamm mit besonders gestalteten Blät tern.

b) Daß diese Deutung richtig ist, geht auch daraus hervor, daß die Zwiebel gleich
der Knospe in einer Blattachsel ihre Entstehung nimmt. Und zwar bilden sich bei der Tulpe die jungen Zwiebeln stets in der Achsel einer Zwiebelschale. (Bei anderen Liliengewächsen entstehen Zwiebeln auch in den Achseln oberirdischer Blätter; s. Knoblauch und Fenerlilie!)

c) Im Gegensatz zu den gewöhnlichen Knospen, die mit der Mutterpflanze in der Regel im Zusammenhange bleiben, führt die Zwiebel ein selbständiges Leben. Sie ist daher genötigt, Nahrung aus dem Boden zu entnehmen, oder anders ausgedriickt,

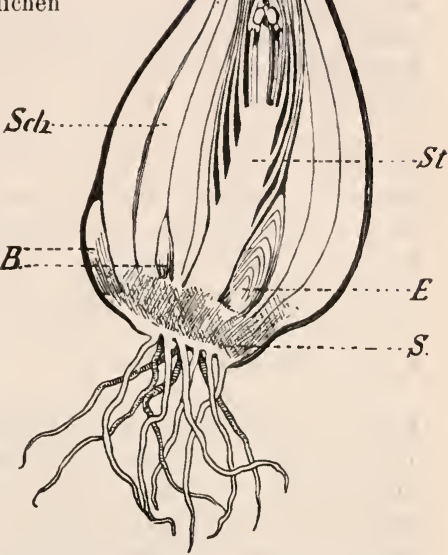

Tulpenzwiebel, längs durchschnitten. S. Zwiebelscheibe. St. Stengel. Sch. Zwiebelschalen. E. Ersatzzwiebel. B. 2 Brutzwiebeln. Wurzeln zu schlagen.

2. Die Bedentung der Zwiebel. I. Wie oben bemerkt, hat die Tulpe in den Steppenländern Westasiens ihre Heinıat. In diesen Gegenden folgt jahrans, jalırein auf eine kurze Regenzeit eine $7-8$ Nonate währende Diirre. Dann vertrocknen alle saftigen Gewächse, und der Boden wird oft steinhart. Nur die mit besonderen Schutzmitteln (nenne solche!) ansgerüsteten Pflanzen oder diejenigen, deren Pfahlwurzeln bis zu den tieferen, stets feuchten Bodenschichten hinabreichen, vermögen die Trocknis zu überdanern. Alle anderen Gewächse sind entweder einjährige Pflanzen, die mit Beginn der Regenzeit ans Samen hervorgehen, schnell Blüten und Früchte treiben und mit Eintritt der Dürre absterben, oder "Stauden", die sich vor den sengenden Strahlen der Sommersonne gleichsam in den Boden fliichten: ihre oberirdischen Teile sterben ab, während die unterirdischen (Wurzelstock, Knollen oder Zwiebeln) am Leben bleiben. So 
zieht sich auch die Tulpe mit beginnender Trockenheit in den Boden zurück. Wenn endlich nach vielen Wochen wieder heftige Regengüsse auf die sonnenverbrannte Steppe herniederrauschen, und das belebende Naß den staubtrockenen Boden erweicht, dann erwacht mit der Tulpe das ganze Heer der Standen aus dem todähnlichen Schlafe, und schon nach kurzer Zeit sind die weiten Gefilde mit Tausenden und aber Tausenden leuchtender Blüten bedeckt. Die Zwiebel ist also (gleich dem Wurzelstocke und der Knolle) ein Mittel der Pflanzen, die ungünstige Jahreszeit zu überdauern. Die Zwiebelgewächse sind daher die Gepräge- (Charakter-) Pflanzen der Steppe. (Darnm werden z. B. in der Bibel auch die "Lilien " so hänfig erwähnt, die noch hente den Steppen Palästinas zur Regenzeit einen wunderbaren Schmuck verleihen.)

Auch für die in unsere Gärten eingewanderte Tulpe hat die Zwiebel die gleiche Bedeutung: der trockene Sommer, sowie der trockene (s. S. 92) nnd kalte Winter würden die Pflanze unbedingt töten, wenn sie sich vor ihnen nicht in die schützende Erde zurückzöge. (Beweise, daß dies auch für die einheimischen Zwiebelgewächse, sowie für alle Liliengewächse gilt, die mit Hilfe von Wurzelstöcken oder Knollen überwintern!)

Die Aufgabe, welche die Zwiebel zu erfüllen hat, macht uns nun leicht folgende Tatsachen verständlich:

a) Wir sagten oben, daß sich die Tulpe gleichsam in den Erdboden flüchtet. Ist denn eine solche Flucht gerade dorthin von Bedeutung? Wie wir Pflanzen, deren Wurzeln oder unterirdische Stämme nicht vertrocknen sollen, in die Erde „einschlagen" (Beispiele!), so ist auch die Zwiebel im Erdboden gegen eine tödlich starke Abgabe von Feuchtigkeit wohl geschützt. Welch hohen Grad von Trocknis die Zwiebel übrigens zu ertragen vermag, geht daraus hervor, daß wir unsere Blumenzwiebeln mit Beginn des Sommers meist aus dem Boden nehmen und bis zum Herbste trocken aufbewahren. Wir müssen aber wohl bedenken, daß sich die Luft unserer Breiten hinsichtlich der Trockenheit mit der der Steppenländer nur selten messen kann!

b) Einen weiteren Schutz gegen das Verdorren bilden die trockenhäutigen, äußeren Zwiebelschalen. (Wir hüllen Gegenstände, die wir feucht erhalten wollen, in Papier, trockene Tücher u. dgl.; Beispiele!) In dieser aus pergamentartigen, ungenießbaren Blättern gebildeten "Kapsel“ besitzt die Zwiebel zugleich ein wichtiges Schutzmittel gegen die Angriffe der im Boden lebenden Tiere, namentlich der gefräßigen Nager.

c) Gegen diese Feinde ist die Zwiebel auch noch durch einen Giftstoff geschïtzt, der Erbrechen erregt.

d) Wie wir gesehen haben, muß die Tulpe in ihrer Heimat bereits wenige Monate nach dem Hervorkommen aus der Erde die Samen gereift haben. Hierzu wäre sie aber ohne den Besitz der Zwiebel sicher anßer stande. Gleich der Kartoffelknolle (s. das.) stellt dieses Gebilde nämlich einen Vorratsspeicher dar, ans dem die Pflanze solange die Baustoffe entnimmt, bis die ïber dem Erd- 
boden hervorgeschobenen Laubblätter im Sonnenlichte neue Stoffe bilden können. Daher fühlt sich die anfangs feste Zwiebel zur Zeit der Blüte bereits weich an (vgl. mit der "keimenden" Kartoffelknolle!). Daß hier wirklich ein Stoffverbrauch stattindet, beweist dentlich die bekannte Tatsache (Versuch!), daß aus Tulpen- (Küchen-, Hyazinthen- und anderen) Zwiebeln, selbst wenn sie ganz trocken liegen, die grünen Blätter hervorbrechen, die sich doch nur auf Kosten der Zwiebel bilden können. Ja, man ist sogar leicht imstande, Tulpen- (Hyazinthen-) Zwiebeln in reinem Wasser bis zum Bliihen zu bringen.

e) Soll die Zwiebel ihre Aufgabe, die Pflanze ïber die ungünstige Jahreszeit "hinüberzuretten", aber wirklich erfüllen, so muß für das absterbende Gebilde Ersatz geschaffen werden: In der Achsel der innersten Zwiebelschale bildet sich eine Knospe, die schnell an Größe zunimmt und zur "Ersatzzwiebel" für das nächste Jahr wird.

Hiermit geht nun ein allmählicher Verfall der „alten" Zwiebel Hand in Hand: ihre Schalen werden von der sich immer mehr dehnenden Ersatzzwiebel nach außen gedrängt und die anfangs prallen, saftigen Gebilde werden immer welker und trockener. Hat die Ersatzzwiebel endlich ihre volle Ausbildung erlangt, dann sind die Schalen der alten Zwiebel zu pergamentartigen Häuten verschrumpft, also (s. Absch. b) zur Schutzhülle der jungen Zwiebel geworden. Die Zwiebel, die wir im Herbste pflanzen, ist also nicht dieselbe, die im Frïhjahre geblïht hat, sondern ein Nachkomme, eine Knospe dieser. (S. dag. die Zwiebel des Schneeglöckchens!)

Öffuet man, nachdem die oberirdischen Teile abgestorben sind, die Ersatzzwiebel, so findet man in ihr Stengel, Blätter und Blüte für das nächste Jahr bereits vollkommen ausgebildet. (Ja sogar die Ersatzzwiebel für das nächste Jahr ist als winzige Knospe bereits angelegt.) Diese Tatsache erklärt uns nun einerseits, wie die Tulpe der Anforderung zu genügen vermag, die die heimatliche Steppe an sie stellt — nämlich schnell zu ergrünen und zu blühen und wie sie andererseits eine unserer ersten Frühlingspflanzen bilden kann. (Vgl. mit anderen Liliengewächsen, sowie mit dem Scharbockskrant und anderen Pflanzen des Frïhjahrs.)

II. Löst man die Zwiebelschalen vorsichtig von der Zwiebelscheibe ab, so findet man außer der Ersatzzwiebel in den Achseln anderer Zwiebelschalen zumeist noch weitere Knospen, die sich gleichfalls nach und nach zu Zwiebeln ausbilden. Mit dem Absterben der Zwiebelschalen wandern sie nach außen, und wenn die Schalen endlich verwesen, dann werden sie frei und geben je einer nenen Pflanze das Dasein. Diese jungen Zwiebeln bezeichnet man dalıer auch treffend als "Brutzwiebeln". Die Zwiebel ist für die Tulpe (und die anderen Zwiebelgewächse) also nicht nur eine Eimrichtnng, die ungünstige Jahreszeit zu überdanern, sondern auch ein Mittel der Vermehrung.

C. Vom Stengel und von den Blattern der Tulpe. 1. Stengel und Blätter, die aus der oft tief im Boden liegenden Zwiebel hervorgehen, müssen eine dicke und nicht selten sogar feste Erdschicht durchbrechen. Wie 
aber vermögen die zarten Blätter und der Stengel, der zndem noch von der sehr empfindlichen Blüte gekrönt ist, eine solche Arbeit zu leisten?

a) Die Blätter sind zu einem Kegel zusammengelegt, dessen Spitze den Erdboden wie ein Keil durchbricht. Der Mantel des Kegels wird von dein derberen, untersten Blatte gebildet, das die zarteren, oberen Blätter, sowie den oberen Stengelteil mit der Blïte schützend umhïllt.

b) Die Spitze des äußeren Blattes, die beim Durchbrechen des Bodens vorangeht, ist kapuzenförmig gestaltet und fast stechend hart.

2. Ist die Erdschicht durchbrochen, so entfalten sich alsbald die Blätter, von denen bei bliihenden Pflanzen in der Regel 3 vorhanden sind. (Stelle die Terhältnisse bei nicht blïhenden Pflanzen fest.) Sie sind ungestielt und umfassen den Stengel scheidenartig. Ihre unverzweigten Nerven laufen dem Rande parallel, ein Merkmal, durch das die einkeimblättrigen Pflanzen (Monocotylen) meist schon auf den ersten Blick von den zweikeimblättrigen (Dicotylen) zu unterscheiden sind.

a) Stengel nnd Blätter sind mit einer bläulichen, abwischbaren Wachsschicht bedeckt, wie wir solche bereits beim Raps fanden (s. S. 17, 2).

b) Die grünen Teile sind ferner vollkommen kahl. Es fehlt ihnen also jede Spnr einer Beharung, durch die z. B. so zahlreiche Sommergewächse (Beispiele!) gegen zu starke Wasserdampfabgabe geschiitzt sind. Wenn wir aber bedenken, daß die Tulpe in der heimatlichen Steppe nur während der feuchten Jahreszeit und in unseren Gärten während des Frïhjahrs grünt, hier wie dort also in einer Zeit, in der der Boden feucht und die Luft stark mit Wasserdampf erfiillt ist, so werden wir diesen scheinbaren Mangel wohl verstehen.

c) Die Blätter stehen am Stengel schräg aufwärts und haben rinnenförmige Gestalt. Die auf sie fallenden Regentropfen (Versuch!) rollen daher nach der Mitte zu (centripetal) ab und gelangen somit an die Stelle, an der sich die Wurzeln finden (s. S. 88, c).

D. Von der Bliite der Tulpe. Die Blütenhülle besteht aus 6 Blättern von sehr wechselvoller Färbung (gib sie näher an!). Obwohl diese Blätter zu zwei dreiblätterigen Kreisen geordnet sind, lassen sie sich nicht als Kelch und Blumenkrone voneinander unterscheiden, wie dies bei zahlreichen anderen Pflanzen der Fall ist. Man bezeichnet die Blütenhülle daher als „einfach" (oder

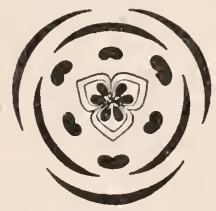

Bliitengrundrig der Tulpe. als "Perigon"). Daß die Blätter des äußeren Kreises dem Kelche aber vollkommen entsprechen, geht nicht nur aus ihrer Stellung, sondern anch daraus hervor, daß sie im Knospenzustande die inneren Blätter wie ein Kelch umhïllen, und daß sie bis kurz vor dem Aufblühen grün sind, während jene dann schon eine bunte Färbung zeigen. Die 6 Sta ubblätter sind gleichfalls zu 2 Kreisen geordnet. Sie umgeben den Stempel, der ans einem dreifächerigen, säulenartigen Fruchtknoten (Querschnitt!) und einer in 3 abgerundete Lappen gespaltenen Narbe besteht. - 
Indem sich die Staub- und Fruchtblätter zu blütenblattartigen Gebilden umwandeln, entstehen die ,gefiillten" Tulpen.

1. Die Tulpe bringt alljährlich nur eine einzige Blite hervor. Da diese aber von a uffallender Größe ist, so vermag sie wohl die Aufmerksamkeit der Insekten zu erregen. Immerhin wäre es aber höchst unsicher, wenn der Fortbestand der Pflanze nur auf dieser einen Blüte beruhte. In Wirklichkeit ist sie darauf ja nicht allein angewiesen; denn außer durch Samen erhält und vermehrt sich die Tulpe ja noch - wie wir gesehen haben - durch die Ersatzzwiehel und die Brutzwiebeln.

2. Obgleich die Blïte keinen Honig enthält, wird sie doch von zahlreichen Insekten besucht. Die große,n Staubbeutel enthalten soviel Staub, daß die Besucher ohne Schaden füir die Pflanze davon speisen können. Der dabei verstreute Blütenstaub wird von den muldenförmig gebogenen Blättern der Blütenhülle aufgefangen und für spätere Gäste aufbewahrt (vgl. mit Klatschmohn und Hundsrose).

3. Im hellen Sonnenscheine breiten sich die Blätter der Blïtenhülle zи einem leuchtenden Stern auseinander, so daß die Blüte für die über sie hinwegfliegenden Insekten noch anffälliger wird. Mit Eintritt des Abends aber schließt sie sich wieder. Bei trübem und regnerischem Wetter öffnet sie sich garnicht (s. S. 3, b).

E. Von der Frucht der Tulpe. Der Fruchtknoten bildet sich zu einer Kapsel aus, die in jedem der 3 Fruchtfächer 2 Reihen Samen enthält, und die sich bei der Reife mit 3 Klappen öffnet. Da der anfangs saftige und brüchige Stengel jetzt trocken und elastisch geworden ist, so vermag der Wind die Samen leicht anszuschütteln (Schleuder!), und da diese leichte, elastische Scheiben darstellen, zugleich weit zu verwehen.

\section{Andere Lilien.}

1. Mit der Gartentulpe hat eine große Anzahl anderer Liliengewächse, die sich alle durch herrlichen Blütenschmuck auszeichnen, Eingang in unsere Gärten gefunden. $\mathrm{Da}$ ist zunächst die wohlriechende, gelbblühende wille Tulpe (T. silvéstris) zu nennen, die aus Südeuropa stammt. Sie hat die Gärten aber vielfach wieder verlassen und sich auf Grasplätzen, in Weinbergen und an ähnlichen Orten angesiedelt. - Als schönste Frühlingspflanze gilt neben der Tulpe die Hyazinthe (Hyacinthus orientális), die in zahlreichen farbenprächtigen Spielarten gezogen wird, und deren Stammform in Kleinasien, Griechenland und Dalmatien zu finden ist. Sie hat zwar weit kleinere Blüten als die stolze Tulpe; dafür sind diese aber von köstlichem Duft und zu ansehnlichen Trauben gehäuft, so daß sie sich den Bestäubern doch weithin kenntlich machen. Bei der niedlichen Bisam-Hyazinthe (Muscári) findet gleichfalls eine Hänfung der kleinen Blüten statt ( Weinträubchen“). Hier aber dienen die oberen Blüten, die weder Stempel noch Staubblätter enthalten, ganz der Insektenanlockung (vgl. mit Schneeball). - Tiefblaue Sterne bilden die Blüten der ebenfalls in unseren Gärten hänfig angepflanzten Meerzwiebeln (Scilla). Eine als Topfpflanze allgemein bekannte Form dieser Gattung ist die weißblühende echte M. (S. maritima), die an den Küsten des 
Mittelländischen Meeres und Atlantischen Oceans ihre Heimat hat (Name!). - Mittelasien hat uns die stattliche Kaiserkrone (Fritillária imperiális) geliefert. Ihre groBen, gelbroten Blüten stellen hängende Glocken dar, so daB der Blätenstaub und der am Grunde der Blütenhüllblätter reichlich abgeschiedene Honig vom Regen nicht erreicht werden können. Die Zwiebel ist durch ein scharfes Gift gegen Tierfraß geschützt. Als ein Sinnbild der Reinheit und Unschuld gilt schon seit den ältesten Zeiten die weife Lilie (Lilium cándidnm). Sie ist in Südeuropa und Westasien heimisch und erfreut uns erst im Hochsommer durch die Pracht ihrer Blüten, mit denen sich nicht einmal „Salomo in aller seiner Herrlichkeit" vergleichen konnte. Die blendend weiße Färbung, der abends stärker werdende Duft, sowie die Größe und Stellung der Blüte lassen daranf schließen, daß wir es hier mit einer Nachtfalterblume zu tun haben (vgl. mit Leimkrant). Auch der Mangel einer Anflugsstelle für. die Besucher, sowie die Stellung und schaukelartige Befestigung der Staubblätter (vgl. mit Wald-Geißblatt) deuten daranf hin. - Die gleichfalls in unseren Gärten häufig zu findende Feuerlilie (L. bulbiferum) mit ihren gelbroten, duftlosen und aufrecht stehenden Blüten ist eine Tagfalterblume wie z. B. die Steinnelke. In den Achseln der oberen Blätter bilden sich nicht selten schwarze Brutzwiebeln, eine Erscheinung, auf die bereits früher hingewiesen wurde. Die stattliche Pflanze, die bei uns heimisch ist, aber nur sehr selten anf Gebirgswiesen angetroffen wird, leitet zu unseren wildwachsenden Liliengewächsen über.

2. Wenn uns im Garten Tulpen und Hyazinthen erfreuen, dann blühen drauBen in Feld and Wald die Goldsternarten (Gágea). Mit Beginn des Abends schließen sich ihre gelben Blüten, und bei regnerischem Wetter öfinen sie sich gar nicht (Bedeutung?). Dann ist von den leuchtenden Blütensternen (Name!) kaum noch etwas zu bemerken; denn die Blätter der Blütenhülle sind auf der Rückseite grünlich gefärbt (s. S. 3, b). Dieselbe Erscheinung ist auch an den weißen, zu einer Dolde gehäuften Blüten des Milchsterus (Ornithógalum umbellátum) zu beobachten. Da die zierliche Pflanze wie die Goldsternarten keinen Stengel bildet, so kann sie auch nur an solchen Orten wachsen, an denen sie trotz ihrer Kleinheit zar Geltung kommt, im niedrigen Grase, an Wegrändern u. dgl. Und will sie von den Nachbarpflanzen nicht überwuchert werden, so muß sie sehr zeitig im Jahre erscheinen. - Letzteres gilt auch von der Schachblume (Fritillária meleágris), die nasse Wiesen mit ihren schachbrettartig gewürfelten, hängenden Blütenglocken schmückt. - Der Türkenbund (Lílium mártagon) dagegen entfaltet seine herrlichen Blüten erst im Juni und Juli. Dafür überragt er aber anch (Höhe bis ' $/ 2 \mathrm{~m}$ ) die niederen Pflanzen seiner Umgebung. Zn dieser Zeit trifft man an sonnigen Stellen längst kein Liliengewächs mehr. Im Schatten des Laubwaldes dagegen findet der Türkenbund (Blätter derber als bei den Frühlingspflanzen) selbst in den heißen Sommertagen noch den notwendigen Schutz. Wie bei der weißen Lilie sind Nachtfalter vorwiegend die Bestäuber der wie ein Turban geformten Blüten. (In welchen Stücken ist die Blüte ihren Bestäubern ${ }_{n}$ angepaßt" ?) - Der Bärenlanch (Állium ursinum) dagegen, der häufig in feuchten Laubwäldern anzutreffen ist, sich aber nur wenig über den Boden erhebt (stengellos!), ist wie das Windröschen eine Frühlingspflanze mit großen, zarten Blättern. Eine häutige Scheide umgibt schützend die zu einer Dolde geordneten, weißen Blüten, bevor sie sich entfalten, und allen Teilen entströmt ein starker Knoblauchsgeruch (Schatzmittel gegen Tiere). Beide Merkmale teilt dic Pflanze mit den zahlreichen Gattungsgenossen, die wir als wichtige

3. K üchengew ürze in Garten und Feld aubanen. Von diesen Lancharten (Állium) ist an erster Stelle die Kiichen- oder Sommerzwiebel (A. cepa) zu nennen, 
die seit den ältesten Zeiten nicht nur als Würze, sondern auch als Gemüse verwendet wird. Obgleich die langen, fast senkrecht stehenden und unterhalb der Mitte bauchig angeschwollenen Blätter und Stengel sehr zart sind, vermögen sie doch selbst heftigen Stiirmen zu widerstehen: sie stellen Röhren dar, die wie alle Röhren (s. Halm des Roggens) eine verhältnismäßig große Biegungsfestigkeit besitzen. Die Zwiebel (verfolge die Kieimung des Samens und die Bildung der Zwiebel!) geht schon bei geringer Kälte zugrunde, ein Zeichen, daß die Heimat der wichtigen Pflanze im Süden (wahrseheinlich im Mittelmeergebiete) zn suchen ist. Im Gegensatz zur ${ }_{n}$ Sommerzwiebel" (Name!) vermag die Winterzwiebel (A. fistulósum), die nicht selten gleichfalls zam Küchengebranch angebaut wirl, sclbst den Winter bei uns in Freien ausznbalten. Ihre Heimat ist aber auch der Südosten von Sibirien. Durch die über die ganze Mitte bauchig erweiterten Blätter und Stengel ist die Pflanze leicht von jener zu unterseheiden. - Röhrenförmige Blätter besitzt auch der allbekannte Schnittlanch (A. sehoenóprasum), der bei uns heimiseh ist und ein mehrfaches Abschneiden der Blätter leicht verträgt (Name! Verwendung?). - Flache Blätter wie der oben erwähnte Bärenlauch hat der stark riechende Knoblanch (A. sativum), dessen Stammpflanze wahrscheinlich in Mittelasien heimisch ist. Er entwickelt in der Dolde neben wenigen, langgestielten, kleinen Blüten zahlreiche, kugelige Brutzwiebeln, die ausgesät sich zu neuen Pflanzen entwickeln. - Mit dem Knoblanch ist wahrscheinlich die Perlzwiebel (A, ophioscórodon) ans derselben Stammpflanze hervorgegangen (Verwendung?). - Gleichfalls eine ${ }_{n}$ Kulturform " ist der Porree (A. porrnm), der als Gewürzpflanze hoch geschätzt wird (Verwendung?) and in Mittelmeergebiete seine Hei-

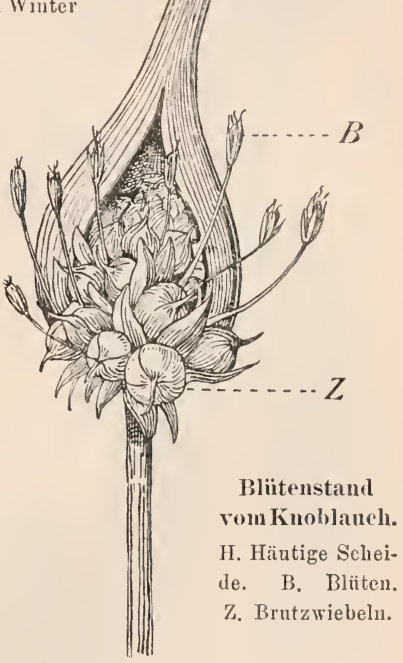
mat hat.

4. Es sind hier endlich noch einige a usländische Pflanzen zu erwähnen, die hei uns im Gewächshause und Zimmer häufig gehalten werden. Dahin gehören vor allen Dingen die Dracheub:iume (Draeæna), die am Gipfel des kahlen Stammes einen Bïschel schwertförmiger Blätter tragen und daher meist für Palmen gehalten werden. Sie sind in den wärmeren Gegenden der alten Welt heimisch nud erreichen zumeist ein anßerordentlich hohes Alter. - Sehr älnnliche Pflanzen sind die Palmlilien (Yucea), die aus dem warmen Amerika stammen. - Die öden Steppen nnd Wüsten Afrikas, besonders des Caplandes, bewohnen die Aloë-Arten (Aloë). Da sie gleich dem Mauerpfeffer und den Kaktusarten (s. das.) ausgeprägte "Fettpflanzen" sind, vermögen sie monatelange Trocknis leicht zu überdanern. Ans dem bitteren Safte der dicken, fleischigen und derben Blätter gewinnt man eine als Abführmittel viel gebrauchte Medizin.

Schmeil, Lehrbach der Botanik. 


\section{Unterfamilie. Herbstzeitlosen (Colchíceae).}

Die Herbstzeitlose (Cólchicum autumnále). Taf. 31.

1. Standort und Blütezeit. Wenn der Herbst seinen Einzug in das Land hält, und auf den Fluren nur noch hier und da ein verspätetes Blümchen anzutreffen ist, dann erschließt auf feuchten Wiesen erst die Herbstzeitlose ihre bläulichroten, zarten Blüten. Die Pflanze blüht also so ganz a n ßer der Zeit (Name!). Da nämlich die Blüten nicht von hohen Stielen ïber den Boden gehoben werden, sondern direkt aus ihm hervorbrechen, so können sie nur dann zur Geltung kommen (Bedeutung?), wenn das Gras auf der Wiese niedrig ist: und das ist außer im zeitigen Frühjahre (rgl. mit Krokus) eben nur im Herbste der Fall.

2. Knolle und Blïte. Woher nimmt aber die Zeitlose, die schon seit Monaten kein grïnes Blatt mehr besitzt, die Stoffe zum Anfbau der Blüte? TVie bei der Tulpe in der Zwiebel, so liegen sie hier in einer Knolle (s. Kartoffelknolle!) aufgespeichert, die wir beim Nachgraben leicht finden (1.). Löst man die dunkelbraune Hïlle (d. i. die Scheide des ersten vorjährigen, jetzt halb verwesten Laubblattes) ab, so sieht man, wie sich die junge Pflanze auf einem kurzen Seitentriebe der Knolle erhebt (2.). Sie ist außer von der genannten braunen Hülle noch von einigen farblosen, scheidenartigen Blättern schützend umgeben und besteht aus einem kurzen Stengelteile, der oben die Blüte trägt, und an dem wir die nächstjährigen Blätter bereits deutlich erkennen.

Da sich die Blüte (I. u. 3.) über dem Erdboden entfalten muß (warum?), sind die Blätter der Blïtenhïlle im unteren Teile zu einer sehr langen Röhre verwachsen. Sie stellt gleich den drei ebenfalls langen Griffeln die Verbindung zwischen den ober- und unterirdischen Teilen her. In allen anderen Stücken ist die Blüte ganz ähnlich wie die der Tulpe gebaut (Beweis!); auch schließt sie sich nachts (4.) und an kalten, regnerischen Tagen (Bedeutung?), an denen sich ja doch keine Bestäuber einstellen. Sobald die Blütezeit vorüber ist, zieht sich die Zeitlose gleichsam wieder in den Schoß der Erde zurück; denn dort sind die zarten Samenanlagen allein vor dem tödlichen Froste geschützt. Die Knollen liegen nämlich stets so tief im Boden, daß die Winterkälte nicht bis zu ihnen vorzudringen vermag (je nach der Gegend daher verschieden tief!).

3. Blätter und Friichte. Sollen die Samen der Herbstzeitlose ihre Aufgabe erfüllen - nämlich die Pflanze weiter zu verbreiten -, so müssen sie oberirdisch ausgestreut werden. Im kommenden Frihjahre streckt sich daher der bisher sehr kurze Stengel stark in die Länge und hebt die Blätter, sowie den schwellenden Fruchtknoten zum Lichte empor (5.). Die drei „tulpenartigen" Lanbblätter bereiten im Sonnenscheine nunmehr Nahrung für die reifende Frucht und neue Vorratsstoffe, die sich in dem kurz bleibenden Stengelgliede zwischen dem ersten und zweiten Laubblatte anhäufen. Infolgedessen schwillt dieser Stengelteil immer mehr an: es bildet sich die neue Ḱnolle, die im nächsten Herbste Blïten treibt, während die alte vollkommen ausge- 


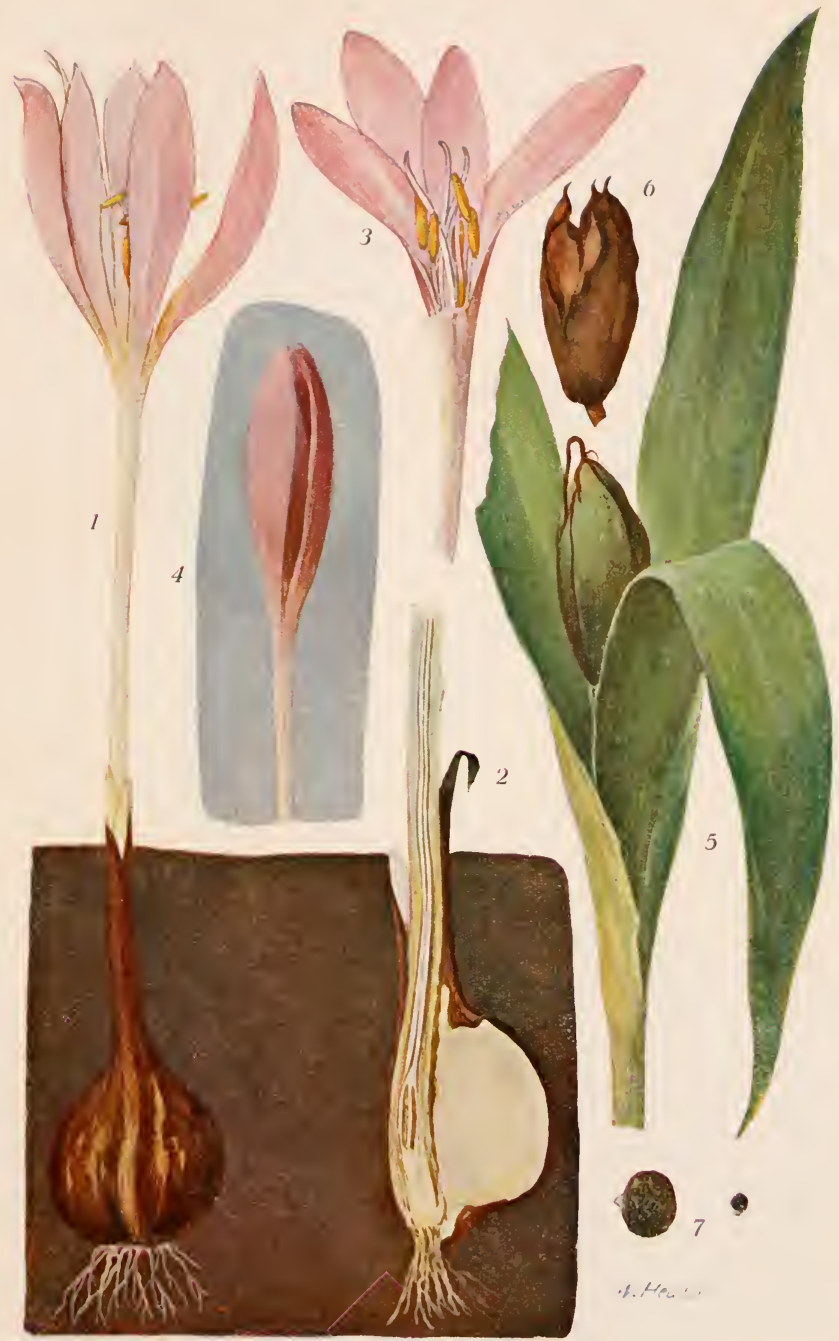

Herbstzeitlose (Colchicum autumnale). 



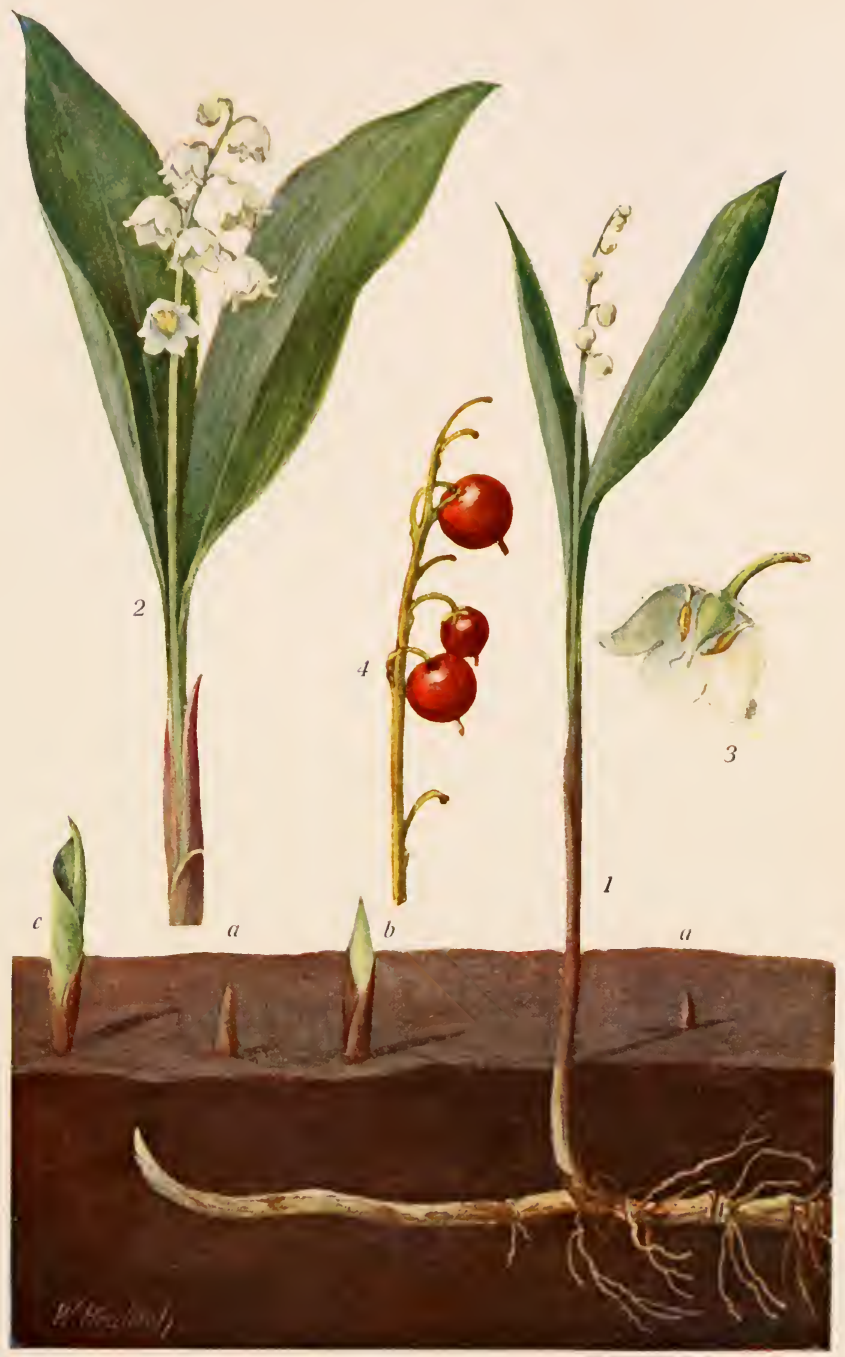

Maiblume oder Maiglöckchen (Convallaria majalis). 
sogen zugrunde geht. (Wir hal, es hier also wie bei der Kartoffelknolle mit einer "Stengelknolle“ zn tun.)

Die Frucht stellt eine dreifächerige Kapsel dar, die sich bei der Reife (Juni) mit 3 Klappen öffnet (6.). Die ausfallenden, brannen Samen (7. in nat. (ir. und 8 mal vergr.) besitzen einen weißen Anhang, der bei Befenchtumg klebrig wird. Infolgedessen haften sie an den Infen der Weidetiere fest, so daß die I'flanze leicht weithin verbreitet werden kann. Die Samen sind wie alle anderu Teile der P'flanze sehr giftig. Daher hïten sich die Weidetiere anch, die gefährliche Zeitlose zu berïhren; nur die Schafe scheinen ungestraft von den Blättern naschen zu dürfen. In der Hand des Arztes wirl dis Gift aber zu einem wichtigen Heilmittel.

\section{Unterfamilie. Spargelartige Pflanzen (Smiláceae).}

\section{Die Matblume ołler das Maiglöckchen (Convallária majális). Taf. 32.}

Wenn sich der La $u b$ wald in junges Grïn gekleidet hat, dann ist er nicht selten ron dem sïßen Dufte des Maiblümchens (Name!) erfüllt. Bereits einige Wochen vorher hatte das Pflänzchen den Waldboden durchbrochen, in dem es mit Hilfe eines unterirdischen Stammes (Wurzelstocks) ïberwinterte (Frühlingspflanze!). Dieses Gebilde, das ganz ähnlich wie beim Windröschen gebaut ist (Beweis!), sendet außer dem Blütenstande gewöhnlich nur noch 2 Laubblätter zum Lichte empor. Einen oberirdischen Stengel, der den Boden spalten könnte, finden wir also nicht. Daher muß das zarte Gewächs besondere Einrichtungen hierfür treffen: Die Laubblätter sind tïtenförmig zusammengerollt. haben den Bliitenstand "zwischen sich genommen" und werden von widerstandsfähigen, bläulichroten Hïllblättern schïtzend umgeben. Der junge, oberirdische Teil stellt somit einen langgestreckten Kegel dar, der selbst festere Erdschichten leicht zu durchdringen vermag (1 a). Sobald diese Arbeit getan ist, sprengen die wachsenden L a ublätter die Hülle $(1$ b.), schieben sich immer weiter daraus hervor ( 1 c) und breiten sich schließlich ans. Die eiförmigen Blattlächen gehen in lange Stiele über, sind mit einem Wachsuberzuge versehen (s. S. 17, 2) und wie die des gleichfalls im Waldesschatten wachsenden Windröschens verhältnismäßig groß (s. S. 7, b). Da die Blätter aber weit derber sind als die dieser Pflanze, so vermag die Maiblume selbst dem trockenen Sommer zu trotzen; erst mit beginnendem Herbste sterben die oberirdischen Teile ab. (Beachte, wie ler stiel des untersten Lambblattes den des anderen scheidenartig umschließt!

Neben den Laubblättern erhebt sich der lange, gemeinsame Bliitenstiel (1. 1. 2.). Er ist oben seharf dreikantig, unten dagegen an der den Blattsticlen angedriickten Seite abgerundet (Bedentung?). Im Endabschnitte trígt er ciue Anzahl kleiner, häutiger Blätchen, ans deren Achseln die kurzgestielten bliiten entspringen. Anfangs stehen diese anfrecht und sind von jenen "Hïllblättchen" schiitzend umgeben; später aber neigen sie sich nach unten und stellen zierliche Glöckchen dar (Name!). In Einzelnen (3.) sind sie wie 
die anderer Liliengewächse gebant (Beweis!); die 6 Blätter der schneeweißen Blïtenhülle sind aber zu einem glockenförmigen, 6 zipfeligen Gebilde verwachsen, das für Honig und Bliitenstaub ein schiitzendes Regendach abgibt (Name!). Da die Blïten zu einer Traube gehäuft und alle nach einer Seite (nach welcher?) gerichtet sind, werden sie trotz ihrer geringen Größe doch auffälig. Vor allen Dingen dürfte es aber der köstliche Duft sein, der die Bestänber zur Einkehr reranlaßt. Thm verdankt die Pflanze in erster Linie anch die Zuneigung des Menschen, der sie gern aus dem Waldboden hebt und in seinen Garten verpflanzt.

Im Herbste lockt die Maiblume abermals Tiere herbei, nämlich Waldvögel, die die roten, saftigen Beeren (4.) verspeisen und die harten Samen verbreiten sollen (s. S. 64,8$)$.

Gleichfalls eine Pflanze des schattigen Laubwaldes ist die Weigwnrz oder das Salomonssiegel (Polygónatum officinále). Das stattliche Gewächs trägt diese Namen

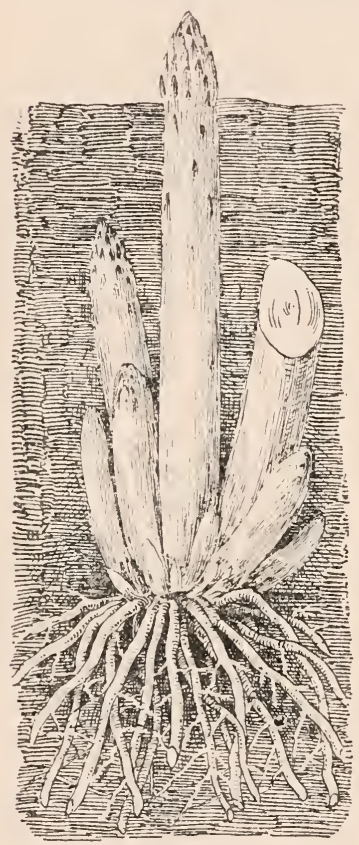

Spargel. Unterirdischer Stamm (Wurzelstock) mit jungen Trieben. Der stärkste Trieb rechts ist "gestochen".

(Verkl.) nach dem großen, weißen Wurzelstocke, an dem beim Absterben des oberirdischen Stengels jedesmal eine siegelartige Höhlung zurückbleibt. Aus den Achseln der großen, zweizeilig gestellten Blätter gehen die Blïten hervor, die langgestreckte, hängende Glöckchen darstellen. - Eine überall häufige Waldpflanze ist anch die Schattenblume (Majánthemum bifólium), die an den beiden herzförmigen Blättern und der aufrecht stehenden Blütentraube am Ende des handhohen Stengels leicht zu erkennen ist. - Das Glied, das der Unterfamilie den Nanıen gegeben hat, ist

\section{der Spargel (Aspáragus officinális).}

Er ist eine einheimische Pflanze, die besonders auf sandigen Triften und im Ufersande der Flïsse noch hentzutage ab und zu wild angetroffen wird. Vor allen Dingen tritt sie uns aber in Garten und Feld auf wohlgepflegten Beeten entgegen; denn schon seit dem Altertume bilden ihre jungen Triebe ein hochgeschätztes Gemüse. Es sind dies zarte, farblose Gebilde (Lichtmangel!), deren fortwachsende Spitzen (Keil!) beim Durchbrechen des Erdbodens durch schuppenförmige Blättchen gegen Verletzung geschützt sind. Die Triebe bilden sich an dem iiberwinternden, nnterirdischen Stamme (Wurzelstocke) und werden der Pflanze eine Zeitlang vom Menschen genommen. (Warum muß man das "Stechen" 
des Spargels auf einige Wochen beschränken? Wann sticht man „ein Spargelbeet tot"? Was geschieht, wenn die Triebe zu tief gestochen werden? Warum sind die Triebe in festem oder gar steinigem Boden hart und holzig?)

Überläßt man die Triebe sich selbst, dann entwickeln sie sich zu meterhohen, baumartig verzweigten Stengeln, die vermöge großer Festigkeit und Zähigkeit selbst den lueftigsten Winden Widerstand leisten können. Statt der Laubblätter gewöhnlicher Form findet man an den Stengeln und Zweigen unscheinbare braune Schuppen. Aus ihren Achseln entspringen Büschel nadelförmiger Gebilde, die gewöhnlich für die Bläter gehalten werden. Ia aber bei allen l'flanzen aus den Blattachseln stets Zweige liervorgehen, so können wir hier auch nur solche vor uns haben. Wie der Stengel und die größeren Zweige sind diese Zweiglein mit Blattgrïn ansgerïstet. Sie sind dennach anch in der Lage, die Arbeiten zu verrichten, die dic Blätter nicht leisten können (warum nicht?) Wir haben es hier also mit einer ähnlichen Erscheinung zu tun wie bei den Kaktusgewiichsen (s. das.), und wie dort werden wir auch hier in dem Fehlen gewöhnlicher Laubblätter ein wichtiges Schutzmittel gegen das Vertrocknen leicht erkennen; denn der Spargel ist ja wie oben erwähnt - eine Pflanze des lockeren Sandbodens, die in ursprïnglichem Zustande sicher alljährlich mehrere Monate mit starkem Wassermangel zu kämpfen lat. Hiermit stelıt auch im Einklange, daß sich der unterirdische Stamm verhältnismäßig tief unter der Erdoberfläche findet, und daß von ilım zahlreiche, sehr lange Wurzeln ausgehen, die den (wasserarmen!) Boden weithin durchziehen.

Aus den Achseln der schuppenförmigen Blätter entspringen auch die grïngelben Blïten, die wie die der Maiblume hängende Glöckchen darstellen. Man findet in ihnen entweder die Staubblätter oder den Stempel meist gänzlich verkiimmert, eine der vielfachen Einrichtungen der Natur, durch die Selbstbestäubung verhindert wird. Die Frïchte sind rote Beeren, die der Terbreitung durch Vögel "angepaßt" sind (Beweis!).

\section{Familie. Binsengewächse (Juncáceae).}

Die Binsengewächse stimmen mit den Liliengewächsen bis auf die unscheinbar grünen oder braunen Blätter der Blütenhülle fast vollkommen überein (Beweis!). - An nassen Stellen findet sich als eine der am häufigsten vorkommenden Formen die FlattelBinse (Juncus effúsus). Aus dem kriechenden, vielfach verzweigten unterirdischen Stamme erheben sich runde, knotenlose, bis etwa ${ }_{12}^{1 / 2} \mathrm{~m}$ hohe Halme, aus denen seitlich zahlreiche Blüten hervorbreclıen. Bei genauerem Zusehen erkennt man jedoch leicht, $\mathrm{daB}$ sich der Blütenstand am Ende des Halmes befindet and die eigentümliche Lage nur dadurch erhält, daß sein stielrundes Deckblatt senkrecht aufgerichtet ist. Die Bläten werden, wie schon ihre Unscheinbarkeit andeutet, durch den Wind bestänbt. Außer dem erwähnten Deckblatte und einigen Blattscheiden am Grunde des Halmes ist von grünen Blättern nichts zu finden. Diese sonst nur bei Pflanzen der trockensten Standorte (z. B. bei den Kaktusgewächsen) zu beobachtende Erscheinung wird uns leicht verständlich, wenn wir bedenken, daß nasser Boden auf die Pflanzen 
wie kalter Boden einwirkt (s. S. 114), und daB die Binsen im Hochsommer oft mit der größten Trocknis za kämpfen haben. Dann versiegen vielfach die Gewässer, an deren Ufern sie wachsen, und der schlammige Boden trocknet so stark aus, daß er "steinhart" wird und in weiten Rissen auseinander klafft. - Ganz wie Gräser erscheinen die Simsen (Lúzula); durch die "Lilienblüten ${ }^{*}$ sind sie jedoch leicht von diesen zu unterscheiden.

\section{Familie. Narzissengewächse (Amaryllidáceae).}

Fruchtknoten unterständig; sonst wie die Liliengewächse.

\section{Das Schnceglöckchen (Galánthus nivális).}

1. Blitezeit. Bevor meist noch die letzten Reste des Winterschnees von der wieder erwachenden Erde verschwinden, öffnet das liebliche Schneeglöckchen schon seine weiße Bläte, die einem zierlichen hängenden Glöckchen gleicht (Name!). Wir begrüßen den Boten des ersehnten Frühlings mit lebhafter Freude und ränmen ihm daher gern ein Plätzchen im Garten ein.

2. Standort. Im Freien trifft man das Schneeglöckchen nur selten und in vielen Gegenden gar nicht an. Wiesen und Laubwälder sind seine ursprïnglichen Standorte. Auf der Wiese findet das spannhohe Pflänzchen aber nur so lange das nötige Licht, als Gras und Kräuter noch niedrig sind, und im Walde, so lange sich das Laubdach noch nicht geschlossen hat. Es ist daher, wie z. B. das Scharbockskrant, gleichsam gezwungen, so zeitig im Jahre zn erscheinen. Darum hat es auch mit beginnendem Sommer seine Lebensarbeit bereits abgeschlossen: die Samen sind gereift und die oberirdischen Triebe abgestorben. Andererseits ist das Schneeglöckchen auch imstande, so frïh zu erscheinen; denn es besitzt wie die Tulpe (s. das.) in der

3. Zwiebel eine Vorratskammer, aus der es die ersten Ausgaben bestreitet. Die Zwiebel ist genau wie bei jener Pflanze gebaut (Beweis!), danert aber mehrere Jahre aus. Bereits im Herbste tritt aus ihr der oberirdische Sprof hervor, der aus zwei

4. Blättern und - falls wir es mit einer „blühreifen“ Pflanze zu tun haben - einer Blüte besteht. Er ist von einem farblosen (Lichtmangel!), häutigen Blatte wie von einer Scheide umgeben und somit gegen Verletzung beim Durchbrechen des Bodens wohl geschützt. Ist die Erdoberfläche erreicht, so stellt das scheidenförmige Hüllblatt das Wachstum ein, das nunmehr von den sich weiter streckenden Blättern gesprengt wird. Die langen, linealen Blätter liegen bis zu diesem Zeitpunkte eng aneinander, so daß ibre Oberseiten einander zugekehrt sind. Infolgedessen sind sie trotz ihrer Zartheit wohl imstande, sich zum Lichte emporzudrängen. Und zwar vermögen sie dies umso eher, als die farblosen Blattspitzen verhältnismäßig lart und fest sind. Die Spitze des "Keils", der den Boden spaltet, ist also wie bei der Tulpe gleichsam gehärtet. Die Blïte dagegen ist nicht imstande, diese Arbeit zu fördern. Sie liegt wohl geschützt zwischen den Blättern, die sie weit überragen und ihr 
somit den Wcg balmen. Um ihr daselbst den nötigen Raum zı schaffen, sind die Blätter rinnig vertieft (Querschnitt!). Bei nicht blühenden Pflanzen dagegen sind sie flach und liegen eng aneinander.

5. Blïte. a) Der von den Blättern gebildete Hohlraum ist sehr eng, so daß uns die Form des langen Blïtenstiels (Schaftes) - er ist mehr oder weniger seitlich zusammengedrïckt - wohl verständlich wird. Anf seiner Spitze trägt er die einzige, anfangs anfrecht stehende Blïte und nnter ihr eine häntige Blïtenseheide, von der die junge Blïte schïtzend umhüllt wird. Wie die beiden grïnen Rippen andeuten, ist die Scheide aus zwei Blättchen hervorgegangen, die innig miteinander verwachsen sind und mithin ihre Aufgabe umso vollkommener erfüllen können. Ein solches Schutzmittel (vgl. mit Knospenschuppen) ist für die zarte Blüte von umso größerer Wichtigkeit, als das Schneeglöckchen ja im Vorfrühlinge blüht, also zu einer Zeit, in der tïglich Frost, sowie kalte Regen- und Schneeschauer zu erwarten sind. Sinkt z. I. das Thermometer wieder einige Grad unter Null, so liegen die Blätter und Blïten des Pliamzchens matt und welk auf dem Boden (s. S. 92). Und wie dann die von der Scheide noch umhïllten Blüten weit weniger dem Verderben ausgesetzt sind als die von diesem Schntzmittel schon befreiten, ist leicht zu beobachten. Darum bleibt anch die Blüte je nach der Witterung von der Scheide kiirzere oder lingere Zeit, beim Eintritt schlechten Wetters sogar wochenlang numgeben.

b) An einem milden Tage endlich wird die Scheide gesprengt, und in schneeiges Weiß gekleidet, tritt die Blüte hervor. Sie neigt sich alsbald zum Erdboden hinab, ist im wesentlichen wie die Tulpenbliite gebant (Beweis!), besitzt aber einen unterständigen Fruchtknoten (s. S. 71, b). Die 3 großen äßßeren Blätter der Blï te n h ülle stehen schräg nach außen; die 3 kleinen inneren dagegen sind fast senkrecht gestellt, so daß sie eine kleine Röhre bilden. Außen besitzen die letzteren je einen halbmondförmigen Fleck und innen mehrere ebenso gefärbte Längsstreifen, zwischen denen der Honig abgeschieden wird. Die großen Beutel der 6 Staubblätter bilden einen Kegel, aus dessen Spitze der Griffel mit der Narbe hervorragt. Sie besitzen je eine borstenartige Verlängerung und öffuen sich an der Spitze mit 2 Löchern, aus denen bei Berührung der Borste trockener Blütenstaub herausfällt. (Versuch! Gib der Blïte dabei aber die natürliche Stellung!)

c) Wenn wir die erwähnten Einzelheiten näher ins Ange fassen, werden wir leicht finden, daß zwischen ihnen ein inniger $\mathrm{Z} n \mathrm{~s}$ a $\mathrm{mm}$ en ha $\mathrm{ng}$ besteht, der allein eine erfolgreiche Bestänbung ermöglicht. Erstens: da die Bestäubung mit Hilfe eines "Streuwerks" erfolgt, muß das Schneeglöckchen trackenen, mehlartigen Blit enstaub besitzen. Zweitens: da der Staub nur aus den Benteln falit, wenn diese erschïttert werden, so muß das Insekt gleichsam gezwungen worden, eine Erschïtterung zu bewirken. Dies geschieht auch; der Honig liegt nămlich nicht offen zu Tage, sondern wird - wie erwähnt - an der Innenwand der Röhre abgeschieden, die von den inneren Blättern 
der Blïtenhülle gebildet wird. In diese Röhre muß das Insekt ein Stiick eindringen, um zu dem süßen Saft zu gelangen. Dabei muß es aber einige der borstenartigen Fortsätze berühren, die Stanbbentel also erschïttern. Drittens: da die Rölıre verhältnismäßig sehr eng ist, kann das Insekt nur dann von dem ausfallenden Staube getroffen werden, wenn deren Öffuung nach unten gerichtet ist. Die Blïte $m n B$ also, anders ausgedrïckt, hängend sein. (Was würde geschehen, wenn sie schräg oder gar aufrecht stände? Warum branchen weite Blüten mit einem Streuwerk diese Stellung nicht zu haben? Vgl. z. B. mit Klappertopf!). Viertens: da der Griffel aus dem Staubbe utelkegel hervorragt, muß die Narbe von dem eindringenden Insekt auch zuerst berïhrt werden. Bringt das Tier nun Bliitenstaub von einer anderen Blüte mit, so tritt Fremdbestäubung ein, die - wie wir schon mehrfach gesehen haben - stets eine erhöhte Fruchtbarkeit im Gefolge hat. Fünftens: soll die Blïte auffällig werden, so dürfen die Blätter des äußeren $\mathrm{Kr}$ reises nicht mit an der Bildung der Röhre beteiligt sein. Da sie im Gegenteil nach außen gespreizt sind, fällt eine geöffuete Blïte weit mehr ins Ange als eine andere, die zwar vollkommen ausgebildet, aber noch geschlossen ist oder sich wieder geschlossen hat. Kurz: Die unscheinbare Blïte ist ein vollendetes "Kunstwerk", wie es menschlicher Scharfsinn kaum auszudenken vermöchte.

d) Das Schneeglöckchen bringt wie die Tulpe alljährlich nur eine einzige Blitte hervor. Da sie aber sehr lange, bei Eintritt schlechten Wetters (Insekten verkriechen sich wieder!) sogar wochenlang "frisch" bleibt, so ist die Möglichkeit, bestäubt zı werden, dadurch wesentlich erhöht. Tritt trotzdem keine Bestäubung ein, so ist das für die Pflanze noch bei weitem nicht mit einer Vernichtung gleichbedeutend: das Schneeglöckchen "rettet" sich ja mit Hilfe der Zwiebel stets auf das andere Jahr hinüber nnd vermehrt sich außer durch Samen noch durch Brutzwiebeln.

e) Wie wir in zahlreichen Fällen gesehen haben (Beispiele!), schließen sich nickende Blüten abends oder beim Eintritt unfreundlicher Witterung nicht; denn bei ihnen sind ja Blütenstaub und Honig wie unter einem Dache gegen Tan und Regen vortrefflich geschiitzt. Beim Schneeglöckchen jedoch findet man an kühlen Morgen, wie die äußeren Blätter der Blütenhülle, die gestern weit gespreizt waren, sich wieder nach innen bewegt und den Bliiteneingang verschlossen haben. Bei kaltem Wetter behalten sie diese Stellung sogar den ganzen Tag ïber bei. Wenn wir bedenken, daß die Pflanze sehr frïh im Jahre bliiht, und daß Wärmeverlust den zarten inneren Blïtenteilen leicht schaden könnte, so wird uns diese Ausnahme von der Regel wohl verständlich. (Bringe abgeschnittene Blïten, die du in ein Gefäß mit Wasser gestellt hast, an einem kühlen Tage aus dem warmen Zimmer in das Freie und umgekehrt!)

6. Die Frucht ist eine Kapsel, die sich von der Spitze ans mit 3 Klappen öffnet. Würde sie wie die Blüte abwärts gerichtet sein, so müßten sämtliche 


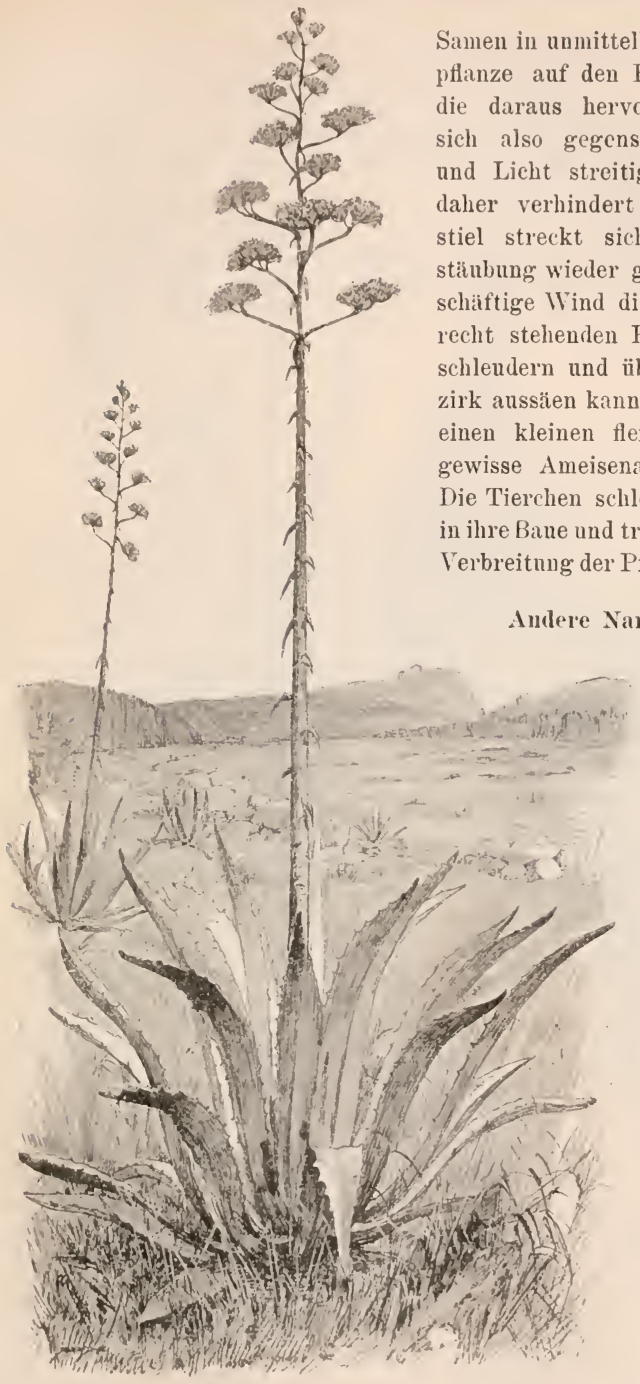

Amerikanische Agave (etwa $1 / 30$ nat. Gr.).
Wenig später als das Schneeglöckchen erschließt das Sommertïrchen (Leucóinm vernum) seine zierlichen, duftenden Blütenglokken (Name!). Es bewohntschattige, fenchte Laubwälder und stimmt mit jener Pflanze in fast allen Stücken überein (daher auch ${ }_{n}$ großes oder wildes Schneeglöckchen"). — Die Narzissen (Narcissus) dagegen entfalten ihre prächtigen Blüten erst, wenn der Frähling wirklich da ist. Am häufigsten finden sich in unseren Gärten dic gelbe $\mathbf{~}$. ( $\mathrm{N}$. pseudonarcissus), die hier und da a uergwiesen auch wild vorkommt, and die echte N. (X. poëticus): 
die wahrscheinlich im Mittelmeergebiete heimisch ist. Wie bei allen Narzissen sind auch bei ihnen die Blätter der Blütenhülle im unteren Abschnitte zu ciner Röhre ver-

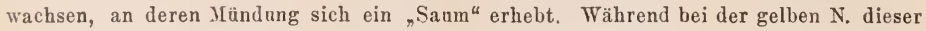
Saum schr groß, die Blütenröhre dagegen kurz ist (Hummelblıme!), hat die weiße, stark duftende Blüte der echten N. einen kurzen Saum (mit scharlachrotem Rande) und eine sehr lange und enge Blütenröhre (Falterblume!).

Auch melirere a usländisehe Glieder der Familie werden bei uns gern gepflegt. So sind die prächtig blühenden Amarýllis-Arten, die aus dem tropischen Südamerika stammen, allgemein bekannte Topfgewächse, und nicht selten treten uns, in Kübel gepflanzt, die mächtigen Blattrosetten der Agaven (Agáve) entgegen. Wie schon die

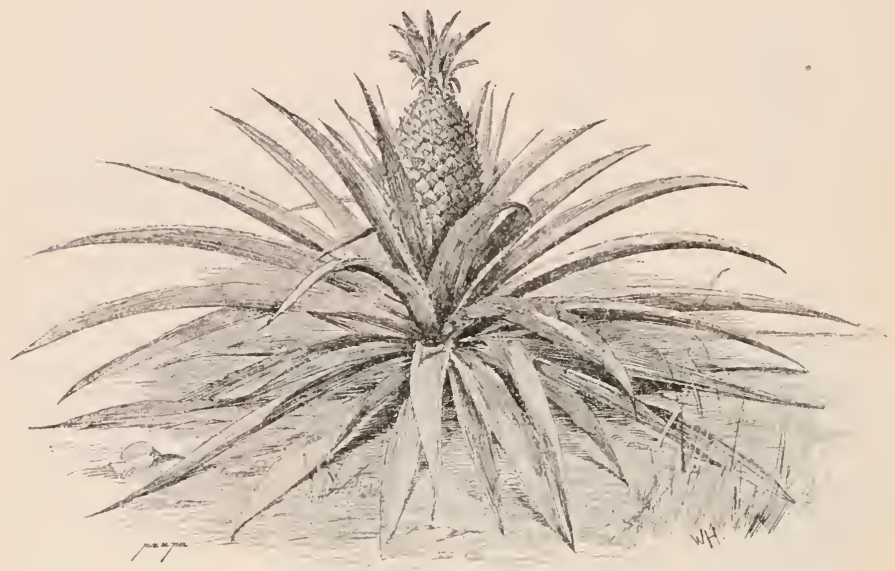

Ananaspflanze mit Fruchtkolben (etwa $1 / 12$ nat. Gr.).

dicken, fleischigen, saftigen Blätter erkennen lassen, haben wir es in den Agaven mit vollendeten „Fettpflanzen" (Succulenten) zu tun, deren Bau wir beim Mauerpfeffer und den Kaktusgewächsen kennen und verstehen gelernt haben. Wir gehen deshalb auch nicht fehl, wenn wir die Heimat der seltsamen Gewächse in einem außerordentlich wasserarmen Gebiete suchen: Sie bewohnen die unabsehbaren Wüsten des heißen Amerika, in denen auch die Kaktusgewächse dem öden Felsboden entsprießen. Gleich diesen zeigen auch die Agaven ein sehr langsames Wachstum. Einige Arten brauchen sogar 100 und mehr Jahre, bis sie ihre volle Ausbildung erlangt haben. Dann schießt aus der Blattrosette schnell ein hoher Blütenschaft empor, der Tausende von Lilienblüten trägt und bei gewissen Arten 6, 10 und mehr Meter hoch wird. Sind die Früchte gereift, dann stirbt die seltsame Pflanze bis auf den mächtigen unterirdischen Stamm ab, aus dem jetzt junge Triebe hervorgehen. Von den wenigen Arten, die für den Menschen eine Bedeutung haben, sei hier nur kurz die sog. amerikanische A. (A. americána) erwähnt, die in Mexiko heimisch ist. Ihre Blätter, die eine Länge von $3 \mathrm{~m}$ erreichen, dienen daselbst 


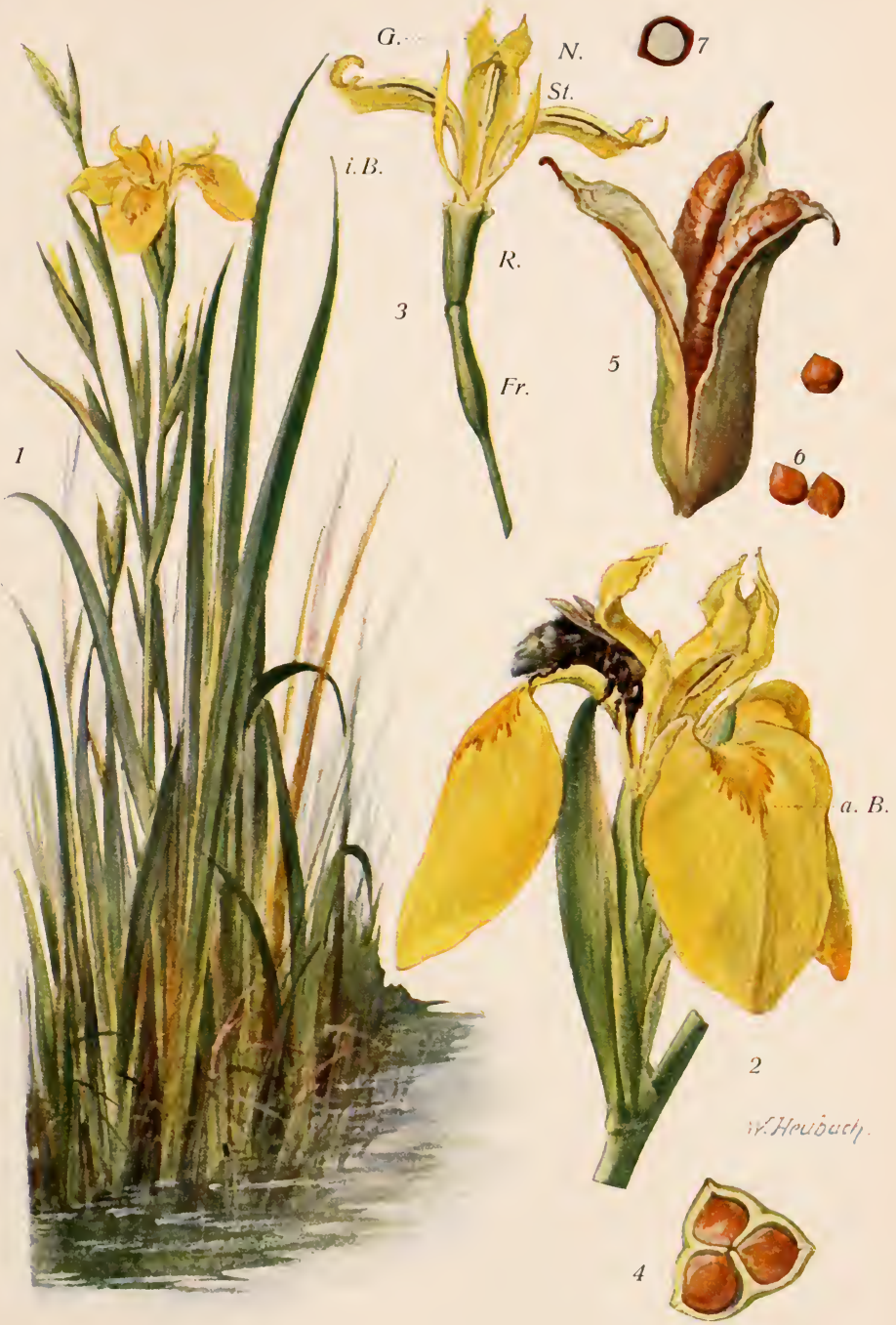

Wasser-Schwertlilie (Iris pseudacorus). 

als Speise; getrocknet verwendet man sie zum Decken der Dächer; aus den zähen Bastfasern bereitet man feste Gespinste und ans dem Safte das Nationalgetränk, die Palque. Wie in zahlreichen anderen wärmeren Ländern, hat sich die Pflanze auch im Mittelmeergebiete vollkommen eingebürgert, woselbst sie wegen der stark bestachelten Blätter gern zur Herstellang undurchdringlicher Zäune angepflanzt wird.

Ein Glied einer nahe verwandten Familie (Bromeliaceae) ist die Ananas (Ánanas sativus), die sich von Mittelamerika ans über alle warmen Länder verbreitet hat und bei nns in Treibhänsern gezogen wird. Aus einem rosettenartigen Busche langer, starrer Blätter erhebt sich der zapfenartige Blütenstand, dessen Achse und Deckbliitter nach und nach fleischig und saftig werden (vgl. mit Erdbeere!). Anf diese Weise entstelit eine gelbe oder orangefarbene Schein- und Sammelfrucht, die in allen Tropenländern als küstlichstes Obst geschätzt und bei uns namentlich als Zusatz zum Wein verwendet wird. Während der Frachtbildung wächst die Acbse durch das einem riesigen Tannenzapfen ähnliche Gebilde and treilut einen Blätterschopf, der, in die Erde gesetzt, sich zu einer neuen Pflanze entwickelt.

\section{Familie. Schwertliliengewächse (Iridáceae).}

Fruchtknoten unterständig, nur 3 Stanbblätter; sonst wie die Liliengewächse.

Die Wasserschwertlilie (Iris psendácorus). Taf. 33.

1. Standort und Blätezeit. Die Ufer der stehenden und fließenden Gewaisser erhalten im M a i und J u n i durch die prächtigen „Lilienblüten“ (Name!) der stattlichen Pflanze oft einen gar herrlichen Schmuck.

2. Stamm, Stengel und Blatt. a) Ans dem dicken, fleischigen Stamme (Wurzelstocke), der in schlammigen Boden dahin kriecht, erheben sich neben zahlleichen beblitterten "Kurztrieben" einige „Langtriebe“ (s. S. $160 \mathrm{~A}$ ). Da letztere bis meterhoch werden, sind sie wohl imstande, die Bliiten über das PHanzendickicht am Ufer zu hcben und somit den Insekten zur Schau zu stellen.

b) Die ungestielten Blïtter umfassen mit ihrem Grunde den Stengel ringsum. Während aber bei der ïberwiegenden Mehrzahl der Pflanzen (Beispiele!) beide IÏ̈lften der Blattflïchen flach ausgebreitet sind, sind sie hier in der Mittellinie so gefaltet, daß sie eine ticfe Rinne bilden. Je weiter nach oben (stelle Querschnitte in verschiedener Höhe her!), dcsto enger wird die Rinne. Schließlich verschmelzen beide Hälften rollkommen miteinander, so daß das Blatt die Form eines Schwertes erhillt (Name!).

Betrachtet man einen Kurztrieb, so sieht man, wie sich dię Blätter, zu zwci Zeilen geordnet, gegeniiberstehen, und wie jedes altere Blatt das nïlist jüngere z. T. umfaßt. (Warum werden solche Blätter wohl „reitende“ genannt?) Entfernt man die älteren Blätter, so kommt man endlich zu einem Blatte, in dessen Rinne das folgende noch gänzlich verborgen ist, und das abermals das nächst jüngere umhüllt n. s. f. Die Blätter sind also gleichsam ineinander geschachtelt, so daß die älteren den außerordentlich zarten jüngeren als schützende Scheiden dienen.

An den wachsenden Langtrieben sind natïrlich dieselben Verhaltnisse 
zu beobachten. Bei ihnen entfernen sich jedoch die Bläter durch Streckung der Stengelglieder weit voneinander, so daß eben ein "Langtrieb" entsteht.

An beiden Arten von Trieben finden sich außerhalb der ältesten Blätter noch einige Hïllblätter, die ihrer Aufgabe entsprechend (Hülle!) nur den unteren scheidenartigen Teil der Laubblätter darstellen.

c) In Gegensatz zn den meisten anderen Pflanzen sind die Blätter der Schwertlilie ferner so gestellt, daß ihre Kanten senkrecht nach unten und oben gerichtet sind. Sie nehmen also die Stellung ein, die wir bei jungen Blättern (s. S. 43, c), sowie bei Pflanzen selur trockener Standorte (vgl. z. B. Stachellattich) als wichtiges Schntzmittel gegen zu starke Verdunstung kennen gelernt haben. Da aber die Schwertlilie stets nur an nassen Stellen vorkommt, woselbst ihr jeder Zeit genügend Wasser zur Verfïgung steht, so bedürfte sie - sollte man meinen - eines solchen Schutzmittels nicht. Wenn wir aber einerseits bedenken, daß nasser Boden stets kalt ist, und daß kalter Boden auf die Pflanzen wie trockener Boden einwirkt (s. S. 114, C), und wenn wir andererseits beobachten, wie im Hochsommer die Gewässer, an deren Ufer die Schwertlilie wächst, oft gänzlich vertrocknen, und der Schlammgrund fast steinhart wird, dann werden wir wohl anderer Meinung werden. Zudem dïrfen wir nicht aus dem Auge verlieren, daß uns bei den Pflanzen zahlreiche Eigentümlichkeiten nur dann verständlich werden, wenn wir ihre nächsten Verwandten berïcksichtigen: mehrere andere Schwertlilien sind nun ausgeprägte Felsenpflanzen, und eine von ihmen (s. S. 238) vermag sogar auf Lehmmanern zu gedeihen, auf denen die meisten auderen Gewächse sehr bald vertrocknen würden.

d) Alle grïnen Teile sind mit einem abwischbaren Wachsbezuge versehen, dessen Bedeutung wir bereits S. 17, 2 erkannt haben.

3. Blïte und Frucht. a) Aus den Achseln der oberen Blätter der Langtriebe gehen blïtentragende Zweige hervor. Wie diese Blätter seiner Zeit in den Rinnen der nächst älteren Schutz fanden, so nmhüllen sie selbst die jungen Blütenknospen.

b) Haben die Knospen die Rinne verlassen, so gewähren ihnen je 2 grüne, scheidenartige Hïllblätter den notwendigen Schutz.

c) Ist die Blïte endlich vollkommen ansgebildet, so drängt sie die Blätter auseinander und entfaltet sich. Das iiberaus zarte Gebilde bliiht jedoch nur eine sehr kurze Zeit (stelle die Blïtendauer genauer fest!). Dafür bringt die Schwertlilie aber nacheinander eine sehr große Anzahl von Blüten hervor, so daß sicher einige davon bestäubt werden und Frïchte ausbilden (vgl. dag. Sclueeglöckchen!).

d) Obgleich die Tulpen- und Schwertlilien-Blüte nach demselben "Plane* gebaut sind (Beweis!), zeigt letztere doch zahlreiche Eigentümlichkeiten. So sind erstlich die 6 leuchtend gelben Blätter der Blütenhülle im unteren Teile zn einer Röhre (3. R.) verwachsen, die dem unterständigen Fruchtknoten (3. Fr.) aufsitzt. Sodann sind die mit einem braunen Fleck (Saftmal!) gerierten Blätter des äußeren Kreises (2. a. B.; in Abb. 3. entfernt) groß und mit dem breiten 
Endabschnitte schräg nach außen gebogen, während die kleinen Blïtter des inneren Kreises (3. i. B.) anfrecht stehen. Ferner ist von den beiden dreiblättrigen Sta ubblattkreisen der Lilienblïte nur der äußere vorhanden, und endlich teilt sich der Griffel in 3 blumenblattartige, zweizipfelige Äste (3. G.). Iiese Gebilde helfen die Auffilligkeit der Blüte erhöhen und dienen den Staubbenteln (3. St.) als schïtzendes Dach. Anf ihrer Unterseite bemerkt man je ein kleines Läpphen, dessen (in der Ruhe angedrïckte) Oberseite die Narbe (3. N.) darstellt.

Im unteren Teile der Röhre tindet sich der Honig. Zu ihm führen unter jedem Griffelaste 2 Kanäle, die für einen dünnen Insektenrïssel gerade weit genug sind (Querschnitt!).

e) Will das Insekt den Honig erlangen - einen anderen Weg gibt es nicht! - so muß es sich anf einem großen Blatte der Blitenhiille niederlassen (Anflugstelle!) und so weit als möglich unter den davorstehenden Griffelast zwängen (2). Ist das Tier groß genug, so streift es dabei zunächst das Narbenläppchen, biegt es nach unten und belegt es mit fremdem Bliitenstaube, falls es bei einer anderen Blïte bereits Einkehr gehalten hat. Dies kann aber nur dann geschehen, wenn das Tier den Blütenstanb auf seinem Rïcken herbeiträgt, oder anders ansgedrückt, wenn der Staubbeutel eine solche Stellung hat, daß ihn das sangende Tier mit dieser Körperstelle beriihrt. Und das ist, wie wir geselien haben, der Fall! - Nachdem das Tier von dem süßen Safte genossen hat, kriecht es aus dem „Engpaß“ wieder hervor. Jetzt aber drïckt es das Narbenlïppchen an den Griffelast, so daß eine Belegung der Narbe mit dem Staube der eigenen Blüte verhindert wird. Dieser ungünstige Fall (warum ungünstig?) tritt jedoch ein, wenn das Insekt sich nach diesem Besuche dem 2. und 3. „Engpaß“ derselben Blüte zuwendet (führe dies näher aus!).

Bei genanem Zusehen wird man nun finden, daß die Entfernung zwischen einem großen Blatte der Blütenhülle und "seinem" Narbenaste bei gewissen Blïten größer ist als bei anderen. In ersterem Falle entspricht diese Entfernung der Höhe (Dicke) einer Hummel, im anderen der einer Schwebfliege. Diese Tiere sind daher auch nur imstande, die Bestänbung ,ihrer Blüte" zu vollziehen. (Führe dies nïher ans! Warum sind Schmetterlinge und kurzrüsselige Insekten vom Genuß des Honigs ausgeschlossen?)

f) Die Frucht stellt, wie ein Querschnitt zeigt (4.), eine dreifächerige Kapsel dar, in der die braunen, breitgedrïckten Samen (6.) gleich Geldstïcken in 3 Reihen „übereinauder geschichtet“ sind. Bei der Reife öffnet sich die Frucht mit 3 Klappen (5.), so daß der Wind die Samen nummehr herausschiitteln kann (Kapseln stehen anf hohen, elastischen Stengeln!). Auf einem Durchschnitt (7.) sieht man, daß sich unter der Samenhülle ein luftgefüllter Hohlraum vorfindet. Infolgedessen sind die Samen schwimmfähig, köunen also durch Wind, Wellen und Strömung leicht weit verschlagen werden, eine Tatsache, die für die Verbreitung einer am Wasser wachsenden Pflanze von größter Bedeutung ist. 


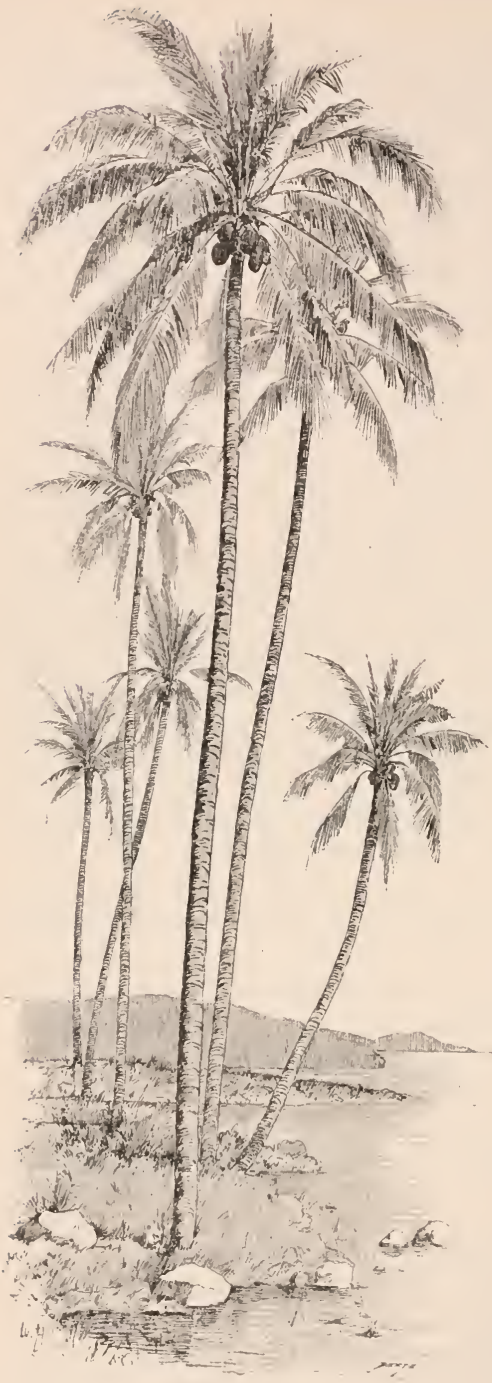

\section{Andere Schwertliliengewiichse.}

Gleich der Wasser-Schwertlilie erfreuen uns im Garten zahlreiche andere Arten der Gattung durch die Pracht ihrer Blüten. Zur Einfassung von Beeten wird gern die blaublühende ZWwerg-Sch. (I. púmila) benutzt, die aus Südost-Europa stammt. Da sie in ihrer Heimat dürre Felsen bewohnt, so vermag sie selbst mit den geringen Wasser- und Nahrungsmengen fürlieb zu nehmen, die ihr die kahlen Lehmmanern zu bieten vermögen. - Eine stattliche Pflanze ist die in Gärten am hänfigsten anzutreffende deutscheSch.(I.germánica), die sich darch groBe, violette Blüten auszeichnet. Sie findet sich hier und da auch verwildert und ist wahrscheinlich gleichfalls aus dem südöstlichen Europa zu uns gekommen. - Ein prächtiger Frühlingsschmuck wird unseren Gärten durch die Krokus-Arten (Crocus) verliehen, die mit der Herbstzeitlose in zahlreichen Stücken übereinstimmen (Beweis!). Da sie nun in ihrer Heimat (in den Alpen und Gebirgen Süddentschlands, sowie besonders im Mittelmeergebiete) gleichfalls Wiesen und Matten bewohnen, so sind sie wie jene Pflanze genötigt, entweder im zeitigen Frühjahre oder (wie andere ausländische Arten) im.Herbste ihre zarten Blüten zu entfalten. A us den großen, getrockneten Narben des Safran-K. (C. sativas) bereitet man besonders in den Mittelmeerländern den Safran, der vorwiegend zum Färben von Backwaren benutzt wird. - Beliebte Gartenzierpflanzen sind auch die zahlreichen Arten der Siegwurz (Gladíolns), deren Bläten zu großen, einseitswendigen Trauben gehäuft sind.

\section{Familie. Palmen (Palmae).}

\section{Die Kokospalme (Cocos nucífera).}

1. Die Kokospalme hat sich von ihrer Heim at aus, die wahrscheinlich im tropischen Amerika zu suchen ist, Kokospalmen, z. T. m. Frächten (etwa $1 / 150$ nat. Gr.). iiber alle heißen Länder des Erdballs 
verbreitet. Besonders am Strande und in der Nähe des Meeres finden sich weitausgedehnte Haine des herrlichen Baumes. Auf einem unverzweigten, säulenartigen Stamme, der eine Höhe von $25 \mathrm{~m}$ erreicht, wiegt sich eine Krone mächtiger Fiederblätter. Da der verhältnismäßig dünne Stamm fast die Biegsamkeit des Roggenhalmes besitzt, und da die bis $4 \mathrm{~m}$ langen Blattflächen in zahlreiche Abschnitte gespalten sind, die dem Anprall des Windes leicht answeichen, so vermag die schlanke Palme selbst dem heftigsten Sturme zu trotzen. Ebenso leicht widerstehen die derben, festen Blïtter den Regengïssen, die in den Tropen mit ganz anderer Heftigkeit zur Erde hernieder rauschen als in unseren Breiten und zartes Laub zerfetzen würden. (Nenne andere Tropenpflanzen mit
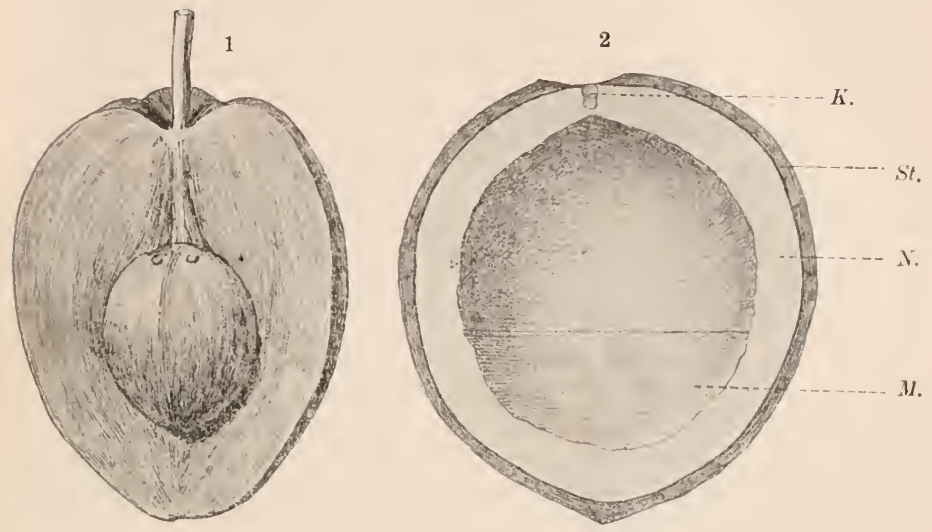

Bau der Kokosuuß. 1 geöffnet, um die steinharte Innensehicht der Fruchtsehale mit den Keimlöchern za zeigen. 2 Der Same von der ${ }_{n}$ Steinschicht ${ }^{\star}{ }^{-S t}$. umgeben (weniger als Fig. 1 verkl.). N. Nährgewebe. M. Milch" ${ }^{\circ}$ K. Keimling.

ähnlichem Blattwerk!) Aus der Achsel eines Blattes entspringt der verzweigte, meterlange $B l$ ïtenstand, der anfänglich von einer mächtigen Blütenscheide schïtzend umgeben ist. Am Grunde seiner Äste stehen einige Stempel-, weiter oben zahlreiche Staubblïten. Beides sind unscheinbare Gebilde, die dementsprechend auf die Bestäubung durch den Wind angewiesen sind. (Inwiefern ist die Anordnung beider Bliitenarten und ihre verschiedene Anzahl für den Baum ron Vorteil?)

2. Die allgemein bekannte Frucht ist eine fast kopforoße Nuß von sehr merkwürdigem Bau (öffne sie!). Die Fruchtschale besteht ähnlich wie bei der Kirsche aus 3 Schichten: einer dünnen Außen-, einer dicken, faserigen Mittelund einer steinharten Innenschicht. Sprengen wir letztere, so stoßen wir auf den "Kern" der Nuß, den Samen. Er stellt eine fleischige Hohlkugel dar, in 
deren Wand der winzige Keimling eingelagert, und die mit einer milchigen Flïssigkeit, der Kokosmilch, angefüllt ist. Die Hohlkugel ist das Nährgewebe, von dem die sich entwickelnde Keimpflanze zehrt (s. S. 101, e), und die "Milch", die bei längerem Lagern der Nuß gleichfalls fest wird, dient demselben Zweck.

Die zarte Keimpflanze wäre aber unmöglich imstande, die starke „Steinschicht" zu sprengen. Darum bleibt die über dem Keimling befindliche Stelle der Schicht so dünn, daß ein Durchbruch leicht erfolgen kann. Da die Nuß 3 Samenanlagen besitzt, von denen sich aber nur eine entwickelt, so finden wir anch 3 "Keimlöcher". Das von der Keimpflanze „benutzte“ Loch ist aber stets am größten und mit der dünnsten „Verschlußplatte" versehen. Die beiden anderen Schichten der Schale dagegen kann das junge Pfänzchen leicht durchbohren: Da der Keimling am oberen Teile der Frucht liegt, muß die KeimpHanze die beiden Schichten an der Ansatzstelle des Fruchtstieles durchbrechen, d. h. dort, wo sie am wenigsten dicht sind.

Als Baustoff dient, dem Keimpflänzchen vorwiegend ein fettes öl (siehe S. 16, A), das in dem Nährgewebe aufgespeichert ist, bei Zutritt von Wasser aber leicht ranzig wird. Um nun ein unzeitiges Eindringen von Wasser zu verhindern, bedarf der Keimling jener festen Hülle, wie sie die dreiteilige Fruchtschale liefert. Auch als wichtiges Schutzmittel gegen Feinde, die nach dem süßen Kern lüstern sind, kommt die mächtige Schutzdecke in Betracht.

Da die faserige Mittelschicht der Schale lufthaltig ist (Schwimmgürtel!), bleibt die Nuß, die durch irgend einen Zufall in das Meer gelangt ist, sehr lange schwimmfähig. Infolgedessen wird sie durch Wellen und Meeresströmungen leicht weit verschlagen und oft erst an ferner Küste wieder an das Land gespült. Auf diese Weise sollen die einsamen Koralleninseln in den Besitz der stolzen Pflanze gelangt sein. (Vgl., wie der Golfstrom Treibholz und Samen westindischer Gewächse an der norwegischen Küste anspült!)

3. Die schlanke Kokospalme ist für die Tropenländer sowohl, wie für den Welthandel einer der wichtigsten Bäume. Der Stamm liefert ein wertvolles Bau- und Nutzholz. Die Blätter dienen zum Bedecken der Dächer, sowie zur Anfertigung von allerlei Flechtarbeiten. Die Gipfelknospe junger Pflanzen wird als Gemüse ("Palmkohl“) verspeist. Durch Abschneiden der Blütenstände gewinnt man einen Saft, aus dem durch Gärnng der berauschende "Palmwein" entsteht (vgl. mit Birke!). Die Mittelschicht der Fruchtschale liefert den Kokosfaserstoff, der zu Decken, Seilen, Bürsten u. dgl. verwendet wird. Aus der harten Steinschale werden in den Tropen Trinkgeschirre u. dgl., bei uns besonders Knöpfe hergestellt. Das Nährgewebe ist von haselnußartigem Geschmack; frisch liefert es eine nahrhafte Speise, getrocknet die Copra, die in ganzen Schiffsladungen zu uns kommt. Durch Auspressen gewinnt man aus ihr ein wertvolles ÖI, das zur Herstellung von Seifen und Kerzen dient. Die Preßrïckstände werden als Viehfutter hoch geschätzt. Der flïssige Teil des Nährgewebes, die Kokosmilch, dient in allen Tropenländern als erfrischendes Getränk. Kurz: es ist kein Teil der Palme, der nicht vom Menschen benutzt wïrde. 


\section{Andere Palmen.}

Was für unsere Heimat der Roggen ist, das ist für den weiten Wüstengürtel, der sich von den $\mathrm{K}$ üsten des A tlantischen 0 zeans quer durch Afrika und über Westasien hinweg bis zum Indas erstreckt, die Dattelpalme (Phoenix dactylifera): sie is t die Brotfruchtpflanzo diesesgewaltigen Ländergebietes. An Gestalt ist sie der Ḱokospalme selır älınlich, hat aber einen etwas dickeren, stark mit Blattnarben bedeckten $\mathrm{Sta} \mathrm{m} \mathrm{m}$ und eine kleinere La u b k rone. Ihre Wurzeln senkt sie bis in die tieferen, wasserführenden Bodenschichten hinab. Infolgedessen vermag sie selbst mitten in der Wüste zu gedeihen, wo nur ein Quell den leißen Sand durchdringt. "Sie taucht", wie der arabische Dichter singt, nden FuB in das Wasser und das Haupt in das Feuer des Himmels*. Da sie eine zweihä u sige P'flanze ist, findet man in den Dattelhainen stets nur wenige Bäume mit Staubblüten. Um aber eine Bestäubung möglichst aller Stempelblüten herbeizuführen, verrichtet der Mensch die eigentlich dem Winde zukommende Arbeit schon seit uralten Zeiten selbst. Er schneidet die aus Staubblüten bestelienden Kolben ab und hängt sie in die Fruchtbäume, und zwar behalten die Blütenstaubkörner außerordentlich lange ihre befruchtende Eigenschaft. Die pflaumenähnliche Frucht enthält einen langgestreckten, steinharten Samen (beobachte dessen Keimung!). Das süße, wohlschmeckende Fruchtfleisch ist das Hauptnahrungsmittel für die vielen Millionen Jenschen, die jene Wiistengebiete bewohnen. Während dort aber die Früchte in allen nur möglichen Formen (frisch oder getrocknet, roh oder gekocht u. s. w.) verzehrt werden, gelangen sie zu uns nar in getrocknetem Zustande.

Wie hei der Kokospalme finden neben den Früchten auch alle anderen Teile des herrlichen Baumes nutzbringende Verwendang: die Dattelpalme liefert

Schmeil, Lehrbuch der Botanik.

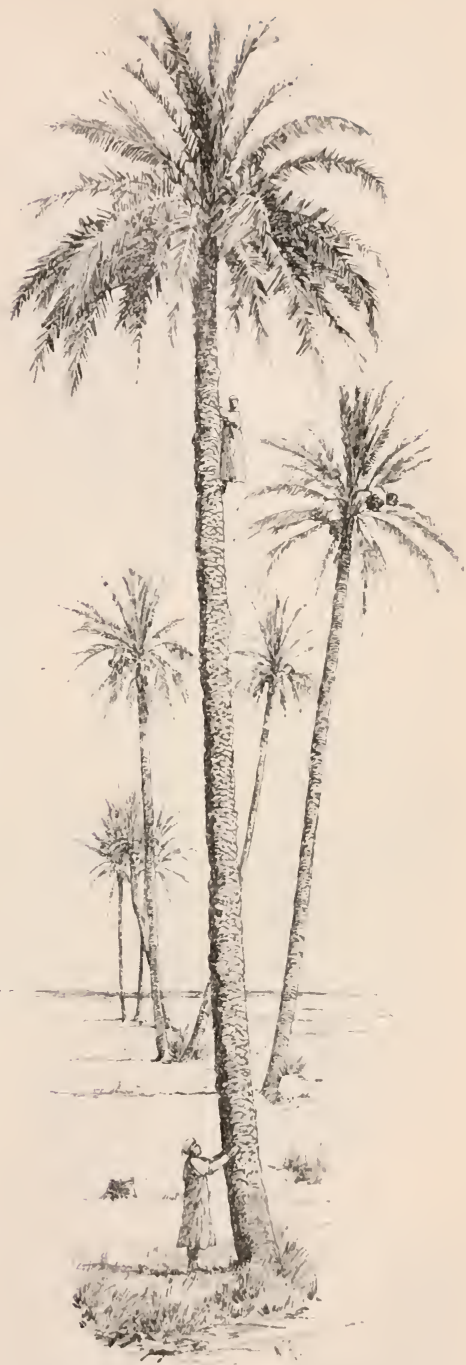

Dattelpalıeı, z. T. mit Fruchtständen (etwa $1 / 100$ nat. Gr.). 
dem Wüstenbewohner alles zum Leben Nötige; sie macht im Verein mit dem Kamele die Wüste erst bewohnbar. Die mächtigen Blätter („Wedel") gelten schon seit dem grauen Altertume als ein $\mathrm{Z}$ eichen des Sieges und Friedens. Darum legen wir auch gern einen ${ }_{n}$ Palmenzweig" auf die Ruhestätte derer, die den Sieg über das Erdenleben davongetragen und den ewigen Frieden gefunden haben.

Wenn auch keine andere Palme den beiden kurz geschilderten Arten an Bedentnng gleich kommt, so sind in anderen Erdstrichen andere dieser stolzen Bäume dem Menschen doch von größter Wichtigkeit. An erster Stelle wäre hier die Ölpalme (Elǽis guineénsis) zu nennen, die an den feuchtheißen Küsten und Flußläufen Westafrikas gedeiht. Sie trägt pflaumenähnliche, orangefarbene Frïchte, deren Fruchtfleisch das "Palmöl" und deren Kerne (d. s. die von der harten Innenschicht der Fruchthülle umschlossenen Samen) das feinere „Palmkernöl" liefern. Beide Ölsorten werden wie das Kokosöl verwendet. - Wie aus den Knollen der Kartoffel und den Körnern des Getreides gewinnt man aus dem weichen Stamminnern zahlreicher Palmen das aufgespeicherte Stärkemehl. Wird dieser wertvolle Stoff in Pfannen erhitzt, so

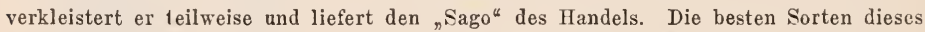
wichtigen Nahrungsmittels geben die echten Sago-Palmen (Metróxylon rúmphii und laeve), die auf den Sunda-Inseln und den Molnkken einheimisch sind. - Die Weillpalme (Raphía) liefert den Bewohnern von Afrika und den dazu gehörigen Inseln einen beliebten Palmwein. Die Oberhaut und Bastschicht der mächtigen Fiederblätter werden bei uns als "Raphia-Bast" namentlich von Gärtnern verwendet. Man bereitet daraus aber auch Iatten und andere Flechtwerke. - Die Elfenbeiupalnen (Phytélephas), die im tropischen Amerika heimisch sind, geben uns in ihren steinharten Samen, den Steinnüssen, ein wertvolles Material zur Herstellung von Knöpfen. - Die Piassava-Fasern, die namentlich zu Besen verarbeitet werden, sind das Fasergeflecht der Blattscheiden mehrerer anderer amerikanischer Palmen. - Das "s p a n is che Rohr" , das bei uns namentlich zum Flechten der Stühle verwendet wird, ist der dünne Stamm der Rotangpalmen (Cálamus), die besonders in Ostindien, dem tropischen Australien und auf den dazwischen liegenden Inseln vorkommen. Es sind Kletterpflanzen der Urwälder, die sich vielfach mit Hilfe bestachelter, peitschenförmiger Fortsätze der Blattstiele an den Stämmen und an den Kronen der Bäume festhalten (vgl. mit Hopfen!). - Die einzige Palme, die in Europa ihre Heimat hat, ist die Zwergpalme (Chamárops) des Mittelmeergebiets. Sie hat im Gegensatz zu allen anderen erwähnten Arten fächerförmige Blätter (Fieder- und Fächerpalmen!) und wird neben zahlreichen anderen Palmen gern als Zimmerpflanze gezogen.

Im AnschluB an die so überaus wichtigen Palmen sei eine andere nicht minder wichtige Tropenpflanze kurz betrachtet:

\section{Die Banane oder der Pisang (Musa sapiéntum und paradisíaca).}

Wie es bei uns nur selten einen Garten gibt, in dem nicht ein Birn- oder Apfelbaum stände, so findet sich iiberall in allen heißen Ländern die Banane in nnmittelbarer Nähe der menschlichen Wohnungen. Aus einem im Boden dahinkriechenden Wurzelstocke erhebt sich ein kurzer knolliger Stamm, der zahlreiche, mächtige Blätter trägt. Die scheidenförmigen Teile der Blattstiele schließen so eng zusammen, daß sie einen bis $10 \mathrm{~m}$ hohen "Scheinstamm" bilden. Fïr dieses wenig widerstandsfähige Stammgebilde sind aber so riesige Blätter, wie 
sie die Banane besitzt, sicher von Nachteil; denn sie bieten ja dem Winde eine sehr große Angriffstläche dar. Soll die Pflanze nicht nmknicken, so muß eine "Korrektur" eintreten: die Blätter zerreißen so, daß sie wie gefiedert erscheinen. Die Seitenr1ppen stehen nämlich rechtwinklig zu der starken Mittelrippe, so daß schon ein mäßig starker Wind die fiir die Pflanze ganz unschädliche „Fiederung “ bewirken muß. Jetztaber verhält sich das Blatt wie ein wirkliches Fiederblatt, dessen einzelne Teile dem Anprall des Windes leicht ausweichen. Aus der Spitze des Stammes erhebt sich der hängende Blüt e n stand, der bald in eine oft zentnerschwere Fruchttraube iibergeht. Die gurkenähnlichen $\mathrm{Fr}$ ii $\mathrm{ch} \mathrm{t} \mathrm{e}$ besitzen je nach der Spielart, von der sie stammen, ein saftiges, süßes oder mehlreiches Fruchtfleisch, das Millionen von Menschen

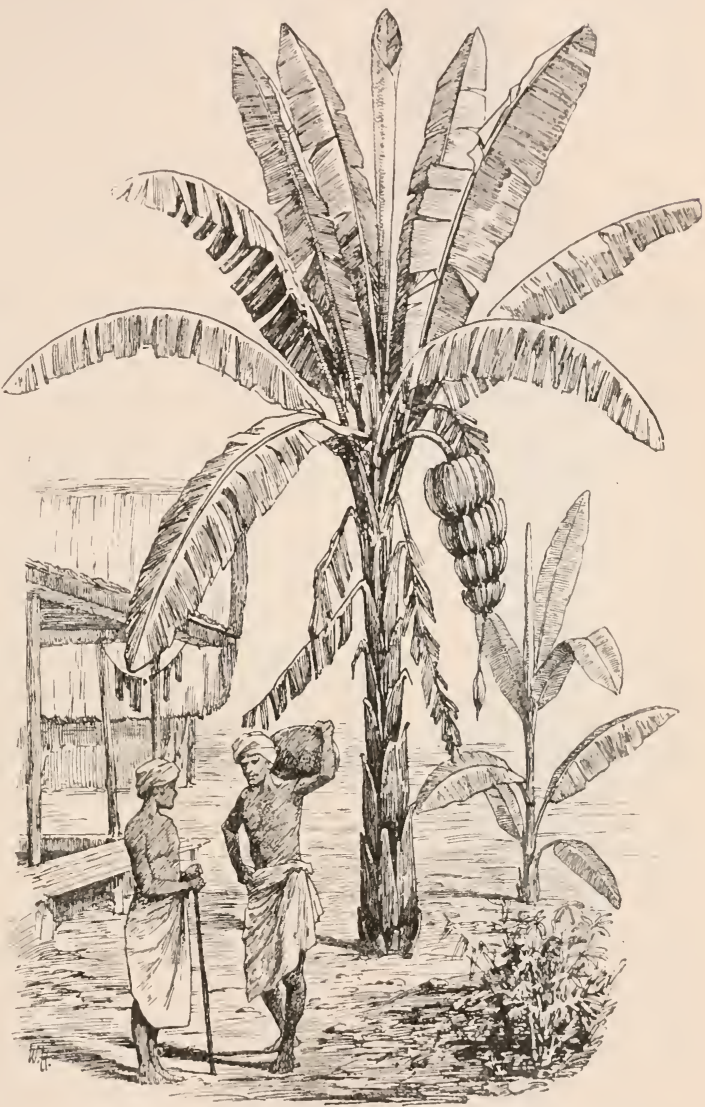

Banane mit Fruchtstand (etwa $1 / 150$ nat. (ir.); dahinter eine junge Pflanze.

zur tilglichen Nahrung dient. - Andere Bananenarten, die vornehmlich auf den Philippinen gedeihen, liefern in den Gefäßbündeln der Blattstiele den festen II anilahanf, der namentlich zu Seilen verarbeitet wird.

Den Bananen nahe verwandt ist der Ingwer (Zíngiber offieinále), der in zahl- 
reichen Tropenländern angebaut wird, Der Warzelstock, der dem der Schwertlilie nicht unähnlich ist, liefert ein bekanntes Gewürz, das besonders zur Herstellung von Likören dient. - Ein anderes verwandtes Gewächs ist das Blnmenrolır (Canna), das in den heißen nnd wärmeren Teilen von Amerika heimisch ist. Die prächtige Pflanze wird ihrer großen, schönen Blätter wegen bei nns in zahlreichen Arten gern zur Bildung von „Blattpflanzen"-Gruppen verwendet.

\section{Familie. Arongewächse (Aráceae).}

\section{Der Aronstab (Arum maculátum).}

1. Der Aronstab ist ein Bewohner schattiger, fenchter La u bwälder. Bereits im Vorfrühli nge, also zu einer Zeit, in der die Bänme noch unbelaubt sind, und die Sonnenstrahlen ungehindert bis zum Boden linabdringen, sprießt er zum Lichte empor. (Beobachte, wie die zusammengerollten Blätter den Boden durchbrechen!) Hierzu ist er wohl befähigt; denn er findet ja die nötigen Baustoffe in einem knollenartigen unterirdischen Stamme fertig vor. Wenn sich die Laubkronen geschlossen haben, beginnt er bald zu vergilben: alles Erscheinungen, wie wir sie an dem Scharbockskrante (s. S. 1, A) kennen und verstehen gelernt haben. Die pfeilförmigen Blattflächen sind zart und groß wie bei zahlreichen Standortgenossen der Pflanze (s. S. 7, b u. c) und meist brann gefleckt wie beim gefleckten Knabenkraut (s. das.). Da sie dentliche Rinnen darstellen (beobachte die Stellung der hinteren Zipfel!) und schräg nach innen geneigt sind, so leiten sie alles Wasser an den langen Blattstielen zur Wurzel hinab. Der Aronstab hat also der Lage seiner Wurzeln entsprechend eine centripetale Wasserableitung (s. S. 88). Stellt man durch ein Stäck der Blätter dïnne Qnerschnitte her, so sieht man bei Anwendung des Mikroskops, daß in den Zellen zahlreiche Nadeln eingelagert sind. Kaut man ein Stiick des Blattes, so dringen diese Gebilde, die ans oxalsaurem Kalke (Kleesalz) bestehen, in die Schleimhäute des Mnndes ein, und man wird zuerst einen süßlichen Geschmack, dann aber ein äßßerst schmerzhaftes Brennen wahrnehmen. Daher liüten sich die pflanzenfressenden Tiere anch vor der verlockend saftigen Speise, oder sie wenden sich nach dem ersten Anbiß mit allen Zeichen des Unbehagens davon ab (stelle entsprechende Versuche an!). Besonders wichtig ist der Pflanze dieses Schutzmittel gegen die Schnecken; denn der feuchte Waldgrund ist ja ein Lieblingsaufenthalt dieser überaus gefräßigen Tiere.

2. In dem gewöhnlich als "Blüte“ bezeichneten Gebilde erkennen wir bei näherem Zusehen leicht einen Blütenstand, der seiner Form nach als Kolben zu bezeichnen ist. Er ist von einem großen, dïtenförmigen und grünlichweißen Hüllblatte, einer sog. Blütenscheide, ungeben, die unten kesselartig erweitert und im oberen Teile weit geöffnet ist. Unter dem meist violett gefärbten, keulenförmigen Abschnitte des Kolbens stehen mehrere Reihen starrer Haare, die bis zur Wand der hier stark verengten Blütenscheide reichen. Der untere Abschnitt des Kolbens ist oben von vielen Staubbättern 
und unten von zahlreichen Stempeln rings umgeben. Da sich diese Gebilde nur in Bliiten finden, so haben wir in ihnen also ebenso viele Stanboder Stempelblïten vor uns. Der Kolben bildet also - wie oben bemerkt - oine Bliitengemeinschaft oder einen Bliitenstand. Den winzigen Blïten fehlt allerdings wie bei zahlreichen anderen Pflanzen (Beispiele!) die Blïtenhïlle. Sie wird jedoch dureh die Bliitenscheide, die im Knospenzustande vollkommen geschlossen ist, hinreichend ersetzt.

Der Blïtenstand des Aronstabs erinnert uns sowohl in seinem Äußern, als auch in den Einzelheiten seines Baues stark an die Blïten der Osterluzei (beweise dies näher!). Wir werden uns daher auch nicht wundern, daß die Bestäubung wie bei dieser Ptlanzo durch Mücken vermittelt wird, die eine Zeit lang in der "Kesselfallenblume" gefangen gehalten werden. Und zwar ist der Vorgang im wesentlichen derselbe (verfolge und beschreibe ihn!). Im besonderen muB jedoch noch folgendes bemerkt werden:

a) Als Mittel, die Bestïuber anzulocken, dient dem Aronstabe außer der Färbung der Blïtenscheide und des keulenförmigen Kolbenabschnittes ein starker Geruch, der uns zwar widerlich erscheint, den Mücken dagegen sicher angenehm ist.

b) Die Honigtropfen, dic von den vertrockneten Narben ansgeschieden werden, sowie ein Teil des reichlich erzeugten melligen Bl iitens ta $u$ bes dienen den Mïcken zur Nahrung. Außerdem ist es

c) die (infolge lebhafter Atmung) e rzengte Wärme, die die Insekten veranlaßt, in der "Kesselfallenblume“ Unterschlıpf zu suchen. I)ie Tierchen finden dort gleichsam ein gehciztes Zimner. Wenn wir den Kolben mit der Zunge berühren, so empfinden wir die Wärme, oder führen wir ein kleines, cmptindliches Thermometer in den

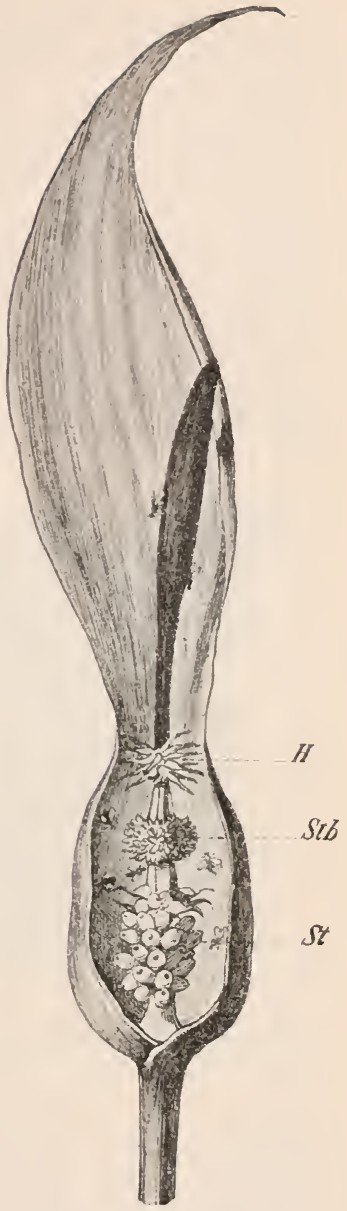

Bliitenstand vom Aroustabe.

H. Haarrense: Ntb. Staubblïtter ; st. Stempel. Nat. (ir.). "Kessel" ein, so sehen wir, daß die Temperatur dort um mehrere Grad ,höher" als außen ist. (liei ausländischen Arten erhöht sich die Innentemperatur sogar um $10-20^{\circ}$ C.) 
d) Als "Anflugsstange" dient den kleinen Gästen der kenlenförmige Kolbenteil.

e) Die "Haarreuse" erlaubt den Gefangenen wohl, das Gefängnis kriechend zu verlassen. Da die Tierchen dem hellen Ausgange aber stets z uf'liegen (vgl. mit den Insekten, die in das brennende Licht fliegen oder die heiße Lampe umflattern!), so bleibt ihnen der Rückweg so lange gesperrt, bis sie ihre Arbeit getan haben, d. h.: erst nachdem die Staubbeutel entleert und die Mïicken (zum erstenmal oder von nenem) mit Blütenstaub beladen sind, wird der Ausgang durch Verwelken der Haare frei.

3. Die Frïchte sind saftige Beeren, die durch lenchtend scharlachrote Färbung die Waldvögel zum Verspeisen einladen (vgl. S. 64,8).

Verwand te: An sumpfigen Stellen nnd an den Ufern stehender Gewässer wächst das Schlangenkraut (Calla palústris), so genannt nach dem Warzelstocke, der wie eine Schlange über den Boden dahinkriecht. Der

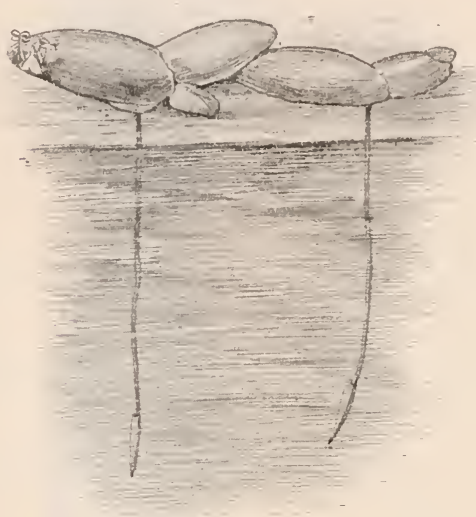

Gemeine Wasserlinse (Lemna minor). Das Pflänzchen links mit einer Blüte. (Etwa 5 mal nat. Gr.) Blütenkolben ist von einer rein weißen Blätenscheide umgeben, Ganz ähnliche "Blüten“ hat die prächtige Zimmerpflanze (Richárdia aethiópica), die unter dem Namen ${ }_{n} \mathrm{Calla}$ " allgemein bekannt ist und in Afrika ihre Heimat hat. Eine schilfähnliche Sumpfpflanze ist der Kalmus (d́corns cálamus). Sein gewürzhafter Wurzelstock wird vielfach als Heilmittel verwendet.

Zn den Arongewächsen zählt man auch die Wasserlinsen (Lemna). Die winzigen Pflänzchen bestehen aus einem blattartigen Stamme, der durch eine oder mehrere senkrecht ins Wasser reichende Wurzeln in wagerechter Lage gehalten wirl. Nor selten bringen die Wasserlinsen unscheinbare Blütchen hervor. Dafür vermehren sie sich aber stark durch seitlich hervorwachsende Sprossen, die selbständig werden oder mit der Mutterpflanze im Zusammenhange bleiben, und zwar geschieht dies oft in einem solchen Maße, daß ganze Gewässer in kurzer Zeit wie mit einem grünen Teppich äberzogen werden.

\section{0. u. 71. Fam. Rohrkolben- und Laichkrautgewächse (Typháceae und Najadáceae).}

1. Rohrkolbengewächse. Der Rohrkollen (Typha) ist ein Bewohner der Sümpfe und Uferränder. Er wächst also dort, wo das Schilf anzutreffen ist. Daher besitzt er gleichfalls eine besondere Einrichtung gegen die Wirkung des Windes, 


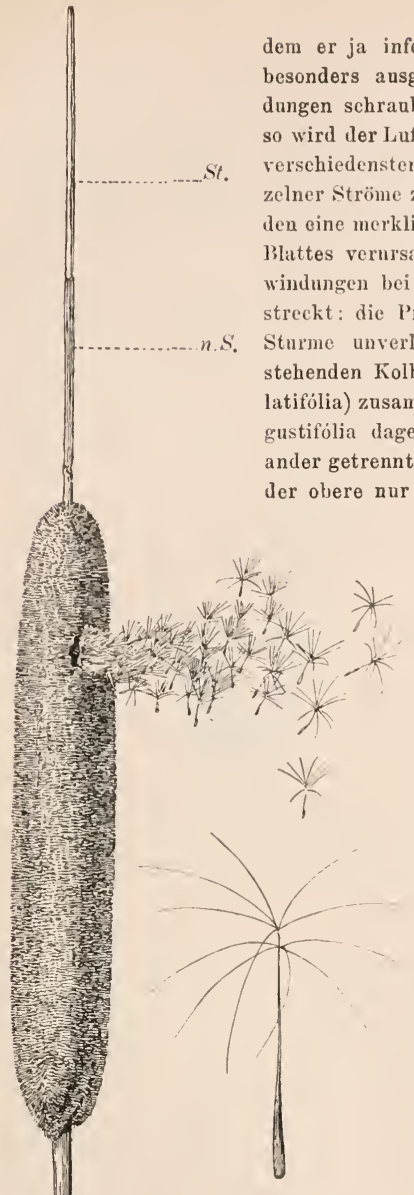

Fruchtstand des schunalblittrigen Rohrkolbens (etwa $1 / 2$ nat. Gir.)

Dis Ausstreuen der Früchte durchden Wind hat soeben begonnen. Unterhall, der verwehten Früchte eine Frucht in etwa 5 mal. lergr. St. Stengelteil, an dem die Stanbbläten saßen; n.s. nackt. Stengelteil.
(Beweis!), ein Zeichen, daß die Pflanze bei der Bestänbung auf die Hilfe des Windes angewiesen ist. Nach dem Ausstreuen des Blütenstaubes vertrocknen die Staubblüten und fallen $a b$, so daB nur der Teil des Stengels, an dem sie standen, als Fortsatz des Fruchtikolbens zurückbleibt. Die Früchte werden, da der Fruchtstiel mit langen Haaren besetzt ist, leicht weit durch den Wind verbreitet. - Eine das Wasser liebende Pflanze ist auch der Igrelskolben (Spargáninm), dervon den kngeligen, stacheligen Fruchtständen den Namen trägt. Seine schwimmfähigen Früchte werden durch das Wasser verbreitet.

2. La ichkrautgewächse. Die Laichkriuter (Potamogéton) sind untergetauchte oder schwimmende Wasserpflanzen. Da sie vom Wasser getragen werden, sind sie wie der Wasserhahnenfuß überaus zarte Gewächse. Die einfachen, in Ähren stehenden Blüten werden über den Wasserspiegel emporgehoben nnd mit Hilfe des Windes bestäubt. - In der Strandzone unserer Meere wächst auf' schlammigem oder sandigem Boden das Seegras (Zostéra). Das grasähnliche Gewächs hat lange, riemenförmige Blätter, die leicht mit den Wogen hin- und herfluten, und bläht wie das Hornblatt (s. das.) unserer Teiche und Seen unter Wasser. Getrocknet liefert das Seegras ein wertvolles Material zum Polstern. 


\section{Familie. Gräser (Gramíneae).}

Stengel (Halm) knotig und meist hohl. Blätter zweizeilig, meist mit je einer gespaltenen Blattscheide und einem Blatthäutchen. Blütenstand eine aus „Ährchen" zusammengesetzte Ähre oder Rispe. Blüten im Schutze sog. Spelzen; mit meist 3 Staubblättern und einem Fruchtbuoten mit meist 2 Narben. Frucht eine sog. Grasfrucht.

\section{Der Roggen (Secále cereále).}

A. Der Roggen und seine Bedeutung. 1. Von den Getreidearten, die in Mittel- und Nordeuropa angebaut werden, hat keine eine so große Wichtigkeit wie der Roggen. Liefert er doch das Schwarzbrot, das für viele Millionen von Menschen einen großen, vielfach sogar den größten Teil der täglichen Nahrung bildet. Dieses Brot ist zwar etwas weniger nahrhaft als
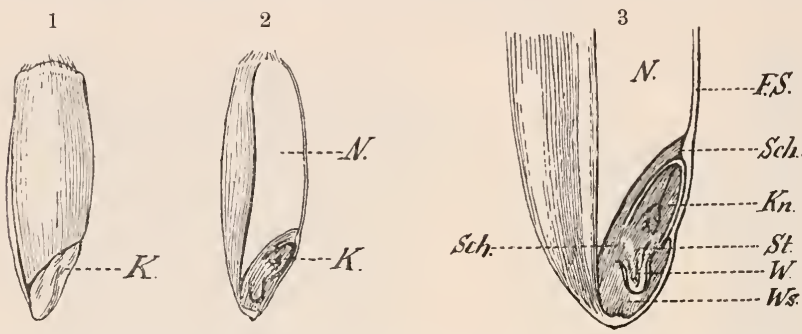

Roggenkorı. 1 von außen; 2 im Längsschnitt (etwa 10 mal vergr.); 3 unterer Teil (stärker vergr.). K. Keimling; N. Nährgewebe; F.s. die miteinander verwachsene Frnchtu. Samenschale; Sch. Schildehen; Kn. Knospe; St. Stengelchen; W. Würzelchen; W's. Wurzelscheide.

das aus Weizenmehl hergestellte Weißbrot, bleibt aber viel länger schmackhaft als jenes und wird uns nie zum Überdruß. Zudem gedeiht der Roggen vielfach auch da, wo kein Weizenban mehr betrieben werden kann; denn die anspruchslose Pflanze nimmt mit einer geringeren Sommerwärme fürlieb als der Weizen und bringt anch auf weniger gutem Boden noch lohnenden Ertrag. Seiner großen Wichtigkeit halber bezeichnet man den Roggen vielfach kurzweg als "das Korn", ein Name, mit dem jedes Volk seine Hanptbrotfrucht belegt. So ist z. B. für die Bewohner Frankreichs der Weizen, für die Südemropäer neben dem Weizen der Mais und für die meisten Völker Asiens der Reis „das Korn". Diese hohe Bedentung erlangen die nnscheinbaren Getreidegräser bekanntlich durch ihre Frucht. Wie dies möglich ist, wird uns leicht die genanere Betrachtung des Roggenkornes zeigen; denn die Friichte aller anderen Grasarten sind im wesentlichen genau so gebant. - Um den Roggen ganz zu würdigen, muß vorher noch des wertvollen Strohes gedacht werden, das er uns liefert. Es wird als Streu für das Vieh, als Häcksel für die 
Pferde, sowie wegen seiner Länge zur Herstellung von Seilen, Strohmatten u. dgl. verwendet.

2. Das Roggenkorn ist ein kleines, grangelbes Gebilde mit einer Längsfurche und einer wohl umgrenzten Stelle am zugespitzten (unteren) Ende. Um den inneren Bau kennen zu lernen, führen wir durch ein etwas aufgequollenes Korn einen Längsschnitt, der genau in der Mitte der Furche verläuft. Dann sehen wir, daß es aus 2 deutlich geschiedenen Teilen besteht, die von einer schïtzenden "Hant" (der miteinander verwachsenen Frucht- und Samenschale, s. S. 258, b) unhüllt sind (F.S.).

a) Nehmen wir eine Lupe zur Hand, so erkennen wir leicht, daß der untere Abschnitt, der äußerlich jene "wohl nmgrenzte Stelle" bildet, die Anlage der jungen Pflanze, den Keimling (K.), darstellt: wir sehen die K nospe (Kn.) mit den ersten Blättern, ein kurzes S t e n gels tii ck (St.) und ein Wür z el c hen (IV.), das von der Wurzelscheide (IVs.) umgeben ist. Der Stengel steht mit einem verhältnismäßig dicken Körper, der nach seiner Form Schildchen (Sch.) genannt wird und sich an den großen oberen Abschnitt der Frucht anlegt, in Verbindung. (Am besten ist die Form des Schildchens zu erkennen, wenn man von einem gequollenen Korne den ganzen Keimling mit Hilfe einer Nadel ablöst.) Da das Schildchen an der Stelle des Stengels entspringt, an der sich bei den zweikeimblättrigen Ptlanzen die Kicimblätter finden (s. S. 99, 2), so betrachtet man es gleichfalls als ein solches („Einkeimblättrige Pflanzen").

b) Stellt man durch den großen oberen

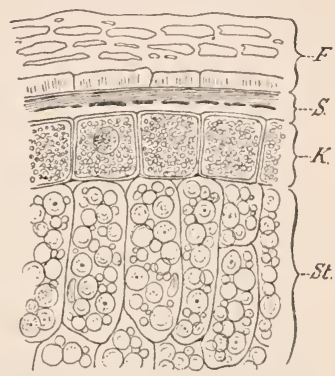

Feinerer Bau des Roggenkorus (Schnitt bei 180 mal. Vergr.).

F. Frnchtschale; S. Samensehale: K. Kleberselicht; St. Zellen, mit Stärkekörnern angefüllt. Abschnitt des Roggenkornes zarte Querschnitte her, so sieht man bei mikroskopischer Vergrößerung, daß unter der umliiillenden "Haut" eine Schicht kürzerer Zellen liegt, die mit feinen Körnchen angefüllt sind. Der von dieser Schicht nmschlossene Ramm dagegen wird von längeren Zellen eingenommen, die wesentlich größere Körner führen. Bei Zusatz einer Jodlösung färben sich die kleinen Körner gelbbraun, die größeren blan, ein Zeichen, daß wir es in ersteren mit Eiweiß, in letzteren mit Stärke zu tun liaben (s. den letzten Abschn. d. Buches!). Wahrend das kiweiß, hier "Kleber" genannt, also in den änßersten Zellen angehäuft ist, findet sich die Stärke in den Zellen, die von der "Kleberschicht" umschlossen sind.

Eiweiß und Stäke sind nun die Stoffe, die der Keimpflanze zum Antban und zur Nahrung dienen. Wührend diese Stoffe bei der Bohne (s. S. 101, e) aber in den Keimblättern eingelagert sind, finden sie sich hier, von dem Kieimlinge vollkommen getrennt, in cinem besonderen Abschnitte des Samens, den 
man als das Sameneiweiß (Endosperm) oder treffender als das Nährgewebe (N.) bezeichnet.

Da nun das Roggenkorn außerordentlich reich an Eiweiß $(11 \%)$ und Stärke $(60 \%)$ ist, und beide Stoffe unentbehrliche Bestandteile der menschlichen Nahrung bilden, so wird uns die Wichtigkeit des Roggens als Brotfrncht ohne weiteres verständlich. Der Keimling, die umhüllende „Haut“, sowie die darnnter lagernde Ḱleberschicht werden beim Mahlen des Getreides durch die Rauhigkeiten der Mühlsteine von den Körnern abgerieben. Sie liefern die Filei e (Verwendung?), während das zertrümmerte Nährgewebe ohne die Kleberschicht das Mehl gibt. Da die Kleberschicht - wie wir gesehen haben sehr reich an Eiweiß ist, so ist auch das Brot, das aus "geschrotenem" Korn hergestellt wird (Schrotbrot, Kommißbrot, Pumpernickel n. dgl.), weit nahrhafter, allerdings auch viel schwerer zu verdanen, als ein aus reinem Nehle bereitetes Gebäck. - Wenn auch die Stärke nicht wie z. B. die der Kartoffelknolle fabrikmäßig gewonnen wird, so werden die Roggenkörner doch gleichfalls zur Herstellung eines stark alkoholhaltigen Getränkes, des Kornbranntweins, verwendet.

B. Aussaat, Keimung und Bestockung. 1. Der Roggen wird im Herbst oder Frühling gesät (Winter- und Sommerroggen; s. S. 252). (Beschreibe, wie der Landmann den Boden für das Saatkorn zubereitet! Gib an, welche Bedeutung die einzelnen Tätigkeiten haben, und wie die Aussaat erfolgt!)

2. Um die Keimung genau verfolgen zu können, säen wir Roggenkörner in Blumentöpfe, die mit feuchter Erde angefüllt sind. Die Körner quellen bald auf, und im warmen Zimmer sprengt meist schon am nächsten Tage der schwellende Keim die iiberdeckende Schale (s. S. 100, a). Wie bei der Bohne (s. S. 100, b) kommt zuerst

a) das Würzelchen zum Vorscheine (Fig. 1 auf S. 251). Es durchbricht die Wurzelscheide, die anfänglich mit wächst und das ïberans zarte Gebilde gegen Verletzung schützt, und bohrt sich in den Boden ein. Gleichzeitig machen sich an dem Stengelchen 2 kleine Anschwellungen bemerklich, die sich gleichfalls zu Wurzeln ausbilden (Fig. 2) und anfänglich auch von Wurzelscheiden umhüllt sind. Zum Unterschiede von der sich zuerst entwickelnden "Ha uptwurzel" bezeichnet man diese als Nebenwurzeln. Bald brechen noch weitere Nebenwurzeln aus dem Stengel hervor, und da alle die Hauptwurzel an Größe und Stärke bald erreichen, so entsteht schließlich ein Büschel gleichartiger Wurzeln (Fig. 3).

b) Da die Wurzelscheide mit zahlreichen Härchen besetzt ist, wird das Korn sofort bei Beginn der Keimung im Boden verankert (s. S. 100, b). Diese Befestigung wird umso sicherer, je tiefer sich die Hauptwurzel in die Erde senkt und je mehr Nebenwurzeln, die gleich der Hanptwurzel mit vielen Wurzelhärchen bedeckt sind, sich entwickeln. Fast gleichzeitig mit der Streckung des Würzelchens beginnt auch die Knospe stark in die Länge zu wachsen. Das Stengelchen dagegen bleibt sehr kurz und ist daher auch nicht imstande, 
die Erde zu durchbrechen (s. S. 100, c). Diese Arbeit muß daher die Knospe selbst verrichten, und dazu ist sie trotz ihrer Zartheit anch wohl befähigt. Ihre Blätter bilden nämlich einen Kegel, dessen Mantel von dem scheidenförmigen ersten Blatte gebildet wird. Diese meist rötlich angelaufene Scheide ist verhältnismäßig fest und widerstandsfähig, so daß sie mit ihrer harten Spitze den Boden wie ein Keil durchbrechen kann (vgl. mit Tulpe, Maiblume). Erst ein Stück über dem Boden öffnet sich die Scheide, um dem zweiten Blatte den Durchtritt zu gestatten.

c) Das urspriinglich harte Roggenkorn wird mit beginnender Keimung weich, und sein $\mathrm{Nahrgewebe}$ verwandelt sich nach und nach in eine milchige Masse. Da nun der Inhalt des Nährgewebes dem Keimling zur Nahrung und zum Aufbau dient, von diesem aber getrennt ist, so muß ein Vermittler zwischen beiden vorhanden sein. Als solcher gibt sich das Schildchen zu erkennen, das - wie wir gesehen haben - mit seiner ganzen Fläche dem Nährgewebe anliegt, auf der anderen Seite dagegen mit dem Keimling in Verbindung steht. Je mehr sich der Keimling entwickelt, desto mehr leert sich anch der Vorratsspeicher, bis die letzten, für den Keimling wertlosen Reste des Kornes schließlich durch Fäulnis zerfallen.

3. a) Noch bevor sämtliche Vorratsstoffe verbraucht sind, ist die Pflanze imstande, sich selbst Nahrung zu erwerben. Sie sendet - wie man bei selır vorsichtigem Nachgraben sehen kann - ihrelW urzeln bis in die tieferen, stets feuclten Bodenschichten hinab. Daher vermag der Roggen selbstauf dem trockensten Sandbodenzu wachsen.

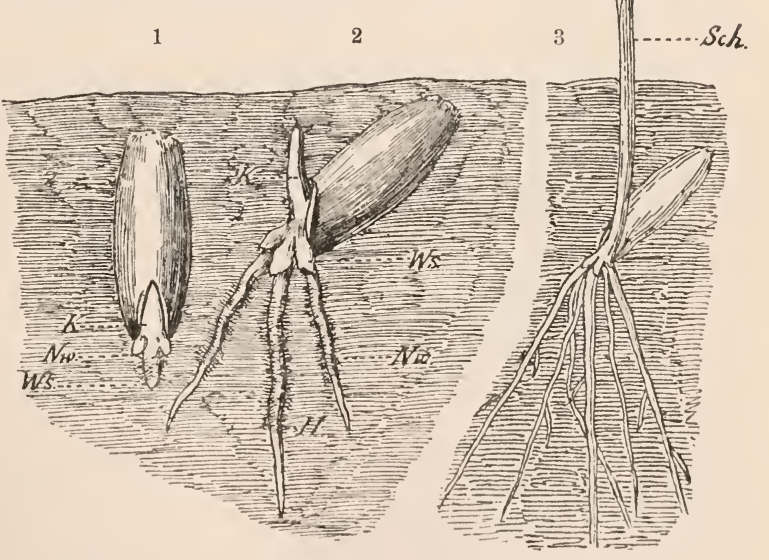

Keimung des Roggenkorns. (Fig. 1 u. 2 etwa 10 mal, Fig. 35 mal vergr.) In Fig. 1 ist die IIamptwurzel noch von der Wurzelscheide muhïlt. K. Knospe; Nw. Nebenwurzeln; Ws. Wurzelseheide; H. Hanptwurzel; Sch. das seheilenförmige erste Blatt; g.Bl. das erste grüne Blatt. 
b) Mit den ersten Wurzeln werden auch die ersten grïnen Blätter gebildet. Der Sommerroggen "schießt" nun schnell empor, und nicht lange währt es, so hat er seine volle Größe erreicht. Der Winterroggen dagegen bleibt während der kalten Zeit niedrig. Im andern Falle wiirde die Schneelast, die auf ihm ruht, seine Stengel zerknicken und ihn somit vernichten. Sinkt das Thermometer bis etwa zum Nullpunkt, so stellt der Roggen das Wachstum ganz ein; denn ohne Wärme gibt es keinen Pflanzenwuchs. Bei mildem Wetter dagegen wäclıst er langsam weiter: aus den untersten Stengelknoten sprießen zahlreiche Zweige hervor, dic oft abermals Zweige treiben. Man sagt: der Roggen bestockt sich. Da nun jeder Zweig (Halm) stets in einer Ähre endigt, so ist eine ergibige Bestockung Vorbedingung einer ertragreichen Ernte. Und da sich nun der Winterroggen reicher als der Sommerroggen bestockt, so wird er anch vorwiegend angebaut.

C. Halm und Blatt. 1. Der Stengel des Roggens (wie der aller Gräser) wird Halm genannt. Obgleich er bis $2 \mathrm{~m}$ hoch und nur wenige Millimeter dick wird, vermag er nicht nur die eigene Last, sondern auch die der Blätter und der Ähre zu tragen. Und wie gegen diesen von oben wirkenden Druck ist das schwache Gebilde auch gegen seitlichen Druck anßerordentlich widerstandsfähig. Biege den Roggenhalm so stark, daß die Ähre den Boden berïhrt, und dn wirst sehen, wie er losgelassen sofort wieder in seine ursprüngliche Lage zurïckkehrt! Oder beobachte, wenn der Wind iiber das Kornfeld weht, wie das "Ährenmeer" wogt und wallt, und wie die Halme sich neigen und biegen, ohne daß auch nur ein einziger geknickt wiirde! Der Roggenhalm ist also ein Gebilde von großer Trag- und Biegungsfestigkeit.

a) Wie bei der Taubnessel (s. S. 146, 1a) hat anch beim Roggen die äußerste Schicht des Stengels unter der Biegung am meisten zu leiden. Dicht unter der Oberfläche des Halmes finden sich daher - wie auf dünnen Schnitten bei schwacher mikroskopischer Vergrößerung leicht zu erkennen ist - Zellen, die sich durch große Widerstandsfähigkeit auszeichnen. Sie haben stark verdickte Wände, sind wie die Bastzellen des Leins (Taf. 9, 7) langgestreckt und mit den zugespitzten Enden fest ineinander gefügt. Während diese "Stiitzzellen" bei der Taubnessel 4 "Pfeiler" bilden, stellen sie hier eine Röhre dar, die noch durch leistenartige Vorsprïnge verstärt ist. Die Leisten erscheinen anf der Oberfläche des grïnen Halmes als helle Längsstreifen.

b) Wie bei der Taubnessel (s. S. 147, b) ist auch beim ansgebildeten Stengel des Roggens das Mark, das bei der Biegung nichts auszuhalten hat, verschwonden: der Halm ist hohl.

c) Nur in den „Knoten" finden sich Querwände (Längsschnitt!), durch die der Halm in eine Anzahl kürzerer Röhren geteilt ist, so daß er eine größere Widerstandsfähigkeit erhält (s. S. 147, c). Und zwar steheı im unteren Halmabschnitte, der am meisten zu tragen und unter dem Winde am stärksten zu leiden hat, die Knnoten viel enger beieinander als im oberen. - Wie auf einem 
Längsschnitte deutlich zu sehen ist, gehören die äußerlich sichtbaren Anschwellungen an den Knoten nicht dem Stengel, sondern den

2. Blattern an. Jedes Blatt besteht aus 2 deutlich geschiedenen Abschnitten, der Blattscheide und der Blattfläche. Da, wo beidezusammenstoßen, erhebt sich ein häutiges Gebilde, das Blatthïutchen.

a)Die Blat ts scheide entspringt an einem Halmknoten und stellt eine offene Röhre dar, deren Ränder aber fest übereinander greifen. Wie jeder wachsende Halm zeigt, sind die Blitter schon vollständig entwickelt, wenn vonden darïber befindlichen Stengelgliedern äußerlich noch nichts wahrzunehmen ist. Stellt man durch diesen Halm einen Längsschnitt her, so sieht man, wie sich in dem von den Blattscheiden gebildeten Hohlraume die jungen Stengelglieder mit ihren Blätern und der Ähre entwickeln. Diese Gebilde sind aber von außerordent-

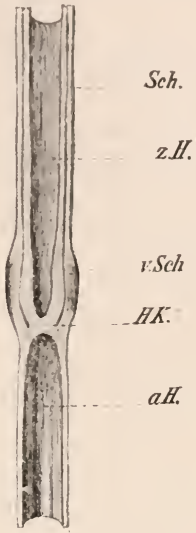

Lïngsschnitt dureh einen Knoten des Rogrgenhalms.

a.H. ansgewachsener, z.H. zarter Teil eines Halmgliedes.

Hk. Halmknoten. Sich. Blattseheide. v.s.ch. deren verdickte stelle ïber dem Halnknoten. licher Zartheit. Schon ein leiser Wind wïrde sie durch Aneinanderschlagen der Halme vernichten, und die Mittagssonne könnte ihnen leicht so viel Wasser in Dampfform entziehen, daß sie vertrockneten. Durch die Blattscheiden, die ihnen in der Entwicklungstark ,,vorauseilen“, erhalten sie also den notwendigen $\mathrm{Schutz}$. Erst nachdem sie gehörig erstarkt sind, wachsen sie nacheinander aus der schïtzenden Hiille hervor. (Gib an, in welcher Weise der Schutz der jungen Teile bei anderen Pflanzen stattfindet!)

Auch spiiter, wenn die Ähre bereits sichtbar geworden, das Wachstum 
aber noch nicht beendigt ist, hat die Blattscheide noch eine große Bedeutung für die Pflanze. Entfernt man die Scheide, so findet man, daß das sonst vollkommen ansgebildete Halmglied unmittelbar über dem Knoten noch zart und weich ist. Hier ist der Halm noch in Streckung begriffen und ermangelt daher der Festigkeit. Schon ein leichter Windstoß wïrde ihn knicken (Versuch!). Von der Scheide umhiillt dagegen, trotzt er, wie wir gesehen haben, selbst heftigen Stiirmen. Die Blattscheiden, die die zarten Wachstumsstellen wie feste Röhren nmschließen, verleihen also zweitens dem Halme die nötige Festigkeit. - Im Gegensatz zu den meisten anderen Pflanzen, die nur an der Spitze des Stengels (und der Wurzel) fortwachsen, treffen wir beim Roggen wie bei allen Gräsern iiber jedem Knoten eine Wachstumsstelle an, eine Tatsache, die uns das schnelle Emporschießen

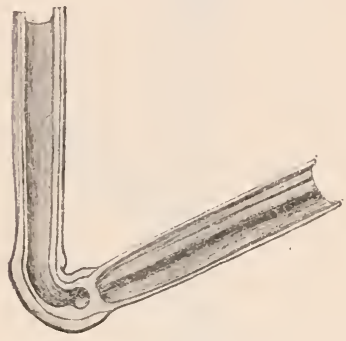

Teil eines Rowrenhalmes, der sich durch "Knickung" am Knoten wieder aufgerichtet hat, im Durchschnitt. der Gräser hinreichend erklärt. (So verlängern sich z. B. die Halme des Bambusrohres während der Zeit des lebhaftesten Wachstums in 24 Stunden nicht selten um $1 \mathrm{~m}$.)

Welche dritte Anfgabe die Blattscheiden $\mathrm{zu}$ erfüllen haben, ist leicht zu erkennen, wenn sich die Halme vielleicht infolge eines heftigen Gewitterregens "gelagert" haben, oder wenn sie auf irgend eine Weise geknickt worden sind (Versuch!) Dann wächst die über dem Knoten liegende, verdickte Stelle der Blattscheide an der Unterseite so stark, daß der Halm daselbst eine Knickung erfährt, und dies dauert so lange fort, bis der über dem Knoten befindliche Halmabschnitt wieder senkrecht steht. Nunmehr können die Halme wieder genïgend von Licht und Luft umspült und die Pflanzen durch den Wind bestäubt werden (s. Absch. D). Die Blattscheide beseitigt also infolge ihres ungleichmäßigen Wachstums die mit der "Lagerung" oder Knickung der Halme verknüpften Gefahren. (Sehr hänfig ist dieses Aufrichten der Halme am Rande der Felder zn sehen, wo nicht selten Pflanzen durch Mutwillen oder dgl. geknickt und ungetreten sind.)

b) Die Blattfläche ist bandartig gestreckt und flattert daher wie eine Fahne mit dem Winde. Infolgedessen bietet sie ihm auch nur eine geringe Angriffsfläche dar, ein Umstand; der nicht wenig dazu beiträgt, daß die Pflanze selbst einem Sturme zu trotzen vermag. Mit der bandartigen Form steht auch im innigsten Einklange, daß (wie dies für die einkeimblättrigen Pflanzen als Regel gilt) die Nerven des Blattes parallel verlaufen.

c) Das Blatthäutchen liegt dem Halme dicht an. Es verhindert daher, daß die Regentropfen (Versuch!), die von der Blattfläche nach dem Halme zu abfließen, zwischen ihn und die Blattscheide gelangen. Im anderen Falle 
miißte dort bald Fäulnis entstehen, die sicher auch die Pflanzenteile selbst ergreifen wiirde.

3. Es kommt nicht selten vor, daß man sich an den Blättern des Roggens (und anderer Gräser) schneidet, wenn man sie schnell durch die Hand zieht. Dies rührt von der Kieselsä u re her, die in großer Menge in den Zellwänden der Oberhant eingelagert ist. Gliiht man Halmteile auf einem Platinbleche, so bleibt das glasartige "Kieselskelett" zuriick. Es dient der Pflanze wie ein Panzer als Schutz gegen änßere Verletzungen, hat aber noch eine andere Bedeutung, wio folgender einfache Versuch lehrt: man lege Garten- oder Weinbergsschnecken Roggenhalme vor, die sich noch im Wachstume befinden. Von einigen Halmen entferne man aber vorher die Blattscheiden, so daß die Tiere zu den jungen Stengelteilen gelangen köınen, die sich im Schutze der Blattscheiden entwickeln, und deren Oberhaut noch nicht verkieselt ist. Dann wird man an den unverletzten Halmen nur geringe, an den von den Blattscheiden befreiten dagegen bald starke Freßspuren bemerken. Die verkieselten Häute erschweren den Tieren also den Angriff. Die eingelagerte Kieselsäure ist demnach ein Schutzmittel des Roggens (der Gräser) gegen die Angriffe der Pflanzenfresser. Freilich Wiederkäuer und Nager werden dadurch nicht abgehalten; wohl aber ist dies bei anderen Grasarten der Fall, z. B. bei dem scharfschneidenden Schilfe, sowie bei zahlreichen Riedgräsern (s. das.). Ja, in gewissen Gegenden des heißen Afrika ist die Verkieselung der Blätter bei zahlreichen Gräsern so stark, daß sie für unsere Haustiere gänzlich ungenießbar werden.

D. Bliite und Frucht. 1. Ä hre. Nachdem immer ein Halmglied nach dem anderen ans der Scheide des vorhergehenden Blattes hervorgekommen ist, tritt endlich auch das letzte ins Freic. Es trägt den Blütenstand, der im gewöhnlichen Leben als Ähre bezeichnet wird.

Entfernen wir die Blüten, so sehen wir, daß der Halm daselbst breit ist und 2 Reihen kleiner, treppenförmniger Absätze besitzt. Auf jedem Absatze der "Achse" steht auf einem winzigen Stiele eine kleine Gruppe von Bliiten, die ein sog. "ïhrehen" bilden. Der Blïtenstand des Roggens ist im botanischen Sinne also eine zusammengesetzte Ähre.

2. Ährchen. Biegen wir die Ähre stark, so ist es leicht, ein Ährchen loszulösen. Es besteht aus zwei wohl geschiedenen Teilen ( 1 u. 2 in der Abb. S. 256), in denen wir unschwer ebensoviele, von grünen, häutigen Blättern oder „Spelzen“ nmhïllte Bliiten erkennen. Zwischen beiden Blïten erhebt sich auf einem fadenförmigen Stielchen ein größeres oder kleineres Gebilde (3), in dem wir den Überrest einer verkïmmerten, stets unfruchtbaren Blïte vor uns haben.

3. Blii te. Zu äußerst am Ährchen sehen wir jederseits ein kleines, kahnförmiges Blatt (K.), das etwa die Stelle des fehlenden Kelches einnimmt und daher als Kelehspelze bezeichnet wird. Darauf folgt je ein größeres Blatt. die sog. äußere Blütenspelze (a. B.). Der Mittelnerv dieses Blattes tritt wie ein Kiel hervor und ist zu einer "Granne" verlängert, die beide mit aufwärts stehenden Stacheln besetzt sind. (Nach welcher Richtung kann man 
darum die Ähre nur durch die Hand ziehen?) Vor und nach der Blütezeit nimmt die äußere Blütenspelze ein zweites, kleineres Blatt, d. i. die mit 2 Kielen ansgerüstete innere Blïtenspelze (i. B.), fast ganz in sich auf. Beide Blätter bilden also gleichsam eine kleine Schachtel, in der die zarten Blütenteile den notwendigen Schutz finden. (S. besonders den Grundriß des Älrchens!)

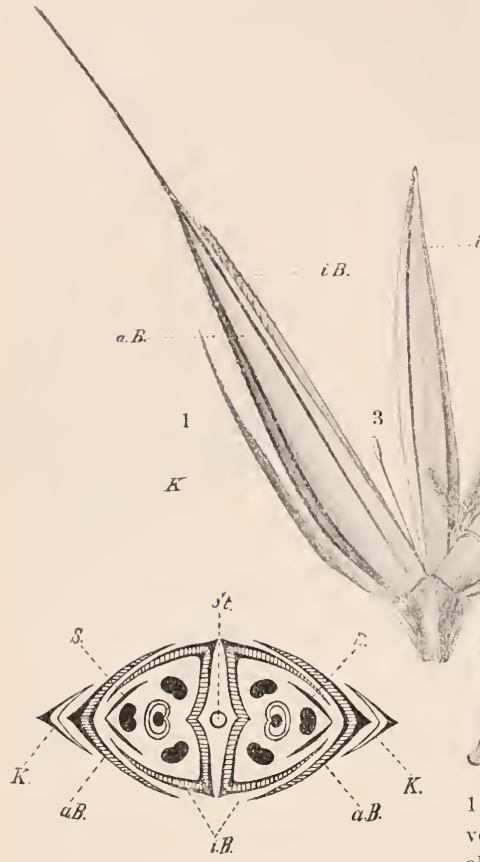

aber nicht immer so weit fortgesehritten, wie

hier dargestellt). K. Kelehspelzen; a.B. äußere Blütenspelzen; i.B. innere Blütenspelzen ; St. Stiel des Ährchens; S. Schwellkörperehen.

Sie vertreten also die fehlende Blütenhïlle, eine Tatsache, die ihre Benennung zur Geniige rechtfertigt.

Jede Blïte besteht aus 3 Staubblättern und einem Fruchtknoten, der 2 große, federartige Narben trägt.

4. Bestäubung. Geht man an einem sonnigen Junimorgen durch die lachende Flur, so sieht man nicht selten aus den wogenden Roggen- (Getreide-) feldern dampfartige Wolken anfsteigen, die der geschäftige Morgenwind weit- 
hin verweht. Der Roggen, „stäubt". Er ist also ein Windblïtler wie z. H. der Haselnußstrauch.

a) Wie bei jener Phanze tinden wir daher anch hier gauz nnscheinbare, duft- und honiglose Bliiten (s. S. $1: 12$ a).

b) Während des Stäubens müssen Stanbblätter und Stempel frei daliegen (warum?). Die ron den Blïtenspelzen gebildete "Schachtel" muB sich daher öffnen. llies bewirken zwei kleine, farblose Gebilde, die sogen. Schwellkörper chen. Sie liegen zwischen dem Fruchtknoten and der äußcren Blïtenspelze, schwellen (Name!) kurz vor dem Stäuben schnell an und drängen infolgedessen die genanute Spelze nach a $\mathrm{B}$ Ben.

c) Während dies geschieht, sind die Staubfäden stark in die Länge gewachsen, so daß schon nach einigen Minuten die Sta abbeutel zwischenden Spelzen hervorins Freie geschoben werden. (Beide Vorgänge sind am besten an abgeschnittenen Ähren im Zimmer zu beobachten. Beschleunigt wird das Aufblühen bekanntlich dadurch, daß man eine „blïhreife" Ähre mit ihrem Halmteile in den Iund nimmt.)

d) Die Staubbeutel hängen nunmehr an den langen, dünnen Fäden aus der Blüte. Schon ein leiser Windhauch vermag daher, sie $\mathrm{zu}$ bewegen und den Blütenstaub aus ihnen zu schïtteln.

e) Von großer Wichtigkeit hierbei ist es, daß die Ähre den höchsten Punkt des Stengels einnimmt, also dem Wiude frei ansgesetzt ist, und daß der Stengel schon durch einen leichten Windstoß ins Schwanken versetzt wird.

f) IVie die meisten Windblïtler stäubt der Roggen im windreichen Frïhling, und zwar geschieht dies nur an trockenen, sonnigen Tagen (vgl. S. 192 d).

g) Die beiden Staubbeutelfächer öffnen sich am oberen, jetzt dem Erdboden zugekehrten Abschnitte

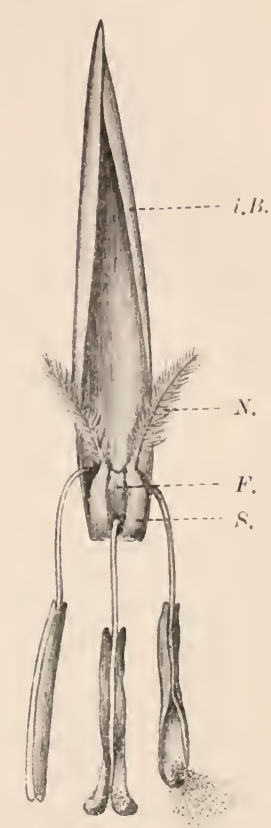

Bliite des Roggens, von außen gesehen und naeh Entfernung der (Kelch- u. änßeren Bliitenspelze.

i. 13. innere Blïtenspelze ; N. Narbe; F. Fruchtknoten: s. Schwellkörperchen. mit je einem Längsriß. Dabei kriimmen sie sich so, daß ihre Endteile gleichsam zwei kleine Löffelchen bilden. Infolgedessen wird der Blïtenstaub, der sich daselbst ablagert, bei ruhiger Luft so lange zurïckgehalten, bis er von ein e m Windhauche, abgeholt" wird. (Was wiirde im anderen Falle geschehen? vgl. S. 192 e. - Beobachte den Torgang an abgeschnittenen Ähren im Zimmer!) Ist dies geschehen, dann sickert aus dem 
nicht klaffenden Abschnitte des Beutels nener Stanb in die "Löffelchen", der abermals verweht wird u. s. f. Sind die Staubbentel endlich entleert, so fallen sie, weil wertlos geworden, ab.

h) Wic die meisten anderen Windblütler wächst der Roggen in großen Beständen, die allerdings vom Menschen geschaffen sind (s. S. 192, g; vgl. hieraufhin auch die anderen Gräscr!). Er erzengt ferner

i) eine große Menge trockenen Blïtenstaubes (vgl. S. 193, h und i), und

k) seine Narben stehen endlich zur Zeit des Stäubens frei da. Sie sind gro Be, f e derartig e Gebilde, also vollendete „Staubfänger“ (s. S. 193, k u. l).

5. Frucht. a) Sobald das Stäuben beendigt ist, schrumpfen die Schwellkörperchen zusammen; die änßere Blïtenspelze legt sich wieder wie ein Schachteldeckel über die innere, und in ihrem Schutze reift nun die Frucht. Da die Ährchen an der Achse in zwei Reihen stehen, und jedes wieder zwei fruchtbare Blüten enthält, so sind die reifen Körner in der Ähre zu vier Längsreihen geordnet.

b) Jede Frucht enthält nur einen Samen, dessen sehr dünne Hülle mit der Fruchtknotenwand verwächst (s. Abb. S. 249). Eine so gebildete Frucht findet sich bei den meisten Gräsern. Sie wird daher Grasfrucht (Karyopse) genannt.

c) Sind die Körner reif, so lösen sie sich aus den Spelzen und fallen, da sie verhältnismäßig schwer sind, in unmittelbarer Nähe der Mutterpflanze zu Boden. Hierzu läßt es der Landmann natürlich nicht kommen. Er mälıt den Roggen vorher ab, bringt ihn in die Scheune nnd schlägt auf harter Tenne die Körner aus den Ähren. (Beschreibe genauer, wie die Ernte und das Dreschen des Getreides erfolgt!) Ans den Körnern, die beim Einernten ausgefallen sind, entstehen zwar neue Pflanzen. Doch deren Nachkommen verschwinden sehr bald wieder, so daß wir trotz des weit ausgedehnten Roggenbanes nirgends verwilderten Roggen antreffen, ein Zeichen, daß wir es in dem wichtigen Gewächs (wie in allen anderen unserer Getreidearten) mit einem Fremdling auf unseren Fluren zn tun haben. Die Stammform des Roggens ist vielmehr im mittelländischen Pflanzengebiete heimisch.

Würden anch beim wildwachsenden Roggen die reifen Körner in unmittelbarer Nähe des Halmes zu Boden fallen, so wäre das für die Pflanze sehr nachteilig (s. S. 10, 3). Er bedarf daher besonderer Einrichtungen, die eine Verbreitung der Früchte ermöglichen. Solche sind anch vorhanden: 1)ie Ährenachse zerbricht erstlich bei der Reife, so daß die Ähre in eine große Zahl kleinerer Teile zerfällt. Die Früchte bleiben ferner von den Spelzen umhüllt. Dadurch wird dem Winde eine große Angriffsfläche geschaffen, so daß er die kleinen Körner leicht verwehen kann. Durch die äußere Blïtenspelze bleibt die Frucht aber auch mit der Granne im Zusammenhange. Da nun das stachelige Gebilde leicht in dem Pelze oder Gefieder vorbeistreifender Tiere hängen bleibt, kaun das Korn endlich auf diese Weise anch weit ver- 
schleppt werden. Zugleich dient die Granne der keimenden Frucht zur Befestigung an den Erdboden. (Welche Einrichtungen haben wir bei anderen Pflanzen kennen gelernt, die eine gleiche Bedeutung laben?)

Diese "Aussäungsvorrichtungen" sind aber fiïr das Einernten des Kornes sehr nachteilig (wieso?). Darum ist der Mensch bestrebt gewesen, sie zu beseitigen, und durch viele Jahrhunderte lange, planmäßige Auslese (s. S. 19) ist ihm dies auch gelungen: Die $̈$ hre zerfält nicht mehr in einzelne Teile; das reife Korn bleibt nicht von den Spelzen nmh üllt, und die (xranne ist brïchig und bedentungslos geworden. Hand in Hand mit dieser "Yeredelung“" ist zugleich eine wesentliche Vergrößerung der Körner erfolgt, kurz: es ist eine von der Stammform in zahlreichen Stiicken abweichende "Kulturform" entstanden. (Beweise, daß die angebauten Gewächse, besonders die Getreidearten, nicht nur ein Erzeugnis der Kultur sind, sondern anch die Kultur - im Gefolge haben!)

E. Feinde. Von der Aussat bis zur Ernte ist die überaus wichtige Pflanze von einem Heer von Feinden umringt: zahlreiche Unkräuter rauben ihr gleich den anderen Getreidearten unserer Felder Licht, Raum und Nahrung; Schmarotzerpilze, von denen besonders der Getreiderost und der Mutterkornpilz genannt sein mögen (s. das.), siedeln sich auf Stengel, Blatt und Blüte an; Engerlinge, Drahtwïrmer und andere Insektenlarven zehren an den Wnrzeln, und von den Frïchten nähren sich Getreidelanfkäfer, Hamster und Feldmaus. Selbst in der sicheren Scheune oder auf dem Kornboden stellen sich oft noch zahlreiche ungebetene Gäste ein, von denen besonder's Mäuse, sowie der weiße und schwarze Kornwurm großen Schaden anrichten können (s. Lehrbuch der Zoologie.).

\section{Andere Getreidearten, Zuckerrohr und Bambus.}

1. Nächst dem Roggen ist der Weizen (Tríticum vulgáre) unsere wichtigste Getreideart. Soweit es Boden und Klima (s. S. 248) nur erlauben, wird er in ganz Europa, sodann aber besonders in Nordamerika und Ostindien angebaut. Er liefert ein sehr feines, weißes Mehl, das, wie bekannt, besonders zu Weißbrot und allerlei feinem Backwerk verwandt wird. Anch gewinnt man aus den Weizenkörnern die Stärke, die n. a. zum Stärken der Wäsche in Gebrauch ist. Von den zahlreichen Spielarten der wichtigen Pflanze treffen wir auf unsern Feldern am häufigsten den unbegrannten Kolben- und den begrannten Bartweizell. -- In Süddentschland und der Schweiz wird hier und da eine andere Weizenart, der Spelt, Spelz oder Dinkel (T. spelta) gebaut, der mit weniger gutem Boden und geringerer Sommerwärme fürlieb nimmt, und bei dem die Ährchen in verhältnismäßig großen Zwischenräumen an der Achse stehen. Wie beim wilden Roggen zerbricht die Ährenachse bei der Reife, und die Körner bleiben von den Spelzen (Name!) umhïllt. Das unreife, gedörrte und von den Spelzen befreite Spelzkorn liefert das "Grïnkorn" oder den "Grünkern" des Handels. 
Wie der Roggen stellt die Gerste (Hórdeum satívum) an die Sommerwärme nur geringe Ansprï̈che. Sie dringt daher gleichfalls weit nach Norden vor. Im Gegensatz zu jener Pflanze (und dem Weizen) stehen bei ihr aber auf jedem Absatze der Ährenachse 3 einblütige Älırchen. Daher sind anch die Körner bei der Reife in 6 Zeilen geordnet. Dentlich ausgeprägt ist dies jedoch nur bei der sechszeiligen G. Greifen die Seitenzeilen ineinander, so haben wir die Verhältnisse, wie sie die vierzeilige G. zeigt. Bei der zweizeiligen G. dagegen ist nur das mittlere der 3 Ährchen fruchtbar. Diese Spielart besitzt daher sehr große, wohlansgebildete Frïchte, die besonders bei der Bierbranerei zur Gewinnung des Malzes verwendet werden. Ferner dienen die Gerstenkörner, die zumeist von den Blïtenspelzen umhüllt aus den Ähren

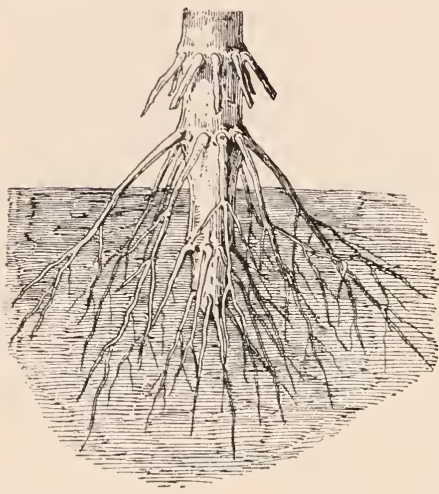

Unterer Teil des Maisstengels mit zahlreichen stützwurzeln (verkl.). fallen, zur Herstellung von Graupen und Gries, und endlich werden sie anch als Futter für die Haustiere hochgeschätzt.

Der Hafer (Avéna satíva) unterscheidet sich von den anderen Getreidearten wesentlich durch den Blïtenstand. der eine sog. Rispe darstellt. Am oberen Teile des Halmes gehen nämlich von den Knoten zahlreiche Nebenstengel aus, die sich zumeist nochmals verzweigen und an den Enden je ein Ährchen tragen. Die von den Spelzen umhüllt bleibenden Körner dienen besonders als Pferdefutter, werden jedoch auch enthülst und geschroten (Hafergrütze) in Breiform vom Menschen verzehrt.

Während die Heimat der genannten Getreidearten wie die des Roggens in den Ländern um das Mittelmeer zu suchen ist, stammt die Hirse (Pánicum miliáceum) wahrscheinlich aus dem mittleren Asien. Ihre Körner sind zwar nur klein; dafür bringt aber die große, einseitig überhängende Rispe deren sehr viele hervor. Sie werden bei uns besonders als Futter für das Hansgeflügel benutzt, finden aber auch als Speise für den Menschen Verwendung.

Der Iais (Zea mays) ist im tropischen Amerika heimisch, wird jetzt aber in allen warmen Ländern, sowie in den milderen Gegenden der gemäßigten Zonen angebaut. Da die wenigen, im Erdboden zur Ausbildung gelangenden Wurzeln die oft mehrere Meter hohe Pflanze nicht zu halten vermögen, brechen aus den unteren Knoten des markhaltigen Stengels seilartige Stïtzwurzeln hervor, dringen in den Boden ein und verzweigen sich daselbst vielfach (vgl. mit einem Fahnenmaste, der durch Tane gehalten wird). Im Gegensatz zu unsern einheimischen und angebauten Gräsern ist der Mais ein einhäusiges Gewächs (s. S. 166, a). Auf dem Gipfel des Stengels erheben sich die zu 
einer großen Rispe geordneten Staubblüten, während die Stempelblüten zu dicken Kolben zusammengedrängt sind. Die Kolben entspringen aus den Blattwinkeln und sind von zahlreichen Blättern unhï̈llt, die den zarten Bliiten den nötigen Schntz gewähren. Da aber die Narben dem Winde ansgesezt sein müssen (warum?), sind diefadenförmigen Griffel von außerordentlicher Länge. Sie treten an der Spitze der Hülle in Form eines Büschels ins Freie. Die großen, meist gelben Früchte werden als Futter für die Hanstiere hoch geschätzt, dienen aber geröstet oder gekocht in siödlichen Ländern auch dem Ilenschen zur Speise. Aus dem Maismehl bereitet der Italiener seine "Polenta", einen Brei, der den ärmeren Volksschichten zur täglichen Nahrnng dient. Bei uns koumt das Melil unter verschiedenen Namen (z. B. als MLondamin) in den Handel und wird vornehmlich zur Herstellung süßer Speisen verwendet. In Mitteleuropa werden die Samen vielfach nicht oder nur ungenügend reif; hier wird die hohe, saftige Pflanze daher besonders als Grïnfutter angebaut.

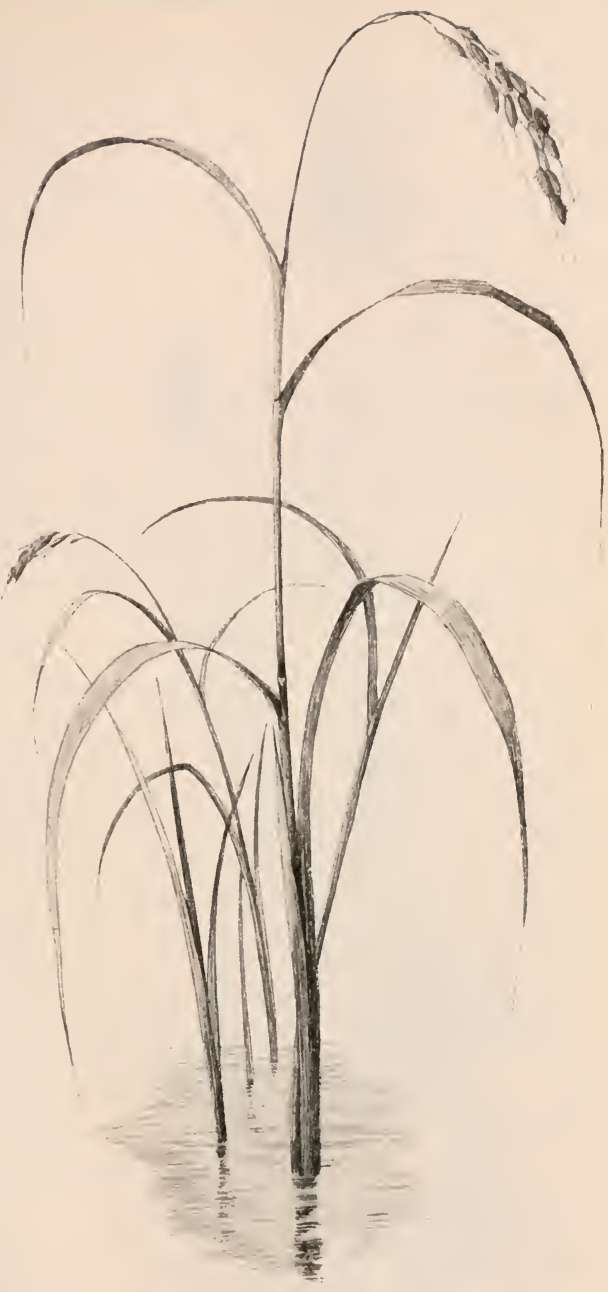

Reispflanzen mit fast reifen Körnern (etwa 12 nat. (ir.

Der Reis (Orýza sativa) nimmt unter allen Getreidearten insofern den ersten Rang ein, als sich von seinen Frïchten bei weitem die meisten Menschen ernähren. Er ist ein Rispengras wio der Hafer, erreicht eine Höhe ron 1,50 m 


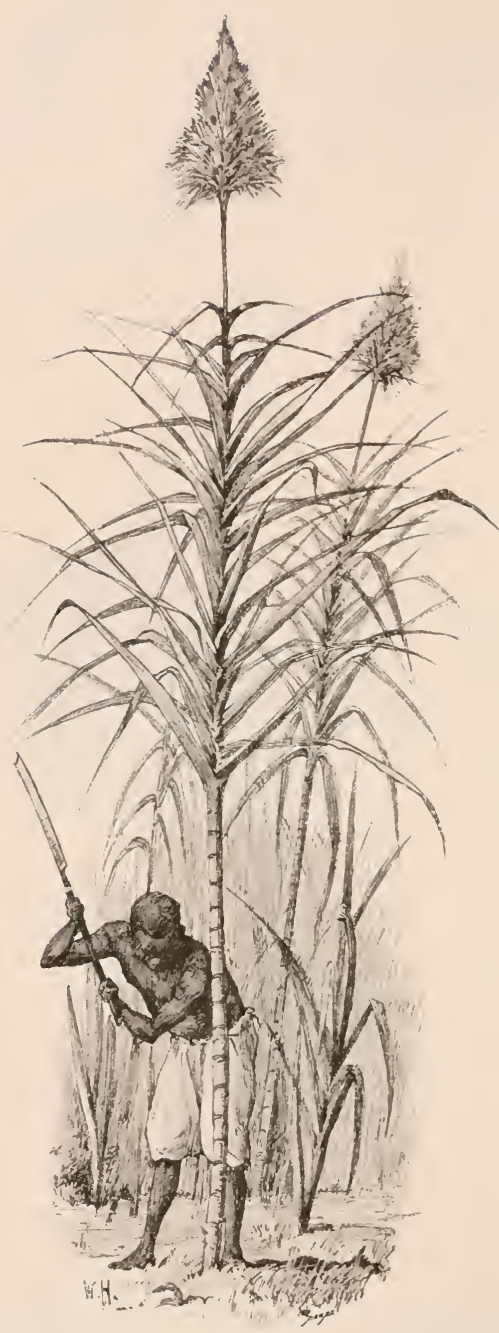

Zuckerrohr, blühend. (Etwa ${ }^{1} 30$ nat. (ir.) und hat sich von Ostindien und dem tropischen Afrika aus über alle heißen und warmen Länder verbreitet. Anch im südlichen Europa wird er mit Erfolg angebaut. Da er eine Sumpfpflanze ist, gedeiht er besonders in Niederungen, die regelmäßig überschwemmt, dadurch aber anch vielfach zu Herden der gefürchteten Sumpffieber werden. Die zu uns in den Handel kommenden Körner sind von den Spelzen befreit und durch ein besonderes Mahlverfahren poliert. Wie aus den Kartoffelknollen und Weizenkörnern bereitet man aus ihnen eine wertvolle Stärke; durch Gärung liefern sie ein alkoholisches Getränk, den Arak.

2. Im Anschln $B$ an die Getreidearten sind noch 2 Gräser zu erwähnen, die gleichfalls für den Menschen eine hohe Bedeutung erlangt haben : das Znckerund das Bambusrohr. Das Zuckerrohr (Sáccharum officinárum), dessen Heimat wahrscheinlich in Ostindien zu suchen ist, wird in allen Tropenländern angebant. Ein Zuckerrohrfeld gleicht einem gewaltigen Schilfdickicht. Aus dem ausdanernden Wurzelstocke erheben sich zahlreiche markhaltige Stengel, die bei $2-5 \mathrm{~cm}$ Stärke eine Höhe von $6 \mathrm{~m}$ erreichen können und je eine endständige Bliitenrispe tragen. Da die älteren Blätter abfallen und die Blattscheiden Narben zurïcklassen, so erscheinen die Stengel am unteren Teile deutlich geringelt. Haben 
die Pflanzen ihre volle Größe erreicht, so beginnt die Ernte. Arbeiter schlagen mit großen Messern die Pflanzen dicht ïber dem Boden ab und entfernen die Blätter, sowie die wenig Mark enthaltende Spitze. Die so zubereiteten Stengel werden zur Fabrik gebracht und kommen zwischen schwere, eiserne Walzen, die das Mark zerquetschen. Der Zuckersaft, der bis $20 \%$ Rohrzucker enthält, fließt in gelblichem Strome in große Gefäße und wird sodann wie der Saft der Zuckerrübe weiter verarbeitet. I us den zuckerreichen Rïckständen gewinnt man durch Gärung den Rum.

3. Die Bambusariiser (Bambriseae) sind in zahlreichen Arten über die ganze Tropenzone verbreitet. Es sind große, oft riesige, ausdauernde Gewächse, die eine Höhe von $40 \mathrm{~m}$ erreichen können und oft weite Landstriche mit dichtem Walde bedecken. Ihre Verwendung ist in den einzelnen Ländern sehr verschieden. Die dicken Halme dienen zum Bau von Hänsern, Hütten und Brücken, zur Herstellung von Wasserleitungen, Flößen u. s. w. Die dünneren Stengel werden als Stützen, Stangen und Mastbäume verwendet; man verfertigt aus ihnen Möbel, Mnsikinstrumente und hunderterlei andere Gegenstände. Schenkelstarke Halmglieder dienen als Wassereimer, kleinere als Becher, Flaschen n. dgl. Aus den knotigen, zähen Ausläufern stellt man die Spazierstöcke her, die bei nns vielfach im Gebrauch sind; die jungen Triebe liefern ein schmackhaftes Gemüse; kurz: es ist nicht zu viel gesagt, wenn man behauptet, daß das Bambusrohr für viele Völker, besonders in Indien und Ostasien, geradezu unentbehrlich ist.

\section{Einheimische Gräser.}

1. Verbreitung der Gräser. Wo wir nns bei einem Gange durch die heimische Natur anch binwenden mögen, überall treten uns Gräser entgegen. Sie bedecken als Getreide einen großen Teil des Feldes; sie bilden die weiten Wiesen- nnd Weideflächen der Niedernngen und Berghänge; sie bewohnen den schwankenden Sumpfboden, wie den hartgetretenen Wegrand; sie gedeihen im kühlen Waldesschatten, wie auf sonnverbrannter Heide; sie nmkränzen in mächtigen Beständen unsere Gewässer und haben auf öder Düne mit Sturm, Sonnenbrand und Dürre einen harten Kampf zu bestehen. Wie bei uns, so ist es auch in allen anderen Ländern der Erde. Soweit das Auge reicht, erblickt man oft fast nichts weiter als Gräser. Man denke nur an die schier unermeßlichen Steppengebiete, wie sie sich in allen Erdteilen finden, an die Pußten Ungarns, an die Pampas und Ljanos Südamerikas, an die Prärien Nordamerikas und wie die „Graswüsten“ alle heißen mögen. Kurz: Die Gräser sind diejenigen Gewächse, die von allen Pflanzenfamilien den größten Teil der Erdoberfläche bedecken.

2. Wiesen und Weiden. Abgesehen von den Getreidefeldern treten uns in der heimatlichen Natur die Gräser besonders auf Wiesen und Weiden in großen Beständen entgegen.

a) Während die Getreidegräser nur ein oder zwei Jahre leben, sind dic Wiesengräser, die ja bleibende Bestände bilden, ausdauerude Ptlanzen.

b) Geht bei den ausdanernden Gräseru die Bestockung so vor sich, wie wir sie beim Roggen kennen gelernt haben, so bilden sich wie dort größere 
oder kleinere "Grasbüsche“, die durch Zwischenränme voneinander getrennt bleiben. Solche Gräser sind also nicht imstande, eine zusammenhängende Grasfläche zu bilden. Wie sich die Wiesengräser bestocken, zeigt uns sehr deutlich die weiter unten erwähnte Quecke. Aus den nntersten Halmknoten brechen zwar gleichfalls Zweige hervor. Sie richten sich jedoch nicht sofort auf, wie dies beim Roggen geschieht, sondern kriechen weit unter der Erdoberfläche dahin, verzweigen sich vielfach und nehmen von allen noch freien Ränmen im Boden Besitz. Aus den Knoten dieser "A usläufer" brechen nun zahlreiche oberirdische Zweige hervor, die entweder nur Blätter oder Blätter und Blïten tragen. Auf diese Weise entsteht die sog. Grasnarbe, das "Grundgewebe" des Wiesenteppichs, in das alle anderen Pflanzen der Wiese (nenne solche!) gleichsam eingeflochten sind.

c) Unsere Wiesen werden im Jahre gewöhnlich ein- oder zweimal gemäht, eine Arbeit, die auf den Weiden die Weidetiere gleichsam selbst besorgen (beschreibe den Verlauf der Hen- und Grummeternte!). Außer den Wiesenpflanzen dürfte es wohl nur noch wenige Gewächse geben, die eine solche beständige Verstümmelung zu ertragen vermöchten. Kaum abgemäht, sprießt das Gras aber von nenem hervor. Já, es erhält sich zumeist ganz allein durch fortgesetzte Sprossung; denn bevor es noch die Samen reifen kann, fällt es zumeist schon der Sense zum Opfer. Die große Widerstandsfähigkeit gegen Verstümmelungen und das hohe Sprossungsvermägon der Gräser sind also weitere Vorbedingungen für das Vorhandensein der Wiesen und Weiden. Wie in unserer Heimat, liefern aber auch in allen anderen Ländern die weiten Grasflächen den Hanstieren ausschließlich oder vorwiegend die Nahrung. Auf den unscheinbaren Gräsern ruhen also in erster Linie Ackerbau (Getreidegräser!) und Viehzucht, die beide wieder den Anfang und die Grundlage aller menschlichen Kultur bilden.

3. Die wichtigsten und häufigsten Arten. Gehen wir zur Zeit der Grasblüte durch Wiese, Feld und Wald, so staunen wir über die groBe Mannigfaltigkeit, die unter den Gräsern herrscht. Wir können daher hier nur die Formen kurz betrachten, die uns am hänfigsten entgegen treten und als Wiesengräser, Unkränter $\mathbf{u}$. dgl. für den Menschen von Bedeutung sind. Der Übersichtlichkeit wegen wollen wir sie wieder in 3 Gruppen ordnen:

a) Ährengräser (Ährchen sitzend oder karz gestielt, eine einfache oder zasammengesetzte Ähre bildend). Als eines der bekanntesten, wildwachsenden Gräser sei zaerst die Quecke (Agropýrum repens) erwähnt, die auf Äckern und Feldern ein überans lästiges Unkrant bildet, aber auch an Wegen und Hecken überall bänfig anzutreffen ist. Die Spitzen der Ausläufer sind durch starre, schuppenartige Blätter geschützt, so daß die Pflanze damit selbst Kartoffelknollen, ja sogar starke Baumwarzeln zu durchbohren and mithin auch von hartem Boden Besitz zu ergreifen vermag. Die Ährchen stehen an der wellenförmig gebogenen Achse ziemlich entfernt and wenden ihr die Breitseite zu. - Durch dieses Merkmal ist die Quecke leicht von dem ziemlich ähnlichen TaumelLolch (Lólium temuléntum) zu unterscheiden, bei dem die Ährchen der Achse die Schmalseite zakehren. Die Pflanze findet sich gleichfalls anter dem Getreide. Da sie 


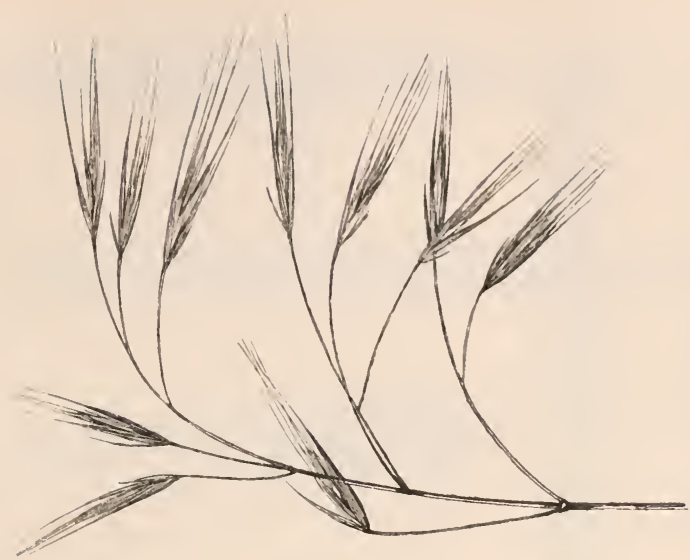

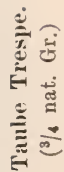

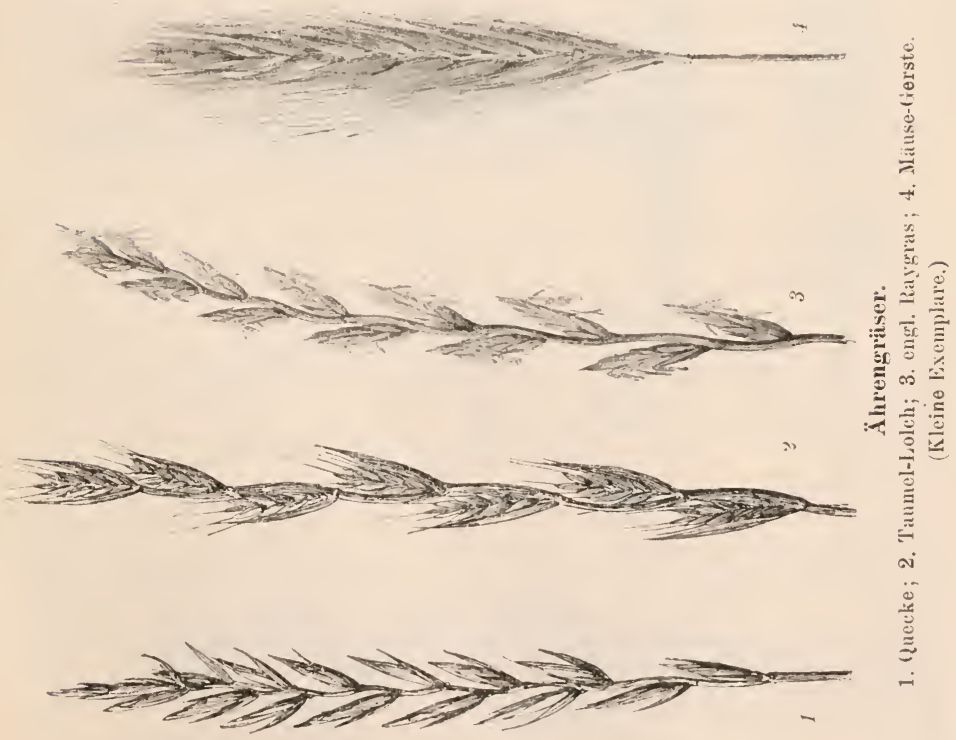



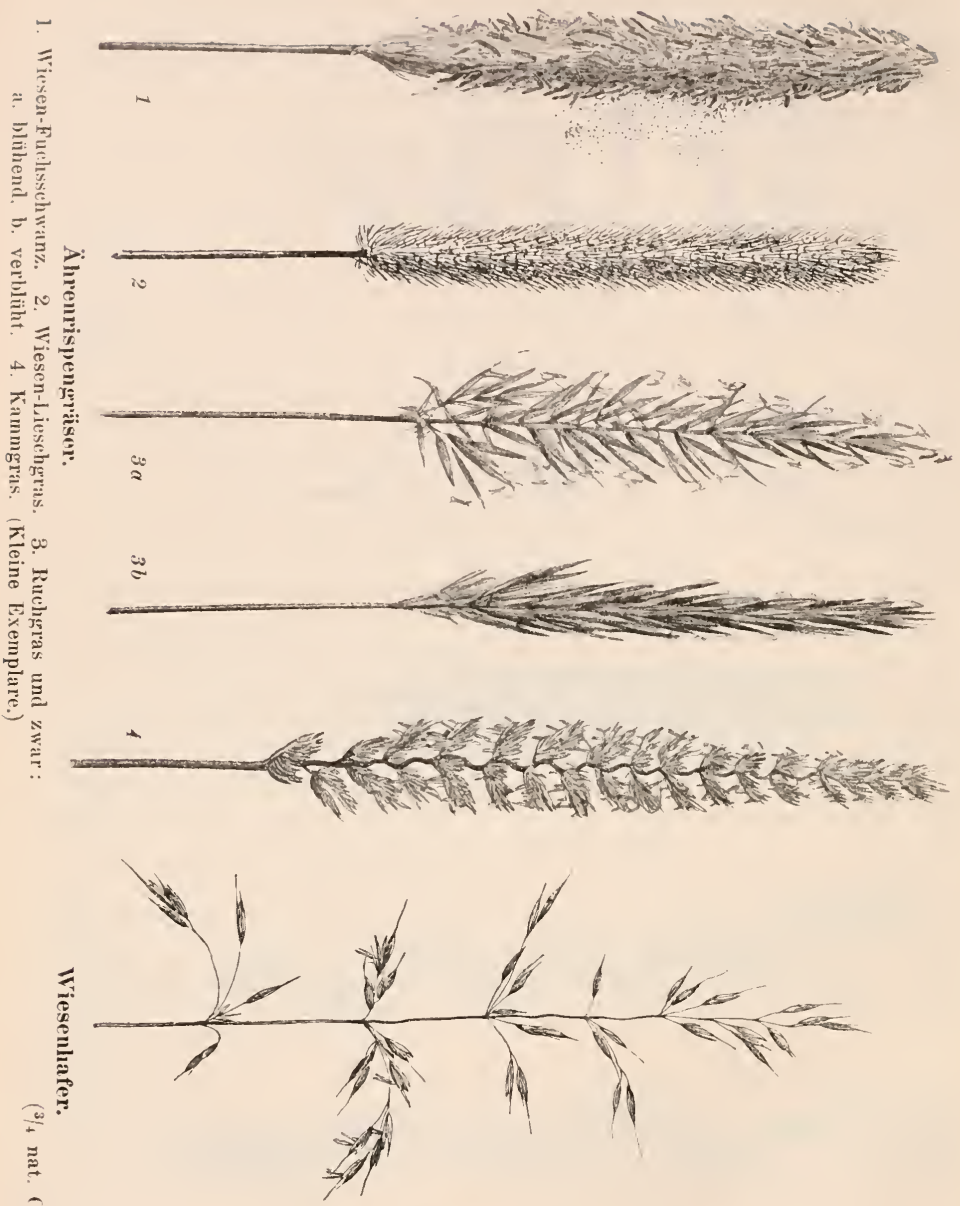

$\overrightarrow{3}$

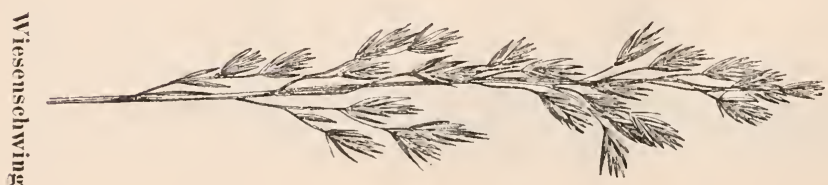


aber einjährig ist (keine Ausläufer!), richtet sie nur wenig Schaden an. Beachtenswert ist sie jedoch durch ihre Körner, die beim Menschen Vergiftungserscheinungen hervorrufen. (Name!) - Der nächste Verwandte des Lolchs ist das englische Raywras (L. perénne) mit sehr ähnlichen, aber zierlicheren Ähren. Da es dichte Rasen bildet, ist es ein wertvolles Futtergras, das auch (namentlich in England; Artname!) gern znr Anlegung von Gras-Beeten verwendet wird. - An Wegen und Mauern findet sich häufig ein Gras, das der angebauten Gerste sehr ähnlich ist, die Mäıse-Gerste (Hórdenm murinum).

b) Ä hrenrispengräser (Ährchen zu meh. reren auf verästelten Stielen, eine ährenförmige Rispe bildend. Dies ist meist erst beim Umbiegen des Blütenstandes zu erkennen!). Der WiesenFuchsschwanz (Alopecúras praténsis), der den Gattungsnamen nach dem kurzen, walzenförmigen Blütenstande trägt, ist eines unserer wichtigsten Wiesengräser. - Dasselbe gilt von dem WiesenLiesehgrase oder Timotheusgrase (Phléum praténse). Sein Blätenstand ist dem der vorigen Art fast gleich, aber länger and dünner, einem kleinen Zylinderputzer ganz ähnlich. - Das Ruchgras (Anthoxánthum odorátum) dagegen bildet nur niedere Rasen. Es verleiht (Name!) dem Hen den würzigen Duft des Waldmeisters, der aber wie bei dieser Pllanze den Weidetieren zuwider ist. Während des Blühens spreizen die Ährchen von der Ährenachse ab, so daB dem Winde ein besserer Zagang zu den Staubbeuteln und Narben geschaffen ist (Bedentung? Beobachte daranfhin auch andere Gräser!) Durch das Einatmen des Blütenstaubes entsteht bei dafür empfänglichen Leuten das sog. Heufieber. - An den kammartigen Ährchen ist leicht das Kammgras (Cynosúrus cristátus) zu erkennen. - Eine ungemein wichtige Pflanze für die Bewohner unserer Meeresküsten ist der Strandhafer (Ammóphila arenária), der dem Sande der Dünen Leben verleiht. Obgleich der Boden, dem das Gras entsprießt, auBerordentlich trocken ist, vermag es ihm loch genügend Nahrung und Wasser zn entziehen; denn es besitzt einen mehrere Meter langen,
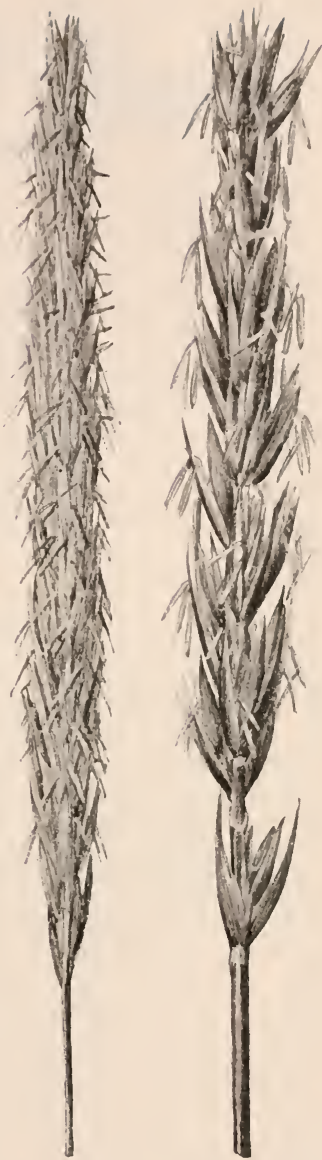

Strandhafer. Strandroggen. (Kleine Exemplare.) vielfach verzweigten Warzelstock, der samt den zahlreichen Wurzeln den Sand nach allen Richtungen durchzieht. Hierdurch erhält die lockere Sandmasse einen festen Halt, so daB sie selbst den heftigsten Angriffe der Stürme und dem donnernden Anprall der Wogen zu widerstehen vermag. Die Dünen werdeh somit 
gleichsam za Bollwerken, die die Ansiedelnngen unı Felder der Menschen schützen, vom Sande bedeckt und von den Fluten vernichtet zu werden. Darum pflanzt anch der Küstenbewohner die wichtige Pflanze vielfach an und behütet sie wie der Binnenländer das Getreide des Feldes. - Die gleiche Bedeutung hat ein zweites, sehr ähnliches Gras, der Strandroggen (Élymus arenárius), der anch im Binnenlande an sandigen Stellen vorkommt, dessen Blïtenstand aber eine Ähre hildet. (Name! Er hätte also eigentlich bei den Ährengräsern erwähnt werden müssen!) Ist der Boden feucht, so breitet sowohl der Strandroggen seine breiten, bellgrünen, als anch der Strandhafer seine schmaleren, dunkelgrünen Blätter flach aus; ist der Sand aber trocken, dann sind die Blätter beider Pflanzen zu langen Röhren zusammengerollt. Durch tiefe Längsfurchen, wie man solche anch an Blättern mehrerer anderer Gräser antrifft, sind sie hierzu wohl befähigt. Welche Bedeutung diese Erscheinung hat, zeigt uns ein einfacher Versuch. Schneiden wir von beiden Pflanzen einige Blätter $a b$, so rollen sie sich nach kurzer Zeit ein. Dadurch verkleinern sie ihre Oberfläche sehr stark, so daß sie jetzt auch nicht mehr soviel Wasser verdunsten wie vordem. Da sich ferner sämtliche Spaltöffnungen auf der Unterseite befinden, jetzt also alle in den windstillen Hohlraum der Röhre münden, so wird durch diese Eimrichtung lie Verdunstung umso mehr eingeschränkt. Steckt man die Blätter darauf ins Wasser, so daß sie jetzt eine solche Ersparnis nicht mehr nötig haben, so breiten sie sich nach knrzer Zeit auch wieder vollkommen aus. Diese Tatsachen erklären uns auch, warum die empfindlichen jungen Blätter beider Pflanzen stets Röhrenform besitzen.

c) R i spengräse $r$ (Blïtenstand wie beim Hafer). Einen wichtigen Bestandteil unserer Wiesen bildet der Wiesenhafer (Arrhenathérum elátius), der seine „haferähnlichen" Rispen oft mehr als meterhoch ïber den Boden erhebt. Die äußere Blïtenspelze der unteren Blïte in jedem Ährchen trägt anf dem Rücken eine lange Granne, die wie die Granne des Reiherschnabels knieförmig gebogen and im unteren Teile korkzieherartig aufgerollt ist. Löst sich das Ährchen bei der Reife los, so wird es wie die Teilfrucht jener Pflanze mit Hilfe dieser Einrichtung in den Boden gebohrt. (Versuch!) - Gleichfalls haferähnlich sind die Trespen (Bromus); sie besitzen aber dicke, lanzettliche Ährchen, deren Kelchspelzen im Gegensatz zum Hafer nicht abspreizen. Mehrere Arten, wie die (S. 265) abgebildete taube T. (B. stérilis), wachsen an unfruchtbaren Stellen, - Durch sehr kleine, meist violett angelaufene Ährchen an haarfeinen Ästen zeichnet sich das Stranßgras (Agróstis vnlgáris) aus. Es überzieht auf Wiesen und Triften, sowie an Acker- nnd Waldränderu vielfach große Strecken wie mit einem zarten Schleier. - Die oft mehr als meterhohe Rasenschmiele (Aira caespitósa) hat eine ähnliche Rispe. Bei ihr sind die Äste aber zumeist bogenförmig abwärts geneigt. Das Wiesenrispengras (Poa praténsis) bildet infolge seiner zahlreichen Auslänfer eine sehr dichte Grasnarbe. Es ist nnser häufigstes Wiesengras, das ein vortreffliches Futter liefert. - Aus knäuelartigen Ährchenmassen besteht die einseitige Rispe des Knäuelgrases (Dáctylis glomeráta). - Auf trockenen Wiesen findet sich hänfig das zierliche Zittergras (Briza média), dessen große, muschelförmige Spelzen wirksame Windfänge für die winzigen Früchte darstellen. - Das Honiggras (Holcus lanátus) ist wollig behaart nnd hat sehr reichblütige, meist rötlich oder violett angelaufene Rispen, die wie beim Ruchgras u. a. während des Blühens stark gespreizt sind. - Dieselbe Erscheinung beobachten wir auch an der einheitswendigen Rispe des Wiesenschwingels (Festúca elátior), das eines unserer besten Wiesengräser darstellt.

Teiche und Seen sind oft von einem weitausgedehnten "Graswalde" unkränzt, 

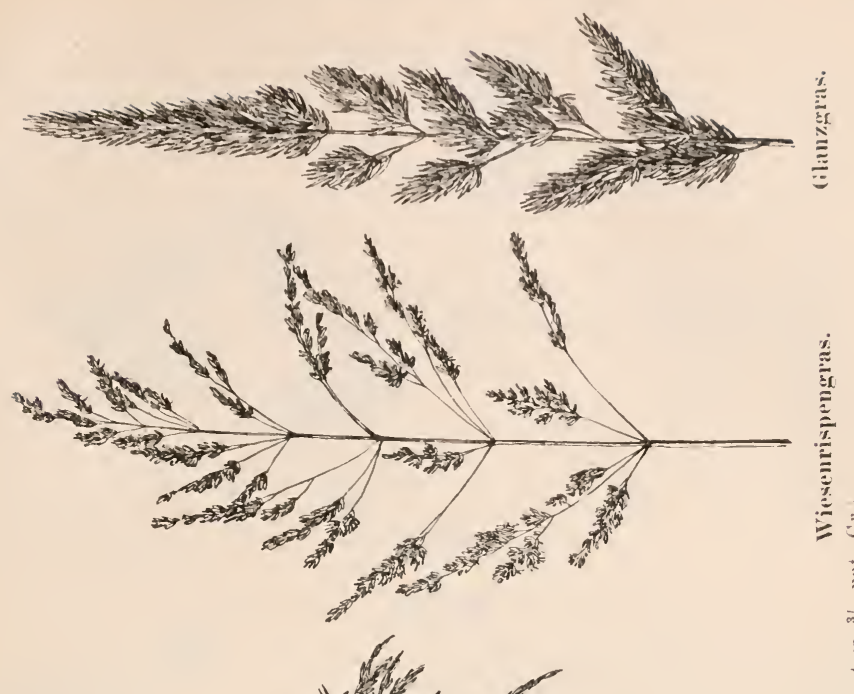

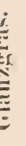

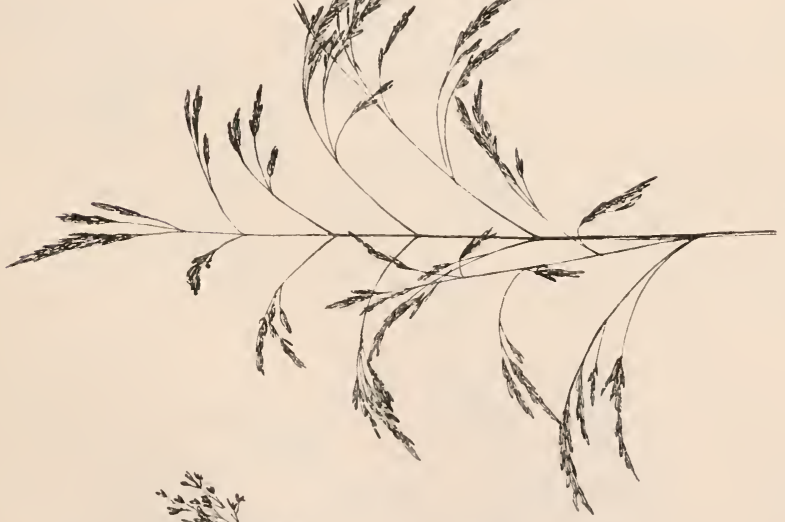

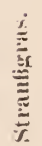

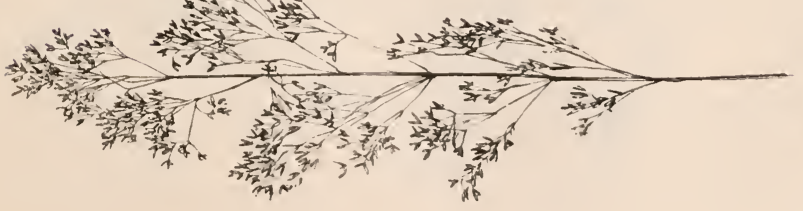



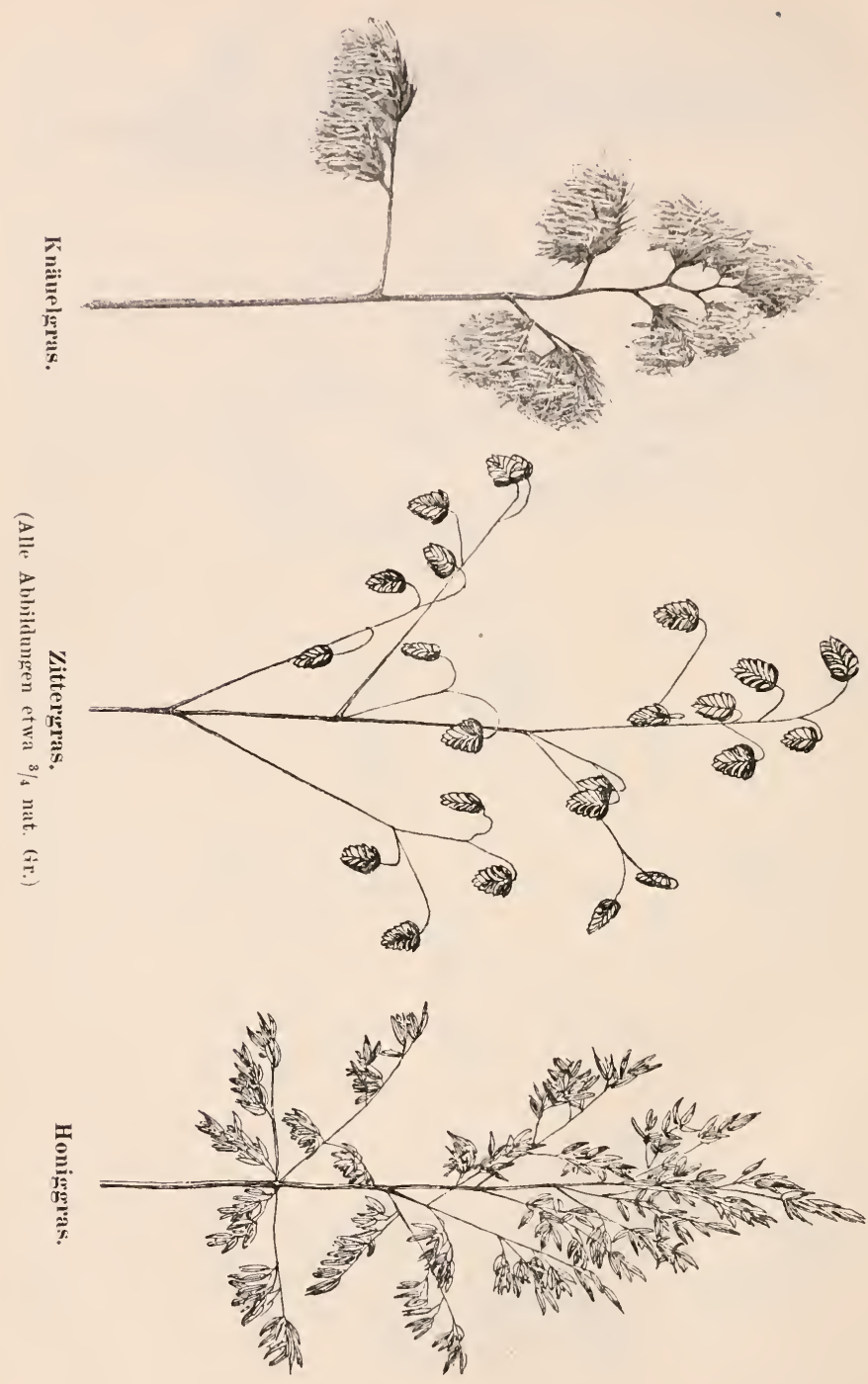
der von dem Schilfe (Phragmítes commúnis) gebildet wird. Mit Hilfe langer Ausläufer dringt das Gras vom Ufer aus bis zu jenen Stellen der Gewässer vor, an denen es infolge geringer Tiefe noch zu leben vermag. Weht ein heftiger Wind, so erscheinen die mächtigen Bestände, als wären sie gekümmt. Da die Innenflächen der Blattscheiden und die Oberseite des Halmes glatt sind, dreht nämlich der Wind die Blätter und stellt sie wie die Wetterfahne auf dem Dache in die Windrichtung. Infolgedessen streift er an ihnen vorbei, so daß der Halm trotz seiner Größe (bis $3 \mathrm{ml}$ und der langen, breiten Blätter selbst vom heftigsten Sturme nicht geknickt wird. Zur Zeit der Fruchtreife sind die Älrchenstiele mit langen, seidenartigen Haaren bedeckt. so daß der Frachtstand einem großen Federballen gleicht. Lösen sich die Ährchen von der Mutterpflanze, so werden sie ein Spiel der Winde. Infolgedessen werden die Früchte leicht über einen weiten Bezirk ausgesät. Bis zur Blütezeit ist von den Haaren nur wenig zu bemerken; sie würden ja auch der Bestäubung nur hinderlich sein. Die langen und festen Halme werden zur Bekleidung von Wänden, zum Berlecken der Dächer, zur Herstellung von allerlei Flechtwerk und dgl. vielfach verwendet. Ein dem Schilfe sehr ähnliches Gras, das sich gleichfalls häufig am Wasser findet, ist das Glanzgras (Phálaris arundinácea). Eine Spielart von ihnı mit weiß-grün gestreiften Blättern wird als . Bandgras ${ }^{\iota}$ gern als Zierpflanze gezogen.

\section{Familie. Riedgräser (Cyperáceae).}

Die Riedgräser sind grasartige Pflanzen („Schein- oder Halbgräser“), die sich mit den echten Gräsern besonders auf sumpfigem, moorigem oder sog. sauerem Boden ( gräser $\left.{ }^{4}\right)$ an der Bildung der Wiesen beteiligen. Da sie aber scharfschneidende Blätter besitzen, die von den Weidetieren vielfach verschmäht werden (Schutzmittel der Pflanzen!), so liefern "saure Wiesen" nur ein schlechtes Futter. Zahlreiche andere Riedgräser lieben wieder den wasserarmen Sandboden.

Die Merkmale, durch die sich die Riedgräser von den echten Gräsern unterscheiden, wollen wir an den Seggen (Carex) kennen lernell, einer Gattung, deren zahlreiche, schwer unterscheidbare Arten überall anzutreffen sind. Wír finden bei ihnen meist einen dreikantigen, knotenlosen Stengel, an dem die Blätter in 3 Zeilen angeordnet sind. Die Blattscheiden sind geschlossen und ohne Blattbäutchen. Die Ährchen sind ans Staub- oder Stempelblüten oder ans beiden Blütenarten zusammengesetzt. Diø Blüten sind unscheinbare Gebilde, die dementsprechend durch Vermittlung des Windes bestäubt werden (weise im einzelnen nach, wie sie hierza eingerichtet sind!) Die Stempelblüten, die nur aus einem Fruchtknoten und einem Griffel mit 2 oder 3 Narben bestehen, sind gleich der Frucht von einem schlauchförmigen Blatte schützend umgeben. Zahlreiche Seggen treiben Ausläufer und tragen daher auf Sandfeldern und Dünen zur Bindung des Flugsandes bei. Dies zeigt z. B. deutlich die Sand-S. (C. arenária), deren Warzelstock meterweit im Boden dahinkriecht. Da er nun hierbei eine gerade Linie einhält, so stehen die aus den Knoten sich erhebenden oberirdischen Triebe so regelmäBig, als wären sie vom Menschen in eine Reihe gepflanzt.

Die übrigen Glieder der Familie haben im Gegensatz zn den Seggen Blüten, die eines ${ }_{n}$ Schlauches ${ }^{4}$ entbehrea und beiderlei Befruchtungswerkzenge einschlieBen. Dies zeigen z. B. die Simsen (Scirpus), die in zahlreichen Formen auf sumpfigen, torfigen Wiesen, an den Ufern der Gewässer und anderen feuchten Stellen anzutreffen sind. Sie ähneln bis auf den Bau der Blüte ganz den Binsen, mit denen sie unter gleichen Lebens- 
bedingungen wachsen (Beweis!). Torfwiesen bewohnt auch das zierliche Wollgras (Erióphorum). Nach der Bestäubung (warum erst dann?) verlängert sich die aus seiden-

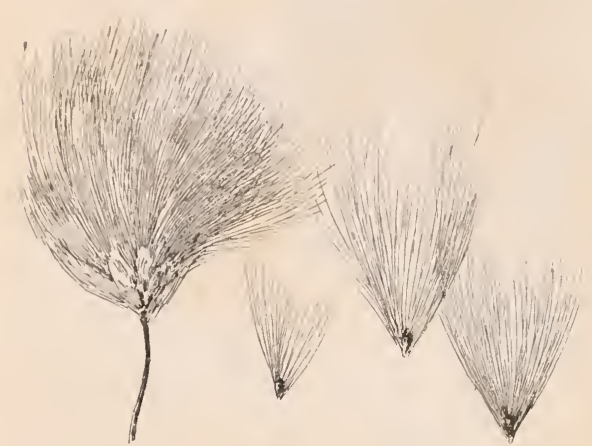

Fruchtahrohen des Wollgrases, ron dem der Wind soelren einige Früchte verweht (nat. (ir.). artigen Haaren bestehende Blütenhülle, so daL jedes Ährchen einen kleinen Wollbüschel darstellt. Zugleich strecken sich auch die Ährchenstiele stark in die Länge. Daher werden die reifen, winzigen Früchte vom Winde leicht losgerissen und wie ein Federball ein Spiel der Lüfte (Bedeutung?). - Ein Riedgras ist auch die im Altertum so hochberühmte Papierstaude (r'ýperus papýrus), die namentlich in Agypten angebant wurde und unserem Papier den Namen gegeben hat. Es ist eine Sumpfpflanze, deren

1-3 m hoher Halm von einem grofen, doldenförmigen Blütenstande gekrönt wird. Zum Zwecke der Papierbereitung schlitzte man den Halm auf und klebte die einzelnen Häute und Fasern in noch feuchtem Zustande aneinander.

\section{Familie. Knabenkrautgewächse oder Orchideen (Orchidáceae.)}

Blüte seitlich symmetrisch. Blütenhülle aus 2 gleichen, dreiblättrigen Kreisen. Meist nur ein Staubblatt, das sich mit der Narbe auf einem Fortsatze des unterständigen Fruchtknotens, dem sog. Säulchen, befindet. Fruchtknoten meist einfächerig. Frncht kapselartig mit sehr zahlreichen, äußerst kleinen Samen.

\section{Das gefleckte Knabenkraut oder die FJecken-0rchis (Orchis maculáta).}

Taf. 34.

A. Eine Frühlingspflanze feuchter Wiesen. Wenn auf feuchten Wiesen das Gras zu sprießen beginnt, kommt auch das Knabenkraut zum Lichte hervor. Es vermag so zeitig zu erscheinen, weil ihm wie dem Scharbockskraute (s. das.) und anderen Frühlingspflanzen Stoffe zum schnellen Aufbau der oberirdischen Teile zur Verfügung stehen. Diese Stoffe sind in einer

1. Knolle aufgespeichert, einem Gebilde, das infolge seiner eigentümlichen Form von jeher die Aufmerksamkeit der Menschen auf sich gezogen hat. Weil es allerlei Segen über den Besitzer bringen sollte, bezeichnete man es als "Christus-, Marien- oder Glückshändchen." Die dunklen Knollen (s. Absch. b) dagegen galten als "Teufelshände nnd Satansfinger".

a) Die Baustoffe sind in den Knollen besonders als Stärke (Jodprobe; (s. S. 138, d) and Pflanzenschleim aufgespeichert und zwar in so großen Mengen, 


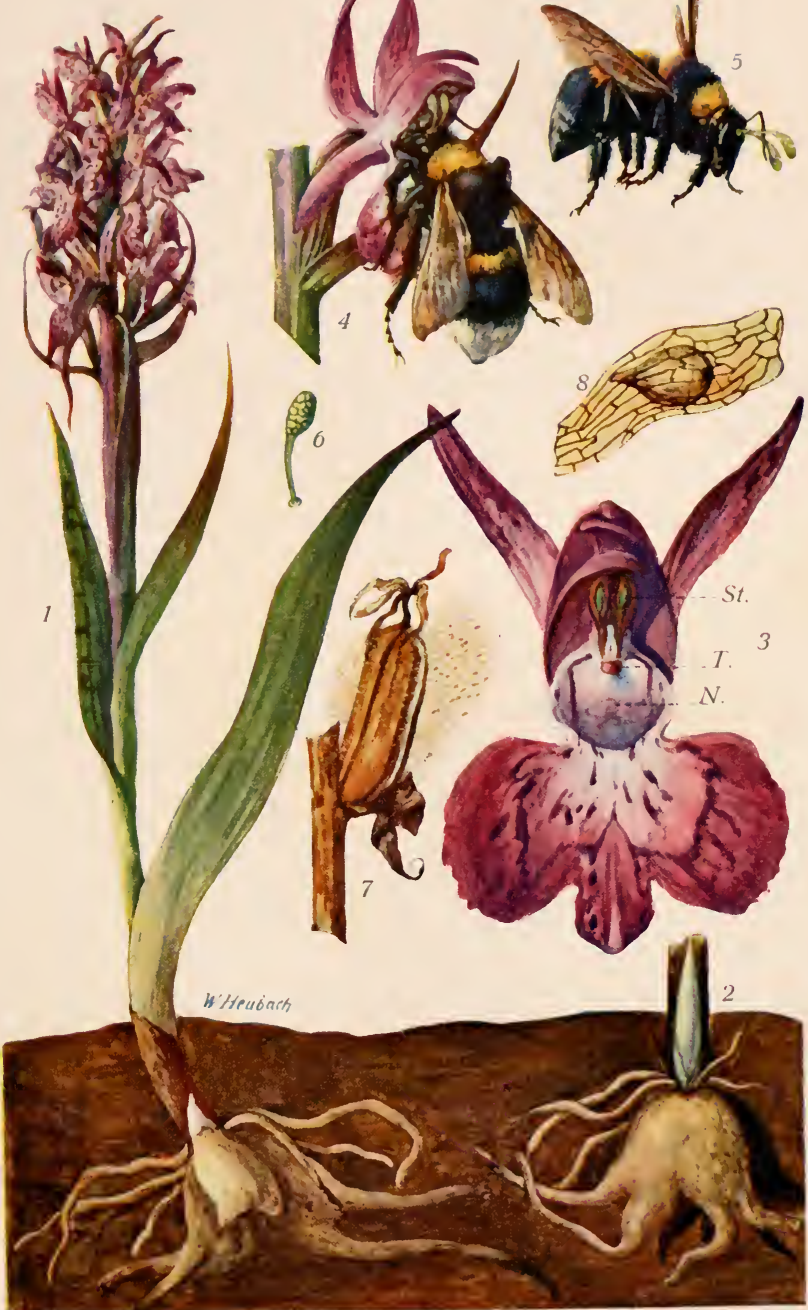

Geflecktes Knabenkraut oder Flecken-Orchis (Orchis maculata). 

daß man aus ihnen ein nahrhaftes, schleimiges Heilmittel, den Salep, herstellen kann. (Zur Gewinnung dieses Stoffes dienen aber zumeist andere und zwar vorwiegend ansländische Arten der Familie.)

b) Gräbt man die Pflanze im zeitigen Frühjahre aus dem Boden, so findet man in der Achsel eines der häutigen Hüllblätter, die den jungen, oberirdischen Trieb umgeben, eine Knospe. Sie treibt einige Wurzeln, die das Hüllblatt durchbrechen und zu einer kleinen Knolle von der Form der "alten" anschwellen. Zur Blütezeit (1) hat sich das Knöllchen schon merklich vergrößert, wïhrend die alte Knolle braun geworden und etwas verschrumpft ist. Intersucht man die Pflanze etwa zur Zeit der Fruchtreife wieder (2), so ist die .junge" Knolle zur Größe der alten herangewachsen, die jetzt dunkelbrann und noch melrr verschrumpft ist. Gräbt man nun endlich nochmals nach, wenn der Herbst ins Land zieht, so ist die "alte" Knolle abgestoßen nnd in Verwesung begriffen. Diese Erscheinungen sind also genau dieselben, wie wir sie an der Kartoffelknolle verstehen gelernt haben, nur daß hier die Bildnng der jungen Knolle in unmittelbarer Nahe der alten erfolgt. Wir haben hier also - kurz gesagt - folgenden Vorgang: während sich aus den Vorratsstoffen, die in der Knolle aufgespeichert sind, die oberirdischen Teile aufbanen, bildet sich an ihr eine „Ersatzknolle" für das nächste Jahr. Als ein für die Pflanze wertloses Gebilde geht die alte Knolle schließlich zu Grunde. An ihre Stelle ist die nene getreten, die prall mit Baustoffen für das kommende Jahr gefïllt ist.

2. Stengel und Blätter. a) In dem Maße, in dem sich die Wurzeln zu der Ersatzknolle ausbilden, vergrößert sich auch die Knospe, aus der die Wurzeln hervorbrechen (1 und 2). Anfangs ist sie noch von dem Hüllblatte, in dessen Achsel sie entsteht, schützend bedeckt (in Fig. 1 ist dieses Blatt entfernt, um die Knospe zu zeigen). Mit dem Verwesen der Hüllblätter wird sie aber frei und stellt jetzt

b) einen kegelförmigen Trieb (2) dar, der selbst die Grasdecke der Wiese leicht zu durchbrechen vermag (vgl. mit Tulpe und Maiblume!). Als Schutzmittel gegen Verletzungen dient ihm eine Scheide

c) farbloser Ḧ̈llblätter, die später braun werden und schließlich verwesen (1.). Hat der Trieb die Erdoberfläche erreicht, so stellen die Hüllblätter das Wachstum ein und werden von den eingeschlossenen Teilen auseinander gedrängt.

d) Am Ende des massiven Stengels findet sich der Blïtenstand, der bisher von den kegelförmig znsammengeneigten Blättern überdeckt war (vgl. mit Tulpe). Da die Blïten den Blicken der Insekten ansgesetzt sein mïssen, streckt sich der Stengel so hoch, wie es das mitwachsende Gras erfordert. (Vgl. dag. Scharbockskraut und Herbstzeitlose, die an demselben Standorte wachsen!)

e) Die Blätter ähneln nach Form und Stellung ganz denen der Tulpe. Sie sind auch wie die Tulpenblätter vollkommen kahl; denn da sie vou der fenchten Frühlingsluft umflutet werden, und da der nasse Wiesengrund Wasser 
zur Genïge liefert, können sie z. B. des schïtzenden Haarkleides entbehren, das wir bei zablreichen Sommer- und Trockenlandpflanzen finden (Beispiel!).

Sie zeichnen sich aber vor den Tulpenblättern meist durch den Besitz schwarzbrauner Flecken aus (Artname!), eine Erscheinung, die gleichfalls mit dem feuchten Standorte in Beziehung zu stehen scheint. Da sich nämlich dunkelgefärbte Körper stärker erwärmen als helle — wir brauchen nur an unsere sommerliche Kleidung zu denken, - so wird sich anch ein von der Sonne beschienenes, dunkelgeflecktes Blatt stärker erwärmen als ein sonst gleiches, aber ungeflecktes Blatt. Je höher aber die Temperatur in dem Blatte ist, desto lebhafter wird es auch das von der Wurzel aufgesogene Wasser verdunsten. Da nun mit diesem Wasser beständig Nährstoffe zu den Blüten emporsteigen, so ist eine starke Verdunstung für diejenigen Pflanzen, denen viel Feuchtigkeit zu Gebote steht, sicher von Vorteil. - Die Verhältnisse des Standortes machen uns anch die geringe Ausbildung der

3. W $\mathrm{urzeln}$ verständlich, die am unteren Teile des Stengels entspringen und die Hüllblätter durchbrechen: die wenigen kurzen, unverzweigten, strang-

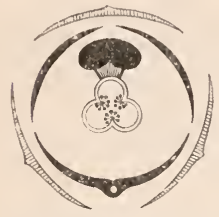

Blïtengrundrił; des Knabenkrautes. artigen Gebilde sind wohl imstande, dem stets feuchten Grunde die nötigen Wassermengen zu entnehmen (vgl. dag. die Trockenlandpflanzen!).

B. Eine Pflanze, die allein durch Insekten bestäubt werden kann.

1. Bl ï te. Die Blüten (1.) nehmen den Endteil des Stengels ein. Sie entspringen ans der Achsel je eines Deckblattes, das ihnen im Knospenzustande als Schutz diente. Der Stiel, auf dem sie sich zu erheben scheinen, ist der unterständige Fruchtknoten. Die Blütenhülle (3.), die in ihren Farben große Verschiedenheiten (lila bis weißlich) aufweist, ist seitlich-symmetrisch (s. S. 30, a) und besteht ans 2 dreiblätterigen Kreisen. Das große mittlere Blatt des äußeren Kreises und die beiden „oberen" Blätter (s. aber Absch. d) des inneren Kreises neigen sich helmförmig zusammen und bilden ein Regendach für die inneren Blïtenteile. Die beiden anderen äußeren Blätter sind langgestreckt, während das untere, innere Blatt eine große dreiteilige, purpur-gefleckte "Unterlippe“ darstellt und in einen langen Sporn ausgezogen ist. Dicht über dem Eingange zum Sporn findet sich auf einem kurzen Fortsatze des Fruclitknotens, dem sog. Säulchen, die große, glänzende Narbe (N.) und darüber das einzige (ansgebildete) Staubblatt (St.). Der Faden des Staubblattes ist mit dem Säulchen so innig verschmolzen, daß nur der Staubbentel sichtbar ist. Er besteht aus உ Fächern, die sich durch einen Längsspalt öffnen. Im Gegensatz zu den meisten anderen Pflanzen, bei denen der Blütenstaub ein feinkörniges Pulver bildet, sind hier stets mehrere Staubkörnchen miteinander verwachsen. Zahlreiche der anf diese Weise entstehenden "Paketchen" sind wieder durch einen Klebstoff zu einem kleinen gestielten 
Kolben (6.) vereinigt, der in einem "Klebscheibch cu" endet. Die Sicheiben beider "Staubkölbchen" sind in einer kleinen "Tasche" (T.) geborgen. 2. Bestäubung. Eine so eigentïmlich gebaute Bliite wird uns wie in allen anderen ähnlichen Fällen nur dadurch verständlich, daß wir ihre Bestäıbung genau verfolgen.

a) Die Blïten sind an sich klein. Da aber viele zu einer ïhre gehäuft sind, werden sie den Insekten wohl auffälig.

b) Die Anfüilligkeit wird vielfach noch dadurch erhöht, daß auch die Deckblätter und der obere Teil des Stengels bunt gefärbt sind (1).

c) Die anfliegenden Insekten - vor allen Dingen sind es Fliegen und Hummeln - finden aut der Unterlippe einen bequemen Sitzplatz (4.). Öffuet uan jedoch einc Bliite, so lange sie sich noch im Knospenzustande befindet, so sieht man, daß dieses Blatt nach oben gerichtet ist, also eine sehr ungünstige Lage hat, um als Sitzplatz für die Bestäuber zu dienen. Es muß daher eine "Korrektur" eintreten :

d) kurz bevor sich die Bliite öffnet, dreht sich der als Stiel dienende Fruchtknoten um $180^{\circ}$ und bringt somit die Blite in die ,richtige" Lage.

e) Zahlreiche, dunkel-purpurrote Flecke und Striche, die alle nach der Öffnung des Spornes hinweisen, bilden vielleicht das ,Saftmal", das dem Blïtengaste zeigt, wo es für ihn etwas zu naschen gibt (s. S. 121, 3).

f) Sobald das Insekt Platz genommen hat, senkt es den Rïssel in den Sporn, der auffallenderweise aber keinen freien Honig enthält. Der in der fleischigen Sporenwand enthaltene sii $B$ e Saft mu von dem Tierchen
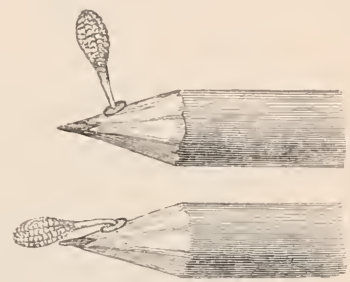

Staublölbchen auf der Spitze eines Bleistiftes. 1 Nach dem Hervorziehen ; 2 einige Minnten darnach. mit Hilfe der Rüsselspitze erst erbohrt werden.

g) Sobald aber das Insekt die zum Sangen notwendige Stellung eingenommen hat, berührt es mit dem Kopfe das "Täschchen", das genau die Blütenmitte einnimmt. Das zarte Häutchen zerreißt infolgedessen, die beiden Klebscheiben werden frei und heften sich dem saugenden Insekt an Stirn oder A agen. Verläßt das Tier daranf die Blüte (4.), so zieht es die beiden Staubkölbchen ans den Staubentelfächern hervor, nnd wie mit 2 Hörnchen geschmïckt, fliegt es davon. Ahmt man diesen Vorgang vielleicht mit Hilfe eines zugespitzten Bleistiftes nach, so sieht man,

h) wie sich die anfangs a ufreht stehenden Kölbchen sehr bald nach vorn herabneigen. Dasselbe geschieht natürlich anch, wenn sie an dem Kopfe eines Insekts kleben (5.). Läßt sich das Tier auf einer zweiten Bliite nieder, so mïssen infolgedessen die Kölbchen gerade die $\Lambda$ a r be ber ii h ren, die sich -ja unterhalb des "Täschchens" befindet: einige Staubkorn-Paketchen bleiben an der klebrigen Narbentläche haften, und - die Bestäubung ist erfolgt. 
C. Eine Pflanze, die durch den Wind verbreitet wird. 1. Durchschneidet man den Fruchtknoten zur Blïtezeit (s. Blïtengrundriß), so sieht man, daß er aus 3 miteinander verwachsenen Blättern besteht, die an den Rändern zahlreiche Samenanlagen tragen. Indem sich bei der Reife diese „Samenträger" von den ïbrigen Teilen der Fruchtblätter ablösen,

2. öffnet sich die Kapsel mit 6 Klappen (7.). Da diese Klappen aber oben und unten vereinigt bleiben, können die Samen nicht auf einmal herausfallen (warum wäre das für die Pflanze von Nachteil?). Wohl aber vermag der Wind durch die Spalten zu streichen,

3. die Samen in kleinen Wolken herauszublasen und weithin zu verwehen. Beides ist umso leichter möglich, als die Samen stanbförmig kleine Gebilde sind. Außerdem umschließt die Samenschale den Keimling wie ein weiter Mantel (8.). Sie bietet dem geschäftigen Winde also eine große Angriffsfläche dar (vgl. mit Löwenzahn).

4. Ein solches Herausblasen der Samen wäre aber bei einer Kapsel, die wie der Fruchtknoten schraubenförmig gedreht ist, nicht möglich (warum nicht?). Wir sehen daher, daß der Fruchtknoten nach erfolgter Bestäubung diese Drehung verliert, sich also wieder gerade streckt (7.).

\section{Andere Knabenkrantgewächse oder Orchideen.}

Die Orchideen gehören wegen des seltsamen Baues der Blüten sicher zu den interessantesten Gliedern der Pflanzenwelt. Viele von ihnen zeichnen sich zudem noch durch Farbenpracht und köstlichen Duft aus. Sie bewohnen die verschiedensten Bodenarten und treten hier in geringerer, dort in gröBerer Anzahl auf. Gegenden mit Kalkboden sind besonders reich daran.

1. In der Gesellschaft der soeben betrachteten Pflanze findet sich das ganz ähnliche breitblättrige Knabenkraut ( 0 . latifólia), das an dem hohlen Stengel leicht zu erkennen ist. - Auf Triften und trockenen Wiesen ist häufig das kleine Salep-K. (0. mório) anzutreffen, das runde Knollen besitzt. - Eine überaus zarte Schattenpflanze (s. S. 7, b und c) ist die Kuckucksblume (Platanthéra bifólia). Die rein-weiße Blütenfarbe, der besonders bei Nacht stark hervortretende Nelkenduft, sowie der lange, enge Sporn lassen uns in ihr leicht eine Nachtfalterblume erkennen (s. S. 39). An denselben Stellen findet sich auch das Zweiblatt (Lístera ováta), dessen unscheinbar grüne, aber sehr honigreiche Blüten besonders durch Schlupfwespen bestäubt werden. Spornlos wie diese Pflanze sind auch die Sumpfwnrz-Arten (Epipáctis), die teils sumpfige Wiesen, teils Wälder, teils den trockensten Sandboden bewohnen. - Die schönste unserer Orchideen ist unstreitig der Frauenschuh (Cypripédium calcéolus), der auf Kalkboden im Schatten des Laubwaldes gedeiht. Er trägt nur wenige, dafür aber umso größere Bläten, deren gelbe Unterlippe einen zierlichen ${ }_{n} \mathrm{Schoh}^{*}$ bildet. - Eine überaus sonderbare Form ist die blasse Nestwurz (Neóttia nidus avis), die im Moder des Waldbodens wurzelt, der Laubblätter entbehrt nnd nur Spuren von Blattgrün besitzt. Gleich der Hopfenseide (s. S. 129) ist sie daher auch nicht imstande, die für das Leben und den Aufbau ihres Körpers nötigen Stoffe zu bereiten. Gräbt man aber nach, so findet man, daB der eigentümlich nestartige Warzelstock (Name!) mit keiner anderen Pflanze in Verbindung steht: das seltsame, gelbe oder bräunliche Gewächs nährt sich von den 
Stoffen, die im Boden schattiger Wälder faulen; es ist also kein Schmarotzer (Parasit) wie die Hopfenseide, sondern ein Fäulnisbewohner (Saprophyt).

2. Wie sich unter dem Einflusse hoher Wärme und groBer Fenchtigkeit die Pflanzenwelt der Tropen zur höchsten Pracht entfaltet, so gilt dies für die Orchideen im besonderen. Die vielgestaltige Pflanzenfamilie ist dort durch Tausende von Arten vertreten, die untereinander in der Schönheit ihrer oft höchst bizarren Blüten wetteifern. Dies zeigt uns schon ein Gang darch eines jener Warmbäuser, in denen bei uns die kostbaren Pflanzen gepflegt werden. Zahlreiche dieser seltsamen Formen sind

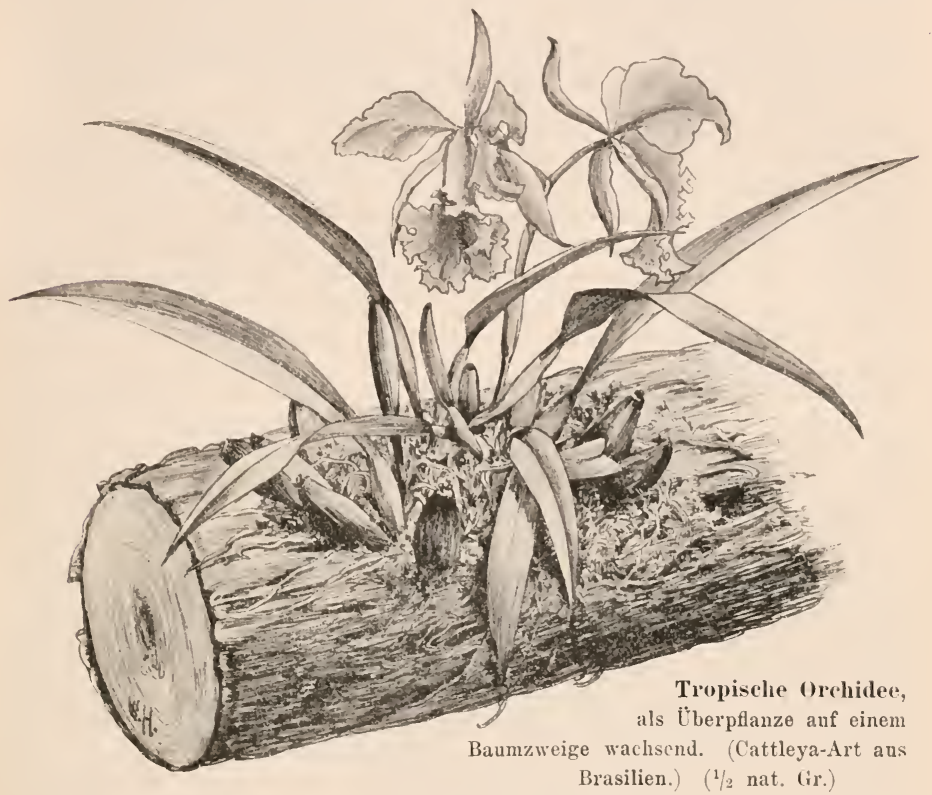

in ihrer Heimat Bewohner der dichten Urwälder. Die Kronen der Baumriesen hindern aber vielfach die Sonnenstrahlen, bis zum Boden zu dringen, so daB dort ein beständiges Halbdunkel herrscht. Die Orchideen sind daher gezwungen, sich einen Standort zu "suchen", an dem sie des belebenden Sonnenlichtes teilhaftig werden: sie siedeln sich als „Überpflanzen" (Epiphyten) mit zahlreichen Gliedern anderer Pflanzenfamilien auf der Rinde der Stämme und Zweige an. Dort breiten sie ihre Wurzeln aus oder lassen sie frei herabhïngen (Lnftwurzeln). Sie nähren sich von dem Staube, den der Wind in die Ritzen und Spalten der Rinde weht, sowie von dem Regen und Tan, der anf sie herabfällt. Tritt in der Heimat der Pflanzen die trockene Jahreszeit ein, so ist ein solcher Standort aber höchst ungünstig. Zahlreiche Arten speichern daher gleich den Kaktasgewächsen (s. das.) in dem knollig angeschwollenen Stamme jeden 
Wassertropfen auf, den sie erlangen kömnen, um während der Zeit der Trocknis aus diesem „Brunnen zu schöpfen“.

Eine dieser Urwaldpflanzen ist die Vanille (Vanílla planifólia), die uns in ihren nnreifen, langen, schotenförmigen Früchten das bekannte köstliche Gewürz liefert. Sie ist im tropisclien Amerika heimisch, wird gegenwärtig aber in fast allen heißen Ländern angebaut. Gleich dem Efea klettert sie mit Hilfe langer Luftwurzeln zum Lichte empor und hat im Gegensatz zu den zahlreichen, farbenprächtigen Orchideen ihrer Heimat nur unscheinbare, grüngelbe Blüten.

\section{5. u. 76. Familie. Froschlöffel- und Froschbißgewächse (Alismáceae und Hydrocharidáceae).}

1. Froschlöffelgewächse. Diese kleine Familie umfaßt einige Gewächse, die man stets im oder am Wasser antrifft. Von schilfartiger Gestalt ist die stolze Schwanenblume (Bútomus umbellátus), die auch Wasserliesch oder Bln men binse genanut wird. Auf hohem Schafte trägt sie eine Dolde prächtig rosafarbener Blüten (beschreibe sie!), die im Knospenzustande von zahlreichen Hüllblättern schützend bedeckt ist. Haben diese Blätter ihre Aufgabe erfüllt, so werden sie trockenhäutig. Die Früchte sind durch Lufträume schwimmfähig, eine Einrichtung, die zu dem Standorte der Pflanze in innigster Beziehung steht. - Mit der Schwanenblume heben auch der allbekannte Froschlïffel (Alisma plantágo) und das schmucke Pfeilkraut (Sagittária sagittifólia) ihre Blätter über den Wasserspiegel empor. Steigt das Wasser aber erheblich, so nehmen die sonst löffel- bezw. pfeilförmigen Blätter (Namen!) die Form langer Riemen an. Dann vermögen sie der Strömung des Wassers zu folgen, während sie sonst leicht zerrissen werden könnten. - Im Gegensatz zu diesen Sumpfpflanzen sind die

2. Froschbibgew ächse wirkliche Wasserbewohner. Das zeigt uns z. B. der zierliche Froschbiß̧ (Hydrócharis morsus ranae), der frei im Wasser schwebt und mithin auch nur in stehenden oder ganz langsam fließenden Gewässern zu leben vermag. Gleich der Seerose breitet er seine schön geformten Blätter, die daher auch in zahlreichen Stücken mit denen jener Pflanze übereinstimmen (Beweis!), anf dem Wasserspiegel aus. (Auf den Herzausschnitt der Blätter bezieht sich der Name der Pflanze.) Die weiben, zarten Blüten (beschreibe sie!) dagegen ragen ans dem Wasser hervor. Als Ersatz für die selten eintretende Fruchtbildung vermehrt sich das zierliche liewächs sehr stark durch Ausläufer, die sich wagerecht unter der Wasseroberfläche dahinziehen und am Encle je eine neue Pflanze bilden. Während des Winters vermag sich aber der Froschbiß in der obersten Wasserschicht, die ja zu Eis erstarrt, nicht zu halten. Er muB demnach wie die Seerose in die frostfreien Tiefen, fliehen". Dies geschieht in folgender Weise: mit Beginn des Herbstes hört die Bildung von Tochterptlanzen auf. Dann lösen sich die Endknospen der Ausläufer ab und sinken zu Boden. Wenn sich aber das Wasser im Frühjahr wieder erwärmt, dann füllen sich gewisse Zellräume dieser „Winterknospen " mit Laft. Infolgedessen steigen die zarten Gebilde wie cin Luftballon empor, öffnen sich, und nicht lange währt es, so ist der Wasserspiegel wieder mit den Blättern der interessanten Planze bedeckt. (Beobachte dies im Aquarium! Untersuche daraufhin auch Wasserschlauch und Wasserfeder!) - Ein anderes Wassergewächs ist die eigentümliche Krebsschere (Stratiótes aloüdes), die ilıren Namen von den stachelig gezähnten, schwertförmigen Blättern trägt. Sie überwintert in frostfreier Tiefe mit Hilfe der 
großen, aløëartigen Blattrosetten, die während der wärmeren Jahreszeit oft die ganze Oberfläche ven Teichen und Tümpeln bedecken. - Unsere gemeinste Wasserpflanze, die Wasserpest (Elódea canadinsis), ist erst um die Jitte des vorigen Jahrhnnderts aus Nordamerika bei uns eingewandert. Anfänglich vermehrte sie sich in einem solchen Maße (Name!), daß sie an einigen Stellen sogar der Schiffahrt binderlich wurde. Diese erstaunliche Vermehrung ist umso merkwürdiger, als die Wasserpest in unsern Gewässern niemals Früchte trägt: die mit Staubbliiten ausgerüstete Form der einhänsigen Pflanze fehlt nämlich bei uns gänzlich. Dafür ist aber das kleinste Brnchstück des zarten Gewächses (vgl. mit Wasserhahnenfuls und anderen Wasserpflanzen!) imstande, Knospen und Warzeln zu treiben (Versuch!). Jetzt hält sich die Vermehrung des Eindringlings: in mäBigen Grenzen, so daß von ihm nichts mehr zu befürchten ist. Wohl aber trägt er, da er die Abfallstoffe der Tiere zum Aufbau des eigenen Körpers verwendet, gleich allen anderen Wasserpflanzen wesentlich zum Reinhalten der Gewässer bei (was folgt daraus für die Besetzung der Aquarien?). 


\section{Gruppe. Nacktsamige Pflanzen (Gymnospérmae).}

Pflanzen, deren Samenknospen nicht in einem Fruchtknoten eingeschlossen sind, sondern sich a of dem offenen Fruchtblatte finden.

\section{Familie. Nadelhölzer (Coníterae).}

Verzweigte Holzgewächse mit nadel- oder schuppenförmigen Blättern.

Die Kiefer (Pinus silvéstris).

Kein Baum bedeckt im mittleren und nördlichen Europa so weite Flächen wie die Kiefer oder Föhre. Obgleich sie auf allen Bodenarten gedeiht, treffen wir sie doch vorwiegend auf Sandboden an. Dort bildet sie oft mächtige Wälder, die nach dem treusten Begleiter des „anspruchslosen“ Baumes, dem Heidekraute, vielfach als "Heiden" bezeichnet werden. Ja, sie ist sogar imstande, den ödesten Sand zu beleben, anf dem kein anderer Baum mehr gedeiht. Wollen wir die merkwürdige Pflanze daher recht verstehen, so mïssen wir uns bei ihrer Betrachtung zunächst fragen, wodurch sie befähigt ist, das Ödland zu bewohnen.

A. Wurzel. 1. Nehmen wir eine junge Kiefer und einen anderen gleichalterigen Baum, die beide auf demselben Grunde gewachsen sind, ans dem Boden, so werden wir finden, daß die Kiefer alle anderen Bänme durch ihr großes und stark verzweigtes Wurzelgeflecht übertrifft. (Sie hat z. B. $12 \mathrm{mal}$ soviel Wurzelfasern als die Fichte.) Diese Tatsache ist schon eine Antwort auf die soeben aufgeworfene Frage: Bäume mit gering entwickeltem Wurzelwerk finden in dem lockeren, sowie wasser- und nahrungsarmen Sandboden weder den nötigen Halt gegen den Anprall der Stïrme, noch die zum Leben notwendigen Wasser- und Nahrungsmengen. Die Kiefer dagegen hält sich in dem lockeren Grunde wie mit Tausenden und Abertansenden von Armen fest. Und da sie mit ihrem mächtigen Wurzelgeflecht eine sehr große Erdmasse durchzieht, vermag sie selbst ans ödem Sandboden die nötigen Wasserund Nahrungsmengen herbeizuschaffen. Sie gedeiht noch an Orten, an denen andere Bäume - verdursten und verhungern müßten.

2. Ziehen sich die Wurzeln eines Baumes, der anf lockerem Sande wächst, flach unter der Erdoberfläche dahin (wie z. B. die der Fichte), so befindet er sich in steter Gefahr, durch den Stnrm entwurzelt zu werden. Die Kiefer dagegen trotzt meist dem heftigsten Anprall. Sie ist nämlich durch eine Pfahlwurzel, die sich tief in den Untergrund senkt, und von der wieder zahlreiche Nebenwurzeln ausstrahlen, sicher im Boden "verankert". Dieser Wurzel wegen vermag die Kiefer umgekehrt aber auch nur auf „tiefgründigem“ Boden zu gedeihen. 
'Felsuntergrund bewohnt sie nur dann, wenn sie mit den Wurzeln in Spalten und Klütte eindringen kann.

3. Die Kiefer ist imstande, selbst die kleinste Menge von Tan und Regen, die den dïrren Boden trïnt, sich dienstbar zu machen; denn sie besitzt zahlreiche, oberflächlich verlaufende Wurzeln. Die feinsten Verzweigungen dieser Wurzeln "trinken" den Tau und Regen, der den Boden fenchtete, und der von der dürftigen P'flanzendecke (Moospolster!) oder von der verwesenden Nadelschicht festgehalten wird. (Beurteile hiernach das Entfernen der abgefallenen Nadeln, der $\operatorname{sog}$. "Waldstren"!) Bei fortgesetztem Wachstum erheben sich die "Tauwurzeln", da sie nach oben weniger Widerstand finden, z. 'T. oft ïber die Erde.

4. Die PHanzen nehmen das Wasser in der Regel durch zahlreiche Wurzelhaare (s. das.) auf, die sich an den Enden der feinsten Wurzeläste tinden. Der Kiefer fehlen aber (gleich den meisteu anderen Waldbäumen) diese Gebilde. Wie sich dagegen bei schwacher Vergrößerung (bei der Buche meist schon mit bloßem Auge) erkennen läßt, sind die Wnrzelenden von einem dichten Geflecht zarter Pilzfäden umsponnen (s. Champignon). Von diesem Pilzmantel gehen zahlreiche Fäden nach außen, durchwuchern den Waldboden and entnehmen ihm Wasser samt den darin gelösten Nährstoffen. Andererseits legen sich diese Fäden aber so dicht nm die Wurzelenden, daß der Baum im stande ist, ihnen das aufgenommene Wasser zu entziehen und für sich dienstbar zu machen. Schon aus der Länge der Fäden geht hervor, daß der Baum den Waldboden auf diese Weise

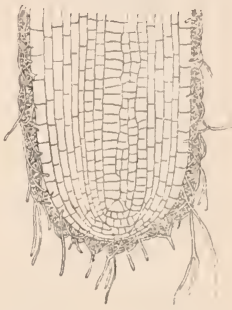

Wurzelende d. Kiefer im Längsschnitt, vou Pilzfäden umsponnen (etwa 200 mal nat. Gr.). weit besser auszunitzen vermag, als wenn seine Wurzelenden wie bei den meisten anderen Pflanzen mit winzig kleinen Wurzelhärchen bedeckt wären. Daß dem wirklich so ist, geht aus sorgfältigen Versuchen hervor, die von Naturforschern angestellt wurden: mall säte Kiefernsamen teils in gewöhnliche, teils in solche Walderde, in der man vorher alle Pilzkeime sorgfältig getötet (kurz: die man „sterilisiert") hatte. Während sich die Samen in der pilzhaltigen Walderde schuell zu kräftigen Pflanzen entwickelten, blieben die im pilzfreien Boden erwachsenen stark zurïck. Einige der kümmerlichen Pflänzchen goß man nun nachträglich mit Wasser, in das man etwas Walderde gebracht hatte, und das demnach zahlreiche Pilzkeime enthielt, und siehe da, die Kiefern gediehen sofort zusehends; die anderen kränkelnden Pflänzchen dagegen begannen bereits nach 2 Jahren - abzusterben. (Versuche, die an Buchen angestellt wurden, führten zu demselben Ergebnis. Im einzelnen sind aber die Beziehungen zwischen Pilz und Wurzel noch ziemlich unbekannt.)

B. 1. Stamm und Zweige sind in der Jugend von einer rötlichen Rinde bckleidet, die sich in papierdünnen Häutchen ablöst. Später werden sie von einer 
dicken, graubraunen Borke bedeckt, die in ansehnlichen Platten abblättert. Da diese Hüllen - wie wir im letzten Abschnitte des Buches noch ansfülnrlicher kennen lernen werden -- vorwiegend aus Kork bestehen, Kork (Flaschenkorke!) aber für Wasserdampf fast nndurchlässig ist, so haben wir es in den Hüllen mit einem Schutzmittel des Banmes gegen zu starken Wasserverlust zu tun. Ein solcher Schutz ist aber für die Kiefer, die besonders auf Sandboden oft mit dem größten Wassermangel zu kämpfen hat, sicher von höchstem Werte.

2. Stamm und Zweige sind gleich fast allen anderen Teilen des Baumes sehr reich an Harz. Schlägt man der Kiefer eine Wunde, oder schneidet man nur eine ihrer Nadeln durch, so fließt dieser stark klebrige Stoff alsbald hervor, verschließt die Wundstelle und verwehrt somit den Pilzsporen, die Krankheit und Fänlnis erregen, den Eintritt. Außerdem dient er aber auch der Pflanze als ein Schutzmittel gegen den Angriff zahlreicher Tiere. Wäre die Kiefer von Harz nicht gleichsam durchtränkt, so würde sie sicher noch weit mehr unter Insekten zu leiden haben, als dies jetzt schon der Fall ist (s. S. 289). $\mathrm{Ob}$ sie aber diesen vermehrten Angriffen standhalten könnte, ist melır als zweifelhaft (vgl. mit Eibe!). (Das Harz mehrerer ausgestorbener Nadelhölzer ist in dem Bernstein erhalten geblieben.)

3. Der Stamm der Kiefer löst sich nicht wie z. B. der der Eiche in mehrere große Äste auf. Er verlängert sich im Gegenteil alljährlich um ein Stück. Auf diese Weise entstebt jener schlanke "Schaft", der eine Höhe von fast $50 \mathrm{~m}$ erreichen kann und von dem Menschen so hoch geschätzt wird.

4. Am Ende des Stammes bildet sich außerdem alljährlich eine Anzahl quirlförmig angeordneter Zweige, so daß der Baum aus soviel „Stockwerken" zusammengesetzt ist, als er Jahre zählt. Diese Zweige verlängern und verzweigen sich in derselben Weise wie der Stamm. Infolgedessen iibertreffen die älteren die jüngeren stufenweise an Länge, so daß der Baum die Gestalt einer regelmäBigen Pyramide annimmt, eine Form, die für die allseitige Belichtung von größtem Werte ist (beweise dies näher!). (Ein Naturforscher nennt die Nadelhölzer ein "mathematisches (ieschlecht". Mit welchem Rechte tut er dies?:)

ว̆. Im Forste stehen die Kiefern so dicht nebeneinander, daß die unteren Zweige der gleichmäßig emporwachsenden Bäume schon nach einigen Jahren in den Schatten gestellt werden. Wie man daselbst aber auch leicht beobachten kann, verkiummert die Kiefer und geht schließlich gänzlich ein, sobald sie von einem Bamme beschattet wird. Sie ist im Gegensatz zu den Schattenpflanzen, die mit einer geringen Lichtmenge fürlieb nehmen (Beispiel!), ein "Lichtba um., der nur im vollen Genusse des Sonnenlichtes gedeiht. Wie dem ganzen Baume, ergeht es aber auch den beschatteten unteren Zweigen: sie sterben ab und lösen sich vom Stamme (der Forstmann sagt: „die Kiefer reinigt sich“). so entstehen die Bäume mit dem hohen, astlosen unteren Stammteile und der kleinen, pyramidenförmigen Krone, wie sie uns im Walde ïberall entgegentreten. Im hohen Alter nimmt die Krone dieser Bäume eine andere Form an. 
Da der "Zuwachs" am oberen Stammende und an den jüngeren Zweigen geringer als an den unteren ist, so breitet sich die Krone ans und wird schließlich schirmförmig. Solche alten, ehrwïrdigen Bäme, die wie Riesen über den Wild emporragen, haben danu fast die Gestalt einer Pinie (s. das.)

Da im diehten Kicfernwalde selbst am hellen Tage ein Halbdunkel herrscht, so finden sich am Boden anch nur wenig lichtberlïrftige Pflanzen (welche hast du angetroffen?). Vor allen Dingen fehlt das Unterholz des Laubwaldes, so daB der Kiefernbestand etwas Einförmiges und Eintöniges erhält. Mit dem Fehlen der „Waldpflanzen und des Unterholzes hängt wieder die grobe Arnut an Tieren zusammen, besonders an Vögeln, die sich von Samen und Beeren nähren und den Laubwald besonders im Frälijahre mit ihrem Gesange erfüllen. Daher die große Stille iu Kiefernwalde und der schwermiitige Eindruck, den er auf uns macht. (Welehe Vügel sind ständige Bewohner des Kieferuwaldes? Wie finden sie dort ihre Nahrung? Beobachte, wie sich an lichten Stellen sofort Pflanzenwuchs einstellt!)

Ist die Kiefer dagegen auf einem freien Stande erwachsen, so sterben die untersten Zweige (wie bei allen Bïmmen) infolge Lichtmangels zwar gleichfalls ab. Jie Krone aber bleibt groß und zeigt lange Zeit die ursprüngliche Pyramidenform. Später rundet sie sich aber mehr und mehr ab, so daß die Kiefer, aus der Ferne gesehen, oft ganz den Eindruck eines L a ubba umes macht. (Beobachte Kiefern, die am Waldrande stehen, also einseitig belenchtet werden!)

6. Anfangs Mai lassen die jungen Zweiglein ("Maitriebe") die Kiefer wie einen mit zahlreichen Kerzen geschmückten Weihnachtsbaum erscheinen. Ein solcher, sich entwickelnder Zweig (zerbrich ilın!) ist außerordentlich zart und saftreich, und daher auch gegen zu starke WVasserabgabe, sowie gegen die Inbilden der Witterung vortrefflich geschïtzt: er steht nicht allein wie z. B. die jungen Blätter der Roßkastanie (s. S. 13, c) senkrecht, sondern ist auch von einer besonderen Hiille umgeben, die die Stelle von Knospenschuppen vertritt (s. S. $41, \mathrm{~B})$. Die Hïlle ist von zahlreichen, häutigen, rostfarbenen Blätchen gebildet, die

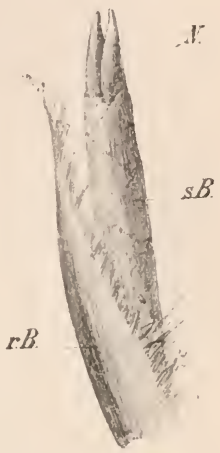

Jumger Kurztrieb ler Kiefer. Er steht in der Achsel eines rostfarbenen Blattrhens (r.B.), das den Mantel des jumgen Langtriebes (. Maritriebes") bilden hilft. nud ist ron einem zweiten Mantel umhüllt. ler ans silberweißen Blättchen (s. B. bestelit. Der Iantel ist an der spitze lureh dis hervorbrechenden Nadeln N.) bereits gesprengt. Etwa 8 mal vergr. am Rande ausgefranst und so untereinauder vertilzt und verklebt sind, daß sie gleichsam einen Mantel für das schutzbediirftige Zweigleiu bilden. Streckt sich der Trieb weiter in die Länge, so zerreißt der „Mantel“, bis schlieblich die häutigen Blättchen bedeutungslos werden nnd, einzeln oder zu Gruppen vereinigt, abfallen. Nach einiger Zeit verlassen die jungen Zweige auch ihre ,Schntzstellung", um immer mehr die Richtung der ausgebildeten auzunehmen. 
Wenn der „Mantel" zerreißt, läßt sich deutlich erkennen, daß jedes häutige Blättchen in seiner Achsel ein winziges Gebilde trägt, aus dem sich später je ein Nadelpaar entwickelt. Nun kommen aber (untersuche darauf jede beliebige Pflanze!) aus den Achseln der Blätter niclit etwa andere Blätter, sondern stets Zweige hervor, ein Zeichen, daß wir es in jenen Gebilden gleichfalls mit Zweigen zu tun haben. Im Gegensatze zu dem ganzen „Naitriebe“, der sich stark in die Länge streckt, bleiben diese Zweiglein allerdings sehr kurz. Es sind „K u rztriebe“, während der größere Zweig, dem sie aufsitzen, einen "Langtrieb" darstellt (s. S. 160, A). - Viel länger als das Zweigstück des Kurztriebes sind seine beiden Blätter, die nach ihrer Form als

C. Nadeln bezeichnet werden. 1. Jetzt, da der Langtrieb noch im Wachsen begriffen ist, sind die Blätter außerordentlich zarte Gebilde. Ihnen kommen daher außer den erwähnten Sclutzmitteln des Langtriebes die häutigen silberweißen Blättchen sehr wohl zu statten, die am Grunde des Kurztriebes entspringen und gleichsam einen zweiten Mantel bilden. Wenn sich etwa Ende Mai der Langtrieb stark zu strecken beginnt, durchbrechen die Nadeln ihre Schutzhülle und treten ins Freie. Die silberweißen Blättchen lösen sich nunmehr zu spinngewebartigen Fäden auf nnd gehen bis auf Reste, die am Grunde der Nadeln zurïckbleiben, bald verloren.

2. Stellt man durch ein Nadelpaar, so lange es noch von der Schutzscheide umhüllt ist, einen Querschnitt her, so sieht man, daß sich die Nadeln in den Raum eines Kreises teilen müssen. Infolgedessen hat der $\mathrm{Qu}$ erschnit jeder $\mathrm{Nadel}$ - auch der ausgebildeten - die Form eines Halbkreises.

3. Die Blätter sind diejenigen Teile der Pflanzen, die das meiste Wasser verdunsten. Da nun die Kiefer auf sehr trockenem Boden auszuhalten vermag, so werden wir wie bei anderen Trockenlandpflanzen (Beispiel!) anch an ihren Blättern Einrichtungen finden, die auf einen sparsamen Wasserve rbra u ch hinweisen:

a) Infolge der Nadelform hat das Blatt eine verhältnismäßig kleine verdunstende Oberfläche (vgl. S. 78, a).

b) Die Außenwand der Oberhautzellen ist - wie man bei mikroskopischer Betrachtung dünner Querschnitte sieht - stark verdickt. Infolgedessen ist sie für Wasserdampf schwer durchdringbar und läßt die Nadel hart und trocken erscheinen.

c) Spaltöffnungen, durch die die Verdunstung des Wassers am stärksten erfolgt, sind in sehr geringer Zahl vorhanden. Da sie zudem tief in die Oberhaut eingesenkt sind, befindet sich über ihnen ein windstiller Raum, eine Einrichtung, die wir bereits bei dem Heidekrant kennen gelernt haben.

4. Die Kiefer verliert alljährlich im September einen größeren, und im Oktober und November einen kleineren Teil ihrer Blätter. Da die einzelne Nadel aber 2-3 Jahre alt wird, so erscheint die Kiefer i mmergrün. Sie unterscheidet sich in diesem Punkte also wesentlich von den Laubbäumen unserer Heimat, die sich im Herbste ihrer gesamten Blätter entledigen müssen, um nicht während des Winters zu vertrocknen und unter der Schnee- 
last zusammen zu brechen (s. S. 91, c). Wie wir soeben gesehen haben, ist die Kiefernadel aber so vortrefflich gegen zu starke Wasserdampfabgabe geschützt, daß die erstere Gefahr für den Baum ganz ausgeschlossen ist. Auch der zweiten Gefahr ist die Kiefer in weit geringerem Grade ausgesetzt als ein Laubbaum; denn zwischen den nadelförmigen Blättern vermögen sich bei weitem nicht so große Schneemassen anzuhäufen als in der dichten Blätterkrone z. B. der Linde oder der Roßkastanie.

Selbstverständlich ist die Schneelast, die die Kiefer zu tragen hat, aber viel größer als die, die auf einem unbelaubten Baume ruht. Daher sind anch - wie hier nachzntragen ist - die Kiefernäste auffallend dick und sehr biegsam. Trotzdem aber hat der Kiefernwald nicht selten unter beträchtlichem „Schneebruch" zu leiden.

Im Herbst verlieren unsere Laubbätme durch den Blattfall eine große Menge von Stoffen, die im Frühjahr wieder ersetzt werden müssen. Die Kiefer dagegen behält ihre Blätter mehrere Jahre hindurch. Sie braucht daher dem Boden auch nicht eine solche Menge von Nährstoffen zu entziehen als ein Laubbaum mit derselben Blattmasse, eine Tatsache, die bei der Nahrungsarmut des Bodens, auf dem die Kiefer zumeist wächst, wohl zu beachten ist. - Auch insofern befindet sich die Kiefer den Laubbäumen gegenüber im Vorteil, als sie im Frïhjahre sofort die Arbeit beginnnen kann, während jene erst die Blätter, d. h. die Werkstätten bilden müssen, in denen die Verarbeitung der rohen Nährstoffe erfolgt.

Die abgefallenen, harten and harzreichen Nadeln verwesen nur sehr langsam. Infolgedessen häufen sie sich nach ond nach zu einer dicken Schicht an, aus der nur wenige Pflanzen Nahrung zu entnehmen vermögen. Dieser Umstand erklärt uns neben der geringen Belichtung die Pflanzenarmut des Kiefernwaldes hinreichend erklärt. Nach erfolgter Verwesung liefern die Nadeln jedoch dieselbe frachtbare Humuserde wie die Laubblätter. In den modernden Nadelmassen finden Pilze, Fichtenspargel und andere "Verwesungspllanzen" günstige Lebensbedingungen; daher auch der auffallende Reichtum des Kiefernwaldes an diesen Gewächsen.

D. Bliiten. Bei der Kiefer sind Staubblätter und Samenanlagen auf verschiedene Blüten verteilt; sie ist also wie z. B. der Haselnußstrauch eine einhäusige Pflanze.

1. Die Staubblïten finden sich in größerer Anzahl am Grunde der jungen Triebe und sehen den Kïtzchen der Laubbäume ähnlich.
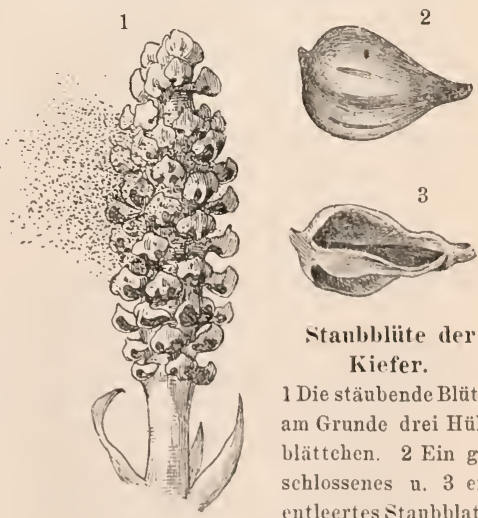

Stanbbliite der

Kiefer.

1 Die stäubende Blüte, am Grunde drei Hüllblättchen. 2 Ein geschlossenes u. 3 ein entleertes Staubblatt. Wie die zweinadeligen Kurztriebe, (Fig. 1 etwa 10 mal, Fig. 2 u. 3 etwa 12 mal vergr.: 
deren Stelle sie einnehmen, entspringen sie aus der Achsel je eines häutigen Blattes, das ihnen mitsamt 3 weiteren Bliittchen in der Jugend als schiitzende Hïlle dient. An der Blïtenachse stehen zahlreiche gelbe Stanbblätter, die -wie man bei Lupenvergrößerung sehen kann - auf der Unterseite je 2 große Stanbbentelfaicher tragen.

2. Die Samenblïten stehen als kleine, rötliche "Zapfen" an der Spitze der jungen Triebe und sind aufänglich von zahlreichen braunen Schuppen, die dem Stengel ansitzen, schïtzend umhïllt. Führen wir durch den Zapfen einen Längsschnitt, so sehen wir, indem wir uns wieder der Lupe bedienen, wie an
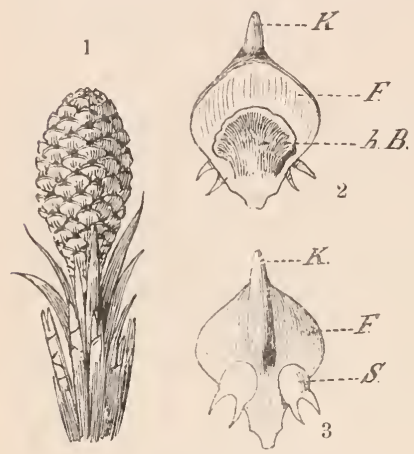

Samenbliite der Kiefer.

1 Die ganze Blüte. An dem stengel, der sie trägt, unten einige junge Kurztriebe (Nadelpare) und dariber mehrere brame sichuppen. -2 Fruchthlatt ron unten und 3 von oben gesehen. F. Fruchtblatt; K. dessen Kiel; h.B. das häutige Blättchen auf der Tnterseite; S. Samenknospe. Fig. 1 etwa 4 mal, Fig. 2 u. 3 etwa 12 mal rergit. einer Längsachse zahlreiche fleischige Blätter entspringen, die wieder auf der Unterseite je ein häutiges Blättchen tragen. Auf der Oberseite sind die fleischigen .. Fruchtblätter oder Fruchtschuppen" mit einem vorspringenden Kiele versehen, neben dem am Grunde der Schuppen die beiden Samenknospen oder Samenanlagen zu finden sind. Während bei den bisher betrachteten Pflanzen die Samenknospen in einem Gehäuse (Fruchtknoten) eingeschlossen sind, das aus einem Frnchtblatte oder aus mehreren Fruchtblättern gebildet ist, liegen hier die winzigen Gebilde frei auf dem Fruchtblatte ("nacktsamige Pflanzen" oder Gymnospermen im Gegensatz zu den "bedecktsamigen Pflanzen" oder Augiospermen). - Da der gereifte Fruchtknoten die Frucht darstellt, so haben wir es in den gereiften Samenanlagen also nicht mit Früchten, sondern nur mit Samen zn tun. Ebensowenig ist auch der entwickelte Zapfen eine Frucht.

Weitere Einzelheiten iiber die

beiden Blïtenarten lernen wir kennen, wenn wir

3. die Bestäubung verfolgen. Sie wird wie z. B. beim Haselnußstrauche durch den Wind vermittelt und kann unso sicherer erfolgen, als die Kiefer wie jene Pflanze zumeist in großen Beständen auftritt (s. S. 192, g).

I. Die Staubblïten sind wie die Blüten aller windblïtigen Pflanzen

a) unscheinbare, duft - und honiglose Gebilde (s. S. 192, a).

b) Sie fiuden sich, wie wir gesehen haben, in größerer Anzahl am Grunde der jungen Triebe. Sie stehen also an der Außenseite der Baumkrone, dem Winde vortrefflich ausgesetzt. 
c) l)er Blïtenstanb wirl in selır großen M engen erzengt (s. S. 193, h). Der Wind, der dureh die Zweige der blïhenden Kiefer streicht, entführt ihn in anselnnlichen Wolken, und nach einem Gewitterregen sind die Waldgewässer, sowie die Ptïtzen, die sich auf den Wegen gebildet haben, davon oft wie mit einer gelben Schicht überzogen. "Es hat Schwefel geregnet", sagen dann die Lente, die sich die Herkunft der gelben Massen nicht erklären können.

d) Schïttelt man einen blïhenden Zweig und fängt den Bliitenstaub durch ein Blatt Papier anf, so sieht man, daß er ein trockenes Pulver darstellt, das von dem Winde leicht verweht werden kann (s. S. 193, i).

e) Zudem trägt jedes Staubkorn jederseits eine luftgefüllte Blase, die als Flngwerkzeng dient. Wie lange der Blütenstaub durch diese luftballonartigen Gebilde schwebend erhalten wird, geht daraus hervor, daß man ihn hïnig in stehenden Gewïssern findet, in deren Umkreise oft auf Meilen hin keine Kiefer anzutreffen ist.

f) Bei Windstille wird der ans den Staubbeutelfächern hervorrieselnde Blütenstanb auf der Oberseite der darunter stehenden Staubblätter abgelagert (s. S. 192, e).

g) Ist aller Blïtenstaub verweht, dann vertrocknen die Staubblïten, fallen ab und lassen am Zweige eine kahle (nadellose) Stelle zurïck.

II. Die Samenblüten sind wie die Stanbblïten

a) duft- und honiglos und trotz iluer roten Färbung ganz unauffällig.

b) Sie nehmen die Spitze der jungen Triebe ein, sind also dem Winde vollkommen frei ausgesetzt.

c) Da die Samenblüten anfrecht stehen, und

d) die Fruchtschuppen sich zur Blïtezeit auseinander tun, vermag der trockene Blïtenstaub leicht zu den Samenanlagen hinabzurollen. Dies erfolgt nun mmso sicherer, als er von

e) den Kielen der Fruchtschuppen gleichsam dem Orte seiner Bestimmung geleitet wird. Dort gelangt er zwischen

f) die Fortsätze, zu denen die Hïlle der

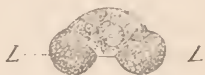

Bliitenstaubkorn der Kiefer mit den beiden Lufthlasen 1.

(ktwa 200 mal verers.

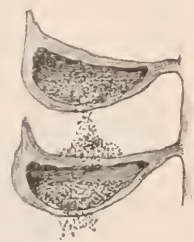

Staubbaitter d. Kiefer. senkrecht durchschuit Aus den stanbbentelfärhern riesclt Blïtenstiul, hervor, der anf der Obersejte des darunter stehenden Blattes alogelagert wirl.

(litwa $15 \mathrm{mal}$ vergr. Samenanlage ausgezogen ist. Wenn sich diese Fortsätze später einrollen, kommt der Blütenstaub unit der Samenanlage selbst in imnigste Berïhrung, so daß eine Vereinigung beider erfolgen kann. Dieser als „Befruchtung bezeichnete Vorgang erfolgt bei der Kiefer aber erst 13 Monate nach der Bestäubnng.

E. Zapfen und Samen. 1. Die zarten Samenanlagen und Blïtenstanbkörnchen, sowie die sich ausbildenden Samen dürfen den Unbilden der Witterung 
aber unmöglich ansgesetzt sein. Die fortwachsenden Fruchtschuppen schließen sich daher nach erfolgter Bestäubung, und ihre Ränder verkleben durch Harz.

2. Im 1. Jahre vergrößert sich der Zapfen nur wenig. Er senkt sich aber langsam, bis seine Spitze schließlich nach unten gerichtet ist. Im 2. Jahre wächst er umso schneller. Die bisher grünen Fruchtschuppen verholzen jetzt und nehmen eine braune Färbung an. In März oder April des 3. Jahres endlich trocknen die Schuppen so stark ein, daß sie auseinander spreizen.

3. Da nun die Zapfen herabhängen, so fallen die ausgereiften Samen sofort heraus. Die federleichten, mit einem flügelförmigen Anhange ausgerüsteten Gebilde werden vom Winde ergriffen und wie die Teilfrucht des Ahorns (s. S. 48) oft weithin verweht. Sind sämtliche Samen ausgesät, so

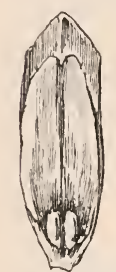

\section{Verholzte}

Fruchtschup.

pe der Kiefer

mit d. beiden

geflügelten

Samen (wenig vergr.). fallen auch die Zapfen herab. (Warum dürfen sie sich nicht vor dem Ausfallen der Samen vom Baume lösen?)

4. Würden die Samen durch anhaftende Regentropfen beschwert, so müßte ihre Verbreitung stark beeinträchtigt werden: Daher öffnet sich der Zapfen auch nur bei trockenem Wetter, und der bereits geöffnete schließt sich wieder, sobald er befeuchtet wird. Selbst schon entleerte, abgefallene Zapfen haben diese Eigenschaft noch nicht verloren (Versuche!).

5. Die Samen keimen mit 5 oder 6 nadelförmigen Keimblättern.

F. Bedeutung. Da die Kiefer eine überaus "genïgsame" Pflanze ist, so vermag der Mensch mit ihrer Hilfe selbst dem unfruchtbarsten Sandboden, auf dem keine andere Nutzpflanzemehr gedeiht, nocheinen Ertrag abzuringen. Ohne sie wären die weiten Ebenen, die sie mit dichtem Walde bedeckt, zum größten Teile öde Wüsteneien, in denen of t kaum ein Mensch lebenkönnte. Sie liefert ein wichtiges Bau-, Werk- und Brennholz. Aus dem gesammelten Harze, das durch Einschnitte in die Rinde zum vermehrten Ausfließen gebracht wird, gewinnt man durch Destillation das Terpentinöl, das besonders zum Auflösen von Harzen (Lacken) verwendet wird. Der Rïckstand bei diesem Verfahren ist das Geigenharz oder Kolophonium. Siedet man das Harz in Kesseln (trockene Destillation), so erhält man das Pech, das als "Faßpech" allgemein bekannt ist. Sehr harzreiches Holz ("Kienholz") gibt beim Verbrennen den Kienruß, der zur Herstellung von Druckerschwärzə, Stiefelwichse nnd dgl. Verwendung findet. Die frisch vom Banm gepflïckten Nadeln werden zu sog. Waldwolle verwendet,die ein gutes Polstermaterial abgibt. Die abgefallenen Nadeln dienen als Streu für das Vieh und dann als Dünger für den Acker. Indem die Nadelschicht unter den Bäumen verwittert, wird der öde Sandboden nach und nach an nährenden Bestandteilen reicher, so daß im Laufe langer Zeit- 
räume schließlich ein fruchtbares Ackerland daraus hervorgeht. Mit der Kiefer ist also das Wohl und Wehe zahlreicher Menschen aufs innigste verknïpft. Daher sind die zahlreichen

(r. Feinle, die den wichtigen Baum oft in verheerender Weise heimsuchen, auch Feinde des Ienschen. Am geringsten ist noch der Schaden, der der Kiefer von den größeren Waldtieren zugefügt wird. Es sei hier nur auf Hirsch, Reh, Wildschwein, Eichhörnchen und andere Nager, sowie auf die Vögel verwiesen, die sich von Waldsitmereien nähren (nenne solche!). Weit gefährlicher sind die zahlreichen niederen Pilze, die in allen Teilen des Baumes schmarotzen. Mit ihnen wetteifert ein Heer von $1 \mathrm{nsekten}$, von denen wieder Kiefernspinner, Nonne, Kiefernspanner und Maikäfer, sowie mehrere Rüsselkïfer, Blattwespen und Borkenkäfer dic verderblichsten sind. Treten diese kleinen, aber geführlichen Feinde in Massen auf, so fallen ihnen selbst ausgedehnte Wälder zum Opfer. Der Mensch ist gegen diese Zerstörer vielfach gänzlich machtlos. Desto mehr räumen unter ihnen aber, abgesehen von Krankleiten und Witterungseinflïssen, die insektenfressenden Vögel (nenne solche!) und die wichtigen Schlupfwespen auf. der beste - Waldschutz! (Nüheres iiber die erwähnten Tiere s. "Lehrbuch der Zoologie".)

\section{Andere Nadelhiblzer.}

1. Gruppe. Fichtenartige Nadelhölzer. Nächst der Kiefer hat unter allen Nadelbäumen die Fichte (Pícea excélsa) für uns die größte Bedeatung (Beweis!). Sie ist der "Christ-, Weihnachts- oder Tannenbaum", der lichtergeschmüekt das schönste unserer Feste verherrlichen hilft. Besonders im Gebirge bildet sie ausgedelinte Wälder. Mit den oberflächlich verlaufenden Wurzeln umklammert sie gern die Felsblöcke. So findet sie selbst in einer dünnen Erdschicht den nötigen Halt. Da ihr aber eine Pfahlwurzel fehlt, wird sie besonders in der Ebene leicht vom Sturm entwarzelt. Bei freiem Stande reichen die untersten $Z$ weige bis zum Boden herab, so dab der stolze Baum eine mächtige Pyramide bildet. Im G'egensatz zur Kiefer, mit der die Fichte in den meisten Punkten völlig übereinstimmt (Beweis!), sind ihre Z weige sämtlich ${ }_{n}$ Langtriebe ${ }^{4}$, die rings von Blättern (Naleln) umgeben sind. Da nun Blätter Schmeil. I.ehrbnch der Botanik.

Ein Schutz dieser Tiere ist also

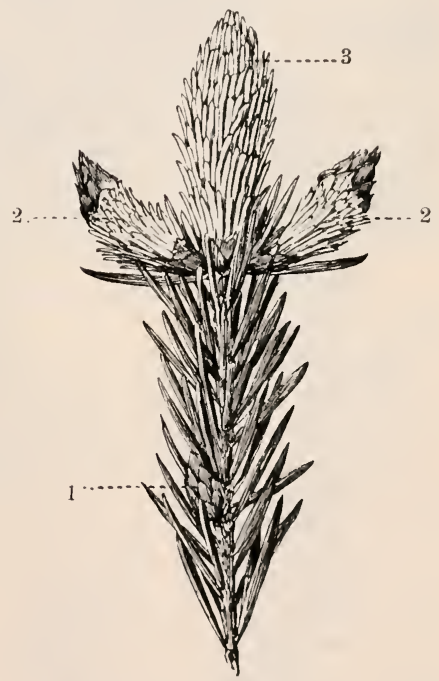

Ein Zweiglein der Ficlıte mit 4 jungen Triehen: 1 ist noclı vollstäudig von läutigen Blättchen umliällt: bei 2 werden die Blätchen als Kappen abgeworfen; bei 3 ist dies bereits geschehen (nat. (ir.). 
nie aus den Achseln anderer Blätter entspringen, so fehlen den jungen Fichtentrieben auch die häutigen Blättchen, aus deren Achseln die nadeltragenden Kurztriebe der Kiefer hervorgehen. Die Fichtentriebe bedürfen aber gleichfalls eines „Knospenschutzes." Ein solcher ist auch vorhanden : er wird von zahlreichen häutigen Blättchen gebildet, die sich am Grunde des Triebes finden, ihn vollständig umhüllen und später in Form einer Kappe abgeworfen werden. - Ein ausgesprochener Gebirgsbaum ist die Tame (Ábies pectináta), die wegen ihres edlen Wachses and zum Unterschiede von der sehr ähnlichen Fichte allgemein Edeltanne genannt wird. Von der rotrindigen Fichte, der "Rottanne", unterscheidet sie sich leicht durch die glatte, weiße Rinde des säulenförmigen Stammes und die zwei-

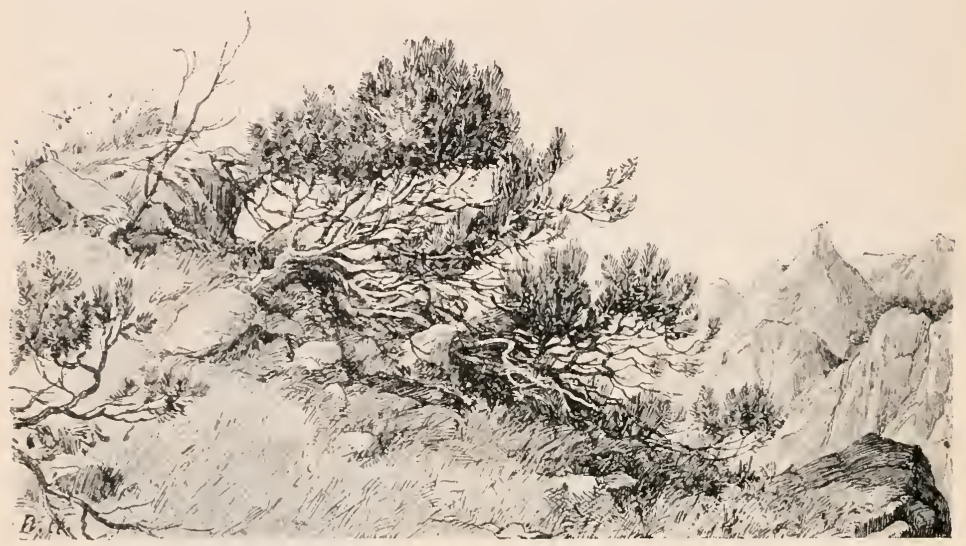

Zwergkiefer im Hochgebirge.

zeilig gestellten Nadeln, die auf der Unterseite 2 weiße Streifen besitzen (daher auch "Silber-oder Weißtanne" genannt). Diese Streifen sind mit Wachs ausgefüllte Rinnen, in denen sich die Spaltöffnungen finden. Da Wachs nicht vom Wasser benetzt wird (Versuch!), können infolgedessen die Spaltöffnungen von anhaftenden Regentropfen auch nicht verschlossen werden. Der notwendige Gasaustausch erfährt daher selbst bei Befeuchtung der Nadeln keine Unterbrechung. Im weiteren Gegensatze zur Fichte hat die Tanne aufrecht stehende Zapfen. Würden daher bei der Reife wie bei unsern anderen „zapfenfrüchtigen“ Nadelbänmen nur die Fruchtschuppen auseinander spreizen, so könnten die Samen aus ihren Verstecken nicht herausfallen. Dies ist aber unbedingt nötig, da die geflügelten Gebilde ja durch den Wind verbreitet werden. Die Fruchtschuppen lösen sich daher zur Zeit der Samenreife von der Zapfenachse ab.

In den Alpen und den hüheren Mittelgebirgen Deutschlands findet sich dort, wo kaum noch ein anderer Baum gedeiht, die Zwergkiefer (Pinus montána). Sie bildet meist niederliegende Büsche und wird daher anch Knieholz, Krummholz, Legfohre oder (in den Alpen) Latsche genannt. Infolge dieser Gestalt wird sie von den riesigen 
Schneemassen, die sich während des langen Winters in ihrem Wohngebiete anhäufen, vollständig zugedeckt, und da ihre Zweige außerordentlieh biegsam sind, wird sie zugleich ganz zu Boden gedrüekt. Wie ein Rosenstamm, den wir im Herbste „umlegen“, wird sie auf diese Weise den austrocknenden Winterstürmen völlig entzogen (s. S. 42 u. 92). In unsern Anlagen findet sich sehr häufig die Weymouthskiefer (P. strobus). Sie stammt aus Nordamerika und ist an den 5 langen, zarten Naleln leicht zu erkennen. - Ein sehr charakteristischer Baum in dem Landschaftsbilde des Mittelmeergebiets ist die Pinie (P. pinea). Sie trägt auf säulenförmigem Stamme eine breite, schirmförmige Krone.

Gleich der Tanne ist die Lärche (Larix europǽa) ein Gebirgsbaum, der aber nur in den Alpen größere Wälder bildet. Wegen des schlanken Wuchses nud der zierlichen Benadelung wird er in Parkanlagen überall gern angepflanzt. Die Nadeln finden sich an den Langtrieben einzeln und an den Kurztrieben in Büseheln. Da sie sehr zarte und weiche Gebilde sind und infolgedessen viel mehr Wasser durch Verdunstung verlieren als z. B. die harten Nadeln der Kiefer, so ist die Lärehe genötigt, im Herbste ihre sämtlichen Blätter abzuwerfen und den Winter unbeblättert wie unsere Laubbäume zu überdauern. - Dieselbe Verteilung der Nadeln ist der Ceder des Libanon (Cedrus líbani) eigen, die nicht nur auf dem Libanon, sondern auch in Kleinasien und auf Cypern anzutreffen ist. Dieser immergrüne, hoehberühmte Baum, der das ehrwürdige Alter von $3000 \mathrm{Jah}$ ren erreicht, lieferte dereinst Salomo das Holz zum Tempelbau. Die mäehtigen Wälder, die die Abhänge des Libanon früher bedeckten, hat menschliche Habgier aber fast vernichtet.

2. Gruppe. Zypressenartige $\mathrm{Nadel}$ hölzer. Der Wacholder (Juniperus commúnis) ist ein immergrüner Strauch oder Baum, der selbst mit dem unfruchtbarsten Boden fürlieb nimmt. An freien Stellen bildet er meist niedrige Biische, deren Zweige sich nicht selten dem Boden eng anschmiegen. Als Unterholz im Walde dagegen wächst er zu schlanken Pyramiden empor, die oft mehrere Meter hoch werden. Während er nämlich im Walde unter den austrocknenden Winden kaum zu leiden hat, sich also

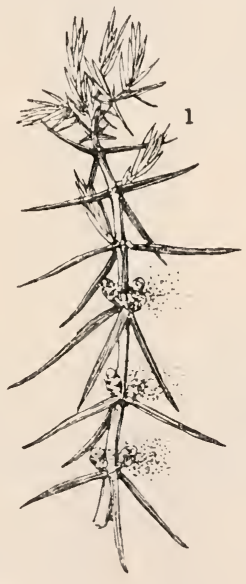

Wacholder mit jungen Trieben. 1 Zweig mit Staubblïten. $2 \mathrm{Zweig}$ mit Samenblüten (d.s. die kleinen Zapfen in den Achseln d. nadelartigen Blätter) und einigen reifen, d. h. vorjührigen Beeren. (Nat. Gr.)

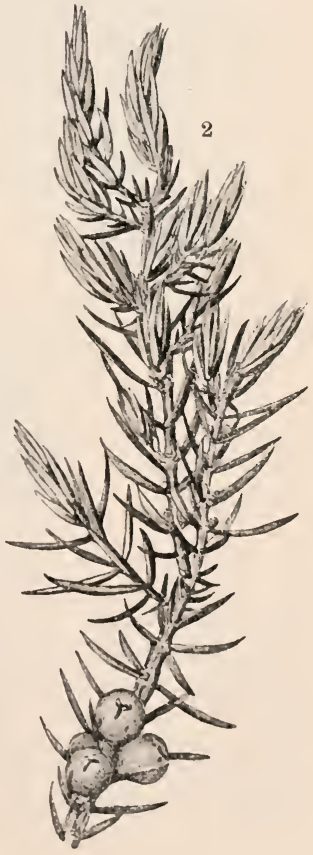


anbeschadet boch über den Boden erheben kann, ist er auf freien Stellen den Stïrmen schutzlos preisgegeben. Darum drückt er sich dort dem Boden möglichst eng an, so daß er dem Winde auch nur eine verhältnismäßig kleine Angriffsfläche darbietet. Staub- und Samenblüten finden sich auf verschiedenen Pflanzen. Die 3 obersten Fruchtblätter der Zapfen verwachsen miteinander, werden fleischig und bilden bei der Samenreife je eine schwarzbraune, blaubereifte Beere, die besonders von der Wacholderdrossel oder dem Krammetsvogel gern verzehrt wird. Da die Samen von einer steinharten Schale umgeben sind, also durch die Verdaungssäfte nicht angegriffen werden, sind die Verzehrer der Becren zugleich die Verbreiter der Pflanze (s. S. 64, a). Die stark aromatisch riechenden Beeren werden auch in der Heilkande, sowie als Küchengewïrz und Räuchermittel ver-

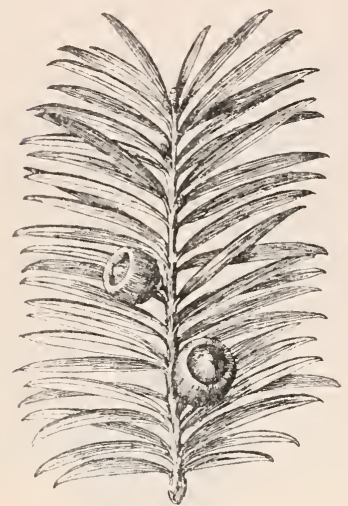
kmospe; H. ilne Hülle; M. Anlage des samenmantels (etwa 20 mal vergr.)

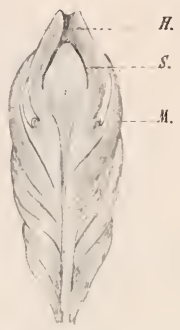

Zweig der Eibe mit 2 reifen Samen (nat. Gr.) Daneben ein junger Zweig blüte: S. diesamenmit einer Samenwendet. - Die immergrïnen Lebensbïme (Thaja) pflanzen wir gern als ein Bild der Hoffnung anf die Ruhestätten der Toten. Ihre prächtigen Pyramiden finden sich aber auch ebenso hänfig in Anlagen. Der aus Nordamerika stammende abendlindische L. (Th. occidentális) verzweigt sich wiederholt in wagerechter Ebene; der in Ostasien heimische morgenländische I. (Th. orientális) dagegen hat senkrecht gestellte $\mathrm{Zwei}$ ge. - Der Friedhofsbaum des Mittelmcergebiets ist die dunkle Kypresse (Capréssus sempérvirens). Sie gleicht im Wuchse der italienischen Pappel nnd ist ein Charakterbaum der sïd-

lichen Landschaft. - Zypressenartige Pflanzen sind auch die berühmten Mammutbïume Kaliforniens (Sequóia gigantéa). Sie erreichen die gewaltige Höhe von mehr als $100 \mathrm{~m}$.

3. Gruppe. Eibenartige Na delbölzer. Diese Gruppe ist bei uns allein durch die Filıe (Taxus baccáta) vertreten, die früher in den Wäldern unserer Heimat sehr häutig war, jetzt aber meist nur noch in Gärten und Parkanlagen anzutreffen ist. Sie ist ein immergrüner Strauch oder ein niedriger Baum, der im Gegensatz zu allen anderen Nadelhölzern vollkommen harzlos ist. Dafür entlıalten aber die zweizeilig gestellten, breiten Nadeln ein scharfes Gift, das sie gegen die Angriffe der zahlreichen Pflanzenfresser schiitzt. Die Samenblüten, die sich von den Staubblüten getrennt anf anderen Pflanzen finden, enthalten nur eine einzige Samenanlage. Wäbrend sie sich zam Samen ausbildet, entwickelt sich von ihrem Grunde aus eine flcischige Hülle, ein sog. Samenmantel, der zar Zeit der Reife fleischig, saftig nnd von lenchtend scharlachroter Färbung 
ist. Er dient wie das Fruchtfleisch der Wacholderbeeren als Anlockungsmittel für fruchtfressende Vögel, die die Pflanze weiter verbreiten.

Andere Familien der naektsamigen Pflanzen sind in unserer Heimat nicht vertreten. Erwähnt seien daher hier nur die Palmfarne ('yeas), die vorwiegend in den Tropen heimisch sind und bei uns vielfach in Gewächshänsern gezogen werden. Ihre prächtigen Fiederblätter sind die bekannten ${ }_{\text {Palmenwedel }}$ oder "Palmenzweige", die wir als ein Zeichen der Trauer gern auf den Sarg der Verstorbenen legen.

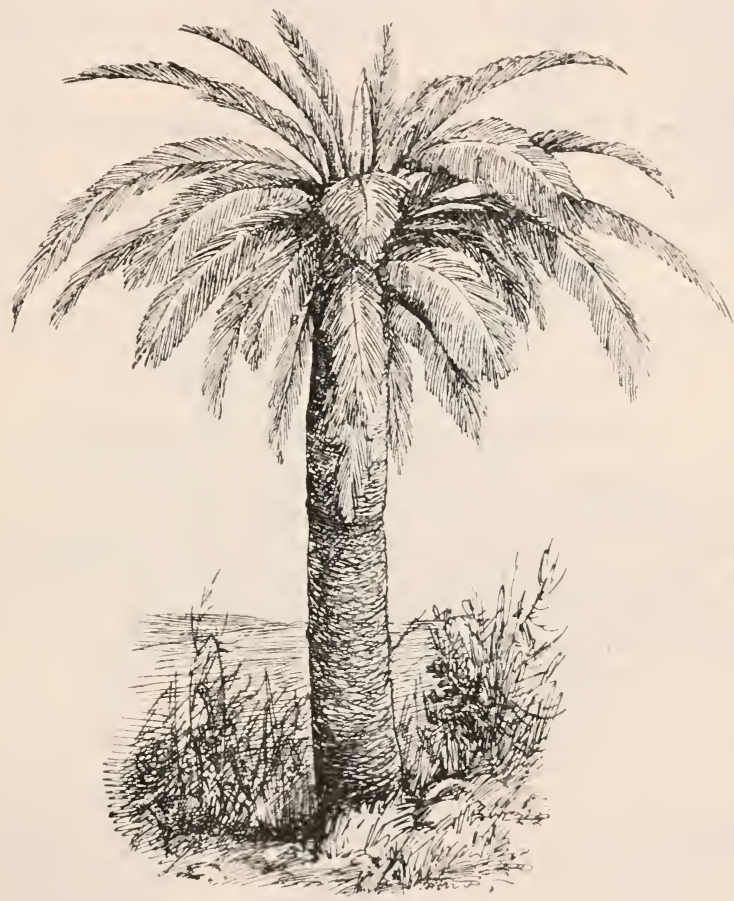

Palmfarn ('yeas revolita) aus (Ostindien. (Etwa 1,100 nat. (ir.) 


\section{Hauptabteilung. Blütenlose- oder Sporenpflanzen (Kryptógamae).}

Pflanzen, die keine Blüten besitzen und deren Vermehrang (vorwiegend) durch Sporen erfolgt.

\section{Gruppe. Farnartige Pflanzen oder Gefäß-Sporenpflanzen} (Pteridóphyta).

Pflanzen, die in Stengel, Blätter und Warzeln gegliedert sind und GefäBbündel enthalten.

\section{Klasse. Farne (Filícinae).}

Stengel einfach oder verzweigt, mit abwechselnd stehenden, meist mehrfach gefiederten Blättern. Sporenkapseln zumeist za Häufchen vereinigt auf der Unterseite der Blätter oder in besonderen Blattabschnitten eingeschlossen.

Der Wurmfarn (Aspídium filix mas). Taf. 35.

A. Vorkommen. Der Wurmfarn ist in schattigen Wäldern überall häufig anzutreffen. Auch an den Ufern der Bäche, die dicht mit Buschwerk bestanden sind, an schattigen Abhängen und ähnlichen Orten siedelt er sich gern an. Wird der Wald oder das Gebüsch, das ihn beschattet, niedergeschlagen, so daß er nunmehr den Sonnenstrahlen direkt ausgesetzt ist, dann macht schon mit Beginn des Sommers das tiefe Grün der Blätter einem krankhaften Gelb Platz, und oft schon nach wenigen Jahren ist von den zahlreichen Farnstöcken, die vorher den Ort besiedelten, kaum noch einer mehr zu finden. Dem Wurmfarn ist wie allen Schattengewächsen eine zu starke Beleuchtung eben genau so nachteilig, wie den Sonnenpflanzen (Beispiel!) das Fehlen der direkten Sonnenstrahlen. - Im Boden schräg eingesenkt findet sich der

B. Stamm (Wurzelstock), der meist ans der Erde etwas hervorragt und daselbst einen Büschel prächtiger Blätter trägt (1). Sonst ist er dicht mit den nicht abfallenden Stielresten abgestorbener Blätter, sowie mit vielen schwar . braunen Schuppen bedeckt. Hierzu kommen noch zahlreiche, faserige Wurzeln, die ihn wie mit einem Filze umgeben. Wie deutlich zu erkennen ist, stirbt der Stamm am Hinterende allmählich ab, während er am Vorderende alljährlich ein Stïck weiter wächst, eine Tatsache, die schon aus der Anwesenheit der zahlreichen Blattstielreste zu erkennen ist. (Der von den Blattstielresten befreite Stamm liefert ein wichtiges Mittel gegen den Bandwurm. Name!) 

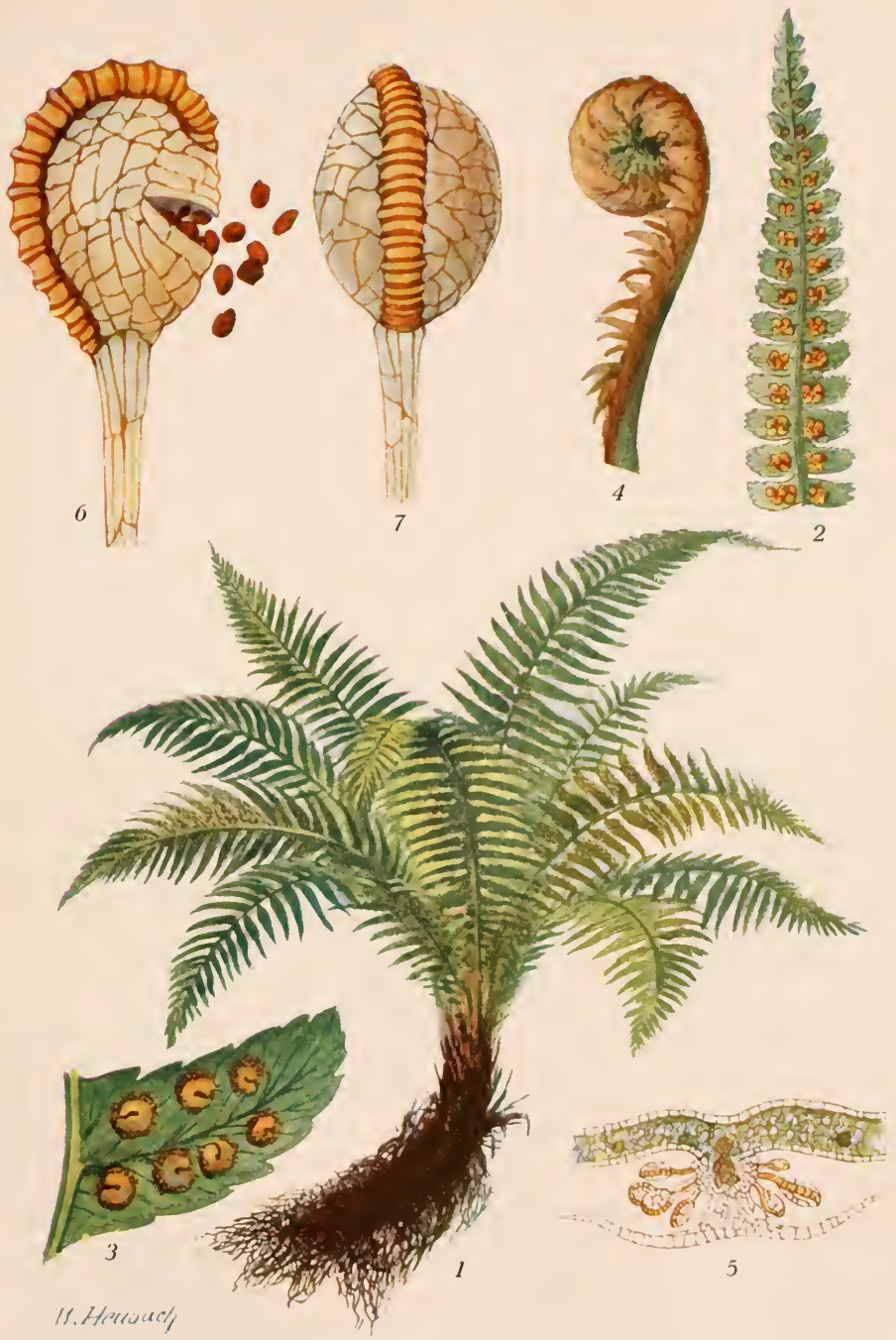

Wurmfarı (Aspidium filix mas). 


\section{.}


C. Bliitter. 1. Die schöngeformten Blitter bilden zusammen meist einen regelmaßigen 'Trichter', so daß alle des belebenden Sonnenlichts teilhaftig werden. Diese Anordnung der Blatter wird uns umso vorteilhafter erscheinen, wenn wir bedenken, daß am Standorte der I'flanze meist ein stark gedämpftes Licht herrscht.

2. Da die Blattflachen sehr dïnn und zart sind, können sie von dem schwachen Lichte doch genügend durchleuchtet werden. Derber, fester oder behaarter Blitter, die nur wenig Wasser verdunsten, und die wir daher bei zahlreichen Trockenlandptlanzen antreffen (Beispiele!), bedarf der Wurmfarn nicht. Im feuchten Waldboden findet er stets Ersatz für die Wassermengen, die er durch Verdunstung an die Luft abgibt. Auch kann er im Gegensatze zu dem Efen, der mit ihm den Waldgrund bewohnt, der derben Blätter wohl entbehren; denn er iiberdanert den Winter ja nicht im grünenden Zustande. Schon dem ersten Froste fallen seine zarten Blätter zum Opfer.

3. Im weiteren Gegensatz zu den meisten Trockenlandpflanzen besitzt der Wurmfarn groBe Blattflächen, die ohne jede Gefahr für ihn beträchtliche Wassermengen verdunsten können. Solche Blätter sind aber für die Pflanze nicht nur „zulässig“, sondern von größtem Vorteil; denn sie sind infolge ihrer Größe trotz des schwachen Lichtes, das am Waldgrunde herrscht, imstande, eine genügende Anzahl von Lichtstrahlen aufzufangen und sich dienstbar zu machen.

4. Wenn auch der Wurmfarn (zumeist) im Schutze der Bäume wächst, sind seine großen und zudem sehr zarten Blätter doch im hohen Grade der Gefahr ausgesetzt, vom Winde zerrissen zu werden. Dieser Gefahr ist nun dadurch begegnet, daß die Blattflächen in zahlreiche Abschnitte geteilt sind, die dem Anpralle des Windes leicht ausweichen, und zwischen denen viele Liicken und Durchlässe vorhanden sind. Die Blätter sind gefiedert; jedes Fiederblatt (2.) ist abermals bis nahe oder ganz anf die Mittelrippe in zahlreiche Abschnitte gespalten, und jedes dieser "Fiederchen" (3.) am Rande wieder mehr oder weniger tief eingeschnitten (beachte die vielfachen Verschiedenheiten, die hier im einzelnen vorkommen!). Da der Blattstiel verhältnismäßig kurz ist, so verschmälert sich die ganze Blattfläche stets nach unten; denn sonst wïrden sich die Fiederblätter daselbst ja gegenseitig das Licht streitig machen.

5. An dem jungen Blatte ist änBerlich von der Teilung der Blattflïche nichts zu sehen. Es ist gleich den einzelnen Fiederblättern schneckenförmig eingerollt und dicht mit braunen, schupenförmigen Haargebilden bedeckt (4.). So bietet der iiberaus zarte Pflanzenteil der austrocknenden Luft nur eine kleine Oberfläche dar, und die Schuppen wirken wie eine Decke, die wir ïber einen naßzuhaltenden Gegenstand breiten (vgl. mit dem jungen Laube der Roßkastanie). Sind die jungen Blätter genötigt, den Erdboden oder die Laubschicht des Waldbodens zu durchbrechen, so kommt infolge der spiraligen Einrollung auch nur der Stengel oder seine Fortsetzung, die feste, dicht mit Schuppen bedeckte Mittelrippe, hierbei in Betracht, wilhrend die sehr 
leicht zu verletzenden Fiederblätter bei dieser Arbeit ganz unbeteiligt bleiben In demselben $\mathrm{Maße}$, wie die Fiederblätter erstarken, rollt sich das Blatt auf, und die braunen Schuppen gehen, weil nnnmehr ohne Bedeutung, nach und nach verloren. - Die Mittelrippe des Blattes zerteilt sich in immer feinere „Nerven“, in denen wir später sog. Gefäßbündel kennen lernen werden. Diese Gebilde finden sich bei allen farnartigen Pflanzen, nicht aber auch bei den Moosen, Algen und Pilzen. Daher nennt man diese Pflanzen zum Unterschiede von jenen, den „Zellkryptogamen", auch „Gefäßkryptogamen ".

D. Fruchthäufchen. 1. Bereits während sich die Blätter älterer Pflanzen aufrollen, findet man an den meisten von ihnen anf der Unterseite hellgrüne, nierenförmige Häutchen, die als Schleier bezeichnet werden. Sie treten je nach der Breite der Fiederblätter und der Fiederchen in verschiedener Anzahl auf, nehmen später eine bleigrane und schließlich eine rotbraune Färbung an (3).

2. Schon mit bloßem Ange erkennen wir, daß jeder Schleier eine große Anzahl brauner Gebilde von der Größe eines Sandkorns bedeckt. Betrachten wir einen feinen Schnitt durch das Blatt (5) bei schwacher mikroskopischer Vergrößerung, so sehen wir weiter, daß wir es in den Gebilden mit Kapseln zu tun haben, die mit je einem Stielchen einer feinen Blattrippe aufsitzen. Untersuchen wir endlich einige dieser Kapseln bei stärkerer Vergrößerung und fïgen wir dem Wasser, in das wir sie zu diesem Zwecke gelegt haben, einen Tropfen Glycerin zu, so sehen wir, wie sie plötzlich aufreißen, und wie aus ihnen eine Menge kleiner Körperchen, sog. Sporen, hervortreten (6.). Diese Erscheinnng wird uns leicht verständlich, wenn wir uns durch einen entsprechenden Versuch von der wasserentzịehenden Eigenschaft des Glycerins überzeugen (lege z. B. ein Stück einer Kartoffel oder eines Apfels in Glycerin und beobachte, wie diese Körper stark schrumpfen!), und wenn wir

3. die „Sporenkapseln" (Sporangien) näher betrachten (6. und 7.). Die Wand eines solchen Gebildes besteht ans einer Schicht platter Zellen, ïber die sich wie die "Raupe" am Feuerwehrhelm ein aus dunkleren Zellen gebildeter „Ring“ erhebt. Diese Zellen haben sehr starke Innen- und Querwände, aber sehr zarte Außenwände. Entzieht das Glycerin ihnen nun Wasser, so stülpt sich die zarte Außenwand nach innen, der Ring wird infolgedessen so verkürzt, daß die Kapsel aufreißt. Dieser Vorgang wiederholt sich während des Spätsommers auch im Freien, nur daß hier das Zerreißen durch das Austrocknen der Kapselwand bewirkt wird.

4. Wie wir im weiteren Verlauf unserer Betrachtung noch sehen werden, gehen aus den Sporen junge Pflanzen hervor. Daher bezeichnet man jede von einem Schleier bedeckte Gruppe von Sporenkapseln (ungenan - wieso?) als F r u ch thä uf e hen.

5. Die Sporen sind also wie die Samen der Blütenpflanzen Vermehrungskörper und daher für das Farnkrant sehr wichtige Gebilde, eine Tatsache, die uns eine Anzahl Erscheinungen und Einrichtungen leicht verständlich macht: 
a) Die Sporen bilden ein staubeines Pulver. Daher können sie leicht durch den Wind verwelıt und iiber einen großen Bezirk ausgestrent werden (Bedentung!). (Lege ein Farnblatt z. Z. der Sporenreife auf ein Blatt Papier und beobachte, welche Mengen von Sporen erzeugt werden!)

b) Eine solche Aussaat kann aber nur ein "trockener" Wind besorgen (wieso?), d. l. ein solcher, der zugleich das Öffnen der Sporenkapseln bewirkt, oder anders ausgedrïckt: das Aufspringen der Kapseln steht mit der Weise der sporenverbreitung im innigsten Einklange.

c) Die Sporen haben eine rauhe Oberfläche. Infolgedessen werden sie wie die rauhen Samen höherer Pflanzen leicht an den Erdboden gefesselt (s. S. 26, b).

d) Den unteren Fiederblättchen, die dem Winde weniger stark ausgesetzt sind als die oberen, fehlen zumeist die Fruchthäufehen.

e) Die Blattoberseite wird allerdings voh Winde am meisten bestrichen. Ihr fehlen aber die Fruchthäufchen; denn die Sporenkapseln sind außerordentlich zarte Gebilde, die gegen Befeuchtung geschützt werden mïssen. Diesen Schutz finden sie a $u \mathrm{f}$ der Blattunterseite nnd

f) durch den Schleier (Name!), der sie bis zur Zeit der Sporenreife bedeckt. Da die staubförmigen Gebilde aber vom IVinde verweht werden sollen, schrumpft der Schleier kurz vor der Aussaat der Sporen stark zusammen.

E. Vorkeim.

1. Säen wir eine Anzahl Sporen auf durchfenchtete IValderde, die in einen Blumentopf gebracht worden ist, und bedecken wir diesen mit einer crlas-
1.

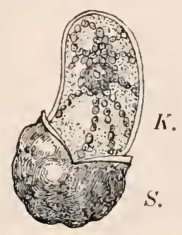

2.

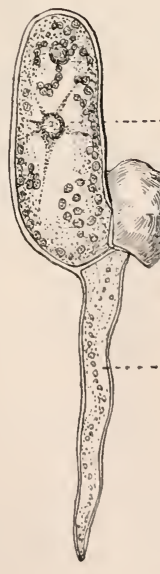

3.

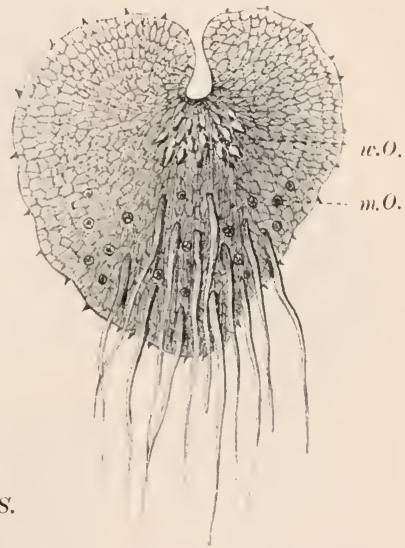

Der Vorkeim des Wurmfarns mul seine Entwicklum.

1. a. 2. Keimende spore in zwei aufeinander folgenden Entwicklnngs\%, ständen.s. spore; K. Keimschlauch; W. das erste Wurzelhaar (etwa 240 mal vergr.). 3. Der ansgebildete Vorkeim, von der Unterseite gesehen. m.0. dic kuppelförmigen fiebilde oder die männlichen Organe; w.O. die flaschenförmigen Gebilde oder die weiblichen Organe (etwa $10 \mathrm{mal}$ vergr.). 
glocke, so zeigt sich auf der Oberfläche der Erde meist schon nach einigen Tagen ein grüner Anflug: die Sporen sind gekeimt, d. h. ihr Inhalt ist in Form eines kurzen Schlauches hervorgetreten. Der "Keimschlauch" wächst zunächst zu einem fadenförmigen und schließlich zu einem blattartigen Körper aus, der lebhaft grün gefärbt ist, herzförmige Gestalt und etwa Pfenniggröße hat. Dieser sog. Vorkeim (Prothallium) ist durch zahlreiche Haare, die am zugespitzten Ende entspringen, am Boden befestigt. (Am bequemsten erhält man Farn-Vorkeime in Gewächshäısern, in denen Farne gezogen werden. Sie finden sich dort läufig auf Blnmentöpfen, an feuchten Wänden und ähnlichen Stellen.)

2. Neben den "Wurzelhaaren" entstehen auf der Unterseite des Vorkeims noch andere Organe, die schon mit der Lupe zu erkennen sind, deren feinereu

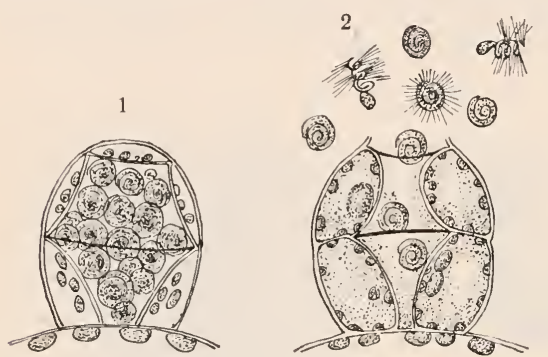

Ein kuppelförmiges Gebilde oder männliches Organ, bei stärkerer, (etwa 350 maliger) Verg. 1 Geschlossen; 2 geöffnet; die Schwärmer kommen aus der öffmung hervor und nehnen korkzieherartige Form an.
Bau uns jedoch erst das Mikroskop enthïllt. $\mathrm{Zu}$ diesem Zwecke legen wir einen Vorkeim (oder besser: sehrdïnne Querschnitte durch einen solchen) in etwas Wasser auf eine kleine Glasplatte (Objektträger). In der Nähe des zugespitzten Endes erblicken wir dann kuppelförmige Gebilde, die im reifen Zustande zahlreiche kugelige Zellen entLalten. Benutzen wir zu unserer Untersuchung einen Vorkeim, der längere Zeit nicht befeuchtet wurde, so sehen wir sehr bald, wie sich eines dieser Gebilde am Scheitel öffnet, und wie die kugeligen Zellen darans hervortreten. Nach wenigen Sekunden verwandeln sich diese Kugeln in korkzieherförmige Körper, die mit Hilfe schwingender Wimpern wie Anfguß- oder Geißeltier. chen schnell durch das Wasser dahinschwimmen (s. "Lehrbuch der Zoologie"). Ehe wir das Schicksal dieser "Schwärmer" weiter verfolgen, müssen wir uns

3. den anderen Organen des Vorkeims zuwenden, die sich als flaschenförmige Gebilde in der Nähe des herzförmigen Einschnittes finden. Bei der Reife fließt aus der Iündung ihres krummen Halses ein farbloser Schleim hervor. Kommt ein Schwärmer einer noch geschlossenen "Flasche“ zu nahe, so schwimmt er "gleichgültig“ weiter. Ist die „Flasche" aber geöffnet, so eilt er der Öffnung schon von einer gewissen Entfernung aus zu, gerät in den Schleim, bohrt sich langsam bis zum Grunde der "Flasche" hinab und verschmilzt dort mit einer Zelle, die schon äußerlich von den benachbarten Zellen abweicht. Derselbe Vorgang spielt sich selbstverständlich auch im Freien ab, wenn Tau- oder 
Regentropfen der Unterseite des Vorkeimes anhaften. Aus der mit dem Schwärmer vereinigten Zelle geht nun im Laufe der Zeit ein junges Farnkraut hervor, das anfänglich mit dem Vorkeim noch in Verbindung steht, nach dem Absterben dieses Gebildes aber eine selbständige Pflanzedarstellt.

4. Dieser Vorgang erinnert uns lebhaft an dieBefruchtung nnd

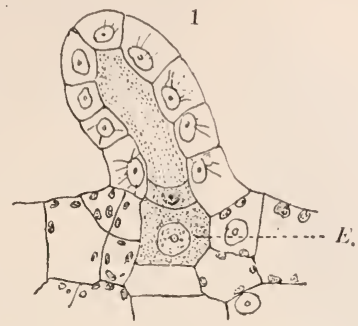

Ein flaschenförmiges Gebilde oder weibliches Organ, bei stärkerer (etwa 250 maliger) Vergr. 1 gesehlossen; 2 geöffıet; E Eizelle.

Vermehrung der Samenpflanzen: der Schwärmer ist einem Blïtenstaubkorne, die im Grunde des flaschenförmigen Orøans liegende Zelle der Samenanlage, das kuppelförmige Gebilde dem Staubblatte und das Haschenförmige dem Fruchtblatte (Stempel) vergleichbar. Da nun aus der Zelle, die der Samenanlage entspricht, eine junge Pflanze hervorgeht wie der Vogel aus dem Ei, so bezeichnet man sie als Eizelle, und da die Ablage der Eier durch die weiblichen Tiere erfolgt, so haben wir in dem flaschenförmigen Gebilde das weibliche Organ (oder das Archegonium) des. Farnes vor uns. Das die Schwärmer liefernde kuppelförmige Gebilde stellt dementsprechend das männliche Organ (oder Antheridium) dar. Während bei den Samenpflanzen beiderlei Organe (Staubblätter und Fruchtblätter) in Blüten eingeschlossen sind, fehlen den Sporenpflanzen die Bliiten. Man bezeichnet sie daher zum Unterschiede von den "Blütenpflanzen“ als,, bl tï ten lose Pflanzen".

5. Der Entwicklungsgang des Farnkrautes von der keimenden Spore bis zur Vereinigung von Eizelle und Schwärmer (Befruchtung) zeigt nun eine

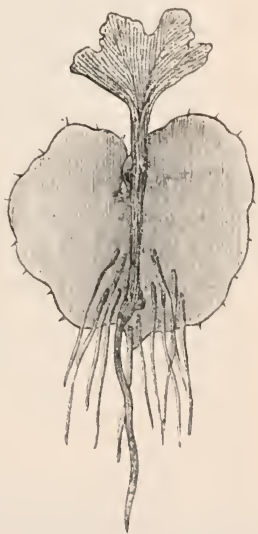

Vorkeim rom Wurmfaru: ans der befruchteten Eizelle ist eine junge Farnpflanze hervorgegangen (etwa 10 mal vergr.). Anzahl von Einzelheiten, die einer nüheren Betrachtung wert sind:

a) Die Tatsache, daß aus der keimenden Spore keine junge Farnpflanze, sondern ein schlanchförmiger Körper hervorgeht, zeigt uns, daß wir in den 
Sporen nicht Samen vor uns haben, wie solche von den Blïtenpflanzen erzeugt werden. Während nämlich jeder Same einen Keimling, d. i. die Anlage zu einer neuen Pflanze, enthält (s. S. 99,2) und daher aus zahlreichen Zellen entsteht, ist die Spore ein einzelliges Gebilde, das demnach anch nicht einen mehrzelligen Keimling enthalten kann (Samen- und Sporenpflanzen). Auch der Umstand, daß die Sporen nicht in Blïten entstehen, oder anders ausgedrïckt, nicht aus Samenanlagen hervorgehen, zeigt, daß sie keine Samen sind.

b) Als einzelliger Körper enthält die Spore auch nur sehr wenig Baustoff für den aus ihr hervorgehenden Keimschlauch. Dieses Gebilde ist daher von Anfang an darauf angewiesen, sich die zum Leben und Wachstum nötigen Stoffe selbst zu erwerben. Ein gleiches gilt natürlich auch für den Vorkeim, zu dem sich der Keimschlauch entwickelt. Beide senden daher "Wurzelha a re" in den Boden, um Nährstoffe daraus zu entnehmen, und sind reich an Blattgrii n, durch das die anfgenommenen Rohstoffe in Nahrungs- und Banstoffe ïbergeführt werden. Hierzn ist aber (s. den letzten Abschn. d. Buches!) unbedingt

c) das Sonnenlicht erforderlich. Die Keimung der Farnsporen und die Bildung der Vorkeime findet daher niemals im Dunkeln statt (wie zumeist die Keimung der Samen).

d) Keimschlauch und Vorkeim sind außerdem ïberaus zarte Gebilde, die sehr leicht durch Vertrocknen zugrunde gehen. Sie entwickeln sich daher auch nur an fenchten Orten. (Daher müssen wir den Blumentopf mit den ausgesäten Sporen in das Licht stellen und, um die Luft beständig feucht zu erhalten, mit einer Glasglocke ïberdecken!) Diese Tatsache erklärt uns auch das häufige Vorkommen der Farne an feuchten Orten, besonders im Grunde fencliter Wälder, sowie ihr gänzliches Fehlen in Wüsten und Steppen. Die Verbreitung der Farne wird auch noch durch

e) die Art und Weise bedingt, in der die Befruchtung stattfindet: Da männliche und weibliche Organe voneinander getrennt sind, so maß eine Verbindung zwischen ihnen stattfinden. Insekten und Wind, die bei den Samenpflanzen eine solche zwischen Staubblatt und Stempel schaffen, kommen hier nicht in Betracht (wieso?). Dagegen ist das Wasser, das als Tau oder Regen den Vorkeim netzt, wohl imstande, eine solche „Brücke" zu bilden. Da das Wasser, das dem Vorkeim anhaftet, aber still steht, müssen die „männlichen Zellen" die Eizelle aufsuchen, oder anders ausgedrïckt, es mïssen freibewegliche Körper, also „Schwärmel" sein.

f) Die Schwärmer können sich wie die Aufguß- und Geißeltierchen aber nur in einer Flüssigkeit bewegen. Daher scheidet das weibliche Organ bei der Reife einen Schleim aus. So wird zwischen dem äußeren Wasser und der Eizelle eine Verbindung hergestellt, wie ihrer der Schwärmer zu seiner Fortbewegung bedarf.

6. Überblicken wir den Entwicklungsgang des Wurmfarns (der mit dem aller anderen Farne iibereinstimmt), so finden wir, kurz gesagt, folgendes: Aus 
den Sporen, die auf "ungeschlechtlichem Wege“ wie eine Art Ableger am Farnblatte entstehen, geht ein Vorkeim hervor, der auf "geschlechtlichem Wege“ (durch Vereinigung von Eizelle und Schwärmer) wieder eine sporentragende Farnpflanze erzeugt. Die Entstehung des Vorkeims aus einem anderen, oder einer sporentragenden Farnpflanze aus einer anderen findet nie statt. Das Farnkraut tritt also in zwei streng von einander geschiedenen und nuter sich ganzunähnlichen Foxmen oderGenerationen a uf: einer ungeschlechtlichen Form, der sporentragenden Farnpflanze, und einer geschlechtlichen, dem Vorkeime. Beide Formen wechseln regelmäßig miteinander ab, ein Vorgang, der darum als Generationswechsel bezeichnet wird (vgl. dieselbe Erscheinung bei den Quallen; s. Lehrbuch d. Zoologie).

\section{Anclere Farne.}

1. Neben dem Wurmfarn zählt der Tïpfelfarn oder das lingelsiį̧ (Polypódium vulgáre) $\mathrm{zu}$ unseren bekanntesten Farnkräutern. Die zierliche, sehr veränderliche Pflanze wächst am Fube alter, mit Moos bewachsener Baumstämme, sowie an Felsen und ähnlichen Orten. Da sie weit kleinere und derbere Blätter besitzt als z. B. der Wurmfarn, so gibt sie auch viel weniger Wasser durch Verdunstung $a b$ als dieser. Sie gedeiht daher selbst noch an sehr trockenen Orten ( $\mathrm{z}, \mathrm{B}$. in Kieferm-

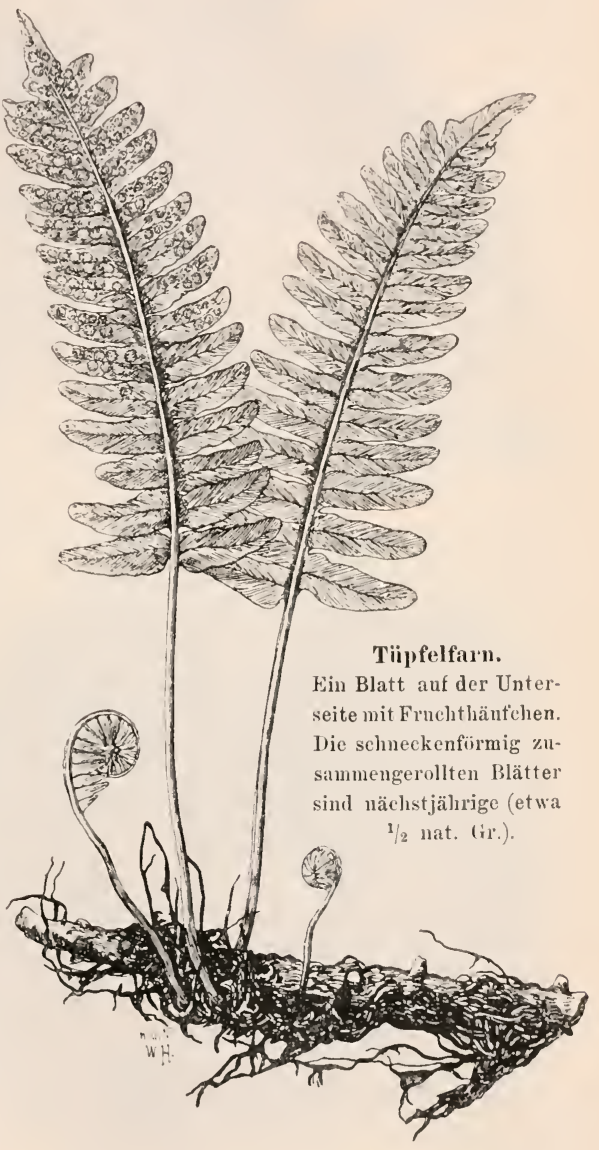
wäldern), und ihre Blätter vermögen sogar den Winter za ibberdauern (s, S. 92). Der geringen Größe entsprechend sind die Blätter nur einfich gefiedert (s. S. 295,4). Die randen Fruchthäufchen sind nicht von einem Schleier bedeckt ( ${ }_{\pi}$ Tüpfelfarn ${ }^{4}$ ). Der im Boden oder unter dem ILose kriechende Wurzelstock ist von siißem Geschuack. Er galt früher als wichtiges 


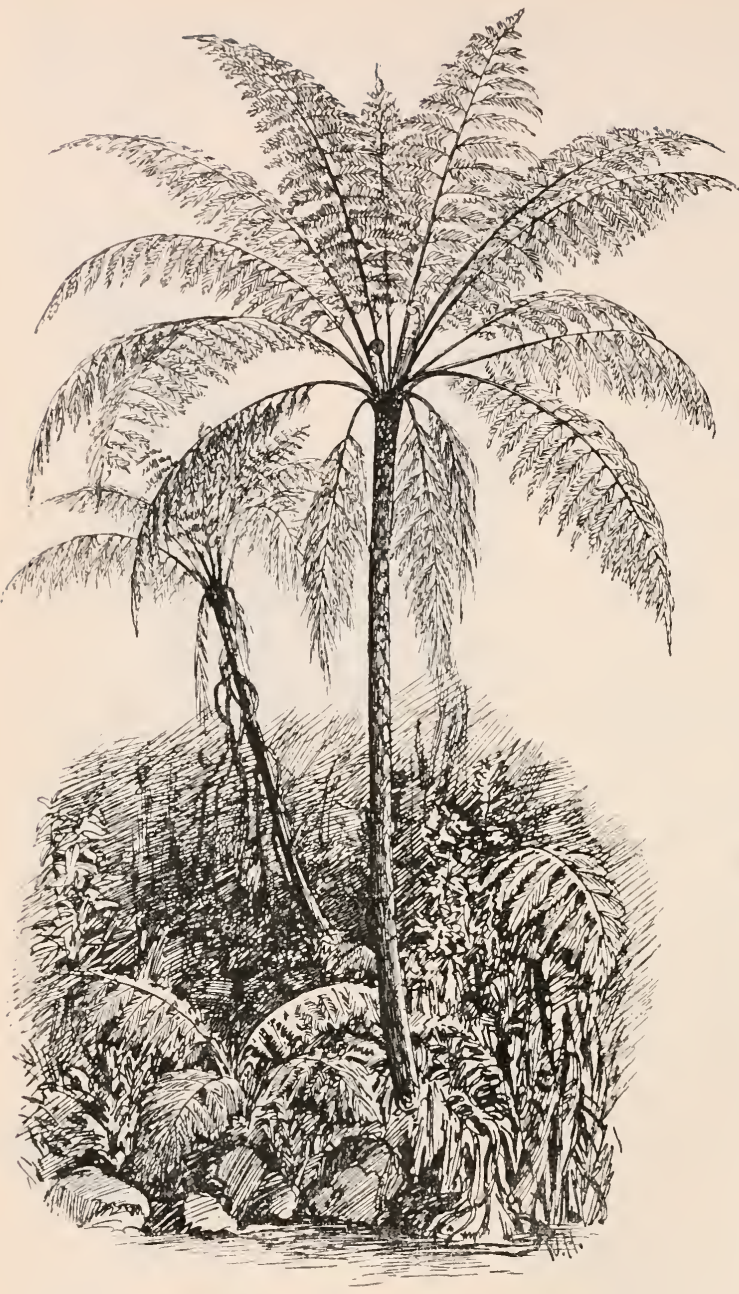

Baumfarne (Alsóphila) im tropischen Australien.
Heilmittel, das der

Sage nach die Engel der leidenden Menschheit auf die Erde gebracht haben sollen („EngelsüB“). - Eine ausgeprägte Wald- und Schattenpflanze dagegen ist der Streifenfarı (Asplénium fílix fémina). $\mathrm{Er}$ ist dem Wurmfarn sehr ähnlich (daher auch "falscher Wnrmfa $r^{\prime \prime}$ genannt), hat aber zartere und kleinere Blätter, sowie streifenförmige Fruchthäufchen (Name!) - Ein anderes Glied der Gattung ${ }_{n}$ Streifenfarn", die zierliche Mauerraute (A. ruta murária), dagegen gibt sich als Trockenpflanze leicht $z u$ erkennen. Sie hat kleine, meist 2-3fach fiederschnittige Blätter von fast lederartiger Beschaffenheit und nimmt mit der geringen Fellchtigkeit fürlieb, die ihr Manerritzen und Felsenspalten bieten. - Gegen

das niedliche Pflänzchen erscheint der Adlerfarn (Pterídium aquilinum) wie ein Riese. Er überzieht den Boden lichter Wälder, Berglehnen und ähnliche Orte oft auf weite Strecken hin mit seinen Blättern, die nicht selten eine Länge von mehreren Metern 
erreichen. Der weit im Boden dahinkriechende, verzweigte Wurzelstock trägt an jedem Zweige alljährlich nur ein dreiteiliges Blatt, das seiner Größe entsprechend wie das des Wurmfarns vielfach gespalten ist. Führt man durch den unteren, schwarzen Teil des Blattstiels einen schrägen Querschnitt, so gibt sieh die Anordnung der Gefäßbündel in Form eines Doppeladlers zu erkennen (Name!). Die Sporenkapseln stehen in einer Linie, die dem Rande der Fiederblättchen parallel läuft. Sie sind außer von einem zarten (inneren) Schleier noch von dem umgeschlagenen Blattrande bedeckt.

2. Da, wie wir gesehen haben, das Vorhandensein der Farne an die Anwesenheit von Feuchtigkeit gebunden ist, so erscheint es uns erklärlich, daß die feuchten Urwälder der Tropen weit reicher an den schönen Pflanzengestalten sind als die heimischen Wälder. Gleich dem Adlerfarn bedecken sie dort den Boden oft wie mit einem grünen Teppich oder siedeln sich mit den Orchideen als Überpflanzen auf Stämmen und Zweigen an. Bei zablreichen Formen erhebt

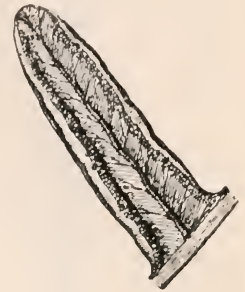

Fiederchen vom Blatte des Aillerfarn mit Sporenkapseln (nat. (ir.). sich der Stengel, der bei den heimischen Arten nnterirdisch bleibt, als säulenartiger Stamm hoch über den Boden. Da diese Ba nmfarne eine Krone groBer, feinzerteilter Blätter tragen, so ähneln sie den Palmen, mit denen sie zu den stolzesten Pflanzengeschlechtern zählen.

3. Viel reicher als in der Gegenwart war die Erde an Farnpflanzen in der Zeit, als sich die Steinkohle bildete. Wie in den Tropen, herrschte damals auch in unserer Heimat ein feuchtheißes Klima, und mäcbtige Wälder von baumartigen Farnen, riesigen Schachtelhalmen und Bärlappen bedeckten den sumpfigen Boden.

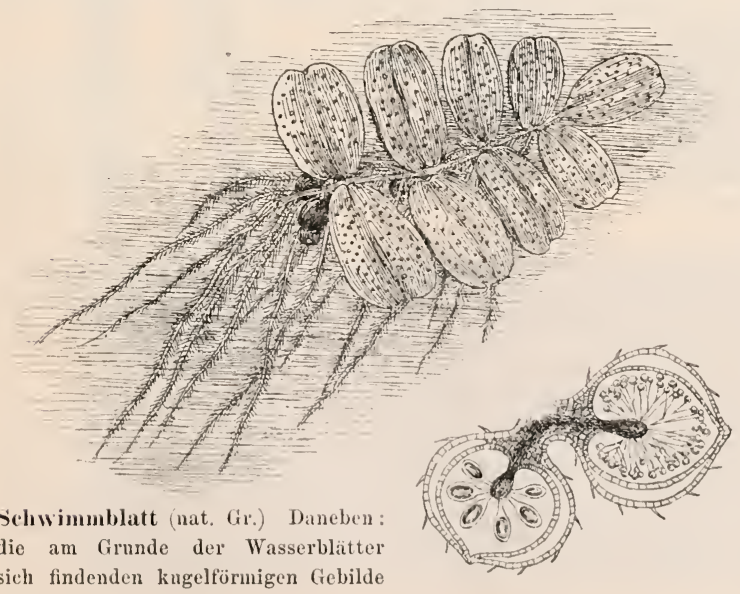

sich findenden kugelförmigen Gebilde

(schwach vergröbert.) Das eine nit wenigen Grobsporen-, das andere mit zahlreichen Kleinsporenkapseln.
Die umsinkenden Stämme wurden von den Flüssen zusammengeschwemmt, vom Meere überflutet und mit Schlamm nnd Sand bedeckt. Die von der Luft somit alogeschlossenen Pflanzenreste verkohlten im Laufe derJahrmillionen allmählieh wie das Holz im Kohlenmeiler : d. h. sie zer- 
setzten sich derart, daß fast nur der Kohlenstoff übrig blieb, der heute als "Steinkohle“ zutage gefördert wird.

4. Von den bisher betrachteten Landfarnen ist die Grappe der Wasserfarne scharf unterschieden. Sie wird von wenigen kleinen Gewächsen gebildet, die das Wasser oder den Sumpf bewohnen und zweierlei Sporen bilden. Während die aus den „Kleinsporen" herrorgehenden Vorkeime nur männliche Organe (Antheridien) tragen, entstehen aus den "Großsporen" Vorkeime mit weiblichen Organen (Archegonien). Die verbreitetste Form dieser eigentämlichen Pfänzchen ist das Schwimmblatt (Salvinia nátans), das sich in stehenden und langsam fliebenden Gewässern findet. Da es nnter fast genau denselben Verhältnissen lebt wie der Wasserhahnenfoß (s. das.), so bildet es wie dieser neben (eiförmigen) Schwimmblätterı Wasserblätter, die in fadenförmige, beharte Zipfel gespalten sind und die Stelle der fehlenden Wurzeln vertreten. Am Grunde der Wasserblätter bilden die vollkommen geschlossenen Schleier kugelförmige Gebilde, die entweder wenige Großsporen- oder zahlreiche Kleinsporenkapseln enthalten.

\section{Klasse. Schachtelhalme (Equisétinae).}

Stengel einfach oder quirlig verzweigt, mit quirlig gestellten, schnppenartigen Blättern, die zu Scheiden verwachsen sind. Sporenkapseln auf der Unterseite schildförmiger Blätter, die am Ende des Stengels ährenartig gehäuft sind.

Der Ackerschachtelhalm (Equisétum arvénse). Taf. 36.

A. Frïhjahrstriebe. Auf Äckern (Name!), Grasplätzen und an ähnlichen Orten brechen im März nnd April zarte, blaß-rotbraune Gebilde, die mit einer ährenartigen Bildnng abschließen (1), aus dem Boden hervor. Es sind die Frühjahrstriebe des Ackerschachtelhalms.

1. Der Stengel ist muverzweigt, längsgefurcht und aus mehreren Gliedern zusammengesetzt, die nach oben länger und dünner werden. Auf dem Querschnitt zeigt er einen großen, mittleren Hohlraum, der sehr regelmäßig von kleinen Kanälen umgeben ist (vgl. mit Roggen!). An den massiven Stengelknoten entspringen

2. die Blätter. Sie sind auffallend klein, quirlförmig angeordnet und bis anf die schwarzen Spitzen miteinander zu je einer Scheide verwachsen, die den Stengel rings umgibt. Diese winzigen und zudem nur teilweise schwach grïnen Gebilde scheinen für die Pflanze gänzlich bedentungslos zu sein. Bei näherem Zusehen aber wird man bald eines besseren belehrt:

a) Wie leicht festzustellen ist, durchbrechen die wachsenden Stengel den Boden mit ihrer Spitze $(1 \mathrm{~b})$. Dabei müßte aber die endständige, zarte „Ähre“ unbedingt verletzt, wenn nicht gar zerstört werden. Wie die gleichfalls noch sehr zarten Stengelglieder ist nnn die Ähre bei dieser Arbeit von den widerstandsfähigen Blättern vollständig umhällt (vgl. z. B. mit der Tulpe!).

b) An den unteren Enden bleiben die Stengelglieder lange Zeit wachstumsfähig und daher zart und weich. An diesen leicht verletzlichen und austrocknenden Stellen sind nun die Stengel von den Blättern wie von 


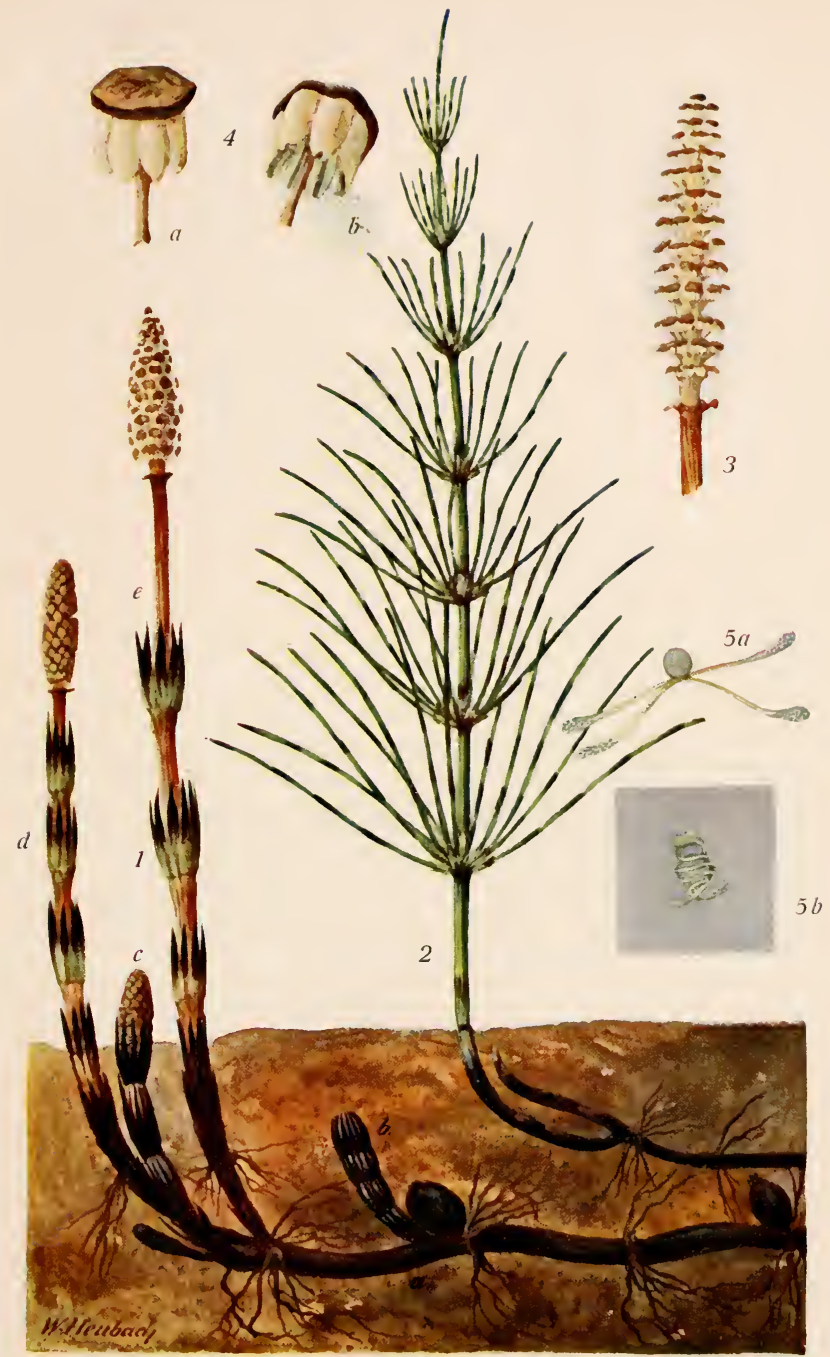

Ackerschachtelhalm (Equisetum arvense). 

schïtzenden Seheiden umgeben. Wir treffen hier also fast dieselben Verhältnisse wie beim Roggen an (s. S. 25.1), mit dem der Schachtelhalm auch das schnelle Wachstum der Stengel gemein hat. Übt man auf einen wachsenden Stengel einen starken Zug aus, so muß er an diesen zarten Stellen selbstverständlich am leichtesten zerreißen. Daher kann man die einzelnen Stengelglieder leicht aus ihren Scheiden herausziehen, ein Umstand, dem die Pflanze den bezeichnenden Namen „Schachtelhalm“ verdankt. (Untersuche daraufhin besonders die Sommertriebe und beobachte, wie sich die oberen Stengelglieder ander's verhalten als die unteren, schon erstarkten!)

3. Die Sporenähre. Über dem obersten Blattquirle, der die Form eines gelappten Ringes besitzt, erhebt sich eine kegelförmige Ähre, aus der bei der Reife ein blaugrüner staub hervorkommt. In ilım haben wir die Sporen der Pflanze vor nus (s. Wnrmfarn). Wir sind daher wohl berechtigt, die Ähre als "Sporenähre" und die Frühjahrstriebe als sporentragende oder "fruchtbare" Triebe zu bezeichnen. Die Sporenälure besteht aus der Fortsetzung des Stengels, der Achse, und

a) zahlreichen "Sporenblättern", die wie die Stengelblätter in Quirlen angeordnet sind. Jedes Blatt hat die Form eines gestielten Schildchens (4), d. h. es besteht aus einem Stiele, der rechtwinklig von der Achse absteht, und einer Platte, die dem Stiele in ihrer Mitte aufsitzt. Wie man an der Anlage der Ähre erkennen kann, stellen diese Blätter ursprïnglich Höcker der Achse dar, die sich an dem freien Ende nach und nach scheibenförmig verbreitern. Da nun diese Scheiben zusammenstoßen und weiterwachsen, so müssen sie sich gegenseitig abplatten: sie nehmen die For'm meist sehr regelmäßiger Sechsecke an, wie wir sie an den ausgebildeten Blättern erkennen.

b) An der Innenseite tragen die Platten je meist seclıs häutige Säckchen, in denen sich die Sporen bilden. Wir haben in ihnen also die Sporenkapseln vor uns (vgl. mit Wurmfarn).

c) Wie uns ein Blick durch das Mikroskop zeigt, besitzt jede Spore zwei sich kreuzende Bänder, die in ihrer Mitte mit der Sporenhaut verwachsen sind und sich am Ende spatelförmig erweitern (5a). Klopfen wir die reife Sporenähre über einem Blatt Papier oder dgl. aus, und hauchen wir die erhaltene Sporenmasse in kurzen Zwischenpausen leicht an, so kommt eine eigentïmliche Bewegung in sie: nach dem Anhauchen nimmt sie das Aussehen feinster Watte an, um kurze Zeit darauf wieder vollständig in Staub zu zerfallen. Hauchen wir die Sporen an, während wir sie unter dem Mikroskop betrachten, so sehen wir, daß die (hygroskopischen) Bänder es sind, die diese Bewegung verursachen: sie nelımen etwas von dem Wasserdampf auf, der in der Atemluft enthalten ist, und rollen sich infolgedessen schnell eng um die Sporen $(5 \mathrm{~b})$; ist die geringe Wassermenge wieder verdunstet, so strecken sie sich auch wieder aus (5a).

Welche Bedeutung hat nun diese eigentiimliche Einrichtung? Die staubförmigen Sporen werden wie z. B. die des Wurmfarns durch den Wind verbreitet. Zur Zeit der Sporenreife schrumpfen daher die Sporenblätter stark Schmeil, Lehrbuch der Botanik. 
zusammen (1 e und 3), so daß der Wind zwischen ihnen hindurch streichen kann. Zugleich öffnen sich die Sporenkapseln nach innen (4b). Infolge des Wasserverlustes der Sporenblätter trocknen aber auch die Bänder der Sporen aus, so daß sie sich ausstrecken. Die Sporen nehmen infolgedessen jetzt weit mehr Platz ein als rordem und drängen sich gleichsam gegenseitig aus der Öffnung

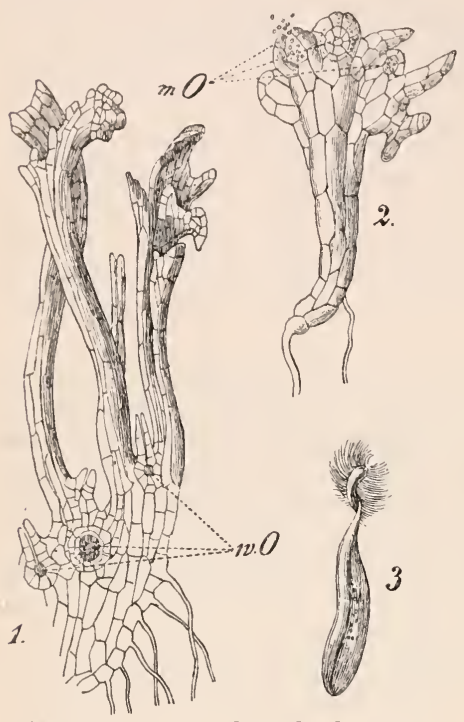

Vorkeim vom Ackerschachtelhalm (etwa $60 \mathrm{mal}$ vergr.). 1. weiblicher Vorkeim; am Grunde mit (w. o.) 3 weiblichen Organen (Arehegonien). Das mittlere ist befruchtet und beginut, sich zu einer neuen Pflanze zu entwickeln. 2. männlicher Vorkeim; an der Spitze mit (m.o.) 3 mänulichen Organen (Atheridien); das linke hat sich geöffnet, so daß die schwärmer entweichen. 3. ein Sehwärmer (stark vergr.). der Sporenkapsel heraus, so daß sie nunmelr vom Winde erfaßt und verweht werden können. (Beobachte an abgeschnittenen Stengeln im Zimmer, wie die Sporen aus den Öffnungen der Kapseln gleichsam hervorquellen!)

Eine erfolgreiche Verbreitung der Sporen ist aber nur bei trockener Luft" möglich (wieso?). Dann aber strecken sie ihre Bänder aus. Sie bieten dem Winde dann also eine große Angriffsfläche dar, so daß sie leicht verbreitet werden können.

Haben die Sporen einen günstigen Platz gefunden, so beginnen sie wie die des Wurmfarns zu keimen und je einen Vorkeim zu entwickeln. Dieses Gebilde hat beim Schachtelhalm etwa die Form eines kleinen Lebermooses, trägt aber entweder nur männliche (Antheridien) oder weibliche Organe (Archegonien). Eine Befruchtung der Eizelle durch einen Schwärmer kann also nur dann eintreten, wenn sich mehrere (männliche und weibliche) Vorkeime nebeneinander entwickeln. Dies ist nun dadurch leicht möglich, daß mehrere Sporen, durch i hre Bänder ineinander gehakt, zusammen durch den Wind verweht werden und an derselben Stelle keimen. - Im ïbrigen erfolgt die Befruchtung, suwie die Bildung der jungen Pflanze aus der befruchteten Eizelle in derselben Weise wie bei den Farnen. (Führe dies näher ans! Beweise, daß auch beim SchachtelhaIm ein Generationswechsel vorhanden ist!)

4. Lebensdauer und Erscheinungszeit. a) Die Frühjahrstriebe sind, wie wir gesehen haben, blasse Gebilde, die. nur ganz geringe Mengen von Blattgrïn besitzen. Sie sind daher gleich allen anderen Pflanzen 
und Pflanzenteilen, denen das Blattgrïn fehlt, auch nicht im stande, die zur Ernährung und zum Wachstum nötigen Stoffe zu bereiten. Sie sterben daher ab, sobald sie ihre A ufgabe erfüllt, d. l. die Sporen ausgestreut haben. (Beweise, daß sie im anderen Falle für die Pflanze nur unniitze „Esser" darstellen würden!)

b) Die Verbreitung der Sporen durch den Wind läßt uns auch das Erscheinen der fruchtbaren Triebe im zeitigen Frïhjahre als nicht unwichtig erkennen. Jetzt sind nümlich die Äcker noch kahl oder die angebauten Pflanzen (Getreide, Klee, Raps u. dgl.) noch niedrig. Später im Jahre dagegen würden die.Ackerpflanzen die Sporenähren, die ja nur auf verhältnismäßig kurzen Stengeln stehen, zum größten Teil ïberragen, also dem Einflusse des Windes entziehen. Andererseits ist es den fruchtbaren Trieben auch möglich, so zeitig im Jahre zu erscheinen; denn sie besitzen in dem

B. 1. unterirdischen Stamme (Wurzelstocke) eine Vorratskammer, in der sie die zum Aufban notwendigen Stoffe fertig vorfinden. Als besondere Behälter für die aufgespeicherte Nahrung finden sich an dem Stamme vielfach noch kleine Knollen (1 a), die wie die Kartoffelknollen kurze, stark angeschwollene Stengelstïcke darstellen. (Beweise, daß die Vorratsstoffe vorwiegend aus Stärke bestehen! s. S. 138, d.)

2. Der Stamm ist im wesentlichen wie der oberirdische Stengel gebaut (Beweis!). Er ist federkieldick, schwarzbraun, vielfach verzweigt, kriecht weit im Boden umher und treibt aus den Knoten zahlreiche faserige Wurzeln. Die miteinander verwachsenen Blätter sind aber noch kleiner als die an dem Stengel des fruchtbaren Triebes. Sie haben ja auch keine Sporenähre, sondern nur die dïnnen, fortwachsenden Spitzen des verzweigten Stammes gegen Verletzung zu schützen. Haben sie diese Aufgabe erfüllt, so sterben sie, weil nunmehr ohne Bedeutung, bald ab.

Da der Stamm meist so tief im Boden liegt, daß ihn der Pflng nicht erreicht, da er ferner nach allen Richtungen Zweige aussendet, so daß sich die Pflanze schnell uiber einen großen Bezirk ausbreitet, und da er endlich zahlreiche oberirdische Triebe bildet, die den Feldpflanzen Nahrung, Raum und Licht wegnehmen: so ist der Ackerschachtelhalm eins der lästigsten Unkräuter.

C. Sommertriebe. 1. Nachdem der Schachtelhalm die fruchtbaren Triebe gebildet hat, sind die im unterirdischen Stamme aufgespeicherten Vorräte fast erschöpft. Der "Speicher" muß daher von nenem gefüllt werden: d. h. die Pflanze muß Triebe bilden, die reich an Blattgrün sind, also unter Mitwirkung des Sonnenlichts neue Vorratsstoffe zu bilden vermögen. Diese tannenbaumähnlichen, lebhaft grïnen Triebe kommen erst im Ma i oder Juni zum Vorschein und daurn den ganzen Sommer ïber aus. (2.)

2. Im wesentlichen sind diese "Sommertriebe" mit den "Frühjahrstrieben" iibereinstimmend gebant. Sie besitzen aber niemals eine Sporenähre ("unfruchtbare Triebe") und tragen an den Stengelknoten Quirle von Ästen. Diese Gebilde durchbrechen den Grund der verwachsenen Blätter, sind deutlich 
gegliedert, tief gefurcht, meist vierkantig und oft nochmals verzweigt. Da die Blätter wie am unterirdischen Stamme nur das wachsende Stengelende zu iiberdecken haben, so sind hier die von ilmen gebildeten Scheiden auch meist kleiner als an den fruchtbaren Trieben.

3. Glüht man einen Stengel oder Zweig auf einem Platinbleche, so bleibt

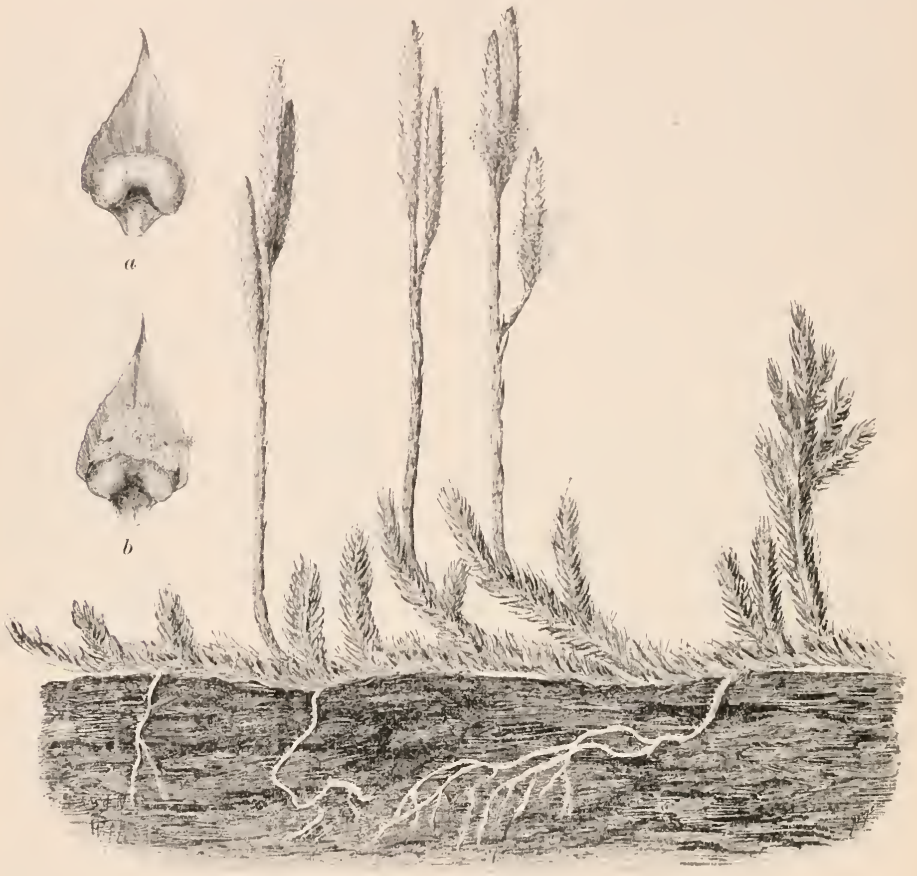

Kolben-Bärlapp (etwa ${ }_{-1 / 2}^{-}$nat. ${ }_{4}^{q} G r$.) Daneben 2 Sporenblätter: a mit gesclilossener, b mit geöffneter sporenkapsel (etwa 5 mal vergr.)

ein zartes "Skelett" von Kieselsäure zurïck, die der Oberhaut in großen Mengen eingelagert ist. Infolgedessen erscheinen die Sommertriebe hart und fest, so daß sie wie die kieselhaltigen Stengel nnd Blätter zahlreicher Gräser und Riedgrïiser (s. das.) vortrefflich gegen Tierfraß geschützt sind. Des Kieselgehaltes wegen wird die Pflanze auch hier und da zum Scheuern kupferner und zinnerner Gefäße benutzt („Scheuerkraut"). 


\section{Andere Schachtelhalme.}

Die wenig Schachtelhalmarten, die wir jetzt noch auf der Erde antreffen, sind die zwerghaften Reste eines untergegangenen Riesengeschlechtes, das wesentlich zur Bildung der Steinkohle beitrug (s. S. 303). Gleich dem Ackerschachtelhalme bildet der Wald-Sch. (E. silváticum), der wie die meisten Waldpflanzen von zartem Bau ist (Bedentung?), fruchtbare nnd unfruchtbare Triebe; erstere ergrünen aber nach der Sporenanssaat und treiben grüne Seitenzweige. - Bei anderen Arten dagegen steht die Sporenähre an der Spitze der grünen Stengel. Dies ist z. B. beim Sumpf-Ścl. (E. palústre), der anf sumpfigen und torfigen Wiesen ein lästiges Unkraut bildet, und beim SchlamıSch. (E. limósum) der Fall, der an denselben Orten, sowie in Sümpfen, Gräben und Teichen seine oft mehr als meterhohen, wenig- oder unverzweigten Stengel treibt.

\section{Klasse. Bärlapp-Gewächse (Lycopódinae).}

Ein besonders in Nadelwäldern hänfiger Vertreter dieser Grappe blütenloser Pflanzen ist der Kolben-Bärlapp oder das Fehlangremmoos (Lycopódium clavátum), ein immergrünes, moosartiges Pflänzchen, das mit gabelig verzweigtem Stengel weit über den Boden dahinkriecht (Schlangenmoos). Die Sporenblätter, die wie bei den Schachtelhalmen zu kolbenartigen Ähren gehäuft sind, tragen an ihrem Grunde je eine große, nierenförmige Sporenkapsel, die sich bei der Reife durch eineu Querspalt öffnet. Da sieh die Sporenähren auf langen Stielen über den Boden erheben, vermag der Wind die Sporen leicht auszusehütteln und zu verwehen. Die winzigen Körper, die die Sporenkapseln als gelbe Wolke verlassen, sind das sog. Hexenmehl, das besonders zum Trocknen wunder Körperstellen dient. - Wie bereits S. 303 erwähnt, haben zahlreiche baumartige Bärlappe die Steinkohlenlager mit bilden helfen. Die riesigen, bis $40 \mathrm{~m}$ hohen Stämme waren mit siegelartigen Blattnarben bedeckt, die bei den Schuppenhïumen (Lepidodéndron) in Schraubenlinien, bei den Siegelbïumen (Sigillária) in Längsreihen angeordnet waren.

\section{Gruppe. Moose (Bryóphyta).}

Pflanzen, die in Stengel nnd Blätter gegliedert sind oder ein laubartiges Gebilde darstellen (s. Lebermoose), denen echte Wurzeln feblen nnd die niemals Gefäbbündel enthalten.

\section{Klasse. Laubmoose (Musci).}

Pflanzen, die stets deutlich in Stengel und Blätter gegliedert sind. Die Blätter sind in der Regel in einer Schraubenlinie angeordnet, und die Sporenkapsel ist meist mit einer

Haube bedeckt.

\section{I)as goldene Fratenhaar oder der Widerton (Polýtrichum commúne).}

A. Das Vorkommen. Das zierliche Moos ïberzieht besonders in feuchten Wäldern, sowie anf Moorboden und an anderen wasserreichen Stellen oft weite Flächen. Während es hier hohe, schwellende Polster bildet, tritt es uns an trockenen Stellen nur in Form niedriger Rasen entgegen. Einen prächtigen 
Schmuck erhalten diese grïnen Moosteppiche, wenn sich über ihnen auf schwankenden Stielen die Sporenkapseln (s. S. 314) erheben. Dann werden uns auch

B. die Namen verständlich, die das zierliche Pflänzchen trägt. Nach den goldgelben, filzigen Hauben, von denen die Kapseln bis zur Reife überdeckt werden, nennt man es ,goldenes Franenhaar, Haarmoos oder Filzmïtze". Früher schrieb man dem harmlosen Gewächs geheime Kräfte zu: es galt als sicheres Mittel „wider das Antun" durch böse Geister und Hexen, so daß es heutzutage noch hier und da als "Widerton" bezeichnet wird.

C. Die Moospflanze. 1. Der feste, elastische Stengel erreicht auf feuchtem Untergrunde eine Höhe von $30 \mathrm{~cm}$. Er stirbt wie die unterirdischen Stämme des Windröschens, der Maiblume und anderer Pflanzen vom unteren Ende her allmählich $a b$, während er oben beständig weiter wächst. Daher ist er meist auch nur am oberen Teile mit grünen, lebenstätigen Blättern besetzt, während sein unterer Abschnitt kahl ist oder braune, d. i. abgestorbene Blätter trägt. Das untere Stengelende ist

2. mit einem braunen Filze bedeckt, der, wie das Mikroskop zeigt, aus vielen verzweigten Zellreihen zusammengesetzt ist. Diese Gebilde befestigen das Pflänzchen im Boden und nehmen Wasser mit den darin gelösten Nährstoffen auf. Sie vertreten also die Stelle der Wurzeln, wie sie die höheren Pflanzen besitzen. Darum werden sie treffend anch als Wurzelhaare bezeichnet. (Wie dem Frauenhaar fehlen auch allen anderen Moosen echte Wurzeln.) In dem Grade, in dem der Stengel von unten her abstirbt, entstehen an ihm immer weiter nach oben neve Wurzelhaare.

3. Die B lät t e r sind in einer Scluran-

(ioldenes Franenhaar (nat. Gr.).

1. Pflanze mit „Moosblüte" ; 2. Pflanze mit endständiger und durchwachsener nMoosblïte"; 3. Pflanze mit Sporenkapsel. benlinie am Stengel angeordnet. Sie haben die Form eines langgestreckten, gleichschenkligen Dreiecks, sind scharf zugespitzt und am Rande fein gesägt (Lupe!). Am Grunde 


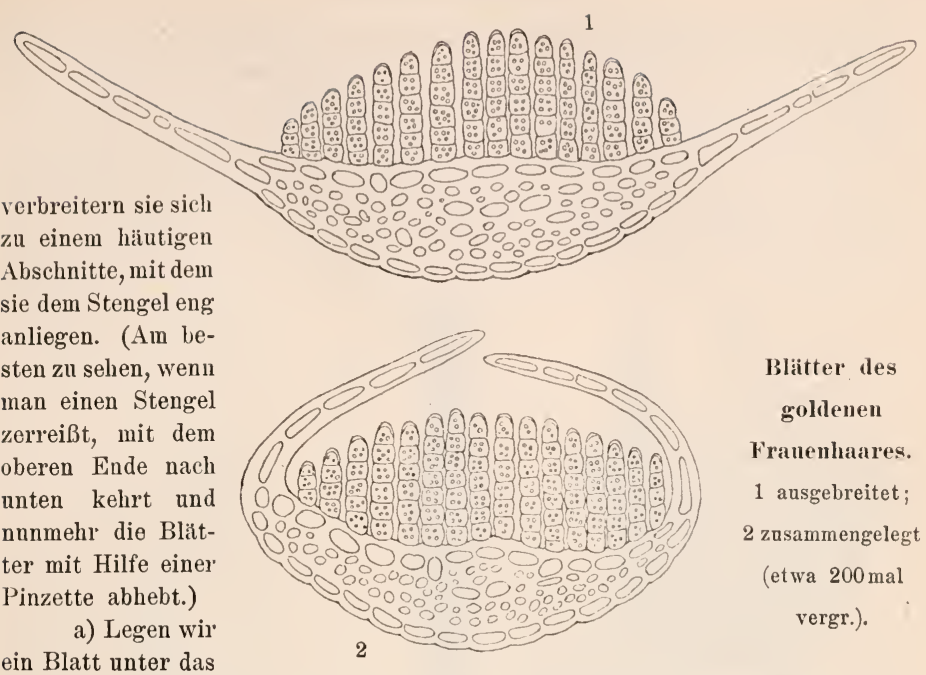

Mikroskop, so erkennen wir leicht, daß es nur aus Zellen zusammengesetzt ist. Es entbehrt also der Gefäße (s. letzten Abschn. d. Buches), wie wir sie bei den höheren Pflanzen antreffen. In gleich einfacherWeise sind auch alle übrigen Teile des Frauenhaares gebaut,desgleichen alle anderen Moose, sowie die Algen und Pilze. Daher werden diese 3 großen Gruppen der blïtenlosen Gewächse den Farnen oder Gefäßkryptogamen als "Zellkryptogamen" gegenïber gestellt (s. S. 296).

An einem Querschnitte des Blattes erkennen wir allerdings, daß eine Art „Mittelrippe" vorhanden ist. Sie besteht jedoch im Gegensatz zu dem entsprechenden Gebilde höherer Pflanzen gleichfalls nur ans Zellen. Da sie dem Blatte aber Halt und Stütze verleihen soll, sind die Wände ihrer Zellen anch stark verdickt.

b) An diesem Querschnitte erkennen wir ferner, daß sich im mittleren Abschnitte der Blattoberfläche Längsleisten erheben, die aus je einer Zellschicht aufgebant sind. (Im Querschnitt erscheinen die Leisten daher als Zellreihen.) Durch diese Gebilde wird die Oberfläche des Blattes wesentlich vergrößert, so daß die Pflanze also auch mehr Sonnenstrahlen auffangen nnd größere Wassermengen verdunsten kann, als wenn die Blätter nur je eine einfache Zellschicht darstellten. Beides ist aber für das Moos von größtem Vorteil; denn die verdunstenden Wassermassen machen anderen Platz, die vom Boden aufsteigen und Nährstoffe enthalten, und unter dem Einflusse des Sonnenlichtes allein werden in den grïnen Blïttern diese Stoffe so nmwandelt, daß sie der Pflanze zar Nahrung und zum Aufbau dienen können.

c) Nimmt man ein Pflänzchen aus dem Boden, so sieht man oft schon nach kurzer Zeit, wie sich die Blätter rinnig zusammenlegen: die 
Seitenteile der Blattflächen schlagen sich nach innen und überdecken die Längsleisten, so daß dicse jetzt weit weniger Wasser verdunsten als vorher. Und zwar ist die Abgabe von Wasserdampf nmso geringer, als sich die Blätter gleichzeitig nach oben dicht an den Stengel legen. (Zusammengefaltete und aufeinandergelegte Wäsche bleibt viel länger feucht, als wenn man jedes einzelne Wäschestïck flach ausbreitet. Warum?) Diese Schutzstellung nehmen die Blätter, wie leicht zu beobachten ist, bei trockener Witterung auch im Freien all. Eine zu starke Wasserdampfabgabe hat für das Franenhaar
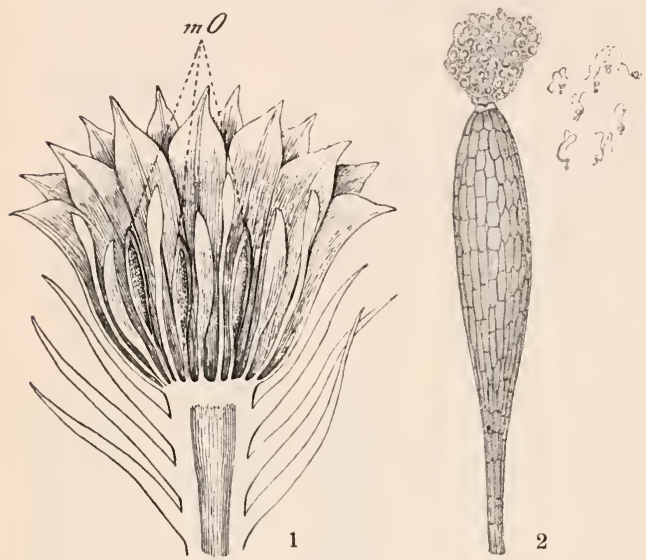

,Moosbliite." 1 senkreeht durchschnitten mit 3 männlichen Organen m.0. (etwa 40 mal nat. Gr.). Daneben eines dieser Organe stärker (etwa 200 mal) vergr. Ans der geöffneten Spitze treten soeben die Sehwämer hervor, die z. T. (rechts) sehon frei geworden sind. wie für jedes andere Gewächs selbstverständlich den Tod im Gefolge. Gegen Wasserverlust ist das zarte Moos jedoch anferordentlich widerstandsfähig. Daher kann es auch in dem trocknen Winter (s. S. 92) seine Blätter behalten, oder anders ausgedriickt, eine immergrüne Pflanze sein.

d) Bietet man cinem scheinbar gänzlich vertrockneten Pflänzchen wieder Wasser dar, so breiten sich die Blätterauch alsbald wieder a us und biegen sich vom Stengel zur ï ck. Stellt man die Pflanze zu diesem

Zwecke mit dem unteren Teile in das Wasser, so geht beides viel langsamer von statten als wenn man den mit grïnen Blättern besetzten oberen Teil in das Wasser legt oder sonstwie befeuchtet, ein Zeichen, daß die Aufnahme des Wassers besonders durch die Blätter erfolgt. Wie groß die Wassermenge ist, die anfgesogen wird, läßt sich am besten erkennen, wenn man einen stark ausgetrockneten Moosrasen anfeuchtet, dessen Gewicht man zu diesem Zwecke vor und nach der Wasseraufnahme genau feststellt (am besten benutzt man zu diesem Versuche Polster des Weiß- oder des Torfmooses). Freilich wird nicht alles Wasser von den Pflanzen selbst aufgenommen. Es wird vielmehr (infolge von Kapillarität) zwischen den Blättern und Stämmchen festgehalten wie in den Poren eines Badeschwammes.

D. Die Befruchtung. 1. Männliche Organe. a) Unter den Pflänz- 
chen des goldenen Fratenhaars finden sich im Mai und Juni stets mehrere, deren Stengel am Gipfel etwas verdickt und deren Blatter daselbst stark verbreitert und vielfach rötlich gefärbt sind. So entstehen dort körbchenartige Bildungen, die im Volksmunde als "Iloosblüten" bezeichnet werden. Nicht selten wächst der Stengel mit gewöhnlichen Blättern weiter, um im nächsten Jahre an seiner Spitze eine nelle "Blüte" zu bilden (s. Abb. 2 auf S. 310).
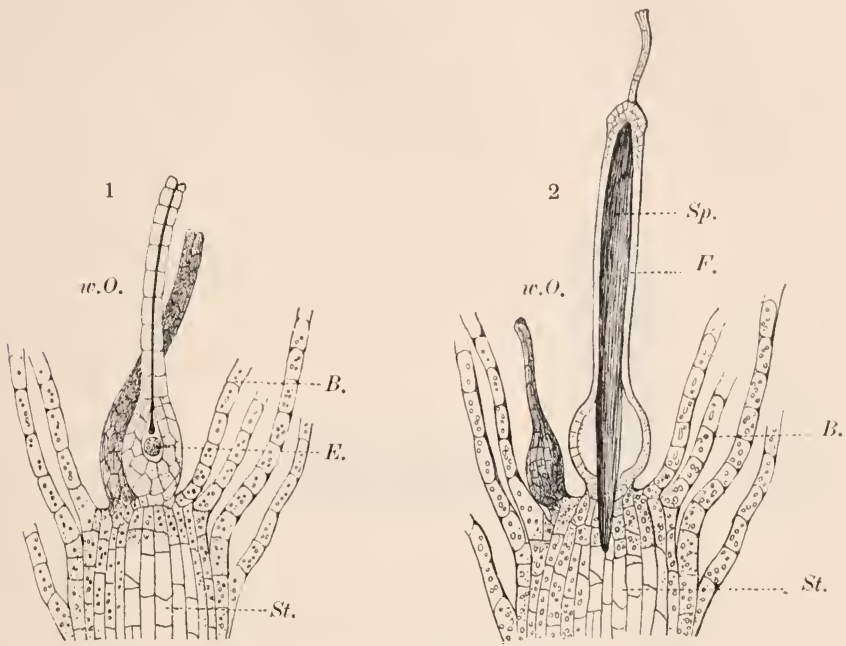

Weibliche Organe eines Mooses (etwa 60 mal vergr.). 1 Zwei dieser flaschenförmigen Gebilde (w.0.) stehen an der Spitze des längsdurchschnittenen stengels (Nt.) und sind von zahlreichen längsdurchschnittenen Blättern (B.) umgeben. Das vordere dieser Organe ist im Längsschnitt gezeichnet, $n m$ die Eizelle (E.) und den mit Schleim gefüllten langen „Hals der Flasche“ zn zeigen. 2 Dieselben Teile, einige Wochen später: Die Eizelle eines der beiden weiblichen Organe wäehst zur gestielten sporenkapsel (Sp.) heran. Das jetzt stabförmige Gebilde, das noch nicht in stiel und Kapsel gegliedert ist, hat sich in den stengel der Pthonze gebohrt und ist ron dem mitwachsenden weiblichen Organe, der $W_{\text {and }}$ ler Flasche" (F.), eingeschlossen. Das 2, weibliche Organ ist abgestorben.

b) Durchschneidet man ein Körbchen senkrecht, so sieht man schon mit Hilfe der Lupe zwischen kleinen, langgestreckten oder spatelförmigen Blättern zahlreiche wasserhelle Schläuche, in denen wir bei Benutzung des Mikroskops

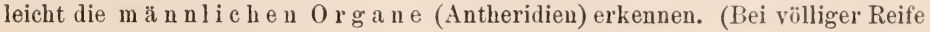
genïgt schon ein leichter seitlicher Druck, um sie aus dem Körbchen herrorzupressen.)

c) Bringt man eineu reifen Schlanch in das Wisser, so öftinet er sich 
alsbald an der Spitze. Es tritt eine teigige Masse hervor, die aus zahlreichen Zellen mit je einem Schwärmer besteht (s. Abb. S. 312). Bald werden diese Gebilde frei und schwimmen mit 2 langen Haaren am zngespitzten Vorderende durch das Wasser dahin.

2. Bei anderen Pfänzchen sind zu derselben Zeit die obersten Blätter knospenartig zusammengeneigt. In den Achseln dieser Blätter finden sich die weiblichen Organe (Archegonien; Abb.S.313). Es sind wie beim Wurmfarn flaschenförmige Gebilde, die je eine Eizelle einschließen. Sie öffnen sich wie bei jener Pflanze an der Spitze und entlassen einen Schleim, durch den die Schwärmer eindringen, um mit der Eizelle verschmelzen zu können. Den Weg zu dieser Zelle finden die Schwärmer durch das Wasser, das ja bei jedem Regen
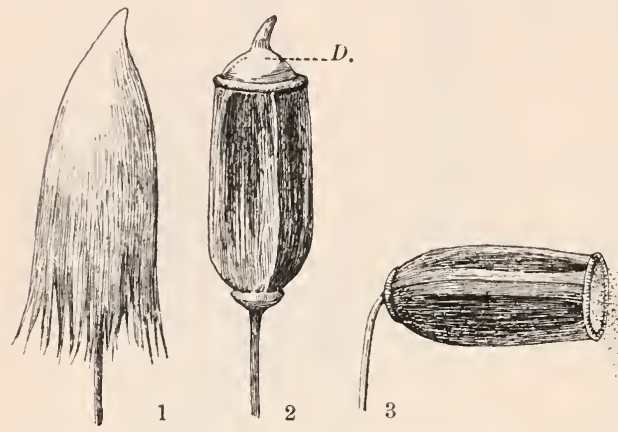

Sporenkapseln des goldenen Franenhaars (etw. 15 mal vergr.). 1 Kapsel mit Haube. 2 Kapsel ohne Haube. D. Deckelchen. 3 Deckelchen abgefallen; der Wind schüttelt die Sporen heraus.

den Moosrasen durchtränkt. - Das Frauenhaar ist also wie z. B. die Salweide eine zweihäusige Pflanze. Eine Befruclitung kann daher nur stattfinden, wenn männliche und weibliche Pflanzen dicht beieinander stelien, oder - anders ausgedrückt - wenn sie einen Rasen oder ein Polster bilden.

3. Von den befruchteten Eizellen entwickelt sich auf jedem Stengel stets nur eine weiter. Sie wächst zu einem langgestreckten Körper ans, der sich nach und nach zu

E. der gestielten Sporenkapsel entwickelt, wie wir sie am Gipfel zahlreicher Moospflänzchen finden.

1. Der untere Teil des Körpers wird zu dem fast fingerlangen Stiele, der sog. B ors te, die unten prächtig rot und oben goldgelb gefärbt ist. Der obere Abschnitt dagegen schwillt stark an und bildet sich zu der Sporen-oder M o o skapsel aus. Indem sich die Borste mit ihrem unteren Ende in das Moosstämmchen einbohrt, bleibt das ganze Gebilde mit der Mutterpflanze in innigstem Zusammenhange.

2. Anfänglich ist die junge "Moosfrucht" von der mitwachsenden Flasche umgeben. Schließlich zerreißt diese Hülle aber: ihr unterer Teil bleibt als die kleine Scheide zurück, die die Borste unten umgibt und inniger mit der Mutterpflanze verbindet; ihr oberer Abschnitt dagegen wird von der Kapsel als goldgelber Filz, die sog. $\mathrm{Haube}$, mit emporgehoben. 
3. Die vierkantige Sporenkapsel (Längs- und Querschnitt!) ist von einem Mittelsäulchen durchizogen und von zahlreichen, grünen Sporen erfüllt. Ihr oberer Teil hebt sich bei der Reife in Form eines Deckelchens ab. Au dem Rande der Kapsel erblickt man dann (Lupe!) eine große Anzahl feiner Zähnchen, deren Spitzen durch ein trommelfellartiges Häutchen miteinander verbunden sind.

4. Entstehung und Ban der Sporenkapsel machen uns nun zahlreiche Verhältnisse der interessanten Pflanze verständlich:

a) Wie die Eizelle, so ist auch der ans ihr hervorgehende Körper anfänglich ïberaus zart. Fïr ihn ist es daher von größtem Vorteil, daß er von der mitwachsenden „Flasche" so lange umhiillt wird, bis er den Witterungseinfliisseu zu widerstehen vermag (vgl. mit dem Schutze, den die Samenanlagen der höheren Pflanzen im Fruchtknoten finden!).

b) Die Sporenkapsel ist zwar ein grünes Gebilde. Da sie aber von der Filzhaube überdeckt ist, so daß das Sonnenlicht nur geschwächt bis zu ihr vorzudringen vermag, ist die "Noosfrucht" auch bei weitem nicht im stande, alle zum Wachstum nnd Leben erforderlichen Stoffe zu bereiten. Sie bleibt daher - wie wir gesehen haben - mit der Mutterpflanze im Zusammenhange.

Diese Verbindung ist jedoch eine ganz andere als z. B. die zwischen der Apfelfrucht und dem Apfelbaume. Zieht man nämlich die Borste vorsichtig aus der Mutterpflanze, so daß ihr Ende aber noch in der Scheide bleibt, nnd steckt man sie darauf wieder fest in das Moosstämmchen, so - wächst die „Moosfrucht" weiter! Man betrachtet daher die Kapsel mit ihrem Stiele als eine besondere Pflanze, die aus dem Moospflänzchen hervorgegangen ist, mit ihm aber im Zusammenhange bleibt und von ihm ernährt wird.

c) Während die Borste schon ziemlich frühzeitig erstarkt, bleibt die Kapsel lange Zeit sehr zart. Ihr ist daher die Haube ein wichtiges Schutzmittel, das sich treffend mit einem Strohdache vergleichen läßt: Wie nämlich ein solches Dach die Hausbewohner vor zu großer Wärme und vor Regen bewahrt, so beschützt auch die Filzhülle die wachsende Kapsel vor zu starker Erwärmung und damit verbundener iibermäßiger Wasserdampfabgabe (Vertrocknen!), sowie vor schädlicher Nässe (Tau, Regen). Sind die Sporen gereift, so daß sie ausgestreut werden mïssen, dann ist die Hülle überflitssig geworden. Sie fällt daher ab.

d) Dasselbe gilt für das Verschlußstïck der sich jetzt wagerecht stellenden Kapsel, für das Deckelchen. Es wird, indem die Kapselwände eintrocknen, abgehoben.

e) Für die Sporen ist es wie für die Samen nun vou größter Wichtigkeit, nacheinander ausgesät zu werden (s. S. 10, 3). Die Kapsel ist daher wie wir gesehen haben - oben nicht einfach offen. Indem sich die Zähnchen 
am Kapselrande etwas emporrichten, heben sie auch das Häutchen mit empor: es entstehen zahlreiche Löcher, durch die die Sporen allmählich

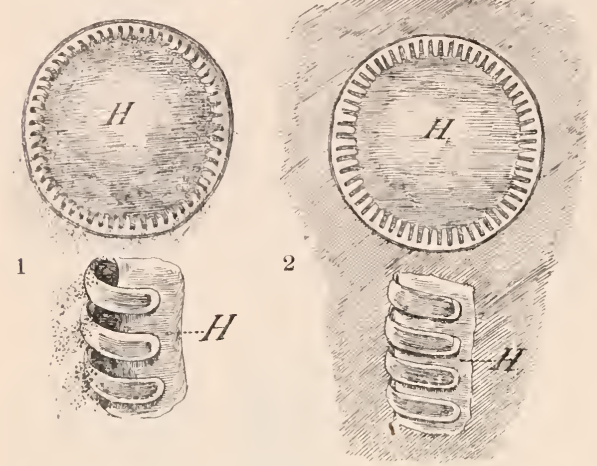

Obere Fliche der Sporenkapsel, die Zähnchen, des Kapselrandes und das trommelfellartige Häntchen (H) zeigend (etwa $30 \mathrm{mal}$ vergr.). 1 bei troekenem Wetter, stänhend; 2 bei feuchtem Wetter: die Löcher sind wieder geschlossen. Darunter noch stärker vergr. einige Zähnchen mml ein Stü̈k des Häntcliens (H), gleichfalls bei trockenem und fenchtem Wetter.

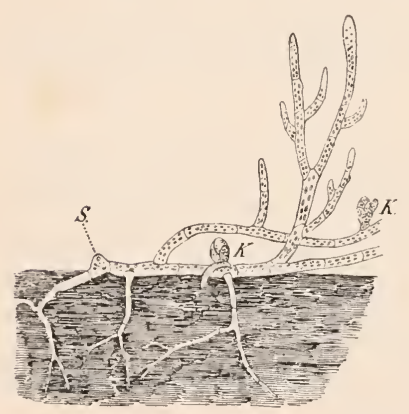

Vorkeim eines Mooses (etwa $200 \mathrm{mal}$ vergr.). s. spore, aus der der Vorkeim hervorgegangen ist. $K$. Knospen. achten!) a usgestreut werden. Die Kapsel hat jetzt also große Ähnlichkeit mit einem Mohnkopfe oder besser mit einer Strensandbiichse.

Eine erfolgreiche Verbreitung der Sporen durch den Wind kann aber nur dann erfolgen, wenn sie trocken sind (wieso?). Darum krïmmen sich die sehr hygroskopischen Zähnchen bei feuchtem Wetter wieder herab und ziehen das Häutchen mit herunter. Infolgedessen verschwinden die Öffnungen wieder, so daß jetzt ein Ausstrenen der Sporen unterbleiben muß. (Durch Befenchtung der Kapseloberfläche leicht zu beob-

f) Obgleich die reife Kapsel wagerecht steht, fallen die Sporen nicht von selbst heraus. Sie muß erst erschüttert werden. Da sie sich nun auf einem langen, sehr elastischen Stiele erhebt, ist hierzu schon ein sanfter Wind im stande.

F. Der Vorkeiun. 1. Die Entwicklang der Sporen läßt sich wie bei den Farnen (s. S. 297, E) durch Aussaat leicht verfolgen. Schon nach wenigen Tagen ist aus jeder Spore ein Keimschlauch hervorgegangen, der sich bald zn dem Vorkeime weiter entwickelt. Dieses Gebilde stellt einen langen, mehrfach verästelten Faden dar, hat also große Ähnlichkeit mit einer verzweigten Fadenalge (s. das.). Da er wie der Torkeim der Farne sich selbst die zum Leben und Vachstum nötigen Stoffe bereiten muß, so findet anch an ihm eine Arbeits- 
teilung statt: melrere farblose oder braune Zweige dringen als Wurzelhare in den Boden und ïbernehmen die Anfgaben der fehlenden Wurzeln, die anderen sind grïn und verarbeiten im Sonnenlichte die aufgenommenen Rohstoffe. (Vorkeime der Moose findet man als grïinen Anflug häufig anf feuchtem Boden, z. B. auf Blumentöpfen.)

2. Am oberen Teile des Torkeims, der nummehr bald zugrunde geht, entstehen kleine Knospen, die zu je einem Moospflänzchen answachsen. Keimen an einem Orte viele Moossporen, so bilden sich demnach anch zahlreiche, dicht beieinander stehende Moospflänzelien: es entsteht ein Rasen oder Polster. - Hiermit sind wir zum Ansgangspunkte unserer Betrachtung zurïekgekehrt.

3. Nunmehr sind wir anch im stande, die Entwicklung der Hoose, die im wesentlichen genan wie beim Franenhaar erfolgt, zu iibcrblicken und mit der der Farne zu vergleichen (s. S. 300,7). Dabei werden wir leicht folgendes finden:

a) Aus der Spore bildet sich der algenartige Vorkeim, ans dem dureh Knospung die Moospflänzchen entstehen. Da die Pflänzchen die männlichen und weiblichen Organe tragen, so bilden sie mit ihrem Vorkeim die geschlechtliche Form oder Generation. - Aus der Vereinigung von Eizelle und sehwärmer geht

b) die gestielte Sporenkapsel hervor, die auf "ungeschlechtlichem Wege" Sporen erzengt. Sie stellt somit die ungeschlechtiche Form oder Generation dar.

c) Da beide Formen regelmäßig abwechseln, haben wir hier wie bei den Farnen einen deutlich ansgeprägten Generationswechsel vor uns. (Welche Unterschiede sind in der Entwicklung der beiden Pflanzengruppen aber vorhanden? Beweise, daß die Sporenkapsel der Moose ihrer Entstehung nach der Farnpflanze entspricht, während andererseits der Vorkeim und die Moospflanze dem Vorkeime der Farne gleich zn setzen ist!)

\section{Die Bedentung und die verbreitetsten Arten der Laubmoose.}

A. Die Bedentung. Die Laubmoose treten uns in der Natur in größtem Formenreichtum entgegen. Sie sind alle im wesentlichen wie das goldene Franenhaar gebant und zeigen infolgedessen auch dieselben Lebenstätigkeiten. Daher eröffnet uns das Verständnis der einen Pflanze zugleich einen Blick anf die Bedeutung aller.

1. Wie das Frauenhaar vermögen die meisten Hoose so stark anszutrocknen, daß sie unter unseren Tritten zerbrechen, und wir sie zu Stanb zermalmen können. Wochenlang verharren sie in diesem Zustande: sobald sie aber von einem Regen benetzt werden, erwachen die schlummernden Lebenstätigkeiten von neuem. Daher vermögen sich viele von ihnen auch an Felsen und Banmstämmen, auf Ästen, Manern und Dächern, kurz an Orten anzusiedeln, an denen sie oft lange Zeit hindurch größter Trocknis ansgesetzt sind. (Warum finden sich Moose [und Flechten] besonders an der "Wetterseite" der Baunstämme?)

Diese Örtlichkeiten sind ferner so arm an Nährstoffen, daß größere Pflanzen hier "verhungern" müßten. Den winzigen Moosen aber genïgen die geringen Erdmengen in den Felsenritzen oder der Staub in den Fugen der Dachziegel und in den Rissen der 
Baumrinde vollkommen. Die größte Ifenge von Nährstoffen nehmen sie allerdings mit dem Regenwasser auf, das sich auf seinem Laufe über die Felsen, an den Baumstämmen herab oder dgl. damit beladet.

Durch die Fähigkeit, an wasser- und nährstoffarmen Örtlichkeiten zu gedeihen, erlangen die Moose eine außerordentliche Wichtigkeit im Haushalte der Natur. Indem sie nämlich den $\mathrm{z}$ wischen den Pflänzchen ihrer Polster herbeigewehten Staub aufsammeln, sowie von unten her beständig absterben und in ${ }_{n}$ Mooserde ${ }^{\alpha}$ zerfallen, vermehren sie fortgesetzt die geringe Erdmasse, in der sie warzeln. Sie sind daher (mit den Flechten) die ersten Ansiedler an Felsen und bereichern selbst den ödesten Boden $\mathrm{nach}$ und $\mathrm{nach}$ an fruchtbaren Bestandteilen. Nach ihnen können sich an diesen Orten Pflanzen ansiedeln, die größere Ansprüche an den Boden stellen, so daß sich im Laufe der Zeit selbst kable Felsen mit einer grünen Pflanzendecke überziehen.

2. Im wasserdurchtränkten Moore dagegen ist der gänzliche Zerfall der abgestorbenen Teile nicht möglich. Gleich der Rasen- und Erdschicht, die der Köhler über den Meiler deckt, verhindert nämlich das Wasser eine genügende Durchlüftung des Bodens, so daB nur eine unvollkommene Zersetzung der Pflanzenteile eintritt (s. S. 114). Wie im Meiler häufen sich daher im Boden große Mengen von Kohlenstoff an: es entsteht der Torf, der zum Unterschiede vom Heidetorf als „Moostorf“ bezeichnet wird. Geht die Torfbildung Jahrhunderte oder Jahrtausende hindurch vor sich, so entstehen schlieBlich mächtige Torflager, wie wir sie z. B. in der norddeutschen Tiefebene and an mehreren Flüssen Bayerns finden.

Der Torf dient dem Menschen nun nicht allein als Brennmaterial, sondern er liefert auch ein (allerdings meist nur dürftiges) Ackerland. Zu diesem Zwecke brennt der Hoorbauer die oberste Schicht der Torflager ab („Höhenrauch“), oder er vermengt die schwarze Torferde mit lockerndem Sande. Ohne den Torf und die ibn erzengenden Moose wären jene Gegenden Sümpfe, die vom Menschen nicht bewohnt, z. T. nicht einmal betreten werden könnten. Wenn unter den Torfbildnern auch die Torfmoose (s. w. u.) die erste Stelle einnehmen, so trägt doch neben zahlreichen anderen Moosarten das zierliche Frauenhaar gleichfalls nicht wenig dazu bei, für den Menschen bewohnbares Land zu schaffen.

3. Wie wir sahen, saugen sich die Ioospolster beim Regen wie ein Schwamm voll Wasser. Bedenken wir nun, daß der Boden der Wälder oft auf weite Strecken hin mit einem grünen Moosteppich bedeckt ist, so können wir ungefähr abschätzen, welch' riesige Wassermenge schon von den Moosen eines einzigen Waldes aufgesogen und festgehalten wird. Schlägt man die Wälder nieder, so gehen auch die schattenliebenden Wald-Moose meist zugrunde. Geschieht dies nun anf einem Gebirge, so stürzen bei heftigem Gewitterregen oder beim Schmelzen des Schnees die Wassermengen wie reißende Ströme za Tale und verwüsten nicht selten die fruchtbaren Ebenen, die sich längs der Flüsse ausdehnen, mitsamt den Wohnstätten der Menschen. Im Verein mit den anderen Pflanzen, die den Waldgrund bedecken, schützt das unscheinbare I oos also die Bewohner der Täler und Niederangen vor verheerenden Über$\mathrm{sch}$ wemmungen.

Von waldlosen Bergrücken fließt das Wasser also in kürzester Zeit ab. Dann versiegen Bäche und Flüsse, so daB Feld und Mensch unter dem Wassermangel stark leiden müssen (führe dies näher aus!). Ist das Gebirge aber mit Wald bedeckt, dann gibt das Moos das eingesogene Wasser nur sehr langsam wieder ab. Es speist also das 
ganze Jahr hindurch die Quellen und Flüsse und versorgt die Täler und Niederungen jahrans, jahrein mit Wasser.

4. Wie die Bäume den Moosen, die den Grund des Waldes bekleiden, Schutz gewähren, so leisten umgekehrt auch die unscheinbaren Pflänzchen ihren Beschützern einen nicht minder wichtigen Dienst: sie bewahren den Boden vor zu starker Austrocknung, so daß die Banmwurzeln beständig das nötige Wasser finden können, und verhindern (besonders an Abhängen) das Wegschwemmen der Erd.

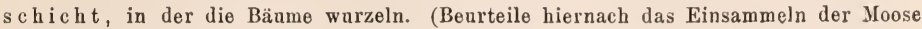
als Streu für das Vieh!) Die gleiche Bedentung haben die Moose auch für die anderen Pflanzen des Waldes, deren Warzeln, nnterirdischen Stämmen, Knollen oder Zwiebeln sie zugleich als schützende Winterdecke dienen (führe dies näher aus!).

5. Wenn wir nun noch bedenken, wie viele niedere Tiere (Insekten, Spinnen, Weichtiere u. s. w.) die Moosrasen beleben oder in ihnen den Winterschlaf halten, wie die „Mooshälmchen “ zahlreichen Vögeln zum Nestbau dienen, wie der If e $\mathrm{n} \mathrm{s}$ h das Iloos zum Anfertigen von Kränzen, zum Verpacken von zerbrechlichen Gegenständen, zum Ausfüllen von Kissen nnd Polstern, zum Verstopfen von Lücken und Ritzen, zur Streu für das Vieh und zu zahlreichen anderen Zwecken verwendet: so werden wir die große Bedeutung ermessen können, die die unscheinbaren Pflänzchen im Naturganzen und für den IIenschen haben! -

6. Wenn das Moos allerdings Wiesen und Äcker äberzicht, dann ist es nichts weiter als ein Unkraut, das den angebauten Pflanzen Licht, Luft, Nahrung und Raum entzieht. Auch von der Rinde der Obstbäume muß es entfernt werden; denn es gewährt den überwinternden Schädlingen einen Unter-

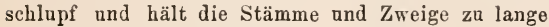
feucht, so daß sie leicht faulen.

B. Von den verbreitetsten Arten seien die wichtigen Torf- oder Sumpfmoose (Sphag-

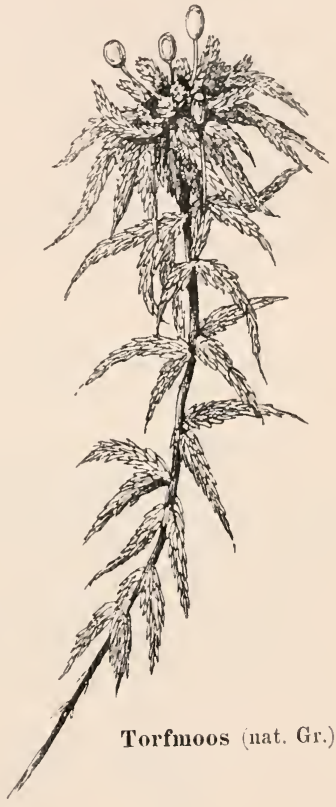
num) zunächst genannt, die in Sümpfen, morastigen Wäldern and an ähnlichen feuchten Stellen große, schwammige Polster bilden. Ihr Stengel ist mit peitschenförmigen Ästchen besetzt, die am Gipfel schopfartig gehänft sind. Warzelhaare sind nur im jugendlichen Zustande vorhanden, ein Zeichen, daB die Aufnahme von Wasser und Nährstoffen auf anderem Wege erfolgen muB. Die Hauptmasse der Blätter besteht nämlich aus großen, inhaltsleeren Zellen, die als Wasserspeicher dienen. Aus gleichen Zellen ist auch die Außenschicht der Stengel and Zweige zusammengesetzt, so daB sich die Pflanze wic ein Schwamm voll Wasser zu saugen vermag. Da nun die Außenwände dieser Hohlräume durchlöchert sind, so erfolgt die Wasseranfnahme auch mit groBer Schnelligkeit. Durch diese farblosen Zellen kann das Blattgrün, das in anderen Zellen angelagert ist, aber nicht recht zur Geltung kommen; daher hat die 
Pflanze eill eigentämlich blaßgrünes Ausschen. - Ähnliche Wasscrspeicher und daher auch eine ähnliche Färbung besitzt das Weißmoos (Lencóbrynm glancum), das an feuchten Waldstellen die bekannten bläulichgrünen oder weiBlichen (Name!), meist krcisrunden Polster bildet. - Der Moosteppich, der den Waldgrund oft meilenweit nnunterbrochen überzieht, ist ans zahlreichen Arten gewoben, unter denen sich die Astmoose (Hypnum und andere Gattungen mit sehr vielen, sehwer unterscheidbaren Formen) durch zierlich verästelte Stämme auszcichnen (Name!). - In Erdlöchern nnd Höhlen lebt das merkwürdige Leuchtıoos (Schistostéga osmundácea), dessen Vorkeim ein mildes, smaragdenes Licht zurückwirft (Name!). Gewisse Zellen des zarten Gebildes stcllen glashelle Kugeln dar, lie gleich Brenngläsern die einfallenden Lichtstrahlen sammeln nnd nach der dem Lichte abgewendeten Seite leiten. Dort befindet sich das Blattgrün, das also durch die gesammelten Strahlen verhältnismäBig stark beleuchtet wird. Infolge dieser Einrichtung vermag das Moos noch in dem Halblankel der Felsenspalten zu gedeihen, also bei einer Lichtmenge, die für keine andere grüne Pflanze mehr genügt. Da nun die gesammelten Strahlen von dem Blattgrün wie von einem Hohlspiegel z. T. zurückgeworfen werden, so erstrahlt das zarte Pflänzchen in einem milden Lichte, das jeden Beschaner entzückt. (Wir haben es hier also mit eiuer ähnlichen Erscheinung wie beim Leuchten der Katzenaugen zu tun; s. Lelirbuch d. Zoologic.)

\section{Klasse. Lebermoose (Hepáticae).}

Pflanzen, die blattartige Gebilde darstellen oder in Stengel und zweizeilig angeordnete Blätter gegliedert sind und haubenlose Sporenkapseln besitzen.

In das Wesen dieser weit kleineren Abteilung der Moose soll uns das BrummenLebermoos (Marchántia polymórpha) einführen, das an Brunnenrändern, feuchten Mauern, Gräben, kurz an nassen Orten häufig anzutreffen ist. Früher wurde es für ein Mittel gegen Leberleiden gehalten, ein Umstand, dem es mit der ganzen Klasse den Namen verdankt. Es ist ein blattartiges, mehrfach gelapptes Gebilde, das durch zahlreiche Wurzelhaare am Erdboden befestigt ist. Im Juni und Juli entwickelt es eigentümliche Äste, die etwa das Aussehen kleiner Hutpilze haben. Bei gewissen Pflänzchen gleicht der "Hut" einem flachen Teller mit gekerbtem Rand, bei anderen dagegen etwa dem
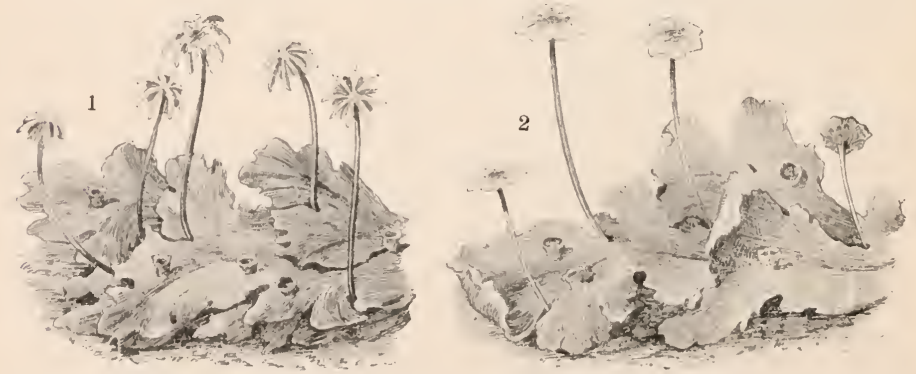

Brumen-Lebermoos: 1 weibliche, 2 männliche Pflanze; beide mit Brutbechern (nat. Gr.). 
Gestell eines aufgespannten Regenschirmes. Während sich an der Oberseite der "Teller" die männlichen Organe (Antheridien) finden, tragen die "Schirmstäbe* an der Unterseite die weiblichen Organe (Archegonien). Beide sind wie beim goldenen Frauenhaar gebaut. Daher erfolgt anch die Befruchtung in derselben Weise. Die aus den Eizellen sich entwickelnden Sporenkapseln besitzen aber keine Hauben. Außer dieser geschlechtlichen Fortpflanzung findet auch noch eine ungeschlechtliche statt. Auf der Oberseite des blattartigen IIauptteils erheben sich nämlich vielfach kleine Becher, in deren Grunde winzige Teile der Pflanze abgeschnürt werden. Vom Regen verschwemmt, wachsen diese Gebilde wie Ableger zu selbständigen Pflanzen heran. Daher werden die Bccher auch treffend als „Brutbecher ${ }^{\alpha}$ bezeichnet.

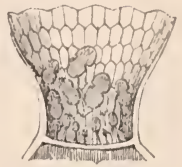

Brutbecher iles Lebernooses im Laingsschnitt mit Ablegern (etwa 15 mal vergr.).

\section{Gruppe. Lagerpflanzen (Thallóphỳta).}

Pflanzen, deren Körper nicht in Stengel und Blätter gegliedert ist, die also ein sog. Lager darstellen.

\section{Krreis. Algen (Algae).}

Lagerpflanzen, die im Wasser oder doch an feuchten Stellen leben und Blattgriin enthalten.

\section{Klasse. Grïnalgen (Chlorophýceae).}

Sehr verschieden gestaltete Pflanzengebilde, die außer Blattgrün keine anderen Farbstoffe enthalten und daher grün erscheinen.

\section{Die Schraubenalge (Spirogýra).}

(Zngleich ein Blick auf die Bedeutung der Algen im allgemeinen.)

A. Vorkommen. An der Oberfläche von Teichen, Tüimpeln und Griaben finden wir während der wärmeren Jahreszeit häufig schlüpfrige, grüne Massen, die wie IVatte aus zahlreichen, unentwirrbaren Fäden bestelıen. Bei Zuhilfenahme des Mikroskops erkenuen wir in ihnen leicht Algen, die in ihrem Ban größere oder geringere Verschiedenleiten aufweisen, also verschiedenen Gattungen und Arten augehören. Da diese Pflanzen frei im Wasser scliweben, so vermögen sie gleich anderen freischwimmenden Gewächsen (Beispiele!) auch nur stehende oder langsam fließende Gewässer zn bewohnen.

Unter diesen Algen ist die zu betrachtende Schraubenalge eine der häufigsten. Wir werden sie leicht heranstinden, wenn wir ihren

B. Bau genïgend beachten, wie ihn umstehende Abbildung erkennen läßt.

1. Das Pflänzchen stellt einen iiberaus $\mathrm{z}$ arten $\mathrm{F}$ a den dar. Eine Luftpflanze von dieser Form müßte kraftlos zusammenfallen oder dem Erdboden 
anfliegen. Eine Pflanze dagegen, die im Wasser schwebt, von ihm also getragen wird, kann diese Gestalt und Zartheit wohl besitzen. (Vgl. hiermit auch die auffallende Größe und Zartheit vieler Wassertiere; s. z. B. Wal und

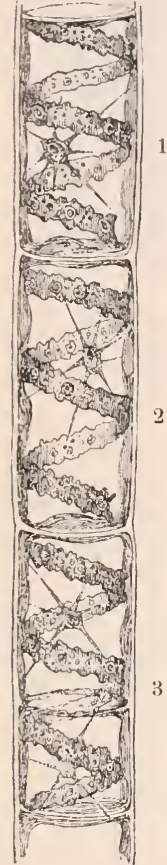

Sichraubenalge : drei Zellen eines Fadens, von denen lie unterste (3) in Teilung begriffen ist (etwa $600 \mathrm{mal}$ vergr.). Qualle im "Lehrb. d. Zoologie".)

Im Gegensatz zu allen bisher betrachteten Gewächsen sind an dem Pflänzchen also weder Stamm, noch Blätter zu erkennen. Einen gleich einfachen Bau besitzen auch alle anderen Algen, sowie die Pilze und Flechten. Da man nun einen solchen ungegliederten Pflanzenkörper als "Lager" bezeichnet, stellt man jene Pflanzen den „Stamm-Blatt-Pflanzen“ als "Lagerpflanzen" gegenïber. (Beweise, daß die Lebermoose den Übergang zwischen beiden großen Gruppen bilden!)

2. a) Der Faden ist aus zahlreichen, walzenförmigen Zellen zusammengesetzt (s. den letzten Abschn. des Buches!), die sich mit je einem kleinen Zimmer vergleichen lassen. Die „Zimmerwände“ sind farblos, durchsichtig und sämtlich mit einer "Tapete" iiberkleidet, die aus einer schleimigen und gleichfalls farblosen Masse gebildet wird. In dieser .Tapete" liegt bei der abgebildeten Form ein schraubenförmig gewundenes Band, das durch einen eingelagerten Farbstoff, das sog. Blattgrün, lebhaft grün erscheint. Dieses Band gibt der ganzen Pflanze das grüne Aussehen und läßt den Namen „Schraubenalge" vollkommen gerechtfertigt erscheinen. (Bei anderen Arten der Gattung "Schraubenalge" treten mehrere solcher Bänder auf.) Durch den Innenraum des "Zimmers", der mit einer wässerigen Flüssigkeit angefüllt ist, ziehen sich von den "tapezierten Wänden" aus mehrere Fäden. Sie krenzen sich alle in einem Punkte und halten dort ein Körperchen, den Zellkern, in der Flïssigkeit schwebend.

b) Da die Wände sehr zart sind, so vermag durch sie Wasser und die in ihm gelösten Nährstoffe leicht in das Innere der Zellen zu dringen. I)aher kann die Pflanze der Wurzeln (oder der Wurzelhaare, wie sie die Moose besitzen) wohl entbehren.

c) Die aufgenommenen Nährstoffe werden wie bei allen anderen grünen Pflanzen aber nur unter dem Einflusse des Sonnenlichts weiter verarbeitet. Daher ist die stark beleuchtete Wasseroberfläche für die Pflanze anch ein sehr geeigneter Aufenthaltsort. Wir finden allerdings auch in tieferen Wasserschichten zahlreiche Algen; jedoch ohne Licht kann keine dieser Pflanzen leben.

C. Vermelırumg. 1. Die watteartigen Massen, die die Schraubenalge anf den Gewässern bildet, vergrößern sich sehr schnell. Wie dies erfolgt, zeigt uns wieder das Mikroskop. An dieser oder jener Zelle beginnt der Kern, sowie 
der gesamte Inhalt sich in 2 Teile zu spalten. Gleichzeitig bildet sich etwa in der Mitte der Längswand der Zelle eine ringförmige Verdicknng, die sich immer weiter nach innen erstreckt, and die schließlich den Zellraum wie eine Querwand durchsetzt. Auf diese Weise wird die Zelle in zwei "Tochterzellen" geteilt, die bald zur Größe der "Mutterzelle" auswachsen (s. Abb.S. 322). Vielfach kommt es nun auch vor, daß die Fäden zerreißen, und daß die Teilstiicke als selbständige Fäden weiter leben.

2. Im Sommer und Herbst trifft man vielfach Schraubenalgen an, die ein eigentïmlich kranses Aussehen haben, und deren Fäden fest aneinander haften. Bringen wir Teile dieser Fäden in einen größeren Wassertropfen, so können wir mit Hilfe des Miskroskops folgendes feststellen: je 2 Fäden haben sich mehr oder weniger parallel zueinander gelegt und von ihren gegenüberliegenden Zellen aus zapfenartige Fortsätze getrieben (a), die schließlich anfeinander gestoßen (b) und verschmolzen sind (c, d und e). Anf diese Weise ist eine Brïcke zwischen je 2 Zellen gebildet, so daß die Fäden bei zahlreichen solcher Verbindungen das Aussehen einer kleinen Leiter erhalten. Nachdem sich die Inhalte beider Zellen infolge Wasserabgabe stark zusaminengezogen haben (c), wandert der Inhalt der einen zu dem der andern hinïber (d); beide verschmelzen alsbald zu einer Spore, die sich abrundet und mit einer dicken, widerstandsfähigen Hiille ungibt (e). Indem die Zellwände verwesen, werden die Sporen schließlich frei. Sie sinken zu Boden und treiben erst im nächsten Frühjahre einen Keimschla u ch (s. S. 298), der bald zı einem nenen Algenfaden heranwächst.

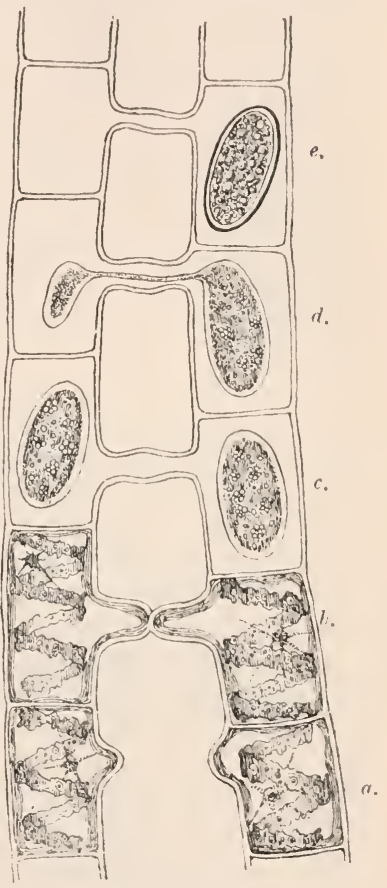

Sporenbildung bei d. Schranbenalge (etwa 600 mal vergr.). (S. Text!)

Wenn wir bedenken, daß die Schranbenalge in der oberen Wasserschicht lebt, also dort, wo ihre zarten Fäden durch das Wintereis zerstört werden müßten, so erscheint uns die Sporenbildung als eine Einrichtung, durch die sich die Pflanze über die ungünstige Jahreszeit hin ïberrettet. Und wenn wir weiter bedenken, wie viel Sporen sich schon in je 2 Algenfäden bilden, und wie leicht diese winzigen Körper vom Wasser fortgespiilt werden können, so werden wir in der Sporenbildung auch leicht ein Mittel zur Vermehrung und Verbreitung der Pflanze erkennen. 
Die Spore entsteht, wie wir soeben gesehen haben, dadurch, daß sich die Inhalte zweier Zellen, d.h. 2 vollkommen gleiche "Wesen" miteinander vereinigen. Diesen Vorgang, den man auch bei niederen Tieren wiederfindet (s. Pantoffeltierchen im "Lehrbuche der Zoologie“), bezeichnet man als Verschmelzung (Conjugation). Da er lebliaft an die Befruchtang erinnert, wie wir sie z. B. bei den Farnen und Moosen kennen gelernt haben (Beweis!), so haben wir es hier gleichfalls mit einem Falle "geschlechtlicher" Vermehrung zu tun. Die einfache Zellteilung dagegen (s. Absch. 1) ist nur ein Vorgang „ungeschlechtlicher" Vermehrung.

D. Bedeutung. 1. Wie wir später sehen werden, dienen den Pflanzen sehr einfach zusammengesetzte Stoffe (Salze, Wasser und Kohlensänre) zur Nahrung. Die Tiere dagegen können nur aus Pflanzen- oder Tierstoffen ihren Leib aufbauen. Sie sind daher in letzter Linie auf Pflanzenstoffe angewiesen. Dies gilt natürlich auch von den Pflanzen und Tieren des Wassers. Da nun die Algen die bei weitem wichtigsten Glieder der Wassergewächse darstellen, so bilden sie auch die wichtigste Nahrungsquelle der Wassertiere.

Außerdem liefern sie diesen Tieren auch einen großen Teil der notwendigen A temluft. Setzen wir z. B. Algen (oder andere untergetauchte Wasserpflanzen) in einem Gefäße mit Wasser direktem Sonnenlichte aus, so sehen wir von ihnen Gasbläschen emporsteigen. Dieses Gas ist leicht als Sauerstoff zu erkennen, der den Tieren bekanntlich zur Atmung dient.

2. Andererseits liefern aber auch die Tiere den Algen (nnd den anderen untergetauchten Wasserpflanzen) einen großen Teil der notwendigen Nährstoffe. Bringt man z. B. Schraubenalgen oder eine andere Algenart in ein Gefäß mit Wasser, das durch faulende Tierstoffe iibelriechend geworden ist, so wird das Wasser nach und nach klarer, und der üble Geruch verschwindet schließlich vollkommen. Hiermit geht eine starke Vermehrung der Algen Hand in Hand: sie haben die sich zersetzenden Tierstoffe in sich aufgenommen und zum Leben und Aufbau ihres Leibes verwendet. Bedenkt man nun, welche Mengen von Tierstoffen (Abfallstoffen und Leichen) in einem Gewässer täglich in Verwesung iibergehen, so ist leicht einzusehen, daß ohne die Tätigkeit der A lgen (und der anderen nntergetauchten Wasserpflanzen) das Wasser bald verpestet sein wïrde, alles tierische Leben also zu Grunde gehen miißte.

Die Wasserpflanzen und unter ihnen in erster Linie wieder die in großen Massen auftretenden Algen sind also - kurz gesagt - die Grundbedingung alles Lebens im Wasser. (Welche Erfahrungen macht man mit Aquarien, die richtig oder unrichtig mit Tieren und Pflanzen besetzt sind?)

\section{Andere Grinalgen.}

1. In der Gesellschaft der Schrauhenalge finden sich zahlreiche andere Algenarten, die längere oder kürzere, einfache oder verzweigte Fäden darstellen, und darum im Volksmunic als Wasserfäden (Confervoideae) bezeichnet werden. Sie schwimmen 
entweder frei an der Oberfäche, oder überziehen Steine, Brïckenpfeiler und andere Gegenstände mit einer grünen Hülle, oder bilden endlich zarte Schleier, die in dem Wasser dahinfluten. Bei den festsitzenden Formen vertritt die unterste, farblose Zelle die Stelle der Wurzel: sie bildet ein Haftwerkzeug, durch das der ganze Faden verankert ist.

Auf ungeschlechtlichem Wege vermehren sich diese Algen außer durch Teilnng durch sog. Schwärmsporen : der Inhalt gewisser oder aller Zellen zerfällt meist in mehrere Teile, die durch einen Riß der Zellwand ins Freie treten und mit Hilfe von Wimpern wie Infusorien durch das Wasser "schwärmen". Nach einiger Zeit kommen diese Körperchen zur Ruhe, setzen sich auf einem Gegenstande fest und wachsen zu je einem neuen Zellfaden aus. Die geschlechtliche Vermehrung erinnert vielfach stark an den entsprechenden Vorgang bei Farnen und Moosen, ist im einzelnen aber sehr verschieden.

Eine "Fadenalge" ist auch die Veilchenalgre (Chroólepus iolíthus), die sich als rotbrauner, veilchenduftender Überzug anf dem Urgestein der Gebirge findet $\left({ }_{n}\right.$ Veilchenmoos, Veilchenstein $\left.{ }^{\prime}\right)$. Sie ist also im Gegensatz zu der Mehrzahl der Algen, deren eigentliche Heimat das Wasser ist, ein Landbewohner.

2. An der Wetterseite der Bäume, an fenchten Mauern und ähnlichen Orten findet sich häufig ein grüner Anflug. Legen wir ein wenig davon in einem Wassertropfen unter das Mikroskop, so löst sich die grüne Masse in eine Menge kugelförmiger Gebilde auf. Jede Kugel stellt eine Alge dar, die nur aus einer einzigen $\mathrm{Z}$ elle besteht (Pleurocóccus und andere (iattungen), Ähnliche Pflänzchen von Kugel-, Zylinder-, Spindel-und anderer Form beherbergt in weit gröBerer Menge das Wasser. Mehrere von ilinen sind vielfach durch ausgeschiedene Gallertmassen zu kleinen Kolonien vereinigt.

Von besonderer Zierlichkeit sind gewisse einzellige Formen (Desmidiáceae), die sich häufig in dem Algendickicht der Süßgewässer, besonders der Torfsümpfe finden. Sie 


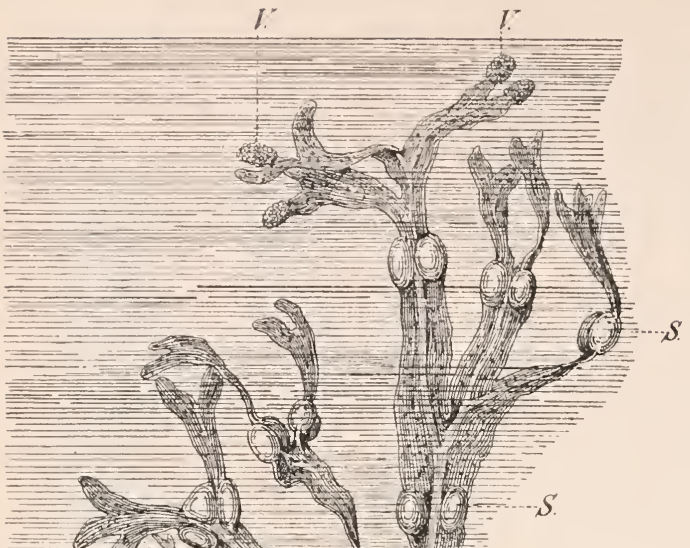

bilden wie die abgebildeten Arten bald ausgezackte Scheiben oder grüne Halbmonde, bald regelmäBige Sterne, Ketten, Bänder und dgl.

3. Zu den Grünalgen stellt man auch die Armleuchtera lgen (Charáceae), die auf dem Boden von Landseen oft förmliche Wiesen bilden, aber auch in Gräben und Tümpeln anzutreffen sind. Sie sind wie die Moose durch Wurzelhaare im Boden befestigt, verzweigen sich armleuchterartig (Name!) und nehmen aus dem Wasser oft soviel Kalksalze auf, daß sie brüchig werden. Die Vermehrungsorgane finden sich an den „Zweigen" als eiförmige, grüne oder als kugelige, rote Körper.

\section{2. und 3. Klasse.}

\section{Braun- u. Rotalgen (Phaeophýceac} und Rhodophýceae).

Unter den Algen oder Tangen des Meeres treten die Grünalgen, die im Süßwasser die Herrschaft führen, stark zurïck. Ihre Stelle nehmen stattlichere Formen ein, die neben dem Blattgrïn noch einen braunen oder roten Farbstoff in ihren Zellen enthalten.

Blasentang mit Haftscheiben an einem Felsen sitzend. S. Schwimmblasen; V. Stellen, an denen sich die Vermehrungsorgane finden. (Etwa $1 / 3$ nat. (rr.)
Daher erscheinen sie bald heller, bald dunkler braun oder rot gefärbt. Da sie (fast ausschließlich) festsitzende Pflanzen sind, so vermögen sie auch nur einen verhältnismäßig schmalen Küstenstrich zu bewohnen. In der Regel reicht dieser Gürtel bis $30 \mathrm{~m}$

und nur bei ganz reinem, klarem Wasser etwa bis $50 \mathrm{~m}$ Tiefe hinab; denn in noch tieferem Wasser ist das Licht so stark gedämpft, daß keine mit Blatt- 
grïn ausgestattete Pflanze die einfachen Nährstoffe zu Lebens- und Baustoffen umzuwandeln vermöchte.

1. Die Bra unalgen sind zumeist größere Pflanzen, die vielfach ausgedehnte "Tangwiesen" oder — wie die größten Arten - förmliche "Tangwälder" bilden. Sie bewohnen die flachen Küstengewässer, in denen sie mit Ebbe und Flut, sowie mit den brandenden Wogen einen harten, beständigen Kampf zu führen haben. Daher wachsen sie auch nur anf felsigem Untergrunde, dem sie sich mit kräftigem, wurzelartigem Haftorgane anklammern können, und besitzen einen zähen, lederartigen Körper. Wïhlen heftige Stïrme das Meer tief auf, so werden sie trotzdem nicht selten losgerissen und in großen Massen an die Kïste geworfen. Dann werden sie von den Strandbewohnern als Dünger auf den Acker gebracht oder verbrannt; denn aus ihrer Asche gewinnt man das wertvolle Jod, das sie dem Meerwasser entziehen.

Die hänfigste Braunalge der Nord- und Ostseeküste ist der Blasentang (Fucus vesiculósus), der eine Länge von $1 \mathrm{~m}$ erreicht, mehrfach gabelig geteilt ist und durch zahlreiche, laftgefüllte Blasen schwimmend erhalten wird (vgl. mit Schwimmgürteln!). Die Enden der Lappen zeigen vielfach ein gekörneltes Aussehen. Dies rührt von krugförmigen Vertiefungen her, in denen sich die Vermehrungsorgane bilden. - An den Küsten der tropischen Meere findet sich der Beerentang (Sargássum bacciferum), dessen Schwimmblasen wie gestielte Beeren aussehen (Name!). Von der Brandung losgerissen treibt er oft in groBen Massen an der Oberfläche des Wassers. Solche Massen führt auch der Golfstrom von den Küsten des mexikanischen Meerbusens hinweg in jenen stromlosen Meeresteil, der sich als "Sargassosee" zwischen den Azoren und Amerika ausdelnt. Dort bedeckt der losgerissene Beerentang mehrere tausend Quadratmeilen. Nirgends jedoch ist die Anhäufung der Tangmassen so stark, daß sie, wie man früher glaubte, der Schifffahrt hinderlich würde, - Die größte Alge, wie überhaupt die größte aller Pflanzen ist der Birutang (Macrocýstis pyrifera). Das bis $300 \mathrm{~m}$ lange Gewächs findet sich an den außertropischen Kïsten der südlichen Erdhälfte und hält sich durch birnartige Blasen (Name!) schwimmend an der OberHäche des Ozeans.

2. Die Rotalgen erreichen nie die Größe der Braunalgen, auf denen sie sich gern ansiedehn. Meist

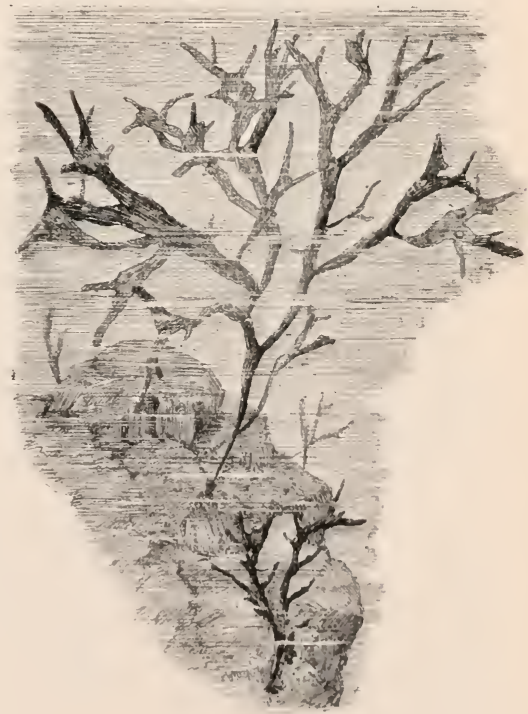

Perltang etwa nat. (ir.). 
aber bewohnen sie die tieferen Wasserschichten, die selbst von den heftigsten Stiirmen nur wenig oder gar nicht erregt werden. Daher wird uns auch die große Zartheit dieser Formen wohl verständlich. Infolge der prächtigen Färbung, die zwischen leuchtendem Scharlach und tiefstem Purpurschwarz schwankt, und der wechselvollen Gestalt verwandeln sie im Verein mit den farbenprächtigen Korallentieren die unterseeischen Felsen in lachende Gärten. Bald bilden sie zwar nur einfache Fäden oder blattartige Flächen; bald aber gleichen sie zierlichen Moosrasen, feinverzweigten Bäumchen, zartblättrigen Farnen und dgl.

Eine in der Nordsee lebende Art, der Perltang (Chondrus erispus), wird getrocknet als Karagaheen- oder ,irländisches Moos“ als Heilmittel gegen Erkrankung der Atemwege benutzt. - Nur wenige, zwerghafte Formen der prächtigen Gewächse finden sich im SüBwasser, und zwar auffallender Weise besonders an den Steinen schnellfieBender Gebirgsbäche.

4. Klasse. Kieselalgen (Diatomáceae).

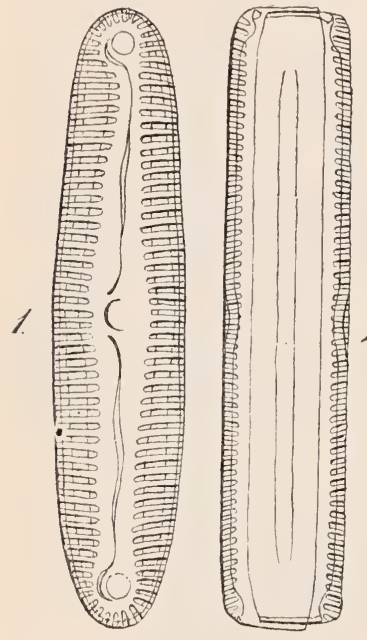

Kieselalgen bekommt man leicht in größter Nenge zu Gesicht, wenn man mit Hilfe des Mikroskops den braunen, schleimigen Überzug untersucht, der sich im Frïhjahre auf Gräben und Pfützen bildet. Auch Algenfäden oder Schlamm wird man danach nur selten vergeblich durchmustern. Die winzigen, einzelligen Pflanzen haben die Form eines Stabes, einer Sichel, eines Keils, eines Kreises, einer Ellipse 2. oder dgl. Sie schweben entweder frei im Wasser, oder gleiten wie ein von geheimnisvollen Kräften getriebenes Schifflein anf fester Unterlage langsam dahin, oder sitzen endlich anf ausgeschiedenen Gallertstielen anderen Körpern auf. Durch einen braunen Farbstoff, der das Blattgrïn verdeckt, erhalten sie ein ledergelbes Aussehen. Die Zellwand besteht aus 2 Schalen, von denen die eine über die andere wie der Deckel uiber die Schachtel greift. Glüht man die Pflänzchen auf einem Glimmerblättchen, so bleibt ein K i es elskelett zurück, das genau die Form der Schalen aufweist (Kieselalgen!). Jetzt erkennt man anch erst deutlich, wie die zarte Zellwand durch Leisten und Rippen verstärkt ist, so daß oft eine iiberans regelmäßige und zierliche Felderung entsteht.

Vergrößert sich der Inhalt der Zelle, so Eine Kieselalge d. Süßwassers (Navícula). 1 Flächenansieht; 2 Kantenans.; 3 Querschn. (Vgr. et. $900 \mathrm{~m}$ ). werden die Schalen auseinander gedrängt. In- 
dem sich der Inhalt so teilt, daß jede Hälfte eine Schale erhält, entstehen 2 Pflänzchen, von denen jede alsbald die zweite, fehlende Schale ausscheidet. Bleiben die bei fortgesetzter Teilung immer neu entstehenden Pflänzchen im Zusammenhange, so bilden sich Kolonien, die zierliche Ketten, Bänder, Scheiben u. dgl. darstellen. Da nun aber die verkieselten Zellwände nicht wachstumsfähig sind, miissen die Pflanzen, die die kleinere Schale erhalten, allmählich auch immer kleiner werden. Dies hat jedoch eine Grenze. Ist die Größe nämlich bis auf einen gewissen Punkt herabgesunken, dann legen sich (in der Regel) 2 Pflänzchen aneinander; ihre Schalen klappen auf; der Inhalt beider tritt hervor, vereinigt sich und bildet eine große Spore, aus der eine Pflanze von der ursprünglichen Größe hervorgeht.

Die Kieselalgen entfalten ihre Bedeutung als Nälrstoffquelle der Tiere (s. S. 324) besonders im Me ere. Zwar bilden hier - wie wir oben schon gesehen haben die Braun- und Rotalgen weite Bestände. Da sich diese ${ }_{n}$ Tangwiesen" und "Tangwälder" aber nur bis zu einer Tiefe von etwa $50 \mathrm{~m}$ erstrecken, so vermögen sie für die ungezählten Tierscharen der Weltmeere auch bei weitem nicht die nötige Nahrung zu liefern. Es muB daher noch eine andere Nah-

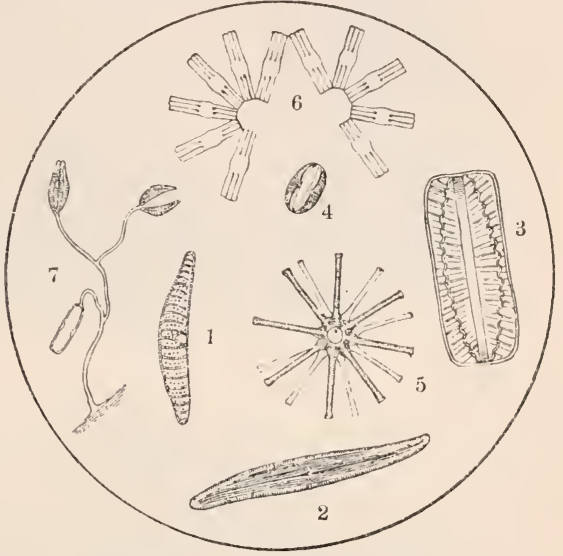

Kieselalgen des Süßwassers. 1-4 einzeln lebende Arten. 5 und 6 freilebende Kolonien. 7 eine Kolonie, die mit Hilfe eines verzweigten Gallertstieles einem festen Gegenstande aufsitzt. (Vergr. $200 \mathrm{mal}$.) rungsquelle vorhanden sein!

Streifen wir mit den feinsten Gazenetzen durch das Meerwasser, und untersuchen wir den „Fang“ mit Hilfe des Mikroskops, so haben wir die gesuchte Quelle: neben zahlreichen kleinen Tieren erblicken wir eine erstaunliche Menge winziger, wunderbar geformter Kieselalgen. Sie bewohnen (mit anderen einzelligen Algen) die stark durchleuchteten oberflächlichen Wasserschichten in ungezählten Myriaden. Während wir glauben, reines, klares Wasser unter dem Kiel unseres Schiffes zu haben, fahren wir also über eine reiche Pflanzenwiese dahin, auf der die kleinsten Tiergeschlechter jahraus, jahrein Nahrung finden. Von diesen Tieren nähren sich wieder die größeren, ja selbst die Riesen der Schöpfung, und von allen hängen endlich auch die Millionen von Menschen ab, die als Fischer, Schiffer, Kaufleute n. s. w. auf den Reichtnm des Meeres angewiesen sind. (Führe dies weiter aus und vgl. dabei besonders das, was in dieser Hinsicht im „Lehrbuche der Zoologie“ über den Hering, den Kabeljau, den Seehund und die Wale mitgeteilt ist!)

Hiermit ist aber die Bedentang der unscheinbaren Pflänzchen noch bei weitem 
nicht erschöpft: indem nämlich die abgestorbenen Kieselalgen auf den Grund des Meeres hinabsinken, dienen sie auch den Bewohnern der tieferen und tiefsten Wasserschichten zur Nalırung. Sie ermöglichen also die Bewohnbarkeit der lichtlosen und darum pflanzenleeren Meerestiefen.

Da nun die verkieselten Schalen fast unvergänglich sind, so häufen sie sich auf llem Boden des Meeres oft zu gewaltigen Massen an. Werden solche Anhäufungen, die sich aber auch in süßen Gewässern bilden können, im Laufe der Jahrtausende über den Wasserspiegel emporgehoben, so entstchen Lager von Diatomeenerde, Kieselgur, oder Polierschiefer, die der Mensch zu verschiedenen Zwecken ansbeutet. (Mit Nitroglyzerin getränkte Diatomeenerde gibt das Dynamit.) Solche Lager finden sich z. B. in der Lüneburger Heile, sowie bei Franzensbad und Bilin in Böhmen. Auf einer mächtigen (bis $30 \mathrm{~m}$ starken) Schicht von Kieselalgen erheben sich auch einige Teile von Berlin und Königsberg.

\section{Kreis. Pilze (Fungi).}

Lagerpflanzen ohne Blattgrün, die daher Schmarotzer oder Fäulnisbewohner sind.

\section{Klasse. Fadenpilze (Hyphomycétes).}

Pilze, die ein Fadengeflecht besitzen.

\section{Unterklasse. Ständerpilze (Basidiomycétes).}

Fadengeflecht melızellig. Sporen entstehen (gewöhnlich in einer Anzahl von je 4) anf verschieden geformten Ständern (Basidien).

Der Feld-Champignon (Psallióta campéstris). Taf. 37, 1.

A. Fruchtkörper. 1. Der "Champignon" bricht im Sommer und Herbst auf Wiesen und Feldrainen, an Wegen und ähnlichen Orten aus dem Boden hervor. Wie ein Längsschnitt zeigt, besitzt er ein festes, weißes "Fleisch" von anisartigem Geruch, das als schmackhafte Speise überall hoch geschätzt wird. Für den menschlichen Genuß eignen sich allerdings zumeist nur die jungen Pilze; denn die alten sind in der Regel von zahlreichen II iicken- und Fliegenmaden durchwïhlt. (Welchen Tieren dient der Pilz ferner noch zur Nahrung?) Seiner Schmackhaftigkeit wegen wird der wertvolle Champignon vielfach anch k ̈̈nstlich gezogen (s. S. 334,3).

2. Vollkommen entwickelt gleicht ein solcher Pilz oder Schwamm einem Schirme. Ein bis $8 \mathrm{~cm}$ hoher Stiel trägt einen flach gewölbten "Hut", der weiß oder bräunlich gefärbt ist und einen Durchmesser von $15 \mathrm{~cm}$ erreichen kann ("Hutpilze“). Auf der Unterseite des Hutes finden sich zahlreiche, radienartig und senkrecht gestellte Blättchen (Lamellen), die anfangs rosa, später dagegen schokolade- bis schwarzbraun aussehen, eine Färbung, die als das sicherste und leichteste Erkennungsmerkmal des Champignons gilt. Alle Blättchen stoßen an den Hutrand an, aber nur die längeren erstrecken sich bis zun Stiele, ohne jedoch mit ihm zu verschmelzen. 

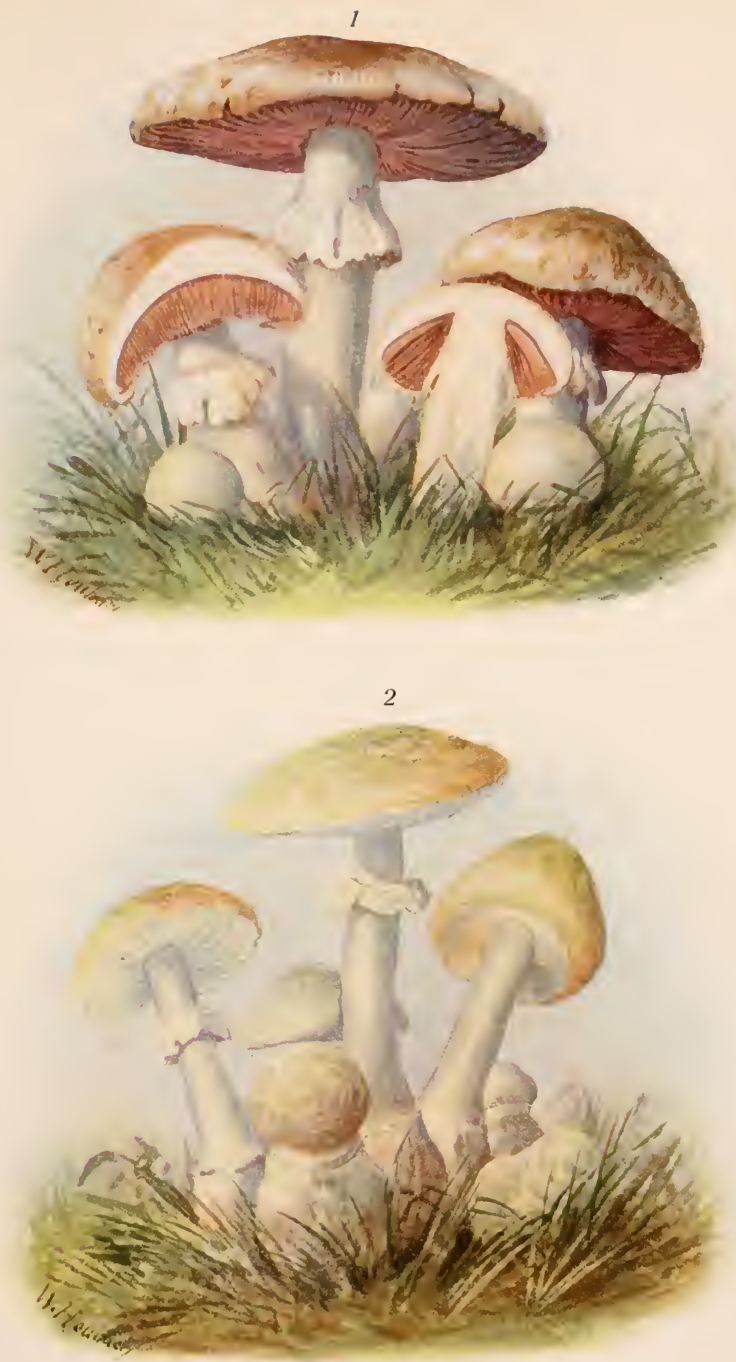

1. Feld-Champignon (Psalliota campestris).

2. Knollenblätterpilz (Amanita bulbosa). 

Durchschneiden wir einen noch ganz jungen Pilz, der wie ein weißes Knnöllchen aus dem Boden hervorbricht und sich in Stiel und Hut zu gliederu beginnt, der Länge nach, so sehen wir, daß sich die leistenartigen Blättchen im Innern des Pilzes bilden. Anch wenn der Pilz bald seine endgiiltige Gestalt erlangt hat, ist von diesen iiberaus zarten Gebilden noch niclits zu sehen: eine Haut, der"sog. Schleier, der sich zwischen Hutrand und Stiel ausspannt,

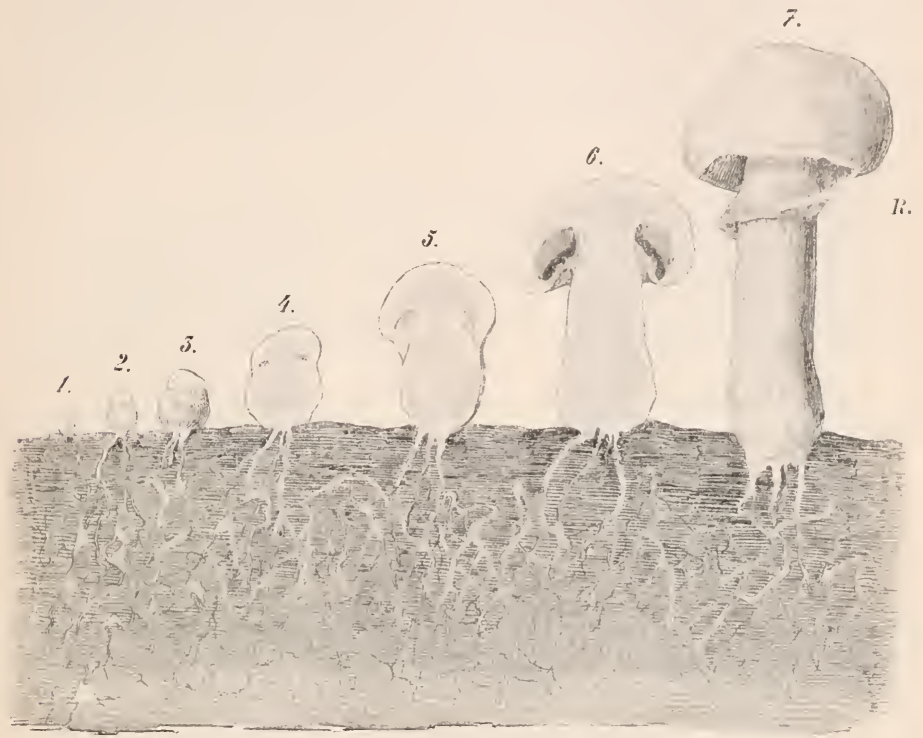

Entwicklung des Champignous. Der Boden ist von einem Falengeflecht durehzogen. 1-3 und 7 von außen gesehen, 4-6 im Längsschnitt. Bei 4 billen sich die Blättehen (Lamellen). Bei 5 und 6 ist der Schleier dentlich ausgebildet. Bei 7 löst er sich rom

Hutrande und bleibt als Ring (R.) zurück.

schiitzt sie vor den Unbilden der Witterung. Erst ganz am Schlusse der Eutwicklung werden die Blättchen sichtbar: Der Schleier reißt an dem Rande des sich stark ausdehnenden Hutes ab und bleibt als „Ring"6 am Stiele zuriick.

3. Stellen wir durch einige dieser Blättchen selır dünne Querschnitte her, so sehen wir mit Hilfe des Mikroskops, daß sie (wie Stiel und Hut) aus zahlreichen Fäden zusammengesetzt sind, die aus aneinander gereihten Zellen bestehen. Die Endzellen der Fäden sind keulenförmige Gebilde, die sich senkrecht iiber die Oberfläche des Blättchens erheben. Mehrere dieser "Kenlen" strecken sich etwas stärker als die anderen und erhalten auf ihrem Scheitel je 2 kleine 
Ausstiilpungen, die an der Spitze kugelig anschwellen. Indem sich diese „Kugeln“ durch je eine Scheidewand von den stielartigen Ausstiilpungen abschließen, entstehen die Sporen. Die keulenförmigen Zellen, auf denen sie sich bilden, nennt man daher "Sporenständ er", während die „unfruchtbar" bleibenden als "Zw ischenzellen" bezeichnet werden. Sie bilden zusammen die sog. Fruchtschicht, die also beide Seiten der Blätter ïberzieht. Wenn man bedenkt, daß die zarten Sporenständer durch die Zwischenzellen gleichsam erst in einen festen Verband eingereiht werden, der ihnen den notwendigen Halt gewährt, so wird man auch die Bedeutung dieser scheinbar nutzlosen Gebilde erkennen. (Da die Sporenständer gleichsam ein Grundgestell, eine Basis der

a.

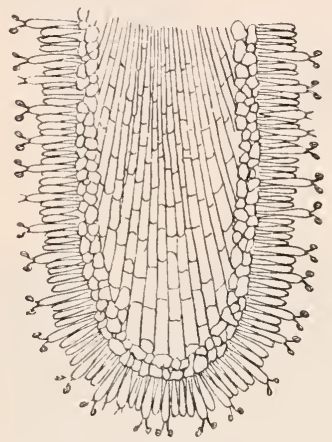

b.

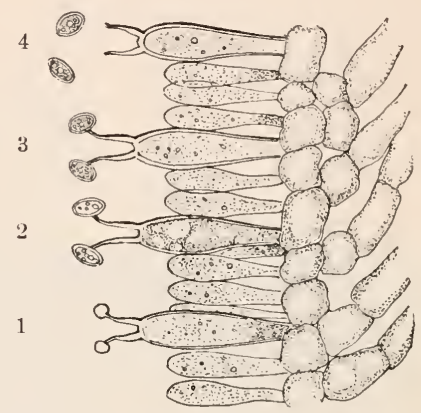

Feinerer Ban der Blittchen (Lamellen) des Champignons. a. ein Querschnitt durch ein Blättchen bei etwa 150 maliger Vergr. b. Die Fruchtschicht bei stärkerer (etwa 800 maliger) Vergr., aus größeren Sporenständern und kleineren Zwischenzellen bestehend. 1-4 die verschiedenen Zustände der Sporenentwicklung.

sich entwickelnden Sporen bilden, werden sie wissenschaftlich "Basidien" genannt. - Ständer- oder Basidienpilze. Im Gegensatz zum Champignon bilden sich bei den meisten dieser Pilze je 4 Sporen auf jedem Ständer.)

4. Die Sporen sehen anfänglich rosa ans, in reifem Zustande aber sind sie von schokolade- bis schwarzbrauner Färbung. Unter günstigen Verhältnissen treiben sie je einen Keimschlauch (s. S. 298) und rufen eine nene Pflanze ins Dasein.

a) Wie uns das Mikroskop zeigt, sind die Sporen sehr klein e Gebilde, können also vom Winde leicht verweht werden.

b) Der Wind ist aber ein sehr unsicherer Verbreiter der Pflanzen. Viele Sporen trägt er sicher dorthin, wo sie sich nicht entwickeln können. Da sie sich aber in sehr großer Anzahl bilden, so ist für einige die Möglichkeit, an einen geeigneten Ort zu gelangen, sicher vorhanden. - Welche Mengen von 
Sporen erzeugt werden, geht daraus hervor, daß die winzigen Körper den farblosen Blättchen der Hutunterseite die ihnen eigene Färbung verleihen. (Legt man den Hut eines ausgebildeten Champignons mit der Unterseite auf ein Blatt Papier, so bilden die ausfallenden Sporen oft schon nach wenigen Stunden eine „Zeichnung“, die alle Einzelheiten der Hutunterfläche wiederspiegelt.)

c) Die Millionen von Sporen bedürfen zn ilırer Bildung aber auch eines verhältnismäßig großen Platzes. Hierzu wïrde die Unterseite des Hutes unmöglich ausreichen, wenn sie durch die Blättchen nicht eine sehr beträchtliche Vergrößerung erfahren hätte. Diese Tatsache macht uns auch das erwähnte Auftreten kurzer Blättchen in dem änßeren Hutabschnitte verständlich: der hier vorhandene größere Raum wird durch das „Einschieben" dieser Blättchen erst vollkommen ausgeniitzt. (Stelle die Größe der Hutunterseite und die der tatsächlich sporenbildenden Fläche nngefähr durch Rechnung fest! Vgl. hiermit die Flächenvergrößernngen, wie sie häufig im Tierkörper vorkommen, z. B. im Baı der Lunge, in der Bildung der Blntkörperchen n. s. w.)

d) Dem Winde muß der Zntritt zu den Sporen offen sein. Wie erwähnt, löst sich daher der schützende Schleier mit beginnender Sporenreife vom Hutrande ab.

e) Da der Hnt anf einem Stiele über den Erdboden gehoben wird, köunen die fallenden oder sich lockernden Sporen vom Winde leicht erfaßt werden.

f) Eine Aussaat der Sporen ist aber nur bei trockenem Wetter möglich (wieso?). Die Unterseite des $\mathrm{Hntes,} \mathrm{der} \mathrm{wie} \mathrm{ein} \mathrm{Regendach} \mathrm{wirkt,} \mathrm{ist}$ daher auch als die passendste Bildungsstätte der Sporen zu bezeichnen.

B. Fadengeflecht. Nimmt man einige Champignons mit dem anhaftenden Erdballen aus dem Boden, so sieht man, daß die Erde von zahlreichen, vielfach verzweigten, weißen Fäden (Hyphen) wie von Spinngewebe dnrclızogen ist. Wäscht man die Erde vorsichtig ab, so sieht man weiter, wie sich die Pilze als kleine Anschwellungen an den Fäden bilden, und wie selbst der vollkommen entwickelte Pilz mit einem Faden oder mit einigen Fäden in Verbindung steht. Die "Champignons" und das Fadengeflecht oder Pilzlager (Mycelium) stehen also im Zusammenhange; es sind Teile derselben Pflanze. Ja noch mehr!

Wie man besonders deutlich an einer künstlichen Champignonanlage sehen kann, lebt das Fadengeflecht sehr lange im Boden. Hat es eine gewisse Ausdehnung erlangt, dann bringt es "Pilze" oft in großer Menge hervor. Sobald diese Gebilde die Sporen ausgestrent haben, vergehen sie sehr schnell; andere sprossen hervor, gehen wieder zn Grunde n. s. f.: das Fadengeflecht dagegen, an dem sich die "Pilze" bildeten, wächst weiter. Es gleicht also etwa einem Obstbaume, der zahlreiche Früchte trägt, die er bei der Reife abwirft. In dem Fadengeflechte haben wir also die eigentliche Pflanze, den eigentlichen Pilz vor uns, während die Gebilde, die wir bisher dem Sprachgebrauche entsprechend als "Champignons, Pilze oder 
Schwämme" bezeichneten, nur die Sporen- oder Fruchtkörper dieser Pflanze oder dieses Pilzes darstellen. Die Pflanze selbst lebt unterirdisch. Ihre Fruchtkörper dagegen werden, wie dies die Windverbreitung der Sporen bedingt, iiber den Boden gehoben.

1. Unter dem Mikroskope geben sich die Fäden als Reihen von Zellen zu erkennen. Hier und da haben sich anch mehrere zu dickeren Strängen vereinigt. Stets aber sind sie so zart, daß sie kraftlos zusammensinken, wenn man sie dem Boden entnimmt. Im Gegensatz zu den oberirdischen Pflanzen, die sich selbst zu halten haben, können die unterirdischen Teile des Pilzes eine solche Zartheit wohl besitzen; denn sie werden ja von der Erde allseitig gestützt und getragen (vgl. mit Wasserpflanzen und Wassertieren!). - Der Fruchtkörper bestelit, wie bereits angedeutet, aus ebensolchen Fäden. Da sie jedoch besonders an der Oberfläche ("Hant") sehr eng aneinander gedrängt sind, sich vielfach verzweigen und durchflechten, so sind sie trotz ihrer Zartheit im stande, einen Körper zu bilden, der sich über den Boden zu heben und den Unbilden der Witterung (Wind, Regen) standzuhalten vermag.

2. Gleich den Wurzeln der höheren Pflanzen durchzieht das Fadengeflecht den Boden nach allen Richtungen und entnimmt ihm die nährenden Bestandteile. Wie wir nun schon mehrfach gesehen haben (nnd im letzten Abschn. des Buches noch genauer sehen werden), nehmen die Wurzeln nur Wasser und Nährsalze auf. Beide steigen in die oberirdischen Teile der Pflanze und werden dort samt der aus der Luft entnommenen Kohlensäure unter Einwirkung des Sonnenlichts von dem Blattgrïn zu allen den Stoffen weiter verarbeitet, aus denen sich der Pflanzenkörper aufbaut. Von Blattgrön finden wir aber in keinem Teile des Pilzes auch nur eine Spnr. Der Champignon ist daher genötigt, diese Stoffe in fertiger Form aufzunehmen. Er entzieht sie dem Boden, in dem er sich mit dem Fadengeflecht ausbreitet, und in dem pflanzliche und tierische Stoffe faulen: er ist ein Fänlnisbewohner (Saprophyt) oder eine Verwesungspflanze.

In gleicher Weise nähren sich auch die meisten anderen Hutpilze. Wir treften sie daher auch besonders an Orten, an denen sich verwesende Stoffe anhäufen. Dies ist nun ganz besonders im Walde der Fall. Sein Boden ist zumeist von einer dicken Schicht modernder, d. i. verwesender Stoffe (Laub, Zweige, abgestorbene Teile der Moose $\mathrm{u}$. dgl.) bedeckt, und der ihm oft entsteigende Moderduft zeigt zur Genüge, daß hier die Verwesnng in vollem Gange ist. Der Wald ist daher die eigentliche Heimat der Hutpilze. Da die blassen Gebilde kein Blattgrün besitzen, also auch nicht des Lichtes bedürfen, so treffen wir sie selbst an den dunkelsten Stellen des Waldes an, also an Örtlichkeiten, an denen keine grüne Pflanze mehr gedeihen kann. (Welche höheren Pflanzen sind gleichfalls Verwesungspflanzen?)

3. Wie uns das häufige Auftreten der Champignons in Mistbeeten zeigt, gedeiht er am liebsten in Boden, der reich an Pferdediinger ist. Will man den wertvollen Pilz zïchten, so bietet man ihm daher solchen Dünger, den man 
zuvor in gewisser Weise zubereitet hat, in Menge dar. In die Kästen, Verschlige und Gruben, die man mit dem Dünger füllt, bringt man etwas von dem Fadengeflechte ("Champignonbrut"), das bald die ganze Dïngermasse durchwuchert und die begehrten Fruchtkörper, die „Champignons", hervorbringt. In der Regel benutzt man znr Zucht des geschätzten Pilzes dunkle Räume, Keller, Schuppen u. dgl. In Frankreich, wo die Champignonzucht ganz besonders in Blïte steht, verwendet man dazu besonders Höhlen, Steinbrüche, nicht inehr „befahrene" Bergwerke und älnliche Örtlichkeiten.

4. Die tïgliche Erfahrung lehrt (stelle entsprechende Versuche an!), daß die Fäulnis durch Wärme und Feuchtigkeit begïnstigt wird. Wenn daher im Sommer und Herbst nach Regentagen warme Witterung eintritt, dann ist die Fäulnis im Boden am lebhaftesten. Dann findet auch der (im Freien wachsende) Champignon die meiste Nahrung. Sein Fadengeflecht zeigt daher jetzt das lebhafteste Wachstum, und jetzt ist für ihn darum auch die Zeit gekommen, seine Fruchtträger zu bilden, die alsbald „wie Pilze aus der Erde hervorschießen". - Dasselbe gilt anch von den Pilzen des Waldes: Spätsommer und Herbst sind die "Pilz- oder Schwammzeit". - Der Champignonziichter bietet seinen Pflanzen jahrans, jahrein die ihnen zusagende Wärme $\left(13-18^{\circ} \mathrm{C}\right)$ und Fenchtigkeit. Er kann daher auch in jeder Jahreszeit "Champignons" ernten.

5. Wie schon erwähnt, gehen die Fruchtkörper des Champignons nach dem Ausstreuen der Sporen alsbald in Fäulnis über, d. h. sie zerfallen in einfache Stoffe, aus denen die mit Blattgrün ansgerüsteten Pflanzen ilhren Körper aufbanen. Dieser Zerfall geht nun sehr schnell vor sich - schon nach wenigen Wochen findet man von Frnchtträgern, die im Freien liegen, meist keine Spur mehr -, viel schneller als bei anderen Pflanzenteilen (Blättern, Zweigen u. s.w.). Indem der Champignon "halbzersetzte" Tier- und Pflanzenstoffe aufnimmt und daraus seine schnell vergänglichen Fruchtkörper baut, macht er die in den toten Pflanzen und Tieren aufgespeicherten Stoffe höheren Pflanzen and damit auch den Tieren (Pflanzenfressern; Fleischfressern) bald wieder zugänglich, oder anders ansgedriickt: er beschleunigt den "Kreislauf der Stoffe" in der Natur (der auf die Tätigkeit der niedrigsten Pilze zuriickzuführen ist; s. S. 348). - Eine gleiche Bedeutung im Naturganzen haben alle anderen Hutpilze (also anch die giftigen!). Ganz besonders groß ist die der Waldpilze, deren schnell vergängliche Fruchtkörper in pilzreichen Jahren ja in erstaunlichen IIassen ans dem modernden Grunde hervorbrechen. (Vgl. die Pilze nach dieser Hinsicht mit den zahlreichen Tieren, die sich von faulenden Stoffen nähren!)

\section{Andere Stäinderpilze.}

Ein Gang durch Feld und Flur, besonders aber durch den herbstlichen Wald zeigt uns, welche erstannliche Mannigfaltigkeit in der Welt der Pilze herrscht. Es können hier daher nur die wenigen Formen berïcksichtigt werden, die uns entweder besonders als wohlschmeckende speise dienen, 
oder deren Genuß dem Menschen schwere Erkrankung, nicht selten sogar den Tod bringt. Ein Merkmal, durch das sich die giftigen Pilze von den eßbaren unterscheiden, gibt es nicht. Man mußsie kennen lernen, genau wie die Beerenfrüchte unserer Heimat (Tollkirsche, schwarzer Nachtschatten - Erdbeere 11. a.). Auch ist wohl zu beachten, daß ganz harmlose Pilze Vergiftnngserscheinungen hervorrufen können, sobald sie in Verwesung iibergegangen sind. Darum sollten nur junge Pilze und zwar kurz nach dem Einsammeln verspeist werden. Selbst das Stehenlassen der Pilze bis zum nächsten Tage hat oft schon großes Unheil angerichtet!

Je nach dem Orte, an dem sich die sporenbildende Trägerschicht findet, lassen sich leicht bestimmte Pilzgruppen unterscheiden.

1. Blitterpilze. Die Fruehtsehieht überzieht (wie beim Champignon) senkrecht gestellte „Blätter ${ }^{*}$ der Hutunterseite.

An denselben Orten, an denen der Feld-Champignon auftritt, aber auch in Wäldern und Gebüschen findet sich sein nächster Verwandter, der weiße Schaf-('l. (Ps. arvénsis). Er ist gleichfalls ebbar und von jenem dureh den hohlen Stiel leicht zu unterscheiden. Diesen beiden Pilzen ist der ïberaus giftige Kuollenblitterpiiz (Amanita bulbósa), besonders im Jugendzustande ziemlich ähnlich, (s. Taf. 37,2). Auf seinen Ge$n n ß$ sind die meisten Pilzvergiftungen znrückzufïhren. An den weiBen Blättern und dem unten knollenförmig angesehwollenen Stiele ist er jedoeh sicherzu erkennen. A uch fehlt ihm stets der charakteristische Anis. geruch des Champignous. Wie man an jungen Exemplaren sehen kann, sind Hut und Stiel von einer gemeinsamen Hülle schützend nmgeben. Bei fortgesetztem Wachstum wird die Hülle gesprengt und bleibt auf dem Hute als Fetzen und an dem knolligen Stiele als häntige Seheide zuriick, beides Merkmale, die dem Champignon stets fehlen. - Beim Fliegenpilz (A. muscária) bilden die Reste der Hülle weiße Flocken auf den scharlachroten Hute. Dieser gleichfalls giftige Pilz erscheint in Wäldern oft in großer Menge. Früher legte man ihn in Milch, die man zum Töten der Fliegen verwendete. Noch giftiger (Name!) ist der Speiteufel (Rússula emética), der besonders in Wäldern wächst. Er ist meist von dunkelbrauner Färbung, besitzt keinen Ring und riecht sehr widerlich. - An Baumstümpfen bricht der gleichfalls giftige Schwefelkopf (Hypholóma fasciculáre) hervor, ein vorwiegend schwefelgelber Pilz (Name!), der ausgebildet schwarz-grüne Blätter hat. - Neben diesen und einigen noch zu nennenden Giftpilzen gibt es aber weit mehr durchaus unschädliche Blättersehwämme, die wie der Champignon z. T. sogar eine vortreffliche speise für den Menschen bilden. Unter diesen dürfte der Gelbling, Pfifferling oder Eierpilz (Cantharéllus cibárius), der im Kiefernwalde oft in großen Trupps anzutreffen ist (Taf. 38, 2), wohl wieder der wichtigste sein. Die dottergelbe Färbung und die am Stengel herablaufenden Blätter sind sichere Erkennungszeichen. - Der sehr ähnliche falsche Gelbling (C. aurantiaens), den man für giftig hält, unterscheidet sich von ihm leicht durch eine deutliche Orangefärbung. Hochgeschätzt ist ferner der Reizker (Lactária deliciósa). Er hat einen meist ziegelroten Hut, der mit orangefarbenen oder grünlichen Ringen geziert ist Bei Verletzungen tropft aus ihm ein rotgelber Milchsaft hervor, während sein sehr giftiger „Doppelgänger", der Giftreizker (L. torminósa), verwundet eine weiße Mileh absondert. EBbar ist auch der Parasolpilz (Lepióta procéra), so lange er jung ist. Er gleicht anfangs einem Paukenschlägel, breitet dann aber seinen braungesehuppten Hut wie einen 

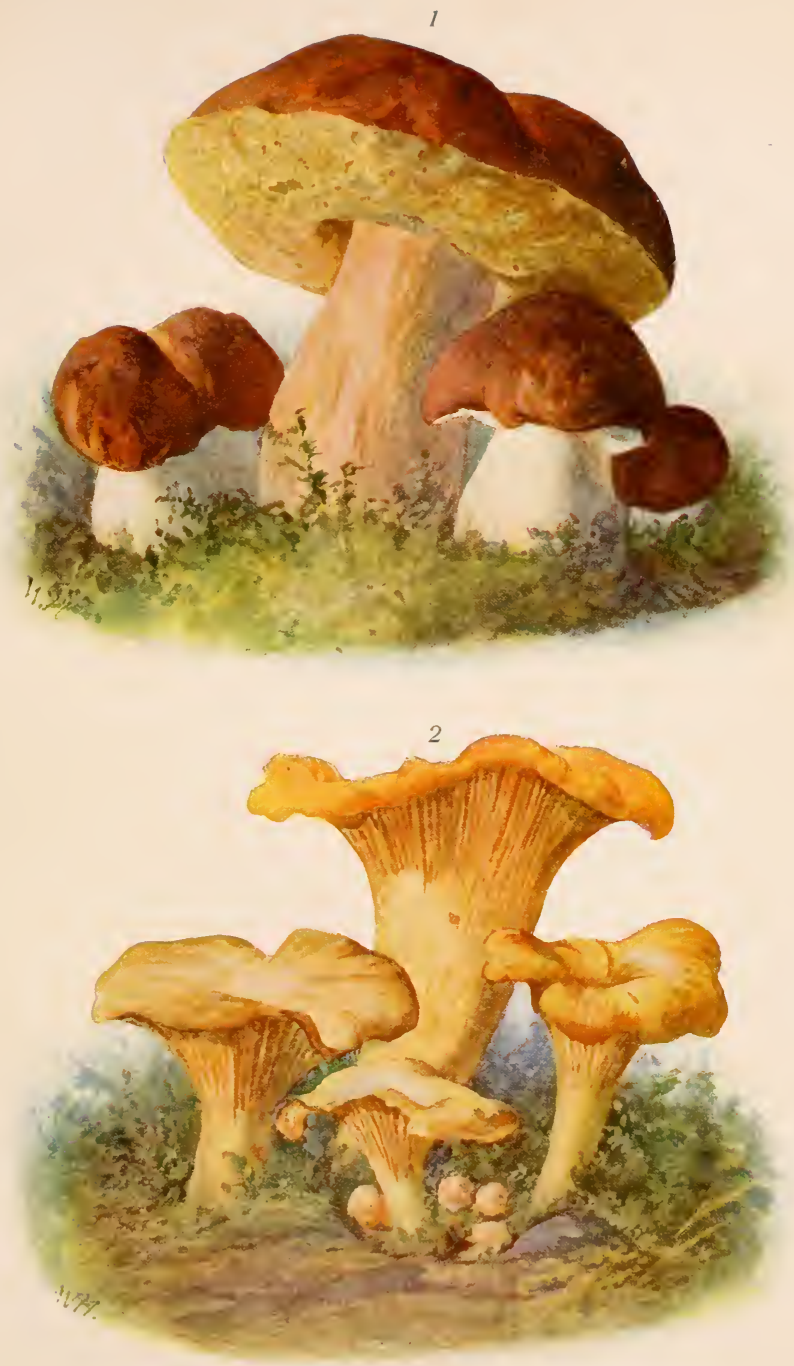

1. Steinpilz (Boletus edulis).

2. Gelbling, Pfifferling oder Eierpilz (Cantharellus cibarius). 
Schirm ("Schirmpilz") aus. Die prächtigen, oft $1 / 8 \mathrm{~m}$ hohen Gebilde brechen an lichten Waldstellen und anf Grasplätzen aus dem Boden hervor.

2. Röhrempilze. Die Fruchtsehicht überzieht die Wandungen von Röhren oder Löchern.

Das Wesen dieser Pilzgruppe können wir leicht am Steinpilze (Bolétus edúlis; Taf. 38, 1) erkennen, der in Laub- und Nadelwäldern vorkommt und einer unserer wertvollsten Speiseschwämme ist. Auf der Unterseite des Hutes finden wir eine leicht. abtremnbare Schicht zahlreicher Röhren, deren Mündungen als feine Löcher erscheinen. Die Röhren sind - wie ein mikroskopischer Schnitt zeigt - mit der Fruchtschicht ausgekleidet. Der dickfleischige Pilz hat einen knolligen, hellbräunlichen und meist netzaderig gezeichneten Stiel und einen heller oder dunkler mattbraunen Hut. Die anfangs weiße Röhrenschicht wird später gelblich und schließlich grünlich. - In der Gesellschaft des Steinpilzes finden sich meist noch zahlreiche andere Glieder seiner Gattung. Von diesen Pilzen sind alle die ebbar, deren Stiel einen Ring besitzt, und von den ringlosen Arten wieder diejenigen, die beim Zerbrechen nicht sofort die Farbe ändern. - Aas den ungenieBbaren Formen ist der überaus giftige Satanspilz (B. sátanas) hervorzuheben. Er ist dem Steinpilz sehr ähnlich, hat aber einen gelben, mit netzartigen, blutroten Flecken überdeckten Stiel, und eine gleichfalls blutrote Röhrenschicht. Sein Fleisch wird beim Durchschneiden rot und schlieblich dunkelblau.

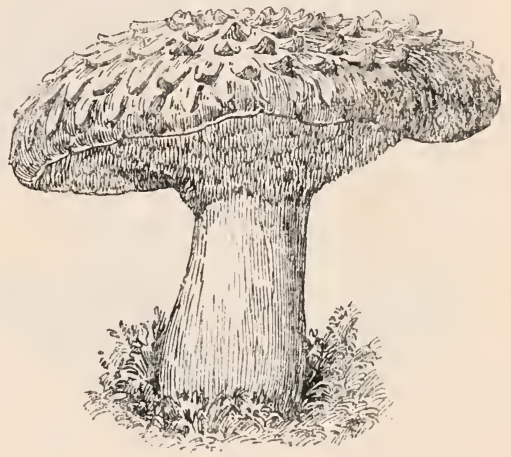

Habichtschwamm (kleines Exemplar).

An Baumstämmen finden sich nicht selten die konsolförmigen Fruchtkörper von Pilzen, deren Fadengeflecht in Holze des Baumes schmarotzt und es nach und nach zerstört. Da diese Fruchtkörper mehrjährig sind, erscheinen sie als feste, widerstandsfahige Gebilde. Sie erhalten alljährlich eine Verdickungsschicht mit einem Röhrenlager, so daß uns ihre eigentümliche Form wohl verständlich wird. Von diesen Pilzen wird besonders der Feuerschwamm (Polýporus fomentárius) zur Herstellung des leielıt brennbaren Zunders benutzt (Verwendung?). Zu diesen Zwecke wird die weiche Innenmasse des Fruchtkörpers in Scheiben geschnitten, stark geklopft und mit salpeterlösung getränkt. - Ein Röhrenpilz ist auch der berächtigte Hausschwamm (Merúlius lácrymans), dessen Fadengeflecht das Holzwerk der Häuser nicht selten gänzlich zerstört und sehr große, lappenförmige und äußerst giftige Fruchtkörper bildet. Da er wie alle Pflanzen ohne Wasser nicht leben kann, so darf nur trockenes Holz zum Bauen verwendet und in den Gebäuden eine sorgfältige Lüftung nie verabsäumt werden.

3. Stachelpilze: Die Fruchtschicht überzieht stachelartige Ausw ü c h se.

Dies ist leicht am Iabichtschwamm (Hýdnum imbricátum) zu sehell, der fast in jedem Nadelwalde vorkommt. Die kleinen Stacheln finden sich auf der Unter- 
seite des schokeladebraunen Hutes, der mit mehreren kreisförmigen Reihen großer Schuppen bedeckt ist. Die Stacheln laufen noch ein Stück an dem weißgrauen Stiele herab nnd stehen so dicht, dab sie der Hutunterseite das Anssehen eines Rehfelles verleihen (daher auch ${ }_{n}$ Rehpilz ${ }^{\star}$ ). Auch andere Arten der Grmppe sind eBbar, keine ist giftig.

4. Keulenpilze: Die Fruchtschicht überkleidet die Oberseite der keulen-oder korallenförmigen Fruchtkörper.

Die Pilze dieser Gruppe sind jung sämtlich ebbar. Am meisten wird der gelle Ziegenbart, Korallempilz oder Hahnenkamm (Clavária flava) geschätzt, der in

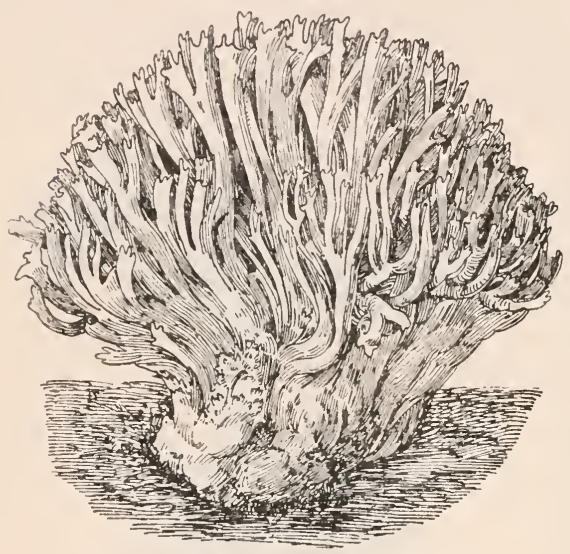

(ielber Ziegenbart (kleines Exemplar). Laub- und Nadelwäldern anzntreffen ist. Seine oft kopfgroBen, gelblichen Fruchtkörper spalten sich in zahlreiche Äste, die sich wiederholt in kleinere Zweige teilen. So entstehen prachtvolle, korallenartige Gebilde (Namen!) von größter Zartheit und oft beträchtlichem Imfange.

5. Batcelpilze: Di e Fruchtschicht überzieht die Wände von Hohlräumen oder Kammern im

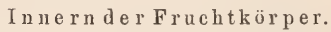
Stellt man durch einen jungen Bovist (Bovista), wie er sich auf Wiesen als weiße Kugel überall findet, dünne Schnitte her, so sieht man bei Anwendung des Mikroskops, daß der Körper gekammert ist, und $d a B$ die Wände der Hohlräume („Banchpilze“) dicht mit sporenbildenden Ständern besetzt sind. Bei der Reife werden die Wände anfgelöst. Dann reißt die äußere Hülle an der Spitze auf, so daß der Wind das braune Sporenpulver verwehen kann. Jung sind die Boviste wie zahlreiche andere Bauchpilze eßbar. - Giftig ist allein der Kartoffelbovist (Sclerodérma vulgáre), der häufig auf Sandboden vorkommt. Die festen Frnchtkörper haben das Aussehen von Kartoffelknollen (Name!), sind innen zuletzt aber ganz schwarz und werden betrïgerischer Weise daber nicht selten den Trüffeln beigemengt.

\section{Unterklasse. Schlauchpilze (Ascomycétes).}

Fadengeflecht mehrzellig. Sporen bilden sich (gewöhnlich in einer Anzahl von 8) in Innern schlauchartiger Zellen.

1. Während der Frïhlingsmonate brechen in Wäldern, auf Wiesen nnd in Gärten Fruchtkörper von Pilzen aus dem Boden, die wesentlich anders aussehen als die der bisher betrachteten Arten. Es sind die überall hoch geschätzten, schmackhaften Morcheln (Morchélla). Auf einem Stiele erhebt sich - je nach der Art - ein kegelförmiger oder abgerundeter Hut von meist grauer 
bis brauner Färbung. Die Oberfläche des hohlen und sehr brïchigen Hutes ist durch netzartige Rippen in zahlreiche Gruben geteilt.

Stellt man durch die Wand des Hutes dïnne Querschnitte her, so sieht man bei Anwendung des Mikroskops, daß die grubigen Vertiefungen außen mit einer Fruchtschicht (s. S. 332) ïberkleidet sind. Die Sporen werden hier aber nicht wie beim Champignon und seinen Verwandten an der Spitze von Ständern, sondern im Innern langgestreckter, schlauchartiger Z ellen gebildet. Zwischen den „Schläuchen", in denen wir je 8 Sporen zählen, beobachten wir wie beim Champignon zahlreiche unfruchtbare „Zw ischenzellen". Bei der Reife schwellen diese Gebilde stark an, so daß sie einen Druck auf die Schlänche ausüben. Da sich diese jetzt nun an der Spitze geöffnet haben, werden die Sporen mit einer ge-

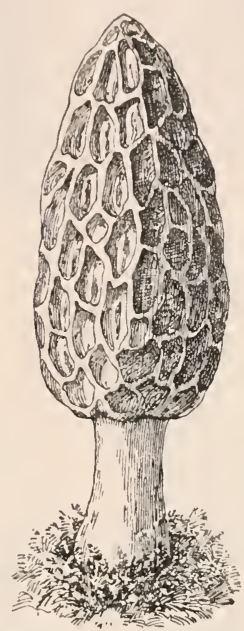

spitz-Morchel (nat. Gr.) Daneben mehrere Pilzfäden mit 3 śchläuchen, die je 8 sporen enthalten,

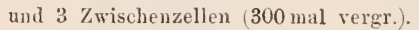

wissen Gewalt heraus geschlendert und somit dem Winde ïberantwortet, der ihre Verbreitung besorgt.

Als "Moreheln" kommt vielfach ein ganz ähnlich geformter Pilz in den Handel, die Speise-Lorchel (Helvélla). Sie wächst in Nadelwäldern und ist an dem nnregelmäßig gelappten Hute zu erkemnen, der zahlreiche "darmartige" Auftreibungen zeigt.

2. Viel höher noch als die Morcheln werden die Triuffeln (Tuber) geschätzt, die zıl den feinsten Delikatessen und Küchengewürzen zählen. Es sind dies die Fracht-

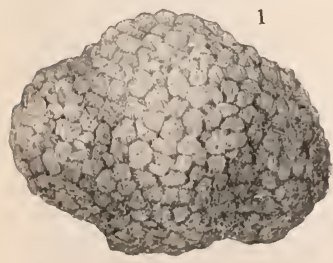

Triiffe
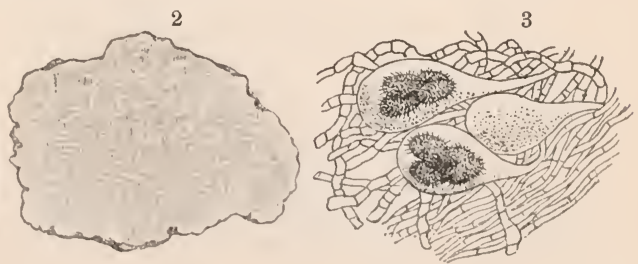

3 Drei Schlïuche, von denen 2 je 4 Sporen enthalten (Vergr. etwa $450 \mathrm{mal}$ ). 

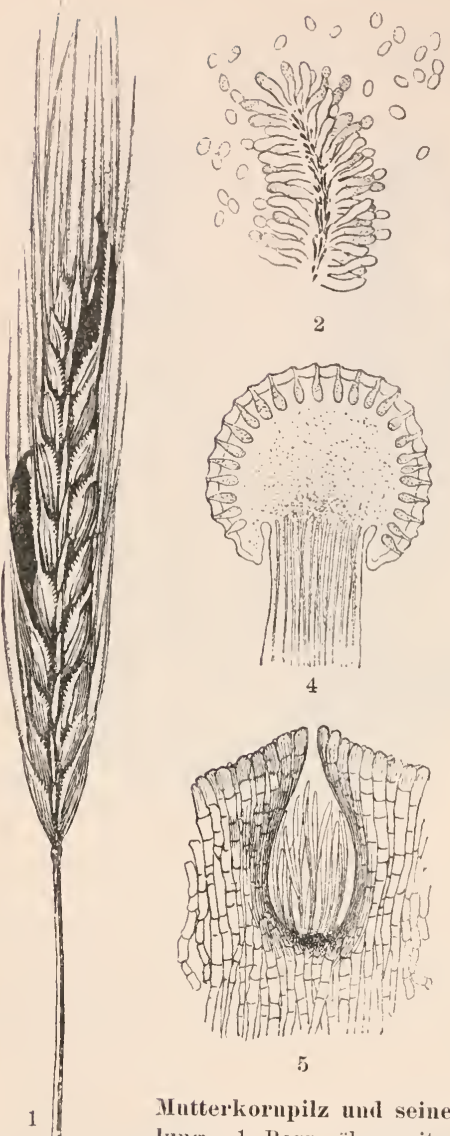

2

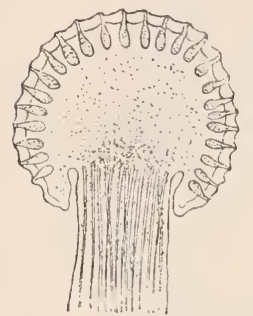

4

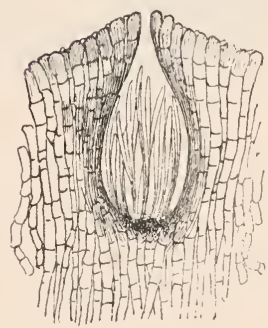

5

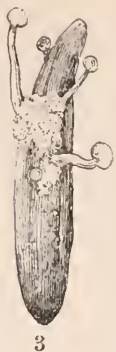

3

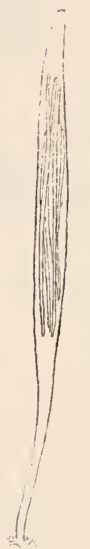

6

Mutterkormpilz und seine Entwickluıg. 1 Roggenähre mit Mutterkorn (nat. Gr.). 2 Pilzfäden, die Sporen abschnüren (Vergr, etwa (;00 mal). 3 Mutterkorn mit Fruchtkörpern (wenig vergr). 4 Längsschnitt durch das Köpfchen eines Fruchtkörpers mit zahlreichen flaschenförmigen Höhlen (Vergr. $25 \mathrm{mal}$ ). 5 Eine solche Höhle mit Sporenschläuchen (Vergr. $120 \mathrm{mal}$ ).

6 Ein Sporenschlauch mit 8 Sporen (Vergr. $700 \mathrm{mal}$ ).

körper von Pilzen, deren Fadengeflecht sich im Waldboden verbreitet. Sie haben das Aussehen von Kartoffelknollen, sind von einer warzigen Hülle umkleidet und besitzen im Innern zahlreiche Kammern, deren Wände mit Sporenschläuchen bedeckt sind. Da die Trüffeln stets unterirdisch bleiben, kanı die Verbreitung der Sporen auch nicht durch den Wind geschehen wie bei den meisten anderen Pilzen; wühlende Tiere allein vermögen diese Arbeit zu leisten (Wildschwein, Dachs, Mäuse, Regenwürmer n. a.). Hiermit stehen auch folgende Tatsachen im innigsten Einklange: die Trüffeln finden sich erstlich nur dort, wo sie den Wühlern leicht $\mathrm{za-}$ gänglich sind, nämlich nahe der Erdoberfäche; sie sind zweitens fleischige, saftige Gebilde, die von den Tieren gern verzehrt werden (vgl. mit den Früchten, deren Samen durch Vögel ausgesät werden!); sic besitzen drittens einen auffallend starken Duft (Verwendung!), wodurch sie den Tieren ihre Anwesenheit gleichsam anzeigen, und ihre Sporen sind viertens mit stacheligen oder netzförmigen Erhöhungen bedeckt, so daß sie ibren Verbreitern leicht und sicher anhaften. Um die begehrten Fruchtkörper zu entdecken, bedient sich der "Trüffeljäger" vorwiegend der Hilfe abgerichteter

Schweine oder Hunde, die ja bekanntlich mit sehr scharfem Geruch begabt sind. Die wertvollen Trüffelpilze bewohnen vorwiegend Eichen- und Buchenwälder anch 
unserer Heimat. Die meisten Trüffeln kommen jedoch aus Südfrankreich nnd Italien zu uns.

3. In den Ähren verschiedener Gräser, besonders des Roggens, findet man nicht selten schwärzliche, große Körper, die bekanntlich als Mutterkorn bezeichnet werden. Sie verdanken ihre Entstehung einem Pilze, dem Mutterkornpilze (Cláviceps purpúrea), der eine sehr merkwürdige Entwicklung durchlänft. Geht man im Frühlinge auf das Feld, so findet man sicher Roggenähren, in denen ein Fruchtknoten süßen Saft ausscheidet. Dieser "Honigta " wird wie alle Süßigkeiten von zahlreichen Insekten gern aufgesucht. (Man braucht oft nur dem Fluge der Honigbiene zu folgen, um eine solche Ähre zu entdecken!) Wie die mikroskopische Untersuchung leicht zeigt, ist dieser Fruchtknoten von Pilzfäden durchzogen, die an der Oberfläche zahlreiche kleine S p o ren abschnüren. Indem nun die Insekten den süßen Saft lecken und zu anderen Ähren fliegen, nehmen sie sicher auch Sporen mit, die dort dieselbe Erkrankung hervorrufen (vgl. den Honigtau mit den Lockmitteln der Blüten und Früchte höherer Pflanzen!). Zur Zeit der Roggenreife geht mit dem Aufhören der Saftzufuhr dem Schmarotzer aber die Nahrung aus! Fruchtknoten von anderen Gräsern, in denen er allein leben kann, findet er erst im nächsten Frühjahre wieder. Wie rettet er sich nun auf diese Zeit hinüber? Bevor der Roggen zu reifen beginnt, legen sich die Pilzfäden besonders im nnteren Teile des Fruchtknotens eng zusammen und wachsen zu einem fast holzharten Körper aus: das ist das Mntterkorn, das die Unbilden des Winters leicht ïbersteht. Auf oder in dem Ackerboden liegt es unverändert bis zur Zeit der nächsten Roggenblüte. (Lege es während des Winter's in einen Blumentopf mit Erde, der im Freien aufbewahrt wird!). Dann bekommt es scheinbar nenes Leben: es treibt eine Anzahl langgestielter, rötlicher Fr u cht körper von der Größe eines Stecknadelkopfes, in denen sich in flaschenförmigen Höhlungen zahlreiche Sporenschlä uche bilden. Die aus den Schlänchen hervortretenden langgestreckten Sporen werden durch den Wind verweht, und die Erkrankung der Fruchtknoten zeigt sich alsbald von neuem. Der Landmann bringt mit dem Intterkorn also einen gefährlichen Feind auf seinen Acker. Da es zudem ein heftiges Gift enthält, das, im Brote genossen, schon oft schwere Erkrankungen hervorgerufen hat, sollte es aus dem eingeernteten Getreide sorgfältig entfernt werden. In der Hand des erfahrenen Arztes dagegen ist es ein wichtiges $\mathrm{Heilmittel.}$

4. Brot, eingemachte Früchte, Fleischwaren, Tinte u.s. w. werden von dem gemeinsten aller Schimmelpilze, dem Pinsel- oder Brotschimmel (Penicíllium crustáeeum), oft wie mit einer dicken, an-

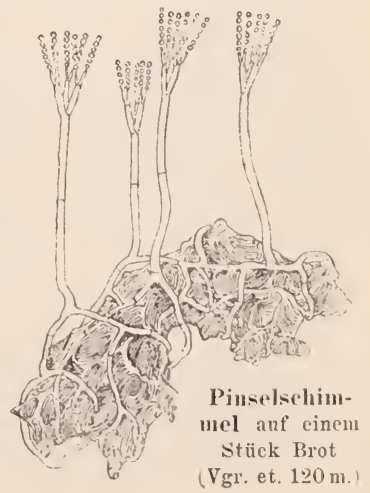


grünen Decke überzogen. Indem er den Stoffen Sauerstoff zuführt, bedingt er deren Verwesung, die für sein Wachstım notwendig ist (s. S. 334, 2). Untersucht man ein wenig von lem Pilze unter dem Mikroskope, so sieht man ein dichtes Fadengeflecht, ans dem sich zahlreiche senkrechte Fäden erheben. Da sich diese Fäden an der Spitze wiederholt teilen und an den Enden zahlreiche Sporen abschnüren, erscheint das Ganze wie ein kleiner Pinsel (Name!). Die Sporen, die der Pilzmasse die blangrüne Färbung verleihen, werden leicht durch den Wind verweht. Und da es an geeigneten Stoffen für den Pilz nirgends fehlt, ist er auf der ganzen Erde zu finden. Sehr selten erseheinen in dem Fadengeflechte winzige, trüffelartige Körperchen mit sporenbildenden Schläuchen, ein Umstand, der die Einreihung des ungebetenen Gastes in die Gruppe der Schlauchpilze verständlich macht.

Die l3lätter der Gretreidearten, Hülsenfrüchtler, Rosen und vieler anderer PHanzen findet man nicht selten wie mit Schimmel äberzogen: es ist das Fadengeflecht zahlreicher Melıltaupilze (Erýsiphe; Name!). Von diesen spinnengewebartigen Faden Iringen Fortsätze in das Blattinnere, die der Pflanze Nahrung entziehen. Infolgedessen erkranken die Blätter, so daß der ganzen Pflanze oft großer Schaden zugefügt wird. - Einer der gefährlichsten dieser Zerstörer ist der S. 65 bereits erwähnte Rebenmehltau (Oidium túckeri) - Auch die als Taschen oder Narren bezeichneten MiBbildungen der Pflaumen werden durch einen Schlauchpilz verursacht ('Taphrina pruni).

5. Zerteilt man ein Köruchen Preßhefe in Wasser, und untersucht man darauf einen Tropfen der trüben Flïssigkeit unter dem Mikroskope, so bemerkt

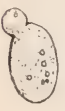

1

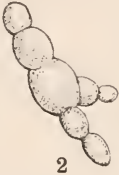

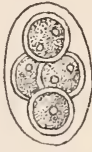

3

Bierluefe. 1 Eine Zelle mit einer Ansstülpung. 2 Eine Kolonie von Zellen. 3 Fine Zelle mit 4 Sporen (1 n. 2 etwa $800 \mathrm{mal}, 3$ etwa $1000 \mathrm{mal}$ vergr.). man darin Tausende von farblosen, kugeligen Zellen, von denen jede ein „Pflänzchen" der Bierhefe (Saccharomýces cerevísiae) darstellt. Bringt man etwas Preßhefe in eine zuckerhaltige Flüssigkeit, so tritt alsbald eine starke Vermehrung der Hefenmasse ein: an den Zellen bilden sich Ausstïlpungen, die zur Größe der Mutterzellen heranwachsen und sich schließlich von ihnen trennen. Erfolgt eine solche Abschnïrung nicht, und treiben die Tochterzellen abermals Tochterzellen, so entstehen kleine Zellkolonien. Gleichzeitig geht mit der Flüssigkeit eine starke Veränderung vor sich: ihr entsteigt unter Schäumen und Brausen Kohlensäure (Nachweis durch Kalkwasser!), und der siiße Geschmack verliert sich immer mehr. Dafür stellt sich aber bald der bekannte Spiritus- oder Alkoholgernch ein: die Bierhefe hat den Zucker in Alkohol und Kohlensäure gespalten, ein Vorgang, der bekanntlich als alkoholische Gärung bezeichnet wird. Auf dieser Fähigkeit der Bierhefe beruht das Branen des Bieres, sowie die Herstellung des Branntweins. Im Großen gezïchtet und möglichst getrocknet, kommt der Pilz als "Preßhefe" in den Handel, die namentlich beim Backen des Kuchens Verwendung findet. Alkohol und Kohlensäure, die hierbei gleichfalls entstehen, treiben die zähen Teigmassen auseinander, so daß ein lockeres, bekömmliches Gebäck entsteht. (Eine andere Hefenart, die in großer Menge im 
Sauerteig enthalten ist, veranlaßt „das Gehen“ des Schwarzbrotteiges.) Bringt man eine dïnne Schicht Bierhefe auf eine Gipsplatte, die man nur mit reinem Wasser befenchtet und mit einer Glasglocke ïberdeckt, so spaltet sich der Inhalt jeder Zelle in meist 4 Sporen (Schlanchpilz!), die, durch dicke Wände geschïtzt, lange Zeit hindurch Trocknis ertragen und olne Nahrung weiter leben können. Die Sporenbildung ist also ein Mittel, durch das sich der Pilz vor dem Untergange schïtzt. Im Freien kommt die Bierhefe nicht vor. Sie ist wie z. B. die meisten Getreidearten eine uralte "Kulturpflanze" von unbekannter Herkunft. Und wie die meisten unserer Nutzpflanzen, bildet anch die Hefe zahlreiche „Rassen“, von denen jede dem Biere gewisse Eigentïmlichkeiten verleiht.

Dasselbe gilt für die Weinhefe (S. ellipsoídens), die aber - wie bereits S. 65 erwähnt - in Freien vorkommt. Daher gärt der Iost ron selbst. Auch die Hefepilze, die die Gärung des „Fruchtweins" verursachen, gelangen mit den Früchten in den ausgepreßten Saft.

\section{3. u. t. Unterklasse. Rost-und Brandpilze(Uredináceae und Ustilagináceae).}

Fadengeflecht mehrzellig. Schmarotzer höherer Pflanzen, deren Sporenmassen an der Wirtspflanze rostartige Stellen bilden oder gewisse Teile der befallenen Pflanzen wie verbrannt erscheinen lassen.

1. Rostpilze. An den Getreidearten sowohl, wie anf wildwachsenden Gräsern findet man vom Juni ab nicht selten gelbe, braune oder schwarze Flecken und Streifen, die wie Rostflecke aussehen (Name!). Die

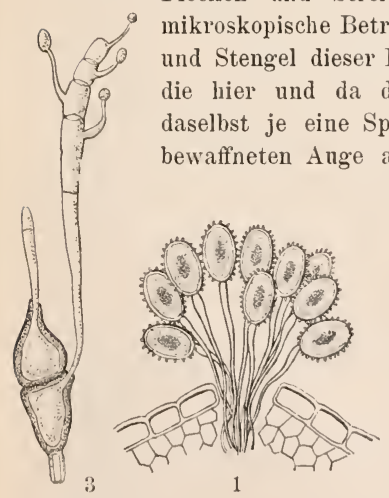

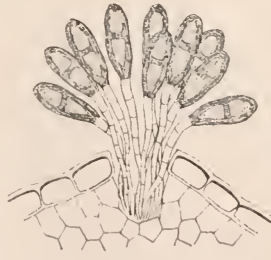

2

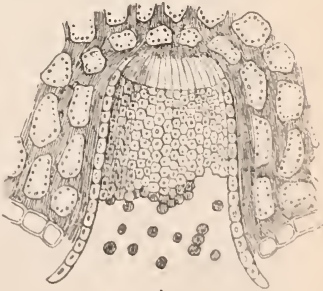

4

Getreiderost. 1 Sommersporen (Vergr. 200 mal). 2 Wintersporen (Vergr. 200 mal). 3 \%wei Wintersporen. Die obere Spore beginnt, einen Pilzfaden zn treiben; an dem vollkommen entwickelten Faden der unteren spore haben sich 4 Frïhjahrssporen gebildet (Vergr. 230 mal). 4 Ein Becherehen von der Lnterseite des Berberitzenblattes; mehrere Bechersporen haben sich bereits abgelöst. (Vergr. 70 mal.) 
im Bereiche ihres Verbreiters, des Windes. Da sich der Pilz anf Kosten seines "Wirtes" ernährt, verkümmern die befallenen Pflanzen oder gehen wohl gar zu grunde. Die Rostkrankheiten des Getreides werden nun von verschiedenen Pilzen hervorgerufen, unter denen als Hauptverwïster der (echte) Getreiderost (Pnccínia gráminis) hervorragt. Hat er sich einmal auf einem Felde eingefunden, so verbreiten seine gelben, roten oder hellbrannen Sporen die Krankeit schnell weiter. Wenn das Getreide zu reifen beginnt, treten in den Rostflecken dunkelbraune Sporen auf, die vermöge ihrer dicken Wände leicht zu ïberwintern vermögen (vgl. mit dem Mntterkornpilze!). Die zuerst erzengten dünnwandigen Sporen, die hierzı nicht im stande sind, bezeichnet man daher zum Unterschied von diesen "Wintersporen" als "Sommersporen". Im nächsten Frühjahre treiben die Wintersporen, die immer zu zweien vereinigt sind, je einen kurzen Pilzfaden, der wieder 4 farblose „Frïhjahrssporen“ erzengt. Gelangen die durch den Wind verwehten winzigen Gebilde auf die Blätter der Berberitze, so keimen sie. Der Keimschlauch dringt in die Blätter ein und erzengt ein Fadengeflecht, an dem auf der Blattunterseite bald kleine, rotgelbe "Becherchen" entstehen. In ihnen bilden sich am Ende senkrechter Pilzfäden Reihen von „Bechersporen", die wieder durch den Wind davongetragen werden. Fallen sie anf Getreide (oder gewisse wildwachsende Gräser), so rufen sie die Krankheit von nenem hervor. Der Pilz durchläuft also einen Generationswechsel (s. S. 301). Da in seiner Entwicklung die Berberitze eine wichtige Rolle spielt, so darf der Stranch in der Nähe von Getreidefeldern nicht geduldet werden. Bemerkt mag noch sein, daß auch an der Oberfläche der Berberitzenblätter kleine „Becher" entstehen, in denen winzige Sporen von unbekannter Bedeutung gebildet werden.

A uf zahlreichen anderen Pflanzen erzeugen andere Rostpilze ähnliche Erkrankungen. - Ein sehr gefährlicher Schädling ist z. B. der Birnenrost (Gymnosporángium sabinae), der auf den Blättern des Birnbaums die "Becher" und anf dem Sadebanme die anderen Entwicklungszustände bildet. - Ier Erbsenrost (Uromýces pisi) wandert von der Cypressen-Wolfsmilch (s S. 68) anf die Blätter der Erbsen und anderer Schmetterlingsblütler. - Andere Rostpilze vollenden wieder ihre ganze Entwicklang auf ein und derselben Pflanze.

2. Die Brandpilze sind gleichfalls Schmarotzer höherer Pflanzen, und zwar vorzugsweise der Gräser. Während das Fadengeflecht die ganze Wirtspflanze durchzieht, erfolgt die Bildang der Sporen jedoch nur an einer bestimmten Stelle, an der Bläte, dem Stengel u. s. w. Die Sporen, die durch den Wind verbreitet werden, bilden dunkle Massen, die die Bezeichnnng ${ }_{n}$ Brandpilze ${ }^{\natural}$ durchaus rechtfertigen. Am häufigsten zu beobachten ist der Flıg- oder Staublırand (Ustilágo-Arten), der die Früchte besonders des Hafers, der Gerste und des Weizens zerstört. - Andere Brandpilze verursachen den Schmierbrand (Tillétia-Arten) : die Getreidekörner scheinen äußerlich unversehrt; innen aber sinıl sie mit einem schwarzen, übelriechenden und schmierigen Sporenpulver (Name!) erfüllt. 


\section{Unterklasse. Algenpilze (Phycomycétes).}

Fadengeflecht besteht (wie der Körper gewisser Algen; Name!) nor aus einer einzigen. meist stark verzweigten und oft sehr umfangreichen Zelle.

In diese große Abteilung der Pilze soll nns der Kartoffelpilz (Peronóspora inféstans) einführen, der die gefürchtete Kartoffelfäule hervorruft. Stellt man z. B. durch ein Blatt einer Kartoffelstaude, die von dieser Krankheit befallen ist, dïnne Schnitte her, so ist mit Hilfe des Mikroskops leicht zı erkennen, daß es wie die ganze Pflanze von einem vielfach verzweigten, aber einzelligen Fadengeflechte durchwuchert wird. Einzelne Äste des Geflechtes brechen wie ein zarter Schimmel aus den Spaltöffnungen an der Unterseite der Blätter hervor, verzweigen sich und schuïren eine Anzahl Sporen ab, die, vom Winde verweht, schnell die Krankheit ïber das ganze Feld verbreiten. Da der Pilz der Pflanze die Nahrung entzieht, bekommen die Blätter schwarzbraune Flecke, nnd schließlich sterben alle oberirdischen Teile ab. Infolgedessen bleiben die Knollen klein, so daß der Ernteertrag meist sehr gering ist. Oft werden aber auch die Knollen selbst von der Krankheit erfaßt: sie erhalten braune Flecke und verwandeln sich schießlich in eine jauchige, ïbelriechende oder in eine trockene, bröcklige Masse (nasse und trockene Fäule). Will man sich gegen den gefährlichen Feind schïtzen, so hat man vor allen Dingen zur Aussaat nur vollkommen gesunde Knollen zu nelimen, sowie alle erkrankten von dem Felde zu entfernen und sorgfältig zu vernichten.

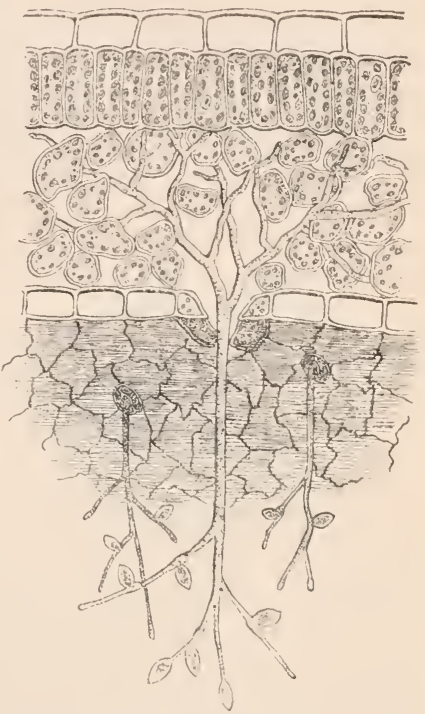

Kartoffelpilz: Querschnitt durch ein von dem Pilze befallenes Kartoffelblatt. A us den Spaltöffnungen der Blattunterseite treten $\ddot{A}$ ste ins Freie, an denen sich Sporen bilden. (Vergr. etwa $200 \mathrm{mal}$.)

Ein anderer, gleichfalls sehr gefährlicher Algenpilz ist der sog. falsche Rebenmehltau (P. vitícola), dessen bereits anf $S .65$ gedacht worden ist. - Wirft man ein totes Insekt in Teich- oder Flußwasser, so bedeckt es sich bald mit den Fruchtträgern les Wassersehimmels (Saprolégnia-Arten). Dieser Pilz siedelt sich vielfach auch auf den Kiemen der Fische an. so daß die Tiere schließlich zu Grunde gehen. - Der Fliegenschimmel (Empúsa muscae) tötet im Herbst große Mengen von Stubenfliegen. Man findet die Tiere dann an den Wänden und Fenstern kleben und von einem Kranze fortgeschleuderter Sporen umgeben, dureh die die Krankheit sehnell weiter verbreitet wird. 


\section{Klasse. Spaltpilze oder Bakterien (Schizomycétes).}

Pilze, die kein Fadengeflecht bilden, sondern nur einzellige, sehr kleine Wesen sind, die sich durch Zweiteilung vermehren.

A. Vom Bau der Spaltpilze. 1. Verteilen wir von dem weißen Belag nnserer Zähne ein wenig in einem Wassertropfen, so erblicken wir bei starker mikroskopischer Vergrößerung zahlréiche farblose Gebilde, die man als Spaltpilze oder Bakterien bezeichnet. Es sind die kleinsten Lebewesen, die wir kennen; erreichen doch viele von ihnen noch nicht einmal $1 / 1000 \mathrm{~mm}$ an Länge. Ihrer Größe nach verhalten sie sich also etwa zum Menschen wie ein Saatkorn zı einem der höchsten Alpenberge.

2. Bei sehr starker Vergrößerung erkennt man, daß der Körper der Spaltpilze aus je einer einzigen Zelle gebildet ist, die allerdings verschiedene Formen aufweist. So haben die Spaltpilze des Zahnbelags die Gestalt einer
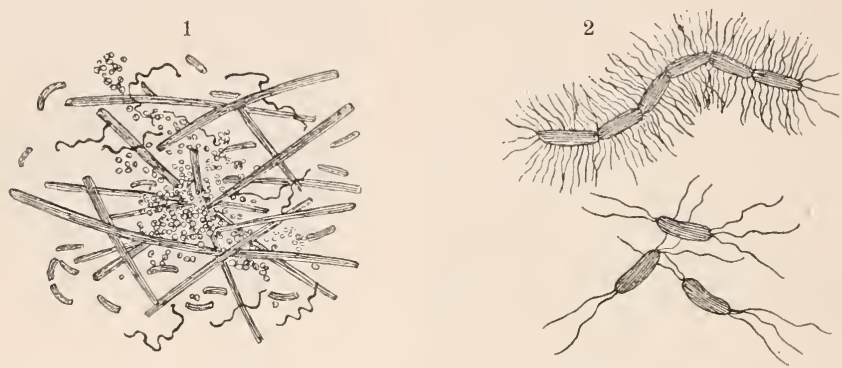

Spaltpilze. 1 Aus dem Belag der Zähne (Vergr. etwa 750 mal). 2 Mit fadenförmigen, als Bewegungswerkzenge dienenden Anhängen (Vergr. etwa 1500 mal).

Kugel oder eines kürzeren oder längeren Stäbchens. Daneben treten in der Regel anch solche auf, die mehr oder weniger gekriimmt oder gar korkzieherartig gewunden sind. Diese Gestalten kehren bei allen Spaltpilzen wieder, so viele man daraufhin auch untersuchen mag. Die kugeligen Formen bezeichnet man als Kokken*), die Kurzstäbchen als Bakterien i. e. S.*) nnd die Langstäbchen als Bazillen ${ }^{*}$ ); die gekr ümmten und gewundenen führen nach ihrer besonderen Gestalt wieder verschiedene Namen, die aber, weil im gewöhnlichen Leben ungebräuchlich, hier ınerwähnt bleiben sollen.

3. Die kleineren Spaltpilze unseres Präparats sind in lebhafter Bewegung. Einige drehen sich nm sich selbst, schwimmen dabei gleichzeitig ein Stïck vorwärts und, olne umznkehren, wieder zurïck; andere zeigen ein eigentïmliches Wackeln und Zittern, und die gewundenen schrauben sich lurtig durch das Wasser.

*) Nach einem gleichlautenden griechischen Worte.

**) Bacillum ist die Verkleinerung von baculum, der Stab. 
Untersucht man einen Tropfen einer Flüssigkeit, in der tierische oder pflanzliche Stoffe faulen, so sind Tansende und Abertausende von Spaltpilzen in Bewegung: oft flimmert infolgedessen das ganze Gesichtsfeld, und das Wasser scheint lebendig geworden zu sein. Daneben gibt es aber auch zahlreiche Spaltpilze, die sich kaum oder niemals bewegen. Bei sehr starker Vergrößerung erkennt man auch die Werkzenge der Bewegung: es sind mehr oder weniger zahlreiche, fadenförmige Anhänge der Zellhaut, die wie bei den Infusorien (s. Lehrb. d. Zool.) regelmäßige Schwingungen oder Drehungen ansfïhren.

4. Steht den Spaltpilzen genïgend Nahrung zur Verfïgung, und herrscht die für sie eine günstige 'Temperatur (s. S. 350, 1), so vermehren sie sich, indem sie sich teilen. Bleiben die "Teilstïcke", von denen also jedes eine selbständige Pflanze darstellt, im Zusammenhange, so entstehen nicht selten kleine Ketten oder längere Stäbe (so bestehen \%. B. die Langstäbchen der ans dem Zahnbelag abgebildeten Formen z. T. aus zahlreichen Kumzstäbchen, was jedoch nur bei Anwendung besonderer Mittel zu sehen ist). Die Vermehrung erfolgt nun bei günstigen Bedingungen (Nahrung; Wärme!) außerordentlich schnell. Sorgfältige Berechnungen haben z. B. ergeben, daß ein Spaltpilz, der $0,001 \mathrm{~mm}$ lang, breit und hoch ist und sich in jeder Stunde einmal

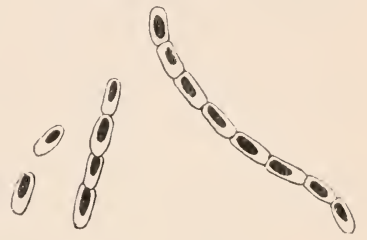

Spaltpilze, die je eine Spore umsehließen. (Vergr. etwa 1500 mal.) teilt, in etwa 6 Tagen eine Masse bilden kann, die den - Erdball an Größe übertreffen würde. Selbstverständlich schließt schon die ausgehende Nahrung eine solche Vermehrung aus; sie ist aber immerhin möglich und für das Verständnis der von den winzigen Lebewesen verursachten Vorgänge von größter Wichtigkeit (s. w. u.).

5. Verdunstet die Fliissigkeit, in der die Spaltpilze leben, oder geht ihnen die Nahrung aus, so haben viele die Fähigkeit, einen Dauerzustand zu bilden: Der Inhalt der Zelle verdichtet sich zumeist und ungibt sich mit einer dicken, widerstandsfähigen Hülle; es ist eine S p ore entstanden. Nach Zerfall der Zellwände werden die Sporen frei. Geraten sie nach Monaten oder Jahren wieder in giinstige Lebensbedingungen, so wird die äußere Haut gesprengt, und je ein lebenskräftiger Spaltpilz tritt daraus hervor. Es gibt aber auch zahlreiche Formen, die ohne Sporen zu bilden ein gänzliches Austrocknen vertragen, also ohne weiteres in einen Danerzustand ïbergehen können. Nun sind - wie erwähnt - die Spaltpilze und demnach auch ihre Sporen außerordentlich kleine Gebilde. Sie werden daher in trockenem Zustande vom Winde leicht emporgewirbelt und sicher nicht selten aut Tausende von Meilen verweht. Als unsichtbarer Staub schweben sie überall in der Atmosphäre und kehren mit anderen Staubteilchen bei ruhiger Luft wieder zur Erde zurïck. Die „Keime“ der Spaltpilze finden sich infolgedessen auf jedem Gegenstande, in jedem Gewässer, knrz: sie sind geradezu „allgegeuwärtig“. 
B. Yon der Tätigkeit der Spaltpilze. 1. Die Spaltpilze entbehren wie alle anderen Pilze des Blattgrïns. Sie sind dalıer ebenfalls anf "fertige" Nallrung angewiesen, die sie gleich dem Champignon zumeist faulenden Tierand Pflanzenstoffen entnehmen. Da sich nun ihre Keime fast ïberall finden, treffen wir sie anch stets da an, wo Fänlnis stattindet.

a) Ein einfacher Versuch wird uns jedoch zeigen, daß sie weit mehr sind als nur Fäulnisbewohner. Wir nelımen 2 Glaskolben mit etwas Wasser, in das wir irgend einen Tier- oder Pflanzenstoff legen. Während wir den Inhalt des einen Kolbens unverändert lassen, kochen wir den des zweiten längere Zeit hindurch, so daß die Spaltpilze oder deren Keime, die sich an dem verwendeten Stoffe, an den Wänden des Glases oder in dem Wasser befinden, getötet werden; denn die Spaltpilze vermögen ebensowenig wie jedes andere Lebewesen der Siedehitze zu widerstehen. Sobald wir das Kochen einstellen, verschließen wir den Kolben durch einen aus gereinigter Watte gebildeten Pfropf, den wir - um etwa anhaftende Spaltpilzkeime zu vernichten - nnmittelbar zuvor über einer Flamme abgesengt haben. Während der Inhalt des ersten Kolbens bald in Fänlnis iibergeht, bleibt der des zweiten unverändert. Sobald wir von ihm aber den Pfropf nur kurze Zeit abnehmen, so daß Spaltpilze oder deren Keime aus der Luft hineinfallen können, tritt in ihm gleichfalls Fäulnis ein. Hieraus geht nun unzweifelhaft hervor, daß die Spaltpilze nicht nur Bewohner, sondern anch Erreger der Fäuln is sind, oder anders ansgedrückt, daß es ohne Spaltpilze keine Fäulnis auf der Erde geben wïrde.

b) Nehmen wir an, letzteres wäre der Fall! Dann würden ungezählte Millionen von Tier- und Pflanzenleichen den Erdboden bedecken, und alle Gewässer wären mit toten Körpern erfüllt. Kein Fleckchen Erde wäre vorhanden, auf dem noch eine Pflanze wachsen könnte, und mit dem Pflanzenleben wäre das Tier- und Menschenleben längst erloschen (warnm?). Die Spaltpilze sind es, die den Zerfall der abgestorbenen Körper bewirken: sie machen also die Banstoffe, die auf der Erdennr in beschränktem Maße vorhanden sind, für neues Leben immer wieder frei; sie bewirken den ewigen "Kreislanf des Stoffes" in der Natnr. (Die eigentlichen Fäulnis bewohner, wie z. B. der Champignon und viele andere Pilze, können also die S. 335 näber gekennzeichnete Arbeit erst beginnen, wenn die Spaltpilze die Verwesung eingeleitet haben.)

c) Im Anschluß an diese wichtige Tatsache sei einer Gruppe von Spaltpilzen knr besonders gedacht. Mit jeder Ernte entziehen wir dem Acker eine große Nenge von Stickstoffverbindungen (meist in Form von Eiweiß). Da die Pflanzen nun nicht die Fähigkeit besitzen, der Luft Stickstoff zu entnehmen, so müssen wir ilınen diesen wichtigen Baustoff durch Düngung des Bodens wieder zuführen. Düngt man aber Pflanzen z. B. mit „frischer" Janche, so sieht man, daß sie kränkeln und schließlich wohl gar absterben. Die in dem "frischen“ Dünger enthaltenen Stickstoffverbindungen mïssen nämlich, um von den Pflanzen verwendet werden zu können, erst in salpetersaure Salze übergeführt werden. 
(Darum ist der Chili-Salpeter ein so vorzïgliches Düngemittel!) Diese Arbeit wird (auf einem lier nicht näher zu verfolgenden, umständlichen Wege) von den Spaltpilzen des Bodens geleistet. Wie anf dem Acker spielt sich diesel Vorgang nun in der ganzen Natur ab: Spaltpilze fïhren die Stickstoffverbindungen, di e von den Tieren ausgeschieden werden, in eine solche Form ïber, dab sievon den Pflanzen wieder als Baustoffe verwendet werden können.

d) Von der soeben ausgesprochenen Regel, daß die Pflanzen nicht im stande sind, ihren Stickstoffbedarf der athmosplärischen Luft zu entnehmen, bilden, wie wir bereits wissen, gewisse Spaltpilze eine Ausnahme, nämlich die Wurzelbakterien in den Knöllchen der Schmetterlingsblütler (s. S. 104). In jüngster Zeit hat man auch noch andere, frei im Erdboden lebende Spaltpilze (und Schimmelpilze) entdeckt, die diese wunderbare Fähigkeit besitzen und darum als "Stickstoffbakterien" bezeichnet werden.

2. Gewisse Spaltpilze rufen in ihren Nährstoffen Veränderungen hervor, die man nicht als Fäulnis, sondern (wie die Einwirkung der Bierhefe auf zuckerhaltige Flüssigkeiten; s. S. 342) als Gä rung bezeichnet. Läßt man z. B. Bier oder Wein bei Zimmerwärme einige Tage offen stehen, so werden sie sauer: der Alkohol ist in Essig umgewandelt; es ist „Essiggärung“ eingetreten. Wiederholt man den in S. 348, a geschilderten Versuch - statt eines faulenden Stoffes muß man natïrlich Bier oder Wein verwenden -, so ist leicht $\mathrm{zu}$ beweisen, daß die Veränderungen in der Flüssigkeit allein durch Spaltpilze hervorgernfen werden. - Auf der Tätigkeit anderer Gärungserreger beruht z. B. die Schnellessigfabrikation, sowie das Sanerwerden der Milch, der Gurken, des Sanerkohls, aber auch der eingemachten Früchte und Gemïse. Durch Gärungsbakterien werden die Bastfasern des Flachses und anderer Gespinstpflanzen aus dem festen Zellverbande gelöst. Durch die Einwirkung von Spaltpilzen erhalten Tabak, Kakao und chinesischer Thee erst den Duft und Wohlgeschmack, den wir an ilınen so hoch schätzen, und durch ihre Tätigkeit entsteht bei der sog. Nachgärung auch "die Blume" des Weines.

3. Als eine zweite Quelle, an der Pflanzen ohne Blattgrün die ihnen zusagende Nahrung finden, haben wir schon mehrfach die Körper anderer Lebewesen erkannt (Beispiele!). Es ist daher durchans nicht zu verwundern, daß sich anch unter den Spaltpilzen zahlreiche $\mathrm{Schmarotzer}$ finden. Sie oder ihre Sporen dringen in die Körper besonders der Tiere und Menschen ein, vermeluren sich daselbst oft außerordentlich schnell, erzengen heftige Gifte und rufen infolgedessen Erkrankn $\mathrm{n}$ en hervor, die vielfach mit dem Tode endigen. Von diesen Krankheiten seien hier nur die verheerendsten genannt: die Schwindsucht oder Tuberkulose, der etwa $1 / 7$ aller Menschen zum Opfer fallen, der Unterleibstyphus, die Diphtherie, die Lungenentzïndung und die Influenza, die gleichfalls alljährlich viele blühende Menschenleben vernichten, die Cholera und die Pest, die beide von ihrer ostasiatischen Heimat aus schon mehrmals als Würgengel über Europa dahingezogen sind, der 
Rotla uf der Schweine und die Pest der Rinder, sowie endlich der If ilzbrand, der ganze Herden von Rindern, Schafen, Renntieren und anderen Pflanzenfressern vernichtet und auch den Menschen nicht verschont.

C. Von unserem Verhalten gegen die Spaltpilze. Je nachdem die vielgeschäftigen Spaltpilze für uns unentbehrliche Mitarbeiter und Gehilfen oder Zerstörer und gar wohl Todfeinde sind, je nachdem werden wir uns ihnen gegenüber auch verhalten. Hierbei müssen wir vor allen Dingen zweierlei im Auge behalten: erstlich, daß die Vorgänge der Fäulnis, Gärung oder Krankheit umso schueller und energischer verlaufen, je schneller sich deren Erreger vermehren, und zweitens, daß die Vermehrung der Spaltpilze umso lebhafter erfolgt, je günstiger die Bedingungen sind, unter denen sie leben (zeige an Beispielen, daß sich auch die höheren Pflanzen, sowie die Tiere ähnlich verhalten!).

1. Unsern Mitarbeitern und Gehilfen müssen wir daher die besten Lebensbedingungen schaffen. Vor allen Dingen werden wir dem Stoffe, den sie veränderu sollen, die geeignetste Zusammensetzung geben, und ihnen wie allen anderen "Nutzpflanzen" den Grad von Feuchtigkeit und Wärme bieten, der für sie gerade günstig ist. So gibt man z. B. der Flüssigkeit, die man bei der Schnellessigfabrikation verwendet, den für den Pilz günstigsten Alkoholgehalt; so befeuchtet man den Flachsstengel, deren Gespinstfasern man gewinnen will; so stellt man die Gurken, wenn sie schnell sauer werden sollen, in einen warmen Raum (anf den warmen Herd) u. s. w. Im allgemeineu sagt den Spaltpilzen eine Wärme von $25-35^{\circ} \mathrm{C}$. am meisten $\mathrm{zu}$.

2. Unsere Feinde unter den Spaltpilzen dagegen suchen wir von den Stoffen, die sie leicht zersetzen, sowie von unserem Körper und dem unserer Hanstiere abzuhalten, und wenn sie eingedrungen sind, so schnell wie möglich zu vernichten.

a) Abgehalten können die fast „allgegenwärtigen" Keime oder Bakterien nur durch die größte Reinlichkeit werden. Dies gilt besonders für die Gefäße, die wir bei der Herstellnng und Aufbewahrung der Speisen verwenden, für unsere Wohnungen und deren Umgebung (Höfe, Straßen u. s. w.), für unsere Kleider, Wäsche und Speisegeräte (besonders in Gasthäusern!), sowie anch für unsern Körper selbst. Vor allen Dingen hüte man sich, mit den Auswurfstoffen solcher Jenschen in wähere Berührung zu kommen, die an einer ansteckenden Krankheit leiden. Wie diese Stoffe, so müssen die Abfälle des menschlichen Haushalts, die vortreffliche „Bakterienherde“ bilden, vernichtet oder doch aus der Nähe der Menschen entfernt werden (führe dies näher aus!).

a) Wie der angestellte Versuch (s. S. 348, a) zeigt, gehen die Spaltpilze durch Siedehitze zu Grunde. Dies gibt uns ein Mittel in die Hand, Stoffe, die dem Verderben leicht ausgesetzt sind, Fleisch, Frïchte, Gemüse, Milch u. a. doch längere Zeit zu erhalten oder zu „konservieren “. Sind in diesen Stoffen, sowie in den zur Aufbewahrung bestimmten Gefäßen alle Keime getötet, so bezeichnet man sie als sterilisiert (sterilis = unfruchtbar). 
Es gibt allerdings auch eine Anzahl von Spaltpilzen, deren Sporen durch die Siedehitze nicht getötet werden. Vermntet man sie in einem zu konservierenden Stoffe, dann muß dieser ïber $100^{\circ} \mathrm{C}$. erhitzt, oder das Kochen stundenlang fortgesetzt oder mehreremale wiederholt werden. Sind in dem letztern Falle die etwa vorhandenen Sporen beim Erkalten gekeimt, so werden die ans ihnen hervorgegangenen Spaltpilze bei der zweiten oder dritten Erhitzung sicher zerstört. - Anch znm Töten von Krankheitskeimen in Betten, Kleidern $\mathrm{n}$. dgl. werden vielfach hohe Hitzegrade angewendet.

c) Wie alle Pflanzen bedürfen die Spaltpilze zum Leben einer gewissen Wärme. Kühlt man einen faulenden oder gärenden Stoff stark ab, so wird man finden, daß die Fäulnis oder Gürung bei einer Wärme von etwa $5^{\circ} \mathrm{C}$ aufhört. Bei dieser Temperatur stellen die Spaltpilze also ihre Lebenstätigkeiten ein. Daher benutzt man besonders für Fleischwaren (Eisschrank!) schon seit langer Zeit die Kälte als Konservierungsmittel. Das großartigste Beispiel solcher „Konservierung“ sind die Leichen der Mamute, die in dem gefrorenen Boden Sibiriens bis auf unsere Tage erhalten sind. - Getötet werden jedoch die Bakterien selbst durch die größte Kälte nicht, die wir erzeugen können.

d) Spaltpilze branchen ferner wie alle Ptlanzen Wasser zu ihrem Bestehen. Entzieht man daher Stoffen, die man erhalten will, große Wassermengen, so gehen die in ihnen enthaltenen, oder die ihnen anhaftenden Bakterien zu grunde, nud deren Sporen können sich nicht entwickeln. Trocknen und Dörren sind daher andere bekannte Konservierungsmittel (Backobst, Stockfisch, getrocknetes Fleisch u.s. w.).

e) Bringen wir in eine Flïssigkeit, in der irgend ein Stoff fanlt, eine starke Lösung von Kochsalz oder etwas Karbolsäure, so hört die Fäulnis nach kurzer Zeit auf: Kochsalz und Karbolsäure sind fïr die Spaltpilze tödliche Gifte. Während die Bakterien also fänhniserregend oder (nach einem griechischen Worte) septisch wirken, sind Kochsalz und Karbolsäure, sowie viele andere Stoffe fänlniswidrige oder antiseptische Mittel.

Mehrerer dieser Mittel bedient sich der Mensch schon seit uralter Zeit, z. B. des Kochsalzes zum Pökeln, des Essigs oder Znckers (in starker Lösung) zum Einkochen der Frïchte, des Ranches zum Ränchern der Fleischwaren. Als er aber in den Spaltpilzen auch die Erreger zahlreicher Kranklieiten erkanute, lernte er zugleich die durch sie bewirkten Ansteckungen, Vergiftungen oder Infektionen verhïten: er tötete die Keime der Bakterien durch Anwendnng von "Desinfektionsmitteln". So behandelt man z. B. hentzutage die Wunden mit Karbolsänre, Jodoform und anderen antiseptischen Stoffen, und die Instrumente der Ärzte, durch die früher die Eitererreger sehr häufig von Wnnde zn Wunde getragen wurden, werden jetzt vor jedem Gebrauch sterilisiert oder einer grïndlichen "Desinfektion" unterworfen. (Wie haben wir uns darnach zu Wunden, Geschwïren n. dgl. an unserem Körper zu verhalten?) - Da bei der Fäulnis stets anch gesundheitsschädliche, ïbelriechende Gase entstehen, so bedienen wir uns der Desinfektionsmittel anch, um Fäulnis und damit verbundene schlechte Gerïche zu verhindern oder zu beseitigen (z. B. in Aborten). 
f) Naturforscher setzten Kleider, Betten, Möbel und andere Gegenstände, in die sie die verschiedensten Krankheitskeime gebracht hatten, den Sonnenstrahlen aus, und siehe di, oft schon nach wenigen Stunden ergab sich, daß die Keime zahlreicher Arten vernichtet waren. In dem Sonnenlich te haben wir also ein Desinfektionsmittel von ganz besonderer Wirkung vor uns. Daher sollte man ron diesem Mittel recht fleißig Gebrauch machen, und vor allen Dingen den Sonnenstrahlen soviel als möglich Zutritt zu unsern Wohn- und Schlafräumen verschaffen (führe dies näher aus!).

g) Um zu erkennen, ob Spaltpilze oder deren Sporen abgestorben sind, bedient man sich eines sehr interessanten Verfahrens. Indem man den Spaltpilzen nämlich die zım Leben nötigen Stoffe gibt, kann man sie wie andere Pflanzen zü chten oder kultivieren. Zu diesem Zwecke setzt man einer Lösung, die diese Nährstoffe enthält, etwas flüssige Gelatine zu, bringt in das Gemisch die zu untersuchenden Bakterien (oder den Stoff, in dem sie enthalten sind) und schüttet alles in eine sterilisierte Glas-

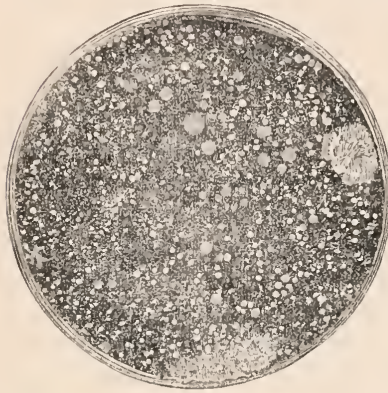

Bakterienkolonien auf Nährgelatine. sie sind aus Keimen hervorgegangen, lie in einem (der Nährgelatine zugesetzten) Tropfen unrcinen Trinkwassers enthalten waren ( $1 / 2$ nat. Gr.) (Bem.: Jerles helle Piinktchen and Fleckehen ist eine Kolonie.) schale. Sind die Keime lebensfähig, so beginnen sie sich bald stark zu vermehren: es entstehen

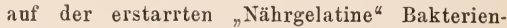
kolonien. Sind sie dagegen abgestorben, dann treten solche Kolonien selbstverständlich nicht auf.

h) Mit Hilfe dieses Verfahrens ist man auch in den Stand gesetzt, unter den Spaltpilzen, die sich - wie erwähnt - vielfach auBerordentlich ähnlich sind, die Feinde des Mensehen von den harmlosen Arten zu unterscheiden. Will man z. B. wissen, ob Trinkwasser Krankheitserreger enthält oder nicht, so setzt man etwas von dem Wasser jener Nährgelatine $z u$, schüttelt das Gemisch, so daß die Keime gleichmäßig verteilt werden, und gießt es wieder in eine Glasschale. Auf der erkalteten Gelatine entstehen jetzt soviel Kolonien, als lebenskräftige Keime vorhanden sind. Alle Kolonien sind aber auch voneinander getrennt und bestehen nur aus je einer einzigen Bakterienart. Überträgt man nun Teilchen dieser Kolonien in je ein anderes Glas mit "Nährgelatine", so hat man die in dem Wasser enthaltenen Bakterienarten streng voneinander geschieden: man hat "Reinkulturen" von ihnen hergestellt. Da die spaltpilze in diesen Kulturen gan\% bestimmten Wuchs haben, so ist man vielfach schon hierdurch imstande, die einzelnen Arten zu erkennen.

\section{Klasse. Schleimpilze (Myxomycétes).}

Pilze, die kein Fadengeflecht bilden, eine schleim- oder rahmartige Masse darstellen und nur z. Z. der Sporenbildung bestimmte Gestalt annehmen.

$\mathrm{Im}$ Wal de findet man auf faulenden Pflanzenteilen nicht selten lebhaft gefärbte, schleimige oder rahmartige II as en; das sind die merkwärdigen Schleimpilze 
(Name!). Der Wald, der ja an verwesenden stoffen äberreich ist, bietet diesen Fä 1 . nis be wo h nerı (besitzen kein Blattgrün!) nicht nur die ihnen zasagende Nahrung. sondern ilrem weichen Körper auch die nötige Feuehtigkeit nud den notwendigen Schutzgegendic a ustrocknendensionnenstrahlen. Bei näherem Zusehen wird man leicht finden, dabsich die eigentiumlichen Wesen kriechend for thewegen, wozn sie durch ihren weichen leib ja besonders befühigt sind.

Eines dieser seltsamen Geschöpfe, das dem verschiitteten gellen Dotter eines Vogeleis gleicht, treffen wit in der Gerberlohe häıfig wieder. „Die Lohe blüht", sagt dann der Gerber. Darum bezeichnet man diesen Schleimpilz als Lohbliite (Fnligo várians). Er durchzicht die loohhaufen netzartig oft metertief. Da die sporen dureh den Wind rerlreitet werden, kommt er zur Zeit der Sporenbildung zur Oberfläehe empor. Die oft tellergrobe Masse zicht sich daun stark zusammen und bildet einen wilerstandsfähigen Frnehtkörper, der sehr viel schwarzbratune sporen enthält (1). Bei Befeuchtung entschlïpft jeder Spore

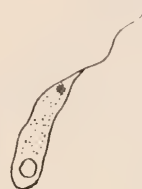

2

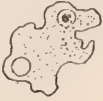

3

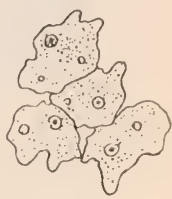

4

Entwicklum eines schleimpilzes is, Text. Vergr. ctwa 600 mal.

ein Gebilde, das wie ein Geißeltierchen (s. Lehrbneh der Zoologie) dureh einen schwingenden Faden in Wasser dahinschwimmt (2). Nach einiger Zeit wird die "Geißel" eingezogen, und das winzige Geschöpf nimmt jetzt die Gestalt eines We ehseltierchens an (s. ebenda), das sich mit Hilfe ausgestreckter Fortsätze kriechend fortlewegt und durch Teilung lebhaft vermehrt (3). Indem mehrere solcher „Wechseltierchen * miteinander verschmelzen (4), entsteht wieder eine jener Schleimmassen, von der wir ansgingen. Das seltsame Wesen gleicht also (wie alle anderen Schleimpilze) in seiner Entwicklung erst einem Geibel-, dann einem Wechseltierchen, kriecht ausgebildet wie letzteres a uf seiner Unterlage dahin, um in der Sporenbildung endlich eine unzweifelhafte Eigenschaft der Pflanzen zu zeigen. Die Schleimpilze werden daher a u eh treffend a ls Pilztiere oder Tierpilze bezeichnet: bildendoch dieseniedrigsten aller Pflanzen einen dentliehen Übergang za dem anderen Reiche der L e bewesen, zn den Tieren.

\section{Kreis. Flechten (Lirhénes).}

Lagerpflanzen, die aus, genossenschaftliclı" lebenden Fadeupilzen und Algen bestehen.

A. Vom Wesen und von der Vermehrung der Flechten. 1. In das IV es en dieser Naturkörper soll uns die Wand- oder Schiissellechte (Xanthiria pariétina) einführen, die an Baumstämmen, Bretterwänden (Name!) und Steinen ïberall läufig zu finden ist. Sie bildet eine gelbe, laubartige, gelappte Masse. die meist mit zahlreichen kleinen, orangefarbenen, schïsselartigen Gebilden bedeckt ist (Name!). Stellt man durch den Flechtenkörper außerhalb dieser "Schüsselchen" zarte Querschnitte her, so sieht man bei Anwendung des Mikroskops, daß er aus einem Geflecht farbloser Fäden besteht, in dessen lockerer Mittelschicht zahlreiche, lebhaft grïn gefärbte, kugelige Febilde eingelagert 
sind. Die Fäden geben sich leicht als ein Pilzgeflecht und die grünen Kugelı als einzellige Algen zu erkennen. Die gleiche $\mathrm{Zusammensetzung} \mathrm{ans}$ eimem Pilze und zahlreichen .l lgen zeigen sämtliche Flechteu.

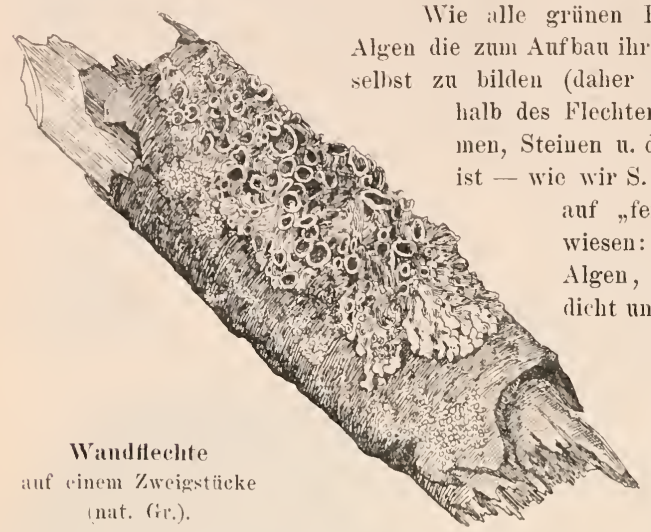

Pflanzen vermögen die Leibes nötigen Stoffe leben sie auch außernkörpers an Baumstämgl.). Der Pilz dagegen 334,2 gesehen haben ige" Nahrung angeer entzieht sie den lie von seinen Fäden ponten werden. Daftr fïhrt er seinen Nahrungslieferanten aber die rohen Nahrungssäfte zu (Wasser und die darin gelösten Salze), schützt sie gegen Austrocknung und

befestigt mit einigen Fäden das ganze „Doppelwesen“ auf der Baumrinde oder dgl. Pilz und Alge haben sich in der Flechte also zu gegenseitigem Vorteile vereinigt, siebildeneine „Ernährungsgenossenschaft" Symbiose; s. S. 105).

2. a) An den Lappenrändern der Wandflechte entdeckt man mit der Lupe häutig feine Körnchen, die sich unter dem Nikroskop als je einige von Pilzfäden dicht umsponnene Algenzellen zu erkennen geben. Diese staubartig kleinen Körper werden leicht durch den Wind verweht und entwickeln sich an einem geeigneten Orte weiter zu Flechten. Sie werden daher treffend als Brntkörperchen (Soredien) bezeichnet (vgl. mit den Lebermoosen!).

b) An dünnen Schnitten durch eins der "Schïsselchen" sehen wir bei Anwendung des Mikroskops, daß wir es in diesen Gebilden mit den Fruchtkörpern des Flechtenpilzes (Apothecien) zu tun haben: wir erblicken genau wie bei den Schlauchpilzen eine oberflächlich liegende Fruchtschicht, die aus Sporenschläuchen und zahlreichen Zwischenzellen zusammengesetzt ist. Die ans den Schläuchen

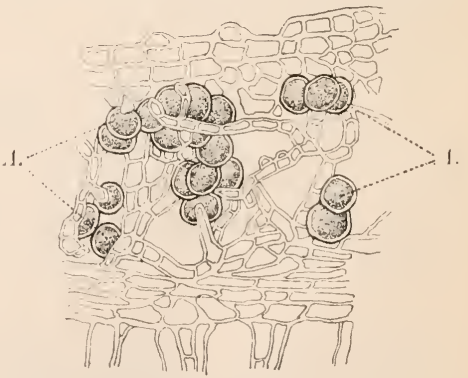

Ban des Flechtenkörpers: in der inneren Schicht des Pilzgeflechts sind zahlreiche Algen (A) eingelagert. Vergr. etwa $350 \mathrm{~m}$.) 
hervorgehenden sporen werden durch den Wind verweht, keimen aber nur, wenn sie eine Alge treffen, mit der sie zusammen eine nene Flechte bilden kömnen. - Aus dem Ban der Fruchtkörper geht hervor, daß der Pilz der Flechte ein Schlauchpilz ist. (Man stellt die Flechten daher auch zu dieser Pilzgruppe. In den Tropen gibt es jedoch auch einige Flechten, an deren Entstehung Ständerpilze beteiligt sind.)

B. Von den wichtigsten Arten und der Bedeutung der Flechten. 1. Schon unter den Flechten der heimatlichen Natur herrscht ein sehr groBer Formenreieh tum.

a) Viele von ihnen,

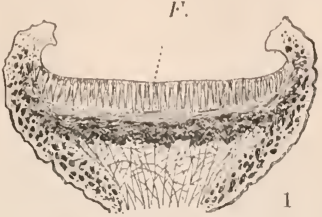

Bau des „Schüisselchens".

1 Längsschnitt dureh e. S'chüsselchen. F, die Fruchtschicht (etwa 30 mal vergr.). 2 Die Fruchtschicht b. stärkerer etwal 600 mal) Vergr. Sp. Sporenschläuche. \%. \%wischenzellen.

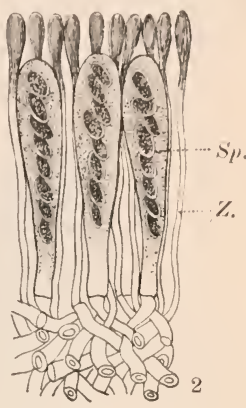

die Krustenflechten, bilden an Bäımen und Felsen, sowie an Erdboden unscheinbare, krastenartige Überzüge. Zu ihnen zählen die Schriftflerhten (Graphis), deren schwarze, strichartige Fruchtkörper die Baumrinden wie mit Hieroglyphen bedecken.

b) Einen blattartigen, mehrfach gelappten Körper, wie wir ihn an der Wandflechte kennen gelernt haben, besitzen die La ubflechten. Sie bedecken mit Arten aus den beiden anderen Gruppen die Stämme und stärkeren Zweige der Bäume oft in dicker Schicht. Von Obstbäumen müssen sie gleich den ansitzenden Moosen (s. S. 319,6) entfernt werden.

c) Die Formen mit anfrechtstehendem oder hängendem, meist mehrfach verzweigtem

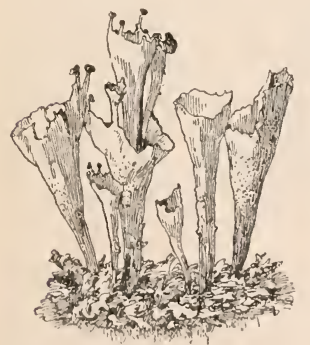

Eine Becherflerhte. Der dem Boden anfliegende laubartige Körper ist lie eigentl. Flechte. Die trichterförmigen rebilde sind die Fruchtträger, die knopf-

förmigen die Frnchtkörper (nat, Gr.). Körper bezeichnet man - weil sie oft zierliche Sträuchlein bilden - als Strauchflechten. - Von den Zweigen besonders alter Gebirgsbänmo hängen in langen bartartigen Strähnen die Bartflechten (Usnea) herab. Die gewimperten Schilde sind die Fruchtkörper. Anf trockenen Heideflächen und dem Boden lichter Gebirgswälder wächst das sog. islänlische Moos (Cetrária islándica). Es hat einen vielteilig gelappten, aufrecht stehenden Körper, der am Ende der Lappen die braunen, scheibenförmigen Fruchtkörper bildet. Früher galt die Pflanze als ein wichtiges Mittel gegen Lungenleiden; in Island (Name!) dient sie dem Menschen vielfach zar Speise. - An trockenen Stellen finden sich häufig Flechten, die zierliche Becher oder Trichter bilden. Das sind die .Fruchtträger- der Becherflechten (Cladónia), und die braunen oder roten Knöpfchen darauf (, Korallentlechten ${ }^{*}$ ) sind dio Fruchtkörper. - '/n diesen Flechten ziihlt auch die Remıtiexflechte (C. rangiferina), deren vielfach verzweigte, 
hohle ${ }_{\pi}$ Stämmchen* auf trockenem Wald- und Heideboden dichte, dicke Polster bilden. Während die Pflanze bei uns nicht verwendet wird, ist sie in den Polarländern besonders während des langen Winters die ansschließliche Nahrung des genügsamen Renntiers (Name!). Da nun von diesem Tiere das Wohl und Wehe des Nordlinders fast einzig und allein abhängt (s. Lehrbuch d. Zoologie), so ist es also das unscheinbare Pflänzchen, das jene Breiten hewohnbar macht. - An den felsigen fiestaden des sïdlichen Atlantischen Ozeans und

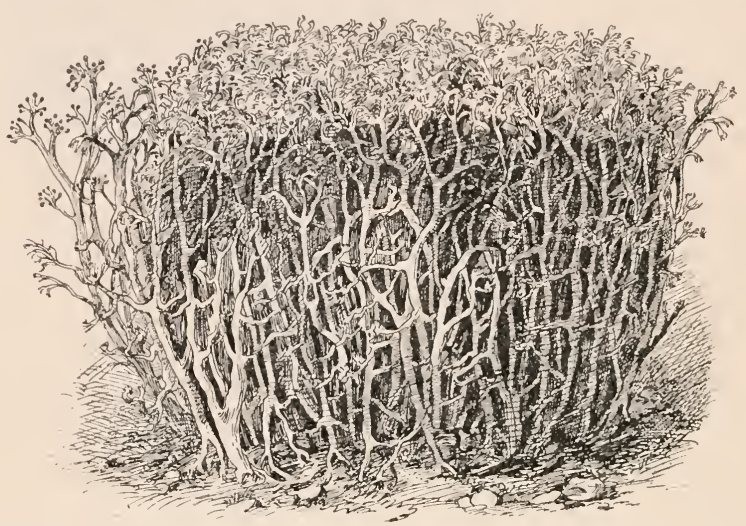

Renutierflechte; ein stück von einem Polster. Dic Stimmehen* links mit Fruchtkïpern lnat. (irs.

an den Kïsten Ostindiens wächst die Lackmmsflechte (Roccélla tinctória), die uns neben mehreren anderen Flechten in dem Lackmus einen überaus wichtigen blauen und roten Farbstoff liefert (Verwendung?).

2. Im Haushalte der $\mathrm{Natar}$ spielen die Flechten fast dieselbe Rolle wie die Moose (s. S. 317). Da sie lange Zeit hindurch die größte Trocknis ertragen können (Versuch!), vermögen sie sich gleich diesen anspruchslosen Pflanzen an Orten anzusiedeln, an denen sie wochenlang von keinem Wassertropfen genetzt werden. An Felsen und vielfach a ch a uf dïrrem Sande bilden sie (mit den Moosen) die ersten Ansiedler.

Gleich jenen treuen Genossen halten sie feruer den herbeigewehten staub fest, und indem sie abgestorben zu Erde zerfallen, machen sie im Laufe der Zeit selbst den härtesten Fels- und den ödesten Sandboden fähig, höhere Pflanzen z u tragen. Da nun von diesen Gewächsen das höhere Tierleben und von beiden wieder der Mensch abhängt (Beweis!), so sind die Fleehten uns gleichfalls ein Beweis dafür daB - wie wir so oft geselıen - das Klcinste und Unscheinbarste in der Natur oft von größter Bedeutung ist. 


\title{
Vom Bau und Leben der Pflanze.
}

\author{
(Morphologie und Physologie.)
}

\section{Abschnitt.}

\section{Vom Bau und Leben der Zelle.}

\section{A. Vom Wesen und von der Bedeutung der Zelle.}

1. Legt man in einen Wassertropfen, der sich auf einer kleinen Glasplatte (Objekttrïger) befindet, einen Algenfaden oder ein Blatt der Wasserpest, wie sie uns beide jedes Gewässer liefert, oder ein Stiick von der Oberhaut eines Blattes, das man mit Hilfe einer Pinzette abgezogen hat (s. Abb. S. 381), oder einen dünnen Querschnitt, den man durch ein Blatt oder irgend einen anderen Pflanzenteil hergestellt hat, so sieht man mit Hilfe des Mikroskops, daß die Pflanze nicht etwa wie ein Stiick Glas oder Eisen ans einer gleichartigen Masse besteht. Ähnlich einem Hause, das aus Steinen aufgebaut ist, ist sie vielmehr aus Körperchen von ganz bestimmtem Bau zusammengesetzt. Da diese Körper vielfach wie die Zellen H. $K$.

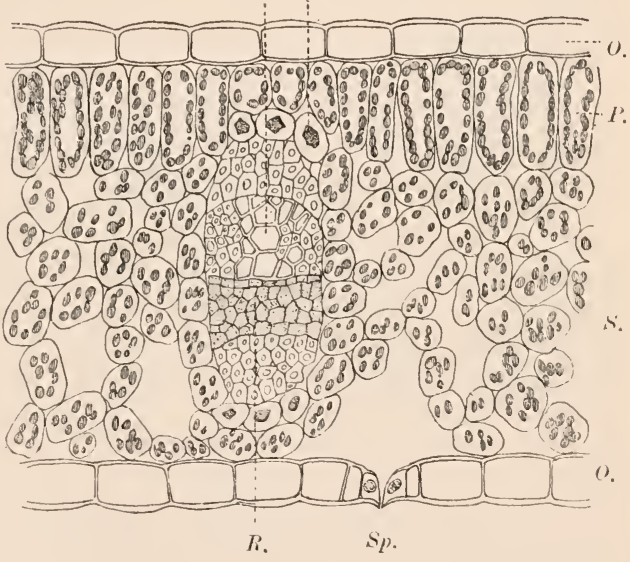

Quersehnitt dureh ein Blatt (Klee), nm den Aufbau aus \%ellen zu zeigen. (Vergr. etwa 320 mal.) (Die Bezeichumgen sind bei tler Wiederholung ler Abh. ant' S. 380 erklïrt. der Bienenwaben geformt sind, wurden sie bei ihrer Entdeckung (i. .1. 1667) „Zellen" genanut, und so bezeichnet man sie heute noch.

2. Ein Baum oder auch schon ein größerer Pflanzenteil, z. B. ein Blatt, eine Wurzel u. dgl., sind aus einer sehr großen Anzahl von Zellen anfgebaut. 
7athlreiche l'flanzen aus den großen (iruppen der Algen und l'ilze (die Kieselalgen, Spaltpilze u. dgl.; s. das.) dagegen bestehen nur aus je einer Zelle. (Daher sind diese Pflanzen zumeist anch sehr klein!). Es gibt also einzellige und mehrzellige Ptlanzen.

3. Im allgemeinen beträgt die Größe der Zellen nur Bruchteile eines Millimeters. Bei den Spaltpilzen geht sie sogar nicht selten unter 0,001 mm herab. Daneben gibt es aber auch Zellen, wie z. B. die der Flachsfasern (s. S. 59, B), die eine Länge von mehreren Zentimetern erreichen können.

4. Ebenso ist auch die Form der Zellen sehr verschieden. Freilebende (d. h. einzeln lebende) oder freiwerdende Zellen, wie z. B. die Hefezellen (s. Abb. S. 342) und die Zellen des Blïtenstambes, haben vielfach die Gestalt einer Kngel (s. 360,3). Zellen dagegen, die sich in festem Verbande befinden, platten sich wie die Zellen der Bienenwabe gegenseitig

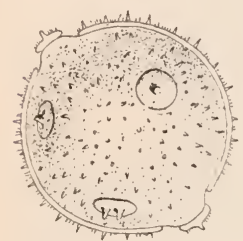

Blïtenstanbkorn

vom Kiirbis (Tergr. etwa $480 \mathrm{mal})$. zumeist $a b$; sie haben die Gestalt eines Würfels, eines Prismas, eines Zylinders oder dgl. Daneben gibt es anch solche von Spindel- oder Sternform: kurz, die Zellen können in fast jeder nur denkbaren Gestalt auftreten. Da Anzahl, Größe und Form beträchtlichen Schwankungen unterliegen, ist in diesen Punkten das Wesentliche der Zellenicht zu finden.

5. Die einzelligen Pflanzen nehmen gleich den vielzelligen Nahrung auf; sie wachsen und vermehren sich wie diese, und viele von ihnen sind sogar imstande, sich frei zu bewegen. Die Zelle, die den Leib dieser Pflänzchen bildet, ist also ein lebendiger Körper. Ebenso sind - wie wir dies im folgenden noch genaner sehen werden - an die Zellen, die sich in festen „Zellverbänden“, z. B. in einem Blatte, einer Wurzel oder dgl. finden, alle Tätigkeiten des Lebens geknïpft. Die Zellen bilden also nicht nur "die Bausteine“, d. l. die Grundbestandteile des Pflanzenleibes, sondern siestellen selbst je einmit Leben ans gerïstetes (tanzes dar.

6. An der lebenden Pflanzenzelle unterscheiden wir in der Regel eine ¿iußere, feste Wandung, die Zellhaut, und einen farblosen Inhalt, der als UTbildungsst off oder P'rotoplasma bezeichnet wird. In den Schwärmsporen der Algen und in gewissen Entwicklungszuständen der Schleimpilze (s. das.) gibt es aber auch Pflanzenzellen, denen (wie den tierischen Zellen) die änßeren Hüllen fehlen. Das Wesentliche an der Zelle kann also nicht die Zellhant, sondern muß das Protoplasma sein: es ist der Lebensträger der einzelnen Zelle, wie der ganzen Pflanze. Wie für die Schnecke das Haus, so ist auch für den Protoplasmakörper die Zellhaut nur das Gebände, in dem or wohnt. 


\section{B. Das Protoplasma und seine Teile.}

1. I)as Protoplasma ist ein Körper von unbekannter chemischer ,Zusammensetzung. Sicher wissen wir nur, daß sich an seinem Aufbau in erster Linie Eiweißstoffe beteiligen.

2. Wie die mikroskopische Betrachtung lebender Zellen zeigt, ist das Protoplasma aus mehreren, regelmäßig wiederkehrenden Teilen zusammengesetzt.

Intersucht man zunächst junge Zellen, wie man sie auf dünnen Schnitten durch wachsende Stengeloder Wurzelspitzen zu Gesicht bekommt, so sieht man in jeder ein rundes Gebilde, den Zellkern. In seiner Nähe bemerkt man einige kleinere Körperclien, die sich durch den Besitz eines Farbstoffes auszeichnen, oder die doch die Fìhigkeit haben, einen solchen zu bilden (s. w. u.). Sie werden daher als Farbstoffträger (Chromatophoren) bezeichnet. Im (regensatz zu diesen festeren Protoplasmaballen ist der ganze iibrige Ranm der Zelle mit einer zähflüssigen, feingekörnelten Masse, demZellplasma, ausgefiillt.

In einiger Ent-

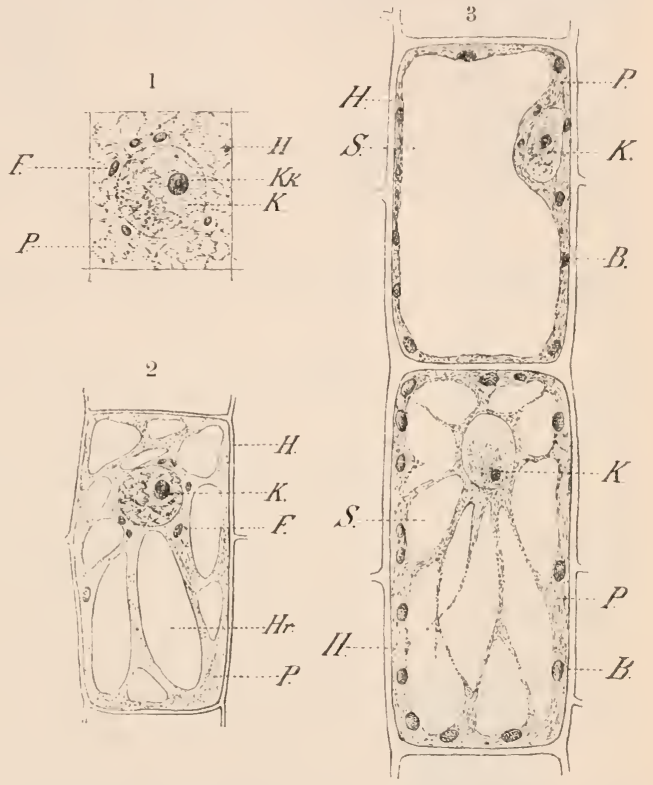

Kellen verschiedenen Alters. 1 Junge Zelle ans der warhenden stengelspitze (Vergr. etwa 600 mal), 2 etwas altere Zelle nul 3 noch altere Zellen (Vergr. etwa 500 mal). H. Zellhaut; P. Protoplasmal (nnl zwar das \%ellplasma): K. Zellkern; Kk. Kernkïrperchen; F. Farbstofteriger, in die noch kein Farbstoff eingelagert ist; B. Blattgrïnkïrper: $\mathrm{Hr}$. mit Zellsaft getiillter. Hohlraum; s. Saftraum.

fermung von der wachsenden Stengel- und Wurzelspitze zeigen die Zellen, die sich durch Wachstum etwas vergrößert haben, zwar dieselben Teile; in dem Zellplasma treten aber kleinere oder größere Hohlrä ume (Vakuolen) auf, die eine Flïssigkeit, den Zellsaft, enthalten. In noch älteren und daher noch größeren Zellen sieht man, wie die Hohlräume miteinander zu einem 
grolien "Saftraume" verschmolzen sind. Das Zellplasma, das anch hier die anderen Teile des Protoplasmakïrpers umgibt, iiberzielit die Zellwände nur als dïnne Schicht oder streckt sich noch in Form von Strängen dnrch den mit Zellsaft erfüllten Raum. Eine solche Zelle lißßt sich treffend mit einem Zimmer vergleichen, dessen Wände, Decke nnd Fußboden (Zellhant!) mit Tapete (Zell-

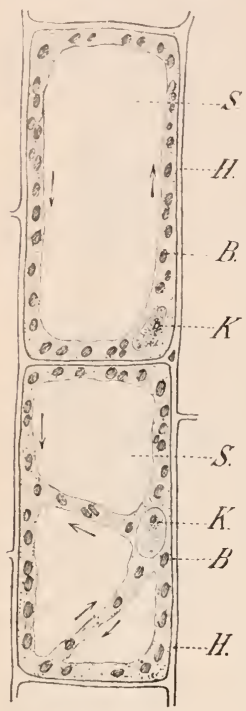

Striimmug des Zellplasmas in $2 \%$ ellen aus dem Blatte der Wasserpest. Die strimmng epfolgt in der lichtung der P'teile. H. Zellhaut; $K$. \%ellkern: B. Blattgriinkörper: $\therefore$ S Saftraum. (Verere etwa 300 mal.) plasma!) iiberkleidet, und durch dessen lufterfiillten Raum (Saftramm!) Fäden (Zelly!ismastränge!) gespannt sind. Betrachten wir die einzelnen Teile des Protoplasmas nälher und beginnen wir mit dem

3. \%ellplasma. Es ist - wie schou erwähnt zumeist eine zihfliissige Masse, die daher „gern“ Tropfenform annimmt. Darum haben - wie oben bemerkt zahlreiche freilebende oder freiwerdende Zellen eben die Gestalt einer Kungel. Bei starkem Wasserverlust kann das Zellplasma aber wie die anderen Teile des Protoplasmas hart und fest werden, ohne jedoch das Leben einzubülien. Das sehen wir z. B. an zahlreichen Samen, die, scheinbar tot, selbst nach Jahren wieder ,erwachen", sobald man ihnen $\mathrm{mr}$ das nötige Wasser und die fïr das Leben notwendige Wärme zur Verfïgung stellt.

a) Trennt man von einem Pflänzchen der überall häutigen Wasserpest eines der durchscheinenden Blättchen ab und legt es unter das Mikroskop, so sieht man, wie das Zellplasma in lebhafter Strömung begriffen ist. Es fließt an den Wänden entlang oder anch in Strängen quer durch den Saftraum. Zellkern und Farbstoffträger, die hier in großer Anzahl vorhanden und lebhaft grïn gefärbt sind (s. Absch.5), gleiten wie Schiffe auf dem Strome dahin. Durch diese Bewegung erfolgt eine beständige Mischung des Zellplasmas an sich, sowie mit den Stoffen, die von außen oder von benachbarten Zellen her in die Zelle eintreten. (Bedentung? Wie muß sich dies in Zellen verhalten, in denen eine solche Striimung nicht stattfindet?)

b) Wie sorgfältige Untersuchungen bei starken Vergrößerungen gezeigt haben, stelit das Zellplasma der einzelnen Zellen vielfach durch zarte Fäden miteinander in Verhindung. Die Fäden durchziehen die trennenden Zellwände und vereinigen somit die gleichsam in verschiedenen Kammern (Zellen) wohnenden Protoplasmakürper der Pflanze (oder doch eine grofie Anzahl dieser Körper) zu einer einheitlichen Masse.

4. Der Zellkern, der meist noch ein oder einige kleine Gebilde, sog. Kernkärperchen enthält, spielt bei der Bildung nener Zellen eine wichtige 
Rolle. Dieser Vorgang erfolgt, von Ausliahnen abgesehen, in der Weise, wie man ihn dentlich an den Staubfadenhaaren aus den Bliitenknospen einer bekannten Gartenptlanze, der 'Tradescautia, verfolgen kann. Bei starker Vergröferung sieht man an den Zellen der Haare, die man in eine schwache Zuckerlösung gelegt hat, wie der anfänglich r'unde Zellkeru (a) sich in die Länge streckt und in zahlreiche Fäden antlöst; wie diese Fäden sich so dann teilen und auseinander rïcken (b); wie sich ferner zwi-

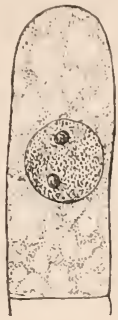

il.

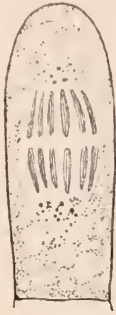

l).

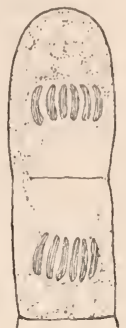

(

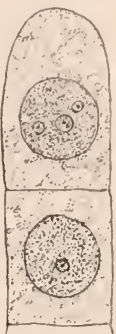

11.

Teilung einer Zelle in den stimbfadenhataren ron Trablestantial ber Vorgang ist in Text beschrieben.

ken des Kernes im Protoplasma eine' Scheidewand bildet (c); wie sich die Teilstücke endlich zu zwei nenen Kernen vereinigen, und wie die Scheidewand mit den Seitenwänden verschmilzt (d). In Verlanf von etwa $1 \frac{1}{2}$ Stunden sind auf diese Weise aus einer Zelle dnrch Teilnng zwei Zellen hervorgegangen.

5. Die als Farbstoffträger bezeichneten, kleineren Protoplasmaballen zeigen eine sehr verschiedene Ausbildung. Legen wir ein Blatt der Wasserpest (s. Abb. S. 360) unter das Mikroskop, so sehen wir in den Zellen kleine, lebhaft griin gefärbte Körper und zwar in so großer Anzahl, daß sie das an sich farblose Blatt für das unbewaffnete Ange grïn erscheinen lassen. Dasselbe gilt auch fïr alle anderen grïnen Pflanzenteile. (Vgl., wie die roten Blutkörperchen die farblose Blutflüssigkeit rot fürben!) Da diese Art der Farbstoffträger in den Blitter'n besonders zahlreich vorhanden sind, bezeichnet man den Farbstoff, dem sie ilı Griin verdanken, als Blattgrïn oder Chlorophyll und sie selbst als Blattgrïn-oder Chlorophyllkörper. Abgesehen von zahlreichen Algen, bei denen sie die Form von Bändern (s. Abb. S.322), Sternen oder Platten haben (s. Abb. S. 3:25), sind sie in der Regel kleine, abgeflachte Körner. Ihre hohe Bedentnng für die Pflanze werden wir später kennen lernen.

In den Blumenblätter'n (Kapuzinerkresse, Ginster II. a.) und in dem Fleische saftiger Friichte (Rose, Eberesche, Weißdorn n. a.) sind die Farbstofftriger vielfach durch einen lebhaft gelben oder roten Farbstoff aus-

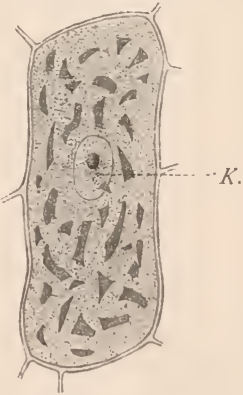

Zelle mit gellen Farbstofftrïgrern ans einem Kelehblatte der kapmyinerkiesse. (Verpre. $5110 \mathrm{mal}$.) 
gezeichnet. Sie verleihen daher den Blïten und Frïchten dieser P'flanzen die auffällige Färbnng, die zum Anlocken der Insekten und Yögel, d. h. der Bestänbungsvermittler und Samenverbreiter, notwendig ist.

In den tieferen, lichtlosen Pflanzenteilen sind die Farbstoffträger endlich farblose Gebilde.

6. Der Zells aft ist eine wässerige Flïssigkeit, in der zahlreiche Stoffe gelöst sind. Je nach der Art dieser Stoffe hat der Zellsaft anch für die Zelle, sowie für die ganze Pflanze eine verschiedene Bedentung. Hier seien nur die wichtigsten Punkte hervorgehoben:

a) Am lıäufigsten finden sich in dem Zellsafte Sänren (z. B. Zitronensäure), Salze (z. B. zitronensaure Salze) und Zucker. Wie eine an solchen Stoffen reiche Flüssigkeit wirkt, soll uns ein einfacher Versuch mit einer "künstlichen Zelle“ zeigen. Wir nehmen einen Glaszylinder, binden über die eine Öffnung luftdicht ein Stiick angefeuchtetes Pergamentpapier (das fast aus reinem Zellstoff besteht; s. S. 365,3), füllen ihn daranf mit einer starken Kochsalzlösung und binden die andere Öffnnng endlich ebenfalls fest mit Pergamentpapier zn. Den so hergerichteten Zylinder legen wir in ein Gefäß mit reinem Wasser. Nacl etwa 24 Stunden finden wir, daß einerseits das Wasser in dem Gefäße ein wenig salzig geworden ist, und daß andererseits die beiden Verschlüsse des Zylinders straff gespannt und stark vorgewölbt sind. Es ist also durch das Pergamentpapier Salzwasser nach anßen und reines Wasser nach innen gedrungen, und zwar ist das Einströmen des reinen Wassers viel stärker gewesen als der Austritt des Salzwassers; denn die Flïssigkeit in dem Zylinder hat sich ja stark vermehrt. Durchstechen wir den Verschluß des Zylinders auf einer Seite, so spritzt die Flüssigkeit daraus in kräftigem Strahle hervor, ein Zeichen, daß die Verschlußstïcke heftig auf den stark vermelırten Inhalt zurïckdrïcken. Wicderholen wir den Versuch, verwenden wir aber statt des Kochsalzes Zncker oder eine Säure, so werden wir dieselben Erscheinnngen beobachten, desgleichen, wenn wir an Stelle verschiedener Flüssigkeiten zwei Gase, z. B. Chlor nnd atmosphärische Luft, benutzen. Und zwar danert der Austausch, der als 0 s mose bezeichnet wird, so lange, bis die Flässigkeiten oder Lnftarten auf beiden Seiten der Scheidewand die gleiche Zusammensetzung haben. (Statt des Pergamentpapiers läßt sich auch eine tierische Haut, z. B. eine Schweinsblase, verwenden.)

Die Pflanzenzelle ist nun ein solcher osmotischer Apparat im kleinen: die Zellhaut entspricht dem Verschlusse und der Zellsaft der Salzlösung. Tritt an sie von außen eine weniger stark gesïttigte Flïssigkeit, so wird sich der Zellsaft vermehren. Ist dagegen die Flüssigkeit, die die Zelle unspült, stärker mit Salzen oder anderen Stoffen gesättigt, so wird der Zellsaft abnehmen. A uf diese Weise erfolgt in der Pflanze ein beständiger Austausch der Stoffe von. Zelle zu Zelle. (Wann kommt der Austausch zum Stillstande?)

In dem Falle, in dem sich der Zellsaft vermehrt, wird die Zellhaut ausgedehnt und straff gespannt, so daß sie infolge ihrer Elastizität anf den Zell- 
inhalt zurïckdrïcken muß. I) iese Spannung, die der Zelle eine gewisse Festigkeit verleiht, bezeichnet man als ihren Turgor. In diesem Zustande befinden sich z. B. alle wachsenden l'flanzenteile. Daher vermögen z. B. die zarten Keime oder jungen Triebe (Tulpe, Maiglöckchen u. s. w.) die Erde zu durchbrechen. Verliert die Zelle vielleicht durch zu starke Verdınstung Wasser, so wird der Turgor geringer; die bisher gespannte Zellhaut und damit die ganze Zelle wird schlaff und weich. Geschieht dies mit vielen oder allen Zellen, dann sagt man: die Pflanze welkt. Führt man der Pflanze wieder genügend Wasser zu (Begießen, Einstellen in ein Gefäß mit Wasser!), so nimmt sie wieder das frühere Aussehen an, ein Zeichen, daß es nur der in ilhren Zellen herrschende Wasserdruck ist, der sie aufrecht hält. (Der Turgor ist - wie wir später sehen werden - für die Pflanze noch in zahlreichen anderen Fällen von größter Bedeutung.)

b) Vielfach sind in dem Zellsafte auch $S$ toffe anfgespeichert, die später zum A ufbau der Pflanze verwendet werden. Das sehen wir z. B. an der Zuckerribe, die in dem Zellsafte der Wurzel große Mengen von Zucker als Baustoff für das nächste Jahr anhänft.

c) Ähnlich wie gewisse Blüten nnd saftige Frïchte durch Farbstoffkörperchen bunt erscheinen, werden andere durch einen im Zellsafte gelösten Farbstoff den Bestänbern und Verbreitern der Pflanze anffällig (Blüte von Rose, Rittersporn 11. a., Frucht von Kirsche, Heidelbeere u. a.). Als Anlockungsmittel tritt bei den Frïchten noch der Zuckergehalt des Zellsaftes liiuzu.

\section{Die Zellhaut.}

1. Bedeutung. Wir haben gesehen, daß der größte Teil des Protoplasmakörpers, das Zellplasma, in der Regel eine zähflüssige Masse darstellt. Es wäre daher numöglich, aus diesem Stoffe eine Pflanze von bestimmter Gestalt, vielleicht gar einen Banm aufzubauen. Das „Banwerk" würde stets in sich zusammensinken und zerfließen (vgl. die Form der Schleimpilze). Umgeben wir aber ein Klümpchen der zähflïssigen Masse mit einer festen Ḧ̈lle, oder bieten wir einer größeren Protoplasmamasse ein Stïtzwerk aus vielen Kammern, in denen sie gleichsam wohnen könnte, dann wäre dies wohl möglich. Wir hätten im ersten Falle eine Zelle oder eine einzellige Pflanze und im zweiten eine Vielheit von Zellen oder eine vielzellige Pflanze geschaffen. Di e H iille, di e der einzelnen Zelle oder der einzelligen Pflanze Form und Gestalt gibt, ist die Zellhaut, und die Gesamtheit aller Zellhä ute bildet das stïtzende Kammerwerk dervielzelligen Pflanzen.

Wie wir gesehen haben wird bei der Bildnng nener Zellen vom Protoplasma eine Scheidewand zwischen die schon vorhandenen Zellwände eingeschoben. Denken wir uns diesen Vorgang längere Zeit fortgesetzt, so müssen schließlich alle Wände, die den Protoplasmakörper einer Zelle umgeben, von diesem 
selbst gebildet sein. T) e lebende l nhalt der Zelle baut sich seine $\mathrm{H}$ iille also selbst, ähnlich wie sich die Schnecke selbst ihr Haus erbaut.

2. Verdickungen. Anfänglich ist die Zellhaut sehr zart und dünn (s. Abb. S. 35.4). In dem Maße aber, in dem sich der Zellinhalt ausdehnt, wächst auch seine Hülle. Hat die Zelle
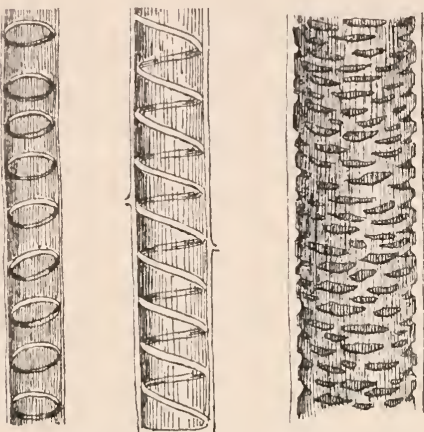

Verdickungen der Zellwand (schematisch). 1 Ringförmige, 2 schranbenförmige mul 3 notzförmige Verdicknngen. ihre volle Größe erreicht, so treten an der Zellwand gewöhnlich Verdickungen auf.

a) Bei Zellen, die eine freie (oder eine teilweis freie) Oberfläche haben, sind die Verdickungen in Form von Stacheln, IVarzen und Leisten gewöhnlich $\mathrm{n}$ a $\mathrm{ch}$ a $\mathrm{n} \beta$ e $\mathrm{n}$ gerichtet. Dies ist z. B. meist bei den Bliitenstaubkörnchen derjenigen Ptlanzen der Fall, die durch Insekten bestänbt werden (s. Abb. S. 358). Infolge der Ranhigkeiten haften die Körnchen fester am Körper der Bestäuber, als wenn sie wie die der windblïtigen Pflanzen eine glatte Oberfläche besäßen.

b) Stellt man zarte Läingsschnitte durch den Stengel z. B. der Somnenrose oder Gartenbalsamine her, so treten uns Terdickungen der Zellhant entgegen, die $n \mathrm{ach}$ in nen gerichtet sind. Die Verdickungen erstrecken sich aber nicht gleichmäßig ïber die ganze Innenfläche der Zellhaut, sonder'n treten uns nur in Form von Ringen und Schrauben oder als Netzwerk entgegen. Zwischen den verdickten Stellen bleibt die Zellwand dïnn.

Diese Terdickungen haben vor allen Dingen die Aufgabe, die Zelle auszusteifen, ihr eine größere Festigkeit zu geben. Ähnlich wie bei einer Mauer, die wir durch stärkere Pfeiler stïtzen, genïgt hierzn schon eine teilweise Verdickung der Zellwand, und zn diesem Mittel wird die sparsame Natur umso "lieber greifen", als diese Art der Aussteifung mit der geringsten Menge von Baustoff ausgefïhrt werden kann. Andererseits sind aber die

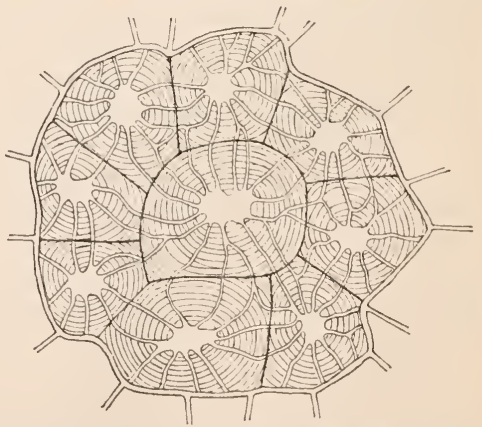

Tiipfelzellen aus einem, steine" des fruchtfleisches der Birme. (Vergr. etwa $500 \mathrm{mal}$.) 
unverdickten Stellen auch für den Stroftverkehr in der Pflanze von grober Wichtigkeit. Wie wir gesehen haben, stellt jede Zelle einen osmotischen Apparat dar. Es muf daher zwischen den pinzelnen Kellen so linge eiu Ansgleich stattinden, so lange ilır Inhalt nicht vollkommen gleich ist. Dieser Austausch der Stoffe geht durch dünne Stellen der Zellhaut num selbstrerständlich leichter und schneller von statten als durch verdickte.

c) Wie der Austausch zwischen Zellhäuten erleichtert wird, die gleichmäßig sehr stark verdickt sind, zeigen nus \%. B. die Zellen, die in dem FruchtHeische der Birne die sog. Steine bilden. Die Wände sind hier von Kanälen durchzogen, die mit denen der benachbarten Zellen genan zusammentreffen. Au diesen Stellen sind die Zellen daher nur durch di ursprïngliche Zellhant getrennt. Die Kanäle bezeichnet man, da sie von der Fläche gesehen wie rundliche Öffuungen erscheinen, als Tï p fel.

Eine besondere Art von Tüpfeln besitzen die Zellen im Holze der Nadelbäume. An dünnen Schnitten z. B. durch Kiefernholz sieht man, wie sich die Verdickungsschicht über der düunbleibenden Stelle der Zellhaut wölbt, ohne sich aber vollkommen zu schließen. Die Verdickung hat also die Form eines Uhrglases, das in der Mitte eine Öffnung besitzt. Von der Fläche betrachtet, erscheint das Gebilde daher wie ein heller Kreis (Öffnung!), der von einem dunkleren "Hofe" (gewölbte Verdicknngsschicht!) umgeben ist. Einen solchen Tüpfel bezeiclınet man daher als gehöften $\mathrm{T}$ ï $\mathrm{p} \mathrm{fe} \mathrm{l}$.

3. Chem is che $\mathrm{Zn} \mathrm{samuensetzung.}$ a) In jungen Zellwänden waltet stets, in ältereu sehr häutig ein Stoff vor, der den Namen Zell-

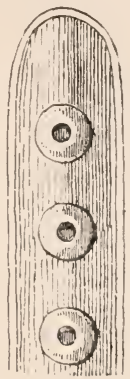

1
2

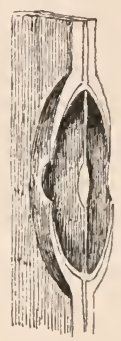

Gehöfte Tïpfel. 1 Teil einer Zelle ans dem Holze der Kiefer mit drei gehöften Tüpfeln, von der Fläche gesehen (Vergr. etwa 300 mal). 2 Ein Tüptel in Iurchschnitt, noch stärker vergrössert (schematisch). stoff oder Zellnlose führt. Er ist ans Kollenstoff, Wasserstoff und Sanerstofi $\left(\mathrm{C}_{6} \mathrm{H}_{10} \mathrm{O}_{5}\right)$ gebildet, und zwar finden sich in ihm die beiden letztgenannten Elemente in dem gleichen Verhïlnisse wie im Wasser $\left(\mathrm{H}_{2} \mathrm{O}\right)$. Die Zellnlose gehört also zu der großen Gruppe chemischer Verbindungen, die man (wegen dieses Verhältnisses!) als Kohlenhydrate bezeichnet. (Fast reine Zellulose ist der als Zelluloid bekannte Körper, ans dem man Bälle, Griffe von Zahubïrsten u. dgl. herstellt.)

Durchtränkt man einige Wattefäden, die aus fast reiner Zellulose bestehen, mit (hlorzinkjodlösung*), so färben sie sich alsbald schön blaı. Mit Hilfe dieses

*) Dieses Reagenz, das wie alle anderen. hier erwähnten Reagenzien in Spezialhandlungen käuflich zu haben ist, erhält man, indem man 20 Teile Chlorzink, 6,5 Teile Jodkalium und 1,3 Teile Jod in 10,5 Teilen Wasser anflöst. 
Stoffes (Reagenz) sind wir also imstande, Zellulose in Pflanzenzellen nachzuweisen. (Führe diesen Nachweis z. B. an dünnen Sclınitten aus Kartoffelknollen!)

Wie uns der Versuch zeigte, durch den wir das Wesen der Osmose kenuen lernten, sind Häute atus Zellulose für Flïssigkeiten (und Gase) sehr durchlilssig. Diese Eigenschaft besitzen daher auch die Häute junger Zellen, d. l. also derjenigen Teile des Pflanzenkörpers, die im lebhaften Wachstum begriffen sind und daher große Mengen von Baustoffen (von außen oder voll benachbarten Zellen her) aufnehmen müssen.

b) Bringt man dünne Schnitte aus Kiefernholz oder einer anderen Holzart in Chlorzinkjodlösung, so tritt keine Blau-, sondern eine Gelbfürbung ein, ein Zeichen, daß mit den Zellhänten eine chemische Veränderung vor sich gegangen ist. Sie sind verholzt. Wie schon die Verwendung des Holzes zum Stützen und Tragen (beim Häuserbau u. dgl.) zeigt, besitzen Pflanzenteile mit verholzten Zellhäuten eine große Festigkeit. Daher tritt eine Verholzung der Zellwände auch besonders in den Teilen des Pflanzenkörpers ein, die eine große Festigkeit und Widerstandsfäligkeit besitzen müssen.

c) Schnitte aus Flaschenkork färben sich in Chlorzinkjodlösung gelbbraun: die Zellwände sind durch Einlagerung von Korkstoff verändert; sie sind verkorkt. Wie die Verwendung des Korkes im täglichen Leben zeigt (Beweis!), ist dieser Körper für Luft und Wasser fast undurchdringlich. Daher wendet - wie wir später sehen werden - die Pflanze den Kork auch dort an, wo es sich u. a. darnm handelt, die Verdunstung stark einzuschränken.

\section{Der ,Zellstaat“"}

1. Arbeitsteilung. Die einzellige Pflanze, wie sie uns in den Ciruppen der Algen und Pilze entgegentritt, ist mit einem Menschen zu vergleichen, der allein in der Wildnis umherschweift. Wie er alles selbst verrichten muß, was zum Leben notwendig ist - er hat sich Nahrung zu suchen, eine Huitte zu bauen, die inn vor den Unbilden der Witterung schïtzt, sich gegen seine mannigfachen Feinde zu verteidigen u. dgl. mehr, - so hat auch die „einzeln lebende Zelle" alle Lebenstätigkeiten zu verrichten. Sie muß - um nur einiges anzufïhren - Nahrungsstoffe aufnehmen und umarbeiten, auf daß sie zum Aufbau des Körpers verwendet werden können; sie hat sich gegen äußere Einflïsse zu wehren, Nachkommen zu erzengen u. dgl. mehr.

In den mehrzelligen Pflanzen dagegen haben wir es mit großen Gemeinschaften von Zellen zu tun, die sich mit wohlgeordneten Staatswesen vergleichen lassen. Wie dort gewisse Bürger (Ackerbaner, Viehziichter u. dgl.) für alle die notwendige Nahrung gewinnen, andere (Handwerker $\mathrm{u}$. dgl.) die sonst zum Leben nötigen Gegenstände herstellen, andere (Kauflente, Schiffer u. dgl.) eine Verteilung dieser Gegenstände und der Nahrung besorgen, andere (Heer, Polizei u. dgl.) den Schutz des Ganzen ïbernehmen: so ist auch in dem "Zellstaate" jedem "Bürger" eine bestimmte Arbeit zuerteilt. Wie ferner nun in einem Staatswesen oder einer Fabrik (Beweis!) infolge dieser "Arbeitsteilung“ die 
Arbeiten besser und vollkommener ausgetïhrt werden, als wenn sie alle von jedem einzelnen Bürger oder Arbeiter verrichtet würden, so auch im Zellstaate. Das ist aber in den menschlichen Gemeinwesen nur möglich, wenn nicht jeder gleich dem in der Wildnis Umherschweifenden in schrankenloser Willkür verfahlirt, sondern sich in eine gewisse Ordnung fügt, sich unter bestimmte Gesetze beugt. So hat sich anch im Zellstaate jedes Glied dem Wohle des Ganzen unterzuordnen.

Wie unter den Menschen der einzeln lebende die tiefste Stellung einnimmt, so sind auch die einzelligen Pflanzen die "niedrigsten". Und unter den "höheren" Gewiichsen haben wieder die eine iibergeordnete Stellung, eine höhere Rangordnung, bei denen die Arbeitsteilung am vollkommensten durchgeführt ist. (Führe dies an der Hand der großen Abteilungen des Pflanzensystems näher aus!)

2. Gewebe. Je nach der Arbeit, die der einzelne Bürger des Staates zu erfïllen hat, ist er anch verschieden ausgeriistet: der Landmann z. B. mit Pflug und anderen Ackergeriten, der Soldat mit Waffen u. dgl. So müssen auch die Glieder des Zellstaates, je nachdem sie diese oder jene Arbeiten zu leisten haben, verschieden ansgerüstet oder - ander's ausgedriickt — verschieden gebaut sein. Gewöhnlich vereinigen sich im Pflanzenkörper nun mehrere gleich gebante und gleich tätige Zelten zu größeren oder kleineren Gruppen (s. z. B. Abb. S. 357); sie bilden sog. Gewebe (erklïre den Namen!), von denen wir die wichtigsten Formen in folgendem kennen lernen werden.

3. Zwischenzellräume. Die Zellen, die ein Gewebe bilden, müßten so sollte man denken - stets lückenlos aneinanderschließen; denn wie wir gesehen haben, wird bei der Zellteilung in der "Nutterzelle" ja nur eine Wand gebildet, die beiden "Tochterzellen" gemeinsam ist. Bei jungen Zellen muf ein enger Zusammenschluß also stets vorhanden sein. Auch bei alteren findet er sich vielfach. Nicht selten aber spaltet sich bei diesen die gemeinsame Scheidewand der Lünge nach. Dann rïcken (s. z. B. Abb. S. 357) die Zellen vielfach so weit auseinander, daß sie nur noch an einem Punkte zusammenstoßen. So entstehen zwischen ihnen oft große, luftgefïllte Liicken, die man als Zwischenzellr:iume bezeichnet.

\section{A bschnitt.}

\section{Vom Ban und Lehen der einzelnen Pflanzenteile. Die Grundformen der Pflanzen.}

1. An den Blütenptlanzen und farnartigen Gewächsen unterscheiden wir eine Menge einzelner Teile, die wir z. B. als Wurzel, Zwiebel, Knolle, Stengel, Halm, Dorn, Blïte, Stempel n. s. w. bezeichnen. Alle diese Teile lassen sich - so verschieden sie auch zn sein scheinen - auf drei Grundglieder zurïckfiilhren: auf Wnrzel, Stamm (oder Stengel) und Blatt. Diese drei Hauptteile unterscheiden 
sich - ganz kurz gesagt — folgendermaßen voneinunder: W' urzel und St amm, die sich oft selır ähnlich sind (unterirdische Stämme!), haben stets ein lang andanerndes Wachstum; während der Stamm aber der Träger der Blätter ist, hat die Wurzel niemals die Fähigkeit, solche zu entwickeln. Die Bläter sind sehr verschieden gestaltete Gebilde, die ihr Wachstum sehr bald einstellen und stets am Stamme entspringen.

Diese drei Grundglieder treten uns nun in sehr verschiedener Ausbildung entgegen. Ohne ihre Entwicklung zu kennen, ist es vielfach sogar unmöglich zu entscheiden ob man in ihnen Wurzel, Stamm oder Blatt vor sich hat. So sind - wie wir bei der Betrachtung der betreffenden Pflanzen bereits geschen haben - z. B. die Knollen des Knabenkrautes Wurzelgebilde, die der Kartoffel dagegen Teile des Stammes (Stengels); so haben wir ferner in den Dornen des wilden Birnbaums Stammgebilde, in den Stacheln des Kaktus dagegen Blätter vor uns us. s. w. Die Grundglieder erscheinen also hier älnlich wie die Jungen zahlreicher Lurche und Insekten (s. Lehrb. d. Zoologie) in einer Verkleidung. Wie bei diesen Tieren redet man daher auch bei ihnen von einer Verwandlnng oder Metamorphose.

2. An dem Faden der Schraubenalge oder dem Fadengeflechte des Champignons ist wie bei allen Algen und Pilzen eine Gliederung in Wurzel, Stamm und Blatt nicht zu entdecken. Einige Algen, wie z. B. der Blasentang (s. S. 326), haben allerdings einige Ähnlichkeit mit den höheren Pflanzen; zur Ausbildung wirklicher Wurzeln, Stämme und Blätter kommt es bei ihnen aber gleichfalls nicht. Einen solchen ungegliederten Pflanzenkörper bezeichnet man als Lager (Thallus). Im Gegensatz zu den höheren Pflanzen, den Stamm-Blatt-Pflanzen (Cormophyten), faßt man daher die Algen und Pilze (Flechten) als Lagerp flanzen (Thallophyten) zusammen (s. S. 322).

3. Die Moose, als die einzig übrig bleibende grolie Abteilnng des PHlanzenreichs, lassen sich in keine der beiden Grappen einfügen. Wälırend sich an dem Lanbmoose stets dentlich Stamm und Blatt unterscheiden läßt, entbehren zahlreiche Lebermoose (s. das.) dieser Gliederung mehr oder weniger vollkommen. Die Moose bilden also den Übergang zwischen den beiden groben Gruppen.

\section{Vom Bau und Leben des Blattes.}

\section{Blattarten und Blattstellung.}

1. Die Blattarten. Das Blatt tritt uns in sehr verschiedener Gestalt entgegen, die mit der zu erfüllenden Aufgabe aber stets in vollendetster Weise übereinstimmt (beweise dies durch die in Abschn. 2 und 3 angefïhrten Beispiele!). Betrachten wir z. B. eine Pflanze des Kinabenkrantes (s. Taf. 34), so sehen wir am unteren Teile des Stengels einige farblose „Hïllblätter", am mittleren die grünen Laubblïtter und am oberen zahlreiche „Deckblätter", ans deren Achseln sich die Blüten erheben. Untersuchen wir hieranf andere Pflanzen, so finden wir bei vielen (Beispiele!) unterhalb oder oberhalb der Lanbbläter gleichfalls Blätter von abweichendem Bau. Es lassen sich demnach 3 Gruppen von Blättern unterscheiden, die man nach ihrer Stellung am Stamme (Zweige) als Nieder- 
blätter, Mittel-oder Laubblätter und Hochblätter bezeichnet. Zu diesen 3 Gruppen kommen bei den Bliitenpflanzen noch 2 weitere hinzu: die Blätter der Blüte (Kelch-, Blumen-, Staub- und Fruchtblätter) und die Keimblatter. Da diese beiden Blattarten später eingehender betrachtet sind, wenden wir uns hier nur den 3 ersteren zu.

2. Die Niederblätter treten uns an unterirdischen Stämmen (Wurzelstöcken) in der Regel als farblose Schuppen entgegen. Sie dienen dort (Windröschen, Tanbnessel u. a.) znmeist der zarten Endknospe des weiterwachsenden Stammes, sowie den in ihren Achseln sich bildenden Zweigknospen als schützende Hüllen (dıher „Hüllblätter"). Eine gleiche Aufgabe haben diejenigen Niederblätter zu erfüllen, die beim Durchbrechen der Erłe "voran gehen“ (Scharbockskraut, Maiblume u. a.), oder die als Knospenschuppen den jungen 'Trieb fest umschließen (s. Roßkastanie). In den Zwiebeln (s. Tulpe) bilden die hier als

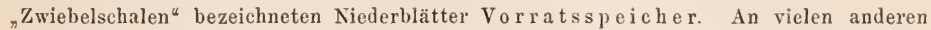
unterirdischen Stämmen dagegen (Wurzelstöcken, Knollen) sind sie so klein, daß ihnen wohl kanm noch eine Bedeutung zukommt.

3. Die Hochblätter sind in der Regel $\mathrm{sch}$ üt zende Decken der jungen Blüten und Blütenstände. Als „Deckblätter" haben wir sie z. B. beim Knabenkraute, als „Hülle

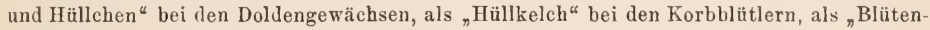
scheide" bei Schneeglöckchen und Aronstab, als "Spelzen" bei den Gräsern, als "Schuppe" an den Kiefernzapfen kennen gelernt n. s. w. Beim Windröschen („Hüllblätter “) haben sie genau die Gestalt der Laubblätter, und bei der Leberblume täuschen sie fast einen Kelch vor. Bei einigen anderen Pflanzen dagegen treten sie in den Dienst der Insektena nlockung (Hain- Wachtelweizen), der Bestäubung (Aronstab), der Frachtbild ung (Becherfrüchtler) oder der Fruchtverbreitung (Linde, Klette u. a.).

4. Die Laubblätter (Mittelblätter), die gewöhnlich als „Blätter " schlechtweg bezeichnet werden, wollen wir hier vorwiegend nur nach ihrem Äußeren betrachten Ihre Aufgabe und Bedentung werden wir in dem nächsten Abschnitte kennen lernen. - An den Blättern z. B. des Scharbockskrautes wird die herzförmige Blattflä che (oder Blattspreite) von einem langen Blattstiele getragen, der sich unten zn einer Blattseheide verbreitert. Solche „vollständigen" Blätter treffen wir jedoch nur selten an.

a) Die Blattscheide dient beim Scharbockskraute, der Möhre a. a. als Schutzmittel für zarte, junge Pflanzenteile; bei den Gräsern (s. Roggen) hat sie anßerdem noch die Bedeutung eines Stiitzorgans. - An Stelle der Scheide finden sich bei mehreren Pflanzen (Beispiele!) rechts und links vom Blattgrunde kleinere oder größere, bleibende oder abfallende Nebenblätter, die z B. bei der Erbse als Schutzmittel junger Teile dienen. Bei der Robinie u. a. sind die Nebenblätter in schützende Dornen umgewandelt.

b) Den Blattstiel haben wir mehrfach (s z. B. RoBkastanie und Weinstock) als ein Mittel der Pflanze erkannt, die sonnenbedärftige Blattfläche in die geeignete Stellung zum Lichte zu bringen. Ebenso haben wir gesehen, wie das federnde Gebilde die Blattfläche schützt, vom Winde und vom Anprall der Regentropfen zerrissen zu werden (s. S. 87, b).

Fehlt der Blattstiel, so bezeichnet man das Blatt als sitzend (Tulpe n. v. a.). Zieht sich die Blattfläche am Stengel noch ein Stück herab, so nennt man das sitzende Blatt herabla ufend (Eselsdistel, Schwarzwurz u. a.), greift die Blattfläche um den Stengel: stengelumfassend (Schlafmohn), und verschmelzen die Flächen zweier gegenüberstehender Blätter miteinander: verw a chsen (Jelängerjelieber). - Ist der 
Blattstiel in der Mitte der wagerecht stehenden Blattfäche angewachsen wie bei der Kapuzinerkresse, so entsteht das schild fö rmige Blatt.

c) Die Blattflä che zeigt sehr verschiedene Ausbildung, so dal.j man eine große Anzahl von Blattformen unterscheilet:

I. Nach dem Verlanf der Nrren oder Adern: lanfen alle Nerven mit der n.Mittelrippe" und untereinander ungefähr parallel, wie dies für die einkeimblättrigen Pflanzen als Regel gilt, so bezeichnet man das Blatt als streifen-oder paralle lnervig; entspringen die Seitenuerven abweclsselnıl oder paarweise in Zwischenränmen von der Mittelrippe, so nennt man das Blatt fiedernervig (z. B. Haselnuli); gehen dagegen mehrere, ungefüh gleichstarke Nervon strahlenförmig vom Ende des Blattstiels alls. so redet man von einem handnervigen Blatte (\%. B. Ahorn).

II. Nach tlem Gesamtumiß ist das Blatt: nadelförmig (Nadelhölzer), linealisch (Gräser), lanzettlich (Weidenröschen), spat elförmig (Gänseblünchen), e iförmig (Birnbaum), elliptis c lı (Kirschbaum), k reisrund (Faulbaum) u. s. w. Alle diese Formen gehen auch ineinander über.

11I. Nach der Form des Blattyrundes bezeichnet man das Blatt u, a. als: nierenförmig (Sumpfdotterblume), he rzförmig (Bohne), pfeilförmig (Ackerwinde), s p i e B för m ig (Melde).

IV. Nach der Beschaffenheit des Randes heiBt das Blatt: g a n zrandig, wenn ohne Einschnitte (Flieder); gesägt, wenn die spitzen Sägezälne in spitzem Winkel zusammenstoßen (Rose); d o p pelt-gesägt, wenn grolje und kleine Sägezähne abwechseln (Erle); schrotsäg förmig, wenn die meist nach unten gekehrten Sägezähne wiederum fein gesägt sind (Löwenzahn); gezähn t, wenn die spitzen Zähne im stumpfem Winkel zusammenstolen oder durch einen sanften Bogen verbunden sind (kleine Brennessel); ge ke r b t, wenn die abgernndeten Ansschnitte in einem Winkel zusammen. stolien (Veilchen); buchtig, wenn Ansschnitte und Einbuchtangen abgerundet sind (Eiche). - Gehen die Einschnitte tiefer, so tritt

V. eine Teilung der Blattfäche ein, die sich ganz nach dem Verlauf der Nerven richten muB. Im Gegensatz zum nngeteilten Blatte nennt man ein Blatt fiederteilig oder fiederspaltig, wenn die Einschnitte zu beiden Seiten der Mittelrippe liegen (Raps), und handförmig geteilt, wenn sie nach dem Grunde des Blattes verlaufen (mehrere Hahnenfußarten). - Reichen die Einschnitte so tief, daß die Blattfläche in mehrere völlig voneinander getrennte Teile oder „Blättchen“ zerlegt wird, so redet man

VI. von einem zusammengesetzten Blatte, zn dem das e infache den Gegensatz bildet. Bestimmend für die Art der Zusammensetznng ist wieder der Verlanf der Nerven: das fiedernervige Blatt wird zum gefiellerten (Rose) und das handnervige zum hand-oder fingerförmigen (Roßkastanie). Besteht das gefiederte Blatt aus mehreren Fiederpaaren und einem Endblättchen, so ist es nnparig-gefiedert (Rose); fehlt das Endblättchen, so heibt es paarig-gefiedert (Erbse); sind die Fiederblättchen wieder gefiedert, so entsteht das doppelt-gefiederte nnd bei fortgesetzter Fiederung das mehrfach-gefiederte Blatt (zahlreiche Doldengewächse und Farnkräuter). Das handförmige Blatt heilt nach der Anzahl seiner Blättchen dreizählig (Wiesenklee), fünfzählig oder gefingert (Fingerkräuter), siebenzählig (Roßkastanie) u. s. w.

5. Besondere Blattformen. Haben die Blätter eine besondere Aufgabe zu erfïllen, so haben sie auch eine besondere Form.

a) Als Blattdornen dienen sie der Abwehr pflanzenfressender Tiere. Während 
bei dem Sauerdorn und den Kaktusarten das ganze Blatt zu Dornen umgewandelt ist, zeigen wie vor kurzen erwïhnt - bei der Robinie nur die Nebenblätter diese Veränderung.

b) Ist das Blatt ein Mittel, den schwachen Stengel an eine Stïtze zu binden, so hat es die Gestalt der Blattranke (vgl. Stengelranke). Beim Kürbis sind von der ganzen Blattfläche nur die Hauptnerven erhalten geblieben: bei der Erbse und vielen anderen Schmetterlingsblütlern dagegen sind allein die obersten Fiederblätter von dieser Verinderung betroften.

c) Bei Somnentau, Wasserschlauch, Kannenstranch, Schuppenwurz und anderen „insektenfressenden Pflanzen" sind die veränderten Bläter Mittel zum Tierfang.

6. Die Blattstellung. Die Blatter jeder Pflanze (also auch Nieder- und Hochblätter, sowie die Blätter der Bliite) sind am Stengel stets in ganz bestimmter Weise angeordnet.

a) Stehen sich, wie z. B. bei der Tanbnessel, je zwei Blätter in gleicher Höhe des Stengels gegeniiler, so nennt man sie gegenständig. Wechseln wie bei dieser Pflanze die Blattpaare so miteinander ab, dab die Blätter über je einer Lücke des vorhergehenden oder nachfolgenden Paares stehen, so heißt die Blattstellung kreuzständig.

b) Entspringen an einer Stelle rings um den Stengel mehr als zwei Blätter, so bezeichnet man sie als quirlständig. (Bei den Blattkreisen zahlreicher Blüten zu heobachten. Bei den Labkräntern sind die Blätter eigentlich gegenständig; denn jeder Qnirl ist ans zwei Laubblättern unl den zu ihnen gehörigen Nebenblattpaaren zusammengesetzt. Dab diese Deutung richtig ist, ergibt sich aus der Tatsache, dab nur ans den Achseln je zweier Blätter Zweige hervorgehen.)

c) Bei den meisten Pflanzen stehen die Blätter einzeln in ungleicher Höhe am Stengel. Diese Stellnng bezeichnet man als zerstreut oder wechselständig. Wiederholen wir aber bei irgend einer dieser Pflanzen den bei der Schwarzwnrz (siehe S. 131, 1 c) ansgeführten Versuch mit dem Faden, so sehen wir dentlich, dal diese scheinbar regellos gestellten Blätter dem Stengel in einer Schraubenlinie angeheftet sind. Mit Hilfe des Fadens kann man anch leicht feststellen, wieviel Umgänge (Schraubenwindungen) nötig sind, $n m$ anf ein Blatt, zn stoben, das genan über dem Anfangsblatte steht, und das wievielte Blatt es von diesem Blatte an gezählt ist. Steben z. B. wie beim Kirschbaume anf zwei Umgängen fünf Blätter, so nimmt gleichsam jedes Blatt ${ }^{2} / 5$-Umgang ein. Diese Blattstellung bezeichnet man daher als ${ }^{2} / 5$-Stellung. Von anderen häufigen Stellungen seien genannt: die $1 / 2$-Stellung bei den Gräsern und vielen Liliengewächsen; die $1 / 3$-Stellung bei zahlreichen anderen einkeimblättrigen Pflanzen; die $2 / 5$ - und $3 / s^{-S t e l l n n g}$ bei vielen zweikeimblättrigen Gewächsen.

\section{Das Blatt als Werkzeng der Aneignung oder Assimilation der Nihlstoffe.}

\section{Die A neignung oder Assimilation der Nährstoffe.}

Das grïne Blatt spielt im Leben der Pflanze eine außerordentlich wichtige Rolle: es ist nämlich erstlich vor allen Dingen das Organ, in dem die aufgenommenen Rohstoffe so umgewandelt werden, daß sie zum Leben und Aufbau der Pflanze zu verwenden siud. Bevor wir jedoch diesen Vorgang verfolgen können, haben wir uns zu fragen, welcher einfachsten Stoffe die Pflanze ïberhaupt bedarf, nm daraus jene Baustoffe zu bilden?

\section{Die Bestandteile und Niihrstoffe der Pflanze. \\ a) Wie wir bei der}


Betrachtung der Zelle gesehen haben, sind alle Teile der lebenden Ptlanze von Wasser durchtränkt. Daher gibt es ohne Wasser kein Pflanzenleben (Vertrocknen der Pflanzen im Blumentopfe! W üsten!). In welcher Menge dieser wichtige Stoff im Pflanzenkörper enthalten ist, zeigt schon ein einfacher Versuch: wir legen irgend einen größeren Pflanzenteil (einen Zweig, eine Kartoffelknolle, einen Apfel oder dgl.), dessen Gewicht wir festgestellt haben, auf den warmen Ofen und wiegen ihn wieder, nachdem er vollkommen ansgetrocknet ist ("Trockengewicht"). Der Gewichtsverlust ist (in erster Linie) auf das verdunstete Wasser zuriickzuführen.

b) Ein solch ansgetrockneter Pflanzenteil ist, wie wir nun weiter wissen, verbrennbar, $d . h$. er enthält $K o h l e n s t$ off. Verkohlen wir irgend einen Pflanzenstoff (z. B. Holzteilchen) in einer Retorte, oder vergleichen wir, wieviel ein stïck Holzkohle und ein gleich großes Stïck ganz trockenes Holz wiegt, so elkennen wir, daß der Kohlenstoff etwa die Hälfte des Trockengewichts der Pflanze ansmacht. Und wie gleichmäßig der Kohlenstoff in der Pflanze verteilt ist, ergibt sich darans, daß an der Holzkohle selbst noch der feinste Ban des Holzes zu erkennen ist. - In den Steinkohlen- und Braunkohlenlagern sind uns, wie wir bereits frïher gesehen haben (s. S. 303), riesige Massen dieses ungemein wichtigen Stoffes aus der Torzeit erhalten geblieben, und der Torf entsteht noch vor unsern Angen durch ein langsames Verkohlen von Pflanzenteilen (s. S. 113B).

c) Wie wir wissen, ist das Protoplasma ein stark eiweißhaltiger Körper. Die Bildung von Eiweiß geht aber nur beim Vorhandensein von Sticks tof $\mathrm{f}$ vor sich.

d) Wasser', Kohlenstoff und Stickstoff entweichen beim Verbrennen der Pflanzenstoffe in gasförmigen Verbindungen. Die zurïckbleibende A sche enthält die mineralischen Bestandteile des Pflanzenkörpers. An der Zusammensetzung dieser Stoffe sind nun sehr verschiedene chemische Grundstoffe oder Elemente beteiligt. Durch Versuche, die von zahlreichen Naturforschern viele Jahre hindurch angestellt wurden, ist jedoch erwiesen, daß zum Anfbau der Pflanze nicht alle in ihr gefundenen Elemente nötig sind.

e) Gewisser Elemente dagegen bedarf die Pflanze zu ihrem Gedeihen unbedingt. Diese sog. Nährstoffe sind anßer dem Kohlenstoffe, dem Wasserund Sauerstoffe (d. s. die Elemente des Wassers, $\mathrm{H}_{2} \mathrm{O}$ ), sowie dem Stickstoffe noch: Schwefel, Phosphor, Kalium, Calcium, Magnesium und Eisen.

2. Die Assimilation der Nïhrsalze. a) Daß die (grüne) Pflanze wirklich aus den genannten Elementen ihren Körper aufbaut, soll uns ein einfacher Versuch zeigen: Wir bieten einer Pflanze (außer der nötigen Wärme und dem notwendigen Lichte) nichts weiter als diese Stoffe in Form einfacher chemischer Verbindungen dar. $\mathrm{Zu}$ diesem Zwecke stellen wir eine "Nährlösung“ her, d. h. wir lösen in je einem Liter destillierten Wassers folgende "Nährsalze" in den angegebenen Mengen auf:

$1 \mathrm{~g}$ salpetersauren Kalk $\left(\mathrm{Ca} 2 \mathrm{NO}_{3}\right)$,

$0,25 \mathrm{~g}$ Chlorkalium (KCl), 
$0,25 \mathrm{~g}$ schwefelsaure Magnesia $\left(\mathrm{MgSU}_{4}\right)$,

$0,25 \mathrm{~g}$ saures phosphorsaures Kali $\left(\mathrm{KH}_{2} \mathrm{PO}_{4}\right)$.

Nachdem wir der Flüssigkeit noch einige Tropfen verdünnter Eisenchloridlösung zugesetzt haben, füllen wir damit ein großes, mehrere Liter fassendes Glasgefäi.

Vorher haben wir bereits in fenchten Sägespänen einige Maiskörner zum Keimen gebracht. Sind die Hauptwurzeln einige Centimeter lang geworden, dann befestigen wir einen Keimling mit Hilfe von etwas Watte so in dem durchbohrten Korke des Gefäßes, daß nur die Wurzeln in die Flïssigkeit tauchen. Stellen wir das Gefäß, nachdem wir es mit einem undurchsichtigen Stoffe umwunden haben (Schutz gegen sonst sich bildende Algen), an ein sonniges Fenster, so beginnt das Pflïnchen sich bald zu entwickeln. Bei regelmäßigem Ersatz des verdunsteten und verbranchten Wassers und öfterem Erneneru der ganzen Flïssigkeit wächst es nach und nach zu einer stattlichen Pflanze heran, treibt Blitten und - falls man für die Bestäubung sorgt - schließlich anch Früichte.

b) Vergleichen wir die Maispflanze mit dem winzigen Naiskorne, aus dem sie hervorgegangen ist, so miissen wir sagen, daß sie eine große Ienge von Pflanzenstoffen gebildet hat. Da der Pflanze aber nichts weiter zur Verfügung stand als Wasser und Nährsalze, sowie die Bestandteile der Luft (Sauerstoff, Stickstoff und Kohlensäure), so muß sie diese Stoffe zum Auf'bau ihres Körpers verwendet haben. Die kohlenstofthaltigen und zugleich verbrennlichen Stoffe nennt man nun - da aus ihnen der Körper der Tiere und Pflanzen, also der der Lebewesen oder Organismen aufgebaut ist -

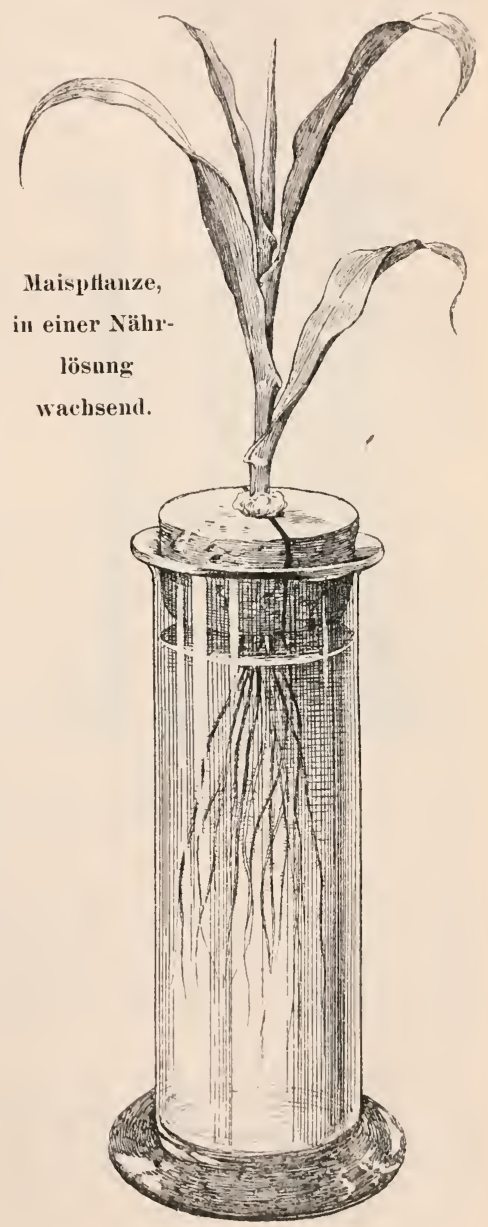


kurz: organische. Die Stotte dagegen, die den 'Tier-oder' Pflanzenleib niemals bilden können, werden darum als anorganische bezeichnet. Wir können von der Maispflanze daher mit anderen, kürzeren Worten auch sagen, daß sie aus ano rganischen Stoffen organische erzeugt hat. Sie hat diese, ihr fremdartigen Stoffe sich gleichsam : ahnlich gemacht oder assimiliert (assimilare = ähnlich machen). [)aher bezeichnet man diese Aneignung anorganischer Stoffe kurz als Assi milation. Würden wir zu unseren Versuchen andere (grüne) Pflanzen verwenden, so wïrden wir denselben wichtigen Torgang beobachten, der in Feld, Wald und Flur sich jahraus, jahrein in größtem Maßstabe vollzieht. - An der Maispflanze sehen wir anch, daf die im Wasser gelïsten Nährsalze mit Hilfe der Wurzel aufgenommen werden. Ein Gleiches geschieht - wie wir täglich beobachten können -bei der Mehrzahl der Pflanzen. (Wie dies geschieht, werden wir jedoch erst später sehen.)

3. Die Issimilation des Kohlenstoffs. a) Unsere Versuchspflanze bildete organische, d. h. kohlenstoffhaltige Verbindungen, ohne daß wir der Nührlïsung auch nur eine Spur von Kohlenstoff zugesetzt hatten. Aus der Nährlösung kann sie demnach den verbranchten Kollenstoff auch nicht erhalten haben. Da sie außer mit der Nährlösung nur noch mit der atmosphärischen Luft in Berïhrung gekommen ist, so müssen wir in ihr die Quelle des Kohlenstoffs vor uns haben.

Wie allgemein bekannt, besteht die Luft aus etwa 79 Raumteilen Stickstoff und 21 Raumteilen Sanerstoff, denen 0,03-0,04\% Kohlensäure (Kóohlendioxyd, (' $\mathrm{O}_{2}$ ) beigemischt ist. Die Kohlensäure ist ein farbloses Gas, das bekanntlich das Schäumen des Bieres, das Anfbrausen des Champagners und der kohlensauren Wasser (Selters u. s. w.) bewirkt. (Beweise die Gegenwart von Kollensäure in diesen Getränken und der Luft mit Hilfe von Kalkwasser!)

b) Wie die Aneignung des Kohlenstoffes erfolgt, soll uns wieder ein Versuch zeigen: wir bringen eine Anzahl Zweige der Wasserpest unter einen Glastrichter in ein Gefäß mit frischem Brunnenwasser. Über die Mündung des Trichters, die sich unter dem Wasserspiegel befinden $1 \mathrm{nu} \beta$, stïlpen wir sodann ein mit Wasser gefïlltes Probierglas und setzen endlich den Apparat dem direkten Sonnenlichte aus. Es währt nicht lange, so steigen von den Pflanzen Luftbläschen empor, die sich in dem Probierglase ansammeln und daraus schlieflich alles Wasser verdrängen. Ist dies geschehen, so schließen wir das Cilas unter Wasser mit dem Daumen, nelmen es aus dem Gefäße und führen einen glimmenden Span hinein. Da der Span sofort mit heller Flamme brennt, so kann das von den Pflanzen a usgeschiedene (ras nichts anderes als Sauerstoff sein.

Wie ist dieser Vorgang nun zu erklären? Lassen wir ein Glas mit Brunnenwasser eine Zeitlang ruhig stehen, so bedecken sich die Wände mit zahlreichen Luftbläschen. Setzen wir dem Wasser ein wenig Kalkwasser zu, so entsteht sofort ein weißer Niederschlag, ein Zeichen, daß die Luft, die dem Wasser beigemischt ist, Kohlensäure enthält. Indem nu die I'flanzen in unserem 
Versuche diese kohlensiimrehaltige Luft aufnehmen (wie dies geschieht, werden wir später sehen!), zerlegen sie zugleich die Kohlensäure in ihre beiden Elemente: der Sanerstoff wird ausgeschieden, der Ko h lenstoff dagegen z u r ii c kbeh a l t e n.

Daß diese Erklairung unzweifelhaft richtig ist, der Sauerstoff also durch Zerlegung der Kohlensïmre gewomnen wird, beweisen folgende Tatsachen: Ist in unserem Versuche die Entwicklung des Sauerstoffs eine Zeitlıng fortgegangen, so wird sie allmählich schwächer, bis sie schließlich ganz anfhört (die Kohlensaimre ist verbrancht!). Leitet man in das Wasser jetzt aber etwas Kohlensïure (durch /ugießen von ein wenig Selterswasser!), so beginnt die Sanerstoffausscheidung alsbald von neuem. ()der: bringt man Teile der Wasserpest in destilliertes, d. h. kohlensämrefreics Wasser (Nachweis!), so tindet eine Sauerstoffausscheidung iiberhaupt nicht statt.

c) Wie unsere Versuchsptlanze verhalten sich alle (grïnen) Gewächse der Erde; sie entziehen den zur Herstellungorganischer Körler nïtigen Kohlenstoff der atmosphärischen Luft und geben ihr den dabei freiwerdenden Sa uerstoff zurïck. Wenn man bedenkt, welch riesige Menge von Kohlenstoff schon ein einziger Wald in seinen Bänmen aufspeichert, und welche Massen davon täglich sämtliche Pflanzen der Erde der Luft entziehen,

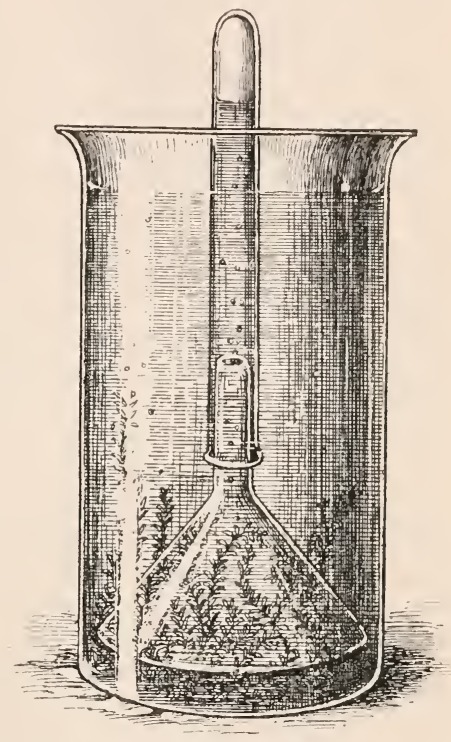

Sanerstolfausscheidung durch \%weige der Wasserpest. so - sollte man denken - mïbte

selbst dieses gewaltige „Kohlenstott-Lager"* schließlich er'schöpft werden. I'urch die Atmung und Verwesung der unzähligen Jillionen von Tieren (und Ptlanzen; s. S. 3!(0), durch das Verbrennen von Holz und Kohlen (Fabriken!) und durch die Tätigkeit der Vulkane wird der Verbranch jedoch immer wieder ausgeglichen, so daß der Kohlensäuregehalt der luft stets derselbe bleibt.

Ebenso verhält es sich mit der Sauerstuffmenge der Luft. Sie miißte infolge der Assimilation der P'flanzen bestïndig vermehrt werden, wenn nicht jedes Tier und jeder Mensch mit jedem Atemzuge etwas von dieser "Lebensluft" verbranchte, und wem nicht bei jeder Verbrenung und Verwesung Samerstofi gebunden wiirde. 
In der Naturindet also eingewaltiger Kreislauf der bei den wichtigen Gasarten statt. Beziehen wir ihn auf die Lebewesen, so müssen wir sagen: die Luftart, derer die Pflanze bedarf (Kohlensäure), atmen Tier und Mensch aus, and die, welche die Pflanze bei der Assimilation ausscheidet (Sanerstoff), ist für Tier und Nensch "Lebensluft". Ohne Pflanzenleben daher - kein Tier- und Menschenleben.

B. Nurgrïne Pflanzen und Pflanzenteile assimilieren.

Alle Pflanzen sind jedoch nicht imstande zu assimilieren. Setzen wir z. B. Kartoffelknollen oder Mohrriben in derselben Weise wie die Wasserpest dem Lichte aus, so tritt keine Sanerstoffausscheidung ein. Es findet also anch keine Assimilation statt. Oder ein anderer Versnch: Setzen wir einen Maiskeimling in eine Nährlösung, der jedoch das Eisen fehlt, so entwickelt sich antangs ein gesundes Pflänzchen. Nachdem das dritte oder vierte Blatt entfaltet ist, stellen sich aber Krankheitserscheinungen ein: die sich jetzt bildenden Blätter bleiben vollkommen weiß, und das Pflänzchen wird immer schwächlicher, bis es schließlich eingeht. Wie die mikroskopische Untersuchung zeigt, sind in den bleichen Blättern keine Blattgrünkörper zu finden. Setzen wir aber der Nährlösung einer zweiten „bleichsüchtigen" Versuchspflanze einige Tropfen verdünnter Eisenchloridlösung zu, so fangen oft schon nach zwei Tagen die weißen Blätter an, grün zu werden; nach wieder einigen Tagen sind sie bereits von anderen grünen Maisblättern nicht $z u$ unterscheiden, und nunmehr schreitet die Entwicklung der Pflanze ungehindert fort. Auf dünnen Querschnitten durch ein Blatt finden wir jetzt zahlreiche Blattgrïnkörper. Diese Versuche beweisen nicht nur, daß zur Bildung des Blattgrïns Eisen notwendig ist, sondern auch, daB die Assimilation an das Vorhandensein des Blattgrïns gebunden ist.

Alle grünen Teile der Pflanze (nenne solche!) vermögen also diese Arbeit zı leisten. Da nun die Lanbblätter besonders reich an Blattgrün sind, stellen sie auch die bei weitem wichtigsten Ernährungswerkzenge der Pflanze dar. Diese Erkenntnis macht es uns z. B. verständlich, warum Bäume eingehen („verhungern“), wenn sie durch Raupenfraß wiederholt alles Laub verlieren, oder wartum das in vielen Gegenden ïbliche Abblättern der Rüben die Pflanzen in ihrer Entwicklung hemmt u. s. w.

1. Die Teile der grünen Pflanzen, die des Blattgrüns en tbehren, vermögen daher auch nicht, anorganisches Material in organisches überzuführen. Die IVurzeln, die Blumenblätter, die mit dicker Borke umkleideten Stämme $\mathfrak{u}$. dgl. müssen daher von den grünen Teilen ernährt und von den dort bereiteten Stoffen aufgebaut werden.

2. In derselben Lage befinden sich auch die blattgrïnfreien (oder sehr blattgrünarmen) Pflanzen. Sie sind genötigt, die zum Leben und Aufbau ihres Körpers notwendigen Stoffe in assimiliertem, fertigem Zustande aufzunehmen. Daher sind diese Pflanzen Schmarotzer oder Fäulnisbewohner, wie 
wir das an den Pilzen, sowie an den bleichen Gestalten ans der großen $\mathrm{Ab}$ teilung der Blïtenpflanzen gesehen haben, an der Flachsseide, dem Fichtenspargel, der Nestwurz n. a. - Eine Ansnahme von dieser Regel bilden jedoch, wie wir bereits frïher bemerkt haben (s. S. 349, d), gewisse Spaltpilze, die, obwohl ohne Blattgrün, doch imstande sind $\mathrm{zu}$ assimilieren.

3. Dies gilt endlich auch für die zahllosen Tiere und II enschen, die die Erde bevölkern. Keines dieser Wesen ist imstande, sich von Wasser, Nährsalzen und Kohlensïure zu ernähren. Alle sind auf die organischen Stoffe angewiesen, die von der grünen Pflanze bereitet werden. Der Kohlenstoff ist in der Natur also beständig auf einer Wanderung begriffen, die immer wieder nach dem Ausgangspunkte zurïckführt: ans der Kohlensäure der Luft geht er zuerst in die grïne Pflanze iiber, baut dann den Leib der Menschen oder der pflanzenfressenden Tiere anf, wandert weiter von den Pflanzenfressern in den Körper der Menschen und Fleischfresser und geht endlich in der von Mensch und Tier ausgeatmeten Kohlensäure wieder in die atmosphärische Luft zurück. Ohne Pflanzenleben kann es also auch aus diesem Grunde weder Tier- noch Menschenleben geben. - Diese Tatsachen machen uns auch verständlich, warum pflanzenreiche Gebiete stets ein reiches Tierleben haben und vielfach dicht von Ienschen bewohnt sind (Beispiele!), und warum umgekehrt die an Pflanzen ärmsten Gegenden des Erdballs (Wiisten, Polarzonen, Eisregionen der Hochgebirge) am wenigsten bevölkert sind.

\section{Die Assimilation erfolgt nur ion Lichte.}

Die grïnen Pflanzen sind jedoch wieder nur unter gewissen Bedingungen imstande zu assimilieren. Verwehren wir den Sonnenstrahlen, zu den Wasserpestpflanzen zu treten - wir brauchen nur die Hand vor das Gefäß zu halten oder es sonstwie zu verdunkeln -, so hört die Sauerstoffausscheidung, also die Assimilation, sofort auf. (Weitere Versuche, die diese Tatsache in noch größerer Deutlichkeit zeigen, s. S. 386 u. S. 388.) Ebenso wenig vermögen Pflanzen, die unter normalen Verhältnissen grün sind, diese wichtige Tätigkeit zu entfalten, wenn sie sich im Dunkeln entwickeln. Folgender Versuch wird uns dies zeigen: Wir lassen einige Maiskörner keimen, die wir zuvor genau gewogen haben, und setzen zwei davon wieder in je ein Glas mit Nährlösung. Beide Gefäße stellen wir nebeneinander (gleiche Lebensbedingungen!), überdecken aber das eine mit einem Pappkasten, so daß das Pflänzchen ohne Licht heranwächst. Nach einigen Wochen nelımen wir die Pflanzen aus den Gefäßen, trocknen sie (unter den gleichen Bedingungen!) und stellen ihr Trockengewicht fest. Es ergibt sich, daß die im Dunkeln gewachsene Pflanze an Gewicht verloren, die andere dagegen stark gewonnen hat. Demnach findet eine S toffvermehrung in der Pflanze, eine Assimilation nur in Gegenwart von Licht statt.

So wenig die Maschinen in den Fabriken selbst klopfen und hämmern, selbst spinnen und weben, selbst pressen und heben - - so wenig vermögen die Pflanzen also von selbst aus unorganischem Materiale organische Stoffe zu be- 
reiten. Wie die Maschinen jene Arbeiten nur leisten können, wenn sie durch die Krraft des Dampfes, des fließenden Wassers oder dgl. in Bewegung versetzt werden, so vermörren die blattgrïnführenden Zellen auch nur zn assimilieren, wenn sie von den Strahlen der Sonne durchlenchtet werden: die Zellen sind also die IV erkzeuge, derer sich die Soune bedient, um organische Stoffe zu bereiten. Ton der Sunne hängt somit alles Leben ab, das Pflanzenleben sowohl, wie das Tier- und Menschenleben. Mit Recht bezeichnen wir sie daher als die "Lebenserregerin", als — die "Mutter des Lebens". Ohne sie wäre die Erde ein in Eis erstarter, mubelebter Ball.

1. In dunklen Räumen (Höhlen und dgl.) vermögen daher auch keine grïnen Pflanzen zı gedeihen, während Schmarotzer und Fäulnisbewohner (Pilze im Holze der Bergwerke und dgl.) dort wohl leben köunen. Daher ist ferner der Pflanzenwuchs in engen Schluchten, am Grunde dichter Wälder, unter belaubten Bäumen (im Garten!) und dgl. umso dïrftiger, je weniger Lichtstrahlen ihren Weg bis zum Boden herab finden. Daher vermögen endlich auch die Pflanzen in solchen Zimmern nicht zu gedeihen, in denen sie oft kamm einen Sonnenstrahl erhalten (vgl. S. 392).

2. Die Tatsache, daß die blattgriinführende Zelle nur im Lichte organische Stoffe bilden kann, macht uns zahlreiche Einrichtungen im Bau der Pflanze leicht verständlich.

a) Pflanzenteile, die Blattgrïn besitzen (Beispiele!), finden sich n ur im Lichte. Stamm und \%weige als die Träger der wichtigsten Werkzeuge der Assimilation, der Blätter, erheben sich daher über den Erdboden.

b) Blattgrïn bildet sich nur in den ä Beren Teilen der Ptlanze, in die das Licht eindringen kann (untersnche daraufhin z. B. Stengel, Fruchtknoten, unreife Frïchte!).

c) Zellen, die Blattgrïn enthalten oder über solchen liegen, haben glashelle Wände, um dem Lichte den Eintritt in das Innere zu gestatten.

d) Sollen die Zellen der Lanbblätter alle durchlenchtet werden, so müssen sie in einer möglichst großen Fläche ansgebreitet sein. Die Blätter sind daher (bis anf wenige Ausnahmen) flächenförmige Gebilde, die sich mit Lichtschirmen vergleichen lassen.

e) Schattenpflanzen mïssen sich mit stark gedämpftem Lichte begnïgen. Dieser Nachteil wird zmmeist durch große und dïnne Blatter ausgeglichen; denn große Blattflächen vermögen auch ein große Anzahl von Lichtstrahlen aufzufangen, und dünne Blätter können selbst von schwachem Lichte noch durchlenchtet werden (zahlreiche Waldpflanzen). (Beobachte hierauf anch Pflanzen derselben Art an verschiedenen Standorten, z. B. Gartenbohne und Rotbuche!)

f) Die Blätter fangen die meisten Lichtstrahlen anf, wenn sie sich senkrecht zur Richtung des einfallenden Lichtes stellen (s. Abb. S. 44). VTichtig hierfür ist der Besitz eines langen, beweglichen Blattstiels, der die Blatttiache in diese Lage bringt und darin erhält (s. z. B. Weinstock). 
g) Am besten muß die Pflanze gedeihen, wenn a 11 e Blätter die ihnen obliegenden Arbeiten erfïllen. Dazu ist aber notwendig, daß auch alle des Lichtes teilhaftig werden. Wie wir bei der Betrachtung der einzelnen l'flanzen bereits gesehen haben, wird dies durch sehr verschiedene Mittel erreicht, die hier übersichtlich znsammengestellt sein mögen:

1. Die unteren Blätter der Zweige (Rolkastanie) oder der ganzen Pflanze (Seharbockskraut) sind vielfach gröber oder länger gestielt als die oberen, 2. Die unteren Zweige sind in der liegel länger als die oberen. Infolgedessen erhalten die Pflanzen eine pyramidenförmige Gestilt oder Krone (Fichte). 3. Blätter, die dem Boden aufliegen, sind zu einer Rosette georlnet (Wegerich). 4. Dasselbe gilt für die unteren Blätter vieler hochstengeliger Pflanzen; die anderen Blätter dieser Pflanzen richten sich immer steiler anf, je höher sie am Stengel stehen (Königskerze). 5. Älnliche Richtung besitzen die Zweige vieler Bäume (Schwarzpappel). 6. An wagerechten $\mathrm{Z}$ weigen werden die Blätten vielfach in eine Ebene gestellt. Da die Blätter zudem oft noeh verschieden grols uncl verschieden langgestielt sind, entsteht oft eine deutliehe Mosaik (Rolkastanie). 7. Einige Blätter sind unsymmetriseh, fügen sich daher leiehter aneinander (Linde). 8. Bei wagerecht liegenden Stengeln und Zweigen tritt vielfach eine Drehung der Stengelglieder ein (Gundermann). 9. Ebenso sind nicht selten Drehungen der Blattstiele zu beobachten (Weinstock). 10. Große Blätter sind oft tief geteilt, gelappt. aus kleineren Blättchen zusammengesetzt u. dgl. (Wurmfarn). Auf diese Weise werden für die unteren Blätter Lichtdurchlässe geschaffen, 11. Große Blätter sind am Stengel weiter anseinandergeriuckt als kleine (Kürbis und Gurke), 12. Die Blätter sind am Stengel gegenständig, krenzständig, quirlständig oder in einer Schraubenlinie angeordnet (s. S. 37l). In letzterem Falle finden sich auf jeder Schraubenwindung meist umso mehr Blätter, je sehmaler sie sind. oder anclers ausgedriickt: breite Blätter haben vielfach $1 / 2$ - oder $1 / 3-$ Stellung; schmalere 2/5- oder 3/s-Stellung u. s. w. (Weiden). (Gib zu den einzelnen Fällen weitere Beispiele an!)

\section{Die Assimilation und der feinere Ban des Lanbblattes.}

1. Die Zellschichten des Laubblattes. Stellen wir durch ein Laubblatt, z. B. vom Klee, dïnne Querschnitte her, so sehen wir bei mikroskopischer Betrachtung, daß das Blatt aus mehreren, dentlich voneinander getrennten Zellschichten aufgebaut ist. An der Obertläche breiten sich platte Zellen aus, die im Querschnitte rechtwinkelig sind. Sie stellen die sog. Oberhaut (Epidermis) des Blattes dar. Darunter findet sich eine Schicht langgestreckter Zellen, die wie die Pfähle eines Pfahl-oder Palisadenwerkes dicht nebeneinander stehen und die darum sog. Palisadenselicht bilden. An diese Schicht legen sich Zellen einer dritten Schicht. Sie sind von nnregelmäßiger Form und treten soweit auseinander, daß sich zwischen ihnen große luftgefïllte Räume (s. S. 367,3) wie in einem Badeschwamme tinden. Unter dieser "Sehw a m m schich t" folgt als AbschluB des Blattes nach unten endlich wieder eine $\mathrm{Oberhaut.} \mathrm{(Es} \mathrm{gibt} \mathrm{aber} \mathrm{auch}$ Blätter, bei denen die beiden mittleren Schichten eine andere Ausbildung zeigen.)

2. Das Blattgriil und dic Blattgriinkörper. a) Wie wir gesehen haben, ist die Assimilation an das Torhandensein von Blattgrïn oder Chloroplyyll gebunden. Die Träger dieses wichtigen Farbstoffes, die Blattgrün- oder ('hloro- 
phyllkörper (s. S. 361), tinden sich in großer Anzahl in den beiden mittleren Zellschichten. Besonders reich daran sind die Zellen der Palisadenschicht. Sie bilden daher das eigentliche "Assimilationsgewebe" und finden sich, ihrer Anfgabe entsprechend, dort, wo sie dem Licht am meisten ansgesetzt sind, nämlich an der Oberseite des Blattes. Der größere Reichtum an Blattgrün, den diese Zellen besitzen, macht uns auch verständlich, warum die Oberseite des Blattes in der Regel dunkler gefärbt ist als die Unterseite.

b) Säen wir Getreidekörner in einen Blumentopf, den wir mit einem Pappkasten überdecken, so entwickeln sich zarte, gelb gefärbte Pflänzchen, die auch

\section{H. $K$.}

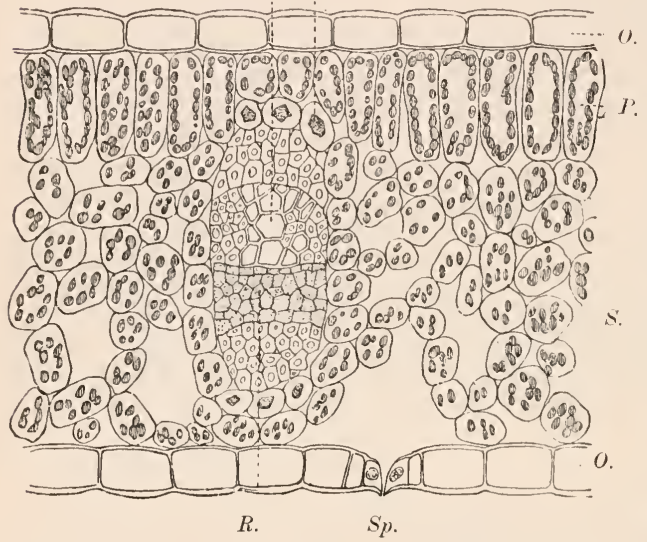

Querschnitt durch ein Laubblatt vom Klee. (). Oberhant; P. Palisadenschicht: S. Schwammschicht; H. und B. Holz-, bezw. Bastteil eines Gefäßbïndels (s. später); K. Zellen mit Kristallen von Kleesalz: Sp. Spaltöffinung. (Vergr. 320mal.) beilängerem Verweilen im Dunkeln nicht ergrïnen. Beseitigen wir aber den Pappkasten, so daß das Licht freien Zutritt zu den Pflanzen erhält, so ergrünen sie alsbald, ein Zeichen, daß (von einigen Ausnahmen abgesehen) das B lattgrïn unter dem Einflusse des Lichtes e $\mathrm{nts}$ e h t.

c) Das Blattgrün läßt sich leicht gewinnen, wenn man grüne Blätter (junge Getreidepflanzen) eine Zeit lang in Wasser kocht und sodann in heißen Alkohol legt. Setzt man einen Teil der gewonnenen Flüs-

sigkeit, die bei durchfallendem Lichte tiefgrün (bei anffallendem infolge von Flnoreszenz dagegen blutrot) gefärbt ist, dem direkten Sonnenlichte aus, so geht das Grün sehr bald in schmutziges Braun iiber. Der andere Teil der Lösung dagegen, den wir im Dunkeln aufbewahren, behält die grüne Färbung noch lange Zeit. Das Blattgrün wird also dnrch diegrellen Sonnenstrahlen zerstört.

Dieser Vorgang muß natürlich anch in der Pflanze eintreten. Da sie aber beständig grün erscheint, so un $\beta$ sich das Blattgrion in dem II a $\beta$, in dem es zerstört wird, fortgesetzt neu bilden. Ist die Zerstörung größer als die Neubildung, so begiunt die Pflanze zu kränkeln, 
bis sie schließlich zugrunde geht; denn ohne Blattgriin gibt es ja keine Assimilation.

Die grïnen Pflanzen müssen daher gegen ein (“bermal) von Licht ge $\mathrm{s}$ c h ü t z t sein. Besonders gilt dies fïr junge Blätter, die das Blattgrün nicht so schnell wieder ersetzen könnten, wie es zerstört werden würde. Bei ihnen finden sich daher in den Zellen vielfach (z. B. beim Kirschbaum, beim Rhabarber, bei der Rose und vielen anderen) r o t e F a r b t o ffe, die das Licht anfsangen und dessen zerstörende Krraft somit abschwächen. Ist das Blatt vollkommen ausgebildet, so macht die Rotfärbung den Schutzmitteln Platz, die dem Blatte wälrend des ganzen Lebens vonnöten sind, und die wir sofort kennen lernen werden.

\section{Die Oberhaut, ein Schutz-}

organ. Ritzt man die Oberhant eines Blattes (z. B. eines Liliengewächses) mit einer Nadel auf, so lassen sich Teilchen davon mit Hilfe einer Pinzette als zarte Hantstïckchen leicht abziehen. Inter dem Mikroskope erkennen wir dann, daß die Oberhantzellen die Form von Platten haben. Sie schließen stets so eng und fest aneinander, daß sie sich, wie wir soeben gesehen haben, nur als znsammenhängende Schicht, als eine feine Haut

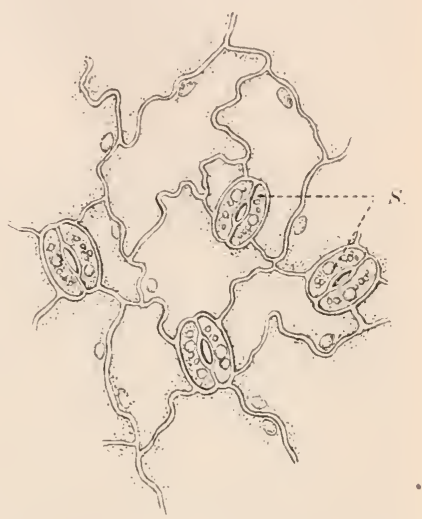

Ein stiock von der Oberlant eines Blattes des Alpenveilchens (Flächenansicht). $\therefore$ Schliebzellen der Spaltöftnungen: s. s. 383. (Vergr. $200 \mathrm{mal}$.) (Name!) von den darunter liegenden Zellen trennen lassen. Vielfach (z. B. bei der Kartoffel, dem Wurmfarn, dem Alpenveilchen u. v. a.) greifen sie noch durch Vorsprïnge und Einschnitte ineinander, so daß sie gleichsam "verzahnt" erscheinen.

Den Innenraum der Zellen nimmt zum weitaus größten Teile farbloser Zellsaft ein. Daher sind alle Teile, die von der Oberhant ïberzogen werden, wip von einem Wassermantel umgeben.

Die $A$ u B enwä $\mathrm{n}$ de sind, wie man an jedem Blattquerschnitte selien kann, stets verdickt und durch Einlagerung wasserdichter, fett ar tiger S to f fe ansgezeichnet. Die äußerste, an diesen Stoffen be-

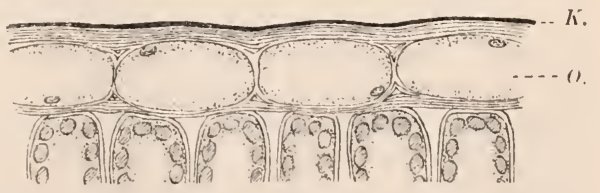

Querschuitt durch die Oberhant eines Blattes. O. Oberhant: K. Korkhäntehen. Inter der Oberhant Teile rou Zellen mit Blattgrünkörpern. (Vergr. 600mal.) 
sunder's reiche schieht erscheint als ein dïmes Häntchen (Korkhäntchen vder liutikula), das sich olne Unterbrechung iiber die ganze Anßenfläche der Oberhant himwegzieht. Setzt man einen Blattquerschnitte konzentrierte Schwefelsäure zu, so werden alle Teile anfgelïst. Nur das Häutchen bleibt zurïck, ein Zeichen fiir seine außerordentliche IViderstandstähigkeit.

Die Oberhaut ist also ein Gewebe von großer Festigkeit, und hierin liegt auch in erster Linie ihre Bedentung: ihre Zellen bilden gleichsam eine ..lebende Mauer", unter derem Schutze die anderen Bürger des „Zellstates" ihre friedlichen Arbeiten verrichten können. Tntersuchen wir dies nïher!

a) Die Assimilationswerkzenge, d. h. die Zellen der Palisaden- (und Schwamm-) schicht, sind außerordentlich zarte, dïnnwandige Gebilde. Jeder W i n dsto $B$ wiirde sie zerfetzen, und jeder leftig a ufschlagende Regentropfen vernichten, wenn sie nicht unter der widerstandsfähigen ()berhant Schntz fänden. Daher besitzen auch zahlreiche Tropenpflanzen, die täglich überaus heftigen Regengüssen ausgesetzt sind, eine so dickwandige Oberhaut, daß die Blätter lederartig erscheinen (z. B. Palmen). (Wie schïtzen wir dïnnwandige, leicht zerbrechliche (iegenstände?)

b) Lïgen die zarten Assimilationswerkzenge frei da, so wïrden sie in kuzer Zeit soviel Wasser durch Verdunstung verlieren, daß sie vertrocknen, d. h. ihre Tätigkeit bald einstellen müßten. Da sie aber, wie wir gesehen, unter einem Wassermantel liegen, und da die Außenhaut der Oberhautzellen durch Einlagerung fettartiger Stoffe für Wasserdampf nur wenig durchlässig ist, so vermögen zahlreiche Pflanzen selbst an sehr trockenen Orten zu bestehen (Beispiele!) Zı diesen beiden Schutzmitteln treten vielfach noch zahlreiche andere, die eine zu starke Verdunstung im allgemeinen zu verhindern haben, und die S. 396 zusammengestellt sind. (Wie halten wir Gegenstände fencht? Stelle mit Hilfe der Wage fest, wieviel Wasser ein geschälter, d. h. der Oberhaut beranbter und ein ungeschälter Apfel in einer gewissen Zeit durch Verdunstung verlieren!). - Pflanzen, die untergetaucht im Wasser leben (Wasserpest, Hornblatt 1. a.), sind der (iefahr des Vertrocknens nicht ausgesetzt. Sie haben daher anch uur eine sehr zarte (Iberhaut. Aus dem Wasser genommen, vertrocknen sie dementsprechend anch in ganz kurzer Zeit.

c) Die Assimilationswerkzeuge müssen - wie bereits erwähnt - auch gegen zu grelles Licht geschützt sein. Pflanzen, die an sehr sonnigen Orten geleihen (z. B. Känigskerze, Beifub, Edelweiß u. v. a.), sind vielfach mit Haardecken iiberzogen, die gleich den Fenstervorhängen als Lichtdämpfer wirken. Andere "Sommenptlanzen" (vor allen Dingen zahlreiche Gewächse des Mittelmeergebietes und der heißen Zone; Beispiele!) haben glatte, glänzende Blätter, 1. H. solche, deren Oberhant viele Lichtstrahlen zuriickwirft., (Wie schützen wir Gegenstände, z. B. Mäbelbezïge, Decken n. dgl., damit sie nicht bleichen, d. h. lamit die Farbstoffe in ihnen nicht durch die Sonnenstrahlen zerstört werden?) 
d) Wie alle Lehenserscheinungen der I'flanzen (und Tirre!) geht auch dir Assimilation nur hei einer gewissen Wirme vor sich. Sinkt die Temperatur zu tief, so stellen die Zellen ihre Tätigkeit ein (unsere l'flanzen im Winter!). Steigt sie zu hoch, damn geschieht dasselbe. (Lege Getreidekr̈rner etwa 15 Minuten lang in Wasser, das anf $60-70^{\prime}$ erwärmt ist. Die Körner keimen ausgesät nicht; ihre Keimlinge sind durch die hohe Temperatur getötet.) Da Wasser die Wärme sehr lange zuriickhält (Versuch!), so schïtzt der Wassermantel der Oberhaut die Assimilationswerkzenge besonders nachts gegen zu starke Abkühlung, und da er zahlreiche Wärmestrahlen einsangt, an heißen Tagen gegen zu große Frwärmung. (Wie sehiitzen wir Gegenstände gegen zu schnellen Wirmeverlust oder gegen zu starke Erwärmung?)

4. Die Durchlifitung der assimilierenden I'flanzenteile. Wir haben gesehen, daß der gesamte Kohlenstoff des Ptlanzenkörpers aus der Kohlensäure der atmosphärischen Luft stammt. Die Luft enthält aber - wie gleichfalls schon frihher bemerkt wurde - nur etwa $0,03-0,04 \%$ dieses Gases, d. h. in 100001 Luft sind nur 3-41 Kohlensänre im Gewichte von etwa $7 \mathrm{~g}$ enthalten. Davon entfallen aber wieder nur $3 / 11$ des Gewichtes anf den Kohlenstoff, d. h. also $21 / 11$ oder noch nicht ganz $2 \mathrm{~g}$. Um diese geringe Menge von Kohlenstoff zu gewinnen, muß die Pflanze also 10000 I Luft von ihrer Kohlensäure befreien. Sicher eine gewaltige Arbeit! Wenn wir nun bedenken, wievielmal $2 \mathrm{~g}$ Kohlenstoff schon in einer mäßig großen Pflanze (Kartoffel!), geschweige denn in einem Waldbaume aufgespeichert sind, so können wir uns ungefähr eine Vorstellung davon machen, welche riesige Luftmenge die Pflanze gleichsam "verarbeiten* muß, um den wichtigen Rohstoff zu gewinnen.

Die Zellen, die diese Arbeit zu leisten haben, können daher nicht eng genug mit der atmosphärischen Luft in Berïhrung kommen. Da aber - wie wir soeben gesehen haben - die zarten, leicht verletzlichen Werkzenge nicht frei daliegen dürfen, so mu $\beta$ die L uft in das Innere der Pflanze eintreten können.

a) Die Oberhaut der grïnen Pflanzenteile besitzt zu diesem Zwecke eine große Anzahl feinster 0 fffnungen, die man nach ihrer Form Spaltöffuungen nenut (s. Abb.S. 381). Sie werden von je zwei halbmondförmigen Zellen, den sog. Sch lie ßzellen, gebildet, die meist einige Blattgrïnkörper enthalten. (Näheres iiber diese Zellen und ihre Bedeutung s. S. 39.1). Da die grïnen Blätter die Hauptnahrungswerkzeuge der Pflanze bilden, so sind sie auch besonders reich an Spaltöffnungen. So besitzt z. B. ein mittelgroßes Kohlblatt etwa 11 Millionen und ein Blatt der Sommenrose gar 14 Millionen dieser winzigen (̈)ffnungen. (Führe solche Berechnungen aus, indem du feststellst, welchen Flächeninhalt das betreffende Blatt und wieviel Spaltöffnnngen es anf jedem Quadratmillimeter hat!)

Werden die Spaltöffinungen verstopft, so muß auch der Luftaustausch zum Stillstande kommen. Sie finden sich daher, gegen Tau und Regen wohl geschuitzt, in der Regel auf der Blattunterseite. Bei der Seerose und anderen Ptlanzen mit Schwimmblatternn dagegen sind sie auf die ()berseite angewiesen. 
Einrichtungen, die eine lïngere Benetzung des Blattes und damit einen Verschlnß der Spaltöffnnngen verhindern, werden wir später noch kennen lernen (s. S. $396, d)$.

b) Die durch die Spaltöffnungen eintretende Luft verteilt sich in den $\mathrm{Z}$ wische $\mathrm{nzellr}$ ä $\mathrm{nmen}$, so daß alle Zellen, die an diesen Kanälen liegen, von ihr umflossen werden. Da nun in den Zellen gleichfalls Luft enthalten ist, die aber eine etwas andere Zusammensetzung zeigt (denke an die Zerlegung der Kohlensäure!), so muß nach dem Gesetze der Osmose (s. S. 362) ein Austausch zwischen beiden "Lnftarten" stattinden. Infolge dieses Vorganges wird aber die Luft in den Zwischenzellräumen verändert, und darum muß anch durch die Spaltöffnungen ein beständiger Austansch von Außen- und Innenluft erfolgen.

c) Der Anstansch durch die Wände der Assimilationszellen geht nun umso schneller von statten, als sie - wie wir schon gesehen haben außerordentlich zart und dünn sind. Die mehrfach erwähnte Schutzbedürftigkeit dieser Zellen liegt also in ihrer Aufgabe begründet.

d) Je mehr die Blattzellen ansgebreitet sind, eine umso größere Oberflïche bieten sie anch der Lnft dar. (Wiederhole den S. 79, e angegebenen Versuch!) Die „flächenförmige" Gestalt der meisten Blätter ist also nicht nur für die Durchleuchtung (s. S. 378, d), sondern auch fïr die Durchlüftung von größter Wichtigkeit.

5. Die Blattnerven. a) Die Zellschichten des Blattes bilden für sich allein einen Körper von größter Zartheit. Sollen sie ansgebreitet sein, wie dies für die Erfüllnng ihrer Aufgabe durchans nötig ist, so bedürfen sie (besonders bei größeren Blättern) wie der Überzng des Regenschirms eines festen Gerïstes, zwischen dessen Teilen (Schirmstäben) sie ansgespannt sind. Dieses Gerïst stellen die Blattnerven oder Blattadern dar.

Für die sehr schmalen Blätter der Nadelhölzer genïgt schon eine einzige Längsstütze: ein Nittelnerv ohne Verzweigung. Bei den gleichfalls oft recht schmalen Blättern der einkeimblättrigen Pflanzen (Gräser, Lilien u. a.). finden sich - wie wir schon S. 370 geselien haben - in der Regel mehrere Längsnerven, die mit dem Hauptnerven, der Mittelrippe, parallel laufen. Bei den zweikeimblättrigen Gewächsen dagegen, die in der Regel breite Blätter besitzen, tritt durch den Blattstiel meist nur ein Hauptnerv ein, der sich wie ein Baum in immer feinere Zweige anflöst. Form, Teilung oder Zusammensetzung der Blattfläche stehen nun wieder mit der Art rer Verzweigung im innigsten Zusammenhange (führe dies näher aus!).

b) Die grüne Blattmasse kann ihre Aufgabe ảuch nur dann erfiillen, wenn sie durch den Wind nicht zerrissen wird. Diese Sicherung verleihen ihr gleichfalls die Nerven. Die Art und Weise, wie dies geschieht, ist im einzelnen sehr verschieden, stets aber so wirksam, daß man selbst nach einem Sturme die Blätter 
meist völlig unverletzt antrifft. (Beachte hierauf besonders die großen und zarten Blätter z. B. des Tabaks, der Walnuß und des Kürbis. Vgl. auch, was iiber diesen Gegenstand bei der Betrachtung des Birnbanms, des Roggens, des Schilfes, des Wurmfarns und der Banane gesagt ist!)

Wesentlich unterstïtzt werden die Nerven hierbei durch die Oberhaut, die am Blattrande stets erheblich verdickt ist. Durch diese Einrichtung erscheinen die Blätter wie ein Tuch oder eine Fahne gleichsam gesä umt. (Über die weitere Bedeutung und den Bau der Nerven s. später!)

E. Welche organischen Körper werden durch die Assimilation gebildet?

Wie die Assimilation im einzelnen verläuft, ist trotz der unablässigen Arbeit zahlreicher Forscher noch durchaus nicht vollkommen enthiillt. In den meisten Pflanzen ist das erste sichtbare Produkt dieses Vorganges ein Kohlenhydrat (s. S. 365), nämlich

1. die Stïrke. a) Die Stärke, wie wir sie im Hanshalte und zu gewerblichen Zwecken gebrauchen (führe dies näher aus!), gewinnen wir aus den Samen einiger Getreidearten (Weizen, Reis), den Knollen der Kartoffel, sowie aus den Stämmen (Sago-Palme) und den Wurzelstöcken einiger ausländischer Pflanzen. Bringen wir ein wenig Stärke in einem Wassertropfen unter das Mikroskop, so erkennen wir, daß sie aus winzigen Körnern zusammengesetzt ist, die je nach der Pflanze, aus der sie stammen, eine verschiedene Form zeigen. So bestehen die Stärkekörner der Kartoffel ans deutlichen Schichten
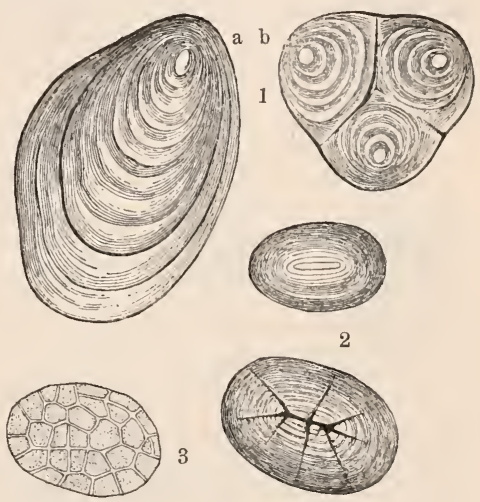

3

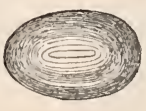

2

Stärkekörner: 1 der Kartoffel; a. einfaches, b. zusammengesetztes Korn. 2 der Bohne; das untere Korn ist - wie hänfig zu beobachten von Spalten durchsetzt. 3 Zusammengesetztes

Korn vom Hafer. (Vergr. etwa $550 \mathrm{mal}$.) um einen exzentrisch gelagerten

Kern. Die Stärkekörner der Getreidearten und Hülsenfrüchte dagegen (die man leicht zu sehen bekommt, wenn man von den durchschnittenen Frïchten oder Samen etwas "Mehl" abschabt) sind konzentrisch gebant. Zwischen den „einfachen" Körnern der Kartoffelstärke findet man auch zusammengesetzte, wie solche $z . B$. beim Hafer und Reis allein vorhanden sind.

Betupfen wir einige Stärkekörner mit einer Jodlösung, so färben sie sich alsbald heller oder dunkler blau bis blauschwarz. In der Jodlösung haben 
wir daher ein vorziigliches Erkennungsmittel der Stärke vor uns. Benutzen wir dieses Reagens, um die Stärkebildung in Blättern nachzuweisen!

b) Zu diesem Zwecke stellen wir eine Kapuzinerkresse, die sich ja leicht im Blumentopfe ziehen läßt, etwa 24 Stunden ins Dunkle und schneiden von ihr sodann einige Blïtter ab. Nachdem wir diese Blätter einige Zeit lang gekocht (Protoplasma wird getötet!) und ihnen durch Alkohol das Blattgrïn entzogen haben, bringen wir sie in eine stark verdünnte Jodlösung: sie bleiben farblos, ein Zeichen, daß sie keine Stärke enthalten. (Dieser Versuch ist zugleich ein Beweis dafuir, daß die Blätter im Dunkeln nicht assimilieren.)

Darauf stellen wir die Pflanze ins Freie und untersuchen an einem Nachmittage wieder einige Blätter auf dieselbe Weise: sie färben sich tiefblau, enthalten also reichlich Stärke. Die in das Blatt und deren grïne Zellen eintretende Kohlensäure ist - wie wir schon gesehen haben - in den Blattgrïnkörpern in ihre Elemente zerlegt worden, und der dabei frei werdende Kohlenstoff hat sich mit den Elementen des Wassers zu Stärke $\left(\mathrm{C}_{6} \mathrm{H}_{10} \mathrm{O}_{5}\right)$ vereinigt. Dieser Vorgang, der sich jedoch wahrscheinlich unter vorhergehender Bildung anderer Körper vollzieht, läßt sich durch folgende Formel ausdriicken :

$$
\begin{gathered}
6 \mathrm{CO}_{2}+5 \mathrm{H}_{2} \mathrm{O}=\mathrm{C}_{6} \mathrm{H}_{10} \mathrm{O}_{5}+\text { freiwerdender Sauerstoff). } \\
\text { (Kohlensäure }+ \text { Wasser }=\text { Stärke }+ \text { fres }
\end{gathered}
$$
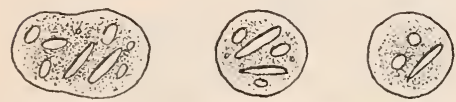

Blattgrïnkörper ans einem Moosblatte, in denen sich dureh Assimilation kleine Stärkekïrnchen gebildet haben. (Selır stark vergr.)

Bei mikroskopischer Untersuchung des Blattes sieht man, daß in den Blattgrünkörpern kleine Stärkekörnchen enthalten sind.

c) Wie die Formel zeigt, besitzt die Stärke genau dieselbe chemische Zusammensetzung wie die Zellulose (s.S.365), in der wir den wichtigsten Baustoff des festen Pflanzengerüstes, der Zellhäute, kennen gelernt haben. Außer in Zellulose geht die Stärke ebenso leicht noch in zahlreiche andere Stoffe über. Thre ganze Wichtigkeit lernen wir aber erst recht ermessen, wenn wir erfahren, daß sie auch an der Bildung des Lebendigen in der Pflanze, des Protoplasmas, beteiligt ist.

2. a) Die Eiweißstoffe, aus denen das Protoplasma vorwiegend besteht, enthalten außer Kohlenstoff, Wasserstoff und Sauerstoff, noch Stickstoff, Schwefel und häufig auch Phosphor. Diese zuletzt genannten Elemente werden in Form von Nährsalzen dem Boden entnommen und vereinigen sich in einer uns noch unbekannten Weise mit den Bestandteilen der Stärke, nachdem diese vorher in ein anderes (lösliches) Kohlenhydrat übergegangen ist.

b) Daß die Pflanze den Stickstoff, obgleich er $79 \%$ der atmosphärischen Luft ausmacht, im Gegensatz zum Kohlenstoff wirklich nur dem Boden zu entnehmen vermag, können wir mit Hilfe einer Maispflanze, die wir wieder in einer Nährlösung ziehen, leicht nachweisen. Setzen wir nämlich der Nährlösung 
statt des salpetersauren Kalkes (Ca $\left.\left.2 \mathrm{~N}_{3}\right)_{3}\right)$ schwefelsamen Kalk (Gips; $\mathrm{CaSO}_{4}$ ) zu, so entwickelt sich das Pflänzchen sehr kïmmerlich, um schon nach einigen Wochen abzusterben.

Einige wenige Pflanzen machen von dieser Regel jedoch eine Ausnahme. Wie wir bereits früher gesehen haben (s. S. 104 u. 349), sind die in den Knnöllchen der Schmetterlingsblïtler lebenden Wurzelbakterien, sowie die im Ackerboden sich findenden Stickstoffbakterien imstande, den Stickstoff der Luft aufzunehmen.

3. Audere Stoffr. Außer Stärke und Eiweiß werden in den ,Zell-Laboratorien" noch viele andere Stoffe gebildet, von denen hier nur die wichtigsten kurz genannt werden können. In zalhlreichen Pflanzen, besonders in der Zuckerrühe und im Znekerrohr findet sich der Rohrzucker (Name!), als wichtiger Baustoff. Die saftigen Früchte z. B. unserer Obstarten verdanken dem Traubenzucker (Name!) ihre SüBe, während Wein-, Apfel- und Zitronensäure ihnen den erfrischenden Gesehmack verleihen (Bedeutung für die Verbreitung der Samen!). Oxal-oder Kleesäure, ein wichtiges Schutzmittel zahlreicher Pflanzen gegen Tierfraß, kommt, an Kalk gebunden (Kleesalz), z. B. im Sauerklee nnd in den Ampferarten vor. Vielfach schlägt sich das giftige Salz in Form von Nadeln oder Kristallen (s. auch Abb. S. 380 ; K.) aus dem Zellsaft nieder (s. Aronstab!). Sehr reich an Gerbst of fe $\mathrm{n}$ ist die Rinde der Eichen. Fette sowohl, als fette öle (d. s. Fette, die bei gewöhnlicher Temperatur flüssig sind) treften wir als wichtige Baustoffe in den Samen oder Früchten von Raps, Lein, Mohn, Olive, Ölpalne und vielen anderen Pflanzen an. Flü chtige oder ätherische öle, die im Gegensatz zu den fetten Ölen auf Papier keinen bleibenden Fettfleck hinterlassen, verleihen zahlreichen Blüten und Früchten ihren Duft (Bedentung?); aber auch manche Blätter sind reich daran (Thymian, Bohnenkraut u. a.). Außer diesen Stoffen haben wir noch (in welchen Pflanzen?) angetroffen: Gummi, Pflanzensehleime, Farbst offe, Alkaloide (Nikotin, Coffein, Opium u. v. a.), Bitterst offe u. dgl, mehr.

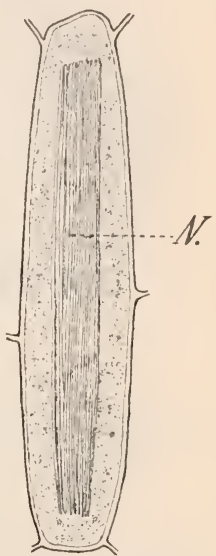

Nadeln aus Kleesalz in einer Blattzelle des Aronstabes.

(Vergr. 200 mal.)

F. I)ie Wandernng, Verwendung und Anfspeicluerung der gebildeten stoffe.

1. Die Wanderung. Untersnchen wir einige Blätter z. B. der Kapuzinerkresse an einem warmen Sommertage mit Hilfe der Jodprobe, so finden wir sie sicher reich an Stärke. Darauf nehmen wir zwei gleichgroße Kork- oder Pappscheiben und befestigen sie durch Nadeln so auf beiden Seiten eines anderen Blattes, da $\beta$ sie sich genau gegenïber liegen. Auf diese Weise haben wir einen Teil der Blattfläche verdunkelt, so daß diese Stelle nicht zu assimilieren vermag. Unterwerfen wir nach zwei oder drei Tagen dieses Blatt der Jodprobe, so finden wir, daß die verdunkelt gewesene Stelle frei von Stärke ist. Die Blattnerven dagegen, die diese Stelle durchziehen, erscheinen bläulich, ein 
Zeichen, daß sie ein wenig Stärke enthalten. Da sich in diesem Teile des Blattes nun keine Stärke bilden konnte, muß sie in die Nerven aus benachbarten Zellen eingewandert sein.

Eine ähnliche Beobachtung machen wir an Blättern (derselben oder irgend einer anderen Pflanze), die bei Sonnenuntergang reich an Stärke waren, wenn wir sie am anderen MIorgen bei Sonnenaufgang wieder untersuchen: die Stärke ist ausgewandert. Da nun anch hier die Blattnerven wieder eine geringe Blantärbung annehmen, so geben sie sich abermals als die Wege zu erkennen, auf denen die Wanderung der Stärke erfolgt.
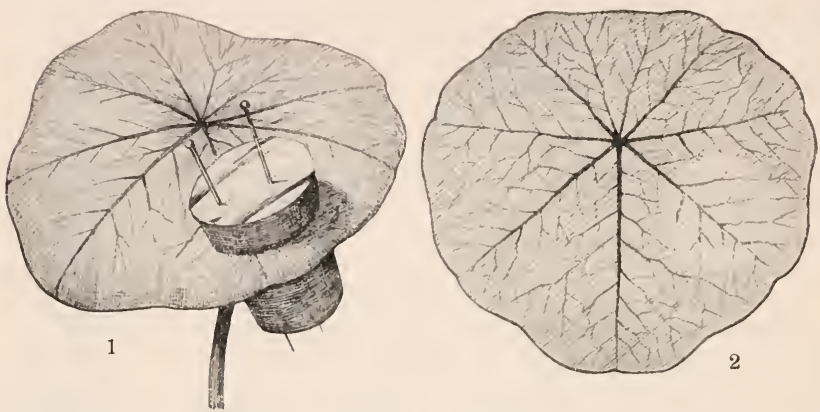

Blatt der Kapuzinerkresse. 1 Durch Korkscheiben teilweise rerdunkelt; 2 nach Entfernung der Korkscheiben und der Jodprobe.

Ein Teil der Stärke und aller anderen Stoffe, die sich in den Blättern gebildet haben, wird sicher dort anch verwendet. Daß aber der größte Teil auswandern muß, geht schon daraus hervor, daß an den Wachstumsstellen (in den Wurzelspitzen, Knospen, Blïten, Frïchten u. dgl.) fortgesetzt Baustoffe verbraucht werden, während die Bildung dieser Stoffe nur in den grünen Teilen und zwar vorwiegend in den Laubblättern stattfinden kann. Die wandernden Stoffe werden - denn einen anderen Weg gibt es nicht! - durch den Blattstiel (wenn vorhanden!) in den Stengel geleitet, in dem sie zu den wachsenden Teilen hinauf oder hinab geführt werden. (In welchen Teilen des Stengels dieses geschieht, werden wir später sehen!) Stellen sich den wandernden Stoffen Zellhäute in den Weg, so müssen sie aufgelöst werden, wie denn in lebenden Pflanzen die organischen Stoffe überhaupt vielfache Veränderungen, Umwandlungen and Zersetzungen erfahren („Stoffwechsel").

2. Die Aufspeicherung. a) Den Keimling, wie er aus dem Samen hervorgeht, sehen wir wachsen, bevor er noch grüne Blätter entwickelt hat, also ehe er zn assimilieren vermag. Einen ganz ähnlichen Vorgang beobachten wir im Großen alljährlich, wenn die Bäume und Sträucher sich neu belauben und die überwinternden Kräuter (Stauden) aus dem Erdboden hervorbrechen. Dieses Wachstum ohne Assimilation 
ist natïrlich nur möglich, wenn zur Bildung der jungen Pflanzenteile Baustoffe zur Verfügung stehen. Die assimilierende Pflanze darf daher nicht sämtliche Stoffe für sich verwenden, sondern ist genötigt, einen Teil davon für die Nachkommen oder die nächstjährigen Triebe aufzuheben, zu reservieren. Dies geschieht, sobald die Pflanze vollkommen ausgebildet ist; denn da sie jetzt nur noch wenig Stoffe für das eigene Wachstum verbraucht, die Blätter aber ihre assimilierende Tätigkeit fortgesetzt entfalten, ist sie auch imstande, diese "R eservest of f e " $z$ " bilden. Jedes Samenkorn wird damit beschickt, und die als Vorratsspeicher dienenden Wurzeln, Wurzelstöcke, Knollen oder Zwiebeln, sowie bei den Holzgewächsen die Stämme und Zweige beginnen sich zu füllen.

b) Reservestoffe sind uns bei der Betrachtung der einzelnen Pflanzen mehrfach entgegen getreten: Kohlenhydrate fanden wir als Stärke in den Körnern der Getreidearten und in der Kartoffelknolle, als Rohrzucker in der Wurzel der Zackerrübe oder, in F ette und $00 \mathrm{le}$ umgewandelt, in den Samen von Raps, Lein, Mohn und anderen Pflanzen; das Eiweiß trafen wir als Kleber in der änßeren Schicht der Getreidekörner; sehr reich daran und darum von hohem Nährwert sind vor allen Dingen die Samen der Hülsenfrüchtler (Bohne, Erbse, Linse u. a.). Um als Banstoffe für junge Pflanzen oder

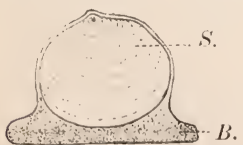

Stiirkebiliner (B.), der ein großes, von ihm gebildetes Stärkekorn (S.) nmschließt.

(Vergr. $5 \pm 0 \mathrm{mal}$.)

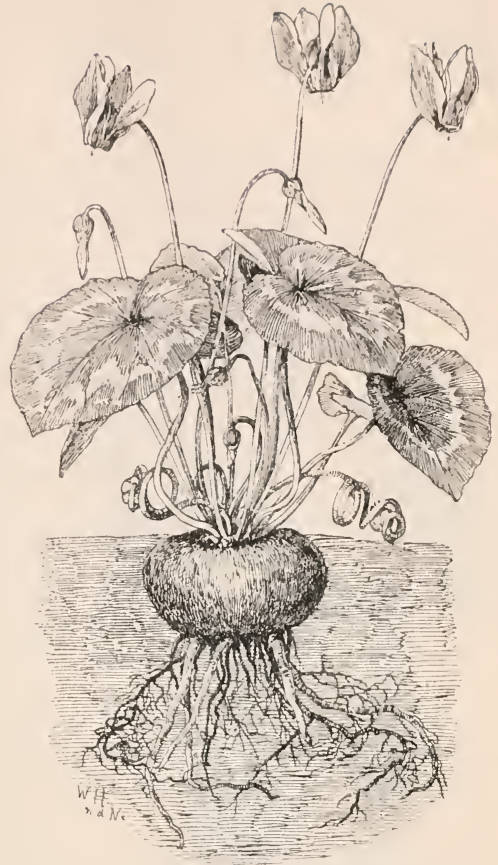

Alpenveilchen, eine Pflanze mit knollenförmigem Stamme, der als Vorratsspeicher dient (etwa $1 / 2$ nat. Gr.). junge Pflanzenteile dienen zu können, müssen die Reservestoffe aufgelöst, verändert oder umgewandelt werlen. Die Eiweißstoffe dienen - ihrer Natur entsprechend - zar Bildung des Protoplasmas, während Stärke, Zucker, Fette und öle sich namentlich in die ihnen ehemisch nahe verwandte Zellulose verwandeln, also den Banstofi für die Zellhänte liefern.

c) Füllt sich ein "Reservestoffbehälter", z. B. eine Kartoffelknolle oder ein Roggenkorn (s. Abb. S. 137 n. 249), mit Stärke, so mïssen die Stoffe, die in die Zellen der Knolle oder des Kornes eindringen, rückverwandelt werden. Hier- 
bei sind nun genan, wie bei der Bildnng der Stärke in den Blättern Farbstoffträger beteiligt (s. S. 361), kleine farblose Gebilde, die man hier als Stärkebildner bezeichnet. - Die Stärke, die wir in den Fabriken gewinnen, ist alles "Reservestärke".

3. Das Blatt als Werkzeng der Atmung und die Atmung der Pfanzen im allgemeinen.

1. Nachweis ler Atmung. Wir haben gesehen, daß die grïnen Pflanzen im Lichte Kohlensäure zerlegen und Sanerstoff ausscheiden. Findet, so muB man sich fragen, bei diesen Pflanzen im Dunkeln auch ein Gasanstausch statt, und wie rerhält es sich mit den Pflanzen und Pflanzenteilen, die des Blattgrüns

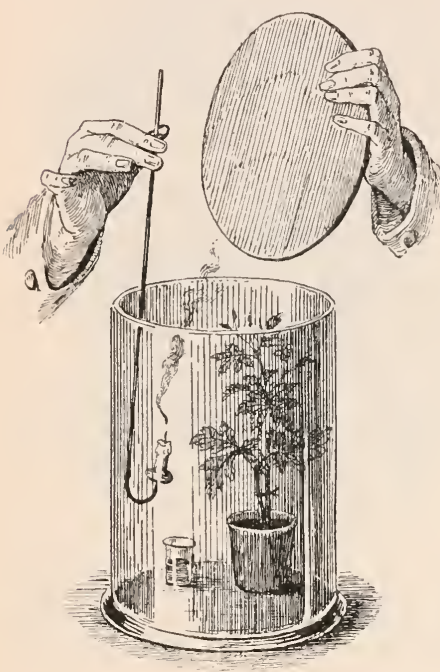

Vorrichtung, die Atmung der Pflanzen nachzuweisen. entbehren und darum nicht assimilieren? Die Antwort hierauf soll uns wieder der Versuch geben:

a) Wir nehmen 2 gleich große Glaszylinder, bringen in den einen eine grüne Pflanze, die in einem kleinen Blumentopfe wurzelt, verschließen beide luftdicht nnd stellen sie ins Dunkle. Nach einigen Stunden öffnen wir das Gefäß ohne Pflanze und senken ein Licht hinein, das wir an einem Drahte befestigt haben. Nachdem aller Sauerstoff der Luft, die das Gefäß erfüilt, verbrancht ist, erlischt die Flamme. (Stelle genan fest, wie lange das Licht brennt!). Wiederholen wir dasselbe bei dem 2. Gefäße, so erlischt die Flamme sofort, ein Zeichen, daß kein Sauerstoff mehr in der Luft vorhanden ist: die grüne Pflanze hat ihn aufgenommen.

Um festzustellen, ob die PHlanze fiï den aufgenommenen Saurstoff auch cine Luftart ausscheidet, wiederholen wir den Versuch, stellen aber auf den Boden jedes Gefäßes ein Schälchen mit Barytwasser. Nach Verlauf mehrerer Stunden sehen wir, wie sich das Barytwasser im leeren Gefäße kaum oder nur wenig, im Gefäße mit der Pflanze dagegen stark getrübt oder gar mit einer Haut überzogen hat: durch Aufnahme von Kohlensäure aus der Luft ist kohlensanres Barium (BaC $\left.\mathrm{C}_{3}\right)$ entstanden (Versuch mit ausgeatmeter Luft!). Die größere Menge dieses Salzes im 2. Gefäße konnte sich aber nur bilden, weil die von ihm eingeschlossene Luft mehr Kohlensänre enthielt als die im ersten Gefäße. Es hat in ihm also eine Vermehrung der Kohlensäure stattgefunden, die allein der Pflanze in Rechnung gesetzt werden kann.

b) Fïllen wir nunmehr einen Glaszylinder von etwa 1 l Inhalt zu einem 
Dritteil mit Pflanzenteilen, die des Blattgrïns entbehren (mit keimenden Erbsen, Blïtenknospen, sich entfaltenden Blïtenköpfen der Wucherblume, jungen Hutpilzen und dgl.), so können wir mit Hilfe des brennenden Lichtes und des Barytwassers ebenfalls feststellen, wie Saucstoft aufgenommen und Kohlensäure abgeschieden wird.

Dieser Vorgang ist nun genau derselbe, ohne den weder Mensch noch Tier zu leben vermag, und den wir als Atmung bezeichnen. Also: D)ie Pflanze - sowohl die griine, als die nichtgrïne - atmet gleichfalls.

2. Bedeutung der $\Lambda$ tmung. a) Wir haben gesehen, daß die bereiteten organischen Stoffe vielfach umgebildet, umgesetzt und verarbeitet werden inïssen, wenn sie der Pflanze wirklich von Wert sein sollen. Diese Arbeiten gehen aber, wie alle Arbeiten, nicht von selbst vor sich! Wie wir uns z. B. durch Verbrennen von Holz oder Kohle cine Kraft schaffen, die die verschiedensten Arbeiten verrichtet (Beispiele!), mïssen auch die P'flanzen fortgesetzt einen Teil der bereiteten organischen Stoffe zu diesem Zwecke „opfern" und Kräfte schaffen, die die "Maschine" ihres Leibes im Gange erhalten. Dies geschieht nun gleichfalls durch eine Verbrennung (Oxydation), d. h. durch eine Verbindung kleinster, kohlenstoffhaltiger Teilchen mit Sanerstoff, der aus der atmosphärischen Luft anfgenommen wird. Wie bei jeder Verbrennung ( $z$. B. der Kohlen) entstehen auch hier Kohlensäure nnd Wärme. Die Kohlensäure wird ansgeschieden; die Wärme aber ist die treibende Kraft für die chemischen Umwandlungen der Stoffe.

Unerwähnt soll aber nicht bleiben, daß gewisse Pilze, besonders spaltpilze, die in sauerstoffarmer Umgebung (Flïssigkeiten n. dgl.) leben, des Sanerstoffs nicht bedürfen, für die der Sauerstoff sogar „ein Gift" ist. Sie gewinnen die notwendigen „Betriebskräfte" durch andere chemische Umsetzungen, die sich in ihrem Körper vollziehen.

b) Daß sich infolge der Atmung wirklich Wärme entwickelt, sehen wir z. B. an den Blïtenkolben des Aronstabes (s. das.), sowie an der zusammengehäuften keimenden Gerste bei der Malzbereitung oder an anderen keimenden Pflanzensamen (Versuch!). In der Regel ist freilich von einer Wirmeentwicklung bei den atmenden Pflanzen nichts zu merken; denn erstlich besitzen die Pflanzen ja eine vernältnismäßig große Oberfläche, so daß sie anch viel Wärme an die umgebende Luft abgeben, und zweitens ist mit der Verdunstung des Wassers durch die Blätter (s. S. 393) eine große Wärmeabgabe verbunden. (Beweise die Richtigkeit beider Behauptungen durch einfache Versuche!)

c) Da in der lebenden Pflanze beständig Umsetzungen der Banstoffe stattfinden, muß auch die PHanze Tag und Nacht atmen. Für PHlanzen und Pflanzenteile, die des Blattgrüus entbehren, ist dies, wie wir gesehen haben, leicht nachzuweisen. An grïnen Pflanzen dagegen ist am Tage davon nichts zu erkennen; denn da in ihnen weit mehr organische Stofte gebildet als verbrannt werden, mïssen die Pflanzen anch weit kräftiger assimilieren als atmen. 
Die Atmung wird daher durch den ihr gerade entgegengesetzten Torgang der Assimilation verdeckt, oder - was dasselbe besagt - am Tage wird die bei der Atmung entstehende Kohlensäure sofort wieder zur Assimilation verwendet, so daß die grïne Pflanze im Lichte statt der Kohlensäure Sanerstoff „ansatmet".

Hindert man Pflanzen, organische Stoffe $\mathrm{zu}$ bereiten oder doch in genïgender Menge zu bilden, so müssen sie immer mehr an Gewicht verlieren. Dies beobachteten wir bereits an der Maispflanze, die wir im Dunkeln wachsen ließen (s. S.377, C). So „veratmen" auch Kartoffelknollen, Rüben und MIöhren während des Winters einen Teil der aufgespeicherten Stoffe. (Stelle dies durch wiederholtes Wägen fest!) Ans dem gleichen Grunde sterben auch die Zimmerpflanzen ab, die infolge zu schwacher Beleuchtung nicht genïgend assimilieren können: sie verhuugern langsam.

Ebenso nachteilig ist natürlich auch eine behinderte Atmung. So sterben z. B. die Pflanzen genau wie die Tiere den Erstickungstod, wenn man ihnen zu lange die "Lebensluft", den Sanerstoff, entzieht (Versuch mit keimenden Samen!). So sieht man - um ein anderes Beispiel anzufïhren - die Obstbäume nicht selten langsam eingehen, wenn sie zu tief oder in zu festes Erdreicl gepflanzt sind, wenn sie öfter unter Überschwemmungen zu leiden haben, oder wenn man deu Boden rings um sie hoch anfschïttet; denn in allen diesen Fällen können die Wurzeln der notwendigen Atemluft nicht teilhaftig werden. Umgekehrt ist ein öfteres Lockern des Bodens für das Gedeihen der angebauten Pflanzen (Kartoffeln, Rüben, Gemüse, Blumen) von Vorteil. Es ist besonders nötig, wenn die Pflanzen bei trockenem Wetter besprengt oder begossen werden müssen, weil dann die oberste Erdschicht leicht $z u$ einer Kruste erhärtet.

3. Wege fïr die Atemluft. Wie wir gesehen haben, findet in den grünen Pflanzenteilen zum Zwecke der Assimilation ein beständiger Gasaustausch statt, der seinen Weg vornehmlich durch die Spaltöffnungen und Zwischenzellräume nimmt. Mit der einströmenden atmosphärischen Laft erhalten auch die atmenden Zellen den notwendigen Sauerstoff, und auf dem gleichen Wege strömt nachts die ausgeatmete Kohlensäure ins Freie. Bei Stengeln, die mit einer Korklage bedeckt sind, ïbernehmen die Rindenporen (s. S. 426) die Aufgabe der Spaltöffunngen, und bei Wurzeln findet der Gasaustansch (in der Regel) durch die Häute der an der Oberfläche liegenden Zellen statt. Bei Wasser- und Sumpfpflanzen (Beispiele!) ist letzteres aber nicht möglich; denn sie wurzeln ja in einem Boden, der meist vollkommen von Sumpfgas erfïllt ist. Stengel und Blätter dieser Pflanzen besitzen aber so große Zwischenzellräume, daß sie ein schwammiges Gefüge annehmen. Da nun diese Räume Kanäle bilden, die sich durch die ganze Pflanze ziehen, so vermag die Atemluft leicht bis $z u$ den Wurzeln hinabzudringen. (S. Abb. S. 13, und wiederhole den mit der Wasserrose angestellten Versuch - s. S. $14 \mathrm{~d}$ - anch mit anderen Wasser- und Sumpfpflanzen!) 
4. Das Blatt als Werkzeug der Verdunstung des Wassers (oder der Transpiration).

1. Nachweis der Verdunstung. Legen wir unter eine Glasglocke einige frisch abgeschnittene, beblätterte Pflanzenteile, so beschlägt die Glaswand, besonder's wenn wir die Glocke „in die Sonne" stellen, bald mit Wassertropfen. Bei einer zweiten, dineben stehenden Glocke, unter der sich keine Pflanzenteile befinden, ist diese Erscheinung nicht zu beobachten. Das Wasser an der Glaswand der 1. Glocke muß daher aus den Pflanzenteilen stammen, und da sich auch dort Wassertropfen finden, wo die Pflanzen die Glocke nicht berïhren, so kann es nur in Form von Wasser d a p f ausgeschieden sein. Wie sich durch weitere Versuche feststellen läßt, findet bei allen lebenden Pflanzen, und zwar zn jeder Zeit eine Ausscheidung von Wasser in Dampfform, eine Verdunstung oder Transpiration statt.

2. Wie erfolgt die Verdunstung? Um dies nachzuweisen, bedienen wir uns des Kobaltpapiers*), das trocken tiefblan, Wasserdämpfen ausgesetzt (oder mit Wasser befeuchtet) dagegen hell rosa gefärbt exscheint. Nachdem wir uns von dieser Farbenveränderung überzeugt haben, legen wir auf eine trockene Glasplatte ein Stïck dieses Papiers, daranf ein Blatt etwa der Schwarzpappel oder des Flieders mit seiner Unterfläche, auf dieses wieder ein Stiick Kobaltpapier und bedecken alles mit einer zweiten Glasscheibe. Nach einigen Minuten sehen wir schon, wie sich das untere Stïck Papier verfärbt, ein Zeichen, daß dem Blatte anf seiner Unterfläche Wasserdampf entströnt. Das der Blattoberfläche anliegende Papier dagegen verfärbt sich nicht.

Untersnchen wir nunmehr die Oberhant des Blattes (s. S. 381), so sehen wir, daß die Blattoberseite wenig oder gar keine, die Unterseite dagegen sehr viele Spaltöffnungen besitzt, ein Zeichen, daß sie es sind, durch die der Wasserdampf entweicht. Bedenken wir, daß die Zellen, die an die Zwischenzellränme grenzen, zartwandige Gebilde sein müssen, die reichlich mit Zellsaft angefüllt sind, so werden wir die Erscheinung leicht verstehen : wie bei jedem fenchten Körper, verdunstet auch bei diesen Zellen beständig ein Teil des Wassers, das sie enthalten, oder von dem sie durchtränkt sind. Der sich bildende Dampf mischt sich mit der Luft, mit der er durch die "Tore" der Zwischenzellrüume, die Spaltöffnungen, ins Freie entweicht. - Da die Außenwände der Oberluautzellen nicht vollständig „luftdicht" sind, so findet anch durch sie eine, wenn auch viel geringere Verdunstung statt.

3. Bedeutung der Verdunstung. a) Wir haben gesehen, daß die Pflanze Wasser und darin gelöste Nährsalze dem Boden mit Hilfe der Wurzel entnimmt, und daß aus diesen Stoffen und der Kohlensäure der Luft besonders in den grünen Blättern organisches Material (Stärke, Zucker, Eiweiß u.s. w.) erzengt wird. Es muß daher von den Wurzeln nach den Blättern ein beständiger Wasser-

*) Dieses Papier gewinnt man, indem man Kobaltchlorür in Wasser auflöst (im Verhältnisse von 1:20), Streifen von Fließpapier damit tränkt und sie sodann trocknet. 
strom fließen. Welchen Weg dieser Strom in Wurzel und Stengel einschlägt, wollen wir hier anßer acht lassen (s. S. 422). Wohl aber miissen wir feststellen, wie die Wasserleitung in den Blättern erfolgt. $\mathrm{Zu}$ diesem Zwecke stellen wir abgeschnittene Stengelteile mit weißen Bliiten (z. B. Tulpen) oder weißfleckigen Laubblättern (z. B. die Spielart vom Mais, die vielfach als Zierpflanze benntzt wird) in ein Gefäß mit Wasser, in dem etwas Eosin gelöst ist. Nach einiger Zeit sehen wir, wie die lebhaft rote Farbstofflösung in den Blattnerven emporsteigt und sich in den Seitenzweigen der Hauptnerven immer weiter über die Blattfläche verbreitet. Wie die Röhren einer Wasserleitung jedem Haushalte das nötige Wasser zuführen, so werden durch die immer feiner sich verzweigenden Blattnerven jeder einzelnen Zell-Werkstat t Wasser und Nährsalze zugeleitet. Das Blatt gleicht also - um einen anderen Vergleich zu benutzen - einer Wiese, die planmäßig bewässert wird. (Stelle nunmehr die dreifache Bedentung der Blattnerven ïbersichtlich zusammen! s. S. 384 u. 388!)

b) Das Wasser, das von der Wurzel aufgenommen wird, enthält aber kaum mehr gelöste Bestandteile (Nährsalze) als gutes Trinkwasser. Da nun ein Teil von ihm durch Verdunstung beständig verloren geht, muß die „Nährlösung" in den Blättern verstärkt (konzentriert) werden. Gleichzeitig wird hierdurch Platz für nenes Wasser geschaffen, so daß ein ununterbrochener "Nahrungsstrom" zu den Blättern emporsteigt und immer neue Rohstoffe emporgehoben werden.

4. Größe der Verlunstung. a) Um festzustellen, welche Wassermenge ein bestimmter Pflanzenteil in einer gewissen Zeit verdunstet, stellen wir z. B. einen beblätterten Baumzweig in ein Glas mit Wasser. Nachdem wir die Oberfläche des Wassers mit einer etwa $1 \mathrm{~cm}$ hohen Ölschicht bedeckt haben, bringen wir das Ganze auf eine Wage. Nach einigen Stunden ist bereits ein erheblicher Gewichtsverlust festzustellen. Daß dieser Verlust nur auf die Verdunstung zurïckgeführt werden kann, die durch den Zweig erfolgt, beweist deutlich folgender "Kontrollversuch": wir füllen ein zweites Glas mit Wasser und öl, können aber bei wiederholter Wägung keinen Gewichtsverlust feststellen.

Wissen wir nun, welche Wassermenge der Zweig in einer gewissen Zeit, z. B. an einem Tage, verdunstet, so läßt sich dies durch Berechnung auch für den ganzen Baum ungefähr feststellen. So hat man z. B. gefunden, daß ein Buchenhochwald von einem Hektar Größe im Durchschnitt täglich etwa 30000 Liter Wasser an die Atmosphäre zurïckgibt, eine Tatsache, die uns den Nutzen der Wälder für die Regenbildung und damit für die Fruchtbarkeit eines Landes, sowie auch die Folgen der Entwald ung deutlich erkennen läßt. In jeder Pflanze steigt gleichsam ein unsichtbarer Wasserstrom vom Boden empor, Im sich in Dampfform in das Luftmeer zu ergießen.

b) Wie in allgemeinen, so wird auch die Verdunstung bei den Pflanzen von mehreren äußeren Umständen stark beinflußt. (Beweise dies für die einzelnen Fälle durch entsprechende Versuche und mit Hilfe der Wage!) 
Erstlich ist hierbei die Temperatur mit bestimmend. Je wärmer die Luft ist, je länger die Pflanze von der Sonne beschienen wird, und je steiler die Sonnenstrahlen auffallen (s. S. 44), desto größer ist anch die Verdunstung und umgekehrt.

Da der Wi nd die mit Wasserdampf gesättigte Luft beständig fortfülırt, so ist zweitens die Verdunstung bei windigem Wetter größer als bei Windstille (Trocknen der Wäsche n. dgl.!). Ähnlich wie bei einem Wasserzerstäuber der Luftstrom das Wasser emporsaugt, wirkt auch der Wind, wenn er über die Pflanzen dahinweht, sangend auf den Wasserdampf in den Zwischenzellräumen.

Drittens: wiez. B. Wäsche bei feuchter Witterung langsamer trocknet als bei trockenem Wetter, so verdunsten anch die Pflanzen umso weniger Wasser, je mehr die Luft mit Wasserdampf erfüllt ist.

Ist die Luft mit Feuchtigkeit gesättigt, so ist die Verdunstung daher ganz oder doch nahezn anfgehoben. Einige Planzen (Kapnzinerkresse, Mais, Weizen, Franenmantel, Erdbeere u. a.) vermögen sich dann dadurch zn helfen, daß sie Wasser in flïssiger Form aus Öffnungen hervorpressen, die den Spaltöffnnungen ganz ähnlich sind. Da diese "Wasser-

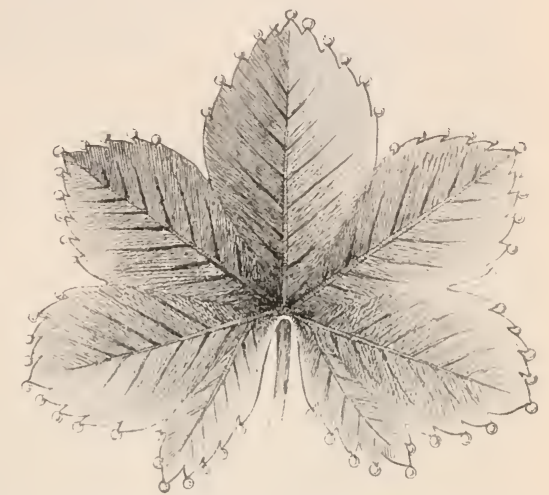

Wassertropfen, aus Wasserspalten hervorgepreßt, an den Zähnen vom Blatte des Frauenmantels (nat. Gr.) spalten" in der Regel am Ende eines großen Blattnerven (Wasserader!) liegen, so treten die ausgeschiedenen Wassertropfen, die gewöhnlich für Tan gehalten werden, meist an den Spitzen, Zähnen oder Rändern der Blätter auf. Stïlpt man über eine solche Pflanze eine Glasglocke, so daß die Verdunstung stark herabgesetzt wird, so kann man die Erscheinung auch am Tage beobachten, ein Zeichen, daß man es hier wirklich mit hervorgepreßtem Wasser zu tun hat.

5. Förderungsmittel der Verdunstung. Wie wir gesehen haben, ist die Verdunstung für die Pflanze von größter Wichtigkeit. Daher haben wir bei vielen der betrachteten Gewäclise auch Einrichtungen angetroffen, die imstande sind, die Verdunstung zu fördern, oder die verhinderı, daß sie unterbrochen werde.

a) Pflanzen, die an feuchten, schattigen Orten wachsen, haben in der Regel gro Be Blattflächen mit zahlreichen Spaltö̊fnungen (viele Sumpf- und Waldpflanzen).

b) Die Blätter dieser Pflanzen sind ferner meist a u Berordentlich zart, d. h. die 
Zellen der Oberhaut sind dünnwandig, also für Wasserdampf verhältnismäßig leicht durchlässig.

c) Die Blätter haben weiBe Flecke, die die Wärme lange Zeit zurückbalten (Wiesenklee, Lungenkraut), oder bra une Flecken, die sich leicht erwärmen (Orchis, Aronstab).

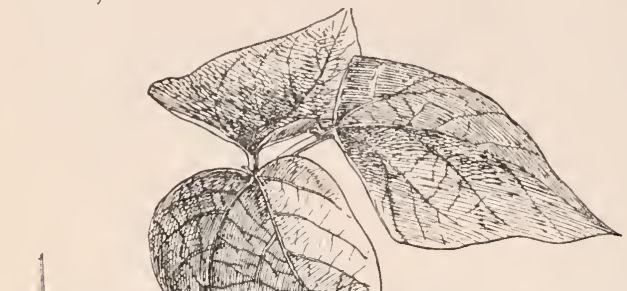

d) Tan oder Regen sind nicht imstande, die Spaltöffnungen zu verschließen, weil das Blatt (oder die ganze Pflanze) mit einer $\mathrm{Wa} \mathrm{chs}$ -

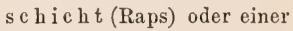
$\mathrm{H}$ a a r d e k e (Salweide) überzogen ist, oder weil die Spaltöffnungen in Verti efungen eingesenkt sind (Heidekraut).

e) Wie wir bei der Betrachtung der Gemüsebohne kennen gelernt haben, verhindert auch die Schlafstellung, die zahlreiche Blätter nachts annehmen, eine starke Befeuchtung durch Tau. Ergänzend sei hier nur noch bemerkt, daB diese Bewegungen in der Regel (Bohne, Klee, Robinie, Sauerklee u. a.) darauf beruhen, daß der Turgor (s. S. 363) der Blattstiele durch den Wechsel der Beleuchtung eine Veränderung erfährt. Wird der Turgor der Zellen, die an der Unterseite liegen, größer, so richten sich die Blätter empor; wird dagegen der Turgor an der Oberseite erhöht, so senken sich die Blätter.

6. Schutzmittel gegen zu starke Verdunstung. Umgekehrt ist eine zu starke Verdunstung für die Pflanzen mit großen Gefahren verknïpft: sie welken oder gehen schließlich durch Vertrocknen zugrunde. Die Gewächse, die auf einem wasserarmen, sonndurchglühten Boden leben oder austrocknenden Winden im hohen Grade ausgesetzt sind, also auf Hochgebirgen, Heideflächen und an ähnlichen Stellen wachsen, bedürfen daher gewisser Schutzmittel gegen diese Gefahren. Als solche haben wir bereits folgende Einrichtungen erkannt:

a) Die verdunstende 0 berflä che ist möglichst beschrän kt, d. h. es treten kleine, schmale, stark zerteilte oder wenige Blätter auf (Heidekraut, Leinkrant, Kuhschelle, Besenginster). Bei dem Heidekraute sind die kleinen Blätter zudem zusammengerollt (Rollblatt). Die Kaktusarten sind meist gänzlich unbeblättert. 


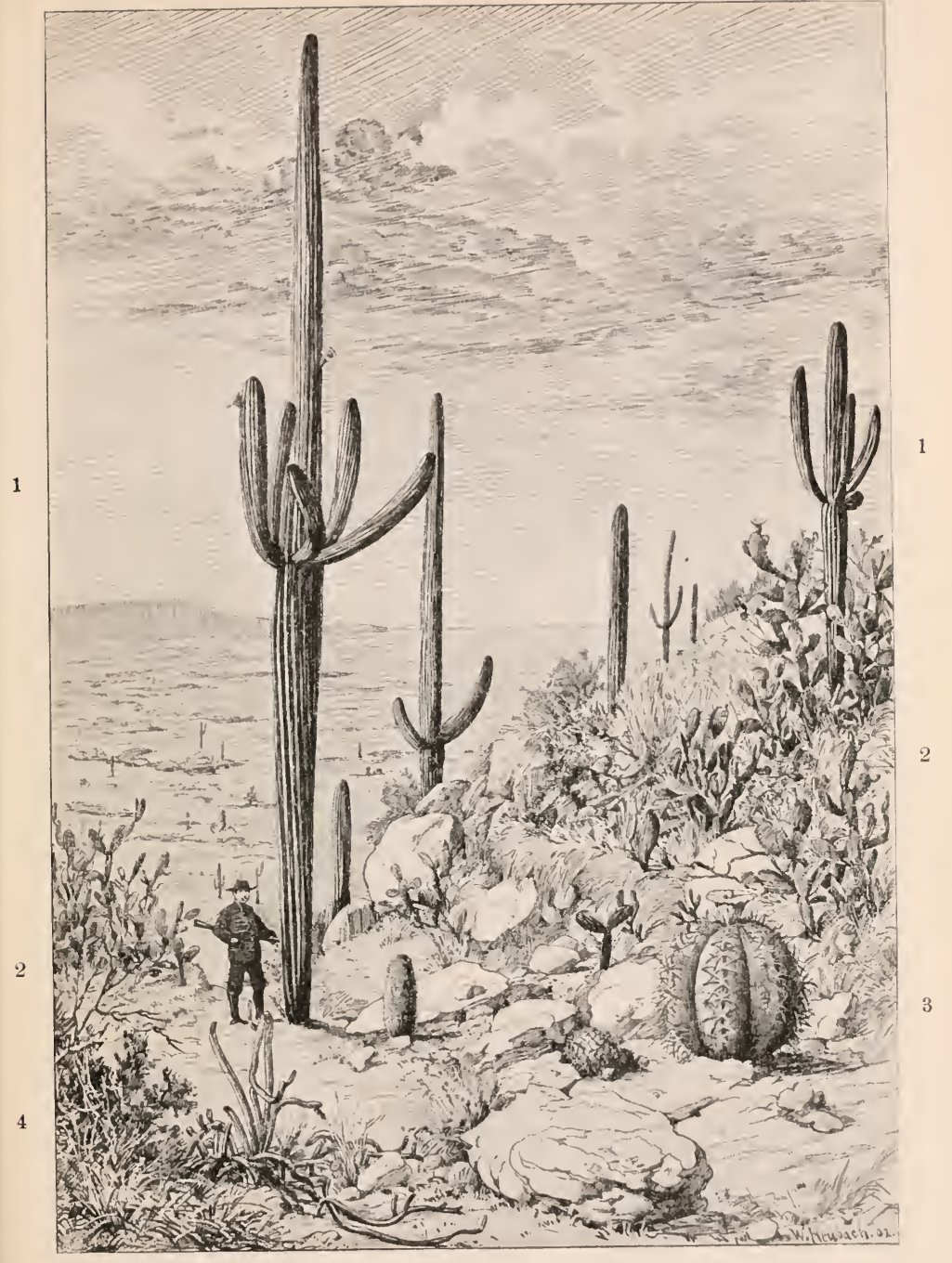

Kaktusgewächse in einer Wüste des nördlichen Mexico. 1 Riesenkaktus. 2 Fackeldisteln. 3 Mehrere Melonenkaktus-Formen. 4 Schlangenkaktus. (Näheres s. S. 80.) 


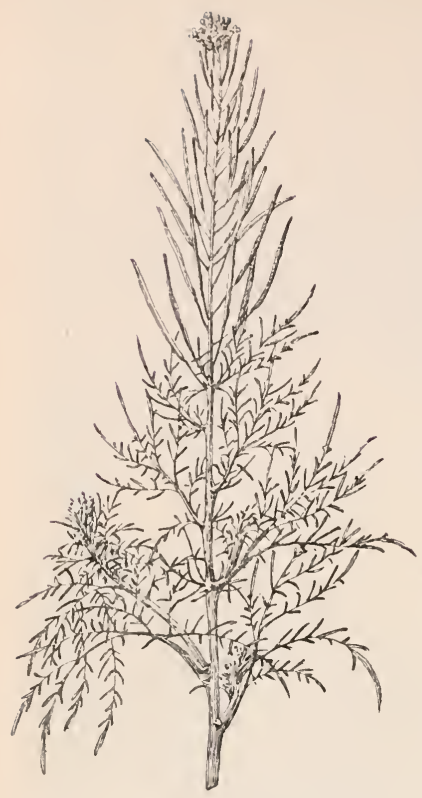

Schuttkresse, eine Trockenpflanze mit vielfach zerteiltem Laube. Oberer Teil (etwas verkl.). b) Mit der Verkleinerung der Oberfäche steht die geringe Anzahl der Spaltöffu ungen im Einklange.

c) Die Blätter sind dem Stengel ang e drü ckt (Heidekraut).

d) Die Blätter sind senkrecht gestellt (junge Blätter der Robkastanie) oder nehmen dabei wohl gar die Richtung von Süden nach Norden ein (Stachellattich).

e) Die Blätter schlagen sich bei zu starker Erwärmung $n$ ach unten (Sauerklce) oder rollen sich der Länge nach z us a men (Strandhafer).

f) Mehrere Trockenlandpflanzen (Mauerpfeffer, Kaktus; tropische Orchideen, die auf Baumstämmen wachsen) speichern in den Blättern oder Stämmen Wasser a uf.

g) Die Anßenwände der 0 berhat zellen sind stark verdickt und in so hohem IaBe mit fettartigen Stoffen durchtränkt (s. S. 381), daß sie für Wasserdampf fast undurchlässig sind (Efen, Kaktusarten).

h) Die Blätter sind mit einem $\mathrm{Wa} \mathrm{chs}$ ï berzuge versehen (Raps; anch viele Früchte, z. B. Weinbeere, Pflaume u, a.).

i) Die Blätter besitzen einen firnis a rtige u Überzug (junge Blätter des Kirschbaums; Knospenschuppen der Roßkastanie).

k) Die Blätter sind auf einer Seite oder auf beiden Seiten mit Ha a ren bedeckt (junge Blätter der Roßkastanie; Edelweiß u. v. a.). -

Die Haare sind, wie man auf Querschnitten durch den betreffenden Pflanzenteil sieht, in ihrer einfachsten Form Ausstülpungen je einer Oberbautzelle. Sie haben die Gestalt eines Kegels (Blumenblätter des Stiefmütterchens), Spießes (Goldlack) oder Zylinders (Samenhaare); sie sind gabelig oder sternförmig geteilt (Hungerblümchen; Graukresse), am Ende knopfförmig angeschwollen(Blüte des Löwenmauls) a. dgl. mehr. Kurze, zugespitzte, dickwandige

Haare bezeichnet man als Borsten (Schwarzwurz). Auch die Brennhaare (Brennnessel), die in einem aus Oberhautzellen gebildeten Becher sitzen, gehören hierher. Treten in den Ausstülpungen Teilungen ein, so entstehen mehrzellige Haare, 
die z. B. bei der Königskerze tannenartig verzweigte, bei der sog. ïlweicle sternförmige und bei den Farnen blattartige Gebilde darstellen. Sind an der Bildung dieser Auswüchse auch noch tiefer liegende Gewebe beteiligt, so entstehen Stacheln (Rose) oler Klimmhaken (Hopfen). Scheiden die Haargebilde klebrige oder andere Stofte ans, so bezeielnnet man sie als Drüsen-Haare (Körner-Steinbrech, Sonnentau u. v. a.). - Schon aus dieser Zusammenstellung geht hervor, $\mathrm{daB}$ die Haarbildungen den Pflanzen nieht nur als Verdunstungsschutz dienen, sondern eine sehr verschiedene $\mathrm{Be}$ dentung haben können (Beweis!).

1) Zu diesen uns hereits genügend bekannten Einrichtungen tritt bei den meisten Pflanzen noch die Fähigkeit hinzu, die Spaltöffnungen zu verschlieben, sobald Wassermangel eintritt. Legt man ein Stück von der Oberlaut z. B. eines Lilienblattes in einen Tropfen Wasser, so sieht man, wie sich zwischen den Schliebzellen (s. S. 383) deutlich wahrnehmbare Spalten befinden. Setzt man aber dem Präparate ein wasserentziehendes Mittel zu, z. B. einen Tropfen Glycerin, so verschwinden die Spalten alsbald. Woranf beruht diese eigentümliche Erscheinung?

Steht der Pflanze genügend Wasser zur Verfügung, so ist der Turgor wie in jeder Zelle auch in den SchieBzellen

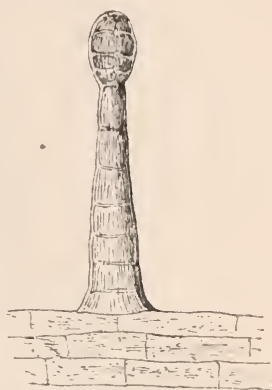

Mehrzelliges Driisenhaar yom Körner-steinbrech (110unal vergr.). verhältnismäBig groß. Da nun die Wände der Schließzellen ungleich dick sind, so müssen sie durch den Turgor auch nngleichmäßig ansgedehnt werden. Die größte Dehnung müssen natürlich die in der Abbildung mit a bezeichneten, langen und dünnen

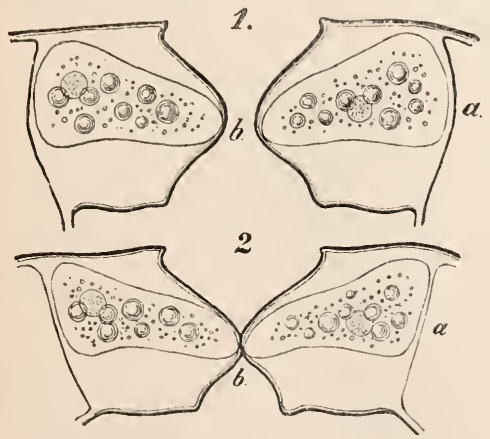

Spaltöffunng aus dem Blatte einer Nieswurz im Qnersehnitte (sehematisiert). 1 geöfinet;

2 geschlossen. Die Bezeichnungen s. Text.

Wandstellen erfahren. Hier werden die Zellen daher höher und naeh außen vorgebuchtet. Infolgedessen müssen aber die entgegengesetzten Zellseiten (bei b) etwas zurücktreten: der Spalt is t jetzt geöffnet. Sinkt bei starker Verdunstung der Turgor, so werden die Wandstellen bei a wieder kürzer und strecken sich gerade. Die Schließzellen werden infolgedessen flacher: $\mathrm{d}$ er $\mathrm{Spalt}$ wird daher immer enger, bis er sehlieblich ganz gesehlossen is t. Die SeblieBzellen, die in der dünnen Wandstelle b gleichsam ein Scharnier besitzen, führen also ganz ähnliche $\mathrm{Be}$ wegnngen aus wie ein Blasebalg, den man öfnet und schließt.

7. Herbstlicher Laubfall.'Wenn unsere Holzpflanzen im Herbste nicht mehr imstande sind, dem abgekühlten Boden die nötige Wassermenge zu entnehmen, dann schïtzen sie sich - wie wir bereits S. 91, c gesehen haben - dadurch vor dem Vertrocknen, daß sie ihr Laub abwerfen. Den friiher gegebenen Hitteilungen sei hier nur noch folgendes hinzugefügt: 
Stellt man durch ein solch abgefallenes Blatt dïnne Querschnitte her, so sieht man, wie die Zellen mit einer Flüssigkeit angefüllt sind, in der sich nur noch einige Öltropfen und Kristalle von oxalsanrem Kalke finden. Die wertvollen Stoffe (Stärke, Eiweiß u. a.) sind in den Stamm gewandert. Es geht also nicht viel mehr als das wertlos gewordene Skelett der Blätter verloren. Wie wir an diesen Querschnitten weiter sehen, beruht die herbstliche Rotfä rbung (z. B. beim wilden Wein) auf dem Vorhandensein roten Zellsaftes, die Gelbfärbung (z. B. beim Ahorn) auf den zerstörten, gelbgewordenen Blattgrünkörpern und die Braunfärbung (z. B. bei den Eichen) auf dem Braunwerden der Zellwände und besonders ihres Inhalts.

\section{Vom Bau und Leben der Wurzel.}

\section{A. Die Aufgaben und Hauptformen der Wurzel.}

1. Wie wir wissen, bant sich die grüne Pflanze unter Mithilfe der Sonnenstrahlen aus Stoffen auf, die sie der Luft (Kohlenstoff) und dem Erdboden (Wasser und darin gelöste Nährsalze) entnimmt. Ein Teil ihres Körpers streckt sich daher in die Luft dem Lichte entgegen, während sich ein anderer, d. i. die Wurzel, in die Erde hinabsenkt. Im Gegensatze zum Tiere, das sich seine Nahrung meist umherstreifend sucht, ist die Pflanze also an den Boden gefesselt.

Sollen aber die oberirdischen Teile vom Sturme nicht zu Boden geworfen so muß die Pflanze fest in der Erde verankert sein. Diese Aufgabe wird gleichfalls von der Wurzel erfüllt.

2. Je größer eine Pflanze wird und je mehr Blätter sie bildet, desto mehr Wasser verdunstet sie auch, und desto mehr ist sie den Angriffen der Winde ansgesetzt. Mit dem Wachstum der ganzen Pflanze muß daher auch die Vergrößerung der Wurzel gleichen Schritt halten. Umgekehrt: je weniger Blätter die Pflanze besitzt, desto geringer ist auch - immer gleiche Verhältnisse vorausgesetzt - ihr Wurzelwerk ausgebildet (Beispiele!). Gleichsam in eine „Nährlösung" eingesenkt sind die Pflanzen, die ganz unter Wasser leben (Wasserpest), oder deren Blätter sich doch unter Wasser befinden (Wasserfeder). Sie besitzen - wie wir bereits S. 382 gesehen haben - eine so zarte Oberhaut, daß sie imstande sind, die Nährstoffe mit ihrer ganzen Außenfläche aufzunehmen. Ihnen fehlen die Wurzeln daher entweder gänzlich (Hornblatt), oder sie dienen ihnen nur zum Festhalten im schlammigen Grunde (Wasserhahnenfuß). Im Gegensatz zu diesen Gewächsen haben die Trockenlandpflanzen meist mit Wassermangel zu kämpfen. Sie sind daher genötigt, ihre Wurzeln tief in den Boden zu senken (Kuhschelle, Wïstenpflanzen) oder sie über einen großen Bezirk auszubreiten (Kiefer). Diese Pflanzen lösen ihre Wurzeln daher zumeist auch in sehr viele und sehr diinne Zweige anf (Kiefer); denn je mehr dies geschieht, umso größer wird anch die aufsaugende Oberfläche (wiederhole den S. 79, c angegebenen Versuch). Sumpfgewächse dagegen, die gleich den Wasserpflanzen 
in einer "Nährlösung“" stehen, haben meist dicke, strangartige und wenig verzweigte Wurzeln (Sumpfdotterblume). Kurz: Di e Ansbildung der Wurzel steht mit dem Alter und der Lebensweise der Pflanze, sowie mit den Bodenverhältnissen im innigsten Einklange.

3. Wie wir bereits an der keimenden Bohne (s. s. 100) beobachtet haben, senkt sich die Wurzel, die den Stengel nach unten fortsetzt, die ${ }_{n} \mathrm{Ha}$ u $\mathrm{t}$ w urzel ${ }^{u}$, wie ein Pfahl in den Boden ( ${ }_{n}$ Pfahlwarzel ${ }^{\star}$ ). Von ihr gehen $\mathrm{nach}$ allen seiten Zweige a us, die wagerecht oder schräg nach unten verlaufen. Würden die Zweige mit der Hauptwurzel senkrecht in den Boden wachsen, so könnte die Pflanze nur eine viel kleinere Erdmenge auf die Nährstoffe hin ausbenten, und sie wäre bei weitem nicht so sicher im Boden befestigt als in diesem Falle. (Vergleiche die Pflanze mit einer Fahne, deren Iast in den Boden gerammt und durch seitliche Taue gehalten wird!) Da sich die \%weige in immer feinere Äste auflösen, so ist bald die ganze Erdmasse, die im Bereiche der Pflanze liegt, ron Tausenden und aber Tausenden feinster Saugwïrzelchen durchzogen („Wurzelballen“ der Topfgewächse!).

4. Wie wir beim Roggen beobaehtet haben und an vielen anderen einkeimblätrigen Pflanzen sehen kömnen, geht die Hauptworzel vielfach bald zugrunde Nebenwurzeln. die aus dem untersten oder einem der unteren Stengelknoten hervorbrechen, ïbernehnen dann ihre Aufgaben. Solche Wnrzeln können sich auch je nach Bedürfnis an allen anderen Pflanzenteilen bilden. Dies sehen wir z. B, an unterirdischen Stämmen (Taubnessel, Maihlume), an Ausläufern (Veilehen, Erdbeere), an Zweigen, die wir als Stecklinge in den Boden pflanzen (Nelke, Weinrebe) u. s, w.

5. Bei zablreichen, besonders tropischen Pflanzen bilden sich Wurzeln, die nicht oder doch erst sehr spät in den Boden eindringen. Solche "Luftwurzeln dienen dem Efen als Werkzeuge zum Anklammern (Klammerwurzeln); die merkwürdigen Mangrovebäume (s. S. 84) erhalten durch weit längere, 5 telzwnreln ${ }^{4}$ in dem Sumpfboden der Küstengewässer den nötigen Halt, und zahlreiche andere Bänme der heißen Zone senden von ihren weitausgreifenden Zweigen "Stützwurzeln ${ }^{\alpha}$, die oft die Stärke mächtiger Stämme erreichen, zum Boden herab (s. Abb. s. 402).

6. Bei wieder anderen Pflanzen haben die Wurzeln noch eine Nebenanfgabe übernommen: sie dienen als Vorratsspeicher für Baustoffe und schwellen daher meist stark an. Ist die Hauptwurzel die Ablagerungsstätte, so wird sie zur Rübe oder M öhre (Zuckerrübe, Möhre); sind es die Nebenwurzeln, so entstehen (Wurzel-)Knollen (Scharbockskrant, Georgine).

\section{B. Die Aufgaben und der feinere Bau der Wurzel.}

1. Das Wachstum der Wurzel. Die wachsende Wurzel dringt, ihren Aufgaben entsprechend, immer weiter im Boden vor. Wie dies geschieht, soll uns folgender Versuch zeigen. Wir lassen einige Samen der Fenerbohne in fenchten Sägespänen keimen. Nachdem die Keimwurzeln etwa $2 \mathrm{~cm}$ lang geworden sincl, tragen wir mit Tusche anf jeder von der Spitze ans zehn kleine Striche auf, die je $1 \mathrm{~mm}$ voneinander entfernt sind. Die Bohnen befestigen wir durch Nadeln anf der Unterseite eines Korkes, der anf eine weithalsige Flasche paßt. Um den Keimlingen die nötige Feuchtigkeit zu geben, haben wir schon vorhcr etwas Wasser in die Flasche gegossen. Nach ctwa 24 Stunden sehen wir, daß 


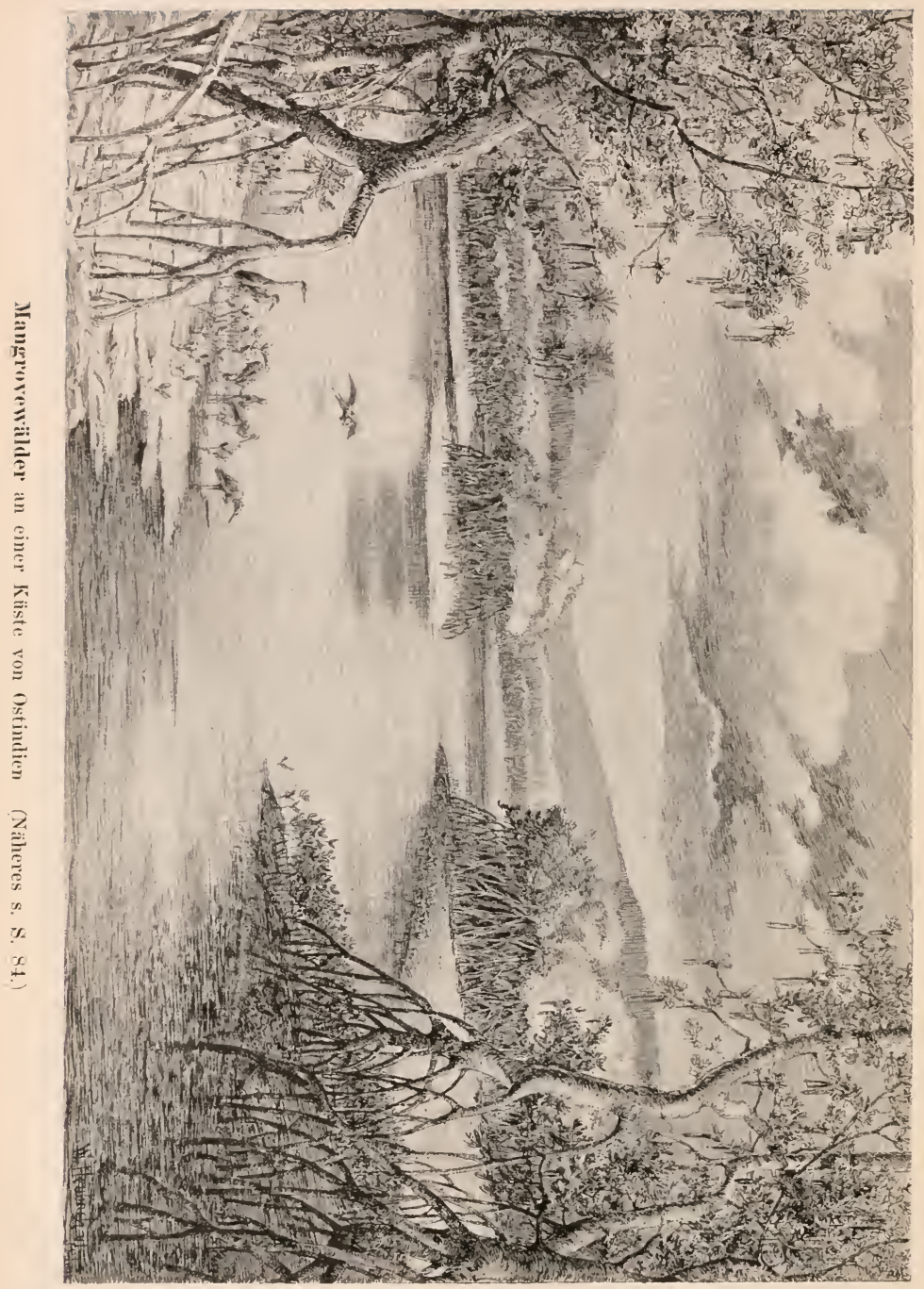


die Wurzeln beträchtlich gewachsen sind. Die Striche sind aber zum Teil nicht mehr gleichmäßig voneinander entfernt wie vordem: Der erste Strich ist von der Wurzelspitze allerdings nur wenig abgerückt; zwischen ihm und dem zweiten Striche, sowie zwischen diesem und dem dritten dagegen sind sehr große Zwischenräume entstanden; dann nehmen die Entfernungeu zwischen den einzelnen Strichen wieder stark ab, und die letzten Striche sind an ihrem Platze geblieben. Hieraus geht deutlich hervor, daß erstlich an den wachsenden Wurzeln sich nur die unteren Teile gestreckt haben, und daß zweitens die Streckung: nicht gleichmäßig gewesen, sondern an der Spitze schwach, dann stark und endlich wieder schwächer erfolgt ist. Ein Gleiches läßt sich an jeder wachsenden Wurzel beobachten: es ist ein nur verhältnismäßig kurzer Abschnitt hinter der Wurzelspitze in

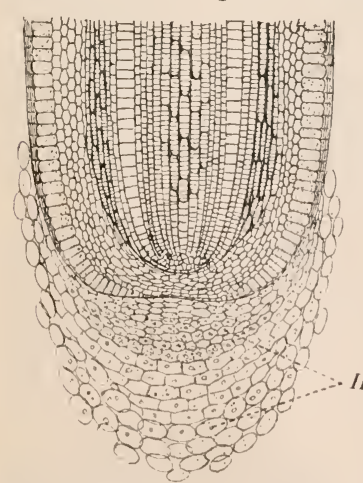

Wurzelluabe (H.) einer Maiswurzel (etwa $100 \mathrm{mal}$ vergr.).

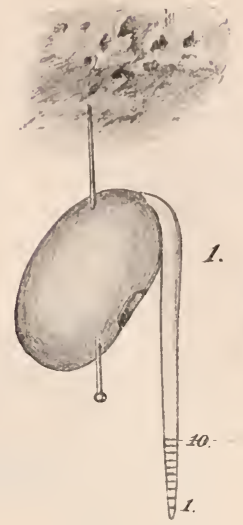

Wachstum der Wurzel. Die

keimende Feuerbohne ist durch eine Nadel an einem Kork befestigt.

Fig. 1: Wurzel mit aufgetragenen Tuschestrichen, die sich nach 24 Stunden durch Wachstum der Wnrzel so verschoben haben, wie

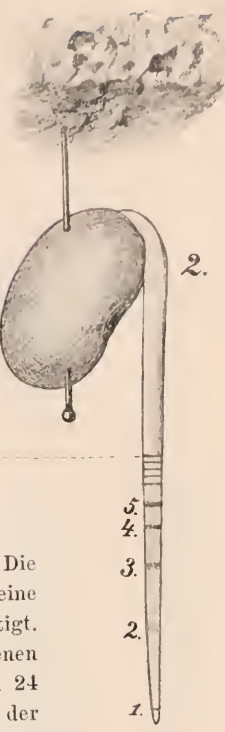
Fig. 2 zeigt. Streckung begriffen, der die Wurzelspitzegleichsam vor sich her schiebt.

2. Die Wurzelhaube. Die in den Boden gestoßene Wurzelspitze ist iiberaus zart, so daß sie an den Kanten der Gesteinstrümmerchen bald verletzt sein würde. Sie bedarf daher eines Schuttzes. Betrachten wir das Wurzelende bei schwacher Vergrößerung (am besten im Längsschnitt), so sehen wir, daß die Spitze von einem kappenartigen Gebilde bedeckt ist. Diese "W n r zelha u be" besteht aus festem II. Gewebe und hat etwa die Gestalt eines Fingerhutes, durch den die Näherin die empfindliche Fingerspitze gegen Verletzungen durch die Nadel bewahrt. Die äußeren Zellen der Haube, die von innen her immer wieder ersetzt 
werden, quellen nach und nach gallertartig auf. Infolgedessen ist die Wurzelspitze glatt und schlüpfrig, wie mit einem Schmiermittel bedeckt. Da sie zudem noch die Form ei nes Ir e gels (Nagels!) besitzt, so vermag sie leicht und ohne Schaden in dem Boden vorzudringen.

3. Die Wurzelhatre. a) Lassen wir irgend welche Samen zwischen feuchtem Fließpapier keimen, so sehen wir, daß die Wurzeln, wenn sie eine gewisse Länge erreicht haben, ïber dem sich streckenden Abschnitte mit vielen, außerordentlich zarten Härchen bedeckt sind. Stellen wir durch eine
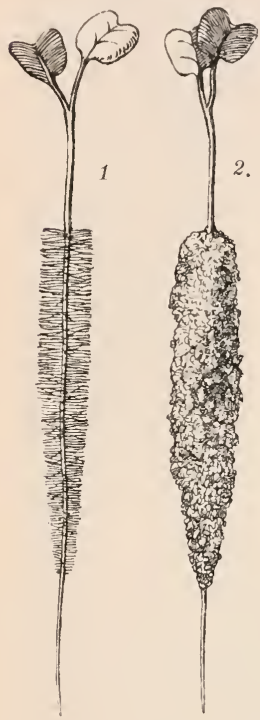

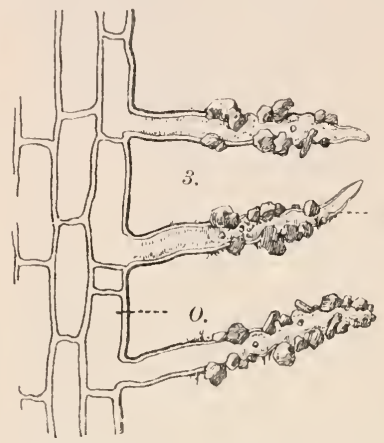

Wurzelhaare. 1. Keimptlanze vom weißen Senf mit Wurzelhaaren, 2, mit anhaftenden Bodenteilchen (nat, Gr.). 3. Wurzelhaare (Wh.) mit Bodenteilchen verklebt; 0 . Oberhautzellen (etwa 200 mal vergr.).

solche Wurzel dünne Qner- oder Längsschnitteher, so erkennen wir, daß diese, $\mathrm{W}$ u rzelha ar e" lange, schlanchförmige Ausstiilpungen der Oberhautzellen darstellen.

Nehmen wir sodannirgend eine Keimpflanze, die in einem Blumentopfe mit Gartenerde gezogen ist, aus dem Boden, so sehen wir, wie die Wurzelhaare dicht mit Erde bedeckt sind. Selbst durch Abspülen in Wasser gelingt es nicht, alle Bodenteilchen zu entfernen; denn die Wurzelhaare sind mit ihnen, wie ein Blick durch das Mikroskop zeigt, fest verklebt, glei chsam verwachsen. Diese Tatsache ist

b) nicht nur für das Festw urzeln der Pflanzen im Boden, sondern auch noch in anderer Hinsicht von größter Wichtigkeit: da die Würzelchen durch die Haare im Boden gleichsam verankert sind, kann die Kraft, die der in Streckung begriffene Wurzelabschnitt entwickelt, nur anf die Wurzelspitze wirken, so daß diese vorwärts getri ebe n werden m n B. Der Wurzelspitze müssen daher anch die Wurzelhaare fehlen.

c) Die Wurzelhaare stehen in hervorragender Weise aber anch im Dienste der anderen Aufgabe der Wurzel: der A ufnahmedes Wassers und der Nährsalze. Durch die Wanilung des Wurzelhaares sind 2 Flüssigkeiten verschiedener Stärke voneinander getrennt: der Zellsaft, der reich an Salzen 
und Säuren ist, und das Wasser des Borlens, das geringe Mengen von Năhrsalzen gelöst enthïlt. Zwischen diesen beiden Flüssigkeiten muf daher ein Austausch stattfinden (s. S. 362). Das Protoplasma, das die Flüssigkeiten durchdringen müssen, ist aber ein lebender Körper mit der Fähigkeit, nur gewissen Stoffen den Durchtritt zu gestatten. Es läßt aus dem Zellsaft nur geringe Stoff-Mengen austreten (s. Absch. g), dafür aber umsomehr Wasser und Nährsalze eintreten. Hierzu sind die Wurzelhare nun umso besser geeignet, als sie die Oberfläche der Wurzel nm ein Vielfaches vergrößern, mit den Bodenteilchen verkleben, sehr zarte Wandungen und die Form langer, dünner Schläuche besitzen. Sie durchdringen jede Lïcke des Bodens und sind imstande, selbst noch die geringste Wassermenge einzusaugen und das kleinste Bodenteilchen auf seine Nälırstoffe auszubenten.

d) Erfolgt die Aufnahme des Wassers und der Nährsalze unter günstigen Bedingungen, so ist eine Vergrößerung der aufsaugenden Wurzeloberfläche nicht vonnöten. Den Sumpf- und Wasserpflanzen (Sumpfdotterblume, Wasserlinse u. v. a.) fehlen daber meist die Wurzelha are. - Wie wir bereits gesehen haben (s. S 281), sind bei den Waldbäumen die Wurzelhaare in der Regel d urch Pilzfädcn ersetzt, die sich weit in dem lockeren Boden ansbreiten und die Wurzeln mit Wasser und Nährsalzen versorgen. Außer bei zahlreichen anderen Pflanzen findet auch bei den Heidegewächsen und vielen Orchideen ein solcher Ersatz statt. Diese Tatsache erklärt uns vollauf, warum liese Pflanzen trotz der sorgsamsten Pflege in unseren Gärten nicht fortkommen.

e) Nimmt man eine Pflanze aus dem Boden, so fällt von den älteren Wurzelteilen die anhaftende Erde leicht ab, ein Zeichen, daß ihnen die Wruzelhaare fehlen. Diese Gebilde sind, wie man in allen Fällen sieht, stets nur auf einen verhältnismäßig kurzen Abschnitt hinter der waclısenden Wurzelspitze beschränkt. In dem $\mathrm{Maße}$, in dem sie sich hier fortgesetzt neu bilden, sterben sie am entgegengesetzten Ende ab. Auf diese Weise kommt die Wurzel immer mit neuen Bodenteilchen in Berührung, denen sie die Nährstoffe noch nicht entzogen hat. Die älteren Teile der Wurzel unkleiden sich mit wasserdichten Korklagen, sind also zur Aufnahme von Wasser nnd Nährsalzen untanglich. (Erkläre, warum man die Pflanzen möglichst mit dem "Ballen" verpflanzen muß, und warum sie in den ersten Tagen nach dem Verpflanzen leicht welken!)

f) Zwischen der A us breitung der Wurzeln und der Art, wie die Pflanzen das Regenwasser a bleiten, besteht eine innige Beziehung (s. S. 88, c). Tropft das Wasser am Umfange der Krone nieder, ist die Wasserleitung also nach auben gerichtet oder zentrifugal, so breiten sich die Wurzeln allseitig so weit aus, dab die mit Wurzelhaaren besetzten feinsten Wurzelzweige im Umkreise der Krone liegen (dichtbelaubte Bäume, Königskexze n. a.). Fließt das Wasser dagegen nach innen oder zentripetal ab, so sind die Wurzeln mehr oder weniger senkreeht nach unten gerichtet und eng zusammengedrängt (Raps, Tulpe u. a.). - Bei dünnbelaubten Bäumen (Birke) sind die Sangwurzeln gleichmäBig unter der ganzen Krone verteilt. - Bei der Vogelmiere (s. S. 40) wird das Wasser durch Haarleisten am Stengel zur Wurzel geleitet (s. Abb. S. 406). Wasser- und Sumpfpflanzen, sowie viele Gewächse, die gesellig beicinander stehe, 
lassen das Wasser in keiner bestimmten Richtung von den Blättern abtropfen (warum nicht nötig?).

g) Welcher Art sind nun die Stoffe, die durch die Wände der Wurzelhaare nach außen dringen? Un dies zu erfahren, nelmen wir einen Blumentopf, der mit feuchtem Sande gefüllt ist, und lassen darin eine Bohne keimen. Vorher aber haben wir in den Sand einige Zentimeter tief eine kleine Marmorplatte gelegt, deren polierte Fläche nach oben gerichtet ist. Nach etwa 14 Tagen

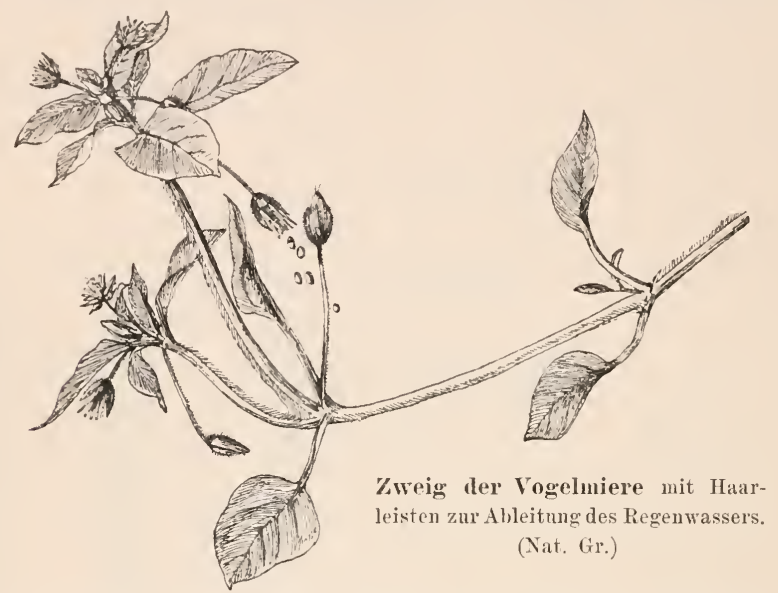

nehmen wir die Platte aus dem Sande hervor und reinigen sie sorgfältig. Dann erkennen wir, daß die Politur ïberall dort, wo die Wurzeln die Platte berührt haben, zerstört worden ist. Die Wurzeln haben also eine Säure ansgeschieden, die kohlensauren Kalk (Marmor) zu lösen vermag. Und wie Kalk, so dürften auch andere Bodenteilchen gelöst und zersetzt werden. Die Pflanze hilft also mit, die notwendige "Nährsalzlösung“ zu bereiten.

4. Die Diingung. Verwesen die Pflanzen dort, wo sie gewachsen sind, so werden dem Boden auch die Stoffe wieder zugeführt, die ihm von den Gewächsen entzogen worden sind. Anders ist dies aber z. B. anf Feldern und Wiesen, von denen alljährlich ganze Wagen voll organischer Stoffe entfernt werden. Diesem Boden müssen daher die für den Pflanzenwuchs wichtigen Stoffe (besonders stickstoffhaltige Verbindungen) wieder zngeführt werden. Dies geschieht durch die Düngung.

\section{Wie das Wachstum der Wurzel von der Schwerkraft beeinflußt wird.}

1. Sehen wir von Ausnahmen ab (Beispiele!), so beobachten wir bei allen Pflanzen, daß die Wurzeln, ihren Aufgaben entsprechend, in den Boden dringen. Diese Tatsache erscheint den meisten Menschen als etwas durchaus Selbstverständliches, das gar nicht des Nachdenkens wert ist. Daß dem jedoch nicht so 
ist, zeigt folgender Versuch: Wir legen einen Bohnenkeimling so in die durchfeuchtete Erde eines Blumentopfes, da 3 die 2-3 cm lange Hauptwurzel genau wagerecht gerichtet ist. Entfernen wir nach etwa 24 Stunden die Erdschicht, die den Keimling bedeckt, so sehen wir, daß das Wurzelende mit den älteren, nicht mehr wachstumsfähigen Teilen der Wurzel fast einen rechten Winkel bildet. Diese Krümmung kann nur dadurch zustande gekommen sein, daß sich der wachsende Wurzelabschnitt an der Oberseite stärker als an der Unterseite gestreckt hat. (Durch Auftragen von Tuschestrichen wie bei dem S. 403 beschriebenen Versuche noch deutlicher zn sehen!).

Die Wurzelspitze

hat also die Richtung, die wir ihr gegeben haben, verlassen und sich wieder dem Nittelpunkte der Erde zngewendet, wie dies für

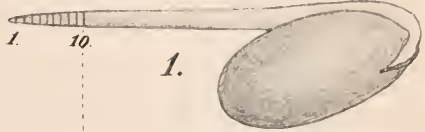
die Erfüllung ihrer Anfgaben durchans nötig ist. Dasselbe beobachten wir an jeder anderen Hanptwurzel: sie dringt mit großer Kraft nicht selten metertief in den Boden und wendet sich immer wieder senkrecht abwärts, wenn sie dnrch einen Stein, einen Fels -

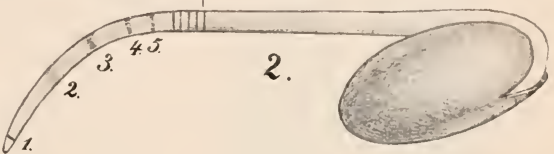

block oder dgl. aus ihrer Richtung verdrängt worden ist.

2. Wodurch wird die Hauptwurzel zu diesem merkwürdigen Verhalten veranlaßt? Schon der Umstand, daß sie stets dem Mittelpunkte der Erde "zustrebt", läßt vermuten, daß hierbei die Anziehung der Erde, die Schwerkraft, im Spiele ist. Wie das Licht die Zimmerpflanzen oder die "Kartoffelkeime" im Keller ,zu sich hinzieht“ (s. S. 413), wird die Wurzelspitze durch die Schwerkraft angeregt oder gereizt, an der Oberseite stärker zu wachsen als an der Unterseite, so daß jene Abwärtskrümmung eintreten muß. Ist diese Erklärung richtig, so mnß eine Keimwurzel, die wir der einseitigen Einwirkung der Schwerkraft entziehen, ein anderes Verhalten zeigen, und das ist der Fall, wie folgender Versuch zeigt: Man befestigt anf einem Metallstabe einen durchfeuchteten Torfwürfel und bestreut ihn mit Samen der Gartenkresse. Die Samen bilden bei Befeuchtung einen klebrigen Schleim (Bedeutung?), haften daher an dem Torfstücke fest und keimen sehr schncll. Setzt man den Metallstab durch ein Uhrwerk in drehende Bewegung - der Torfwiirfel muß in der Stunde etwa 2 senkrechte Umdrehungen machen -, so ist die Seite jeder Keimwnrzel, die 
jetzt nach oben gekehrt ist, nach einer Viertelstunde nach unten gerichtet u. s. f. Die Schwerkraft kann daher nicht anf eine Seite besonders einwirken und sie zu stärkerem Wachstum veranlassen. Die Wurzeln wachsen daher allseitig gleich stark in der Richtung weiter, in der sie zufällig aus dem Samen hervorgetreten sind.

3. Die aus der Hauptwurzel hervorgehenden Seitenwurzeln wachsen, wie wir wissen (s. S. 100, b), stets senkrecht oder schräg abwärts. Bringen wir sie aus dieser Lage (Umdrehen des Blumentopfes!), so nehmen sie die ihrer „inneren Natur“ entsprechende Richtung alsbald wieder ein. Ähnliche Beobachtungen werden wir später (s. S. 411) auch an den Stammgebilden machen; kurz: wir selien, daß zahlreiche wachsenden Pflanzenteile durch die Schwerkraft beeinflußt, gereizt werden. Die Eigenschaft der Pflanze, auf diese Kraft zuantworten, zu reagieren, bezeichnet man als Geotropismus.

4. Legt man Bolnnenkeimlinge auf den Boden (olıne sie also mit Erde zn berlecken), so krümmt sich die Wurzelspitze zwar gleichfalls abwärts, ist aber meist nicht imstande, in die Erde einzudringen. Hierzu, sowie zum Heransziehen der Keimblätter aus der Samenschale bedarf der Keimling eines festen Stïtzpunktes: der Samen muß am Boden gleichsam verankert werden.

Den angebauten Pflanzen schaffen wir die notwendige Befestigung an „das Keiml)ett ${ }^{4}$, indem wir die Samen (Früchte) mit einer Schicht Erde bedecken. Die Früchte vom Reiher- und Storchschnabel haben die Fähigkeit, sich in die Erde zu bohren, nnd die Keimlinge der seltsamen Mangrovebäume dringen wie zugespizte Pfähle in den schlammigen Untergrund. Viele Samen rollen infolge ihrer Form und Kleinheit in jede Bodenritze; größere Samen oder Früchte wie ๘. B. Haselnuß and Eichel vermögen meist nur dadurch an einem geeigneten Orte zum Keimen zn gelangen, dab sie von Tieren verschleppt werden. Bei anderen Samen oder Früchten verklebt die Samen- oder Fruchthülle dureh einen zähen Schleim (Lein, Wegerich) oder durch anhaftende Teilchen des Frnchtfleisches (Kürbis) mit dem Boden. Bei wieder anderen dienen haarförmige (Salweide) oder dornige Anhängsel (Möhre), grubige Vertiefungen (Mohn) oder warzenförmige Erhöhungen (Schlüsselblnme) der Samen- oder Frnchtschale dem gleichen Zwecke. •

\section{Vom Bau und Leben des Stammes.}

\section{A. Aufgabe, Wachstum und Formen des Stammes.}

1. Aufgabe des Stammes. Die Laubblätter haben wir als die Werkstätten kennen gelernt, in denen aus anorganischen Stoffen organische gebildet werden. Da dies aber nur unter dem Einflusse des Sonnenlichtes geschieht, nnd cla einer der wichtigsten Nälrstoffe, der Kohlenstoff, der Luft entnommen wird, so müssen die Blätter dem Lichte und der Luft möglichst frei ausgesetzt sein. Eine freie Stellung ist auch für die Blüten notwendig, wenn sie von den Insekten oder dem Winde bestäubt werden sollen, desgleichen für die vielen Früichte oder Samen, die zu ihrer Verbreitung auf Tögel oder den Wind angewiesen sind (Beispiele!). Genan wie wir die Wäsche frei anfhängen, um sie der Luft und den Sonnenstrahlen anszusetzen, oder wie wir Aufschriften, die 
weithin gesehen werden sollen (Wegweiser, Firmenschilder, Bekanntmalchungen u. dgl.), hochan Hänsern oder auf langen Stangen befestigen, so m ï ssen anch Blätter, Bl ïten und Frïchte durch lange Träger möglichst hoch ïber den Boden gehoben werden. Diese Träger bilden die Stämme, die bei größeren Pflanzen (Beispiele!) zumeist noch verzweigt, bei den größten (Bäumen) in der Regel sogar vielfach verzweigt sind.

2. Wachstum und Verzweigung des Stammes. a) Legt man die äußerste Spitze eines Zweiges der Wasserpest unter das Mikroskol, oder stellt man durch das entsprechende Stïck einer Landpflanze dïnne Längsschnitte her, so ist zn erkennen, daß ein solches Stamm- oder Zweigende aus protoplasmareichen, zartwandigen Zellen anfgebant ist, die eng aneinander schließen. Da sich diese Zellen durch Teilung lebhaft vermehren, wa ch s en Stamm und Zweige an dieser Stelle fortgesetzt in die Länge. Den meist kegelförmigen Endabschnitt bezeichnet man daher als Wachstums- oder Vegetationskegel.

An jenen Pflanzenteilen sehen wir weiter, wie an dem Stamme kleine Höcker und Wülste entstehen, die, je weiter von der Stammspitze entfernt, immer mehr die Gestalt von Blättern annehmen. Die Blätter sind also ihrer Entstehung nach nichts anderes als Hervolstïlpungen des Stammes. Der Stamm oder Zweig bildet mit seinen Blättern einen sog. SproB.

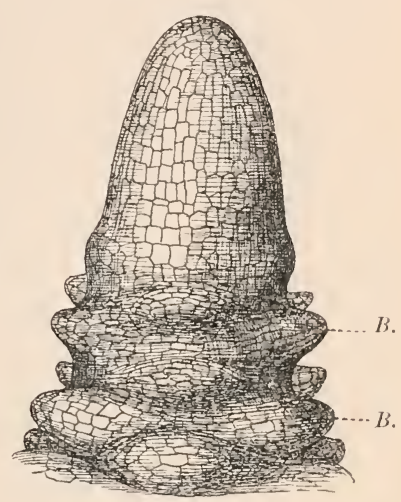

Wachstumskegel der Wasserpest (200 mal vergr.). B. Blattanlagen.

Indem sich der jugendliche Stamm in die Länge streckt, werden die Blätter soweit voneinander entfernt, wie dies für jede Pflanze eigentümlich ist.

Die Stellen des Stammes, an der die Blätter entspringen, sind vielfach angeschwollen (Lippenblïtler); man bezeichnet sie daher als Stengelknoten. Das zwischen je zwei Stengelknoten liegende Stammstïck heißt Stengelglied. ()ft bleiben die Stengelglieder so kurz, daß die Blätter fast ohne Zwischenraum aufeinander folgen. Solche verkürzte (gestauchte) Stämme findet man z. B. bei Pflanzen, deren Blätter eine Rosette bilden (Wegerich, Schlïsselblume u. a.).

b) In allgemeinen eilen die jungen Blätter in ihrer Ausbildung dem sich streckenden Stamm- oder Zweigende vorans. Sie legen sich schïtzend iiber den sehr zarten Wachstumskegel, decken sich gegenseitig und bilden eine Knospe. Die Wachstnmsstelle des Stammes bedarf daher im Gegensatz zur wachsenden Wurzelspitze keines besonderen Schutzorgans (Wurzellaube!). Soll die Knospe 
ungünstige Zeiten (Winter, lange Dürre) ïberstehen, so wird sie meist durch besondere Blätter (Knospenschuppen) und andere Mittel fest abgeschlossen (s. S. 41, B). Bei den unterirdischen Stämmen (Windröschen, Maiblume n. a.), bei denen die Knospe den oft festen Boden durchdringen muß, sind die den Schutz bewirkenden Blätter sehr fest („Hüllblätter“).

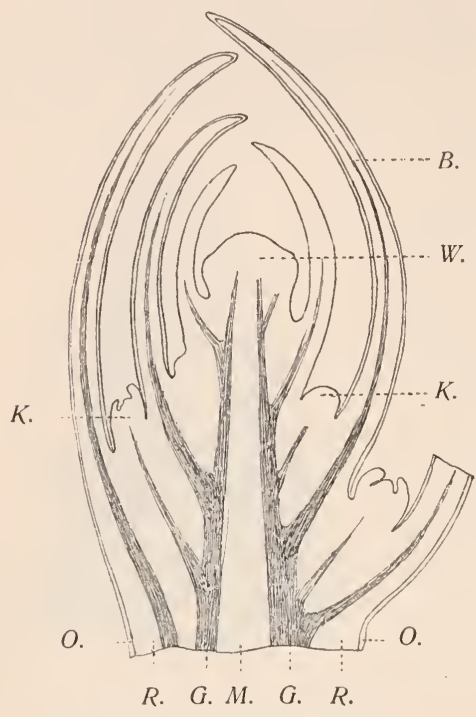

Längsschnitt durch eine Endknospe (schematisch). W. Wachstumskegel; B. Blätter; K. Achselknospen. Wegen der ïbrigen Bezeichnungen vgl. den zweiten Abdruck dieser Abb. auf S. 416 .

An dïnnen Schnitten durch die Kinospe, z. B. der Linde, erkennt man, daß sich in den Blattachseln Anlagen zu beblätterten Seitenzweigen bilden. Entweder wachsen diese Anlagen gleich weiter oder sie verharren im Knospenzustande. Im Gegensatz zu den "Endknospen", die das Wachstum des Stammes oder Zweiges oft viele Jahre lang fortsetzen, bezeichnet man diese Knospen als A chselknospen. Da die Zweige aus den Achseln der Blätter entspringen, stimmt die Stellung der Zweige mit der der Blätter iiberein (Beispiele!).

c) Bei gewissen Pflanzen besitzen aber anch ältere Teile die Fähigkeit, Knospen nnd damit nene Sprosse zu erz e ug en. Am häufigsten treten uns solche Sprosse als "Stockansschlag“ geköpfter Bäume (Weiden, Pappeln, Robinie u. a.) oder als "Wurzelbrut" entgegen (Pflaumenbaum, Weißdorn u. v. a.). Anch ans Blättern (Wiesenschaumkrant) oder

Wurzelstïcken (Meerrettich, Löwenzahn u. a.) können sie hervorgehen.

d) Je größer die Blätterlast ist, die ein Stamm zu tragen hat, eine umso größere Festigkeit muß er besitzen. Verhältnismäßig kleine Pflanzen von kurzer Lebensdauer (ein- oder zweijährige Gewächse; Beispiele!), die sog. Kräuter, haben daher nur einen weichen, saftigen und meist grünen Stamm. Er erliegt der Winterkälte und wird iu der Regel st tengel genannt. Einen hohlen Stengel, der durch verdickte Knoten und Querscheidewände dentlich gegliedert ist, bezeichnet man als $\mathrm{Halm}$ (Giäser). Trägt der Stengel nur eine Bläte oder nur einen Blütenstand, so nennt man ihn Schaft (Schneeglöckchen, Hyazinthe).

Dauert der Stanm mehrere oder viele Jahre aus (ausdauernde Pflanzen), so finden in ihm weitgehende Verholzungen statt (s. später). Er wird zum Holzstamm (kurz 
nur Stamm $^{\prime}$ genannt), der die größten Lasten zu tragen vermag und gegen die Winterkälte oft außerordentlich unempfindlich ist (Beispiele!). Bei den Strä uchern lösen sich die meist zahlreichen Stämme vom Boden aus in Äste auf. Bei den Bä umen dagegen bleibt der untere Stamuteil unverzweigt.

3. Abweichende Stammformen. Bei zahlreichen Pflanzen haben der Stamm oder gewisse Zweige andere Aufgaben zu erfüllen, als die Blätter, Blüten und Früchte möglichst frei zu stellen. Diesen Sonderaufgaben entspricht dann auch die Form dieser amgewandelten Stammgebilde :

a) Seitenzweige, die am Grunde von Stämmen entspringen, nehmen häufig die Gestalt sog. Ausläufer an. Sie liegen dem Boden auf (Erdbeere, Veilehen u. a.) oder kriechen unter der Erde fort (zahlreiche Gräser, Riedgräser a. a.), schlagen an den weit auseinander gerückten Stengelknoten meist Wurzelı und bilden oberirdisehe Sprosse. Löst sich der Zweig später von der Mutterpflanze, so führen die Sprosse von nun ab ein selbständiges Leben (Vermehrung!).

b) Holzige Zweige, die in eine stechende Spitze auslaufen, sind die Dornen. Sie dienen als Sehutzwehr gegen größere Pflanzenfresser (wilder Birnbaum, Schwarz- und Weißdorn n. a.).

c) Stengelranken, wie wir sie beim Weinstock kennen lernten (s. S. 62), dienen der Anheftung schwacher Stämme an eine Stütze.

d) Mit Hilfe unterirdischer Stämme vermögen andere Gewächse, die sog. Standen, die für sie ungünstige Zeit des Jahres zu überstehen. Für die Pflanzen unserer Heimat (Schlüsselblume, Maiblume u. v. a.) ist diese Zeit der Winter; für die der warmen oder wärmeren Gegenden der regenlose Sommer (s. Tulpe). Bei Beginn dieser Zeit sind die im Erdboden wohl geborgenen Stämme mit Baustoffen angefüllt, während die oberirdischen Teile absterben. Nach ihrer Form unterscheidet man diese Stammgebilde als unterirdisehe Stämme i. e. S. (Wurzelstöcke, Rhizome), Zwi ebeln (s. Tulpe) und Knollen (s. Kartoffel).

\section{B. Die Richtung der Stämme und Zweige.}

1. Einwirkung der Scliwerkraft. a) Es gibt zwar einige Pflanzen, deren oberirdische Stämme dem Erdboden aufliegen (Gundermann, Pfennigkrant u. a.), im allgemeinen aber stehendiese Pflanzenteile iiberall anf der Erdkugel senkrecht. Selbst auf Berglehnen und anderen schrägen Flächen ist dies der Fall. Legen wir einen Samen in die Erde - ganz gleich, welche Lage wir dem von der Samenhant umhüllten Keimlinge gegeben haben! -, sein Stengel wächst in jedem Falle senkrecht nach oben. Sind Baumstämme durch den Wind umgestürzt, aber noch nicht völlig entwurzelt, so stellt sich der wachstumsfähige Teil des Gipfeltriebes nach kurzer Zeit wieder in die Lotrichtung. Hat sich das noch grüne Getreide gelagert, so richten sich die Halme durch einseitiges Wachstum gewisser Knoten wieder empor (s. S. 254). Kurz: solche und ähnliche Beobachtungen können wir tagtïglich machen, wenn wir mit offenen Augen durch die Natur wandern.

Auch künstlich können wir diese Erscheinungen leicht hervorrufen: legen wir z. B. den Blumentopf, in dem wir irgend welche Keimpflänzchen gezogen haben, wagerecht, so krümmen sich die Stengel alsbald so stark, daß 
sie wieder senkrecht zu stehen kommen; dasselbe beobachten wir an jeder Zimmerpflanze, ja sogar an abgeschnittenen Stengelteilen (an jungen Laubund Blïtenzweigen, am Schafte des Löwenzahns u. s. w.), die wir z. B. so in einen mit fenchtem Sande gefiillten Blımentopf stecken, daß sie wagerecht zu liegen kommen.

b) Wiederholen wir jetzt den Versuch, durch den wir die einseitige Wirkung der Schwerkraft auf Pflanzenteile aufheben können (s. S. 407,2), so sehen wir, daß sich die Stengel gleich den Wurzeln nach allen Richtungen des Raumes erstrecken. Dies ist ein deutliches Zeichen dafür, daß die senkrechte Stellung der Stämme, sowie das Znrïckkehren wachsender Stengelteile in die Lotrichtung unter dem Einflusse der Schwerkraft erfolgt, oder kurz: daß wir es hier mit geotropischen Erscheinungen zu tun haben (s. S. 408).

Ein Stengelteil, der ans der senkrechten Stellung gebracht ist, wird wie die wagerecht gelegte Hauptwurzel in unserem Versuche einseitig von der Schwerkraft gereizt. Wie wir nun in jedem Falle beobachten könuen (besonders deutlich an den Knoten des sich anfrichtenden Grashalms!), wird das Wachstum der Unterseite gesteigert, das der Oberseite dagegen gehemmt, so daß ein Anfrichten des Stengels erfolgen muB. Auf senkrecht stehende Stämme wirkt die Schwerkraft wie auf senkrecht gerichtete Hauptwurzeln ringsum gleich: sie wachsen daher aufallen Seiten auch gleich stark, d. h. sie behalten die senkrechte Richtung bei.

c) Die Schwerkraft wirkt anf die Stämme aber genau umgekehrt wie anf die Hauptwurzel: während diese erdwendig oder positiv-geotropisch ist, sind die (oberirdischen) Stämme erdflïchtig oder negativ-geotropisch. Wie wir das Eindringen der Hauptwurzel in den Boden als durchaus zweckmäßig erkannten, so steht auch die Erdflüchtigkeit der Stämme mit ihrer Aufgabe in innigstem Zusammenhange: denn soll der Stamm die Blätter in der Luft und im Lichte ausbreiten, sowie Blüten und Früchte freistellen, so muß er sich möglichst hoch über den Erdboden erheben.

d) Derselben Aufgabe haben anch die Zweige zu dienen. Da aber der Platz senkrecht ïber dem Boden bereits „vergeben" ist, mïssen sie sich schrïg aufwärts oder wagerecht stellen. Diese Richtung behalten sie wie die Seitenwurzeln (s. S. 408, 3) anch mit größter Zähigkeit bei: sucht man sie z. B. durch Anbinden senkrecht zu stellen, so schlägt der wachstumsfähige Endteil doch wieder die ursprïngliche Richtung ein. Gleiche Beobachtungen kann man auch an den unterirdischen Stämmen (Wurzelstöcken) machen, die wagerecht oder schräg im Boden liegen: alles Zeichen, daß diese Pflanzenteile gleichfalls unter dem Einflusse der Schwerkraft stehen. Während Hanptwurzel und Stämme die Richtung des Erdradius innehalten, schneiden diese die Lotrichtung. Da man nun eine Linie die eine andere schneidet, eine Transversale (i. w. S.) nennt, so bezeichnet man jene Pflanzenteile als transversal-geotropisch. (Beobachte, wie sich häufig ein Seitenzweig senkrecht richtet, wenn eine Pflanze den Gipfeltrieb verloren bat!) 
e) Durch den EinfluB der Schwerkraft vermögen auch die schwachen Stengel der windenden PfIanzen zum Lichte emporzusteigen. Wie dies in einzelnen erfolgt, haben wir bereits bei der Bohne (s. S. 101,4) kennen gelernt. Ergänzend sei daher hier nur folgendes bemerkt: Wir wissen, daß der übergeneigte Stengelteil dieser Pflanze beständig nach links im Kreise schwingt. Wie das oben erwähnte Abwärtskrümmen der wagerechten Wurzelspitze oder das Anfwärtskrümmen des gleichfalls wagerecht gelegten Stengels kommt diese Bewegung dadurch zustande, daß der schwingende Stengelabschnitt an ler entgegengesetzten, also rechten Seite fortgesetzt im Wachstum gefördert wird. Ahmen wir diese Bewegung mit Hilfe eines Gummischlauches, der am Unterende etwa in einen Schraulsstock gespanut ist (unterer, feststehender Stengelabschnitt!), genau nach, so erkennen wir deutlich, daß der Gipfel eime doppelte Bewegung ausfiihrt: einmal dreht er sich wie ein Uhrzeiger im Kreise, sodann aber auch wie der Stift, der die Uhrzeiger trägt, um seine (eigene) Längsachse. Daher wandert $^{\text {* }}$ ein Tuschestrich, den wir an dem schwingenden Stengelteile anbringen, mit jeder Kreisbewegung des Gipfelteils auch einmal nm den Stengel. Es kommen mithin fortgesetzt andere Stengelteilchen in die Seitenlage, so daf die Bewegung ununterbrochen weiter gehen mub. Ist die Stuitze umschlungen, so tritt - wie wir weiter an der Bolme beobachtet haben - eine Streckung des Stengels nach oben ein, eine Erscheinung, in der wir leicht einen negativ geotropisehen Vorgang erkennen. - Wie bei der Bohne erfolgen auch hei den Winden und zahlreichen anderen Kletterpflanzen die Windungen in entgegengesetzter, bei dem Hopfen und Geißblatte dagegen in derselben Richtung, in der sich der Uhrzeiger bewegt: die Pflanzen sind links- bezw. re chtswindend.

2. Einwirkung des Lichtes. a) Zimmerptlanzen, die am Fenster stehen, neigen sich dem Lichte zu, und die "Kartoffelkeime" im Keller strecken sich den schwachen Lichtrahlen entgegen, die durch das kleine Fenster eindringen. An Bäumen und Sträuchern, die am Waldesrande, an Mauern oder im Schatten höherer Bäume wachsen, lassen sich oft ganz ähnliche Erscheinungen beobachten: ihre Stämme und Zweige sind mehr oder weniger nach der Lichtseite geneigt, sodaß die Kronen oft eine merkwürdige Gestalt annehmen. Diese und viele ähnliche Tatsachen zeigen, daß die Pflanzen unter dem Einfllnsse des

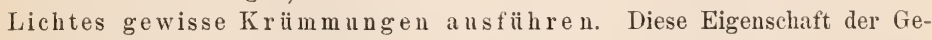
wächse bezeichnet man als $\mathrm{H}$ eliotropism us.

b) Wie wir z. B. an Zimmerpflanzen leicht beobachten können, sind jedoch nur wachsende Pflanzenteile (Zweigenden u. dgl.) imstande, dem Einflusse des Lichtes Folge zu leisten oder kurz: sich heliotropisch zu krümmen. Tragen wir an wachsenden Stengeln, so lange sie noch ganz gerade gestreckt sind, (2uerstriche mit Tusche aut, die je $1 \mathrm{~mm}$ voneinander entfernt sind, so sehen wir nach erfolgter Krïmmung, daß sich die Striche anf der Schattenseite weit voneinander entfernt haben, während sie auf der "Lichtseite" nur wenig oder" gar nicht anseinander gerïckt sind. Das Licht hat die Pflanzenteile alsogereizt, a uf der Schattenseite stärker zu wachsen als a $f^{\circ}$ der Lichtseite, so daß jene Krïmmngenstattinden muten. (Dieser Versuch läft sich besonders gut mit Keimpflanzen anstellen.)

c) Wie in den beobachteten Fïllen suchen fast alle oberirdischen Stämme und Zweige (bei einseitiger Belenchtung) das Licht anf und wachsen in der 
Richtnng des Lichtes weiter. Sie sind lichtwendig oder positiv-heliotropisch, eine Erscheinung, die mit der Aufgabe dieser Pflanzenteile (s. S. 408, 1) wieder aufs innigste zusammenhängt.

Die meisten Kletterwurzeln (Efeu), Ranken (Weinstock) und Erdwurzeln dagegen fliehen das Licht (beweise dies durch entsprechende Versuche!). Sie sind, wie es zur Erfüllung ihrer Aufgabe gleichfalls notwendig ist (Beweis!), lichtscheu oder negativ heliotropisch.

Wie man an den Zimmerpflanzen sehen kann, suchen die Blätter gleich den Stämmen und Zweigen das Licht anf und stellen sich ihm zumeist senkrecht entgegen. (Beobachte, wie sich mit der Richtung des Lichtes anch die Stellung der Blattflächen ändert!) Auf diese Weise fangen sie (s. Abb. S. 44) die größtmögliche IIenge von Lichtstrahlen auf, eine Tatsache, die für die Assimilation von höchster Wichtigkeit ist. Die Blätter sind also transversalheliotropiseh.

Kurz: wie zur Schwerkraft, nehmen auch die Pflanzenteile zum Lichte genan die Lage ein, die für ihr Leben notwendig ist. Bringt man sie aus dieser Lage, so suchen sie dieselbe, solange sie noch wachstumsfähig sind, wieder zu erlangen. (Inwiefern ist es für das efeublättrige Leinkrant von Vorteil, daß seine Blütenstiele positiv-, seine Fruchtstiele dagegen negativ-heliotropisch sind?)

3. Einwirkung durch Berührung. Gleich den windenden Pflanzen vermögen auch die rankenden nur dadurch ihre Blätter, Blüten und Früchte in die Luft und das Licht zu erheben, daß sie sich an fremden Gegenständen aufrichten. Sie bedienen sich der Ranken, in denen wir bereits Stengel- (Weinstock) oder Blattgebilde (Erbse) erkannt haben. Bei einigen Pflanzen (Waldrebe, Kapuzinerkresse u. a.) übernehmen es die Stiele der sonst unveränderten Blätter, den schwachen Stamm an die Stützen zu binden.

Wie wir nun bei der Betrachtung des Weinstocks gesehen haben (s. S. 62), gehen mit der Ranke, sobald sie bei ihren kreisenden Schwingungen auf eine Stütze trifft, eine Anzahl wichtiger Veränderungen vor sich: die Berührung der Stütze wirkt a uf die Ranke alsowie ein Reiz. Durch den Reiz wird das Rankenende veranlaßt, sich zu krümmen, d. h. auf der AuBenseite stärker als a uf der Innenseite zu wachsen und dadurch die Stütze zu umschlingen. Ist die Befestigung erfolgt, dann rollt sich der freie Rankenteil korkzieherartig ein, and die ganze Ranke verholzt, ein Zeichen, daß der Reiz a uch a uf Teile fortgepflanzt wird, die mit der Stütze nicht in Berührung gekommen sind. Wir haben es hier also mit einer ähnlichen Reizleitung zu tun, wie sie in unseren Nerven stattfindet. (Eine Fortleitung des Reizes können wir deutlich z. B. auch an den Drüsenhaaren des Sonnentaublattes, sowie an den Blättern der Sinnpflanzen beobachten. Wie wirkt der Reiz beim wilden Wein und bei anderen rankenden Kletterpflanzen unserer Fluren und Gärten?)

\section{Der Bau des Stammes in seinen Grundzügen.}

1. Die "Bausteine“ des Stammes. Wie wir gesehen haben, nimmt der Stamm dadurch fortgesetzt an Länge zu, daß sich die Zellen, die den Wachstumskegel aufbanen, durch Teilung lebhaft vermehren. Diese Zellen sind aber, 
ihrer Aufgabe entsprechend (Teilung!), außerordentlich zartwandige Gebilde. Die älteren Stammteile, die ans diesen Zellen hervorgehen, können aus einem solchen Baunateriale jedoch unmöglich bestehen; denn sie haben ja nicht nur ihr eigenes Gewicht, sondern auch das der Zweige, Blätter, Blïten und Früchte zu tragen, sowie dem Anpralle des Windes und der Regentropfen Widerstand zu leisten. Die Wände der Zellen müssen daher mit fortschreitendem Alter an Festigkeit und Widerstandsfähigkeit zunehmen.

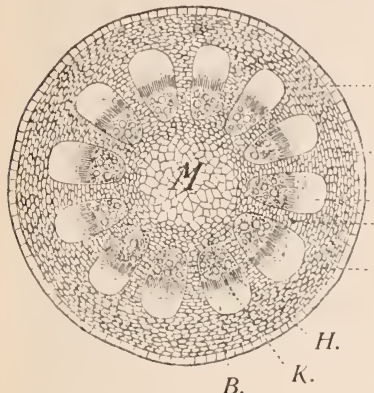

B. $K$.
$O$.

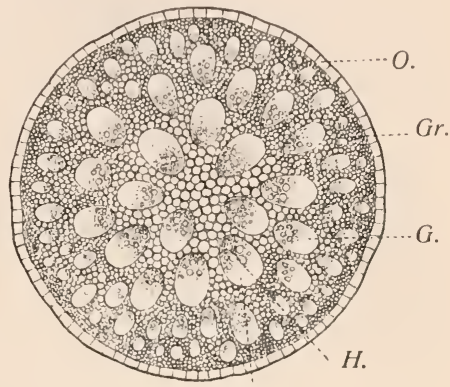

B.

1.

2.

Querschnitt eines Stammes (schematisch) 1. von einer zweikeimblättrigen Pflanze oder einem Nadelholze, 2. von einer einkeimblättrigen Pftanze. O. Oberhaut; Gr. Grnndgewebe; G. GefäBbïndel. In Fig. 1. ist das Grundgewebe (Gr.) wieder geschieden in: II. Mark; R. Rinde und Ms. Markstrahlen. Die Gefäßbündel sind aus einem Holzteile (H.) und einem Bastteile (B.) zusammengesetzt. Zwischen diese Teile schiebt sich in Fig. 1. das Kambium (K.).

Außerdem sind, wie wir gleichfalls schon gesehen haben, die Zellen des Wachstumskegels vollkommen gleichartig, so daß jede einzelne alle zum Leben und Wachstum notwendigen Arbeiten verrichten kann. Da die Arbeiten im "Zellstaate" aber besser und vollkommener ausgeführt werden, wenn sie auf die einzelnen „Bürger“" verteilt sind (s. S. 366), so tritt (bei höheren Pflanzen) wie im Blatte und der Wurzel auch im Stamme eine bis ins einzelnste gehende Arbeitsteilung ein.

Sollen die Zellen des Wachstnmskegels zu Bausteinen älterer Stammteile werden, so müssen mit ihnen also tiefgreifende Veränderungen vor sich gehen. Unter dem Wachstumskegel beginnt die Gleichartigkeit der Zellen daher bereits zu schwinden, und die Veränderungen werden umso größer, je tiefer die „lebenden Bausteine" unter dem Stammende zu liegen kommen. In ausgebildeten Stamnteilen haben sie ihre Entwicklung beendigt.

2. Der Bauplan des Stammes. Stellen wir durch den ansgewachsenen Stengel einer krautigen PHanze in verschiedener Höhe dïnne Querschnitte 
her, so ergibt sich iiberall folgendes: In der änßersten Zellschicht erkennen wir die uns bereits bekannte Oberhaut (s. S. 381) leicht wieder. Die ganze [nnenfläche unseres Schnittes * wird von rundlichen Zellen eingenommen. In dieses maschenartige ., (Frundgewebe" (Name!) sind scharf umgrenzte Zellgruppen eingelagert, die man als $\mathrm{Gefä} \beta \mathrm{b}$ iindel bezeichnet. - Aus diesen iibereinstimmenden Befunden geht hervor, daß der Stengel einen Zylinder von Grundgewebe darstellt, der außen von der Oberhaut bedeckt und in seiner ganzen Länge von zahlreichen Gefäßbündeln durchzogen ist.

Den niederen Pflanzen (Moosen, Algen und Pilzen) fehlen die Gefäßbündel stets. Sie stehen daher den übrigen Gewïchsen, den „Gefälpflanzen“ (Farn- und Blätenpflanzen), als "Zellpflanzen" gegenüber.

Untersuchen wir Vertreter der drei großen Gruppen der Blütenpflanzen, so erkennen wir, daß in dem gemeinsamen Bauplane ihrer Stämme ein wichtiger Unterschied vorhanden ist (s. Abb. S. 415):

a) Auf (querschnitten durch einen krautigen Stengel oder jungen Zweig einer

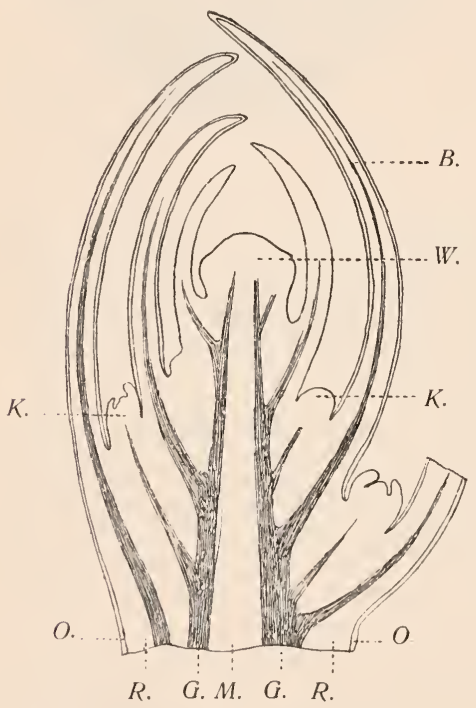

Längsschuitt durch den oberen Teil eines Stammes einer zweikeimblattrigen Pflanze (schematisiert). W. Wachstumskegel; B. Blätter, in deren Achseln sich Knospen (K.) bilden. Die iibrigen Bezeichnungen wie in der vorhergehenden Abbildung. zweikeimblättrigen Pflanze oder eines Nadelholzes sehen wir, daß die Gefäßbündel in einem dentlichen Kreise um die Längsachse des Stengels (oder den Mittelpunkt des Querschnitts) gelagert sind. Hiedurch wird das Grundgewebe in zwei deutlich voneinander getrennte Teile geschieden: in das II a rk, das innerhalb, und die Rinde, die außerhalb des Gefäßbündelringes liegt. Die Teile des Grundgewebes, die die einzelnen Gefäßbündel voneinander trennen - und Mark und Rinde verbinden, werden als Markstrahlen bezeichnet. (An jungen Zweigen des Pfeifenstrauches sind alle diese Teile schon mit unbewaffnetem Auge zu erkennen.)

b) An Querschnitten durch den Stengel einkeimblättriger Pflanzen (z. B. vom Mais oder von einem Liliengewächse) erkennen wir, daß die Gefäßbündel unregelmäßig in dem Grundgewebe verstreut sind. Es findet daher hier auch keine dentliche Sonderung 
des Grundgewebes in Mark, Rinde und Markstrahlen statt. Die den zweikeimblättrigen Pflanzen entsprechenden Teile des Grundgewebes werden jedoch gleichfalls als Mark oder Rinde bezeichnet.

3. Die Verbindung des Stammes mit Blatt und Wurzel. a) Wie man sich durch Quer- und Längsschnitte, die man durch krantige Stengel oder junge Zweige herstellt, leicht ïberzeugen kann, biegen in jedes Blatt ein oder melirere Abzweigungen von Gefä $B$ bïndeln ein. Dort bilden sie die Nerven oder Adern des Blattes, die sich aus uns bereits bekannten Grïnden (s. S. 394) immer feiner verzweigen. Bein Zerreißen des Wegerichblattes treten uns die Gefäßbündel als zähe, feste Stränge entgegen. Auch die Nerven in den einzelnen Blütenteilen und in den Frïchten sind nichts anderes als Gefäßbündel und deren Verzweigungen.

b) Ebenso stehen auch die Gefäßbïndel des Stammes mit dem einzigen Gefä $\beta$ bündel der Wurzel im Zusammenhang (s. Abb. S. 429). Dieser feste Strang durchzieht die Wurzel der Länge nach. Er ist von einer dicken Rinde umgeben, die wieder von einer Oberhant bedeckt ist. Im Innern des Gefäßbïndels ist vielfach ein lockeres Mark vorhanden: der Bau der Wurzel stimmt also im wesentlichen mit dem des Stengels überein.

\section{Die Gefäßbündel.}

Betrachtet man ein Gefäßbündel auf Querschnitten, die man durch den Stengel einer Blïtenpflanze hergestellt hat, so läßt sich leicht folgendes feststellen: Wie die Anwendung von Chlorzinkjodlösung zeigt (s. S. 365), besitzen die nach innen gerichteten Bestandteile der Gefäßbïndel im Gegensatz zı den nach außen liegenden stark verholzte Wände. Das Gefäßbündel besteht also aus zwei Teilen: dem inneren Holzteile und dem äußeren Bastteile. Zwischen beiden liegt - jedoch nur bei den zweikeimblättrigen Pflanzen und Nadelhölzern eine Schicht sehr zartwandiger Zellen, das Kambium.

Die Gefäbbündel der Blätter, die Blattnerven, sowie die der Wurzeln bestehen wie hier ergänzend erwähnt sein mag - gleichfalls ans Holz- und Bastteil (s. Abb. S. 380). Da sich die Gefáßbündel der Blätter gleichsam aus dem Stengel heransbiegen, muß bei ihnen der Holzteil nach oben, und der Bastteil nach unten gerichtet sein. Das Gefäßbündel der Wurzel besteht - wie die Abb. S. 429 zeigt - aus mehreren Holz- und Bastteilen, die so im Kreise gelagert sind, dab sie miteinander abwechseln.

1. Der Holzteil. Schon auf dem Querschnitte erkennen wir, daß der Holzteil aus sehr verschiedenen Bestandteilen zusammengesetzt ist. Auf Längsschnitten tritt uns dies noch deutlicher entgegen. Zuerst sehen wir lange, weite Röhren, deren Wände verschiedenartige Verdickungen aufweisen (s. S. 364). Sie sind aus ïbereinander liegenden, zylindrischen oder prismatischen Zellen dadurch hervorgegangen, daß sich deren Querwände auflösten. Man bezeichnet sie als Holzgefäße oder kurz als Gefäße (daher: Gefäßbündel!), und zwar unterscheidet man nach der Form der Wandverdickungen Ring-, Schrauben-, Netz- 
und Tüpfelgefäße. Sie sind im Durchschnitt etwa $10 \mathrm{~cm}$, in Ausnahmefällen aber (z. B. bei der Eiche und Robinie) einen oder gar mehrere Meter lang und erscheinen auf dem Querschnitte oft schon dem unbewaffneten Auge als Löcher oder Poren (s. Abl). S. 421).

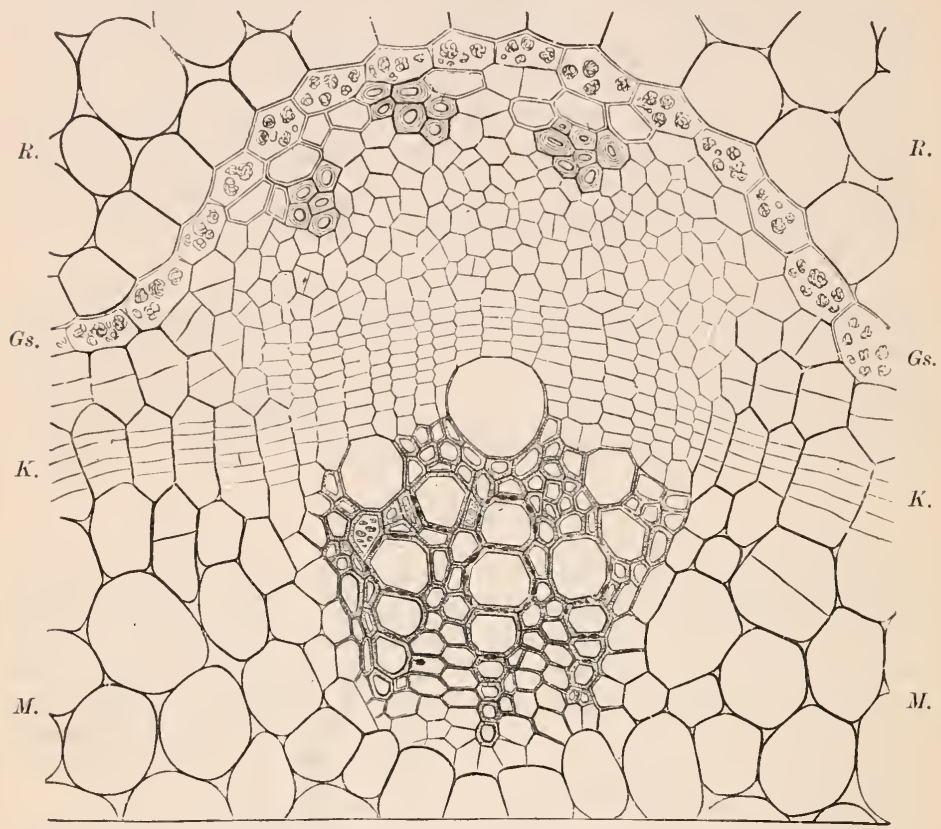

Quersehnitt eines Gefäßbiindels ans dem Stengel einer Keimpflanze des Wunderbaumes (Rieinus). R. Die angrenzenden Zellen der Rinde. (is. Die G e fä $B$ b ii ndelseheide (Zellen mit Stärkekörnern angefüllt). K. Kambinm. Zwischen (is. und K. der Bastteil der GefäBbündel mit Gruppen dickwandiger Bastfasern. M. The angrenzenden Zellen des Markes. Zwischen K. und M. der Holzteil des Gefäßbündels, aus verschieden weiten Gefäßen, dickwandigen Holzfasern und Zellen mit nnverdickten Wäuden bestehend.

Neben den Gefäßen treten in der Regel noch ganz ähnliche Gebilde von geringerer Weite auf. Sie sind aber nicht durch Verschmelzung von Zellen entstanden, sondern selbst Zellen. Daher werden sie auch „Ge fäßzellen“ genannt. (In den Gefäßbündeln der Gefäß-Sporenpflanzen finden sich - trotz des Namens statt der Gefäße in der Regel nur Gefäßzellen.)

Zwischen den Gefäßen und Gefäßzellen liegen meist noch Gruppen von 
Zellen gewöhnlicher Form, die entweder stark verdickte oder nnverdickte Wände besitzen. Die Zellen der ersteren Art sind langgestreckt, besitzen zugespitzte Enden und werden als Holzfasern bezeichnet. Die anderen Zellen sind kürzer, prismatisch, enthalten Protoplasma und dienen gleich allen anderen lebenden Bestandteilen der Stämme bei ausdauernden Gewächsen während des Winters als Vorratskammer für Baustoffe (Stärke oder Öl). Gefäße, Gefäßzellen nnd Holzfasern verlieren, nachdem sie vollständig ausgebildet sind, ihren Inhalt: es sind

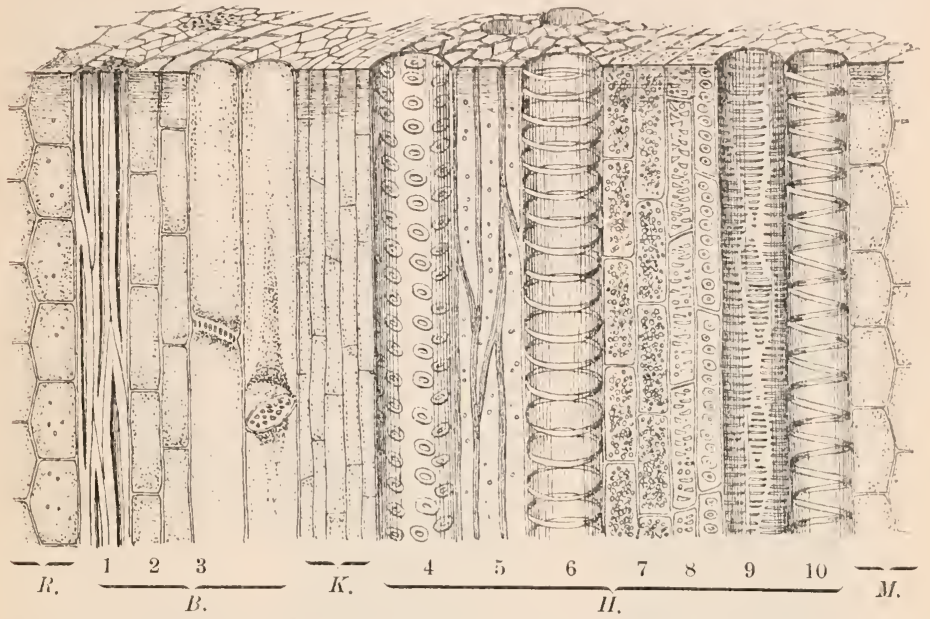

Längsschnitt durch ein Gefißbündel eincr zweikeimblättrigen Pflanze (schematisch.) R. Die angrenzenden Zellen der Rinde. B. Bastteil und zwar: 1 Bastfasern, 2 zartwanlige Bastzellen, 3 Siebröhren. K. Kambinm. H. Holztejl mnd zwar 4 TüpfelgefäB, 5 Holzfasern, 6 RinggefäB, 7 prismatische Zellen, mit Stärkekömern angefüllt, 8 fefäßzellen, 9 NetzgefïB, 10 SchraubengefäB. II. Die angrenzenden Zellen des II a rkes.

dann tote, aber - wie wir weiter unten sehen werden - nicht etwa wertlose Bestandteile des Stammes. - Kocht man Holz mit verdünnter Natronlauge, so zerfällt es in seine Bestandteile. Dieses Verfahren wird im großen angewendet, um aus dem Holze das Material zu gewissen Papiersorten zu gewinnen. Wird das Holz nur zerrieben, so erhält man den „Holzschliff“". Dieser findet Verwendung bei der Herstellung geringerer Papiere ( ${ }_{n}$ Holzpapiere $\left.{ }^{4}\right)$, die besonder's zu Zeitungen u. dgl. gebraucht und nach kurzer Zeit gelb werden.

2. Der Bastteil. Auch der Bastteil bestelit aus verschieden geformten Bestandteilen. Stets finden sich lange Zellreihen, deren Scheidewände zwar exhalten geblieben, aber siebartig durchlöchert sind („Siebplatten“). Diese sog. Siebröhren enthalten außer etwas Protoplasma, das die Wände ïberkleidet, 
eine mehr oder weniger verdünnte Eiweißlösung, die durch die Siebplatten von Zelle zu Zelle wandert.

Neben gleichfalls zartwandigen, aber rundlichen oder prismatischen Zellen treten im Baste noch langgestreckte Zellen mit sehr dicken Wänden auf. Diese zähen und festen Bastfasern sind es, die man vom Flachs, Hanf und einigen Brennesselgewächsen, sowie von der Linde und zahlreichen anderen Pflanzen gewinnt und zur Herstellung von Gespinsten oder Flechtwerken, zum Anbinden u. dgl. verwendet.

Die Zellen der Rinde, die an den Bastteil grenzen, sind in der Regel von den übrigen Rindenzellen versehieden. Sie enthalten meist zusammengesetzte Stärkekörner und bilden- die sog. Gief ${ }^{-} B b \ddot{u ̈}_{n}$ d e l s cheide.

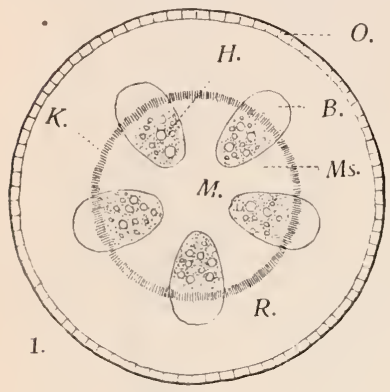

Dickenwachstum der Stiimme (schematisch). 1. Qnersehnitt durch einen einjährigen Stamm mit einem geschlossenen Kambium-Zylinder (K.).

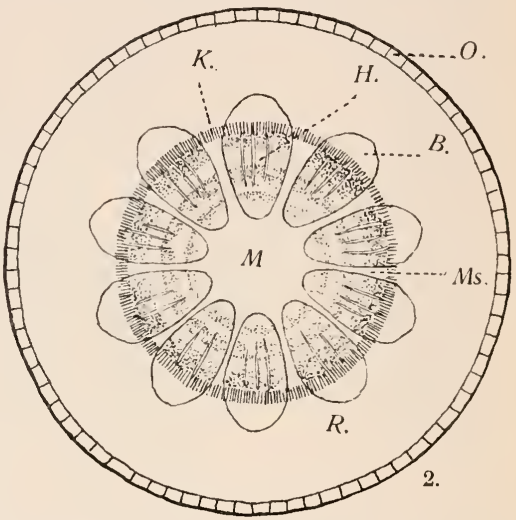

2. Quersehnitt dureh einen dreijährigen Stamm. Zwischen je 2 GefäBbïndel hat sich ein nenes Gefäßbündel eingeschoben. Die Holzteile (H.) der Gefäbbündel lassen je $\mathbf{3}$ Jahresringe erkennen; in ihnen haben sieh einige (radienartig verlanfende) Nebennarkstrahlen gebildet. Die übrigen Bezeichnungen wie in Abb. S. 415.

3. Das Kambiun und das Dickenwachstum der Stämme. Die krantigen Stengel einjähriger Pflanzen erleiden in ihrem Bau keine wesentliche Veränderung. Anders dagegen verhält es sich mit dem (oberirdischen) Stamme derjenigen Pflanzen, deren Leben viele Jahre währt, und deren Krone immer mehr an Umfang zunimmt: Ihr Stamm wächst fortgesetzt in die Dicke und entwickelt sich nach und nach zu einer mächtigen Holzsäule, die die riesige Last der Krone tragen und selbst den stärksten Stürmen trotzen kann. Wie bilden sich nun diese Holzmassen?

a) Die "Holzgewächse" unserer Heimat gehören sämtlich den zweikeimblättrigen Pflanzen oder den Nadelholzgewächsen an, bei denen - wie wir gesehen haben - die Gefäßbündel zu einem Kreise geordnet, und Holz- und Bastteil dieser Bündel durch eine Kambiumschicht getrennt sind. Indem die Gefäßbïndel größer werden und sich neue zwischen ihnen bilden, verschmelzen die 
Holzteile nach und nach zu einem massiven Holzkörper, der die Reste des Jarkes umschließt.

Ebenso vereinigen sich anch die Bastteile der Gefäßbündel. Sie bilden mit der Rinde einen hohlen Zylinder, der den Holzkörper umgibt und gemeinhin als Baumrinde oder kurz als "Rinde" bezeichnet wird.

Gleichzeitig haben sich in den Markstrahlen die Zellen, die an das Kambium grenzen, durch Teilung ebenfalls in Kambium verwandelt (s. Abb. S. $418 \mathrm{~K}$ ). So entsteht ein sehr dïnner Kambium-Zylinder, der Rinde und Holzkörper voneinander trennt und auf dem Querschnitte des Stammes als Kreis erscheint. (An dünnen Zweigen des Pfeifenstrauches ist dieser Kreis schon mit bloßem Ange dentlich zu erkennen.) Da die Zellen des Kambiums außerordentlich zart sind, so lassen sie sich durch Klopfen leicht zerstören. Daher vermögen die Kinder die Rinde z. B. der Weidenzweige vom Holzkörper leicht abzulösen, um daraus Pfeifen herzustellen.

b) Die Kambiumzellen sind nun gleich den Zellen des Waclistumskegels imstande, sich durch Teilung fortgesetzt zu vermehren. Die neu entstehenden Zellen bilden sich nach

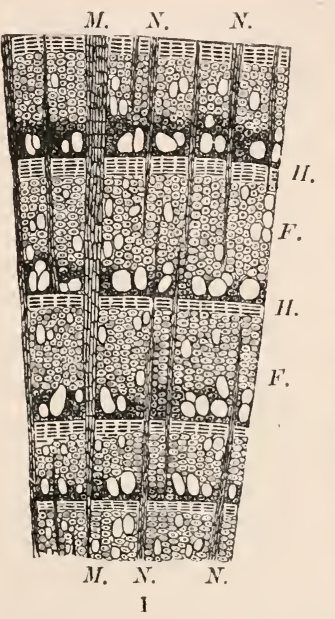

M. M. M. M.

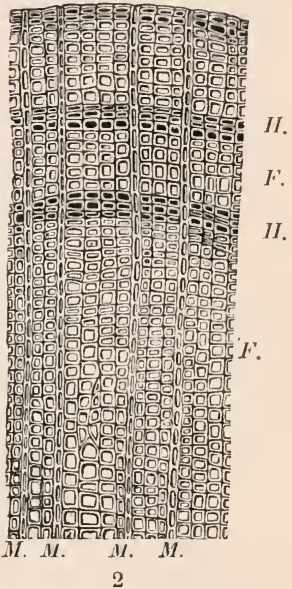

Quersehnitte durch das Holz eines Laub- und eines Nadelbaumes. $1 \mathrm{Holz}$ der Buele (nit zahlreichen Gefäben). $2 \mathrm{Holz}$ der Fichte (besitzt keine GefäBe). F. Das lockere Friihjahrs-, H. das festere Herbstholz, das die Grenzen der Jahresringe bildet. II. Markstrahlen. X. Nebenmarkstrahlen, die blind im Holze endigen.

innen zu Gefäßen, Gefäßzellen, Holzfasern und prismatischen Holzzellen, nach außen dagegen zu Siebröhren, Bastfasern und anderen Bestandteilen des Bastes um. Auf diese Weise erhalten Holz und Bast einen Zuwachs: der Stamm wächst in die Dicke. Wie die Erfahrung zeigt, ist die Nenbildung des Holzes bei weitem größer als die des Bastes.

Da die Gefäßbündel der einkeimblättrigen Gewäclıse keine Verdieknngssehicht, kein Kambium, enthalten, besitzen die Stämme dieser Pflanzen bis a f A usnahmen (Drachenbäume, Palmlilien und ein Teil der Palmen) auch kein Dickenwachstum. - In dem Maße, in dem die Stämıne dicker werden, nehmen anch die Wurzeln der betrefienden Pflanzen fortgesetzt durch Dickenwachstum zu (Bedeutung?). 
c) Der Zuwachs geht in unseren Breiten (wie in allen außertropischen Gegenden) nur vom Frühjahre bis zum Herbste vor sicl. In der Regel besitzt nun das Holz, das sich im Frïhjahre bildet, dünnwandigere Bestandteile von größerer Weite und ist reicher an Gefäßen als das später im Jahre entstehende. Daher lïßt sicl das lockere, poröse Frühjahrsholz meist leicht von dem festeren und dichteren Herbstholze nnterscheiden. So kommt es in der Holzmasse zur Bildung von Jahresringen, deren Anzahl bei normalem Wachstum das Alter der Bäume angibt. - Das Holz der Nadelbäume bestelıt (vom 2. Jahresringe ab) nur aus Gefäßzellen.

Mit dem Holze der älteren Jahresringe geht in der Regel eine wichtige Veränderung vor sich. In die Wände oder Hohlräume der einzelnen Bestandteile lagert sich Gerbstoff oder Gummi ein, Stoffe, die das Holz gegen den Angriff Fäulnis erregender Pilze schïtzen. (Wozu verwenden wir die Gerbstoffe?) Hierdurch erhält das Holz eine dunklere Farbe, so daß es sich als Kernholz meist deutlich von dem helleren Holze der jüngsten Jahresringe, dem Splint, abhebt. (Im Kernholze mehrerer Bäume, z. B. der Weiden, lagern sich keine Schutzstoffe ab. Was beobachten wir daher häufig an Weidenstämmen?)

d) Das Kambium, das sich zwischen den einzelnen Gefäßbündeln gebildet hat, besitzt gleichfalls ein fortgesetztes Wachstum. Durch seine Tätigkeit werden die Markstrahlen nach beiden Seiten verlängert. Werden Holz- und Bastteil der Gefäßbündel immer breiter, so beginnt auch das Kambium in den Gefäßbïndeln an gewissen Stellen und zu verschiedenen Zeiten Markstrahlengewebe zu erzeugen. So entstehen die Nebenmarkstrahlen, die blind im Holze oder Baste endigen (s. Abb. S. 420 u. 421).

\section{E. Leitungsbahnen im Stamme.}

1. Die Leitungsbalınen für Wasser und Nährsalze. a) Mit Hilfe einer Eosinlösung haben wir früher nachgewiesen (s. S. 394), daß die Gefäßbündel der Blätter, die Blattnerven, die Kanäle sind, die den Blattzellen Wasser und Nährsalze zuführen. Wiederholen wir den Versuch mit einer Balsamine, die einen möglichst durchscheinenden Stengel besitzt, so sehen wir schon von außen, wie das rotgefärbte Wasser allein in den Gefäßbündeln des Stengels em porsteig t.

Stellen wir nun durch diese oder andere Stengel, in denen wir eine Farbstofflösung emporsteigen ließen, Querschnitte her, so erkennen wir, daß nur der Holzteil der Gefäßbündel gefärbt ist. Wir dïrfen daher auch annehmen, daß in ihm die Leitung des Wassers und der daringelösten Nährsalze erfolgt.

b) Benutzen wir zu unseren Versuchen Zweige eines Bammes, so stellt sich heraus, daß sich nur der Holzkörper und zwar besonders in den äußeren Schichten färbt, während Mark und Rinde unverändert bleiben. Also auch hier ist das $\mathrm{Holz}$ das wasserleitende Gewebe, und zwar steigt der Wasserstrom nur in den jüngsten Jahresringen, im Splint, empor. 
Sehr deutlich erkennen wir dies auch, wenn wir am Grunde eines beblätterten Astes, der mit dem Baume im Zusammenhange bleibt, einen mehrere Centimeter breiten Rindenring bis auf das Holz entfernen. Da die Blätter des Zweiges nicht vertrocknen, das Mark aber bereits verschrumpft ist, so kann das Wasser nur im Holze emporgestiegen sein. Nun sehen wir nicht selten Bäume lebhaft grünen, in denen alles ältere Holz durch Fäulnis zerstört ist (hohle Weiden u. a.), ein Zeichen, daß die Leitung des Wassers wirklich nur in den jüngsten Jahresringen, also im lebenden Holze, erfolgt.

c) Schwierige Untersuchungen haben nun ergeben, daß das Wasser (meist mit Luftblasen untermischt) in den Hohlränmen der Gefäße und Gefäßzellen emporsteigt. Diese Tatsache macht uns leicht verständlich, warum diese Gebilde die Form langgestreckter Röhren besitzen, warum sie in der Längsrichtung der Stämme verlaufen (Wasserleitungsröhren!), wie für sie die Beseitigung von Querwänden (Gefäße!) ein Vorteil ist, und warum ihre Wände nur teilweise verdickt sein dïrfen.

d) Durch welche Kräfte das Wasser in dem Holze emporgetrieben wird, ist von der Wissenschaft bisher noch nicht mit voller Sicherheit festgestellt. Wie wir bereits wissen, spielt die Verdunstung hierbei eine wichtige Rolle: Die Blattzelle, die Wasser verloren

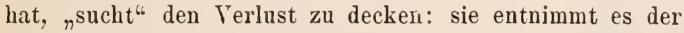
zweiten, diese der dritten u. s. f. Auf diese Weise wird das Wasser gleichsam von Zelle zu Zelle weitergegeben wie der Eimer, der „durch dor Hände lange Kette fliegt".

Eine andere Kraft, die hierbei tätig ist, ist der sog. IV urzeldruck, von dessen Vorhandensein wir uns leicht in folgender Weise ïberzeugen können: Wir schneiden eine kräftige Pflanze (Sonnenrose oder dgl.), die wir im Blumentopfe gezogen haben, oder eine Weinrebe dicht über dem Boden $a b$ und befestigen auf dem Stengelstumpfe mit Hilfe eines Gummischlauches eine lange, senkrecht stehende Glasröhre. Halten wir den Boden feuclit, so steigt in dem Glasrohre bald Wasser empor. Dieses Wasser ist von den Wurzelhaaren aus dem Boden gesogen, durch die Rindenzellen in das Gefäßbündel der Wurzel und von hier aus in die Gefäßbündel des Stengels geleitet. Da es nun ohne die saugende Wirkung der Blätter in dem Glasrohre loch emporsteigt, so ist dies ein Zeichen, daß es mit großer Kraft (,Wurzeldruck") in den Stengel gepreßt wird. An "blutenden" WVeinreben steigt der Saft sogar 10 und melır Meter hoch empor.

2. Die Leitungsbahnen für Baustoffe. Die Gefäßbündel des Blattes, die Blattnerven, haben wir auch als

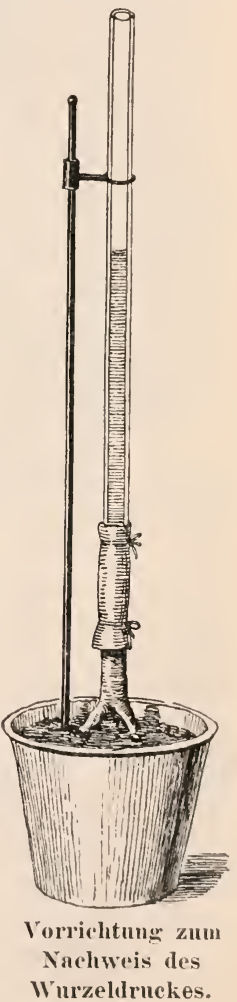


die Ableitungsbahnen derjenigen organischen Stoffe kennen gelernt, die im Blatte nicht verbraucht werden (s. S. 388). Diese Stoffe gelangen durch den Blattstiel in den Stamm, um dann den Orteu des Verbrauchs zugeführt zu werden.

a) Die löslichen Stoffe (Kohlenhydrate, lösliche Eiweißstoffe) wandern auf osmotischem Wege leicht von einer lebenden Zelle des Stammes zur anderen. Sie bedürfen daher keiner besonderen Leitungsbahn.

b) Anders verhält es sich dagegen mit den fertigen Eiweißkörpern, für die die Zellwände ein unüberwindliches Hindernis darstellen. Sie fließen - wie wir bereits gesehen haben - in den Siebröhren des Bastes auf oder nieder. Wird ein Stamm oder Zweig in der soeben angegebenen Weise geringelt oder

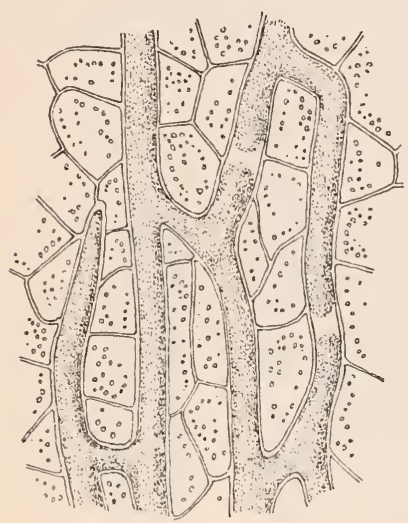

Verzweigte Milchröhren aus einem Blatte des Lattichs. (Vergr. etwa $250 \mathrm{mal}$.) fest umschnürt, so stanen sich die Nahrungssäfte meist oberhalb dieser Stelle, so daß eine wulstige Verdickung entsteht. Diese Erscheinung ist z. B. an Spalierbäumen, deren Zweige zu fest angebunden wurden, sowie an den Stämmen der Waldbäume zu sehen, die von dem Geißblatt umwunden sind.

c) Da der Milchsaft zahlreicher Pflanzen (Wolfsinilcharten, Mohn, Schellkrant, Löwenzahn u. v. a.) Stärkekörner, Eiweiß- und andere wertvolle Stoffe enthält, so ist es sehr wahrscheinlich, daB auch die Mil chröhren Leitungsbahnen für Baustoffe darstellen. Diese langgestreckten, meist vielfach verzweigten Kanäle durchziehen alle Teile der betreffenden Gewächse. - Die Bedeutung des Milchsaftes als Schutzmittel gegen Weidetiere und als VerschluBmittel von Wunden haben wir bereits bei der Betrachtung der Sonnen-Wolfsmilch kennen gelernt.

3. Die Markstrahlen als Ieitungsbahnen. Die Leitungsbahnen des Wassers und der fertigen Eiweißstoffe laufen im Stamme also nebeneinander her, und bei den zweikeimblättrigen Pflanzen und den Nadelhölzern schiebt sich zwischen sie sogar noch eine Trennungsschicht, das Kambium, ein. Nun gebrauchen aber z. B. die wachsenden Bestandteile des Holzes Eiweiß und umgekehrt die jungen Basiteile Wasser; die sich lebhaft teilenden Kambiumzellen benötigen beider Stoffe u. s. f. An der Außenseite des Stammes geht ferner durch Verdunstung fortgesetzt etwas Wasser verloren, das ersetzt werden muß: kurz, es müssen zwischen den Längleitungen Querverbindungen vorhanden sein. Diese sind durch die uns bereits bekannten Markstrahlen geschaffen.

Je dicker ein Stamm wird, desto mehr muß auch der Transport der Stoffe von innen nach außen und umgekehrt anwachsen. Hand in Hand hiermit geht 
daher auch eine Vermehrung der Verkehrswege: es schieben sich - wie wir gesehen haben - Nebenmarkstrahlen ein.

\section{F. Die Bekleidung der Stämme.}

1. Die Oberhaut. Wie wir gesehen haben, ist der junge Stamm gleich dem Blatte von einer festen Oberhaut überkleidet. Den krautigen Ståmmen einjälıriger Pflanzen genügt dieses wichtige Sclutzmittel (s. S. 381) vollkommen. Auch bei einigen mehrjälırigen Gewächsen (Mistel, Ginster- und Kaktusarten u. a.) bleibt die Oberhaut während einer längeren Zeit oder gar das ganze Leben hindurch erhalten. Es müssen sich dann natürlich ihre Zellen durch Teilung fortgesetzt vermebren, so daß das weiter werdende "Kleid" den in die Dicke wachsenden Stämmen folgen kann. Daher behalten diese Stämme (Zweige) auch die grüne Färbung, die auf dem Blattgrïnreichtum der obersten Rindenzellen berult (vgl. mit Laubblatt), und die wir bei den meisten einjälırigen Pflanzen antreffen.

Bei der überwiegenden Melırzalıl der ausdauernden Gewächse dagegen besitzt die Oberhaut nicht die Fähigkeit, weiter zn wachsen: sie wird von den dicker werdenden Stämmen gesprengt und löst sich schließlicli in Fetzen ab.

2. Der Kork. Bevor die Oberhant verloren geht, muß daher eine neue Schutzdecke gebildet werden. Dies geht in der Regel so vor sich, daß die der Oberhant anliegenden Rindenzellen sich lebhaft zu teilen beginnen. Während die innerste Schicht dieser Tochterzellen teilungsfähig bleibt, lagern die äußeren Zellen Korkstoff (s. S. 366) in ihre Wände ein und sterben bald ab. Anf diese Weise entsteht ein fast luft- und wasserdichter Mantel abgestorbener "Korkzellen", der die sclıützenden Aufgaben der Oberhaut in erhöhtem Maße erfüllt.

Ist die Korklage, die außen fortgesetzt abschilfert, nur dünn, so er-

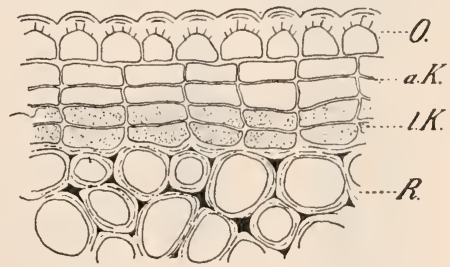

Bildung des Korkmantels. Querschnitt dureh die Rinde eines jungen Erlenzweiges. Während die Oberbant (O.) noch vorbanden ist, bilden sich in der Rinde Korkzellen (K.). Die untere Schicht dieser Zellen (I. K.) besteht aus lebenden, die obere (a.K.) aus abgestorbenen Zellen. R. Rindenzellen mit stark verdickten Wämlen. (Vergr. etwa $450 \mathrm{mal}$.) lält der Stamm eine glatte Oberfläche, wie wir sie bei der Rot- und Weißbuche, sowie beim Haselnußstrauche finden. Korkeiche und Feldulme dagegen bilden sehr dicke Korkmassen, die alljährlich um eine Schicht verstärkt werden. Die Birke besitzt eine weiße Korkhïlle, die in papierdünnen Streifen abblättert.

3. Die Borke. Entsteht die Korkschicht in größerer Entfernung von der Stammoberfläche, so werden den außerhalb von ihr liegenden Geweben Wasser und Nahrung entzogen, so daß sie absterben müssen. Diese toten Massen bilden mit der Korkschiclt die Borke. 
Beim Weinstock und Kirschbaum löst sich die Borke in Form von Bändern und Streifen, bei der Platane und an den Stämmen alter Kiefern als Platten, bei anderen (Fichte, Birnbaum u. a.) als Schuppen los. Bevor dies aber geschieht, ist bereits eine neue Korklage tiefer im Stamme gebildet. Ein Gleiches geschieht auch bei den Bäunen, die ihre Borke als einen nach und nach dicker werdenden Mantel lange Zeit behalten. Da sich nun der Stamm immer mehr ausdelınt, so werden die toten Borkemassen gesprengt: sie erhalten Risse, wie wir dies bei der Eiche und vielen anderen alten Bäumen sehen.

4. Die Rindenporen. Wie bei den Blättern, geht anch an den Stämmen, die von Oberhaut umkleidet sind, der Wechsel der Atemluft dureh die Spaltöffnungen vor

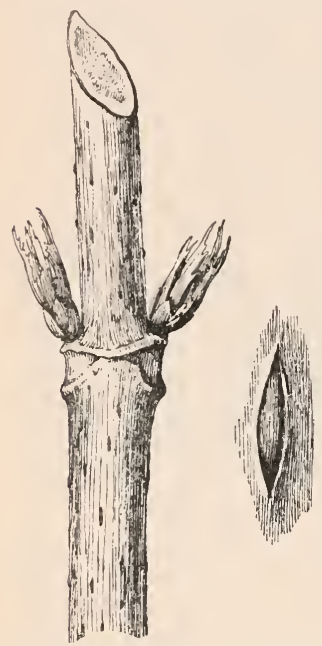

Riudenporen an einem cinjährigen Zweige des Holuuders (der zwei Winterknospen trägt). (Nat. (ir.). Daneben eine Risdempore b, etwa 10 facher Vergr. sich (s. S. 392). Wenn aber die Oberhaut durch einen Korkmantel ersetzt wird, so verschwinden auch die Spaltöffnungen. Da nun der Kork ein fast luftdichter Körper ist (Flaschenkork!), ohne Atmung aber keine lebende Zelle bestehen kann, so müssen $\mathrm{z}$ wischen Innnen- und A ubenluft neue Verbindungen geschaffen werden. Sie finden sich in den sog. Rindenporen, d. s. Haufen locker miteinander verbundener Zellen, deren Zwischenzellräume der Laft als Einund Ausgangskanäle dienen. Da diese Zellen gleichsam über den Kork- oder Borkenmantel hervorquellen, so erscheinen sie besonders an jungen Stämmen wie von lippenförmigen Verdickungen umgeben. Dort, wo diese Gebilde fellen, wird die Durchlüftung dureh die Markstrahlen vermittelt, die die Rinde bis zur Außenfläche durchsetzen.

5. Die Heilung von Wunden. Schon durch die kleinste Verletzung ist den Sporen der Schmarotzerpilze ein Eingang in das Innere des Pflanzenkörpers geschaffen. Daher suchen die Pflanzen die Wunden alsbald zu schließen. Ein vortreffliches Mittel hierzu ist der Kork, der sich durch Teilung aller lebenden Zellen an der Wundstelle bildet. Gehen bei Bäumen die Wunden bis ins Holz hinein, so wuchert das "Wundgewebe" so stark, daß die Verletzung bald vollkommen ${ }_{n}$ überwall t" ist.

Wunden fügen wir den Stämmen auch beim $\mathrm{V}$ eredeln zu (s. S. 86). Indem Edelreis und Wildling Wundgewebe erzengen, findet bald ein Verschluß der Wunde statt. Gleichzeitig verschmelzen auch die wuchernden Kambiumschichten beider, da sie sich innig berühren, miteinander. Die von dieser gemeinsamen Kambiumschicht gebildeten Holz- und Bastschichten gehören dann sowohl dem Edelreise, wie dem Wildlinge an, d. l. beide Teile sind vollkommen miteinander verwachsen. Auf gleiche Weise versehmelzen nicht selten ganze Bäume, wenn sich durch gegenseitige Reibung an ihnen Wunden bilden, die bis zum Kambium reichen (nzweibeinige Bäume"). 


\section{G. Festigkeit der Stämme.}

1. Notwendigkeit eines festen Geriistes. Wie wir früher gesehen haben (s. S. 363), erhalten alle Pflanzenteile durch den Turgor eine gewisse, zum Teil sogar ziemlich große Festigkeit. Die Spannung der Zellhänte nimmt aber sofort ab, wenn die Pflanzen z. B. mehr Wasser verdunsten als sie durch die Wurzeln aufnehmen können. Dann werden die Stengel schlaff, und die Blätter hängen welk herab oder liegen dem Boden auf. Größere Pflanzen oder gar Bäume können daher bezüglich ihrer Festigkeit anf den Turgor allein nicht angewiesen sein. Wie der Bammeister bestimmten Teilen seines Werkes, nämlich den Balken, Pfeilern, Säulen, Bogen u. dgl,, die Arbeit des Stützens und Tragens zuweist, so ist auch bei größeren Pflanzen die Herstellung der notwendigen Festigkeit gewissen Bestandteilen ïbertragen, die zusammen ein festes Gerïst bilden. (Han vergleicht das Gerüst der Ptlanzen auch mit dem Knochengerüst oder Skelett der Wirbeltiere und redet daher von einem .,Skelett der Pflanzen". Führe den Vergleich im einzelnen durch!)

2. Bestandteile des Geriistes. a) In den Holz- und Bastfasern haben wir bereits Bestandteile des Stammes kennen gelernt, die vermöge ihrer stark verdickten Wände der Festigkeit dienen. Stellen wir Längs- und Querschnitte z. B. durch einjährige Zweige des Pfeifenstranches her, so enthüllt uns das Mikroskop, daß auch außerhalb der Gefäßbüudel ähnliche dickwandige und langgestreckte Zellen vorkommen. Sie bilden hier einen hellen Ring, der die Gefäßbündel umgibt und schon mit der Lupe zu erkennen ist. Wie sorgfältige Untersuchnngen ergeben haben, besitzen alle diese faserförmigen Bestandteile des Pflanzenkörpers ein Tragvermögen, das im allgemeinen gleich dem des besten Schmiedeeisens, bei einigen Pflanzen sogar dem des Stahls ist. Dabei ist die Dehnbarkeit der Fasern 10-15mal größer als die des Schmiedeeisens.

b) Fast gleiche Festigkeit besitzen diejenigen Rindenzellen des Pfeifenstrauchs, die der Oberhaut unmittelbar angrenzen, oder die Zellen, die die vier Eckpfeiler des Taubnesselstengels (s. S. 147) aufbanen. Sie haben rundliche Form und sind nur an den Kanten stark verdickt. Im Gegensatz zu den Fasern besitzen sie also dünne Wandstellen, die sich noch durch Wachstum vergrößern, und durch die hindurch Stoffe ausgetauscht werden können. Daher verwendet die Natur diese Zellen stets in Pflanzenteilen, die noch in der Ausbildung begriffen sind. Die Fasern dagegen sind tote Zellhautgerïste, die wachsenden Teilen nicht folgen können. Sie finden daher auch nur in ansgebildeten Geweben Verwendung.

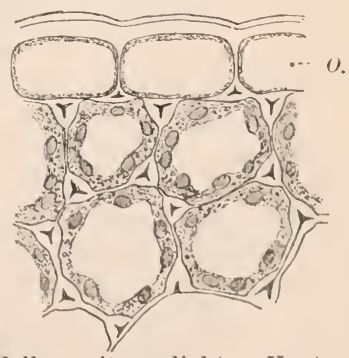

Zellen mit verdickten Kanten unter den Oberhautzellen (1). 1 eines Blattstieles. (Vergr.eetwa $600 \mathrm{mal}$. 
c) Rundliche Zellen mit gleichmäßig verdickten Wänden, wie wir sie bereits aus dem Fruchtfleische der Birne kennen lernten (s. Abb. S. 364), sind die dritte Art der Bansteine, die die Natur verwendet, um ihren Kindern die notwendige Festigkeit zu geben.

3. Konstruktion des (ieriistes. a) Nun kommt es bei einem Bauwerke nicht nur anf die Art des Baumaterials, sondern ebenso auf dessen richtige Verwendung an. Daß hierbei die Natur genan wie ein Baumeister verfährt, der mit der geringsten Menge des Materials die größte Leistung zu erreichen sucht, haben wir bereits an zwei Beispielen, dem Stengel der Taubnessel und dem Halm des Roggens gesehen. Wir haben dort anch (s. S. 146, B) gefunden, daß die Stämme Trag- und Biegnngsfestigkeit besitzen müssen, daß die äußerste Schicht des Stammes unter der Biegung (Wind!) am meisten zn

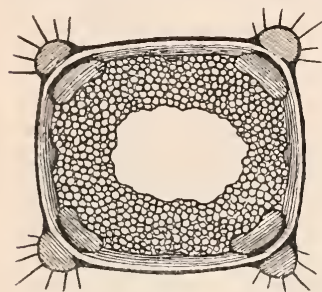

Querselinitt durch einen Stengel der weißen Taubnessel, um die Eckpfeiler zu zeigen. (Etwa 40 mal vergr.) leiden liat, und daß darum dort nur das festeste Baumaterial verwendet werden kann. Während bei der Taubnessel das Festigkeitsgewebe 4 Stränge bildet, die dem Stengel als ebensoviele Pfeiler dienen, stellt es beim Roggen eine geschlossene Röhre dar. Würden wir die Stengel anderer Pflanzen daraufhin untersuchen, so wïrden wir zwar finden, daß ihr Ban im einzelnen sehr verschieden ist, stets aber den Grundgesetzen der Baukunst entspricht.

Wir staunen vor den himmelanstrebenden Türmen, vor den Eisenbrücken, die sich in kühnen Bogen über den Strom spannen: aber wie plump erscheint doch selbst der schlankste Fabrikschornstein gegen den unscheinbaren Grashalm! Oder wo gäbe es ein Bauwerk der Erde, das soweit von der Richtung des Lotes abgebogen werden könnte, wie etwa der Stamm eines jungen Baumes, geschweige denn wie ein Getreidehalm, der sich im Winde bis zum Boden neigt und unbeschädigt in die senkrechte Stellung zurückkehrt? Die Baukunst, die der Mensch in Jahrtausende langem Ringen geschaffen hat, übt die Natur schon seit Anbeginn alles Lebens mit unvergleichlicher Meisterschaft!

b) Wird die Krone eines Baumes vom Sturme geschüttelt und der Stamm gebogen, so haben die Wurzeln wie die Ankertaue eines Schiffes, das im Hafen liegt und vom Sturme hin- und hergeworfen wird, einen gewaltigen Zug auszuhalten. Die Wurzeln müssen also zugfest ,konstruiert" sein. Wollte man die Ankertaue aufdrehen und alle Stränge, aus denen sie hergestellt sind, zur Befestigung des Schiffes so verwenden, daß sie etwas voneinander entfernt wären, so würde bald der eine oder andere Strang reißen; denn bei jeder Bewegung des Schiffes würden einige Stränge besonders in Anspruch genommen werden und den Zug nicht aushalten. Sind die Stränge dagegen fest zum Tau vereinigt, so.wird der Zug auf alle gleichmäßig verteilt, und sie vermögen selbst 
heftigen Angriffen zu widerstehen. Ebenso verhält es sich mit den "Ankertauen" der Bäume, den Wurzeln: sie können nicht wie die biegungsfest gebauten Stämme zahlreiche Gefäßbündel besitzen, die in einem großen Kreise nahe der Außenfläche angeordnet sind; die Holz- und Bastfasern, die ihnen die Festigkeit verleihen, miissen vielmehr in der Mitte seilartig zusammengedrängt sein. Auf diese Weise entsteht ein einziges, aber sehr dickes Gefäßbündel, das - wie wir schon gesehen haben - aus mehreren Holz- und Bastteilen besteht. Die Leistung, die die Wurzel zu erfïllen hat, erklärt uns also ihren Ban vollkommen?

Wie die Wurzeln haben anch zahlreiche unterirdische Stämme, die Stengel der Kletterund untergetanchten Wasserpflanzen (besonders diejenigen schnellfließender Gewässer), so-

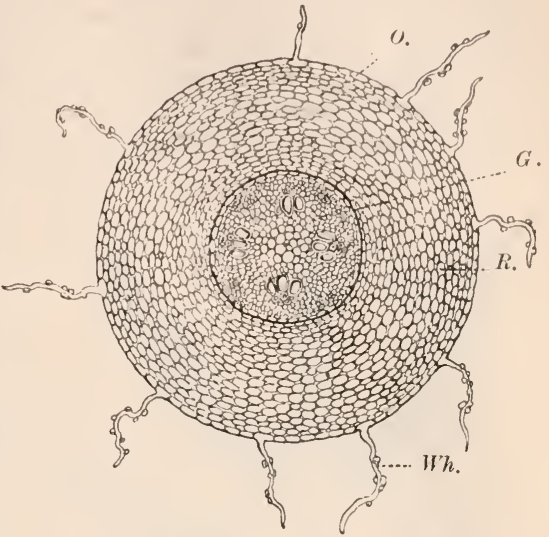

Querselmitt durch eine junge Wurzel Pinde; G Gefäßbündel, das ein leckeres Mark einschliebt. (Die weitesten Bestandteile des Gefäßbündels sint Getäße.)

wie die Blatt- und Fruchtstiele oft einen heftigen Zug auszuhalten (Beweis!). Bei ihnen sind daher die Bestandteile, äie die Festigkeit verleihen, gleichfalls mehr oder weniger der Mitte zugedrängt.

\section{Vom Ban und Leben der Blüte.}

\section{A. Die Fortpflanzung und die Blïte.}

1. Notwendigkeit und Arten der Fortpflanzung. Wie für Mensch und Tier tritt für jede Pflanze - und wäre es der ehrwürdigste Baumriese einmal der Tod ein. Soll ihre Art nicht aussterben, so ist sie ge. nötigt, Nachkommen zu erzeugen. Diese Aufgabe ist bei den höchststehenden Pflanzen, die uns hier allein beschäftigen sollen, bestimmten Teilen, den $B l u ̈ t e n$, übertragen. In ihnen werden Fortpflanzungskörper, S amen, gebildet, die sich von der Mluterpflanze trennen, und ans denen sich unter günstigen Verhältnissen Pflanzen derselben Art entwickeln. (Über die Fortpflanzung des Sporenpflanzen s. das.)

Viele Pflanzen sind jedoch imstande, sich noch anf andere Weise fortzupflanzen, z. B. die Erdbeere durch Ansläufer, die Kartoffel durch Stengelknollen 
das Scharbockskraut durch Wurzelknollen und zu Knöllchen umgewandelte Knospen (Brutknollen in den Blattachseln), die Tulpe und Feuerlilie durch Brutzwiebeln, das Windröschen durch Verzweigung des unterirdischen Stammes, der Weinstock durch einwurzelnde Reben („Stecklinge“ der Gärtner!) u. dgl. melır. Viele dieser Pflanzen haben sogar die Fähigkeit, keimfähige Samen hervorzubringen, gänzlich oder fast gänzlich eingebüßt. So lassen sich z. B. unsere edlen Obstsorten, sowie zahlreiche Spielarten des Weinstocks und der Erdbeere nicht durch Samen fort-

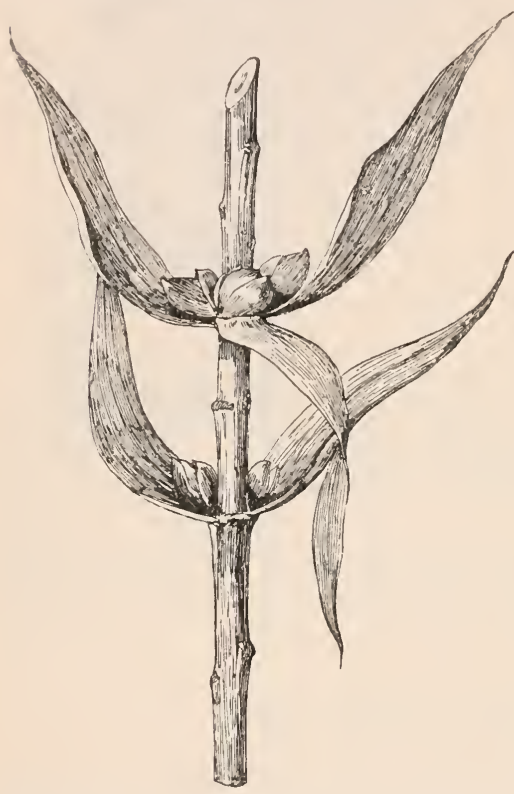

Brutzwiebeln in den Blattachseln der Fenerlilie (nat. (ir.) Die Blätter, in deren Achseln sich keine Brutzwiebeln gebildet hatten, sind entfernt. pflanzen, oder so bildet das Scharbockskraut in der Regel keine Samen aus. Diese zweite Art der Fortpllanzung besteht also darin, daß sich ein Teil des Pflanzenkörpers, der sich außerhalb der Blüte gebildet hat, von der Lutterpflanze loslöst und nunmehr ein selbständiges Leben führt. Im Gegensatz zu der sog. geschlechtlichen Fortpflanzung, wie sie in der Blüte erfolgt, bezeichnet man diese Vermehrungsweise als die ungeschlechtliche (vegetative).

\section{Wesen und Bestandteile} ler Blüte. a) Die Blüte findet sich stets am Ende des Stammes (Zweiges) und wird in der Regel von einem längeren, blattlosen Stammteile, dem Blïtenstiele, getragen. Denken wir uns den sehr kurzen Endabschnitt des Stammes, dem die dicht gedrängt stehenden Blütenteile ansitzen, in die Länge gestreckt, so erkennell wir leicht, daß die Blïte nichts anderes als ein endständiger Zweig oder Sproß (s. S. 409) ist. Da dieser Sproß aber eine bestiminte Aufgabe zu lösen hat, nämlich Samen hervorzubringen, so kann es nicht Wunder nehmen, daß er z. B. von einem mit Laubblättern besetzten Zweige erheblich abweicht. (Vgl. mit einem solchen Zweige z. B. die Zwiebel, in der wir gleichfalls nur einen Stammteil mit besonder's gestalteten Blättern erkannt haben.)

b) Der Stammteil der Blïte ist (ähnlich wie bei der Zwiebel oder bei der Bildung von Blattrosetten) stark verkürzt und wird Blüten- oder später Fruchtboden genannt. Die von ihı entspringenden Blätter sind (bis auf Ausnahmen) 
in Kreisen angeordnet, von denen man in "vollständigen" Blïten vier unterscheidet: die Kelch-, Blumen-, Staub- und Fruchtblätter.

c) Fehlt einer der 4 Blattkreise, dann bezeichnet man die Blüte als unvollständig (Beispiele!). Enthält sie nur Staubblätter, so wird sie Staub- oder männliche Blüte genannt. Sincl nur die Fruchtbliatter vorhanden, so heibt sie St empel-oder weibliche Blüte. Je nachdem sich die Staul- und Stempelblüten nun wieder auf derselben P'flanze (Haselnußstraueh) oder auf verschiedenen Pflanzen finden (Weide), bezeichnet man die Gewächse als ein-oder zweihäusig. Besitzt die Bliite Staub- und Frachtblätter, so heibt sie Zwitterbliite (Mohn, Tulpe n. v. a.).

\section{B. Die Teile der Blüte.}

1. Die Kelch- und Blumenblïtter. a) Die beiden äußeren Blattkreise bilden für die zarten inneren Blütenteile ein schützendes Dach: daher werden sie auch als Blütenh üllen bezeichnet. Bei vielen Pflanzen (Beispiele!) haben sie diesen Dienst nur so lange zu leisten, als sich die Blüte im Knospenzustande befindet, bei anderen dagegen bis zum Absterben der Blüte (Oberlippe der Taubnessel- und Leinkrautblïte $u$. a.), und bei noch anderen (z. B. Tulpe, Scharbockskraut) führen sie zum Zwecke des Schutzes regelmäßig wiederkehrende Be-

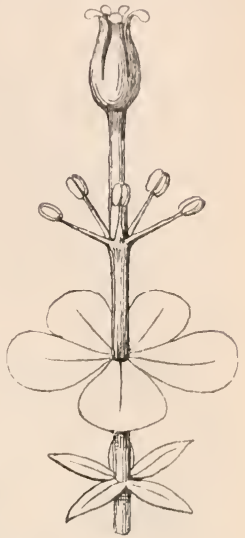

Bliite, deren Teile weit auseinander gerïekt sind (Sehema). wegungen aus: die Blïte öffnet und schließt sich; sie "wacht und schläft".

Da das öffnen und Sehließen zu ganz bestimmten Zeiten des T'ages stattfindet (Beispiele!), muß hierbei das Licht im Spiele sein. Zahlreiche Blüten (Tulpe, Scharbockskraut) bleiben aber bei kaltem Wetter den ganzen Tag über gesehlossen. Werden sie jedoeh in ein warmes Zimmer ge!racht, so öffnen sie sieh alsbald, ein Zeichen, daß auf sie auch die Wiarme einen wielitigen Einflub ansübt.

Welcher Art ist aber dieser Einfluß? Wie sieh z. B. an der Tnlpe durcls regelmiBig zu wiederholende Messungen nachweisen lïbt, sind ihre Blumenbläter in einem fortgesetzten W a e h s $\mathrm{tum}$ begriffen. Sobald dies aber heentet ist, finden anch keine Schlieblewegnngen mehr statt. Diese Tatsaehe liibt schon erkemnen, daß heide Erscheinungen in innigem Zusammenhange stehen. Und so ist es auch: die Blumenblätter der Tulpe und jener anderen Pflanzen besitzen nämlich die Eigentümlichkeit, dureh Licht- mol Wïmeschwankungen so beeinfußt zu werden, daß ihre verschiedenen Seiten nugle ichmäßig wachsen. Bei Abnahme des Lichts und der Wärme - in der Regel also mit Beginn des Abends wachsen die Blätter an der Unterseite mehr als an der Oberseite. Infolgedessen bewegen sie sich anfwärts: die Blïte schließt sich also. Findet der nmgekehrte Vorgang statt, so öffnet sich die Blïte. - Auf dieselhe Weise geht anch das Schließen und öflnen der Blütenköpfe zahlreicher Korbblütler vor sich (Löwenzahn, (iäıseblïmchen u. a.).

b) Die beiden Blattkreise der Blütenhülle sind in der Regel (Beispiele!) von verschiedener Beschaffenheit und Färbung. Die Blätter des äußeren Kreises sind meist grün wie die Laubblätter, die des inneren dagegen zum Anlocken der 
Bestäuber (s. S. 442) abweichend gefärbt. Dann bezeichnet man die Blütenhülle als . doppelt" und ihre Kreise bekanntlich als Kelch und Blumenkrone. Sind beide Kreise von gleicher Beschaffenheit (Tulpe), oder ist nur ein Kreis vorbanden (Windröschen), so redet man von einer e in fa c he n Blütenhülle (oder einem Perigon).

c) Die Blätter beider Kreise bleiben unter sich entweder getrennt (Scharbockskrant), oder sie verwachsen mehr oder weniger vollkommen miteinander (Kartoffel, Schlüsselblume u. a.). Aus den freien Endabschnitten (Zipfeln, Zähnen u. dgl.) läßt sich zumeist noch erkennen, aus wieviel Blättern ein solcher Kelch oder eine solche Blumenkrone hervorgegangen ist. Es findet jedoch keine nachträgliche Verwachsung der Blätter statt, sondern der verwachsene Teil erhebt sich - wie wir dies bereits bei der Betrachtung der Schlüsselblume kennen gelernt haben - vom Blïtenboden als ringförmiger Wall. Verschmelzen die Staubblätter mehr oder weniger mit dem Walle, aus dem die Blumenkrone hervorgeht, so erscheinen sie dieser eingefügt (Schlüsselblume, Schwarzwurz u. v. a.).

2. a) Die Staubbliitter (Staubgefäße) lassen im Gegensatz zu den Bestandteilen der Blütenhülle nur schwer erkennen, daß sie Blattgebilde sind. Bei mehreren Pflanzen, z. B. bei der Seerose (Taf. 3, 2), findet aber zwischen ihnen
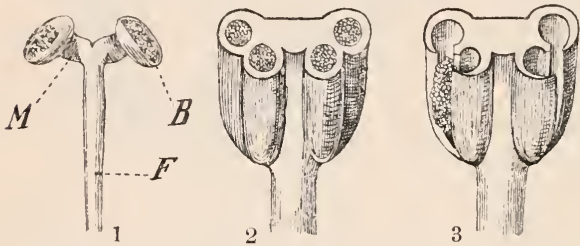

Staubblätter. 1 Staubblatt des Feld-Thymians: Stanbfaden; B. Stanbbenteltächer; M. Mittelband (hier sehr groß). 2 und 3 schematische Darstellung vom Bau des Staubbentels. Bei 2 sind die Fächer geschlossen, bei 3 geäflnet. und den Blumenblättern ein deutlicher Übergang statt, und in zahlreichen gefüllten Blüten, z. B. in der Rose, verwandeln sie sich in Blumenblätter zurück, so daß ihre Blattnatur außer Frage steht.

b) Die Staubblätter sind in der Regel aus S t a u bfaden und Staubbeutel zusammengesetzt. Der Beutel besteht meist wieder aus 2 Sta ubbeutelfächern, die durch einen Fortsatz des Stanbfadens, das sog. Mittelband, zusammengelıalten werden. Auf Querschnitten durch den unreifen Beutel sieht man, daß jedes Fach 2 Hohlräume enthält, in denen durch wiederholte Zellteilung der Bliitensta ub (Pollen) entsteht. Bei der Reife öffnen sich beide Hohlränme durch einen gemeinsamen Längsriß, aus dem der Blütenstaub hervorquillt. Seltener erfolgt das Öffnen durch Löcher (Kartoffel, Heidekraut u. a.) oder durch Klappen (Sauerdorn u. a.).

Meistens stehen die Staubblätter, deren Anzahl in den einzelnen Blüten großen Schwankungen unterliegt, frei da. Es gibt jedoch auch zahlreiche Fälle, in denen die Staubfäden (Schmetterlingsbliitler, Hartheu u. a.) oder die Staubbeutel (Korbblütler, Kürbis u. a.) miteinander verwachsen sind. (S. das Linnésche System.) 
c) Die Blütenstaubkörner geben sich unter dem Mikroskope in der Regel als einzellige Gebilde von sehr verschiedener Form, Farbe und Größe zu erkennen. Außer von einer zarten Innenhaut sind sie noch von einer festen Außenhaut umgeben, die als Schutzmittel gegen Verletzung und Wasserverlust (Vertrocknen!) dient.

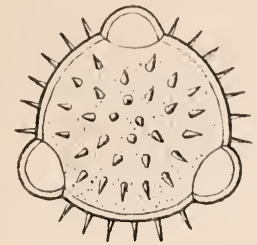

1

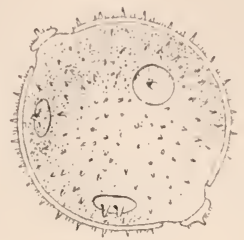

2

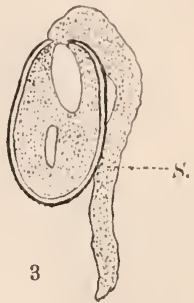

Blïtenstaubkörmer 1 von der Sonnenrose (Vergr. etwa 900 mal); 2 vom Kürbis mit deekelartigen Bildnngen der Aubenhant (Vergr. etwa $480 \mathrm{mal}$ ); 3 von der Nirzisse, einen Keimschlauch (S.) treibend (Vergr. etwa $350 \mathrm{mal}$ ).

Bringen wir Blïtenstanbkörnchen in Wasser, so saugen sie in der Regel sofort soviel davon ein, daf sie stark aufschwellen und platzen. Dasselbe geschieht natïrlich auch, wenn sie durch Regen oder Tau befeuchtet werden. Daher hat die Natur sehr verschiedenartige Einrichtungen getroffen, um die zarten Gebilde gegen Befeuchtung zu schützen:

Zahlreiche Blïten sind wagerecht gestellt, hängend oder schräg nach unten geneigt (Königskerze, Glockenblmue, Kartoffel n. a.); ein Blïtenteil ist zum sichutzlach mugeformt (Lippenblütler, Knabenkrantgewächse n. a.); Hïllblätter otler gar Lanbblättcr übernehmeu den Schutz (Aronstab n. a.; Linde); die Blütenröhre ist sehr eng, oft noch Anrch Schuppen oder Haare versperrt (Vergißmeinnicht, Ehrenpreis); die Blüten oder Blïtenstände schließen sich abends und bei Eintritt ungünstiger Witterung (Scharbockskraut, Löwenzahn), oder sie werden nickend (Erdbeere, Mröre), oder es tritt beides zugleich ein (Windröschen, Wiesenschaumkraut); die geöffneten Staubbeutel schließen sich naclıts oder bei feuchtem Wetter (Wegerich) n.s.w.

Legen wir Blütenstaubkörnchen in wenig Wasser, dem etwas Zucker und Gelatine zugesetzt sind, so platzen sie nicht. Ihr Inhalt aber stülpt sich, von der zarten Innenhaut umgeben, nach außen und wächst wie bei den keimenden Sporen (s. S. 298) zu je einem langen Keimsclilauche (Pollenschlauche) heran. Um dem Schlauche, dessen Bedeutung wir später kennen lernen werden, leicht den Durchtritt zu gestatten, hat die feste Außenhaut viel-

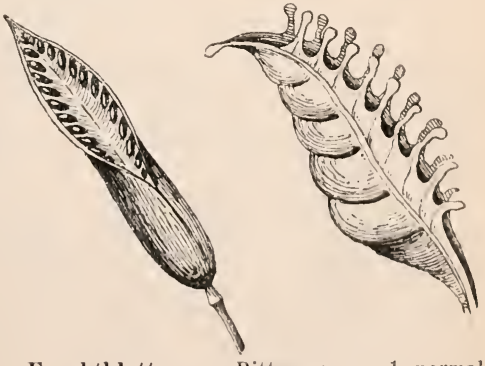

Fruchtblatt vom Rittersporn. 1 normal ausgebildet, 2 miBgebildet. 
fach diinne oder scharf abgegrenzte Stellen, die durchbrochen oder deckelartig abgehoben werden.

3. a) Die Fruchtblätter lassen ihre Blattnatur oft noch recht deutlich erkennen: in zahlreichen Blüten (Rittersporn u. a.) sehen sie fast wie kleine Laubblätter aus, und in mißgebildeten Blüten kann man nicht selten eine Rückbildnng zl wirklichen, grünen Laubblättern beobachten.

b) Bei den Nadelhölzern und ihren nächsten Verwandten hat das Fruchtblatt seine ursprüngliche Blattgestalt bewahrt (s. das.). Bei allen anderen Blitenpflanzen dagegen hat es sich allein oder mit anderen seinesgleichen zu einem Stempel umgebildet. So ist deutlich zu erkennen, daß der Stempel z. B. der Erbse aus einem Fruchtblatte dadurch entstanden ist, daß dessen Ränder miteinander verwachsen sind, oder daß der der Schlüsselblume aus 5 Fruchtblättern auf dieselbe Weise gebildet ist. Die Verwachsungsstellen der Fruchtblätter sind meist noch als $\mathrm{N}$ ähte sichtbar.

c) Der untere Teil des Stempels, der Fruchtknoten, ist ein Gehäuse oder Behălter für die sehr zarten Samenanlagen oder Samenknospen. Da - wie

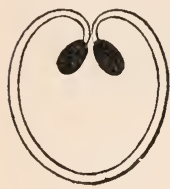

1

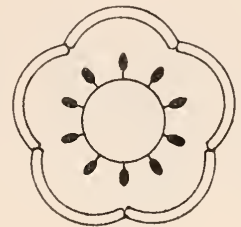

2

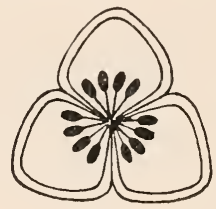

3

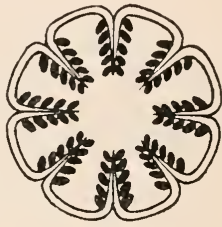

4

Bau des Fruchtknotens (schematisch). 1 Der Fruehtknoten besteht aus einem Fruehtblatte (Erbse). 2 Er wird aus 5 Fruchtblättern gebildet; die Samenanlagen sitzen an einem säulenartigen Zapfen, der vom Blütenboden aus in den Hohlraum tritt (Schlüsselblume). 3 Dreiblätteriger Fruchtknoten (Tulpe), dessen Innenraum durch Scheidewände in 3 Fächer geteilt ist. 4 Vielblätteriger Fruchtknoten (Mohn), dessen Innenraum unvollkommen gefächert ist.

soeben erwähnt - die Fruchtblätter der Nadelhölzer und ihrer Verwandten sich nicht zu Stempeln unformen, liegen hier die Samenanlagen frei da, ein Um. stand, auf dem die Scheidung der Blütenpflanzen in "bedecktsamige" und nnacktsamige" beruht.

Verwachsen die Fruchtblätter nur mit ihren Rändern, so stellt das Innere des Fruchtknotens einen einzigen Hohlraum dar (Erbse, Schlüsselblume). Erstrecken sie sich aber mehr oder weniger weit in den Innenranm, so wird dieser wie durch Scheidewände vollkommen oder unvollkommen in Fächer geteilt (TuJpe, Klatschmohı1). Zu diesen "wahren" Scheidewänden treten ab und zu noch "falsche", die nur Wucherungen der Fruchtblätter darstellen. Wir treffen sie z. B. bei den Krenzblütlern (s. Blïtengrundriß S. 18) und beim Flaclis an (s. Taf. 9, 5). Mehr- 
fach (z. B. bei der Schlïsselblume) ragt in den Hohlraum des Fruchtknotens vom Blütenboden aus ein sänlenartiger Zapfen.

d) Nach oben setzt sich der Fruchtknoten in einen stielartigen Teil, den Griffel, fort, der in der $\mathrm{Narbe}$ endigt. Ist nur ein Fruchtblatt vorhanden, oder sind die Fruchtblätter im oberen Teile völlig miteinander verschmolzen, so tritt auch nur e in Griffel mit einer Narbe auf (Erbse, Schlïsselblume). Ist die Verwaclsung der Fruchtblätter dagegen nur auf den Fruchtknoten beschränkt, so sind mehrere Griffel mit ebenso vielen Narben vorhanden (Nelkengewächse u. a.). Bei mehreren Pflanzen (Mohn, Tulpe u. a.) fehlt der Griffel gänzlich.

4. Der Blütenboden. Je nach der Form des Blütenbolens nimmt der Fruchtknoten zu den übrigen Bliitenteilen eine versehiedene Stellung ein. Ist der Blütenhoden mehr oder weniger emporgewölbt, so steht der Fruehtlinoten höher als die anderen Blütenteile: er ist oberständig (Seharbockskraut, Raps, Mohn u. v.a.). Vielfach ist der Blätenboden aber napfoder krugförmig ausgehöhlt. Dann steht der Fruchtknoten tiefer als die ïbrigen Blütenteile. Verwachsen in diesem Falle Blütenboden und Fruchtknoten miteinander (wie bei Apfel, Birne, Möhre un. a.), so bezeiehnet man das aus beiden entstehende Gebilde, das dann die übrigen Bliitenblattkreise trägt, als
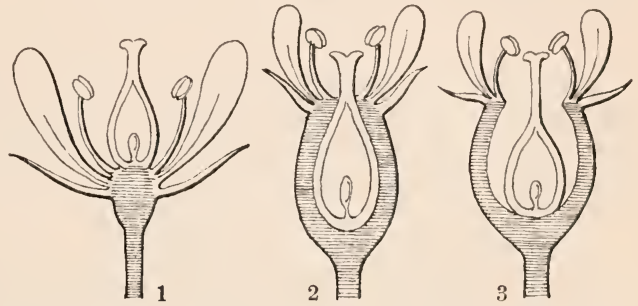

Stellung des Fruchtknotens (schematisch). $1 \mathrm{Er}$ ist oberständig, 2 nnterständig, 3 mittelständig. Der Blütenboden ist schraffiert gezeichnet. un te rständigen

Fruchtknoten. Tritt eine solche Verschmelzung nicht ein (wie bei Kirschbaum und Rose), so redet man von einem $m$ ittelst ändigen Fruehtknoten. (Vgl, auch die Abbildungen der erwähnten Bliiten!)

5. Bliitengrumdrif. Stellt man z. B. dnrch eine Nelkenblïte kurz vor ihrer Eutfaltung dicht über dem Grunde einen Querschnitt her, so werden alle Blütenteile daron getroffen. Man erkennt auf diesem Schnitte leieht die Anzahl der Teile, ihre Verteilnng auf die einzelnen Blattkreise und die Stellnng, die sie zueinander haben. Eine sehematische Zeiehnnng dieses Bildes ist der GrundriB oder das Diagramm der Blüte. Bei den meisten Bliiten, z. B. bei denen der Tanbnessel oder der Schlïsselblume, muß man aber, nm sämtliche Verhältnisse kennen zn lernen, mehrere Querschnitte in verschiedener Höhe führen. Trägt man darauf die versehiedenen Bilder, die dic Sclınitte lieferten, so in eine Zeichnnng ein, dab ihre Mittelponkte zusammenfallen, so erhält man gleiehfalls den gew ünschten Grumlriß. Sind Blïtenteile miteinander verwaehsen, so werden sie im Grundriß als rerbunden gezeichnet. (Vgl. anch s. 3, Anm.)

Die Blïte (oder der Blütengrundrib) z. B. der Śchlïsselblume läßt sich durch zehn Sehnitte, die durch den Mittelpunkt gehen, in je 2 gleiche Teile zerlegen führe dieso Schnitte!). Hält man den einen dieser Teile an die Fläche eines spiegels, so wird er durch sein Spiegelbild zu einer ganzen Blüte ergänzt. Die Teile sind also spiegelbildlich 
gleich oder symmetrisch. In den Bläten dieser Pflanze sind ferner Kelch-, Blumen-,
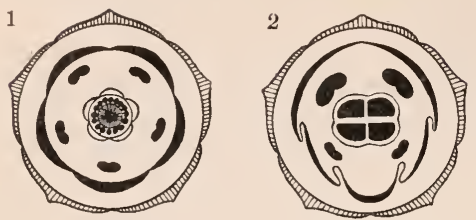

Blütengrundrisse. 1 GrundriB einer strahligen oder regelmäßigen Blüte(Schlüsselblume). 2 Grundriß einer zweiseitig-symmetr. Blïte (Tanbnessel). Staub- oder Fruchtblätter so regelmäBig um den Mittelpunkt gelagert, als strahlten sie von ihm ans wie die Radien vom Mittelpnnkte des Kreises. Blüten dieser Art werden daher als strahlig-symmetrisch oder kurz: als strablig oder regelmäBig bezeichnet. Die Blüten (oder die Blütengrundrisse) der Tauhnessel, des Veilchens und vieler anderer Ptlanzen dagegen lassen sich nur durch einen Schnitt in 2 symmetrische Teile zerlegen. Sie sind also zweiseitig- oder kurz: seitlich-symmetrisch.

\section{Die Blütenstände.}

Es kommt verhältnismäßig selten vor, daß eine Pflanze nur eine einzige Blüte hervorbringt (Tulpe, Schneeglöckchen). Sind, wie in der Regel, mehrere oder zahlreiche Blïten vorhanden, so stehen sie entweder einzeln in den Blattwinkeln wie bei der Taubnessel, oder sie sind zu Blütengemeinschaften oder Blïtenständen gehänft (Beispiele!).

Den Stengelteil der Blütengemeinschaft, dem die einzelnen blütentragenden Zweige oder die gestielten oder ungestielten Blüten entspringen, bezeichnet man als die Hauptachse des Blütenstandes. Die aus ihm hervorgehenden Zweige werden daher Nebenachsen genannt. Da die Verzweigung nun sehr verschieden erfolgt, zeigen die Blütenstände eine große Mannigfaltigkeit. Wie überall in der Natur herrscht aber auch hier eine feste Ordnung, eine bestimmte Gesetzmäßigkeit : die Blütenstände lassen sich - so verschieden sie auch gestaltet sein mögen - bei näherem Zusehen auf drei Hauptformen zurückführen:
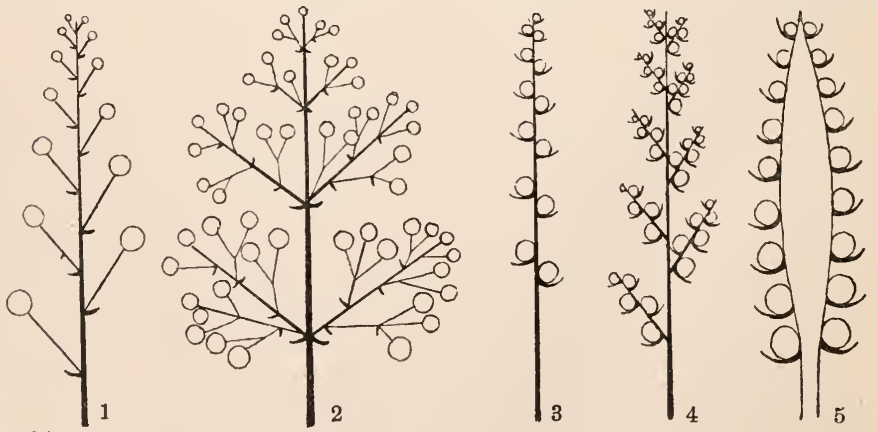

Traubige Blïtenstände (Schema).. 1 Traube; 2 Rispe; 3 Ähre; 4 zusammengesetzte Ähre; 5 Kolben. 
1. Traubige Blütenstände. Die Hauptachse verlängert sich (bis zu einer gewissen Größe) fortgesetzt durch Wachstum und ïbertrifft die Nebenachsen an Länge und Stärke. Da die unteren Blïten lie älteren sind, so entfalten sie sich zuerst. Das Aufblühen erfolgt also von unten nach oben oder - wenn die Bliiten gestielt sind - von auBen nach imnen (centripetal). (Jiese Erscheinung ist in den Abbildungen durch die verschiedene (iröße der Kreise kenntlich gemaeht, dnrch die die Blüten angedeutet sinul.)

a) Trägt die Hauptachse langgestielte Blüten, so nennt man den Blütenstand eine Tra ube (Maiblume u. a.). - Eine Traube, deren Nebenachsen wieder Trauben (oder gar Rispen) bilden, wird Ris pe genannt (Weinstock; Rispengräser; bei letzteren tragen die Rispenäste aber Ähren!)

b) Sind die Blïten ungestielt (oder ganz kurz gestielt), so entsteht eine Ä hre (Eisen- und Bingelkrant). - Findet sich an Stelle jeder Blïte eine kleine Ähre, ein sog. Ährchen, so hat man eine znsammengesetzte $\ddot{A} h r e$ vor sich (Roggen und viele andere Gräser). Eine Ähre mit fleischiger Achse ist ein Kolben (Aronstab). Hat die Älıre nnscheinbare Blüten und fällt sie nach dem Verblühen oder der Fruchtreife als (ianzes ab, so nennt man sie $\mathrm{Kätzehen} \mathrm{(zahlreiche} \mathrm{Laubbäume).} \mathrm{Ein} \mathrm{Kätzchen,} \mathrm{dessen}$ Aehse und Deckschuppen bei der Fruchtreife holzig werden, wird als Zap fen bezeichnet (die meisten Nadelholzbäume).

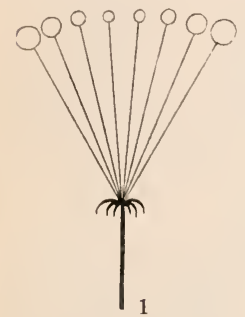

Doldige Blïtenstände (Schema).
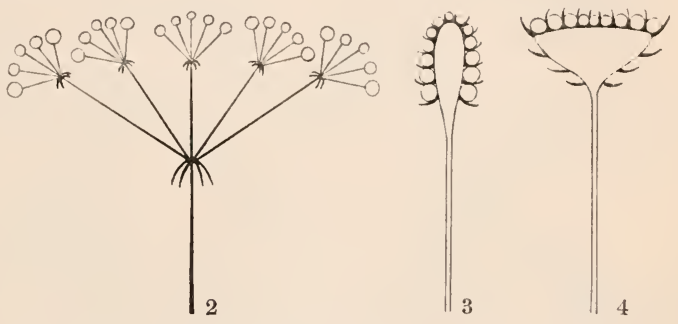

1 Dolde; 2 zusammengesetzte Dolde; 3 Köptchen; 4 Bliitenkörbchen.

II. Doldige Blütenstände. Die Hauptachse "hört plötzlich anf", ist also verkürzt. Die Nebenachsen entspringen an einem Punkte. Das Anfblühen erfolgt gleichfalls von anßen nach innen (centripetal).

a) Erheben sich von der verkürzten Hanptachse gestielte Bliiten (die zmmeist in einer Ebene liegen), so lieißt der Blütenstand eine Dolde (Schlüsselblume, lifen). Stellt jede Nebenachse wieder eine kleine Dolde (,Döldchen“) dar, so entsteht die zus a m m e ngesetzte Dolde (die meisten Doldenpflanzen).

b) Stehen anf der verkïrzten Hauptachse dicht gedrängt zahlreiche ungestielte (oder ganz kurz gestielte) Blüten, so hat man ein Köpfehen vor sieh (Grasnelke). Ist das Köpfchen von Hüllblättern umgeben, so nemnt man es Blüt enkürbchen (Korbblütler).

III. Trugdoldige Blütenstünde. Die Hauptachse ist dureh eine endständige Bläte abgeschlossen, die als die älteste sich zuerst öfinet. Tnterhalb dieser Blïte entspringen ein oder mehrere Nehenachsen. Sie schließen gleichfalls mit je einer Blïte ab, die sich nunmehr entfaltet. Auf' diese Weise kann sich die Verzweigung mehrfach wiederholen. Das 
Aufblühen schreitet hier also - gleichfalls dem Alter der Blüten entsprechend - von innen nach außen fort (centrifugal).

a) Unter der endständigen Blüte der Hauptachse entspringen an einem Punkte 2 oder mehrere Nebenachsen, die sich wiederholt wie die Hauptachse verzweigen können. Da bei diesem Blütenstande die Blüten vielfach ähnlich wie bei der Dolde in einer Ebene liegen, nennt man ihn Trugdolde (Wolfsmilch, s. Taf. 10; Schafgarbe, Ackerhornkraut u. a.).
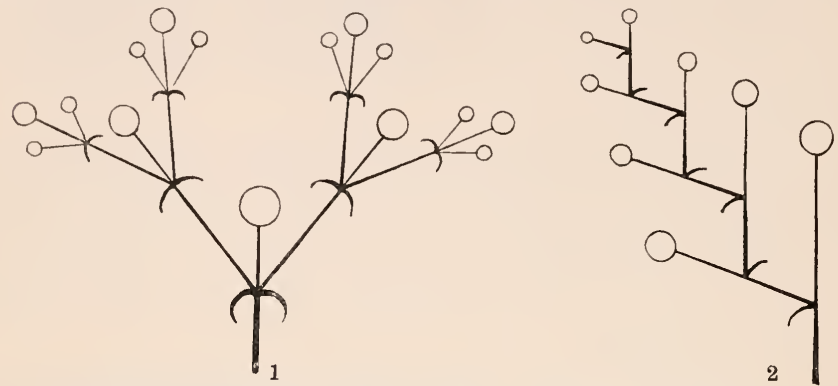

Trugdoldige Bliitenstände (Schema). 1 Trugdolde; 2 Wickel.

b) Unter der endständigen Blüte der Hauptachse entspringt nur eine Nebenachse, die fortgesetzt abwechselnd rechts und links wieder je einen Nebenzweig treibt. Ein solcher Blütenstand wird Wickel genannt (Schwarzwurz und viele andere Rauhblatt-Gewächse).

\section{Die Bestäubung der Blüte.}

1. Es ist eine bekanute Tatsache, daß eine Blüte nur dann Samen hervorbringt, wenn auf ihre Narbe reifer Blütenstaub von einer Pflanze derselben Art gelangt, oder kurz, wenn die Pflanze bestäubt wird. Der Nachweis hierfür ist leicht zu erbringen. Schneidet man z. B. aus Tulpenblüten die Staubblätter, bevor sich deren Beutel geöffnet haben, vorsichtig heraus, und umwickelt man die Blüten dann (um die Insekten abzuhalten!) mit engmaschiger Gaze, so bleiben sie unfruchtbar. Überträgt man jedoch auf die Narben anderer, aber ebenso behandelter Blüten mit Hilfe eines feinen Pinsels Blütenstaub, der aus anderen Tulpenblüten stammt, so tritt sicher in den meisten Fällen Samenbildung ein.

2. Auf ganz ähnliche Weise läßt sich anch dartun und ist von Naturforschern vielfach aufs sorgfältigste festgestellt worden, daß bei der Bestäubung einer Blüte mit ihrem eigenen Blütenstaube oder kurz: bei Selbstbestäubung in der Regel keine oder nur schwächliche Samen entstehen. Stammt der Blütenstaub dagegen von anderen Blüten derselben oder noch besser einer zweiten Pflanze, erfolgt also Fremdbestäubung, so bilden sich zahlreiche und kräftige Samen.

Es gibt allerdings gewisse Blüten, z. B. die sog. "Sommerblüten" des 
Veilchens und der stengelumfassenden Taubnessel, die, weil sie sich nicht öffnen, auf Selbstbestäubung angewiesen sind. Auch bei zahlreichen offenblütigen Pflanzen tritt, wie wir gesehen haben (s. z. B. Sonnenrose), dieser Vorgang ein, wenn die Belegung der Narbe mit fremdem Staube aus irgend einem Grunde (Kălte, IIangel an Besuchern u. dgl.) unterblieben ist, und endlich haben wir in der kleinblitigen Form des Stiefmittterchens auch eine Pflanze kennen gelernt, die sich fortgesetzt nur selbst bestäubt. In der Regel aber ist die Fremd-

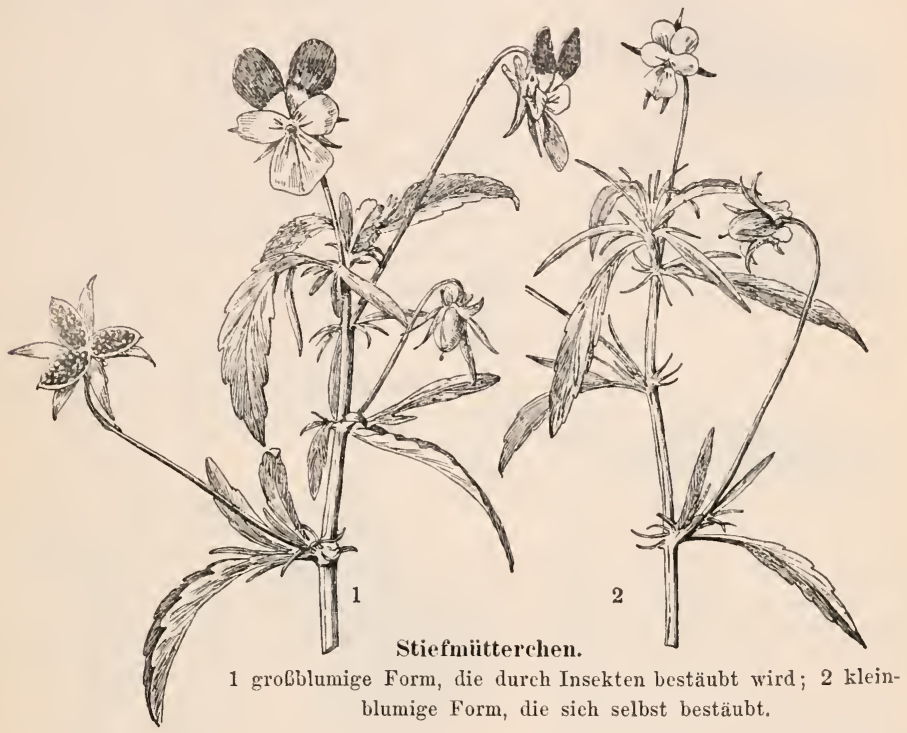

bestäubung der von den Pflanzen gew ï nschte" Vorgang. Gewisse Pflanzen (z. B. Roggen) bleiben sogar bei Selbstbestäubung vollkommen unfruchtbar. Daher hat die Natur auch die mannigfachsten Nittel ansgebildet, um eine Belegung der Narbe durch fremden Blütenstaub herbeizuführen:

a) Staublätter und Stempel sind auf versehiedene Blüten verteilt; die Pflanzen sind also ein- oder zweihäusig (s. Haselnußstrauch und salweide).

b) Bei Blüten, die Staubblätter und Stempel entlalten, also sog. Zwitterblüten sind, wird Selbstbestäubung vermieden, wenn $s$ ta ubblät te und $\mathrm{s}$ tempel nieht z u gleicher Zeit reifen. Meist (Glockenblume, Somnenrose u. a.) öfnen sich die Staubbeutel bereits, wenn die Narben noch vollkommen unentwickelt sind (n rorstäubende ${ }^{-}$ Blüten). Der umgekehrte Fall ( $n$ nachstäubende ${ }^{*}$ Blüten) tritt seltener ein (Sonnen-Wolt'smileh, Wegerieh, Osterluzei, Aronstab u. a.).

c) Reifen in Zwitterbluten Staubbeutel und Narben zu gleieher Zeit, so ist 
Selbstbestäubung vielfach ausgeschlossen oder doch stark behindert, weil die beiden Blütenteile so gestellt sind, daB sie sich nicht berïhren können (Wiesensalbei, Orchis, Schwertlilie u. a.).

d) Zu demselben Ziele führt anch die Verschiedengriffligkeit (s. S. 122),

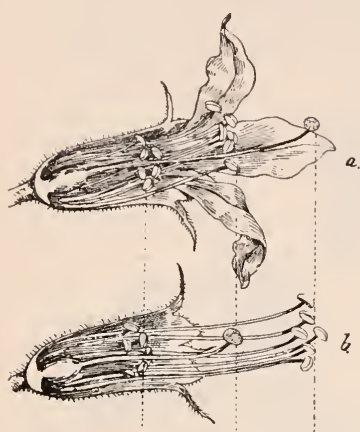

die wir bei Schlüsselblume, Wasserfeder, Lungenkraut und Weiderich fanden.

3. Soll die „gewünschte" Fremdbestäubung eintreten, so muß die oft weite Strecke, die zwischen Staubbeutel und Narbe liegt, überbrückt werden. Da die Pflanze hierzu allein nicht imstande ist, muß sie sich fremder Hilfe bedienen. In den meisten Fällen spielen Insekten oder der Wind, in wenigen (s. Hornblatt und Seegras) das Wasser oder Vögel (bei Tropenpflanzen) die Rolle des Vermittlers. Damit die Übertragung des Blïtenstaubes zur Narbe nun möglichst glatt und sicher vonstatten geht, sind eine große Zahl von Einrichtungen getroffen, die hier für die allein wichtigen "Insekten- und Windblütler" übersichtlich zusammengestellt sein mögen :

\section{Insektenbliitler.}

\section{A. Was die Pflanze ihren Bestäubern}

Bliiten des IVeiderichs. (Kelch zur Hälfte und Blumenblätter zum größten Teil entfernt.) a. lang-, b. mittel- und c. kurzgrifflige Form. Die Linien verbinden die Narben mit denjenigen Staubblättern, deren Blïtenstaub auf ihnen allein volle

Fruchtbarkeit bewirkt.

bietet. Der Transport des Blütenstaubes von Blüte zu Blüte wird von den Insekten selbstverständlich nicht absichtlich oder freiwillig besorgt. Die Tiere kommen stets nur ihres eigenen Vorteils willen zur Pflanze.

a) Sie finden in den Blüten vor allen Dingen einen süßen Saft (Nektar), der gewöhnlich als Honig bezeichnet, im Körper der Biene aber erst in Honig verwandelt wird (s Lehrb. d. Zool.).

Diese für die Besucher bestimmte Flüssigkeit wird von "Honigdr üsen* (Nektarien) abgeschieden, die sich an allen Blütenteilen finden können (vgl. z. B. Linde, Scharbockskrant, Veilchen, Möhre und Weinstock), und mehrfach in besouderen Behältern, den sog. „Safthaltern", aufbewahrt (Veilchen, Leinkraut u. a.). Je nachdem er mehr oder weniger tief in der Bläte dargeboten wird, je nachdem ist er auch nur Insekten von bestimmter Rüssellänge zugänglich (vgl. z. B. Mölre, Raps, Veilchen, Steinnelke und (reißblatt). Knrzrüsselige Insekten suchen den siißen saft, den sie in ,rechtmäßiger" Weise nicht erbeuten können, vielfach durch ,Einbruch“ zu erlangen (Taubnessel u. a.). - Bei gewissen Pflanzen (s. Orchis und Goldregen) muß der süße Saft vom Besucher erst erbohrt werden. - Staubbeutel und Narbe stehen stets in dem Wege, der zum Honig führt (Bedeutung ?). 
Zahlreiche Blüten besitzen für die honigsaugenden

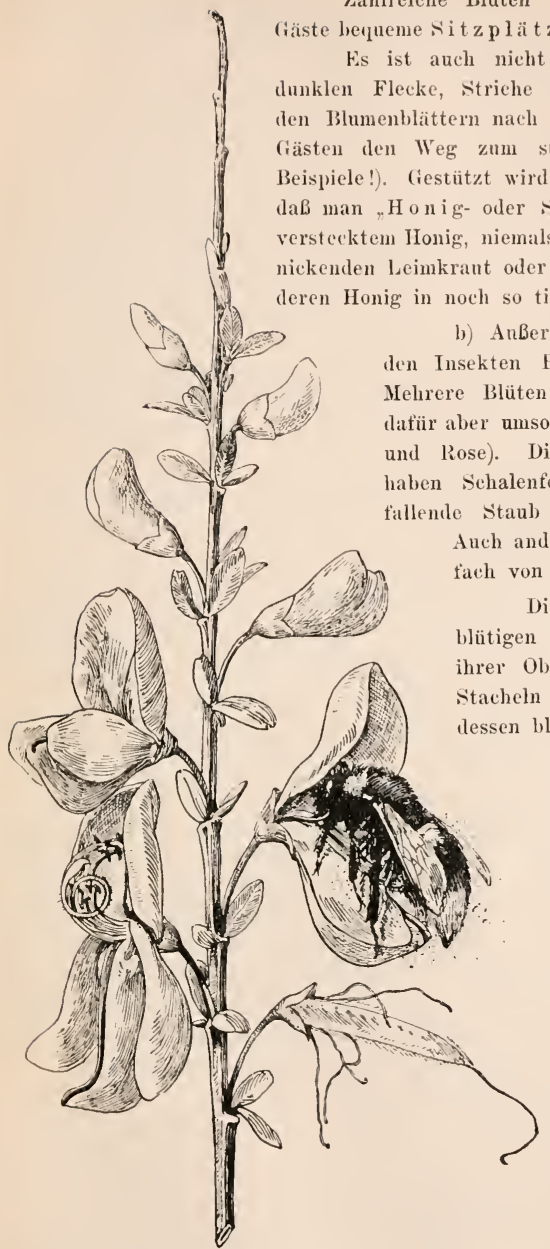

Bliiten des Besenginster's. Die Flïgel der Schmetterlingsbliite dienen der sangenden Hummel als Sitzplatz. (Näheres s. S. 110.)
Die Blütenstaubkörner der insektenPflanzen sind in der Regel an oder Warzen bedeckt. Infolgesie an den geöffneten staubbeuteh und später an den Körper der Tiere leicht hängen. (Beweise, daß bei Veilchen, Heidekraut, sehneeglöckchen u. a. die Art der Bestäubung trockenen Bliitenstaub voraussetzt !)

c) Blüten, die die Form großer, hängender Glocken haben. gewähren ihren Besuchern śehutz gegen Kälte und Nässe (Glockenblume, Fingerhut u. a.). Bei Osterluzei und Aronstab werden die Insekten im Blütengrunde längere Zeit gefangen gehalten.

1) Beim Feigenbaume hieten die Bliiten den Bestiubern $\mathrm{B} \mathrm{r}^{\mathrm{t}} \mathrm{t}$ stäten fïr die $\mathrm{Nach}$ $\mathrm{kommen}$.

B. Wie die Pflanze ihre Bestäuber anlockt. Gleich dem 
Gastwirte und Kaufmanne, die ihr Geschäft durch Firmenschilder kenntlich machen, muß auch die Pflanze ihren Bestäubern anzeigen, daß bei ihr ein, gedeckter Tisch za finden ist. Die $B l u ̈$ teen $m$ üssen a uffällig sein.

a) Sie erheben sich daher (bis auf Ausnahmen) nicht nur über das Laub, sondern

b) besitzen anch eine Färbang, die deutlich vom Grün des Untergrundes absticht („Blumen ${ }^{\circ}$. In der Regel ist diese „Lockfarbe ${ }^{*}$ den Blumenblättern eigen. Da, wo diese Blätter verdeckt sind, treffen wir einen bunt gefärbten Kelch an (Heidekraut n. a.). Seltener sind Blumen- nnd Kelchblätter durch Buntfärbung ausgezeichnet (Tulpe, Rittersporn). Die nach außen gekehrte Seite der bunten Blätter ist stets die prächtigere (Scharbockskraut). In Auswahmefällen sind auch die Staubblätter (Salweide) oder gar die Hüllblätter der Blüte (Hain-Wachtelweizen) in den Dienst der Anlockung der Gäste gestellt. Erhöht wird die Auffälligkeit in seltenen Fällen durch Verwendung versehiedener Farben (Saubohne, Hain-Wachtelweizen). Blïten, die durch Nachtschmetterlinge bestänbt werden, haben eine helle, weil im Finstern allein noch bemerkbare Färbung (Nachtkerze u, a.).

c) Da kleine Blüten einzeln nicht weithin sichtbar sind, vereinigen sie sich zu B l n meng e me in s ch a f t e n oder Blütenständen (s. S, 436). Häufiger als in Einzelblüten treten hier Farbengegensätze auf (besonders bei den Korbblütlern; Beispiele!). Auch dadurch, daß sich die Randblüten (zahlreiche Korbblütler, Schneeball) oder die nach außen gerichteten Blumenblätter dieser Blüten (Möhre) vergrößern, wird die Auffälligkeit erhöht. Znm Teil ,verzichten “ diese Blüten sogar auf die Erzeugung von Samen (Schneeball, Sonnenrose). In gewissen Fällen werden die Blütengemeinschaften erst durch Blätter auffällig, die nicht zu den Blüten gehören (Sand-Strohblume, Edelweib).

d) Da die Insekten durchweg kurzsichtige Tiere sind, können von ihnen die Bläten stets nur aus der Nähe wahrgenommen werden. Auf viel weitere Entfernung wirkt der D uft, der den Blüten entströmt, als Anlockungsmittel. Je nach der Insektenart, deren Besuch die Pflanze vorwiegend wünscht, ist auch der Duft ihrer Blüte verschieden. Die wichtigsten Bestäuber (Bienen, Hummeln, Schmetterlinge) lieben Düfte, die auch uns angenehm sind. Blüten dagegen, die besonders von Fliegen bestäubt werden, riechen (für uns!) oft sehr unangenehm (Weißdorn, Aronstab). Am deutlichsten ist diese Erscheinung an den sog. Aasblumen (Stapélia) zu beobachten, die wegen ihrer Ähnlichkeit mit Kaktusarten gern in Blumentöpfen gezogen werden: ihre Blüten riechen ekelhaft nach Kot, auf dem sich die Bestäuber gern umhertreiben. - Unscheinbare Blüten (Weinstock; s. dag. wilder Wein) oder solche, die eine versteckte Lage haben (Linde), oder sich in der Nacht entfalten (Geibblatt a. a.), haben meist einen besonders starken Duft.

C. Wie die Pflanze unwillkommene Blütengäiste abhält. Alle Tiere, die, ohne eine Bestäubung der Blüten herbeiführen zu können, Honig und Blütenstaub verzehren oder wohl gar die ganze Blüte zerstören (z. B. Schnecken), sucht die Pflanze wie alle sonstigen Feinde (Beispiele!) von sich abzuhalten. Die größte Zahl der unwillkommenen Blütengäste bilden die Tiere, die am Stengel emporkriechen (Ameisen, Schnecken u. a.). Aber auch alle die anfliegenden Tiere, die beim Besuch der Blüte weder Staubbeutel noch Narbe berühren, gehören hierher. Gegen diese unnützen Näscher sind die Pflanzen durch sehr mannigfache Mittel geschützt:

a) Der den Blüten entströmende D uft wirkt nur auf die Vermittler der Bestäubung anziehend, auf andere Insekten abschreckend. 
b) Von der Oberfläche des Stengels (Leimkraut) oder von Drüsenhaaren (KörnerSteinbrech) werden Kle bst of fe abgeschieden.

c) Die Blätter bilden Wasserbecken (Kardendistel).

d) Stengel, Blütenstiel oder andere Teile sind mit stechenden Borsten oder St a cliel li besetzt (Schwarzwurz).

e) Bei einigen Ptianzen wird a Berlialb der Blüte Honig abgesehieden (Zaunwicke).

f) Die Blüten bilden hängende Glocken oder dgl., deren Rand kletternde Insekten nicht überwinden können (Glockenblume).

g) Die Bläten sind während der Zeit gesehlossen, während der ihre Bestäuber ruhen (Scharbockskraut).

l) Blüten oder Blütenstände sind von festen Hüllen umgeben, die von den Insekten nicht durchbissen werden können (Steinnelke, Sonnenrose).

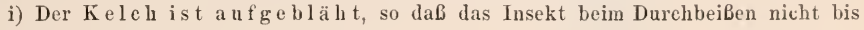
zum Honig vorzudringen vermag (Taubenkropf).

k) Der Honig ist in langen, engen Kanälen geborgen (Leinkraut) oder dureh Haare oder andere Mittel verdeckt (Taubnessel, Glockenblume), also kleinen Tieren unzagänglich. (Warum fehlen den Wasserpflanzen Mittel gegen ankrieehende Insekten?)

\section{IVindbliitler.}

Die zahlreichen Einrichtungen, durch die sich die windblätigen Pflanzen auszeichnen, haben wir besonders bei der Betrachtung des HaselnuBstrauches, des Roggens und der Kiefer bereits kennen gelernt:

a) Die Blüten sind unseheinbar, duft- und honiglos; sie sind daher auch viel einfacher gebaut als die der Insektenblütler; die Blütenhüllen sind klein oder fehlen gänzlich.

b) Die Staubeutel sind dem Winde stets frei a usgesetzt, so daß der Blütenstaub leicht ausgeschüttelt und verweht werden kann. Daher finden sich die Bläten oder Blütenstände stets am Unfange der Pflanze. Entweder ist die ganze Pflanze (Gräser), oder der Blütenstand (Kätzchen, Rispen), oder das einzelne Staubblatt (Gräser) leicht vom Winde zu bewegen. Bei den Nesseln wird der Blütenstaub dureh plötzliehes Aufspringen der Beutel in die Luft gesehleudert.

c) Vielfach blühen die Pflanzen im windreichen Frühlinge. Dann sind die Sträucher oder Bäume (Haselnubstrauch, Pappel u. a.) meist noch nnbelaubt, so daß der Wind zu den Blüten freien Zutritt hat.

d) Windblütige Pflanzen kommen gewöhnlich in groben Beständen vor.

e) Da der Wind den Blütensta ub planlos verstreut, erzeugen die Pflanzen grobe Mengen davon.

f) Die Blütensta ubörnersind trocken, klein and glatt. Infolgedessen können sie leicht aus den Staubbeuteln geweht und über große Bezirke ausgestrent werden. Bei zahlreichen Nadelbäumen (Kiefer) sind sie noch mit besonderen Flugcinriehtungen versehen.

g) Die $\mathrm{Narben}$ stehen frei, sind zumeist sehr grob und gleichen oft federartigen Gebilden. 


\section{E. Die Befruchtung der Blüte.}

Wie wir gesehen haben, bringt eirie Pflanze nur dann Samen hervor, wenn sie bestäubt wird. Die bloße Berührung der Narbe durch den Blütenstaub genügt hierzu aber bei weitem nicht: die Bestäubung ist erst die Einleitung $z u$ höchst wunderbaren Vorgängen, die sich im Stempel abspielen. Um diese Vorgänge zu verstehen, müssen wir zuerst den Bau

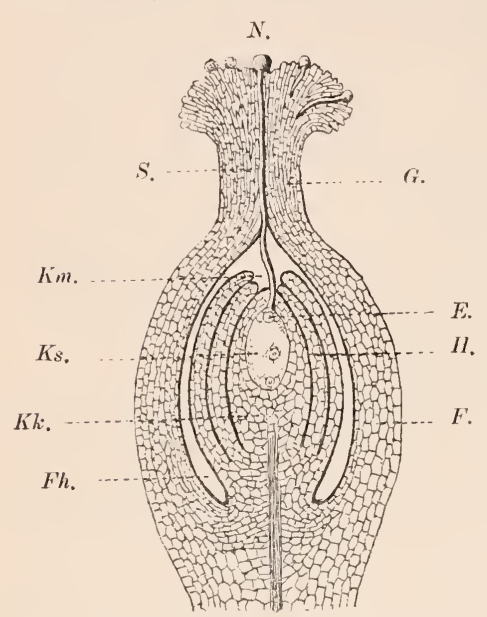

Befuchtung der Bliite (schematisch). In dem Frnchtknoten (F.) findet sich eine aufrechtstehender Samenknospe, die fast den ganzen Hohlraum (Fh.) einnimmt. An der Samenknospe erkennen wir den Knospenkern (Kk.), dessen Hüllen (H.) und den Knospenmund (Km.) Der Knospenkern schließt den Keimsack (Ks.) mit der Eizelle (E.) ein. Anf der Narbe (N.) mehrere Blütenstaubkörnchen, die z. T. einen Keimschlanch getrieben haben. Der Keimschlauch des in der Mitte liegenden Kornes dringt soeben in den Keimsack ein. (S.) hat den Griffel (G.) durchwachsen und

1. der Samenknospen oder Samenanlagen näher kennen lernen. Wie mißgebildete Fruchtblätter (s. Abb. S. 433) oft deutlich erkennen lassen, gehen die Samenknospen (in der Regel)aus Randteilen der Fruchtblätter hervor. Sie finden sich, auf kurzen Stielchen sitzend, in dem Fruchtknoten daher zumeist an den Verwachsungsstellen der Fruchtblätter oder an den Scheidewänden, die von diesen Blättern gebildet werden. Auch dem Blütenboden oder dem Säulchen, das von ihm in den Hohlraum des Fruchtknotens ragt, können sie angeheftet sein (Schlüsselblume u. a.).

Den inneren Bau der zarten Gebilde enthüllt uns das Mikroskop, wenn wir dünne Querschnitte durch einen Fruchtknoten betrachten.*) Wir erblicken in der Mitte einen eitörmigen Körper, den Knospenkern, der bis auf eine Stelle, den Knospenmund, von (meist) zwei becherartigen $\mathrm{Hüllen}$ bedeckt ist. Unter den Zellen des Knospenkerns fällt eine durch besondere Größe auf, die man als Keim sack bezeichnet. Indem der Kern dieser Zelle in mehrere Stücke zerfällt, und indem die einzelnen Teilstücke von Protoplasma umlagert werden, bilden sich im Keimsack mehrere kleine Zellen. Unter diesen Zellen hat wieder eine, die in der Nähe des Knospenmundes liegt, eine besondere Be-

*) An den sehr kleinen, durchsichtigen Samenknospen des Fichtenspargels und der Orchideen sind die einzelnen Teile bei mikroskopischer Vergröberung sehon von außen zn sehen; bei ihnen wird aber der Knospenkern vollständig vom Keimsack eingenonmen. 
deutung: sie wird Eizelle genannt, weil von ihr die Bildung der neuen Pflanze ihren Ausgang nimint.

Die Entwicklung der Eizelle zur jungen Pflanze tritt jedoch nie von selbst ein, sondern nur dann, wenn 'Teile eines Blütenstaubkorns in sie einwandern. Wie ist dies aber möglich, da ja bei der großen Mehrzahl der Samenpflanzen, den bedecktsamigen Gewächsen, die Samenknospen in Fruchtknoten eingeschlossen sind?

2. Das Bliitenstaubkorn, das anf die Narbe gelangt ist, stellt für die Pflanze ein wertvolles Gut dar, das daher festgehalten werden muß. Dieser Aufgabe dienen die Wär z ch en oder $\mathrm{Hä} \mathrm{r} \mathrm{c} \mathrm{h} \mathrm{en,} \mathrm{die} \mathrm{der} \mathrm{Narbe} \mathrm{meist} \mathrm{ein} \mathrm{samtartiges} \mathrm{Aus-}$ sehen verleihen, sowie die klebrige Flüssigkeit, die von der Narbenoberfläche ausgeschieden wird. (Warum besitzen die Windbliitler oft eine federige Narbe?)

Sobald das Blïtenstaubkorn aber von der Narbenfeuchtigkeit benetzt wird, beginnt es - genall wie in dem früher angestellten Versuche (s. S. 433) zu schwellen und einen Keimschlauch zu treiben. Der Schlauch durchwächst wie ein Pilzfaden das lockere Gewebe des Griffels, dringt in die Höhle des Fruchtknotens ein und gelangt durch den Knospenmund in den Knospenkern der Samenanlage. Indem nun ein Teil vom Inhalte des Keimschlauchs (also (les Blïtenstaubkorns!) in die Eizelle übertritt, wird diese befruchtet, d. h. befähigt, sich zu einer jungen Pflanze zu entwickeln.

(Bei den nacktsamigen Pflanzen sind die frei auf den Fruchtblättern liegenden Samenknospen etwas abweichend gebaut. Die Blütenstaubkörner rollen, wie wir bei der Betrachtang der Kiefer gesehen hahen, zwischen 2 Fortsätze der Hülle, also in den Knospenmund, woselhst sie von einem Flüssigkeitstropfen festgehalten werlen and schließlich je einen Keimschlanch treiben.)

\section{Vom Bau und Leben der Frucht und des Samens.}

1. Wie entsteht die Frucht? Während nach erfolgter Befruchtung die Staubblätter, die Blumenkrone und meist auch der Kelch vertrocknen und abfallen, vergrößert sich der Fruchtknoten fortgesetzt: er entwickelt sich zur Frucht, in der die zarten Samenanlagen, wohlgeborgen gegen nachteilige Einflüsse von außen, zu Samen heranreifen. Die Fruchtknotenwand bildet sich zur Fruchthülle oder Fruchtschale aus.

Da aus jedem Fruchtknoten eine Frucht hervorgehen kann, so entstehen in Blïten mit mehreren Fruchtknoten auch mehrere Früchte (z. B. zahlreiche Hahnenfußgewächse). Stehen diese "Früchtchen " in innigem Zusammenhang, so bilden sie eine Sammelfrucht (Himbeere, Brombeere). Beteiligen sich an der Bildung der Frucht noch andere Blütenteile außer dem Fruchtknoten, so entsteht eine Scheinfrucht, wie wir dies bei Apfel, Hagebutte und Erdbeere gesehen haben. Feige, Maulbeere und 
Ananas stellen sogar ganze Fruchtstände dar. (Welche dieser Früchte sind Schein- und Sammelfriichte zugleich?)

2. Wie entsteht der Same? a) Mit der Entwicklung der Frucht vollzieht sich gleichzeitig die Ausbildung der Samenknospe zum Samen. Nach der Be-

Zweig r. Pfaffenvorschanenden oder
Fruchttragender

hïtchen. Die aus

den (rosafarbenen)

Fruchtkapseln heran Fäden heraushängenden Samen sind von einem (orangefarbenen) Samenmantel umgeben.
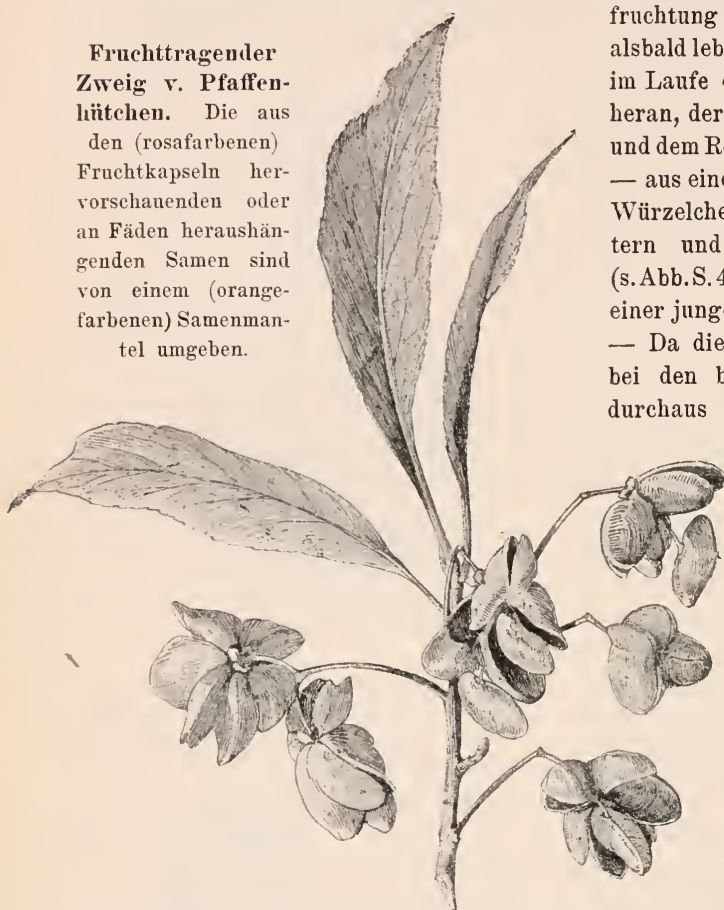

fruchtung beginnt die Eizelle sich alsbald lebhaft zu teilen. Sie wächst im Laufe der Zeit zu dem Ke ime heran, der - wie wir an der Bohne und dem Roggenkorn gesehen haben - aus einem kleinen Stengel, einem Würzelchen,ein oder zwei Keimblättern und einer Knospe besteht (s. Abb.S.452 u. 248) : also alle Teile einer jungen Pflanze erkennen läßt. - Da die Anzahl der Keimblätter bei den bedecktsamigen Pflanzen durchaus fest steht, so stellen deren beide Hauptabteilungen, die zweikeim- und einkeimblättrigen Pflanzen, durchaus natiirliche Gruppen dar.

b) Mit dem Wachstum des Keimes geht auch in dem Keimsacke eine lebhafte Vermehrung der Zellen vor sich. Indem sich diese Zellen mit Stoffen füllen (Eiweiß, Stärke, Fett u. dgl.), die dem

Keimling in der ersten Zeit des Wachstums zur Nahrung dienen, entsteht das Näh rg ew e be, das auch als Sameneiweiß (Endosperm) bezeichnet wird. Bei zahlreichen Pflanzen (z. B. bei d. Schmetterlings- u. Kreuzblütl.) wird das Nährgewebe von dem Keime bald wieder verdrängt. Die Nährstoffe finden sich dann in den mächtig angeschwollenen Keimblättern eingelagert, wie dies z. B. die Bohne (s. das.) deutlich erkennen läßt.

c) Während sich die geschilderten Vorgänge abspielen, bilden sich die zarten Hüllen der Samenknospe zur Samenhülle oder Samenschale aus. Löst sich der reife Same von dem Stielchen ab, von dem er getragen wird, so bleibt an der Samenschale ein matter Fleck, eine Narbe, der sog. Nabel zurück.

d) Bei gewissen Pflanzen entsteht aus dem Teile des Knospenkerns, der dem Knospenmunde entgegengesetzt ist, eine saftige Hülle, der Samenmantel (Pfaffenhütchen, 
Eibe, Muskatnuß) oder ein kleiner fle is chiger A nhang (Veilchen, Schellkraut u. a.).

e) Würden die reifen Samen, deren Anzahl oft viele Tausende beträgt (Distel, Königskerze u. a.), einfach zum Boden herabfallen und im Bereiche der Mutterpflanze keimen, so würden sich die jungen Pflanzen einander Raum, Luft und Nahrung streitig machen und gegenseitig vernichten. Die Samen müssen daher über einen möglichst großen Bezirk ausgestreut werden.

Zu einer solchen Wanderschaft über weite Strecken wäre aber ein junges, ausgebildetes Pflänzchen nicht imstande. Es würde bald so stark verletzt sein, durch Verdunstung soviel Wasser verlieren und unter der Kälte des Winters so leiden, daß es sicher zugrunde gehen würde. Das wandernde Pflänzchen muß daher ganz anders gestaltet sein: nämlich so, wie es uns als Keim in dem Samen entgegentritt. Hat sich fer Keim vollkommen entwickelt, so hört er auf zu wachsen, und er sowohl, als die übrigen Teile des Samens verlieren den größten Teil ihres Wassers. So kommen alle Lebenstätigkeiten oft jahrelang fast gänzlich zum Stillstande. Ton der festen und widerstandsfäligen Samenschale umhüllt, gleichsam also wohl verpackt, und selbst gegen die größte Trocknis vollkommen unempfindlich tritt das junge Pflänzchen seine Wanderung an. Setzt man Samen, die im Wasser aufgequollen sind, der Kälte aus, so gehen sie zumeist zugrunde (s. S. 1CO, a). Dieses Schicksal hätten natürlich auch die Samen, wenn sie von der Mutterpflanze mit einem reichlichen Wasservorrate versehen wären: die Wasserarmut des Samens ist also auch notwendig, um die auf der Wanderung begriffenen Nachkommen gegen die tödliche Kälte unempfindlich za machen. Bedenken wir nun noch, wie die Pflanze den wandernden Kindern als erste Ausgabe bei ihrer Ansiedlung am neuen Orte einen $\mathrm{Nahrungsvorrat}$ mit auf den Weg gibt, so erscheint uns das unscheinbare Samenkorn als ein wahres Wunderwerk der Natur.

Viele Samen beendigen ihre Wanderung allerdings an einem Orte, der für ihre Entwicklung durchaus ungeeignet ist: ihre Keimpflänzchen finden hier weder einen Boden, der ihnen zusagt, noch die nötige Menge von Wasser, Licht und Wärme, und nicht lange währt es, so sind Tausende und Abertausende der zarten Gebilde von Nachbarpflanzen ïberwuchert und getötet worden. Daher muß die Pflanze - soll ilire Art nicht atssterben - eine so große II nge von Samen hervorbringen.

3. Wie gelangen die Samen ins Freie? Erstes Erfordernis für eine erfolgreiche Wanderung ist, daß die Samen aus der Frncht befreit werden. Dies geschieht je nach der Art der Früchte auf sehr verschiedene Weise:

A. Trockene Frïhte. Thre Fruchtschalen sind bei der Reife trocken; rielfach sogar holzig oder lederartig. (Vgl. zu den in dieser Übersicht angeführten Beispielen die früher gegebenen Abbildungen!)

I. Enthailt die Fracht nur einen Samen, so ist es für ihn sicher von Vorteil, wenn er auf seiner Wanderung von der schützenden Fruchtsehale umsehlossen bleibt. 
Solche Früchte öffnen sich daher in der Regel nicht. Sie werden als Schließfrïchte bezeichnet (Scharbockskraut, Windröschen).

a) Hartschalige Schließfrüchte werden $\mathrm{N}$ üs se genannt (Haselnuß, Eichel).

b) Schließfrüchte mit lederartiger Hülle finden sich bei den Gräsern und Korbl, lïtlern, Bei den ersteren bezeichnet man sie als Grasfrü chte (Frucht- und Samenhülle sind verwachsen),

c) bei den letzteren werden sie Achänen (Frueht- und Samenhülle sind nicht verwachsen) genannt.

II. Gewisse mehrsamige Früchte zerfallen in 2 oder mehrere Teile, die je einen Samen enthalten und sich daher genau wie Schließfrüchte verhalten. Früchte dieser

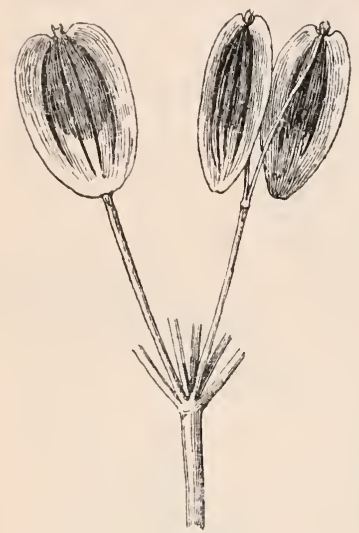

Spaltfrucht einer Doldenpflanze (Pastinake). An der rechten Frueht ist die Spaltung eingetreten. (Nat. Gr.) Art bezeichnet man als Spaltfriichte (Ahorn, Doldengewächse, Reiherschnabel, Malve, Wolfsmileh u. a.)

III. Die bei weitem meisten mehrsamigen Trockenfrüchte springen auf und entlassen auf diese Weise die Samen. Sie heißen Kapselfrüchte und öffnen sich durch Klappen (Veilchen), Löcher (Molın) oder Deckel (Bilsenkrant). Bei Regenwetter schließen sich zum Sehutze der Samen die Klappen und Löcher vielfach (Schlüsselblume, Glockenblume u. a.). (Die Frueht der Roßkastanie rechnet man trotz ihrer fleischigen Fruchthülle zu den Kapselfrïchten.) - Besondere Formen von Kapseln sind folgenile Frïchte:

a) Die Balgfrucht oder Balgkapsel. Sie ist ans einem Fruchtblatte gebildet und offnet sich nur an ler Verwachsungsstelle des Blattes (Rittersporn und die meisten anderen Hahnenfußgewächse).

b) Die Hülse. Sie besteht gleichfalls aus einem Frnehtblatte, springt aber an der Verwachsungsstelle und längs der Mittelrippe auf (Erbse und alle anderen Schmetterlingsblütler).

c) Die Schote. Sie ist aus 2 Fruchtblättern hervorgegangen, die sich bei der Reife von einer bleibenden Scheidewand ablösen (Raps und alle anderen Kreuzblütler).

B. Saftige Früchte. Die zu dieser Gruppe zählenden Früchte zeichnen sich durch saftige und fleisehige Fruchthüllen aus. Obgleich sie zumeist mehr- bis vielsamig sind, öffnen sie sich nicht von sellst (es sind also ,Sehliebfriichte"). Ihre Samen können vielmehr nur dureh Vermittlung gewisser Tiere, denen das saftige .Frnehtfleiseh" zur Nahrung dient (s. S. 64, a), oder durch Fänlnis der Fruchthülle ins Freie gelangen. (Dasselbe gilt anch von den oben erwähnten saftigen Sammel- und Scheinfrüchten, die in dieser O'bersicht unberücksiehtigt geblieben sintl.)

I. Besteht die Frnchtwand aus einer häntigen Außen- und einer saftigen Innenschicht, so bezeichnet man die Frucht als Beere (Weinbeere u. v. a.). Auch Kürbis, Apfelsine und Zitrone rechnet man zu den Beeren.

II. Ist die Fruchtwand aus drei Teilen znsammengesetzt: einer äußeren häutigen, einer mittleren fleischigen unl einer inneren harten Schicht, so hat man eine Stein- 
frucht vor sich (Kirsche, Pflaume u. a.). Bei der KokosnuB ist die Mittelschicht faserig. Auch die Walnub ist eine Steinfrucht.

4. Wie werlen die Samen verbreitet? So notwendig es für die Samen ist, aus der (vielsamigen) Frucht herauszufallen, so genügt dies für ihr Fortkommen aber noch bei weitem nicht. Sie mïssen vielmehr - wie wir oben gesehen haben - iiber einen möglichst weiten Bezirk verstreut werden.

Hierzu ist die Pflanze nur ausnahmsweise imstande. Da sie selbst der Ortsbewegung entbehrt, muß sie sich fremde Kräfte dienstbar machen, mit deren Hilfe sie weite Reisen über Länder und Meere ausfïhrt, nämlich dieKraft des fließenden oder strömenden Wassers', des Windes, der Tiere und des Menschen.

I. Die Samen werden mit Gewaltaus den Friicliten geschleudert, wie wir dies bei Veilchen, Reiherschnabel (Teiltrüchtchen!), Wiesenstorchschnabel, SonnenWolfsmilch, Besen-

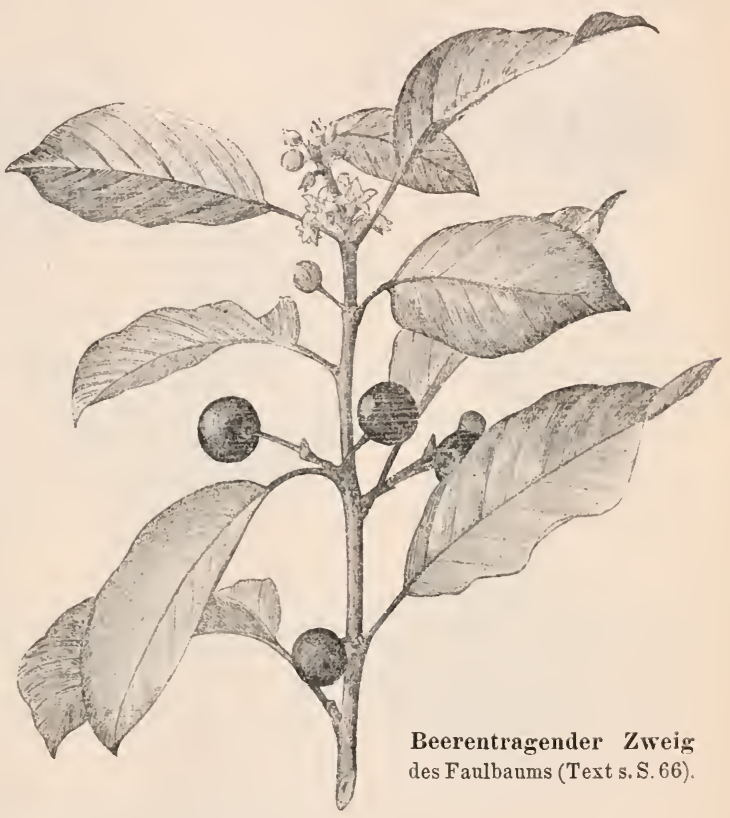
ginster nnd anderen Schmetterlingsblütlern, Sauerklee, Spritzgurke, Springkraut und Gartenbalsamine kennen gelerut haben (vgl. auch bez. der folgenden Beispiele die früher gemachten Mitteilungen).

II. Fließendes oder strömentes Wasser besorgt die Verbreitung der Samen oder Früchte. Flüsse und Bäche führen, besonders wenn sie aus ihren Ufern treten, zahlreiche Samen und Früchte mit fort, die an oft weit entfernten Orten wieder landen (Gebirgspflamzen in der Ebene). Ein Gleiches wird an Meeresströmungen beobachtet (Kokosnuß). Gewisse Pflanzen besitzen für den Wassertransport besondere Einrichtungen:

a) Die Früchte öffnen sieh nur bei Regenwetter, so dab die Samen leicht in Ritzen und Lücken des Bodens gespült werden (Manerpfeffer).

b) ZahIreiche Wasser- und Sumpfpflanzen haben sehwimmfähige S a men o der Fr ï e h te (See- und Teichrose; Wasser-Schwertlilie, Igelskolben, Schwanenblume, Froschlöffel, Pfeilkraut). 
III. Der Wind verweht Samen oder Früchte (SchlieBfrüchte oder Teile von Spaltfrüchten, ansnahmsweise auch ganze Fruchtstände). Die für diese Art der Verbreitung geschaffenen Einrichtungen sind außerordentlich mannigfaltig:

a) Die Samen werden durch den Wind aus den geöffneten Früchten geschleudert. Die Stengel oder Fruchtstiele der Pflanzen sind feste und elastische Gebilde. Die ganze Einrichtung stellt also eine Schleuder einfachster Art dar (MIohn, Schlüsselblume u. v. a.).
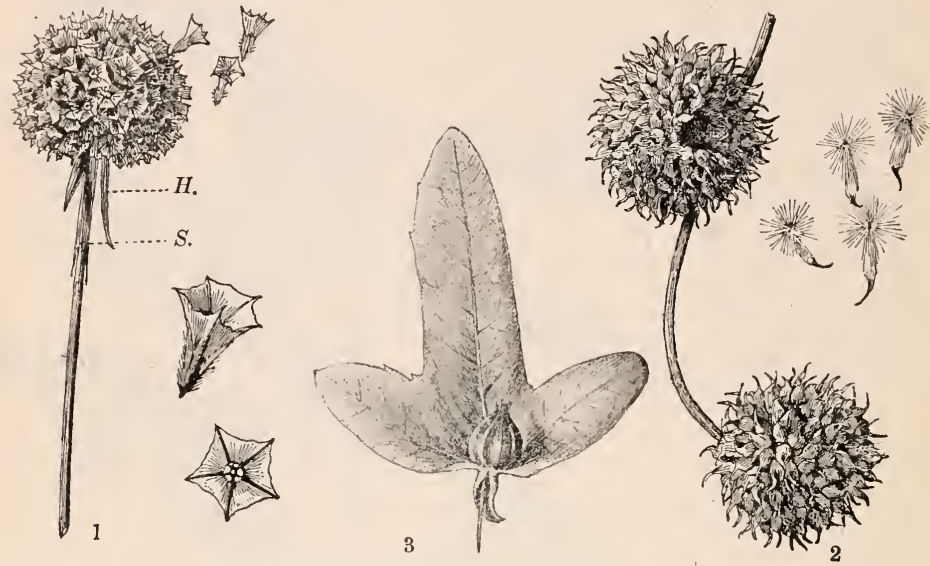

Früchte, die durch den Wind verbreitet werden. 1 Fruchtstand der Grasnelke: der bleibende Kelch ist zum Fallschirm ausgebildet. (H, Hüllblättchen, die unten die heutige Scheide S. bilden; s. S. 124). 2 Zwei Fruchtstände der Platane: Früchte sind durch Haarbildungen flugfähig. 3 Nüßchen der Hainbuche: der Fruchtbecher ist zum Flugorgan umgebildet.

b) Die Samen sind staubförmig klein (Orchis; Sporen).

c) Die schwimmfähigen Samen und Früchte werden a uf stehenden Gewässern durch den Wind wie Schiffe fortgetrieben (s. oben).

d) Die Samen und Früchte sind mit verschiedenartigen Haarbildungen a usgerüstet. Diese Haare entspringen aus dem Fruchtstiele (Rohrkolben). Sie entstehen aus der Blütenhülle (Wollgras) oder dem Griffel (Küchenschelle). Sie finden sich an der Frucht (Löwenzahn und viele andere Korbblütler; Platane) oder am Samen (Weide, Pappel u. v. a.).

e) Die Samen, Früchte oder Frachtständebesitzen Flugeinrichtungen anderer und zwar sehr verschiedener Art. Die Flügel gehen hervor aus dem H ällblatte (Fruchtstände der Linde; Hopfen), aus dem Fruchtbecher (Hainbuche), aus dem Kelche (Grasnelke) oder aus der Blumenkrone (Wiesenklee). Sie entspringen an der Frucht (Ahorn, Birke u. v. a.) oder haften dem Samen an (Kiefer u. v. a. Nadelhölzer). 


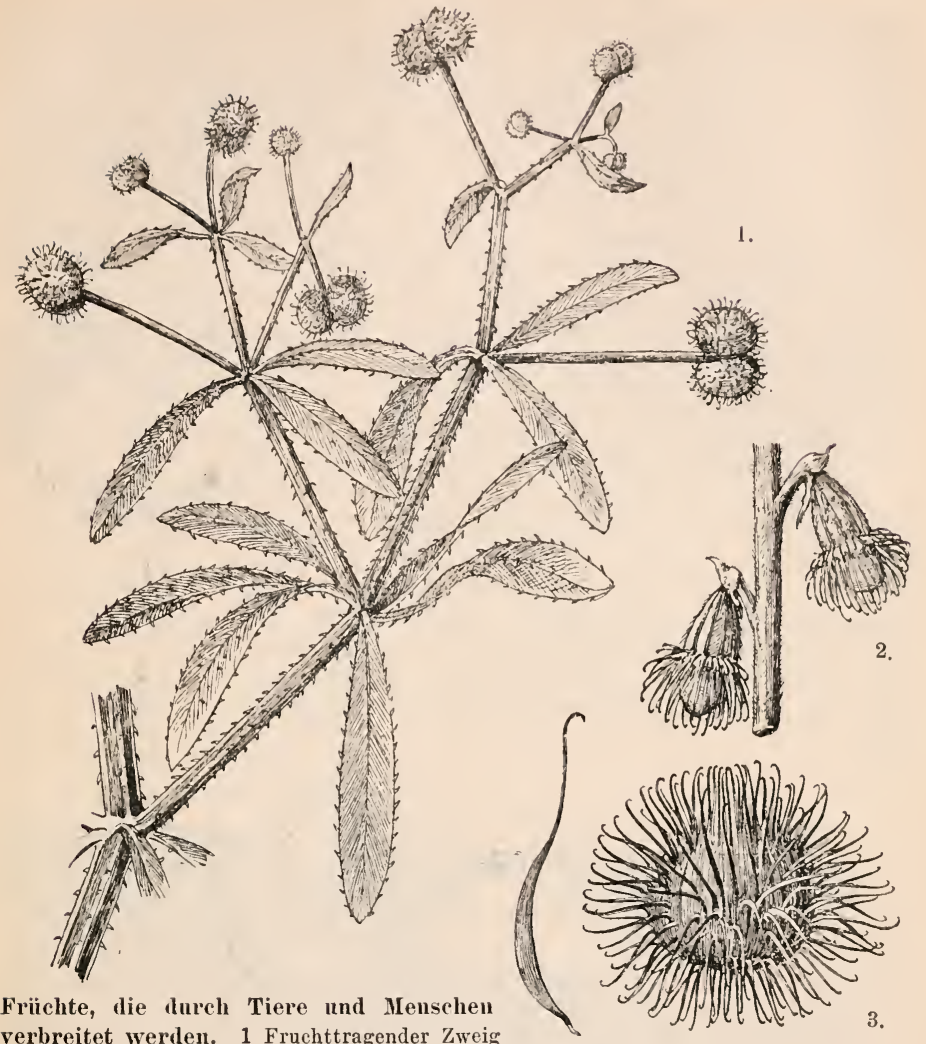
verbreitet werden. 1 Fruchttragender Zweig vom Klebkraute (s. S. 168). 2 Zwei Früchte vom Odermennig (s. S. 98). 3 Fruchtkopf der Klette; daneben ein Blatt des Hüllkelches (s. S. 188).

1V. Die Verbreitung der Samen und Frïchte erfolgt durch Tiere und Menschen.

a) In an haftenden Erd-und Schlamm teilehen (gelegentlich anch in Wassertropfen) werden Samen und Früchte an den Füßen zahlreicher Tiere, besonders der Wasservögel, sowie des Menschen verschleppt.

b) Durch menschliche Verkehrsmittel findet fortgesetzt eine beabsichtigte (Kulturpflanzen) oder unbeabsichtigte Verbreitung statt. In Hafenorten, an Eisenbahndämmen $\mathrm{u}$. dgl. siedeln sich viele ansländische Pflanzen an.

c) Die Pflanzen bilden Vorrichtungen a us, dureh die ilre Samen oder Früchte Tieren (Menschen) angeheftet werden. 
Dieses Anheften geschieht entweder durch $\mathrm{K} 1 \mathrm{ebst}$ of f e (Samen der Herbstzeitlose, der See- and Teichrose; Mistelbeeren), oder durch hakige oder mit Widerhaken besetzte Borsten. Diese Hakenborsten finden sich am Deckblatt (Granne vieler Gräser), am Blïtenboden (Odermennig), am Hüllkelche (Klette), am Griffel (gem. Nelkenwarz) oder an der Fruchthülle (Zweizahn, Klebkraut, Doldenpflanzen, rauhblättrige Gewächse).

d) Tiere, namentlich Vögel, werden zu Verbreitern der Pflanzen, indem sie die saftigen, fleiseligen Frucht-oder s a menteile verzehren (s. S. 64,a). Durch anffallende Färbung oder angenehmen Duft der Früchte oder durch beide Jittel zugleich werden die Verbreiter vielfach angelockt. Da die Samen durch feste Hüllen (Samenhülle oder bei den Steinfrüchten innere Schicht der Fruchthülle) geschützt sind, werden sie von den Verdauungssäften der Tiere nicht zerstört. (Pflanzen, die nicht auf die Verbreitung durch Tiere angewiesen sind, besitzen niemals saftige Früchte.)

Die genießbaren Teile werden geliefert von der Achse und den Deckblättern des Blütenst a ndes (Ananas), vom Blütenboden (Apfel-

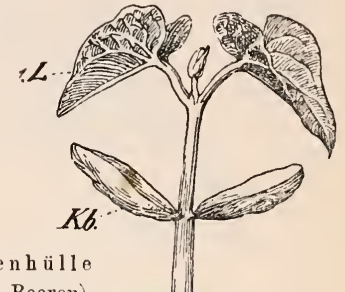
frucht, Erdbeere, Hagebutte, Feige), von der Blütenhülle (Manlbeere), von der Fruchthülle (Steinfrüchte, Beeren), vom Samenmantel (Pfaffenhütchen, Muskatnuß, Eibe), vom S a menanh ange (Veilchen, Schellkraut u. a.). - Haselnuß, Bachecker, Eichel, Walnuß u. a. werden durch Tiere verschleppt, denen die wohlschmeckenden Kerne als Nahrungsmittel dienen.

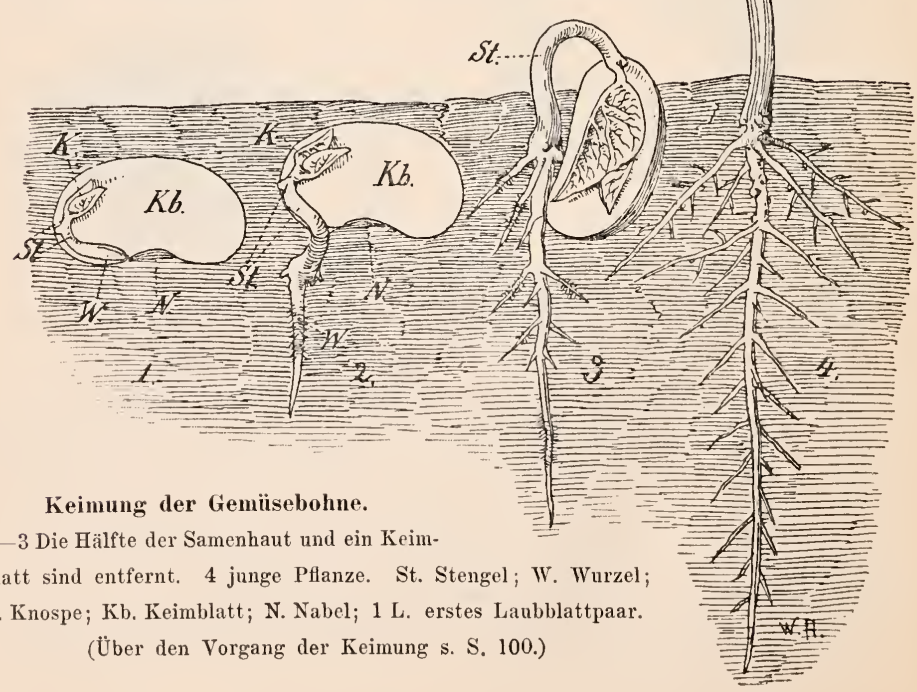


5. Wie entwickelt sich aus dem Samen die junge Pflanze? Hat der Same seine Wanderung beendet, und findet er an dem Orte, an den ihn der Zufall getragen hat, die nötige Feuchtigkeit, Würme und Luft (Sauerstoff zur Atmung!), so erwacht er aus dem Ruhezustande: er beginnt zu keimen. Wie dies im einzelnen erfolgt, haben wir bereits bei der Bohne und dem Roggenkorn verfolgt (s. das.). Auch daß es für den Samen von größter Wichtigkeit ist, hierbei am Boden fest verankert zu sein, haben wir gesehen (s. S. 408, 4). Daselbst haben wir uns auch die mannigfachen Mittel ins Gedächtnis zurückgerufen, durch die die Samen hierzu befähigt sind, und die wir bei der Betrachtung der einzelnen Pflanzen kennen gelernt haben. Findet nun auch die Keimpflanze die zum Gedeihen notwendigen Bedingungen, und geht sie aus dem Kampfe, den sie mit tierischen und pflanzlichen Feinden (Schmarotzern), besonders aber mit den Nachbarn um Boden, Wasser, Luft und Licht führen muß, siegreich hervor, so entwickelt, sie sich weiter und ist nach einer gewissen Zeit selbst befähigt, die Erhaltung ihrer Art fortzuführen. 


\section{Anhang.}

\section{1. Über Pflanzensysteme.}

1. Die Art. Es ist eine jedermann bekannte Tatsache, daß die Nachkommen einer Pflanze (oder eines Tieres) ihrer Mutter im hohen Grade ähnlich sind, wenn sie auch von ihr, ebenso wie untereinander, in gewissen nebensächlichen Merkmalen (in der Größe der Blätter, der Färbung der Blüte und dgl.) etwas abweichen. So sind z. B. die Pflanzen, die aus den Samen der Gemüsebohne hervorgehen, stets wieder Gemüsebohnen. Eine gleiche Übereinstimmung wie zwischen der Mutterpflanze und ihren Nachkommen findet man auch zwischen allen Einzelwesen (Individuen) der Gartenbohne, wann und wo man sie auch beobachten mag. Pflanzen, die nntereinander so große Übereinstimmung zeigen wie die Mutterpflanze und ihre Nachkommen, faßt man zu einer nArt" (Spezies) zusammen. Die in unserem Beispiele berücksichtigten Pflanzen gehören also der Art nGemüsebohne" (Phaseolus vulgaris) an.

Wie zwischen der Mutterpflanze und ihren Nachkommen keine vollkommene Übereinstimmung herrscht, so auch zwischen allen zu einer Art gehörigen Gliedern. Die Unterschiede zwischen diesen Pflanzen sind jedoch nicht so groß, daß man sie als verschiedene Arten ansehen könnte. Man redet daher von Abarten, Spielarten (Varietäten), „Formen“ und dgl. (s. S. 19).

2. Die Gattung. Durchmustert man die Pflanzenwelt, so wird man in der Feuerbohne (Phaseolus multiflorus) bald eine zweite Pflanzenart finden, die mit der Gemüsebohne in allen wesentlichen Merkmalen (besonders im Bau der Blüte und der Frucht) übereinstimmt. Beide nahe "verwandte" Arten faßt man zu einer "Gattung" zusammen, die man als „Bohne" (Phaseolus) bezeichnet.

Auf dieser Einteilung in Gattungen und Arten beruhen auch

3. die Doppelnamen, die die Pflanzen (Tiere) in wissenschaftlichen Werken fiihren. So wird die Gemüsebohne als Phaseolus vulgaris (d. i. gemeine Bohne) und die Feuerbohne als Phaseolus multiflorus (d. i. vielblütige Bohne) bezeichnet. Während das erste Wort des botanischen Namens die Gattung angibt, zu der eine Pflanze zählt (Phaseolus), ist das zweite (vulgaris bezw. multiflorus) die Bezeichnung der Art.

Da nun die Volksnamen der Pflanzen in den verschiedenen Gegenden vielfach verschieden sind) man denke nur an den Löwenzahn, der auch Butter- 
blume, Speckblume, Kettenblume, Pfaffenröhrlein, Ringelblume, Pustblume, Sonnenblume und dgl. genannt wird!), und da mehrere Pflanzen in verschiedenen Landesteilen denselben Namen führen (welche Pflanzen werden z. B. nicht alle als Kuhblume bezeichnet?), so wären bei Anwendung dieser Namen Verwechslungen unausbleiblich. Ganz unmöglich wäre es aber für einen Botaniker, sich die Volksnamen zu merken, die eine Pflanze bei den verschiedenen Völkern führt. Darum hat man den Pflanzen (Tieren) in der Wissenschaft einen ganz bestimmten Namen gegeben, der der latein is chen Sprache entlehnt ist und auf der ganzen Erde Gültigkeit hat.

4. Das System. Mehrere nahe "verwandte" Gattungen werden wieder zu einer Familie, mehrere Familien wieder zu größeren Abteilungen zusammengefaßt u. s. f. Auf diese Weise gewinnt man schließlich eine Anordnung aller Pflanzen nach ihrer Verwandtschaft oder kurz: ein Pflanzensystem.

So bilden nach dem Systeme, das diesem Buche zugrunde gelegt ist, die Gattungen Bohne, Erbse, Wicke, Klee u. s. w. die Familie der Schmetterlingsblüter;

die Familien der Schmetterlings- und Krenzblütler, der Hahnenfuß- und Doldengewächse u. s. w. die Unterklasse der getrenntblumenblättrigen Pflanzen; die Unterklassen der getrenntblumenblättrigen, verwachsenblumenblättrigen und blumenblattlosen Pflanzen die Klasse der zweikeimblättrigen Pflanzen; die Klassen der zweikeim- nnd einkeimblättrigen Pflanzen die Gruppe der bedecktsamigen Pflanzen;

die Gruppen der bedeckt- und nacktsamigen Pflanzen die Hauptabteilung der Samenpflanzen;

die Hauptabteilungen der Samen- und Sporenpflanzen das PfIanzenreich.

Pflanzensysteme sind nun in sehr großer Zahl aufgestellt worden. Je nachdem man bei der Gruppierung der Gewächse nur einige Merkmale oder den gesamten inneren oder äußeren Bau berücksichtigt, je nachdem erhält man Systeme von sehr verschiedenem Werte. Systeme der ersteren Art bezeichnet man als künstliche. Die anderen dagegen sind natürliche; denn sie wollen nicht nur einen bequemen Überblick über den Reichtum der Pflanzenwelt schaffen, sondern zugleich die verwandtschaftlichen Beziehungen, die die Pflanzen untereinander verknüpfen, zum Ausdrucke bringen.

5. Das künstliche System Linnés. Von den zahlreichen künstlichen Systemen ist das von dem berühmten schwedischen Naturforscher Linné im Jahre 1735 aufgestellte bis in die Gegenwart von einer gewissen Bedentung geblieben. Es dient nämlich heute noch als das bequemste Hittel, Pflanzen zu nbestimmen", d. h. ihre Stellung im (natürlichen) Systeme anfzufinden. Linné gründete seine Einteilung der Gewächse auf das Vorhandensein, die Anzahl und die Einfïgung der Staub- und Fruchtblätter und unterschied in folgender Weise 24 Klassen, die er wieder in Ordnungen einteilte: 


\section{A. Blütenpflanzen. (Kl. 1-23.)}

\section{Blïten enthalten Staubblätter und Stempel (Zwitterblüten). (K1. 1-20.)}

1. Staubblätter frei. (K1. 1-15.)

a) Stanbblätter von gleicher Länge. (Kl. 1-13.)

1. Klasse 1 Staubblatt (Tannenwedel).

2. , 2 Staubblätter (Ehrenpreis, Salbei, Flieder).

3. 3 " (die meisten Gräser, Schwertlilie).

4. $, 4, \quad$ (Wegerich, Pfaffenhütlein, Skabiose).

$5 . \quad 5 \quad$, (Rauhblatt-, Veilehen-, Doldengewächse).

6. . 6 (viele Liliengewächse, Narzissengewächse).

7. 7 (RoBkastanie, rote Kastanie).

$8 ., 8$, (Heidekräuter, Heidelbeere, Nachtkerze).

$9 . \quad 9 \quad$. 9 (Schwanenblume).

10. $-10 \%$ (Nelken, Storchschnabel, Steinbreche).

11. . $11-20, \quad$ (Weiderich, Odermennig, Reseda).

12. " mehr als 20 Staubblätter, dem oberen Rande des becher- oder krugförmigen Blütenbodens (scheinbar dem Kelchrande) eingefügt (Rosengewächse).

13. mehr als 20 Staubblätter, einem Blätenboden eingefügt, der weder Becher- noch Krugform besitzt (Hahnenfußgewächse).

b) Staublätter nicht von gleicher Länge. (Kl. 14 und 15.)

14. Klasse 2 längere und 2 kürzere Staubblätter (die meisten Lippen- und Rachenblütler).

15. r 4 längere und 2 kürzere Staubblätter (Krenzblütler).

2. Staubblätter verwachsen. (Kl. 16-20.)

16. Klasse Staubfäden zu 1 Bündel verwachsen (Storchschnabel- und Malvengewächse).

17. $, \quad, 2$ Bündeln verwachsen (die meisten Schmetterlingsblütler).

18. $, \quad, 3$ oder mehr Bündeln verwachsen (Tüpfel-Hartheu).

19. , Staubbentel zu einer Röhre verwachsen (Korbblütler).

20. " Staubblätter und Stempel verwachsen (Knabenkrautgewächse).

II. Blïten enthalten entweder Staubblätter oder Stempel (sind eingeschlechtlich).

(Kl. 21-24.)

21. Klasse Staub- und Stempelblüten auf derselben Pflanze (einhänsige Pflanzen: viele Kätzchenblätler, Kürbis).

22. > Stanb- und Stempelblüten auf verschiedenen Pflanzen (zweihäusige Pflanzen: Weiden, Pappeln).

23. Mit Zwitter- und eingeschlechtlichen Blüten (Esche).

\section{B. Blütenlose Pflanzen:}

gehören alle zur 24. Klasse.

(Farnpflanzen, Moose, Algen, Pilze, Flechten.) 
6. Die natiirlichen Systeme. Wir haben bei unseren Betrachtungen über den Bau und das Leben der Pflanze (s. S. 357 u. ff.) eine ganze Anzahl natürlicher Gruppen kennen gelernt (Zell- und Gefäßpflanzen; Samen- und Sporenpflanzen; bedecktsamige und nacktsamige Pflanzen u.s. w.). Diese Einteilung ist, so einfach, ja selbstverständlich sie uns jetzt erscheint, das Ergebnis einer fast hundertjährigen Arbeit zahlreicher Forscher.

Den ersten Versuch, die Pflanzen nach ihrer natürlichen Verwandtschaft zu ordnen, unternahn der französische Botaniker de Jussieu (1789). Als Haupteinteilungsgrund diente ihm die Anzahl der Keimblitter (keimblattlose, ein- und zweikeimblättrige Pflanzen). Das schon wesentlich verbesserte System des Genfer Professors Decandolle (1813) gründete sich in seinen Hauptabteilungen bereits auf den inneren Bau (Zell- und Gefäßpflanzen). Nach diesen Männern sind zahlreiche Forscher bestrebt gewesen, uns einen immer tieferen Einblick in die natürliche Verwandtschaft der Pflanzen zu eröffnen. - Das diesem Buche zugrunde gelegte System hat in der "Inhaltsübersicht" eine übersichtliche Darstellung erfahren.

\section{2. Über die geographische Verbreitung der Pflanzen.}

A. Auf jedem Gange durch die freie Natur sehen wir, daß andere Pflanzen im Waldesschatten gedeihen als auf offenem Felde, andere am plätschernden Bache als auf sonndurchglïlter Heide, andere im stillen Tale als auf sturmgepeitschter Höhe u. s. w. Die Beschaffenheit des Bodens, sowie Wärme, Liclıt und Feuchtigkeit bedingen - wie wir an zahlreichen Beispielen gesehen haben - in erster Linie diese Verschiedenheit.

Durchwandern wir einen größeren Bezirk unseres Vaterlandes, oder treten wir aus der Ebene in das Gebirge ein, so beobachten wir einen noch viel größeren Wechsel. Am deutlichsten tritt er uns entgegen, wenn wir einen hohen Berg, vielleicht gar einen solchen der Alpen, besteigen: am Fuße des Berges reift der Weinstock seine Trauben; weiter oben nimmt uns der Laubwald auf; darüber folgt Nadelwald; die Bäume werden, je höher wir kommen, umso zwerghafter und machen nach und nach dem Krummholze Platz; in noch höherer Lage beginnnen die Blütenpflanzen immer mehr zu schwinden, um schließlich Flechten und Moosen die Herrschaft zu überlassen. Die höchste Spitze des Berges (Alpen!) ist jahraus, jahrein mit Schnee und Eis bedeckt, entbehrt daher auch alles Pflanzenlebens. (Vgl., wie diese Anfeinanderfolge der Pflanzen mit ihrer Verteilung über die Erdoberfläche, oder kurz: wie die senkrechte und wagerechte Verbreitung der Pflanzen übereinstimmen!)

Reisen wir in ein fremdes Land, so tritt uns daselbst meist eine vollkommen fremdartige Pflanzenwelt entgegen. Je mehr wir uns dem Pole nähern, 
desto dürftiger wird der Pflanzenwuchs, um wie auf dem Gipfel des Alpenberges endlich ganz aufzuhören. Lenken wir unsere Schritte aber nach Süden, so beobachten wir das Gegenteil: in den sonnigen Ländern um das Mittelmeer treffen wir auf Orange, Zitrone, Olive und Feige; je näher wir dem Äquator kommen, desto häufiger werden die stolzen Gestalten der Palmen; tropischer Urwald mit einer Fülle fremder Formen und einem ungeahnten Reichtum von Blüten und Farben bedeckt weithin den Boden, und in den öden Wüsten und Steppen treten uns in der Gesellschaft anderer Trockenlandgewächse seltsame Fettpflanzen (s. S. 79) entgegen; kurz: die Pflanzendecke der Erde zeigt in den einzelnen Ländern, Erdteilen und Zonen oft außerordentliche Verschiedenheit.

B. Wie unsere kurze Betrachtung schon zeigt, ist diese Verschiedenheit in erster Linie durch das Klima, also durch Wärme und Fenchtigkeit bedingt. Da sich jedoch in Ländern mit demselben oder mit ähnlichem Klima, z. B. im Mittelmeergebiete und Kaplande, durchaus nicht immer dieselben Pflanzenarten, Gattungen und Familien finden, kann das Klima auch nicht allein ausschlaggebend sein.

Eine wichtige Rolle spielen bei der Verbreitung der Pflanzen über den Erdball die Veränderungen, die das einzelne Gebiet in früheren Zeiträumen erfahren hat. So sind z. B. aus der Eiszeit, in der ein großer Teil Mitteleuropas von gewaltigen Gletschern bedeckt war, zahlreiche Pflanzen erhalten geblieben, die wir heute noch auf den höchsten Erhebungen unserer Mittelgebirge, sowie in den Alpen antreffen.

Ein anderer Umstand, der hierbei beachtet werden muß, ist die Verbreitungsfähigkeit der Pflanzen. So haben wir z. B. gesehen, daß das kanadische Berufskraut und die Wasserpest sich bei uns vollkommen heimisch gemacht haben, daß das Frühlings-Kreuzkrant infolge der vortrefflichen Flugausrüstung seiner Früchte immer weiter nach Westen vordringt, daß die Verbreitung des Pfaffenhütleins mit der des Rotkehlchens vollkommen zusammenfällt u. s. w.

Endlich ist auch der Einfluß, den der Mensch auf die Natur a us übt, für die Zusammensetzung der Pflanzenwelt in den einzelnen Bezirken von größter Wichtigkeit: Aus fernen Zonen und Ländern führt er zahlreiche Kulturpflanzen ein (Beispiele!), die die heimischen Gewächse vielfach verdrängen. Man denke nur an die riesigen Flächen, die z. B. mit Getreide bestellt, und auf denen die „eingeborenen" Unkräuter nach Kräften unterdrückt werden. Mehrere der angebauten Pflanzen entziehen sich wieder der Pflege der Menschen: sie verwildern und machen genau den Eindruck, als ob sie seit uralten Zeiten Glieder der heimischen Pflanzenwelt wären (Nachtkerze). Durch den Verkehr werden ferner zahlreiche andere Pflanzen von Land zu Land, ja sogar von Erdteil zu Erdteil verschleppt (s. S. 451,b). Am klarsten zeigt sich aber die umgestaltende

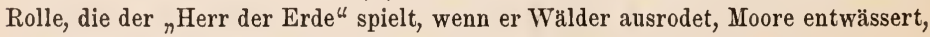
Sumpfgebiete trocken legt, öde Landstriche bewässert und dgl. mehr. 
C. Die Gesamtheit der Pflanzen, die einen bestimmten Bezirk (z. B. Deutschland oder die Schweiz) bewohnen, bezeichnet man als dessen Flora. Weicht die Pflanzenwelt eines Gebietes von der eines anderen wesentlich ab, so hat man zwei verschiedene Pflanzen-oder Florengebiete vor sich.*

1. Das a rktisehe Gebiet umfabt alles Land, das ungefähr vom nördlichen Polarkreise umschlossen wird. In Nordamerika reicht es jedoch bis über den $60^{\circ}$ nach Siiden hinab. Da in diesem Gebiete nur ein etwa dreimonatlicher sommer herrscht, vermögen einjährige Pflanzen ihre Samen nicht zu reifen; sie fehlen daher. Die ausdauernden Gewächse bleiben, da sie in der kurzen Zeit nur wenig Baustoft erzeugen können, niedrig, sehmiegen sich als Schutz gegen die eisigen Winde dem Boden an oder ziehen sich (Standen) während des langen Winters ganz in den Boden zurück. Aut weiten Flächen, den Tundren, sind Flechten und Moose die herrschenden Pflanzen. Kulturgewächse fehlen.

2. Das europäisch-sibirisehe Waldgebiet erstreckt sich über alle Lünder Europas bis fast zum Mittelmeere, sowie über Sibirien mit Ausnahme des nördlichen Teiles. Die Sommer sind mäBig warm. Im Winter findet eine Unterbrechung des Pflanzenlebens statt (Laubfall u. s. w.). Im Norden und Osten finden sich besonders Nadelwälder, in den anderen Teilen Laubwälder. Wiesen, Heiden und Torfmoore bedecken weite Fläehen. Kulturpflanzen: Getreide, Kartoffel, Obstbäume, z. T. auch der Weinstoek.

3. Das Mittelmeergebiet wird von den Ländern gebildet, die an das Mittelmeer grenzen. Lederartiges Laub und dichte Behaarung sind Sehutzmittel gegen die Dürre des langen Sommers. Da die Winter mild sind, findet meist kein Laubfall wie in unseren Gegenden statt. Die Laubbäume sind daher vielfach immergrün: Ölbaum, Lorbeer, Oleander, Granatbaum, Johannisbrotbaum, Myrte, immergrüne Eichen. Nadelhölzer sind Pinie und Zypresse; heimisch ist hier auch die Zwergpalme. Kulturgewächse sind außer den genannten: Zitrone, Orange, Feige, Kastanie, Korkeiche, Maulbeerbam, Weizen, Mais, z. T. auch der Reis.

4. Das innerasiatisehe Steppengebiet umfaßt Turkestan, Tibet und die Mongolei. Das Klima ist ausgeprägt kontinental: heiße, troekene Sommer wechseln mit strengen Wintern ab. Daher ist fast das ganze Gebiet Steppen- und Wüstenland. Die Grassteppen ergrünen nach den Frühlingsregen sehr schnell, und zahlreiche Zwiebelund Knollengewächse (s. Tulpe) brechen aus dem Boden hervor. Die ausdanernden Pflanzen, die sich wie diese Gewächse nieht in die Erde zurückziehen können, haben als Schutz gegen die Sommerdürre starre, feste Blätter, oder sind fast oder gänzlich blattlos. Salzsteppen überziehen weite Bezirke. An Flüssen und da, wo künstliche Bewässerung stattfindet (z. B. in Mesopotamien), gedeihen Reis, Weizen, Baumwolle, Dattelpalme, Kürbisgewächse.

5. Im chinesiseh-japanisehen Gebiete herrschen - je nach der mehr sïdlichen oder nördlichen Lage der einzelnen Landschaften - heiße oder warme Sommer und milde oder strenge Winter. Pflanzen, die den tropischen, mittelländischen und unseren heimischen Gewäehsen gleichen, kommen daher vielfach nebeneinander vor.. $D_{u}$

* Angeführt sind in der folgenden ťbersicht nur die Pflanzen, die in dem Bache berïcksichtigt wurden. 
die Niederschläge regelmäßig und reichlich erfolgen, ist der Ackerban hoch entwickelt. Kulturpflanzen: Tee, Reis, Weizen, Zuckerrohr, Baumwolle, Indigo, Orangen, Zitronen, weißer Maulbeerbaum, Palmfarne.

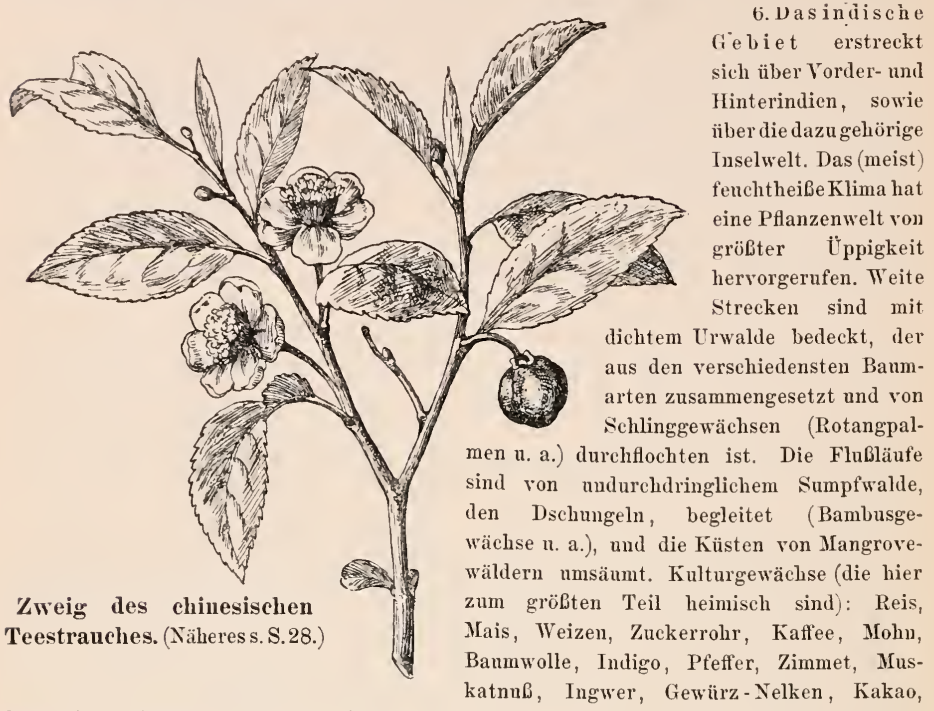

Sagopalme, Banane, Bambus, Futtapercha n. a.

7. Die Sahara ist sehr heiß und fast regenlos. Weite Flächen sind daher ohne jeden Pflanzenwuchs. Die an anderen Stellen anftretenden Gewächse zeigen alle Merkmale ausgeprägter ödlandpflanzen (tiefgehende Wurzeln, kleine, dichtbehaarte Blätter und dgl.). Nur da, wo ein Quell den Boden durchbricht (Oasen), können Knlturpflanzen angebaut werden, unter denen die hier heinische Dattelpalme die Hauptrolle spielt.

8. Das Sudangebiet ist im Westen vorwiegend heib und feucht. Daher finden sich hier große Urwälder (Kamerun!). Sonst ist das Land heiß und trocken und dementsprechend vorwiegend Steppe. Heimiseh sind in dem Gebiete: Kaffee, Ölpalme, Affenbrotbanm, Wnnderbaum (Ricinus), Papierstande, kaktusähnliche Wolfsmileharten. Angebaut werden neben der Ölpalme fast alle Kulturgewächse Indiens.

9. Das Kalaharigebiet hat infolge seines trockenen, heißen Klimas Wüstencharakter. Dornige Sträucher, Akazien und Zwiebelgewächse (s. Absch. 4) sind die vorherrschenden Pflanzen.

10. Das Kapgebiet: Das Land an den Küsten ist warm und feucht. Hier gedeihen daher dieselben Nutzptlanzen wie in Mittel- und Südeuropa. Das Innere des Landes ist regenarm, daher zumeist Stéppe. Hier finden sich besonders Heidekräuter, Aloëarten, Zwiebelgewächse, kaktusartige Wolfsmilchgewächse und die S. 442 erwähnten Aasblumen.

11. A ustralien hat am Nordrande tropisches, im Süden Nittelmeerklima. Die 
Kulturpflanzen sind daher auch die tropischen oder südeuropäischen. Die zwischen beiden Bezirken liegende Hanptmasse des Erdteils ist heib und trocken, daher vorwiegend Wüste und Steppe. Die lichten, Buschwälder" werden besonders von Eukalyptusbäumen gebildet. Die tropischen Urwälder sind reich an Baumfarnen und Farnpalmen.

12. Das nordamerik anisehe Waldgebiet reicht von der Grenze des arktischen Gebiets bis nach Florida und zur Mündung des Mississippi. Das Klima entspricht dem des europäisch-sibirischen Gebiets (s. Absch. 2). Im Norden finden sich

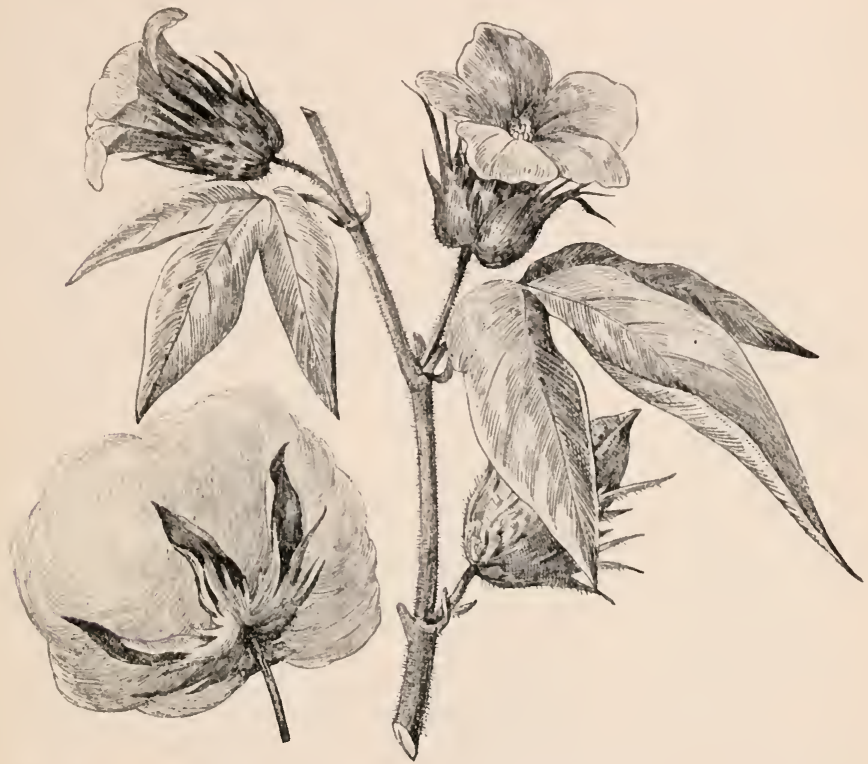

Zweig der Baumwolle. Dameben eine geöffnete Fruchtkapsel, aus der die langen Samenhaare (Baumwolle!) hervorquellen. (Näheres s. S. 53.)

unermebliche Nadelwälder, im Süden winterkahle Laubwälder und im südlichsten Teile immergrüne Laubbäume und tropische Pflanzen. Im Norden gedeihen die Kulturpflanzen Europas, im Sïden Reis, Mais, Zuckerrohr, Baumwolle, Tabak.

13. Das kalifornische Küstengebiet entspricht etwa dem Mittelmeergebiete. Es besitzt gleichfalls zahlreiche immergrüne Laubhölzer. Die Kulturgewächse sind die jenes Gebiets.

14. Das Präriegebiet breitet sich westlich rom Mississippi aus. Heiße, trockene Sommer wechseln mit strengen Wintern ab. Daher finden sich hier wie an anderen ähnlichen Stellen der Erde weite, baumlose Grassteppen, die Prärien. Im Nordwesten finden sich zahlreiche Salzwüsten; im Süden bilden Kaktusarten und Agaven wichtige Bestandteile der Pflanzenwelt. 
15. Im mexikanischen $\mathrm{Gebiete}$ herrschen sehr verschiedene Verhältnisse: Am Golfe von Mexiko sind unter dem Einflusse tropischen Klimas anch Tropenwälder entstanden. Außer den einheimischen Nutzpflanzen, der Vanille und der Ananas, werden hier alle anderen Kulturpflanzen der Tropen angebaut. - Das Hochland ist vielfach wïstenartig. Daher finden sich hier Kaktusarten und Agaven, beides ausgesprochene Trockenlandpflanzen. Kultiviert werden Agaven, Fackeldisteln, Ölbaum, Weinstock u. a. - Am Stillen Ocean sind zahlreiche tropische Urwälder anzutreffen.

16. Westindien hat ein feuchtheißes Klima und demzufolge überaus üppigen Pflanzenwuchs. Angebaut werden alle tropischen Kulturpflanzen. Der Nelkenpfefferbaum ist hier heimisch.

17. Das Orinokogebiet zeigt am Rande die Verhältnisse Westindiens. Das Innere ist heiß und trocken, wird daher vorwiegend vou Savannen (Llanos) mit geringem Baumwuchs eingenommen.

18. Das Gebiet des Amazonenstroms ist feuchtheiB und wird an Üppigkeit des Pflanzenwuchses von keinem anderen Bezirke der Erde übertroffen. In den unermeBlichen Urwäldern (und z. T. auch in denen der Nachbargebiete) sind der Kakao-, Mahagoni- und Cedrelabaum, sowie verschiedene Arten der Kautschukbäume heimisch.

19. Das brasilianische Gebiet umfaBt Brasilien südlich des Amazonenstromgebiets. Der heiße und feuchte östliche Teil ist mit üppigem Urwalde bedeckt. Der Westen ist trocken und heiß. Daher haben sich hier Savannen gebildet. Hier finden sich auch jene merkwürdigen Wälder (Catingas), deren Bäume im Sommer das Laub abwerfen (Schutz gegen Vertrocknen!). Angebaut werden zahlreiche Tropengewächse, besonders Kaffee.

20. Das Gebiet der tropischen Anden von Südamerika. Der Westabhang der Anden ist heiß und wasserarm. Hier ist wahrscheinlich die Heimat der Kartoffel und der Bohne zu suchen. Auf den höheren Teilen des Gebirges sind die Fieberrindenbäume zu Hause. Am Ostabhange gedeihen in feuchtheißem Klima alle Kulturpflanzen der Tropen.

21. Das Pampasgebiet ist heiß und trocken, daher vorwiegend Grassteppe mit geringem Baumwuchs.

22. Das Gebiet von Chile. Das Klima ist ähnlich wie das der Mittelmeerländer. Da die Trockenzeit aber länger als ein halbes $\mathrm{Jahr}$ währt, ist Chile ein baumarmes Land. In wohlbewässerten Teilen gedeihen die Kulturgewächse des MittelmeerSebietes. Hier ist auch die Fuchsia heimisch.

23. Das antarktische Gebiet umfaßt Süd-Chile und das Feuerland. Im warmen, nördlichen Teile finden sich immergrüne Laubwälder und gedeihen alle mitteleuropäischen Kulturpflanzen; der mittlere Teil ist besonders reich an Buchenwäldern, der südliche dagegen von öden Tundren (s. Absch. 1) bedeckt. 


\section{Namen- u. Sachregister.}

Abies 290.

Acacia 112.

Acanthus 153.

Acer 48.

Achillea 184.

Ackerdistel 188.

Ackergänsedistel 189.

Ackergauchheil 124.

Ackerhornkraut 41.

Ackerkrummhals 135.

Ackerrettich 21.

Ackersenf 21.

Ackerskabiose 173.

Ackerspark 41.

Ackersteinsame 135 .

Ackerwinde 127.

Aconitum 11.

Acorns 246.

Adansonia 53.

Adlerfarn 302.

Aegopodium 73.

Aesculus 41.

Aetherische Öle 387.

Aethusa 73.

Affenbrotbaum 53.

Agave 234.

Agrimonia 96.

Agropyrum 264.

Agrostemma 39.

Agrostis 268.

Ahorn 48.

Ährchen 255.

Ähre 255. 437.

Ährengräser 264.

Ährenrispengräser 267.

Ailanthus 50 .

Aira 268.

Ajuga 150.

Akazie, echte 112. falsche 109 .

Akelei 11.

Alchemilla 98.

Alectorolophus 156.

Algen 321.

Algenpilze 345.

Alismaceae 278.

Alkoloide 387.

Alliaria 22.
Allinm 224.

Alnus 199.

Aloë 225.

Alopecurus 267.

Alpenrosen 119.

Alpenveilch.124.389.

Alsineae 40.

Althaea 50.

Amanita 336.

Amaryllidaceae 230.

Amaryllis 234.

Ameisenptlanzen 109.

Ammophila 267.

Ampelopsis 66.

Ampferarten 215.

Amygdalus 93.

Anagallis 124.

Ananas 235.

Anchusa 134.

Anemone 6.

Anethum 72.

Angiospermae 1.

Anis 73.

Antheridium 299.

Anthoxanthum 267.

Anthriseas 73 .

Antirrhinum 154.

Apetalae 190.

Apfelbaum 90.

Apfelsänre 387.

Apfelsine 49.

Apium 72.

Aprikose 93.

Apothecium 354.

Aquilegia 11.

Araceae 244.

Arak 262.

Araliaceae 75.

Archegonium 299.

Aristolochia 219.

Armeria 124.

Armleuchtergew. 326.

Arnica 184.

A ronstab 244.

Arrhenatheram 268.

Artemisia 185.

Artocarpus 209.

Arum 244.

Asarum 213.
Ascomycetes 338 .

Asparagus 228.

Asperifoliaceae 130 .

Asperula 169.

Aspidium 294.

Asplenium 302.

Assimilation des' Koh-

lenstoffes 374 .

- der Nährsalze 372.

Aster 183.

Astmoos 320.

Atmang 390 .

Atripelix 216.

Atropa 141.

Atropin 142.

Aufspeicherung der

Nährstoffe 388.

Augentrost 156.

Aurikel 123.

Ausläufer 401.

Avena 260.

Azalea 119.

Bachbungen-Ehrenpreis 156.

Bakterien 346.

Baldrian 173.

Balgfrucht 448.

Ballota 151.

Balsamine 58.

Bambusgräser 263.

Banane 242.

Bandgras 271.

Baobab 53.

Bärenklau 73 .

Bärenklaue, echte 153.

Bärenlauch 224.

Bärlappgew. 309.

Bartflechten 355.

Bartweizen 259.

Basidienpilze 332.

Basidiomycetes 330 .

Basilienkrant 151.

Bast 416.

Batate 129.

Bauchpilze 338.

Baum 411.

Baumfarne 303.
Baumwolle 53.

Bazillen 346.

Becherflechten 355.

Becherfrüchtler 190.

Bedecktsamige Pfl. 1.

Beere 448.

Beerentang 327.

Befrachtung 444.

BeifuB 185.

Beinwurz 130.

Bellis 183.

Berberis 11.

Berberitze 11.

Berufskraut, kanadisches 185.

Berteroa 22.

Besenginster 110.441.

Besenkresse 22.

Bestäubung 438.

Beta 216.

Bettlerläuse 184.

Betula 198.

Bidens 184.

Bienensaug 146 .

Bierhefe 342.

Bilsenkraut 145.

Bingelkraut 68 .

Binsengewächse 229.

Birke 198.

Birnbaum 85.

Birnenrost 344 .

Birntang 327.

Bisamhyazinthe 223.

Bittersüß 141.

Blasenstrauch 109.

Blasentang 327.

Blatt, Bau u. Leben 368.

Blätterpilze 336.

Blattformen 370 .

Blattgrün 379.

Blattkeimer 1. 99.

Blattnerven 384.

Blattstellnng 371 .

Blaubeeren 118.

Blumenbinse 278.

Blumenblätter 431 .

Blumenblattlose

Pflauzen 190. 
Blumenkohl 20.

Blüte, Bau n. Leben 429.

Bliitenboden 430.435 .

Blïtengrundriß 3.

Blütenkörbchen 437.

Blütenlose Pfl. 294.

Blïtenpflanzen 1.

Blütenstände 436 .

Blütenstaubkörner 433. 445 .

Bocksbart 189.

Boehmeria 206.

Bohne 99.

Bohnenkraut 151.

Boletus 337.

Borago 135.

Boretsch 135.

Borke 425.

Bovist 338.

Brandpilze 343. 344.

Brassica 16. 19.

Braunalgen 326.

Braunkohl 20.

Braunwarz 154.

Brechnußbaum 127.

Brennessel 205.

Briza 268.

Brombeere 98.

Bromeliaceae 235.

Bromus 268.

Brotfruchtbaum 209.

Brotschimmel 341.

Brunella 151.

Brunnenkresse 22.

Brunnen-Lebermoos 320.

Brutbecher 321.

Brutknollen oder -knospen 4. 430.

Brutkörperchen 35̃4.

Brutzwiebeln 221. 430.

Bryonia 168.

Bryophyta 309.

Buche 197.

Buchsbaum 69.

Buchweizen 214.

Buschwindröschen 6 .

Butomus 278.

Butterblume 180 .

Buxus 69.

Cactaceae 80.

Calamus 242.

Calla 246.

Calluna 113.

Caltha 9.

Camclina 23.
Camellia 28.

Campanula 160.

Cannabis 207.

Cantharellus 336.

Capparis 10 .

Caprifoliaceae 171.

Capsella 22.

Cardamine 21.

Carduus 187.

Carex 271.

Carpinus 197.

Carum 73.

Caryophyllaceae 36 .

Caryophyllus 84.

Cassavestrauch 69 .

Castanea 198.

Catingas 462.

Cattleya 277.

Ceder d. Libanon 291.

Cedrelabaum 50.

Cedrus 291.

Centaurea 186.

Centifolie 96.

Cerastium 41.

Ceratonia 112 .

Ceratophyllum 210.

Cereus 81.

Cetraria 355.

Ceylon-Zimtbaum 214.

Chaerophyllum 73.

Chamaerops 242.

Champignon 330.336.

Characeae 326.

Cheiranthus 21.

Chelidonium 26.

Chenopodium 216.

Chinarindenbm. 171.

Chinin 171.

Chlorophyceae 321 .

Chlorophyll 361.

Chondrus 328.

Choripetalae 1.

Christbaum 289.

Christrose 11.

Chromatophoren 359.

Chrooleprs 325.

Chrysanthemum 183. 184.

Cichorium 188.

Cicuta 73.

Cinchona 171.

Cinnamomum 214.

Cirsium 187.

Citrus 49.

Cladonia 355.

Clavaria 338.

Claviceps $3+1$.

Clematis 8.
Cochlearia 23.

Cocos 238.

Coffea 169 .

Coffein 170 .

Colchicum 226.

Colutea 109.

Compositae 174.

Confervoideae 324 .

Coniferae 280.

Conium 73.

Convallaria 227.

Convulvulus 127.

Copra 240.

Coriander 73 .

Cormophyten 368.

Cornus 77.

Coronaria 39.

Corydalis 27.

Corylus 190.

Crassulaceae 78.

Crataegus 90.

Crocus 238.

Cruciferae 16.

Cucumis 167.

Cucurbita 162.

Cumarin 169.

Cupiliferae 190.

Cupressus 292.

Cuscuta 129.

Cyane 186.

Cycas 293.

Cyclamen 124.

Cydonia 90.

Cynoglossum 134.

Cynosurus 267.

Cyperaceae 271.

Cyperus 272.

Cytisus 110.

Dactylis 268 .

Dahlia 183.

Daphne 213.

Dattelpalme 241.

Datura 145.

Daucus 69.

Delphinium 10.

Desmidiaceae 325.

Diagramme 3. 435.

Dianthus 36.

Diatomeae 328.

Diatomeenerde 330.

Dicentra 27.

Dickblattgew. 78 .

Dickenwachstum 420.

Dicotyleae 1. 99.

Digitalis 154 .

Dill 72.

Dinkel 259.

Dipsacus 173.
Disteln 187.

Dolde 437.

Doldengewächse 69 .

Donnerkraut 80.

Dornen 411.

Dotterblume 9.

Dracaena 225.

Drachenbäume 225 .

Drosera 33.

Düngung 406 .

Eberesche 90.

Ebonit 69.

Ecballium 168.

Echium 134.

Edelkastanie 198.

Edeltanne 290.

Edelweiß 186.

Efeu 75.

Efeu-Ehrenpreis 156 .

Ehrenpreis 155.

Eibe 292.

Eibisch 53.

Eiche 196.

Eierpilz 336.

Einkeimblätterige

Pflanzen 218.

Eisenkraut 153.

Eiweißstoffe 386.

Elaeagnus 125.

Elaeis 242.

Elfenbeinpalmen 242.

Elodea 279.

Elymus 268.

Empusa 345.

Endivie 188.

Endosperm 446.

Engelsüß 301.

Enziangew. 124.

Epilobium 83.

Epipactis 276.

Epiphyten 277.

Equisetinae 304.

Equisetum 304.

Erbse 103.

Erbsenrost 68. 344.

Erdbeere 97.

Erdrauch 27.

Erdrauchgew. 27.

Erica 117.

Ericaceae 113.

Erigeron 185.

Eriophorum 272.

Erle 199.

Ernährungsgenossenschaft 105. 354 .

Erodium 54.

Erophila 22.

Eryngium 73. 
Erysiphe 342.

Erythraea 127.

Esche 125.

Esparsette 110

Espe 204.

Essigbaum 50.

Estragon 185.

Eukalyptusbäume 84.

Euphorbia 66.

Euphorbiaceae 66.

Euphrasia $15 \%$.

Evonymus 66.

Fackeldistel 80 .

Fadenalge 325 .

Fadenpilze 330 .

Fagus 197.

Färberröte 169.

Farne 294.

Farbstoflträger 359 .

Faulbaun 66 93. 449.

Fäulnisbewohner 276.334.

Federharz 69. 209.

Feigenbaum 208.

Feigendistel 81 .

Feigwurz 3.

Feldehampignon 330 .

Feldmännertrea 73 .

Feldquendel 151.

Feldrittersporn 10.

Feldsalat 173.

Feldthymian 151 .

Feldulme 209.

Felicinae 294.

Fenehel 72.

Festuca 268.

Fette Öle 387 .

Fetthenne 80.

Fettkraut 35.

Fettpflanzen 80.225. 234.

Feuerbohne 99.

Feuerlilie 224.

Fenersehwamm 337.

Ficaria 1.

Fichte 298.

Fichtenspargel 118.

Ficus 69. 208.

Fieberrindenb. 77 .

Filicinae 204.

Filzmiitze 310.

Fingerhut 154.

Fingerkraut 98.

Flachs 58.

Flachsseide 130.

Flammendes Herz 27.

Flatterbinse 229.

Flatterrüster 210.
Fleehten 353.

Fleckenorchis 272.

Flieder 124.

Fliegenpilz 336.

Fliegensehimmel 345.

Flockenblume 187.

Flugbrand 344 .

Foeniculum 72.

Fortpflanzung 129 .

Föhre 280.

Fragaria 97 .

Frangula 66.

Frauenflachs 153.

Frauenhaar, goldenes 309.

Frauenschul 276.

Fraxinus 125.

Fritillaria 223. 224.

Froschbibgew. 278.

Froschlöffelgew. 278.

Frucht, Bau u. Leben 445.

Fruehtblätter 434 .

Fruehtboden 430 .

Friillingskreuzkraut 184.

Fuehsia 83.

Fuchsschwanz 267.

Fueus 327.

Fuligo 353.

Fumariacea $2 \overline{7}$.

Fungi 330 .

Gagea 224 .

Galanthus 230.

Galeobdolon 150.

Galeopsis 151 .

Galium 168. 169.

Gamanderehrenpreis 155.

Gänseblümchen 183.

Gänsedistel 189.

Gänsefingerkraut 98 .

Gänsefulgew. 216.

Gartenaster 183.

Gartenaurikel 123.

Gartenbalsamine 58.

Gartenglockenbl.162.

Gartenkerbel 73.

Gartenkresse 23.

Gartennelke 39.

fiartenprimel 123.

(iartencettich 21.

Gartenrose 96.

Gartensalat 188.

Gartensalbei 151 .

Gartenschierling 73 .

Gartenstiefmütterchen 33.
Gartenthymian 151 .

Ganchheil 124.

Gefäßbïndel 417 .

Gefïkrryptogamen 295.

GefïB-Sporenptl. 294. Gummi arahicum 11:3.

GeiBblatt 171 .

Geißblattgew. 171.

Gelbling 336.

Giemüsebohne 99.396. 452.

Gemüsekohl 10.

Generationswechsel 301. 317. 344.

Genista 111.

Genossenschaftsleben 105.

Gentiana 124.

Gentianaceae 124.

Georgine 183.

Geotropismus 408. 412.

Geraniaceae 54

Geranium 57.

Gerbstoff $38 \%$.

Gierste 260.

Getreide 248.

Getreiderost 344

Getrenntblumenblättrige $\mathrm{PH}, 1$.

Geum 96.

Gewebe 367 .

Gewürznelkenl. 84 .

Giersch 73.

Giftreizker 336 .

Gilbweiderich 124

Gladiolus 238.

Glanzgras 271.

Glechoma 150 ).

Gleiße 7:3

Gloekenblume 160 ,

162

Glockenblume,

falsche 11 .

Glockenheide 137.

Glyeyrrhiza 111.

Gnaphalium 186.

Goldknüpfchen 5 .

Goldlack 21.

Goldnessel 150 .

Goldregen 110.

Goldstern 2:24.

Gossypium 53.

Götterbaum 50.

Gramineae 248 .

Granatbaum 84

Graphis 355 .

Gräser 248.

Grasfrucht 259.
Grasnelke 124.

(iraukresse 2.2.

Griulgen 321.324 .

Griinkern 25!?.

Grummi 69.

Kirsch- 90).

Gummibaum 69. 209. blaner 84 .

Gummibaum nenlollïndiseher 84.

Gundermann 150.

Günsel 15).

Gurke 167.

Guttapercha 69.

Gymnospermae 280.

Gymnosporangium 344.

Haare 398.

Haarmoos 310.

Habichtskraut 189.

Habichtsschwamm 337.

Hafer 260.

Hagebutte 96 .

Hagedorn 90.

HalinenfuB 4. 5.

Hahnenfußgew, 1.

Hahnenkamm 338

Hainboehe 197. 450.

Hainwachtelweiz.157.

Halbgräser 271.

Hanf 207.

Hartgummi 69.

Harthea, Tüpfel- 28.

Hartriegel, roter $7 \mathrm{~s}$.

Haschisch 207.

HaselnuBstrauch 190.

Haselwurz 213.

Hauheehel 111.

Hansschwamm 3:37.

Hauswurz 80.

Heckenkirsche 172.

Hedera 75.

Hedrich 21.

Hefepilze 342.

Heidekorn 113. 214.

Heidekraut 113. 117.

Heidelbeere 218.

Heilenelke 39.

Helianthus 174.

Heliotropismus 413.

Helichrysum 15.̃.

IIelleborus 11.

Hellerkraut 23 .

Helvella 339 .

Hepatica 8. 320 .

Heracleum 7 ? 
Herbstzeitlose 226.

Herzblatt 82.

Hesperis 21.

Heterostylie 122.

Hevea 69.

Hexenmehl 309.

Hieracium 189.

Himbeere 97. 445.

Himmelsgerste 4 .

Himmelsschlüsselchen 120.

Hirse 260.

Hirtentäschelkr. 22.

Hocbblätter 369 .

Hohlwurz 27.

Hohlzahn 151.

Holcus 268.

Holz 417.

Holzäpfel 90.

Holzbirnen 85̃.

Holunder 172.

Honiggras 268.

Honigmale 121. 441.

Honigtau 341.

Hopfen 207.

Hopfenseide 129.

Hordeum 260. 267.

Hornblatt 210.

Hornbaum 197.

Hornklee 111.

Hornkrant 41.

Hornsträucher 77 .

Hottonia 123.

Huflattich 184.

Hülse 448.

Hülsenfrüchte 108.

Humulus 207.

Hundspetersilie 73 .

Hundsrose 94.

Hundszunge 134.

Hungerblümchen 22.

Hutpilze 330.

Hyazinthe 223 .

Hybriden 97.

Hydnum 337.

Hydrocharis 279.

Hyosciamus 145 .

Hypericum 28.

Hypholonna 336.

Hyphomycetes 330 .

Hypnum 320.

Jahresringe 422 .

Jasione 126.

Jasmin 82 .

Jelängerjelieber 172.

Igelskolben 247 .

Ilex 66.

Immergrün 127.
Immerschön 186.

Immortelle 186.

Impatiens 58 .

Indigopflanzen 111.

Ingwer 243.

Insektenblütler 440 .

Insektenfressende

Pflanzen 33. 35.

Jod 327.

Johannisbeere 82 .

Johannisblut 28.

Johannisbrotb. 112.

Johanniskraut 28.

Ipomoea 129.

Iris 235.

IrländischesMoos328.

IsländischesMoos35̃5.

Judenkirsche 142 .

Juglandaceae 198.

Juglans 199.

Juncus 229.

Juniperus 291.

Kaffee 169.

Kaiserkrone 224.

Kakaobaum วั4.

Kaktusgewächse 307.

Kälberkropf 73 .

Kalla 246.

Kalmus '246.

Kambium 420.

Kamelie 28.

Kamille 184.

Kammgras 267.

Kannensträucher 355 .

Kapern, deutsche 10.

Kapernstrauch 10.

Kapselfrüchte 448.

Kapuzinerkresse 58.

Karagaheenmoos 328.

Kardendistel 173.

Karotte 70 .

Karthäusernelke 36 .

Kartoffel 135. sübe 129.

Kartoffelbovist 338 .

Kartoffelpilz 345.

Karyopse 258.

Käsepappel 52.

Kastanie (Roß-) 41. edle 198. rote 48 .

Kätzchen 437.

Kätzchenblütler 190.

Katzenkraut 173.

Kautschukbäume 69.

Keimung 452 .

Kelch 431.

Kellerhals 213.
Kerbel 73 .

Kernholz 422.

Kernobstgewäehse85.

Kesselfallenbl 245.

Kettenblume 180.

Keulenpilze 338.

Kiefer 280.

Kieselalgen 328.

Kieselgur 330.

Kirschbaum 90. 93.

Klammerwurzeln 401.

Klappertopf 156 .

Klatschmohn 23.

Klatschrose 23.

Kleber 389.

Klebkraut 168. 451.

Klee 110.

Kleesalz 387.

Kleesäure 387.

Kleeseide 130.

Kletten 188. 451.

Knabenkraut 272.

Knackmandeln 93.

Knäuelgras 268.

Knautia 173.

Kniebolz 290.

80. Knoblauch 225.

Knoblauchsrauke 22.

Knollen 135. 411.

Knollenblätterpilz 336.

Knospe 409.

Knöterich 214. 215.

Kohl 19. 20.

Kohlrabi 20.

Kohlrübe 20 .

Kokken 346.

Kokospalme 238.

Kolben 437.

Kolbenbärlapp 309.

Kolbenweizen 259.

KompaBpflanze 188.

Königin der Nacht 81.

Königskerze 155 .

Köpfchen 437.

Kopfkohl 20.

Kopfweide 200.

Kopulieren 86.

Korallenflechten 355 .

Korallenpilz 338.

Korbblütler 174.

Korbweide 204.

Kork 425.

Korkeiche 198.

Korn 248.

Kornblume 186.

Kornelkirsche 77 .

Körnersteinbrech 82.

Kornrade 39.
Kotyledonen 99.

Krachmandeln 93.

Krapp 169.

Krebsschere 27.

Kresse 22. 23.

Kreuzblume 49.

Kreuzblütler 16.

Kreuzkraut 184.

Kriechenpflaume 9:3.

Krokus 238.

Krummhals 135.

Krummholz 290.

Krustenflechten 355 .

Kryptogamae 294.

Küchenzwiebel 224 .

Kuckucksblume 276.

Kuckacksnelke 39.

Kuhschelle 8.

Kümmel 73 .

Kürbis 161 .

Labiatae 146.

Labkraut 109.

Lackmusflechte 356 .

Lactaria 336.

Lactuca 188.

Lagerpflanzen 321. 368.

Laichkränter 247 .

Lamium 146. 150.

Landolphiastr. 6!.

Lappa 188.

Lärche 291.

Larix 291.

Lathraea 158.

Lathyrus 109.

Latschen 290.

Lattich 188.

Laubblätter 369 .

Laubfall 93. 399.

Laubflechten 355.

Laubmoose 309. 319.

Laucharten 224.

Laurus 214.

Läusekraut 157 .

Lebensbäume 292.

Leberblume 8.

Lebermoose 320.

Legföhre 290.

Leimkraut 39.

Lein 58 .

Leindotter 23.

Leingewächse 58 .

Leinkraut 153. 151.

Leitungsbahnen in

Stamme 422.

Lemna 246.

Lens 109.

Lepidium 23. 
Lepidodendron 309.

Lepiota 3:3t;.

Ler'hensporn 27.

Leuchtmoos 320 .

Leucobryum 320 .

Leucoium 23:3.

Levkoje 21.

Lichenes 3 ā3.

lichtnelke 40 .

liebesapfel 142.

lieschgras 367 .

Liguster 125.

Lilie 224.

Liliengewächse 218.

Limone 49.

Linaceae 58.

Linaria 153. 154.

Lincle 50.

Linse 109.

Liпum 58.

Lippenblütler 146.

Liriodendron 11.

Listera 276.

Lithospermum 134.

Lohblüte 353.

Loleh 264.

Lolium 264.

Lonicera 171.

Loranthaceae 210.

Lorbeerbaum 214.

Lorchel 339.

Lotosblume 16.

Lotus 111.

Löwenmanl 154

Löwenzahn 180 ).

Luftapflanze 168 .

Lungenkraut 133

Lupine 111.

Luzerne 111.

Luzula 2:30.

Lycium 143

Lycopodium 30 !.

Lysimachia 124 .

Lythrum 83.

Macis 211.

Macrocystis 327 .

Mädesüß 9 ๖.

Magnolie 11.

Mahagonibaum 49.

IIahonia 12.

Majanthemum 2:28.

Iaiblume 2.27.

Maiglöckchen 227.

Majoran 151 .

Mais 260.

Malvaceae 52.

Malvengewächse $\mathbf{5 2}$.

Janumutbäแme $29 *$.
Mandelbaum 93.

Mummel 12.

Mangroveb. 84. 402. Musa 242.

Manihot 69.

Manilahanf 243.

Maniokstrauch 69 .

Männertreu 73. 156.

Marchantia 320.

Marienglocke 162.

Mrark 416.

Markstrahlen 416 . 424.

Maronen 198.

Maßliebehen 183.

Maté 66 .

Matricaria 184.

Matthiola 21

Manerpfefter 78 .

Mauerraute 302.

Naulbeerbanm 208.

Mäusegerste 267.

Medicago 111.

Neerrettich 23.

Meerzwiebehn 223.

Nehltanpilze 342.

Melampyrum 157.

Melandryum 40.

Meldenarten 216.

Melilotus 110.

Melone 16.

Melonenkaktus 397.

Mentha 151.

Mereurialis 68 .

Merulius 337.

Nespilus 90 .

Metamorphose 368.

Metroxylon 242

Nieren 40.

Niere, rote 124.

Milchsaft 424.

Milchstern 224.

Mimosa 112.

Minzen 151.

Mirabelle 93.

Mischlinge 97 .

IIispel 90.

Mistel 210.

Mohngewächse 23. 26.

Möhre 69.

Molirrübe 69 .

Monocotyleae 217.

Nonotropa 118.

Moosbeere 118.

Moosblüten 313.

Moose 309.

Moraceae 208.

Morcheln 338.

Morphium 26 .

Mor'us 208.
Muscari 22.2:3.

Musci 319.

Muskatbliite 214.

Muskatnubbum 214

Mutterkornpilz 341

Ilyosotis 134 .

Myriophyllum 210.

Myristica 214.

Myrte 84.

Iyxomycetes 352 .

Nachtkerze 8:3.

Nachtlichtnelken 40 .

Nachtschatten 141.

Nachtschattengew. 135.

Nachtriole 21.

Nacktsamige Pft. 280.

Nadelhölzer 280.

Näglein 39.

Näbrgewebe 446 .

Nährstoffe der Pflanzen 371.

Najadaceae 246.

Narcissus 233.

Yarzissengewächse 230.

Nasturtium 2.2.

Natterkopif 134.

Navicula 328.

Nebenmarkstralilen 425.

Nektar 440

Nelken 36.

Nelkenpfett'erb. 84 .

Nelkenwurz 96.

Nelumbo 16.

Neottia 276.

Nepenthes 35.

Yerium 127.

Nesselgewächse 205.

Nestwurz 276.

Neugewïrz 84.

Nicotiana 143.

Niederblätter 369 .

Nieswurz 11. 399.

Nikotin 144.

Nixblume 12 .

Nuphar 16.

Nubfrucht 448 .

Nymphaea 12.

Oberliaut 381.

Ochsenzunge 134.

Ocimum 151 .

Odermennig 98. 451.

Oidium 65. 34는

Okulicren 8t:

Olea 125.
Oleaceae 124

Oleander 127.

Ölbaum 125.

(livenbaum 125.

ilpalme 242.

(i)weidle 125.

Onagraceae 8:3.

Onobrychis 110 .

Ononis 111

Oenothera 83.

Opium 26.

Opuntia 81 .

Orangenbaum 49.

(1)rchis 272

Origanum 151

Brnithogalum 224

Grobanche 159.

Gryza 261.

Osmose 362 .

Osterblume 6 .

Osterluzei 212.

Oxalis 57.

Uxalsänre 387 .

Palmfarne 293.

Palmen 238.

Palmlilien 225.

Palmweide 199.

Panicum 260.

Paeonia 11.

Papaver 23. 26.

Papierstande 272.

Papilionaceac 99.

Pappeln 204.

Pappus 174. 182.

Paprikapflanze 14:.

Paraguay-Tee 66.

Parasolpilz 336.

Parnassia 82.

Pastinake 72.

Paria 48.

Pechnelke 40.

Pedicularis 157 .

Pelargonium 57.

Penicillinm 341 .

['ensees 33.

Perigon 222.

Perltang 328.

Perlzwiebel 2.5.

Peronospora 66. 34.5.

I'etersilie $7: 3$.

Petroselinum 7:3.

P'etunie 145.

Pfatfenhütlein

Pfetterminze $15 \mathrm{l}$

P'effer, spanisth. 142.

Pfefterstranch 2.5

Pfeifenstranch 8:2. 213. 
Pfeilkrant 278.

Pfemigkrant 124 .

Pferdebohne 109.

Pfitferling 336.

Pfingstrose 11.

Pfirsiche 93.

Pflanzengebiete 459.

Pflanzensysteme 454 .

Pflaume 93.

Pfropfen 86.

Phalaris 271.

Phanerogamae 1.

Phaeophyceae 326.

Phaseolus 99.

Philadelphus 82.

Phleum 267.

Phoenix 241.

Phragmites 271.

Phycomycetes 345 .

Physalis 142.

Phytelephas 242.

Phytenma 162.

Piassavafasem 242.

Picea 289.

Pilze 330.

Pilztiere 3553.

Piment 84 .

Pimpinella 73.

Pinguicula 35̃. 159.

Pinie 291.

Pinselschinmel 341.

Pinus 280. 290.

Piper 215.

Pirola 118.

Pirus 85.

Pisang 242.

Pisum 103.

Plantago 159.

Platane 210. 450.

Platanthera 276 .

Platterbse 109.

Pleurococcus 325.

Plumbaginaceae 124.

Poa 268.

Polierschiefer 330.

Polygala 49.

Polygonatuin 228.

Polygonum 214.

Polypodium 301.

Polyporas 337.

Polytrichum 309.

Pomeae 85̃.

Pomeranze 49.

Populus 204.

Porree 225.

Potamogeton 247.

Potentilla 98.

Preibelbeere 118.

Primel 120.
Primulaceae 120.

Prothallinm 298.

Protoplasma 358.

Prumeae 90.

Prunus 90. 93.

Psalliota 330.

Pteridium 302.

Ptericlophyta 294.

Puccinia 344.

Pulmonaria 133.

Pulsatilla 8.

Punica 84.

Purpurwinde 129.

Pnstblume 180.

Pruamidempappel 204.

\section{Qnecke 264.}

Quendel 151.

Querens 196. 198.

Quitte 90.

Rachenblütler 153.

Radieschen 21.

Rainfarn 184.

Rainweide 125 .

Ramiepflanze 206.

Ranke 22.

Rankenile Pfl. 414.

Ranunculaceae 1.

Ranuneulus 5.

Raphanistrum 21 .

Raphanus 21.

Raphia 242.

Raps 16.

Rapskohl 20.

Rapünzchen 173.

Rasenschmiele 268.

Rauhblättr, Gew. 130.

Raygras, engl. 267.

Rebenmehltan 65.

$$
342 .
$$

falscher 65.345 .

Reblans 66.

Rehpilz 338.

Reiherschnabel 54 .

Reine-claude 93.

Reis 261.

Reizker 326.

Ruster 209.

Reseda 27.

Reservestoffe 389.

Rettich 21.

Rhabarber 215 .

Pheum 215.

Rhizome 411.

Rhizophora 84.

Rhododendron 119.

Rhodoplyyceae 326.

Rhus วo.

Ricinns 68.

Rinde 421.

Rispe 437.

Robinie 109.

Roggen 248.

Rosaceae 85.

Roseae 94.

Rosen 94.

Rotdorn 90.

kische 20 .

Rubia 169.

Rüböl 16.

Rübsen 20.

Rubus 97.

Rnm 263.

Rumex 215.

Rüster 209.

Salat 188.
Ribes 81. 82.

Richardia 246 .

Riedgräser 271 .

Riesenkaktus 81.397. Salomonssiegel 228.

Rindenporen 426.

Ringelblume 180.

Rispengräser 286.

Rittersporn 10.

Roccella 356.

Röhrenpilze 337.

Rohr, spanisches 242.

Rohrkolben 247

Rohrzucker 387. 389.

Rosenäpfel 95 .

Rosenartige Gew. 85.

Rosenkohl 20.

Rostpilze 343.

Robkastanie 41.

Rotalgen 326.

Rotangpalmen 242.

Rotbuche 197.

Rotkehlchenbrot 66 .

Rottanne 290

Rübe, weiße 20.

Teltower oder mär-

Rübenkohl 20.

Ruchgras 267.

Rühr mich nicht an 58 .

Runkelrübe 216 .

Ruprechtskraut 57.

Russula 336.

Rutaceae 49.

Saatwicke 109.

Saccharomyces 342 .

Saccharum 262.

Safrankrokus 238.

Saftmale 121. 441.

Sagittaria 278.

Sagopalme 242.
Salbei 151.

Salepkuabenkr. 273.

Salicaceae 199.

Salicornia 217.

Salix 199.

Salvia 151.

Salvinia 304.

Salweide 199.

Salzpflanzen 217.

Salzkraut 217.

Sambueus 172.

Samen, $444-446$.

Samenpflanzen 1.

Sammetpappel 53.

Sandsegge 271 .

Sandstrohblume 185.

Sanguisorba 98.

Sapindaceae 41 .

Saponaria 39.

Saprolegnia 345.

Saprophyt 277. 334.

Sargassum 327.

Sarothamnus 110 .

Satanspilz 337.

Satureja 151.

Saubohne 109.

Sauerampfer 21 õ.

Sauerdorn 11.

Sauerkirsche 93 .

Sauerklee 57.

Sauerkleezew. 57.

Saxifraga 81 .

Saxifragaceae 81 .

Scabiosa 173.

Schachblume 224.

Schachtelhalme 304.

Schafchampignon 330.

Schafgarbe 184.

Schafskabiose 162 .

Scharbockskraut 1.

Schattenblume 228 .

Schanmkraut 21.

Scheingräser 271

Schellack 209.

Schellkraut 26.

Schenerkraut 308.

Schierling 73.

Schilf 271.

Schimmelpilze $3+1$.

Schirmpilz 337.

Schistostega 320.

Schizophycetes 346 .

Schlafäpfel 95 .

Schlafmohn 26.

Schlammschachitelhalm 309.

Schlangenkaktus 81 . 397. 
Schlangenkraut 246 .

Schlangenmoos 309 .

schlauchpilze 338.

Schlehe 93.

schleimpilze 352 .

S'chliebfrueht 448.

Schlüsselblnme 120.

Schmetterlingsblütler 99. 108.

schmiele 268.

Schmierbrand 344 .

Schneckenklee 111.

schneeball 172.

Schneebeere 173.

Schneeglöckchen 230.

Schneerose 11.

Schnittlauch 225.

Schötchen 22.

schote 19. 448.

Schraubenalge 321.

Schrifttlechten 355 .

Schuppeubäume 309.

Schuppenwurz 158.

Schüsselflechten 353.

Schuttkresse 22. 398.

Schuttbingelkraut 68 .

Schwanenblume 278.

Schwarzdorn 93.

Schwarzerle 199.

Schwarznessel 151.

Schwarzpappel 204.

schwarzwurz 130.

Schwarzwurzel 189.

Schwefelkopt 336 .

S.hwertlilie 235.

Schwimmblatt 304.

scilla 223.

Scirpus 271.

sicleroderma 338.

Scorzonera 189.

Scrophularia 154 .

Secale 248.

Sedum 78.

Seegras 247.

Seerose 12. 16.

Seggen 271.

Seidelbast 213.

Seitenkraut 39.

Sellerie 72.

Sempervivum 80.

Senf 21.

Senfkohl 20.

Senecio 184.

Sequoia 292.

Siegelbäume 309 .

siegwurz 238.

sigillaria 309.

Silberpappel 204.

silbertanne 290.
Silene 39.

Sileneac 36.

Simsen 230. 271.

Sinapis 21.

Sinnptlanzen 112.

Sisymbrium 22.

Skabiose 162.

Smilaceae 227.

Solanaceae 135.

Solanum 135. 141.

Sommereiche 196.

Sommertürchen 233.

Sommerwurz 159.

Sommerzwiebel 224.

Sonchus 189.

Sonnenblume 174.

Sounenrose 174 .

Sonnentan 33:

Sonnenwolfsmilch 66 .

Sorbus 90.

Soredien $35 ّ 4$.

Spaltfriichte 448.

Spaltpilze 346.

Span. Pfeffer 142.

Sparganium 247.

Spargel 228.

Spark 41.

Speiselorchel 339.

Speiteufel 336.

Spelt 259.

Spelz 259.

Spergula 41.

Sphagnum 319.

Spierstaude 98.

Spinat 216.

Spirogyra 321.

Spitzahorn 48.

Spitzkeimer 218.

Spitzmorchel 339.

Spitzwegerich 159.

Splint 422.

Sporenptlanzen 294.

Springkraut 58.

Spritzgurke 168.

Stachelbeerstr. 81 .

Stachellattich 188.

Stachelpilze 337.

Stachys 151 .

Stamm, Bau und Leben 408.

Stammblattpfl. 368.

Ständerpilze 330.

Stapelia 442.

Stärke 385.

Stärkebildner 390 .

Staubblätter 432.

Staubbrand 344 .

Stechapfel 145.

Stechpalme 66 .
Stecklinge 401. 430. Tausendgüldenkr.12\%.

Steinbrech 82.

Steineiche 196.

Steintrüchte 448.

Steinklee 110.

Steinnelke 36.

Steinnüsse 242.

Steinobstgew. 90.

steinpilz 337.

Steinsame 135.

Stellaria 40.

Stelzwurzeln 401 .

Sternmiere 41.

Stiefmütterchen 32 . Thymian 151 .

Stockausschlag 410. Thymus 151 .

Stockrose 53.

Storchschnabel54.57.

Stranthaf'er' 267.

Strandroggen 268.

Stratiotes 278.

Strauch 411.

Strauchflechten 35̃5.

Straubgras 268.

Streifenfarn 302.

Strohblume 185.

Strychnos 127.

Sturmbut 11.

Succulenten 80. 234.

Sumpfdotterblume 9.

Sumpflieide 117.

Sumpfmoos 319 .

Sumpfspierstaude 98.

Sumpfvergibmeinnicht 134.

Sumpfwurz 276.

Sumpfzweizahn 184.

Sïßholz 111.

Süßkirschbaum 90.

Swietenia 49.

Symbiose 105. 354 .

Sympetalae 113.

Symphoricarpus 173.

Symphytum 130.

Syringa 124 .

Tabak 143 .

Taglichtnelke 40 .

Tanacetum 184.

Tange 326.

Tanne 290.

Taphrina 342.

Taraxacum 180 .

Täschelkrant 22.

Taubenkropf 39 .

Taubenskabiose 173.

Taubnessel 146150 .

Taumelkerbel 73 .

Taumelloleh 264 .

Tausendblatt 210.
Tansendschönchen 183.

Taxus 2912.

Teestrauch 28. 460 .

Teichrose 16.

Teufelskralle 162.

Tenfelszwirn 129.143.

Thallophyta 321.368.

Thea 28.

Theobroma 54.

Thlaspi 23.

Thuja 292.

Tierpilze 353.

Tilia 50.

Tilletia 344.

Timothensgras $21 ; 7$

Tollkirsche 141 .

Tomate 142.

Torfmoos 319.

Tragopogon $18 \%$.

Transpiration 393 .

Trapa 83.

Traube 437.

Traubenkirsche 93.

Traubenwickler 66 .

Traubenzncker 38T.

Traneresche 125.

Trauerweide 204

Trespen 268.

Trifolium 109.

Triticum 259

Tropaeolum 58.

Trüffel 339 .

Trugdolde 438.

Tuber 339.

Tulpe 218.

Tulpenbaum 11.

Tïpfelfarn 301.

Tiipfelharthen 20.

Turgor 363.

Türkenbund 2'24.

Tussilago 184.

Typha 246.

Utberpflanzen $2 \pi$. 303.

Ulmacea $20 \mathrm{~s}$.

Ulmaria 98.

Ulmengewächse 2us

Umbelliferae 6!).

Uredinaceste $34: 3$.

Uromyees 341

Urtica 2(5). 206.

Urticularia 35, $15 \%$

Usnea 355.

Ustilago 344 
Vaccinium 118.

Valeriana 173

Valerianella 173.

Vanille 278.

Vegetationskegel409.

Veilchell 29. 32.

Teilchenalge 325.

Veilchengewächse 29.

Veilehenmoos 3:5.

Veilchenstein 3.25.

Verbaseum 155.

Verbena 153

Verdunstung 393.

Veredeln der Obstbänme 86 .

Vergibmeinnicht 134

Veronica 155.

Verschiedengrifflichkeit 122.

Verwachsenblumenblättrige Pfl. 113.

Viburnum 172.

Vicia 109.

Victoria 16 .

Vinca 210.

Viola 29.

Visearia 40.

Viscum 210.

Vitis 60 .

Vogelbeerbaum 90.

Vogelkirsche 93.

Vogelknöterich 214.

Vogelmiere 40. 406.

Vogelwicke 109.

Vorkeim 298. 316 .

Wacholder 291.

Wachstmmskegel 409

Trachtelweizen 157.

Walderdbeere 97.

Waldgeißblatt 171

Waldmeister 169.

Waldrebe 8 .

Waldschachtelh. 309.

Waldweidenröschen 83.
Walnußbaum 199.

Wanderung d. Nährstoffe 387.

Wandflechte 353 .

Wasserfäden 324.

Wasserfarne 304.

Wasserfeder 123.

WasserhahnenfuB 5.

Wasserknöterich 215.

Wasserliesch 278.

Wasserlinse 246 .

Wassermelone 168 .

Wassernuk 83.

Wasserpest 279. 409.

Wasserrose 12.

Wasserschimmel 345.

Wasserschwertlilie 235.

Wasserschlauch 35 .

Wasserspalten 395 .

Wau 27.

Wegerich 159.

Wegmalve 52.

Wegwarte 188.

Weichselkirsche 93.

Weidengewächse 199.

Weidenuöschen 83.

Weiderich 83. 440.

Weilunachtsbaum 289.

Wein, wilder 66 .

Weinhefe 343 .

Weinpalme 242.

Weinrebengew. 60.

Weinstock 60 .

Weinträubchen 223.

Weibbuche 198.

Weißbirke 198.

Weibiorn 90.

Weibklee 110.

Weißmoos 320.

Weibtanne 290.

Weißwurz 228.

Weizen 259.

Welschkohl 20.

Wermut 185.

Weymouthskiefer 291
Wicke 438.

Wicken 109.

Widerton 309.

Wiesenbocksbart 189. Yucca 225.

Wiesenflockenbl. 187.

Wiesenfuchsschwanz 267.

Wiesenglockenblume 162.

Wiesenhafer 268.

Wiesenklee 109.

Wiesenknopf' 98 .

Wiesenlieschgras267.

Wiesenplatterbse109.

Wiesenrispengras 268.

Wiesensalbei 151 .

Wiesenschaumkr. 21.

Wiesenstorchschn.57. Zellzwischenräume

Wiesenwachtelweizen 157.

Wrindblütler 191.25\%. Ziegenbart 338 .

Windende Pfl. 413. Ziest 151.

Windengewächse 127. Zimtbaum 214 .

Windenknöterich214. Zingiber 243.

Windröschen 6. 8. Zitıonenbaum 4\%.

Winterastern 184. Zittergras 268.

Wintereiche 196. Zitterpappel 204.

Wintergrïn 118 . Zostera 247.

Winterzwiebel 225.

Wirsingkohl 20.

Wohlverleih 184.

Wolfsmilch 66. 68 .

Wollgras 272 .

Wollkraut 155 .

Wucherblume 183.

Wnnderbaum 68.

Wurmfarn 294.

Wurzel, Bau и. Leben 400.

Wurzelbakterien 104.

Wurzelbrut $\$ 10$.

Wurzeldruck 423.

Wurzelliaare 404.

Wurzelhanbe 403.
Zuckermelone 168.

Zuckerrohr 262.

Zuckerrübe 216 .

Zweiblatt 276 .

Zweikeimblättrige

Pflanzen 1. 99.

Zweizahn 181.

Zwergkiefer 290.

Zwergpalme 242.

Zwergschwertlilie 238.

Zwetsche 93.

Zwiebel 218. 224.

Zwitterblüte 431 .

Zypresse 292. 
Vom Lehrbuch der Botanik werden, wie vom "Lelırbuche der Zoologie“ gleichfalls gekürzte Ausgaben erscheinen und zwar:

\title{
Leitfaden der Botanik,
}

sowie

\section{Grundriss der Naturgeschichte.}

2. Heft:

\section{Pflanzenkunde.}

\author{
Über die
}

\section{Reformbestrebungen}

auf dem Gebiete des

\section{naturgeschichtlichen Unterrichts}

von

Dr. O. Schmeil.

4. verbesserte und vermehrte Auflage. $\rightarrow$ Preis $1 \mathrm{Mk} .40 \mathrm{Pf}$.

Die Broschüre enthält eine kritische Beleuchtung aller Vorschläge, die bezüglich einer Umgestaltung des naturgeschichtlichen Unterrichts bisher gemacht worden sind, und legt - wie die Kritik einstimmig ausgesprochen hat - in durchaus zwingender Weise dar, welche Richtung die Reform einzuschlagen hat, wenn der Unterricht dem heutigen Stande der Pädagogik und der Naturwissenschaften entsprechen soll; sie stellt sich demnach dar als eine theoretische Begrïndung der Gedanken, die der Verfasser in seinen Schulbiichern niedergelegt hat, oder als ein ausführliches Vorwort zu diesen Werken.

Obgleich die Arbeit erst im Dezember 1896 erschienen ist, liegt sie jetzt bereits in vierter Auflage vor. Für ihren Wert sprechen zahlreiche Pressstimmen, die auf Wunsch gerne zur Verfügung stchen. 
Im Terlage ron, Erwin Nägele und E. Schweizerbart sind ferner noch erschienen:

Breddin, G., Nachahmungserscheinmen bei Rhynchoten. Mit 1 Tafel. 1896. gr. 8".

('hum, C.. Die Beziehnngen zwischen dem arktischen und antarkitischen Plankton. Mit I Karte. 1897. gr. 8n. M. 2.80

Friedrich H., Eine nene Sichmarotzermilhe unseres Bibers. Mit 1 Tafel. 1896. gr. $8^{0}$.

II. -.40

Gerbing, W., Die Charakterrögel des nordwestlichen Thuiringer Waldes. 1901. gr. $8^{\circ}$.

II. -40 .

Grote, Robert, Beiträge zur Entwicklung des Wiederkäuermagens. Mit 1 Tafel. 1897. gr. $8^{n}$.

II. $1 .-$

Leonhardt, E., Der gemeine Flussaal. Ein Beitrag zur Kenntnis seiner Naturgeschichte, sowie seiner wirtschaftlichen Bedentung. 1902. gr. $8^{0}$.

II. 1.20

Leydig, Fr., Nene Beiträge zur anatomischen Kenntnis der Hautdecke und der Hautsinnesorgane der Fische. Mit 4 Tafeln. 1879. gr. $4^{\circ}$.

I. 2.50

Linstow, 0. v., Die Fortpflanzungsgeschichte der Aale. 1900. gr. $8^{\circ}$.

II. -.60

Marshall, W., Gefliigelziichter, Tierärzte, Menschenärzte und zoologische Wunder. 1901. gr. $8^{0}$.

Die Thierwelt Chinas. 1900. gr. $8^{\circ}$.

II. -.60

M. -.40

Schmeil, 0., Copepoden des Rhätikongebirges. Nit 4 Tafeln. 1893. gr. $8^{0}$.

II. 2.- -

- Nene Spaltfusskrebse der Fama der Provinz Sachsen. 1895. gr. $8^{\circ}$.

II. -.40

Schnee, Verschleppte Schlangen in der Provinz Sachsen. 1895. gr. $8^{n}$.

II. -.40

Schoenichen, W., Über Tier- und Menschenseele. Mit 10 Figuren im Text. 1900. gr. $8^{\circ}$.

II. -.60

Schulze, E., Catalogus mammalium enropaeorum. 1900. gr. $8^{0}$.

II. -.50

Taschenberg, 0., Die Flöhe. Die Arten der Insektenordnung Suctoria nach ihrem Chitinskelett monographisch dargestellt. Nit 4 Tafeln. 1880. gr. $8^{\circ}$.

II. 3.-

- Die Lehre von der Urzengung sonst und jetzt. Ein Beitrag zur historischen Entwicklung derselben. 188\%. gr. 8". M. 1.-

Wolterstorff, W., Über ausgestorbene Riesenrögel. Mit $2 \mathrm{Ab}$ hildungen. 1900. gr. $8^{0}$.

II. -.60

Wolterstorff, W., Die Tritonen der Intergattung Euproctus Gené. Mit 1 Tafel. 1902. gr. $8{ }^{\circ}$.

II. $1 .-$ 
,<smiles>CCC</smiles>

$-$

$-$<smiles>C1=CCCCCC1</smiles>
1 


North Carolina State University Libraries

QK47.S350 1903

LEHRBUCH DER BOTANIK FUR HOHERE LEHRANSTALTEN ||||||| || || |||||||||||||||| ||| || || |||||||||||

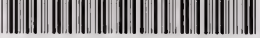
S02776906 M 